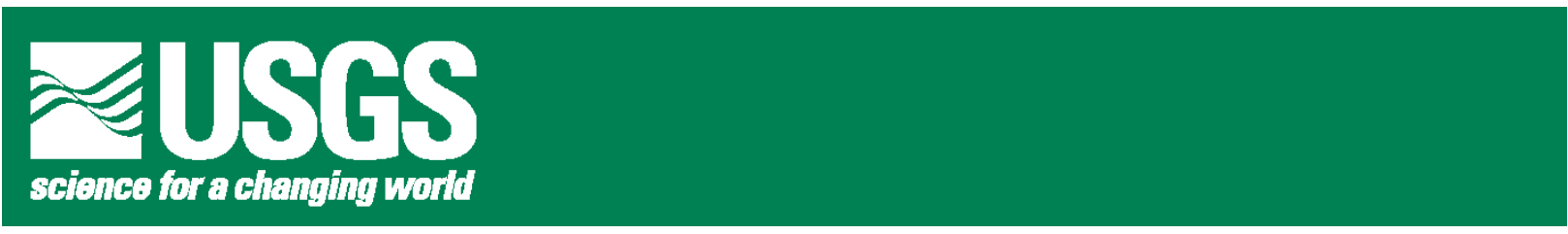

\title{
RECORDS AND HISTORY OF THE UNITED STATES GEOLOGICAL SURVEY
}

Clifford M. Nelson, Editor

U.S. Geological Survey Circular 1179

\section{CONTENTS}

Inventory of the Records of the United States Geological Survey Record Group 57: In the National Archives

Compiled by Renée M. Jaussaud

The United States Geological Survey 1879 - 1989

U.S. Geological Survey Circular 1050

$$
\text { By Mary C. Rabbitt }
$$

2000

U.S. Department of the Interior

U.S. Geological Survey 
INVENTORY OF THE RECORDS OF THE UNITED STATES GEOLOGICAL SURVEY

\title{
RECORD GROUP 57
}

IN THE NATIONAL ARCHIVES

\author{
Compiled by Renée M. Jaussaud \\ United States Geological Survey \\ and \\ National Archives and Records Administration
}

1999 


\section{Contents}

List of Directors of the United States Geological Survey vi

Introduction 1

Records of the Predecessor Surveys, 1847-82

United States Geological Exploration of the Fortieth Parallel ("King Survey"), 1867-81 7

United States Geographical and Geological Survey of the Rocky Mountain Region ("Powell Survey"), 1869-82 10

United States Geological and Geographical Survey of the Territories ("Hayden Survey"),
1847-81

United States Geographical Surveys West of the One Hundredth Meridian ("Wheeler Survey"),
$1871-80$

General Photographs, 1870-74 21

Records of the United States Geological Survey, 1839-1997 22

Office of the Director, 1879-1987 22

General Records, 1879-1987 23

Program and Office Files, 1921-68 28

Statt Geologist tor I'erritories and Island Possessions, 1946-53 29

Office of the Chief Geographer, 1943-80 30

General Records, 1950-72 30

Records relating to the Pan-American Institute for Geography and History, 1943-80 32

General Cartographic Records, 1839-1981 36

General Photographs, 1864-1959 37

Administrative Division, 1879-1972 40

Records concerning Personnel, 1879-1965 40

Records concerning Administration, 1901-72 42

Division of Book Publication, ca. 1874-1995 44

General Records, 1879-1995 44

Illustrations Section, ca. 1874-1948 45

Texts Section, 1887-1916 49

Records concerning the "Geologic Atlas of the United States," 1893-1945 50

Division of Engraving and Printing, 1890-1988 51

Geologic Division, 1867-1997 54

Samuel Franklin Emmons Papers, 1879-87 56

Arnold Hague Papers, 1867-1929 57

General Correspondence and Field Notebooks, 1867-1970 61

Records concerning the Geologic Names Committee, 1899-1969 67

Records concerning West Indian Geolngic Surveve 1917-25 69

General Cartographic Records, 1872-1997 71

General Photographs, 1893-1906

Paleontology and Stratigraphy Branch, 189/-1960 is

Division of Alaskan Mineral Resources, 1901-7 78

Section of Areal Geology, 1907-19

Mineral Deposits Branch, 1881-1953 80 
Base Map Unit, 1941-60 85

Foreign Geology Section, 1942-47 86

Theoretical Geophysics Branch, 1942-96 87

Trace Elements Planning and Coordination Office, 1946-62 89

Alaskan Geology Branch, 1946-78 91

Fuels Branch, 1908-96 93

Military Geology Branch, ca. 1918-64 97

National Mapping Division, 1853-1995 100

General Records, 1879-1982 102

Records concerning Cooperation, 1926-49 107

Records concerning Aerial Photography and Mapping, 1925-83 108

Records concerning Triangulation, Control, and Computing, 1882-1973 110

Records concerning Emergency Relief Activities, 1933-43 112

General Manuscript Cartographic Records, 1853-1990 113

General Published Cartographic Records, 1865-1995 116

General Photographs, ca. 1880-1900 125

General Motion Pictures, 1947-74 127

Records of the Plans and Coordination Branch, 1942-60 128

Records concerning the National Cartographic Information Center, 1934-78 129

Water Resources Division, 1888-1996 130

Records of the Irrigation Survey and Hydrographic Division, 1888-99 131

General Records, 1907-96 133

Fiscal Records, 1897-1912 138

Administrative Records, 1908-63 140

Records concerning Cooperation, 1903-66 145

Records concerning Hydrologic Data and Reports, 1892-1953 157

White Mountains Investigation, 1896-1932 161

Records concerning the Superpower Survey, 1918-23 165

Planning Section, 1953-71 168

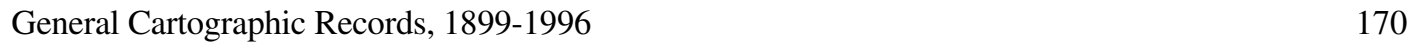

Surface Water Branch, 1904-63 173

Ground Water Branch, 1890-1954 178

Quality of Water Branch, 1913-63 185

Division of Power Resources, 1913-47 189

Water Utilization Division, 1924-52 194

General Hydrology Branch, 1889-1966 197

Office of Radiohydrology, 1947-75 199

Conservation Division, 1894-1980 200

General Records, 1901-80 202

General Cartographic Records, 1921-34 205

Mineral Classification Division, ca. 1900-1980 206

Branch of Oil and Gas Operations, 1920-68 210

Mining Branch, 1933-41 212

Water and Power Branch, 1894-1961 214

Branch of Connally Act Compliance, 1937-71 216

$\begin{array}{ll}\text { Alaskan Branch, 1899-1996 } & 217\end{array}$ 


\section{Organization Charts}

1. 1921

2. 1958

\section{Appendices}

1. Select List of Legislation

2. Office of the Director - Correspondence and Related Records, ca. 1906-48 (entry 49)

3. Office of the Dire ztor - Central Classified Files, 1912-53 (entry 51)

4. Office of The Director - Central Classified Files, 1953-74 (entry 52):

1st Subseries (1953-68)

2d Subseries (1968-74)

5. Staff Geologist for Territories and Island Possessions - Recorcs of John Calvin Reed (Sr.), 1946-53 (entry 60)

6. Division of Engraving and Printing - General Correspondence Files, 1941-49 (entry 132)

7. Geologic Division, Arnold Hague Papers - Working Papers and Reference Material, ca. $1883-1915,1929$ (entry 146)

8. Geologic Division - General Correspondence Files, 1890-1922 (entry 159)

9. Geologic Division - General Correspondence Files, 1899-1952 (entry 160)

10. Geologic Division - Records concerning Division Employees, 1930-53 (entry 164)

11. Geologic Division - Geologists' Field Notebooks and related Records, 1867-1939 (entry 172)

12. Geologic Division - Microfiche Copies of Geologists' Field Notebooks, 1871-1969 (entry 173)

13. Geologic Division - Photographic Prints depicting Geological Formations and Features, ca. 1893-1906 (entry 204)

14. Paleontology and Stratigraphy Branch - Office Files of Josiah Bridge, 1922-53 (entry 209)

15. Mineral Deposits Branch - General Administrative and Correspondence Files, 1909-53 (entry 219)

16. Fuels Branch - General Administrative Files, 1925-53 (entry 268)

17. National Mapping Division - General Administrative Files, 1879-1947 (entry 288)

18. National Mapping Division - General Administrative Files, ca. 1890-1953 (entry 289)

19. National Mapping Division - Correspondence of Officials in Charge of Field Surveys, 1918-49 (entry 296)

20. National Mapping Division - Records concerning Cooperative Mapping Projects, 1926-49 (entry 304)

21. National Mapping Division - Records concerning Aerial Mapping, 1927-48 (entry 307)

22. National Mapping Division - Special Topographic Map Series, 1865, 1886-1983 (entry 342)

23. Plans and Coordination Branch - Administrative Files, 1942-60 (entry 405)

24. Water Resources Division - General Correspondence Files, 1907-53 (entry 412)

25. Water Resources Division - Circular Letter File, 1918-53 (entry 415)

26. Water Resources Division - Administrative Orders, Circulars, and Memorandums, 1915-55 (entry 416)

27. Water Resources Division - Correspondence concerning District Engineers and other Division Employees, 1908-57 (entry 433)

28. Water Resources Division - Records concerning Interstate River Compacts and Regional Projects, 1923-54 (entry 455)

29. Water Resources Division - Records of the Subcommittee on Hydrologic Data of the Federal Interagency River Basin Committee, 1947-48 (entry 491)

30. Ground Water Branch - Administrative Correspondence Files, 1919-43 (entry 574)

31. Ground Water Branch - Administrative Correspondence Files, 1944-53 (entry 575)

32. Quality of Water Branch - Records concerning Field Offices and Laboratories, 1939-52 (entry 601)

33. General Hydrology Branch - General Correspondence Files, 1920-59 (entry 636)

34. General Hydrology Branch - Records concerning Programs and Projects, ca. 1915-58 (entry 637)

35. General Hydrology Branch - Reports and other Records concerning Water Sources for Livestock, 1942-59 (entry 638) 
36. General Hydrology Branch - General Files of the Reports Section, 1889-1966 (entry 639)

37. Conservation Division - Mission Control Files, 1901-80 (entry 642)

38. Conservation Division - Reports and other Records concerning the Operation of Power Systems on Federal Lands, 1907-48 (entry 644)

39. Water and Power Branch - Records concerning Land and Stream Classification, 1894-1961 (entry 675) 


\section{Directors of the United States Geological Survey}

Name and Date of Oath of Office

1. Clarence (Rivers) King: May 24, 1879

2. John Wesley Powell: March 19, 1881

3. Charles Doolittle Walcott: June 30, 1894

4. George Otis Smith: April 30, 1907

5. Walter Curran Mendenhall: December 24, 1931

(Acting Director from December 23, 1930)

6. William Embry Wrather: May 7, 1943

7. Thomas Brennan Nolan: January 27, 1956

8. William Thomas Pecora: September 25, 1965

9. Vincent Ellis McKelvey: December 8, 1971

10. Henry William Menard: March 28, 1978

11. Dallas Lynn Peck: September 2, 1981

12. Gordon Pryor Eaton: March 14, 1994

13. Charles George Groat: November 13, 1998 


\section{Introduction}

The United States Geological Survey (USGS) was founded by an act of Congress dated March 3, 1879 (20 Stat. L., 394-395). The provisions of the act specified that "the salary of the Director of the Geological Survey, which office is hereby established, under the Interior Department, who shall be appointed by the President by and with the advice and consent of the Senate, six thousand dollars: Provided, That this officer shall have the direction of the Geological Survey, and the classification of the public lands and examination of the Geological Structure, mineral resources and products of the national domain." The act directed the termination of the three ongoing geological and geographic surveys (predecessor surveys) and the deposit of the USGS and other Federal scientific collections in the National Museum. Other clauses specified ethics for USGS employees. The act also provided for the publication of an annual report of the operations of the USGS, maps, and technical reports, a program of publications exchange, and the establishment of a library.

Although the agency was commonly referred to as the United States Geological Survey and routinely used that title on official publications, it was by the act of May 18, 1992 (106 Stat. L., 171), that the Federal Geological Survey officially became the United States Geological Survey

The act of August 7, 1882 (22 Stat. L., 329), directed the USGS "to continue the preparation of a geologic map of the United States." The legal interpretations of "national domain" in the USGS establishing legislation (or organic act) had restricted the agency's operations to the public-land States and Territories west of the Mississippi River. As geologic mappers required accurate large-scale topographic maps on which to compile their data and interpretations, the new law was interpreted by the USGS as authorizing topographic and geologic mapping in the remainder of the United States. The Survey entered into cooperative arrangements with the States to conduct field examinations and compile maps.

Continuous funding for water-resources investigations by the USGS dates from the act of August 18, 1894 (28 Stat. L., 398), that specifically authorized "gauging the streams and determining the water supply of the United States, including the investigation of underground currents and artesian wells in arid and semiarid sections." The "Weeks Act" of March 1, 1911 (36 Stat. L., 962), added responsibility for the examination of lands before they were purchased to "promote or protect the navigation of streams on whose watersheds they lie."

The land-classification work specified in the organic act was not an active function of the USGS until 1906. That year the General Land Office and the USGS entered into a cooperative agreement that specified that the USGS was to be chiefly responsible for the examination and classification of lands and report its findings to the General Land Office for action. In 1908 the Land Classification Board was established in the Geologic Branch. In 1925 when the Bureau of Mines was transferred to the Department of Commerce the Mineral- and Oil-Leasing Divisions of the Bureau of Mines were transferred to the USGS. With the transfer the USGS' new Conservation Branch acquired responsibility for administering the provisions of the Mineral Leasing Act of February 25, 1920 (41 Stat. L., 437), and related legislation that formed the basis of regulatory responsibilities in the USGS.

In 1907 the USGS established a Technologic Branch to administer the programs of fuel- and structural-materials testing and analysis. The act of May 22, 1908 (35 Stat. L., 226), provided for investigations into the causes of mine explosions. A Mine Accidents Division was set up in the Technologic Branch to conduct these investigations. In 1910 most of the Technologic Branch's functions were transferred to the newly created Bureau of Mines. The same year structural-materials studies were transferred to the Bureau of Standards.

By 1920 the operational units that would carry out USGS programs for the next sixty years were in place the Geologic Branch, Topographic Branch, Water Resources Branch, and Land Classification Board (later the Conservation Branch) [Organization Chart 1]. 
The first USGS Director, Clarence King, established field offices. John W. Powell, the second Director, closed the field offices and all off-season work was done at the Washington headquarters. Later the operational units found that field offices increased the staff's time for field work and ensured the direct oversight of year-round operations such as stream gaging. The location and number of field offices differed from one operational unit to another depending on type of work and need.

USGS staff served on USGS committees, such as the Geologic Names Committee, that drew on the experience and expertise of employees to better administer the agency's programs; departmental and regional field committees, such as the Water Resources Committee, to coordinate departmental programs and formulate long-range plans within the department; and interagency and coordination committees, such as the Pacific Northwest Coordination Committee, to facilitate cooperation between agencies of the Federal Government. USGS staffers also attended meetings of other departmental committees as observers or to serve a liaison function. The professional staff of the USGS also participated in conferences and meetings of professional, industrial, and international scientific organizations.

In the 1930's the USGS undertook programs with funds appropriated for economic recovery under the administration the National Recovery Administration, the Public Works Administration and the Work Projects Administration. The level of cooperative work between the operational units of the USGS, particularly the Topographic and Water Resources Branches, and other Federal agencies and States increased with funding provided by economic-recovery appropriations.

During World War I and World War II the USGS reoriented its programs to support the war effort. Just before the United States entered World War I USGS geologists were gathering data about worldwide strategic-mineral production and consumption. During the war many experienced topographers were commissioned in the military to prepare maps. The water-resources staff made studies of ground water for the use of military installations. USGS involvement in World War II occupied more of the civilian staff over a longer period of time. The Branches worked under agreements with and funding from elements of the War Department to compile strategic terrain intelligence reports on enemy held areas, to identify the locations of critical minerals available to the enemy, and to prepare topographic maps of areas occupied by United States forces.

The growth of USGS programs and staff after World War II required fundamental changes in organizational structure. To handle the increased administrative demands on the Branch Chiefs, staff positions were created in the Divisions. In 1946 two staff units were add to the Topographic Branch, the Plans and Coordination Branch and the Research and Technical Branch. In 1948 the Technical Control and Programs Control Branches were added to the Water Resources Branch; an Executive Officer began work in the Geologic Branch; and the position of Chairman of the Unit Plan Committee was created in the Conservation Branch. In 1949 Federal branches were renamed divisions with subordinate branches; the divisions were restyled branches, with subordinate sections and units.

Under Reorganization Plan No. 3 of 1950 other organizational and administrative changes were made in the USGS. The plan vested some of the authority that had been exercised by the Director in the Secretary of the Interior. In the next several years the staffing plans of the Divisions were evaluated with the object of reorienting the lines of authority. The process was essentially complete in by 1958 [Organization Chart 2].

In the 1930's it became evident to USGS geologists that oil-bearing geological structures in the California and Gulf of Mexico coastal plains extended offshore. In 1945 an Executive Order placed the natural resources of the Continental Shelf under the jurisdiction of the Secretary of the Interior. The Submerged Lands Act of 1953 established Federal jurisdiction over the Continental Shelf. The Outer Continental Shelf Lands Act of 1953 encouraged the exploration and development of fossil fuel and other mineral resources. Geological and geophysical exploration on the outer continental shelf was conducted by the Geologic Division and oversight of leasing and, later, application of environmental-protection laws, was the responsibility of the Conservation Division. 
The National Environmental Policy Act of 1969, Coastal Zone Management Act of 1972, Water Resources Research Act of 1984, and other legislation about national environmental policy that reflected growing public concern about environmental and conservation matters augmented the work of the USGS. The Water Resources Division expanded a network of gaging stations set up to measure the flow of fresh water into estuaries.

The Geologic Division developed new techniques for the study of marine geologic structures to determine environmental hazards associated with offshore drilling facilities. The Topographic Division used data from earthobserving satellites and high-altitude aircraft to compile maps to aid in land-use planning. The USGS established a data center in 1973 to collect data from remotely sensed sources under the Earth Resource Observation Systems (EROS) Program.

The Office of Earth Sciences Applications (OESA) succeeded the Land Analysis and Information Office, which had been established in 1975. Records concerning the earlier programs of the predecessor unit, the Geographic Applications Program are described with the records of the Office of the Geographer (entries 61, 65, and 66). The OESA was abolished in 1982 and its functions were dispersed to the National Mapping, Geologic, and Water Resources Divisions.

The Office of the Naval Petroleum Reserve in Alaska (ONPRA) was established in the Office of the Director of the Geological Survey in 1977. In 1974 the Navy Department began a new exploratory program in Alaska's Naval Petroleum Reserve No. 4. The program was expanded with funds authorized by Congress. The Naval Petroleum Reserves Production Act of April 5, 1976 (90 Stat. L., 303), renamed the reserve the National Petroleum Reserve in Alaska and assigned the Department of the Interior oversight of the exploratory program and other duties associated with management of the reserve. In 1977 these tasks were delegated to the USGS. The program was terminated in 1982 and the oil and gas fields turned over to the North Slope Borough.

In 1982 the Minerals Management Service (MMS) was created by Secretarial Order 3071 (January 19, 1982) and amendment 1 (May 10, 1982) under the authority of Section 2 of Reorganization Plan 3 of 1950. The same year administrative functions relating to outer-continental-shelf leasing responsibilities in the Conservation Division were transferred to MMS. The following year revenue-management responsibilities of the Conservation Division were also transferred. Onshore leasing responsibilities on public and Indian lands were transferred to the Bureau of Land Management.

In 1993 Secretarial Order 3173 (September 29, 1993) established a National Biological Survey in the Department of the Interior composed of functions transferred from the United States Fish and Wildlife Service, National Park Service, Bureau of Land Management, Minerals Management Service, Office of Surface Mining Reclamation and Enforcement, United States Geological Survey, and Bureau of Reclamation. The agency, renamed the National Biological Service in 1995, was responsible for providing scientific support and other assistance to other Federal agencies in forming policies that would effect the conservation and management of the biological resources of the United States. In 1996 the National Biological Service was abolished under the provisions of the act of April 26, 1996 (110 Stat L., 1321-165) and its functions transferred to the USGS, where it was reconstituted as the Biological Resources Division.

The United States Bureau of Mines was abolished under provisions of the act of April 26, 1996 (110 Stat. L., 1321-167). Functions relating to minerals information and analysis were transferred to the USGS.

An important source of related records is Record Group 48, Records of the Office of the Secretary of the Interior. The USGS has been a bureau of the Department of the Interior since the agency's establishment in 1879. The records of the Office of the Secretary of the Interior contain many series that document departmental oversight of the functions and programs of the USGS. The records of the Office of the Secretary are organized in two major subgroups, pre-1907 and post-1907. The information presented herein is intended to highlight those series that contain readily identifiable and significant records relating to the USGS. Where entire series are cited the dates given are those of the series and not necessarily the items contained in the series that relate to the USGS. 
An inventory of Record Group 48, Records of the Office of the Secretary of the Interior is available at the National Archives and Records Administration (NARA).

In the pre-1907 records administrative oversight of the USGS is documented in the letters received and letters sent of the Patents and Miscellaneous Division. Four other series in this division also contain records relating to the USGS and its predecessor surveys: (1) letters received relating to the United States Entomological Commission, 1877-80; (2) letters relating to the Geological Survey and its predecessors, 1868-80; (3) reports of the Geological Survey, 1883-87; and (4) records relating to forest reserves, 1891-1902. Matters in which the USGS was involved relating to areas under the jurisdiction of the General Land Office or the Bureau of Indian Affairs were handled through the Lands and Railroads Division and the Indian Division, respectively, and are documented in the letters received and letters sent of those divisions. The records of the Lands and Railroads Division also include a series of records relating to specific reclamation projects, 1889-1907. The records of the Appointments Division included several series that contain records relating to the USGS: (1) central office appointment papers, 1849-1907, which include a few files items relating to the nomination and appointment of Directors of the USGS, including Clarence King, John W. Powell, and Charles D. Walcott; (2) departmental appointment papers, 1879-1906, which concern the appointment of the USGS's scientific and technical employees, clerks, messengers, and others, but not seasonal field employees who were hired in the field; and (3) record cards for employees of the USGS, 1918 (for individuals with surnames beginning with the letters L-Z).

In the post-1907 records the central classified files contain significant records about the USGS. In the central classified files dated 1907-53, most of the records documenting oversight of the USGS are in section 7 - Geological Survey. There are also related files in section 1 - Administrative, section 8 - Bureau of Reclamation, and section 11Bureau of Mines. The central classified files dated 1954-58 contain pertinent records in section 3 - Geological Survey. The later central files, 1959-63, 1964-68, and 1968-72 include information about the USGS dispersed among many programs areas. Other post-1907 records also contain records about USGS activities. The general subject files, 193958, of the Office of the Solicitor include files titled Geological Survey, oil and gas, water and power, and the outer continental shelf. The records of the Division of Information include press releases relating to the USGS in several sub-series dated 1938-61, 1959-62, and 1963-74. The records relating to legislation, in two series dated 1907-53, and 1954-58, are an important source of information about legislative mandates that affected USGS programs. The records concerning the department war history, 1941-48, contain a draft history of USGS activities during World War II. The general records, 1946-51, of the Minerals and Fuels Division; the central files, 1947-53, of the Program Staff; and the central classified files, 1937-56, of the Division of Land Utilization contain files titled Geological Survey.

Several bureaus were formed entirely, or in part, or enhanced from functions that originated in the USGS. The records of those agencies that are found in the National Archives are designated: Record Group 49, Records of the Bureau of Land Management (created when the Division of Grazing, formed from functions transferred from the USGS, was merged with the General Land Office); Record Group 70, Records of the United States Bureau of Mines; Record Group 90, Records of the Public Health Service; Record Group 95, Records of the Forest Service; Record Group 115, Records of the Bureau of Reclamation; and Record Group 423, Records of the Minerals Management Service.

Other records that contain information about cooperation with the USGS include Record Group 9, Records of the National Recovery Administration; Record Group 23, Records of the Coast and Geodetic Survey; Record Group 27, Records of the Weather Bureau; Record Group 68, Records of the United States Coal Commission; Record Group 77, Records of the Office of the Chief of Engineers; Record Group 79, Records of the National Park Service; Record Group 106, Records of the Smithsonian Institution; Record Group 114, Records of the Soil Conservation Service; Record Group 126, Records of the Office of Territories; Record Group 135, Records of the Public Works Administration; Record Group 138, Records of the Federal Energy Regulatory Commission (formerly the Federal Power Commission); Record Group 142, Records of the Tennessee Valley Authority; Record Group 232, Records of the Petroleum Administrative Board; Record Group 298, Records of the Office of Naval Research; Records Group 
320, Records of the Office of Minerals Exploration; Records Group 324, Records of the Board on Geographic Names; and Record Group 326, Records of the Atomic Energy Commission.

Summary descriptions of the records comprising each of the record groups are in the "Guide to Federal Records in the National Archives of the United States" (1995). The Guide also described records of the United States Geological Survey that are located in NARA field branches. The USGS records in the National Archives Branches are records and files that were created or maintained by the field offices of the USGS.

More than 20,000 USGS field notebooks or files, 2,600 map groups, 2,000 folders, and 70,000 aerial photos (some annotated) that remain in the custody of the agency are in the Field Records Library, Special Collections, USGS Library, Denver, Colorado, where they support the agency's work-in-progress. These materials, which date from 1871, include field and compilation maps, annotated topographic maps, planetable sheets, correspondence, drafts of papers, unpublished reports, well logs, and analysis reports.

The records described in this inventory constitute Record Group 57, Records of the United States Geological Survey in the National Archives of the United States. The records are located in Archives II in College Park, Maryland. This inventory includes all the records of the United States Geological Survey that were accessioned to the National Archives as of December 31, 1997. The records consist of textual materials, maps and plans, aerial photographs, still photographs, motion pictures, and sound recordings. The textual records are in the custody of the Textual Archives Services Division (NWCTC). The non-textual records are in the custody of the Special Media Archives Services Division (NWCS). The footage given is in linear feet unless otherwise stated.

The records in this inventory are organized in sections by the organizational units that created or maintained the records. Thereunder the records are described in series. A series is defined as a collection of records that is arranged by a systematic filing system (decimal, alphabetical, chronological, map series), that share a unique format (indexes, geologists' field notebooks, microfiche), or were maintained as a set of files by an organizational unit to document a program area or function. Whenever possible the nontextual records (maps and plans, aerial photographs, still pictures, motion pictures) are described with related textual records. The nontextual materials that do not relate to any particular series of textual records; they are described in a general category at the division level. All the appendices, with the exception of Appendix 1 (a select list of legislation) and Appendix 7 (a summary list of series contents), are complete file-title lists.

The nontextual records are maintained in specialized custodial units. The maps and plans, aerial photographs, still pictures, and motion pictures are in the Special Media Archives Services Division (NWCS) in the National Archives and are accompanied by the designation NWCS. A few nontextual records are filed with the textual records and are so indicated with the series description.

Sources for the history of the USGS include the three volumes by Mary C. Rabbitt, "Minerals, Lands, Geology for the Common Defence and General Welfare, Volume 1, Before 1879" (1979), "Volume 2, 1879-1904" (1980), and "Volume 3, 1904-1939" (1986) published by the U. S. Government Printing Office as USGS Special Books.

A fourth volume (1939-1979) is being prepared. Earlier analyses comprise those by Charles D. Walcott, 1904, "The United States Geological Survey: Its Origin, Development, Organization, and Operations," USGS Bulletin 227, and the Institute for Government Research (IGR), 1918, "The United States Geological Survey, Its History, Activities, and Organization" published in New York and London by D. Appleton \& Company as its Service Monograph of the United States Government No. 1. A book-length interpretive history of the early years of the USGS is Thomas G. Manning, 1967, "Government in Science: The U.S. Geological Survey, 1967-1894," published in Lexington by the University of Kentucky Press. For detailed evaluations of the immediate predecesor surveys of the USGS, see

Richard A. Bartlett, 1962, "Great Surveys of the American West," published by the University of Oklahoma Press, and Chapters XI-XV in William H. Goetzmann, 1966, "Exploration and Empire: The Explorer and the Scientist in the Winning of the American West," published in New York by Alfred A. Knopf. 
Cooperation between the USGS and NARA in the years since 1980 facilitated the production of this inventory. The compiler thanks Clifford Nelson (USGS) and Sharon Thibodeau (NARA) for their encouragement and supervision. At NARA, archivists Charles Dewing, William Heynen, Deborah Lelansky, Edward McCarter, Michele Pacifico, Joseph Schwarz, Richard Smith, Alan Walker, and Charles Zaid contributed to the completion of the work. Nelson and Robert Kvasnicka (NARA) also served as technical reviewers and revisers of the draft versions.

The inventory was edited using the standards of the USGS and the U.S. Government Printing Office. 


\section{RECORDS OF THE PREDECESSOR SURVEYS, 1847-82}

United States Geological Exploration of the Fortieth Parallel

("King Survey"), 1867-81

The United States Geological Exploration of the Fortieth Parallel was founded by an act of Congress for legislative, executive, and judicial expenses dated March 2, 1867 (14 Stat. L., 457). The legislation authorized "the Secretary of War to direct a geological and topographical exploration of the Territory between the Rocky Mountains and the Sierra Nevada mountains, including the route or routes of the Pacific (transcontinental) railroad." Civilian geologist Clarence King was placed in charge of the reconnaissance. On March 21, Brigadier General Andrew A, Humphreys, Chief of the Army Corps of Engineers, directed King to map and examine and describe the geological structure, geographical condition, and natural resources of this belt of country, especially its economically important mineral deposits and mining districts. Humphreys later extended the work to the eastern slope of the Rockies. King's organization completed its field work in 1872 and published all but one of its final reports before King closed has accounts and resigned his appointment on January 18, 1879. O. C. Marsh's "Odontornithes," the exploration's last volume, appeared in 1880. For a list of these reports, see Laurence F. Schmeckebier, 1904, "Catalogue and Index of the Publications of the Hayden, King, Powell, and Wheeler Surveys," USGS Bulletin 222.

Geologists' field notebooks compiled during the survey by Clarence King (No. 5243) and Samuel F. Emmons (Nos. 1108 to 1113) are part of the records described in entry 172.

Many of the records concerning the "King Survey" described in this inventory have been published as National Archives and Records Administration (NARA) Microfilm Publication M622, "Records of the Geological Exploration of the Fortieth Parallel ("King Survey"), 1867-81."

1. LETTERS RECEIVED FROM THE WAR AND TREASURY DEPARTMENTS. Mar. 21,1867 Apr. 11, 1870. 2.5 in. 1 vol.

Arranged chronologically, except for a few printed circulars found in the front of the volume.

Mounted and bound letters received from the War Department, chiefly the Corps of Engineers, defining the mission and authorizing the organization and operations of the "King Survey," and letters from the Treasury Department concerning fiscal matters. A Treasury Department circular issued in 1877 (No. 27) is bound in the front of the volume. Also inserted but not mounted into the volume are Corps of Engineers Circulars dated October to December 1867 (Nos. 26 to 47, incomplete).

This volume has been published as part of NARA Microfilm Publication M622.

2. LETTERS RECEIVED FROM THE OFFICE OF THE CHIEF OF ENGINEERS. Apr. 12,1870 May 13, 1881. 4 in. 1 vol.

Arranged chronologically, except for letters dated Sept. 2, 1876 through Nov. 22, 1879, which were bound in reverse order.

Mounted and bound letters received relating to funding, equipment, personnel, scientific specimens, field operations, reports, and photographs. Included are letters from the Treasury Department, other War Department offices, the Department of the Interior, the New York State Museum of Natural History, the Royal Society of London, and private individuals. 
This volume has been published as part of NARA Microfilm Publication M622.

\section{LETTERS RECEIVED FROM THE TREASURY DEPARTMENT AND THE PUBLIC PRINTER.}

Apr. 1, 1870 - Jan. 29, 1879. 2.5 in. 1 vol.

Arranged in two segments in the order given above, and thereunder in rough chronological order.

Mounted and bound letters received relating to King's accounts as disbursing agent and to arrangements for publishing the findings of the "King Survey." Army Corps of Engineers and Treasury Department circulars, regarding the duties of disbursing officers, dated 1863-1869, are inserted in the middle of the volume. The contents of the volume measure 0.75 in.

This volume has been published as part of NARA Microfilm Publication M622.

4. LETTERS SENT TO THE CHIEF OF ARMY ENGINEERS. Mar. 28, 1867 - Jan. 18, 1879. 2.5 in. 1 vol.

Arranged chronologically.

Handwritten copies of letters (some with copies of enclosures), telegrams, and reports concerning field operations, fiscal and administrative matters, and compilation of reports. Among these letters is Clarence King's official report to Andrew A. Humphreys, dated Nov. 27, 1872, regarding the exposure of the "Diamond Hoax," the fraudulent occurrence of diamonds in Colorado. Geologist's field notebook No. 1113 (part of the records described in entry 172 in this inventory) contains notes relating to the diamond frauds.

This volume has been published as part of NARA Microfilm Publication M622.

\section{PHOTOGRAPHIC PRINTS. ca. 1868-72. 6 in.}

Arranged by agency assigned number. Most of the photographs bear captions giving the subject and name of the photographer. This is series KS (NWCS, still pictures).

Mounted prints (8 in. x 11in.) of areas mapped as part of a survey of Nevada, California, Utah, and Wyoming. Most of the photographs were taken by Timothy H. O'Sullivan. The subjects include Donner Lake Pass, California; Mono Lake, California; East Humboldt Mountains, Nevada; Fort Ruby, Nevada; Virginia City, Nevada; hot springs and mining operations in Nevada; Big Cottonwood Canyon, Wasatch Mountains, Utah; Salt Lake City, Utah; and examples of limestone, granite, and additional rock types and formations, and other geologic features.

There are also mounted prints of the Mount Shasta area taken by Carlton E. Watkins.

Many of the photographs have corresponding original negatives, series KN, and color transparencies, series KSP, both in Record Group 77, Records of the Office of the Chief of Engineers. 
6. PHOTOGRAPHIC PRINTS. ca. 1867-72. 5 in.

Arranged numerically by original negative number. Most of the photographs are captioned. This is series KSU (NWCS, still pictures).

8 in. $x 11$ in. mounted prints of areas mapped in Nevada, California, Utah, and Wyoming. Subjects include Tertiary (Eocene) sandstone in Echo Canyon, Utah; Green River Canyon, Utah; Wasatch Mountains, Utah; Austin, Nevada; East Humboldt Mountains, Nevada; and. Pyramid Lake, Nevada. Some of the photographs carry handwritten annotations indicating that the photographer was Timothy H. O'Sullivan.

The original negatives are in Record Group 77, Records of the Office of the Chief of Engineers, series KN. 
United States Geographical and Geological Survey of the Rocky Mountain Region

("Powell Survey"), 1869-82

John Wesley Powell began his first exploration of the Colorado River in 1869 with appropriations (15 Stat. L., 253, June 11, 1868) for rations for his party to be issued by the Secretary of War. An act of July 12, 1870 (16 Stat. L., 242), made a direct appropriation for the survey of the Colorado River and its tributaries to be expended under the direction of the Secretary of the Interior. From 1871 to 1873 the explorations were conducted under the sponsorship of the Smithsonian Institution. With the act of June 23, 1874 (18 Stat. L., 207), Congress returned supervision of Powell's western survey to the Secretary of the Interior where it was renamed the "Geological and Geographical Survey of the Territories, Second Division.” Beginning with the appropriation act of July 31, 1876 (19 Stat. L., 120), the survey became known as the United States Geographical and Geological Survey of the Rocky Mountain Region. The survey was terminated on June 30, 1879, by the act of March 3, 1879 (20 Stat. L., 394), the same law that created the USGS.

Some photographs relating to the "Powell Survey" are part of a general collection that is described in entry 41. Geologists' field notebooks compiled by Grove K[arl] Gilbert (Nos. 3391 to 3411, and 3415) are part of the records described in entry 172 .

7. LETTERS RECEIVED. 1869-79. $2 \mathrm{ft} .10$ vols.

Arranged chronologically by year and thereunder alphabetically by surname or official title of correspondent.

Chiefly mounted and bound letters, but also included are postcards, circulars, legislative bills, newspaper clippings and a large plat showing areas surveyed by Hayden, Powell, and Wheeler and the area to be surveyed by Wheeler in 1874 (Vol. 2). The letters are from scientists, professional societies, the Secretaries of the War, Interior, and Treasury Departments, members of Congress, Secretary of the Smithsonian Institution, inhabitants of the intermountain regions, expedition members and others. The records concern the organization and objectives of Powell's expeditions, administration of Indian agencies, Indian languages and customs, public lands in arid regions, processing and publication of reports, the Philadelphia Centennial Exposition, the establishment of the USGS, and other subjects.

These records have been published as National Archives and Records Administration (NARA) Microfilm Publication M156, "Letters Received by John Wesley Powell, Director of the Geographical and Geological Survey of the Rocky Mountain Region, 1869-79."

8. $\quad$ PRESS COPIES OF LETTERS SENT. Oct. 3, 1876 - June 30, 1879. 6 in. 4 vols.

Arranged in rough chronological order. The volumes contain partial indexes to names of addressees.

Letters to the Secretary of the Interior, members of Congress, other government officials, the Secretary of the Smithsonian Institution, geologists, and others concerning the printing and distribution of reports, Indian ethnography, western exploration, the Philadelphia Centennial Exposition, and the establishment of a national geological survey.

Many of the letters are not legible. These letters have not been microfilmed. 
9. MAPS TO ACCOMPANY A "REPORT ON THE LANDS OF THE ARID REGION OF THE UNITED STATES.” 1878. 3 items. [NWCS, maps and plans]

The maps, from Powell's volume, are titled "Map of the United States exhibiting the Grants of Lands made by the General Government to Aid in the Construction of Railroads and Wagon Roads," and "Rain Chart of the United States." The latter, using color shading and isohytal lines, shows the distribution of the mean annual precipitation in rain and melted snow. The second map is a copy of a chart compiled for the Smithsonian Institution in 1868.

10. RECORDS RELATING TO THE GEOLOGY OF THE BLACK HILLS. ca. 1879. 2 items. [NWCS, maps and plans]

A map titled "Geological Map of the Black Hills of Dakota," and a panoramic illustration titled "Bird's Eye View of the Black Hills." On the illustration different geologic strata are indicated by symbolic birds in flight.

Both items are by Henry Newton, who, with Walter P. Jenney, examined the geology and mineral resources of the Black Hills in 1875 for the Interior Department. Acts of Congress on July 31, 1876 (19 Stat. L., 120), and June 14, 1878 (20 Stat. L., 120), authorized the payment of their expenses. Newton and Jenney's report (text, 1880; atlas, 1879) appeared under the auspices of the "Powell Survey."

11. MISCELLANEOUS MAP. n.d. 1 item. [NWCS, maps and plans]

A contour drawing of an area in Utah.

12. STUDIES OF THE HENRY MOUNTAINS. n.d. 31 items. [NWCS, maps and plans]

Geologic sketches by Clarence E. Dutton and Grove K. Gilbert.

13. MAP OF UTAH TERRITORY. 1878. 2 items. [NWCS, maps and plans]

Two copies of a shaded relief map "representing the extent of the irrigable, timber, and pasture lands." The map is based on atlas sheets from the "Powell Survey" with added information from the "Hayden, King, and Wheeler Surveys." The map also shows the location of railroad lines, wagon roads, trails, telegraph lines, and towns.

14. ATLAS SHEETS OF THE GRAND CANYON. 1882. 1 vol. and 3 pages. [NWCS, maps and plans]

Titled an "Atlas to accompany the Monograph on the Tertiary History of the Grand Cañon District," by Captain Clarence E. Dutton. Comprised of dramatic panoramic scenes of the Grand Canyon and adjacent plateaus and colorcoded geologic maps of the Grand Canyon and adjacent areas that were published in 1882 as sheets in the atlas of USGS Monograph 2.

\section{JOSEPH HENRY WHEAT ALBUM OF RIVER, LAND, ETHNOGRAPHIC, AND MISCELLANEOUS} VIEWS. 1871-74. 1 album. 3 in.

Arranged in four sections as described below and thereunder by NARA assigned number. The numbers used for the first three sections correspond to caption entries found in a journal complied by Major John W. Powell. A copy 
of that part of the journal that contains the captions accompanies the photographs. The original journal is in the National Anthropological Archives in the Smithsonian Institution. The four sections are PR, PL, PE, and PM (NWCS, still pictures).

Stereoscopic prints ranging in size from 3 in. x 4.5 in. to 7.5 in. x 9.5 in. The "River Views" are chiefly photographs of sections of the Green and Colorado Rivers, side canyons, portages, camp sites, waterfalls, and parks. Some photographs are identified in the journal as part of series such as the "Red Canyon Series," Canyons of Desolation Series," and "Echo Park Series." The photographers were Elias O. Beaman, James Fennemore, and John K. Hillers.

The "Land Views" show plateaus, mountains, and tributary and adjacent streams such as Kanab Creek, Rio Virgin, and Servier River. The photographers were James Fennemore, and John K. Hillers.

The "Ethnographic Views" consist chiefly of various tribes of Indians living in the vicinity of the Colorado River and its tributaries, including Paiutes, Uintas, and Navajos. The photographer was John K. Hillers.

The miscellaneous items include photographs of waterfalls, geologic formations, sections of rivers, and groups of buildings. The photographers are not known.

There are annotated references to corresponding negatives for some of the photographs, which are part of the records described in series PS, entry 87. The photographs were collected by Joseph H. Wheat, a topographer with the USGS, and given to Claude H. Birdseye, Chief Topographic Engineer of the USGS, for the agency's permanent files. Other photographs taken by Wheat are described in entry 400. 
United States Geological and Geographical Survey of the Territories

("Hayden Survey"), 1847-81

The western surveys led by Ferdinand V. Hayden were begun under the provisions of the act of Congress dated March 2, 1867 (14 Stat. L., 470), that supplied appropriations to meet Federal funding deficiencies. The legislation authorized "a geological survey of Nebraska ... under the direction of the commissioner of the general land office." The next year the work was expanded beyond Nebraska by the act of July 20, 1868 (15 Stat. L., 119). From 1869 to 1873, Hayden's organization was known as the U. S. Geological Survey of the Territories; the act of June 22, 1874 (18 Stat. L., 143), added "and Geographical" to its title. Work was done in Colorado, Idaho, Montana, New Mexico, and Wyoming. This survey was terminated on June 30, 1879, by the act of March 3, 1879 (20 Stat. L., 394), the same law that founded the USGS.

Some photographs relating to the "Hayden Survey" are part of a general collection that is described in entry 41. Geologists' field notebooks compiled by Henry Gannett (Nos. 3871 and 3872), and William H. Holmes (Nos. 38783882) are part of the records described in entry 172. Microfiche copies of geologists field notebooks compiled by Frederic M. Endlich (Nos. 731-737), Archibald R. Marvine (Nos. 718-730, 830C and 830D, and 1963), Albert C. Peale (Nos. 1964-1977 and 2010 and 2011), and Hayden (No. 2014) are part of the records described in entry 173.

Many of the records concerning the "Hayden Survey" described in this inventory have been published as National Archives and Records Administration (NARA) Microfilm Publication M623, "Records of the Geological and Geographical Survey of the Territories ("Hayden Survey'), 1867-79."

16. LETTERS RECEIVED. Jan. 4, 1866 - Mar. 21, 1874. 10 in. 7 vols.

Arranged in rough chronological order. Several letters from Leo Lesquereux, dated 1868, are bound after the 1873 letters. Undated and partial letters are dispersed throughout the series.

Mounted and bound letters from members of Congress, editors of professional journals, popular magazines and newspapers, the Secretary of the Interior and other departmental officials, academic geologists and specialists in allied fields, railway company agents, State geological and agricultural agencies, military officers, the Smithsonian Institution and museums, the American Geographical Society and other professional organizations, lithographers and engravers, private individuals, and many others. The letters chiefly concern the processing, printing, and distribution of illustrations and reports based on Hayden's western explorations, particularly of the Yellowstone region. Other letters concern the analysis of plant and fossil specimens, theories on the composition and correlation of geologic formations, and methods of conducting topographic surveys. A few items are letters of introduction or application to accompany expeditions. Many letters are personal in content.

These letters have been published as part of NARA Microfilm Publication M623.

\section{LETTERS RECEIVED. 1871-79. $4 \mathrm{ft}$.}

Arranged in two alphabetical sequences, 1871-77 and 1872-79, by surname of correspondent or title of agency, and thereunder chronologically.

Chiefly letters received, but also includes statements of accounts and expenses, and telegrams. Most of the letters are from the same correspondents and concern the same subjects as the records described in entry 16.

The series also contains letters concerning Indian ethnology, especially languages, and the geological and topographical work of field parties. 
These records have been published as part of NARA Microfilm Publication M623.

\section{LETTERS RECEIVED FROM PERSONS IN FOREIGN COUNTRIES. ca. 1859-79. 2 ft.}

Arranged alphabetically by name of foreign country, thereunder alphabetically by surname of correspondent, and thereunder in rough chronological order.

Chiefly letters concerning the exchange of professional papers. Other letters concern Hayden's honorary membership in foreign professional societies. A few of the letters that are not in English are accompanied by a translation. About a quarter of the collection consists of letters from England. The letters from German States are filed under Germany and thereunder alphabetically by State.

The letters were published as part of NARA Microfilm Publication M623.

19. LETTERS RECEIVED AND RELATED RECORDS FROM GOVERNMENT AGENCIES. 1867-79. 2 in.

Arranged by agency and thereunder chronologically.

Letters received, circulars, receipts, and other fiscal records from officials of the Agriculture, Interior, and Treasury Departments, the Office of Indian Affairs, and the General Land Office. The records concern the printing and distribution of Hayden's reports and maps; furnishing specimens, maps, and photographs for the Philadelphia Centennial Exhibition in 1876 and the Paris Exposition in 1878; free entry of books and equipment; disbursement of funds; and the scope of Hayden's western surveys. There are a few letters from private persons transmitted by the Interior Department.

These records have been published as part of NARA Microfilm Publication M623.

\section{PERSONAL LETTERS RECEIVED. 1847, 1853-66, 1874-76. 5 in. 2 vols.}

Arranged as shown below and thereunder in rough chronological order. There is a list of the correspondents inside the front cover of each volume.

Mounted and bound letters from professional colleagues and others concerning Hayden's academic career and membership in professional societies, collection and analysis of fossil specimens, stratigraphic investigations, and publication of reports based on his work in western explorations. Many of the letters are from Fielding B. Meek, Hayden's collaborator in paleontology and stratigraphy, including all those dated 1874-76. Other correspondents include H. Haines, James Hall, Joseph Henry, Eugene W. Hilgard, Isaac Lea (the 1847 letter), Eben N. Horsford, Alpheus Hyatt, J. E. Keller, John L. LeConte, Joseph Leidy, J. Peter Lesley, Joseph Lovering, John S. Newberry, Charles C. Parry, Frederic W. Putnam, William F. Raynolds, Benjamin Silliman, Jr., William Stimpson, "Hall of the Academy of St. Louis," W. J. Taylor, Edward Tuckerman, Gouvernor K. Warren, Josiah D. Whitney, Horatio C. Wood, Jr., and Amos H. Worthen. Also included, in alphabetical sequence, is a letter signed by Ferdinand V. Hayden acknowledging his appointment as a "Lieutenant Colonel by brevet in the military service of the United States." Hayden served as a Surgeon of Volunteers during the Civil War.

These letters were accessioned by the National Archives from the Smithsonian Institution in about 1954. At that time no letters were located for surnames beginning with the letters A to G. 
These letters have been published as part of NARA Microfilm Publication M623.

21. RECORDS CONCERNING THE CONTROVERSY OVER CIVILIAN VERSUS MILITARY SURVEYS AND RELATED MATTERS. ca. 1872-78. 5 in.

Arranged by subject. Many items are undated.

Includes drafts of reports, letters received, circulars, congressional documents, working notes, statements made before congressional committees, lists of geological and topographical reports based on western surveys, and petitions from universities expressing preference for civilian rather than military control of western surveys.

The records concern the accomplishments of the "Hayden Survey," the work of other civilian surveys and military surveys, conflicts between the various surveys, zoological specimens, the Philadelphia Centennial Exhibition in 1876, and establishment of the U.S. Entomological Commission.

These records have been published as part of NARA Microfilm Publication M623.

The Patents and Miscellaneous Division of Record Group 48, Records of the Office of the Secretary of the Interior, include records relating to the U. S. Entomological Commission, established by an act of March 3, 1877

(19 Stat. L., 357).

22. LETTERS RECEIVED AND OTHER RECORDS CONCERNING THE WAR DEPARTMENT. 1867-74, 1876-77. 1 in. 1 vol. and unbound papers.

Arranged in two segments, mounted and bound and unbound, and thereunder in rough chronological order.

Chiefly letters received and special orders from the War Department, but also includes a few letters from the Secretary of the Interior, Treasury Department circulars, and copies of letters sent by Hayden. The records concern transportation, subsistence, equipment, disbursements, military escorts, the publication of reports, and a proposal to establish a signal station on Pike's Peak.

These records have been published as part of NARA Microfilm Publications M623.

\section{SUMMARY OF ACCOUNT OF FERDINAND VANDEVEER HAYDEN WITH THE TREASURER OF} THE UNITED STATES. $1869-80.0 .5$ in. 1 vol.

Arranged chronologically.

A list of checks or vouchers showing the amounts of payment. A total of the payments was made at approximately monthly intervals. There is no indication to whom or for what purpose the payments were made.

This volume has been published as part of NARA Microfilm Publication M623.

24. FISCAL RECORDS. ca. 1872-80. 2 in. 1 vol. and unbound papers.

Arranged by type of record and thereunder in rough chronological order.

Receipted bills, vouchers, check stubs, letter received, and related records concerning salaries, transportation, lithography, and other expenses. 
These records have been published as part of NARA Microfilm Publication M623.

25. LEDGERS. 1878-80. 2 in. 2 vols.

Arranged by name of individual or business firm and thereunder chronologically. The smaller second volume contains an index to the accounts.

The entries for each account include the date of each deposit or expense, sometimes the type of expense, and the amount. Debits are balanced against credits.

These volumes have been published as part of NARA Microfilm Publication M623.

26. LEDGER KEPT BY ALBERT CHARLES PEALE. 1871-74. 0.5 in. 1 vol.

Arranged by account and thereunder chronologically.

Each entry gives the date, to whom or for what purpose the expenditure was made (or from whom funds were received), and the amount. Most of the volume titled "Cash" appears to be an itemized record of Peale's personal expenses. A few pages are devoted to accounts for Hayden and other individuals. Debits are balanced against credits. Peale served as a geologist with the "Hayden Survey," 1871-79, and the USGS, 1883-92.

This volume has been published as part of NARA Microfilm Publication M623.

27. APPLICATIONS FOR POSITIONS, RECOMMENDATIONS, AND REQUESTS FOR PUBLICATIONS. 1870-79. 5 in.

Arranged alphabetically by surname of applicant or correspondent.

Chiefly applications submitted by professors, college students, military officers, miners, engineers, clerks, surveyors, topographers, geologists, artists, and other persons. The letters of recommendation are from members of Congress, college professors, and others. Also included are requests for geological publications.

These records have been published as part of NARA Microfilm Publication M623.

28. MISCELLANEOUS LETTERS RECEIVED. 1867-79. 0.25 in.

Arranged by correspondent and thereunder chronologically.

Letters from Edward D. Cope, Ernest Ingersoll, Joseph Leidy, Fielding B. Meek, an insurance agent, government officials, and others concerning western surveys, publications, and other subjects. Also included is a copy of a letter sent to the owner of a silver mine.

These letters may have once been part of the letters received described as entry 17.

These letters have not been microfilmed. 
29. ATLAS VOLUMES. 1877, 1881. 2 volumes and 6 items. [NWCS, maps and plans]

These volumes, the first and second editions of the "Geological and Geographical Atlas of Colorado and Portions of Adjacent Territory," contain three series of maps. The first series covers the entire State of Colorado and consists of a triangulation map, a drainage map, an economic (land-classification) map, and a general geologic map (at 1:760,320). The second series consists of six topographic maps and six geologic maps of Colorado and adjacent portions of Utah, Arizona, and New Mexico (at 1:253,440). The third series consists of geologic sections and geologic panoramas. A few pages from the 1881 atlas are filed separately. All the maps are double folio.

30. MAPS OF YELLOWSTONE PARK AND ADJACENT AREAS. ca. 1868-78. 15 items. [NWCS, maps and plans]

Printed maps showing topographic features of Yellowstone National Park and areas within and adjacent to the park including Upper Geyser Basin on the Firehole River, Lower Geyser Basin on the Upper Madison River, Shoshone Geyser Basin, Mammoth Hot Springs, Gibbon Geyser Basin, and those parts of Montana and Wyoming Territories drained by the Madison, Gallatin, and Upper Yellowstone Rivers.

31. MAPS OF PARTS OF WYOMING, IDAHO, UTAH, AND ADJACENT AREAS. ca. 1877-79. 11 items. [NWCS, maps and plans]

Printed black and white maps showing topographic features; color-coded maps showing geologic strata; a color-coded map showing the land classification of economic resources (arable land, grass, forest, and coal); the east half of a map showing the locations of Salt Lake City, Ogden City, and what appears to be part of the shoreline of the Great Salt Lake; and panoramic views (on one sheet) in the vicinity of the Wind River Mountains and the

Teton Range.

32. MISCELLANEOUS MAPS. ca. 1873. 3 items. [NWCS, maps and plans]

The maps are titled as follows: "Preliminary map of Southwestern Colorado and part of the Adjacent Territories showing the Location of Ancient Ruins," undated, by George B. Chittenden, Topographer; "Preliminary map of Colorado showing the region surveyed in 1873"; and "Sketch showing the Primary and Secondary Triangulation of 1873."

33. "HAYDEN SURVEY” ARTWORK. 1869-72. 53 items. 3 in.

Arranged by geographic area as described below and thereunder by assigned number. These are series HAA, HAB, and HAC (NWCS, still pictures).

Ink drawings (30 in. $x$ 7in.) showing panoramic views along the route of the Union Pacific Railroad in Wyoming and Utah; ink drawings (15 in. x 7.5 in.) of the Laramie Range, Platte River, and Sweetwater River Valley; and pencil sketches of areas along the Yellowstone River in Montana.

The drawings are unsigned but have been attributed to Henry W. Elliot. 
34. PHOTOGRAPHS TAKEN BY WILLIAM HENRY JACKSON. 1869-78. 5 albums and loose items. $21 \mathrm{ft}$.

Arranged by record format (original glass negatives, albums, and contact prints), and thereunder by agency assigned number. The photographs are captioned and dated. A second edition of a catalog of these photographs was published in 1875 as United States Geological Survey of the Territories Miscellaneous Publication No. 5, "Descriptive Catalogue of the Photographs of the United States Geological Survey of the Territories for the Years 1869 to 1875 , Inclusive ... W. H. Jackson, Photographer." This is series HS (NWCS, still pictures).

A collection of photographs reflecting activities of the "Hayden Survey" in Nebraska, Wyoming, Colorado, Utah, Idaho, and Montana. Many of the photographs show scenes in Yellowstone Park, including creeks, waterfalls, hot springs, canyons, geologic features, and camp sites. Other photographs show prominent landmarks such as Pike's Peak, Gateway to Garden of the Gods, Garden of the Gods, Long's Peak, Berthold Pass, Mountain of the Holy Cross, Uinta Mountains, Teton Range, Pulpit Rock, Mont., Laramie Peak, Wyo., Hayden's Cathedral, and Mount Lincoln, Colo.. The photographs of towns include Wasatch, Utah, Helena, Mont., Salt Lake City, Utah, Corinne, Utah, Ogden, Utah, Willard City, Utah, Malad, Idaho, South Pass City, Wyo., Atlantic City, Wyo., Cheyenne, Wyo., and Fort Hall, Idaho. There are also a few photographs showing mining operations (flumes, hydraulic mining, "panning out," cradling, and sluicing); railroad beds and infrastructure, including railroad cuts, trestle work, bridges, and stations; military posts, including Fort Fetterman and Fort Laramie; scenes of workers quarrying granite for the Mormon Temple; Bannock Indians; and the Mission or Crow Indian Agency.

There are also photographs of the towns of Juárez and Chihuahua, Mexico.

35. PHOTOGRAPHS OF INDIAN RUINS, LANDSCAPES, AND GEOLOGIC FORMATIONS. 1874. 0.75 in.

Arranged by agency assigned number. This is series HSA (NWCS, still pictures).

Mounted sepia prints by William H. Jackson. About half of this series is duplicated in the records described in series HS, entry 34.

36. PHOTOGRAPHS OF LAKE TAHOE AND VICINITY. n.d. 8 items.

Mounted prints published by the W. H. Jackson Photo Co., Denver, Colorado. This is series HSB (NWCS, still pictures). 
The linear topographic surveys of the western United States conducted by the War Department before the Civil War were revived when 1st Lieutenant George M. Wheeler, of the Army Corps of Engineers, received orders to make a mapping reconnaissance of portions of southern Nevada to identify sites for military posts and transportation routes to improve communications in the Department of California. In 1871 Wheeler extended his geographical (and then also geological) reconnaissance into Arizona. On June 6, 1872 (17 Stat. L., 367), Congress began funding the plan Wheeler had submitted to Brigadier General Andrew A. Humphreys, the Chief of Engineers, for establishing an astronomical base from which to map, on 95 same-sized quadrangles, the topography of the entire country west of the 100th Meridian. Wheeler was promoted to Captain on March 4, 1879. His survey was terminated June 30, 1879, by the act of March 3, 1879 (20 Stat. L., 394), that established the USGS.

Some photographs relating to the "Wheeler Survey" are part of a general collection that is described in entry 41. Field notebooks compiled by geologist Grove K. Gilbert (Nos. 3372 to 3390) are part of the records described in entry 172.

The major portion of the records from the "Wheeler Survey" are in Record Group 77, Records of the Office of the Chief of Engineers; other records are at Fort Belvoir, Virginia, and at Yale University.

\section{REPORT OF THE "WHEELER SURVEY" IN 1872. n.d. 2 in.}

A handwritten draft titled "Progress Report upon Geographical and Geological Explorations and Surveys West of the 100th Meridian in 1872, under the direction of Brigadier General Andrew A. Humphries [sic] Chief of Engineers, by 1st Lieutenant George M. Wheeler, Corps of Engineers, in Charge." The report, published in 1874, concerns astronomical, geological, and natural-history observations; reconnaissances of mining districts in Arizona, Nevada, and Utah; agriculture and irrigation; communication routes; sites for military posts; timber lands; Indians; Colorado River canyons; and an analysis of the organization and progress of Wheeler's western explorations to 1872 . The manuscript is paginated, many segments of the original are not in this file.

\section{RECORDS RELATING TO INDIAN ETHNOLOGY AND SPANISH INSCRIPTIONS. 1874-80. 1 in.}

Arranged chronologically.

Reports prepared by "Wheeler Survey" members and others concerning Indian dances observed at Jamez Pueblo in 1874 (two of the three drafts of this account include a sketch of a ceremonial headdress worn during the dance); a list of southwestern Indian languages compiled from observations by survey members during 1872-75; and letters concerning translations of Spanish inscriptions found on rock surfaces.

An endorsement found in the records indicates that they were once part of the Letters Received, 1824-1881, of Record Group 75, Records of the Office of Indian Affairs (file reference: I1237-1874 New Mexico).

\section{PHOTOGRAPHIC PRINTS. 1871-73. 3 in.}

Arranged chronologically by year of survey and thereunder numerically by original plate number. All the photographs have captions giving the subject and name of the photographer. This is series WS (NWCS, still pictures). 
Mounted prints (8 in. x 11 in.) of photographs taken by Timothy H. O'Sullivan and William Bell. Chiefly landscapes showing views of the Grand Canyon; Black Canyon, Colorado River; rock formations; Alpine Lake in the Sierra Nevada, Calif.; Camp Apache, Ariz.; Inscription Rock, N. Mex.; Canyon de Chelly, Ariz.; and a mission church and houses at Zuni Pueblo.

Original negatives are in Record Group 106, Records of the Smithsonian Institution, series WB; and Record Group 77, Records of the Office of the Chief of Engineers, series WA.

40. PHOTOGRAPHIC PRINTS. 1871-73. 2 in.

Arranged by agency assigned number. All the photographs are captioned. This is series WSA (NWCS, still pictures).

Prints (8 in. x 11 in.) taken by Timothy H. O'Sullivan include views of buildings at Camp Whipple, Ariz., Camp Apache, Ariz., Camp Halleck, Nev., and Camp Mojave, Ariz.; Shoshone Falls, Idaho; the mouth of Kanab Canyon, Utah; Canyon de Chelly, Ariz.; Inscription Rock, N. Mex.; and Lt. George M. Wheeler and his survey party in camp. 
41. STEREOGRAPHIC PRINTS OF SURVEYS OF THE AMERICAN WEST. 1870-74. 8 in.

Arranged by name of photographer - John K. Hillers ("Powell Survey”), William H. Jackson ("Hayden Survey"), and Timothy H. O'Sullivan ("Wheeler Survey"), and thereunder by assigned number. Most of the prints bear captions. This is series SV (NWCS, still pictures).

Mounted prints ( 3 in. $\mathrm{x} 4$ in.), produced for commercial distribution, showing geologic formations, Native Americans, the Grand Canyon and canyons of tributary streams, Indian Pueblos and ruins, geysers and hot springs in Yellowstone National Park, Canyon de Chelley and other landscapes.

Original stereographic negatives for some of the prints are described in series HS, entry 34, and PS, entry 87; and Record Group 106, Records of the Smithsonian Institution, series WA. 
RECORDS OF THE UNITED STATES GEOLOGICAL SURVEY, 1839-1997

Office of the Director, 1879-1987

The act of March 3, 1879 (20 Stat. L., 394) that established the USGS provided for the appointment of a Director, nominated by the President and confirmed by the Senate. The act made the Director responsible for planning and administering the programs of the USGS in accordance with the provisions of the establishing act and subsequent legislation, and for functioning as the agency's chief scientific officer. In the early years the Secretary of the Interior, acting on the Director's recommendations, appointed the permanent members of the USGS staff; the Director made temporary appointments. The Director also selected the leaders of the agency's geographic, thematic, and other administrative units, supervised their work, and reviewed the progress and reports documenting the data gathered and analyses made by their field and laboratory investigations. The Director was assisted in these administrative and related duties by an Executive Officer (1881-94), a Chief Clerk (from 1881), a General Assistant (1883-92), and an Assistant in Geology to the Director (1897-1900).

Legislative mandates and increased appropriations expanded the administrative responsibilities of the Director. By 1901 geologic (including hydrographic) and topographic investigations were administered by established organizational units headed by individuals with dual scientific and administrative responsibilities. In 1912 the position of Administrative Geologist was created (Survey Order 14) to serve as the Director's administrative deputy and as Acting Director in the absence of the Director.

The position of Assistant Director was established in 1944. That individual was to serve as a "principal assistant to and deputy of the Director, with commensurate authority" (Survey Order 147). In general the Assistant Director advised the Director on the long-term scientific and technical programs of the USGS. The Administrative Geologist chiefly handled matters relating to the daily management and administration of the agency.

Other specialized staff and advisory positions added to the Directors Office included the Staff Geologist for Territories and Island Possessions in 1946 (Survey Order 156; later Staff Coordinator), and the reestablished Executive Officer in 1948 (Survey Order 169). With the creation of the position of Executive Officer, the Administrative Geologist was made responsible for serving as a scientific consultant to the Director. In the 1950's the positions of Associate Director and Assistant Director were added to the Director's Office.

In the 1920's George W. Holland transferred from the General Land Office to the USGS and joined the staff as a land classifier. Holland was trained as an attorney and gave legal advice on matters under review by the Land Classification Board (later Conservation Branch). He was eventually reclassified as an Attorney in that branch. As part of a departmental reorganization in 1935 Holland was transferred to the Solicitor's staff in the Office of the Secretary of the Interior. In 1943 the Secretary of the Interior established the Office of Chief Counsel in the USGS. In 1947 the Chief Counsel's Office was organizationally placed in the Conservation Branch. In 1950 the Office of the Chief Counsel of the USGS was assigned to the Director's Office (Survey Order 205).

Under the authority of Reorganization Plan 3 of 1950 the Survey underwent an lengthy evaluation and reorganization process that ultimately reserved some of the authority that had been exercised by the Director to the Secretary of the Interior and reoriented the location and lines of authority in the operating units. 
42. INDEX TO LETTERS RECEIVED. $1880-89.1 .5 \mathrm{ft} .6$ vols.

Arranged chronologically by year and thereunder alphabetically by name of correspondent or subject.

A typescript index to the letters received described in entry 44 showing the names of writers followed by the subject and file number of each of their letters. Entries for persons mentioned and subjects give a cross reference to the names of the writers. When a letter is referred to the USGS by another agency or member of Congress, a cross reference is made under the author's name to the agency or individual that forwarded the letter. When a person is the subject of a letter a cross reference is made to the author where an abstract of the contents appear.

These records have been published as part of National Archives and Records Administration (NARA) Microfilm Publication M590, "Letters Received by the United States Geological Survey, 1879-1901."

43. REGISTERS OF LETTERS RECEIVED. January 8, 1879 - November 12, 1901. 4 ft. 26 vols.

Arranged chronologically.

Registers of the letters received described in entry 44. The entries show the date of receipt, name and address of writer, date of letter, assigned file number, and action taken. There is one volume per year except for 1889, 1899, and 1900 for which there are two volumes. Missed letters are entered at the end of the year.

The latest consecutive entry is dated April 30, 1901. It is followed by 12 entries made in March, October, and November of letters dated in January, March, and April 1901. There is a letter dated May 1, 1901 that apparently was recorded on April 30, 1901. There is no explanation in the records to account for this enigma. No later registers have been found.

These registers have been published as NARA Microfilm Publication M157, "Registers of Letters Received by the United States Geological Survey, 1879-1901."

44. LETTERS RECEIVED. 1879-1901. $50 \mathrm{ft} .54$ vols. and unbound records.

Arranged chronologically by year and thereunder by assigned number. For the period, 1879-89, the letters are in bound volumes. Indexes and registers for the letters received are described in entries 42 and 43.

Chiefly letters received together with reports, memorandums, tables, accounting records, maps, and other records concerning topographic and geologic surveys; investigations of coal and mineral resources, particularly in Alaska and the Western States; water-resource investigations; boundaries of forest reserves and Indian reservations; USGS publications; personnel matters; and general administration of USGS programs. The letters received from 1901 to the creation of the central classified files in 1912 do not appear to have survived.

These records have been published as part of NARA Microfilm Publication M590, "Letters Received by the United States Geological Survey, 1879-1901.” 
45. INDEX TO LETTERS SENT. 1879-83. 4 in. 2 vols.

Arranged chronologically by year and thereunder alphabetically by surname or official title of addressee or subject.

A typescript index to a portion of the letters sent described in entry 46 showing the name or official title of addressee, followed by the subject and page number of each letter sent. Many entries for persons mentioned and subjects give a cross reference to the addressee.

This index has been published as part of NARA Microfilm Publication M152, "Letters Sent by the United States Geological Survey, 1879-1895.”

46. LETTERS SENT. July 7, 1879 - December 17, 1895. 6 ft. 35 vols.

Arranged chronologically. An index to the 1879-83 letters is described in entry 45 .

Handwritten copies of letters sent to the Secretary of the Interior (including monthly and annual reports) and other Federal officials, members of Congress, geologists outside the Federal Government, heads of USGS field teams, railroad companies, engravers and publishers, and private individuals concerning topographic, geologic, and other field work, appointment and assignment of personnel, USGS publications, appropriations and expenses, and related matters. Many of the letters are followed by the file number of the pertinent letter received (entry 44).

Notations in the margins beginning in 1885 (volume 27) are probably references to press copies of the letters sent. The press copies have not survived.

The letters sent have been published as part of NARA Microfilm Publication M152, "Letters Sent by the United States Geological Survey, 1879-1895."

47. RECORDS CONCERNING A PROPOSAL TO ESTABLISH OLYMPIC NATIONAL PARK. 1891. 4 items

These records were once part of the Letters Received, 1879-95 (entry 44), but were removed by the National Archives staff and laminated.

The records consist of a letter from James Wickersham to John W. Powell, Director of the USGS, transmitting maps and an article concerning the proposed Olympic National Park. The maps are part of this series. The article, "An Olympic National Park in the Olympic Mountains, Washington," by James Wichersham, is filed with the letters received - file 1245-1891 (entry 44).

48. LETTERS RECEIVED BY JOHN WESLEY POWELL REGARDING HIS RESIGNATION AS DIRECTOR. May 11 - 23, 1894. 15 items.

Arranged chronologically.

The writers were Capt. John G. Bourke, Theo. B. Comstock (President, University of Arizona), Mrs. Caroline H. Dall, William M. Davis (Harvard University), L. S. Dubois, James Hall, Robert Hay, John W. Hoyt, Alpheus Hyatt, Henry B. McFarland, P. W. McKinney, Thomas C. Mendenhall (U. S. Coast and Geodetic Survey), Eugene A. Smith (State Geologist of Alabama), Ralph S. Tarr, and J. C. Welling, 
49. CORRESPONDENCE AND RELATED RECORDS. ca. 1906-48. $4 \mathrm{ft}$.

Arranged alphabetically by subject. A file title list appears as Appendix 2 in this inventory.

Letters received, copies of letters sent, memorandums, reports, USGS orders and other administrative issuances, speeches and addresses, press releases, allotment statements and other fiscal records, statistical tables, congressional bills, and maps. The records concern the organization and administration of the agency's geologic and topographic mapping programs, World War I mapping programs, budgets and appropriations, USGS committees, cooperation with other Federal agencies and States, coal-land classification, mineral-resource investigations, withdrawal of land for water-power sites and other uses, and personnel matters. A few items are marked personal and confidential. A few letters are marked with correspondence control numbers assigned when the letter was received and indexed (see entry $50)$.

Of particular interest are two manuscripts: "Report on a proposed system of administration and improvement of the Glacier National Park," 1910, by Robert B. Marshall [Cooperation - Federal], and "The Physical History of the Yosemite Valley," 1922 by François E. Matthes [Yosemite Valley].

\section{CORRESPONDENCE CONTROL CARDS. 1918-48. $175 \mathrm{ft}$.}

The cards are divided into two groups. The first group of cards, from the years 1918-22, is organized in two segments. The first segment is arranged alphabetically by surname of correspondent, title of organization or agency, and thereunder chronologically. The second segment is arranged alphabetically by title of Federal agency and thereunder chronologically.

The second group of cards, from 1923-48, is organized chronologically by year and thereunder in two alphabetical sequences by surname of individual and title of agency or organization. This group also includes cards for internal communications from unit chiefs to the Director and memoranda from the Director to unit chiefs. There is only one set of cards for the years 1946 and 1947.

The 4"x 6" cards typically show the name of correspondent, date of receipt, assigned control number, date of letter, subject or abstract of contents, referrals, date of reply, and file disposition. Some cards also show a file number from the classification scheme shown in Appendix 3 in this inventory.

Most of the letters were referred to and filed in the Central Classified Files of the Office of the Director (entry 51). A few letters are found in entry 49. Letters are also found in the central files of the major program divisions: Geologic Division (entries 159 and 160), Topographic Division, later National Mapping Division (entry 288), Water Resources Division (entry 412), and Conservation Division (entry 642).

Because the cards are arranged by correspondent rather than by subject, the correspondence control cards have a limited usefulness for research purposes.

\section{CENTRAL CLASSIFIED FILES. 1912-53. $226 \mathrm{ft}$.}

Arranged according to a numeric-subject classification scheme. A list of extant files appears as Appendix 3 in this inventory. Several annotated copies of the file classification manual are located in entry 49 (in a file titled Subject Classification Scheme, Central Classified Files). The files include a few items dated as early as 1899. The correspondence control cards (entry 50) can be used to locate some documents in the files. Accretions to this series are boxed separately as shown on the file list. 
Correspondence, memorandums, congressional documents, telegrams, press releases, circulars, orders and other administrative issuances, agenda and minutes of meetings, allotment statements and other fiscal records, project summaries, work plans, periodic program reports, contracts and agreements, and maps.

The records concern organization and management, especially appointment and assignment of personnel, and processing and distribution of publications; administration of program areas, such as geologic and topographic surveys, water-resource investigations, particularly forest-watershed surveys, and land classification. This series also contains records concerning conferences, expositions, and meetings of professional associations; cooperation with Federal and State agencies; participation on USGS, departmental, and interagency committees, public-works programs, and defense related activities. The succeeding series of Central Classified Files, 1953-74, is described in entry 52 .

52. CENTRAL CLASSIFIED FILES. 1953-74. $145 \mathrm{ft}$.

Organized in two sub-series, 1953-68 and 1969-74, and thereunder arranged according to a subject-numeric classification scheme. The records found in subordinate portions of the "Meetings" section of the files are organized by time interval, 1953-56, 1956-59, 1959-62, 1962-65, and 1965-68, and thereunder in rough alphabetical order by title of organization or organization. Within subject classes, the arrangement is chronological. A file title list appears as Appendix 4 in this inventory.

Correspondence, memorandums, regulations, orders, circulars and other administrative issuances, financial charts, reports and related records, minutes of meetings, cooperative agreements with States and municipalities, opinions of the departmental Solicitor, drafts of river compacts, press releases, program proposals and plans, and drafts of congressional bills.

The records concern policy formulation and the administration and management of USGS programs. Specific subject areas include appropriations and allotments, budget formulation and justification, personnel classifications and appointments, interdepartmental, departmental, and USGS committees, commissions and advisory groups, cooperation with Federal and State agencies and compilation and printing of maps and other publications.

Records concerning the implementation of programs are generally found among the files of USGS subordinate units.

53. MONTHLY REPORTS. 1882-90. $2.5 \mathrm{ft} .8$ vols.

Arranged in two segments: for the years 1882-84, organized chronologically by year and thereunder alphabetically by surname of the reporting official, and thereunder chronologically by month; for 1885-90, arranged chronologically by month and thereunder by report but not alphabetically by surname of author.

Narrative reports by heads of field units and, in some instances, those by individual staff members. Some reports include maps or sketches of geologic features. Most of the 1882-84 reports and some of the later reports are annotated with assigned letters received numbers. The indexes for the letters received are described in entry 42 .

These records have been published as part of NARA Microfilm Publication M590, "Letters Received by the United States Geological Survey, 1879-1901.” 
The first file is marked "general", the remaining files are arranged alphabetically by name of publishing firm, publisher, publication, or journalist.

Correspondence, magazine and newspaper clippings, USGS statements and informational issuances, and related records concerning statistical data and other information furnished by the USGS for publication in newspapers, popular magazines, professional journals, catalogs, and yearbooks.

\section{RECORDS CONCERNING UNITED STATES PARTICIPATION IN THE FOURTH WORLD POWER} CONFERENCE. $1949-50.1 .5$ in.

Arranged in rough chronological order.

Correspondence, memorandums, the report of the United States delegation, a conference program, charts, a copy of the articles of association and by-laws of the American National Committee, and related records concerning the Fourth World Power Conference held in London, July 10-15, 1950. The records also concern the status of the United States National Committee as a member of the World Power Conference, a suggestion to reorganize the United States National Section to broaden the scope of its technical work to include to include the social and economic aspects of world power problems, and the designation of USGS staff members to serve on a committee with representatives of the Bureau of Mines and the Federal Power Commission to prepare a report for the London meeting. Manuscript and printed copies of the report, "Energy Resources of the United States," are part of the records.

The World Power Conference was formed in 1924 with headquarters in London. The Conference facilitated the exchange of ideas between producers and consumers of power resources, and scientific and technical specialists, to find the most efficient use of the world's fuel and power resources. Other records concerning USGS participation in the conference are described in entry 268.

\section{MEETING FILES. Nov. 1979 - Sept. 1987. $17 \mathrm{ft}$.}

Arranged chronologically. A list of the meetings accompanies the records.

The records concern meetings and other events attended by Dallas L. Peck in his official capacity as Director of the USGS. Included are advisory boards and committees, national and international scientific organizations, regional and State associations, and foundations and events such as conventions, conferences, symposiums, and dedications. There are also records relating to meetings with USGS division and regional staffers, other government executives, particularly the Secretary of the Interior and other Interior Department officials, Presidential staff members, officials of the Commerce, Agriculture, and Energy Departments, the National Research Council, and the National Academy of Sciences.

The records include programs, correspondence, handwritten notes, agendas, schedules, copies of papers, speeches delivered by the Director and other event participants, minutes, reports, questionnaires, slides, brochures, testimony before congressional committees, and related records. The records concern discussions of current scientific topics and program areas such as earthquake-hazards reduction, coordination of the Earth Resources Observation Systems (EROS) Program, mineral exploration, and water-resources development. 
Program and Office Files, 1921-68

57.

RECORDS CONCERNING NAVAL OIL RESERVES. 1921-27. 4 in.

Arranged by subject or type of record and thereunder chronologically.

The series includes a summary history of the establishment of Naval Oil Reserves Nos. 1 and 2 (Elk Hills and Buena Vista Hills, respectively, in California) and No. 3 (Teapot Dome in Wyoming); a report of the Secretary of the Interior to the President dated June 3,1922, submitted to Congress on June 7, 1922, concerning contracts for drilling oil wells on naval oil reserves; an unsigned, manuscript report, compiled as of 1923 and titled "History of the Midwest Organizations with Special Reference to the Oil Refining or Purchasing Contracts"; correspondence; Executive Orders; maps; geologists' summary reports; and other records concerning, litigation, leases, drilling, and withdrawals. Also contains minutes of meetings, correspondence, a draft of the final report, and other records concerning the President's Commission on Oil Reserves. The records also include references to Naval Oil Reserve No. 4 in Alaska and to Naval Oil Shale Reserves in Colorado (No. 1), and Utah.

On March 25, 1924, President Calvin Coolidge appointed a three-person Commission on Oil Reserves to consider the situation in each of the naval oil reserves, in view of the Navy's need for fuel oil, and make recommendations to protect and (or) enlarge the reserves. George O. Smith served as Chairman of the Commission.

58. HAROLD ERNEST VOKES FILE. 1942-45. 5 in.

Arranged by subject or type of record.

Draft and final copies of press releases, speeches, memorandums, reports, and internal administrative issuances concerning the organization and programs of the USGS during World War II. The records also contain information about postwar plans and a draft of a history of the USGS in World War II. Duplicate copies of parts of the draft history are part of the Records of the Office of the Secretary of the Interior, Record Group 48, in the National Archives

59. RECORDS CONCERNING USGS PARTICIPATION ON AGENCY AND INTERAGENCY COMMITTEES. 1944-68. $10 \mathrm{ft}$.

Arranged by name of committee or other organization, thereunder by type of record (when appropriate), and thereunder chronologically.

Correspondence, memorandums, minutes and summaries of meetings, program and technical reports, budget estimates and other fiscal records, organization charts, administrative and other processed issuances, and maps. The records document USGS representation on and cooperation with interagency and departmental committees, particularly those involving river basins. The USGS cooperated in the compilation of hydrologic data, mineralresource surveys, and projects for converting saline water. The interagency committees represented in the records are those concerning the Arkansas-Red-White Basins, Columbia River Basin, Missouri River Basin, and New EnglandNew York; field committees represented in the records concern Alaska, Colorado River, Great Basin, Eastern, Missouri River Basin, Northeast, Pacific Central, Pacific Northwest, Pacific Southwest, Phoenix, and Southwest. Others represented in the records are the committees Artificial Precipitation, Saline Water Conversion, Conservation, Research and Development. Other organizations represented in the records include the Task Force on Ecological Survey and Research, Montana Natural Resources Council, National Minerals Advisory Council, and the Federal Council for Science and Technology.

There are also files concerning the USGS's General Staff Committee including chronological files dated from August 1961 to December 1962. 
In 1946 the position of Staff Geologist for Territories and Island Possessions was established by Survey Order 156. John C. Reed (Sr.) was appointed to the position. Reed had been Acting Chief Alaskan Geologist. The duties of the Staff Geologist including acting as an advisor and consultant to the Director on matters relating to USGS work in the territorial possessions of the United States and coordinating the work of the major line units of the agency in those areas. The position title was later changed to Staff Coordinator for Foreign and Territorial Functions.

\section{RECORDS OF JOHN CALVIN REED (SR.), STAFF GEOLOGIST FOR TERRITORIES AND ISLAND} POSSESSIONS. 1946-53. $4 \mathrm{ft}$.

Arranged according to a decimal classification scheme, and thereunder chronologically. See Appendix 5 in this inventory for a file title list.

Chiefly correspondence and memorandums, but also includes statistical tables and summaries, reports, handwritten calculations and notes, quarterly reports of the Topographic Division, completed "authority of field work" forms, press releases, newspaper clippings, copies of congressional bills, minutes of meetings, travel vouchers, copies of itineraries, circulars, plats, and other records concerning Reed's role as coordinator of the various activities of the USGS in Alaska and other U.S. possessions.

Includes information relating to project proposals and active investigations and surveys in Alaska, Hawaii, Puerto Rico, Virgin Islands, and Trust Territories; appropriations and allotments for these projects and Reed's office; cooperation with other Federal agencies, including the Bureau of Land Management, Bureau of Reclamation, Bureau of Mines, War Department, Alaska Road Commission, National Park Service, and Department of Agriculture; Reed's recommendations and comments regarding projects, personnel, and publications; and his participation on committees and advisory boards, and other official activities as staff geologist.

Most of the records pertain to Alaska. Specific projects mentioned include the Alaska Terrain-Permafrost Program (dating from 1943), Alaska Volcano Investigations, Alaska Coal Investigations, and the Arctic Health Institute.

For other records on Alaska, see the records of the Division of Alaskan Mineral Resources, entries 216 and 217; records concerning the Aleutian Volcano Project, entry 249; the records of the Alaskan Geology Branch, entries 258265; records of the Alaska Terrain and Permafrost Section of Military Geology Branch, entry 285; records concerning Land and Stream Classification, entry 675, and the Central Files of the Alaskan Branch, entry 680.

For other records concerning Reed's service with the USGS, see entry 681. 
Arch C. Gerlach was appointed Chief Geographer of the USGS in 1967. Since 1962 Gerlach had been on a parttime detail to the USGS from his position as Chief of the Geography and Map Division at the Library of Congress. He held the position of Staff Geographer and was responsible for organizing and managing the National Atlas Project. In 1966 he was also assigned responsibility for overseeing the newly inaugurated Geographic Applications Program in the USGS. The program was initiated by the National Aeronautics and Space Administration, which funded research centers in several government agencies to study the application of data from remote sensors in aircraft and spacecraft to cartography, geology, hydrology, and other disciplines.

Gerlach retired in 1972 and was succeeded as Chief Geographer by James R. Anderson. In 1975 the Geographic Applications Program was made part of the newly established Land Information and Analysis Office (LIA). In 1980 the LIA was renamed the Office of Earth Science Applications and the LIA's Geography Program was transferred to the National Mapping Division.

\section{General Records, 1950-72}

\section{GENERAL ADMINISTRATIVE FILES. 1962-71. $2 \mathrm{ft.}$}

Arranged by subject or type of record, and thereunder chronologically.

Correspondence, memorandums, reports, and statistical budget summaries relating to the general functions and management of the Office. Also included are correspondence regarding requests and plans for Arch C. Gerlach to deliver lectures, write articles or review books, and copies of publishers' appraisal forms; correspondence, memorandums and reports regarding the proposed and approved plans for the USGS Geographic Applications Program, especially the Earth Resources Observation Systems Program, and the USGS Urban Program, in which the Geography Office cooperated in a study of stress areas resulting from urban growth; agenda, minutes, reports of meetings, and other records relating to the mapping of quantitative information, orbital remote-sensing data, and the development of the mineral resources of the oceans.

\section{WORKING PAPERS OF ARCH CLIVE GERLACH. 1950-72. 10 in.}

Arranged by subject or type of record, and thereunder chronologically.

Personal professional correspondence, memorandums, published papers, copies of speeches and lectures, newspaper clippings, award certificates, photographic prints, and other memorabilia concerning Gerlach's career and professional activities as a geographer and government official. Also includes correspondence, copies of itineraries, passports, and certifications documenting Gerlach's travels as an employee of the Library of Congress and as a member of various professional organizations, particularly the Pan American Institute of Geography and History (PAIGH) and the International Geographical Union (IGU), employment applications, reports of security investigations, and other personnel records relating to Gerlach's career with the Federal government.

Other records relating to PAIGH are described in entries 67-78. 
63. RECORDS CONCERNING ARCH CLIVE GERLACH'S PARTICIPATION IN INTERNATIONAL PROFESSIONAL ORGANIZATIONS. 1950-72. $3 \mathrm{ft}$.

Arranged by subject, and thereunder chronologically.

Correspondence, memorandums, agenda, minutes of meetings, reports, conference papers, copies of resolutions and directives, statistical summaries, bulletins, maps, and other records concerning Gerlach's participation and leadership in international professional organizations and their committees and conferences. The organizations documented include the International Geographical Union (IGU), the Pan American Institute of Geography and History (PAIGH), and the International Cartographic Association.

Also contains correspondence, memorandums, reports, bulletins, and maps relating to Gerlach's role in the publication of an International Atlas by Rand McNally and Company in 1969; lists and some payment requisitions for expenses incurred by members of the U.S. National Committee of the IGU; transparencies, magazines and photographic prints used in the U.S. National Exhibit at the 21st International Geographical Congress in 1968; photographic prints of standard exhibit panels prepared by the USGS's Exhibits Committee relating to geographic topics; and reports in Spanish (some have English translations).

64. RECORDS CONCERNING THE CATALOGING OF CARTOGRAPHIC MATERIALS. 1953-55. 0.5 in.

Arranged by type of document.

Correspondence, memorandums, reports, minutes of meetings, and processed issuances regarding the classification and cataloging of cartographic materials. Included is a Special Libraries report on map cataloging (1953), and an IGU report on map classification (1955). Gerlach was a member of the Commission on the Classification of Geographic and Cartographic Publications. These records were maintained by Gerlach while he was Chief of the Map Division at the Library of Congress. The records include printed reference material dated 1904.

65. RECORDS CONCERNING THE GEOGRAPHIC APPLICATIONS PROGRAM. 1965-71. $8 \mathrm{ft}$.

Arranged by subject or type of record, and thereunder chronologically.

Correspondence, memorandums, reports, manuscripts, publications, and other records relating to the general functions and programs of the Geographic Applications Program (GAP); agenda, minutes of meetings, working papers, conference papers, conference summaries, manuscripts, publications, statistical summaries, newsletters, chronological files (January 1, 1967 to December 31, 1971), graphs, charts, and maps documenting the relationship between the Chief Geographer and the Program, and the plans and projects of the committees and conferences sponsored by the National Academy of Sciences, the National Research Council, the Earth Resources Observation Systems (EROS) Program, the National Aeronautics and Space Administration (NASA), the Interagency Committee on Land Use Information and Classification, and the Agency for International Development. Also included are photographic prints of some GAP exhibits, and the participants in an EROS Program meeting in 1971; transparencies and photographs used as illustrations at meetings of NASA's Aircraft Program; and copies of flight logs and mission reports from NASA's remote-sensing aircraft missions.

66. REEL-TO-REEL TAPES. June 1971. 3 items

A taped record of some of the sessions of the Interagency on Land Use Information and Classification Conference in June 1971. Summaries of the tapes are with the records described in entry 65. 
The Pan-American Institute of Geography and History (PAIGH) was created in 1928 by a resolution of the sixth Inter-American Conference of Ministers in Havana. The Institute's mission is to encourage, coordinate, and publicize geographic and historical studies concerning the Western Hemisphere and to promote international cooperation among the American nations in these fields. In 1929 the Institute's headquarters were established as a General Secretariat in Mexico City. The organization functioned independently until 1949 when it was absorbed by the Organization of American States (OAS) and became the first of six specialized institutes.

The Institute's work is accomplished through its General Assembly, Directing Council, General Secretariat, Commissions, and National Sections. The General Assembly, usually meeting quadrennially, and Directing Council, usually meeting annually, are responsible for determining administrative and program policies that are implemented by the General Secretariat. In 1943, 1947, 1949, and 1969, respectively, Commissions on Cartography, Geography, History, and Geophysics were created to concentrate efforts in these specialized fields. Most technical work is performed by the Commissions, their Committees, and their Working Groups. A quadrennial Consultation (Conference) is held by each Commission at which current projects are evaluated, new projects are authorized, and scholarly and technical presentations are made. Each member nation is represented in equal numbers in the General Assembly, Directing Council, and Commissions. A National Section is comprised of all the members of a particular nation's delegation to PAIGH.

\section{RECORDS RELATING TO THE PAN-AMERICAN INSTITUTE OF GEOGRAPHY AND HISTORY.} 1955-77. 5 in

Arranged by type of document.

Correspondence, membership lists, copies of articles, annual and semi-annual reports, newspaper clippings, photographs, and lists of training films available through PAIGH. The records relate to appointments of Institute officers, cooperation with national sections, budget matters, and status of projects, particularly the tectonic and geologic maps of South America, and the TANDIL Project - consisting of experimental work to determine the accuracy of photogrammetric surveys. Some of the records are in Spanish.

68. RECORDS RELATING TO MEETINGS OF THE GENERAL ASSEMBLY. 1945-77. 10 in.

Arranged chronologically by meeting and thereunder by subject.

Chiefly programs, including draft versions, agenda, including preliminary and final, lists of delegates, and printed copies of the "Final Act" - a report on the organization and processing of a meeting of the General Assembly. Also included are memorandums, photographs of exhibits and groups of delegates, reports of the United States delegation, lists of maps and reports, guidance and position papers for the U. S. delegation, and other records.

The records concern the planning and organization of meetings of the general assembly. There is some information about preliminary meetings and meetings of the Consultation on Cartography.

Some of the records are in Spanish.

69. RECORDS RELATING TO MEETINGS OF DIRECTING COUNCIL. 1956-72. 5 in.

Arranged chronologically by meeting. 
Chiefly reports of the United States delegation to the Council, correspondence, reports of consultations, and final reports of meetings. Some of the records are in Spanish.

The Directing Council, comprised of one delegate from each member country, meets annually between assemblies to carry out the administrative business of the institute.

70. RECORDS RELATING TO THE COMMISSION ON CARTOGRAPHY. 1957-79. 15 in.

Arranged by subject.

Correspondence, memorandums, agenda, progress reports, copies of technical papers, lists of members, minutes of meetings, resolutions and other records relating to the organization, meetings, and work programs of the committees and subcommittees of the Commission. There are also other records concerning the reorganization of the Commission in 1966 and the establishment of an aerial-camera test range in Latin America.

\section{RECORDS CONCERNING CONSULTATIONS ON CARTOGRAPHY. 1943-73. 2 ft.}

Arranged chronologically by date of consultation and thereunder by subject.

Chiefly programs and agenda, minutes, reports of committees and subcommittees, reports of the U. S. delegation to the Commission on Cartography, resolutions and recommendations, final acts, and copies of technical papers, but also including correspondence, memorandums, exhibit lists, photographs of exhibits, handwritten notes, and itineraries.

The records concern the coordination of work programs and the exchange of data between national sections under the auspices of the technical committees and subcommittees of the Commission on Cartography.

\section{RECORDS RELATING TO THE COMMISSION ON GEOGRAPHY, THE COMMISSION ON HISTORY, AND THE SPECIAL COMMITTEE ON GEOPHYSICAL SCIENCE. 1944, 1950-75. 3 in.}

Arranged by commission or committee.

Chiefly processed issuances on PAIGH letterhead comprising summary minutes, reports, reolutions, and recommendations, but also including correspondence, and minutes of meetings. The records relate to commission and committee functions, organization, and personnel. The 1944 item is a copy of the program for the Second Pan American Consultation on Geography and Cartography. Some of the records are in Spanish.

\section{RECORDS RELATING TO THE WORKING GROUPS OF THE COMMISSION ON CARTOGRAPHY. 1961-78. 5 in.}

Arranged by work group and thereunder by type of record.

Correspondence, copies of technical papers, reports and other records concerning the meetings and recommendations of the working groups. The recommendations addressed such matters as map symbols and standards, geodetic control networks, use of digital map data, and technical map specifications. 
74. RECORDS OF THE UNITED STATES NATIONAL SECTION. 1961-69. 5 in.

Arranged in rough chronological order.

Correspondence, list of members of the National Section of the United States (1968), draft regulations (1961), a draft copy of a "statement in support of legislation to authorize [a] U. S. Contribution to the Pan American Institute of Geography and History" (1965), and a paper titled "Program Narrative - Pan American Institute of Geography and History."

The records concern membership, organization, and objectives of the National Section, the nomination of Arch C. Gerlach to be Vice President of PAIGH in 1964, and discussion about the United States quota payment to the Institute.

\section{RECORDS OF THE UNITED STATES NATIONAL SECTION OF THE COMMISSION ON} CARTOGRAPHY. 1964-80. $10 \mathrm{in.}$

Arranged in four sections: correspondence, meetings, special projects, and progress reports, and thereunder in rough chronological order.

Correspondence, memorandums, minutes of meetings, lists of delegates, agenda, copies of the reports of the United States National Section to the Commission, and related records. The records concern the preparation of Section reports and exhibits, submission of technical papers, nominations for United States vacancies on committees and working groups of the Commission, discussion of proposed resolutions, formulation of work programs, and review of budget and administrative issues.

There are some reference materials dating from 1954 in the last folder.

\section{RECORDS RELATING TO THE TECHNICAL CONFERENCE ON SPECIAL MAPS. $1965.1 \mathrm{in.}$}

Arranged by type of record.

Memorandums, programs, list of delegates, a captioned group photograph of participants, speeches, working group discussion guides, copies of technical papers, and a list of equipment owned by the Military Geographical Institute of Peru.

The conference was held January 18-26, 1965, in Ottawa, Canada.

Some of the records are in Spanish.

77. BOLETIN AEREO. 1955-72. 3 in.

Arranged as follows: the Spanish language original, from March 1955 to September-October 1972, and an English translation, from September-October 1967 to January-February 1971.

The newsletter disseminates a summary of the activities of PAIGH. 
78. REFERENCE MATERIAL. ca. 1948-76. 5 in.

Arranged by meeting or name of organization.

Technical papers, agenda, programs, minutes of meetings, delegate and membership lists, printed reports and brochures, photographs, speeches, correspondence, and memorandums concerning meetings, conferences and symposiums sponsored by international organizations relating to cadastral surveys and mapping. The meetings include the First Pan American Conference on Cadastre (1971), Conference of Latin American Geographers (1970), I Symposium on the Natural Resources of Cuba (1958), North American Symposium on Urban Surveys and Mapping (1969), and United States National Working Group on Cartography (1961-62).

There is also a file concerning studies sponsored by the Division of Earth Sciences of the National Academy of Sciences (1960-61). 
General Cartographic Records, 1839-1981

79. MAPS SHOWING THE LOCATIONS OF POST OFFICES. 1839. 2 items. [NWCS, maps and plans]

A map of Illinois and Missouri, and a map of Mississippi, Louisiana, and Arkansas showing the locations of post offices, post roads, canals, and railroads. The maps were compiled by David H. Burr.

80. MAP SHOWING ARMY DEPLOYMENT IN FLORIDA. 1856. 1 item. [NWCS, maps and plans]

A "Sketch showing the Positions and Communications Established by the Army in its Operations against the Seminole Indians South of Mosquito Inlet, Florida."

81. MAP OF THE UNITED STATES. ca. 1880. 12 items. [NWCS, maps and plans]

A mounted oversize manuscript map of the United States in 12 sections. The large-scale map shows State and county boundaries, cities and towns, railroad lines, and Indian reservations.

82. PLATS OF TAXABLE LANDS IN MCCORMICK COUNTY, SOUTH CAROLINA. 1934. approx. 240 items. [NWCS, maps and plans]

The small tracings, which show land surveys, are arranged numerically by school district, 1 to 27 , and thereunder by site. There are no folders for districts numbered 12, and 20 to 23. There are also two folders for unlisted sites and a folder containing alphabetical lists of land owners, taken from tax lists.

83. ORGANIZATION CHARTS AND AN ADMINISTRATIVE MAP. 1935-53. 24 items. [NWCS, maps and plans]

The series consists of charts showing organizational relationships within the USGS, a map showing the locations of the principal field offices of the agency (1953), and a historical organization chart for the Water Resources Division compiled in 1953.

\section{MAPS THAT ACCOMPANIED A REPORT TO THE OFFICE OF THE NATIONAL PETROLEUM}

RESERVE. 1981. $2 \mathrm{ft}$. [NWCS, maps and plans]

Arranged in record cases Nos. 2 to 5.

Exploration maps and charts of areas in Alaska compiled as part of a Technical Services Contract. Included are depth, structure, isopach, and paleoenvironmental maps; correlation cross sections; and test charts and diagrams. There is no narrative report with these records.

In 1976 Naval Petroleum Reserve No. 4 was renamed the National Petroleum Reserve in Alaska. The Office of the National Petroleum Reserve in Alaska (ONPRA) was established in the Office of the Director of the USGS in 1977 to oversee and manage the program. In 1984 the Barrow gas fields, Walakpa gas discovery site, and other lands within the reserve were transferred to the North Slope Borough for exploration and development. 


\section{PHOTOGRAPHIC PRINTS OF VIEWS OF THE WESTERN UNITED STATES AND OTHER} SUBJECTS. ca. 1864-1910. 23 items.

Arranged by NARA-assigned number. This is series MW (NWCS, still pictures).

The series consists of unidentified views of landscapes in the Western United States, including views of mountain ranges and bodies of water. The identified photographs include an autographed portrait of John W. Powell; a view of the Uinta Mountains; a prospector "mushing" the trail on the Fairbanks-Valdez Road in Alaska; Twin Falls of the

Snake River, Idaho; a group portrait of USGS personnel taken about 1882; and a portrait of the members of the State Geological Survey of California, taken in 1864, which includes Clarence King.

86. PHOTOGRAPHIC PRINTS OF THE WEST BY WILLIAM HENRY JACKSON. ca. 1869-86. $1 \mathrm{ft}$.

Arranged by NARA-assigned number and thereunder roughly by size. This is series WJ (NWCS, still pictures).

Mounted prints that provide photographic documentation of the areas explored by the "Hayden Survey," especially mountain ranges, canyons, water falls, and hot springs, in and adjacent to Yellowstone National Park. Other subjects include views of a Shoshone Indian village and its chief, Washakie, the Cimarron landslide in Colorado in 1886, and Chihuahua, Mexico.

Interspersed are some photographs stamped "W. H. Jackson Co.," which were taken by Jackson after he established a commercial photography business in Denver in 1879.

Original negatives for some of the prints are described in series HS (entry 34).

87. THE JOHN K. HILLERS PHOTOGRAPHIC COLLECTION. ca. 1871-1900. 4 albums and loose items. $12 \mathrm{ft}$.

Arranged by format (mounted, unmounted, and glass-plate negatives), and thereunder unarranged. Most of the photographs have captions and dates. A caption list prepared by the agency is available for researcher use at the National Archives. This is series PS (NWCS, still pictures).

The photographs were collected by John K. Hillers (originally Johann Karl Hillers), a photographer with the "Powell Survey," who joined the USGS in 1881 and served as Chief of its Photographic Laboratory, 1883-1900. Many of the photographs were taken by Elias O. Beaman, James Fennemore, and Hillers, photographers with the "Powell Survey." The subjects include the Colorado and Green Rivers, and adjacent tributaries and canyons; geologic formations, landscape scenes, and panoramas; settlements and railroad stations; survey party members, camp sites, boats and other equipment; and Indian ruins.

Other photographs illustrate early activities of the USGS including scenes of damage caused by the 1886 Charleston earthquake; views of geologic formations near Baltimore and at the head of Chesapeake Bay;

Niagara Falls and the New River, West Virginia; mountains, rivers, springs, waterfalls, mines, and quarries in the southeastern United States; Zion and Yellowstone National Parks; and wax models from a mountain-making laboratory experiment done by Bailey Willis in 1891. 
Arranged in two sets - geologic staff and topographic staff. This is series OV (NWCS, still pictures).

Oval-portrait photographs (about $2.5 \mathrm{in}$. high) mounted on unbound album pages. The first set includes photographs of geologists, geologic aids, assistant geologists, palaeontologists, and statisticians. The second set includes photographs of topographers, assistant topographers, topographic engineers, junior engineers, and geographers. Most of the photographs are captioned with the name of the individual, position titles, and what may be dates of service.

89. PHOTOGRAPHS TAKEN IN THE FIELD BY GEOLOGISTS, HYDROLOGISTS AND OTHER PERSONNEL OF THE USGS. ca. 1871-1959. 18 ft. 140 albums.

Arranged by name of photographer (chiefly geologists) or subject. Some of the albums do not give the name of the photographer. Some of the albums have a table of contents. Many of the photographs are captioned. This is series GH (NWCS, still pictures).

Photographs taken by geologists include subjects such as geologic strata, natural rock formations, landscapes, and panoramic views; mines and mining facilities, miners' homes, quarries, ore pits, mills, and processing plants; iron, manganese, sandstone, limestone, and bauxite deposits; beach ridges, corals and sand dunes; and undated aerial photographs of parts of the Potomac River and tributary streams near Washington D. C. and the New Jersey coastline. There are photographs from most regions of the United States, and Yukon Territory, the Panama Canal Zone, the Bahamas, Haiti, the West Indies, and Brazil. The photographers named on the album covers are Edwin H. Barbour, Ernest F. Burchard, Charles Butts, Robert R. Coats, C. Whitman Cross, Lincoln G. Eakins, Henry G. Ferguson, Ernest Howe, James Jackson, Willard D. Johnson, Philip B. King, Esper S. Larsen, Willis T. Lee, Hugh D. Miser, Fred H. Moffit, Louis M. Prindle, John R. Stacy, Lloyd W. Stevenson, Thomas W. Vaughan, Wendell P. Woodring, and Ralf R. Woolley. Other photographers are named on the captions that accompany many of the pictures.

Several USGS parties visited Alaska. Their photographs cover towns, mines, logging operations, and dog stations (Prindle, 1903); marble quarries (Burchard, ca. 1913); cabins, glaciers, mines and thin sections (Moffit, 1940); and native activities, USGS camps, and glaciers (Coats, 1940-47).

Of particular interest are photographs of Indian hogans and pictographs (Lee); photographs taken in 1959 of damage from an earthquake in Montana (Stacy); buildings made of local sandstone and granite (Burchard); homemade windmills in Nebraska in 1898 (Barbour); photographs in Switzerland and of the Jura Mountains in 1887 (Jackson); and a captioned group portrait of district engineers who attended a Water Resources Division Conference of District Engineers on October 17-23, 1923 (box 6).

Photographs taken by hydrologists chiefly document various surveys of the Grand Canyon and adjacent areas. Included are a collection of stereoscopic prints of boats and equipment, survey party members in camp, geologic formations, and landscapes attributed to Hillers taken during his service with the "Powell Survey," 1871-72 (box 2); photographs showing river scenes, Indian pictographs, and landscapes taken by Eugene C. LaRue during a survey of the Grand Canyon, and Cataract and Glen Canyons in 1914-23 (8 albums); and photographs of the Grand Canyon area taken by Norman W. Carkhoff in 1901 while with a party of geologists that included Nelson H. Darton, Walcott, and Gilbert (box 1). One album contains photographs, taken in 1918-21, of constructed and proposed dam sites, power plants, reclamation and power project sites, waterfalls, lakes, rivers, and ranches located chiefly in Idaho, Montana, Utah, and Wyoming. Also included are photographs taken by Ralf R. Woolley during a survey of the Green River Basin, 1920-22; camp sites, dinosaur quarries, dams under construction, streams, power plants, reservoirs, and proposed dam sites located in the western United States, 1923-29; and scenes of Silver City, New Mexico, 1924, Chicago, Illinois, 1927, Ogden, Utah, 1929, and Rainbow, Utah, 1929. The Woolley photographs are in 3 albums. 
Some of the these photographs are duplicated in other series held by the Still Pictures Division. These albums once were part of a large collection of albums held by the USGS. It is possible that there will be significant accretions to this series.

\section{MISCELLANEOUS PHOTOGRAPHS. n.d. 8 items}

Unarranged. [Filed with the textual records.]

Undated and untitled photographs including posed groups of individuals (one is annotated with the dates of the resignation, transfer or death of the pictured individuals), office scenes, and what appears to be a formal dedication of a building, perhaps the new Interior Department Building. 
In the early years of the USGS, the Director administered the agency's programs and supervised its personnel with the sometime assistance of an Executive Officer, a General Assistant, a Chief Disbursing Clerk, and a Chief Clerk, who was responsible for the preparation of USGS letters and reports, action on incoming letters, and preparation of forms and maintenance of other records relating to appointments and personnel. In 1894 the Director merged these and other functions in an Administrative Branch. The new branch included a Division of Documents, Correspondence, and Records; the Library; and a Division of Disbursements and Accounts. A decade later the Administrative Branch comprised three divisions--Executive, Disbursements and Accounts, and Illustrations--and the Library.

By 1920 the Administrative Branch was composed of the Executive Division, Division of Accounts, Division of Scientific and Technical Field Equipment, and the Library. In 1925 the Administrative Branch was abolished by Survey Order 116, but the functions and duties of the former Branch remained under the supervision of the Chief Clerk. In 1948 Survey Order 168 abolished the position of Chief Clerk and the Administrative Geologist temporarily assumed supervision of many of the Chief Clerk's duties. That same year the position of Executive Officer was reestablished by Survey Order 169 as a staff position in the Director's Office to advise the Director in matters relating to business management with supervision of functions formerly under the Chief Clerk. Supervision of the Library had been transferred to the Geologic Branch in 1947.

In 1953 Survey Order 222 established an Administrative Division under the Executive Officer comprised of the Budget Office, Organization and Management Office, Accounts Branch, Service and Supply Branch, and Rocky Mountain Service and Supply Branch, in Denver, Colorado (established in 1951). In the next two years the USGS established within the division a Pacific Coast Branch, in Menlo Park, California, a Mid-Continent Branch in Rolla, Missouri, and an Atlantic Branch, in Washington, D.C.

Records concerning Personnel, 1879-1965

91. APPLICATIONS REGISTER. Jan. 1879 - Apr. 1886. 2 in. 1 vol.

Arranged by year and thereunder by assigned number. The front of the volume contains an index to applicants. The index is divided into Ethnologic Applications and Geologic Applications.

Entries include the file number, name of applicant and residence, date of application, position applied for, by whom recommended, action, and remarks. Applications are filed with the records described in entry 44. The pages used in the volume are folios 1-120 and 200-202.

92. APPOINTMENTS REGISTER. 1879-90. 1 in. 1 vol.

Arranged by name of appointee. The front of the volume contains an index to appointees.

Entries include the name of the appointee, position, State of birth, State appointed from, date of appointment, where employed, compensation, and remarks. Notes concerning resignations and reappointments extend to 1895 . No other appointments registers have been found.

Records relating to the appointment of USGS personnel, from 1879 to 1907 are part of the records of the Appointments Division, Record Group 48, Records of the Office of the Secretary of the Interior. 
Arranged alphabetically by name of employee.

Statements completed by USGS employees showing their position and salary, date and place of birth, race (if colored), marital status, employment history and military service. Some forms also requested education information, and names and positions of relatives in U.S. Government service. Most of the forms were completed in 1922.

94. RECORDS RELATING TO PERSONNEL CLASSIFICATION. 1921-41. 5 in.

Arranged by subject or type of record.

Departmental and other circulars (chiefly issued by the Bureau of Efficiency, Civil Service Commission and Personnel Classification Board), memorandums, reports, and summaries of service ratings and final ratings for the Personnel Classification Board concerning the classification, efficiency ratings, and promotions of USGS employees. Most of the records date from 1923.

The Personnel Classification Board was established as an independent board under the provision of the Classification Act approved May 4, 1923 (42 Stat. L., 1488). The Board was abolished June 30, 1931 and its functions assumed by the newly created Personnel Classification Division of the United States Civil Service Commission.

95. PERSONNEL "NOTES." 1926-34. 3 in.

Arranged chronologically.

Processed issuances, usually compiled at one-week intervals, showing appointments, assignments and transfers, furloughs, changes of address, changes of name of newly married female employees, and retirements for central office and field staff.

96. TABULATIONS OF PERSONNEL ALLOCATIONS AND RELATED RECORDS. 1959-65. 8 in.

Arranged by year and thereunder by type of record.

The bulk of the series is consists of computer printouts titled "Detail of Personal Services," 1959-65. The contents are arranged by organizational unit and thereunder in groups by grade of employee.

Columnar information includes name of employee, grade, position title, organization code, and salary. A second set of computer printouts is titled "Payroll Master Listing," 1964-65. The contents are arranged in rough alphabetical order by name of employee. Information about each employee includes their grade, salary, organization code, and date of birth.

Also included are completed oversized statistical tables titled "Summary of Obligations for Research and Development, R \& D Plant and Data Collection; and Manpower Requirements for Research and Development." The forms, completed in 1962, project data for fiscal years 1961-66 and 1970. The data was compiled for a study undertaken by the National Science Foundation for the Federal Council for Science and Technology. 
97. REPORTS. 1901-12, 1926-27, 1930. $2 \mathrm{ft}$.

Arranged by year, thereunder by type of report, and thereunder by USGS unit.

Monthly, annual, and administrative reports received by the Director of the USGS concerning the personnel, status of projects, projected program of work, and other subjects from organizational units and individuals in charge of field parties. Some reports are accompanied by statistical tables or lists. A few of the reports are edited and annotated. The 1926-30 (monthly) reports are from the Geologic Division. Also included are copies of a few reports from the Director of the USGS to the Secretary of the Interior.

98. ESTIMATES OF APPROPRIATIONS AND RELATED RECORDS. 1925-49. $2 \mathrm{ft}$.

Arranged chronologically by year, and thereunder by type of record.

Completed statements, and forms accompanied by justifications concerning annual budgets. The records were compiled 1925-1949 and concern fiscal years 1926-50. There are no records for fiscal year 1931 in the file.

99. RECORDS CONCERNING BUDGET FORMULATION. 1932-69. $19 \mathrm{ft}$.

Arranged in two segments: first (1932-45), chronologically by year and thereunder by type of record; and second (1946-69), chronologically by year and thereunder by assigned number.

In the second segment, the last two digits of the fiscal year in which the file was compiled precede the file number for files created to 1958; thereafter, the fiscal year follows the file number.

Budget estimates, summaries and justifications, allotment statements, tabular reports, directives, circulars and other administrative issuances, organization charts, graphs, correspondence, memorandums, and press releases. Also contains records concerning research and development, interagency, regional and State programs, foreign- survey projects, and personnel.

100. ORGANIZATIONAL RECORDS. 1925, 1944-69. $1.5 \mathrm{ft}$.

Arranged by type of record, organizational unit or subject.

Chiefly organization charts and Survey Orders (Nos. 150 to 252) and Amendments, but also including correspondence, memorandums, management studies, handwritten notes, minutes and meetings, and other records concerning the organizational structure and functions of the organizational units of the USGS. There are also records concerning the impact of the Interior Department's regionalization program on the USGS. The records include a list of Survey Orders (1 to 252) that shows the date, subject, and status of each order.

There are no separate organizational files for the Water Resources or Alaska Divisions, although these units are discussed in memorandums and studies that are part of the records. The 1925 item is a USGS organization chart. 
101. ADMINISTRATIVE ISSUANCES. 1950-72. $8 \mathrm{ft}$.

Arranged by type of issuance and thereunder chronologically as follows: Administrative Memoranda, 1950-56 [boxes 1 and 18]; Administrative Circulars, 1951-55 (Nos. 1 to 88) [box 1]; Manual Releases, 1956-72 (Nos. 1 to 1299) [boxes 2-12 and 19]; Survey Orders, 1951-59 (Nos. 212 to 251) [box 13]; and Administrative Digests, 1952-72 (Nos. 1 to 576) [boxes 13-17]. Revisions and amendments of numbered issuances are filed by approval date. These sets are not complete.

Chiefly draft and final copies of issuances, including related forms and charts, issued by the authority of the Director of the USGS, or an official designated by the Director, and were effective throughout the agency.

Draft, background, and signed copies of the issuances are interspersed.

The Administrative Memoranda and Administrative Circulars interpreted policy regarding administrative actions and set forth the formal procedures for preparing and processing contracts, authorizations, travel orders, and other forms. Both issuances were replaced by the Manual Releases which gave notice of official changes in the official Manual of the USGS. Survey Orders supplemented the Manual in providing detailed explanations of organizational changes, definitions of unit functions and relationships, and the establishment of USGS boards, committees, and other advisory bodies. Administrative Digests were intended to inform succinctly USGS managers about all changes or actions that effected agency policy and programs.

102. DEPARTMENT OF THE INTERIOR PRESS RELEASES RELATING TO THE USGS. 1928-59. $10 \mathrm{in.}$

Arranged chronologically.

Processed press releases announcing the results of hydrologic and geologic investigations and the availability of maps and charts for public examination or for sale. A few of the press releases are accompanied by maps.

This series does not contain press releases for 1929, 1930, 1936, 1937, and 1939.

Press releases relating to the USGS are found in several post-1907 series in Record Group 48, Records of the Office of the Secretary of the Interior. 
In the early years of the USGS the Director, the Executive Officer, and the Chief Clerk oversaw the editing of the agency's publications. By 1884 the volume of manuscript material to be reviewed prompted the Director to delegate regular editorial responsibility to an Editor. In 1894 a Publications Branch was established composed of an Editorial Division (thereunder Sections of Textual Publications, Geologic Maps, and Topographic Maps), a Division of Illustrations (thereunder a Photographic Laboratory), and a Division Engraving and Printing.

In 1912 the functions of the Branch were placed under the supervision of the Administrative Geologist. In 1953 Survey Order 223 established a Publications Office. In 1959, by Survey Order 252, that Office was succeeded by a Publications Division under the supervision of a Publications Officer. The Division consisted of the Office of the Division Chief, the Branch of Texts, the Branch of Technical Illustrations, the Branch of Map Reproduction, and the Branch of Distribution. In 1980 the Publications Division was abolished; its responsibilities for producing texts and maps were assigned, respectively, to the Geologic Division and the National Mapping Division. Responsibility for producing geologic maps later passed to the Geologic Division.

General Records, 1879-1995

103. CATALOGS OF PUBLICATIONS OF THE USGS. 1879-1969. 9 vols. [NWCS, maps and plans]

The first volume covers publications for 1879-1961. The remaining volumes are annual supplements. The supplements do not form a complete set.

104. LISTS OF NEW PUBLICATIONS OF THE USGS. 1970-95. 99 items. [NWCS, maps and plans]

Arranged by list number.

A monthly catalog.

105. PUBLISHED CIRCULARS. 1970-87. 6 vols. and 3 items. [NWCS, maps and plans]

Arranged by Circular number.

Circulars 601-C, 758, 810, 826, 1003, and 1011. These Circulars are not accompanied by separate maps. The map that accompanied Circular 780 is in this series, but that Circular is not in the series. 
106. PRESS COPIES OF LETTERS SENT BY THE DIVISION OF ILLUSTRATIONS. August 19, 1891 January 7, 1904, and November 26, 1904. 4 in. 4 vols.

Arranged chronologically. The dates overlap between the volumes. The first and last volumes contain indexes.

Letters sent to the Director of the USGS, the Government Printing Office, and authors of monographs and others concerning the processing and review of maps, photographs, drawings, and other illustrations published by the USGS in its official publications and annual reports. Also includes monthly and annual narrative reports to the Director about the work of the Division.

107. PRESS COPIES OF LETTERS SENT BY THE SECTION OF ILLUSTRATIONS. July 11, 1898 - July 6, 1938. 4 ft. 16 vols.

Arranged chronologically. Most of the volumes are indexed by subject.

Chiefly letters to the Director of the USGS recommending illustrations to be included in agency publications, annual reports on the work of the Section (beginning with fiscal year 1903), and requesting the transfer and assignment of personnel to the Section. Also includes letters to other USGS officials, the Government Printing Office, engravers, and authors of papers undergoing review, and copies of instructions that accompanied the illustrations concerning the type and method of reproduction. Beginning in 1904 the volumes contain mounted carbon copies of letters sent.

These volumes were begun by John L. Ridgway, who succeeded De Lancey W. Gill as Chief of the Section, when Gill resigned to become the Illustrator at the Bureau of American Ethnology.

108. RECORDS OF THE COMMITTEE ON ILLUSTRATIONS. 1900-1909. 5 in. 2 scrapbooks.

Arranged chronologically. The second volume (1904-9) contains an index to authors and subjects.

Includes minutes of committee meetings, memorandums, letters to the Director of the USGS recommending maps and other illustrations for monographs, publication summaries, bulletins and reports published by the USGS, regulations governing the transmittal of illustrations to the agency, and handwritten notes.

The committee, chaired by the Chief of the Illustrations Section, comprised representatives from the divisions that submitted proposed publications for review.

109. ILLUSTRATIONS FOR BULLETINS. 1884-1948. approx. 1500 items. [NWCS, maps and plans]

Arranged numerically from 4 to 960 .

Chiefly mounted drawings, maps charts, photographs, graphs, and etchings, which accompanied bulletins of the USGS including information relating to paleontology, mineralogy, geology, geography, oceanography, petrology, and related sciences. Some earlier illustrations, have the same letter number and date of receipt stamps as the related original incoming correspondence was filed the letters received, entry 44. 
110. ILLUSTRATIONS FOR MONOGRAPHS. 1890-1915. approx. 300 items. [NWCS, maps and plans]

Arranged numerically from 1 to 54. There are gaps in the records.

Mounted drawings, maps, photographs, photomicrographs, photoengravings, charts, geologic profiles, and other records relating mostly to paleontology, geology, mineralology, petrography, glaciology, and topography. There are a considerable number of records relating to the iron-bearing districts of the United States and many drawings illustrating paleontological discoveries. Of particular interest are the records for USGS Monograph 32, Part 2, "Geology of the Yellowstone National Park." Most of the illustrations are captioned and the maps include color keys. A manuscript copy of a portion of Monograph 32, Part 1 is part of the records described in entry 146.

111. ILLUSTRATIONS FOR PROFESSIONAL PAPERS. 1902-38. approx. 700 items. [NWCS, maps and plans]

Arranged numerically from 2 to 215 . There are gaps in the records.

Chiefly mounted photographs, diagrams, sketches, maps, photomicrographs, and charts. There are also instructions for reproduction of material.

112. ILLUSTRATIONS FOR WATER-SUPPLY PAPERS. 1905-48. approx. 600 items. [NWCS, maps and plans]

Arranged numerically from 140 to 999 . There are gaps in the records.

Photographs, charts, graphs, diagrams, plans, drawings, maps, and other records.

113. ILLUSTRATIONS FOR ANNUAL REPORTS OF THE USGS. 1882-1932. approx. 200 items. [NWCS, maps and plans]

Arranged by date of publication. The illustrations are for the $2 \mathrm{~d}$ to $53 \mathrm{~d}$ annual reports of the USGS. There are no records for reports $5,6,10,24$ through 44 , or 47 through 49 .

Photographs, microphotos, diagrams, drawings (chiefly of fossils), graphs, sketches, maps and other records to accompany annual reports.

114. ILLUSTRATIONS FOR MISCELLANEOUS PUBLICATIONS. ca. 1874-1932. approx. 150 items. [NWCS, maps and plans]

Arranged according to a list that is with the records.

Drawings, charts, maps, photographs geologic profiles, graphs, sketches, diagrams, and other records relating to various publications issued by the USGS, filed in envelopes with the following labels: "Preparation of Illustrations", by John L. Ridgway; "Physiographic Folio No. 2 of the Geology and Mineral Resources of the Copper River District, Alaska"; "Topographic Atlas - Folio No. 3 of the Bird's Eye View of Niagara River and Vicinity"; "Trademark of the United States Geological Survey'; "Handbook for Topographers"; "Handbook for Field Geologists"; "Manual of Instructions for Topographic Surveying"; "King's Survey of the 40th Parallel - [Fielding B.] Meek's Report"; and "Contributions to Paleontology," by Charles A. White (extracted from the 12th Annual Report of the "Hayden Survey"). 
Also included are illustrations relating to military camps; illustrations to accompany reports on the Cape Nome, Norton Bay, and Copper River areas; and the original and proofs of a special map made for President Harding's trip to Alaska in 1923; and a copy of a map of Washington D. C. compiled for the Conference on the Limitation of Armaments.

115. ILLUSTRATIONS FOR CIRCULARS. 1933-34. approx. 50 items.[NWCS, maps and plans]

Arranged by Circular number 2, 6, 7, 8, and 9 .

Maps, diagrams, graphs, photographs, and other records.

116. ILLUSTRATIONS FOR PRESS MEMORANDA. 1923-25. approx. 80 items. [NWCS, maps and plans]

Arranged according to a list that is with the records.

The series is comprised chiefly of maps, but also includes some diagrams, graphs, charts, copies of press notices, and other records illustrating geology, gas fields, oil, potash development, gold mines, coal beds, quicksilver deposits, cooperative geological surveys, wells, production of electric power, nonmetallic mineral resources, and the availability of water.

117. STOCK ORIGINALS. n.d. approx. 35 items. [NWCS, maps and plans]

This series includes a view of Mt. Rainier from Paradise Peak; a view of the Niagara River and vicinity; illustrations for an atlas of Texas; and an envelope of "stock cuts" for USGS Water-Supply Papers.

118. LISTS OF ILLUSTRATIONS. ca. 1917-33. approx. 200 items. [NWCS, maps and plans]

Unarranged.

Each oversized card lists the illustrations, usually by chapter, for one USGS publication. There are cards for Bulletins, Water-Supply Papers, Monographs, Professional Papers, and Guide Books. In addition to giving to publication series and number, the cards provide a brief description of each illustration, state the type of original illustration (photograph, drawing, tracing), furnish a record of the form of reproduction (zinc etching, halftone), state the printed size, and note the approval of proofs.

119. PHOTOGRAPHIC PRINTS. n.d. 3 in.

Arranged alphabetically by name of photographer and thereunder by subject. This is series ISC (NWCS, still pictures).

Mounted prints showing the Grand Canyon, Glacier National Park, Yellowstone National Park, Devils Tower, mountains, glaciers, geologic features, waterfalls, river canyons, deserts, and landscape scenes in Alaska, Arizona, California, Colorado, Georgia, Maryland, Montana, Nebraska, New Mexico, North Carolina, South Dakota, Utah, Washington, and Wyoming. The photographers are identified on the prints as [Ralph] Arnold, [Marius R.] Campbell, [Robert H.] Chapman, [Norman W.] Carkhuff, [C. Whitman] Cross, [Nelson H.] Darton, [Grove K.] Gilbert, R[obert]. T. Hill, [John K.] Hillers, [Albert ] Johannsen, [Arthur] Keith, [Walter C.] Mendenhall, [Charles D.] Walcott, and [Bailey] Willis. 
Unarranged. This is series ISD (NWCS, still pictures).

The illustrations consist of an $11 \mathrm{in.}$ x 14 in. mounted watercolor of a field which is signed by De Lancey W. Gill who was, according to the caption, in charge of the USGS Division of Illustrations; an 8 in. x 11.5 in. unmounted lithograph with the caption "view of The Black Forest, Mount Hope and Sierra Prieta," by E. Stout (taken from a sketch made by Albert H. Campbell for the topographical report of the Pacific Railroad Survey of the 35th Parallel); and a 3 in. $x 7$ in. unmounted watercolor of a tree-lined road with a caption on the reverse "found in Hersey Munroe's

photo album[,] Wells probably painted this for Mr. Munroe, Topographer."

\section{PHOTOGRAPHIC PRINTS. ca. 1881-1941. 5 in.}

Arranged by Professional Paper and thereunder by NARA assigned number. A few of the photographs have captions. This is series ISA (NWCS, still pictures).

Various sized halftone prints showing streams, ponds, geologic formations, and landscapes used as illustrations in USGS Water-Supply Paper 489, "The Occurrence of Ground Water in the United States, with a Discussion of Principle" (by Oscar E. Meinzer, 1923), and gaging stations used as illustrations in USGS Water-Supply Paper 871, "Summary of Yearly Discharge at Gaging Stations in North Atlantic Storage Basins" (anonymous, 1941).

\section{PRINTS AND CORRESPONDING NEGATIVES OF PANORAMAS IN THE VICINITY OF THE COLORADO, GREEN, AND SAN JUAN RIVERS. ca. 1930. 0.5 in.}

Arranged by agency assigned numbers. Narrative descriptions of the photographs accompany the records. This is series ISB (NWCS, still pictures).

Photographs taken by Harry A. Aurand, Consulting Geologist, showing mesas, plateaus, buttes, and geologic formations. The photographs are annotated with names of topographic and geologic features.

The photographs were sent to Roger W. Toll, Superintendent of Yellowstone Park, in 1935. 
Texts Section, 1887-1916

123. PRESS COPIES OF LETTERS SENT BY THE SECTION OF TEXTS. Oct. 29, 1887 - Dec. 31, 1906. 10 in. 5 vols.

Arranged chronologically. Volumes 3, 4, and 5 contain partial indexes.

Copies of letters sent to authors, printers, USGS officials, and other persons concerning the editing, processing, and printing of technical papers submitted to the Division for publication.

Also includes copies of periodic progress reports from the Section to the Director.

124. REPORTS OF THE SECTION OF TEXTS. Jan. 1907 - Dec. 1916. 10 in. 4 scrapbooks.

Arranged chronologically.

Monthly and annual reports to the Director on the status of USGS publications. 


\section{RECORDS CONCERNING THE PRODUCTION AND DISTRIBUTION OF THE "GEOLOGIC ATLAS OF THE UNITED STATES” AND OTHER USGS PUBLICATIONS. 1893-99. 0.5 in.}

Arranged by subject, and thereunder roughly chronologically.

Correspondence, memorandums, circulars, statistical summaries, handwritten notes, a list of atlas sheets to be published, and other records concerning the production, distribution, and publicizing of the "Geologic Atlas of the United States" and its folios during 1893-97. There is also a report dated July 27, 1894, from a committee appointed by the Director "To prepare a plan for the distribution of the atlas folios." The committee was comprised of Grove K. Gilbert, Samuel F. Emmons, and Bailey Willis. Included are a few documents relating to Monographs and Bulletins published by the USGS during 1895-99. Related records are described in entry 146.

In 1889 the USGS began the process of shaping the format of a proposed series of published geologic-atlas sheets. The folios were published from 1894 to 1945 . In 1949 the Director discontinued the publication of the geologic-atlas folios and approved a new series of geologic-quadrangle maps.

126. GEOLOGIC ATLAS FOLIOS. 1894-1945. approx. 240 items. [NWCS, maps and plans]

Arranged by folio number.

Each folio contains a general introduction and an essay on the area covered by the atlas sheets. Some folios also contain topographic maps and copies of photographs. Most of the folios are bound. 
In 1882 the USGS presented its plan of publication for its texts and maps, including general nomenclature, colors and symbols for geological cartography, and conventional characters for diagrams. By 24 Stat. L., 255 (August 4 , 1886) Congress prohibited the USGS from preparing illustrations for or publishing its reports until appropriations were made for these purposes in response to the detailed estimates of the costs of engraving, printing, and binding required from the agency for Fiscal Year 1888 and thereafter. High-quality chromolithographs and other images from stone distinguished many of the visual products in the early years of the USGS and those of its four predecessor surveys, but the lowest-bid contracts required of the Public Printer also produced nonuniform maps and illustrations. In 1890 the USGS hired a Chief Engraver and established the Division of Engraving and Printing. In 1894 the division became a part of the Publications Branch.

The Division also did a considerable amount of lithographic work for other Government agencies. The outside work during slack intervals enabled the Division to maintain a large enough work force to expeditiously process USGS maps during times of heavy demand.

127. MAP REPRODUCTION CARDS. ca. 1901-13. $7 \mathrm{ft}$.

Arranged alphabetically by name of job.

Cards (4 in. x 6 in.), titled "Correction Sheet," "Miscellaneous Work," "Geology" or "Topographic Sheet," that give information such as job number, dated entries tracing the progress of the job, and dates completed and delivered.

The cards show orders for a wide variety of items including mineral-survey plats, atlas sheets, index maps, crosssection rulings, charts, diagrams to accompany Presidential Proclamations, farm unit plats for reclamation projects, fire-escape signs, ledger sheets, and index circulars. In addition to filling requests for USGS offices, the unit also did work for the Bureau of Indian Affairs, Forest Service, Hydrographic Office, Weather Bureau, Interstate Commerce Commission, Territorial Governors, the Post Office Department, and other agencies.

128. SYMBOLS USED ON TOPOGRAPHIC AND GEOLOGIC MAPS. ca. 1890-1984. 7 items. [NWCS, maps and plans]

Brochures, tables, memorandums, and instructions showing lettering, conventional signs, symbols and features used on topographic and geologic maps.

129. PRINTING SAMPLES AND INSTRUCTIONS. ca. 1911-23. 34 items. [NWCS, maps and plans]

Arranged by format.

Mounted geologic sheets; photographs; drawings from photographs; and sketches of rock samples, geologic strata, flora, and fossils illustrating color-coding schemes and methods of color-enhancing photographs. The printed instruction sheets show the symbols to be used on maps.

130. SAMPLES OF TECHNIQUE. ca. 1947-48. approx. 30 items. [NWCS, maps and plans]

Included are examples of quadrangle maps compiled in the field, planimetric sheets showing contouring by field personnel, multiplex-compilation sheets, color separations, and metal mounts. 
131. RECORDS CONCERNING PATENTS. ca. 1936-39. 3 in.

Arranged by patent.

Chiefly copies of patents obtained by Federal employees and others for plotting machines and processes of making maps from aerial photographs, aerial-photograph calculators, and other apparatus for compiling maps from photographs. Also includes correspondence regarding Charles Collier's patent for the "Slotted Templet Method" for making maps.

The original patents date as early as 1887 .

132. GENERAL CORRESPONDENCE FILES. 1941-49. 2 ft.

The files are arranged by assigned number. A file title list appears as Appendix 6 in this inventory.

Chiefly correspondence, but also includes memorandums, reports, technical circulars, instructions for mapprocessing methods, maps, and other records concerning the organization and work of the Division, map publication and distribution, cooperation with other agencies and State geological surveys, and the development of map-processing methods.

133. PUBLISHED MAP PLATES AND CHARTS FROM BULLETINS. ca. 1904-78. approx. 240 items. [NWCS, maps and plans]

Arranged numerically by Bulletin number from No. 16 to No. 1451. A few of the maps are folded.

134. PUBLISHED MAPS FROM MONOGRAPHS. ca. 1934-64. 21 items. [NWCS, maps and plans]

Copies of maps that accompanied Monographs No. 11 to No. 64.

135. PUBLISHED MAPS FROM PROFESSIONAL PAPERS. ca. 1901-88. 10 vols. and approx. 600 items. [NWCS, maps and plans]

Arranged by number assigned to the Professional Papers.

Various sized maps that accompanied USGS Professional Papers numbered 20 to 1386B. There are also a few copies of the Professional Papers. Included are two copies of USGS Professional Paper 950, "Nature to be Commanded': Earth-Science Maps Applied to Land and Water Management," (1978). About one-third of the maps are folded.

136. MAPS THAT ACCOMPANIED WATER-SUPPLY PAPERS. 1914-72. 100 items. [NWCS, maps and plans]

Arranged by Water-Supply Paper from No. 338 to 2039-B. 
137. MAPS THAT ACCOMPANIED OPEN FILE REPORT 86-482. 1987. 3 items. [NWCS, maps and plans] The title of the report is "Potential for Aquifer Compaction, Land Subsidence, and Earth Fissures in the Tucson Basin, Pima County, Arizona." 
Geologic Division, 1867-1997

The major program areas of the USGS began in the Geologic Division's ancestral units. In 1879 Director King organized the USGS in two thematic units (Mining Geology and General Geology) and four geographic-geologic divisions (Rocky Mountain, Colorado, Great Basin, and Pacific) west of the 100th Meridian. King planned to establish similar geographic units for the region east of that meridian as soon as Congress officially extended USGS work outside the public-land States and Territories. Geologists in these divisions studied and mapped stratigraphic sequences, geologic structures, and mineral deposits. They were accompanied in the field by topographers who produced the large- to small-scale cartography required as bases for the geologic maps. Investigations and mapping by the field parties generated data and analyses that informed the early work of the Land Classification Board.

By the late-1880's Director Powell had abolished King's geographic-geologic divisions and their headquarters at Denver, Salt Lake City, and San Francisco. In their place he created a geologic unit of nine geographic and three thematic divisions, supported by eight divisions--six of paleontology, one of chemistry and physics, and one of petrography--all of which were centered at Washington, D.C. In 1889 Powell combined all these divisions in a Geologic Branch led by Grove K. Gilbert, who served as its "Chief Geologist" until 1892 when that position and the paleontologic units were discontinued. Charles D. Walcott, as "Geologist in charge of Geology and Paleontology" during 1893-94, abolished the remaining divisions and organized the staff as a single unit. Each experienced geologist and paleontologist was made chief of an independent field party, to carry out with younger aides geologic investigations within specific regions. These chiefs continued to report to Walcott after he became the third Director. In 1900 Walcott reorganized the Geologic Branch into eight thematic divisions, each in charge of a specialist, to separate the scientific and administrative control of the work. In 1902, Walcott united the Divisions of Areal Geology, Pleistocene Geology, Paleontology, Economic Geology or Metalliferous Deposits, and Economic Geology of Nonmetalliferous Deposits, as the Division of Geology and Paleontology. To head the new division, Walcott selected C. Willard Hayes, who led the nonmetalliferous unit, as the "Geologist in Charge." In 1907, just before he became the Smithsonian Institution's fourth Secretary, Walcott requested the Secretary of the Interior to change Hayes' title to "Chief Geologist." As Chief Geologist, Hayes led a Geologic Branch composed of the Geologic Division (also known as the Division of Geology and Paleontology), the Division of Alaskan Mineral Resources, the Division of Mining and Mineral Resources, and the Division of Chemical and Physical Research.

Reorganizations continued in the Geologic Branch after 1904. In 1944 the Geologic Branch was recast into three divisions - Administrative Division, Division of Economic Geology, and Division of Areal Geology and Basic Sciences. In 1946 the Division of Economic Geology comprised the sections of Metalliferous Deposits, NonMetalliferous Deposits, Fuels, Trace Elements, and Foreign Geology. The Division of Areal Geology and Basic Sciences was composed of the sections of Engineering Geology, Areal Geology, Chemistry and Physics, Paleontology and Stratigraphy, Geophysics, Petrology, Military Geology, and Geologic Information and Reports.

The appropriations act of August 7, 1882 (22 Stat. L., 329), directed the USGS to undertake the collection of statistics relating to mines and mining, other than gold and silver. A core staff was formed to do the work. That staff became the Division of Mining and Mineral Resources. The statistical compilations prepared by the Division were published annually as "Mineral Resources of the United States." The Division was transferred to the Bureau of Mines in 1926. In 1996 a portion of the disestablished Bureau of Mines joined the Geologic Division as its Minerals Information Team.

Chemical laboratories were established in the Denver and San Francisco field offices in 1880 and 1882, respectively, to conduct analyses of rock and mineral samples. The act of August 7, 1882, specifically directed the USGS to make chemical analysis of iron, coal, and oil. In 1883 a central laboratory was set up in Washington, D.C. under a Chief Chemist. By 1890 the two field laboratories were closed and all the analysis work was centered at headquarters. There are no records of the Division described in the inventory, but there are records concerning the Division in the central files of the Geologic Branch (entries 159 and 160). 
Cooperative geologic mapping and research with the States began in 1899 .

A Division of Alaskan Mineral Resources was established in 1903 and became an independent branch in 1922. The Land Classification Board was established in 1908 and became an independent branch in 1912.

In 1947 administrative oversight of the Library was transferred from the Office of the Chief Clerk to the Geologic Branch.

To handle increased administrative demands on the Chief Geologist and coordinate programs of the Division, the staff position of Executive Officer was established in 1947. In 1948 two Assistant Chief Geologists were appointed. In 1949 the Branch was renamed the Geologic Division and the Divisions were converted to Branches with subordinate sections. By 1953 many of the sections had been reorganized as branches. Several branches had been relocated to field offices, including the Engineering Geology and General Geology Branches in Denver, the Alaskan Geology Branch in San Francisco, and a small, but growing, branch of the Library in Denver. 
Samuel F. Emmons joined the United States Geological Exploration of the Fortieth Parallel ("King Survey") as a volunteer assistant geologist. When the USGS was created in 1879 Emmons was appointed one of the agency's five principal geologists.

138. REGISTER OF LETTERS RECEIVED. July 16, 1879 - May 22, 1887. 2 in. 1 vol.

Arranged chronologically. There is an index at the beginning of the volume.

A register of letters received showing correspondent's name, date of letter, date received, subject, and file number. The letters, which dealt primarily with administrative and support services, have not been found.

139. LETTERS RECEIVED. 1880-85. 3 in.

Arranged as follows and thereunder chronologically: Geological Survey Headquarters, Miscellaneous, Andrew A. Blair, George F. Becker, C. Whitman Cross, Arnold Hague, Ernest Jacob, William H. Leffingwell, Anton Karl, Clarence King, John D. McChesney, Raphael Pumpelly, James C. Pilling, Alfred M. Rogers, Charles D. Walcott, and Allen D. Wilson.

The letters concern geologic and topographic field work (a few letters constitute progress reports), publication of reports, compilation of statistical data concerning mineral resources for the Tenth Census, and assignment of personnel. Many of the letters in the miscellaneous file are from mining engineers, officials of mining companies, and academic geologists.

These letters are not entered in the register described in entry 138

140. LETTERS SENT. Sept. 1879 - Dec. 1887. 5 in. 2 vols.

The entries are arranged chronologically. Each volume contains a partial index.

Handwritten copies of outgoing letters signed by Samuel F. Emmons, Geologist in Charge, or Alfred M. Rogers, Disbursing Agent. The letters concern the geologic and topographic work of the Rocky Mountain Division. Many of the letters are scientific reports, narrative reports of monthly progress reports, or concern administrative matters. 


\section{Arnold Hague Papers, 1867-1929}

Arnold Hague served as a salaried assistant geologist with the United States Geological Exploration of the Fortieth Parallel ("King Survey"). When the USGS was created in 1879, Hague was appointed one of the agency's five principal geologists. In 1883 Hague headed a party, including geologist Walter Weed, physicist William Hallock, and chemist Frank Gooch, that mapped and studied the geologic structure, geysers, and hot springs of Yellowstone National Park and adjacent areas.

141. LETTERS RECEIVED. 1880-1916. 5 in.

Arranged in two groups: chiefly letters from the Director and Chief Clerk of the USGS, arranged chronologically (July 20, 1880 - February 26, 1906); and letters arranged alphabetically by correspondent's surname (1882-1916).

The first group also includes copies of letters from Hague to the Director of the USGS, and a letter from John W. Powell regarding the revision of regulations governing the publication of geologic-atlas sheets.

The second group consists of letters from (in most cases the files contain only one to a half-dozen items): George S. Anderson, 1894, 1897; Carl Barus, 1883; Irving E. Beeman, 1904; Charles P. Berlsey, 1904; Julius Bien \& Company, 1905; L. D. Burling, 1913; George W. Card, 1905; Victor K. Chestnut, 1904; Hiram M. Chittenden, 1894-1904; Frank W. Clarke, 1884; John M. Clarke, 1916; C. Whitman Cross, 1882-83; William H. Dall, 1902; Arthur P. Davis, 1906; Arthur L. Day, 1916; Walter W. de Lacy, 1888; Clarence E. Dutton, 1884; Robert L. Faris, 1916; Myron L. Fuller, 1916; Archibald Geikie, 1896-97; Frank A. Gooch, 1887-88; G. Brown Goode, 1894; William H. Hallock, 1883-1911; Georgianna A. Hallock, 1912; Moses Harris, 1888; Ferdinand V. Hayden, 1885; J. E. Haynes, 1915; C. Willard Hayes, 1902-8; William H. Holmes, 1908; Joseph P. Iddings, 1890-96; Thomas A. Jaggar, Jr., 1895-1926; Albert Johannsen, 1908; David S. Jordan, n.d.; James F. Kemp, 1912; Francis P. King, 1897-98; Frank H. Knowlton, 1894, 1907; Samuel P. Langley, 1896; Andrew C. Lawson, 1907; Elmer Lindsley, 1898; John W. Meldrum, 1916; Thomas M. Moody, 1888, Richard B. Moore, 1906-9; Theodore S. Palmer, 1893; Albert C. Peale, 1884, 1906; Francis C. Phillips, 1887-92; Gifford Pinchot, 1905; John Pitcher, 1902; Richard Rathbun, 1916; Charles W. Raymond, 1887; John L. Ridgeway, 1904; W. F. Sanders, 1884; Charles S. Sargent, 1897; W. A. Satchell, 1898-1916; Timothy W. Stanton, 1894-96; Charles H. Stuart, 1888; Lester F. Ward, 1889; Walter H. Weed, 1889-1914; George M. Wheeler, 1884; James E. Whitfield, 1888; and George M. Wright, n.d. The second group also contains a few copies of letters sent.

The letters primarily concern Yellowstone National Park, specifically topographic and geologic surveys, publications, analysis of waters from hot springs, and observations on eruptions of geysers. Included are letters from the Park Superintendent, Army officers posted at Yellowstone, USGS and academic geologists, Smithsonian Institution officials, and private persons commenting on articles about Yellowstone.

142. PRESS COPIES OF LETTERS SENT. 1881-1904. 16 in. 12 vols.

Arranged in two groups: eight volumes, dated 1881-93; and four volumes, dated 1887-1904. Most of the volumes contain partial indexes. The first volume contains a few letters dated 1886 and 1892.

Copies of typed and handwritten letters to USGS officials, members of professional societies, academic and foreign geologists, conservationists, publishers, Army engineers, Secretaries of the Interior, railroad company executives, mining engineers, members of Congress, and superintendents of Yellowstone Park. Included are reports on field work, information concerning publications, estimates of expenses, rock and mineral samples, legislation, status of Yellowstone Park, forest reserves, geologic nomenclature, and related matters. Many of the letters contain personal information about Hague but many of the handwritten letters are illegible. 
For later letters, see entry 143.

143. UNBOUND LETTERS SENT. 1904-16. 1.5 in.

Arranged chronologically.

Typescript copies of letters sent by Hague to USGS officials, academic geologists, publishers, officials of the Smithsonian and others concerning publications about Yellowstone Park, proceedings of professional societies, and related matters. Earlier letters sent are described in entry 142.

\section{RECORDS CONCERNING NATIONAL FOREST POLICY. 1890-97. 1 in.}

Arranged in rough chronological order.

Correspondence, memorandums, reports, copies of legislative bills and congressional documents, and other records concerning management of the Nation's forest resources. Many of the records concern the work of a committee appointed by the National Academy of Sciences, as requested by the Secretary of the Interior on February 15, 1896, to consider and recommend a national-forest policy.

Arnold Hague served on the committee.

145. BIOGRAPHICAL NOTES CONCERNING OTHNIEL CHARLES MARSH. n.d. 1 in.

Arranged in two groups: handwritten notes and typewritten text.

Outlines, memorandums, and reminiscences concerning Marsh's life and career compiled for a biography, including a copy of an article published in the USGS's 21st Annual Report, pp. 189-204. There are notes on events in Marsh's life dating from the late 1860's. These records were found among Hague's official papers.

146. WORKING PAPERS AND REFERENCE MATERIAL. ca. 1883-1915, 1929. $3 \mathrm{ft}$.

Arranged by subject or type of record. See Appendix 7 in this inventory for a summary list of file contents. A detailed checklist of the series contents is with the records.

Handwritten and typed chapter drafts (by Hague and others), lists of rock and fossil specimens, abstracts of geologic field notebooks, illustrations, chapter outlines, correspondence, printed items, photographs, and other records gathered by Hague for use in compiling Parts I and II of U. S. Geological Survey Monograph 32, "Geology of Yellowstone National Park." Part II was published in 1899 as "Descriptive Geology, Petrography, and Paleontology," by Hague and six other authors. The series includes the nearly completed manuscript ( 22 of 23 chapters) for Part I, "General Geology," which was not published. The records concern geologic strata, hot springs and geysers, volcanic activity, plant life, geologic nomenclature, and related matters.

Also included are records concerning "The Geologic Atlas of the United States," and geologic surveys in Cuba and Puerto Rico. 
147.

1 in.

Arranged chronologically.

Letters, memorandums, lecture notes, and other records concerning Yellowstone Park, the United States Geological Exploration of the Fortieth Parallel ("King Survey"), geographic names, James Bridger, and other matters.

\section{ABSTRACTS FROM GEOLOGISTS FIELD NOTEBOOKS CONCERNING THE YELLOWSTONE} REGION. 1883-97. 1.5 in.

Arranged in four intervals: $1883-89,1884-91,1893$, and 1897, and thereunder by author or subject. The dates are those of the abstracted notebooks.

Typescript abstracts, including information on hot springs, geysers, glaciation, drainage, rock types, and climate. The region covered includes large areas outside the present-day boundaries of Yellowstone National Park.

Most of the original field notebooks and many related notebooks are part of the records described in entry 172. The abstracts are chiefly from notebooks 3832 through 3953.

149. METEOROLOGICAL DATA. 1885-89. 3 in.

Arranged in four sets: $1885-86,1885-87,1885-89$, and 1888-89, and thereunder by location and date.

Temperature and barometric pressure observations taken by two Army surgeons posted at Camp Sheridan and three members of the USGS. Most of the data was collected at Mammoth Hot Springs. The records include an undated, unsigned report of precipitation and evaporation data recorded for areas in Yellowstone Park.

150. PUBLICATIONS. 1869-1912. 4 in.

Arranged by subject.

Chiefly published and reprinted monographs and articles by Hague and others concerning the exploration and geology of the Yellowstone area, annual reports of the Superintendent of Yellowstone National Park (1880, 1882-83, 1885-89, 1891-92, 1894-96, and 1903), and a tourist map of the Park based on explorations in 1882. Included is an offprint of an article titled "On the Discovery of Actual Glaciers in the Mountains of the Pacific Slope," by Clarence King, 1871, from The American Journal of Science and Arts. The dates given in the title line are publication dates.

151. PRESS COPIES OF LETTERS SENT CONCERNING DISBURSEMENTS. 1886-93. 2 in. 2 vols.

Arranged chronologically. Each volume has an index to surnames of addressees.

Letters and completed forms concerning expenses incurred by the field parties working in Yellowstone Park. The letters are signed by Hague, as Special Disbursing Agent. Most of Volume 2 was not used. 
152. REFERENCE MAPS. 1867, ca. 1878-91, 1916. 76 items. [NWCS, maps and plans]

Included are triangulation maps, contour drawings, and sketches plotted and compiled by Henry Gannett in 1878 while he was with the "Hayden Survey"; General Land Office maps of Oregon, Washington, and Wyoming; maps showing geologic sections and strata; an undated blueprint map showing the layout of Fort Yellowstone; and undated drawings and maps of various geysers and basins.

The earliest item is a map, published in 1867, of the "Yellowstone and Missouri Rivers and their Tributaries " as explored by Capt. William F. Raynolds in 1859-60. The map is color coded to show the approximate areas occupied by various indigenous Indian tribes, including the Sioux, Mountain Crows, Gros Ventres, M [illegible], Mandan, Blackfoot, Blood, and River Crow. The 1916 item is a map of the glacier system of the Pacific Forestry Reserve.

153. ANNOTATED CONTOUR SHEETS. 1897. 4 items. [NWCS, maps and plans]

Annotated contour sheets, 2 each for the Crandall Creek and Ishawooa areas. Some of the annotations label topographic features and geologic strata. The name F[rancis]. P. King appears on the sheets.

154. YELLOWSTONE SURVEY TRACINGS. Oct. 19, 1885. 6 items. [NWCS, maps and plans]

Arranged by assigned number from 1 to 6 . There is no number 5 .

Tracings showing surveys of hotel sites at the Grand Canyon of Yellowstone Falls, Norris Geyser Basin, Upper Geyser Basin, and in the vicinity of Old Faithful Geyser. The tracings are signed "B. P. Tilden, Surveyor."

155. ORIGINALS AND PROOFS OF A YELLOWSTONE FOLIO. ca. 1883-85. 48 items. [NWCS, maps and plans]

A bundle of materials consisting chiefly of parts of topographic-quadrangle maps (some are annotated); contour drawings; geologic maps; blueprint maps showing areas in and adjacent to Yellowstone National Park; caption lists; a narrative introduction; and a columnar sheet listing geysers, springs, rivers, and other water-sample collection points, giving the date of sample collection, temperature, the results of various chemical analysis, and remarks. Entries on the columnar sheet are dated 1883-85. The remainder of the records in this series are undated.

156. TRACINGS OF RIVER CHANNELS IN YELLOWSTONE NATIONAL PARK. ca. 1884. 7 items. [NWCS, maps and plans]

Cross-section and profile tracings of river and creek channels in Yellowstone National Park. Numbers assigned to streams on the tracings correspond to numbers on a rough drawn map of the waterways in the Park. A note states that these tracings were done by [William] Hallock.

\section{REFERENCE FILE OF WILLIAM HENRY WEED. ca. 1878-83. 17 items. [NWCS, maps and plans]}

The series consists of topographic and geologic maps and drawings used by William H. Weed as part of his work in Yellowstone National Park under Arnold Hague. Included are maps of Mammoth Hot Springs, Upper Geyser Basin, and other areas in Yellowstone National Park compiled by Henry Gannett when he was with the "Hayden Survey" and later when he served as Chief Geographer of the USGS; and an undated geologic map of the Upper Geyser Basin that is annotated "topography by Anton Karl, sketched by Joseph Bien, geology by Arnold Hague and William Henry Weed." 
General Correspondence and Field Notebooks, 1867-1970

158. INDEX TO THE GENERAL CORRESPONDENCE FILES (OF THE GEOLOGIC DIVISION). 1899-1915. 3 in.

Arranged alphabetically by subject. Entries for individual documents are arranged chronologically or by subject.

An incomplete index on 5 in. $x 8$ in. cards to the records described in entry 159. In addition to a file number, the entries include the date, author, and (or) subject of each document. There are no entries for individuals. There are entries for government agencies. Most of the entries date from 1902. There are cross references to a small card index which is not among the records in the National Archives. Some documents indexed in this series were not found in the records described in entry 159.

159. GENERAL CORRESPONDENCE FILES. $1890-1922.18 \mathrm{ft}$.

The files are arranged by subject or surname of individual and arranged numerically. The contents of the files are in rough chronological order. Frequent gaps occur in the numbers. Most of the records are dated 1902-15. A partial index to these files is described in entry 158. A file title list appears as Appendix 8 in this inventory.

Includes correspondence, reports on projects and field work (many in the form of letters and memorandums); agreements between the USGS and State agencies; circulars, orders, and other administrative issuances; justifications for field work in certain regions and preparation of maps; minutes of meetings; legislative bills and congressional documents; lists of employees; newspaper clippings; annotated maps; drafts of research papers, field notes of mineral surveys; photographs; and faunal charts.

The records concern cooperation with State geological surveys; coordination of projects with other Federal agencies; USGS representation at international mapping conferences; contracts with private and academic geologists to conduct field work and compile map folios; composition and work of USGS geologic field parties; qualifications, examinations, appointments, salaries, and other personnel matters; administrative procedures; budgets and appropriations; printing and distribution of maps; expositions; topographic surveys; collection of rock specimens and fossils; geologic nomenclature; petrography, paleontology, seismology, and other geologic specialties; classification of coal and asphalt lands; examination of mining claims in forest reserves; chemical analyses; and appearances of USGS geologists as expert witnesses on behalf of the Justice Department in litigation involving mineral lands.

160. GENERAL CORRESPONDENCE FILES. 1899-1952. 75 ft.

Arranged according to a decimal classification scheme, and thereunder chronologically. A few subject classes are subdivided further by subject or by surname of correspondent. A file title list appears as Appendix 9 in this inventory.

Correspondence, memorandums, USGS and Departmental orders, periodic progress reports from Division units, annotated maps, minutes of meetings, cooperative agreements with States, justifications, estimates of expenses, financial statements and other fiscal records, lists of employees, printed and processed articles and monographs, coresample analyses, lists of rock specimens transferred to the National Museum of Natural History, and geologic reports on strategic-mineral resources, dam and reservoir sites, and other subjects. 
The records concern cooperation with State governments and Federal agencies; participation on interdepartmental committees and commissions; war-minerals investigations (World War I); appointments, assignments, and other personnel matters; administration and organization of the Geologic Division; oil, oil shale, and gas investigations; publication and distribution of maps, professional societies; metal, nonmetal, and fertilizer-resource surveys; glacial drift; and earthquakes, volcanoes, and other topics of geologic investigations.

Records dating from 1899 are in File 220, Plans, Estimates, and Allotments; records dating from 1910 are in File 321, Manuscripts submitted for Geological Survey Publications; records dating from 1911 are in File 410.4, Forest Service; and records dating from 1905 are in File 500, Cooperation with State Governments. Most of the records date from 1916.

161. RECORDS CONCERNING OTHNIEL CHARLES MARSH. 1885-99. 0.75 in.

Arranged chronologically.

Letters received, copies of letters sent, memorandums, essays, copies of journal articles, and newspaper clippings. The records concern the importance of paleontology as a research tool in conducting geologic surveys, Marsh's field work for the USGS as its vertebrate paleontologist from 1882, and the controversy surrounding Marsh's decision to retain fossils collected by him and his assistants during USGS-funded field work.

162. DATA COLLECTED BY COLLIER COBB CONCERNING SWAMPLAND, TIMBER, AND DRAINAGE. 1887. 1 in.

Arranged by State: Florida, Georgia, North Carolina, and South Carolina.

Replies to Cobb's questionnaire that requested data on swampland area, prevailing timber, and effect of drainage on health in the respondent's county. Some of the replies include data, others refer Cobb to more knowledgeable individuals. These records, donated by the Harvard University Archives, were compiled by Cobb while he was an undergraduate at Harvard. He was also a part-time assistant to Nathaniel S. Shaler, a Harvard professor and part-time geologist with the USGS.

163. MONTHLY WORK REPORTS. 1901-48. $30 \mathrm{ft}$.

Arranged alphabetically by surname as follows: 1901-20, A to R; 1914-23, L to Y; 1923-28, R to W; 1931-33 L to W; 1934-48, C and D; 1901-48, R to Z; 1916-48, A to Z; 1931-51, D to Y; 1955-56, A to Z; and 1952-58, A to $\mathrm{Z}$.

Cards (5 in. $\mathrm{x} 8$ in.) completed by geologists, assistant geologists, paleontologists, chemists, special agents and others, to describe duties and percentages of time spent on each. Some reports of field personnel include a diagram, with latitude and longitude, that show the portion of the quadrangle surveyed. Later cards sometimes include project title or number.

164. RECORDS CONCERNING DIVISION EMPLOYEES. 1930-53. $24 \mathrm{ft}$.

Arranged alphabetically by surname. A list of the names appears as Appendix 10 in this inventory. 
The records include correspondence, memorandums, reports, administrative issuances, draft manuscripts, cooperative agreements, copies of articles, press releases, transcripts of meetings, list of metallurgical samples, completed “Agreement for Mineral Exploration and Development" forms, handwritten notes, vouchers, telegrams, newspapers clippings, job applications, organization charts, and plats.

The records contain information about many of the research programs administered by the Geologic Division and offer substantive insight into the planning, staffing, administration, and progress of field projects. Projects discussed in these files include investigations of mines and ore-bearing strata, ore milling and production, deposits and reserves of strategic minerals (Page and Peoples files), thermal waters and hot springs, tectonics, analyses of mineral specimens, commodity resource studies, mineral-resource appraisal and exploration, and establishment of a national minerals policy (Lasky file).

The records also concern administrative matters such as field organization, field conferences, personnel appointments and assignments, publication of professional papers, appropriations, and cooperation with other Federal agencies, especially the Bureau of Mines, Atomic Energy Commission, Defense Minerals Administration, and National Park Service, State agencies, academic institutions, mining companies, and other private enterprises.

Most of the records date from 1940.

165. DIVISION “PERSONNEL” FILES. ca. 1946-55. 10 in

Arranged alphabetically by name of employee.

Contents of the files vary. Included are correspondence, memorandums, telegrams, service-record cards, efficiency ratings, completed job-application forms, position descriptions, clippings of newspaper obituaries, letters of recommendation for awards. There are files for geologists and administrative staff. Screened files can be made available to researchers.

The files were maintained by the Geologic Division and are not official personnel files.

166. RECORDS CONCERNING ORGANIZATION, MANAGEMENT, AND PROGRAMS. 1947-54. 2.5 ft.

Arranged alphabetically by organizational unit, program area, or other subject, and thereunder chronologically. Included are a few items dating from 1943.

Primarily correspondence and memorandums, but also includes Survey Orders and other administrative issuances, budget estimates and justifications, program plans and proposals, progress and other narrative reports, minutes of meetings, press releases, staff-function charts, processed reports and reprinted articles, drafts of scientific monographs, photographs, and maps.

The records concern the organization and functions of units in the Division, planning and coordination of projects, 10-year plans, status of mapping programs, and cooperation with States and other Federal agencies.

167. REPORTS AND OTHER RECORDS CONCERNING DIVISION PROGRAMS. 1945-69. $10 \mathrm{ft}$.

Arranged by subject. 
Chiefly periodic reports, but also includes budget summaries, estimates, allotments and other fiscal records, summaries and minutes of meetings, correspondence, memorandums, project abstracts, organization plans, and copies of legislation concerning the allocation and administrative of Geologic Division personnel and financial resources. Also includes records concerning regional and interagency programs, cooperation with field and staff committees, and ongoing review and appraisal of Division programs

168. PROJECT FILES. ca. 1948-70. $27 \mathrm{ft}$.

Arranged numerically. Most of the numbers up to 1256 are preceded by two letters identifying the divisional unit that administered the project. Many numbers are missing. Records concerning unnumbered projects are in the last box.

Documents typically found in each file include forms showing project description, project status, allotments of funds, project summary, and work plans. Memorandums and maps also form a part of some files. Some of the projects concern the development of new research techniques and equipment, but most concern domestic and international field work in areas such as geologic mapping; terrain-intelligence studies; oil, oil shale, and gas investigations; mineral-resource studies; compilation of permafrost and landslide data; aeromagnetic studies; and radioactive-waste disposal. Annotations on file labels show that a few projects were begun before 1900. Some of the projects were undertaken in cooperation with Federal and State agencies.

\section{RECORDS RELATING TO COOPERATION WITH THE DEPARTMENTAL COMMITTEE ON ECONOMY AND EFFICIENCY. 1910-11. 1 in.}

Unarranged.

Completed questionnaires, correspondence, memorandums, lists of employees, printed circulars, and other records concerning the organization and management of the Division in 1910. The Departmental Committee was the channel through which directives and reports flowed between Interior Department components and the President's Commission on Economy and Efficiency.

\section{RECORDS CONCERNING DIVISIONAL REPRESENTATION ON COMMITTEES. 1949. 5 in.}

Arranged by committee, and thereunder chronologically.

Chiefly minutes of meetings, but also includes reports, work program plans, and correspondence concerning interagency river-basin committees, departmental field committees, and the USGS' coordination committee.

171. ALLOTMENT LEDGERS. 1902-10, 1913-19. 5 ft. 21 vols.

Arranged by fiscal year, some years are in more than one volume, thereunder by allottee or account, and thereunder chronologically. The first volume has an alphabetical index. In the remaining volumes, the allotment accounts are arranged in rough alphabetical order.

A typical entry shows the allotment granted at the beginning of the fiscal year, the name or title of the allottee, the date and description of the expenditure, a voucher number, and a running balance. The expenditures included salaries, and office and field expenses. 
172. GEOLOGISTS' FIELD NOTEBOOKS AND RELATED RECORDS. 1867-1939. 1032 volumes and unbound records. $27 \mathrm{ft}$.

Arranged by assigned number (frequently notebooks by one geologist or for a geographical area have consecutive numbers), and thereunder, within each notebook, by date of entry, subject, type of data, or location. Some notebooks contain an index to their contents. Some numbers between 3483 to 3565 were assigned twice.

The unbound records are in envelopes or bundles and also have assigned numbers. A numerical list of the contents of this series appears as Appendix 11 in this inventory.

The field notebooks mostly contain observations on the geology of areas defined by geographical, geological, statutory (i.e., Yellowstone National Park), or other criteria. The notebooks include narrative entries on stratigraphic units and geologic structures, cross-sections and other sketches, maps of mine shafts and tunnels, lists of rock samples, chemical analyses of minerals, mine-production statistics, computations for dams and reservoirs, triangulation and angle-traverse data, and related information. Some notebooks contain mounted typescript notes, newspaper clippings, and printed materials.

The unbound records include correspondence, drafts of papers, photographs, sketches, maps (including annotated topographic maps), and (on note cards) bibliographies, geologic notes, and indexes (usually to field notebooks).

Many notebooks contain information on several geologic and geographic regions. Most of the notebooks were compiled in the Western United States, especially in the Bisbee (Arizona), Black Hills (South Dakota), Butte (Montana), Coeur d'Alene (Idaho), Globe (Arizona), Goldfield (Nevada), Leadville (Colorado), Mercur (Utah), and Tintic (Utah) mining districts. A few notebooks contain information on areas in the Eastern United States. Some of the notebooks were compiled during visits to Canada, Central and South America, and Europe.

Included are notebooks that predate the founding of USGS in 1879. Some of the geologists served with the direct predecessor surveys and with State geological surveys. There are a few notebooks compiled by hydrologists concerning probable locations for dams and reservoirs.

More than 20,000 additional USGS field notebooks are in the Field Records Library, Special Collections, USGS Library, Denver, Colorado, where they support the agency's work-in-progress. Microfiche copies of some of the field notebooks in the Field Records Library are described in entry 173.

\section{MICROFICHE COPIES OF GEOLOGISTS' FIELD NOTEBOOKS. 1871-1969. 3 ft.}

Arranged in two collections by assigned number. The first series of numbers were assigned to notebooks accessioned by the USGS Library up to 1953 when a new series of numbers was begun. The second collection is differentiated by the notation "No." before each number. Often notebooks compiled by one individual or concerning one geographic area or project carry sequential numbers. Some notebooks contain an index to their contents. A list of the microfiche copies appears as Appendix 12 in this inventory. These copies are on negative diazo fiche.

The notebooks contain notes and narrative observations on geologic strata (often identified by quadrangle, atlas sheet, or geographic region), including correlations, profiles, and vertical-angle traverse measurements, topographic features, coal, petroleum, phosphate, iron, and other mineral deposits, mineral-land classification, well logs, and mining operations, including copies of data from mining company records, and sketches of mine workings.

Also included are itineraries, transmittal letters, memorandums, drafts of professional papers, lecture notes, lists (of rock specimens, thin sections, and photographs), newspaper clippings, index cards, notes taken from geological literature, and reports compiled by chemists and engineers. 
There are sets of notebooks concerning geographic areas such as the goldbelt regions in California and Eastern Oregon, the Fort Peck Indian Reservation, coal fields in Montana, brown-iron areas in east Texas, mineral fuels in Colorado, Utah and Wyoming, and oil and gas fields in Oklahoma, Kansas, Colorado, and Kansas, and special projects such as railway guidebooks, the Black Hills Rim Project, and a study of the ecological features of the Sagadohoe Bay tidal flat (Maine). There are also notes concerning observations in British Columbia, Mexico, Cuba,

Haiti, and Paraguay. The notebooks that predate the establishment of the USGS were compiled by geologists associated with the direct predecessor surveys.

The original notebooks are in the custody of the USGS Field Records Library in Denver, Colorado. The microfiche copies do not duplicate the original notebooks described in entry 172. Some notebook contents are typed. Many of the fiche are illegible and as a result compiler and content information on some of the fiche labels could not be verified by an examination of the fiche contents. 
USGS Director Charles D. Walcott established a Committee on Geologic Names on February 17, 1899, "to consider all names of geologic formations or other divisions of rock classification with a view to determining whether they comply with the rules of nomenclature adopted for the Survey publications and to recommend such action as may be advisable in any individual case to secure unity of nomenclature under the rules." Walcott selected Fred B. Weeks as the committee's chairman; Weeks reported to Bailey Willis, the Assistant in Geology to the Director. Willis led the committee during 1901-3; he and subsequent chairpersons reported to the Chief Geologist. As its initial work, the committee compiled and published in 1902 (USGS Bulletin 191) a bibliographic, synonomic, and distributional list of North American geologic formations, a project begun by the "Hayden Survey" and continued intermittently by the USGS after 1879. This compilation led to the multivolume Lexicon of Geologic Names of the United States. As the Geologic Names Committee monitored and standardized geologic names and usage, it also acted as a forum for discussion and its members served on national and international committees responsible for the review of codes of stratigraphic nomenclature. The three regional review-staff offices established in 1961 became Geologic Names Subcommittees in 1995; their chairpersons now form the USGS-wide Geologic Names Committee, led by the agency's Chief Paleontologist.

174. MINUTES OF MEETINGS OF THE GEOLOGIC NAMES COMMITTEE. 1899-1969. 8 ft. 16 vols. and unbound records

Arranged chronologically.

The folder in the first box contains letters to the Director from the Committee on Geologic Names, 1899-1900, concerning recommendations on geologic terminology. The 16 volumes contain only minutes of meetings and memorandums, 1901-31. The remaining records are chiefly minutes of meetings but also include correspondence, memorandums, handwritten notes, stratigraphic correlation charts, and related documents. Some minutes are accompanied by sound recordings (on flexible disks).

The meetings concern the approval or disapproval of geologic names used in USGS publications. The USGS was concerned with ensuring that staff members used terminology that was in conformance with the Code of Stratigraphic Nomenclature adopted in 1933 and subsequently revised in 1961.

The minutes dated 1940-42 (box 11) deal solely with the classification of Carboniferous and Permian rocks.

\section{STRATIGRAPHIC SUMMARIES OF GEOLOGIC LITERATURE. n.d. 8 ft.}

Arranged alphabetically by State, and thereunder numerically by geographic area. For most States, a map is included whose areas are numbered to correspond to the summaries.

The summaries, on 4 in. $x 6$ in. cards, include the title of the paper, publication or other source, name of the author, date of publication, and information concerning the geologic names listed. Maps, geologic tables, and correspondence are interspersed among the cards. The summaries, dating from 1894 to 1937 (a few extend to 1940), were abstracted by M. Grace Wilmarth, Secretary of the Committee on Geologic Names, in connection with the compilation of USGS Bulletin 896, "Lexicon of the Geologic Names of the United States (including Alaska)," published in 1938. 
176. STRATIGRAPHIC SUMMARIES OF "OUTSIDE" GEOLOGIC PUBLICATIONS. n.d. 16 ft.

Arranged alphabetically by State, Territory, or country, and thereunder chronologically by date of publication, from 1821 to 1937.

The summaries, on 6 in. $x 8$ in. cards, include the title of the publication, author, date, volume and page numbers, and the names of geologic units--with a description of their characteristics. The summaries also contain geologic tables and correlation charts. A few oversize maps and tables are included. The summaries are from USGS Bulletins, Professional Papers, and other publications, State geologic literature, and professional and scientific journals. These summaries were used in compiling correlation charts.

177. TENTATIVE CORRELATION CHARTS. ca. 1925-36. 121 items. [NWCS, maps and plans]

Chiefly handwritten tentative correlation charts of named geologic units and formations, compiled by M. Grace Wilmarth, Secretary of the Committee on Geologic Names. Also included is a printed chart titled "Stratigraphic position of the named subdivision of the Keweenawan Series of Michigan (June 1, 1929). 


\section{Records relating to West Indian Geologic Surveys, 1917-25}

In 1917 the USGS received a letter from the Department of State requesting an investigation of the mineral resources of Haiti, in accordance with the Treaty of September 16, 1915, between the United States and Haiti. The treaty stated that the United States would aid in the development of the agricultural industries and mineral resources of the Haitian Republic.

In 1917 the USGS also received a request from the head of the military government of the Dominican Republic soliciting the agency's help in surveying the country's topography, geology, and natural resources. The USGS in extending its search for war minerals to the Caribbean and Latin America in 1918, had sent geologist Henry G. Ferguson to the Dominican Republic. During the next spring USGS topographer Glenn L. Smith and USGS geologist T. Wayland Vaughan visited the Dominican Republic and Haiti to plan the surveys, to be made in cooperation with the Smithsonian Institution, Carnegie Institution, and the New York Botanical Garden. On July 1, 1919, the USGS Topographic Branch established a Division of West Indian Surveys, led by Smith, to organize, coordinate, and direct the work to 1923. Geologic Branch geologists were furloughed from the Section of Coastal Plain Investigations to conduct the geologic surveys in both countries. In Haiti USGS topographers, also furloughed from the agency, experimented with mapping from aerial photographs.

Records of the topographic portion of these USGS surveys of the Dominican Republic have been published as part of NARA Microfilm Publication T282, "Geological Survey and Marine Corps Surveys and Maps of the Dominican Republic, 1919-1923."

178. RECORDS RELATING TO A GEOLOGIC SURVEY OF THE DOMINICAN REPUBLIC. 1917-23. 2 in.

Arranged by subject.

Correspondence, reports, summaries of surface-water and rock-sample analyses, copies of mining laws and regulations, handwritten notes, maps, and other records concerning geologic and topographic surveys done by USGS geologists at the request of the Military Government. The principal geologist was Henry G. Ferguson. Some of the preliminary field work was done by T. Wayland Vaughan, Chief of the Section of Coastal Plain Investigations. Included is information on fossil deposits, petroleum reserves, and mineral resources.

179. RECORDS CONCERNING A GEOLOGICAL SURVEY OF HAITI. 1917-25. 5 in.

Arranged by subject.

Correspondence, reports, copies of mining laws, forms for water-sample and rock-specimen analyses, other records concerning organization and management of the survey project, appointments, accounts, and expenditures, and publication of the final report. A few of the items are in French. The survey was planned and led principally by Wendell P. Woodring, appointed Geologist in Charge. 
180. GEOLOGIC MAP OF THE UNITED STATES. 1932. 11 items. [NWCS, maps and plans]

A printed, color coded map, at 1:2,500,000, compiled by George W. Stose. The map is in sections with an appropriate legend for each section.

181. MAPS OF NORTH AMERICA AND THE UNITED STATES. 1893-1976. 7 items. [NWCS, maps and plans]

The maps are titled: "Reconnaissance Map of the United States showing the Distribution of the Geologic Systems so far as known," 1893; "Location of the Fertilizer Industry in the United States - 1935"; "Geologic Map of the United States," 1941; "Estimated Effective Ground Conductivity in the United States," 1954; and "Subsurface Temperature Map of North America," 1976.

182. GEOLOGIC QUADRANGLE MAPS. 1939-96. approx. 1840 items. [NWCS, maps and plans]

Arranged numerically.

The maps are numbered from GQ-1 to GQ-1778. Most of the maps are folded.

183. GEOLOGIC MAP INDEXES. 1945-74, 1985, 1991. 150 items. [NWCS, maps and plans]

Arranged alphabetically by State.

Included is a computer-derived index to geologic maps of North Dakota (1985). Some are bound booklets.

184. STATE GEOLOGIC MAPS. 1872, 1909-92. 127 items. [NWCS, maps and plans]

Arranged alphabetically by State.

In addition to geologic strata some of the maps also show the locations of oil, gas, and coal deposits. The 1872 map is a "Preliminary Geological Map of Minnesota" by Newton H. Winchell, State Geologist.

185. COUNTY GEOLOGIC MAPS. 1900-1960. 20 items. [NWCS, maps and plans]

Maps for counties in Arizona (1957-60), California (1947, 1958), Hawaii (1938), Kentucky (1919, 1938), and Maryland $(1900,1902,1911)$. The maps were compiled by State agencies with cooperation from the USGS.

186. LOCAL AREA SPECIAL PUBLISHED GEOLOGIC MAPS. ca. 1912-71. 39 items. [NWCS, maps and plans]

Arranged alphabetically by State. 
Some of the maps are accompanied by geologic charts.

187. FOREIGN GEOLOGIC MAPS. 1872, 1944-74. 39 items. [NWCS, maps and plans]

Alphabetically by county or other location as follows - Antarctica (published in New Zealand) 1963; Brazil, 1944; Costa Rica, 1962; Cuba, 1947, 1954; Ethiopia, 1970; Guatemala, 1967; Malaya, 1948-66; Mexico, n.d.;

New Zealand, 1963; Santo Domingo (copy of an 1872 map); Scotland, 1971, 1974; Sudan, 1958; Tanzania, 1974; Trinidad, 1947-61; Tunisia, n.d.; and Venezuela, 1950.

188. MAPS BY STATE AGENCIES. ca. 1910-77. 29 items. [NWCS, maps and plans]

Arranged alphabetically by State.

Geologic maps and correlation sections compiled by State geologic, mining, and other agencies.

189. MAPS BY THE GEOLOGICAL SOCIETY OF AMERICA. ca. 1953-65. 12 items. [NWCS, maps and plans]

The series consists of a tectonic map of the Alaska Peninsula, at 1:1,000,000 (GSA Memoir No. 99), geologic maps of the Alaska Peninsula, at 1:250,000 (GSA Memoir No. 99), a geologic map of the Beartooth Mountains in Montana and Wyoming, at 1:126,720 (GSA Bulletin, Volume 72), and geologic maps of areas in California, at 1:62,500 (GSA Memoir No. 35).

190. MINERAL INVESTIGATION RESOURCE MAPS. 1949-92. approx. 115 items. [NWCS, maps and plans]

A set of general maps (1949-53) followed by numbered maps from MR-1 to MR-96 (1952-71)

Geologic maps showing geologic strata, sedimentary formations, and other geologic features. Most of the maps are folded. An unnumbered "general resource map," published in 1942 and reprinted in 1959, is at the end of the series with the folded materials..

191. MAPS SHOWING LOCATIONS OF FIELD PROJECTS. 1949-64. 4 items. [NWCS, maps and plans]

Maps showing the locations of geologic field projects in Alaska (1964) and the United States $(1949,1952)$. The latter maps have insets for Alaska, Hawaii, the Canal Zone, Puerto Rico, and the Virgin Islands.

192. MISCELLANEOUS INVESTIGATIONS SERIES MAPS. 1954-97. 11 vols. and approx. 3240 items. [NWCS, maps and plans]

The series consists of published maps and map sets numbered from I-1 to I-2596. The subjects of the unbound maps include the availability of ground water and the magnetic field of the earth. The bound map sets include "Paleotectonic Maps of the Jurassic System," "Paleotectonic Maps of the Triassic System," "Geology of the Solar System," "Atlas of Oblique Maps," "Atlas of the Exclusive Economic Zone, Western Conterminous United States," "Atlas of the United States Exclusive Economic Zone, Gulf of Mexico and Eastern Caribbean Areas," "Atlas of the United States Exclusive Economic Zone, Bering Sea," and "Atlas of the United States Exclusive Economic Zone, 
Atlantic Continental Margin.” The map series was titled 'Miscellaneous Geologic Investigation' until 1974 when the series title was changed to 'Miscellaneous Investigations.' Most of the unbound maps are folded.

193. MAPS SHOWING THE STATUS OF GEOLOGIC MAPPING. 1951-55. 7 items. [NWCS, maps and plans]

Maps showing the status of geologic mapping in Alaska (1953, 1954, 1955), and the United States $(1951,1955)$. The United States maps have insets for Alaska, Hawaii, the Canal Zone, Puerto Rico, and the Virgin Islands. This series also includes a map showing "completed, current and proposed geologic mapping program - Navajo-Hopi Indian Reservations," dated December 1, 1953.

194. MISCELLANEOUS FIELD STUDIES MAPS. 1951-96. approx. 1100 items. [NWCS, maps and plans]

The maps, which show mineral deposits and geologic sections, are numbered from MF-2 to MF-2355. This map series was titled "Mineral Investigations Field Studies Maps" until 1973 when the title was changed to "Miscellaneous Field Studies Maps." Most of the maps are folded.

195. GEOLOGIC AND GEOGRAPHIC MAPS. 1968-81. 5 items. [NWCS, maps and plans]

The folded maps are titled: "Geothermal Resources of Washington," 1981 (GM-26); "Geographic Map of the Northwestern Hijaz Quadrangle Kingdom of Saudi Arabia," 1973 (GM-204B); and "Geographic Map of the Southern Najd Quadrangle Kingdom of Saudi Arabia," 1978 (GM-211B). The flat-filed items are geologic maps of the Chewelah Mountains Quadrangle, Stevens County, Washington, and mines in the Eagle Mountain area, Washington, 1968 (GM$5)$.

196. GEOLOGIC MAPS OF ANTARCTICA. 1973-89. 7 items. [NWCS, maps and plans]

These published maps, numbered from A-2 to A-14, were compiled in cooperation with the U. S. Antarctic Research Program. One of the items is a geologic map of Antarctica showing the Pensacola and Thiel Mountains (Folio 12, Geology, Antarctic Map Folio Series) published by the American Geographical Society in 1969.

197. GEOLOGIC MAP OF THE EAST HALF OF THE UNITED STATES. 1974. 2 items. [NWCS, maps and plans]

The map's scale is 1:2,500,000. The legend is on a separate sheet. The explanatory text that accompanied the map was published as USGS Professional Paper 901, "Explanatory Text to Accompany the Geologic Map of the United States" (by Philip B. King and Helen M. Beikman, 1974). The map is oversized. The map and text were reissued on CD-ROM as USGS Digital Data Series DDS-11 (by Paul G. Schruben, Raymond E. Arndt, and Walter J. Bawiec; software display by Russell A. Ambroziak, 1994).

198. MAPS OF THE CIRCUM-PACIFIC REGION. 1990-96. 8 items. [NWCS, maps and plans]

The maps, numbered from CP35 to CP44, were prepared as part of the Circum-Pacific Map Project, an activity of the Circum-Pacific Council for Energy and Mineral Resources. 
199. HYDROGEOLOGIC MAP. 1991. 2 items. [NWCS, maps and plans]

Two copies of a map titled "Geothermal Resources of Montana," at 1:1,000,000, showing locations of thermal springs and thermal wells. The map is designated HM-4.

200. GEOLOGIC MAP OF ARKANSAS. 1993. 1 item. [NWCS, maps and plans]

An oversized map at 1:500,000.

201. A MAP TITLED “THIS DYNAMIC PLANET: WORLD MAP OF VOLCANOS, EARTHQUAKES, IMPACT CRATERS, AND PLATE TECTONICS.” 1994. 2 items. [NWCS, maps and plans]

The map scale is 1:30,000,000 at the equator. The map is oversized.

202. A “MAP SHOWING THE THICKNESS AND CHARACTER OF QUATERNARY SEDIMENTS IN THE GLACIATED UNITED STATES EAST OF THE ROCKY MOUNTAINS.” 1993. 1 item. [NWCS, maps and plans]

The map, at 1:1,000,000, shows the northeastern States, the Great Lakes, parts of Southern Ontario, and the Atlantic Offshore Area.

203. GLORIA IMAGERY AND DATA FILES. n.d. 3 compact disks. [NWCS, maps and plans]

The compact disks are titled: "GLORIA Imagery and Bathymetry from the U.S. EEZ [Exclusive Economic Zone] off Washington, Oregon, and California"; “Gloria, East Coast, Disk A (Image Maps)”; and "Gloria, East Coast, Disk B (Data Files)." GLORIA is the acronym for Geological LOng-Range Inclined Asdic. 
204. PHOTOGRAPHIC PRINTS DEPICTING GEOLOGICAL FORMATIONS AND FEATURES. ca. 18931906. 111 albums. $13 \mathrm{ft}$.

Arranged in alphabetical order by geologic feature or subject category. Each photograph is captioned and includes the surname of the photographer. Many of the photographs are dated. Albums 6 and 7 are bound together. A list of the features and subjects appears as Appendix 13 in this inventory. This is series SA (NWCS, still pictures).

Black and white photographs taken by geologists and other USGS personnel during field surveys. The geologic features shown in the photographs include anticlines and synclines, caves and caverns, craters, deltas, fault-zone structures, flood plains, glacial drainage and valleys, lava flows, oil fields, mountain peaks, potholes, quarries, rivers, shore topography, springs, terraces, volcanic features, and waterfalls.

Subjects include the Grand Canyon, Niagara Falls and Yellowstone Falls, mines and mining activities in the United States and foreign countries, views of fault lines and damaged buildings after the 1906 San Francisco earthquake, and oil fields in California.

Collateral subjects in a few of the photographs include street scenes and panoramic views of towns. 
Investigations in paleontology have been an integral part of USGS missions since the establishment of the agency, whose organic law specified "reports upon general and economic geology and paleontology." The statute also required the USGS to deposit its fossils and other scientific collections in the National Museum when the specimens were "no longer needed for work in progress." Some of the early work by USGS paleontologists of identifying and correlating fossils to aid stratigraphic studies and geologic mapping continued investigations begun by the direct predecessor surveys. By the mid-1880's the USGS geologic unit contained five small-sized paleontologic divisions: vertebrates, Paleozoic invertebrates, Mesozoic invertebrates, Cenozoic invertebrates, paleobotany, and fossil insects. By 1894 these units had been replaced by a combined Division of Paleontology, which was retained during the reorganization of the Geologic Branch in 1900 and restyled a section in the Branch's Geology and Paleontology Division in 1902. In 1907 the Section was renamed Paleontology and Stratigraphy. During the reorganization of the Geologic Branch in 1944, the Section became part of the new Division of Areal Geology and Basic Sciences. When the Geologic Branch became a Division in 1949, the Section was restyled the Branch of Paleontology and Stratigraphy and continued operations under that name until all of the Geologic Division's branches were disestablished during the reorganization in 1995.

\section{OFFICE FILES OF EDWARD OSCAR ULRICH. 1897-1939. $3 \mathrm{ft}$.}

Arranged alphabetically by subject, surname of correspondent, or title of official position, and thereunder in rough chronological order - Abstracts, biological, 1931; George H. Ashley, 1910-31; H. Foster Bain, 1901-32; Florence Bascom, 1907-20; Ray S. Bassler, 1900-1924; Joshua W. Beede, 1903-23; Ernest R. Buckley, 1904-14; Henry A. Buehler, 1904-32; Charles Butts, 1910-29; William B. Clark, 1897-1916; John M. Clarke, 1901-20; E. S. Cobbold, 1925-34; Ura Cram, 1926-31; Henry B. Cushing, 1907-18; Charles E. Decker, 1927-30; Frank W. DeWolf, 1913-18; Director, 1902-31; Ira Edwards, 1924-31; George M. Ehlers, 1918-36; August F. Foerste, 1904-32; F. Julius Fohs, 1903-29; Chief Geologist, ca. 1908-31; George H. Girty, 1902-18; Winifred Goldring, 1918-33; Charles N. Gould, 1902-28; C. Willard Hayes, 1906; William O. Hotchkiss, 1914-32; Edmund O. Hovey, 1909-22; G. Marshall Kay, 1929-34; Arthur Keith, 1908-16; Edward M. Kindle, 1905-36; William A. Nelson, 1913-26; Albert H. Purdue, 1904-10; Percy E. Raymond, 1909-29; Reports, miscellaneous, n.d.; Rudoff Reudemann, 1905-33; Frederick W. Sardeson, 1913-33; Thomas E. Savage, 1908-18; Charles Schuchert, 1899-1934;

Claude E. Siebental, 1906-7; Timothy W. Stanton, 1912-31; Charles K. Swartz, 1910-16; Edward O. Ulrich, 1901-37; Stuart Weller, 1904-18; and Joseph F. Whiteaves, 1902-8. There are also miscellaneous files arranged alphabetically: A, 1902-35; B, 1896-1939; C, 1902-35; D, 1904-35; E, 1917-36; F, 1905-35; G, 1905-35; H, 1902-37; I, 1918-32; J, 1909-33; K, 1901-33; L, 1902-34; M, 1900-1939; N, 1902-35; O, 1931-32; P, 1906-38; R, 1903-35; S, 1902-36; T, 1908-34; U, 1916-32; V, 1904-32; and W, 1898-1932.

Primarily correspondence, but also includes memorandums, drafts of professional papers, minutes of meetings, drill-core logs, newspaper clippings, tables of geologic formations and tentative correlations of geologic formations, sketches of mine shafts, annotated geologic maps, photographs, a glass slide, and a glass vial containing a rock specimen.

The records concern investigations of lower Paleozoic formations by the USGS, State, and academic geologists, and critical analyses of their conclusions, to establish uniformity in stratigraphic classifications and nomenclature.

Ulrich was an Associate in Paleontology at the National Museum, 1914-44. 
206. MANUSCRIPT REPORTS AND OTHER RECORDS RELATING TO GEOLOGIC INVESTIGATIONS. ca. 1904-52. $6 \mathrm{ft}$.

Arranged by subject or type of record.

Chiefly typed and handwritten manuscript reports, some accompanied by annotated topographic and geologic maps, but also including faunal and specimen lists, work reports, notes on field trips, and administrative issuances. Some of the records concern bauxite, zinc, and other strategic-minerals investigations.

207. RECORDS CONCERNING THE [CHRONOSTRATIGRAPHIC] OZARKIAN SYSTEM. ca. 1916-42. $2.5 \mathrm{ft}$.

Arranged by subject or type of record.

Chiefly copies of manuscripts, mostly by Edward O. Ulrich, Josiah Bridge, Charles L. Dake, and illustrations of tribolites. Also included is correspondence, handwritten notes, logs of test-well drillings, tables showing correlations of "Ozarkian" faunal zones, annotated geologic maps, and copies of Josiah Bridge's masters' thesis, "The Middle Ordovician Section in East Central Missouri," of 1922, his doctoral dissertation, "The Geology of the Eminence Region," of 1929, and a typewritten set of lectures by Thomas C. Chamberlain "Principles and Theories of Geology'" course 60, 1916-17. The field investigations to "establish" the "Ozarkian System" were conducted primarily in Oklahoma and Missouri.

208. FIELD NOTEBOOKS. 1920, 1929-49. 2 ft. 25 vols. and unbound papers.

Arranged in rough order by geographic location.

Handwritten notes and sketches, usually daily, of field investigations in paleontology and stratigraphy, and transcribed drill-test logs and notes from other geological sources. Some notebooks also contain attached photographs and annotated geologic maps. Other notebooks contain inserted loose items, such as letters, note cards, and maps. Many of the notebooks, including the two labeled "1920 Ventura, Colo.," appear to have been compiled by Josiah Bridge.

209. OFFICE FILES OF JOSIAH BRIDGE. 1922-53. $4 \mathrm{ft}$.

Arranged in rough alphabetical order by surname of correspondent or subject. Most of the records date from 1930. A list of file title headings appears as Appendix 14 in this inventory.

Includes correspondence, drafts and critiques of professional papers, reports on field work, stratigraphic charts, lists of fossils from well cuttings, lists of specimens, newspaper clippings, catalogues, book lists, lecture and conference papers, Survey Orders and other administrative issuances, maps and sketches, and photographs. The records concern bauxite surveys, cooperation with State geologists and oil companies, and professional review of the analyses and correlation of stratigraphic units.

210. FIELD NOTES OF CHARLES LAWRENCE DAKE. 1930-31. 4 in. 2 vols.

The contents are arranged chronologically. 
A bound typewritten compilation of "Field Notes on Studies of the Southwest Cambrian and Ordovician." A few sketch maps and fossil drawings are included. The second volume contains excerpts from the first.

\section{CHRONOLOGICAL FILE CONCERNING THE 1944 EDITION OF A TECTONIC MAP OF THE} UNITED STATES. 1934-46. 3 in.

Arranged chronologically.

Chiefly correspondence, but also includes memorandums, sketches of map symbols, and annotated maps. The tectonic map was prepared under the direction of the Committee of Tectonics, Division of Geology and Geography, of the National Research Council, and published by the American Association of Petroleum Geologists. The Chairman of the Committee was Chester R. Longwell of Yale University. The USGS representative (member) was Philip B. King.

\section{RECORDS CONCERNING THE 1962 EDITION OF A TECTONIC MAP OF THE UNITED STATES.} 1955-65. $10 \mathrm{in.}$

Half of the records are arranged alphabetically by surname of addressee; the remainder are arranged in rough chronological order.

Correspondence, memorandums, progress reports, summaries of meetings, annotated maps, and press releases. Includes a few references to a proposed Tectonic Map of the World. The 1962 map, a revision of the tectonic map issued in 1944, was compiled and published cooperatively by the USGS and the Tectonic Map Committee of the American Association of Petroleum Geologists.

213. MONTHLY REPORTS. Oct. 1949 - Dec. 1950. 0.25 in.

Arranged chronologically.

Typescript and processed reports of branch programs. Some working papers are interspersed through the file.

\section{STAFF MEMBERS MONTHLY ACTIVITY REPORTS. 1950-52. 4 in.}

Arranged alphabetically by name of staff member.

Completed forms with blocks for group or project number (later forms request the operating unit in this space), number of days on duty, approximate time at various activities, reports on referred collections, status of current reports, and summary of activities. The report sets are not complete for each staff member.

\section{TABLES OF HISTORICAL GEOLOGY. n.d. 7 items. [NWCS, maps and plans]}

The tables concern the following areas - Northern Rocky Mountains and Plains, Southern Midcontinent Region, Appalachian Basin, Southwestern United States, and North Central Region. All the tables bear the handwritten note "preliminary." 
An act of March 2, 1895 (28 Stat. L., 939), appropriated funds specifically for "an investigation of the coal and gold resources in Alaska" by the USGS. Since 1889 Survey staff members had accompanied Coast and Geodetic, War Department, and privately sponsored expeditions to Alaska and gathered information about its geography and resources. Later acts of Congress increased the appropriations and expanded USGS work in Alaska.

The Division of Alaskan Mineral Resources was created in the Geologic Branch in 1903. The Division continued the work of preparing geologic and topographic maps of Alaska as part of the mineral-resource investigations. Later the Division also was made responsible for water-resources investigations, classification of its public lands, and the collection of mineral statistics in Alaska. In 1922 the Division was separated from the Geologic Branch as the Alaskan Mineral Resources Branch under a "Chief Alaskan Geologist."

Other records concerning USGS work in Alaska are described in the records of the Staff Geologist for Territories and Island Possessions, entry 60; the records of the Alaskan Geology Branch, entries 258-265; records concerning the Aleutian Volcano Project, entry 249; records concerning the Alaska Terrain and Permafrost Section of the Military Geology Branch, entry 285; records of the Alaskan Branch, entries 680-686; and records concerning Land and Stream Classification, entry 675.

216. FISCAL RECORDS CONCERNING FIELD EXPENSES FOR ALASKA MINERAL INVESTIGATIONS, 1901-2. 1.5 in.

Arranged by type of record.

Summary appropriation forms, abstracts of disbursements, vouchers, payrolls, and related records maintained by Walter C. Mendenhall, Special Disbursing Agent.

217. RECORDS CONCERNING THE CUNNINGHAM COAL LAND CLAIMS. ca. 1905-7. 39 items. [NWCS, maps and plans]

The records consist of tracings; planetable sheets showing the locations of coal sections surveyed in 1905 (including a key map of Cunningham Claims); and a printed map titled "Map of the Bering River Coal Field," which shows the distribution of the various kinds of coal and locations of coal sections. 
Areal Geology became a operational division in the Geologic Branch in 1900. Two years later the division became a section of the Geology and Paleontology Division. Between 1913 and 1922 the unit was divided into the Section of Eastern Areal and Structural Geology and Section of Western Areal and Structural Geology. In 1927 the section was made part of a new Section of Areal Geology and the Geology of Nonmetalliferous Deposits, which in 1944 became part of the newly created Division of Economic Geology. In 1945 Areal Geology was separated and transferred as a section to the Division of Areal Geology and Basic Sciences. In 1947 Areal Geology was renamed General Geology. The section was responsible primarily for investigating the nature and extent of geologic structures; its studies also helped to establish regional stratigraphic frameworks. One of the principal goals of the work involved improving the geologic map of the United States.

\section{RECORDS CONCERNING AREAL GEOLOGY. 1907-19. 5 in.}

Arranged alphabetically by subject, and thereunder chronologically.

Chiefly correspondence, but also includes memorandums, progress and technical reports, statistical summaries, handwritten notes, and other records, concerning the Section of Western Areal and Structural Geology and the Section of Eastern Areal and Structural Geology. Information included relates to field examinations for mapping and other areal-geology projects; mapping for the folios of the "The Geologic Atlas of the United States" by USGS and contract geologists; allotments and expenditures for field examinations and folio projects; editing and publishing folios; and cooperation with the War Department and the Forest Service. 
The "examination of the ... mineral resources ... of the national domain" was a part of the founding mission of the USGS and a Mining Geology Division was established in 1879 to administer the work. In 1894 the unit was reconstituted as the Division of Mineral Resources in the Geologic Branch. In the reorganization of the Geologic Branch in 1900 studies of mineral deposits were placed in a Division of Economic Geology, divided into the Section of Investigations of Metalliferous Ores and the Section of Nonmetalliferous Economic Deposits. Also called Metalliferous Deposits and Nonmetalliferous Deposits, two sections remained coherent entities under several organizational units. In 1947 Survey Order 163 merged the two sections as the Mineral Deposits Section in the reestablished Division of Economic Geology. The functions of the Section remained the same except for the addition of physical-exploration functions transferred from the Bureau of Mines. Surface work such as trenching was assigned to the Mineral Deposits Section. Functions associated with geophysical exploration were assigned to the Geophysics Branch. In 1949 the Mineral Deposits Section became a Branch.

\section{GENERAL ADMINISTRATIVE AND CORRESPONDENCE FILES. 1909-53. 12 ft.}

Arranged according to a decimal classification scheme. A file title list appears as Appendix 15 in this inventory.

Includes correspondence, memorandums, periodic program-status reports, telegrams, budget-allocation forms and other fiscal records, Departmental circulars, Survey Orders and other administrative issuances, project summaries, information releases, minutes of meetings, reports on mineral resources by nongovernment organizations, drafts of professional papers, maps, charts, and photographs. The records concern the administration of Branch programs; cooperation with other units of the USGS, Departmental field committees, other Federal agencies, State agencies, and professional associations such as the American Society for Testing Materials; strategic-minerals surveys during World War II and other field investigations; and public-works projects.

220. ATLASES TO ACCOMPANY MONOGRAPHS. 1881, 1883, 1903. 4 vols. [NWCS, maps and plans]

The atlases are titled "Atlas to Accompany the Geology of the Comstock Lode and the Washoe District," by George F. Becker, 1882; "Atlas to Accompany a Monograph on the Geology and Mining Industry of Leadville, Colorado," by Samuel F. Emmons, 1883; and "Atlas to Accompany Monograph XLV on the Vermilion Iron-Bearing District of Minnesota," by J. Morgan Clements, 1903.

221. MICROSCOPE SPECIMENS OF MINERALS FOUND IN GRANTS PASS QUADRANGLE, OREGON. 1908. 10 in.

Forty-one glass slides ( 1 in. x 1.75 in.) numbered from 7017 to 7077.

222. DESCRIPTIONS OF MINERALS FOUND ON THE FT. BELKNAP INDIAN RESERVATION AND IN THE JEFFERSON NATIONAL FOREST, MONTANA, WITH ACCOMPANYING MICROSCOPE SPECIMENS. 1921. 8 in.

Arranged numerically by assigned number.

Descriptive cards numbered from 1 to 121 give the locality where the sample was found, characteristics of the sample, and often on the reverse of the card, a description of the surrounding rocks where the sample was found. Each card has an attached envelope containing a slide specimen. 
Arranged by mineral, geographic area, or by type of record.

Includes core logs of bore holes, reports on chemical analyses of soil samples, correspondence, maps, newspaper clippings, reports on field investigations, reprints of articles from professional journals, congressional documents, information bulletins, and photographs. The records concern efforts by Federal agencies, sometimes at the request of private individuals and mining companies, to ascertain the quality and extent of deposits of bromine, iodine, potash, saltpeter, sodium nitrates, and talc.

224. RECORDS OF GERALD FRANCIS LOUGHLIN CONCERNING MINING GEOLOGY IN LEADVILLE AND OTHER AREAS. 1901-23. 5 in.

Arranged by subject.

Handwritten notes, diagrams, plats, memorandums, correspondence, reports, photographs of rock specimens, and other records concerning coal and other minerals and mines.

\section{MANUSCRIPT MAPS AND TABLES RELATING TO THE LEADVILLE AND TINTIC MINING} DISTRICTS. 1884-1919. approx. 240 items. [NWCS, maps and plans]

Included are sketches, tracings, blueprints, and regional maps showing the locations of mines, geologic strata intersecting mine shafts, and mine-tunnel layouts, sometimes including raises and winzes; and columnar tables giving an analysis of ores from various mines for the years 1879-1912. Of particular interest is a map of the Leadville Mining District showing the town of Leadville and the locations of mine shafts as of 1911 in the vicinity of the town

\section{OFFICE FILES OF ERNEST FRANCIS BURCHARD. 1915-45. $10 \mathrm{in.}$}

Arranged by surname of correspondent, official title, or subject.

Chiefly correspondence, but also includes memorandums, administrative issuances, and printed items concerning USGS programs and publications, cooperation with Federal and State agencies, and participation in the activities of professional associations. Of particular interest are records concerning USGS field investigations in Cuba.

Burchard served as Chief of the Section of Iron and Steel Metals from 1917 to 1944.

\section{RECORDS CONCERNING STRATEGIC MINERALS. 1940-50. $1.5 \mathrm{ft}$.}

Arranged by surname of geologist, subject, or type of record.

Includes correspondence, draft manuscripts, reports on field work, press releases, maps and mine-production statistics concerning USGS field surveys to locate workable deposits of strategic and critical minerals. Much of the work was undertaken in cooperation with the Bureau of Mines, the War Production Board, the Reconstruction Finance Corporation, and State geologists. 
Arranged in two sections--external correspondence and internal correspondence--and thereunder alphabetically by surname of correspondent or subject.

Chiefly correspondence with State and academic geologists, mining companies, other Federal agencies and USGS officials. Includes references to nickel and tungsten, and to bauxite and other minerals.

229. REPORTS AND RELATED RECORDS CONCERNING ARKANSAS BAUXITE. 1942-46. 15 in..

Arranged alphabetically by name of ore deposit.

Chiefly War Mineral Reports from the Bureau of Mines that concern bauxite deposits in Arkansas. The reports include information on test drill holes, location, ownership, geology, reserves, value, and analyses. A few reports are annotated. Also includes some correspondence.

230. ORE-BODY REPORTS OF THE ARKANSAS BAUXITE PROJECT. 1944-45. 10 in.

Arranged in rough alphabetical order by name of ore deposit.

Typescript reports by USGS geologists (including an abstract of each report). The contents of the reports follow the same format: deposit location, accessibility, surface conditions, exploration data, geology, stratigraphy, character of the ore, structure and origin of the deposit, reserves, and logs of drill holes.

231. RECORDS CONCERNING THE LOCATION OF ARKANSAS BAUXITE DEPOSITS. 1941-43. 2 in.

Arranged by type of record.

Correspondence with mining companies, data furnished by mining companies concerning the ore deposits, laboratory-analysis reports, drill-hole data sheets, and handwritten notes. The records appear to have been gathered by the Bureau of Mines for use in compiling War Mineral Reports.

232. MAPS RELATING TO THE ARKANSAS BAUXITE DISTRICT INVESTIGATION. 1942-45. approx. 1200 items. [NWCS, maps and plans]

Some of the items are arranged by mine or ore body.

Included are contour maps, maps of mine shafts and tunnels (including caved areas), planetable sheets, graphs, geologic cross sections, drilling plans, and deep drill-hole reports (on cards). The records concern investigations of the location, extent, and mineral and chemical composition of bauxite-ore deposits. There are also records concerning bauxite-ore processing. The last folder contains a memorandum, dated February 10, 1944, concerning the format and content of written reports on bauxite-ore deposits.

\section{CORRESPONDENCE CONCERNING NONMETALLIFEROUS INVESTIGATIONS. 1942-47. 3 in.}

Arranged alphabetically by surname of geologist. 
Correspondence and related records that concern field surveys to locate deposits of calcite, corundum, mica, quartz, scheelite, talc, and other minerals.

\section{RECORDS CONCERNING MAGNESITE INVESTIGATIONS. 1942-48. 4 in.}

Arranged by subject or type of record.

Progress reports on field work, correspondence, and a draft copy of the final report on magnesite deposits, primarily those in Nevada and California. The draft report includes plats that show the locations of the deposits.

Eugene Callaghan, a commodity geologist with the USGS, supervised the investigations. The ultimate objective of the program was a comprehensive report on the commercially important magnesite resources of the United States. The records also contain frequent references to brucite deposits.

\section{RECORDS CONCERNING WESTERN DOLOMITE INVESTIGATIONS. 1942-46. 2 in.}

Arranged by type of record.

Monthly progress reports, preliminary reports of findings, and correspondence. The field work was conducted primarily in Washington, Idaho, and Montana, but the records also refer to field reconnaissances in other Western States. The chief aim of the program involved determining the location and extent of high-grade dolomite deposits.

\section{REPORTS ON MINERAL EXPLORATION PROJECTS. 1946-51. $1.5 \mathrm{in.}$}

Arranged by title of report: Southeast Phosphate Studies (Florida), Bear River Phosphate (Idaho), Maryland Clay (Maryland), Colorado Plateau Exploration, Tri-State Lead-Zinc District (Missouri, Kansas, Oklahoma), Mineral Resource Studies, and Geochemical Prospecting Unit.

Chiefly periodic progress and summary reports. Some reports are accompanied by other types of documents such as minutes of meetings, correspondence, expenditures forms, and maps.

\section{RECORDS RELATING TO EMPLOYEES' MILEAGE AND OTHER FIELD EXPENSES. 1949. 1 in.}

Arranged by project number.

Chiefly memorandums or notes showing mileage and, sometimes, related expenses. Files C180 and C195 also include progress reports.

\section{RECORDS OF THE SECTION OF COOPERATION. 1917-19. 15 in.}

Arranged in two sequences alphabetically by subject, Federal agency, private firm, and correspondent's surname.

Correspondence, memorandums, statistical tables and summaries, monthly and technical reports, handwritten notes, publications, congressional documents, copies of Survey Orders, newspaper clippings, and other records concerning the administration, policies, and functions of the Cooperation Office during World War I. 
The records primarily concern cooperation with Federal agencies (particularly the war agencies), foreign countries, and private firms to supply narrative and statistical data on minerals. Also included is information on Federal control of minerals, Geologic Division publication of compiled mineral data, personnel matters, and equipment and supplies. A few records are interspersed that concern the Joint Information Board on Minerals and Derivatives, established February 14, 1918, to coordinate mineral investigations and exchanges of information in the Federal Government. The geologist-in-charge of cooperation served as the Board's Executive Secretary.

239. ANNOTATED PRINTED MAPS SHOWING WORLD MINERAL DEPOSITS. 1918. 154 items. [NWCS, maps and plans]

Arranged alphabetically by country or region.

Most of the sheets are base maps from Stanford's Library Map editions. Some of the maps are annotated to show the locations of oil, oil shale, coal, bauxite, iron, phosphate, and other minerals. The maps were published as part of the "World Atlas of Commercial Geology," (Washington, D.C., 1921).

The atlas was published in two parts: Part I, Distribution of Mineral Production, and Part II, Water Power of the World. The compilation of the atlas was begun in response to a request from the Secretary of State in December 1917.

240. MAPS OF THE MISSOURI RIVER BASIN. 1945-51. 33 items. [NWCS, maps and plans]

Maps showing the findings of geologic mapping and mineral resource investigations. Some of the maps are part of the following series of maps - "Missouri Basin Studies, Sand and Gravel Deposits," "Mineral Resources of the Missouri Valley Region," "Missouri Basin Studies, Construction Materials and Non-metallic Mineral Deposits," and "Missouri Basin Metallic Mineral Deposits." 
In 1946 a staff unit called the Base Map Control and Research Unit (also known as the Base Map Unit) was established in the Geologic Branch. The staff was responsible for maintaining an inventory of the base-map requirements of the Geologic Branch, providing a liaison with the Topographic Branch regarding technical problems relating to the use of aerial photographs in compiling geologic maps, and conducting research on the photogrammetric compilation of geologic data.

\section{RECORDS CONCERNING THE BASE MAP UNIT. 1941-60. $2 \mathrm{ft}$.}

Arranged by subject.

Correspondence; memorandums; maps; plats; technical reports; statistical tables and summaries; handwritten notes and calculations; bound reports; priority lists of the Geologic Division's mapping needs; completed order forms; price lists for maps; diagrams; circulars; press releases; a list of maps prepared and published by the Division; and other records relating to the administration, procedures, and policies of the Base Map Unit. Included is information concerning the procurement and distribution of maps within the Division; the priorities set and justifications made for mapping projects; cooperation with the USGS's Topographic Division and Federal units, such as the Department of Defense, Department of Agriculture, Bureau of Mines, and Soil Conservation Service; aerial- photo mapping; and contracts with private firms to furnish maps for the Geologic Division.

Also included are agendas, minutes of meetings, reports, memorandums, correspondence, and other records concerning the General Staff Committee, 1951-52. The Chief of the Unit was a member of the Committee.

The majority of the records date from 1946 to 1959. Many of the records dating from 1941-46 appear to be from the office files of Joseph W. Peoples, the geologist-in-charge of mapping for the Geologic Division before the Base Map Unit was established. 
In 1944 a Committee for Cooperative Investigations Abroad was established to coordinate requests from other U.S. Government agencies and foreign governments regarding geologic work (especially on mineral resources) outside the continental United States and Alaska. The committee, composed of one representative from each section in the Division of Economic Geology, was responsible to the Chief of the Division of Economic Geology. In 1946 the committee was renamed the Section of Foreign Geology. Survey Order 171 merged the Foreign Geology Section with the Alaskan Section in 1948 and renamed it the Section of Alaskan and Foreign Geology (redesignated a branch in 1949). In 1952 Survey Order 216 established a separate Alaskan Geology Branch and the former Branch was renamed the Foreign Geology Branch. In 1969 the Foreign Geology Branch was restyled the Office of International Geology; it became an office-level unit in 1971, with two branches--Latin American and African Geology, and Middle Eastern and Asian Geology.

\section{REPORTS AND RELATED RECORDS CONCERNING STRATEGIC MINERALS IN BRAZIL.} ca. 1942-47. $14 \mathrm{ft}$.

The files are arranged by assigned number.

Correspondence with the State Department and local mine operators and agents, field-investigators' reports, maps and charts, photographs, and production and sales data concerning the purchase of strategic and critical minerals. Some of the records are in Portuguese.

The records were maintained in the Rio de Janeiro office of the U.S. Commercial Company. The company was incorporated in 1942 as a subsidiary of the Reconstruction Finance Corporation.

\section{RECORDS CONCERNING THE QUARTZ COMMODITY PROGRAM IN BRAZIL. 1944-45. 10 in.}

Arranged chronologically by date of report. Some general files are at the end of the series.

Chiefly narrative and statistical reports concerning mine development, contracts with owners, quartz production and sales. Also included are maps and charts, cross sections of quartz deposits, drawings of quartz crystals, and photographs.

The Quartz Commodity Program was administered by the Foreign Economic Administration.

\section{REPORTS AND RELATED RECORDS CONCERNING THE MICA COMMODITY PROGRAM IN}

BRAZIL. 1943-46. 10 in.

Arranged by type of record.

Chiefly field reports, compiled jointly by USGS geologists Montis R. Klepper and David M. Larrabee, and a Brazilian mining engineer, that contain a description of mine workings (frequently illustrated by sketches), production data, and geologic setting. Also included are engineers' reports, monthly mine-production reports, correspondence, and photographs. Some records contain information on other minerals. A few of the records are in Portuguese.

The program was administered by the Foreign Economic Administration. 
The functions that became the core work of the Geophysics Section of the Geologic Branch were transferred in 1936 from the Bureau of Mines under the provisions of 49 Stat. L., 1787, as originally recommended in 1933 by the Interior Department's Science Advisory Board. Known originally as the Geophysical Prospecting Section, the unit became the Geophysics Section of the Division of Areal Geology and Basic Sciences in 1946, a year before additional functions relating to geophysical exploration were transferred to it from the Bureau of Mines. The Section conducted magnetic, electrical, gravimetric, seismic, and geothermal investigations. The Section, restyled a Branch in 1949, continued to exist as a unit through several reorganizations of the Geologic Division. In 1961 the Geophysics Branch was renamed the Theoretical Geophysics Branch; in the following year, the Branch was transferred from the Division's Office of Geologic Processes to its new Office of Experimental Geology.

In 1945 the USGS began a study of volcanoes in the Aleutian Islands area. The work was initially funded by the Military Intelligence Division of the Office of the Chief of Engineers. After World War II funding was provided by the Office of Naval Research. At first the work was assigned to the Alaskan Branch. After the Alaskan Branch was abolished in 1946, and its geologic work was transferred to the Geologic Branch, the Aleutian volcano investigations were assigned to the Geophysics Section.

In 1948 the Geophysics Section, in cooperation with the United States Navy, conducted a preliminary gravimetric and oceanographic survey of a portion of the continental shelf in the Gulf of Mexico.

\section{RECORDS CONCERNING PROJECTS. 1942-62. $4.5 \mathrm{ft}$.}

Arranged by project, and thereunder either by type of record or chronologically.

Correspondence, tables, charts and maps, memorandums, progress and summary reports, draft and processed reports, budget allotments and justifications, and work plans.

The records concern projects such as gamma-radioactivity and seismic-refraction surveys done in conjunction with nuclear tests conducted by the Atomic Energy Commission in Nevada, geothermal profiles and permafrost studies of areas in Alaska, thermal and seismic investigations in the South Pacific, and proposed mineral-resource explorations of the continental shelf by the Bureau of Mines.

Also included is a list, compiled in 1956, of geophysical ground surveys, arranged by State, and with location maps, report lists, and references to unprocessed data.

The continental shelf records date from 1942. The remaining records date from 1950.

246. WORKING PAPERS OF IRWIN ROMAN. 1944-49. 15 in.

Arranged by subject or type of record.

Chiefly statistical tables and summaries, but also includes maps, plats, handwritten notes and calculations, and memorandums and diagrams that relate to gravity surveys in Missouri and Kansas, and the "Double Dip-Needle Project" in Woonsocket, Rhode Island. Also included are the reference materials, data, and preliminary report concerning an experimental survey near Shullsburg, Wisconsin, to test a method of interpreting electrical-resistivity measurements made by a form of the single-probe method. 


\section{RECORDS CONCERNING RADIATION INVESTIGATIONS. 1946-62. $3 \mathrm{ft}$.}

Arranged by subject, and thereunder roughly chronologically.

Chiefly correspondence and memorandums, but also includes reports, statistical tables and summaries, completed work-plan and summary-of-expenditure forms, handwritten notes and calculations, annotated drafts of papers, publications, newspaper clippings, graphs, diagrams, and other records concerning the administration and programs of the Radiation Section of the Theoretical Geophysics Branch. Included is information relating to the plans, progress, and results of Radiation and Trace Elements investigations; and budget requests, allotments, and expenditures. Cooperation with other USGS divisions, Federal agencies, especially the Atomic Energy Commission, and foreign countries; research and use of radiation instruments and equipment; and personnel matters. Some of the projects include radon and helium investigations in Texas; gamma-ray spectrum studies; airborne radiation survey of Liberia; resistivity studies; uranium in core samples; the Atomic-Waste Disposal Program; and seismic exploration and research.

Also included are agendas, minutes, abstracts, copies of papers, and press releases concerning United Nations Conferences and other professional meetings.

248. GEOPHYSICAL INVESTIGATIONS MAPS. 1946-96. approx. 910 items. [NWCS, maps and plans]

Unnumbered maps followed by maps numbered from GP-1 to GP-1016. The maps show the results of magnetic reconnaissance surveys. The series includes a map titled "Black and White Composite Magnetic Anomaly Map of the United States" (GP-960G), prepared in cooperation with the Society of Exploration Geophysicists. Most of the maps are folded.

\section{RECORDS CONCERNING GEOPHYSICAL INVESTIGATIONS OF THE ALEUTIAN VOLCANO} PROJECT. 1948-54. $1.5 \mathrm{ft}$.

Arranged by subject or type of record.

Included are reports, working papers, seismograph-report forms, data on the calibration of scientific instruments, and tiltmeter records. Also included are photographs of volcanic activity and aerial contact prints. The first box contains a 1952 summary of the work. The last box holds labeled envelopes containing artifacts (spear points) and rock fragments.

The Aleutian Volcano Project was a joint investigation of the USGS and the Office of Naval Research. Most of these records were compiled or gathered by Austin E. Jones, a member of the Volcano Investigations Unit based at Adak Island.

250. MAPS, CHARTS, AND GRAPHS CONCERNING MINERAL DEPOSITS IN MINNESOTA. n.d. 31 items. [NWCS, maps and plans]

The records appear to show locations of ground magnetic readings. 
Work on trace elements, which began in the Metals Section of the Division of Economic Geology, was assigned to the newly established Trace Elements Unit in 1945. Later the unit was renamed the Trace Elements Planning and Coordination Office (TEPCO). Briefly in 1949 and 1950 the office was under the immediate direction of the Trace Elements Planning Committee. TEPCO was organizationally a staff function in the Office of the Chief Geologist.

TEPCO was responsible for coordinating the scientific and technical assistance rendered to the Atomic Energy Commission by the Geologic Branch (later Geologic Division) in the exploration for and appraisal of sources of strategic minerals, particularly radioactive raw material under the provisions of the Atomic Energy Act of August 1, 1946 (60 Stat. L., 755), and the Defense Production Act of September 8, 1950 (64 Stat. L., 798). Much of the field work was done by the staff of the Mineral Deposits Branch.

\section{RECORDS CONCERNING USGS EXPLORATION AND WITHDRAWAL OF MINERAL-BEARING} LANDS. $1946-56.5$ in.

Arranged by subject, and thereunder chronologically.

Chiefly correspondence and memorandums, but also includes reports, statistical tables and summaries, handwritten notes, plats, and other records, concerning the withdrawal from entry of mineral lands bearing radioactive ores and their subsequent restorations in Colorado, Utah, Wyoming, and on the Navajo Indian Reservation. Recommendations regarding withdrawal and restorations were made to and acted upon by the Mining Branch of the Conservation Division under the provisions of the Atomic Energy Act of 1946.

Also contains information relating to USGS policies on field investigations, the release of drilling information to the public, and the agreements made between property owners and the Federal Government for drilling exploration.

\section{ATOMIC ENERGY COMMISSION CHRONOLOGICAL FILE. 1947-62. $5 \mathrm{ft}$.}

Arranged chronologically.

Chiefly correspondence and memorandums, a few of which are accompanied by reports, statistical summaries, handwritten notes, plats, and diagrams concerning cooperation between the TEPCO and the Atomic Energy Commission (AEC). The records contain information relating to the planning, progress, and results of cooperative projects, particularly uranium investigations; publication of reports; results of laboratory analysis; allotments and expenditures; and personnel matters. Related records are described in entry 253.

253. CHRONOLOGICAL FILES. 1948-60. $6 \mathrm{ft}$.

$$
\text { Arranged chronologically. }
$$

Correspondence and memorandums concerning the administration and programs of the TEPCO. Included is information relating to investigations of uranium and related trace elements, cooperation with the AEC, results of laboratory analysis, conferences and meetings, allotments and expenditures, and personnel matters.

For other records relating to cooperation with the AEC, see records described in entry 252. 
254. TRACE ELEMENTS PRELIMINARY RECONNAISSANCE REPORTS. 1951-1955. 15 in.

Arranged alphabetically by State (including the Territory of Alaska), and thereunder chronologically. The first file contains an index to the reports that lists them by assigned number.

The reports include date; examiner's name; property name; owner, and location; mine workings; type of examination; type of counter used; type, age, and analysis, if a radioactive deposit was present; wall rocks, ore minerals, and gangue minerals of the mine; and potential production.

\section{RECORDS CONCERNING TEPCO-AEC CONFERENCES. 1947-56. 1 in.}

Arranged chronologically.

Correspondence, memorandums, and reports concerning conferences and meetings of the Trace Elements Planning and Coordination Office and the Atomic Energy Commission. Included is information relating to cooperative projects, such as radiation, uranium, and helium investigations, and nuclear irradiation studies; methods of research; land withdrawals for exploration; and allotments and expenditures.

256. RECORDS CONCERNING THE BUDGET OF THE TRACE ELEMENTS PROGRAM. 1955-56. 0.5 in.

Arranged chronologically.

Memorandums, statistical tables and summaries, and handwritten calculations concerning the budget for the Trace Elements Program" in Fiscal Years 1956 and 1957. The program was co-sponsored by the USGS Geologic Division and the Atomic Energy Commission's Division of Raw Materials. Also included is a "Report of the Committee on the Geologic Division's Future Nuclear Energy Program."

257. MAPS THAT ACCOMPANIED TRACE ELEMENTS MEMORANDUMS. 1954-59. 8 items. [NWCS, maps and plans]

Arranged by Trace Elements Memorandum number.

Maps prepared in cooperation with the Atomic Energy Commission showing locations of radioactivity anomalies. 
The Alaskan Geology Branch was established in 1946 with headquarters located in San Francisco, California, and a coordination and liaison office in Washington, D. C. The branch was made responsible for all the functions of the Alaskan Section of the former Alaskan and Foreign Geology Branch. The new branch also assumed the functions and responsibilities of the Aleutian Investigations Unit of the Areal Geology Branch.

The Navy Oil Unit, also referred to as the Navy Oil Program, had been organizationally part of the former Alaskan Section, but was managed from the Director's Office. Beginning in 1944 USGS geologists mapped the surface geology, studied subsurface samples and geophysical data, and conducted airborne-magnetic surveys to improve their understanding of the geologic framework and assess the resources potential of areas within and adjacent to Naval Petroleum Reserve No. 4. In 1945 the Navy Department transferred a portion of an appropriation made to investigate the oil prospects to the USGS, whose personnel operated out of a field office and laboratory in Fairbanks, Alaska.

In 1945 an Operating Committee was formed, which functioned as a Board of Directors for the entire exploratory program. The committee was originally made up of the Director of Naval Petroleum Reserves, the Director of the USGS, the Project Manager of Arctic Contractors, a representative of Hoover, Curtice, and Ruby, a representative of the Secretary of the Navy, and a representative of the Bureau of Yards and Docks. A representative of the Army-Navy Petroleum Board was added later. Although funding for exploratory work ceased in 1953, geologists continued to work in the vicinity of the Reserve. Between 1977 and 1982 the USGS managed a Navy- and Interior-sponsored program of exploration to access the oil and gas potential of the entire reserve, which had been renamed in 1976 the National Petroleum Reserve in Alaska.

\section{MINUTES OF MEETINGS AND RELATED RECORDS CONCERNING THE OPERATING COMMITTEE OF THE NAVY OIL UNIT. 1946-52. $3 \mathrm{ft}$.}

Arranged by meeting (some nonconsecutive meetings are grouped together), and thereunder by type of record.

Includes agendas, minutes and transcripts of meetings, correspondence, reports presented to the committee, and maps depicting results of seismic surveys. Included are some working papers of the Executive Operating Committee. The minutes of the meetings do not form a complete set.

259. WEEKLY REPORTS OF THE OPERATING COMMITTEE OF THE NAVY OIL UNIT. July 1946 June 1953. $2 \mathrm{ft}$.

Arranged chronologically.

Weekly reports from the project manager, at Point Barrow, Alaska, to the Chairman of the Operating Committee, concerning the status of construction projects. Some reports are accompanied by financial statements, work schedules, test-well logs, and reports of technical personnel.

260. LOGS OF BRANCH DAILY CORRESPONDENCE. Jan. 2 - June 30, 1957. 5 in.

Arranged chronologically.

Chiefly copies of outgoing letters and memorandums concerning Branch programs, including activities of the Navy Oil Unit. There are also technical reports and forms showing the status of projects. 
261. BRANCH RECORDS CONCERNING CORE SAMPLES. 1947-53. 6 in.

Arranged by type of record, test site, or type of test.

Chiefly core-analysis data forms and record sheets, but also includes some correspondence, memorandums, and charts of test wells.

262. BRANCH REPORTS. 1946-53. $4 \mathrm{ft}$.

Arranged by type of report--preliminary, special, and regular--and thereunder by assigned number.

Typescript and processed reports compiled by USGS geologists concerning investigations of the region in northern Alaska designated as Naval Petroleum Reserve No. 4. Most of the reports are accompanied by maps and charts.

263. MISCELLANEOUS RECORDS OF THE NAVY OIL UNIT. 1949-53. 2 in.

Arranged by subject.

Includes correspondence, memorandums, reports, maps information issuances, and maps concerning photogeology; status of Navy projects at Point Barrow, Alaska; stratigraphic nomenclature; and Operating Committee study programs.

264. PUBLISHED ALASKA QUADRANGLE MAPS. 1905-50. 77 items. [NWCS, maps and plans]

Arranged by series and thereunder by number.

The file contains "old series" maps numbered from 540A to 657, and "new series" maps numbered from 3 to 54. The series also includes index maps (1912 and 1927) to the "old series" items.

265. GEOLOGIC MAPS OF ALASKA. 1957, 1978. 5 items. [NWCS, maps and plans]

The maps are printed. The 1978 map is in sections. 
Beginning in 1908 a number of organizational units were formed in the Geologic Branch to investigate the occurrence and extent of mineral-fuel deposits. In 1913 the two geographic-fuels units in the Section of Economic Geology were given separate status as the Sections of Eastern and Western Mineral Fuels. In 1917 these sections were recast by commodity as well as geography in three sections--the Geology of Eastern Coal Fields, the Geology of Western Coal Fields, and the Geology of Oil and Gas Fields. The two coal sections were merged as the Geology of Coal Fields in 1919. The coal and oil-gas units were consolidated in 1924 as the Geology of Fuels Section. In 1949 the Fuels Section was restyled the Fuels Branch. In the 1960's the Fuels Branch became the Branch of Organic Fuels and then the Branch of Organic Fuel and Chemical Resources. The latter unit again was divided by commodity in 1972 into the Branches of Oil and Gas Resources, Coal Resources, Chemical Resources, and Uranium-Thorium. The first two of these units retained their names after 1972. During the 1980's the Branch of Chemical Resources was renamed Sedimentary Mineral Resources before being merged with the Uranium-Thorium unit as the Branch of Energy Minerals.

266. STATISTICS CONCERNING INTERNATIONAL COAL IMPORTS AND EXPORTS. 1913-17. 2 in. 1 vol.

Entries are arranged by country or geographic area and thereunder by year. A table of contents appears inside the front cover.

The entries consist of three columns showing the amount of coal produced, imported, and exported. Often the county from which it was imported or to which it was exported is listed with the amount. Many counties listed have no entries.

The statistics may have been gathered as part of an analysis of the availability of coal at coaling ports for Allied ships during World War I. There is a particular emphasis on the importance of regional coal supplies, especially those supplies originating in the United States and Great Britain. An undated typescript copy of an article titled "The Strategic Importance of the World's Coaling Stations" is inserted in the volume.

\section{RECORDS RELATING TO FOSSIL-FUEL INVESTIGATIONS. 1921-49. $4.5 \mathrm{ft}$.}

Arranged alphabetically by State or geographic area, and thereunder by region, project, or other subject. There are a few miscellaneous files boxed at the end of the series. Records concerning Utah date from 1930 and records concerning Wyoming date from 1921. The remaining records date from 1942.

The records consist of correspondence, memorandums, work plans, progress reports, logs of drill holes, press releases, maps and charts, expense statements, conference summaries, and printed reports.

The records concern the compilation of topographic and geologic maps to facilitate the discovery and assessment of coal, oil, oil-shale, tar-sand, and natural-gas reserves. Some field investigations were done in cooperation with the Navy Department, Bureau of Mines, and State agencies. Most of the records concern investigations initiated because of World War II. 
Arranged by numeric-subject file system. A list of file titles appears as Appendix 16 in this inventory. The Bureau of Mines file (3.b) contains records dating from 1925 and the Preparation of Maps and Reports File (20.e) contains records dating from 1931. The remainder of the records date from 1944.

Correspondence, memorandums, administrative issuances, budget justifications and other fiscal records, proposals for field work, periodic reports, minutes of meetings, conference summaries, annotated maps, Professional Papers, organization charts, press releases, copies of legislation, and cooperative agreements.

The records concern branch organization and programs; continental-shelf work; oil, oil-shale, natural-gas, and traceelements investigations; cooperation with State agencies, and departmental and interagency committees; personnel matters; appropriations, allotments and budgets; and participation in the Fourth World Power Conference.

Arranged alphabetically by State or area, and thereunder chronologically--by project or geographic area. The larger files are titled Appalachian, Alabama, Arkansas, Florida, Kansas, Kentucky, Maryland, Michigan, Mississippi, North Carolina, Oklahoma, Pennsylvania, Tennessee, Texas, and Virginia. The State listed sometimes indicates only the location of the field office, not where the work was done. Most of the records date from 1944. The records concerning Kansas date from 1923 and the records concerning Mississippi date from 1936.

Correspondence, memorandums, periodic reports of progress, drafts of professional and technical papers, press releases and other information issuances, work plans and program proposals, cooperative agreements, summary reports on fossils, logs of drill holes, gas-production data and maps.

The records concern administrative matters such as the location of field offices and assignment of personnel; cooperation with States; and oil, oil-shale, coal, and natural-gas investigations.

\section{RECORDS CONCERNING WESTERN FIELD INVESTIGATIONS. 1938-54. $12 \mathrm{ft}$.}

Arranged alphabetically by State (California, Colorado, Idaho, Missouri, Montana, New Mexico, North Dakota, Oregon, South Dakota, Utah, Washington, and Wyoming), and thereunder by project or geographical area.

The Missouri file chiefly concerns the Missouri River Basin. Records concerning California and New Mexico begin in 1938. The remaining records date from 1943.

Correspondence, memorandums, press releases, progress reports on field work, allotment forms, program proposals, drafts of Professional Papers, summary reports on fossil deposits, logs of drill holes, and maps and sketches.

The geologic surveys were undertaken to determine the probable location and extent of oil, oil-shale, natural-gas, coal, and tar-sand deposits. The surveys frequently resulted in the revision of geologic maps.

271. MISCELLANEOUS ADMINISTRATIVE AND PROJECT FILES. 1949-54. $2 \mathrm{ft}$.

Arranged by subject. 
Correspondence, memorandums, project progress reports, summaries of meetings and conferences, administrative issuances, personnel lists, work plans, and maps. The records concern the scope of branch programs and the status of individual projects.

272. PHOTOGRAPHS OF AN OIL-SHALE PLANT. ca. 1927. 22 items. 1 booklet.

Arranged by assigned number (from 62 to 85 ). Some numbers are missing. This booklet is filed with the textual records.

Mounted and black and white photographs are bound in a booklet titled "Supplement to Experimental Oil Shale Plant Pictorial Report." The photographs show retorts, the crusher, hopper, condenser assembly and other equipment.

The location of the report is not known.

273. CENTRAL CLASSIFIED FILES. 1953-58. $8 \mathrm{ft}$.

Arranged according to the same subject-numeric file system used for the Central Classified Files, 1953-74, described in entry 52 (appendix 4).

Correspondence, memorandums, allotment forms and other fiscal records, press releases and processed issuances, proceedings of regional supervisors' conferences, project descriptions, and program plans.

The records concern the development and administration of branch programs, cooperation with State agencies, assignment of personnel, organization and location of field offices, and related matters. Most of the projects discussed in these files concern coal investigations.

274. MAPS SHOWING THE LOCATIONS OF OIL AND GAS FIELDS. 1914-64. 18 items. [NWCS, maps and plans]

An unnumbered series of printed maps titled "Oil and Gas Fields of the United States." All of the maps are in two sections. All of the maps are at 1:250,000. The legend varies from map to map.

275. MAPS PUBLISHED IN THE OIL AND GAS JOURNAL. 1932, 1934. 3 items. [NWCS, maps and plans]

The maps are titled "The Oil and Gas Journal's Map of Oil and Gas Pools in the United States and Canada," and "The Oil and Gas Journal's Map of Oil and Gasoline Trunk Pipe Lines in the United States."

276. OIL AND GAS INVESTIGATION MAPS. 1944-92. approx. 270 items. [NWCS, maps and plans]

The maps numbered from 1 to 109 are preliminary maps. Maps numbered from 110 to $224-\mathrm{C}$ on carry the prefix "OM." Some of the maps are folded. 
277. OIL AND GAS INVESTIGATION CHARTS. 1944-96. approx. 160 items. [NWCS, maps and plans]

The preliminary charts are numbered from 1 to 39 . Charts numbered from 55 to 148 carry the prefix "OC." About half of the maps are folded.

278. MAPS SHOWING THE LOCATIONS OF COAL FIELDS IN THE UNITED STATES. $1908-61$.

18 items. [NWCS, maps and plans]

Most of the maps are in sections and some are accompanied by text.

279. COAL MAPS. 1935-49. 23 items. [NWCS, maps and plans]

Unnumbered maps showing areas in Alabama, Colorado, Georgia, North Carolina, Oklahoma, Utah, Washington, and Wyoming. Twelve of the maps are of Oklahoma and are dated 1935 and 1944.

280. COAL INVESTIGATION MAPS. 1950-95. approx. 180 items. [NWCS, maps and plans]

Arranged numerically from C1 to C146. Many of these maps are folded.

281. COAL MAP OF NORTH AMERICA. 1988. 2 items. [NWCS, maps and plans]

An oversized special geologic map at 1:5,000,000. The map is in two sections, north half and south half. The map is accompanied by a booklet of explanatory text. 
The Geologic Branch established an informal unit in June 1942 to prepare "geologic reports for military use in areas of strategic importance." The Military Geology Unit (MGU) was equivalent organizationally to a Section. The MGU operated under an interdepartmental cooperative agreement, formalized the following October, between the War and Interior Departments. With direction and funds from the Office of the Chief of Engineers, the MGU's staff prepared intelligence reports about the terrain, engineering concerns, soils and geology, ground-water resources, and available construction materials on the areas selected by the Army Engineers. The MGU played a significant role in planning for the invasion of Sicily, but its work thereafter in World War II was focused on the Pacific.

The MGU was formalized as in 1946 and restyled a Branch in 1949. The Military Geology Branch (MGB) conducted a wide range of special studies for the U.S. Army and its Engineers, the U.S. Air Force, the Defense Intelligence Agency (DIA), and the Civilian Intelligence Agency. The MGB's Strategic Studies (1945-72) contributed to the comprehensive, small-scale products of the National Intelligence Survey. Other Cold-War programs by the MGB included Pacific Engineer Intelligence (1959-65), Pacific Geologic Surveys (1946-62), Alaska Terrain and Permafrost (1947-65), USGS Team in Europe (1954-64), Austere Landing Sites (1956-70), Special Intelligence (195972), and Nuclear-Test Detection (1962-72). In 1960 the USGS established a Special Projects Branch (SPB); the SPB and the MGB reported to the Office of Interagency Programs and Special Services. Administrative control of the two branches passed to the Assistant Chief Geologist (ACG) for Engineering Geology in 1963 and to the ACG for Environmental Geology in 1969. Most of the MGB's functions had been given to the DIA and other agencies before the Branch was disestablished in 1972. The SPB was discontinued in 1980.

\section{GENERAL CORRESPONDENCE FILES. 1943-53. 2 ft.}

Arranged by subject, and thereunder chronologically.

Primarily correspondence, but also includes project plans, reports, memorandums, minutes of meetings, conference agendas and summaries, lists of geographic names, charts, and graphs. The records concern the allocation of personnel, allotments and expenditures, and other administrative actions relating to terrain and permafrost investigations in Alaska, geologic surveys of the Pacific Basin, postwar topographic and mineral-resource surveys in Central Europe, and technical cooperation with the Joint Research and Development Board, created in 1946, and its successor, in 1947, the Research and Development Board (Department of Defense).

\section{REPORTS ON GEOLOGIC INVESTIGATIONS OF WESTERN NORTH PACIFIC ISLANDS AND}

RELATED MATTERS. ca. 1947-64. $3 \mathrm{ft} .78$ volumes and unbound papers

Arranged by subject.

Chiefly bound reports, catalogues, bibliographies, gazetteers, and technical manuals compiled by the Military Geology Branch (for the Office of the Chief Engineer, General Headquarters, Far Eastern Command) translating and summarizing Japanese geological literature. The subjects include mineral and fuel resources, terrain studies, soil surveys, geophysical-research methods, and related geologic studies. Some of the reports were prepared with the assistance of the Soil Conservation Service of the Department of Agriculture. There are also processed monographs concerning water supplies, harbor development, and construction of airstrips and storage depots. Geographic areas addressed include Ryukyu-Retto, the northern Ryukyus, Okinawa, the Palau Islands, the Mariana Islands, Formosa (Taiwan), and Japan. Some reports include maps and copies of photographs. 
There are similar reports on areas in Korea, the Aleutian Islands, and Germany. A file of unbound material consists of questionnaires, correspondence, notes, and manuscript reports concerning water supplies for cities in Japan.

Related records are described in entry 628.

\section{RECORDS CONCERNING PACIFIC GEOLOGIC SURVEYS. 1947-60. $5 \mathrm{ft}$.}

Arranged by subject or type of record, and thereunder chronologically.

Correspondence, periodic reports of progress, memorandums, statistical data, drafts of technical papers and studies, drill-core analysis charts, meeting summaries, index maps, photostatic copies of maps complied by Japanese geologists, and bibliographic lists concerning mineral resources, water supplies, sanitation, topography, and geology of areas that include Japan, Korea, Manchuria, the Ryukyu Islands, the U.S. Trust Territory of the Pacific Islands, and Guam.

The Pacific Geologic Surveys Section, located in Tokyo, also cooperated with United States military authorities, searched university libraries to compile lists of resource materials, translated technical papers, and maintained liaison with mining companies.

\section{RECORDS OF THE ALASKA TERRAIN AND PERMAFROST SECTION. 1945-54. $7 \mathrm{ft}$.}

Arranged alphabetically by project, surname of individual, agency, or other subject.

Correspondence, orders, circulars and other administrative issuances, minutes of meetings, financial statements, allotment summaries and other fiscal records, memorandums, program plans, progress and project status reports, analysis of drill cores and soil samples, and topographic and geologic maps. The records concern Alaska projects, such as the Aleutian volcano investigations, Arctic Research Laboratory, hydrologic surveys, land classification, naval petroleum reserves, and administrative matters relating to personnel assignments, cooperation with the Army Corps of Engineers, departmental field committees, and other USGS units, and publication of professional papers based on field work.

286. PRELIMINARY MAPS CONCERNING STRATEGIC-MINERALS INVESTIGATIONS. ca. $1940-46$. 33 items. [NWCS, maps and plans]

Printed geologic maps and correlation charts showing geologic strata and deposits of minerals such as bauxite, and occurrences of copper, iron, lead, phosphate, tungsten, and zinc. Some maps are labeled "War Mineral Investigations."

287. GERMAN-LANGUAGE GEOLOGIC MAPS. ca. 1918-44. approx. 4200 items. [NWCS, maps and plans]

Arranged by county or region, and sometimes thereunder by subject. Some maps concerning a city or area are in bound sets. About one quarter of the maps are folded to accompany booklets in file cases. Some maps are marked "Heringen Collection."

Included are published maps, topographic and geologic maps, tracings, and what appear to be annotated air-photo maps. The maps, which generally concern military geology, economic geology, lithology, topography, and water 
resources, center on specific subjects such as vegetation and soil types, locations of raw materials, industrial infrastructure, ground-water and surface-water resources, floods and canals, coastlines and river deltas, and highway and railroad systems. Some of the maps are in color.

The maps and booklets in the file cases also include information about geography; coordinates for aircraft; and charts of power stations, sub-stations, and generating systems. Some of the booklets dedicated to a region or country include information about the number of hotels, post office and telephone facilities, and kilometers to the nearest large city. Some of the counties and regions covered in these materials are France, Belgium and the Low Countries, the British Isles, Ireland, the Scandinavian counties, the Baltic States, Poland, the European portions of the USSR, Italy, Romania, Malta, Greece, Turkey, Yugoslavia, the Middle East, North African countries, and India. 
Operations by the USGS Topographic Branch originated in part in the practice by the "King Survey," from its beginning in 1867, of mapping topography and geology simultaneously in the field. The territorial surveys led by Hayden and Powell adopted this method early in the 1870's. When Congress did not establish the proposed "Coast and Interior Survey" in 1879 to conduct all geodetic, land-parceling (cadastral), and topographic surveys, Director King began within the USGS a modest program of topographic mapping led by Chief Topographic Engineer Allen D. Wilson, who had served with the "King Survey" and the "Hayden Survey." Wilson's topographers provided the base maps the USGS required for the geologic mapping of mining districts and geologic regions in the West. Congress also did not approve restoring the "Wheeler Survey" or establishing an equivalent agency within the War Department for national mapping, but an act of August 7, 1882 (22 Stat. L., 329), provided increased funds to the USGS "to continue the preparation of a geological map of the United States." As Congress had disapproved earlier resolutions to extend officially USGS work outside the public-land States and Territories, this statute was intended by its sponsors to authorize the agency's operations nationwide.

Under the new law, Director Powell hired additional topographers and began the nationwide program of topographic mapping, supervised by Chief Geographer, Henry Gannett, a veteran of the "Hayden Survey" and the Tenth Census. The work and field organization of the USGS Geographic Branch (later Topographic Branch) was organized by geographic regions, "but controlled by geologic considerations." Sections of drawing, astronomy and computing, and instruments supported the Branch's geographic sections and subsections. In 1888 Congress began making specific line-item appropriations for topographic surveys.

Director Walcott reorganized the Topographic Branch into the Divisions of Triangulation and Topography and four geographic sections in 1894, placed its employees under civil-service rules, and improved the quality of their products. In 1896 Walcott transferred Gannett to other duties and took direct administrative charge of the Branch. In the same year Congress authorized the placement of bench marks by USGS topographers and the sale to the public of their topographic maps. Control of the Branch passed in 1900 to a Topographic Committee led by Richard U. Goode, whom King had appointed to the USGS in 1879. In 1907 the Branch was reorganized according to a plan prepared by a committee headed by Robert B. Marshall, who was made Chief Geographer in 1908. In 1919 the title of the Branch's chief was restored to Chief Topographic Engineer. Claude H. Birdseye led the Topographic Branch between 1919 and 1929.

An act of March 3, 1891 (26 Stat. L., 1103), authorized the creation of forest reserves and placed them under the administrative control of the Interior Department's General Land Office (GLO). In 1896 Director Walcott established within the Topographic Branch a Division of Geography and Forestry, administered by Gannett, to handle matters concerned with general geography, including the preparation of papers and the compilation of related maps. The act of June 4, 1897 (30 Stat. L., 34), directed the Secretary of the Interior to survey public lands that had been or might be designated as forest reserves. An act of February 1, 1905 (33 Stat L., 628), transferred the management of the forest reserves, renamed national forests, to the Department of Agriculture's Bureau of Forestry, which had been established as a Division in 1881. The USGS shifted the classification of the national forests to the Bureau of Forestry, but retained as a separate line item the topographic and special surveys of the national forests until they were combined in 1918 with the general line item for topographic surveys. An act of March 4, 1907 (34 Stat. L., 1269), renamed the Bureau of Forestry the Forest Service.

The Topographic Branch continued to be organized chiefly by regions. In 1905 the Branch comprised the Divisions of Western Topography, Eastern Topography, and Geography. The field work, processing of field data, and map preparation was supported by Sections of Triangulation and Computing, Inspection of Surveying and Mapping, and Instruments and Records. In 1907 the Branch reformed its geographic units into Atlantic, Central, Rocky Mountain, and Pacific Divisions. By 1921 their support units were organized in sections responsible for computing, drafting, inspection and editing, relief maps, and photo mapping. Thomas P. Pendleton served as Chief of the Section of Photographic Mapping. 
During and after World War I the Topographic Branch actively developed or refined techniques and instruments for improving aerial photography and using the products to compile maps. Chief Topographic Engineer Birdseye encouraged the Branch's experiments with the new photogrammetric methods of mapping for surveys in the United States and in Haiti. In 1923 Birdseye led the second half of the USGS survey of the topography along, and the water-power, irrigation, and flood-control potential of, the Colorado River; subsequently, he supervised the ground and photogrammetric mapping of the site of Hoover Dam. In 1933 the USGS and the new Tennessee Valley Authority (TVA) began cooperative projects that included a multiplex-photogrammetric survey of the entire valley to provide coverage by first planimetric and then topographic maps. In World War II some of the TVA-project veterans continued the strategic-mapping program for the War Department, including aids to strategic and tactical bombing, and other operations in the combat theaters, and the strategic-mineral surveys. Branch personnel also developed the trimetrogon method of rapidly producing topographic maps, shaded-relief maps, and aeronautical charts of areas worldwide.

In 1946 the Topographic Branch established the Plans and Coordination Division and Research and Technical Control Division as headquarters-staff units to handle administrative matters and coordinate Branch functions. The two Staff Engineers appointed in 1945 became Assistant Chief Topographic Engineers in charge of these new divisions. They advised the Chief Topographical Engineer on matters relating to long-range planning and program development and those involving research strategies and technical standards. In 1949 the Topographic Branch was restyled a Division and its subordinate divisions became branches. In the same year, in response to increasing exploratory work on the continental shelf, the Division began including on its topographic maps that showed coastal and navigable waters information about underwater contours, certain obstructions, and other landmark features.

In 1980 the Topographic Division was reorganized and renamed the National Mapping Division. The Divisions received from the Director's Office the Geography Program of its Land Information and Analysis (LIA) Office and the major portion of the discontinued Publications Divisions. LIA was renamed the Office of Earth Sciences Applications, but discontinued in 1982 and its Earth Resources Observation Systems Program passed to the National Mapping Division. 
General Records, 1879-1982

288. GENERAL ADMINISTRATIVE FILES. 1879-1947. $57 \mathrm{ft}$.

Arranged numerically in subject categories, and thereunder in rough chronological order. A few subjects are further subdivided alphabetically by surname of correspondent. Records relating to some subjects were filed under several numbers. As an example, files concerning the Forest Service are numbered 100.3 and 162. A list of file titles appears as Appendix 17 in this inventory.

Correspondence; annual, project, and field inspection reports; memorandums; State and Federal legislative bills and related documents; minutes of meetings; circulars, Survey Orders and other processed issuances; allotment tables, financial statements and other fiscal records; plats and maps; lists of employees; and newspaper clippings.

The records document the functions and programs of the Topographic Division, particularly its mapping programs undertaken in cooperation with municipalities, counties, States, Federal agencies, interdepartmental committees, and other USGS units; development of systematic mapping symbols and uniform scales for government maps; and adoption of photogrammetric techniques and advanced map-making processes. Also included are records relating to map editing and printing, the Board of Surveys and Maps, the Temple bill (Temple Act of 1925; 43 Stat. L., 1011), position classification and other personnel matters, and emergency-relief projects. A compilation, prepared about 1910, shows the funds allocated by the USGS for topographic mapping from 1879 (File 19). Many of the early records concern appropriations, expenditures and estimates, and USGS cooperation with States. There are a few items dated after 1947.

289. GENERAL ADMINISTRATIVE FILES. ca. 1890-1953. $55 \mathrm{ft}$.

Arranged by subject according to a decimal-classification scheme, and thereunder chronologically. Some subjects are subdivided by surname of correspondent, agency, company, State, geographic area, project, or type of record. The file system was adopted from the one used for the General Classified Files, 1912-53, of the Office of the Director (entry 51). A list of file titles appears as Appendix 18 in this inventory.

Correspondence, memorandums, departmental and USGS administrative issuances, estimates, justifications and other fiscal records, annotated maps and plats, USGS press releases, minutes of General Staff Committee meetings, legislative and other congressional documents, magazine and newspaper clippings, periodic reports of Division activities, telegrams, photographs, and resolutions, minutes of meetings and reports of professional organizations.

The records primarily concern administration of topographic-mapping programs; cooperation with States, USGS units, Interior Department agencies, departmental and interdepartmental committees, other Federal agencies, and foreign countries; development of mapping techniques and methods; appropriations; personnel matters; and liaison with professional associations. A large segment of the records is designated File 571, Cooperation with States. This file, which is arranged alphabetically by State or other area, contains many of the records in this series dated before 1947. The earliest document is an cooperative agreement with Rhode Island in 1888.

The records also concern triangulation surveys and topographic mapping, and include cooperative agreements, State legislative bills and documents, reports on surveys (some reports include a history of topographic surveys in a State), and sketches of triangulation stations. This file includes records concerning survey work in Cuba, Haiti, Hawaii, and Santo Domingo. Other files document work in geographic areas: File 573, Alaska (the records date from 1900); and File 900, divided into the Atlantic, Central, Rocky Mountain, and Pacific Regions.

Earlier central files of the Division are described in entry 288 and later central files in entry 290. 
290. CENTRAL CLASSIFIED FILES. ca. 1947-59. $84 \mathrm{ft}$.

Arranged according to a subject-numeric classification system, the same as that used for the central classified files, 1953-74, of the Office of the Director (entry 52). A list of file titles appears as Appendix 19 in this inventory. The primary subject headings are Accounting (from 1939), Budget, Buildings and Grounds, Committees, Communications (from 1939), Contracts, Cooperation (from 1944), Education, Equipment and Supplies, Forms, Information (from 1924), Inventories, Legal, Map Distribution, Map Production, Meetings, Organization and Management, Personnel (from 1939), Programs and Plans, Public Relations, Records, Reports and Statistics, Reproduction, Research, Security, Topographic Surveys (from 1938), Transportation, and Vehicles. The dates given in parentheses above show the date of the earliest document found in that subject category. Many subjects are further subdivided by project, USGS unit or region, committee, Federal agency, or State. Many files contain documents dating from 1947, but most of the records date from 1953.

Correspondence; memorandums; monthly narrative and statistical reports from Division units; reports on conferences, field trips, and mapping projects; minutes of meetings and reports of interagency committees, boards, and the General Staff Committee; newspaper clippings; press releases; Survey and departmental orders, and other administrative issuances; budget justifications, project authorizations, and other fiscal records; annotated maps; cooperative agreements; congressional bills and documents; and mapping instructions and specifications.

The records concern the administration of topographic survey and mapping programs; budgets and allocation of funds; cooperative projects; organization and management of the Division; mapping techniques and instruments; policies and procedures relating to the compilation, revision, and distribution of maps; and personnel matters.

291. HISTORICAL RECORDS COLLECTION. ca. 1879-1975. $25 \mathrm{ft}$.

Arranged by type of record or subject. A box list showing most of the series contents is in the first box. Records of a similar type or relating to the same subject are often, but not always, found together.

An eclectic collection of materials that relate to the personnel, programs, and history of the Topographic Division. Included are instructions, technical manuals, brochures, pamphlets, drawings, and photographs concerning aerial photography and apparatus (some items are in German, French, and Italian); newspaper clippings, lists, birth certificates, award citations, memorials, biographies, and other items concerning the appointment, service, and professional accomplishments of the Topographic Division personnel; notes, manuscripts, and correspondence concerning the history of the Division; memorandums, Survey Orders and other administrative issuances, organization charts, correspondence, copies of legislation, summaries of staff meetings and conference, and press releases relating to the organization and operation of the Division and the USGS.

This collection was gathered and maintained by Nell Carico, a member of the Topographic Division staff.

292.

FISCAL RECORDS CONCERNING FIELD EXPENSES OF THE GEOGRAPHIC DIVISION. 1887-88.

6 in.

Arranged chronologically (2nd quarter of 1887 and 2nd quarter of 1888) and thereunder by type of document.

Vouchers, abstracts of disbursements, and other related records for salaries, transportation, lodging, equipment, and expenses of field parties--chiefly in California. The records were compiled by James C. Pilling, Special Disbursing Agent. 
Arranged in rough chronological order.

Chiefly correspondence, completed forms, vouchers, lists of equipment, and other records relating to Tufts' service with the 29th Engineers, American Expeditionary Forces, while on military leave from the Division.

Tufts' duties, while stationed in France, included delivering lectures on the interpretation of aerial photographs.

294. REFERENCE FILE. ca. 1917-41. 10 in.

Arranged by subject or type of record. A subject titles list accompanies the records.

Includes principally typescript, processed, and printed copies of articles, reports, and professional papers, but also contains correspondence, minutes of meetings, newsletters, and bulletins of the American Engineering Council, biographies of prominent topographers, congressional documents, and other records concerning mapping programs in the United States and other countries. The records include an author's edition of a "Report of Geographical Field Work in the Yellowstone National Park," (in 1878) by Henry Gannett. Of particular interest is a file containing recommendations made by the Board of Surveys and Maps regarding adoption of the Harriman Geographic Code System for the indexing of maps. These papers appear to have been collected by Claude H. Birdseye.

295. RECORDS CONCERNING COLORADO RIVER EXPEDITIONS. ca. 1917-29, 1938. $1 \mathrm{ft}$.

Arranged by subject. A list of file titles is part of the records.

Chiefly diaries, magazine excerpts, newspaper clippings, reports, press releases, lists of supplies, and other records concerning Claude H. Birdseye's survey of the Grand Canyon in 1923. Also contains reports, copies of articles, and clippings concerning other Colorado River expeditions; printed brochures and other records relating to Hoover Dam and national parks; and reports, on post cards addressed to the Director of the USGS, made by Amos Burg during his Colorado River trip in 1938.

The early records and annotations to the records were added later by a member of the Division staff.

296. CORRESPONDENCE OF OFFICIALS IN CHARGE OF FIELD SURVEYS. 1918-49. 5 ft.

Arranged alphabetically by surname of official. A list of folder headings appears as Appendix 19 in this inventory. To aid researchers the field-office location of each individual as determined from the file contents is shown on the list. Some individuals were seasonal field personnel before becoming supervisors.

Included are letters received and copies of letters sent, instructions on the conduct of field work, reports on projects, memorandums, telegrams, completed forms showing allotments and balances of funds, annotated quadrangle maps, and photographs.

The records concern the funding and administration of cooperative-mapping projects, including the status of projects and proposed projects; cooperation with Federal, State, territorial, and municipal agencies, particularly the Land Classification Branch, National Park Service, Tennessee Valley Authority, and Public Works Administration; 
field-office operations and personnel matters; discussions about types of field equipment; the disposition of field notes, computation books, photographs, and other records created in the course of projects; corrections to quadrangle maps; map symbols and colors; and evaluation of aerial-photographic methods.

This series is particularly valuable for information regarding the establishment of a photogrammetric unit in the USGS [Pendleton file].

\section{REPORTS CONCERNING FOREST SERVICE MAPPING PROJECTS. 1934-38. 2 in.}

Arranged by national forest as follows: Bitterroot and Nez Perce, Cabinet and Flathead, Cibola, Crook, Gila, Humboldt, Kaniksu and Coeur d'Alene, Lassen, Lincoln, Lolo, and Santa Fe.

Narrative reports, some with maps and photographs, of topographic surveys within selected areas of national forests. The positions of some personnel employed on the surveys were funded by various programs for emergency relief. The surveys were done by personnel of the Maps and Surveys Section of the Forest Service. Of interest is a report titled "Summary of the Field Activities of the Maps and Surveys Section of the Branch of Engineering of the Forest Service, Region 5."

298. SPECIAL MAGAZINE FILE. 1947-53. 4 in.

Arranged alphabetically by name of magazine, publisher, titles of articles, or surname of author.

Correspondence, copies of manuscripts, memorandums, copies of addresses and speeches, and USGS circulars. Chiefly concerning approval of technical articles written by Topographic Division staff members that were intended for publication in magazines and professional journals, and papers to be presented at professional meetings. There are also draft chapters for agency manuals.

The subjects of the papers include photogrammetry and aerial mapping, development of mapping techniques, equipment used for aerial mapping, the uses of topographic mapping to aid in river development and highway construction. There are a few papers by individuals not employed by the USGS.

299. PUBLICATIONS RELATING TO TOPOGRAPHIC SURVEYS AND MAPPING. 1920-55. 56 items. [NWCS, maps and plans]

Copies of circulars, bulletins, instructions, and other publications relating to topographic surveys and the preparation of topographic maps. Of particular interest are items titled USGS Administrative Publication, "The Preparation of Illustrations for Reports of the United States Geological Survey, with [a] Brief Description of Processes of Reproduction," (John L. Ridgway, 1920); USGS Bulletin 788-E, "Topographic Instructions of the United States: E. Topographic Mapping," (William M. Beaman, 1929); and USGS Circular 101, "Surveying and Mapping in Alaska," (Gerald A. FitzGerald, 1951).

Original illustrations relating to the Ridgway administrative publication are described in entry 114.

300. TOPOGRAPHIC MAP SPECIFICATION SHEETS. ca. 1955-70. $1.5 \mathrm{ft}$.

Arranged alphabetically by State or Possession and thereunder alphabetically by project name. 
Completed "Specification Sheet for Mapping Project" forms. Information blocks include the project name, State, project number, area, aerial photography, quadrangles, controls, compilation, finishing, and remarks. Not all the blocks are completed on all the forms.

\section{RECORDS CONCERNING “THE NATIONAL ATLAS OF THE UNITED STATES.” 1954-71. 7 in.}

Arranged by subject, and thereunder chronologically.

Correspondence, memorandums, copies of authorizations, reports, newspaper clippings, press releases, and publications relating to the formulation, development, and publication of the National Atlas. Also includes the minutes of meetings and reports of the National Academy of Sciences' Committee on the National Atlas, 1954-61; and photographic prints of the Atlas project's staff, the completed Atlas, and the presentation of the Atlas to the Secretary of Interior, Rogers C. B. Morton.

The USGS began the National Atlas project in 1962, but had to suspend operations in July 1963 because of reductions in the Department of the Interior's appropriations. Refunded in 1965, the project continued under the guidance of Arch C. Gerlach until the Atlas was published in 1970. William B. Overstreet succeeded Gerlach as director of the project in 1967.

302. "THE NATIONAL ATLAS OF THE UNITED STATES". 1970. 1 vol. and 63 items. [NWCS, maps and plans]

A bound copy of "The National Atlas of the United States," accompanied by supplemental sheets and overlays.

303. UNNUMBERED AND MISCELLANEOUS REPORTS. 1971-82. 4 items. [NWCS, maps and plans]

This series consists of the following items: a metric coordinate reader, with explanatory text; a bound booklet titled "Progress Report on the Cartographic Activities of the United States, January 1, 1977-December 31, 1981," (for presentation to the XIV Pan American Consultation on Cartography in Santiago, Chile, March 22-April 3, 1982); a copy of Landsat Data Users NOTES, Issue No. 21, January 1982; and 7 maps concerning the "Terrain Analysis of the Lunar Equatorial Belt," (preliminary report, July 1, 1964). 
304. RECORDS CONCERNING COOPERATIVE-MAPPING PROJECTS. 1926-49. $6 \mathrm{ft}$.

Arranged by project, geographic area, State agency, and other subjects. A list of file titles appears as Appendix 20 in this inventory.

Correspondence, memorandums, reports, instructions, map and instrument specifications, telegrams, annotated maps, tracings, congressional documents, invitation and bid forms, allotment statements and other fiscal records, agreements, and photographs.

The records chiefly concern mapping projects undertaken in cooperation with municipalities, counties, State agencies, Army Corps of Engineers, Bureau of Indian Affairs, National Park Service, Forest Service, Department of Justice, Federal Power Commission, and units of the USGS. Some of the projects were funded with emergency-relief appropriations.

Most of the files are marked 212 and may have once been part of a larger file.

305. RECORDS CONCERNING JOSEPH HYDE PRATT. 1938-41. 2 in.

Arranged in rough chronological order.

Chiefly correspondence and reports relating to Pratt's efforts, as an Engineer Consultant with the Division, to formulate a policy of cooperation between the USGS and State governments to plan, fund, and administer topographic-mapping programs.

306. RECORDS CONCERNING THE CONFERENCES ON INTER-AMERICAN RELATIONS IN THE FIELD OF EDUCATION. 1939. 4 in.

Arranged by type of record.

Reports, speeches, lists of participants, program notes, and other records concerning the four conferences held in October and November 1939. Claude H. Birdseye attended the conferences. 
Records concerning Aerial Photography and Mapping, 1925-83

307. RECORDS CONCERNING AERIAL MAPPING. 1927-48. $6 \mathrm{ft}$.

Arranged by Federal agency, private company, USGS organizational unit, geographic area, or other subjects. A list of file titles appears as Appendix 21 in this inventory.

Correspondence, memorandums, annotated plats and index maps, reports, fiscal records, invitation and bid forms, contracts, photographs, and specifications for photographic equipment and prints.

The records concern mapping programs undertaken in cooperation with, and based on aerial prints furnished by, the military air services, Soil Conservation Service, Forest Service, and other Federal agencies. One folder contains records dating from 1920 documenting the acquisition of aerial photographs from the Army Air Service [later the Army Air Corps]. An act of March 4, 1929 (45 Stat. L., 1595-1596) authorized the USGS to enter into contracts with private companies for aerial photographs. Many records also relate to the design, testing, and operation of aerialphotographic equipment, and concurrent developments in the methods and process of compiling maps from aerial prints.

Many of the files are marked 211 and may have once formed part of a larger file.

308. RECORDS RELATING TO THE AMERICAN SOCIETY OF PHOTOGRAMMETRY. 1925, 1938-41. 5 in.

Arranged by meeting or subject.

Minutes of meetings, programs, correspondence, memorandums, photographs of meetings, drafts of papers, articles, and other printed material concerning photographic instruments and techniques, and related records relating to the annual, semiannual, and Board of Direction meetings of the American Society of Photogrammetry. Also includes records concerning the work of several of the Society's committees and other subjects. Most of the records date from 1938-40.

Claude H. Birdseye served as President of the Society and on several of its committees.

309. MAPS CONCERNING AERIAL PHOTOGRAPHY IN THE UNITED STATES. 1938, 1947-72. 25 items. [NWCS, aerial photography]

Color-coded index maps showing the areas photographed by government and commercial firms, 1947-72. The 1938 map shows areas photographed by certain types of single-lens and multiple-lens cameras, and quadruple cameras. The maps are accompanied by processed explanatory statements issued by the USGS's Map Information Office that list the government agencies and commercial firms that maintain collections of aerial photographs, address the uses of index maps of photographs, discuss the availability of aerial photographs, and mention the principal types of photography obtained and used by photographers.

310. INDEXES FOR AERIAL PHOTOGRAPHY. ca. 1935-43. approx. 770 items. [NWCS, aerial photography]

Arranged in three sets - original negatives, 8 in. x 10 in. prints, and 20 in. x 24 in. prints, and thereunder within each set alphabetically by project symbol. 
Indexes to aerial-photography projects principally for areas in Arkansas, California, Kansas, Kentucky, Maine, Massachusetts, Michigan, Missouri, New Hampshire, New Mexico, New York, Oregon, Rhode Island, Texas, Vermont, and Wisconsin. Most of the indexes are at scales of 1:20,000, 1:27,000, and 1:43,000.

311. AERIAL PHOTOGRAPHY. ca. 1935-43. 186 film cans. [NWCS, aerial photography]

Arranged on rollfilm by symbol and roll number. A film-can locator is available in the research room. There are also 105 -mm positive aerial indexes arranged by entry number as found in Special List 25, "Aerial Records in the National Archives."

The series related to aerial photography projects principally for areas in Arkansas, California, Kansas, Kentucky, Maine, Massachusetts, Michigan, Missouri, New Hampshire, New Mexico, New York, Oregon, Rhode Island, Texas, Vermont, and Wisconsin. Most of the photography was done at 1:20,000, 1:27,000, and 1:43,000.

312. MAPS SHOWING THE STATUS OF AERIAL PHOTOGRAPHY OF ALASKA. 1946-47. 4 items. [NWCS, maps and plans]

Maps showing the status of vertical and trimetrogon aerial photography of Alaska.

313. STATUS OF AERIAL MOSAICS OF THE UNITED STATES. 1947-73. 7 items. [NWCS, maps and plans]

Color-coded index maps of the United States showing areas for which aerial mosaics have been compiled by or for government agencies or commercial firms. The 1967 and 1973 maps include insets for Alaska, Hawaii, Puerto Rico, and the Virgin Islands.

\section{COLOR-IMAGE PHOTOMAP QUADRANGLE MAPS OF UNITED STATES BOUNDARIES AND} PORTS OF ENTRY. 1977-83. approx. 250 items. [NWCS, maps and plans]

All the maps are at 1:25,000. The series does not include any maps showing the Alaska-Canadian boundary. 


\section{Records concerning Triangulation, Control, and Computing, 1882-1973}

315. TRIANGULATION RECORD BOOKS. ca. 1882-1906. $2 \mathrm{ft} .17$ vols.

The first 11 volumes are arranged by subject or geographic area: Appalachian Party, New Mexico, Meridian Lines, Indian Territory ( 2 vols.), Montana, Black Hills, Atlantic, New York and Maine, Rocky Mountains, and Pacific. The remaining six volumes, which provide nationwide coverage, are arranged by assigned number.

Each volume has an alphabetical index to triangulation stations.

The volumes were compiled from field notes and other primary sources. The entries include the geodetic location of triangulation stations, primary triangulation and primary traverse computations, and other observations. The data furnished control for topographic quadrangle maps. The Meridian Lines volume also includes a few drawings showing the location of the stations and ground marks, relative to nearby structures and natural features, that control the meridian line.

The Pacific Triangulation Book includes notes on sites in Alaska and observations made by the "Wheeler Survey."

\section{MICROFILM COPIES OF TOPOGRAPHIC SURVEY FIELD COMPUTATION NOTEBOOKS.}

1882-1963. approx. 3750 microfilm rolls. [NWCS, maps and plans]

Arranged in two sets - 35-mm microfilm and 16- $\mathrm{mm}$ microfilm. The $35-\mathrm{mm}$ microfilm is arranged numerically by microfilm roll numbers from 1 to 3658, assigned after the microfilm was accessioned by the National Archives, with gaps and additional numbers containing A and B suffixes. Roll numbers from 3594-3598 were used twice. There is a microfilmed list (on roll 3598) of the notebooks copied on rolls 1-1988, covering the period 1882-1947. The list shows, for each notebook, the microfilm number, book number, State, type of survey, observer, and year. No list has been found for the remainder of the rolls. The 16- $\mathrm{mm}$ microfilm is arranged by microfilm-roll numbers from C505 to C604, assigned by the USGS. The numbers appearing on the 16-mm microfilm rolls, from C505 to C604, continue one of the $35-\mathrm{mm}$ microfilm lots previously accessioned by the National Archives.

Microfilm copies of topographic-survey notebooks containing field date and office computations relating to triangulation, transit traverse, and leveling. There are notebooks for Haiti (rolls 1960-1966) and Antarctica (roll 3593). Each microfilm roll covers several notebooks, not necessarily concerning the same area or recorded by the same surveyor. The microfilming was done by the USGS in lots with a separate sequence of roll numbers assigned to each lot. An index in the custody of the USGS may refer to the original roll numbers.

The contents of many of the rolls of microfilm deal with vertical and horizontal control are duplicated on the microfiche described in entry 317.

317. MICROFICHE COPIES OF HORIZONTAL AND VERTICAL CONTROL NOTEBOOKS. ca. 1947-73. 35 binders. [NWCS, maps and plans]

Arranged in two sets - horizontal-control notebooks and vertical-control notebooks, and thereunder by notebook number from AH-1 to AH-1319o (binders 1 to 8) and AV-1 to AV-1675c (binders 1 to 14). Chiefly transit traverse and electronic-traverse records. Each notebook in labeled with the State, project (sometimes), quadrangle, type of record, name of observer, and the year the record was made.

Many of the notebooks were also reproduced on the microfilm described in entry 316. 
318. STATUS OF VERTICAL AND HORIZONTAL CONTROL IN THE UNITED STATES. 1948, 1952. 3 items. [NWCS, maps and plans]

Two sets of color-coded index maps (1st edition, 1948; 2d edition, 1952) showing the status of vertical control (levels) and horizontal control (triangulation and transit traverse) as reported by the USGS, Coast and Geodetic Survey, and other Federal agencies. 


\section{Records concerning Emergency Relief Activities, 1933-43}

319. RECORDS CONCERNING PUBLIC WORKS TOPOGRAPHIC SURVEY PROJECTS. 1933-41. $10 \mathrm{in.}$

Arranged by subject.

Chiefly copies of rules and regulations, Executive orders, operating procedures and other processed issuances, memorandums, and correspondence concerning project planning, cooperative programs, appropriations and expenditures, status of projects, employment, and related subjects. The series also contains completed forms--"Project Report for Planning of Federal Construction and Repairs" (one set for each State including Alaska, Puerto Rico, and Washington, D.C.)--that outline a 6-year national mapping program (1938-43).

The projects were funded initially by the Emergency Relief Appropriation Act of April 8, 1935 (49 Stat. L., 115).

320. RECORDS CONCERNING TEMPORARY APPOINTMENTS. 1933-40. 5 in.

Arranged by name of appointee in two alphabetical sequences: one for appointees in South Carolina, and the second for all other appointees.

Copies of notifications of appointment, efficiency reports by supervisors, and internal memorandums concerning appointments and temporary personnel. The central office and field positions were funded by emergency-relief appropriations.

321. WEEKLY REPORTS CONCERNING TEMPORARY APPOINTMENTS. 1933-43. 5 in.

Arranged chronologically.

Tabular reports concerning changes in the number of appointments to temporary positions with the Division that were funded by the Public Works Administration. 
322. MANUSCRIPT QUADRANGLE MAPS. ca. 1889-1945. approx. 62,000 items. [NWCS, maps and plans]

Arranged alphabetically by name of quadrangle.

Included are planetable sheets, metal mounts, annotated advance sheets, and corrected published quadrangle maps, often with the name of the editor and date of changes. Some of the manuscript maps are labeled "original drawing."

323. MANUSCRIPT UNITED STATES BASE MAPS. ca. 1899-1914. approx. 80 items. [NWCS, maps and plans]

Contour and shaded-relief planetable sheets and tracings. Some are signed by William O. Tufts.

324. MANUSCRIPT STATE BASE MAPS. ca. 1902-24. approx. 60 items. [NWCS, maps and plans]

Arranged in two sets - numbered maps and maps arranged alphabetically by State.

The series consists of planetable sheets and tracings drawn to show drainage areas, contour intervals, and shaded relief. Some of the manuscripts were done by Gilbert Thompson and John H. Renshawe.

325. BOUNDARY INFORMATION MAP FILES. ca. 1853, 1889-1914. approx 180 items. [NWCS, maps and plans]

Most of the maps are in bound sets. Areas covered are the international boundary between the United States and Canada from the Strait of Georgia to the Atlantic Ocean, the international boundary between the United States and Canada from Cape Muzon to Mount St. Elias, and the international boundary between the United States and Mexico. Also included is a copy of a map based on surveys made by Capt. William H. Emory in 1853 of the boundary between the United States and Mexico, accompanied by several loose maps showing that same boundary area dated 1889-1914.

326. TRIANGULATION-CONTROL PLANETABLE SHEETS. ca. 1887-1929. approx. 1150 items. (NWCS, maps and plans)

Arranged numerically from 1 to 1144 .

Many of the sheets are metal mounts. Some of the sheets are annotated with the quadrangle name, scale, name of compiling topographer, and date.

327. PLANETABLE SHEETS OF COUNTY SURVEYS. 1888, 1906-21. approx 280 items. [NWCS, maps and plans]

Arranged by State, not alphabetically, and thereunder by county.

The series consists of planetable sheets and tracings for counties in the States of Alabama, Florida, Georgia, Hawaii, Louisiana, Mississippi, North Carolina, Pennsylvania, South Carolina, Texas, and Virginia. Many of the 
sheets for counties in the southeastern United States, Mississippi, and Texas were compiled as part of soil surveys. The 1888 sheets are for areas in Texas.

328. PLANETABLE SHEETS OF THE CUSTER BATTLEFIELD NATIONAL CEMETERY. ca. 1891. 2 items. [NWCS, maps and plans]

The maps show the location of the cemetery and the approximate positions of troop commands at the Battle of the Little Big Horn in Montana Territory in 1876.

329. MISCELLANEOUS PLANETABLE SHEETS. 1896-1921. 44 items. [NWCS, maps and plans]

The records consist of 16 sheets showing a survey of Oahu Island, Hawaii, by the Army Corps of Engineers in 1913; 4 sheets of the Idaho National Forest, ca. 1921; 6 undated and untitled sheets showing parts of Clallam and Jefferson Counties, Washington; and 18 sheets showing primary traverses in Tennessee, 1896.

330. PLANETABLE SHEETS OF MINING DISTRICTS. ca. 1907-8. 50 items. [NWCS, maps and plans]

The records concern the Virgilina Copper District in Virginia and North Carolina, and the Gold Hill Mining District in North Carolina.

331. PLANETABLE SHEETS OF THE VIRGILINA [NORTH CAROLINA-VIRGINIA] SPECIAL SHEET. 1908-9. 24 items. [NWCS, maps and plans]

The scale is $1: 24,000$

\section{SURVEYS OF MILITARY FORTS. ca. 1911-18. 90 items. [NWCS, maps and plans]}

Included are planetable sheets showing surveys of Mulberry Island, Virginia (part of Camp Abraham Eustis), and Camp Bragg, North Carolina; a blueprint map of Fort Monroe, Virginia, and vicinity; manuscript sheets showing Fort Hancock, Georgia; an annotated published map of the Fort Omaha Balloon Field; and five envelopes containing completed printed note sheets that record information about the location and condition of wagon bridges, railway stations, railway bridges, roads, and aviation fields in the vicinity of Fort Omaha.

333. MAPS OF THE IDAHO-MONTANA BOUNDARY. n.d. 7 items. [NWCS, maps and plans]

Six manuscript maps and one tracing showing the entire boundary.

334. MOUNTED MANUSCRIPT CONTOUR MAPS OF THE WASHINGTON-IDAHO BOUNDARY LINE. ca. 1911. 1 item. [NWCS, maps and plans]

The map was published as part of USGS Bulletin 466, "Retracement of the Boundary Line Between Idaho and Washington from the junction of Snake and Clearwater Rivers Northward to the International Boundary" (by Robert B. Marshall, 1911). 
335. MANUSCRIPT CONTOUR MAPS OF PYRAMID LAKE AND VICINITY, NEVADA. ca. 1912.

33 items. [NWCS, maps and plans]

336. METAL-MOUNT RELIEF MAPS. ca. 1913-23. 15 items. [NWCS, maps and plans]

Colored relief maps of the following areas - Lock Haven, Pennsylvania, San Francisco, California, Cleveland to New York City, the District of Columbia with portions of adjacent Virginia and Maryland, New York City and vicinity, Rocky Mountain National Park, Seven Devils, Idaho, Grand Canyon National Park, Glacier Peak National Park, Mesa Verde National Park, Mount Rainier National Park, and Yosemite National Park. Some of the maps are labeled J[ohn]. H. Renshawe and some are dated.

337. SHADED-RELIEF METAL BASE MAPS. ca. 1914-25. 13 items. [NWCS, maps and plans]

Included are maps of Yellowstone National Park; Kentucky, New Mexico, New York and Long Island, central North Carolina, Ohio, and West Virginia; and irrigated areas in northern California,

338. MANUSCRIPT CONTOUR MAP OF BENNETTS WELL, CALIFORNIA. n.d. 2 items. [NWCS, maps and plans]

The map's scale is 1:40,000 and it is accompanied by a photographic overlay.

339. METAL-MOUNT FIELD SHEETS. ca. 1942-57. 231 bundles. [NWCS, maps and plans]

Each bundle is labeled with the State and thereunder the areas or quadrangle names of the enclosed sheets.

340. PHOTOGRAMMETRIC COMPILATION SHEETS. ca. 1942-54. approx. 6,000 items. [NWCS, maps and plans]

Arranged by State and thereunder by sheet title.

Each sheet is stamped with a task record showing dates and names of individuals making corrections, control checks, sterocompulations, and related operations. Sheets for Puerto Rico and the Virgin Islands are at the end of the series.

341. ANNOTATED QUADRANGLE MAPS. ca. 1976-90. approx. 15,000 items. [NWCS, maps and plans]

Arranged in sets by State.

Published 7.5-minute topographic quadrangle maps annotated with names of geographic features; historic sites and ruins; ponds, lakes, reservoirs, dams, ditches, and canals; towns and schools; and other subjects. The annotated maps were used in the Phase II compilation of the National Geographic Names Data Base.

The series includes annotated maps for Washington, D.C., American Samoa, Guam, and the Virgin Islands. 
General Published Cartographic Records, 1865-1995

342. SPECIAL TOPOGRAPHIC MAP SERIES. 1865, 1886-1983. approx. 930 items. (NWCS, maps and plans)

Arranged alphabetically by subject or map title. Oversized maps are filed separately. See appendix 22 in this inventory for a list of the series contents.

Included are shaded-relief, panoramic, and land-classification maps. Areas covered included those administered by the National Park Service, mining districts, national forests, cities and counties, military camps and forts, experimental farms, naval petroleum reserves, and prison sites. The 1865 item is a map of Yosemite Valley; a notation on the map states that it was drawn by "J[ames]. T. G[ardiner]."

Most special topographic maps relating to Alaska and Hawaii are in separate series.

343. MICROFILM COPY OF HISTORIC REFERENCE FILE OF TOPOGRAPHIC QUADRANGLE MAPS. 1884-1977. 260 rolls. [NWCS, maps and plans]

The 35-mm microfilm is arranged in two sets: maps dated 1884-1972 are on rolls 1 to 193, and maps dated 197377 are on rolls 194 to 260. Notes filed with the microfilm indicate that the National Cartographic Information Center has computer-sorted catalogs designed to be used with this microfilm.

344. “ATLAS OF MASSACHUSETTS.” 1884-90. 1 vol. [NWCS, maps and plans]

A bound set of maps at 1:62,500 plus an index map compiled by the USGS in cooperation with the Topographical Survey Commission of the Commonwealth of Massachusetts. A cover page states that the set consists of 54 maps. Only 50 maps were found at the time this inventory was compiled.

345. “TOPOGRAPHIC ATLAS OF THE UNITED STATES: PHYSIOGRAPHIC TYPES.” 1900. 1 vol. [NWCS, maps and plans]

A set of folio maps and descriptive text, compiled by Henry Gannett, describing a coast swamp, a graded river, an overloaded stream, appalachian ridges, ozark ridges, ozark plateaus, hogbacks, volcanic peaks, plateaus and necks, alluvial cones, and a crater. The map scales vary.

346. "PHYSICAL GEOGRAPHY OF THE TEXAS REGION.” 1900. 1 vol. [NWCS, maps and plans]

The maps, compiled by Robert T. Hill, are part of a series - "Topographic Atlas of the United States." The maps are preceded by descriptive text. The atlas contains illustrations of topographic forms, types of mountains, plains and scarps, rivers and canyons; and a map of Texas and adjacent Territories.

347. PROGRESS MAPS. 1888, 1917, 1934. 4 items. [NWCS, maps and plans]

Arranged as described below. 
A negative photostatic copy of an index map showing the areas covered by aerial mapping in southwestern Louisiana in 1934; a color-coded map, dated 1888, of the United States showing locations of topographic surveys of interior areas and the coastline, triangulation work done by the USGS and the U.S. Coast and Geodetic Survey (USC\&GS), and the location of astronomic stations for the USGS and the USC\&GS; an index map, dated 1917, showing areas covered by topographic mapping (including insets for Alaska and the Sacramento and San Joaquin Valleys of California) west of the 97th Meridian; and a second index map, dated 1917, showing topographic and geologic surveys in that part of the United States lying east of the 97th Meridian.

348. "LAND FORMS OF THE UNITED STATES.” ca. 1891. 14 items. [NWCS, maps and plans]

A stapled 14-page set of sample quadrangle maps showing landforms designated as: youth, maturity, old age, rejuvenated region, young volcanic mountain, moraines, drumlins, river flood plains, a fiord coast, and barrier-beach coast. The contour intervals vary from map to map. Four pages of explanatory text precede the maps.

349. MAP SHOWING AREAS TRAVERSED BY THE DEATH VALLEY EXPEDITION. 1892. 1 item. [NWCS, maps and plans]

A printed map showing parts of California, Nevada, Arizona, and Utah traversed by a Division of Economic Ornithology and Mammalogy (later the Bureau of Biological Survey) party under the direction, successively, of Theodore S. Palmer and C. Hart Merriam in 1891. The map, which shows captioned topographic features, was compiled by Charles H. Fitch, a topographer with the USGS.

350. MAPS OF THE UNITED STATES. 1899. 2 items. [NWCS, maps and plans]

A relief map and a contour map of the continental United States compiled by Henry Gannett. Both are September 1899 reprints of the edition of December 1896.

351. PUBLISHED STATE MAPS. 1889-1990. approx. 840 items. [NWCS, maps and plans]

Arranged alphabetically by State. Oversized maps are filed separately.

Topographic, relief, geologic, and index maps. Some of the maps are in sections. There are maps dated before 1900 for Connecticut, Massachusetts, and Oklahoma (Indian Territory). About one-third of the maps are oversized. There are maps for Tutuila Island and the Manua Islands, American Samoa, at the end of the oversized segment.

352. PUBLISHED COUNTY TOPOGRAPHIC MAPS. 1902-95. approx. 540 items. [NWCS, maps and plans]

Arranged alphabetically by State, Arkansas, California, Colorado, Connecticut, Illinois, Iowa, Kansas, Kentucky, Maryland, Michigan, Minnesota, Missouri, New Mexico, Ohio, Pennsylvania, Utah, Virginia, Washington, Wisconsin, and West Virginia, and thereunder by county.

Most of the maps are at 1:50,000 and 1:100,000. The earliest maps are Jefferson County, Kentucky, 1912; Topography of Election Districts, Maryland, 1902; and Muskingum County, Ohio, 1912.

There are also oversized maps for counties in the States of California, Connecticut, Pennsylvania, and Virginia. 
353. MAP OF CADDO COUNTY, OKLAHOMA. 1903. 2 items. [NWCS, maps and plans]

A topographic map in two sections showing locations of lands reserved for various school purposes, locations of lands reserved for various Indian purposes, and locations of proposed and completed bridges.

354. PUBLISHED METROPOLITAN AREA MAPS. 1885-1974. approx. 170 items. [NWCS, maps and plans]

Arranged alphabetically. The oversized maps are filed separately.

Included are aerial maps and topographic-atlas sheets. There are maps dated before 1904 for Boston, Pittsburgh, New York, St. Louis, and Washington, D.C. Some of the maps were compiled by city agencies. A few of the maps are in sections. Almost half of this series consists of oversized maps.

355. MAPS SHOWING MAJOR PHYSIOGRAPHIC PROVINCES AND REGIONS OF THE UNITED STATES. 1916-46. 4 items. [NWCS, maps and plans]

Printed maps showing physiographic divisions $(1919,1946)$ and provinces $(1916,1941)$ of the United States. Division and province outlines and names were suggested by the Association of American Geographers.

356. "MAP OF MILITARY ACTIVITIES.” 1918. 1 item. [NWCS, maps and plans]

A printed map of the contiguous United States showing military department boundaries and locations of military installations, including posts, depots, hospitals, schools, aviation fields, and chemical-warfare sites. The map was compiled by "A[cheson] F. Hassan, Captain, Engineers."

357. "SPECIAL REPRINT OF THE CITY PORTION OF THE MAP OF WASHINGTON, D.C., AND VICINITY." 1918. 1 item. [NWCS, maps and plans]

A map bearing printed annotations chiefly showing the locations of Federal and District government agencies; but also labeling recreation fields, parks, and municipal bathing pools; headquarters of service organizations; steamboat wharves; electric-railroad stations; and other sites. The map was part of a brochure that was produced for the Conference on the Limitation of Armaments, November 11, 1921. A copy of the brochure is with the records described in entry 114.

358. TOPOGRAPHIC MAPS OF THE REPUBLIC OF HAITI AND THE DOMINICAN REPUBLIC. ca. 1919-20. 25 items. [NWCS, maps and plans]

Arranged by county and thereunder by geographic area or quadrangle.

The series consists of printed maps in Spanish (Dominican Republic) and French (Haiti). 
359. STATUS OF TOPOGRAPHIC MAPPING AND INDEX OF QUADRANGLE MAPS. 1922-78. 1 vol. and 40 items. [NWCS, maps and plans]

Arranged in rough alphabetical order by State. Some States are grouped together regionally.

Included are maps concerning the status of orthophotoquad, topographic, and intermediate mapping; a bound set of topographic-quadrangle-map indexes (1937); index maps and 7.5 sheets, for the San Joaquin Valley, California, 1914; and a map titled "Status of Topographic Mapping in the United States," accompanied by a handwritten note stating that "this map shows defense zone as described by War Department, September 2, 1942."

360. PLANNING MAPS. ca. 1934. 2 items. [NWCS, maps and plans]

Two base maps titled "Administrative Planning Map of the United States," undated, and "Proposed Plan for Completion of Topographic Mapping of the United States," 1934. Both maps show 15-minute-quadrangle subdivisions and include inserts for Alaska, Hawaii, the Philippine Islands, the Canal Zone, Puerto Rico, and the Virgin Islands.

361. PUBLISHED MAPS OF THE UNITED STATES. ca. 1890-1987. approx. 150 items. [NWCS, maps and plans]

The series includes base, outline, relief, and contour maps at scales from 1:10,000,000 to 1:2,500,000. Also included are a map of the southeastern United States prepared for the Tennessee Valley Authority $(1: 1,000,000)$, and a map showing the physical divisions of the United States $(1: 7,000,000)$.

Many of the maps in this series are oversized. Included among the oversized maps is a relief map by John $\mathrm{H}$. Renshawe dated $1920(1: 3,168,000)$.

362. MAPS OF AREAS ADMINISTERED BY THE NATIONAL PARK SERVICE. 1939-93. 12 items. [NWCS, maps and plans]

Topographic and relief maps of national parks, a national monument, and a national recreation area.

363. "MOUNT HOOD AND VICINITY, OREGON-WASHINGTON.” 1984. 1 item. [NWCS, maps and plans]

A contour map at 1:100,000.

364. MAP SHOWING THE NATIONAL WILDERNESS RESERVATION SYSTEM. 1987. 2 items. [NWCS, maps and plans]

Two copies of a map of the United States showing areas designated as part of the National Wilderness Reservation System. A map of Alaska is on the reverse.

365. MAP OF ISLE ROYALE NATIONAL PARK, MICHIGAN. 1987. 1 item. [NWCS, maps and plans]

The scale is 1:62,500. This map is oversized. 
366. MAP OF THE NATIONAL WILD AND SCENIC RIVER SYSTEM. 1990. 1 item. [NWCS, maps and plans]

A map of the United States showing segments of rivers classified as wild, scenic, or recreational. On the reverse is a map of Alaska.

367. PUBLISHED MAP OF INDIAN LAND AREAS. 1992. 1 item. [NWCS, maps and plans]

The map shows the boundaries of Federal Indian Reservations, locations of State reservations, and boundaries of Alaskan Regional Corporations.

368. "SPECIAL DEDICATION ISSUE, VIENNA QUADRANGLE, VIRGINIA.” July 12, 1974. 1 item. [NWCS, maps and plans]

A 7.5-minute topographic map bordered by photographs illustrating USGS mission areas.

369. INDEXES TO PUBLISHED QUADRANGLE MAPS. ca. 1911-89. 890 items. [NWCS, maps and plans]

Arranged in three sets - new editions, old editions, and folded indexes, and thereunder in alphabetical order by State within each set..

The new edition indexes, labeled "current" on the drawers, are dated about 1976 to 1989 and include indexes for Antarctica and the United States. The old edition indexes are dated about 1916 to 1979 and include indexes for Antarctica, Puerto Rico, the Virgin Islands, and the United States. The folded indexes, in the last drawer, are dated about 1916 to 1982, and also include indexes for Antarctica.

370. PUBLISHED INTERNATIONAL MAP OF THE WORLD TOPOGRAPHIC SHEETS. 1912-76.

110 items. [NWCS, maps and plans]

Arranged alphabetically by name of sheet.

Many of the maps bear the statement "this map follows the sheet lines and numbering system of the International Map of the World, but does not conform to the specifications for the series in all respects." Indexes to topographic maps of the United States published at 1:1,000,000 are in the first drawer.

371. INDEXES TO TOPOGRAPHIC AND OTHER MAPS. ca. 1980-95. 119 items. [NWCS, maps and plans]

Arranged alphabetically by State. These maps are folded and stored in boxes. State map lists are at the end of the series.

372. PUBLISHED 1:250,000-SCALE QUADRANGLE MAPS. ca. 1889-1989. approx. 2000 items. [NWCS, maps and plans]

Arranged alphabetically by State and thereunder alphabetically by name of quadrangle. 
373. PUBLISHED 1:250,000-SCALE QUADRANGLE MAPS OF CANADA. ca. 1954-66. 12 items. [NWCS, maps and plans]

Arranged alphabetically by sheet name.

374. PUBLISHED 1:125,000-SCALE QUADRANGLE MAPS. ca. 1886-1949. approx. 2100 items. [NWCS, maps and plans]

Arranged alphabetically by State and thereunder by name of quadrangle.

375. PUBLISHED 1:100,000-SCALE QUADRANGLE MAPS. ca. 1974-94. approx. 2000 items. [NWCS, maps and plans]

Arranged alphabetically by State and thereunder by name of quadrangle.

376. PUBLISHED 1:63,360-SCALE QUADRANGLE MAPS OF ALASKA. ca. 1948-94. approx. 2800 items. [NWCS, maps and plans]

Arranged alphabetically by quadrangle name.

377. PUBLISHED 1:62,500-SCALE QUADRANGLE MAPS. ca. 1888-1967. approx. 15,000 items. [NWCS, maps and plans]

Arranged alphabetically by State and thereunder alphabetically by quadrangle name.

378. PUBLISHED 1:48,000-SCALE QUADRANGLE MAPS. ca. 1906-50. approx. 40 items. [NWCS, maps and plans]

Arranged alphabetically by State and thereunder alphabetically by quadrangle name.

This series includes 1 oversized item.

379. PUBLISHED 1:31,680-SCALE QUADRANGLE MAPS. ca. 1908-49. approx. 1825 items. [NWCS, maps and plans]

Arranged alphabetically by State and thereunder alphabetically by quadrangle name.

380. PUBLISHED 1:24,000-SCALE QUADRANGLE MAPS. ca. 1908-94. approx. 102,000 items. [NWCS, maps and plans]

Arranged alphabetically by State and thereunder alphabetically by quadrangle name.

Most of the maps date from about 1930. Some of the maps are provisional editions. 
381. PUBLISHED 1:24,000-SCALE QUADRANGLE MAPS OF GUAM AND THE VIRGIN ISLANDS.

1954-82. 40 items. [NWCS, maps and plans]

Arranged by island group and thereunder alphabetically by quadrangle name.

382. OVERSIZED PUBLISHED 1:24,000-SCALE QUADRANGLE MAPS. 1949-92. 17 items. [NWCS, maps and plans]

Arranged as follows - Juneau and vicinity, Alaska; Del Mar, Imperial Beach, Imperial Beach-Baja California Norte (experimental edition), La Jolla, and Oxnard, California; Wilson, Florida; and Mentor, Ohio.

383. PUBLISHED 1:25,000-METRIC-SCALE QUADRANGLE MAPS. ca. 1978-93. approx. 260 items. [NWCS, maps and plans]

Arranged alphabetically by State and thereunder alphabetically by quadrangle name.

The States covered in the series are - Alaska, California, Hawaii, Massachusetts, Michigan, Nevada, New Hampshire, New York, Rhode Island, South Dakota, Vermont, and Washington.

384. TOPOGRAPHIC AND RELIEF MAPS OF HAWAII. ca. 1910-57. 22 items. [NWCS, maps and plans]

All the maps are at 1:62,500. Some of the editions were reprinted at a later date.

385. TOPOGRAPHIC QUADRANGLE MAPS OF SOUTH CAROLINA. 1918-19. 34 items. [NWCS, maps and plans]

All the maps are at 1:21,120. A few are reprints of the editions of 1918 and 1919.

386. TOPOGRAPHIC MAPS OF PUERTO RICO. 1935-82. 377 items. [NWCS, maps and plans]

Arranged roughly by scale and thereunder alphabetically by name of quadrangle.

387. TOPOGRAPHIC MAP OF THE ISLAND OF GUAM. 1953. 1 item. [NWCS, maps and plans]

The map is at $1: 62,500$.

388. TOPOGRAPHIC MAPS OF AMERICAN SAMOA. 1963. 3 items. [NWCS, maps and plans]

The maps show Tutuila and Manua Islands at 1:24,000. 
389. MAP OF THE “TRUST TERRITORY OF THE PACIFIC ISLANDS.” 1973. 1 item. [NWCS, maps and plans]

The map is at 1:4,000,000. There are insets for islands, island groups, and atolls.

390. STATUS OF TOPOGRAPHIC MAPPING OUTSIDE THE CONTINENTAL UNITED STATES. 1957.

3 items. [NWCS, maps and plans]

The areas shown are Alaska, Hawaii, Wake, Midway, American Samoa, Guam, the Canal Zone, Puerto Rico, and the Virgin Islands.

391. MAPS OF ANTARCTICA. ca. 1956-93. 174 items. [NWCS, maps and plans]

A series of reconnaissance maps, dated 1959-88, at 1:250,000, forms the largest part of this series. There is also a set of maps, dated 1956-60, at 1:500,000, showing the Australian and African quadrants of Antarctica. Other items consist of topographic maps, satellite-image maps, and photomaps.

392. ANTARCTIC SKETCH MAPS. ca. 1960-67. 35 items. [NWCS, maps and plans]

The scale is 1:500,000. The maps were compiled in cooperation with the National Science Foundation in support of scientific activities of the U.S. Antarctic Research Program.

393. SATELLITE-IMAGE MAPS. 1972-94. 57 items. [NWCS, maps and plans]

The regular sized maps are arranged as follows: Pakistan, ca. 1992; Antarctica, 1973-92; and the United States, 1972-94. The last group includes maps showing the conterminous United States, vegetation types, biodiversity management status, Central United States earthquakes, 1974-91, and Bay Area earthquakes, 1972-89. The oversized maps, which are filed separately, show McMurdo Dry Valleys, Antarctica; the Washington D.C. area; and a satelliteimage mosaic map of Florida

Some of the maps were produced with an experimental-printing technique that consisted of a silver-ink overprint of feature names.

394. RADAR IMAGE MAPS OF UGASHIK, ALASKA. 1980. 12 items. [NWCS, maps and plans]

Consisting of radar-image, radar-image-mosaic, and radar-stereo maps, and maps done under contract using "Synthetic Aperture Radar Imagery (SAR System)."

395. RECORDS CONCERNING AND USING MAP PROJECTIONS. 1982-94. 2 volumes and 1 item. [NWCS, maps and plans]

The records consist of two volumes - "Ground Water Atlas of the United States," labeled as segment 7, Idaho, Oregon, and Washington, part of Hydrologic Investigations Atlas 730-H (1994), and "Louisiana Barrier Island Erosion Study: Atlas of Sea-Floor Changes from 1878 to 1989" (1994); and a sheet illustrating "The Properties and Uses of Selected Map Projections," dated 1982. 
396. LAND-USE AND LAND-USE COVER MAPS. 1969-83. approx. 230 items. [NWCS, maps and plans]

Arranged numerically from L-1 to L-203. An index accompanies the maps.

The maps show urban or built-up land, agricultural land, rangeland, forest land, water, wetland, barren land, tundra, and perennial snow and ice. Some of the maps are folded.

397. VEGETATION AND LAND-COVER MAPS. 1987. 7 items. [NWCS, maps and plans]

The maps are numbered from L-205 to L-211. These maps are folded.

398. RECORDS RELATING TO DIGITAL-CARTOGRAPHIC DATA FILES. 1985-87. 3 vols. [NWCS, maps and plans]

The volumes are titled "Digital Line Graphs from 1:1,000,000-Scale Maps," and "Digital Line Graphs from 1:2,000,000-Scale Maps."

399. SPECIAL-PROJECTS MAPS. ca. 1994. 2 items. [NWCS, maps and plans]

The series consists of a color-coded map, titled "Ground Shaking in San Francisco," showing the relative shaking hazard to buildings of varying heights built on different rock types; and a map titled "Alaska National Interest Lands, Conservation Act, December 2, 1980, P.L. 96-487," that shows boundaries of areas administered as part of the National Wildlife Refuge System, National Park System, Bureau of Land Management System, National Wild and Scenic Rivers System, and National Forest System. 
General Photographs, ca. 1880-1900

400.

JOSEPH HENRY WHEAT ALBUM OF MISCELLANEOUS VIEWS. ca. 1880-1900. 1 album. 1.5 in.

Arranged by NARA-assigned number. This is series MA (NWCS, still pictures).

Mounted photographs that vary in size from 8 in. x 6 in. to 10 in. x 13 in., and chiefly showing streams, farms, cities, and towns; a few depict industrial infrastructure in North Carolina and Tennessee. Also included are views of sites in Yellowstone National Park. A few of the photographs are captioned and dated.

A few of the photographs are duplicated in series PS (entry 87).

The photographs were collected by Joseph H. Wheat, a topographer with the USGS, and given to Claude H. Birdseye, USGS Chief Topographic Engineer (1919-29), for the agency's permanent files.

The photographic records described in entries 401 to 403 concern Robert B. Stanton's survey of the Colorado River in 1889 and 1890. Stanton, acting Chief Engineer of the Denver, Colorado Canyon, and Pacific Railroad, conducted a survey of the Colorado River for the purpose of establishing a railway route from coal fields in Colorado to the Pacific Coast. Many of the photographs were entered as Exhibit No. 176 in the case of the United States vs. Utah (284 US 534). An original copy of the diary Stanton compiled during the trip is in the New York Public Library. It contains some information about the locations where some of the photographs were taken. Many original

photographic items from the "Stanton Survey" were donated to the USGS for Claude H. Birdseye's use in planning an expedition down the Grand Canyon in 1923. The records described in entry 295 concern Birdseye's survey of the Colorado River.

401. GLASS NEGATIVES. 1889-90. 11 items. 1 in.

Arranged by NARA-assigned number. This is series RSA (NWCS, still pictures).

Copies of lithographic views ( 8 in. $x 10$ in.) of the Colorado River, a copy of a sketch showing the steamboat U.S. Explorer (Ives Expedition, 1857-58), and portraits of John Hislop, Assistant Engineer, and Frank M. Brown, President of the Denver, Colorado Canyon, and Pacific Railroad Company.

402. PAPER NEGATIVES AND CORRESPONDING CONTACT PRINTS. 1889-90. 2 in.

Arranged by record format and thereunder by NARA-assigned number. The images are not captioned or dated. This is series RSB (NWCS, still pictures).

The images show views of the Colorado and Green Rivers, natural rock formations, and members of the survey party on the trail and in camp.

403. PHOTOGRAPHIC PRINTS AND CORRESPONDING ORIGINAL NEGATIVES. 1889-90. 7 albums and negatives. $3 \mathrm{ft}$.

Arranged by record format and thereunder by agency assigned number. Some prints have captions. This is series RS (NWCS, still pictures). 
Mounted 7.5 in. x 5.5 in. prints showing the Colorado and Green Rivers, El Dorado Canyon, the Cottonwood and Mojave Valleys, natural rock formations, plant and animal life, members of the survey party, camp sites, the Daniel Bonelli family, Fort Mojave, Arizona, U.S. Cavalry troopers, and Indians.

The photographs were taken by Stanton and Franklin A. Nims. 
General Motion Pictures, 1947-74

404. MOTION-PICTURE FILMS RELATING TO TOPOGRAPHY AND MAPPING. 1947-74. 16 reels.

Arranged by item number. The film is in the custody of NWCS, motion pictures.

The fifteen films are titled: Mapping the Earth's Surface (1969); Earth Resources, Mission 73; The Tellurometer, A Microwave System of Precise Distance Measurement; Topographical Mapping by Photogrammetric Methods [2 films carry this title]; Negative Scribing for Map Reproduction, A Training Film; Precise Leveling for Topographic Mapping; An Introduction to Photo Interpretation for the Discovery and Evaluation or Natural Resources; Preparation of Topographic Manuscripts for Reproduction, A Training Film (ca. 1951); Supplemental Control for Topographic Mapping, A Training Film (ca. 1952); Transit Traverse for Topographic Mapping, A Training Film (ca. 1950); Leveling for Topographic Mapping, A Training Film (ca. 1950); Triangulation for Topographic Mapping, A Training Film; What on Earth, \#5 Maps for Man (1974); and Global Concepts in Maps (1947). When determined the copyright date appears in parenthesis after the film title. All the films are in color and include a sound track. The first film is on two reels. The remaining films are one reel each. 
The Plans and Coordination Division (later Branch) was established as a staff unit in the Topographic Branch as part of a reorganization in 1946. The Branch was composed of four sections - Map Information Office, Estimates and Plans, Production Control, and Liaison and Coordination. The Branch had general responsibility for budget estimates, planning for mapping programs, production schedules, liaison with Federal and State officials on mapping matters, and coordination of operations with the Topographic Branch.

\section{ADMINISTRATIVE FILES. 1942-60. $8 \mathrm{ft}$.}

Arranged by subject, and thereunder in rough chronological order. Similar subject headings appear in several places. Most of the files are clamped together. Oversize items and bound reports are inserted between the files. A list of file titles appears as Appendix 23 in this inventory.

Letters sent, letters received, memorandums, narrative and statistical reports, budget justifications and other fiscal records, transcripts of meetings and conferences, press and radio releases, contract and bid forms, regulations, technical memos of instruction, departmental orders, personnel bulletins and other administrative issuances, maps, and congressional documents.

The records concern cooperation with other units of the USGS, departmental committees, and Federal agencies, and States; coordination and management of USGS mapping projects; and allocation of resources for long-term and special projects. 


\section{Records concerning the National Cartographic Information Center, 1934-78}

In 1919 Executive Order 3206 created the Federal Board of Surveys and Maps, composed of one representative each of 14 Federal Agencies and commissions, to coordinate the making of maps, standardize results, and avoid unnecessary duplication of work. The Board was instructed to create a central information office in the USGS to collect, classify, and furnish to the public information concerning all map and survey data available from Federal and other sources. The Topographic Division established a Map Information Office (MIO) to conduct these operations. Four other Federal agencies and 23 nonfederal organizations were added to the Board before it was abolished in 1942 by Executive Order 9094 and most of its functions transferred to the Bureau of the Budget. In 1945 the Branch reorganized the MIO to continue the central-information function. In 1974, the National Cartographic Information Center succeeded the MIO and continued to act as an interagency center to facilitate access to the cartographic holdings of Federal, State, and county government agencies, and those of private organizations.

406. RECORDS CONCERNING NATIONAL MAPPING PLANS. 1934-36. 5 in.

Arranged by subject.

Correspondence, minutes of meetings of the Federal Board of Surveys and Maps and its Special Committee on Map Planning (1934), memorandums, press releases and other processed issuances, magazine and newspaper clippings, questionnaires to and responses from Federal and State agencies and professional organizations regarding current mapping projects and anticipated mapping needs, draft reports of the Special Committee, and other records concerning national mapping programs.

Most of the records concern the Special Committee on Map Planning (1934), which formulated a 10-year national mapping plan; the Special Committee on the National Mapping Plan of 1936, established pursuant to Senate Resolution 281, 74th Congress, to prepare a revision of the 1934 national mapping plan; the Pendleton Plan; and a mapping program sponsored by the American Engineering Council.

Claude H. Birdseye, as Chief of the Division (1919-29), represented the USGS on the Federal Board of Surveys and Maps, and served as Chairman of the 1934 and 1936 Special Committees.

407. THE NATIONAL CARTOGRAPHIC INFORMATION CENTER NEWSLETTER, 1975-78. 11 items. [NWCS, maps and plans]

The newsletter is a technical publication intended to inform the cartographic community about the activities of the National Cartographic Information Center. 
In 1906 the USGS changed the name of its Hydrographic Branch to the Water Resources Branch. The Branch continued to be supervised by a Chief Hydrographer, who administered three major divisions--Hydrographic, Hydrologic, and Hydro-Economic. In 1907 the Hydrographic Division became the Surface Water Division, the eastern and western sections of the Hydrologic Division were merged as the Ground Water Division, and the Hydro-Economic Division was renamed the Quality of Water Division. Under these names the three divisions conducted thereafter the major long-term work of the Branch. Between 1913 and 1963 the Water Resources Branch was led by a Chief Hydraulic Engineer In 1963 the title was changed to Chief Hydrologist. The Branch was renamed a Division in 1949 and its divisions became branches.

Other functions were given organizational-unit status within the Water Resources Branch. After the passage of an act of February 19, 1909 (35 Stat. L., 639), to provide for enlarged homesteads, and an act of December 29, 1916 (39 Stat. L., 862), to provide for stock-raising homesteads, Branch personnel made field classifications of areas of the public lands that were or might be applied for under the laws and reported their findings to the USGS Land Classification Board. In 1925 the Water Resources Branch's Division of Land Classifcation Investigations, the Land Classification Branch (restyled in 1922), and the mineral-leasing and related regulatory functions received from the Bureau of Mines were joined to form the Conservation Branch.

The establishment and functions of the Divisions of Power Resources and Water Utilization are described with the records of those units.

In 1948 the Water Resources Branch was reorganized. The Water Utilization Division was renamed the Technical Control Division and a Program Control Division was established as a second staff unit to handle increased administrative demands in the Central Office. The Program Control Division included Interagency, Field Relations, and Fiscal Control Sections.

The growth of separate field organizations for each of the operating Branches in the Water Resources Division prompted the creation of Water Resources Councils in 1949. The Councils, established in all States or geographic regions where they linked two or more district offices, coordinated the Division's field programs and facilitated the cooperative programs with States and local agencies. In the mid-1960's the Division's local offices in each State were consolidated into single Division-type districts.

The Division underwent extensive reorganizations in the 1950's and 1960's. In 1956 the Offices of Assistant Chief Hydrological Engineers for Program and Development and for Operations, Regional Hydrologists for the Pacific Coast, Rocky Mountain, Mid-Atlantic, and Atlantic Coast areas, and six administrative and research Sections in the Central Office that included Foreign Hydrology (founded in 1952) and Radiohydrology (founded in 1947) were established or modified. The Technical Coordination Branch was renamed the General Hydrology Branch. From 1967 the Chief Hydrologist was aided by three Assistant Chiefs--Administration and Technical Services (later Operations), Reports and Data Processing (later Scientific Publications and Data Management), and Research and Technical Coordination. This reorganization terminated the Branches of General Hydrology and Program Control; their functions passed to the Research and Technical Coordination Office, which retained administrative control of the Branches of Surface Water, Ground Water, and Quality of Water, and the Offices of Remote Sensing and Radiohydrology. The Foreign Hydrology Section was renamed the Office of International Activities; the Section, the Office of Water Data Coordination (created in 1965), and the Regional Hydrologists reported to the Chief Hydrologist. Reorganizations of the Division in the 1980's and 1990's added to the number and modified the responsibilities and titles of the Assistant Chief Hydrologists.

Entry 508 lists the three published volumes and the three completed but unpublished volumes in "A History if the Water Resources Division, U. S. Geological Survey" that cover the years to 1966. 
The Irrigation Survey (also known as the Powell Irrigation Survey) was established in the USGS under the provisions of an act of October 2, 1888 (25 Stat. L., 526). The act was passed "for the purpose of investigating the extent to which the arid region of the United States can be redeemed by irrigation, and the segregation of the irrigable lands in such arid region, and for the selection of sites for reservoirs and other hydraulic works necessary for the storage and utilization of water for irrigation and the prevention of floods and overflows, and make the necessary maps ... the work to be performed by the Geological Survey under the direction of the Secretary of the Interior." The Irrigation Survey was organized with two major units: a Topographic Survey, led by Almon H. Thompson, to prepare maps of areas under investigation: and a Hydraulic Survey, led by Clarence E. Dutton, to gage streams and identify suitable sites for irrigation systems, and to design dams, canals and other necessary structures. The Irrigation Survey undertook a systematic program of streamflow measurement. On August 30, 1890 (26 Stat. L., 391), Congress repealed that portion of the act of 1888 that created the Irrigation Survey. After 1890 some limited stream-gaging work continued, and ground-water studies began, respectively, in the USGS Topographic and Geologic Branches.

On August 18, 1894 (28 Stat. L., 398), Congress appropriated funds specifically "For gauging the streams and determining the water supply of the United States, including the investigation of underground currents and artesian wells in arid and semiarid regions." To conduct the work a Hydrographic Division, led by Frederick H. Newell, a veteran of the Irrigation Survey, was formed in the Topographic Branch. The new unit was transferred to the Geologic Branch in 1895. Cooperative hydrographic surveys with the States began in 1895; co-funded work dates from 1900. Following the passage of the Reclamation Act on June 17, 1902 (32 Stat. L., 388), the Hydrographic Division was made a Branch equivalent to the other major line units of the USGS, with Newell as it Chief Hydrographer. In 1903 the Branch contained of a Division of Hydrography for stream-gaging activities, a Division of Hydrology for ground-water investigations, Division of Hydro-Economics for analyses of water quality and economic potential, and the Reclamation Service. Director Walcott led the Reclamation Service, established in 1902, and Newell served as its Chief Engineer. In 1906 Newell left the Hydrographic Branch to spend more time with the newly independent Reclamation Service. Walcott hired Marshall O. Leighton as Chief Hydrographer and his Branch was renamed the Water Resources Branch. On March 9, 1907, the Reclamation Service, led by Newell, was separated from the USGS and established as an Interior Department agency; the Service was renamed the Bureau of Reclamation in 1923.

\section{RECORDS CONCERNING FIELD OPERATIONS. 1889-90. 3 in.}

Arranged chronologically.

Correspondence, reports, telegrams, newspaper clippings, graphs, and charts concerning surface-water studies in the arid regions west of the 100th meridian. Specific records include: "A Report on Fieldwork in Bear River Valley, 1889," by USGS hydrographer Robert Robertson, which includes a sketch map of the Cache Valley, and a draft "Report on the Irrigation of the Espanola Valley, 1889," also by Robertson; correspondence and reports received by Clarence E. Dutton from Robertson regarding his irrigation studies in the Utah and Arkansas Divisions; correspondence between Frederick H. Newell, Hydraulic Engineer in charge of the Rio Grande Division, and hydrographer Harold M. Dyar, including Dyar's report on stream gaging in the Rio Grande Division; correspondence relating to precipitation studies received by Newell from climatologist George E. Curtis, including a statistical summary of the yearly precipitation in Colorado, 1884-1889; and a progress report from Newell outlining the hydrographic work completed in Montana, Colorado, New Mexico, and Texas in June 1890.

Of particular significance is John W. Powell's report that outlines his principles and policies regarding irrigation, and his analysis of attitudes and events, from 1867 to about 1890, that influenced the development of United States water policy. 
Arranged by author's name, and thereunder chronologically.

Reports, which include correspondence, statistical summaries, diagrams, sketches, maps, published reports, and newspaper clippings, relating to irrigation studies in Nebraska, Oregon, and Idaho. Included are the reports of William P. Trowbridge, a USGS topographer, concerning irrigation studies in Oregon and Idaho in 1893, and a report by Charles P. Ross, a civil engineer and Chairman of the Nebraska Commission of the National Irrigation Congress, concerning his measurements in 1894-95 of the North Platte River in Nebraska. The majority of the reports (1894-98) were written or compiled by Oscar V. P. Stout, a Professor of Civil Engineering at the University of Nebraska, and relate to the water supply in Nebraska. Specific reports discuss the gaging of Nebraska streams and measurements of water-well heights, particularly across the Platte River Valley at Kearney, Nebraska.

410. DISBURSEMENT LEDGERS. Nov. 1888 - Dec. 1889. 1 in. 2 vols.

Arranged in two chronological periods. The first ledger covers the period November 30, 1888 to June 30, 1889; the second ledger, July 1 to December 30, 1889. The entries in each ledger are arranged by administrative unit, and thereunder chronologically.

Individual entries give the date, voucher number, the amount, to whom paid, and disbursement classification. Entries are classified as: instruments, services, supplies, subsistence, field expenses, hired transportation, travel, bonded railroads, and stock. These classifications are explained in the front of the first ledger. Both ledgers include entries for supplemental allotments and summary accounts. The corresponding vouchers have not been found.

411. JOURNALS OF EXPENDITURES OF THE HYDROGRAPHIC DIVISION (IRRIGATION DIVISION). Aug. 1894 - May 1899. 2 in. 4 vols.

Arranged for the most part chronologically. Entries for August to December 1894 are arranged by State, and thereunder chronologically.

Individual entries give the date, to whom paid, purpose of expenditure, and amount. Beginning with the second volume (July 1896), a register number is also included. These registers have not been found. Beginning with the third volume (August 1897), a voucher number is given. The corresponding vouchers have not been found. 
General Records, 1907-96

412. GENERAL CORRESPONDENCE FILES. 1907-53. $22 \mathrm{ft}$.

Arranged alphabetically by subject. A list of file titles appears as Appendix 24 in this inventory.

Correspondence, reports, memorandums, bulletins, circulars, directions, requisitions, vouchers, copies of contracts, copies of rules and regulations, copies of court decisions, automobile-accident forms, legislation, press releases, newspaper clippings, articles, publications, pamphlets, statistical summaries, graphs, charts, plats, and other records regarding the administration, policies, programs, and operations of the Water Resources Division. Of particular interest are the reports documenting the investigations of the water resources of California, also called the "Marshall Plan"; 1921, the Red River Basin, 1948-53 (in the Canadian Government file); the quality of water in Forestville and Suitland, Maryland and McLean, Virginia, 1919 (in the Investigations file); and a proposal to construct hydroelectric facilities below Great Falls and the Potomac River, 1921 (in the Levering Correspondence file). The file concerning the Southwest Drought of 1951 contains compiled tables showing precipitation, runoff, ground- and surface-water measurements, and reservoir contents. Other records, such as the collection of statements from District Engineers in response to the question "Why Continuous Stream Gaging?" in 1928, show the development of Division policy.

These records also show the cooperation of the Division with other USGS units, other Federal agencies, especially the Bureau of Indian Affairs, Fish and Wildlife Service, National Park Service, Bureau of Reclamation, War Department, Weather Bureau, States, municipalities, independent bodies, such as the Tennessee Valley Authority and the National Research Council, and foreign countries. Also included are correspondence, reports, memorandums, agendas, minutes, speeches, seminar papers, conference papers, published reports, press releases, attendance lists, and other records regarding the Division's participation in meetings, seminars and conferences.

Interspersed are photographic prints, including those of various Division exhibits at fairs and expositions, equipment, and an illustrated report on the water supply in Shenandoah National Park in 1935 (in the National Park Service file).

\section{3. “CONFIDENTIAL CORRESPONDENCE.” 1922-35, 1942-49. 10 in.}

Arranged chronologically.

Correspondence, memorandums, and reports deemed confidential by the Chief of the Division that concern personnel problems, theoretical or technical disagreements between staff members, internal and external complaints regarding the Division's work or staff members, and questions about cooperative agreements and funding.

Responses were usually prepared by the Chief Hydraulic Engineer, the Assistant Chief, or other staff members with specialized knowledge of the problem area. Of particular interest are a collection of reports written by the Division's district engineers outlining stream gaging completed in 1925 in cooperation with the Bureau of Indian Affairs.

414. CENTRAL CLASSIFIED FILES. 1945-76. $137 \mathrm{ft}$.

Arranged in two subseries and thereunder according to a subject-numeric classification, the same as that used for the central classified files of the Office of the Director (entry 52). The primary subject headings are Accounting, Budget, Buildings and Grounds, Committees, Communication, Computation, Contracts (2nd subseries), Cooperation, 
Councils (1st subseries), Education, Equipment and Supplies, Forms, Information, Inventions, Investigations, Land, Legal, Map Distribution, Map Production, Mapping Techniques, Meetings, National Defense, Organization and Management, Paleontology and Stratigraphy (1st subseries), Personnel, Programs and Plans, Public Relations, Publications, Records, Reports and Statistics, Reproductions, Research, Security (2nd subseries), Sedimentation and Erosion (2nd subseries), Topographic Surveys (2nd subseries), Transportation, Travel, Vehicles, Water (General), Water (Ground - 2nd subseries), Water Quality, and Water (Surface). Most of the records date from 1953 to 1972.

Correspondence, memorandums, directives, reports, issuances, circulars, bulletins, press releases, publications, pamphlets, requisitions, vouchers, copies of contracts, copies of rules and regulations, statistical charts and summaries, graphs, plats, diagrams, and other records regarding the administration, policies and programs of the Water Resources Division. These records also show cooperation with other USGS units, other Federal agencies, especially the Department of the Army, the Atomic Energy Commission, the Bureau of Reclamation, and independent bodies, such as the Tennessee Valley Authority and the National Science Foundation. Includes agendas, minutes, and other records regarding the Division's participation on regional, international, and interagency boards and committees. Also contains catalogs and price lists relating to equipment and supplies, copies of applications and diagrams regarding inventions, copies of contracts of easement for access to land, personnel requests for action, drafts of articles and reports submitted for publication, and photographic prints of USGS offices and labs, and other subjects.

Of particular interest is a collection of membership reports, compiled in 1963, that give the name of committees on which the Division was represented, the basis for establishing the committees, their purpose and type, conditions for their meetings and reports, and the committees' termination dates (in the Committee, Membership Reports file 1 st subseries).

\section{CIRCULAR LETTER FILE. 1918-53. $7 \mathrm{ft}$.}

Arranged alphabetically by subject. A list of file headings appears as Appendix 25 in this inventory. The records contain an index that outlines the subject classification of the circulars.

Circulars and memorandums prepared by the Water Resources Division or received from other USGS units, the Office of the President, the Office of the Secretary of the Interior, and other Federal agencies that were intended to guide the Division's policies and programs. Also contains bulletins, pamphlets, booklets, correspondence, copies of forms, reports, publications, statistical summaries, plats, and photographs that accompany the circulars.

\section{ADMINISTRATIVE ORDERS, CIRCULARS, AND MEMORANDUMS. 1915-55. $6 \mathrm{ft}$.}

Arranged in two segments and thereunder alphabetically by name of office, title of official, subject or type of record. A list of file title headings appears as Appendix 26 in this inventory.

The first segment (white and green folder labels) contains administrative issuances and memorandums from the Secretary of the Interior and other departmental officials. The second segment, and bulk of the series (yellow folder labels), contains administrative issuances and memorandums from the Director, Division and Branch Chiefs, and Chief Clerks. Also included are correspondence, budget summaries, copies of legislation and congressional documents, copies of forms, reports, minutes of meetings, conference papers, newspaper clippings, lists of contracts, statistical charts, vouchers, maps, and photographs.

The records concern the organization and management of the Water Resources Division, particularly administrative procedures, budget and payroll, fair employment practices, employee assignments, travel, and publications; intraagency and interdepartmental committees, cooperation with other Federal agencies and State governments; Alaska investigations; the Columbus Development Laboratory; and tax exemptions for some oil companies. 
Arranged alphabetically by city, frequently the city where the documents were filed (the duty station of the Division official) rather than the city receiving the contract. The series also contains a file for Alaska, filed in alphabetical sequence, and files for other subjects located at the end of the series: Thetford, Vermont; University of Alabama; Miscellaneous (Washington, D.C. and Virginia); and Miscellaneous (statistical data for 1940 regarding gaging stations).

Contracts, certificates of award, bid and acceptance forms, copies of leases, correspondence, memorandums, statistical summaries, and specification outlines regarding new or renewed contracts by the Water Resources Division for service, equipment, leased space, and rights-of-way through private property. Occasionally, the contracts are accompanied by purchase orders, rate charts, copies of forms, pamphlets, advertising bulletins, plats, diagrams, and photographic prints.

418. RECORDS RELATING TO THE PRESIDENT'S WATER-RESOURCES POLICY COMMISSION. 1950. 3 in.

Arranged by river basin - Ohio, Tennessee, Connecticut, Alabama, Delaware, and Potomac - or subject.

Chiefly reports and statements prepared by the Eastern Field Committee, State water boards and commissions, and the Water Resources Division and submitted to the Commission for use in its reports "A Water Policy for the American People" and "Ten Rivers in America's Future." The series also includes correspondence and memorandums.

\section{RECORDS CONCERNING THE TOPOGRAPHIC NEEDS OF THE WATER RESOURCES DIVISION.} 1950-56. 10 in.

Arranged by subject or type of record: Topographic Needs; Summary of Topographic Mapping Procedures; a group of files arranged alphabetically by State or Territory; Division Report, March 1954; and index cards.

Memorandums, recommendation reports, justification reports, priority lists, circulars, statistical summaries, and maps regarding the Division's need for topographic maps. Also included are topographic-map indexes for each State that delineate the mapping status of the quadrangles in the States; two sets of topographic-map indexes for the United States, one that outlines published maps and the other quadrangle names; published-map lists and bulletins; a reprinted article on Federal surveys and maps; a paper presented to the Public Documents Committee of the American Library Association about the USGS Map Information Office and a set of 3 in. x 5 in cards recording water studies that were scheduled or in progress.

420. OFFICE FILES OF GLENN LANE PARKER. 1930-49. 5 in.

Arranged alphabetically by subject.

Correspondence, memorandums, reports, legislation, publications, statistical tables, maps, and photographic prints relating to water-resources investigations, particularly those of the Gila River, the Colorado River, and the Fontana Dam Project of the Tennessee Valley Authority; and a "Report of Referee" concerning litigation to divert ground water found in the Raymond Basin in California. Also includes agendas, minutes, and circulars regarding the Munitions Board Water Committee and records relating to internal personnel problems. 
Of particular interest is a memorandum by John C. Hoyt, dated September 13, 1934, regarding the development and use of water-stage recorders by the USGS.

Parker served as Chief Hydraulic Engineer of the Division from 1939 to 1945.

421. OFFICE FILES OF CARL GUSTAVE PAULSEN. 1946-60. 10 in.

Arranged alphabetically by subject.

Correspondence, memorandums, copies of speeches, conference papers, programs, and other records relating primarily to addresses written and delivered by Carl G. Paulsen, Chief Hydraulic Engineer of the Division from 1946 to 1957. Of particular interest is the file relating to the celebration of the USGS 75th Anniversary in 1954. There are also reports, press releases, agenda, minutes, and statistical summaries relating to Paulsen's role as the USGS representative between 1951 and 1959 on a number of boards and committees, which included the Columbia River Engineering Board, and the Interior Department's Special Board for Reviewing Principles for Exchange of Water and Power between the United States and Canada.

For records relating to Paulsen's tenure as Chairman of the Arkansas River Compact Administration, 1957-60, see the records described in entry 486.

422. OFFICE FILES OF LUNA BERGERE LEOPOLD. 1960-65. $10 \mathrm{in.}$

Arranged alphabetically by subject.

Correspondence, memorandums, progress reports, legislation, resolutions, press releases, copies of newspaper clippings, agendas, speeches, attendance lists, published bulletins and reports, directories, statistical summaries, and other records relating to Luna B. Leopold's participation on the American Meteorological Society's Committee on Water Resources, 1961 to 1965, and his chairing of the Water Task Force of the Potomac Project in 1965.

Also includes records regarding research proposals.

Leopold served as Chief Hydraulic Engineer from 1957 to 1963, when the position title was changed to Chief Hydrologist. He continued as Chief Hydrologist until 1966.

423. BRANCH NEWSLETTERS. 1918-25. 10 in. 8 vols.

Arranged by month, and thereunder by district office.

Copies of monthly Branch newsletters, which contain narrative reports, statistical tables and summaries, reprinted correspondence, lists of applications before Federal Power Commission, copies of congressional bills concerning appropriations and allotments, and photographic prints. Also included are reports on Branch projects in the districts and Washington office, personnel matters; status of reports and publications, and other subjects of interest to Branch employees. 
424. OPEN-FILE REPORTS AND WATER-RESOURCES INVESTIGATIONS REPORTS (WRIR). $1972-96$. Approx. $200 \mathrm{cu}$. ft.

Arranged alphabetically by State, thereunder by type of report, and thereunder roughly by report number.

Printed and processed reports concerning water-resource management plans, water-quality assessments, flood investigations, chemical composition of rain samples, ground-water flow, wells and springs, and related subjects.

At the time this inventory was compiled this series had not been processed and reboxed by the National Archives staff.

For related maps see the records described in entries 137 and 555. 
Fiscal Records, 1897-1912

425. JOURNAL OF EXPENSES OF THE HYDROGRAPHIC DIVISION. May 1897 - Feb. 1904. 7 in. 7 vols.

Arranged for the most part chronologically, with a few disbursements arranged by subject.

Individual entries give the date, to whom paid, purpose of expenditure, voucher number, and amount. After April 1, 1901, the voucher and ledger numbers are excluded for the most part and the volume title changes to "Gaging Streams." The corresponding vouchers and ledgers have not been found. The volume for the period March 23, 1903, to February 23, 1904, includes a list of staff members of the Division of Hydrology's Eastern Section.

426. LEDGER OF STREAM-GAGING EXPENSES. July 1902 - Dec. 1903. 2 in. 1 vol.

Arranged by name of payee or subject, and thereunder chronologically. An incomplete index, arranged alphabetically by name, is in the front of the volume.

Individual entries give the date, to whom paid, purpose of expenditure, amount, and (what may be a) register number. The corresponding registers have not been found.

427. OPERATIONS LEDGER. July 1901 - July 1905. 1 in. 1 vol.

Arranged by category as follows: New York, Maine, New York City, Office of Indian Affairs, North Carolina, Nevada, Forestry, and Oklahoma Territory.

Individual entries give the date of daily disbursements, to whom paid, purpose of expenditure, and amount that relates to daily disbursements. Many of the disbursements concern expenses incurred in the examination of forest reserves and the revenues obtained from the sale of town lots in Oklahoma Territory. Also included are a memorandum attached to a page in the Forestry section that outlines the duties and authorizations of the field officials participating in forestry examinations, and a letter of April 16, 1903, from Frederick H. Newell to Mrs. Jennie T. Davis (a statistical expert with the Division of Hydrography), regarding the condition of the account for the examination of forest reserves.

428. DISBURSEMENT LEDGER. July 1903 - Feb. 1905. 2 in. 1 vol.

Arranged by State, administrative unit of the Hydrographic Division, or name of payee, and thereunder chronologically. An index, arranged alphabetically, is in the front of the volume.

Individual entries give the date, to whom paid, purpose of expenditure, amount, and (what may be) register and voucher numbers relating to administrative expenditures of the Hydrographic Division. The corresponding registers and vouchers have not been found. Inside the front cover is a statement of account from Herbert M. Wilson, dated March 12, 1904.

429. DISBURSEMENT LEDGER FOR STREAM GAGING. July 1904 - June 1906. 3 in. 2 vols.

Arranged by payee, State, region, or administrative unit, and thereunder chronologically. An index, arranged alphabetically, is in the front of each volume. 
Individual entries in Volume I (Fiscal Year 1905) give the date, to whom paid, purpose of expenditure, date span of expenditure, amount, and (what may be) voucher and register numbers. Attached to the inside front cover is a list summarizing allotments and expenditures for the States, regions and offices. Page 221 contains a letter and a list of expenses, dated August 17, 1905, from Grove K. Gilbert to Frederick H. Newell regarding Gilbert's expenditures for fiscal year 1905. Individual entries for Volume II (Fiscal Year 1906) give the date, charge-sheet number, voucher number, to whom paid, by whom paid, amount, and purpose of expenditure. The corresponding vouchers, registers, and charge sheets have not been found.

430. APPROPRIATIONS LEDGER. July 1907 - June 1908. 2 in. 1 vol.

Arranged by appropriation account, and thereunder chronologically. An index, arranged alphabetically by subject, State, and agency is in the front of the volume.

Individual entries give the date, to whom paid, purpose of expenditure, amount, and monthly total balance for such accounts as river measurement, ground water, quality of water, debris investigation, and land drainage and cooperative work with State and Federal agencies. Individual entries for transportation requests give (what may be) a voucher number, date, charge sheet number, to whom paid, place of departure, destination, method of travel, amount, and account charged. The corresponding vouchers and charge sheets have not been found.

431. DISBURSEMENT LEDGERS FOR STREAM-GAGING APPROPRIATIONS. July 1907 - June 1910. 5 in. 3 vols.

Arranged by appropriation account, and thereunder chronologically. Indexes, arranged alphabetically by subject, State, district, and agency, are in the front of Volumes II and III.

Individual entries give the date, to whom paid, voucher number, amount, balance, and monthly balance for such accounts as river measurements, ground-water and debris investigations, and cooperative work with the States and on the Moqui and Navajo Reservations. Each volume is for a fiscal year. Correspondence, memorandums, and quarterly statements, regarding transfer of funds, credits, debits, adjustments to accounts, and recommendations, are in the front of Volumes II and III. Volume III also has loose papers appended to the ledger pages throughout the volume showing expenditures for fiscal year 1911.

432. APPROPRIATIONS LEDGER. July 1911 - Sept. 1912. 2 in. 1 vol.

Arranged by account name.

Individual entries give the date, to whom paid, voucher number, charge sheet number, transfer of expenditures, direct expenditures, total expenditures, and monthly credit and disbursement summaries for water-resources activities in certain States and regions and the Territory of Hawaii. Included are accounts for stream gaging, pumping investigations, chemistry of underground water, cooperation with States and Federal agencies, and administrative costs. Correspondence and financial statements from Thomas G. Gerdine to John H. Lewis regarding the transfer of vouchers and expenditures of the Deschutes River investigation are inserted in the volume. 


\section{Administrative Records, 1908-63}

433. CORRESPONDENCE CONCERNING DISTRICT ENGINEERS AND OTHER DIVISION EMPLOYEES. 1908-57. $31 \mathrm{ft}$.

Arranged alphabetically by surname. A list of file titles appears as Appendix 27 in the inventory.

Correspondence and memorandums relating to personnel matters, such as appointments, leave, transfers, military service, recommendations, and retirement. These files appear to have been maintained as an informal personnel file by the Division. Most of the files concern district engineers, hydraulic engineers, and geologists. There are also files for aids, administrative staff, and consultants.

Also included are circulars, investigative reports, conference papers, publications, newspaper clippings, copies of legislation, statistical charts, plats, diagrams, photographs, and other records relating to Division programs including water-power and irrigation development, artesian wells, swamp lands, flood investigations and prediction, and stream gaging, including joint international gaging stations along the United States-Canadian border; well-drilling machinery and methods, current meters, and water-stage recorders; and land entries under the Cary Act, Enlarged Homestead Act, and Stock-Raising Homestead Act. The records also document Division cooperation with the States and other Federal agencies, particularly the Bureau of Reclamation, Forest Service, National Park Service, Bureau of Indian Affairs, Weather Bureau, and Federal Power Commission.

Of particular interest is a report done for the Electric Bond and Share Company, titled "The Utilization of the Boundary Waters of Northern Minnesota," by H. N. Sullivan, Consulting Engineer, Los Angeles, CAECA, 1927. Ralf R.Woolley asked that the report be retained in the Division's files. It was placed in his file.

The records include files for three Division employees who, as of 1938, held dual appointments with State agencies: Max H. Carson (Hawaii), Lynn Crandall (Idaho), and Joseph J. Dirzulaitis (Virginia). The dual- employment status of these employees was approved, in accordance with Executive Order 7796, by the Secretary of the Interior on March 10, 1938.

Most of the records are dated 1911-46.

\section{RECORDS CONCERNING THE DISTRICT AND FIELD OFFICES OF THE SURFACE WATER} BRANCH. 1916-51. $12 \mathrm{ft}$.

Arranged for the most part alphabetically by district or field office, and thereunder chronologically. Alaska materials appear in alphabetical sequence. The first two files are general files apparently maintained in the office of the Chief of the Surface Water Branch.

Chiefly correspondence and memorandums to and from the district engineers, but also includes reports, press releases, newspaper clippings, statistical summaries, plats, graphs, and other records regarding the administration, operations, and projects of the district and field offices of the Surface Water Branch. Included is information on allotments and estimates for field activities, the compilation and submission of field data, the status of stream-gaging and river-survey projects, personnel and payroll matters, and cooperation with other Federal agencies, States, and municipalities.

The majority of the records date from 1944. Files with records dated before 1944 are: Asheville, 1930, Baton Rouge, 1929, Bismarck, 1931, Columbia, S.C., 1940, Honolulu, 1942, Iowa City, 1935, Jackson, Mississippi, 1930, Lincoln, Nebraska, 1933, Los Angeles, 1916, Ocala, 1930, Oklahoma City, 1930, Pierre, 1931, Pittsburgh, 1930, Raleigh, 1933, St. Louis, 1935, Salt Lake City, 1931, Santa Fe, 1943, and Tucson, 1941. 
435. RECORDS CONCERNING THE FIELD OFFICES OF THE GROUND WATER, QUALITY OF WATER, AND WATER UTILIZATION BRANCHES. 1946-53. 2.5 ft.

Arranged alphabetically by district or field office, thereunder by Branch, and thereunder chronologically.

Chiefly correspondence and memorandums to and from the district engineers and geologists, with some reports, agendas, minutes, handwritten notes, statistical summaries, and other records regarding the administration, operations, and projects of the district and field offices of the Branches of Ground Water, Quality of Water, and Water Utilization.

Included is information on allotments and estimates for field activities, compilation and submission of field data, personnel and payroll matters, proposed projects, studies for the Department of Defense, and cooperation with other Federal agencies, States, and municipalities. There is also a file from a field office in Agana, Guam, concerning a cooperative agreement with Guam for water-resources investigations, including water-feasibility studies and installation of gaging stations.

436. CASE FILES RELATING TO OFFICE SPACE FOR DIVISION FIELD OFFICES. 1921-53. 3 ft.

Arranged alphabetically by name of city, followed by a file for Alaska and two general files.

Correspondence, memorandums, completed "Space Summary for Building" and "Occupancy Confirmation" forms, floor plans, telegrams, handwritten notes, newspaper clippings, and other records that concern the leasing of office, laboratory, and storage space for field and district offices. The files include information about negotiations for space in buildings on university campuses.

437. PROCEEDINGS OF A BRANCH CONFERENCE OF ENGINEERS. Dec. 1914. 2 in.

Unarranged.

Copies of the papers delivered on such subjects as the functions of the central and district offices, progress and utilization reports, manuscript preparation and illustrations, automatic gages, the Stevens continuous water-stage recorder, Friez's improved automatic water-state register, measurement of drainage areas, classification of land, and accuracy of streamflow data. There is also an introductory statement.

438. ANNUAL REPORTS. 1933-47. $3 \mathrm{ft}$.

Arranged chronologically by year. For each year, a Branch report precedes District reports arranged alphabetically by field office or engineer's surname. There are no District reports for 1947.

Narrative reports, statistical summaries, correspondence, memorandums, personnel lists, and other records concerning Branch programs and projects, including cooperation with Federal agencies, States, and municipalities.

439. QUARTERLY REPORTS. 1943-48. 1.5 in.

Arranged chronologically.

Narrative reports, accompanied by statistical summaries and lists of personnel, regarding personnel changes, investigations, publications in progress, and other Branch activities. Reports for 1943-March 1946 are quarterly 
reports of the Branches with some Division level information. Reports for the quarters 1947-48 are Division-level reports. Not all quarters are represented.

440. MONTHLY PROGRESS REPORTS OF THE DIVISIONS AND FIELD OFFICES. Sept. 1934 June 1935. $2 \mathrm{ft}$.

Arranged chronologically, and thereunder by Division and alphabetically by field office.

Narrative reports, with statistical summaries and tables, concerning the status of projects, public-works programs, and other cooperative investigations; internal reports and laboratory work; gaging stations; Division publications; and personnel matters.

441. RECORDS CONCERNING SIX-YEAR CONSTRUCTION AND REPAIR PLANS FOR FEDERAL PUBLIC WORKS. 1937, 1939, and 1941. 4 in.

The records for the first six-year plan, 1939 to 1944 (compiled in 1937), are arranged by subject, and thereunder alphabetically by State; records for the second six-year plan, 1941 to 1946 (compiled in 1939), are arranged by subject. A separate memorandum, dated 1941, is attached to the second set of plans.

Report forms, statistical summaries, and memorandums regarding the plans, estimates, and justification for proposed Federal Public Works projects during two six-year periods. The plans, submitted in 1937 and 1939, cover construction and repair projects relating to the work of the Water Resources Division.

442. BUDGET FILES. 1929-53. $2.5 \mathrm{ft}$.

Arranged chronologically.

Each file usually contains reports, statistical summaries, correspondence, memorandums, lists, circulars, copies of legislation, and other records regarding budget estimates, justifications, appropriations, allotments, and limitations for fiscal years 1931 to 1953. Also included are copies of applications for funds, statistical summaries, and other records concerning appropriations made by the Federal Civil Works Administration and the National Emergency Council for Division projects from 1933 to 1936.

443. ADMINISTRATIVE RECORDS OF THE FISCAL MANAGEMENT SECTION. 1947-56. 4 ft.

The general files at the beginning of the series are arranged by subject; the remainder are arranged by Surface Water and Ground Water areas, thereunder by district or field office, and thereunder roughly chronologically.

Chiefly correspondence and memorandums, but also includes lists of projects, statistical summaries, vouchers, and other records regarding estimates, allotments, and transfer of funds for the Division's programs in the field; project

authorizations; correspondence and memorandums concerning cooperative agreements; discrepancies in district accounts; damage claims; and purchase of equipment. Two items in the Iowa City, Iowa file are dated 1942.

\section{RECORDS OF THE FISCAL MANAGEMENT SECTION CONCERNING COOPERATIVE AGREEMENTS. 1945-63. $13 \mathrm{ft}$.}


Arranged in two time segments, 1947-57 and 1945-63; thereunder by Branch, then alphabetically by State or Territory, and thereunder chronologically.

Copies of cooperative agreements, completed "cooperative agreement transmittal-program description" forms, "fiscal abstract" forms, "advise of allotment" forms, correspondence, memorandums, statistical tables and summaries, and other records relating to the Division's cooperative agreements with States, counties, municipalities, water districts, tribal councils, and universities. The agreements concern water-resources investigations; recommendations and approvals for projects; and estimates, allotments, modifications, reimbursements, and transfer of funds for cooperative projects.

The files in the first time segment (1947-57) ceased to be administratively active in 1952, although documents were added up to 1957. This part of the series also contains a greater number of project descriptions. The majority of the records in the second time segment (1945-63) date from 1951, include more cooperative agreements, and contain documentation on combined investigations by the branches

445. MONTHLY PROGRESS REPORTS OF DISTRICT ENGINEERS CONCERNING CONSTRUCTION AND MAINTENANCE. April 1950 - May 1951. 5 in.

Arranged chronologically.

Statistical reports collected by the district engineers for the Bureau of Labor Statistics, Department of Labor, showing the cost of construction and maintenance at the field offices.

446. RECORDS CONCERNING ANNUAL ESTIMATED EXPENDITURES FOR CONSTRUCTION AT THE FIELD OFFICES. 1957-59. 3 in.

Arranged chronologically.

Statistical reports, memorandums, correspondence, and lists regarding the estimated expenditures for construction at the field offices for calendar years 1957 and 1958.

447. ESSENTIAL-DOCUMENT INVENTORIES FROM FIELD OFFICES. Feb. 1951. 4 in.

Arranged alphabetically by State.

Listing of inventory reports compiled by the field offices in response to a Division Circular, dated January 29, 1951, directing offices to identify documents deemed indispensable to the USGS in the event of a major disaster. Most reports include office name, brief description of the records, priority level, location of records, linear feet, cabinet and floor-space requirements, and recommendations for microfilming or additional security measures.

Also included with some of the reports are related indexes, memorandums, and handwritten notes.

448. RECORDS CONCERNING THE ORGANIZATION OF THE DIVISION. ca. 1932-56. 3 ft..

Arranged by subject or alphabetically by State in which field offices are located.

Memorandums, reports, drafts of reports, correspondence, handwritten notes, press releases, lists of Division field offices and USGS committees, statistical summaries, organizational charts, graphs, completed questionnaires, and other 
records regarding the activities, organization and reorganization of the Division. Also included are reports, memorandums, statistical summaries, and other records concerning various special committees, established by the Division to study its organization and make recommendations, and the USGS Committee on Organization and Management; and reports, statistical summaries, and sample registers regarding the Division's "obligation registers" (a day-to-day record, arranged chronologically by date of project, of the Division's obligations and expenditures). Most of the records date from 1942.

\section{RECORDS CONCERNING GENERAL STAFF COMMITTEE REVIEW OF FIELD PROJECTS.}

1953-57. $1.5 \mathrm{ft}$.

The first eight files are arranged by subject, and thereunder chronologically; the remainder of the series is arranged alphabetically by field committee, and thereunder chronologically.

Correspondence, memorandums, reports, minutes, attendance lists, administrative circulars and bulletins, statistical summaries, newspaper clippings, handwritten notes, and other records relating chiefly to decisions and recommendations made by the USGS General Staff Committee concerning the work of various field committees. Included is information relating to members of the committees; committee activities, meetings, projects and funds; and the General Staff Committee's review of their projects and reports. The records also reflect subjects of concern to the General Staff Committee, including Alaska development, reviews of reports by the Soil Conservation Service and Army Corps of Engineers, and legislation affecting water-resources policy. 
Records concerning Cooperation, 1903-66

450. MISCELLANEOUS CORRESPONDENCE FILES CONCERNING THE INTERNATIONAL JOINT COMMISSION ON UNITED STATES-CANADIAN WATER INVESTIGATIONS. 1917-56. $10 \mathrm{in}$.

Arranged chronologically.

Correspondence; memorandums, reports, statistical summaries, press releases, newspaper clippings, transcripts of meetings, lists of gaging stations, copies of legislation, plats, photographic prints of gaging stations, and other records concerning the International Joint Commission, the International Engineering Committees and Boards (chiefly the Souris-Red River Engineering Board, the Columbia River Engineering Committee, and the Interior Board on International Water and Power), joint management of international streams, power development, and gaging measurements on boundary waters, and meetings and conferences regarding joint investigations.

Also includes a series of reports titled "Water Power Resources of Canada," dated from 1942 to 1956, written by the Dominion Water and Power Bureau (of the Canadian Department of Mines and Resources) and later the Water Resources Division (of the Department of Northern Affairs and National Resources).

The International Joint Commission was created in 1912 under the provisions of the Boundary Waters Treaty of January 11, 1909, which provided that the governments of the United States and Canada agree to refer requests for investigations and reports on waters of common interest to the Commission.

451. FINANCE AND BUDGET FILES. 1940-57. 6 in.

Arranged chronologically.

Correspondence, memorandums, statistical summaries and tables, handwritten notes, copies of legislation, transcripts of statements made before the House Appropriations Committee, and other records relating to estimates, allotments, and distribution of funds for the International Joint Commission's investigations, and USGS participation in these projects.

\section{RECORDS CONCERNING THE ADMINISTRATION OF INTERNATIONAL WATERWAYS.} 1914-63. $15 \mathrm{ft}$.

Arranged geographically by waterway from east to west in the following order: St. John River, Passamaquoddy River, St. Croix River, St. Lawrence River, Niagara Falls, Great Lakes, Roseau River, Souris-Red River, Pembina River, Sage Creek, Frenchmen River, Battle Creek, Lodge Creek, St. Mary and Milk Rivers, Deer and Miner's Creeks, Kootenai River, Osoyoos Lake, Columbia River, Yukon River; and thereunder chronologically or by type of document.

Correspondence, memorandums, reports, statistical summaries, press releases, newspaper clippings, minutes, copies of speeches, transcripts of proceedings of Commission meetings, handwritten notes, plats, diagrams, processed reports and pamphlets, and other records concerning the joint operation of international streams between the United States and Canada, power development on international rivers, gaging measurements from stations on boundary waters, commission investigations, and commission and engineering-board meetings concerning the waterways.

The Great Lakes files contain compiled hydrologic data dated ca. 1870-1923 (from the files of Robert E. Horton), the Yukon River file contains hydrologic data from the early 1910's, and the Milk and St. Marys' Rivers files contain Frederick H. Newell correspondence dated 1914-15. 
Of particular interest are the bound reports on the Passamaquoddy Tidal Power Project (1950-63), correspondence concerning the conservation of Niagara Falls (1953), and a set of inspection reports concerning the "Utilization of Water in the Milk River Basin within the Blackfeet Indian Reservation, Montana" (1960-63).

Also included are a set of annotated aerial-mosaic contact prints of Sage Creek and glass slides and photographs, undated, that appear to be of a Rosseau River flood and flood damage.

\section{RECORDS CONCERNING COOPERATION WITH STATE AND TERRITORIAL GOVERNMENTS.} 1903-30. $6 \mathrm{ft}$.

Arranged alphabetically by State, Territory or subject, and thereunder chronologically. The subject files are Hetch Hetchy (with the California files) and Washington Irrigation and Development Company. Also included, at the end of the series, is a list of State Geologists, and other cooperative program officials for the years 1915 to 1936, that gives names, addresses, occupations, and the USGS organizational unit involved.

Chiefly correspondence, but also includes memorandums, reports, handwritten notes, statistical summaries, copies of legislation, plats, cooperative agreements, vouchers, and other records regarding the Division's cooperation with the governments in water-resources investigations. Included is information relating to various cooperative projects, reimbursements, transfer of funds and sharing costs, allotments and estimates, and the assignments of local officials and Division employees.

454. RECORDS CONCERNING RIO GRANDE JOINT INVESTIGATION. 1935-37. 3 in.

Arranged in four files designated: "General," "Ground Water," "Robert Follansbee," and "B[erkeley]. Johnson."

Correspondence, memorandums, reports, and statistical summaries concerning a study sponsored by the National Resources Committee to survey the available water supplies of the Upper Rio Grande River to determine an equitable allocation of water to Colorado, New Mexico, and Texas. The Public Works Administration allotted the funds to the National Resources Committee at the request of the Rio Grande Compact Commission. Includes information on surface-water, ground-water, and quality-of-water investigations, distribution of funds, and personnel matters.

455. RECORDS CONCERNING INTERSTATE RIVER COMPACTS AND REGIONAL PROJECTS. 192354. $3 \mathrm{ft}$.

Arranged alphabetically by name of river, region, or project. See Appendix 28 in this inventory for a list of file titles.

Correspondence, copies of legislation, minutes of meetings, draft and final copies of compacts, conference and other memorandums, telegrams, copies of compact resolutions, maps, lists of gaging stations, budget estimates and justifications, copies of articles and other printed items, reports, newsletters, and other records relating chiefly to USGS oversight of stream-gaging stations required for the operations of compacts and projects. Other subjects include appropriations, the formation of compacts and the role of the Federal representative on compact administrations, and cooperation with International Commissions, State agencies, private corporations and Federal agencies such as the Bureau of Reclamation, and the Army Corps of Engineers. 
The first file is titled General Compact Commissions. The remaining files are arranged alphabetically by river and thereunder chronologically.

Correspondence, reports, memorandums, agendas, minutes and proceedings of technical meetings and conferences, drafts of compact agreements, publications, statistical summaries, newspaper clippings, and other records concerning the administration, funding, plans and programs of the Bear, Delaware, and Pecos River Joint Investigations and the Boise River Silt Project. Also includes a correspondence file concerning the release of USGS data on the Columbia River flood of May 1948 to the Department of Justice. The file on general-compact commissions contains correspondence and memorandums regarding Federal representation on interstate-compact commissions.

457. RECORDS RELATING TO STATE LAWS FOR COOPERATION IN WATER RESOURCES INVESTIGATIONS. Feb. - Apr. 1941. 6 in.

Arranged by State or type of document.

Correspondence, memorandums, and copies of State legislation and publications received from district engineers by the Chief Hydraulic Engineer. These documents were submitted in response to a circular, dated February 6, 1941, that requested information about State water laws, particularly those provisions granting States the authority to cooperate with the USGS on water-resources investigations. Includes copies of State laws and publications for Arkansas, Maryland, Minnesota, Missouri, New England States, New Jersey, North Dakota, Oklahoma, Oregon, South Dakota, Virginia, and Wyoming.

458. RECORDS CONCERNING STATE WATER-RESOURCES COUNCILS. 1949-57. $4 \mathrm{ft}$.

Arranged alphabetically by State or Territory followed by two regional files - New England Council and Pacific Northwest Council, and thereunder chronologically.

Chiefly minutes, but also includes correspondence, memorandums reports, agendas, newspaper clippings, and other records. The earlier records usually contain more information about problems faced by the Councils at their inception. Both sequences contain information on the organization, objectives, administration, plans, projects, and recommendations of the State Councils. There are a few items dating from 1946.

The Division set up State Water-Resources Councils (Water Resources Division Circular dated May 6, 1949) to facilitate coordination between the various field offices of the Division's Ground Water, Surface Water, and Quality of Water Branches administered by the branches' field supervisors. The Councils were established to plan and coordinate projects, negotiate cooperative agreements with State and municipal agencies, and to supervise the consolidation of administrative services in the Branch offices.

\section{RECORDS CONCERNING COOPERATION WITH OTHER FEDERAL AGENCIES. 1916-52. 2 ft.}

Arranged alphabetically by name of agency or subject.

Correspondence, reports, memorandums, congressional documents, copies of articles, processed issuances, budget summaries and maps, plans, public notices, and other records concerning cooperation with the Departments of 
Commerce, Agriculture, Army, and State, the Army Corps of Engineers, the Bureau of Standards, the U.S. Board on Geographic Names, the Coast and Geodetic Survey, and other agencies.

The cooperative projects included the determination of ground-water supplies for agricultural-experiment stations, cemetery maintenance, and military installations; maintenance of stream-gaging stations for flood control, mining operations, hydroelectric-power production, and irrigation; Alaska stream investigations; stream-gage and

water-meter calibration tests; USGS participation in the European Recovery Program; and assistance to international river commissions.

460. RECORDS CONCERNING COOPERATION WITH THE ARMY CORPS OF ENGINEERS. 1915-45. 5 in.

Arranged chronologically.

Chiefly correspondence, but also includes reports, memorandums, circulars, minutes, proceedings, attendance lists, statistical summaries, maps, and other records concerning cooperation with the Corps of Engineers in water- resources programs, particularly the intercoastal waterway, flood control, stream gaging, and field tests of measurement devices.

\section{CORRESPONDENCE WITH DISTRICT ENGINEERS CONCERNING COOPERATION WITH THE ARMY CORPS OF ENGINEERS. 1928-44. 15 in.}

Arranged alphabetically by field office, and thereunder chronologically.

Consists for the most part of correspondence between the Chief Hydraulic Engineer and district engineers, but also includes reports, memorandums, statistical summaries, lists, maps, and other records regarding cooperation with the Corps of Engineers in water-resources programs, particularly stream-gaging and flood-discharge measurements.

\section{RECORDS CONCERNING COOPERATIVE STREAM-GAGING PROGRAMS WITH THE ARMY} CORPS OF ENGINEERS. 1928-31; 1936-43; 1951-66. 4.5 ft.

Arranged in rough chronological order and thereunder by geographical area or district office.

Correspondence, memorandums, reports, statistical summaries, tables, lists of cooperative stations, completed report forms on river gages, copies of legislation, vouchers, handwritten notes, plats, maps, and other records regarding cooperation with the Corps of Engineers in the construction, maintenance, and operation of gaging stations; estimates, allotments, and appropriations for cooperative programs; special studies prepared by the Division for the Corps of Engineers; and proposals and recommendations by the district engineers for new stations and equipment. Also contains some information relating to cooperative stream-gaging projects with the Weather Bureau.

\section{CORRESPONDENCE WITH THE ARMY CORPS OF ENGINEERS CONCERNING EQUIPMENT.}

1933-41. 1 in.

Arranged chronologically.

Correspondence, memorandums, and other records containing information about the acquisition and cooperative use of equipment. 
464. REPORTS FROM DISTRICT ENGINEERS CONCERNING COOPERATIVE FUNDS AND

ESTIMATES. 1940. 2 in.

Arranged alphabetically by surname of the district engineer, and thereunder chronologically.

Correspondence, reports, and statistical summaries regarding funds available for cooperative stream-gaging work for the Army Corps of Engineers and the USGS during fiscal year 1940, and estimates of funds required to finance stream gaging in the districts during fiscal year 1941.

465. RECORDS CONCERNING BRANCH PARTICIPATION IN A PIG-IRON SURVEY. 1942.6 in.

Arranged by subject or type of record.

Correspondence, memorandums, bulletins, copies of regulations, lists of foundries, copies of "Preference Rating Orders", pamphlets, statistical summaries and tables, and other records relating to the branches' participation in a survey of the use of pig iron. The War Production Board's Division of Industry Operations requested the survey. The National Park Service and the General Land Office also participated in organizing the survey.

466. WAR-SERVICE REPORTS. 1944-45. 0.5 in.

Arranged by type of record.

Chiefly final summary reports, for the interval from July 1 to September 2, 1945, from District Engineers in response to Water Resources Division Circular of October 25, 1945. The reports usually contain information about types of projects, name of agency or applicant, and information gathered. Also included are statistical summaries, covering the period January-August 1945, of requests for assistance by Federal, State, and other applicants prepared in the central office, apparently based on monthly reports.

\section{RECORDS CONCERNING HYDROLOGICAL STUDIES FOR THE MISSISSIPPI VALLEY}

COMMITTEE. Jan. 1934 - Jan. 1935. 2 in.

Arranged chronologically.

Chiefly correspondence, but also includes memorandums, reports, statistical summaries, maps, and other records relating to rainfall and runoff studies made by the USGS for the Mississippi Valley Committee of the Public Works Administration.

The first page of this file states that this material comprises Volume 1 and refers to a Volume 2. No Volume 2 has been found.

468. RECORDS CONCERNING STREAM-FLOW STUDIES IN THE MISSISSIPPI RIVER VALLEY. Nov. 1933-Dec. 1934. 4 in.

Arranged chronologically.

Chiefly correspondence, but also includes memorandums, reports, statistical summaries, diagrams, and other records relating to stream-flow studies to aid navigation and flood control in the Mississippi River Valley. The USGS 
undertook these studies in cooperation with the Mississippi Valley Committee and its successor, the Water Section of the Technical Committee of the National Resources Board. The Mississippi Valley Commission (Army Corps of Engineers), the Section of Hydrology of the American Geophysical Union, and the Flood Protection Data Committee of the American Society of Civil Engineers, advised and collaborated with the USGS on the work.

\section{RECORDS RELATING TO FEDERAL EMERGENCY-RELIEF PROJECTS. 1933-38. 2 ft.}

Arranged by subject, and thereunder chronologically or alphabetically by the surname of the district engineer.

Correspondence, memorandums, employment reports, project reports, copies of legislation, statistical summaries, graphs, and other records concerning applications, proposals, estimates, allotments and transfer of funds, purchases of equipment, and recommendations for relief projects supervised by the USGS and financed by the various Federal relief agencies. Includes information on Public Works Administration's studies of the floods of 1936, analyses of water samples, and construction of stream-gaging stations; Civil Works Administration projects to assemble and analyze stream-flow records and repair stream-gaging stations; Works Progress Administration projects to repair or replace stream-gaging stations and equipment damaged or lost in floods; and Federal Emergency Relief Administration projects to assemble and tabulate streamflow data, to establish stream-gaging stations, and to investigate drought relief.

470. RECORDS CONCERNING FUNDING OF PUBLIC-WORKS PROJECTS. 1933-38. 5 in.

Arranged by subject, and thereunder chronologically or by State.

Memorandums, correspondence, statistical summaries, reports, applications for funds, completed forms, and other records regarding the Division's allocation of estimates and allotments for public works projects. The completed forms, compiled in 1934, show estimates of public-works funds for new river-measurement stations by State, with river and location, and type of structure and equipment. Other forms compiled at the same time give the estimated cost of rehabilitating existing river-measurement stations showing river and location, and specifying type of structure and equipment.

Also includes lists of counties for which Division projects were being financed with public-works funds; a report on the possible establishment of a Department of Conservation; and a report on the floods of 1935-36 in New York State by Arthur W. Harrington and Hollister Johnson.

\section{CORRESPONDENCE AND OTHER RECORDS CONCERNING WEATHER BUREAU STREAM-} GAGING STATIONS. 1933-34. 3 in.

Arranged in rough alphabetical order by the surname of the district engineer.

Chiefly correspondence between the district engineers and the Chief Hydraulic Engineer, but also includes some reports, lists, and other records relating to recommendations and estimates for the construction and repairs of gaging stations for the Weather Bureau, installation of recorders at cooperatively maintained stations, and other cooperative activities concerning the rehabilitation of gaging stations with Public Works Administration funds.

\section{REPORTS AND RELATED RECORDS CONCERNING MAINTENANCE OF WEATHER BUREAU STREAM-GAGING STATIONS. 1934-35. 6 in.}

Arranged alphabetically by the surname of the district engineer, and thereunder chronologically. 
Chiefly reports from District Engineer concerning the replacement or rehabilitation of gages. Each report concerns one gaging station and usually contains the following information categories: location, date of original establishment of station and responsible agency, drainage area, type of gage, bench marks, control, type of measurement, flood history, winter conditions, regulations and diversions of the stream, anticipated accuracy of the record, cooperating agency, and a sketch showing the location of the gage. The series also includes correspondence, statistical summaries, plats, drawings, photographs, and other records relating to the inspection, rehabilitation, and replacement of Weather Bureau stream-gaging stations by funds provided by the Public Works Administration.

\section{RECORDS CONCERNING FUNDING AND MAINTENANCE OF WEATHER BUREAU STREAM- GAGING STATIONS. 1933-37. 5 in}

For the most part arranged alphabetically by the surname of the district engineer, and thereunder chronologically. Two general files at the beginning of the series are arranged chronologically.

Correspondence, memorandums, reports, lists, statistical summaries, drawings, and other records concerning installation of wire-weight gages and recorders, and the construction inspection, and repair of gaging stations for the Weather Bureau with Public Works Administration funds. Also includes information regarding the allotment and transfer of PWA funds, and the loan of equipment between the Weather Bureau and the USGS.

\section{RECORDS RELATING TO PROPOSED WORKS PROGRESS ADMINISTRATION PROJECTS.} 1935-42. 5 in.

Arranged alphabetically by State, and thereunder chronologically.

Correspondence, memorandums, reports, project applications, completed proposal forms, statistical summaries, diagrams, and other records regarding estimates of cost, work schedules, and the status of proposed projects. Typical projects to be supervised by the USGS included the construction, repair, and improvement of stream-gaging stations, and the installation of cableways across streams.

\section{RECORDS CONCERNING WORKS PROGRESS ADMINISTRATION PROJECTS. 1936-38. 7 in.}

Arranged alphabetically by the surname of the district engineer, and thereunder chronologically.

Chiefly correspondence, but also includes memorandums, project-authorization forms, lists, and other records concerning Works Progress Administration allotments and expenditures for repair and replacement of stream-gaging stations and equipment damaged or lost in floods.

\section{WEEKLY AND SEMIMONTHLY REPORTS CONCERNING WORKS PROGRESS ADMINISTRATION EMPLOYMENT AND PAYROLLS. 1936-37. 5 in.}

Arranged by week or semimonthly periods, and thereunder by district office.

The reports include completed forms and statistical summaries. Also includes memorandums relating to the allotments made for Works Progress Administration employment, the number of employees on WPA payrolls, and the amount expended. 
Arranged for the most part alphabetically by the surname of the district engineer, and thereunder chronologically. A few general files are found at the beginning of the series.

Correspondence, memorandums, circulars, reports, lists, and statistical summaries regarding appropriations, allotments, expenditures, and the status of projects supervised by the USGS, as authorized by the Public Works Administration Act of 1938. Projects supervised included surveys of flood and drought conditions, and the construction, repair, and improvement of stream-gaging stations.

478. RECORDS CONCERNING COOPERATION WITH THE SOIL CONSERVATION SERVICE. 1933-44. 5 in.

Arranged for the most part chronologically. The file at the end of the series is arranged alphabetically by the surname of the resident engineer.

Chiefly correspondence, but also contains circulars, lists, statistical summaries, an undated Soil Conservation Service Directory, photographs of a "silt sampler" (1936), lists of projects and maps, and other records regarding USGS cooperation with the Soil Conservation Service on various projects, including the measurement of streamflow and silt, publication of the results of various investigations, and the sharing and dissemination of information. Also contains information on expenditures and transfer of funds for cooperative projects.

479. CORRESPONDENCE WITH DISTRICT ENGINEERS CONCERNING COOPERATION WITH THE SOIL CONSERVATION SERVICE. 1933-42. $2 \mathrm{ft}$.

Arranged alphabetically by the surname of the district engineer, and thereunder chronologically.

Chiefly correspondence, but also includes some memorandums, between the district engineers and the Chief Hydraulic Engineer, regarding cooperation with the Soil Conservation Service (SCS) on projects to construct, repair, and improve stream-gaging stations and surveys of floods and droughts. Includes information regarding estimates, allocations, expenditures, the status and results of projects, inspection of SCS projects by USGS district engineers, cooperative use of equipment, and requests for supplies.

\section{REPORTS OF RESIDENT ENGINEERS ON SOIL CONSERVATION PROJECTS. 1934-39. 10 in.}

Arranged in monthly groups varying from 5 to 12 months, thereunder alphabetically by the surname of the district engineer or State, and thereunder chronologically.

Chiefly weekly reports submitted by resident engineers, with some interspersed correspondence and three annotated photographs taken in 1935 of Coon Creek, Wisconsin. The records relate to USGS soil-erosion control projects. Includes information on stream and silt measurements, silt analyses, local precipitation, and runoff data. 
481. RECORDS CONCERNING COOPERATION WITH THE SOIL CONSERVATION SERVICE.

1954-57. 10 in.

Arranged by subject, and thereunder chronologically.

Correspondence, memorandums, reports, administrative issuances, handwritten notes, newspaper clippings, copies of legislation, agendas, minutes, attendance lists, statistical summaries, maps, and other records regarding USGS cooperation with the Soil Conservation Service in the Watershed Protection and Flood Prevention Program, watershed demonstration projects and the processing and publishing of project records, and the compilation of the SCS Watershed Handbook. Also includes information on USGS cooperation in the compilation of the Department

of Agriculture's National Inventory of Soil and Water Conservation Needs--published in 1962 in the "Basic Statistics of the National Inventory of Soil and Water Conservation Needs" (Statistical Bulletin 317).

482. RECORDS OF BRIGADIER GENERAL HANS KRAMER CONCERNING NEGOTIATION OF THE ARKANSAS RIVER COMPACT. 1945-49. 15 in.

Arranged alphabetically by subject, and thereunder chronologically.

Correspondence, memorandums, reports, minutes, transcripts of meetings, membership lists, drafts of compacts, copies of signed compacts, copies of legislation, certificates of ratification, press releases, newspaper clippings, and other records relating to Kramer's official duties, negotiation of the compact, operation of the John Martin Reservoir, and cooperation with the Federal Power Commission, Department of Agriculture, and the Army Corps of Engineers. Includes correspondence, reports, and statistical summaries, and tables regarding investigations conducted by the "Committee on Engineering Data and Studies of the Colorado," which the Commission established on March 26, 1946, to assemble and analyze engineering data needed to formulate the compact. Also contains a 1943 report of the Special Master (a judicial official) concerning the U.S. Supreme Court case, "The State of Colorado vs. The State of Kansas and the Finney County Water Users' Association."

Many of the transcripts of the Commission's meetings also are in entry 484.

\section{RECORDS OF BRIGADIER GENERAL HANS KRAMER AS CHAIRMAN OF THE ARKANSAS RIVER COMPACT COMMISSION. 1949-60. $2 \mathrm{ft}$.}

Arranged by subject, and thereunder chronologically.

Correspondence, memorandums, computed reports, annual reports, statistical summaries, newspaper clippings, copies of rules and regulations, agendas, minutes of meetings, attendance lists, schedules, committee reports, photographs, plats, graphs, and other records concerning the organization, operation, and investigations of the Arkansas River Compact Administration (ARCA). Includes files relating to a study on the feasibility of establishing a permanent fishpool in the John Martin Reservoir, the investigations of Caddo Reservoir, and the Frying Pan-Arkansas water-diversion project in Colorado. Also contains information on the ARCA's cooperation with and review of the Army Corps of Engineers' John Martin Reservoir Project; the Department of Agriculture's Fountain River Watershed Project, the Bureau of Reclamation's Purgatoire River Project, Trinidad, Colorado. Other records relate to the ARCA's cooperation with the Arkansas-White-Red Basin Inter-Agency Committee and its subcommittee. The majority of records date from 1949 to 1956, but also include the daily reports of the operation of Caddo Reservoir, from January 1957 to April 1960, and copies of the minutes from the meetings in 1959 and 1960 of the Arkansas-White-Red Basin Interagency Committee. Many of the minutes from ARCA's meetings also are in entry 485. 
484. TRANSCRIPTS OF MEETINGS OF THE ARKANSAS RIVER COMPACT COMMISSION. Jan. 1946Dec. 1948. 10 in.

Arranged chronologically.

Brigadier General Hans Kramer's copies of the transcripts of ARCA's meetings, generally held every 2 or 3 months. Copies of many of these transcripts also are in entry 482.

485. MINUTES AND OTHER RECORDS OF THE ARKANSAS RIVER COMPACT ADMINISTRATION. 1949-55. 5 in.

Arranged chronologically or by subject.

Chiefly minutes of ARCA's regular, annual, and special meetings, but with some minutes of meetings that predate congressional approval of the compact in 1950. Also includes copies of regulations, plats, and Brigadier General Hans Kramer's report to Congress in 1949 regarding the Arkansas River Compact. Copies of some of these minutes also are in entry 483.

\section{RECORDS OF CARL GUSTAVE PAULSEN AS CHAIRMAN OF THE ARKANSAS RIVER COMPACT ADMINISTRATION (ARCA). 1957-60. 3 in.}

Arranged chronologically.

Minutes of meetings, correspondence, memorandums, reports, annual reports, and other records relating to the implementation of the compact's provisions.

For earlier records relating to Arkansas River Compact Administration, see entries 482-485.

487. GENERAL RECORDS OF THE LAKE MEAD AND LAKE HEFFNER PROJECTS. 1947-56. 3 ft.

Arranged by subject or type of record, and thereunder chronologically.

Correspondence, memorandums, drafts of reports, completed reports, press releases, handwritten notes, newspaper clippings, statistical summaries, photographs, plats, and other records regarding the administration and operations of the Lake Mead and Lake Heffner projects. Also includes vouchers, purchase orders, completed "bill of lading" forms, and summaries of expenditures relating to estimates and allotments, transfer of equipment, and travel and expenses of personnel; and correspondence and memorandums regarding cooperation with other departments and with the Bureau of Reclamation, Weather Bureau, and reports from conferences on the Lake Mead project; and reproductions of Lake Heffner data. It should be noted that records concerning both projects appear in many of the files, contrary to the information given on the file labels. Records concerning the Lake Mead project date from 1947. Records concerning the Lake Heffner project date from 1950.

The Lake Mead project, in cooperation with the Bureau of Reclamation and the Navy Department, investigated the sedimentation, salinity structures, and water budget for Lake Mead, Nevada. The Geologic and Topographic Divisions also participated in the Lake Mead project. The joint Federal study of seepage and evaporation in Lake Heffner, Oklahoma, determined and evaluated water losses.

Related records are described in the following three entries and entry 637. 
A three-volume processed report, "Lake Mead Comprehensive Survey of 1948-49," prepared for internal use.

489.

VOLUME AND AREA COMPUTATIONS FOR THE LAKE MEAD PROJECT. 1948-49. 1 in.

Most of the computation tables are numbered consecutively, and followed by a few loose papers.

Working statistical summaries, charts, tables and graphs, and other records.

490. RECORDS CONCERNING THE LAKE MEAD SEDIMENTATION SURVEY. 1948-49. $1 \mathrm{ft} .4 \mathrm{vols.}$ and unbound material. [NWCS, maps and plans]

Arranged by subject and sometimes thereunder by site.

Included are handwritten notes, level notes, graphs showing water-temperature measurements and water-level data, triangulation and other control-coordinate sheets, lists of triangulation-station locations, and notebooks and note cards with sounding observations.

491. RECORDS OF THE SUBCOMMITTEE ON HYDROLOGIC DATA OF THE FEDERAL INTERAGENCY RIVER BASIN COMMITTEE. 1947-48. $3 \mathrm{ft}$.

The records are in envelopes arranged by assigned number, from 1 to 56. See Appendix 29 in this inventory for a list of the maps found in the records. The appendix gives each map number (1 to 79), river basins and drainage areas covered by each map, and the envelope number where the map and related records can be found. The map numbers do not correspond to the envelope numbers. Many files contain information on several maps.

Chiefly annotated maps and statistical summaries showing the priority rating of each station for river basins and drainage areas. These records were compiled by the work groups of the Subcommittee. Also includes correspondence, lists of proposed hydrologic stations, copies of instructions, memorandums, and minutes of meetings relating to the proposals and recommendations of subcommittee members for gaging stations and ground-water investigations; and computer print-out sheets of the processed data regarding proposed hydrologic stations. The last box contains a typed summary arranged by map number giving the locations of stations, a justification for each station, State, and priority rating.

The Subcommittee included representatives from the following agencies: USGS, Army Corps of Engineers, Bureau of Reclamation, Weather Bureau, Bureau of Indian Affairs, Forest Service, Soil Conservation Service, Fish and Wildlife Service, Bureau of Land Management, Federal Power Commission, International Boundary and Water Commission, Public Roads Administration, Public Health Service, Southwest Power Administration, and the Tennessee Valley Authority. Each agency presented its general needs and uses for hydrologic data at regional conferences of the Subcommittee. The river-basin work groups then considered the needs of each agency in setting priorities for the establishment of each proposed river station.

492. RECORDS CONCERNING POSSIBLE DEVELOPMENT OF THE GREAT FALLS OF THE POTOMAC RIVER AS A HYDROELECTRIC POWER SITE. 1908, 1910-12. 5 in.

Arranged in two chronological sequences: 1908; and 1910-12. 
The records for 1908 include correspondence, reports, memorandums, statistical summaries, and newspaper clippings regarding the amount of electricity, coal, and gas used by the Federal and District governments in the District of Columbia.

Of particular interest is a report by Marshall O. Leighton, Chief Hydrographer, on "The Use of Power by the General and District Governments in the District of Columbia," and a report by a U.S. Assistant Attorney on the legal rights of the United States and the District to the waters of the Potomac and power privileges at Great Falls.

The records for 1910-12 include correspondence, reports, memorandums, statistical summaries, plats, diagrams, maps, handwritten notes, and other records concerning the USGS study of the practicability of developing water power on the Potomac River at or near Great Falls, to supply energy for the District's street lights and other artificial-lighting needs.

493. RATING TABLES FOR SINGLE-POINT AND COMBINATION METER MEASUREMENTS TAKEN AT CHEVY CHASE, MARYLAND. 1909-12. 0.5 in.

Unarranged.

Completed forms, apparently used in comparison tests of these two meters. 
Records concerning Hydrologic Data and Reports, 1892-1953

494. NOTEBOOKS RECEIVED FROM THE BUREAU OF RECLAMATION. 1892-1928. 8 in. 9 volumes

Arranged in chronologically by date of compilation.

The notebook contents are: field notes on Pecos River meanderings (Reed, 1892); administrative notes and diary entries on travel in western states (Newell, 1894); notes on triangulation sites (location and author not given, 1899); level notes on Menominee drainage, Michigan (Herdman, 1919); level notes on the Lake Waccamaw tract, North Carolina (Bissell, 1928); and notes on the Potillas Canal, Damsite and Reservoir, and Upper Millinea Reservoir, Puerto Rico (Pace, n. d.).

495. FIELD NOTEBOOKS CONTAINING HYDROLOGICAL DATA. 1907. 4 in. 8 volumes and an index.

Arranged by assigned number. The index to the notebooks is arranged by county, and thereunder alphabetically by town.

Notebooks compiled by Stephen R. Capps and Frederick G. Clapp that contain data on underground water in northern Indiana. A typical notebook contains rough topographic sketches showing the location of wells or springs; narrative description of areas where sites are located, type of well, depth, and nature of geologic strata; and well-record tables, showing the name of the owner, county, town, name of the driller, depth, method of construction, year, size, depth to water, volume of flow, type of pump, yield, and other information.

496. STATISTICAL REPORTS FOR THE DIVISION'S PROGRAM OF 1949. 5 in.

Arranged by type of document in three sets, thereunder by State or district office, and thereunder by Branch.

The first set of reports show the estimated number of daily and periodic stream-gaging stations and the sources which funded their operations. The second set shows the estimated distribution of staff time by activity. The third set shows an analysis of the 1949 program by activity interests.

497. RECORDS RELATING TO FORMULATION OF THE ANNUAL BUDGET FOR 1951. 1949-50. 5 in.

Arranged by type of record, thereunder by Branch, and thereunder by field office or project.

Forms, completed for Fiscal 1950, showing estimates of the type and number of water records collected by the States under various sources of funds, schedules of projects begun or ongoing, estimates of obligations by functions, statistical summaries, and other records. The records were compiled in accordance with Fiscal Order 49-16 of June 20, 1949, and Fiscal Instruction 22.2, dated June 22, 1949.

\section{ANNUAL STATISTICAL REPORTS CONCERNING HYDROLOGIC DATA COLLECTED AND} PROJECT INVESTIGATIONS. 1950-53. $1.5 \mathrm{ft}$.

Arranged chronologically, thereunder by Branch, and then by district or field office.

Reports, accompanied by a few memorandums, and oversized statistical tables, giving the annual statistics for the hydrologic data collected by the Division in cooperative and other programs, a brief description of the investigations by the branches, their sources of funding, and plans for publication. 
Arranged chronologically: reports for April 1951 to September 1951 are arranged by month; the remainder by quarter, and thereunder by Branch, and thereunder by district or field office.

Copies of "Report of Data Requested" that give statistical summaries for the sources of requests (other Federal agencies, States, municipalities, other local units, commercial firms, and individuals). Includes the major use of the data, the types of requests and data furnished, and the adequacy of replies; and the "Record of Data Requested," which gives narrative summaries of the requests and replies. Also contains a few memorandums and oversized statistical tables.

The requests were received by the Division from Federal agencies, States, municipalities, countries, water districts, and private firms for information relating to streamflow records, the design and operation of water-supply systems, pollution and flood investigations, and the general development of water resources.

\section{RECORDS CONCERNING "THE DYNAMICS OF WINDMILLS," BY J. ALFRED GRIFFITHS.} 1898-99, 1901. 3 in.

A complete copy of Griffiths' manuscript including statistical summaries and graphs computing the efficiency of windmills; an 1899 letter (19 pages) from Thomas O. Perry to Frederick H. Newell, Hydrographer, giving a detailed critical review of the manuscript; and a 1901 letter from Griffiths inquiring about publication of the manuscript. The series also contains two partial annotated copies of the manuscript.

501. UNPUBLISHED MANUSCRIPTS. 1904-6. 9 in.

Arranged in the order given below.

Manuscripts for "Hydrography of the Colorado River Drainage Basin (to the end of 1904)," by Edward C. Murphy; "Percolation and Evaporation," by Robert. Horton (ca. 1904); and "Report on Hydrographic Investigations in the Sacramento Basin, California," by Samuel G. Bennett (ca. 1906). The manuscripts contain statistical summaries. Horton's manuscript includes a letter and a memorandum containing recommendations and editorial remarks. Bennett's manuscript contains a plat.

\section{ANNOTATED "SUMMARIES OF THE CLIMATOLOGICAL DATA FOR THE UNITED STATES BY}

SECTIONS." ca. 1909. 5 in.

Arranged by geographical sections of the United States.

A set of Weather Bureau publications containing summaries of climatological data including narrative reports, tables, and maps. Many of the maps have annotations by Henry Gannett, a member of the Topographic Branch staff.

\section{PLANS AND DIAGRAMS RELATING TO EQUIPMENT FOR THE COMPILATION OF HYDROLOGIC} DATA IN CANADA. 1911. 7 items.

Plan for a current-meter rating station and diagrams of a (cable) car for a station at Calgary, Alberta ( 3 items); and the rating curves for Gurley's electric meters (4 items). The plans and diagrams were prepared by the Irrigation Office of the Department of Interior, Dominion of Canada. 
504. RECORDS CONCERNING STREAM-GAGING STATIONS IN WEST VIRGINIA, OHIO, AND

KENTUCKY. 1915-16. 2 in.

Arranged by State, as listed above, and thereunder by river, stream, or creek.

Reports (describing river stations), graphs, and printed maps concerning stream-gaging stations, rating curves, and topography of streams.

505. REPORTS OF DAILY GAGE READINGS AT THE PUMPING STATION IN MEMPHIS, TENNESSEE. July 11, 1922 - August 29, 1923. 5 in.

Arranged chronologically.

Completed forms showing hourly gage readings and other data, sometimes accompanied by comments. Some forms include numerical information about the operation of the engine, pumps, and boilers.

\section{TABLES OF AREA OF WATER BODIES IN THE MERRIMACK AND CONNECTICUT RIVER}

BASINS. Undated. 21 pages.

Information on the Merrimack River tables is arranged geographically, beginning with the East Branch of the Pemigewasset River, and progressing down the basin in the order in which the tributaries empty into the Merrimack River; information on the Connecticut River tables is arranged geographically, beginning with the Third Connecticut Lake and progressing down the basin.

Tabular data concerning the area of all the principal water bodies in the Merrimack River Basin (lakes, ponds, and reservoirs). Data for each water body include its name (when known), longitude and latitude, mean sea-level elevation, area of water surface in acres, and an approximate description of its location. Also included is a summary table for all principal tributaries.

\section{BACKGROUND DATA FOR WATER-SUPPLY PAPERS. 1935-40. $19 \mathrm{ft}$.}

Arranged numerically by Water-Supply Paper, 771, 772, 796F, 796G, 798, 799, 800, 837, 838, 839, 842, 843, $844,867,869,915,966$, and 1066, thereunder by subject, surname of correspondent, or type of data.

Working and printed copies of statistical summaries and tables, annotated manuscripts and maps, graphs, charts, narrative and bound reports, published articles, oversized statistical tables, plats, copies of offset sheets, photographic prints, and other records that appear to have been used in the preparation of water-supply papers. These records relate chiefly to the effects of storms and floods on river-basin areas. The statistical data contain hydrological and meteorological information, including precipitation, runoff, and discharge measurements, riverflow computations, measurements of ocean-wave height, and ground-water analyses.

Also includes correspondence, memorandums, and minutes of meetings regarding the plans and progress of project investigations, collection of data, transfer of funds, loan of data and supplies, recommendations to correct or amend the water-supply papers, and publication of the papers.

Many of the publications were prepared with the aid of funds from the Works Progress Administration and Public Works Administration. Information was received from a number of cooperating sources, including the Weather Bureau, Army Corps of Engineers, Soil Conservation Service, National Resources Planning Board, and State agencies. 
Of particular interest are records relating to an investigation by the National Resources Planning Board's Subcommittee on the Gila Basin, which was asked to report on the relationship between land-improvement practices and quality and quantity of water in the Gila Basin in Arizona and New Mexico. The Subcommittee was established in 1940 after a report that the Department of Agriculture's soil-conservation practices had harmful effects on streamflow that resulted in losses to the San Carlos Indian Reservation and surrounding area. These records appear to have been added as a follow up to USGS Water-Supply Paper 796-F, "Geology and Ground-Water Resources of the Valley of the Gila River and San Simon Creek, Graham County, Arizona" ( by Maxwell M. Knechtel, 1938).

508. ANNOTATED MANUSCRIPTS AND OTHER RECORDS RELATING TO "A HISTORY OF THE WATER RESOURCES BRANCH OF THE UNITED STATES GEOLOGICAL SURVEY," VOLUMES 2, 3, AND 4 (1919-1947) BY ROBERT FOLLANSBEE. 1949, 1953. 2 ft.

Arranged by volume, followed by a general reference file.

Annotated manuscripts of the three unpublished volumes of Follansbee's history of the Water Resources Branch: Volume 2, "Years of Increasing Cooperation, July 1, 1919 to June 30, 1928"; Volume 3, "Years of 50-50 Cooperation, July 1, 1928 to June 30, 1939"; and Volume 4, "Years of World War II, July 1, 1939 to June 30, 1947." The general file contains memorandums concerning the manuscripts, and photographic prints of Nathan C. Grover, staff, field laboratories, gaging stations, wells, and equipment.

A cloth copy of Follansbee's Volume 1, "A History of the Water Resources Branch of the United States Geological Survey, to June 30, 1919," donated by the estate of Charles S. Howard, a pioneer in water-quality investigations, has been placed with the records. The volume was formally published by the U.S. Government Printing Office in 1994 as a USGS Special Book.

In 1990 the USGS published the fifth volume in this series, "A History of the Water Resources Division, U.S. Geological Survey: Volume 5, July 1, 1947 to April 30, 1957," by George E. Ferguson, and others. The sixth volume, "A History of the Water Resources Divisions, U. S. Geological Survey: Volume VI, May 1, 1957, to June 30, 1966: The Years of Change," by Hugh H. Hudson, Joseph S. Cragwall, and others appeared in 1996. A seventh volume, covering the years 1966-1976, is being prepared. 
White Mountains Investigation, 1896-1932

The collection of waterflow and precipitation data in the White Mountains region was undertaken under the provisions of the act of March 1, 1911 (36 Stat. L., 962), known as the "Weeks Act," in cooperation with the National Forest Reservation Commission.

\section{SUBJECT FILES OF THE SURFACE WATER DIVISION OFFICE IN NORTH WOODSTOCK, NEW} HAMPSHIRE. 1911-12. 15 in.

Arranged alphabetically by subject or surname of correspondent, and thereunder roughly chronologically.

Chiefly correspondence, but also includes reports, monthly reports, memorandums, completed contracts and employment forms, vouchers, account sheets, receipts, statistical summaries, a ledger of nonexpendable property, catalogs, publications, plats, diagrams, and other records regarding the White Mountains Investigation.

The correspondence is chiefly between the Engineer-in-Charge, John C. Hoyt, or the Assistant Engineers, Charles R. Adams and Guy C. Stevens, and various Junior Engineers, assistants, and goods suppliers. Included is information on the progress of the investigations, the collection and analyses of data, instructions and recommendations, field employees, expenses, and the purchase of supplies.

510.

DATA FILES. 1906, 1911-12. $2 \mathrm{ft}$.

Arranged as follows: Ammonoosuc River, Anderson Brook, Burnt Brook, Covert Brook, Fabyans (meteorological observations at various sites), Flume Brook, Gibbs Brook, Mad River (at Waterville), Mad River (West Branch), Shoal Pond Brook, and Zealand River, followed by three general files.

Statistical summaries, sometimes accompanied by charts and correspondence, of the data collected as part of the White Mountains Investigation. The statistical summaries, sometimes termed field notes, give river-height observations, precipitation and runoff data, and the mean figures for the snow and water equivalent of drainage sites. There are also a few pages of correspondence concerning hydrographic work in the White Mountain region dated 1906 in the last folder.

511. RECORDS CONCERNING DISTRIBUTION OF EXPENSES. May 1911- March 1913. 3 in.

Arranged in two parts: the first by month, and thereunder chronologically; the second by drainage project.

Completed charge sheets showing the distribution of expenses incurred from the White Mountains Investigation; each sheet gives the date, to whom paid, and total amount and purpose of expenditure. Also includes completed account sheets for various drainage projects that give voucher number, date, to whom paid, and purpose of expenditure.

The corresponding vouchers have not been found.

512. DISTRIBUTION JOURNAL OF THE NORTH WOODSTOCK OFFICE. Oct. 31, 1911-Apr. 10, 1912. 1 in. 1 vol.

Arranged in numerical order by voucher number. 
Individual entries give the voucher date, voucher number, to whom paid, date forwarded, amount, purpose of expenditure, contract field number, contract data, and remarks. Some of the corresponding contracts can be found in entry 509.

The corresponding vouchers have not been found.

\section{ADMINISTRATIVE RECORDS. 1911-13. 4 in.}

The first two files are arranged by subject; the remaining files are arranged chronologically by month.

Correspondence, handwritten notes, lists of property (purchased, loaned, and abandoned or lost), ledger sheets, bills, vouchers, and statistical summaries regarding the purchased, rented, and abandoned or lost equipment and property of the White Mountains Investigation, the loan of equipment from the Weather Bureau and Forest Service, the payment of storage and rental fees, and housing and expense accounts for the members of the Investigation.

\section{RECORDS CONCERNING PRECIPITATION DATA. July - December 1911. 10 in.}

Arranged by the following streams or gaging sites: Ammonoosuc, Crawfords, Waterville, North Woodstock, East Branch, and Zealand, and thereunder by location of recorded observations.

"Gage Height Observations" notebooks that contain dates, observer's name, precipitation data, and remarks on meteorological and rain-gage conditions.

515. DATA COMPILATIONS AND OTHER RECORDS. 1896, 1903-6, 1911-13. 10 in.

Arranged by subject, but not all the documents that pertain to a subject are found together.

Statistical summaries, charts, drafts of reports, completed reports, plats, correspondence, and photographic prints that were apparently compiled and maintained by the North Woodstock Office. Includes data on precipitation measurements, the ratio of flood period to crest, runoff analyses, and flood intensity; reports on soil studies, spring runoff, and the relations of forests to streamflow; and narrative descriptions of gaging stations. Also contains some runoff data from 1896, some correspondence dated 1904, a report on the hydrography of the White Mountains region during September 1903 to October 1906, and lists of photographs taken by various observers in 1912.

516. WATER-DISCHARGE MEASUREMENTS AND CURRENT-METER NOTES. August 1911 August 1912. 10 in.

Arranged alphabetically by river station, and thereunder chronologically.

Discharge-measurement notes taken for the White Mountains Investigation that include date, location, width, area and mean velocity of water at station site, discharge measurements, time of measurement, method of suspension, and notes on weather and station conditions.

\section{FIELD NOTES CONCERNING GAGING STATIONS AND READINGS. 1911-12. $1 \mathrm{ft.}$}

Arranged by the surname of the engineer, and thereunder chronologically. 
Daily narrative entries by the field engineers of the White Mountains Investigation that include information on their work procedures, installation and maintenance of gaging stations, meteorological conditions, and gage readings. Some of the field notes include statistical data.

\section{RECORDS OF RIVER STATIONS. 1911-12. 4 in.}

Arranged alphabetically by river station or other site: Ammonoosuc River near Breton Woods, Ammonoosuc River near Twin Mountain, Halfway Brook, Jackman Brook, Lost River, Mad River above Flume Brook, Mad River below Flume Brook, Moosilauke River below Pike Brook, North Woodstock Meteorological Station, Osceola Brook, Pemigewasset River at Plymouth, Middle Branch Pemigewasset River at North Woodstock, Pike Brook near mouth, Shoal Pond, and Stillwater Meteorological Stations.

Chiefly statistical summaries that include data for meteorological observations, rain-gage measurements, gageheight observations, precipitation intensity, and discharge and runoff measurements taken at various river stations in New Hampshire. Many files also contain blueprint copies of forms describing the station including information such as station location, drainage area, type of gage, channel, date established, and a sketch showing the location of the gage.

\section{ORIGINAL GURLEY PRINTING-GAGE RECORDS. February-November 1912. 25 spools.}

Arranged by brook, and thereunder chronologically.

Original print-out tapes from Gurley stream gages for Anderson Brook, Burnt Brook, and Shoal Pond Brook. Each spool of tape is annotated to show the place and time span of measurements.

520. REPORTS AND OTHER RECORDS CONCERNING THE HYDROGRAPHY OF THE WHITE MOUNTAINS IN NEW HAMPSHIRE AND OTHER REGIONS. 1911-13, 1932. 5 in.

Arranged roughly by subject.

Chiefly reports, but also includes correspondence, statistical summaries, tables, photographic prints and negatives, and other records relating chiefly to the hydrographic investigations of the White Mountains. Included are the original annotated draft and a 1960 reproduction of the final report of the investigation, "The Relation of Forests to Stream Flow," and an undated digest of the report; photographic prints and negatives of timber land in the White Mountains region; a preliminary report, dated 1904, of the hydrographic work in the White Mountains region; and a list of gaging stations and a report on the hydrographic investigations in the Appalachian Park region. Also includes correspondence, dated 1932, regarding the transfer of White Mountains records by the district engineer to the central office of the USGS.

521. CONTOUR MAPS [RELATING TO THE WHITE MOUNTAINS INVESTIGATION]. 1911-12. 19 items. [NWCS, maps and plans]

Arranged by watershed or stream.

The maps show the locations of stream-gaging stations, snow scales, and rain gages. The maps were compiled in cooperation with the National Forest Reservation Commission. There is an original and a copy of each map. The series is accompanied by later topographic-quadrangle maps of the area, which were probably added to the collection for reference purposes. 
Arranged by subject.

Statistical tables and summaries, reports, correspondence, and handwritten notes concerning water resources in the White Mountain area. Includes information relating to streamflow data, storage reservoirs, and forest conditions. Interspersed in the files concerning the Connecticut River at Oxford, New Hampshire, and Ten Mile River are correspondence, statistical tables, and graphs, dated 1913-25, concerning inquiries and analyses on the waters of this region.

\section{PHOTOGRAPHS RELATING TO THE WHITE MOUNTAINS INVESTIGATION FROM THE JOHN} CLAYTON HOYT COLLECTION. 1911-12. 1 album. 1 in.

Unarranged. Each print is captioned and dated. This is series JCH (NWCS, still pictures).

Black and white prints, varying in size from 3.25 in. x 4.25 in. to 3.25 in. x 5.5 in., show snow scales, streamgaging stations and drainage basins. The streams show are Anderson, Burnt, Flume, Gibbs, and Shoal Pond Brooks, and the Ammanoosac, Mad River and West Branch Mad River. There are also a few photographs showing logging operations and members of the study party at the Stillwater Camp.

Negatives for the photographs bearing numbers preceded by the letter"A" are described in series WMN (entry 525).

A note found with the photographs states that these items were salvaged from Hoyt's collection.

524. PHOTOGRAPHIC PRINTS. 1911-12. 2 albums and unmounted photographs. 6 in.

The photographs in the albums are unarranged. The unmounted photographs are arranged in two sets "A" and "B" and thereunder by agency assigned number. Many of the prints carry titles and dates. This is series WM (NWCS, still pictures).

Black and white prints showing gaging stations, snow-scale sites, erosion scars, cut-over land, forest growth and scrub cover, and panoramic views of watersheds and drainage basins. The streams shown in the photographs are the Ammonoosuc River, Anderson Brook, Burnt Brook, Covert Brook, Flume Brook, Gibbs Brook, Halfway Brook, Jackman Creek, Lost River, Mad River, Moosilauke River, Pike Brook, West Branch Mad River, Shoal Pond Brook, and Zealand River. Most of the photographs were taken in 1912.

Negatives for many of the prints with numbers preceded by the letters "A" and "B" are described in series WMN (entry 525).

\section{PHOTOGRAPHIC NEGATIVES. 1911-12. 10 in.}

Arranged in two sets "A" and "B," and thereunder numerically by agency assigned number. This is series WMN (NWCS, still pictures).

Black and white negatives (4 in. x 6 in.) corresponding to the photographs described in series JCH (entry 523) and WM (entry 524). 


\section{Records concerning the Superpower Survey, 1918-23}

The Sundry Civil Expenses Act of June 5, 1920 (41 Stat. L., 911), included provisions for an investigation by the USGS of the electrical-power requirements of the industrial region between Boston and Washington, D.C., and the preparation of a report on the benefits of establishing a comprehensive system to provide electricity to industrial users in the region. The investigation also was known as the Superpower Survey. The Water Resources Division provided administrative support for the work. The findings of the survey were published in 1921 as USGS Professional Paper 123, "A Superpower System for the Region between Boston and Washington," by William S. Murray and others.

\section{RECORDS CONCERNING THE ORGANIZATION OF THE SUPERPOWER SURVEY. 1918-20. 1 in.}

Unarranged.

Chiefly copies of letters from utilities, industries, railways, engineering associations, newspaper editors, and others to the USGS, Interior Department officials, and members of Congress justifying a superpower investigation. Also includes copies of data, a project budget, and background statements prepared by the Water Resources Division for the use by the USGS Director during appearances before congressional committees.

\section{ADMINISTRATIVE FILES. 1918-22. 5 in.}

Arranged by subject.

Correspondence, processed reports, and other records concerning the organization and expected benefits of the superpower survey, publication of the survey report, and coordinated hydroelectric development based on recommendations in the report. Also includes a reply (from the Secretary of the Interior) to an inquiry from Col. Joseph H. Pratt, North Carolina Geological and Economic Survey, regarding a survey of superpower potential in the Southeast, and a draft of a proposed Federal Charter to incorporate the North Atlantic Superpower Company, prepared by Edward G. Buckland, a member of the Superpower Survey Advisory Board.

\section{CORRESPONDENCE WITH SUPERPOWER-SURVEY STAFF AND OTHERS. 1919-23. 5 in.}

Arranged chronologically.

Mostly copies of letters sent by the Chief Hydraulic Engineer and other USGS officials and letters received from the Chairman, William S. Murray, Engineer-Secretary, Henry Flood, Jr., and Chief Clerk, John J. Madigan of the Superpower Survey, concerning the organization and responsibilities of the survey team, appointments, requests for information and related topics. Also includes correspondence with other individuals interested in the superpower survey and copies of reports, memorandums, and statistical tables depicting river flow and amounts of power generated by utilities.

529. CORRESPONDENCE OF THE CHAIRMAN, WILLIAM SPENCER MURRAY. 1920-21. 5 in.

Arranged in rough alphabetical order by subject, name of correspondent, or organization. 
Chiefly correspondence with engineering associations, newspaper editors, and others concerning engineering problems associated with the development of hydroelectric resources, and the impact and anticipated benefits of the superpower-survey report. Also includes copies of articles, reports, speeches and printed items.

\section{CORRESPONDENCE FILE OF THE CHIEF CLERK, JOHN J. MADIGAN. 1920-21. 2 in.}

Arranged in rough chronological order.

Correspondence and telegrams relating to appointments, travel, expenses, and related matters.

\section{ENGINEERING-STAFF CORRESPONDENCE AND DATA FILES. 1920-21. $2 \mathrm{ft}$.}

Most of the files are arranged alphabetically by name of utility, railway, or other subject. Three untitled files are at the end of the series.

Chiefly maps showing the areas served by utilities. Also including maps showing the location of railway lines and the generating stations serving the lines, tables and graphs, annual reports of utilities, reports on survey-team field trips, and other records.

\section{MINUTES OF THE ADVISORY BOARD. 1920-21. 3 in.}

Arranged chronologically.

Minutes of eight meetings, held in New York and Washington, D.C., between Sept. 24, 1920, and June 23, 1921. Also includes minutes of an Engineering Staff meeting on May 29, 1921, and an executive session of the Advisory Board after a special meeting on May 13, 1921.

\section{STATISTICAL COMPUTATIONS FOR HYDROELECTRIC DEVELOPMENT. 1918-21. 5 in.} 3 binders.

Arranged by name of river.

Tables, diagrams, and graphs showing the discharge of water at power sites, comparative flow of tributaries, average and minimum years' duration of flow, elevation of crest, and kilowatt-days of power available from natural flow. Many measurements date from 1909 interspersed with some data from the 1880's. The computations are for the Delaware, Hudson, Black, Raquette, Potomac, Susquehanna, Lehigh, St. Lawrence, and Connecticut Rivers.

534. SUPPORTING DATA FILES. 1919-21. $10 \mathrm{in.}$

Arranged by subject.

Contains steam-electric-power analysis sheets, data regarding the hydroelectric potential of various rivers (contains some data from the 1890's), lists of electric-power utilities in the northeast superpower region, progress reports, tabulated data, memorandums, correspondence, tables, graphs, and other records used to compile the superpower-survey report. There is also a set of replies to letters sent out by Lorin E. Imlay, Division Engineer, Power and Transmission, to electric power companies, cable companies, and manufacturers of transmission equipment 
requesting information about experience with and opinions about power-station capacity and transmission circuits, transmission of electric power over long distances, continuity of transmission line service and related questions.

\section{DRAFT REPORT OF THE SUPERPOWER SURVEY. 1921. 5 in.}

An incomplete, edited, annotated draft of the superpower-survey report. Some of the appendixes have different titles and numerical designations than those with the final report, which was published as USGS Professional Paper 123, "A Superpower System for the Region between Boston and Washington" (by William S. Murray and others, 1921). Also includes correspondence concerning the content and format of the report.

536. NEWSPAPER CLIPPINGS. 1920-22. 3 in. 1 binder and unbound papers.

The unmounted clippings are arranged alphabetically by name of the newspaper; the clippings in the binder are unarranged.

The unmounted clippings concern the superpower-survey proposal and formation of the survey team. The remaining clippings concern public reaction to the superpower-survey report. 


\section{Planning Section, 1953-71}

The Planning Section was established in 1956 as part of a general reorganization of the Water Resources Division. The Section succeeded the Program Control Branch, which had been established in 1948 as a staff unit. The functions of the Section included administration and coordination of programs, allocation of funding to the operating branches, and negotiation of agreements and oversight of cooperative projects. The Section reported to the Assistant Chief Hydrologist for Program and Development.

\section{PROGRAM FORMS AND OTHER RECORDS FROM THE PLANNING SECTION CONCERNING COOPERATION WITH FEDERAL AGENCIES. 1953-70. $3.5 \mathrm{ft}$.}

Arranged chronologically in three blocks: 1953-60, 1959-64, and 1963-70, and thereunder alphabetically by Federal agency or unit. The 1963-70 material forms the largest segment of the files.

Completed "Yearly Work Plan," "Project Description," and "Summary of Program" forms that provide objectives, descriptions, justifications of the cooperative programs, estimates and allotments, personnel information, and plans for publication. Also includes progress reports, lists of projects, memorandums and statistical summaries relating to proposals for new or further investigations review of projects, and estimates and allotments.

\section{PROGRAM FORMS AND OTHER RECORDS FROM THE PLANNING SECTION CONCERNING COOPERATION WITH STATES AND LOCAL UNITS. 1956-68. $5 \mathrm{ft}$.}

Arranged in the following three chronological segments: 1956-59, arranged alphabetically by State or Territory; 1960-61, arranged by region, thereunder chronologically, and then roughly alphabetically by State; and 1962-68, alphabetically by State (only includes Maryland through Wyoming).

Completed "Summary of Program" (including preliminary and revised versions), "Cooperative Agreement Transmittal-Program Description," and "Yearly Work Plan" forms that cover objectives, descriptions, and justifications of cooperative programs with States, countries, municipalities, water districts, Indian tribes, and other associations, estimates and allotments, personnel information, and plans for publication. Some of the forms are accompanied by memorandums, reports, and plats.

\section{PROGRAM FORMS AND OTHER RECORDS FROM THE PLANNING SECTION CONCERNING FEDERAL PROJECTS COMPLETED OR TERMINATED. 1957-67. 14 in.}

Arranged chronologically.

Chiefly completed "Yearly Work Plan" or "Project Description" forms, but also includes correspondence, memorandums, copies of work proposals, project reports, statistical summaries, completed project-review forms, newspaper clippings, handwritten notes, and other records relating to Federal projects completed or terminated by the Division. Contains recommendations to continue, terminate, or revise certain projects, and information regarding program allotments. Also includes a few memorandums, dated 1969, regarding the Lake Mead Evaporation Study and recommendations for recalibration. 
540. PROGRAM FORMS AND RELATED RECORDS FROM THE PLANNING SECTION CONCERNING COOPERATION WITH STATES AND FEDERAL AGENCIES. ca 1964-71. $7 \mathrm{ft.}$.

Arranged by type of form in two segments: "Project Descriptions" and "Summary of Program," and thereunder alphabetically by State. At the end of the first segment there are four additional files: Headquarters, Atlantic Coast Region, Rocky Mountain Region, and Pacific Region.

Chiefly completed "Project Description" (included revised versions) and "Summary of Program" forms that give objectives, descriptions, justifications of the cooperative programs, estimates and allotments, personnel information, and pleas for publication. Some of the forms are accompanied by "Project Proposal" statements, "Scope and Method" memorandums, maps, project outlines, and press releases. Of particular interest is a "Project Description" form concerning a cooperative project with the National Aeronautics and Space Administration to study erosion on the lunar surface (Rocky Mountain Region file).

541. PROJECT PROPOSALS AND OTHER RECORDS FROM THE PLANNING SECTION. 1968-69. 8 in.

Arranged in numerically by assigned number.

Chiefly project proposals completed for fiscal years 1968 and 1969. Also included are memorandums, reports, handwritten notes, work plans, copies of legislation, publication, newspaper clippings, statistical summaries, and other records concerning proposals, allotments, expenses, and Division cooperation with the States and other Federal agencies. A few items date from 1952. 
542. MANUSCRIPT MAPS OF RIVERS, RESERVOIRS, DAM SITES, AND RELATED AREAS. ca. 1903-43. approx. 1700 items. [NWCS, maps and plans]

Arranged alphabetically by river, river basin, reservoir, dam site, lake, pond, quadrangle name (Grand Coulee), area (Red Lake Indian Reservation, lower portion), or topographic feature (Nisqually Glacier).

Chiefly planetable sheets interspersed with a few tracings. Some of the manuscripts are accompanied by transmittal letters. Many of the manuscript maps were compiled in the field by topographers with the Conservation and Water Resources Divisions of the USGS, the Army Corps of Engineers, and State agencies. Some maps are based on drawings made by the Hydrographic Branch in the 1880's. Most of the maps are in sets.

543. PUBLISHED MAPS OF RIVER SURVEYS. 1912-69. approx. 1090 items. [NWCS, maps and plans]

Arranged alphabetically by name of river.

Most of the maps are in sets, which often include plan sheets, dam-site sheets, and profile sheets.

544. PUBLISHED MAPS OF DAM AND RESERVOIR SITES. 1926-71. approx. 160 items. [NWCS, maps and plans]

Arranged alphabetically by State - Alaska, Arizona, California, Colorado, Idaho, Montana, Nevada, Oregon, and Washington - and thereunder by site.

Some of the maps show the locations of gaging stations, and depict river profiles. Some sets of maps are stapled together.

545. MAPS OF THE UINTA INDIAN RESERVATION. 1899-1900. 18 items. [NWCS, maps and plans]

Two sets of manuscript maps: the Indian Reservation, showing a 20 -ft. contour interval, and the canal line on the reservation showing a 5 -ft. contour interval. The surveys were done by Cyrus C. Babb, a hydrographer with the USGS.

546. RIVER-BASIN BASE MAPS. 1912-50. 8 items. [NWCS, maps and plans]

The areas covered are the "Southwest River Basins," "Colorado River-Great Basin - Pacific Central Areas," "Colorado River Valley Surveys," and "Roseau River Valley."

547. CONTOUR MAP OF THE STORAGE RESERVOIR OF THE BIG HORN CANYON IRRIGATION AND POWER COMPANY. 1916. 1 item.

A blueprint map showing a segment of the Big Horn River in Wyoming and Montana and a detailed contour map of a small section of the river located on the Crow Indian Reservation. There is also a table giving the calculated storage area between the contours. The map was compiled by the company and submitted to the Billings, Montana, 
Land Office in 1917. The map is marked "Exhibit J(1)., Duplicate." It is not known how the map became part of the records of the USGS. This map is filed with the textual records.

548. MISCELLANEOUS WATER RESOURCES DIVISION MAPS. ca. 1918-78. 10 items. [NWCS, maps and plans]

The maps are arranged as follows: low-water-table contour map of the sump area in the Closed Basin of the San Luis Valley, Colorado, 1946, with a transmittal letter; map to accompany a report "The Live Stock Industry and Grazing Conditions in Arizona," 1918, with textual material; water-level change maps showing locations of observation and irrigation wells, and irrigations wells used as observation wells, Utah, about 1962; a map titled "South Lake Tahoe Folio: Flood and related Debris Flow Hazards Map," 1978; and a "Map of the Platte-Republican Divide Area, Nebraska," showing contours of the water table and depth to water below the land surface, 1948.

549. ADMINISTRATIVE MAPS. 1927-69. 11 items. [NWCS, maps and plans]

Six of the maps show district boundaries and locations of field offices (1927-48). The remaining maps, titled "United States Water Resources Development" (1958 and 1969), show surface water and related land-resources development completed or under construction.

550. MAPS OF THE TENNESSEE RIVER BASIN. 1933. 3 items. [NWCS, maps and plans]

Maps titled "Mineral Resources of the Tennessee River Basin and Adjacent Areas" and "Tennessee River Basin." The second map shows locations of river-gaging stations, principal dam sites, and locations of constructed power dams.

551. MAP OF RIVER-MEASUREMENT STATIONS IN GEORGIA. 1940. 1 item. [NWCS, maps and plans]

A blueprint map titled "River Measurement Stations Operated by the Atlanta District, U. S. Geological Survey in Cooperation with [the] Georgia Division of Mines, Mining, and Geology and other Federal Agencies as of December 31, 1940."

552. MAP SHOWING THE NORMAL ANNUAL PRECIPITATION FOR COLORADO. 1931-60. n.d. 1 item. [NWCS, maps and plans]

This oversized map is at 1:500,000.

553. HYDROLOGIC-INVESTIGATIONS ATLAS MAPS. 1954-96. approx. 780 items. [NWCS, maps and plans]

The maps are numbered from HA-1 to HA-739. Some maps are bound or stapled into sets. Most of the maps are folded.

554. HYDROLOGIC UNIT MAPS. ca. 1974-90. 63 items. [NWCS, maps and plans]

Arranged alphabetically by State. Some States are grouped by region. 
The maps show regional, subregional, and cataloging unit boundaries. Most of the maps are folded.

555. WATER-RESOURCES INVESTIGATION REPORT MAPS. ca. 1976-87. 54 items. [NWCS, maps and plans]

The maps are numbered from WRI 76-77 to WRI 86-4079. Some of the maps related to waste disposal in the State of Washington. Most of the maps are folded.

Related Water Resource Investigation Reports are described in entry 424.

556. INDEXES TO WATER RESOURCES INVESTIGATIONS. 1976-79. 45 items. [NWCS, maps and plans]

Arranged alphabetically by State. Indexes to reports, maps, and other USGS publications. 
Stream gaging, the original and basic function of the Surface Water Division (later Branch), began as part of the work if the Irrigation Survey in 1888, but was not mentioned specifically in its authorization. The Irrigation Survey was abolished in 1890. Frederick H. Newell joined the Topographic Branch as a topographer and continued thereafter some limited work in stream gaging. The act of August 18, 1894 (28 Stat. L., 398), appropriated funds specifically for stream gaging. Under the Irrigation Survey the collection of data on streamflow was carried out only in the Western States. In the 1890's, in response to serious flooding and concerns about the availability of water for municipal purposes, stream-gaging stations were established in several Eastern States and the District of Columbia.

In 1902 the Division of Hydrography was given branch status as the Hydrographic Branch. A Division of Hydrography conducted the stream-gaging work for the new Branch, which in 1906 became the Water Resources Branch. In 1907 the Division of Hydrography was renamed the Surface Water Division. By 1920 the USGS had entered into cooperative agreements with the Bureau of Reclamation, the Office of Indian Affairs, the National Park Service, the Weather Bureau, the Forest Service, the Office of the Chief of Engineers, and many States to conduct stream-gaging work and share data.

\section{CENTRAL CLASSIFIED FILES. 1950-63. $6 \mathrm{ft}$.}

Arranged according to the same subject-numeric classification scheme used for the central classified files, entry 52, and thereunder roughly chronologically. The file classifications are: Accounting, Committees, Communications, Education, Equipment and Supplies, Information, Meetings, Organization and Management, Personnel, Programs and Plans, Records, Reports and Statistics, Reproduction, Transportation, Water - General, and Water - Surface.

Memorandums, reports, correspondence, circulars, minutes of meetings, pamphlets, handwritten notes, newspaper clippings, printed articles and other publications, copies of Survey Orders, manuscript contributions to "Water Resources," the Division newsletter (1955-61), completed work-proposal and personnel-action forms, statistical tables and summaries, graphs, diagrams, and other records concerning the administration, policies, and programs of the Surface Water Branch. The primary subject areas concern appropriations and allotments, publications, personnel matters, and Division and Branch research.

Of particular interest are the "Organization and Management" files that document the reorganization of the Water Resources Division in 1956. Also included are agendas, programs, and reports of meetings of the "Speaker's Club" (1956-61); applications, lecture outlines, and study guides relating to courses given by the USGS and other Federal agencies and institutions; and photographic prints of equipment used by the Branch.

Other records relating to specific program areas are in the Central Classified Files of the Division (entry 414) and in records concerning the Branch's specific programs and projects.

\section{RECORDS CONCERNING STUDIES OF THE OHIO RIVER BASIN. 1904-17. 2 ft.}

\section{Arranged by type of record.}

Correspondence, memorandums, reports, statistical tables and summaries, handwritten notes, lists of illustrations, maps, newspaper clippings, published reports, and other records concerning studies of the Ohio River and its tributaries for the "Ohio River Special Paper," which was "to preserve and present, in available form, the many long-time records of gage heights collected by the Army Corps of Engineers, the Weather Bureau and others." Includes 17 field notebooks that contain data on runoff, discharge, gage heights, and precipitation; columnar sheets showing gage 
heights, dating from 1938; reports relating to droughts, forest conditions, and rainfall and runoff conditions; 4 in. x 6.5 in. reference cards concerning gage-height data published between 1872 and 1907 (each card gives the gage location, ownership of gage, and duration and publisher of record). Also contains photographic prints of rock carvings ("Indian picture rocks") at Smith's Ferry, Pennsylvania, Wellsonville, Ohio, and Jackson County, Ohio; and photographs of Water Works Gage at Cincinnati, Ohio, and the Chattanooga and Tennessee Rivers Power Company's plant.

An envelope contains a rock from the bottom of the Ohio River at Smith's Ferry, as an example of those on which picture writings were made by the Indians. The files do not contain a copy of the "Special Paper."

559. SCRAPBOOK RELATING TO FLOODS. 1912-14. 2 in. 1 vol.

Arranged in rough chronological order; the front of the volume contains a table of contents.

Includes newspaper clippings, pamphlets, publications, reports, transcripts of articles from newspapers, and congressional documents relating to floods and flood prevention. Among the specific rivers mentioned are the Mississippi, Scioto, Miami, Dayton, and Ohio. Of particular interest are the records concerning the Ohio flood of March and April 1913. The scrapbook appears to have been compiled by Albert H. Horton, District Engineer in charge of surface-water investigations in the Ohio River Basin.

\section{RECORDS OF THE PLANS AND OPERATIONS SECTION CONCERNING GAGING STATIONS.} 1928-52. 15 in.

Arranged by subject, and thereunder chronologically.

Chiefly statistical summaries and tables, but also includes correspondence, memorandums, circulars, handwritten notes, lists of suggested gaging stations, and other records relating to estimates and allotments for the cost installation, operation, and maintenance of gaging stations, recommendations for new stations, and the status of existing stations.

561. GENERAL CORRESPONDENCE AND RECORDS OF THE PLANS AND OPERATIONS SECTION. 1947-60. $5 \mathrm{ft}$.

Arranged chronologically by year, and thereunder when appropriate by subject or State.

Correspondence; memorandums; statistical tables and summaries; reports; circulars; completed allotment-ledger forms, "allotment advice forms," "cooperative agreement transmittal forms" (1957-60 only), and "program description forms"; vouchers; maps; plats; computer-printout sheets; and other records regarding the obligations, appropriations, and allotments for cooperative and noncooperative programs of the Branch, and its district and field offices; proposals and recommendations for research and development; and the installation and maintenance of gaging stations. Cooperative programs documented are those for the Bureau of Reclamation, Army Corps of Engineers, Federal Interagency River Basin Committee, Missouri River Basin Committee (1953), and the Northeastern States for flood investigations (1955-56).

\section{DATA SHEETS FOR STANDARD CURRENT METERS. ca. 1923-62. 15 in.}

Arranged in two sets by the serial number assigned to each meter.

Chiefly "rating curve" and "observations and rating curve" charts, "observation sheets," and "comparisons of ratings" forms completed by the National Bureau of Standards. The forms variously show the type of meter, manufacturer, condition of the meter, method of rating, numerical and charted test results, and date and test number. 
Also included are transmittal forms describing meters being shipped, which give the title of the agency that owned the meter, correspondence and memorandums. Most of the meters were the property of or used by the Army Corps of Engineers, Bureau of Indian Affairs, Fish and Wildlife Service, Department of Agriculture, California State Division of Water Resources, municipalities, irrigation districts, electric utilities, and research institutes.

\section{RECORDS CONCERNING METERS AND METER RATINGS. 1930-56. 16 in.}

Arranged by subject.

Correspondence, reports, statistical tables and summaries, handwritten notes and calculations, diagrams, graphs, photographic prints of meters, and other records concerning the cost, design, and use of meters; observation and rating curves; Branch recommendations regarding the use of certain meters; and other data for current meters. Pygmy Current Meters, Miniature Current Meters, Ice Experimental Meters, Ott Meters, and Experimental "AA"-Type Current Meters are discussed in the records.

\section{OFFICE FILES OF JOSEPH VAN BRUNT WELLS, CHIEF OF THE SURFACE WATER BRANCH.} 1949-59. 10 in.

Three general files precede nine files arranged by subject.

Chiefly correspondence and memorandums, but also includes newspaper clippings, minutes of meetings and other records relating to personnel matters, activities of professional staff members, suggestions submitted by employees for improving the Branch, and personal activities of Joseph Wells. Several files contain correspondence, memorandums, minutes of meetings, copies of citations, completed personnel-history forms, and forms for the "Report of Compensation Advancement in Recognition of Superior Achievements" that relate to Incentive and Honor awards for the Branch staff.

\section{PHOTOGRAPHS RELATING TO A GEOLOGICAL SURVEY OF THE GREEN AND COLORADO} RIVERS. 1914, 1915, 1921. 2 albums. 2.25 in.

Arranged by agency assigned number. All photographs are captioned and dated. Each album is accompanied by hand-drawn maps showing where the photographs were taken. This is series GC (NWCS, still pictures).

Black and white photographs taken by Eugene C. LaRue, a hydraulic engineer with the USGS, and others during a 1921 survey down the Green and Colorado Rivers from the town of Green River, Utah to Marble Canyon, near the site of the proposed Lees Ferry dam. A large number of the photographs show the proposed location of a major dam and power station at Lees Ferry. Other photographs include panoramic views of the town of Green River, distant mountains, the Colorado River and adjacent plateaus, tributary streams, and Rainbow Bridge; an Indian cliff house, pictographs, and artifacts; and the survey party traversing rapids and in camp.

\section{RECORDS CONCERNING STREAM-GAGING PROCEDURES, OPERATION, AND PROJECTS.} 1920-39. $1 \mathrm{ft}$.

Arranged by subject.

Correspondence, memorandums, reports, statistical tables and summaries, graphs, plats, copies of legislation, publications, and other records concerning the accuracy of stream-gaging procedures and stream-flow records; 
construction, operation and maintenance of stream-gaging stations; and the measurement of stream and flood flow. The Colorado, Coosa, San Juan, Deschutes, Mouse (Souris), Columbia, and Snake Rivers are mentioned by name. Also included is information relating to cooperation with other Federal agencies, States, municipalities, water districts. and research institutions on stream-gaging projects; the New England floods of 1927; a report by Joseph T. Pardee, about 1927, on the "Geology of Damsites on Skagit and Sauk Rivers, Washington"; and correspondence and other records concerning the work of the Run-Off Committee of the Boston Society of Civil Engineers (1920-23).

\section{RECORDS CONCERNING GAGING PROJECTS ON STREAMS CONTIGUOUS TO THE} UNITED STATES AND MEXICO. 1925-33. 2 in.

Arranged chronologically.

Correspondence, memorandums, reports, press releases, vouchers, statistical summaries, handwritten notes, plats, and other records concerning stream-gaging projects and seepage investigations on the water boundary between the United States and Mexico. The funds for these projects were allotted by the American sections of the International Water and Boundary Commissions. Includes information relating to the distribution of funds; coordination of streamgaging work with Mexico; and the construction, operation and maintenance of gaging stations in boundary waters.

\section{REPORTS AND OTHER RECORDS SENT TO THE TECHNICAL STANDARD SECTION CONCERNING THE HIGHWAY PROGRAM. 1940-62. 6 in.}

Arranged alphabetically by State and thereunder alphabetically by stream or river.

Chiefly reports, with statistical tables and summaries, plats, and diagrams which discuss flood-flow characteristics at proposed bridge sites in Minnesota, South Carolina, and Washington. Also includes memorandums concerning technical and editorial comments and recommendations. These records may have once been part of a larger series and were retained as a sample.

\section{FIELD NOTEBOOKS CONCERNING DRAINAGE AREAS IN THE UNITED STATES. ca. 1908-44.} 10 in. 30 vols.

Arranged by drainage area and thereunder, when appropriate, by subject or type of data.

Annotated field notebooks of USGS engineers which contain compilations of drainage-area acreage, runoff, and water-power potential. The first nine volumes concern a study of runoff and horsepower in the United States, prepared for the Conservation Commission in 1908 and summarized in USGS Water Supply Paper 234, "Papers on the Conservation of Water Resources" (by Henry Gannett and others, 1909). Other field notebooks include information on drainage areas of the Ohio River Basin (ca. 1909-16); Santa Ynez River (1924); Salton Sea (1932); Potomac River Basin (1920, 1930); Delaware and Raritan River Basins (1922-44); and Kanawha River Basin (1935-36).

The related maps are described in entry 570 .

570. MAPS OF THE DELAWARE, POTOMAC, AND NEW-KANAWHA RIVER BASINS. ca. 1920-22. 2 in.

Arranged by river basin. These maps are filed with the textual records. 
Chiefly quadrangle maps. Some of the maps are annotated. Also included is a 1922 chart showing stream-gage readings from sites in the Delaware River Basin.

571. RECORDS CONCERNING THE NEW-KANAWHA RIVER STUDIES. ca. 1933-36. 15 in.

Arranged by subject or type of record.

Statistical tables and summaries, reports, correspondence, memorandums, copies of testimony, copies of "Bill of Complaint," maps, handwritten notes, newspaper clippings, and other records concerning the data collected by the Surface Water Division on the New-Kanawha River at the request of the Federal Power Commission. The USGS was asked to furnish expert testimony regarding stream flow at certain points in the New-Kanawha River Basin for the court case "United States vs. Appalachian Electric Power Company." The U.S. Government sought to compel the power company to procure a Federal Power Commission license for a power project on the New River, in the vicinity of Radford, Virginia.

Included in the records are drainage and stream-flow measurements; gage-height records; and a notebook for JuneJuly 1936, maintained by Charles H. Pierce, a Senior Hydraulic Engineer with the Division, who compiled much of the data for this case and appeared as an expert witness.

572. REFERENCE FILE CONCERNING HYDRAULIC RESEARCH AND DEVELOPMENT. ca. 1930-49.

$7 \mathrm{ft}$.

Arranged by subject.

Correspondence, memorandums, drafted and final reports, statistical tables and summaries, circulars, bulletins, pamphlets, brochures, printed articles, publications, newspaper clippings, handwritten notes, annotated manuscripts, diagrams, graphs, plats, maps, price lists for equipment, and other records. These materials appear to have been maintained as a general-reference file on research and development by the USGS and other Federal agencies that related to hydraulics, particularly surface-water issues. Includes records on the projects of the National Hydraulic Laboratory of the Bureau of Standards and research proposals submitted by Surface Water Division members; the USGS Manual on stream-gaging procedures (Water-Supply Paper 888); research on the role of the engineer in discharge measurements by wading; and artificial controls, equipment, and structures used, recommended, or criticized by the Division. Also contains information on the scientific research in the Federal Government, including a series of essays on the origins and development of research in various agencies. Includes some photographic prints of USGS exhibits, artificial controls, and equipment.

573. RECORDS RELATING TO THE 1955 CONFERENCE OF THE SURFACE WATER BRANCH. 1955-57. 2 in.

Arranged by type of record.

Agendas, minutes, correspondence, and a copy of a speech by Arthur A. Baker, USGS Administrative Geologist, delivered to the Conference of Supervisory Personnel of the Surface Water Branch. The conference was held October 17 to 20, 1955, in Denver, Colorado. 
In 1893-94 geologists Nelson H. Darton and Grove K. Gilbert began separate investigations of ground-water resources, partly in connection with their stratigraphic and structural studies of the High Plains and Rocky Mountains. The "investigation of underground currents and artesian wells in arid and semi-arid sections" was authorized by the act of August 18, 1894 (28 Stat. L., 398), that required the USGS to determine the Nation's water supply.

Ground-water work was administered by the Geologic Branch's Division of Hydrography until 1902, when the Division became the Hydrographic Branch. The Eastern and Western Sections of the Branch's Hydrologic Division were merged in 1907 to form the Ground Water Division. An act of August 21, 1916 (39 Stat. L., 518), added to the Division's responsibilities the location, development, and protection of watering places on the desert and arid portions of the public lands. The Division was renamed the Ground Water Branch in 1949.

\section{ADMINISTRATIVE CORRESPONDENCE FILES. 1919-43. $59 \mathrm{ft}$.}

Arranged in four time sequences: 1919-1939; 1940-1941; 1942; and 1943; and thereunder alphabetically by State, subject, or surname of individual. A list of file-title headings appears as Appendix 30 in this inventory.

Chiefly correspondence, memorandums, and reports (weekly, bi-weekly, and monthly), but also includes statistical tables and summaries, copies of cooperative agreements, minutes of meetings, critical reviews of manuscripts, circulars, handwritten notes, bound reports, vouchers, completed contracts, newspaper clippings, advertisements, graphs, charts, plats, maps, and other records concerning the administration, policies, programs, and operations of the Ground Water Division and its district and field offices. The records show cooperation with the National Park Service, Veterans Administration, Bureau of Mines, Army Corps of Engineers, other Federal agencies, State agencies, and organization such as irrigation districts. The records document the Branch's participation in various projects, such as the Columbia Basin Irrigation Project, Delaware River Drainage Basin Project, Pecos River Joint Investigation, Rio Grande River Joint Investigation, investigations in the Platte River Valley, and various soil erosion projects.

Of particular interest are completed interview forms (boxes 27, 28, and 93) compiled by Branch staff members of Federal government and nongovernment experts on subjects such as ground-water conditions, water supplies, and wells. The forms give the date, name and address of the interviewee, name of the staff member who conducted the interview, information and advice offered, publications cited, and sometimes references to related correspondence.

For later administrative correspondence see entry 575.

\section{ADMINISTRATIVE CORRESPONDENCE FILES. 1944-53. $33 \mathrm{ft}$.}

Arranged in three parts: 1944-47, in which each year is divided into two segments, alphabetically by State or Territory, and alphabetically by subject or surname of individual; 1948-53, arranged alphabetically by State or Territory; and 1948-53, arranged alphabetically by subject or surname of individual. A list of file titles appears as Appendix 31 in this inventory.

Chiefly correspondence, memorandums, and reports, but also includes statistical tables and summaries, circulars, handwritten notes, bound reports, vouchers, completed employment-compensation forms, completed contracts, newspaper clippings, advertisements, graphs, charts, plats, maps, and other records, concerning the administration, policies, programs, and operations of the Ground Water Branch and its district and field offices. Included are records documenting the Branch's participation in Alaska ground water research, the Colorado River Basin Project, Missouri River Basin Project, Navajo Indian Reservation Project, Passanaquiddy Tidal Power Project, Upper Embayment Mississippi Investigation, and Project Mahoney (to prepare a report demonstrating the need for an accelerated program 
of research in the Nation's water resources). These records also show cooperation with other USGS units, such as the Pacific Northwest Water Resources Council; other Federal agencies, especially the Bureau of Reclamation, Army Corps of Engineers, Bureau of Land Management, Bureau of Indian Affairs, Fish and Wildlife Service, and Federal Power Commission; interagency units such as the Arkansas-White-Red Interagency Committee, Interagency River Basin Committee, and Interagency Committee on Hydrologic Data; States; municipalities;

water districts; independent bodies, such as the Conservation Foundation; and professional associations.

Of particular interest is a file containing correspondence, statements, copies of articles and other records (1947 - Congressional Hearings, Material) gathered to support an appropriation for ground water investigations. The appropriation had been dropped from the 1948 Interior Department appropriation bill and replaced with a clause in the "gaging streams" section prohibiting the USGS from making any more ground-water investigations.

The series also includes correspondence, memorandums, reports, programs, agendas, minutes, conference papers, and other records that relate to meetings, seminars, and conferences in which the Branch participated including the United Nations' Scientific Conference on the Conservation and Utilization of Resources.

For earlier administrative correspondence see entry 574.

576. REFERENCE FILE OF DAVID GROSH THOMPSON. 1921-38, 1940-41. 6 in.

Arranged by subject.

Correspondence, reports, statistical tables and summaries, graphs, handwritten notes and statistical calculations, pamphlets, printed articles, and other records (many of which were compiled by Thompson) that relate to analyses of hydrologic problems, particularly concerning ground water and artesian wells. Also includes annotated drafts of papers written by Thompson, and correspondence and memorandums concerning ground-water laws.

\section{CORRESPONDENCE AND OTHER RECORDS CONCERNING DAVID GROSH THOMPSON'S} STUDY OF THE UTILIZATION OF GROUND AND SURFACE WATER IN THE UNITED STATES. 1930-33. 2 in.

Arranged, for the most part, alphabetically by State; followed by a general file arranged roughly chronologically.

Chiefly correspondence between Thompson and State officials and interested specialists that relates to requests for information on the consumption of ground and surface water in the United States, for use by Thompson in several reports and a professional paper. Also included are handwritten notes, publications, a list of correspondents, and a statistical table of the Public Works Supply Systems in the United States, compiled by Thompson.

For much of the data received by Thompson see entry 578.

578. RECORDS CONCERNING PUBLIC WATER SUPPLIES IN THE UNITED STATES. ca. 1930-39. 5 in.

Arranged for the most part alphabetically by State; the last file is arranged by type of record.

Chiefly statistical tables and summaries, maps, and publications compiled by David G. Thompson for use in his study of the utilization of ground and surface water in the United States. Also includes copies of "Waterworks NewsRecord" for June 13, 14, and 15, 1939, printed tables, and a few pieces of correspondence. Much of the data was furnished by States and interested specialists, at Thompson's request; see entry 580. 
579. RECORDS OF DAVID GROSH THOMPSON CONCERNING THE COMMITTEE ON UNDERGROUND WATERS OF THE AMERICAN GEOPHYSICAL UNION. 1932-42. 3 in.

Arranged alphabetically by surname of correspondent, and thereunder chronologically.

Correspondence, circulars, handwritten notes, and reports concerning Thompson's participation in the American Geophysical Union, as chairman of its Committee on Underground Water. Includes information on ground-water studies, compilation of an international bibliography by the committee, publications, committee membership, and meetings and symposiums.

580. RECORDS CONCERNING USGS RESPONSES TO GROUND-WATER-RELATED INQUIRIES. ca. 1939-51. 17 in.

Arranged alphabetically by State. Two files arranged by subject are at the end of the series.

Chiefly correspondence sent to district officials from drilling companies, private individuals, and State and municipal officials acknowledging information supplied or services rendered by the USGS. This correspondence was gathered by the district offices and sent to the Chief Hydraulic Engineer in response to a request by the House Appropriations Subcommittee in February 1947 for the names and addresses of well drillers who have requested information from the USGS, the nature of the information requested, and complimentary letters regarding ground-water investigations. USGS district officials continued to send this type of correspondence to the Washington Office until 1951. Also contains interdepartmental correspondence and memorandums, address lists of well drillers, and other records. A general file includes correspondence sent to the Washington Office from foreign officials, Federal agencies, private firms, and individuals concerning cooperation, and an file of "acknowledgments" for 1946 that shows the receipt of publications or information by public officials or private individuals.

581. "MONTHLY REPORTS OF SIGNIFICANT HAPPENINGS." July 1953 - Dec. 1954.10 in.

Arranged chronologically by month, and thereunder alphabetically by State.

Memorandums and narrative reports that describe significant monthly events, such as meetings, status of projects, personnel actions, and professional activities, in the district and field offices. A list at the front of each file gives the State and date the reports were received from June to November 1954.

582. PROJECT RECORDS FROM DISTRICT AND FIELD OFFICES. 1942-48. 10 in.

Arranged alphabetically by State or Territory, and thereunder chronologically.

Copies of "Summary Report on Investigations in Progress" that give project title, date started, percentage statistics of field work completed, computations and reports completed, and remarks. These reports are for varying lengths of time.

583. MONTHLY PROGRESS REPORTS. 1914-42. $4 \mathrm{ft}$.

Arranged chronologically. 
Copies of monthly reports containing narrative and statistical tables and summaries sent to the Chief Hydraulic Engineer from the Ground Water Division concerning projects, publications, personnel action, and professional activities of staff. Also includes copies of "Summary Report on Investigations in Progress." Includes district and field-office reports, and individual service reports, dating from the 1930's.

\section{RECORDS CONCERNING PERSONNEL. 1943-51. $1.5 \mathrm{ft}$.}

Arranged alphabetically by surname of individual.

Chiefly correspondence and memorandums, but also includes reports, copies of itineraries, completed personnel forms, and other records concerning various ground-water personnel. Included is information on field-work and research projects, preparation of papers and reports, professional activities, and personnel matters. This appears to have been a part of the administrative correspondence; for similar information on other ground-water personnel see the Administrative Correspondence files, 1919-53, described in entries 574 and 575.

\section{RECORDS CONCERNING MINERAL WATERS IN THE UNITED STATES COLLECTED BY ALBERT} CHARLES PEALE. ca. 1890-1904. 1.5 in.

Completed questionnaires arranged chronologically, accompanied by a few pieces of correspondence and reports.

Primarily completed questionnaires, dated 1899 to 1901, sent by the Division of Mineral Resources to the owners of various springs, that give the name, location, and owner of spring, the estimated number of gallons sold in 1899 and 1900 (about half the forms give data for 1899 and the remainder cover 1900), and whether or not the spring was used as a resort. The correspondence and reports concern the chemical analyses of particular springs.

These records were collected by Peale, a geologist who served with the "Hayden Survey" (1871-79), the USGS (188398), and the U.S. National Museum (1898-1914).

\section{RECORDS CONCERNING MINERAL WATERS IN THE UNITED STATES. ca. 1895-1930. 8 in.}

The records are arranged alphabetically by State, followed by two general folders.

Chiefly advertising pamphlets, brochures, and broadsides that relate to mineral-spring water and resort springs, some of which include chemical analyses of the water and are annotated. Also includes correspondence and reports concerning the chemical analyses of spring water, a typescript list of mineral springs in the United States for 1906 compiled by the Bureau of Chemistry (Department of Agriculture), some reprinted articles regarding mineral springs and resorts in the United States, and other records.

587. RECORDS RELATING TO SALINITY STUDIES IN THE CONNECTICUT RIVER BASIN. 1934-39. 15 in.

\section{Arranged by type of record.}

Progress and other reports, statistical summaries and tables, graphs, diagrams, drawings, correspondence, plats, printed articles, tide tables, State publications, and other records relating to studies sponsored by the Works Progress Administration and the Connecticut State Water Commission. 
588. REFERENCE FILE ON THE SALINITY OF WATER. ca.1907-36. 2 in.

Arranged by type of record.

Primarily printed material that concerns the salinity of ocean water. Also includes a typed report, "Memoranda on the Composition of Sea Water," which contains reprints and synopses of articles and statistical summaries dated 1873 to 1912. The material in this memoranda appears to have been collected by Richard B. Dole. Also includes a few items concerning mineral springs in the United States and Europe.

589. "DIARIES" OF TRAVEL BY OSCAR EDWARD MEINZER. 1938, 1939, 1944. 3 in. 2 binders and 1 folder.

Arranged by trip and thereunder in rough chronological order.

"Diaries" that include daily entries, itineraries, correspondence, memorandums, names and addresses of people met on the trips, newspaper clippings, photographic prints, maps, and other records concerning Oscar E. Meinzer's official travel to the Western States, June 5 to July 11 and August 27 to October 9, 1938; a meeting in New York City, December 29, 1938, to January 1, 1939; Southern States, October 6 to November 21, 1939; and Southeastern States, October 5 to $28,1944$.

\section{RECORDS CONCERNING THE VOLUME ON "HYDROLOGY" OF THE NATIONAL RESEARCH COUNCIL'S "PHYSICS OF THE EARTH" SERIES. 1937-43. 2 ft.}

Arranged by chapter.

Correspondence, annotated drafts, lists of illustrations, diagrams, plats, photographic prints, and handwritten notes relating to the fifteen chapters of the "Hydrology" volume (IX) that is part of the National Research Council's series on the "Physics of the Earth," published by McGraw-Hill. Oscar E. Meinzer edited this volume.

\section{RECORDS CONCERNING OSCAR EDWARD MEINZER'S PARTICIPATION IN PROFESSIONAL ORGANIZATIONS. 1937-48. 17 in.}

Arranged alphabetically by subject or surname of correspondent, and thereunder roughly chronologically or alphabetically.

Correspondence, memorandums, circulars, programs, agendas, minutes of meeting, reports, membership and mailing lists, and other records relating to Oscar E. Meinzer's participation in the American Geophysical Union, particularly its Section of Hydrology, the Commission on Subterranean Water of the Association of Scientific Hydrology of the International Union of Geodesy and Geophysics, and their various committees and commissions. The records pertain to Meinzer's role as a representative of the USGS and as a member of these organizations, and contain information relating to meetings, conferences, and activities of the organizations, publication of papers, elections, membership drives, financial matters, and travel. Also includes statistical summaries outlining the cooperative funds of the Ground Water Division from 1908 to 1938, and correspondence relating to Meinzer's paper, "Our Water Supply," which was read before the Washington Academy of Sciences in March 1937, and later reprinted in many journals. Some of the records are in French and Spanish. 
592. CIRCULARS OF THE HYDROLOGY SECTION OF THE AMERICAN GEOPHYSICAL UNION.

1931-33. 0.5 in.

Arranged chronologically.

Circulars issued by the Section concerning its formation, organization, purpose, membership, and interest in the publication of hydrological papers and bibliographies.

Oscar E. Meinzer served as Chairman of the Section during these years.

593. CORRESPONDENCE AND OTHER RECORDS RELATING TO THE INTERNATIONAL COMMITTEE ON UNDERGROUND WATER. 1936-46. 5 in.

Arranged alphabetically by country or geographic area.

Oscar E. Meinzer's correspondence with hydrologists in other countries concerning the International Committee on Underground Water (of the International Association of Scientific Hydrology, a part of the International Union of Geodesy and Geophysics). Includes requests for delegates to the Committee; recommendations for conference topics and papers; and information concerning Meinzer's travel abroad, international hydrologists' visits to the United States, and the exchange and publication of papers. Also contains some mailing lists of scientists interested in the study of ground water for Africa, Australia, Great Britain (in the England folder), the Soviet Union (in the Russia folder), and Sweden; a list of papers to be presented by the Section of Scientific Hydrology of Japan at the 1939 General Assembly of the International Union of Geodesy and Geophysics; and a report on the "Economy of Groundwater" by M. Wegenstein, a Swiss engineer. Some of the correspondence is in German, French, and Spanish.

594. RECORDS RELATING TO THE WASHINGTON ASSEMBLY (MEETING) OF THE INTERNATIONAL UNION OF GEODESY AND GEOPHYSICS, 1939. 1936-39. 3 in. 2 binders.

Arranged in two binders, and thereunder according a table of contents.

Reports, programs, minutes of meetings, circulars, copies of papers, statutes (by law), lists of delegates, and other records concerning the Seventh Assembly of the International Association of Scientific Hydrology, and its

Commission on Subterranean Water, of the International Union of Geodesy and Geophysics held in Washington, D.C., September 4 to 15, 1939. Some of the records are in French, Spanish, and German.

For related records see entry 598.

595. MISCELLANEOUS RECORDS CONCERNING THE ASSEMBLY (MEETING) OF THE INTERNATIONAL ASSOCIATION OF SCIENTIFIC HYDROLOGY, OSLO, NORWAY, 1948. 1937, 1947-48. 1 in. 1 binder.

Arranged by type of record.

Circulars, correspondence, copies of papers, lists of delegates, and a mailing list concerning the Eighth Assembly of the International Association of Scientific Hydrology (IASH), held in Oslo, Norway, August 19 to 28, 1948.

Also includes a list (in French) of members of the IASH, statutes (bylaws) of the International Union of Geodesy and Geophysics, and a 1937 report (1 page) of the Commission on Underground Water. 
596. CORRESPONDENCE AND OTHER RECORDS CONCERNING THE ASSEMBLY (MEETING) OF INTERNATIONAL ASSOCIATION OF SCIENTIFIC HYDROLOGY, OSLO, NORWAY, 1948. 1947-48. 7 in.

Arranged alphabetically by country.

Oscar E. Meinzer's correspondence with hydrologists in other countries concerning the Assembly of International Association of Scientific Hydrology (IASH), held in connection with the International Union of Geodesy and Geophysics, in Oslo, Norway, August 19 to 28, 1948.

Includes requests for papers, recommendations for topics of papers, and information concerning publication of the papers. Also contains copies of papers, accompanied by plats, diagrams, and statistical tables; circulars; handwritten notes; and copies of the proposed program for the 1948 Assembly and IASH's statutes (bylaws).

Some of the correspondence and papers are in French and German.

597. PROGRAMS AND CIRCULARS RELATING TO INTERNATIONAL GEOLOGICAL CONGRESSES. 1933, 1938-39. 0.5 in.

Arranged chronologically.

Programs for the International Geological Congresses in 1933 in Washington, D.C. (16th Session), and in Amsterdam (scheduled for 1938, but not held); a list of registrants for the 1933 Congress; and circulars concerning the 1940 Congress in London (18th Session, but not held until 1948).

598. MISCELLANEOUS FILES. 1939, 1947-48. 0.5 in.

Arranged roughly chronologically, and thereunder by type of record.

Chiefly information on the 1939 and 1948 assemblies of the International Association of Scientific Hydrology, and its Commission on Subterranean Water of the International Union of Geodesy and Geophysics that includes correspondence, circulars, tentative proposals for meeting topics, lists of members and invitations to delegates, mailing lists, and copies of George W. Musgrave's paper on the infiltration of ground water.

For related records see entry 594. 
In 1901 Frederick H. Newell expanded hydrographic investigations to include quality-of-water studies concerned with the pollution of municipal water by sewage. A Division of Hydro-Economics was established in 1903 within the Hydrographic Branch to study the quality, composition changes, pollution, and economic potential of water. In 1907 the Division was renamed the Quality of Water Division. In 1910 analysis of polluted water was transferred to the Public Health Service. The Division remained responsible for analyzing the mineral composition of surface and ground waters to determine their value for domestic and industrial use. The Division was merged with the Ground Water Division in 1910 and 1918. The Quality of Water Division's Washington office closed in 1908; when the Division regained it separate organizational identity, most of the laboratory work was done under contract. The Quality of Water Division was restyled a Branch in 1949.

599. CENTRAL CLASSIFIED FILES. 1941-63. $21 \mathrm{ft}$.

Arranged according to the same subject-numeric classification scheme used for the Central Classified Files, entry 52, and thereunder roughly chronologically. The file classifications used for these files are: Accounting, Budget, Committees, Education, Equipment and Supplies, Forms, Information, Inventions, Map Distribution, Mapping Techniques, Meetings, National Defense, Organization and Management, Personnel, Programs and Plans, Publications, Public Relations, Records (cross reference sheet only), Reports and Statistics, Research, Scientific and Professional Organizations, Security, Sedimentation and Erosion, Transportation, Vehicles, Water (General), and Water (Quality).

Correspondence, memorandums, progress and technical reports, statistical tables and summaries, handwritten notes, bulletins, pamphlets, printed articles and other publications, monthly and quarterly reports, copies of bids and contracts, purchase orders, completed requisition forms, price lists, newspaper clippings, plats, maps, and other records concerning the administration, operation, policies, and programs of the Branch. A large portion of the records comprise "Program and Plan" files that document cooperative projects with other agencies, such as the Bureau of Reclamation and Soil Conservation Service, interagency River Basin Commissions and Committees; States; and institutions. Other subject areas concern estimates, appropriations, allotments and expenditures; publications; personnel matters; and equipment and supplies. Of particular interest are the records relating to Saline Water Research (Programs and Plans files).

Also includes programs, agendas, minutes of meetings, conference proceedings, annotated papers, lists of attendees, and other records relating to Branch, interagency, and professional meetings and conferences.

The majority of records date from 1952.

600. BIANNUAL AND QUARTERLY REPORTS OF DISTRICT AND RESEARCH OFFICES. 1949-58. 5 in.

Arranged by type of report as described below.

Quarterly "Chemical Quality" analysis reports (1955-58), which give number of samples analyzed and "total adjusted complete analyses" for USGS projects, other Federal agencies, and States; biannual statistical and narrative reports (1955-58) summarizing Division investigations in progress or completed stating source of funds, estimates of personnel used, percent of project completed, and publication plans; quarterly statistical reports (1949-58) on sediment analyses completed for cooperative projects that show the project name, number of bottles analyzed, and total analyses made for concentrated and particle-sized, suspended-sediment or depth-integrated samples. 
Arranged alphabetically by State, Federal agency, or subject, and thereunder roughly chronologically. A list of file titles appears as Appendix 32 in this inventory.

Chiefly correspondence and memorandums, but also contains reports, statistical tables and summaries, handwritten notes, completed water-analysis forms, cooperative agreements, copies of contracts, purchase orders, requisition forms, vouchers, blueprint floor plans and photographic prints of the Ohio Regional Laboratory, diagrams, plats, newspaper clippings, and other records, concerning the administration, operation, policies, and programs of the Branch's field offices and laboratories. The records include information on proposals and plans for projects; progress of field and lab work; allotments, appropriations, and expenditures; equipment and supplies; publications; personnel matters, and meetings of the Arizona Water Resources Council (Colorado River Basin File). Many of the Branch's projects were undertaken in cooperation with other units of the Water Resources Division and the USGS; Federal agencies, such as the Bureau of Reclamation, Fish and Wildlife Service; the Departments of the Army and Air Force; State agencies; and universities.

Also contains correspondence, memorandums, agendas, programs, lists of attendees, abstracts and copies of papers, and other records concerning participation in the professional meetings and conferences of the American Chemical Society and American Water Works Association. The Alaska-General file contains records dated 1918-50. Most of the remaining records date from 1946.

602. OFFICE FILES OF WILLIAM DENNIS COLLINS. 1913-46. $10 \mathrm{in.}$

Arranged alphabetically by subject, and thereunder roughly chronologically.

Correspondence, memorandums, reports, handwritten notes, copies of papers, pamphlets, printed articles and other publications, statistical tables and summaries, vouchers, one photographic print each of the Colorado River (near Grand Canyon, Arizona) and Grand Coulee Dam, and other records concerning Collins' participation in and supervision of water-quality studies. Primarily investigations of arsenic poisoning, industrial poisoning, tuberculosis (in cooperation with the Public Health Service), radioactivity, salinity of larger coastal rivers and tidal waters, and rainwater. Also includes an annotated manuscript from 1927 by Collins, and others, on the "Chemical Character of Waters of Rhode Island"; and information on Collins' professional activities during 1940 in the American Chemical Society and at the Eighth American Scientific Congress.

Collins served with the Surface Water Division until 1909 when he became the Food Investigation Chemist for the Bureau of Chemistry in the Department of Agriculture. In 1920 he rejoined the USGS as the Chief of the Quality of Water Division. He remained in that post until 1946.

603. CORRESPONDENCE AND OTHER RECORDS CONCERNING A COOPERATIVE STUDY OF DISSOLVED SOLIDS IN AND HARDNESS OF GEORGIA WATER. 1937-39. 2 in.

Arranged chronologically.

Primarily correspondence, but also includes statistical summaries, memorandums, and other records concerning a cooperative project with Georgia's Division of Mines, Mining, and Geology to investigate the public-water supplies. Part of the project involved a study, assisted by the State Department of Public Health, of the chemical character of the larger sources of public-water supplies. This was the first of a planned series of 48 studies by the Quality of Water Branch of all the public-water supplies of the United States. 
604. RECORDS CONCERNING THE ST. FRANCIS RIVER SILT PROJECT. 1939-40. 1 in.

Arranged by type of record, and thereunder chronologically.

Correspondence, graphs depicting silt computations, memorandums, and other records relating to a stream-gaging and silt investigation of the St. Francis River, Missouri.

\section{RECORDS CONCERNING A STUDY OF SEDIMENTATION AND QUALITY OF WATER IN THE MISSOURI RIVER BASIN. 1945-49. 8 in.}

Arranged chronologically.

Chiefly correspondence and memorandums, but also includes progress and technical reports, statistical summaries, handwritten notes, newspaper clippings, publications, vouchers, maps, and other records relating to sediment and quality-of-water studies made in cooperation with the Missouri Basin Interagency Committee.

Includes information on research proposed and in progress, research data and analyses, installation and operation of sediment stations, personnel matters, allotments and appropriations, equipment, and supplies. The Missouri Basin Interagency Committee was established on May 5, 1945.

606. RECORDS RELATING TO LABORATORIES, SPACE, AND EQUIPMENT. 1945-46. 1 in.

Arranged by subject, and thereunder roughly chronologically.

Correspondence, completed requisition forms, purchase orders, statistical summaries, diagrams, and other records relating to space and equipment for the central and branch chemical and sediment laboratories, and the installation and operation of sediment-sampling equipment for a study of sedimentation and quality of water in the Missouri River Basin.

607. RECORDS RELATING TO THE MISSOURI BASIN FLUME CONTRACT. 1948. 1 in.

Arranged by type of record, and thereunder roughly chronologically.

Diagrams, completed bidding forms, memorandums, completed requisition forms, and some correspondence received from Paul C. Benedict, the district engineer at Lincoln, Nebraska, relating to the contract for the construction of a reinforced-concrete flume and gage well on the Middle Loup River, at Dunning, Nebraska.

608. RECORDS CONCERNING RESEARCH AND DEVELOPMENT. 1946-52. 2 in.

$$
\text { Arranged chronologically. }
$$

Memorandums, reports, correspondence, statistical tables and summaries, handwritten notes, completed "Abstract of Research and Development Projects" forms, printed articles, and other records relating to research and development in the Branch and its field offices. Includes information on estimates and allotments, distribution of funds, and proposed, recommended, and completed research projects. 
609. INVENTORY FORMS AND INDEX CARDS CONCERNING PUBLISHED AND UNPUBLISHED ANALYSES OF SURFACE WATERS USED FOR IRRIGATION. 1947-48. 2 ft.

Divided into forms printed on 5 in. $x 8$ in. cards arranged by drainage area, and thereunder by name of river; and 3 in. $\mathrm{x} 5$ in. cards arranged alphabetically by author, Federal or State agency, irrigation district, and others.

The first set of cards are completed "Inventory of Published and Unpublished Analyses of Surface Waters of Irrigation" forms that give name of drainage basin and stream, stream location, drainage area above station, duration of record, availability of drainage records, number of analyses, frequency of sampling, composite period, analytical values reported, reference number, remarks, and date and source of information. Some of the information dates from 1905. These forms were compiled for the Subcommittee on Hydrologic Data of the Federal Interagency River Basin Committee. The 3 in. $x 5$ in. cards give references to published and unpublished reports and data concerning surface waters for irrigation and the quality of those surface waters. 
During World War I the Water Resources Branch was made responsible for preparing a weekly report of the power production and consumption by the States. In 1918 the Division of Power Resources was established to continue the collection of those statistics and the preparation of periodic reports. The Division also provided engineers to conduct field investigations on behalf of the of the Fuel Administration. The Fuel Administration was created in 1917 to compile statistics on the production, distribution, and consumption of coal, and to devise plans for the conservation of power. The Division also gathered statistics for regions of the world relating to developed water power.

In 1936 the Federal Power Commission took over responsibility for compiling and distributing information about the production and consumption of power in the States. When the Division of Power Resources was abolished in 1945, the Water Utilization Division assumed functions relating to the collection of information about developed water power by the States and the compilation of an annual report based on the collected data.

\section{RECORDS CONCERNING FEDERAL POWER COMMISSION PROJECTS. 1921-47. 5 ft.}

A general file followed by files arranged numerically by project number (1 to 1854). These project numbers appear to have been assigned by the Federal Power Commission.

Chiefly correspondence and memorandums, but also includes USGS "Semiannual" and "Annual" reports to the Commission regarding stream-gaging field work; progress reports; statistical tables and summaries; copies of applications for permits and licenses sent to the Commission; copies of Commission agreements; diagrams; graphs; plats; and other records relating to USGS assistance in the review and approval of Commission projects. Most of the work completed by the USGS concerned investigations for the Commission relating to applications to construct water works, supervision over construction of stream-gaging stations by licenses, inspection of those stations, confirmation of licensee compliance in the maintenance of stream data, and supervision of the construction and operation of transmission lines.

\section{MINUTES OF MEETINGS AND OTHER RECORDS CONCERNING THE FEDERAL POWER}

COMMISSION. 1921-29. 4 in.

Arranged chronologically.

Chiefly minutes of Federal Power Commission meetings, but also includes press releases, lists of applications for licenses, memorandums, and other records concerning the authorization, extension, and rejection of permits and licenses under the Federal Water Power Act of June 10, 1920 (41 Stat. L., 1063). Also included is a printed copy (1921) of the "Tentative Draft of Rules and Regulations for the Establishment and Maintenance of a System of Accounts of Licensees Under the Federal Water Power Act."

\section{REPORTS AND CORRESPONDENCE. 1943-44. 18 pages.}

Arranged chronologically.

Annual reports of the Division for 1943 and 1944; quarterly reports for January, March, and June 1944; and correspondence concerning publications of the USGS on water power. 
613. REPORTS AND OTHER RECORDS CONCERNING DEVELOPED AND POTENTIAL WATER POWER AND TOTAL CAPACITY OF WATER WHEELS IN THE UNITED STATES. 1922-44. 2 in. 1 binder.

Arranged chronologically, with the exception of the last three items. A table of contents accompanies the records.

Statistical and narrative reports concerning the developed and potential water power in the United States (1922, 1925-30), and the capacity of water wheels at water-power plants in the United States (1931-41). Also includes statistical data relating to developed water power in the United States in 1908 that was published in USGS WaterSupply Paper 234, "Papers on the Conservation of Water Resources" (by Henry Gannett, and others, 1909); a statistical and narrative report (ca. 1940) on the total capacity of water wheels in the United States from 1869 to 1917; and a press release showing water-power development in the United States and Canada during 1940-44.

\section{REPORTS AND PRESS RELEASES CONCERNING DEVELOPED AND POTENTIAL WORLD}

WATER POWER. ca. 1924-45. 3 in.

Arranged by subject or type of record, and thereunder chronologically.

Annual statistical and narrative reports and press releases concerning the developed and potential water power of the United States and the world. Some of the reports were issued by the Federal Power Commission.

\section{REFERENCE FILE OF ALBERT HOWARD HORTON. 1918-32. 4 in.}

Arranged by type of record.

Publications, statistical summaries, and handwritten notes concerning hydroelectric power and power potential in the United States. Includes bound copies of USGS Professional Paper 123, "A Superpower System for the Region between Boston and Washington" (by William S. Murray and others, 1921) and maps relating to the Northeastern Superpower Survey (one copy is annotated).

Horton was Chief of the Power Resources Division from 1919 to 1945.

616. RECORDS CONCERNING PRODUCTION OF POWER. 1919-28. 8 in. 5 binders.

Arranged in two sets of binders (1919-24 and 1924-28), and thereunder arranged by subject. A table of contents begins each set.

Reports, memorandums, correspondence, statistical tables and summaries, handwritten notes and calculations, diagrams, graphs, and other records concerning developed and potential hydroelectric power; consumption and cost of coal and oil; output of electricity in the United States; operation of power plants; generator capacity of public-utility power plants; and other subjects related to power production.

\section{REPORTS CONCERNING PUBLIC UTILITY PLANTS. 1919-37. 10 in.}

Arranged chronologically.

Statistical and narrative monthly and annual reports, including graphs, compiled by the Division concerning the production of electricity and consumption of fuel by public-utility plants in the United States. The Federal Power 
Commission compiled the statistics for the monthly reports, beginning in July 1936, and those for the 1937 annual report.

Annual reports from 1920 to 1926 were published in USGS Water-Supply Paper 579, "Power Capacity and Production in the United States" (by Carroll R. Daugherty and others, 1928).

618. RECORDS CONCERNING DEVELOPED WATER POWER OF THE UNITED STATES. 1920-40.

$2 \mathrm{ft}$.

Arranged alphabetically by State or Territory, and followed by one general file.

Chiefly copies of "Report on Developed Water Power" that give the name of stream and power plant, location and operator of the plant, number of water wheels and generators, use of power, and average number of hours the plant is in operation. Also includes statistical reports for water-power plants of 100 horsepower or more, lists of plants in operation, memorandums, a 1939 congressional report on plants in the United States (76th Cong., 1st Sess., Sen. Doc. 123), and other records. Most of the records date from 1933.

619. REFERENCE FILE CONCERNING PRODUCTION AND CONSUMPTION OF POWER. 1922-40. 3 in.

Arranged alphabetically by subject.

Printed articles and other publications, handwritten notes and calculations, statistical tables and summaries, correspondence, press releases, diagrams, and other records concerning consumption and efficiency, coal resources and rates in the United States, interstate transmission of power, water power, and other subject areas related to power production and consumption. Also included is a processed issuance: "A List of References on the United States Geological Survey and Its Work," a 1934 bibliography compiled by James T. Ruby, an undated conference proof copy of a paper delivered at the First World Power Conference in Holland titled "Latest Developments in the Use of Electricity for Heating Purposes in general and especially for Domestic Purposes," and a booklet titled "Instructions for Measurement of Water" compiled in 1930 by John F. Deeds for use by Oil and Gas Supervisors employed by the Conservation Division.

\section{RECORDS CONCERNING THE PRODUCTION, CONSUMPTION, AND REGULATION OF} ELECTRIC POWER. 1925-39. 2 in.

Arranged alphabetically by subject.

Reports, statistical tables, hand calculations and summaries, correspondence, memorandums, and other records concerning the consumption of fuel and comparable fuel rates; capacity of electric generating plants and prime movers in the United States; and production of electricity by public utility plants, and pumped water for power.

Also includes printed articles and a copy of a speech by George O. Smith, Chairman of the Federal Power Commission, relating to public-utility regulation; a pamphlet and congressional document concerning the St. Lawrence Treaty; and a copy of the newspaper Appleton Post-Crescent for Thursday, September 29, 1932, that was issued in celebration of the "Fiftieth Anniversary of the World's First Hydro-electric Central Station." 
621. REPORTS CONCERNING ELECTRIC POWER RECEIVED FROM OTHER AGENCIES. 1925, 1927, 1932, 1938-45. 7 in.

Arranged by subject.

Chiefly processed monthly and annual reports and statistical summaries, and other records compiled by the Federal Power Commission concerning the production of electricity and consumption of fuel, capacity of generating plants, electric-power supply in the United States, and transmission of energy across State and international boundaries.

Also includes printed reports (1927, 1932, and 1937) from the Bureau of Census (Department of Commerce) on electric-light and power stations, and a printed report (1925) from the Committee on Farm Power (Department of Agriculture) that concerns power used on farms in the United States.

622. STATISTICAL REPORTS AND OTHER RECORDS OF THE EDISON ELECTRIC INSTITUTE. 1943-46. 2 in. 1 binder.

Arranged by type of report, and thereunder chronologically.

Printed reports of "Weekly Electric Power Output" that give statistical data on the amount of electrical energy distributed by the electric-light and power industry; monthly reports on sources and disposal of energy; and a printed statistical bulletin for 1944 ("The Electric Light and Power Industry in the United States"), and two press releases (1944 and 1945) on the electric-light and power industry.

623. CONSULAR REPORTS AND OTHER RECORDS CONCERNING FOREIGN WATER SUPPLIES. 1913-41. $1.5 \mathrm{ft}$.

Arranged alphabetically by country, and thereunder alphabetically by city when appropriate. A partial listing of the foreign publications accompanies the records.

Narrative and statistical reports concerning the amount, chemical characteristics, and use of public-water supplies in foreign countries. These reports were prepared in the U.S. consulate offices of the respective countries in reply to a memorandum and questionnaire, dated September 1924, sent by the Department of Commerce's Bureau of Foreign and Domestic Commerce. Also includes publications, some of which are in Spanish, French, German, Italian, Portugese, Dutch, and Swedish; correspondence; maps; plats; handwritten notes; and other records. Most of the records date from 1925 to 1935 .

624. CONSULAR REPORTS AND RECORDS CONCERNING NEW CONSTRUCTION AND OPERATION OF FOREIGN WATER-POWER PLANTS. 1938-41. $2 \mathrm{ft}$.

Arranged alphabetically by country, and thereunder chronologically.

Narrative and statistical reports, correspondence, foreign publications, press releases, handwritten notes, maps, questionnaires, and other records from U.S. consular officers concerning the new construction and operation of waterpower plants and hydroelectric-power facilities. Also includes statistical data compiled by consular officers on waterpower plant construction, annual questionnaires, and streams; locations of plants; total capacity of water wheels; heights of water head of dams; and notations of new plants or extensions of old ones. The 1938 questionnaires were submitted by the Bureau of Foreign and Domestic Commerce of the Department of Commerce and forwarded to the 
USGS for processing; the 1939 to 1941 forms were submitted directly to the USGS. Some of this data was used for yearly articles on world power written by the USGS for the Encyclopedia Britannica (see entry 626).

\section{RECORDS CONCERNING FOREIGN WATER SUPPLIES. ca. 1936-39. 4 in.}

Arranged alphabetically by name of country, and thereunder alphabetically by name of city. Two general files are at the end of the series.

Chiefly a handwritten draft of a report on available water supplies of foreign countries compiled from information gathered from about 1919 to 1939. Also includes a copy of "Water Works and Sewage" (April 1933); typed notes obtained from the Quality of Water Division; and a memorandum on the public-water supplies in South America.

626. RECORDS CONCERNING DEVELOPED WATER POWER OF THE WORLD. ca. 1936-44. 10 in.

Arranged alphabetically by subject.

Narrative and statistical reports, correspondence, annotated drafts of articles, completed forms that "Report on Developed Water Power," publications, clippings from the Encyclopedia Britannica, lists of consular-district posts, maps, graphs, foreign copies of Reclamation Era for 1937 and 1938, Service Directories for 1940 and 1941, and other records concerning developed water power throughout the world. Some of the reports were compiled from data sent by consular officers in foreign countries (see entry 624) for yearly articles on world power in the Encyclopedia Britannica. Also includes copies of speeches by Millard F. Bowen relating to the St. Lawrence Ship Canal.

627. REPORT TITLED "HARDNESS OF WATER SUPPLY IN EUROPE, NORTH AFRICA, AND THE MIDDLE EAST." 1943. 1/8 in.

Copy of a narrative and statistical report prepared by the Office of Strategic Services.

This report has been classified and is labeled "Restricted."

628. REPORTS CONCERNING THE WATER SUPPLIES OF JAPANESE CITIES. ca. 1946. 0.25 in.

Arranged by name of city: Gifu, Kobe, Kokura, Kyoto, Okayama, Osaka, Sakai, and Wakayama.

Narrative and statistical reports written by Frederick S. Blach, a water-supply consultant. Includes information that relates to sources of water; clean reservoirs; pumping stations; and the capacity, quality, distribution, consumption, and projected development of water supplies.

Related reports are described in entry 283. 
Water Utilization Division, 1924-52

The Water Utilization Division was established in 1910 to conduct the field examinations of public lands associated with the investigation of water-power sites, right-of-way, Carey Act segregations, and enlarged homesteads for the Land Classification Board. The Division also made similar field examinations on Indian Reservations. In 1917 the Division was merged with the newly established Division of Enlarged and Stock-Raising Homesteads, which became the Land Classification Investigations Branch in 1922. In 1925 the field employees who were assigned to investigations relating to enlarged and stock-raising homesteads were transferred to the Conservation Branch. In 1931 the Water Utilization Division was reestablished, but most of its field work was done by employees of the Surface Water Division.

When the Division of Power Resources was abolished in 1945 the Water Utilization Division assumed functions relating to the collection of information about developed water power by the States and the compilation of an annual report based on the collected data. In 1948 the Water Utilization Division was renamed the Technical Coordination Branch, which became the General Hydrology Branch in 1956.

\section{LETTERS SENT AND MEMORANDUMS. 1933-40. $2 \mathrm{ft}$.}

Arranged chronologically, and thereunder by assigned number.

Copies of letters sent and memorandums chiefly from the Chief Hydraulic Engineer, the Hydraulic Engineer in charge of the Water Utilization Division, the Director of the USGS, and the USGS staff concerning Division projects, estimates, and allotments, staff reports, Division publications, and personnel matters. The records also show cooperation with the International Joint Commission, Canada's Dominion Water Power and Hydrometric Bureau, the Federal Power Commission, Works Projects Administration, Soil Conservation Service, Bureau of Reclamation, Army Corps of Engineers, the Mississippi Valley Committee, and State agencies. The last file contains letters sent, from 1936 to 1940, by the USGS Chief Clerk, in response to requests for information on floods, flood control, and USGS publications.

630. BUDGET FILES. 1940-44. 5 in.

Arranged chronologically.

Copies of "allotment ledger" sheets that give allotments, reimbursements for division projects from other Federal units, and summary statements; completed ledger sheets that show division expenditures; completed purchase orders, requisition and voucher forms, and statistical summaries; and tables of salary distribution. Includes correspondence and memorandums concerning allotments and expenditures, a list of Division reports on floods; and one copy of an "allotment ledger" sheet that gives the Division's financial statement at the close of June 30, 1944.

\section{PHYSIOGRAPHIC DATA RELATING TO FLOOD FLOW. 1939-41. $6 \mathrm{ft}$.}

Arranged according to a numeric system: files whose number sequence begins with 1 pertain to the New England and Mid-Atlantic States; files whose number sequence begins with 3 pertain to Pennsylvania, West Virginia, and Ohio. The last file is unnumbered and contains an annotated manuscript by Walter B. Langbein. No file sequence begins with the number 2 . 
Statistical tables, statistical summaries, handdrawn maps, annotated printed maps, and graphs showing base data, land slope, stream densities, discharge measurements, precipitation data, land elevations, and other physiographic data. Also includes oversized statistical tables that summarize the topographic and discharge characteristics of

New England river basins; and Langbein's annotated manuscript titled "Topographic Characteristics of Drainage Basins and their Hydrologic Significance," accompanied by some edited parts of the manuscript and a memorandum from the editor. The manuscript was published as USGS Water-Supply Paper 968-C, "Topographic Characteristics of Drainage Basins" (1947).

These records were compiled as part of a cooperative project with the Works Progress Administration (Project O.P. No. 765-23-3-6) to collect topographical data in the Northeastern and North-Central States, as a basis for studying the topography's effect on stream flow and flood flow. Langbein supervised the project, under the general direction of the Water Utilization Division. Headquarters were established in Boston and Pittsburgh.

\section{RECORDS CONCERNING HYDROLOGIC STUDIES DIRECTED BY WILLIAM GLENN HOYT AND WALTER BASIL LANGBEIN. 1924-25, 1933-42. 15 in.}

Arranged by subject.

Chiefly correspondence and memorandums, but also includes reports, statistical tables, plats, charts, diagrams, printed articles, and other records concerning cooperative projects directed by William G. Hoyt and Walter B. Langbein. The projects include a study of flood peaks on Massachusetts streams; a WPA-funded study of flood volumes; an investigation of surface-water hydrology of metropolitan New Jersey; and a study of the quality and quantity of water in the Upper Gila Basin, Arizona. Also contains records relating to Hoyt's chapter on "Storage" prepared for a volume on hydrology for the National Research Council; drafts of an article (1942) by Hoyt about "John Wesley Powell, Pioneer Conservationist"; and records concerning USGS sponsorship of a project to standardize the methods of rating rivers for the American Standards Association. When the USGS ended its sponsorship of the standardization project in 1941, the USGS kept the records for 1924-25 and 1933-43, but gave the American Standards Association the records for 1926-32.

For other records relating to the Upper Gila Basin project, see entry 507; for other records relating to the National Research Council's volume on hydrology, see entry 590.

\section{ADMINISTRATIVE RECORDS CONCERNING RALF RUMEL WOOLLEY. 1939-49. 5 in.}

Arranged in rough chronological order. A file on the Colorado River-Great Basin in Utah in 1940 is at the end of the series.

Correspondence, memorandums, staff reports, newspaper clippings, statistical summaries, plats, and other records maintained by Ralf R. Woolley regarding the administration of USGS water-utilization programs in Utah. The correspondence is chiefly between Woolley and the Washington office of the Water Utilization Division. Also includes reports and conference papers written by Woolley, and programs and minutes relating to his participation in conferences.

Of particular interest is Woolley's paper on "Water Utilization Development--Jurisdiction over Water Resources." The article outlines the history of water-rights legislation; projects in California, Idaho, Nevada, Oregon, Utah, and Wyoming; and the involvement of the Federal Government. The paper also contains a bibliography of the principal reports concerning water utilization prepared by the USGS between 1890 and 1943.

Woolley joined the USGS in 1917 as a hydraulic engineer. By 1939 he was in charge of the Water Utilization Division at Salt Lake City, Utah; by 1942 he also chaired the Colorado River Basin Committee. He served with the USGS in Utah until his death in 1948. 
634. RECORDS CONCERNING THE SPECIAL INVESTIGATIONS OF FLOODS. 1935-52. $3 \mathrm{ft}$.

Arranged chronologically by year, thereunder by subject, and when appropriate thereunder by the surname of the district engineer.

Correspondence, memorandums, reports, statistical tables and summaries, graphs, plats, newspaper clippings, handwritten notes, pamphlets, photographic prints of floods and flood damage, and other records concerning the investigations of floods in the United States between 1935 and 1942. Special floods studied include those in New York, July 1935; Northern California, December 1937; Southern California, Boston, Massachusetts, and Texas, 1938; Kentucky and the Lower Colorado River, 1939; Southeastern States, August 1940; and Pennsylvania, June 1941 and July 1942. 
General Hydrology Branch, 1889-1966

The General Hydrology Branch, successor to the Technical Coordination Branch, was established in 1956 to examine the fundamental problems of hydrology and to conduct research and prepare studies in fields that were not part of the responsibilities of the other operational units. The Technical Coordination Division (later Branch) (successor to the Water Utilization Division), established as a staff unit in 1948, was responsible for coordinating the research activities and field investigations of the operational units in the Water Resources Branch. The General Hydrology Branch was abolished in 1967.

\section{MANUSCRIPT COPY OF "HYDRAULIC INVESTIGATIONS OF SLUICE-GATES AND ORIFICES."} ca. $1930-33,1949,1951.1$ in.

An undated annotated draft of a paper by Robert E. Horton, Harry R. Leach, and Roswell D. Trimble. Also includes some original drawings, diagrams, tables, and photographic prints dated 1930 to 1933. Correspondence, dated 1949 and 1951, concerns the publication of the report accompanies the manuscript. The paper describes and gives the results of a series of experiments carried out in August 1929 at the Hydraulic Laboratory of the University of Iowa.

636. GENERAL CORRESPONDENCE FILES. 1920-59. $7 \mathrm{ft}$.

Arranged by subject or surname of the individual, and thereunder roughly chronologically or alphabetically. A list of file title headings appears as Appendix 33 in this inventory.

Chiefly correspondence and memorandums, but also includes statistical summaries and tables, graphs, vouchers, purchase orders, bound reports, publications, handwritten notes, photographic prints, and other records concerning the administration, finances, policies, and programs of the General Hydrology Branch, and its predecessors (the Technical Coordination Branch and the Water Utilization Division). These records also show cooperation on runoff investigations with other units of the USGS; other Federal agencies, especially the Bureau of Reclamation, Bureau of Land Management, Bureau of Indian Affairs, the Interior Department's Office of Land Utilization, and the Army Corps of Engineers; and independent bodies, such as the Bonneville Power Administration and the University of Washington. Also included are agendas, minutes and other records relating to branch participation on interagency interdepartmental, regional, and international boards and committees; and employment applications, position-description forms, and other records relating to employees of the branch. Also contains "reservoir inventories" for Northern Michigan, Idaho, and California that include the reservoir name, location, date completed, height and area, capacity, uses, and owner.

\section{RECORDS CONCERNING PROGRAMS AND PROJECTS. ca. 1915-58. $15 \mathrm{ft}$.}

Arranged by subject, and thereunder roughly chronologically. A list of file title headings appears as Appendix 34 in this inventory.

Correspondence, memorandums, reports, statistical tables and summaries, plats, charts, abstracts, and minutes of meetings, attendance lists, printed reports and bulletins, newspaper clippings, legal briefs, manuscripts, handwritten notes, photographic prints, and other records regarding the programs and projects coordinated by the General Hydrology Branch. A large part of the records relate to Branch cooperation with the International Joint Commission on investigations of the Waterton-Belly, Columbia, Kootenai, Red, Souris, Roseau, St. Mary and Milk, and other rivers; the International Boundary and Water Commission's investigations of waterways contiguous to Mexico;

the Interior Department's Board on International Water and Power; the Pacific Northwest Governors' Policy Committee; and the Interagency Water Resources Policy Review Committee. 
The series also contains records concerning the Water Loss Research Program, which includes the Lake Hefner, Lake Mead, and Bruning, Nebraska, Evapotranspiration Studies; the Soil and Moisture Program; and the Interchange of Persons Program with Japan.

Other records relating to the Lake Hefner and Lake Mead Studies are described in entries 487-490.

638. REPORTS AND OTHER RECORDS CONCERNING WATER SOURCES FOR LIVESTOCK. 1942-59.

$3 \mathrm{ft}$.

The files are arranged by year and thereunder by report; the five files at the end of the series are arranged by subject. A list of the reports appears as Appendix 35 in this inventory.

Chiefly narrative reports, accompanied by plats, graphs, statistical summaries, correspondence, and memorandums, prepared by Division geologists, regarding water sources for livestock in grazing districts in Arizona, California, Colorado, Idaho, Montana, Nevada, New Mexico, Oregon, Utah, and Wyoming. The subject files include correspondence, memorandums, lists of reports, handwritten notes, press releases, statistical summaries, and other records relating to the preparation and transfer of the reports, proposals for new or further investigations, descriptions of active projects, and personnel matters.

Studies of stock-well sites were compiled in response to requests from the Bureau of Indian Affairs, Bureau of Land Management, and the National Park Service. The Division of Water Utilization coordinated the investigations and reports until 1949, when the responsibilities were assumed by the Technical Coordination Branch. In 1956 the duties were transferred to the General Hydrology Branch.

639. GENERAL FILES OF THE REPORTS SECTION. 1889-1966. 9 ft.

Arranged according to a numerical system (1800 to 6011). A list of file-title headings appears as Appendix 36 in this inventory.

A wide range of records comprise these files. Some, but not all, of the following documents are found in each file - correspondence, memorandums, statistical tables and summaries, technical and progress reports, annotated articles and manuscripts, publications, graphs, diagrams, plats, handwritten notes, newspaper clippings, completed 3 in. $\mathrm{x} 6$ in. cards that record discharge measurement, field notebooks, copies of congressional bills, photographic prints, and other records which appear to have been maintained as a reference file by the Reports Section. The files contain both administrative records and technical data relating to the reports and publications of the Division. Most of the records relate to surface-water issues, although other types of water studies are represented. Includes information on stream-gaging procedures, measurements, and equipment; accuracy of discharge and runoff records; available water resources and power in the United States; water-resources investigations in various States; compilation of data for reports; and the proofreading and publication of Water-Supply Papers and Division reports. 
Office of Radiohydrology, 1947-75

A Section of Radiohydrology was established in 1947 to coordinate Division investigations funded by the Atomic Energy Commission (AEC). Most of the work of the Section concerned cooperation with the AEC (including its Division of Reactor Development and Division of Military Applications) and the Office of Earthquake Research and Crustal Studies in the study of reactor-development technology and other issues including the location and construction of reactors, the storage and disposition of radioactive gases and other waste by-products of reactor operations, thermal pollution, and the effects of activities associated with weapons testing and the PLOWSHARE Program. The research sites included the Hanford Reservation in Washington, the Los Alamos Scientific Laboratory in New Mexico, the Nevada Test Site, the Savannah River Plant in South Carolina, the Knoll Atomic Power Laboratory in New York, and the National Reactor Testing Station in Idaho.

The Section also investigated the occurrence of radioactivity and selected radioelements in natural waters. In 1963 the Section was abolished and its functions were transferred to the Ground Water Branch. In 1966 the Section was organizationally reestablished and in 1967 became an Office.

640. RECORDS CONCERNING RADIOACTIVITY OF WATER RESOURCES PROJECT. 1947-58. $3 \mathrm{ft}$.

Arranged by subject, and thereunder roughly chronologically.

Correspondence, memorandums, technical and progress reports, statistical tables and summaries, completed "Statement of Water Analysis" forms, completed "Radioactivity of Natural Water--Sample Record" forms, reports on water samples by National Bureau of Standards, handwritten notes, newspaper clippings, printed articles and other publications, diagrams, and other records concerning cooperative investigations of the radioactivity of natural waters of the United States. The radioactivity investigations involved branches of the Water Resources Division and the Geologic Division; the Atomic Energy Commission (AEC); and the National Bureau of Standards. Includes information on proposals and plans for research; research progress; estimates, allotments, and expenditures; data collected; equipment and supplies; and personnel matters. Also contains records that document the AEC's program on radioactive-waste disposal.

\section{RECORDS RELATING TO RADIOACTIVE-WASTE DISPOSAL. $1947-756 \mathrm{ft}$.}

Arranged by subject.

The records include correspondence, project proposals, memorandums, copies of articles, handwritten notes, annotated topographic maps, charts and graphs, drafts of technical papers, lists of reports, newspapers clippings, work plans, "Summary of Program" forms, and "Request for Project Authorization" forms. There are also fiscal records relating to program funding, salaries, budgets, and reimbursable accounts that include completed "Obligation of Funds" forms, ledger account pages, "Adjustment Voucher" forms, "Estimates of Appropriations" narrative forms, and budget justifications.

There are also correspondence, reports and other records relating to negotiations with the governments of Colorado, South Carolina, and Oregon by Chem-Nuclear Services to operate nuclear-waste burial sites in those States; and manuscript copies of research papers relating to aquifer investigations, exploratory test holes, disposition of radioactive effluents, evaluations of seismic risk, ground-water flow rates, gas injection, and other hydrologic and geologic studies.

Most of the records date from the interval 1961-71 
The first-named responsibility of the USGS in its establishing legislation was "the classification of the public lands." Director King decided, and the Public Lands Commission of 1879-80 confirmed, that land classification by the USGS was not intended to supercede the pre-sale classifications of the General Land Office. Instead King "concluded that the intention of Congress was to begin a rigid scientific classification of the national domain for the general information of the people of the country." King planned "a series of land maps" to "show all those features upon which intelligent agriculturists, miners, engineers, and timbermen might hereafter base their operations" and also to "be of the highest value for all students of the political economy and resources of the United States."

USGS geologists, topographers, and hydrologists, as part of their programmatic field work, collected information about the character of the public lands, including therein the fossil fuels that also formed the basis of much of the agency's subsequent work in pre-disposition classification.

USGS contributions to the pre-sale classification of the public lands began in the summer of 1905 when the General Land Office (GLO) asked the USGS to examine some contested coal lands in Utah. The USGS had just added to its scientific investigations of coals and lignites the study of their efficiency as fuels. Continuing USGS classifications of the coal and other natural-resources lands began in 1906, under a cooperative agreement between the GLO, in response to the President's request to the Secretary of the Interior to determine which coal deposits were so valuable that their lands should be withdrawn from entry. The USGS reported its findings to the GLO for action, a working arrangement that remained generally the same for many years.

In 1908 the Land Classification Board was established as a section in the Geologic Branch's Division of Geology. The close relationship between the Board and the Geologic Branch is evident by the number of early records found in the Conservation Division files marked with Geologic Branch file numbers. The Land Classification Board was administered by a Geologist.

In 1912 the Land Classification Board was separated from the Geologic Branch and made organizationally equivalent to a branch. The Land Classification Board was now organized in two divisions--Division of Mineral Classification and Division of Hydrographic Classification--each of which were made up of a number of classification boards. The boards made decisions regarding the classification of land based on information furnished by the Geologic, Topographic and Water Resources Branches. All correspondence with other agencies of the Federal Government regarding land classification matters was handled by the Board.

In 1920 some functions relating to applications for rights-of-way and the preparation of agreements to develop power on public lands were transferred to the Federal Power Commission. The Land Classification Board continued to assemble information regarding potential water power on public lands and to make recommendations regarding the segregation of lands valuable for water-power development.

Until 1921 the Land Classification Board had been financed by assessments on funds appropriated for the other three operating units of the Survey. Beginning in 1917 the Land Classification Board received line-item appropriations for examination and classification. In 1922 the Land Classification Board was renamed the Land Classification Branch.

The Oil Leasing and Mineral Leasing Divisions of the Bureau of Mines were transferred to the USGS in 1925. The responsibility for administering the Mineral Act of 1920 and supplemental and amended laws, including the collection of royalties, formerly assigned to the Bureau of Mines, were made the responsibility of the Land Classification Branch, then renamed the Conservation Branch. The new Branch comprised the Mineral Leasing, Mineral Classification, Homestead, and Power Divisions. In 1926 the Branch began receiving line-item appropriations for mineral-lease enforcement. 
Another major change in the responsibilities of the Branch came from the transfer of the field employees from the Division of Enlarged and Stock-Raising Homesteads of the Water Resources Branch. The employees formed the first field staff of the Branch. The functions transferred from the Water Resources Branch were combined with those of the Homestead Division to form the Division of Agricultural Use Classification, later called the Agricultural Division.

In 1933 instructions supplemented Departmental Order 659 for cases concerning petitions for enlarged or stockraising homesteads and GLO requests regarding public lands containing a spring or water hole where the Conservation Branch could not act without further field examination. The USGS was instructed to refer these cases to the Division of Investigations in the Office of the Secretary of the Interior for the necessary field examinations. The Division of Investigations prepared a report based on the examination for the USGS for action in the case of the homesteads and submitted a report to the GLO, with a copy to the USGS, in cases concerning water holes.

In 1935 the functions of the Agricultural Division were transferred to the newly established Division of Grazing (later the Grazing Service). Those functions included action on applications for agricultural classification, public-water reserves, and water holes, requests for reports from the operational units of the USGS, preparation of orders of withdrawal, and related actions concerning enlarged homesteads, stock-raising homesteads, and Nevada ground-water reclamation. In 1946 the GLO and the Grazing Service were merged to form the Bureau of Land Management.

In 1948 the staff position of Chairman of the Unit Plan Committee was created in the Conservation Branch. In 1949 the Conservation Branch was renamed the Conservation Division and the subordinate organizational units that had been Divisions were designated Branches.

An Executive Order in 1945 placed the natural resources of the Continental Shelf under the jurisdiction of the Secretary of the Interior. The Submerged Lands Act (67 Stat. L., 29), and the Outer Continental Shelf Lands Act (67 Stat. L., 462) were passed in 1953 to encourage the exploration and development of the oil, gas, and other mineral resources of the Outer Continental Shelf. Beginning in 1954 the Conservation Division administered the mineralleasing laws on the Outer Continental Shelf.

In 1982 the Minerals Management Service (MMS) was created by Secretarial Order 3071, under the authority of Section 2 of Reorganization Plan 3 of 1950. The USGS Conservation Division's administrative functions relating to leasing responsibilities for the Outer Continental Shelf were transferred to the new agency. The following year revenue-management responsibilities of the Conservation Division were also transferred to the MMS. Onshore-leasing responsibilities on public and Indian lands were transferred to the Bureau of Land Management. 
General Records, 1901-80

642. MISSION CONTROL FILES. 1901-80. $213 \mathrm{ft}$.

Arranged in two chronological segments dated 1901-75, and 1976-80. There are two early items, dated 1887 and 1899, in the files. A list of file-title headings appears as Appendix 37 in this inventory.

Correspondence, memorandums, reports, statistical tables and summaries, copies of legislation, handwritten notes, newspaper clippings, press releases, copies of agreements, leases and contracts, copies of briefs, depositions, and court decisions, transcripts of hearings, computer-printout sheets, completed forms for "Log of Oil and Gas Wells" and "Lessee's Monthly Report of Sales and Royalty," lists of coal reserves by States, microfiche copies of reports, and other records concerning the administration, policies, and programs of the Division. Includes information concerning Federal contracts to sell gas, oil, helium, and coal; storage of gas and leasing of tar sands; government litigation and Division involvement in giving testimony and preparing reports; meetings and conferences to discuss and plan Division programs, and recommendations to other agencies and Congress on programs and policies; and cooperation with other Federal agencies, especially the Atomic Energy Commission (AEC), Department of Defense, General Land Office (and its successor the Bureau of Land Management), Bureau of Indian Affairs, and Forest Service. Includes records relating to the Division's cooperation in the AEC's PLOWSHARE Program for developing peaceful applications of nuclear energy, and participation in Project Rulison to assess the commercial feasibility of stimulating a natural-gas reservoir by using nuclear explosives. There are also records relating to USGS oversight of oil and gas exploration on the Outer Continental Shelf and investigation of disasters such as the Santa Barbara oil spill.

Also includes agendas, minutes, attendance lists, transcripts of meetings, reports, lists of members to various committees, and other records relating to the Division's participation in field, interdepartmental, interagency, congressional, and advisory committees. Of particular interest are the files on Indian-land regulations dating from 1901 that include correspondence and copies of rules and regulations relating to leasing Indian lands for oil, gas, and, coal mining; royalties accrued by Indian lands; and the sale of those lands.

A few files on the file-title list consist of cross references to the Royalty Accounting Office and Administrative Office. The records of those offices are not in the National Archives.

643. RECORDS OF CONSERVATION BRANCH ATTORNEY GEORGE WEST HOLLAND. 1922-31. 0.25 in.

Arranged in rough chronological order.

Chiefly telegrams, letters, and memorandums concerning George W. Holland's travel and expenses. Also included is information relating to Holland's trips to Florida to investigate phosphate withdrawals.

\section{REPORTS AND OTHER RECORDS CONCERNING THE OPERATION OF POWER SYSTEMS ON FEDERAL LANDS. 1909-48. $20 \mathrm{ft}$.}

Arranged alphabetically by name of utility, company, or other permittees, and thereunder roughly chronologically. A list of file-title headings appears as Appendix 38 in this inventory.

Narrative and statistical annual reports submitted to the USGS in compliance with the acts of February 15, 1901 (31 Stat. L., 790), and March 4, 1911 (36 Stat. L., 1253, 1254). In lieu of these reports, the permittees often sent copies of their reports prepared for the Federal Power Commission, State Regulatory bodies, and stockholders. 
Also includes completed USGS forms for "Schedule for Annual Report"; correspondence; transcripts of hearings; printed articles; newspaper clippings; and other records concerning the development of waterpower resources on the public domain by public utilities and other organizations operating under Federal power permits or grants.

Contains information that relates to the generation, distribution, and delivery of electric energy; use and alterations made of structures located on land under permit or grant; sources of power; total energy sold and revenues accrued; and operation and maintenance expenses of hydroelectric plants.

\section{RECORDS CONCERNING RED RIVER OIL OPERATIONS. 1924-26. 2.5 ft.}

The records are divided into two sets: the first part is arranged according to a decimal classification scheme; the second part is grouped alphabetically by subject. Thereunder, both sets are arranged chronologically. Oversized well-production records, arranged chronologically by month, follow the first two sets.

Chiefly correspondence, statistical tables and summaries, but also includes memorandums, reports, vouchers, copies of contracts, bank-deposit slips, canceled checks, handwritten notes and calculations, congressional and court documents, completed "Statement of Disbursing Account" forms, maps, and other records concerning the administration of the Red River Oil Operations in Oklahoma. Contains information that relates to the disbursement and expenditure of funds; oil produced and sold; bids for and purchase of government oil produced; equipment and supplies; personnel matters; insurance for and maintenance of wells; and claims for land rental. Also includes completed (oversize) forms for "Recapitulation Daily Gages" that give well numbers, tank numbers and size, gage reading, and barrels produced.

The Red River Oil operation was established by an act of March 4, 1923 (42 Stat. L., 1448), to administer the Red River oil fields in Oklahoma that had been placed under Federal receivership as a result of a suit between Texas and Oklahoma in the U.S. Supreme Court. Managed initially by the Bureau of Mines, the operation was transferred to the USGS on July 1, 1925. The operations were terminated on December 1, 1925, when the land was turned over to the claimants.

646. RECORDS CONCERNING COOPERATION WITH THE FEDERAL POWER COMMISSION. 1917-49. 15 in.

Arranged by subject, and thereunder chronologically.

Correspondence, memorandums, statistical tables and summaries, technical and annual reports by the USGS for the Commission, copies of Commission reports, regulations, decisions, and printed procedures, press releases, a list of Commission projects, and other records concerning USGS cooperation with the Federal Power Commission. Includes information relating to Division supervision over power projects with permits or licenses under construction and subsequent operations; appropriations, allotments, and expenditures; applications to the Commission for permits and licenses; completion of forms and reports by district engineers on Commission projects; and USGS investigations for court cases involving the Appalachian Power Company (1935-36) and the New-Kanawha Power Company (1934-40). Also contains a list of applications for preliminary permits and licenses (Serial No. 1 to 2032, for the years 1920-49) that gives the serial number, date, name of applicant, project title and description, and proposed use of project.

\section{RECORDS CONCERNING THE SALES OF GOVERNMENT ROYALTY OIL TO SMALL} REFINERIES. 1946-62. $3 \mathrm{ft}$.

Arranged numerically by contract-offer number (1 to 17). Offers 1 to 9 are arranged first by preliminary correspondence and then by refining company, and thereunder roughly chronologically; offers 11 to 17 are arranged chronologically. There is no contract offer No. 10. 
Chiefly correspondence, but also includes memorandums, statistical tables and summaries, bid reports and summaries, abstracts of bids, copies of agreements and specifications for sales, copies of briefs, lists of eligible refineries and submitted applications, handwritten notes, and other records concerning the purchase and sale of government royalty oil to small refineries under the Small Refinery Preference Act of July 13, 1946 (60 Stat. L., 533). Includes information on the specifications and bids; applicants; rejections of bids; termination of royalty oil contracts; and protests by individuals or refining corporations concerning discontinued sale of certain fuels, and the awards of purchase to certain companies. 


\section{General Cartographic Records, 1921-34}

648. MAPS SHOWING STATIONS AND TRANSMISSION LINES. ca. 1921-22. 2 items. [NWCS, maps and plans]

Maps for Pennsylvania (1920) and West Virginia (1921) showing "stations and transmission lines used in public service."

649. MAPS OF INDIAN RESERVATIONS IN OKLAHOMA. 1929-34. 4 items. [NWCS, maps and plans]

The maps are titled "Map of the Cheyenne and Arapaho Indian Reservation, 1933; "Map of Restricted Indian Land - Cheyenne and Arapaho Reservation," 1929; "Map of Restricted Indian Land - Iowa, Kickapoo, Sac \& Fox, and Pottawatomie-Shawnee Reservations," 1934; and "Map of the Wichita, Kiowa, Comanche, and Apache Reservations," 1933. 
The Division of Mineral Classification was established in 1912 within the Land Classification Board when the Board was separated from the Geologic Branch and made organizationally equivalent to a branch. The Board was renamed the Land Classification Branch in 1922. When the name of the Branch was changed to the Conservation Branch in 1925, the Mineral Classification Division remained as an organizational unit. The Division was responsible for the classification of the public lands with respect to their mineral resources, in accordance with the provisions of the Mineral Leasing Act of February 20, 1920 (41 Stat. L., 437), and later supplemental and amending legislation, and preparation of reports advising the General Land Office (later the Bureau of Land Management) on actions to be taken regarding the disposition lands under the public-land laws. Field examinations were done chiefly by the Geologic Branch. In 1949 the Conservation Branch was restyled a Division. The functions of the Division were transferred to the Geologic Division in 1982 when the Conservation Division was abolished.

650. LAND-CLASSIFICATION INDEX CARDS. ca. 1900-1922. $16 \mathrm{ft}$.

Arranged by State or Territory, thereunder by principal meridian and quadrant, thereunder by range, and thereunder by township.

Cards (5 in. x 8 in.) labeled coal, coal - noncoal, mineral - nonmineral, oil - nonoil, phosphate, and oil shale. Each card shows one township. On most of the cards, sections are colored in to delineate land withdrawn pending classification, classified coal land, classified noncoal land, and land restored without classification.

Narrative information includes dates of letters to the Register and Receiver, orders, classification, and examination, usually with the name of the examiner.

651. INDEX TO WITHDRAWAL, MODIFICATION, AND RESTORATION ORDERS. ca. 1910-66. 15 in.

Arranged by type of order, thereunder by coal, helium, oil shale, phosphate, potash, petroleum, and mineral land, and thereunder alphabetically by State or Territory.

Cards ( 3 in. $x 5$ in.) showing the date of the order and legal land description or number of acres. Sometimes the dates of Land Classification Board minutes and actions also are given.

652. CLASSIFICATION, WITHDRAWAL, AND RESTORATION BOOKS. 1903-24. 3 ft. 19 vols.

Arranged in eight sets: coal withdrawals, restoration, and classification, 1906-9 (3 volumes), coal classifications, 1910-24 (4 volumes), coal restorations, 1910-21 (5 volumes), coal withdrawals, 1910-13 (2 volumes), petroleum reserves - withdrawals, 1903-24 (2 volumes), petroleum reserves - restorations and modifications, 1909-15 (1 volume), phosphate reserves, 1908-15 (1 volume), and phosphate restorations, 1908-15 (1 volume). The contents of the volumes are arranged chronologically. Some of the volumes have a table of contents.

Chiefly copies of letters, with township lists, to the Commissioner of the General Land Office and the Secretary of the Interior describing lands affected by orders of withdrawal, modification of withdrawal, or restoration.

There are also a few similar letters to the Commissioner of Indian Affairs and the Forest Service. The volumes also contain a few annotated maps, township diagrams, and memorandums. Many of the letters and lists are annotated. Some of the letters bear handwritten file numbers and appear to have once been part of the General Correspondence Files, 1890-1922, (entry 159) of the Geologic Division. 
Arranged alphabetically - Alabama, Alaska, Arizona, Arkansas, California, Colorado, Idaho, Montana, New Mexico, Nevada, Oregon, North Dakota, South Dakota, Utah, Washington, and Wyoming, thereunder by principal meridian and quadrant, thereunder by range, and thereunder by township.

Chiefly color-coded township plats showing the location of land reported as coal-bearing (there are a few plats that also show iron- and oil-bearing land), land withdrawn pending classification, classification status of land, and dates of withdrawal and restoration orders. Some plats also indicate the monetary value of mineral-bearing land.

\section{CORRESPONDENCE AND OTHER RECORDS RELATING TO COAL-LAND CLASSIFICATION.} 1906-72. 15 in.

Arranged by type of record or subject and thereunder in rough chronological order.

Chiefly correspondence, transmittal letters and coal-land classification orders, but also including minutes of the Coal Classification Board, memorandums, circulars, newspaper clippings, copies of articles, regulations, proclamations, and instructions. Many of the records relate to the procedures drafted and adopted by the Coal Classification Board to examine, classify, and assign value to coal-bearing lands. The procedures extended to the compilation and format of reports submitted to the Board including the designation of symbols to be used on maps accompanying the reports. Other records concern the implementation of policies established by the Secretary of the Interior and the Director of the USGS, cooperation with other units of the USGS, the General Land Office, the Bureau of Indian Affairs, and the Forest Service, coal-land leases, oil- and gas-prospecting permits, and designations under the stock-raising homestead act.

655. RECORDS CONCERNING PETROLEUM WITHDRAWALS IN CALIFORNIA. 1907-21, 1931. 4 in.

$$
\text { Arranged chronologically. }
$$

Chiefly correspondence, memorandums, and lists of land but also including copies of withdrawal and restoration orders, reports on oil-field examinations, depositions, telegrams, and photographs. The records concern the examination and classification of oil-bearing lands, principally in the Sunset-Midway, McKittrick, and Coalinga Oil Districts, cooperation with the Department of Justice in a suit to recover oil lands patented to the Southern Pacific Railroad Company, and establishment of Naval Petroleum Reserves. The correspondence is with other units of the USGS, the Secretary of the Interior and the First Assistant Secretary, Department of Justice attorneys, the Commissioner of the General Land Office, oil company executives, and private consultants.

There are two untitled and undated oversize maps at the end of the series. One appears to show the rough location of the McKitterick and Sunset Oil Districts. The second map, stamped "Ralph Arnold" (a geologist with the USGS), covers that part of California from San Jose to the International Boundary. It is annotated to show the location of proven, probable, and possible oil fields.

656. COAL, POTASH, PHOSPHATE, AND POTASSIUM-LAND CLASSIFICATION, WITHDRAWAL, AND RESTORATION FILES. $1908-80.3 \mathrm{ft}$.

The files are organized in two parts. The coal-land files are arranged alphabetically by State or Territory and thereunder by order number. The remaining files are arranged by State, mineral, or type of order. 
Chiefly correspondence, memorandums, and withdrawal, modification, and restoration orders, but also includes handwritten notes, diagrams and sketches showing the locations of mineral-bearing lands and leases, annotated printed maps showing withdrawn mineral-bearing tracts, completed coal-prospecting permits, monthly reports of coalprospecting permits, photographs, and geologic reports.

The records concern the withdrawal and restoration of mineral-bearing lands, operations of mining companies and individual prospectors, and cooperation with the General Land Office (and its successor the Bureau of Land Management), the Bureau of Mines, the Forest Service, and the Bureau of Indian Affairs.

There is also a file concerning the mineral character of lands in the diminished Crow Indian Reservation.

Some minutes of the Coal Classification Board are part of the records described in entry 654 .

657. RECORDS CONCERNING THE CLASSIFICATION OF NORTHERN PACIFIC RAILROAD GRANT LANDS. $1909-26.5$ in.

Arranged in four sets as described below and thereunder chronologically.

The first set, 1909-17, 1924, is comprised chiefly of correspondence with the General Land Office, but also includes correspondence with geologists in the field, the Secretary of the Interior, and attorneys for the railroad, memorandums, lists of classified land, copies of land-classification reports, and annotated maps and township plats. The two 1924 items concern General Land Office (GLO) Circulars 930 and 931. The records concern the examination and classification of land as to its mineral or nonmineral character under the acts of February 26, 1895 (28 Stat. L., 683), and June 25, 1910 (36 Stat. L., 739).

The second set, 1910-17, is comprised of letters from the GLO transmitting lists of lands within the limits of the railroad grant and requesting examination and classification of those lands. There is also a list of lands involved in the "Garfield Agreement."

The third set, 1911-22, consists of letters from the GLO regarding land classified as nonmineral.

The fourth set, 1911-26, consists of copies of letters to the GLO transmitting exhibits showing the classification of railroad-grant lands. Copies of the exhibits are not in the file.

658. MINUTES OF THE METALLIFEROUS-LAND CLASSIFICATION BOARD. March 1, 1912 -

May 19, 1913. 0.5 in.

Arranged chronologically.

The minutes concern the classification of Northern Pacific Railroad grant lands, compilation of State "Safety Maps," which show areas classified as mineral, nonmineral, or not yet classified, and the legal and geologic phases of land-classification work, especially with regard to Indian-reservation lands. Included is a draft of a paper titled "Principles Governing Mineral Land Classification," by Frank C. Calkins, April 17, 1912, accompanied by critical notes from readers. It is not known if this series comprises a complete set of the minutes.

659. RECORDS CONCERNING INDIAN-LAND CLASSIFICATION. 1912-17. 3 in.

Arranged by name of Indian Reservation. 
Chiefly copies of letters sent to the Commissioner of Indian Affairs comprising reports "as to the mineral character and power site or reservoir possibilities" of Indian lands. A separate file contains correspondence and minutes of meetings of the Metalliferous Board, April 25 and July 22, 1912, concerning iron deposits in the Blackfoot Reservation, Montana.

660. CROSS-REFERENCE SHEETS CONCERNING LAND CLASSIFICATION. 1912-16. 0.25 in.

Arranged chronologically.

Land-description summaries shown by township and range indicating lands classified as mineral or nonmineral in character. The summaries were directed chiefly to the Office of Indian Affairs, but also to the General Land Office, the Secretary of the Interior, and the Secretary of Agriculture. Each sheet carries a reference to a complete list of lands. Those lists have not been found.

661. OVERSIZE MAPS SHOWING LOCATIONS OF SEGREGATED COAL LANDS AND COAL FIELDS 1929, 1935. 8 items

Arranged by county or land district: Carbon and Emery Counties, Utah (1929); Stigler-Poteau District (2 maps), Howe District, Wilburton District, McAlester District, and Lehigh District, Oklahoma (1935); and Huerfana and Los Animas Counties, Colorado (n.d.). The maps are filed with the textual records.

All the county and district maps show coal-bearing land and location and names of companies operating coal mines. Some of the maps also show railroad lines, gas wells, and other features.

662. INDEX TO PUBLIC-LAND ORDERS. 1942-47. 6 in.

Arranged numerically by order number, 1-393. Some numbers do not appear in the index.

Cards (4 in. x 6 in.) showing State or Territory, Federal Register citation (volume, number, page), date of order, purpose, and sometimes the legal-land description.

There are two sets of cards at the end of the series: the first lists the orders as they appeared in the Federal Register, and the second organizes the orders by State or Territory.

\section{A MAP SHOWING MAPPING AND CLASSIFICATION PROGRESS TO JANUARY 1964. 1 item}

An oversized color-coded map of the United States showing geologic-mapping area in progress, geologic mapping completed, classification minutes submitted, classification minutes approved, areas being classified from subsurface data or published reports, and areas containing withdrawn mineral lands. The map is filed with the textual records. 
Oil and Gas Leasing functions were transferred from the Bureau of Mines in 1925 and assigned to the newly established Mineral Leasing Division. In 1932 a separate Oil and Gas Leasing Division was established. The Division was renamed the Oil and Gas Leasing Branch in 1949. The Branch was responsible for supervising the prospecting, development, and production of oil and gas from leases on Federal, Indian, and certain naval-petroleumreserve lands. In 1959 the Branch was renamed the Branch of Oil and Gas Operations. The functions of the Branch were transferred to the Bureau of Land Management in 1983.

664. RECORDS MAINTAINED BY HALE BRYAN SOYSTER CONCERNING PROPOSALS TO CONSERVE OIL AND GAS. 1934-43. 5 in.

Arranged by subject, and thereunder chronologically.

Chiefly correspondence, but also includes memorandums, reports, statistical tables and summaries, copies of testimony, hearing proceedings and speeches, handwritten notes, newspaper clippings, copies of House bills, and other records relating to Hale B. Soyster's cooperation with committees concerned with petroleum conservation. Soyster completed studies and testified before the Petroleum Sub-Committee of the House Interstate and Foreign Commerce Committee (also known as the "Cole Committee"). This committee undertook investigations of the oil industry, and proposed a bill (H.R. 7372, 76th Congress, 1st Session) to conserve petroleum and control the production of oil and natural gas.

Soyster also testified before the National Resources Board's Temporary National Economic Committee regarding the conservation of petroleum on the public domain and Indian lands.

Soyster served as the Chief of the Oil and Gas Leasing Division from 1932 to 1943, and as Chief of the Conservation Branch from 1943 to 1944.

\section{RECORDS CONCERNING BRANCH CONFERENCES. 1930-68. $1.5 \mathrm{ft}$.}

Arranged chronologically.

Copies of papers, minutes, correspondence, memorandums, transcripts of proceedings, handwritten notes, newspaper clippings, and other records relating to Branch conferences and meetings that concern the policies and procedures of the Branch's oil- and gas-leasing programs. Also included are "Flexograph" recordings of the Oil and Gas Supervisor's conference of April 1949, and Harold G. Barton's (Chief of the Branch) notebook from the Supervisor's Conference in September 1956.

666. RECORDS CONCERNING OIL- AND GAS-LEASING FORMS AND REGULATIONS. ca. 1920-52. 1.5 ft.

Arranged by subject, and thereunder roughly chronologically.

Correspondence, memorandums, reports, copies of blank leases, leasing and operating regulations, Federal codes, and congressional bills, statistical tables and summaries, minutes of meetings, transcripts of conference proceedings, newspaper clippings, handwritten notes, bulletins, and other records that concern revisions of leasing forms (particularly those applying to Indian lands) and regulations for oil and gas operations. Includes information relating to proposed and accepted oil- and gas-leasing forms and operating regulations, active oil-leases on Indian lands and USGS 
supervision over work on these lands; lack of compliance with leasing and operating regulations; and changes in oillease bidding rules and royalty rates as leasing forms were amended.

667. NATURAL-GAS GASOLINE STATISTICS. 1923. 0.5 in. 1 oversized volume.

The entries are arranged by State, thereunder alphabetically by county, and thereunder by name of oil company or operator. Each entry has an assigned number. The significance of the numbers is not known.

The folio-style columnar sheets are divided into two sections. Column headings in the "consolidated statement" section include stocks - January 1, 1923, production, purchased consumed by company, sales, losses, stocks December 31, 1923, and total quantity of raw natural-gas gasoline. Column headings in the "detailed statement" include list of plants operated, name of plant, location of plant, daily capacity of plant (gallons), quantity and value of gasoline produced, price per gallon, quantity and yield of gas treated, and quantity of raw product.

\section{STATISTICAL DATA CONCERNING OIL AND GAS OPERATIONS IN THE UNITED STATES.} 1934- 59. $1.5 \mathrm{ft}$.

Arranged by subject, and thereunder chronologically.

Chiefly statistical tables and summaries, but also includes correspondence, memorandums, reports, copies of articles, graphs, maps, handwritten notes and calculations, and other records concerning oil and gas resources in the United States. Contains data that relates to estimated oil and gas reserves; wildcat-drilling operations; royalty accruals from public lands; and the production of oil, gas, coal, and other minerals in the United States.

669. MONTHLY REPORTS. 1924-66. 36 ft. 165 vols.

Arranged chronologically by month, and thereunder by district.

Narrative monthly reports from the district offices of the Branch that also contain statistical tables and summaries, correspondence, graphs, diagrams, plats, and photographic prints. Includes information on the number and status of oil- and gas-prospecting permits and new oil leases on public, Indian, and military lands, naval reserves, and the Outer Continental Shelf; number of wells drilled for oil and gas; U.S. Government royalties accrued from oil, gas, and gasoline produced from government lands; recommendations for investigations; and personnel matters.

The first three volumes (volumes 2 and 3 are bound together) were compiled by the Bureau of Mines.

670. MAPS CONCERNING THE LOCATIONS OF OIL-FIELD LEASES. ca. 1934. 16 items. [NWCS, maps and plans]

Included are maps that appear to have accompanied a letter dated January 26, 1937, to the Secretary of the Interior from the Texas Pipeline Company and signed by L. E. Burrows. One of the maps is titled "The Texas Pipeline Company Map of Midcontinent Oil Trunk Pipe Line Systems," January 1, 1934. The other unlabeled maps appear to show oil leases in Louisiana, New Mexico, and Texas.

Other items in this series are a "Geologic and Structure Contour Map of the Osage Oil Field, Weston County, Wyoming," 1935; a printed undated drawing of the "Inner Harbour [and] Navigation Canal of the Greater Port of New Orleans;" and an undated item titled "An Index of Sheets Issued by various Governments on a Uniform Scale of $1: 1,000,000$ ” for sale by the International Map Company, Inc. 
Mining Branch, 1933-41

The Mining Division was established in 1930 to exercise functions formerly administered by the Oil and Gas Leasing Division. The Mining Division was for responsible the application of various mineral-leasing laws regarding operations and activities concerned with the prospecting, development, and production of various minerals, fuels, and fertilizers under leases on Federal and Indian lands. The Mining Division was renamed the Mining Branch in 1949. The name of the Branch was changed to the Branch of Mining Operations in 1959.

\section{REPORTS AND OTHER RECORDS CONCERNING EMERGENCY-RELIEF-FUNDED MINE-SAFETY PROJECTS. 1933-35. $6 \mathrm{ft}$.}

Arranged by Federal-project number (No. 55 to 66), and thereunder chronologically.

Chiefly monthly progress and final reports that include correspondence, statistical summaries, newspaper clippings, plats, and photographic prints concerning civil- and public-works projects to preserve and protect mines on the public domain and Indian reserves. Includes projects to eliminate health hazards at mines, safeguard mine openings, fill abandoned mine shafts, prevent the flooding of mines, and control outcrop fires.

Entry 674 contains additional information about some of these projects.

\section{RECORDS CONCERNING COOPERATION ON PUBLIC WORKS PROJECTS. 1933-36. 7 in.}

Arranged by State as follows: California, Colorado, Montana, North Dakota, Oklahoma, Utah, and Wyoming, and thereunder chronologically.

Chiefly correspondence, but also includes memorandums, statistical summaries, reports, plats, newspaper clippings, photographic prints, and other records concerning Public Works projects to control and extinguish coaloutcrop fires at mines, and safeguard mine openings. Includes information on appropriations, allotments and expenditures, progress of projects, personnel matters, and location of mines. Also contains records that relate to the plugging and abandonment of sodium-prospect wells in California and a study of rock formations and their relation to the occurrence of oil and gas in Osage County, Oklahoma.

Some of these projects are discussed in entry 671.

673. RECORDS CONCERNING PUBLIC WORKS PROJECTS ON INDIAN COAL LANDS IN OKLAHOMA. 1933-37. 5 in.

Divided into the McAlester and Miami Districts, and thereunder roughly chronologically.

Chiefly correspondence, but also includes memorandums, reports, statistical summaries, handwritten notes, copies of articles, photographic prints, and other records concerning Public Works projects on restricted and segregated Indian coal lands in Oklahoma. The projects were begun to reduce the hazards of mine fires and floods.

Includes information on appropriations, allotments and expenditures, progress of projects, personnel matters, and supplies. 
674. RECORDS CONCERNING COOPERATION WITH NEW-DEAL AGENCIES ON MINES AND MINE SAFETY. 1933-41. 5 in.

Arranged by subject.

Correspondence, memorandums, reports, statistical tables and summaries, newspaper clippings, handwritten notes, circulars, and copies of the National Industrial Recovery Act (NIRA) of June 16, 1933 (48 Stat. L., 195). NIRA codes and Public Works Administration (PWA) rules and regulations, copies of articles, plats, photographic prints and other records concerning the Division's cooperation with the National Recovery Administration, Civil Works Administration, and PWA. Includes information on the Division's work on the mining lands of the public domain and on Indian reserves; appropriations, allotments, and expenditures for cooperative projects; personnel matters; and specific projects such as safeguarding mine openings from fires, protection of Indian mines from natural hazards, and inspection of coal leases. Also contains a copy of the agendas, minutes, codes, and bylaws resulting from the American Mining Congress meeting on June 26, 1933 concerning cooperation under the NIRA; and completed PWA project reports for 1938. 
A Division of Hydrographic Classification was created when the Land Classification Board achieved branch status in 1912. The Division was renamed the Power Division when the Land Classification Branch (1922) was renamed the Conservation Division in 1925. By 1940 the unit had been renamed the Water and Power Division. The Division was renamed the Water and Power Branch in 1949. The Branch was responsible for classifying the public lands with regard to their water-power and water-storage possibilities. The Branch was renamed the Branch of Waterpower Classification in 1959.

675. RECORDS CONCERNING LAND AND STREAM CLASSIFICATION. 1894-1961. $54 \mathrm{ft}$.

Arranged according to a numeric system. A list of file headings appears as Appendix 39 in this inventory.

Chiefly narrative and statistical reports, but also includes publications, congressional reports, statistical tables and summaries, plats, maps, completed USGS forms for "Water Power Development" and "Power Classification," completed permit applications to appropriate State waters, correspondence, memorandums, photographic prints and negatives, diagrams, press releases, newspaper clippings, handwritten notes, and other records concerning investigations of lands and streams on the public domain and Indian reserves to determine waterpower and storage possibilities. Includes reports that relate to potential and available power resources, sufficiency of water for irrigation and municipal uses, use of water and power by industries, proposed and existing dam and reservoir sites, utilization and improvements of existing water and power supplies, and recommendations for withdrawal of land for power purposes.

Many of these reports evaluate the feasibility of proposed water-power projects being considered for permits and licenses by the Federal Power Commission. Similar reports also were prepared for the Forest Service; the General Land Office, and its successor, the Bureau of Land Management; the Bureau of Reclamation; the Army Corps of Engineers; and the Bureau of Indian Affairs.

Most of the records date from 1910.

676. LAND-CLASSIFICATION MAPS AND RELATED RECORDS. 1899-1934. 68 items. [NWCS, maps and plans]

The series consists of maps of the following areas and subjects: Mt. March and vicinity, 1899, 1904; Utah, 1931; the Central Great Plains, undated; the Northern Great Plains, undated; Northwest Colorado, 1930; Southwest Colorado, 1930; Washington, 1902 (4 parts); water resources of the Snake River Basin, 1932 (2 parts); the Pine Region of Minnesota, 1899 (6 parts); Northwest Wyoming, about 1934; and Southwest Wyoming, about 1934.

The maps are accompanied by processed issuances titled "Land Classification of Western Colorado," 1933; "Utilization of Water Resources of [the] Snake River Basin," 1932; and "Land Classification of the Central Great Plains," 1931 (bound in 4 parts).

677. ADMINISTRATIVE-CONTROL MAPS. ca. 1901-46. 6 vols. [NWCS, maps and plans]

Bound sets of maps grouped as follows: Arizona, California, Colorado and Idaho, Montana, New Mexico and Oregon, and Nevada. 
The maps show original plottings and drawings of rights-of-way and easements granted under the acts of February 15, 1901 (31 Stat. L., 790), and March 4, 1911 (36 Stat. L., 1253). Shown are the locations, ownership, and serial numbers of each permit or grant for proposed and existing railroads, highways, telegraph and telephone lines, pipelines, transmission lines, reservoirs, tunnels, and canals associated with irrigation and power projects. The maps are at 1:250,000. The handwritten annotations are very small and difficult to read without a magnifying glass. 
Branch of Connally Act Compliance, 1937-71

In 1958 activities relating to enforcement of the Connally ("Contraband [or 'Hot'] Oil") Act of February 22, 1935 (49 Stat. L., 30), were transferred from the Office of Oil and Gas in the Office of the Secretary of the Interior to the USGS and placed in the Office of the Chief of the Conservation Branch. In 1963 all functions of the Federal Petroleum Board relating to the Connally Act were transferred to the newly established Branch of Connally Act Compliance. The branch was abolished in 1966.

678. RECORDS CONCERNING THE ADMINISTRATION OF THE CONNALLY ACT. ca. 1940-69. $9.5 \mathrm{ft}$.

Arranged alphabetically by district office, and thereunder numerically by case number. The district office records are followed by files arranged by subject.

Case files, including correspondence, memorandums, copies of briefs and complaints, transcripts of hearings, statistical tables and summaries, well-production and well-status reports; copies of forms for "Producer's Monthly Report" and "Refiner's Monthly Report," newspaper clippings, handwritten notes, plats, diagrams, printed court documents, and other records concerning the investigations and litigation resulting from noncompliance with the Connally "Contraband Oil" Act. Many of the records in these files were compiled as evidence and exhibits for the litigation proceedings.

Also includes records relating to the enforcement of subpoenas, budget appropriations for Connally Act enforcement, Connally Act compliance activities in 1966, and oil fields exempt from reporting requirements under Connally Act regulations (1962). Also statistical summaries of tanker and barge commercial shipments of petroleum products from the Gulf Coast (1947-64); a publicity file for 1965-66 that includes photocopies of newspaper clippings; and a binder containing a compilation of certain pleadings and decisions from contested Connally Act litigation, assembled to present pertinent issues raised in the administration and enforcement of the act.

679. GENERAL RECORDS. ca. 1937-71. $4 \mathrm{ft}$.

Arranged by subject or type of record.

Correspondence, memorandums, handwritten notes, statistical summaries, monthly reports, speeches, press releases, handbooks, aerial photographs, and other records concerning implementation of Connally Act regulations, amendments to the regulations and re-delegations of authority; cooperation with other Federal Agencies, especially the Department of Justice; slant-well and trucking investigations; management and staffing of district offices; and transfer of the functions of the Federal Petroleum Board to the Branch of Connally Act Compliance in 1963.

Also included is a case docket showing the disposition of Connally Act violation cases (K-05000 to K-05935); exhibits and background material relating to a "Mineral Disposal Study" (1966) compiled by a task group studying the pricing and disposal of federally owned mineral resources; and records concerning the suspension of enforcement of Connally Act regulations by the Federal government and subsequent disposition of records maintained by the district offices. Most of the inquiry letters received after the branch was abolished were filed in this series. 
The Division of Alaskan Mineral Resources, established in 1903 within the Geologic Division, was the only major unit of the USGS organized to work in a specific geographic area. In 1922 the Division was separated from the Geologic Branch and given branch status. The title of the new Branch's chief was changed from Geologist-in-charge to Chief Alaskan Geologist. The Branch of Alaskan Mineral Resources was renamed the Alaskan Branch in 1925 by Survey Order 118. As the unit's field parties conducted geologic and topographic studies, and then water-resource investigations, in effect it was a small version of the USGS. The Alaskan Branch was abolished in 1946 and its functions in geology, topography, water resources, and public-land classification were distributed to the appropriate operational units of the USGS. In addition to the Branch records described below, records concerning USGS work in Alaska are described in the records of the Staff Geologist for Territories and Island Possessions, entry 60; the records of the Division of Alaskan Mineral Resources, entries 216 and 217; records concerning the Aleutian Volcano Project, entry 249; the records of the Alaskan Geology Branch, entries 258-265; records concerning the Alaska Terrain and Permafrost Section of the Military Geology Branch, entry 285; and records concerning Land and Stream Classification, entry 675 .

\section{CENTRAL FILES OF THE ALASKAN BRANCH. 1899-1952. 2.5 ft.}

Arranged according to a decimal-classification scheme, and thereunder roughly chronologically. A file concerning the termination of the Branch follows the main files.

Correspondence, memorandums, monthly and annual reports, technical and progress reports, statistical tables and summaries, handwritten notes, completed field-work report forms, press releases, newspaper clippings, lists of manuscripts and maps in preparation, travel vouchers, maps, and other records concerning the administration and programs of the Alaskan Branch. Specific projects covered are Public Works Projects No. 69, special mapping work, and No. 162, for mineral-resources surveys; an aerial-survey expedition in 1926 in cooperation with the Navy Department; and land surveys at Yakutat and Annette Island in 1940 in cooperation with the War Department. Also contains records on mapping activities in Alaska furnished by the USGS to the Federal Board of Surveys and Maps and the Science Advisory Board's Committee on Mapping Services; and reports of meetings from the Board of Surveys and Maps (1931-39).

Of particular interest are the monthly and annual reports, and reports of field work, dating from 1899, that concern geologic and topographic projects; Alaska mining development; cooperation with other Federal agencies, such as the Forest Service, the Alaska Road Commission, and the Bureau of Biological Survey; maintenance of a testing lab at College, Alaska; appropriations and allotments for Alaska projects; personnel matters; and publications. A file, dated 1946-52, relating to the termination of the Branch in 1946 was added subsequently by John Calvin Reed (Sr.).

681. ADMINISTRATIVE CORRESPONDENCE CONCERNING JOHN CALVIN REED (SR.). 1931-38.

2 in.

\section{Arranged chronologically.}

Included are letters reporting on progress of work, copies of letters of instruction to Reed, telegrams, requests for supplies, abstracts of allotments and expenditures, tabulations of field expenses, and an injury claim. The two files concern Reed's activities as associate geologist for the Alaskan Branch, 1932-1941. The files were maintained in the Washington, D.C. offices of the USGS.

Office files of John C. Reed (Sr.) as Staff Geologist are described in entry 60. 
682. ALASKA ALPHABETICAL MAP FILE. ca. 1892-1944. approx. 400 items. [NWCS, maps and plans]

Arranged alphabetically by name of nearest large town or geographical feature.

Included are tracings, blueprints, annotated published maps, metal mounts, and planetable sheets. Some of the maps originated with the General Land Office and the Coast and Geodetic Survey. The maps concern regional topography, townsites, railroads, water-power reconnaissance surveys, coal lands, coal-land claims, and related subjects. There are also maps showing roads and trails, 1941-42 (Juneau); and a large map showing Glacier Bay and adjacent glaciers, 1892, by Henry F. Reid (Mt. Fairweather). Of particular interest are two envelopes of sketches, with diary notes on the reverse of a few of the sketches, compiled by Ernest de K. Leffingwell in connection with his survey of the Arctic coast of Alaska, about 1910-13. The envelopes are labeled Flaxman Island and Beechey Point. A map titled "Barrow Point and Port Moore, 1853," and stamped "E. de K. Leffingwell" is filed under Barrow Point.

683. ALASKA DECIMAL MAP FILE. ca. 1898-1941. approx. 850 items. [NWCS, maps and plans]

Arranged by decimal numbers. It is not known who assigned the decimal numbers or the significance of the numbers. There is no correlation between these decimal numbers and the decimal file system used for the Central Files of the Alaska Branch.

The records are in the form of manuscript maps, blueprints, planetable sheets, annotated published maps, and metal mounts. Included are contour maps, geologic-reconnaissance maps, reference maps from the Coast and Geodetic Survey, parts of quadrangle maps, topographic-reconnaissance maps, and tactical maps compiled by the Army Corps of Engineers in 1940-41 (file 21.1). The subjects include highway routes, river systems and headwaters, regions of Alaska, mining districts, glaciers, areas explored by seasonal survey parties, positions of camera stations, and naval petroleum reserves. Some of the maps carry information on both sides.

684. MISCELLANEOUS MANUSCRIPT MAPS OF ALASKA. ca. 1900-1940. approx 100 items. [NWCS, maps and plans]

Some of the maps are arranged in groups by name of quadrangle. The remainder are unarranged.

Included are annotated printed maps, sketches, planetable sheets, and blueprints. Subjects include the route of the Harriman Expedition (1899), telegraph stations, mountain ranges, and railroad lines. Of particular interest is a copy of a "Chart of part of the North West Coast of America from Point Rodney to Point Barrow by Captain F[rederick]. W. Beechey, R.N., F.R.S., in His Majesty’s Ship Blossom,” 1826-27.

685. PUBLISHED MISCELLANEOUS MAPS OF ALASKA. ca. 1902-96. 26 items. [NWCS, maps and plans]

Arranged by assigned number.

The items include a map showing the locations of aviation fields (existing and proposed) and route of a proposed international highway; the location of the proposed route of the Pacific Yukon Highway; locations of air fields, hydroplane landings, and a zeppelin field near Fairbanks; topography of the Mt. McKinley region, Copper River and Chistochina River Region, and headwaters of the Copper and Tanana Rivers; topographic-reconnaissance maps of Seward Peninsula and the Innoko-Iditarod region. Other subject areas covered by the maps include the status of geologic surveys, locations of gold and coal deposits, and locations of national-interest lands. Most of the maps in this series were collected by the Alaskan Branch and its predecessor the Division (later Branch) of Alaskan Mineral Resources. A few later miscellaneous items relating to Alaska were placed with these records because of the similar subject matter. 
686. PHOTOGRAPHS OF SUBJECTS IN ALASKA. ca. 1912-41. 1.5 in. 1 album.

Arranged by subject. There is a general table of contents. This is series AL (NWCS, still pictures).

The first part of the album contains photographs taken by Merl La Voy when he accompanied the Parker-Browne Expedition on a climb of Mt. McKinley in 1912. La Voy sent the photographs to the USGS in 1924.

Other photographs of subjects in Alaska taken by various photographers fill the remainder of the album. The subjects include commercial vessels, railroads, towns, residents, scenery, glaciers, mines, and earthquake damage. A few of the photographs were taken from an airplane. 


\section{Appendix 1}

Select List of Legislation

March 3, 1879 (20 Stat L., 394-395), created the USGS and terminated the three ongoing geological and geographical surveys (predecessor surveys) led by Ferdinand V. Hayden, John W. Powell, and George M. Wheeler

August 7, 1882 (22 Stat L., 329), directed the continued preparation of a geological map of the United States; the collection of statistics about mines and mining; and the conducting of chemical analyses of iron, coal, and oil

July 7, 1884 (23 Stat. L., 212), provided that scientific employees of the USGS be selected exclusively for their qualifications as professional experts

March 3, 1887 (24 Stat. L., 527), required the USGS hereafter to itemize its estimates (requests for appropriations)

March 20, 1888 (25 Stat. L., 618-619), authorized the investigation of the feasibility of constructing reservoirs for the storage of water in the arid regions of the United States

October 2, 1888 (25 Stat. L., 526-527), authorized the investigation of "the extent to which the arid regions of the United States can be redeemed by irrigation, and the segregation of the irrigable lands in such arid region, and for the selection of sites for reservoirs and other hydraulic works necessary for the storage of water and prevention of floods and overflows" (resulted in the creation of the Irrigation Survey); an appropriation for the compilation of the report on the mineral resources of the United States; and extended paleontological, and physical chemical researches; and geologic and topographic surveys in various parts of the United States

August 30, 1890 (26 Stat. L., 391), repealed the provisions of the act of October 2, 1888, establishing the Irrigation Survey

March 3, 1891 (26 Stat. L., 1103), provided for the establishment of forest reserves

April 12, 1892 (27 Stat. L., 395), provided that the facilities for research and illustration of the USGS and other agencies be made accessible to scientific investigators and to students of institutions of higher education incorporated by Congress or the District of Columbia

July 31, 1894 (28 Stat. L., 197), authorized the Secretary of the Interior to name one of the geologists to act as Director of the USGS in the absence of the Director

August 18, 1894 (28 Stat. L., 398), appropriated funds for "gauging the streams and determining the water supply of the United States, including the investigation of underground currents and artesian wells in arid and semiarid sections"

March 2, 1895 (28 Stat. L., 939), provided for the investigation of the coal and gold resources of Alaska

February 26, 1896 (28 Stat. L., 683), provided for the classification of mineral lands situated as part of grants to the Northern Pacific Railroad in Idaho and Montana

May 14, 1896 (29 Stat. L., 120), provided for rights-of-way for reservoirs, canals, and electric power generation, manufacture, or distribution 
June 11, 1896 (29 Stat. L., 435), provided that in topographic surveys elevations be determined and marked on the ground by iron or stone posts or permanent bench marks

June 4, 1897 (30 Stat. L., 34), provided for the survey of public lands that have been or may be designated as forest reserves

June 17, 1902 (32 Stat. L., 388), the "Newlands Act" created a reclamation fund; the Reclamation Service was established within the USGS on July 8

February 4, 1904 (33 Stat. L., 33), provided for analyzing and testing of coals and lignites to determine their fuel values and most economic utilization

February 1, 1905 (33 Stat. L., 628), provided for the transfer of the administration of forest reserves to the Department of Agriculture and its Bureau of Forestry (established as a Division in 1881); the USGS retained topographic and special surveys of the forest reserves until the line item was merged with the general topographic surveys in 1918

May 22, 1908 (35 Stat. 226), provided for investigations of the causes of mine explosions and led to the creation of the Technologic Branch

May 27, 1908 (35 Stat. L., 349), provided for continuing the chemical analysis and testing of coal, lignites, and other mineral fuels; and continuing the investigation of structural materials

February 19, 1909 (35 Stat. L., 639), Enlarged Homestead Act

May 16, 1910 (36 Stat. L., 370), created the Bureau of Mines, principally by transferring the Technologic Branch; structural-materials testing passed to the Bureau of Standards

March 1, 1911 (36 Stat. L., 961-963), the "Weeks Act," provided for the protection of the watersheds of navigable streams and created the National Forest Reservation Commission

July 17, 1914 (38 Stat. L., 509-510), withdrew from agricultural entry lands classified or reported as containing phosphate, nitrate, potash, oil, gas, or asphaltic materials

June 9, 1916 (39 Stat. L., 219), provided for the examination and classification of the Oregon and California Railroad Company's land-grant lands and other grants of rights-of-way or use permits whose titles revest in the U.S. Government

August 21, 1916 (39 Stat. L., 518), provided for the location, development, and protection of desert-watering places

December 29, 1916 (39 Stat. L., 862), the "Stock-Raising Homestead Act"

June 12, 1917 (40 Stat. L., 145), provided for the examination and classification of lands to determination their suitability for enlarged homesteads, stock-raising homesteads, public-watering places and stock driveways; and the location, development, and protection of springs, streams, and water holes on arid public lands

October 1, 1917 (40 Stat. L., 297), the "Potash Leasing Act" - provided for the exploration and disposition of potassium deposits 
July 1, 1918 (40 Stat. L., 669), directed the USGS to conduct for the War Department (WD) special topographic and other surveys selected by the WD

February 25, 1920 (41 Stat. L., 437), the "Mineral Leasing Act"

June 5, 1920 (41 Stat. L., 910-911), created the Superpower Survey “for a survey of power production and distribution"

June 10, 1920 (41 Stat. L., 1063), the "Federal Water Power Act" created the Federal Power Commission

September 22, 1922 (42 Stat. L., 1023), created the United States Coal Commission

February 27, 1925 (43 Stat. L., 1011), the "Temple Act" directed the USGS to enter into cooperative agreements with the States to complete a topographic map of the United States within 20 years

May 18, 1933 (48 Stat. L., 58), created the Tennessee Valley Authority

June 16, 1933 (48 Stat. L., 195), the "National Industrial Recovery Act"

June 28, 1934 (48 Stat. L., 1269), the "Taylor Act" passed to "stop injury to the public grazing lands"; the Agricultural Division of the USGS Conservation Branch was transferred in 1935 to the Grazing Service

February 22, 1935 (49 Stat. L., 30), the "Connally Act" regulated interstate and foreign commerce in petroleum and its products

August 26, 1935 (49 Stat. 838), amended the "Federal Water Power Act" of 1920

April 26, 1938 (52 Stat. L., 235), authorized "the procurement and transportation of strategic and critical materials" to be determined by the Secretary of the Navy

June 20, 1938 (52 Stat. L., 816), continued the Pubic Works Administration (PWA) and appropriated funds for surveys and mapping by Federal agencies to be administered by the PWA

December 24, 1942 (56 Stat. L., 1086), allowed the acquisition of lands for stream-gaging stations

August 1, 1946 (60 Stat. L., 755), the "Atomic Energy Act" provided for the withdrawal of lands bearing radioactive ores

January 27, 1948 (62 Stat. L., 6), the "United States Information and Educational Exchange Act"

April 3, 1948 (62 Stat. L., 137), the "Foreign Assistance Act"

September 8, 1950 (64 Stat. L., 798), the "Defense Production Act"

October 10, 1951 (65 Stat. L., 373), the "Mutual Security Act"

July 9, 1952 (66 Stat. L., 454), restricted the USGS share of topographic mapping or water-resource investigations in cooperation with States or municipalities to not more than 50 percent of cost

May 22, 1953 (67 Stat. L., 29), the "Submerged Lands Act" provided for United States jurisdiction over the lands and natural resources of the Continental Shelf 
August 7, 1953 (67 Stat. L., 462), the "Outer Continental Shelf Lands Act" provided for the leasing of lands of the continental shelf for the exploration for and development of mineral resources

August 4, 1954 (68 Stat. L., 666), the "Watershed Protection and Flood Protection Act"

August 13, 1954 (68 Stat. L., 708), the "Multiple Mineral Development Act"

August 21, 1958 (72 Stat. L., 700), the "Minerals Exploration Act"

August 23, 1958 (72 Stat. L., 837), extended the authorization for USGS work to Antarctica and the Trust Territory of the Pacific Islands

August 28, 1958 (72 Stat. L., 959), the "Federal Employees International Organization Service Act"

September 4, 1961 (75 Stat. L., 424), the "Act for International Development"

September 5, 1962 (76 Stat L., 427), expanded the authorization for the USGS to work outside the national domain

September 3, 1964 (78 Stat. L., 890), the "Wilderness Act"

July 22, 1965 (79 Stat. L., 244), the "Water Resources Planning Act"

October 15, 1966 (80 Stat. L., 951), authorized contracts for scientific and technical research

October 27, 1972 (86 Stat. L., 1280), the "Coastal Zone Management Act"

December 31, 1973 (87 Stat. L., 975), the "Flood Disaster Protection Act"

September 3, 1974 (88 Stat. L., 1079), the "Geothermal Energy Research, Development, and Demonstration Act"

April 5, 1976 (90 Stat L., 303), the "Naval Petroleum Reserves Protection Act"

October 7, 1977 (91 Stat. L., 1098), the "Earthquake Hazards Reduction Act"

September 17, 1978 (92 Stat. L., 601), the "National Climate Program Act"

December 30, 1982 (96 Stat. L., 1972), authorized the USGS "to accept lands, buildings, equipment, and other contributions from public and private sources and to prosecute projects in cooperation with other agencies, Federal, State, or private"

January 7, 1983 (96 Stat. L., 2201), the "Nuclear Waste Policy Act"

March 10, 1983 (97 Stat. L., 1557), established the "Exclusive Economic Zone [EEZ] of the United States of America" and yielded a USGS program to map the EEZ

March 22, 1984 (98 Stat. L., 97), the "Water Resources Research Act"

July 17, 1984 (98 Stat. L., 451), the "Remote Sensing Commercialization Act" 
July 17, 1984 (98 Stat L., 468), the "Barrow Gas Field Transfer Act"

September 28, 1984 (98 Stat. L., 1675), the "High Plains States Groundwater Demonstration Program Act"

December 22, 1987 (101 Stat. L., 1407), the "Global Climate Protection Act"

September 22, 1988 (102 Stat. L., 1760), the "Continental Scientific Drilling and Exploration Act"

November 16, 1990 (104 Stat. L., 2975), the "Antarctic Protection Act"

November 16, 1990 (104 Stat. L., 3096), the "Global Change Research Act"

May 18, 1992 (106 Stat. L., 171), part of the "National Geologic Mapping Act" (106 Stat. L., 166), confirmed language in the Interior Department Appropriation Act of November 13, 1991 (105 Stat. L., 1000), renaming the Geological Survey the United States Geological Survey

October 28, 1992 (106 Stat. L., 4163), the "Land Remote Sensing Policy Act"

October 30, 1992 (106 Stat. L., 4693), the "Western Water Policy Review Act"

April 26, 1996 (110 Stat. L., 1321-165), transferred the National Biological Service's funds to the USGS. The statute also gave the USGS the U.S. Bureau of Mines' authority "to conduct mineral surveys and to determine mineral values"

August 5, 1997 (111 Stat. L., 1107), the "National Geologic Mapping Reauthorization Act" 


\section{Appendix 2}

Office of the Director - Correspondence and Related Records, ca. 1906-48 (entry 49)

Accounts, Division of, 1906-19

Addresses, Speeches, 1908-47

Administrative Geologist, 1906-30

Anniversary (40th) of the Geological Survey, 1919

Auction Sales - Pacific Division, 1925

Budget and Administrative Letters, 1928, 1945-48

California Cooperation (Audit of funds disbursed by James R. Gaskill from the State of California Cooperative Account and other Accounts), 1923-25

California Cooperation - Data (bank statements) [related to audit], 1923-24

Coal, 1907-11, 1929

Coal Commission - United States, 1923-29

Comptroller General of the United States, 1926, 1939, 1942-43

Conference - Other Departments (cooperation with the General Land Office and the Forest Service), 1908-13

Congressional thanks for Federal Activities, 1928-29

Conway Controversy [resignation of two clerks, sisters surnamed Conway], 1920

Cooperation - Federal, [includes a report by Robert B. Marshall on Glacier National Park], 1908-37

Cooperation with States, 1908-32

Distribution of Survey Publications, 1916-23

Engraving and Printing, 1915-23

Executive Division (Business Methods, Regulations, Personnel), 1910-11

"Fiscal Regulations of the United States Geological Survey" [Manuscript copy, no date]; other records in file concerning expenditures, 1917-19

[Louis G.] Freeman Case [regarding a promotion], 1919-20

Geology, 1907-23

Humor [facetious letters and comments], 1909-32

Illustration Section, 1909-22

Insurance, 1926

Land Classification and Withdrawals, 1907-29

Land Classification Board, 1917-22

Laws relating to the Geological Survey [typescript and printed copies], 1879-1912 with gaps

Legislation regarding land, 1911

Letters Unanswered, personal dictation, 1904-12

Library [includes an index to the classification scheme of the USGS Library dated 1909], 1909-22

Library Hours, 1911-21

(Geologic) Map Editing, 1910-18, 1937

(Topographic) Map Descriptions, 1916-21

(Topographic) Maps, 1911-30

Memorandums [regarding file maintenance], 1915-19

Mineral Resources, 1908-27, 1937 \& 1943

Newspapers Clippings titled "Uncle Sam at Your Service" regarding work of the Geological Survey, 1930

Miscellaneous Official Correspondence, 1905-9

Numerical File [appropriations and statements of work], 1918-20

Oil, 1910-33

Oil (Naval Reserve No. 3, Teapot Dome) [Missing] 
Opportunities Report [an outline of a proposed report by van Bloch titled "Statement of Opportunities for Economic Growth in Relation to Departmental Programs"], 1946

(Survey) Orders, 1908-25

Orders, Department, 1912-42

(Survey) Organization, 1908-32

Personnel [2 folders], 1907-43

Personnel Committee, 1915-39

Photographic Laboratory, 1915-19

Photographs [missing]

Pinchot - Ballinger, 1908-10

Policy, 1907-31

Publications, 1909-42

Relations with the Public, 1907-30

Subject Classification Scheme, Central Classified Files, 1912 [several annotated copies]

Subsistence Costs, n.d.

Supplemental Estimate [of appropriation], 1917

Survey, Committee on Revision of the Regulations, 1918 [out of order because of size, filed in box 7]

Telegrams and Correspondence, 1924 [regarding California Cooperation audit]

Texts, 1911-12

Topography, 1907-31

"United States" in title of Geological Survey, 1937

Vouchers and Invoices [regarding California Cooperation audit, with 4 folders concerning accounts]

Water Power, 1909-14

Water Resources, 1915-29

Yosemite Valley [typescript copy of "The Physical History of the Yosemite Valley" by François E. Matthes], 1922 


\title{
Appendix 3
}

\author{
Office of the Director - Central Classified Files, 1912-53 (entry 51)
}

* Indicates that part of the file is boxed separately from the main series

** Indicates that the entire file is boxed separately from the main series

Titles in italic are added to provide clarity, no file exists

\section{GENERAL (Miscellaneous)}

000 General

001 Commendations of work of Survey

001.01 Recommendations, commendation of outside parties, firms by the Survey

001.1 Outside individuals, organizations, businesses, and agencies

001.2 Bouquets

001.3 Commendations, congratulations, endorsements by the Survey

002 Criticisms of the work of Survey

$002.1 \quad$ From individuals outside the Survey

002.2 From within the Survey

003 Complaints, nuisances, suggestions, etc

003.1 By the Survey

003.2 Against the Survey

003.3 Within Survey

004 Requests for interviews with Survey officials

004.1 Interviews, etc. asked for by Director (empty folder)

004.2 Interviews arranged by Director with Gov[ernment]. officials, etc. for others (empty folder)

005 Invitation received by Director and other Survey Officials

005.1 Director asked to suggest officials to serve on committees, etc.

005.2 Invitations of Director to others (empty folder)

006 Introductions, Guests of Survey, Invitations to Associations., etc. to visit

006.1 Introductions, etc., by Director or Survey to others

007 Donations made to Survey (all kinds)

008 Miscellaneous and unclassified correspondence; legislation to eliminate illiteracy; Spanish Influenza; Institute for Government Research; and processed issuances titled - "Personnel Notes"

009 Lunch facilities

010 Miscellaneous Requests

$017 * *$ For Survey employees to work for private firms

020 Congressional Legislation

021 Re: bills to Create Board of River Regulations and to regulate water power projects

023 Mineral Control Act (1918)

024 Resolutions, Acts of States, Territories, etc. (alphabetically by organization, State, locality or individual)

025 Re: legislation concerning the budget, programs and policies of the Survey (general files, followed by subject files in alphabetical order, followed by bill files arranged by branch of Congress and thereunder by bill number, without regard to session or date)

030 Publicity

031 Requests for Press Notices and processed copies of press notices

031.1 Press bulletins and processed copies of press releases

033 Publication of articles before release date

033.1 Complaints and other correspondence [empty folder] 
033.2 Unpublished information to be considered confidential, loan of manuscripts, advance information, policy as to giving out information

034.01** Radio interviews and series

035.1** Correspondence with George W. Parsons regarding desert watering place work

040 Congresses, Conventions, Expositions, Conferences (general files followed by files arranged alphabetically)

044 Personnel Classification Board and job classifications

044.07 Joint Commission on Reclassification of Salaries

070 Library

044.071 (files organized job category) i.e. typing, law, engineering

071 Books, documents, publications, etc.

071.1 Loaned to others by Survey

073 Re: Geological Depository Libraries

074 Courtesies of the Library extended others by Survey

077 Exchange privileges

078 Translations

080 Scientific Discoveries, claims of

081 Re: Patents by Survey Employees (arranged alphabetically by surname of employee)

081 Patent for Willard D. Johnson Tripod Heads (oversize file in box 533)

082 Re: Survey to sent representatives to witness demonstrations of inventions

083 Use of Landin Float-Letter Method

\section{ADMINISTRATIVE}

100 Administrative

100.01* Survey History; Organization; Reorganization; Inspection; and Civil Defense

100.01** Surveying and Mapping Consolidation

100.01A** National Academy of Science Plan for Reorganization of Surveys

100.01B** Dockery Commission Recommendation to create U. S. Survey

100.01C** Consolidation of surveying Division of GLO and Topographic Branch of Geological Survey

100.01D** Plan for a Bureau of Surveys and Maps

100.01E** Report of the Joint Committee on Reorganization of the Executive Departments

100.01F** Transfer of Geodetic Work of Coast Survey to Geological Survey

100.01G** Transfer of Topographic Branch of Geological Survey to Coast and Geodetic Survey

$100.01 \mathrm{H}$ Consolidation of the Departments of Interior and Agriculture

100.01I Transfer of Mineral Leasing

100.01J Transfer of Geophysical Research to Survey

100.1 Administration of Labor Force; functions of Branches

100.2 Administration of Clerical Force

100.3 Administration of Messenger Force

100.5 Administration of the Library

100.6 Administration of Section of Field Equipment

101 Debts of Employees

102 Credential and Identification cards, passes

102.1 Passes

102.2 Permission to take packages from the building

102.3 Credentials and Identification cards

102.4 Survey personnel under arrest

103 Handling and Filing of Correspondence

103.1 Correspondence re: files and filing systems

103.12* Destruction of useless papers

103.14Certified copies of records, records loaned 
103.2 Handling of Correspondence

103.21Methods of procedure, plans for handling, reference of and form of letters

103.22Correct grammar, phrases, position titles

103.23Letters requiring special attention, response time to letters

103.24Translations of letters requested of other Bureaus, Departments, etc (empty folder)

103.25Use of clips

103.26Transmitting extra carbon copies of letters

103.28Endorsements on correspondence

103.32Referral of letters within Survey

103.34Routing of letters, documentation regarding

103.35Referral of letters to other agencies

103.37Routing slips

103.4 Instructions for preparing a letters for the Secretary's signature

103.6 Delegations of Authority

104 Multigraphing, Mimeographing, Hecktographing, etc.

105 Creation of new positions, assignment of duties and changes in positions

105.1 Assignment of duties

107 Law and authority governing operations of Geological Survey

108 Extra copies of letters in which the Director is interested

108.1 Letters to Director during his absence re: office matters (from Survey Chiefs)

108.2 Letters written by the Director to branch chiefs and other while away or just prior to his leaving

108.3 Letters from men in the field or on trips

108.4 Letters to the Director

109 Memoranda signed by Chief, Executive Division

110 Relations with Departments, Independent Offices (not including cooperation)

$110.1 \quad$ Smithsonian Institution and Museum

110.11Survey doing work for Smithsonian

110.12Re: International Exchange Service

110.13Smithsonian does work for Survey

110.14Smithsonian requests information

110.15Specimens, etc., deposited with the National Museum for exhibition

110.2 Commerce, Department of

110.21Plans for joint investigations between Standards or other Bureaus and Survey

110.22Work done for Department and its bureaus

110.24Commerce and bureaus to do work for Survey or offers to assist in work

110.25Information furnished by Commerce and its Bureaus, copies of maps and records given

110.26Information requested by Commerce and its bureaus or furnished by Survey

110.27Survey asked to prepare examination for position in

110.3 Panama Canal

110.4 U. S. Boundary Survey (International Boundary Commission, Alaskan Engineering

110.5 Labor, Department of Commission, Alaska Railroad)

110.51Tables, statements, information, etc., furnished Labor (including monthly reports of contracts for work in buildings, etc.)

110.53Work done for Labor

110.6 District of Columbia

110.7 Interstate Commerce Commission

110.71Information requested of Interstate Commerce Commission

110.72Official Bulletin

110.8 White House (Executive Offices)

110.9 Correspondence with foreign embassies and Consular Offices 
110.10 Federal Trade Commission

110.111 General, Council of National Defense

110.111A Miscellaneous (arranged alphabetically by surname of individual)

110.111B Mineral and mineral products

110.111C Council of National Defense and War Industries Board

110.111D National Research Council

110.111E National Defense Council

110.111F National Archives and Federal Register

110.112 National Advisory Committee for Aeronautics

110.113 Bureau of Efficiency

110.113A Efficiency Ratings

110.113B Duplicate Work

110.113C Recommendations

$110.114 \quad$ U. S. Tariff Commission

110.115 Committee on Public Information

110.116 Food and Fuel Administration

110.117 Pan American Union

110.118 U. S. Shipping Board

110.119 War Trade Board

110.120 Capital Issues Commission

$110.121 \quad$ U. S. Railroad Administration

110.122 Veterans Bureau

110.123 Coal Commission

110.124 Public Buildings and Public Parks

110.125 Federal Power Commission

110.126 Architect of the Capital

110.127 Federal Civil Works Administration

110.1271 Federal Emergency Relief Administration

110.128 Tennessee Valley Authority

110.129 Emergency Conservation Work

110.131 Public Works Administration, General

110.132 Public Works Administration, Estimates and Allotments; Emergency Relief Appropriations

110.134 Public Works Administration, Secretary's Orders

110.135 Public Works Administration, Reclamation, Boulder Dam Investigation

110.135 Public Works Administration, Mississippi Valley Committee

110.135 Public Works Administration, Cooperation with Departments

110.1351 Public Works Administration, Cooperation with Branches in Survey

110.136 Public Works Administration, Requests by States (alphabetically by State or Territory)

110.137 Public Works Administration, Purchase of Supplies, Equipment

110.138A Public Works Administration, Personnel Procedure, General

110.138B Public Works Administration, Personnel Procedure, Internal Instructions and Details

110.138C Public Works Administration, Personnel Procedure (alphabetically by individual surname)

110.140 Public Works Administration, General

110.140 Public Works Administration, Miscellaneous Reports

110.140 Public Works Administration, Monthly Progress Reports

110.140 Public Works Administration, Monthly Reports on Expenditures

110.140 Public Works Administration, Form ES 118 
110.140 Public Works Administration, Monthly Apportionments

110.140 Public Works Administration, Report of Obligations and Impounded Savings, Form B

110.140 Public Works Administration, Report of Allocation from PWA Form 235

110.140 Public Works Administration, PWA Form 236

110.140 Public Works Administration, Reports to Federal Employment Stabilization Board

110.140 Public Works Administration, Miscellaneous Reports

110.140 Public Works Administration, U. S. Employees Compensation Commission

110.141 National Recovery Administration

110.142 Public Works Administration, Code of Fair Competition for the Petroleum Industry and Petroleum Administrative Board

110.142 Public Works Administration, Petroleum Board, Press Releases

110.142 Public Works Administration, Circulars

110.142 Public Works Administration, Bulletins

110.142 Public Works Administration, Press Releases

110.142 Public Works Administration, Information requested by or furnished

110.142 Public Works Administration, Detail of Employees

111 Interior Department

111.1 Survey asked to consider employees for vacancies who are to be dropped because of reduction in force, appropriation etc.

111.2 Survey requested to furnish certified copies, copies of files, employees to testify, etc., within the Department

111.3 Complaints, criticism, suggestions, etc., made by Director or Survey to other Bureaus

111.4 Courtesies extended to Survey field parties, etc.

111.5 Other Bureaus doing work for Survey

111.6 Survey doing work for other bureaus (also see Cooperation) [general files followed by files arranged alphabetically by name of bureau, office or other organizational unit with the Department]

111.7 Survey requested to verify figures, statements, etc., for Departments or bureaus, information furnished (articles furnished for Bureau publications)

111.71 Survey requests information from other Bureaus

111.8 Overlapping of work, decisions, correspondence, etc., as to whether work comes under Survey or not, joint correspondence on matters relating to more than one bureau

111.82Survey asks permission to use information obtained by other bureaus in Survey reports,

112 Justice, Department of publications, joint publications

112.1 Opinions of Attorney-General; Solicitor or Assistant Attorney General for Interior

112.2 Requests for investigations with view toward prosecution; employees to give opinions or to make examinations; or testify

112.21Information requested by Justice, or work requested by it or done for it

112.3 Survey requested to furnish certified copies, statements, etc.

112.5 Justice asked to prosecute theft, depredation cases, etc. for Survey

112.6 Justice asked to represent Survey men against whom charges have been made

112.9 Information requested of Justice by Survey (incl. use of Justice Library)

113 Post Office Department

113.1 Requests by Survey to make investigations; fraudulent use of mails

113.2 Requests made by P. O. for investigations of alleged illegal holdings

113.5 P. O. objects to Survey accepting stamps for payment of maps

113.6 Requests that Survey do work for Post Office

113.7 Postmasters to act as agents for sale of maps, authority

114 Treasury Department

114.1 Opinions of Comptroller 
114.11Social Security Tax

114.12General Accounting Office Circulars and Regulations

114.2 Free entry form customs for goods for use of Survey, exception from interference

114.41Courtesies to be shown parties of other countries at Survey request

114.6 Requests for detail of employees to make investigations

114.7 Work done for Survey or information furnished it

114.72Treasury Agents posing as members of field parties to make investigations

114.81Requests for Information

115 Civil Service Commission

115.01 State Civil Service Commissions

115.1 Examinations

115.2 Promotion Examinations

115.3 Civil Service Rules and Regulations

115.5 Political Activities of employees

115.6 President's Council on Personnel Administration; President's Committee on Civil Service Improvement

115.9 Re: rating examination papers

116 State Department (including Commission for Equitable Distribution of Water of Rio Grande)

116.1 Requests from State for documents, reports, data, etc., commendation of reports received by Survey

116.2 Requested to take appropriate action toward meeting claims against U. S. for services, etc., on Associations, Congresses, etc.

116.3 State requested to represent Survey on official matters abroad through Embassies

116.4 Information requested by State Department

116.5 Work done for State or Commission for Equitable Distribution of Water of Rio Grande; Rio Grande Compact Commission

116.6 State Department requests that all correspondence with representatives of foreign governments be carried on through it and not directly

116.8 Detail of Survey Employees

117 Navy Department

117.1 Correspondence re: oil reserves in California for use of Navy

117.2 Special Boards, Committees, etc, appointed by Navy Department

117.3 Information requested by Survey of Navy Department

117.5 Information requested by Navy Department, loan of maps

117.6 Work done for Navy Department

117.7 Work done by Navy (incl. sending communications through radio stations)

117.8 Protection of mines by Navy

118 War Department (General; Special file regarding War information)

118.2 Work done for War Department

118.21Survey requests assistance from War Department

118.3 Requests Survey to recommend employees for positions

118.31Survey requested to consider War Department employees for positions

118.32Survey offers topographers, etc. to War Dept. for use in connection with Mexican trouble; suggest reserve of corps of professional men, etc.

118.321 Recommendations for Professional Corps

118.323* Deferments; Selective Service Status

118.325 Survey Employees who have entered military service

118.326 Deaths of employees while in military service

118.33Registration of Survey employees for the draft

118.5 Use of information obtained from War Dept. by Survey; permission asked to take photographs in War Dept. reservations, etc., or do work on same for military reasons 
118.6 Information requested by or furnished War Department

118.61Re: correspondence with Board of Officers on River Floods; conferences, cooperation etc.

118.7 Use of transports for transportation of Survey employees

118.8 Information requested by Survey of War Department

118.9 Request by War Department that publications be withheld temporarily

119 Agriculture Department

119.2 Work done for Department or Bureaus

119.3 Work done for Forest Service (including verification of records)

119.4 Work done by Agriculture for Survey

119.41County agricultural agents to sell maps

119.5 Information requested of Agriculture or furnished by it; corrections, etc. suggested by Forest Service

119.6 Information requested by Agriculture

119.7 Survey employees to testify as witnesses for agriculture, or detailed to or from Agriculture

120 Temporary Employment

121 Authorizations and correspondence re: authorizations

126 Reports of temporary employment

126.1 Monthly reports

128 Re: wages paid in field parties of various branches, should be same grade of work

130 Administrative and Executive Reports

130.1 Miscellaneous periodical reports of branches, etc.

131 Monthly reports of Chiefs of Branches to Director (alphabetically by Branch)

131.1 Monthly reports of Executive Division

131.14Field Equipment

131.15Division of Field Equipment

132 Monthly report of Director to Secretary

133 Annual Report of Chiefs of Branches to Director

133.1 Annual reports of Executive Division

134 Annual Report of Director to Secretary

135 Annual Report of Secretary to President

135.1 Material furnished Secretary for his annual report

137 Other reports and material furnished Secretary

137.1 Resume of useful and important work of Survey

137.2 Plans for future work, including plan of operations of Survey

137.5 Special articles, reports, statements prepared for Secretary or Department (alphabetically by subject)

138 Reports and material furnished the President

139 Reports and material furnished Congress or Congressional Committees

$139.1 \quad$ House of Representatives

139.2 Distribution of Publications

139.3 Survey publications printed and distributed

139.4 Number of employees who travel

139.5 Reports on Congressional Hearings

$140 *$ Boards and Committees

141 Departmental Committees

141.001 Coordination Committee files and reports

141.01Committee to Revise Travel Regulations, transportation matters

141.02Committee on the Central Tabulating Service

141.03Board for Disposal of Useless Property

141.04Joint Committee on Combining Surveying Work

141.08Water Resources Committee 
141.10Statistical Planning Committee

141.12Program Committee

141.15Committee on Publications

141.16Special Oil Committee

141.17Committee on Legislation

141.18Defense Resources Committee

142 Survey Committees

142.01Personnel

142.02Budget Committees

142.031 Condemnation of Property

142.04Committee on Library

142.08Advisory Committee to assist Director on matters in connection with new building

142.10Committee on Geologic Names

142.13Committee in charge of labeling and classification of lantern slides and photographs

142.14Committee on Field Equipment

142.16Millionth Map Committee

142.18Physiographic Committee

142.20Committee on Marginal Legends

142.21Fire Trespass

142.23Topographic Mapping Policy Committee

142.24Advisory Committee to U.S. Geological Survey

142.25General Staff Committee

142.26Management Services Committee

142.27Publication Committee

142.28Denver Survey Committee

142.29Survey Safety Committee

142.3 Property Board of Review

142.30Alaska Survey Committee

142.31Alaska Field Staff

142.32Foreign Activities Committee

142.33Geologist Staffing Committee

143 Presidential Committees

143.1 President's Commission on Economy and Efficiency

143.01Committee on National Land Problems

143.10National Emergency Council

143.11National Defense Council

143.12Joint Research and Development Board

143.13National Minerals Advisory Council

143.14Water Resources Policy Committee

$143.2 \quad$ U.S. Geographic Board

143.21National Resources Committee

143.3 Board of Surveys and Maps

143.4 Oil Commission

143.5 Federal Oil Conservation Board

143.7 President's Commission for the Conservation of the Public Lands

143.8 The President's Employment Commission

$144.1 \quad$ Joint Committee on Printing

145 Survey requested to designate representatives to attend conferences and meetings on subjects relating to Survey work 
146 Interdepartmental Committees

146.01Interdepartmental Mineral Committee

146.02Interdepartmental Committee on Foreign Cooperation

146.03Interdepartmental Petroleum Committee

146.07Interdepartmental Committee on Aerial Surveying

146.09National Land Use Planning Committee

146.10Oil Pollution of Navigable Waters

146.11Sub-marginal Lands

146.12Committee on Alaska

150 Rules and Regulations

150.1* Director's Orders

150.11 Administrative Circulars

150.2Chief Clerk's orders (Office orders)

$151^{* *}$ Departmental Orders; draft of a Departmental Order on investigations of irregularities

152 Executive orders

160 Leave of absence (Correspondence re: General Regulations re: leave)

160.2 Accrued leave

160.3 Military leave and military camp leave

160.4 Compensation to injured employees

160.7 Miscellaneous leave statements for Department and others

161 Annual leave

161.1 Tardiness (including excessive time taken for lunch and leaving work early)

161.3 Credit for overtime work

162 Sick Leave; rules re: quarantine, etc.

163 Furlough and leave without pay; re: penalties therefore

164 Hours of labor, extension of, changes in, incl. field offices

165 Methods of charging, form of leave cards, time reports, and application, etc.

166 Special leave requested or granted employees to attend celebrations, reunions

167 Legal holidays, half holidays, State holidays

170 Mail

170.1 Opened by Survey by mistake; not for Survey, or Survey employees

171 Registered and Special delivery

172 Unregistered

173 Complaints, suggestions, etc. (by Post Office)

173.1 Complaints by Survey

173.2 Complaints within Survey, suggestions, instructions

174 Special Reports, statements, etc. re: handling mail

175 Use of "Frank", decision re:, etc.

180 Personnel (Survey's policy with respect to personnel)

180.02 Policy regarding recommendations

180.1 Employees doing outside work

180.2 Civil Service Commission regulations and procedures

180.3 Probational Appointments

180.4*Policy of Survey re: employees having interest in mineral lands, holding stock, making investigations for private parties, testifying in courts

180.5 Director's policy with respect to promotions

180.6 Re: employees holding positions with States, Territories or Municipalities

180.7 Re: payment of State or territorial taxes by members of Survey parties

180.8 Re: uniformity of pay

180.9 Re: photographs of employees

180.10Detailed employees and renewal of details 
180.11Changes of name

180.12District System

180.13Re: transfer to and from other Departments

180.14Increase in Compensation

180.15Nominal Salary Employees

180.16Oaths of Office

180.17Separations from service and reinstatements

180.18Reductions on force

180.19Date of Birth; Change in Legal Residence

180.20Separations of Temporary Employees

180.21Physical Examination

180.212 Fingerprints

180.22Apportionment

180.23Affidavits

181 Personnel matters to be handled by Executive Division; by Administrative Geologist

182 Accidents, disability or death of employees

182.1 Reports of accidents, disability or death; compensation (alphabetically by surname of individual)

184 Persons not in Survey who claim to be or to have been; also requests for information as to whether persons have ever been, etc.

184.1 Survey requests information re: person from outsiders

184.2 Addresses of employees and addresses of persons to notify in case of an emergency

184.3 Requests for addresses of, recommendations for former employees

184.4 Requests for information about salaries and duties

185 Income Tax Information requested by States

186 Statistical statements, tables, and lists regarding personnel (alphabetically by subject - some of the subject files were removed, wholly or in part, from the decimal system shown below)

186.01Afro-Americans in Survey

186.02Employees charged to the first six districts of Pennsylvania

186.03Showing State or Territory of employees of Survey working in D. C.

186.08Lists of Geologists

186.09List of employees whose wives or husbands are in government employ.

186.12Colored persons certified for positions

186.13Employees in Utah or Idaho appointed without examination

186.14Addresses of Survey employees residing in Baltimore

186.16Information re: salaries, work, titles, etc., for Rep. Buchanan, also for Rep. Campbell and Sen. Gore

186.17List of those in charge of field parties in Oregon

186.19Employees qualified to drive auto and motor trucks

186.21Statement showing amount returned to Treasury is certain per cent of salary of employees was withheld

186.22Employees transferred to or from Survey, July 1913 - October 1914

186.23List, classified by States, of field officials of survey; list of field offices and number of employees

186.25List of messengers and messenger boys in Survey, number under 21 years old

186.27List of employees in Alaska

186.28List of employees in Colorado on December 8, 1915

186.29Number of male and female employees working in D. C. and in Field

186.32Statements re: ages of employees

186.38Number of employees from Kentucky who are located in D. C.

186.40Number of Jewish employees in Survey 
186.41Number of employees receiving $\$ 1200$ and more from the southern United States

186.42List of employees from Georgia

186.44Employees from Louisiana

186.45Employees from Illinois

186.47Employees from Kansas

186.48Employees of Survey who are not citizens of the United States

186.54Stenographers earning less than $\$ 1200$ per year

186.61Evening classes for Government employees

186.62Employees from New Mexico

186.65World War I support activities in Pennsylvania

186.66Employees under 16 years of age

187 Efficiency Ratings

188 Retirement

188.1 Circulars and decisions re: retirement qualifications

188.2 Automatic, compulsory retirement

188.3 Retirement funds

188.4 Retirement circulars

188.5 Department wants Survey opinion regarding charges preferred by Special Agents against officials; should they be given chance to reply and have their reply investigated and made part of the record; salaries and deductions from salaries

188.6 Reemployment of annuitants

\section{FINANCE AND ACCOUNTS}

200 Finance and Accounts

200.1 Organization of Accounts Division

200.2 Organization of Disbursing Office

201 Payrolls and payroll procedures

201.01 Standard Government Civilian Allowance Regulations

201.02 Retirement Fund Deductions

201.1 Payroll changes

201.2 Assignment of Pay

201.4 Pay checks delivered by mail

201.5 Forged checks, lost checks, etc., stop payment, checks to be paid to others

201.51Brittenham Case

202 Authority to approve accounts and vouchers

203 Rendition of accounts

204 Accounts, methods of keeping, etc.

204.1 Keeping accounts, vouchers, allotments, appropriation accounts

205 Certification and examination of accounts

206 Disbursing officers, special disbursing clerks, special disbursing agents, etc.

206.2 Statements as to amount of credit, balances

207 U. S. depositories of public moneys, certification of deposits, etc.

208 Miscellaneous correspondence re: bills and accounts

210 Budget and finance letters, circulars, bulletins

$210.1 \quad$ Estimates and statements regarding accounts

210.2 Condition of Current Appropriations

210.4 Reporting Forms and Requirements (alphabetically by agency or board)

211 Appropriations

211.01 Inquiries regarding appropriations

211.1 Annual estimates and justifications

211.2 Deficiency bills 
212 Allotments

212.01 Survey allotment by Department for contingent fund, correspondence, etc.

212.1 Printing and binding

212.2 Assessments against allotments

212.3 Allocations of funds for printing

212.4 Approval of attendance of employees at professional meetings

212.52A printed copy of Mid-Century Alaska

213 Transfer from one fund to another (from Branches, Departments, etc.)

213.1 Transfers within Survey

213.2 Transfers of funds to other Branches, Bureaus, Departments, etc.

214 Deposits to credit of Survey

220 Authorizations

221 Numbered authorizations for expenditure

230 Leases, contracts and agreements (Except cooperative agreements)

231 Leases

232 Contracts and agreements

240 Bonds

243 Surety companies and attorneys authorized to do business with or appear before the Department

250 Transportation of government property and employees

250.1 Re: travel, authority for

250.2 Re: government paying expenses for attending meetings of associations, societies, etc.

250.3 Re: transportation requests

250.4 Shipment of household goods

251 Freight and Express

252 Passenger Traffic Officer

252.1 Street car tokens

256 Re: purchase of cars and maintenance of motor-cycles, automobiles and other passenger-carrying vehicles

256.01 Authorization for use of privately owned automobiles

257 Automobile accidents

258 Automobile Insurance

260 Sale of maps, documents, waste lumber, empty bottles, and misc. articles

270 Claims (alphabetically by surname)

280 Allowances to employees

281 Per diem in lieu of subsistence

283 Advances of funds

284 Housing of personnel

285 Allowance for quarters

286 Travel expenses associated with transfer of station

300 Equipment and Supplies

\section{EQUIPMENT AND SUPPLIES}

300.1 Purchase of supplies, including opinions, decision, etc., on subject (supplies for field services)

300.2 Central Stock Room

300.4 Care of equipment, supplies

300.6 Requests for information re: supplies and equipment used by survey re: new inventions, development, etc.; information as to where supplies can be purchased

301 General Supply Committee

301.1 Schedules, lists of award, etc. (changes in Supply Com. Circulars)

301.21Permission to purchase in open market 
301.22Substandard supplies

301.24Survey asked to test materials

301.3 Estimates of supplies needed requested

302 Supplies, machinery, instruments, etc. accepted for trial

303 Status of property, care of (including livestock)

303.1 Unserviceable or abandoned; disposition of

303.2 Exchanged

303.41Borrowed

303.42Loaned

303.5 Lost, stolen or strayed

303.6 Property returns and inventories

303.8 Transfer of instruments, property, etc. to Survey (Gifts or purchase)

303.81Transfer of surplus property

303.82Shipment of property

303.9 Surplus property

304 General correspondence regarding stationary and supplies

304.1 External (except Department)

304.2 With Department and Supply Division

304.3 Internal

304.4 Requisitions for supplies (Executive Division)

304.7 Typewriters

305 General Correspondence re: printing and binding

307 Circulars, catalogues, solicitations re: supplies or work, including material offered for sale

310 Bids and Specifications

311 Office Supplies (furniture, etc. incl. bicycles)

312 Stationary and map paper

313 Duplicating apparatus and material (incl. typewriters)

314 Machinery and parts

317 Printing, binding and other similar publication work or Engraving Division work; engraving supplies

320 Buildings and Grounds

$320.1 \quad$ Arrangement of space in new building

320.2 Re: site for new building

320.3 Consolidation of services, relocation of office staff

320.4 Re: moving to new building

$320.6 \quad$ Name plates

321 Quarters in public buildings

$321.1 \quad$ Requests for (alphabetically by State or Territory)

322 Maintenance and repairs

323 Requests for additional space

324 Exchange of space, re: moving material stored to betters quarters

324.1 Arrangements for making more space; personal belongings to be removed; correspondence re: change in assignment of rooms

325 Offers of buildings to be erected for Survey or old buildings. for rent of sale

326 Loan of quarters to other Departments, Office, Commissions

328 Survey Fire, Correspondence regarding it, damage done, estimates on etc.

$328.1 \quad$ Fire drills, fire prevention, fire alarms, etc. correspondence

331 Telegraph

$331.1 \quad$ Messages

331.4 Internal instructions re: delivery of telegrams, forms of receipt of

331.9 Radio-telegraphic service 
332 Telephone

332.1 Requests for repairs, changes, installations of phones, etc.

332.11Telephone expenses

332.2 Instruction re: telephone service

332.3 Re: charging of private calls

332.4 Correspondence re: telephone directory

332.5 Report of number of calls, etc.

345 Distribution of the Congressional Record

346 Distribution of U. S. Postal Guide

360 Building services

364 Elevator service

370 Laundry

400 Geology

\section{GEOLOGY}

401 Organization of Geologic Branch and monthly reports

402 Analysis of samples, etc. by Geologic Branch for Survey

410 Geologic Investigations

411 Requests for (Including requests that geologists make investigations) (alphabetically by State, Territory or foreign country)

412 Surveys and work for other countries

413 Suggestions, recommendations, etc. that scope of Survey's geologic work be widened

414 Re: bids of parties, firms, etc. on Geologic work for Survey

417 Suggestions, etc. re: geologic work by Director

420 Requests for Geologic Information

420.1 Requests for information made by or furnished to Survey

421 Correspondence re: bringing buyers and sellers of geologic products together

424 Requests for advice along geologic lines

425 Requests for information as to reliability of reports of parties, firms, etc. doing geologic work

426 Correspondence regarding geologic terms

427 Requests for opinions as to work done by State surveys; advice asked, etc.

428 War Minerals Relief Commission

429 Information from foreign countries

429.1 Data regarding mineral deposits in foreign countries

430 Specimens and fossils

431 Requests for specimens

432 Specimens submitted to Survey for its information; specimens loaned Survey

433 Specimens to be sent to National Museum

435 Collection offered to Survey for sale

438 Requests for authority to collect specimens, fossils, etc.

439 Re: restrictions placed by other governments on collections of fossils, specimens, etc.

440 Miscellaneous replies to inquiries

450 General correspondence and instructions with respect to work in the various divisions in the Branch

451 Division of Chemical and Physical Research

452 Mineral Resources

453 Section of Mineralogy

454 Areal Geology

455 Section of Geology of Iron and Steel Alloy Metals

456 Work in Alaska (alphabetically by agency, project, subject or surname of individual)

457 Section of Coastal Plain Investigation 
458 West Indian Geologic Surveys

459 Section of Foreign Mineral Reserves

460 Re: field parties and Officers

461 Assignments, disagreements, etc. in camps; camp administration

462 Miscellaneous

465 Field and Regional Offices

$470 *$ Cooperation (Lists of State Geologists)

470.1 Corrections to lists

471 With States (alphabetically)

471.1 Correspondence

472* With Departments, Bureaus and Independent offices (alphabetically)

473 With Branches of Survey

474 With other countries and governments (alphabetically)

475 With private individuals, firms, corporations, etc. (alphabetically)

476 With museums, etc.

480 Volcano investigations

500 Topography

500 TOPOGRAPHY

501 Organization of Branch; instructions re:, authority of conferences

502 "Instructions to Topographers" to be published by branch

510 Requests for topographic surveys and work (a general file followed by files arranged alphabetically by

State, Territory, or country)

510.1 Survey furnishes information

510.2 Survey requests information

511 Topographic Surveys for other countries

512 Requests for information re: authority under which surveys are made

514 Requests for topographic information as to Territory covered, expedition of work

515 Re: areal-topography and other information furnished Survey

516 Aerial photography, requests for information (alphabetically by person, organization, State government, or Federal agency)

520 Boundaries

530 Elevations and Bench Marks

531 Replies to inquires

532 Moved or destroyed

540 Progress of topographic mapping in the United States

541 Use of aerial photography to make maps

542 Cooperative surveys

545 Status of topographic mapping

546 Proposed modification of the Temple Act

550 National Parks

551 Re: establishment of

552 Re: surveying and engineering supervision of construction within National Parks

559 Removal of preliminary survey markings

570 Cooperation

571* With States (alphabetically by State, Territory or country)

571.1 Projects in Illinois and Pennsylvania

572* With Departments, Bureau and Independent offices (alphabetically)

573 With Branches of Survey

574 With other countries and governments

575 With private individuals. firms, corporations, etc. 
580 Survey replies to inquiries regarding maps of particular areas

590 Geographic names, Boards, and other miscellaneous correspondence re: topographic matters

591 Information re: Geographic names

595 Organization of State Geographic Boards and Societies

596 Quarters for Survey personnel outside Washington, D. C.

597 Damage to property by Survey personnel

598 Alleged trespass by Survey personnel on private property

600 WATER RESOURCES

600 Water Resources

601 Organization of branch

602 Water Analysis, Statement re: to be referred to Chief Hydrographer, etc.

603 Claims of undue influence being made in making Water Resources reports, preference being shown

610 Requests for information and general correspondence re: Surface Water

610.1 Information requested by Survey or furnished to it

610.2 Information requested by Survey or furnished to it

610.3 Samples of water, etc. furnished Survey for its information

611 Stream gaging (alphabetically by Federal, State and local agencies, organizations or individuals)

611.1 Establishment, abolishment or destruction of or continuation of gaging stations

611.2 Comments requested on reports re: stream gaging

611.3 Information requested re: stream gages, method of installing, etc.

612 Power site withdrawals

613 Utilization and conservation of water power

613.1 Commissions and organizations engaged in water utilization and conservation

613.2 Re: water utilization and conservation in foreign countries

613.3 Inquiries about financial assistance from the government in the development of water power

613.4 Replies to inquiries regarding water power development

613.5 Replies to inquiries regarding the production of electricity and use of coal to produce electricity

614 Storage, storage possibilities, reservoirs, etc.

615 Irrigation and irrigated lands

616 Drainage

617 Floods, flood levees, overflow lands and ditches

619 Correspondence re: bids for well drilling

620 Ground water levels (alphabetically by name of agency, organization or individual)

620 Ground water levels - reports furnished to the Office of Production Management and the War Production Board

620** Correspondence with Senator Harry Byrd

621 Wells, artisan (sites etc.) (alphabetically by name of agencies, municipalities, organizations or individuals)

622 Mineral Springs

623 Drouth

630 Water Power Surveys including Superpower Survey

630.2 Superpower Survey staff

631 Superpower Survey, general files and minutes

632 Superpower Survey Advisory Board, minutes

633 Superpower Survey, requests for information

634 Superpower Survey, request for information to prepare report

634.1 Cooperation

634.3 Requests for information from the Interstate Commerce Commission

635 Publication of articles concerning the Superpower Survey

637 Revisions of the Superpower Survey report 
640 Requests for examination and investigation (alphabetically by State, municipality, Territory, project, organization or individual)

645 Progress of work, plans

650 Water Resources information furnished to or requested by Survey

661 General correspondence regarding purchase of land under provisions of the Weeks Act

662 Reports made for the National Forest Reservation Commission (arranged by assigned number)

670** Cooperation

671* With States for water resources investigations (alphabetically by State or Territory)

671.1 Purchase orders (alphabetically by State or Territory)

672 With Departments, Bureaus, and Independent agencies (arranged alphabetically)

673 With individuals, corporations, etc., general correspondence re: Survey assisting private parties, policy of Survey (arranged alphabetically)

674 With other countries and governments

675 Miscellaneous correspondence

680 Geological Survey field offices (Water Resources Branch)

681 Confidentiality of information gathered by Survey on private property

690 International Joint Commission

700 Land Classification

\section{LAND CLASSIFICATION}

701 Organization of Branch, personnel

702 Land Board conferences

710 Land Classification, status of work

720 Withdrawals

721 Power Sites

722 Regarding mineral and coal lands, withdrawals and leasing of; cooperation with the General Land Office

723 Policy regarding mineral leases

730 Stock raising homesteads

731 Announcements of

740 Grazing district under the Taylor Grazing Act

741 Wells located within grazing districts; assignment of personnel

750 National Monuments

751 Areas set aside as

760 General requests for land information

761 General correspondence regarding the Mineral Leasing Act

771 Cooperation with States, agreements

772 Cooperation with Departments, Bureaus, and Independent agencies (arranged alphabetically)

773 Cooperation with companies

780 Value of work, establishment of district offices

790 Regarding agreements for cooperative or unit development

791 Royalty rates, payments

800 Publication Branch

800 PUBLICATION BRANCH

800.1 Section of Illustrations

800.2 Section of Distribution

800.3 Engraving Division

808 Re: use of photo Lab by outsiders

809 Re: purchase of "Graham Company's" plant for Engraving Division

810 Special maps and printed reports for Department or others

810 Ohio Shale, notes with tables and annotated maps (oversized, in box 534) 
811 Special maps, printed reports, views, etc. made for Department; special additions, corrections, changes, etc. for Department

812 Special maps, atlas sheets, documents, reports, guide books etc. (including correspondence re: "Contributions to General Geology")

812.1 Requests that maps be published

812.5 Mineral Resource Map of Southern States

820 Instructions, suggestions, etc., regarding publications

821 General instructions, suggestions, comments, etc. by Director or Private Secretary

822 Criticisms, commendations, suggestions, complaints, etc. from others than Director or his Private Secretary

822.1 From other agencies, outside organizations, and individuals (arranged alphabetically)

823 Forms of footnotes, bibliographic entries

824 Special comments, description, criticisms of maps, introductory chapters

824.1 Introductory chapters, etc., requested by others for publication

825 Re: forms of text expression, etc., use of less technical rather than more technical terminology

826 Refusal of firms, corporations, etc., to give information; intimation that favoritism is shown in using information from corporations, etc.

827 Miscellaneous

831 Distribution of publications

831.01 Distribution Office

831.1 Re: "promises" of publications, plans and forms used for distribution, etc.

831.2 Furnishing publications to students, educational institutions, etc.

831.3 Transfer of distribution of documents to Government Printing Office

831.5 Destruction by Government Printing Office of inactive publications

831.7 Transfer of publications and maps from the Capitol (House or Senate) to Survey

831.9 Maps, etc. to be given gratis in certain instances

832 Regarding reprints or publications out of stock

832.1 Requests for reprinting of publications (external)

832.2 Corrections or revisions to be made for reprints of publications

832.4 Re: stock on hand, reduction of, accessions, etc.

833 Publications withdrawn from publication

833.1 Survey requests that publications be destroyed on account of being incorrect

834 Price schedules

834.1 Changes in prices of sale publications (including reduction in price because of Survey fire)

834.2 Sale editions of publications

835.1 Director's reserve list

837 Lists of publications, correspondence

838 Quota of Congressmen; exchange of maps on quota, etc.

839 Requests for information as to probable dates of issuance; delays in issuance, expedition of issuance 839.1 Survey requests information re: when publications can be expected, etc.

841 Editing of publications, maps, and manuscripts; general correspondence, Editor's Docket

841.1 Editing of publications, corrections, etc. to be made

841.2 Survey asked to pass on quality of manuscripts for other Bureaus, Departments, etc.

841.21Other bureaus requested to criticize, review, etc. manuscripts

841.3 Edition of manuscripts; care of manuscripts, correspondence re: manuscripts, loss of manuscripts; submission of manuscripts; also correspondence with authors

842 Handling and review of manuscripts; requests by Survey employees to seek outside publishers 842.2 Requests made by Branches or individuals to publish papers

842.3 Requests made by Survey for permission to use unpublished information from other Bureaus, Departments, or outside parties 
842.4 Requests made by other Bureaus, Departments, States, and publishers for permission to publish manuscripts; approval of papers

842.7 Firms, etc. request permission to use Survey maps for advertising purposes

842.8 Data submitted to Survey for publication

843 Requests for Engraving, Printing, Lithographing, etc.

843.2 From outside persons, firms, cities, States, etc.

843.3 Survey policy of furnishing transfers to outside parties, States, etc., requests for

843.4 Re: work Survey does for Government Printing Office (bids by Survey)

843.5 Cost of map work

844 Estimates on cost of publications

845 Schedule of editing illustrations and Engraving dockets

850 Survey requested to criticize, correct, edit, etc. articles re: its work

860 Photographic Laboratory and Illustrations

861 Photographs, lantern slides, moving pictures and negatives

863 Cuts and illustrations, including correspondence re: wiping off stones

863.1 Necessity for illustrations of publications

863.2 Approval or rejection of illustrations

864 Half-tones and zinc etchings

869 Re: space for storage of prints and photographs, negatives, cuts, etc.; destruction of useless ones; retention of those which may be desired for further use

870 Cooperation

871 With States

872 With other agencies

873 With Branches of Survey

874 With private firms, individuals, corporations, etc.

890 Miscellaneous publication correspondence

891 Copyright laws re: government publications

892 Protests against publications in present form as infringement on private enterprise; Survey work competing against outside firms, etc.

893 Regarding land outside U. S. boundaries shown on maps

894 Requests for information as to methods of printing, engraving and filing maps and folios

895 Correspondence re: International topographic maps

897 Marshall Plan - regarding reservoir sites in California 


\section{Appendix 4}

Office of the Director - Central Classified Files, 1953-74 (entry 52)

\section{$\underline{1 \text { st Subseries (1953-68) }}$}

The contents of this series is listed in two subseries, 1953-68 and 1968-74

Terms in italic are added to provide clarity, they are not file titles

Oversized files are filed at the end of each subseries

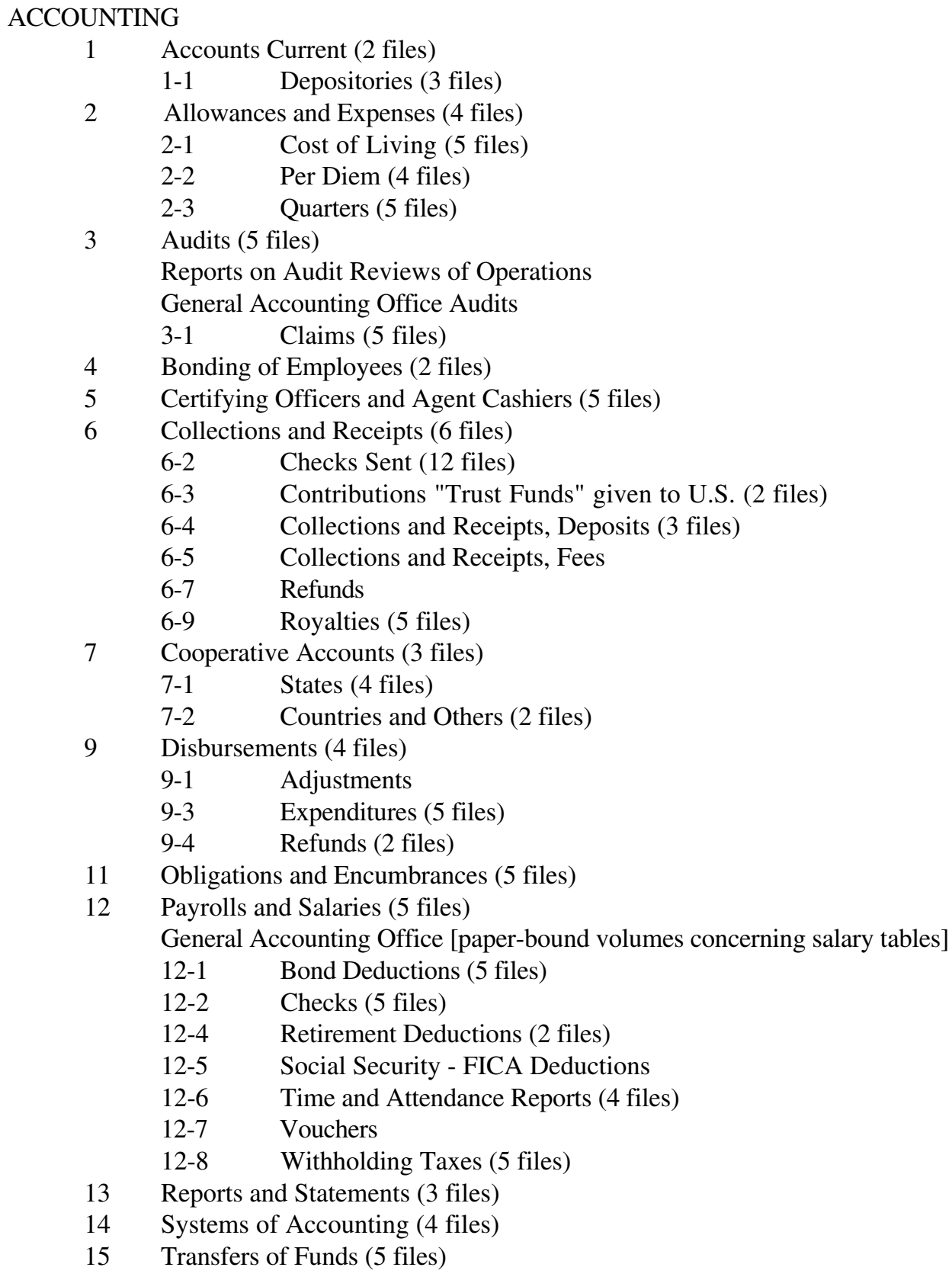


16 Vouchers and Invoices (4 files)

17 Working Funds (5 files)

18 State and Local Taxes (3 files)

Tabular Counts of Employees by Series, Branch and Grade as of June 30, 1954

Monthly Financial Reports

Financial Charts

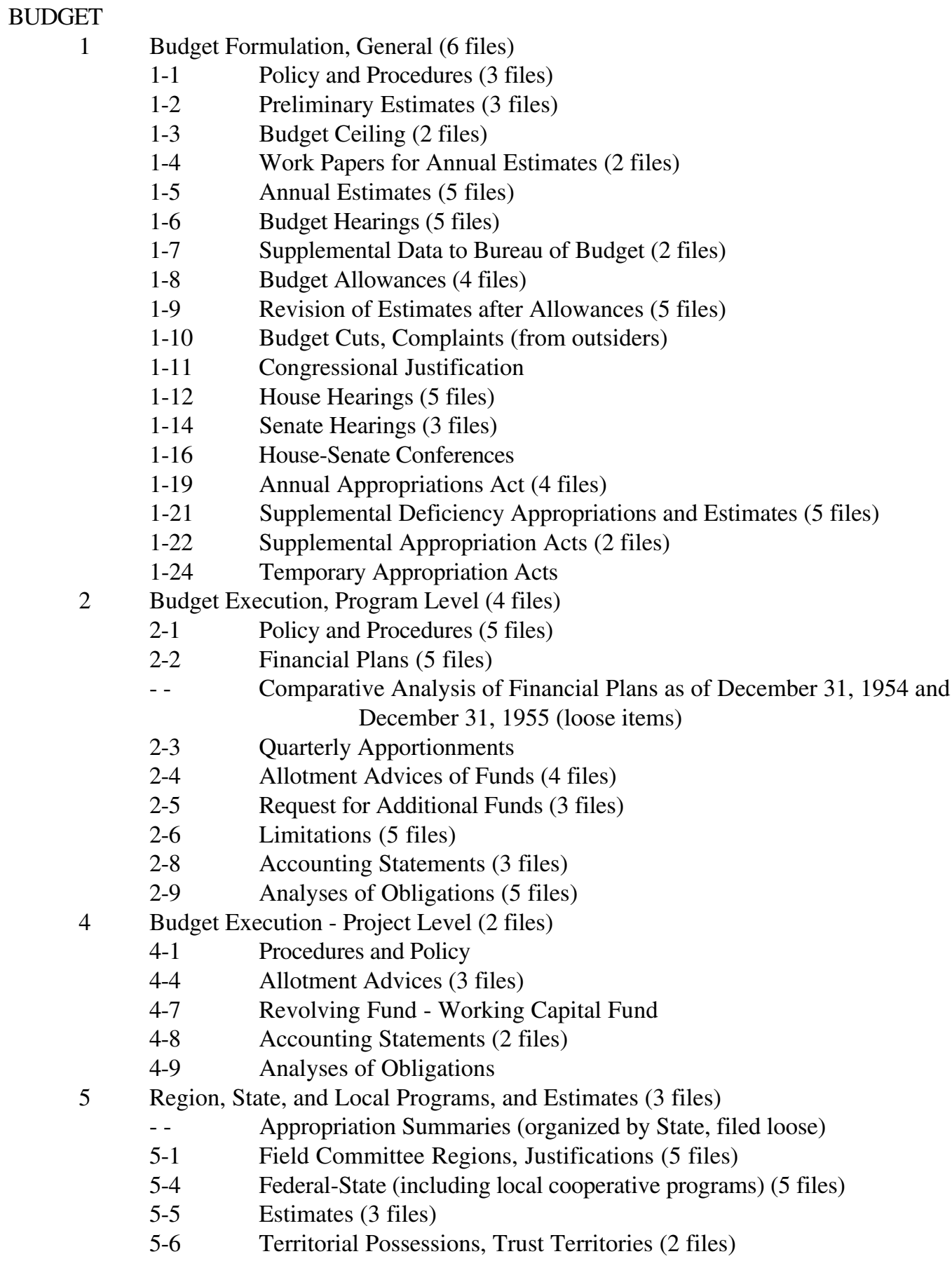


Interagency Programs and Estimates (4 files)

6-1 Miscellaneous Agencies (5 files)

6-2 Army Map Service

6-3 State Department

6-4 General Services Administration

6-5 Interior Department, Bureau and Offices (4 files)

6-6 Army (3 files)

6-7 Air Force (2 files)

6-8 Navy (3 files)

6-9 Foreign Activities (State-MSA, ICA) (4 files)

6-10 Atomic Energy Commission (3 files)

6-15 Defense Minerals Exploration Administration (2 files)

6-25 Tennessee Valley Authority

\section{BUILDING AND GROUNDS}

- $\quad$ General

$1 \quad$ Acquisition (4 files)

1-1 Deeds, Titles, Mortgages

1-2 Leases and Leasing (5 files)

2 Damage and Protection (3 files)

2-1 Fire - Drills (5 files)

2-2 Guarding - Keys (5 files)

2-3 Passes (5 files)

2-3.1 Library of Congress

$9 \quad$ Space

9-1 Washington (5 files)

9-1 New Building

9-2 Field (5 files)

9-2 (alphabetically by name of State, Territory or possession)

9-3 Parking (5 files)

10 Utilities and Services (5 files)

10-1 Heating, Lighting, Power (4 files)

10-2 Refrigeration and Air Conditioning (4 files)

COAL

$1 \quad$ General (3 files)

5 Classification

6 Coking Coal

6-1 Coke Fields

7 Composition

7-1 Analysis

8 Drill Hole Records, Logs

$9 \quad$ Exploration and Development (4 files)

9-2 Contractors (2 files)

10 Fields

10-1 Alaska (Mr. Reed)

10-1 Domestic (2 files)

10-1 Deep River Coal Field, North Carolina (2 files)

10-1 General

10-2 Foreign 
11-2 Withdrawals and Withdrawn Land

\section{COMMITTEES}

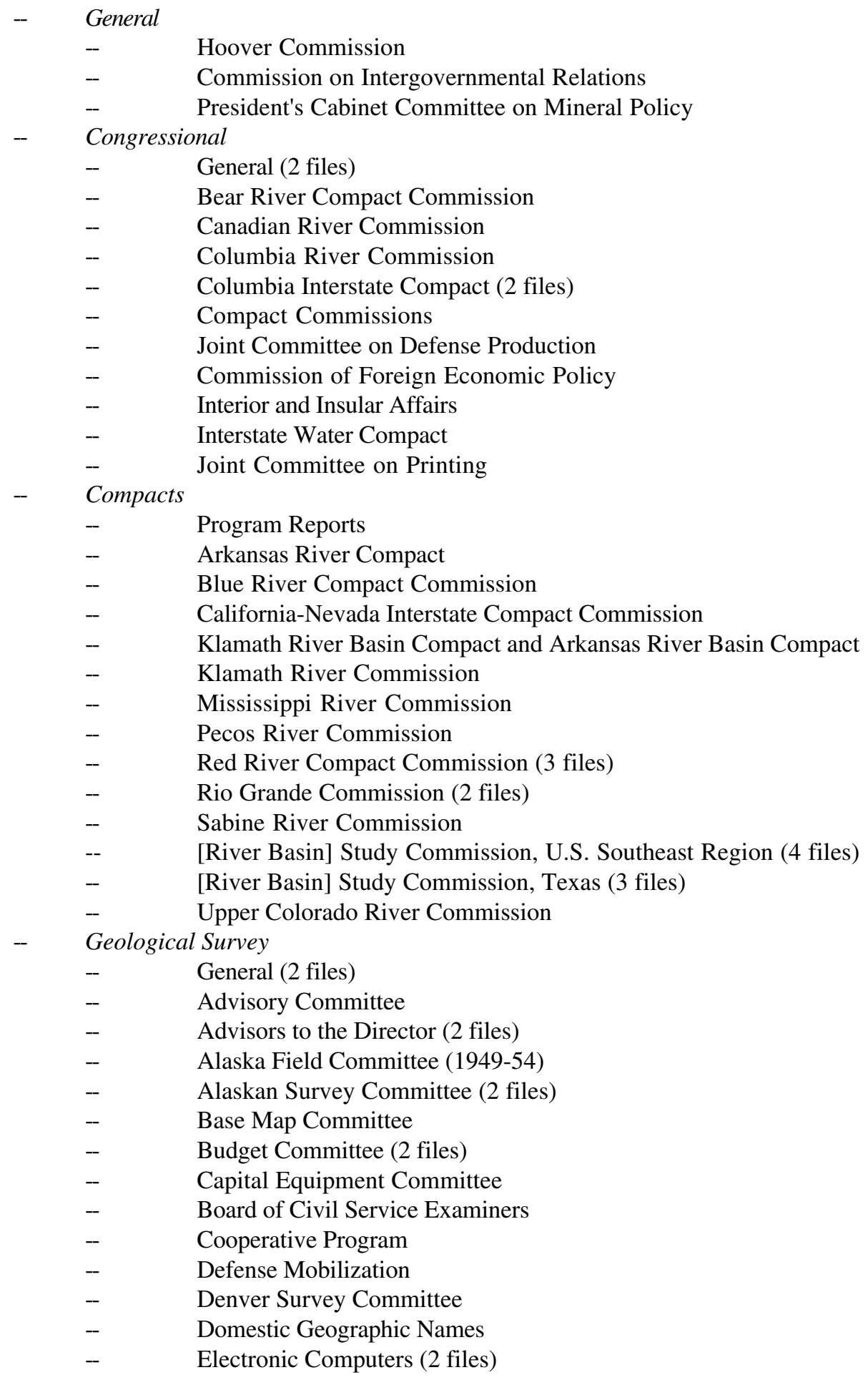




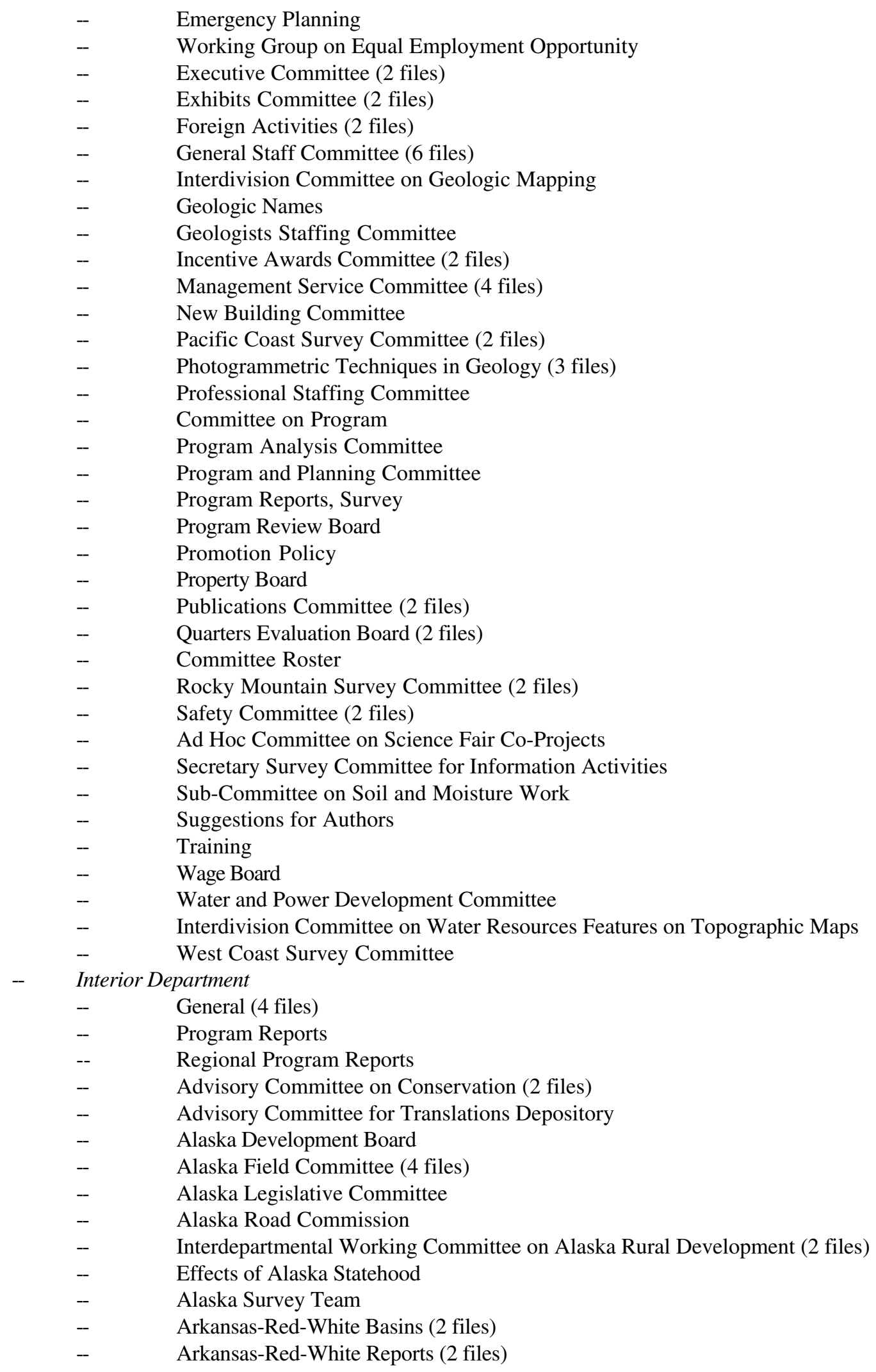




\begin{tabular}{|c|c|}
\hline- & Automatic Data Processing Committee \\
\hline- & Bench Marks, Survey Markers, Monuments \\
\hline- & Colorado River-Great Basin \\
\hline- & Columbia River Basin Committee (2 files) \\
\hline- & Congressional Liaison Council (2 files) \\
\hline- & Coordination of Reports \\
\hline- & Deferment \\
\hline- & Energy Staff \\
\hline- & Field Committee Chairmen (3 files) \\
\hline- & Interior Field Committees ( 2 files) \\
\hline- & Advisory Committee on Fish and Wildlife (3 files) \\
\hline- & Committee Chairmen, General \\
\hline- & Board on Geographic Names \\
\hline- & Intern Advisory Committee \\
\hline- & Juneau Administrative Committee \\
\hline- & Mississippi-Great Lakes Field Committee \\
\hline- & Missouri River Basin Committee (2 files) \\
\hline- & Missouri River Basin Field Committee (6 files) \\
\hline- & Missouri River Basin Field Committee, Minutes (2 files) \\
\hline- & Missouri River Basin Committee, Quarterly Reports \\
\hline- & Missouri River Basin Field Committee, Quarterly Reports (3 files) \\
\hline- & Missouri River Basin Field Committee, Annual Reports (3 files) \\
\hline- & Missouri River Basin Field Committee Regional Program Reports ( 2 files) \\
\hline- & Missouri River Basin Field Committee, Departmental Information \\
\hline- & North Central Field Committee \\
\hline- & Northeast Field Committee (7 files) \\
\hline- & Northeast Field Committee, Minutes \\
\hline- & Interdepartmental Committee on Outdoor Recreation (3 files) \\
\hline- & Pacific Northwest Field Committee (5 files) \\
\hline- & Pacific Northwest Field Committee, Minutes \\
\hline- & Pacific Southwest Field Committee (6 files) \\
\hline- & Pacific Southwest Field Committee, Minutes (2 files) \\
\hline- & Pacific Southwest Field Committee, Semi-annual reports (3 files) \\
\hline- & Radio Advisory Committee \\
\hline- & Research and Development (2 files) \\
\hline-- & Safety Committee (2 files) \\
\hline- & Saline Water Conversion \\
\hline- & Soil and Moisture Committee \\
\hline- & Southeast Field Committee \\
\hline- & Southeast Field Committee Staff (3 files) \\
\hline- & Southwest Field Committee (7 files) \\
\hline- & Secretary's Survey Committee on the Geological Survey \\
\hline- & Technical Review Staff \\
\hline- & Departmental Travel Committee \\
\hline- & President's Advisory Committee on Water Resources Policy \\
\hline- & Water Resources Research \\
\hline- & President's Committee on Youth Fitness \\
\hline- & President's Council on Youth Fitness, Departmental Advisory Board (2 files) \\
\hline
\end{tabular}




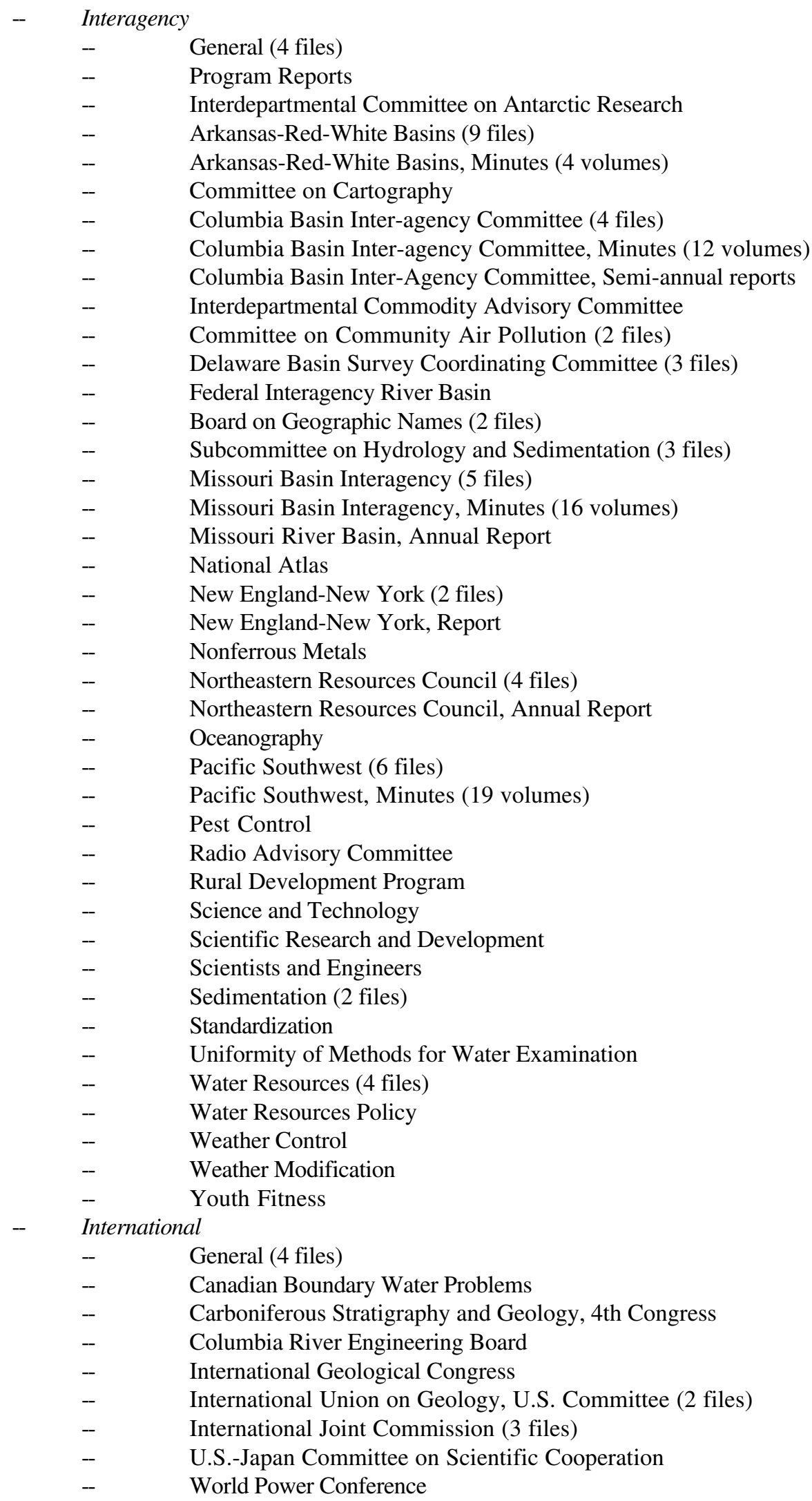




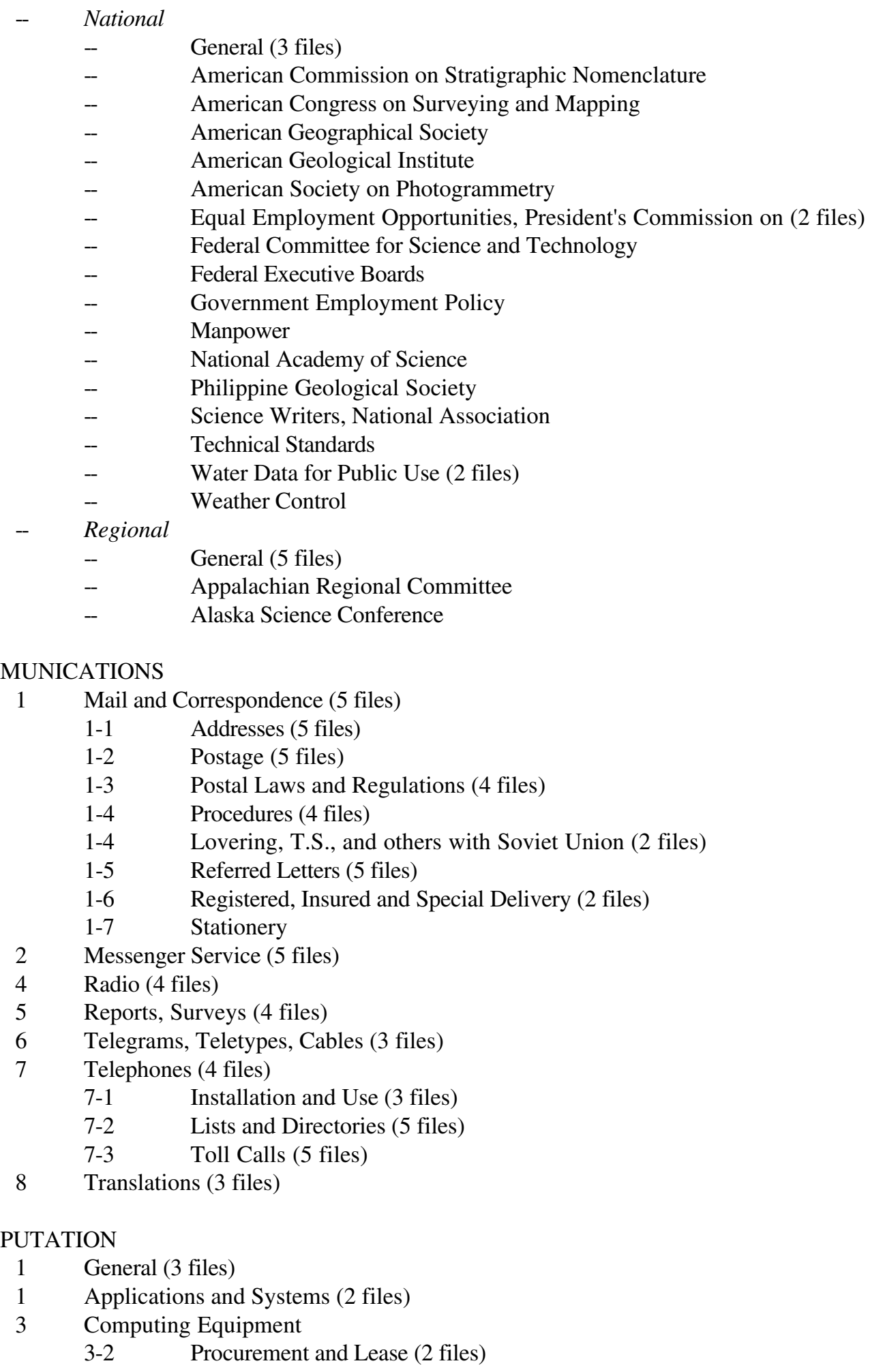




\section{CONTRACTS}

- $\quad$ General (5 files)

-- $\quad$ General, A-M, N-Z (6 files)

- $\quad$ Compliance (2 files)

- $\quad$ United Electrodynamics, Inc

- $\quad$ Woods Hole Oceanographic Institute [Institution]

\section{COOPERATION}

1 Consultants and Laboratories (2 files)

2 Educational Institutions, General

2 Educational Institutions, A-M and N-Z (4 files)

2 Educational Institutions, alphabetically by name of institution (119 files)

3 General:

Federal Agencies (3 files)

Advanced Research Projects Agency (3 files)

Agency for International Development

Agency for International Development, A-M and N-Z (2 files)

Agency for International Development (alphabetically by name of country) (24 files)

Agriculture Department (4 files)

Air Force (7 files)

Alaska Railroad (3 files)

Alaska Road Commission

Area Redevelopment Administration (2 files)

Army, Department of (6 files)

Army, U.S.

Army Map Service (3 files)

Army, Mississippi River Commission

Atomic Energy Commission (7 files)

Bonneville Power Administration (3 files)

Bureau of the Budget (3 files)

Central Intelligence Agency

Census, Bureau of (3 files)

Civil Aeronautics Administration

Civil Service Commission (3 files)

Coal Research, Office of

Coast and Geodetic Survey (6 files)

Coast Guard (2 files)

Commerce, Department of (3 files)

Defense Atomic Support Agency

Defense, Department of (3 files)

Defense Intelligence Agency

Defense Minerals Procurement Agency

Defense Minerals Exploration Administration

Defense Mobilization, Office of (2 files)

Federal Aviation Agency (2 files)

Federal Civil Defense Administration

Federal Housing Administration (3 files)

Federal Power Commissions (3 files)

Fish and Wildlife Service (3 files)

Foreign Operations (2 files)

Forest Service (4 files) 
General Accounting Office (3 files)

General Services Administration (3 files)

Government Printing Office (3 files)

Health, Education and Welfare, Department of (3 files)

Housing and Home Finance Agency

Indian Affairs (4 files)

International Cooperation Administration, (3 files)

International Cooperation Administration, A-M, N-Z (2 files)

International Cooperation Administration (alphabetically by name of country) (53 files)

International Joint Commission

Justice, Department of (3 files)

Labor, Department of (3 files)

Land Management, Bureau of (7 files)

Library of Congress (3 files)

Minerals Exploration, Office of (3 files)

Mineral Mobilization (3 files)

Minerals and Solid Fuels

Mines, Bureau of (7 files)

Mutual Security Agency

National Academy of Science (3 files)

National Advisory Committee for Aeronautics

National Aeronautics and Space Administration (4 files)

National Capital Planning Commission

National Cultural Center (2 files)

National Museum, Smithsonian Institution (3 files)

National Oceanographic Data Center

National Park Service (9 files)

National Research Council (3 files)

National Science Foundation (7 files)

Navy, Department of (7 files)

Oil and as, Office of (3 files)

Outdoor Recreation, Bureau of ( 3 files)

Peace Corps (2 files)

Petroleum Administration for Defense

Post Office Department

Public Health Service (3 files)

Public Housing Administration

Public Roads, Bureau of (3 files)

Reclamation, Bureau of (7 files)

Reconstruction Finance Corporation

Saline Water, Office of (2 files)

Secretary's Office

Securities and Exchange Commission

Small Business Administration (3 files)

Smithsonian Institution

Snow, Ice and Permafrost Research Establishment

Soil Conservation Service (4 files)

Standards, Bureau of (3 files)

State, Department of (6 files)

Supreme Court of the United States

Tariff Commission (3 files) 
Tennessee Valley Authority (3 files)

Territories, Office of (3 files)

Treasury Department (3 files)

Trust Territories of the Pacific (2 files)

Veterans Administration

Water and Power Development

Weather Bureau (3 files)

White House

Yards and Docks, Bureau of

3-1 Intrabureau (3 files)

$4 \quad$ Foreign and International:

General (3 files)

Foreign and International (alphabetically by country, geographic area, organization or project)

(129 files)

4-1 Individuals

$5 \quad$ Scientific and Professional Organizations:

General (2 files)

General, A-M, N-Z (4 files)

Amerada Petroleum Corporation

American Association of Petroleum Geologists (2 files)

American Geographical Society

American Geological Institute

American Geophysical Union (2 files)

American Legion Auxiliary (2 files)

American Metal Climax, Inc.

American Municipal Association

American Petroleum Institute

American Potash and Chemical Corporation

American Society of Civil Engineers

American Society of Photogrammetry

American Society of Planning Officials

American Zinc Company - Tennessee

American Zinc, Lead and Smelting Company

Anaconda Company (3 files)

Anglo American Corporation

Aqua-Ran Water Supplies, Inc.

Arizona Interstate Stream Commission

Atlantic Seaboard Corporation

Attschul, Gilbert

Battelle Memorial Institute (2 files)

Bear Creek Mining Company (3 files)

Big Piney Oil and Gas Company

Binnie and Partners

Boy Scouts of America (3 files)

British Petroleum

Brunswick Mining and Smelting Corporation

Buckeye Irrigation Company

Burgess Publishing Company

Burnt Hill Tungsten and Metallurgical Ltd.

Columet and Hecla, Inc.

Carter Oil Company 
Cassair Asbestos Corporation

Cherry Valley Improvement Association

Cities Service Company

Colorado Fuel and Iron Corporation

Colorado River Board of California

Continental Oil Company

Conwest Exploration Company

Cummings Prospecting Syndicate

Downing, Warwick M.

Dubois, C. C. (Belgium)

East Texas Geological Society

Ely, McCarthy and Duncan

Ewing, McDonald, Inc., J. A.

Fairchild Aerial Surveys

Fenno, Richard F.

Florida Flood Control District (Central and Southern)

Ford Motor Company

Frese, Walter F.

Geological Society of America

Geophysical Service Inc.

Glare Research Institute

Goodnews Bay Mining Company

Graton, L. C.

Greater Washington Educational Television Association, Inc.

Gulf Research and Development Company

Gulf Oil Corporation

Hanna Coal and Oil Corporation

Harza Engineering Company

Hawaiian Sugar Planters' Association

Heath Steel Mines, Ltd.

Heylmun, E. B.

Husky Oil Company

Inter-American Geodetic Survey

International Geological Abstracting Service

International Petroleum Company

Johnson, Roy M.

Kennecott Copper Corporation (2 files)

Lane-Well Company

Lavino, E. J.

Magnolia Petroleum Company

Metro Asbestos Processors, Ltd.

Missouri-Kansas-Texas Lines

Moly-Four Corporation

Montana Cooperative Wildlife Research

Montgary Exploration Ltd.

Mountain Fuel Supply Company

National Broadcasting Company

National Geographic Magazine

New Jersey Zinc Company (2 files)

Oliver Iron Mining

Outdoor Recreation Resources Review Commission 
Pacific Science Congress

Page Milk Company

Palo Alto Mining Corporation

Palomar Oil and Refining Corporation

Pan American Petroleum Corporation

Parker, Glenn

Pure Oil Company

Quebec Lithium Corporation

Recordak Corporation

Reed Research, Inc.

Resources for the Future

Reynolds Mining Corporation

Richfield Oil Corporation (2 files)

Rockefeller Foundation

Salt River Valley Water Users Association (2 files)

Schlumberger Well Surveying Corporation

Science Service (co-projects)

Shuiling, H. J.

Scripps Institution of Oceanography

Seismograph Service Corporation

Sheffield Steel Corporation

Shell Oil Company (2 files)

Southern Railway System

Sperry-Sun Well Surveying Company

Standard Oil Company

Standard Oil Company of California

Stanford Research Institute

Steffner Production, Wayne

Sullivan Consolidated Mines, Inc.

Technical Studies, Inc.

Texas, The Railroad Commission of

Tidelands Exploration Company

Tipton and Kalmbach, Inc

United Geophysical Corporation

United States Steel Corporation (2 files)

Utah Construction and Mining Company

Utah Tourist and Publicity Council

Utex Exploration Company

Vare Industries

Walker Engineering Commission

Washington Board of Trade

Water Resources Development Corporation

Woods Hole Oceanographic Institute

Wyoming Historical and Geological Society

$7 \quad$ State, and Local Agencies, and Governments:

General (4 files)

Files (arranged alphabetically by State, Territory or possession) (229 files)

\section{EDUCATION}

-- General

$1 \quad$ Fellowships (5 files) 


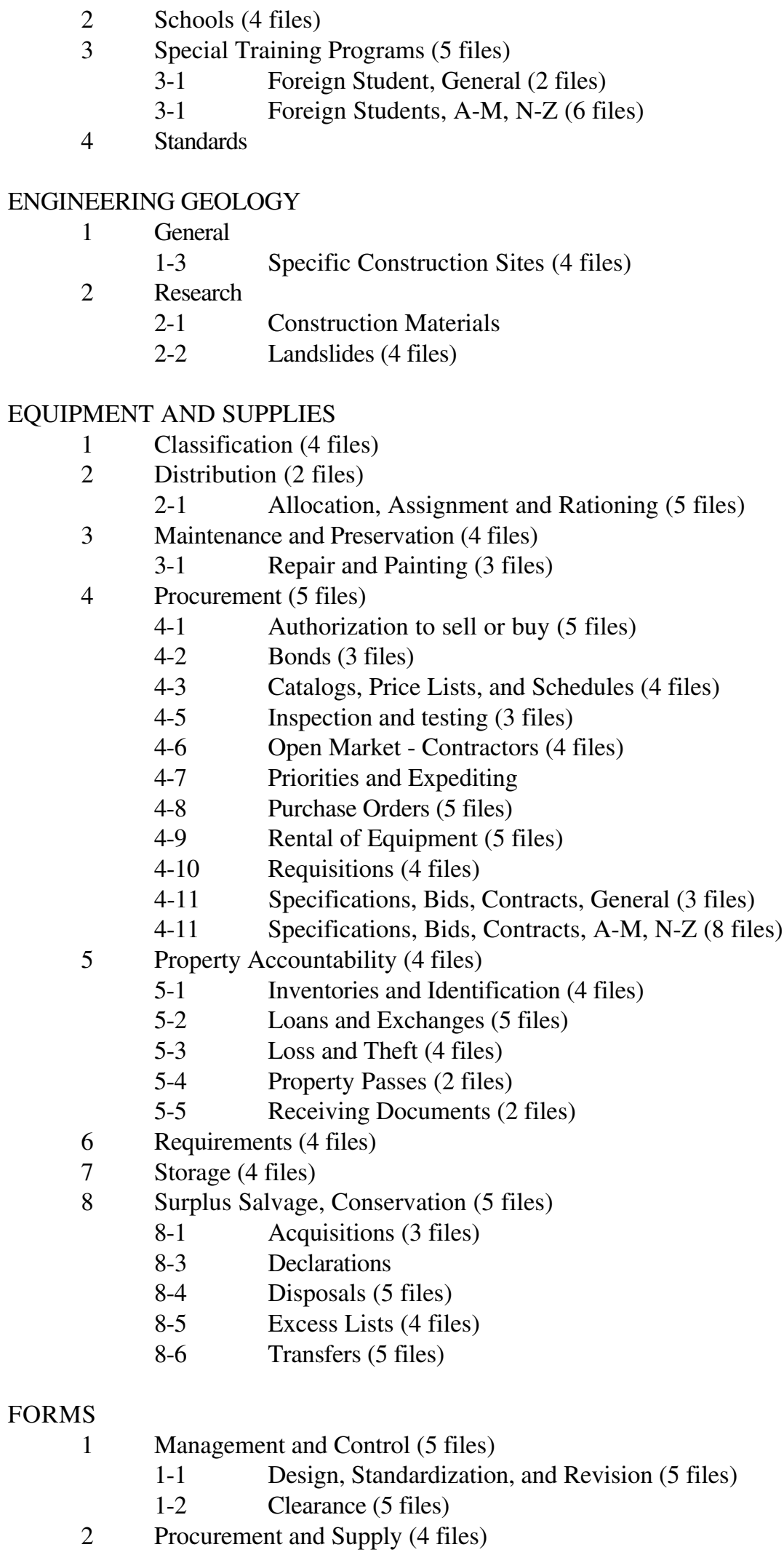

FORMS

$1 \quad$ Management and Control (5 files)

1-1 Design, Standardization, and Revision (5 files)

1-2 Clearance (5 files)

2 Procurement and Supply (4 files) 
2-1 Requests for copies or Supplies (4 files)

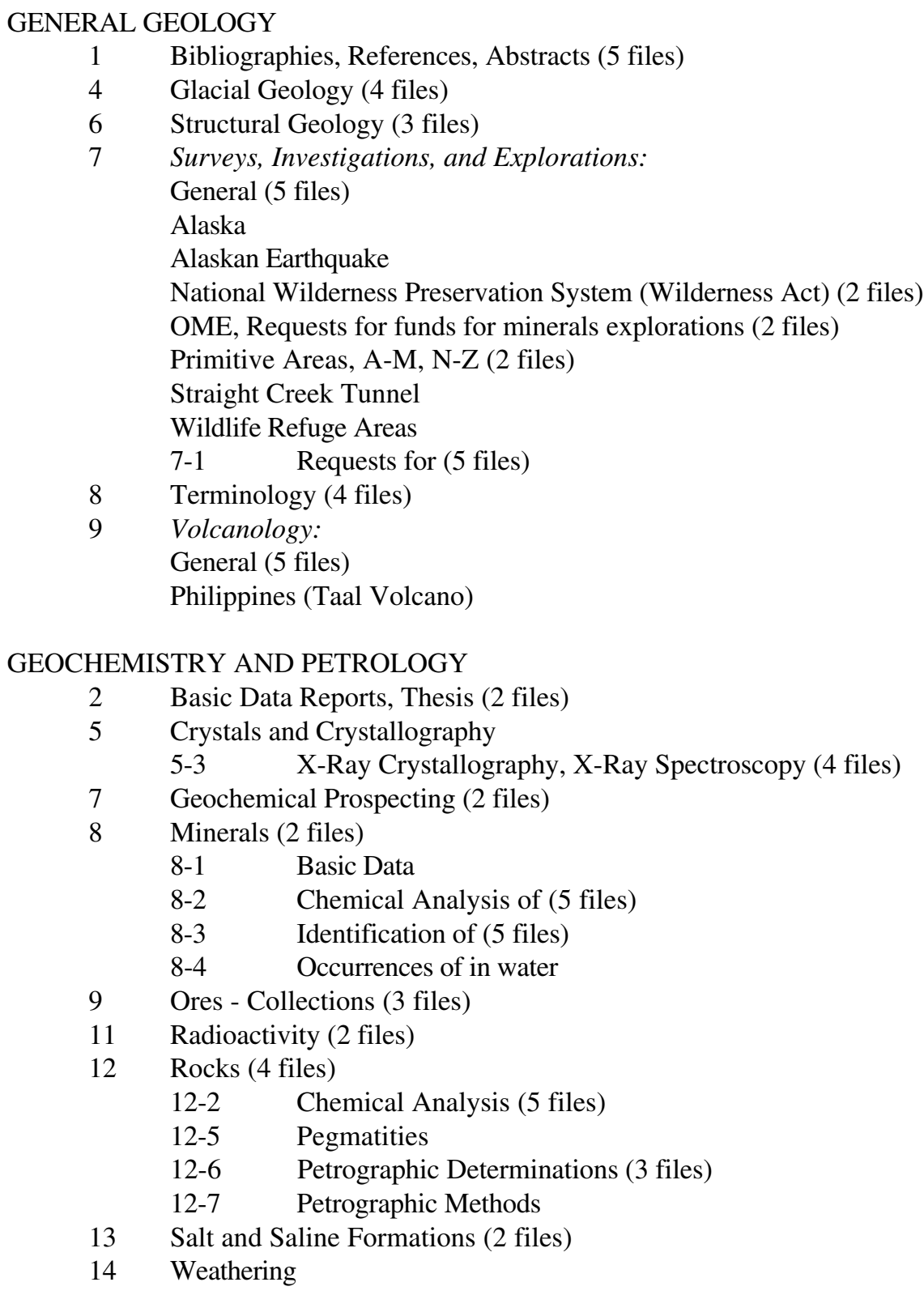

\section{GEOPHYSICS}

1 Gravity (4 files)

1-3 Gravity Exploration (4 files)

2 Magnetism (2 files)

2-2 Magnetic Instruments

2-3 Magnetic Exploration (4 files)

3 Seismology (3 files)

3-1 Earthquakes (4 files)

3-2 Elasticity

3-3 Seismic Exploration (5 files) 


$\begin{array}{lll} & 3-3 & \text { Lake Superior (2 files) } \\ & 3-3 & \text { Massachusetts Area } \\ 4 & \text { Electricity } & \\ & 4-1 \quad \text { Earth Currents - Radio Waves (2 files) } \\ & 4-2 & \text { Electrical Explorations (3 files) } \\ & 4-3 \quad \text { Electromagnetic Exploration (3 files) } \\ 5 & \text { Radioactivity (2 files) } \\ & 5-1 \quad \text { Exploration (2 files) } \\ 6 & \text { Well Logging - Depository Core Library (2 files) } \\ & 6-3 \quad \text { Thermal (3 files) }\end{array}$

\section{INFORMATION}

1 Bibliographies (4 files)

1-1 Domestic

2 Directories (4 files)

2-1 City (2 files)

2-2 Congressional (Directories ) (4 files)

3 Distribution and Sale of Geological Survey Publications (4 files)

3-1 Agents - Commercial Firms (4 files)

3-6 Government Agency Purchase (4 files)

3-7 Mailing Lists, General

3-7 Mailing Lists, A-M, N-Z (6 files)

3-8 Policy

4 Geological Survey Exhibits:

General (4 files)

Exhibits, Fairs, Expositions, and Demonstrations (4 files)

New York World's Fair

5 Films:

Geological Survey Exhibits, Powell Centennial

General (2 files)

A-M, N-Z (4 files)

6 General Policies (3 files)

Eruption of Kilauea, A-M, N-Z (2 files)

6-1 Permission to quote or use publications, general

6-1 Permission to quote or use publications, A-M, N-Z (6 files)

6-2 Inspection by public of field notes, maps, etc. (4 files)

$7 \quad$ Graphic (3 files)

8 Libraries (5 files)

8-1 Experimental

8-2 Technical

9 Manuscripts (editing of) (5 files)

9 "Brooks" Manuscript

10 Photographs (3 files)

10 Patterson, E. F.

10 A-F, G-M, N-Z (3 files)

11 Press and Radio Releases (7 files)

12 Publications (5 files)

12 A-M, N-Z (6 files)

12 Professional Paper 424

12 Water-Supply Paper 1800 
Bulletin 1142-H

12-1 Reports in Preparation (5 files)

12-2 Published Reports (4 files)

12-2 Philmont County Report

12-3 Unpublished Reports (3 files)

12-3 A-M, N-Z (4 files)

12-3 Atlas, Lead-Zinc

12-4 Research and Technical Data (3 files)

12-5 Non-technical Data (2 files)

13 Publications of Outside Organizations, A-C, D-M, N-Z (3 files); A-M, N-Z (2 files)

13 Outside Bulletins and Pamphlets

13 Mining Year Book, 1958

13 Outside Organizations, Approval for Publication

13 Publications of Outside Organizations A-F, G-M, N-R, S-Z (4 files); A-F, G-M, N-Z (3 files)

13-1 Newspapers and Clippings (4 files)

14 Radio and Video Broadcasts (4 files)

15 Recordings (2 files)

16 Requests for Information, General A-M, N-Z (6 files); A-F, G-M, N-Z (9 files)

16 National Association of Counties

16 Niagara River - American Falls (2 files)

16 Potomac River

16 Rainbow Bridge

16-1 Requested by Geological Survey (3 files); A-M, N-Z (4 files)

17 Speeches, Lectures, Statements:

17 General, A-M, N-Z (2 files)

17 Industrial College of the Armed Forces, Lectures (4 files)

17 Speeches, Addresses (2 files)

17 Aandahl, Fred G.

17 Hardy, Royce A.

17 Nolan, Thomas B.

17 Seaton, Fred[erick]. A.

17 Statements (3 files)

17 Lectures

17 Speeches, General (2 files); A-M, N-Z (4 files)

17 Speeches by Survey Officials (2 files)

17 Papers (2 files)

\section{INVENTIONS}

1 Copyrights, Patents, Trademarks, Applications, General (3 files)

1 Mechanical, Digital Punch Reports

1 Morris and Pillmore, Exaggeration Profile Plotter

1 General (2 files); A-M, N-Z (6 files)

1-2 Permission to Use (2 files)

\section{INVESTIGATIONS}

- $\quad$ General

\section{LAND}

1 General (2 files)

1 Acquired (3 files)

2 Classification and Appraisal (2 files); A-M, N-Z (4 files) 
2 Powersites, Classification, Appraisal, A-M, N-Z (2 files)

3 Indian (4 files)

3-1 Oil Lands, Leases of Nominations for (4 files); A-M, N-Z (2 files)

$4 \quad$ Use and Conservation (5 files)

$5 \quad$ Withdrawals and Restorations (5 files)

\section{LEGAL}

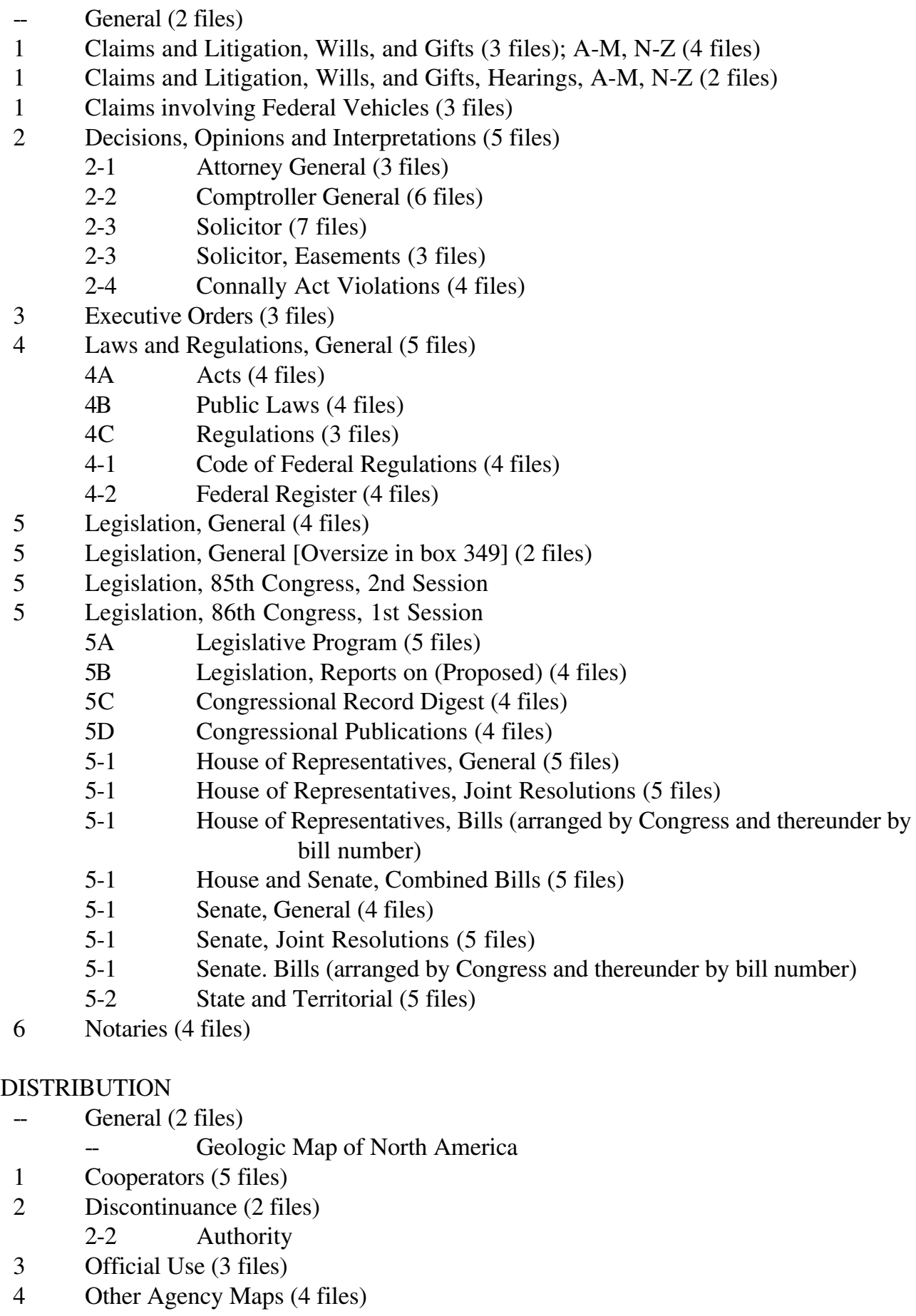




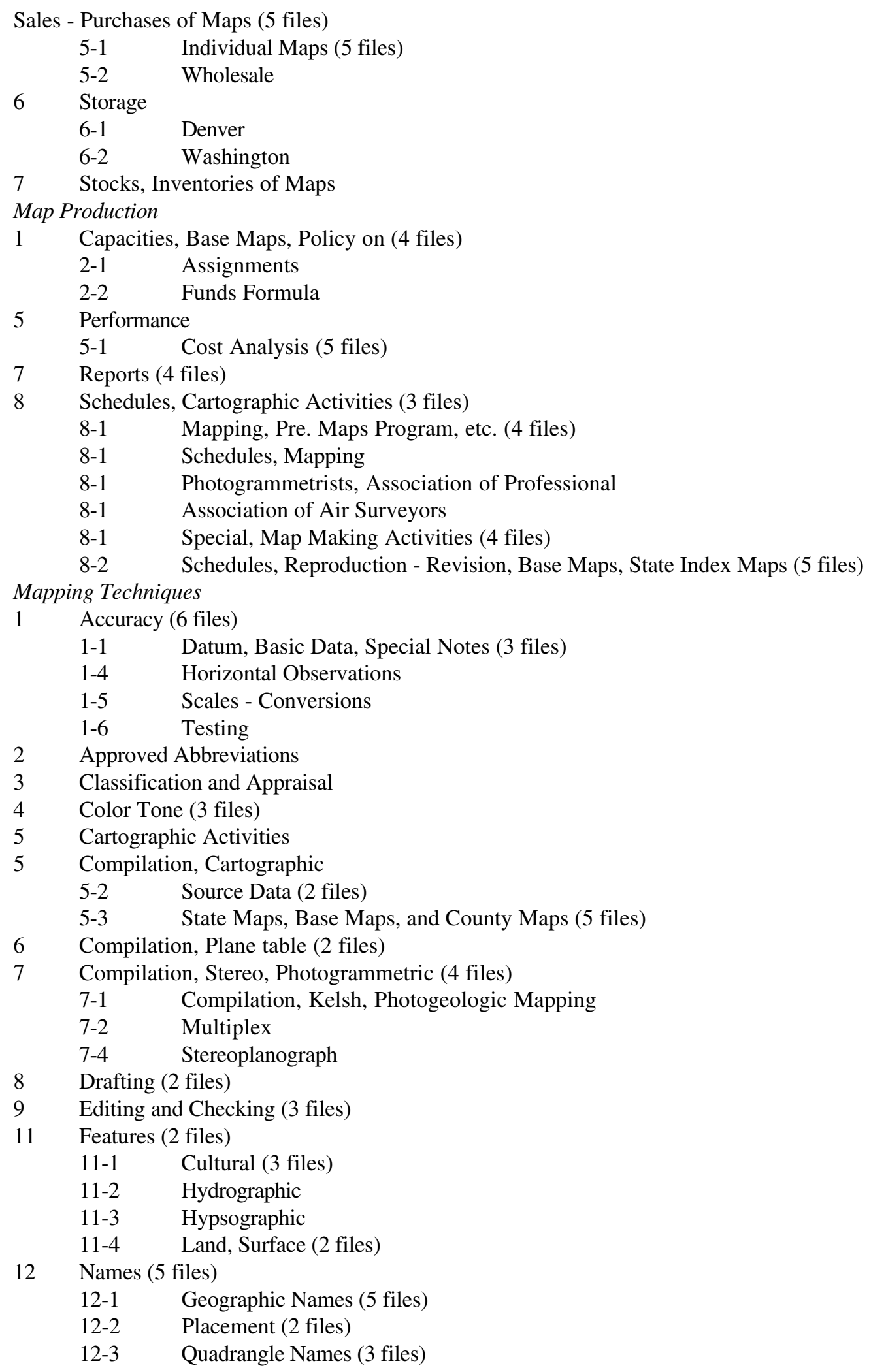


13 Photography, including Aerial Photography (5 files)

13-1 Availability Procurement (5 files)

13-2 Delivery

14 Plate Separation (Color Separation) (2 files)

15 Projections and Grids (2 files)

16 Research and Development

16-5 Reports

16-7 Serial Numbering

18 Standards (2 files)

19 Symbols (3 files)

\section{MEETINGS}

General (2 files)

1 Engagements, Invitations:

General (2 files)

Files (arranged alphabetically by name of individual, organization, geographic area or meeting)

A-M, N-Z (6 files)

Fischer, William A.

Johnston, William D.

Nolan, Thomas B. (2 files)

Pecora, William T.

2 Interior Department (4 files)

Files (arranged alphabetically by program area, name of individual, subject, agency or committee)

2-1 Geological Survey (4 files)

2-1 General (4 files)

2-1 Authorization to attend

2-1 Employment Policy

2-1 Fuels Branch

2-1 Geology

2-1 Geochemistry and Petrology Branch

2-1 Conference on the Hydrology of Volcanos

2-1 Land Classification

2-1 Petroleum Geology Colloquim

2-1 Paleontology and Stratigraphy Branch Lexicon Project

2-1 Regional Engineers, Topographic Division

2-1 Water Resources Division

Inter-Bureau

2-2 General (5 files)

2-2 Bureau of Land Management

2-2 Compliance Officers

2-2 Correspondence Workshop "Plain Letters"

2-2 Field Conferences - Property and Records

2-2 Field Executive Management Conference

2-2 Geological Survey - Fish and Wildlife Service

2-2 Joseph A. Holmes Safety Associations

2-2 Legislative Expediters

2-2 Mines, Bureau of

2-2 National Park Service

2-2 Oil Shales - Mines - Geological Survey

2-2 Property Management Personnel

2-2 Scientific Research and Development, Committee for 
Interagency:

General (5 files)

Antarctic Activities, Argentina

Antiquities Act, Conference on

Archaeological Remains, Recovery of

Army-Interior Mapping, Charting and Aerial Photography Plan

Army-Geological Survey

Atomic Energy Commission

Commerce-Interior Departments

Defense, Department of

Delaware Basin Survey Meeting

Federal Management Conference USCSC

Federal Map Users Conference (2 files)

Forest Service

Frequency Control, 10th Annual Symposium on

Housing and Home Finance Agency

Interagency Advisory Group (U. S. Civil Service Commission) (4 files)

Interior

Interstate Compact - Oil and Gas Conserve

Motor Equipment Conference

National Inventory of Soil and Moisture Conservation Needs

National Science Foundation

Naval Research Laboratory (2 files)

Navy-Geological Survey

Nonferrous Metals Advisory Committee, Interdepartmental

Outer Continental Shelf

Personnel Executives Conference

Petroleum and Natural Gas, Committee on

President's Committee on Government Contracts

Regional Inter-Agency Supply Management Conference

Saline Water Commission

Small Business Administration

State Department

Water Resources Basic Data Program

Weather Bureau

4 International:

General (5 files)

Arctic Geology, International Symposium on

Australia and Oceania, Conference on Geological Map of

Botanical Congress, 8th International

British Commonwealth Survey Officers Conference

Buenos Aires, Antarctic Symposium of

Canada, National Research Council of

Canadian-U.S. Mapping

Carboniferous Stratigraphy, 4th Congress

Cartographical Conference, International

Cartography, Pan American Consultation, 8th

Cartography, VII Consultation on

Centenary Congress

Commonwealth Mining Congress, 6th

Conservation of Nature and Natural Resources, International Union of 
Continental Shelf

Crystallography, International Union of

Cuban Congress on Petroleum, 1st

Economic Commission for Asia and Far East (5 files)

Electronic and Nuclear Energy Exhibit Conference, International 5th

Geodesy and Geophysics, International Union of (3 files)

Geological Map of the World, Commission for the

Geological Science, International Union of

Geological Society of America

India Geological Society

Industrial Chemistry, International Congress of

Inter-American Conference regarding the Outer Continental Shelf

International Atomic Energy Agency

International Conference on Permafrost

International Conferences '56 and '57

International Congress on Quaternary Research IV

International Geological Congress (5 files)

International Geophysical Year

International Hydraulic Congress

International Hydrological Decade

International Law of the Sea

International Law of the Sea, Meetings

International Map of the World

International Society of Photogrammetry

International Union of Geodesy and Geophysics (2 files)

International Union of Geological Sciences

Japan, Geological Society of

Map of the World, Commission for the

Mexico Geological Congress

Nuclear Geophysics, Conference of

Pacific Science Conference

Pacific Science Congress

Pakistan Science Conference, 9th

Paleontological Society

Pan American Institute of Geography and History

Pan American Soil Conservation Congress

Peaceful Uses of Atomic Energy

Peru Geological Congress

Photogrammetry, International Congress and Exposition of

Photogrammetry, International Society of (2 files)

Photogrammetry, International Society of, 9th

Photogrammetric Research, International Organization for

Plenipotentiaries, International Conference of

Quaternary Research, International Association on

Radiocarbon Conference

Royal Netherlands Meteorological Institute

Russia

Science and Human Welfare

Sedimentology, 5th International Congress of

Soil Mechanics, International Society of

South American Congress on Botany, 3rd 
Teheran

Tokyo (Pacific Geologic Mapping Program)

United National Economic Commission for Asia and Far East

United Nations (2 files)

United Nations Educational, Scientific and Cultural Organization (2 files)

Water Desalination, International Symposium on

Water for Peace, International Conference on

Watershed Management Tour and Seminar, FAO Sponsored

World Meteorological Organization

World Petroleum Congress

World Petroleum Congress, 4th

World Power Conference, 5th

World Power Conference, National Committee on

Zoological Congress, International

Zoological Nomenclature, International Trust for

$5 \quad$ National:

General (5 files)

AIME (American Institute of Mining and Metallurgical Engineers)

Alaskan Science Conference (3 files)

American Anthropological Society

American Association for the Advancement of Science (3 files)

American Association of Petroleum Engineers

American Association of Petroleum Geologists (3 files)

American Association of State Geologists

American Astronautical Society

American Chemical Society

American Commission on Stratigraphic Nomenclature

American Congress on Surveying and Mapping (5 files)

American Forestry Association

American Geographical Society

American Geological Institute (3 files)

American Geophysical Union (2 files)

American Institute of Mining Engineers

American Institute of Mining, Metallurgical and Petroleum Engineers (4 files)

American Management Association Conference on Data Processing

American Military Engineers, Society of

American Mining Congress (5 files)

American Road Builders, Association of

American Society for Public Administration

American Society of Civil Engineers (4 files)

American Society of Photogrammetry (5 files)

American Standards Association

American State Geologists, Association of (5 files)

Americana Zinc Institute

Associated Universities, Inc.

Boy Scouts of America (2 files)

Case Institute of Technology

Chamber of Commerce, U. S.

Computing Machinery, Association for, 12th

Conservation Education Association

Defense Mobilization Committee 
Engineers and Architects Day

Exchange of Persons, National Conference on

Federal Government's Accountants Association

Geological Society of America (3 files)

Government Contracts, President's Committee on

Government Employment Policy, President's Committee on

Holmes Safety Association, Joseph A. (2 files)

Independent Petroleum Association of America (2 files)

Instrument Symposium and Research Equipment, 8th

Izaak Walton League of America

Lead Industries Association

Mineralogical Society of America

National Petroleum Council

National Resources Conference

National Rivers and Harbors Congress

National Science Foundation (2 files)

National Science Teachers Association

National Secretaries Association (2 files)

National Water Research Symposium

National Water Resources Institute

National Watershed Congress

Occupational Safety, President's Committee on

Pacific Geophysical Institute

Pacific Science Congress

Petroleum Engineers, Society of

Petroleum Sciences, Conference on Education in

Photogrammetrists, Association of Professional

Resources for the Future

Resources for the Future, Forum '58

Society of Petroleum Engineers

Soil Conservation Districts, National Association of

Water Pollution, National Conference on

6 State, City, and Regional

General (5 files)

Alaskan Science Conference

Ardmore Geological Society

Brookings Institution Conference

California Public Outdoor Recreation Plan Committee

Colorado School of Mines

Colorado Mining Association

Denver Chamber of Commerce

Engineers and Architects, D.C. Council of

Geological Society of Washington

Kentucky

Kentucky Department of Economic Development

Maine Department of Economic Development

Minerals and Petroleum Conference, 3rd

Montana Natural Resources Council

North Carolina

Northwest Mining Association

Pennsylvania Water Resources Council 
Regional Conferences

Society of Economic Geologists Symposium, March 1966, New York City

Spokane Conference on Geophysics and Photogeology

State Governments, Council of

Texas - Urban Environmental Studies

Utah Geological Society

Washington Litho Club

Washington Power Commission

Water Systems Council

Waterusers - Water District \#36 (Idaho)

Western State Engineers, Association of

Yuma County Water Users Association

\section{MILITARY GEOLOGY}

- General

1 Alaska Terrain and Permafrost

1-1 Surveys and Studies (2 files)

1-2 Reports (2 files)

2 Pacific Islands (2 files)

2-1 Surveys and Studies

2-2 Reports

3 Strategic Engineering Studies

3-1 Surveys and Studies

3-2 Military Geology

\section{MINERAL COMMODITIES}

1 General (5 files)

8 Barite

9 Bauxite (3 files)

18 Calcite, optical (2 files)

19 Colemanite

20 Quartzite

22 Chromite

23 Cobalt

24 Columbium

33 Feldspar

34 Fluorspar (2 files)

44 Ilmenite

48 Iron

49 Kaolinite

52 Limestone

53 Lithium

55 Magnesium

56 Manganese (2 files)

57 Mica

57-1 Mirabilite

58 Molybdenum

58-1 Navajoite

62 Pegmatites

63 Phosphate 
65 Potassium Salts

68 Mercury

81 Sulphur

83 Titanium

87 Tin

88 Titanium

92 Tungsten

93 Uranium

\section{MINES AND MINING}

- $\quad$ General (2 files)

1 Companies and Operators, Applications (4 files)

2 Drainage (2 files)

3 Leases and Leasing (2 files)

3-1 Mineral Rights (2 files)

$5 \quad$ Placer Claims (2 files)

6 Prospecting (3 files)

7 Operations

7-1 Excavating, Tunneling and other Advance Work

7-4 Stripping, Overburden

8 Safety and Accidents (3 files)

8-1 Coal Combustion (2 files)

8-5 Safety and Accidents (Disasters) (3 files)

8-6 Fires

8-9 Orders and Regulations

9 Survey - Reports (3 files)

NATIONAL DEFENSE

1 General (3 files)

1 Civil Defense (4 files)

1 Liaison Officer (4 files)

1 Operation Alert (2 files)

1 Radiological Monitoring (4 files)

2 Water Problems

3 Construction and Housing (3 files)

6 Manpower (4 files)

7 Military Defense

\section{OIL AND GAS}

-- General

1 Accumulation and Sale of Oil (4 files)

2 Analysis

3 Discoveries

3-1 Rates

4 Drill Samples (2 files)

4-1 Core Studies (2 files)

4-2 Methods of Examination

4-3 Storage

$5 \quad$ Drilling Operations (5 files)

5-1 Deep Drilling

6 Exploration and Development (2 files) 


\begin{tabular}{|c|c|}
\hline 6 & Katalla-Yakataga Development Contract \\
\hline 6 & Exploration and Development Contracts (4 files) \\
\hline \multirow[t]{3}{*}{6} & Outer Continental Shelf \\
\hline & 6-1 Exploration and Development \\
\hline & Oil Possibilities (3 files) \\
\hline 7 & Geologic Structures \\
\hline 8 & Gases \\
\hline & Helium (4 files) \\
\hline 9 & Oil Companies Utilization (5 files) \\
\hline & 9-1 $\quad$ Pipelines \\
\hline 10 & Oil Fields \\
\hline & 10-1 Alaska \\
\hline & New Mexico \\
\hline & Oklahoma \\
\hline & Texas \\
\hline & 10-1 States (2 files) \\
\hline 12 & Prices and Taxes \\
\hline & 12-1 Crude Oil \\
\hline & Gasoline \\
\hline & 12-3 Natural Gas \\
\hline 13 & Production Estimates (5 files) \\
\hline 14 & Prospecting Methods \\
\hline & 14-6 Surface \\
\hline 15 & Reserves \\
\hline & NPR \#2 Utah \\
\hline & NPR \#3 Wyoming \\
\hline & NPR \#4 Alaska \\
\hline & 15-2 Naval Petroleum Reserves (3 files) \\
\hline 16 & Reservoirs \\
\hline 18 & Storage (3 files) \\
\hline & 18-1 Underground (4 files) \\
\hline 20 & Transportation \\
\hline 21 & Valuation of Properties \\
\hline 22 & Well Logs \\
\hline & 22-3 Radioactive \\
\hline
\end{tabular}

\section{OIL SHALE}

- $\quad$ General

1 Analysis

3 Exploration and Development (3 files)

4 Lands (2 files)

\section{ORGANIZATION AND MANAGEMENT}

1 Administrative Issuances, General (4 files)

1 Comptroller General, General, Regulations

1 Director's Memos

1-1 Administrative Circulars

1-2 Administrative Digests (4 files)

1-3 Administrative Service Letters (3 files)

1-4 Budget Bulletins (3 files)

1-4 Budget Bulletins, Effects of Alaska Statehood 
1-5 Budget Circulars (4 files)

1-6 Budget and Finance Letters [numbered] (5 files)

1-6a Budget and Finance Letters, Supplements (3 files)

1-7 Handbook (General) (3 files)

1-7 Handbook (Official Organization)

1-7 Correspondence and Style Handbook

1-7 Emergency Handbook (Civil Defense), Interior Department, Geological Survey Chapter

1-7 Handbook, Watershed Protection, Soil Conservation Service, Under Public Law 566

1-10 Management Highlights (2 files)

1-11 Manuals (General)

1-12 Departmental Manuals (General) (5 files)

1-12a Departmental Manuals, Releases

1-13 Manuals (Survey) or Survey Manual (4 files)

1-13a Survey Manual Releases (2 files)

1-13b Administrative Division (2 files)

$1-13 \mathrm{c} \quad$ Conservation Division (2 files)

1-13d Geologic Division (2 files)

1-13e Publication Division (2 files)

1-13f Topographic Division (2 files)

1-13g Water Resources Division (2 files)

1-14 Personnel Management Letters (2 files)

1-14a Procurement and Supply Letters (2 files)

1-15 Secretary's Orders, General

1-15a Secretary's Orders, Revisions and Amendments (3 files)

2 Establishment, Reorganization, Liquidation and Consolidation (3 files)

2 Geophysical Institute (Hawaii)

2-1 Decentralization or Dispersal of Activities (3 files)

2-2 Functions and Delegation (3 files)

2-3 Interior Department (3 files)

2-4 Geological Survey:

General

Branches, Units, Division, etc.

Administrative Division (3 files)

Computation Branch (2 files)

Conservation Division (3 files)

Institute of Water Research

Mount Carmel Office

Roswell Office

Denver Library

Electronics Section

Federal Petroleum Board

Geologic Division (3 files)

Legal Activities

Library

Mid-Continent Center

Menlo Park Office

Photo Unit

Phreatophyte Research

Public Inquiries Office (2 files)

Division of Publications

Rolla, Missouri Office 

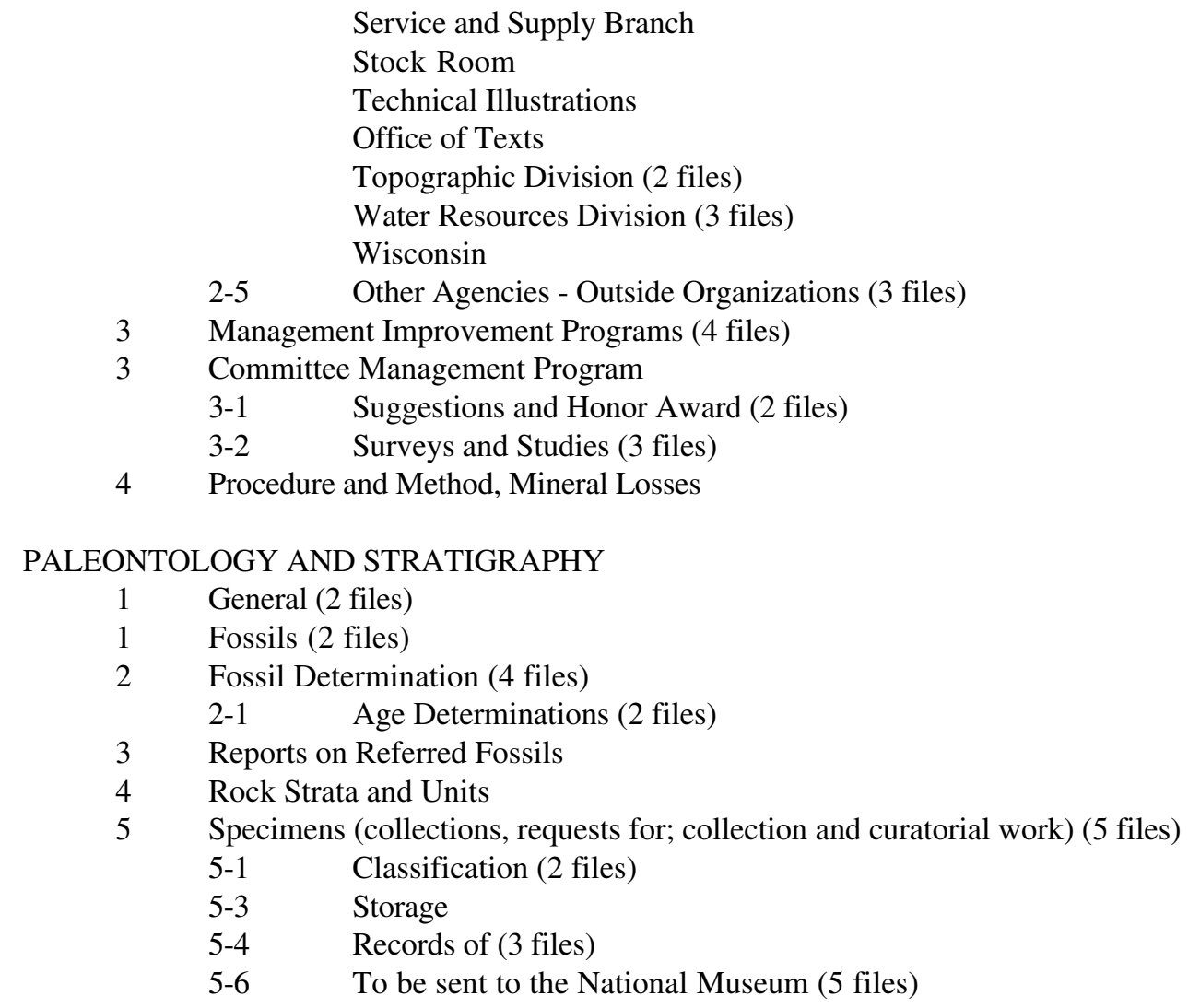

PERSONNEL

$1 \quad$ Appointment Procedures (5 files)

1-1 Consultants (5 files)

1-2 Competitive and Non-competitive (3 files)

1-3 Excepted (4 files)

2 Bulletins and Pamphlets, News Posters (4 files)

2-1 Boards and Committees of Expert Examiners (4 files)

2-2 Management Notes (2 files)

2-3 Personnel Bulletins

3 Classification, Duties, Salaries (5 files)

3-1 Allocation Standards (2 files)

3-2 Classification Act Positions (4 files)

3-3 Civil Service Commission (4 files)

3-4 Job Descriptions, New Positions, Position Review (5 files)

3-5 Schedule A or Excepted Positions (5 files)

3-5 Postdoctoral Research Program by NAS-NRC

3-6 Wage Rates and Ungraded Positions (5 files)

4 Conduct (3 files)

4-1 Commendations (5 files)

4-2 Complaints, Charges, Debts (5 files)

4-3 Disciplinary Action (2 files)

5 Court Attendance (9 files)

6 Delegation of Authority (10 files)

6-1 Departmental 
6-2 Field

$7 \quad$ Details or Assignments of Employees (9 files)

7-1 Foreign (8 files)

7-2 Reimbursable Details (5 files)

7-3 Rotation (3 files)

8 Displacement - Reassignments (5 files)

8-1 List of Displaced Career Employees

9 Employee Relations (4 files)

9-1 Awards, Citations, and Employee Suggestions (18 files)

9-1 Awards and Citations (Foreign Government Awards) (3 files)

9-1 Awards and Citations, Honor Awards and Length of Service

9-1 Incentive Awards (4 files)

9-1 Incentive Awards, Quarterly Report

9-1 Incentive Awards Committee (2 files)

9-1 Awards and Citations, William A. Jump Memorial Award

9-1 Awards and Citations, Cash Award for Superior Service

9-1 SCROLL, Brazilian Geological Society

9-1 Quality Increases (2 files)

9-1 Awards and Citations, Awards for Superior Performance (6 files)

9-1 20 Year Service Awards (3 files)

9-1 30 Year Service Awards (7 files)

9-1 More Than 30 Years Service (2 files)

9-2 Blood Donors (4 files)

9-3 Clubs and Societies (4 files)

9-4 Contributions (Solicitation of Funds) (5 files)

9-5 Counseling, Income Tax Information (4 files)

9-6 Employee Compensation (4 files)

9-7 Employee Participation in Management

9-8 Employee Services and addresses and Biographical Data (5 files)

9-9 Grievances (5 files)

9-10 Outside Work of Employees (8 files)

9-11 Political Activities (5 files)

9-12 Recreation, Welfare and Education (5 files)

9-13 Unions, Credit Union, etc. (5 files)

10 Hours of Duty (Overtime) (9 files):

Branch of Budget and Finance (3 files)

Branch of Computation (3 files)

Conservation Division

Denver Office

Director's Office (3 files)

Duplication Section (3 files)

Pacific Coast

Branch of Personnel (3 files)

Branch of Service and Supply (3 files)

Branch of Technical Illustrations

Water Resources Division

Administrative Division (2 files)

11 Identification Cards (5 files)

12 Inspection Reports (4 files)

12-1 Civil Service Commission Inspection Reports (5 files)

12-2 Departmental 
13 Laws and Regulations (4 files)

13-1 Acts

13-2 Departmental Circulars (Civil Service Commission) (5 files)

13-3 Executive Orders

13-4 Policy and Procedures (5 files)

13-5 Secretarial Orders

14 Leave and Holidays (13 files)

15 Military Service (5 files)

15-1 Deferment (5 files)

15-2 Military Leave (4 files)

15-3 Preference, Reemployment Rights, Defense Transfers (3 files)

15-4 Reserve Activities (3 files)

16 Performance Ratings (5 files)

16-1 Appeals

16-2 Instructions (4 files)

16-3 Reports (3 files)

17 Personnel Ceilings (5 files)

17-1 Personnel Files (3 files)

18 Promotions and Demotions (8 files)

19 Records and Reports (5 files)

19-1 Budget (2 files)

19-2 Employment Reports (6 files)

19-3 Inventory (2 files)

20 Recruitment, Staffing Patterns and Ceilings (8 files)

20-1 Applications (8 files)

20-2 Certificates, CSC (2 files)

20-3 CSC Appointment Requirements (5 files)

20-4 Examinations and Tests (5 files)

20-5 Investigations (2 files)

20-6 Mobilization and Utilization of Personnel (5 files)

20-7 Qualification Standards (4 files)

20-8 USC Authorities

20-9 Vacancy Lists (5 files)

20-10 Waiver of Foreign Residence Requirements (2 files)

21 Retirement and Social Security (4 files)

22 Safety, Reports on (5 files)

22-1 Accidents [14]

22-1 Alaska Drowning (an incident)

22-2 First-Aid Treatment (5 files)

22-3 Inspection and Instructions

24 Separations (5 files)

24-1 Exit Interviews

24-2 Reductions in Force (4 files)

24-3 Removal for Cause (5 files)

24-4 Resignations (5 files)

24-5 Retirement (5 files)

25 Training (11 files)

25 Training, Industrial College of the Armed Forces

25-1 Department Management Training Program (5 files)

25-2 In-Service (8 files)

25-3 Orientation (5 files) 
25-4 Training in Foreign Relations and Languages

25-4 Training in a Non-Government Facility (8 files)

26 Transfers (5 files)

26-1 Transfers to Outside Organizations other than Federal

27 Registers, Eligibles on (2 files)

\section{PHYSICAL EXPLORATIONS}

4 Core Storage

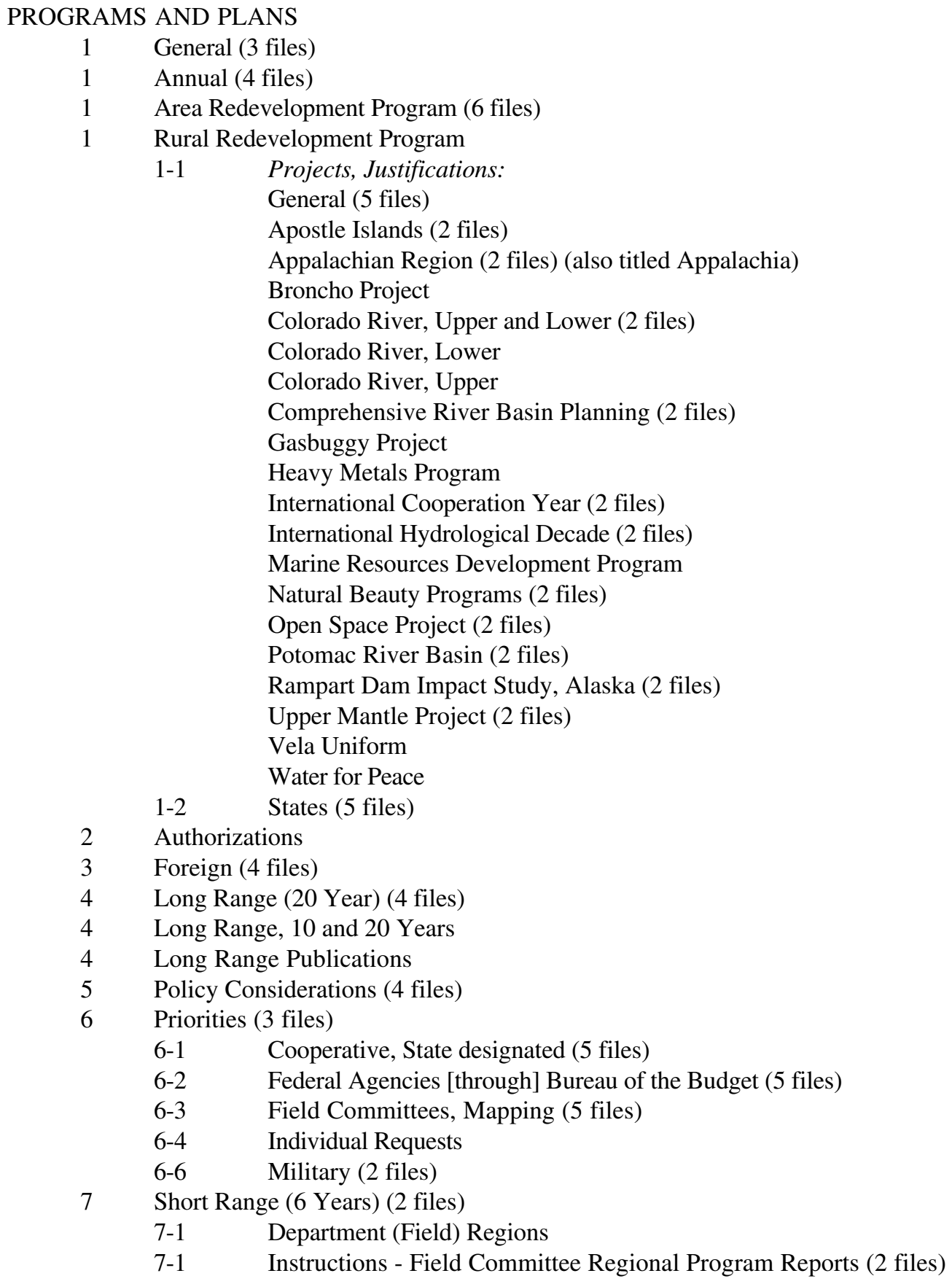


7-2 Regional Program Report

7-3 States

8 Special Programs:

General (5 files)

Antarctica (3 files)

Argo

Arid Lands

EROS - Earth Resources Observation Satellites (4 files)

Estuarine Research

International Year of the Quiet Sun

Long Range Plan, U. S. Geological Survey, Comments and Suggestions from Government, Industry, Education on the (filed loose)

Oceanography (3 files)

Rutile and Titaniferous Materials Development Program

PUBLIC RELATIONS

1 Commendations, Congratulations (2 files)

1 Commendations, Congratulations, A-M, N-Z (6 files)

2 Criticisms and Complaints (2 files)

2 Criticisms and Complaints, A-M, N-Z (6 files)

2 International Helicopters, Inc.

2 "Mussling the Geologists"

3 Petitions and Resolutions (6 files)

$4 \quad$ Introductions (5 files)

5 Representatives and Visitors (2 files)

5 Representatives and Visitors, A-M, N-Z (8 files)

6 State and Cooperating Officials, List of (5 files)

7 Sympathy, Condolence (5 files)

8 U.S.G.S. Personnel Serving on Committee Boards and Outside Organizations as Advisors (4 files)

9 Service and Communication with the Public

\section{RECORDS}

- $\quad$ Memo For:

A-M, N-Z (6 files)

Baker, Arthur A.

Lyddan, R[obert]. H.

Nichols, Herbert B.

Nolan, Thomas B.

Wayland, Russell G.

Woodward, Douglas R. (3 files)

1 Anonymous and Crank Letters (4 files)

2 Certified or Authenticated Copies (2 files)

2 Certified or Authenticated Copies, A-M, N-Z (6 files)

3 Disposition and Storage (5 files)

3-1 Disposal (3 files)

3-2 Inventories (2 files)

3-3 Reports (5 files)

3-4 Transfer to Federal Records Center

3-5 Transfer to National Archives (3 files)

3-6 Transfer between Federal Agencies

3-7 Transfer within Interior Department (2 files) 
$4 \quad$ Filing Systems and Procedures (2 files)

5 Management (2 files)

5-1 Surveys

6 Microphotography

7 Personal (5 files)

7 Mr. Baker's Letters

7 Mr. Nolan's Letters

$7 \quad$ Nichols, Herbert B.

8 Requests to and from National Archives and Federal Records Center

9 Disclosure of Documents from NARS

\section{RELATED SCIENCES}

1 Archeology

$4 \quad$ Mathematics

4-1 Computations and Methods

$6 \quad$ Physics

\section{REPORTS AND STATISTICS}

- $\quad$ General

1 State of the Union Message

1 Management or Control (2 files)

1-1 Congressional Committees, Reports to (General) (5 files)

1-1 House Armed Services Committee

1-1 Joint Committee on Atomic Energy

1-1 House Committee on Government Operations (3 files)

1-1 Senate Committee on Government Operations (2 files)

1-1 Hoover Commission

1-1 House Appropriations Committee (2 files)

1-1 House Government Information Subcommittee (Scientific and Technical)

1-1 House Committee on Interior and Insular Affairs (2 files)

1-1 Senate Committee on Interior and Insular Affairs (3 files)

1-1 House Subcommittee on Intergovernmental Relations

1-1 Joint Economic Committee

1-1 House Sub-Committee on Manpower Utilization (3 files)

1-1 Mineral and Water Resources Reports - States

1-1 Select Committee on National Water Resources

1-1 Special Sub-Committee to the President's Committee on Government Contracts

1-1 Senate Sub-Committee on Reorganization and International Organization

1-1 Senate Appropriations Committee (2 files)

1-1 Special Senate Committee on Space and Astronautics

1-1 House Appropriation Committee, Surveys and Investigations (2 files)

1-1 House Committee on Space and Astronautics (2 files)

2 General

2 Interior Department (2 files)

2 Achievements, Accomplishment, Administrative

2 Administrative - Confidential

2 Secretary's Office, Acting, Under, Assistant (7 files)

2 Assistant Secretary, Mineral Resources

2 Assistant Secretary, Public Land Management

2 Assistant Secretary, Water and Power

2 Secretary 


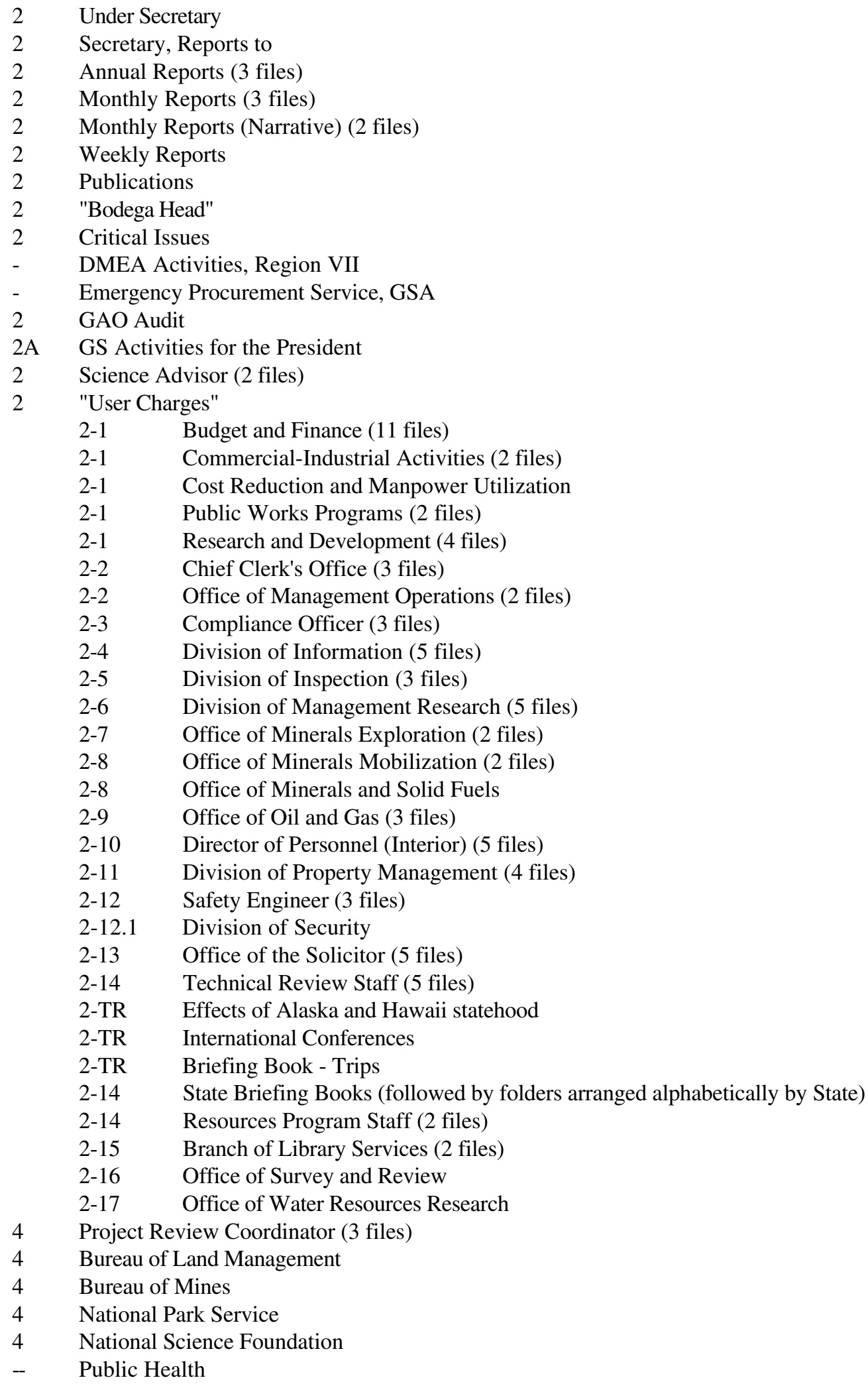




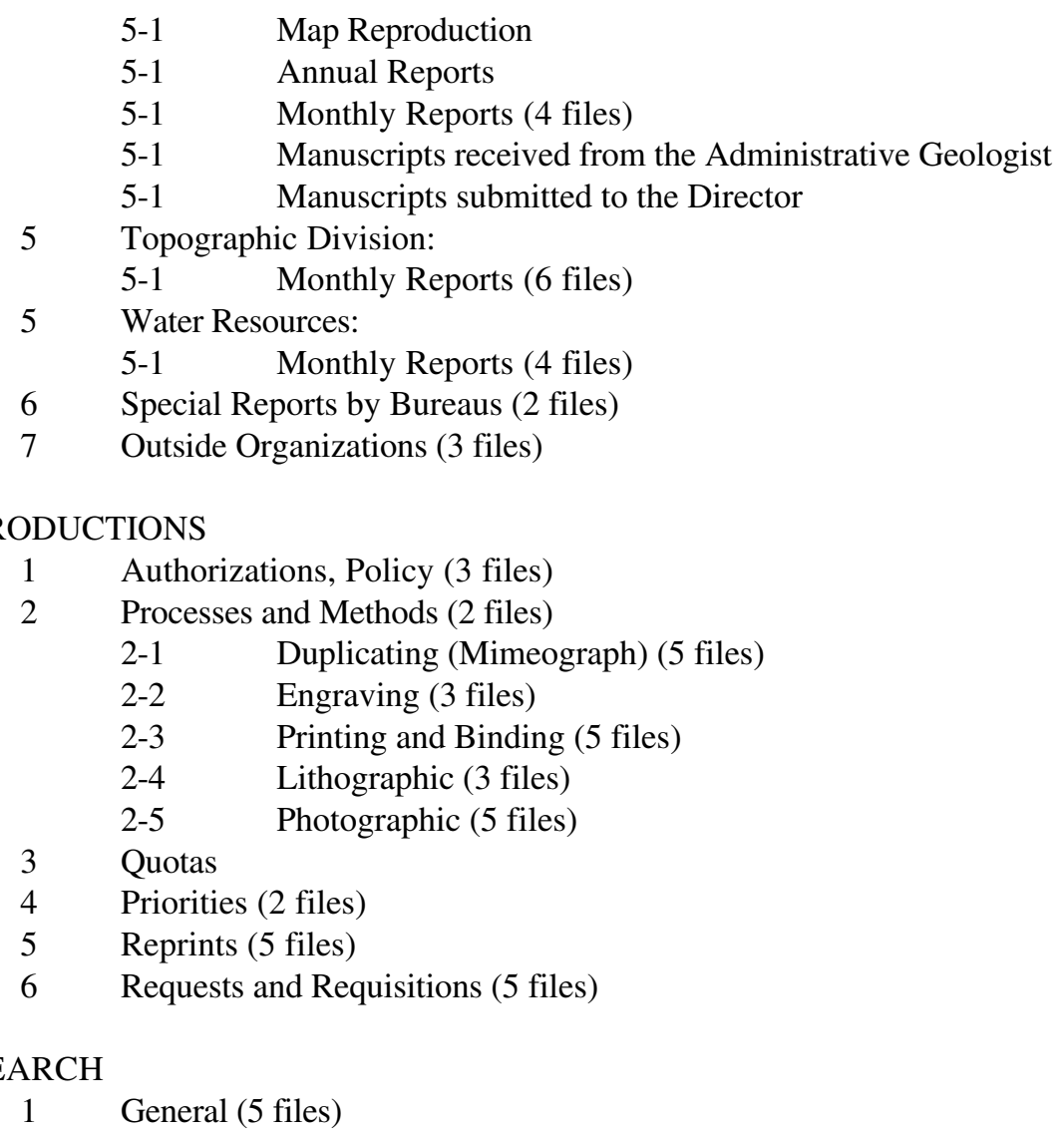

\section{SEDIMENTATION AND EROSION}

1 General

\section{TOPOGRAPHIC SURVEYS}

-- General

1 Aerial Surveys, Policy (5 files) 
2 Boundaries (5 files)

3 Coordination and Planning (2 files)

6 Field Completion Surveys (2 files)

7 Geodesy

7-2 Elevation and Benchmarks (5 files)

7-3 Levels (3 files)

7-7 Triangulations

$8 \quad$ Requests for Surveys (5 files)

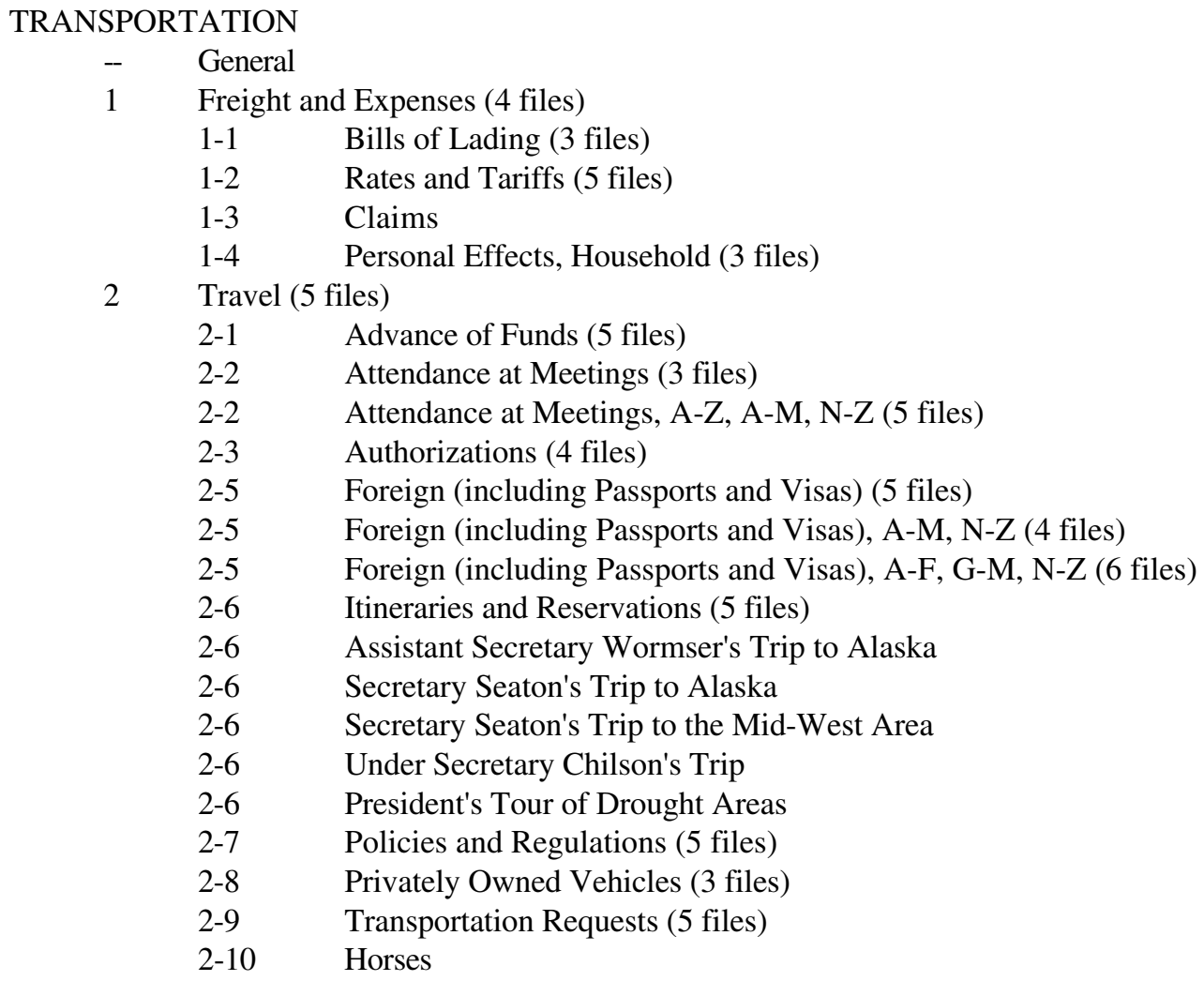

\section{VEHICLES}

1 General:

Assignment and Use, Policies (4 files)

Motor Pools (6 files)

files (alphabetically by State or Territory (119 files)

1-1 Storage, Salt Lake City

2 Accidents (5 files)

2 Accidents, except claims (6 files)

3 Credit Cards

4 Inspection

6 License Plates (2 files)

8 Maintenance, Repairs, Performance (4 files)

10 Permits to Operate, Operator's Test (4 files)

11 Procurement, Limitations (5 files)

12 Reports (5 files) 
13 Surplus or Unserviceable

13-2 Disposals (3 files)

14 Tires and Tubes

\section{WATER, GENERAL}

1 Hydraulics

1 Hydraulics, Investigations (5 files)

1 Canal III, Florida

1-2 Field Projects

1-3 Laboratory Projects

2 Hydrology (4 files)

2-1 Drought (3 files)

2-2 Evapo-Transpiration (5 files)

3 Irrigation and Reclamation

3-1 Plans (2 files)

3-2 Projects (2 files)

3-3 Sites

$4 \quad$ Laws

4-2 A Program for Reducing the National Flood Damage Potential

$5 \quad$ Maps and Charts

5 Gaging Stations, Stream Flow

6 Phreatophtes Control (4 files)

8 Power (4 files)

8-1 Projects (3 files)

8-2 Sites

$9 \quad$ Supply (5 files)

9-1 Agriculture

9-2 Domestic (2 files)

9-4 Industrial (2 files)

9-6 Reports (3 files)

10 Utilization and Conservation (4 files)

10-1 Consumption

10-3 Observation, Key Wells

10-5 Soil and Moisture Conservation (5 files)

\section{WATER, GROUND}

2 Basic Data Investigation (5 files)

2 Delmarva Peninsula Hydrologic Study

2-1 Earthquake Fluctuation Data (2 files)

2-2 Salt Water Encroachment (3 files)

2-3 Spring Schedules (2 files)

2-4 Water Levels, Tables (4 files)

4 Measurements (4 files)

4-2 Methods (2 files)

5 Occurrence and Characteristic (3 files)

6 Reports (5 files)

7 Wells (5 files)

7-1 Drilling Contracts (4 files)

7-2 Drilling Specifications

7-4 Observations, Core Depository (3 files) 
9 Quality of Water, Florida

9-3 Results of Water Investigations, Libya

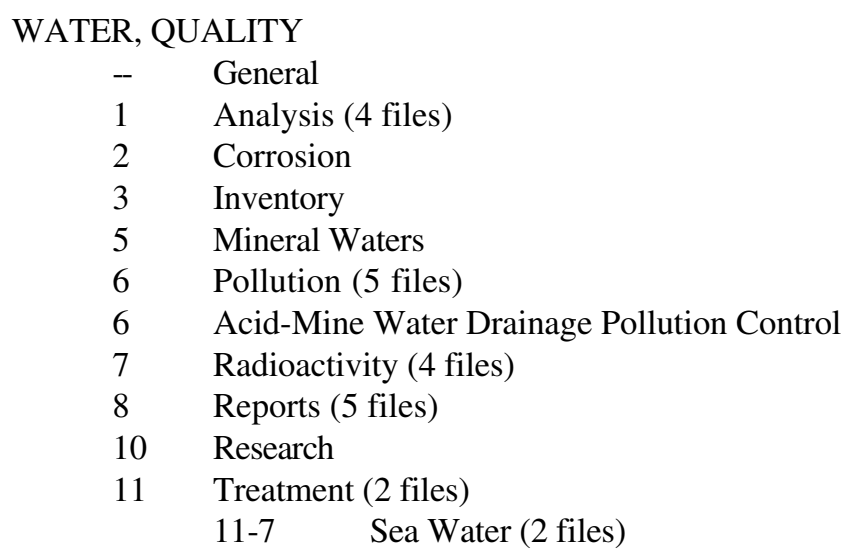

WATER, SURFACE

1 Aerial Studies

2 Basic Data (4 files)

3 Characteristics

3-2 Stage Discharge Relations

$4 \quad$ Floods (5 files)

$4 \quad$ Pacific Northwest and California Floods, December 1964

4 Flood Study, Colorado

4-1 Control (5 files)

4-2 Damage (2 files)

4-3 Frequency (3 files)

$5 \quad$ Gaging Stations (4 files)

6 Laboratories (2 files)

7 Measurements (3 files)

7-1 Apparatus (2 files)

7-2 Indirect Determination

7-3 Special Methods

8 Reports (2 files)

8-2 Compilations - Restudy

8-5 Reports of and for other Agencies (4 files)

9 Reservoirs, Lakes, Dams

9-1 Sites

9-2 Surveys (2 files)

10 Rivers and Streams

10-1 Surveys (3 files)

WEATHER

1 General (4 files)

2 Rainfall (2 files)

2-2 Measurement

3 Snow

3-2 Measurement

4 Temperature

4-1 Air

$5 \quad$ Wind and Velocity 
Office of the Director - Central Classified Files, 1953-74 (entry 52)

\section{2nd Subseries (1968-74)}

These files are dated 1968-74 unless otherwise noted.

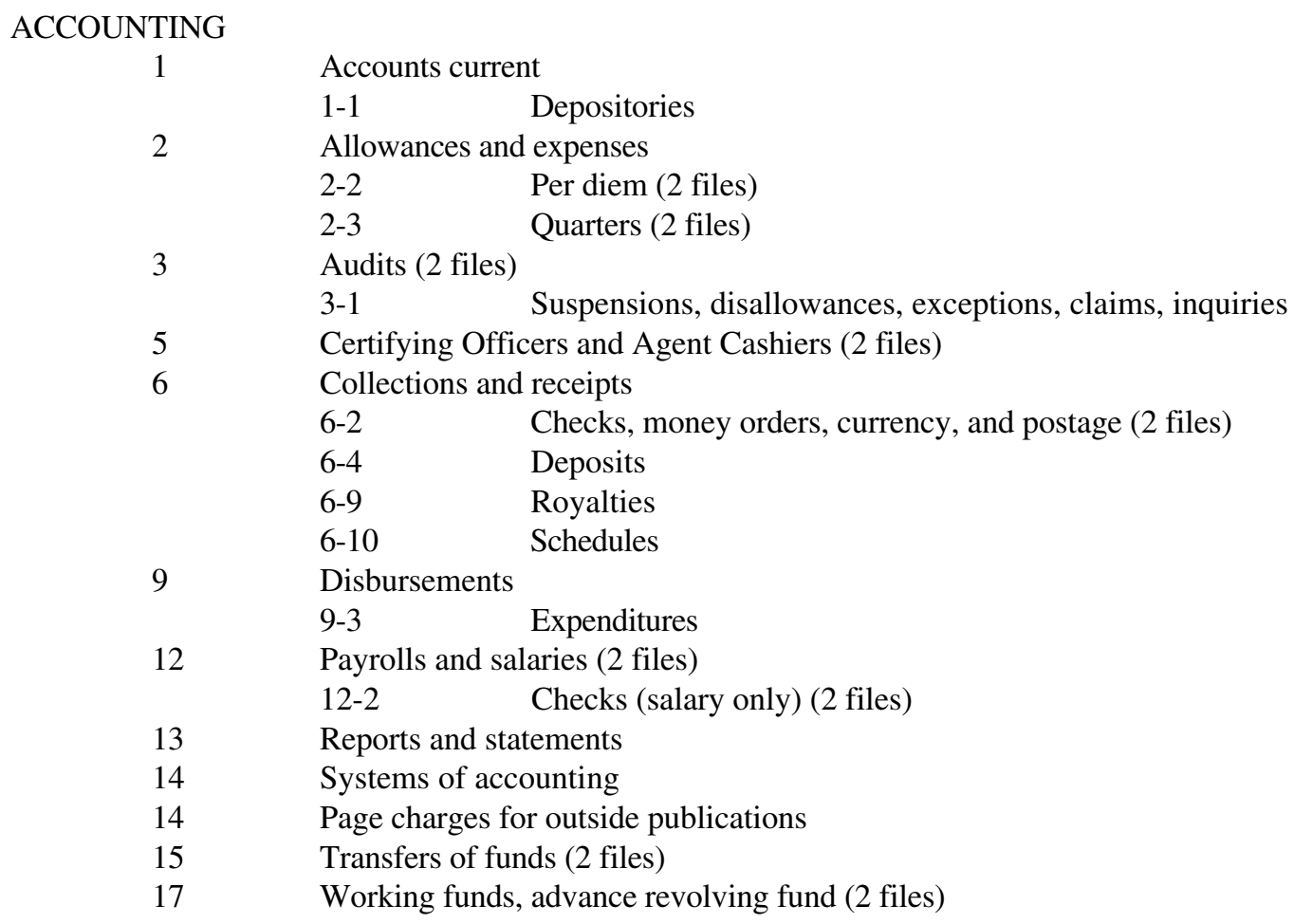


$5 \quad$ Regional, State and local programs and estimates (2 files)

$\begin{array}{ll}5-1 & \text { Field Committee regions, justifications (2 files) } \\ 5-4 & \text { Federal, State (2 files) } \\ 5-5 & \text { State and local programs, general } \\ \text { Interagency } & \text { Programs and Estimates } \\ 6-1 & \text { Miscellaneous agencies } \\ 6-5 & \text { Bureaus and offices of Interior Department }\end{array}$

\begin{tabular}{|c|c|c|}
\hline \multicolumn{3}{|c|}{ BUILDINGS AND GROUNDS } \\
\hline 1 & Gen & \\
\hline & $1-1$ & Leasing \\
\hline 2 & Dan & rotection ( 2 files) \\
\hline & $2-1$ & Fire (2 files) \\
\hline & $2-2$ & Guarding ( 2 files) \\
\hline & $2-3$ & Passes (2 files) \\
\hline & $2-4$ & Permission for use of grounds and establishments \\
\hline 3 & Des & nstruction \\
\hline & $3-1$ & Plans, drawings, and specifications (2 files) \\
\hline 4 & Dire & gns, bulletin service \\
\hline 5 & Dis 1 & \\
\hline 7 & Mai & nd preservation ( 2 files) \\
\hline 8 & Rep & ta (2 files) \\
\hline 9 & Spa & \\
\hline & $9-1$ & Washington (2 files) \\
\hline & $9-2$ & Field (2 files) \\
\hline & $9-2$ & Alaska (2 files) \\
\hline & $9-2$ & Arizona \\
\hline & $9-2$ & Arkansas \\
\hline & $9-2$ & California (2 files) \\
\hline & $9-2$ & Colorado (2 files) \\
\hline & $9-2$ & Delaware \\
\hline & $9-2$ & Florida \\
\hline & $9-2$ & Georgia \\
\hline & $9-2$ & Iowa \\
\hline & $9-2$ & Kansas \\
\hline & $9-2$ & Kentucky \\
\hline & $9-2$ & Louisiana \\
\hline & $9-2$ & Maryland \\
\hline & $9-2$ & Massachusetts (2 files) \\
\hline & $9-2$ & Minnesota \\
\hline & $9-2$ & Missouri (2 files) \\
\hline & $9-2$ & North Dakota \\
\hline & $9-2$ & Ohio \\
\hline & $9-2$ & South Carolina \\
\hline & $9-2$ & South Dakota (2 files) \\
\hline & $9-2$ & Virginia (2 files) \\
\hline & $9-2$ & Washington (2 files) \\
\hline & $9-2$ & Wisconsin \\
\hline & $9-3$ & Parking (2 files) \\
\hline
\end{tabular}


COAL

$\begin{array}{ll}1 & \text { Anthracite } \\ 2 & \text { Bibliographies, reports, etc. } \\ 9 & \text { Exploration and development } \\ 11 & \text { Lands }\end{array}$

COMMITTEES

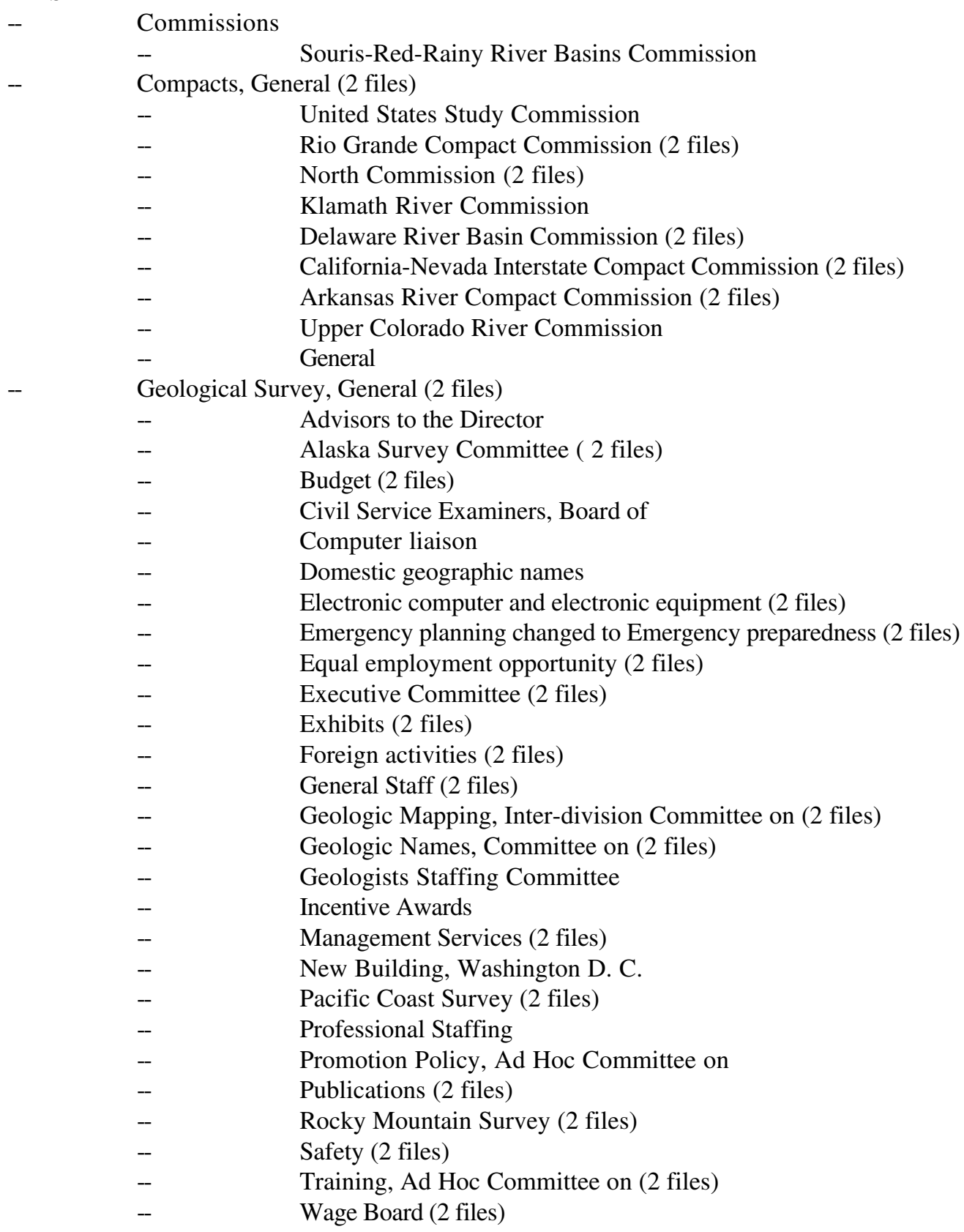




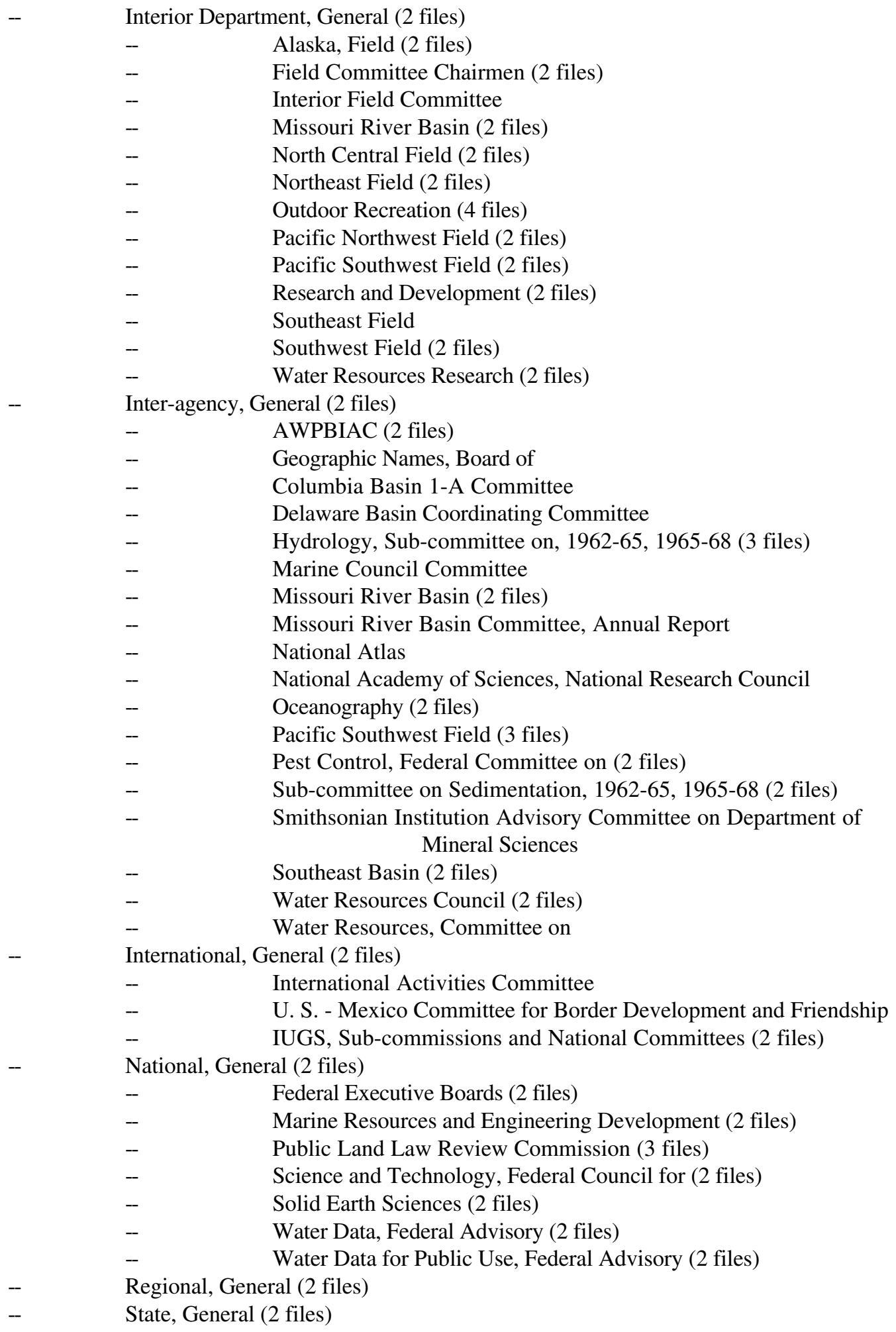




\section{COMMUNICATIONS}

1

Mail and correspondence (2 files)

1-1 Addresses (2 files)

1-2 Postage (2 files)

1-3 Postal laws and regulations

1-4 Procedures (2 files)

2 Messenger Service (2 files)

3 Public Address and Inter-Office Systems

3-1 Christmas greetings

$4 \quad$ Radio

$5 \quad$ Reports (2 files)

6 Telegrams, teletypes, and cablegrams (2 files)

7 Telephones (2 files)

7-1 Installation and use (2 files)

7-2 Lists and directories

\section{CONTRACTS}

$\begin{array}{ll}- & \text { General (2 files) } \\ - & \text { Compliance } \\ - & \text { General, A-M (2 files) } \\ - & \text { General, N-Z (2 files) }\end{array}$

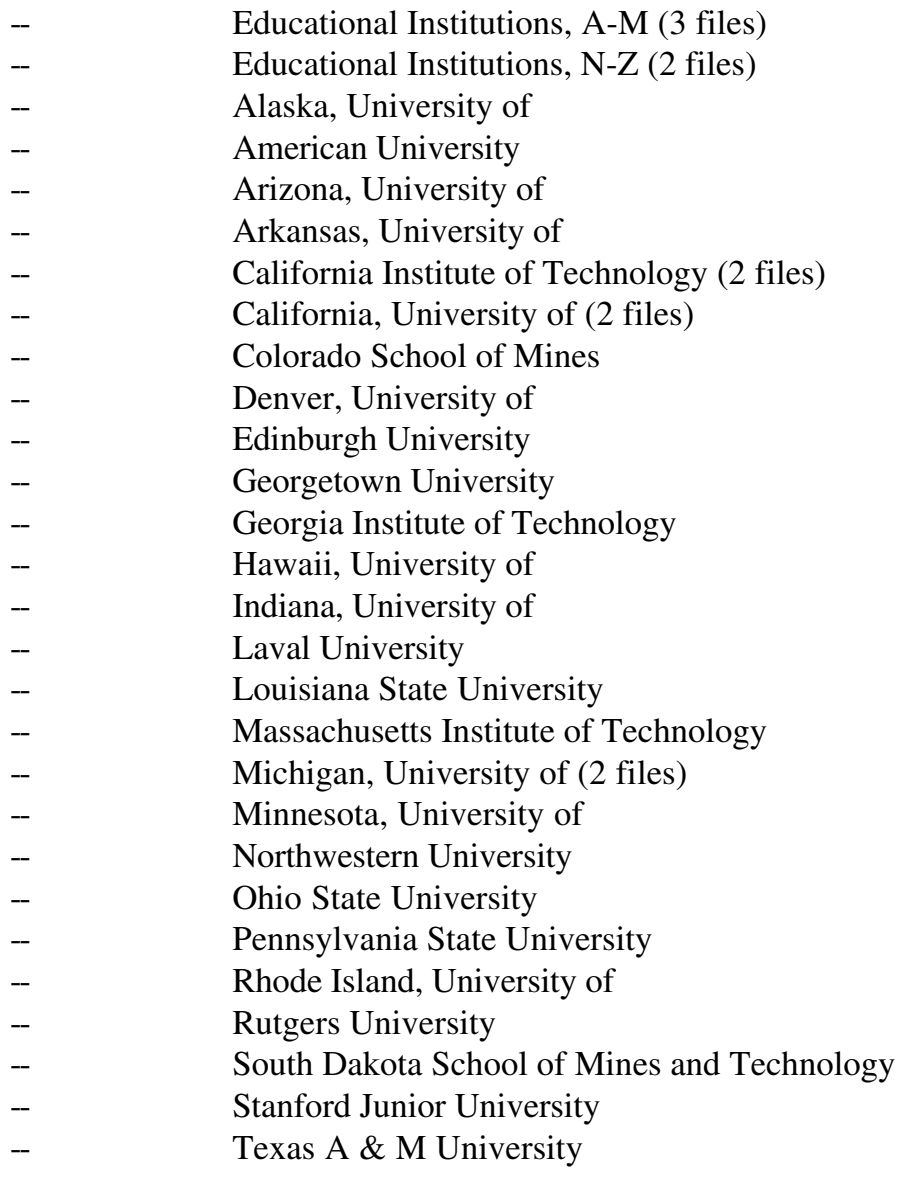




$$
\begin{array}{ll}
- & \text { Utah State University } \\
- & \text { Washington, University of } \\
- & \text { Wisconsin, University of }
\end{array}
$$

General (2 files)

$-$

$-$

$-$

$-$

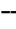

$-$

-

$-$

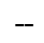

$-$

$-$

$-$

$-$

$-$

$-$

$-$
Advanced Research Projects Agency (3 files)

Agency for International Development, A-M (2 files)

Agency for International Development, N-Z (2 files)

Afghanistan

Africa

Bolivia

Brazil

India

Indonesia

Jordan

Korea

Latin America

Pakistan

Philippines

South America

Viet Nam

Agriculture Department of (2 files)

Agriculture, Department of, Research Service (2 files)

Air Force (4 files)

Alaska Power Administration

Alaska Railroad

Army Map Service

Army, U. S. (4 files)

Army Topographic Command

Atomic Energy Commission (9 files)

Bonneville Power Administration (2 files)

Budget, Bureau of (2 files)

Census, Bureau of (2 files)

Civil Service Commission (2 files)

Coal Research, Office of (2 files)

Coast Guard, U. S. (2 files)

Commerce, Department of (2 files)

Defense Atomic Support Agency (2 files)

Defense, Department of (2 files)

Defense Intelligence Agency (2 files)

Defense Mobilization, Office of

Economic Development Administration

Economic Opportunity, Office of

Emergency Planning, Office of (2 files)

Emergency Preparedness

Environmental Protection Agency

Environmental Quality Control

Environmental Science Services Administration \& Office of Aeronautical Charting and Cartography (2 files)

Equal Opportunity, Office of

Executive Office of the President (2 files)

Federal Aviation Administration (2 files) 


\begin{tabular}{|c|c|}
\hline -- & Federal Civil Defense Administration \\
\hline- & Federal Housing Administration (2 files) \\
\hline- & Federal Power Commission (2 files) \\
\hline- & Federal Water Pollution Control Administration (2 files) \\
\hline- & Federal Water Quality Administration \\
\hline- & Fish and Wildlife Service (2 files) \\
\hline- & Forest Service (3 files) \\
\hline- & General Accounting Office (2 files) \\
\hline- & General Services Administration (2 files) \\
\hline- & Government Printing Office (2 files) \\
\hline- & Health, Education, and Welfare, Department of (2 files) \\
\hline- & Housing and Urban Development, Department of ( 2 files) \\
\hline- & Indian Affairs, Bureau of (2 files) \\
\hline- & Internal Revenue Service \\
\hline- & Justice, Department of ( 2 files) \\
\hline- & Labor, Department of (2 files) \\
\hline-- & Land Management, Bureau of (6 files) \\
\hline- & Library of Congress (2 files) \\
\hline- & Management and Budget, Office of \\
\hline- & Marine Resources, Office of \\
\hline- & Minerals and Solid Fuels (2 files) \\
\hline- & Minerals Exploration, Office of \\
\hline- & Minerals Mobilization, Office of \\
\hline- & Mines, Bureau of (4 files) \\
\hline- & National Academy of Science (2 files) \\
\hline- & National Aeronautics and Space Administration (7 files) \\
\hline- & National Air Pollution Control Administration \\
\hline- & National Audiovisual Center \\
\hline- & National Capitol Planning Commission \\
\hline- & National Cultural Center \\
\hline- & National Museum (2 files) \\
\hline-- & National Oceanographic and Atmospheric Administration \\
\hline- & National Oceanographic Data Center (2 files) \\
\hline- & National Park Service (4 files) \\
\hline- & National Research Council \\
\hline- & National Science Foundation (3 files) \\
\hline- & Navy, Department of (3 files) \\
\hline- & Oil and Gas, Office of (2 files) \\
\hline- & Outdoor Recreation, Bureau of (3 files) \\
\hline- & Peace Corps \\
\hline- & Post Office Department (2 files) \\
\hline- & Public Health Service (2 files) \\
\hline- & Public Roads, Bureau of (2 files) \\
\hline- & Reclamation, Bureau of (4 files) \\
\hline- & Saline Water, Office of (2 files) \\
\hline- & Science and Technology, Office of (2 files) \\
\hline- & Small Business Administration (2 files) \\
\hline- & Smithsonian Institution (2 files) \\
\hline- & Soil Conservation (2 files) \\
\hline- & Southeast Power Administration \\
\hline- & Standards, National Bureau of (2 files) \\
\hline
\end{tabular}




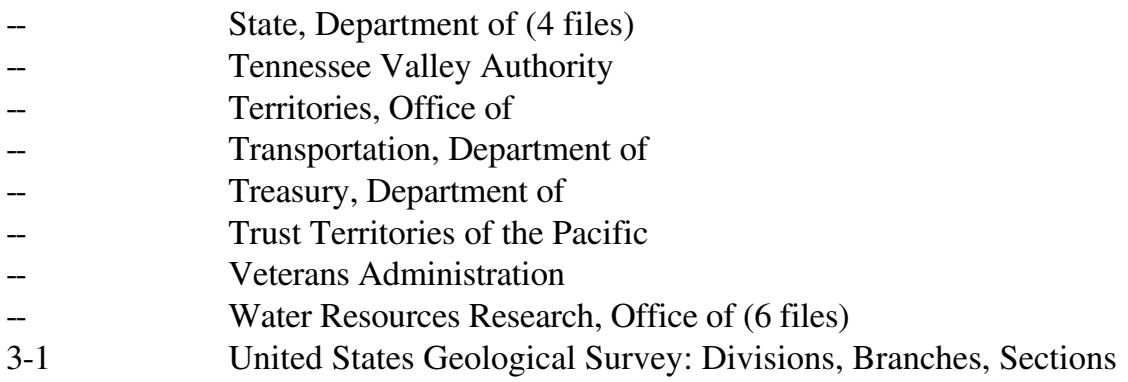

General (2 files)

\begin{tabular}{|c|c|}
\hline- & Alabama (2 files) \\
\hline- & Alaska (2 files) \\
\hline- & Arizona (2 files) \\
\hline- & Arkansas (2 files) \\
\hline- & California (5 files) \\
\hline- & Colorado (2 files) \\
\hline- & Connecticut (3 files) \\
\hline- & Delaware (2 files) \\
\hline- & District of Columbia (2 files) \\
\hline-- & Florida (3 files) \\
\hline- & Georgia (2 files) \\
\hline- & Guam (2 files) \\
\hline- & Hawaii (2 files) \\
\hline- & Idaho (2 files) \\
\hline- & Illinois (2 files) \\
\hline- & Indiana (2 files) \\
\hline- & Iowa (2 files) \\
\hline- & Kansas (2 files) \\
\hline- & Kentucky (2 files) \\
\hline- & Louisiana (2 files) \\
\hline- & Maine (2 files) \\
\hline- & Maryland (2 files) \\
\hline- & Massachusetts (2 files) \\
\hline- & Mexico \\
\hline- & Michigan (2 files) \\
\hline- & Minnesota (2 files) \\
\hline-- & Mississippi (2 files) \\
\hline- & Missouri (2 files) \\
\hline- & Montana (2 files) \\
\hline- & Nebraska (2 files) \\
\hline- & Nevada (2 files) \\
\hline- & New Hampshire (2 files) \\
\hline- & New Jersey (2 files) \\
\hline- & New Mexico (2 files) \\
\hline-- & New York (2 files) \\
\hline- & North Carolina (2 files) \\
\hline- & North Dakota (2 files) \\
\hline- & Ohio (2 files) \\
\hline- & Oklahoma ( 2 files) \\
\hline- & Oregon (4 files) \\
\hline
\end{tabular}




$\begin{array}{ll}- & \text { Pennsylvania (2 files) } \\ -- & \text { Puerto Rico (2 files) } \\ -- & \text { Rhode Island (2 files) } \\ - & \text { Samoa } \\ - & \text { South Carolina (2 files) } \\ - & \text { South Dakota (2 files) } \\ - & \text { Tennessee (2 files) } \\ - & \text { Texas (2 files) } \\ - & \text { Utah (2 files) } \\ - & \text { Vermont (2 files) } \\ - & \text { Virginia (2 files) } \\ - & \text { Virgin Islands (2 files) } \\ - & \text { Wake Island } \\ - & \text { Washington (3 files) } \\ - & \text { West Virginia (2 files) } \\ - & \text { Wisconsin (2 files) } \\ - & \text { Wyoming }\end{array}$

EDUCATION

1 Fellowships, grants, scholarships (2 files)

2 Schools

3 Special training programs

3-1 Foreign students, A-M (2 files)

3-1 Foreign students, N-Z (2 files)

\section{ENGINEERING GEOLOGY \\ 1 General Purpose Geologic Mapping \\ 1-1 City and industrial areas \\ 1-3 Specific construction sites (2 files) \\ 2 \\ Research \\ 2-2 Landslides}

\section{EQUIPMENT AND SUPPLIES}

2

3

4

5

\section{Distribution}

2-1

Maintenance and preservation (2 files)

Procurement (2 files)

4-1

4-3

4-8

4-9

4-10

4-11

4-11

4-11

Property Accountability
Allocation, assignment, and rationing

Authorization (2 files)

Catalogs, price lists, and schedules (2 files)

Purchase orders (2 files)

Rental of equipment (2 files)

Requisitions (2 files)

General

Specifications, bids, contracts, A-M (2 files)

Specifications, bids, contracts, N-Z

5-1 Inventories and identification

5-2 Loans and exchanges (2 files)

5-3 Loss and theft

$7 \quad$ Storage

8 Surplus, salvage and conservation (2 files)

8-6 Transfers (2 files) 
FORMS

$1 \quad$ Management or control

1-1 Design, standardization and revision

\section{GENERAL GEOLOGY}

Bibliographies, references, abstracts (2 files)

Structural geology of areas

Surveys, investigations, explorations, reports (2 files)

National Wilderness (2 files)

OME, requests for funds for minerals exploration

OME, requests for funds for mineral exploration, A-M

OME, requests for funds for mineral exploration, $\mathrm{N}-\mathrm{Z}$

Primitive areas, A-M (2 files)

Primitive areas, N-Z (2 files)

Wildlife refuge areas

7-1 Request for (2 files)

8 Terminology (2 files)

9 Vulcanology

9-1 Volcanic gases

\section{GEOCHEMISTRY AND PETROLOGY}

$2 \quad$ Basic data

$8 \quad$ Minerals

8-2 Chemical analyses of

8-3 Identification of

12 Rocks

12-2 Chemical analyses (2 files)

\section{GEOPHYSICS}

1

Gravity

1-3 Gravity exploration

3

Seismology (2 files)

3-1 Earthquakes (2 files)

3-3 Seismic exploration (3 files)

$6 \quad$ Well logging

\section{INFORMATION}

Abstracts, bibliographies

2 Directories (except telephone) (2 files)

- $\quad$ Topographic Division, Committee Directory

3 Distribution and sale of Geological Survey publications (2 files)

3-1 Agents, commercial firms

3-6 Government agency purchases, GPO (2 files)

3-7 Mailing lists, A-M (2 files)

3-7 Mailing lists, N-Z (2 files)

Exhibits, fairs, expositions, demonstrations (2 files)

"Powell Centennial"

Films, motion pictures, film strips, A-M (2 files)

Films, motion pictures, film strips, N-Z (2 files)

General policies "Soviet Block Countries," 1954-56 
6-1 Permission to quote or use publications, A-M (2 files)

6-1 Permission to quote or use publications, N-Z (2 files)

6-1 Permission to use or quote publication, 1955-56 (3 files)

6-2 Inspection by public of Geological Survey field notes, maps

\section{INVENTIONS}

LAND

Libraries, depositories (2 files)

Manuscripts, editing, care of (2 files)

Photographs, still pictures, slides

Photographs, slides, A-M

Photographs, slides, N-Z

Press releases, radio releases (2 files)

Publications, Geological Survey, A-M (2 files)

Publications, Geological Survey, N-Z

Stock notices, list of (2 files)

12-1 Reports in preparation, revision list of (2 files)

12-2 Published reports (2 files)

12-2 National Atlas (2 files)

12-3 Unpublished reports, open file, A-M (2 files)

12-3 Unpublished reports, open file, N-Z (2 files)

12-4 Research and technical data, storage and retrieval

12-5 Non-technical data

Publications, outside approval of [1956]

Publications of outside organizations, A-F (2 files)

Publications of outside organizations, G-M (2 files)

Publications of outside organizations, N-Z (2 files)

13-1 Newspapers and clippings (2 files)

Radio and video broadcasts (2 files)

Requests for information, general, A-F (4 files)

Requests for information, general, G-M (4 files)

Requests for information, general, N-Z (5 files)

General, Chief Geographer (3 files)

Requests for information, general, Raymond C. Willey

16-1 Requests by Survey for information or publications, A-M (2 files)

16-1 Requests by Survey for information or publications, N-Z (2 files)

Lectures, Industrial College of the Armed Forces

Papers, A-M (2 files)

Papers, N-Z (2 files)

Speeches, lectures, statements, A-M (2 files)

Speeches, lectures, statements, N-Z (2 files)

Speeches, lectures, statements, William T. Pecora

General (2 files)

1 Patents, copyrights and trademarks, A-M (2 files)

1 Patents, copyrights and trademarks, N-Z (2 files)

- $\quad$ General

$1 \quad$ Acquired

2 Classification, appraisal, determination, appeals, A-M (2 files) 
Classification, appraisal, determination, appeals, N-Z (2 files)

3 Indian (2 files)

$$
\text { 3-1 }
$$

$3-1$

$-$

$3-1$

$3-1$

3-1

3-1

3-1

3-1

3-1

3-1

3-1

3-1

$3-1$

$3-1$

3-1

Oil lands, leases of, nominations for, A-M (2 files)

Oil lands, leases of, nominations for, N-Z (2 files)

Santa Barbara letters, insufficient addresses

Santa Barbara Channel, February-April 1969

Santa Barbara Channel, May-June 1969

Santa Barbara Channel, July-August 1969

Santa Barbara Channel, September-December 1969

Santa Barbara Channel, January 1970

Santa Barbara Channel, February-March 1970

Santa Barbara Channel, March-April 1970

Santa Barbara Channel, May-August 1970

Santa Barbara Channel, September-December 1970

Santa Barbara Channel, January-June 1971

Santa Barbara Channel, July 1971- June 1974

Gulf of Mexico, March-May 1970

Gulf of Mexico, June 1970-June 1971

Use and conservation (2 files)

Withdrawals and restorations (2 files)

LEGAL

General (2 files)

Claims, etc., involving Federal vehicles (2 files)

Claims, litigations, wills, gifts, hearings, A-M (2 files)

Claims, litigations, wills, gifts, hearings, N-Z (2 files)

Decisions, opinions and interpretations ( 2 files)

2-3

Solicitor (2 files)

2-4

Connally Act violations

Executive Orders

General, laws and regulations, drafts on (2 files)

4-1

Code of Federal Regulations (2 files)

4-2

Federal Register (2 files)

Acts (2 files)

Public Laws (2 files)

Regulations (2 files)

Outer Continental Shelf Regulations

Outer Continental Shelf Regulations, Enclosures 1 \& 2

Outer Continental Shelf Regulations, Enclosure 3

Outer Continental Shelf Regulations, Enclosures 4 \& 5

Outer Continental Shelf Regulations, Enclosure 6

General, legislation (2 files)

Programs (2 files)

Reports regarding proposed bills (2 files)

Congressional Record

5-1 General

5-1 House Resolutions

5-1 House Joint Resolutions (2 files)

5-1(A) House of Representatives (2 files)

5-1 Senate and House of Representatives (3 files)

5-1 Senate Joint Resolutions (2 files) 


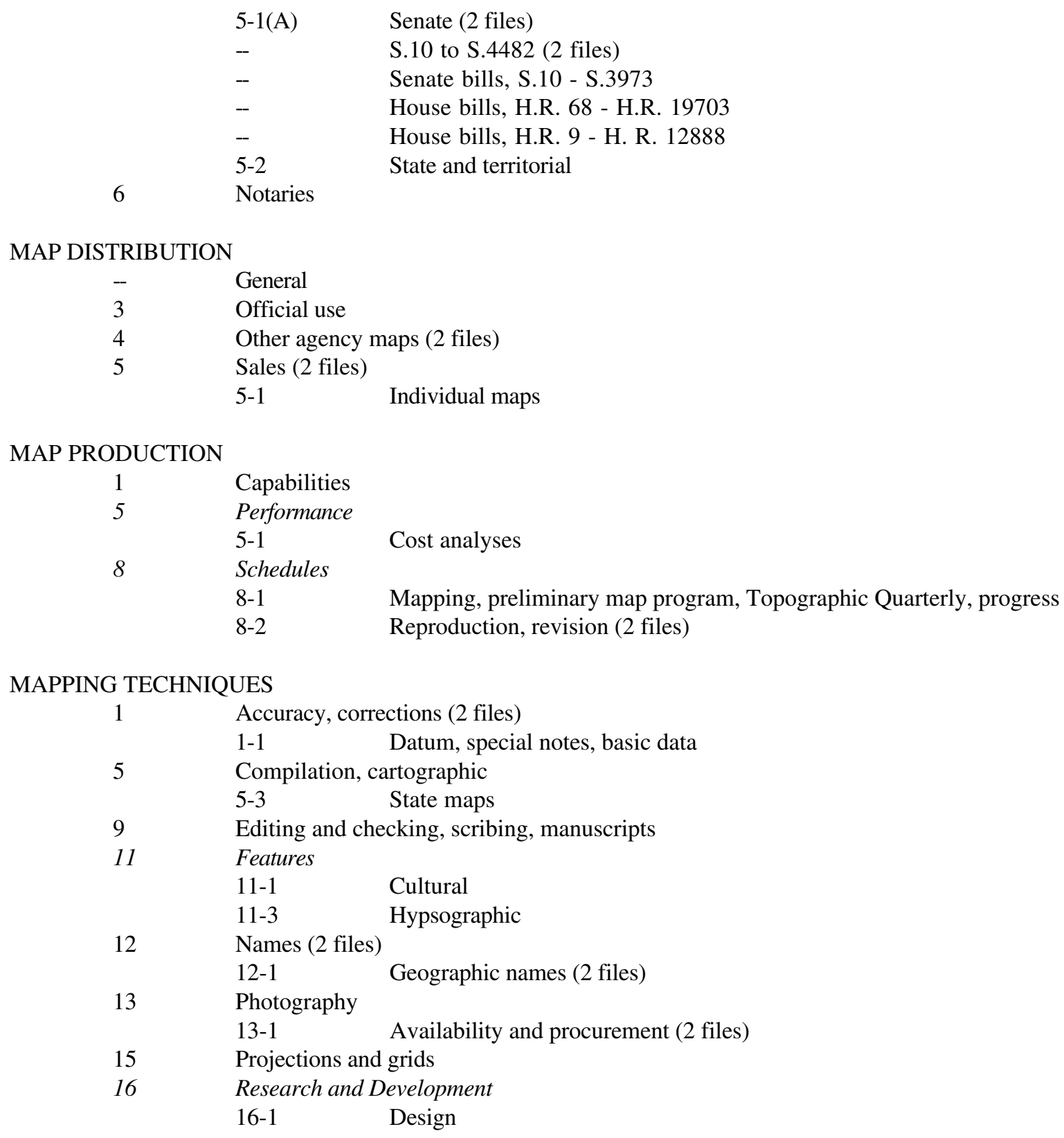


Inter-agency Advisory Group (2 files)

International (4 files)

Economic Commission for Asia and the Far East

Geological Map of the World, Commission for (2 files)

International Geographical Congress

International Geological Congress (2 files)

International Geographical Union (2 files)

IUGS

Pan American Institute of Geography and History (2 files)

World Petroleum Congress (2 files)

U. S. - Japan natural resources development (2 files)

National associations (4 files)

National [American] Association for the Advancement of Science (2 files)

American Association of Petroleum Geologists (2 files)

American Association of State Geologists (2 files)

American Congress on Surveying and Mapping; American Society of Photogrammetry (3 files)

American Geological Institute

American Geophysical Union (2 files)

American Institute of Mining, Metallurgical and Petroleum Engineers (2 files)

American Mining Congress (2 files)

American Society of Photography (2 files)

Geological Society of America (2 files)

State associations, city regional (2 files)

Alaska, all organizations (2 files)

Arctic Institute

Coastal States Conference on Ocean Mining Law

Mineral Resources of the World Ocean

Newport Symposium

Offshore Technology Conference (2 files)

Rocky Mountain Oil and Gas Association (2 files)

Woods Hole Oceanographic Institution

Wyoming Association of Petroleum Landmen

MINES AND MINING

$5 \quad$ Placer claims, Lode claims

$7 \quad$ Operations

7-4 Stripping, overburden

$8 \quad$ Safety and Accidents

8-9 Orders and regulations

NATIONAL DEFENSE

-- General

1 Liaison

OIL AND GAS

1 Accumulation (2 files)

3 Exploration and development

3-1 Rates

$5 \quad$ Drilling operations

5 Reports on Continental Shelf

5-1 Deep drilling 
$6 \quad$ Exploration and development contracts (2 files)

9 Oil companies, utilization (2 files)

12 General

12-1 Crude oil

12-2 Gasoline

12-3 Natural gas (2 files)

13 Production, estimates (3 files)

15 Reserves

15-2 Naval petroleum reserves (2 files)

18 Storage

18-1 Underground

20 Transportation

OIL SHALE

- $\quad$ General

3 Exploration and development (2 files)

$4 \quad$ Lands

\section{ORGANIZATION AND MANAGEMENT}

1

Administrative issuances ( 2 files)

1-2 Administrative Digests (2 files)

1-3 Administrative Service Letters (2 files)

1-4 Budget Bulletins (2 files)

1-5 Budget Circulars (3 files)

1-6 Budget and Finance Letters

1-6a Budget and Finance Letters, Supplements

1-7 Handbooks

1-8 Fiscal Management Memorandum

1-10 Management Highlights (2 files)

1-11 Manuals

1-12 Departmental Manual (2 files)

1-13 Survey Manual (2 files)

1-13b Administrative Division (2 files)

1-13d Geologic Division

1-13e Publications

1-13f Topographic Division

1-13g Water Resources Division (2 files)

1-14 Personnel Management Letters (2 files)

1-14a Procurement and Supply Letters

1-15 Secretary's Orders

2 Establishment, Reorganization and Liquidation (2 files)

2-1 Decentralization or dispersal of activities (2 files)

2-2 Functions and delegations

2-3 Interior Department (2 files)

2-4 National Center for Earthquake Research

2-4 Water Quality Standards, States (3 files)

2-4 Mapping Activities (2 files)

2-4 Office of the Director (2 files)

2-4 Administrative Division (2 files)

- $\quad$ National Technical Programs Task Force

- $\quad$ National Technical Projects Task Force 


\begin{tabular}{|c|c|}
\hline - & $\begin{array}{c}\text { Branch of Management Analysis, MDS Reports } 3 \& 4 \text {, Summary of major } \\
\text { changes during the 1960's concerning employees }\end{array}$ \\
\hline $2-4$ & Computer Center Division (4 files) \\
\hline - & Branch of Connally Act Compliance \\
\hline $2-4$ & Conservation Division (2 files) \\
\hline -- & Electronic Computer Material, Mr. Wayland \\
\hline $2-4$ & Geologic Division (2 files) \\
\hline $2-4$ & Publications Division (2 files) \\
\hline $2-4$ & Topographic Division (2 files) \\
\hline $2-4$ & Water Resources Division (2 files) \\
\hline $2-5$ & Outside agencies \\
\hline $2-5$ & Outside organizations \\
\hline \multicolumn{2}{|c|}{ Management Improvement Program } \\
\hline $3-2$ & Surveys and studies (2 files) \\
\hline \multicolumn{2}{|c|}{ Field Offices and Personnel (2 files) } \\
\hline
\end{tabular}

\section{PALEONTOLOGY AND STRATIGRAPHY}

$2 \quad$ Fossil determinations

$5 \quad$ Specimens

5-6 Specimens to be sent to the National Museum (2 files)

\section{PERSONNEL}

Appointment procedures (2 files)

$$
\text { 1-1 Consultants (2 files) }
$$

3 Classification, duties and salaries (2 files)

3-2 Classification Act, position

3-3 Civil Service Commission, post audits

3-4 Job description (new position, position review) (2 files)

3-5 Schedule A or excepted position - high level, super (2 files)

3-5 Postdoctoral Research Program, NAS-NRC (2 files)

3-6 Wage rates and ungraded positions, WEA, seasonal (2 files)

4 Conduct (2 files)

4-1 Commendation letters for Presidential consideration

4-1 Commendations (2 files)

4-2 Complaints, charges debts (2 files)

Court attendance, jury duty, testimony, A-M (2 files)

Court attendance, jury duty, testimony, N-Z (2 files)

Delegation of authority, A-M (2 files)

Delegation of authority, N-Z (2 files)

River Master

Details or assignments of employees, A-M (2 files)

Details or assignments of employees, N-Z (2 files)

7-1 Foreign, A-M (2 files)

7-1 Foreign, N-Z (2 files)

7-2 Reimbursable details (2 files)

7-3 Rotation

8 Displacement, reassignment, abolishment of position (2 files)

9 Personnel

9-1 Awards and citations (2 files)

9-1 Employee suggestions

9-1 Superior performance awards 


\begin{tabular}{|c|c|c|}
\hline & $9-1$ & Transmittals, Incentive Awards Committee \\
\hline & $9-1$ & Quality increases, A-M \\
\hline & $9-1$ & Quality increases, N-Z \\
\hline & $9-1$ & 20 years Service Award \\
\hline & $9-1$ & 30 years Service Award, A-Z \\
\hline & $9-1$ & 30 years Service Award, A-M \\
\hline & $9-1$ & 30 years Service Award, N-Z \\
\hline & $9-1$ & More than 30 years service \\
\hline & $9-2$ & Blood Donors (2 files) \\
\hline & $9-3$ & Clubs and societies, IDRA (2 files \\
\hline & $9-4$ & Contributions, solicitation of funds ( 2 files) \\
\hline & $9-5$ & Counseling \\
\hline & $9-8$ & Employee services and addresses, biographical data (2 files) \\
\hline & 9-9 & Grievances, thefts, losses \\
\hline & $9-10$ & Outside work of employees, A-M (2 files) \\
\hline & $9-10$ & Outside work of employees, N-Z (2 files) \\
\hline & $9-11$ & Political activities, lobbying, voting (2 files) \\
\hline & $9-12$ & Recreation, welfare and education (2 files) \\
\hline & $9-13$ & Unions, credit unions \\
\hline 10 & \multicolumn{2}{|c|}{ Hours of duty (2 files) } \\
\hline 12 & \multicolumn{2}{|c|}{ Inspection reports ( 2 files) } \\
\hline- & \multicolumn{2}{|c|}{ Inspections in the Geological Survey, 1955} \\
\hline & $12-1$ & Civil Service Commission (3 files) \\
\hline \multirow{2}{*}{13} & \multicolumn{2}{|c|}{ Laws and regulations } \\
\hline & $13-4$ & Policy and procedures (2 files) \\
\hline 14 & \multicolumn{2}{|c|}{ Leave and holidays, A-M (2 files) } \\
\hline 14 & \multicolumn{2}{|c|}{ Leave and holidays, N-Z (2 files) } \\
\hline \multirow[t]{4}{*}{15} & \multicolumn{2}{|c|}{ Military service } \\
\hline & $15-1$ & Deferment (2 files) \\
\hline & $15-3$ & Preference, reemployment rights \\
\hline & $15-4$ & Reserve activities \\
\hline \multirow[t]{3}{*}{16} & \multicolumn{2}{|c|}{ Performance ratings ( 2 files) } \\
\hline & $16-1$ & Appeals \\
\hline & $16-3$ & Reports \\
\hline \multirow[t]{2}{*}{17} & \multicolumn{2}{|c|}{ Personnel ceilings ( 2 files) } \\
\hline & $17-1$ & Personnel folders (2 files) \\
\hline 18 & Prome & demotions, A-M (2 files) \\
\hline 18 & Prome & demotions, N-Z (2 files) \\
\hline \multirow[t]{2}{*}{19} & \multicolumn{2}{|c|}{ Records and reports (2 files) } \\
\hline & $19-2$ & Employment \\
\hline \multirow[t]{6}{*}{20} & \multicolumn{2}{|c|}{ Recruitment, staffing patterns, rosters (2 files) } \\
\hline & $20-1$ & Applications, A-M (2 files) \\
\hline & $20-1$ & Applications, N-Z (2 files) \\
\hline & $20-6$ & Mobilization and utilization of personnel \\
\hline & $20-9$ & Vacancy lists (2 files) \\
\hline & $20-10$ & Waiver of foreign residence requirements, aliens ( 2 files) \\
\hline 21 & \multicolumn{2}{|c|}{ Retirement and Social Security } \\
\hline \multirow[t]{4}{*}{22} & \multicolumn{2}{|c|}{ Safety, reports on (2 files) } \\
\hline & $22-1$ & Accidents, general \\
\hline & $22-1$ & Accidents, A-M (2 files) \\
\hline & $22-1$ & Accidents, $\mathrm{N}-\mathrm{Z}$ \\
\hline
\end{tabular}




$\begin{array}{lll} & 22-2 & \text { First Aid and treatment (2 files) } \\ 24 & \begin{array}{l}\text { Separations } \\ 24-2\end{array} & \text { Reduction in force (2 files) } \\ & 24-3 & \text { Removal for cause, death (2 files) } \\ & 24-4 & \text { Resignations (2 files) } \\ & 24-5 & \text { Retirement, former employees (2 files) } \\ & \text { Training, general } \\ 25 & \text { Training, A-M (2 files) } \\ 25 & \text { Training, N-Z (2 files) } \\ & 25-4 \quad \text { Employee training in a non-government facility (2 files) } \\ 26 & \text { Transfers, Federal (2 files) } \\ & 26-1 \quad \text { Transfers, to outside agencies } \\ 27 & \text { Registers, eligibles on }\end{array}$

\section{PROGRAMS AND PLANS}

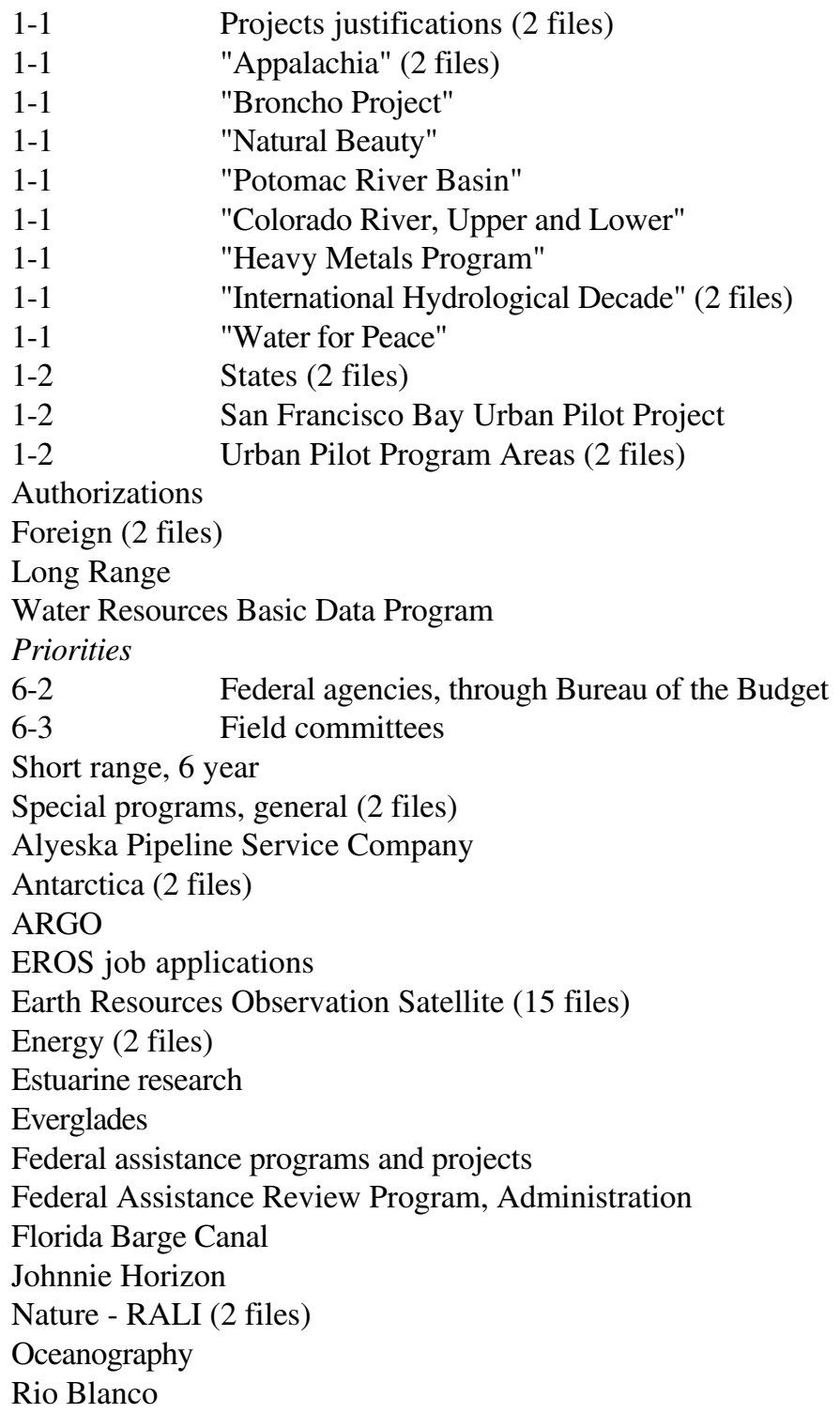


Rulison

Rutile Development Program

Seabed study

Southwest energy

Tektite

Western U. S. Water Plan Study (2 files)

\title{
PUBLIC RELATIONS
}

Commendations, congratulations and greetings, A-M (2 files)

Commendations, congratulations and greetings, $\mathrm{N}-\mathrm{Z}$ (2 files)

Criticisms and complaints, A-M (2 files)

Criticisms and complaints, N-Z (2 files)

Urban mapping complaints

Petitions and resolutions (2 files)

Introductions, recommendations (2 files)

Representatives and visitors, A-M (2 files)

Representatives and visitors, N-Z (2 files)

Sympathy, condolence (2 files)

Geological Survey personnel serving on committees, boards, outside (2 files)

Service and communication with the public ( 2 files)

\section{RECORDS}

- $\quad$ Memorandums for, A-M

-- $\quad$ Memorandums for, $\mathrm{N}-\mathrm{Z}$

$1 \quad$ Anonymous and crank letters

2 Certified or authenticated copies, A-M (2 files)

2 Certified or authenticated copies, N-Z (2 files)

3 Disposition (2 files)

3-3 Reports

$5 \quad$ Management

5-1 Surveys

Personnel

Requests from the National Archives

Inspection of documents

\author{
REPORTS AND STATISTICS \\ $1 \quad$ Management and Control \\ -- $\quad$ Office of Emergency Planning, Stockpile Reports \\ - $\quad$ Stockpile Reports to Congress \\ 1-1 Congressional Committees, reports to (2 files) \\ 1-1 Armed Services Committee, Special subcommittee of the House of \\ Representatives \\ 1-1 Foreign Operations and Government Information, House, Subcommittee \\ (2 files) \\ 1-1 Atomic Energy, Joint Committee on \\ 1-1 Government Operations, House committee on, "Dawson Committee" (2 files) \\ 1-1 Government Operations, House committee on, "Jones Committee" \\ 1-1 House Appropriations Committee (2 files) \\ 1-1 Mineral and Water Resources Reports, States (2 files) \\ 1-1 Interior and Insular Affairs, House of Representatives (2 files) \\ 1-1 Space and Aeronautics, House committee on (2 files)
}




\begin{tabular}{|c|c|c|}
\hline & $1-1$ & Aeronautical and Space Science, Senate Committee (2 files) \\
\hline & $1-1$ & Senate Appropriations Committee (2 files) \\
\hline & $1-1$ & Government Operations, Senate Committee (2 files) \\
\hline & $1-1$ & Senate Interior and Insular Affairs Committee ( 2 files) \\
\hline & $1-1$ & Surveys and Investigations \\
\hline & $1-1$ & Senate Service Committee \\
\hline & $1-1$ & Senate Committee on the Judiciary \\
\hline & $1-1$ & Senate Committee on Printing \\
\hline & $1-1$ & Joint Committee on Printing \\
\hline & $1-1$ & Joint Committee on Defense Production \\
\hline 2 & Secre & ice (32 files) \\
\hline 2 & Secre & ding File (2 files) \\
\hline 2 & Scien & r (5 files) \\
\hline 2 & Annu & \\
\hline 2 & Mont & s (2 files) \\
\hline 2 & $\mathrm{Cam}_{1}$ & ridge, Kentucky ( 2 files) \\
\hline 2 & Lynd & nson Library material (2 files) \\
\hline 2 & Bode & files) \\
\hline 2 & AEC & or comments (4 files) \\
\hline 2 & Repo & el outlay (2 files) \\
\hline 2 & User & files) \\
\hline 2 & Weel & (2 files) \\
\hline & $2-1$ & Division of Budget and Finance (3 files) \\
\hline & $2-1$ & Budget, Office of (6 files) \\
\hline & $2-1$ & Budget Status, reports on \\
\hline & $2-1$ & Commercial industrial activities (2 files) \\
\hline & $2-1$ & Cost reduction and manpower conservation ( 2 files) \\
\hline & $2-1$ & Public works program \\
\hline & $2-1$ & Research and development (4 files) \\
\hline & $2-2$ & Office of Management Operations (4 files) \\
\hline & $2-4$ & Division of Information (2 files) \\
\hline & $2-6$ & Division of Management Research (5 files) \\
\hline & $2-8$ & Office of Minerals and Solid Fuels ( 2 files \& 1 booklet) \\
\hline & $2-9$ & Office of Oil and Gas (2 files) \\
\hline & $2-10$ & Director of Personnel (2 files) \\
\hline & $2-10$ & Personnel Management, Office of (2 files) \\
\hline & $2-13$ & Solicitor's Office (2 files) \\
\hline & $2-13$ & Solicitor's Office, legislation \\
\hline & 2-14 & Resource Program Staff \\
\hline & 2-14 & Program Support Staff \\
\hline & $2-15$ & Branch of Library Services (2 files) \\
\hline & $2-16$ & Office of Survey and Review (6 files) \\
\hline & 2-17 & Office of Water Resources Research \\
\hline 4 & Proje & Coordination \\
\hline & $4-1$ & GS comments, general (2 files) \\
\hline & $4-1$ & Corps of Engineers, A-M (2 files) \\
\hline & $4-1$ & Corps of Engineers, N-Z (2 files) \\
\hline & $4-1$ & Corps of Engineers, public notices \\
\hline & $4-1$ & Corps of Engineers, notices and public hearings and review reports \\
\hline & $4-1$ & $\begin{array}{l}\text { Corps of Engineers, notices and public hearings and review reports, A-M } \\
\text { ( } 2 \text { files) }\end{array}$ \\
\hline
\end{tabular}


4-1 Corps of Engineers, notices and public hearings and review reports, N-Z

4-1 Bureau of Land Management (2 files)

4-1 Bureau of Reclamation (2 files)

4-2 $\quad$ FPC project numbers (2 files)

- $\quad$ FPC projects, filed by assigned number, 78 to 2639

4-3 Work plans, watersheds (2 files)

4-3 Work plans, watersheds, A-M (2 files)

4-3 Work plans, watersheds, N-Z (2 files)

4-3 Margaret Creek Watershed Area, Ohio

4-3 Escondido Creek Watershed, Texas

Internal audits, General (2 files)

Internal audits, Administrative Division (2 files)

Internal audits, Computer Center Division

Internal audits, Conservation Division (2 files)

Internal audits, Geologic Division (2 files)

Internal audits, Office of Minerals Exploration

Internal audits, Publications Division

Internal audits, Topographic Division

Internal audits, Water Resources Division (2 files)

Staffing patterns (5 files)

Public Inquiries Office

$-$

$5-1$

Divisions, general

5-1 Branch of Computation

5-1 Key Operating items, supply and service

- $\quad$ Conservation Division reports to the Director, for the period July 1965 to

5-1 Administrative Division

5-1 Conservation Division (2 files)

- $\quad$ Key Operating items, payroll (2 files)

-- $\quad$ Personnel (2 files)

5-1 Geologic Division (6 files)

5-1 Publications Division, monthly reports (3 files)

5-1 Publications Division (2 files)

5-1 Publications, manuscripts submitted to the Director (6 files)

5-1 Topographic Division (2 files)

5-1 Water Resources Division (5 files)

- $\quad$ Publication - "Reclamation Era: A Water Review Quarterly"

5-1 Outside organization (4 files)

$6 \quad$ Special reports by bureaus

$7 \quad$ Illinois Geological Survey (2 files)

$7 \quad$ Outside organizations

REPRODUCTION

Authorizations and policy, 1956

Authorization, policy

Processes and methods

$2-1$

Duplicating

$2-3$

$2-4$

Printing and binding

2-5 Photographic enlargement, prices of (2 files) 


$\begin{array}{ll}4 & \text { Priorities } \\ 6 & \text { Requests and requisitions (2 files) }\end{array}$

RESEARCH

- $\quad$ General

SECURITY

$1 \quad$ Buildings and equipment, protection (2 files)

$4 \quad$ Information and Publications

$5 \quad$ Personnel (2 files)

Classification, downgrading, declassification

5-2 Investigation and clearance

TOPOGRAPHIC SURVEYS

1 Aerial surveys, policy

2 Boundaries, geographic centers, location of (2 files)

$7 \quad$ Geodesy

7-2 Elevations and bench marks, geodetic control surveys (2 files)

7-3 Levels

$8 \quad$ Requests for surveys (2 files)

TRANSPORTATION

2

Travel (2 files)

2-2

2-3

$2-5$

$2-5$

$2-5$

$2-5$

$2-5$

$2-5$

2-6

2-7

2-8

2-9

Attendance at meetings (2 files)

Authorizations - ExPost Facto - requests for approval (2 files)

General, foreign (4 files)

General, foreign, Canada (3 files)

General, foreign, A-F (5 files)

General, foreign, G-M (5 files)

General, foreign, N-Z (6 files)

General, foreign, Mexico

Itineraries and reservations (2 files)

Policies and regulations (2 files)

Privately owned vehicles

Transportation requests

\section{VEHICLES}

$1 \quad$ Assignment and use (2 files)

$1 \quad$ Motor pools, general (2 files)

1 Motor pools, West Virginia

4 Inspection

6 License plates

8 Maintenance and repairs

11 Procurement limitation re: specifications

12 Reports

13 Surplus or Unserviceable

13-1 Disposal

WATER, GENERAL

1 Hydraulics, investigations (2 files) 


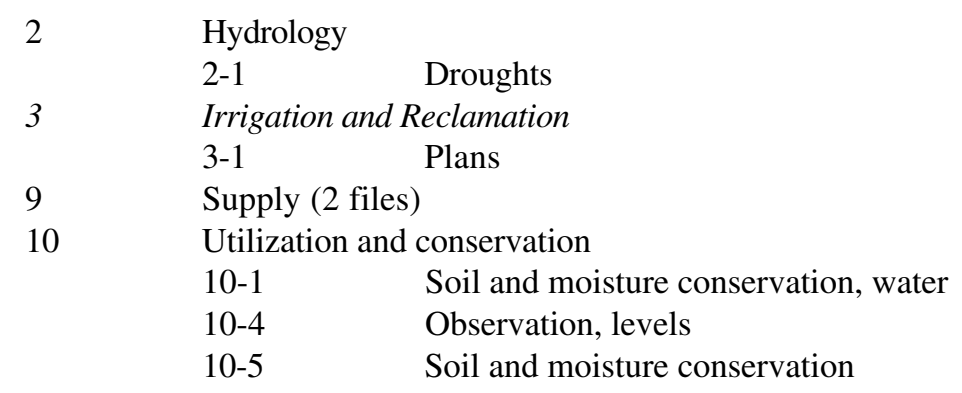

WATER, GROUND

\begin{tabular}{lll}
2 & \multicolumn{2}{l}{ Basic data, investigations, projects, laws (2 files) } \\
4 & $\begin{array}{l}\text { Measurements } \\
4-1\end{array}$ & Instrumentation \\
7 & Wells & \\
& $7-1$ & Drilling contracts, test drilling
\end{tabular}

WATER, QUALITY

1 Analyses

2 Corrosion

6 Pollution (2 files)

8 Reports, study, investigation, storage projects (2 files)

9 Requirements

WATER, SURFACE

$4 \quad$ Floods, information on disasters (2 files)

4-1 Control (2 files)

4-2 Damage

$5 \quad$ Gaging stations, stream flow (2 files)

$7 \quad$ Measurement

$8 \quad$ Reports

WEATHER

$2 \quad$ Rainfall

$\begin{array}{lll}2-2 & \text { Measurement } \\ \text { Temperature } & \\ 4-1 & \text { Air }\end{array}$ 


\section{Appendix 5}

Staff Geologist for Territories and Island Possessions - Records of John Calvin Reed (Sr.), 1946-53 (entry 60)

1.0

1.1

2

2.0

2.1

2.2

2.20

2.201

2.201

2.203

2.205

2.206

2.207

2.207

2.208

2.209

2.3

2.31

2.41

2.51
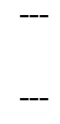

$-$

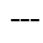

4.4

5.0

5.004

5.005

5.006

5.03

5.05

5.06

5.1

5.2

5.30

5.32

5.6

6.1

6.2

6.3

6.34

7.0

Office of the Staff Geologist, 1946-50

John C. Reed, 1946-50

Geological Survey, Legislative and Policy Items, 1946-51

Director, Assistant Director, 1946-52

Correspondence with Offices under the Director's Office, 1946-52

Geologic Division File, 1946-52

Alaskan Geology Branch Correspondence, 1945-52

R. F. Fellows, 1946-50

Correspondence with Alaska Section employees, 1948-51

Alaska Terrain-Permafrost Program, 1943-52

Alaska Volcano Investigation (General Geology Branch), 1946-53

Alaska Metals, 1946-53

Alaska Nonmetals Program, 1946-52

Alaska Cement Program, 1947-51

Alaskan Coal (Investigations and Industry), 1946-52

Alaska Trace Elements, 1946-53

Topographic Division, 1948-51

Topography - Alaska, 1946-52

Water Resources Program - Alaska, 1946-52

Conservation Division in Alaska, 1946-53

Preliminary Report on Water-Power Resources of Little Susitna River and Cottonwood Creek, Alaska, by Fred F. Lawrence, March 1949

Water Utilization - Ship Creek, near Anchorage, Alaska, by Jesse L. Colbert, May 1951

Preliminary Report on Water Power Resources of Power Creek near Cordova, Alaska, by Arthur Johnson, March 1949

Preliminary Report on the Geology along the Route of a proposed tunnel to develop hydroelectric power from Eklutna Lake, Alaska, by F. F. Barnes, n.d.

President's Scientific Research Board, 1947

Correspondence with Reginald Price, 1949-50

Ivan Bloch, 1946-51

Departmental Committee on Arid and Semi-Arid Regions, 1949-50

Interdepartmental Petroleum Committee, 1950-51

Division of Power, 1946-47

Bureau of Land Management, 1946-52

Board on Geographic Names, 1950-52

Bureau of Reclamation, 1946-52

Bureau of Mines, 1946-52

Alaska Railroad, 1946-53

Alaska Road Commission, 1947-52

National Park Service, 1948-52

Department of the Army, 1946-52

Agriculture Department, 1946-52

Correspondence with the Navy, 1947-52

Arctic Health Institute Proposal, 1948-50

Alaska Development Board, 1946-52 
7.1

10.00

10.00

10.00

10.00

10.0

10.0

10.0

$--$

$---$

10.01

10.4

10.5

10.5

10.5

10.5

12.0

12

12.01

Territorial Department of Mines, 1947-52

Geological Survey - Alaska - Office Space, 1947-52

Survey - Alaska - Equipment, 1949-52

Cooperative Work - Geological Survey in Alaska, 1950-51

Alaska Service, Supply Branch, 1950-53

Report on Field Activities of the Geological Survey in Alaska, 1947 season

Plans and Reports on field activities for the 1947 \& 1948 seasons, 1947-48

Alaska, Miscellaneous, 1947-50

Alaska Development Program, 1947-48

5-year Program of Service Expansion in Alaska, 1947-48

Technical Subcommittee on Minerals, 1948-49

Interagency Committee on the Development of Alaska (including Subcommittees and Technical Committees, 1947-48 (2 files)

Survey Activities - Puerto Rico, 1947-51

Survey Activities - Virgin Islands, 1946-49

Survey Activities - Guam [missing]

Survey Activities - Hawaii, 1948-52

Survey Activities - Trust Territories, 1950-52

Correspondence with E. L. "Bob" Bartlett (Delegate from Alaska), 1946-52

Congressional Correspondence, 1946-52

Washington News Letter from Office of E. L. "Bob" Bartlett, Delegate in Congress from Alaska, 1952-53

Third Report of the Committee on Group Settlement in Alaska, 1949 


\section{Appendix 6}

Division of Engraving and Printing - General Correspondence Files, 1941-49 (entry 132)

Maps, 1941-48

M Maps (Multi-color), 1941-48

P Maps (Planimetric), 1948

PR Maps (Post Route), 1948

PR Maps (Puerto Rico), 1947-48

R Maps (Relief), 1944-46, 1948-49

T Maps (Topographic Map Instructions), 1941

WD Maps (War Department), 1941-43

W Maps (Atlas Sheets) (Waterlining), 1941

Sheets, 1941-48

Sheets (Alaska), 1938, 1941

Priorities for work in hand, 1948

Negatives, 1947-48

Scales, 1944-47

W Machines (Waxing), 1944-46

B Processes (Buscher), 1944

Index Map of the World (1:1,000,000 scale), 1940-43

Millionth Scale Maps, 1945-48

Outside Work, 1944-48

PO Outside Work (Post Office Department), 1941-43

S Outside Work (State), 1941-43

Outside Work (Topography) (Target and Approach Charts), 1942-43

TVA Outside Work (Tennessee Valley Authority), 1940-43

T Outside Work (Transportation Maps), 1941-43

Filing System, 1947

Committee on Supplies, 1943

Complaints, 1941-46

Stones and Preparation, 1940-45

Correspondence, 1947-48

Explosion, 1945

MR Committees (Map Reproduction), 1943

PS Committees (Photographic Supplies), 1943

Index Circulars and Maps, 1945-46

Blanks, 1942, 1944

Plants (Map Reproduction), 1947-48

Reports, 1944-48

A Reports (Annual), 1941-47

BR Budget Reports, 1940-41

P Reports (Progress), 1946-47

SMP Reports (Saving Manpower Program - in Government Agencies), 1942-43

R Reports (Tyding's \#1 and \#2), 1942-43

Wooded Areas, 1943

Repairs, 1941-43

Engraving, 1941-46

Patents, 1911, 1942 


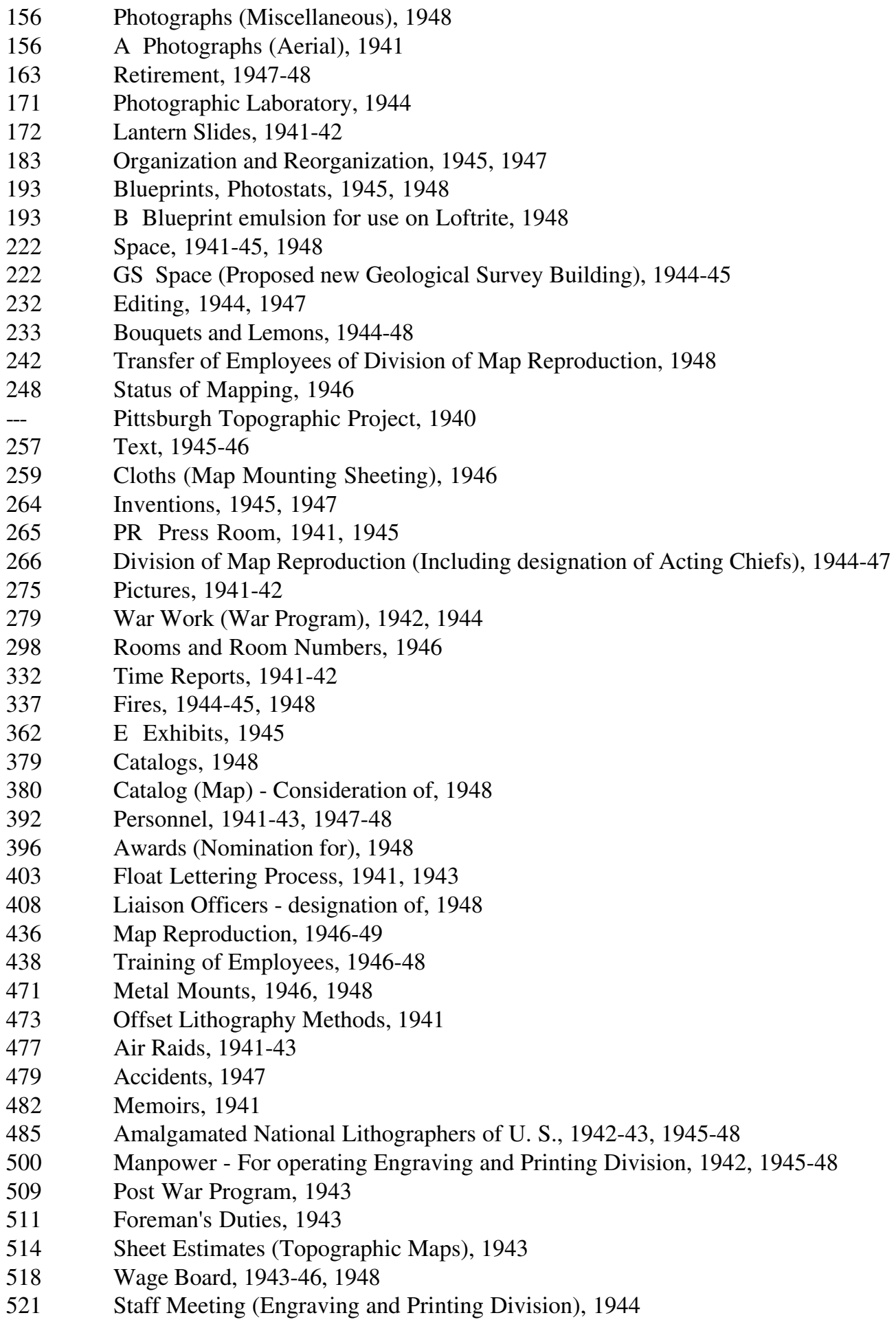




\section{Appendix 7}

Geologic Division, Arnold Hague Papers - Working Papers and Reference Material, ca. 1883-1915, 1929

(entry 146)

11.

12.

13.

17.

20.

21.

22.

23.

$-$

36.

37.

38.

39.

40.

41.

42.

43.

44.

45.

46.

47.

50.

51.

53.

55.

56.

58.
Suggestions for the preparation of manuscripts and illustrations, 1890-91; Rules for classification and nomenclature, Geologic Atlas of the United States, 1902-3

List of and notes concerning rock specimens collected in the Absaroka Range, Gallatin Range, Mount Everts, and in Yellowstone Park

Manuscript material on the Yellowstone Park area

Table of contents and outline of proposed chapters, Monograph XXXII, part I

Notes on Yellowstone National Park, 1915

Manuscripts written by Joseph P. Iddings on Yellowstone National Park with attached notes regarding publication of a portion of the manuscript in Monograph XXXII, Part II; letter from Dr. Whitman Cross, July 1929, regarding the manuscripts

Illustration for Monograph XXXII (6 envelopes marked b, c, d, e, f, and g)

Manuscripts and Illustrations for Chapters 1 to 15, Monograph XXXII, Part 1 (31 envelopes)

Manuscripts on "Excelsior Geyser Basin"; and "Firehole Geyser Basin,"

Manuscripts on "The Geyser Basins," and the "Upper Geyser Basin"

Manuscripts on "Thermal Springs and Geysers Yellowstone National Park - Geographical Distribution and Geological Occurrence"; and "Thermal Springs and Geysers, Yellowstone Park Plateau"

Notes on the algae of Yellowstone National Park by William Albert Satchell

Abstracts made by Hague from Satchell's manuscript [see 36]

Colored plate reproductions for use as illustrations for Geyser chapters

Notes on observations made in Yellowstone National Park. 1885

Manuscript on "The Gases of Thermal Waters," accompanied by a report by Francis C. Phillips to Hague, January 26, 1888

Correspondence and report regarding gas analysis by Francis C. Phillips

Notes on origins of park names [Yellowstone]

"The Hot Springs of Iceland" by Thorkell Thorkelsson, 1910

A treatise on "the question whether the boiling thermal springs carry vadose or juvenile water" (filed with item \#43 above)

Notes on Huckleberry Mountain and Big Game Ridge

Notes on rocks of Skye and other islands

Card references to literature regarding volcanic activity

Typewritten - "Method of Testing for Oxygen" by Professor Phillips regarding his examination of samples of gas found in Yellowstone National Park

Letters and abstracts from papers regarding the radio-activity of thermal waters - Herman Schlundt and Richard B. Moore

Tabulation and analysis of rhyolites from Yellowstone National Park

Translation of parts 2 to 5, pages 9-230, of D. De Launay's "Search, Curbing, and Management of Thermo-Mineral Springs"

Notes on thermal waters

T. A Jaggar's letters to Hague and lists of photographs regarding the Absaroka Range, 1893, 1897-99 [2 envelopes]

An untitled document in an envelope labeled 'Absaroka for International Congress'

Parts of manuscripts, notes, and abstracts from reports on the Absaroka Range in an envelope labeled "Duplicate material"

Catalogue of rocks collected in the Absaroka Range in 1893 and 1897 seasons 
59. Notes and photographs on Firehole Basin

60B. Illustrations for Gibbon Basin

61. Original manuscript on Geyser Basin

62. Lists and notes on geysers in Yellowstone National Park

63. Miscellaneous papers relating to hot springs [items marked a, b, c, d, g, and h]

64. Notes on geysers and hot springs

65. Notes on Mammoth Hot Springs; Mount Everts Section; and travertine deposits

66. Notes on Mammoth Hot Springs

67. Manuscript on "Geology of Mammoth Hot Springs and Adjacent Country" with a list of illustrations for Mammoth Hot Springs Chapter

68. Notes on hot springs, most on Norris Basin

69. List of hot springs in Yellowstone National Park; and notes on Norris Geyser Basin

70. Notes on Norris Basin and hot springs

71. Manuscript titled "Norris Geyser Basin and Gibbon River Thermal Areas"; notes on geysers and hot springs; and photographs of Recess Spring, Thorium Spring, Realgar Spring, Mud Springs, and Roaring Mountain [no photographs were found]

Miscellaneous notes on geysers and hot springs

73. Outline of chapters on geysers and hot springs

74. Photographs of Hidden Spring, central vent of Monarch Geyser, close up view of Hidden (or Gable) Spring, Black Growler, Constant Geyser, and The Fissure (or New Crater).

75. Miscellaneous note on Norris Basin

76. List of papers of W. H. Weed sent from Norwalk, Connecticut, February 1914; list of geysers in Lower Geyser Basin and Norris Basin; a list M. P. Skinner's Yellowstone National Park photographs; and miscellaneous notes

Notes on Yellowstone National Park; notes on Paleozoic and Mesozoic sediments; and chart of comparative sections of the Gallatin Range "Formation of Siliceous Sinter"

Fragmentary notes by W. H. Weed on geyser basins

Notes on the Lower Geyser Basin, 1902

Photographs of Hymen Terrace, Fissure Spring, Blue Spring, Hot River, Hymen Spring-Liberty CapThe Thumb, Elephants Back, Narrow Gauge Fissure, Pulpit Terrace, Mammoth Hot Springs, Cupids Cave, Minerva Springs, and Silver Gate

Miscellaneous notes

91. Notes on the height of Yellowstone Falls by William Hallock

92. $\quad$ W. H. Weed's "Yellowstone Park Notes," 1891

93. Manuscript on "Physical Features of the Yellowstone National Park"

94. Manuscript on the lakes in Yellowstone National Park

95. Original manuscript on "Mammoth Hot Springs"

96. Notes on 'thermal waters and sediments'

97. Notes on "Lake Shore Hot Springs"

98. Notes on quadrant quartzite with notation - "extract from D. D. Condit's paper"

99. $\quad$ Manuscripts on "Early Acid Breccias"

100. Manuscripts: "Early Acid Breccias"; "Region of Crandall Creek"; and "Crandall Creek Area" 
Typescript copy of an article in the Evening Post, Vol. LVII, 1858, titled "Description of the Great Shoshone Falls, on the Snake River, or Lewis's Fork of the Columbia," by George Gibbs

102. "Notes on the principles underlying rock classification" by George F. Becker

103. Notes on basalts

104. Notes on igneous rocks of the Great Basin

106. Geological notes on Cuba

107. Translated copy of "Laws of Deformation of Strata"

108. Handwritten notes in an envelope labeled "Address for Thermal Springs"

109. Notes on Mount Everts

110. A clipping titled "Yellowstone National Park" by F. V. Hayden from Johnson's Universal Cyclopedia, Volume VIII

113. Partial manuscript titled "Uplift of the Range"

114. Memorandum on Clark's Fork Valley

115. "Notes on the Geology North of Crandall Quadrangle"

116. Miscellaneous notes and data 


\section{Appendix 8}

Geologic Division - General Correspondence Files, 1890-1922 (entry 159)

1.1

1.2

Committee on Revision of Survey Regulations, 1902-11

Committee on Advertising and Distribution of Survey Publications, 1902-7

International Committee on Geologic Nomenclature (of common interest to Geological Survey and Geological Survey of Canada), 1903-12

Library Committee, 1903-15

Examination of records, 1901-15

Committees, 1903-15

Geologic Atlas (geologic classification and nomenclature), 1902-3

Boutwell, John M., 1902-11

Accounts, 1912-15

Fire losses, 1913

Per diem, 1914

Service Bulletin, 1913

Supplies, 1913-14

Shipments, 1913

Wilson, Herbert M. (Technologic Branch), 1903-10

Vaughan, T. Wayland (Coastal Plain Investigations), 1909-15

Bien, Morris, 1902-7

Ulrich, Edward O., 1902-15

Topographic, 1903-14

Topographic work requested by the Geologic Branch, 1909-14 (6 files)

Requests for Topographic Survey annual budget, 1915

Requests for special surveys, 1914-15

Quadrangle names, 1914-15

Special engraving, 1914

Special topographic maps, 1915

Petrography, 1902-9

Palache, Charles, 1902-11

Mendenhall, Walter C., 1902-8

Gregory, Herbert E., 1903-15

Caracristi, C. F. Z., 1902-3

Newsom, John F., 1902-6

Kummel, Henry B., 1900-1915

Faunal charts, 1902-3

Howe, Ernest, 1906

Colorado, 1902-15

Bibbins, Authur, 1902-9

Schuchert, Charles, 1902-14

Woodson, J. A. - Pike County, Arkansas, oil and asphalt deposits, 1902

Cleland, Herdman F., 1914

Burchard, Ernest F., 1902-15

Clapp, Frederick G., 1904-13

Reid, Harry Fielding, 1902-14 (3 files)

Bailey, Willis, 1902

Tarr, Ralph S., 1901-12 


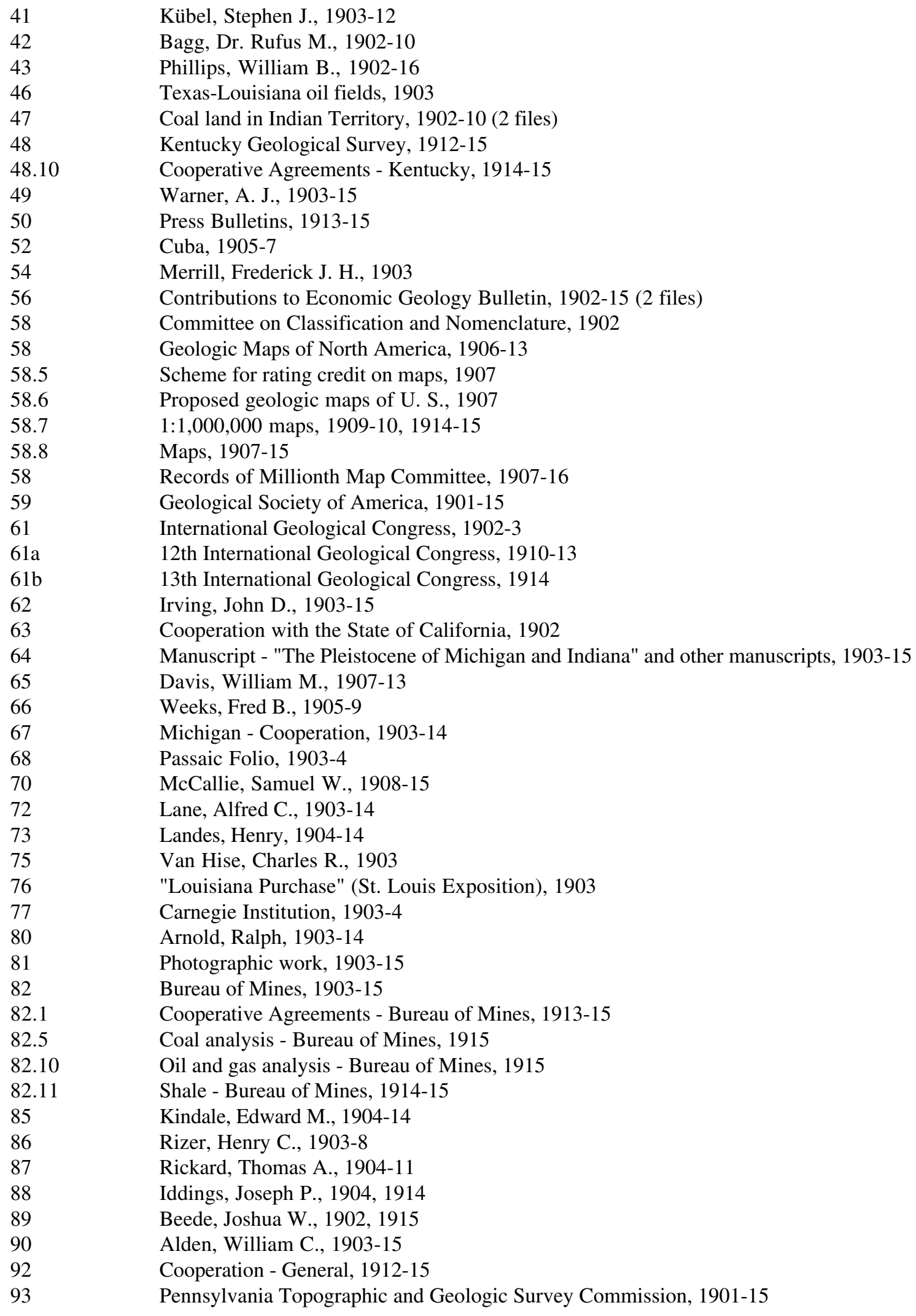

Contributions to Economic Geology Bulletin, 1902-15 (2 files)

Committee on Classification and Nomenclature, 1902

Geologic Maps of North America, 1906-13

Scheme for rating credit on maps, 1907

Proposed geologic maps of U. S., 1907

1:1,000,000 maps, 1909-10, 1914-15

Maps, 1907-15

Records of Millionth Map Committee, 1907-16

Geological Society of America, 1901-15

International Geological Congress, 1902-3

12th International Geological Congress, 1910-13

13th International Geological Congress, 1914

Irving, John D., 1903-15

Cooperation with the State of California, 1902

Manuscript - "The Pleistocene of Michigan and Indiana" and other manuscripts, 1903-15

Davis, William M., 1907-13

Weeks, Fred B., 1905-9

Michigan - Cooperation, 1903-14

Passaic Folio, 1903-4

McCallie, Samuel W., 1908-15

Lane, Alfred C., 1903-14

Landes, Henry, 1904-14

Van Hise, Charles R., 1903

"Louisiana Purchase" (St. Louis Exposition), 1903

Carnegie Institution, 1903-4

Arnold, Ralph, 1903-14

Photographic work, 1903-15

Bureau of Mines, 1903-15

Cooperative Agreements - Bureau of Mines, 1913-15

Coal analysis - Bureau of Mines, 1915

Oil and gas analysis - Bureau of Mines, 1915

Shale - Bureau of Mines, 1914-15

Kindale, Edward M., 1904-14

Rizer, Henry C., 1903-8

Rickard, Thomas A., 1904-11

Iddings, Joseph P., 1904, 1914

Beede, Joshua W., 1902, 1915

Alden, William C., 1903-15

Cooperation - General, 1912-15

Pennsylvania Topographic and Geologic Survey Commission, 1901-15 


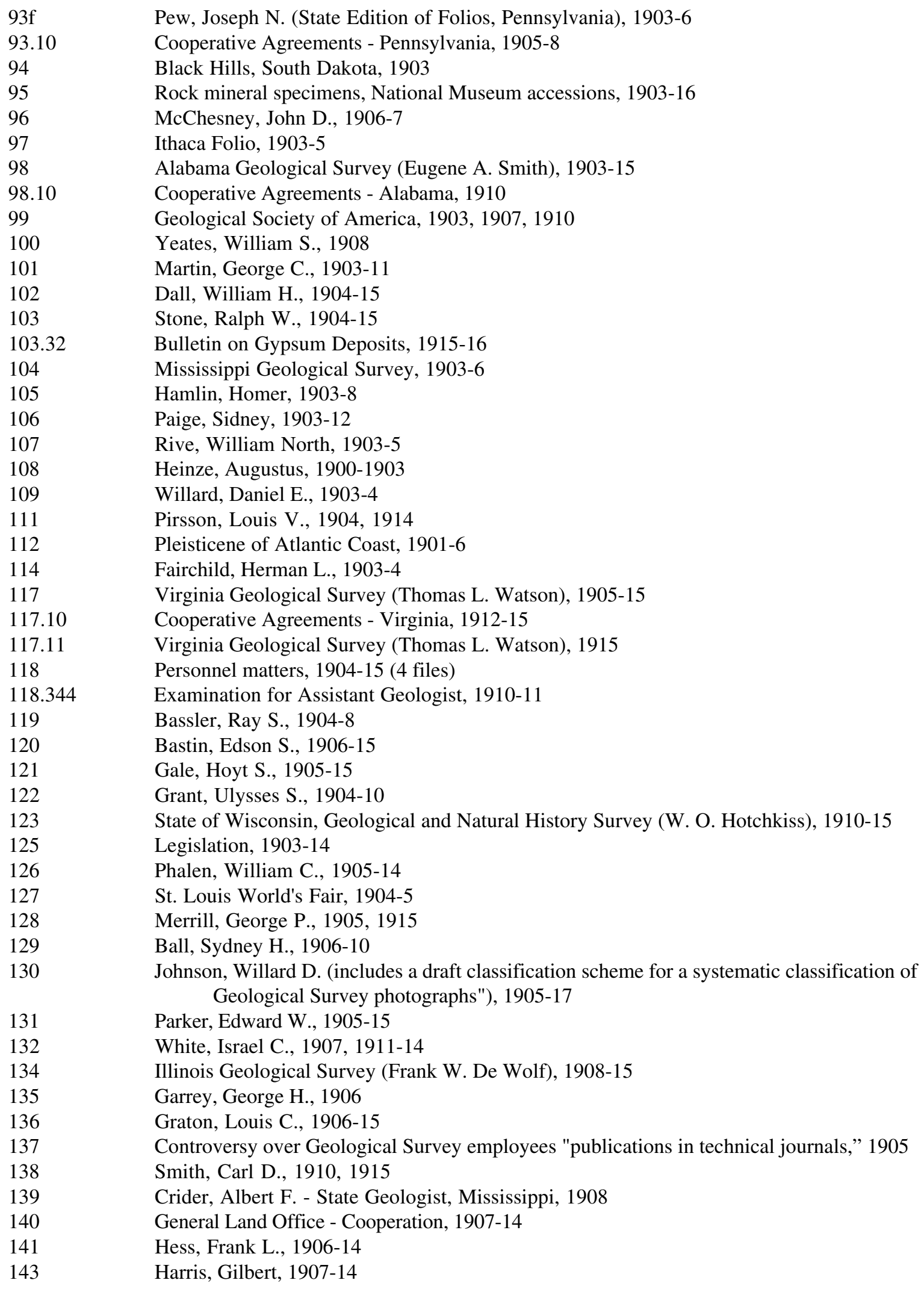

Pew, Joseph N. (State Edition of Folios, Pennsylvania), 1903-6

Cooperative Agreements - Pennsylvania, 1905-8

Black Hills, South Dakota, 1903

Rock mineral specimens, National Museum accessions, 1903-16

McChesney, John D., 1906-7

Ithaca Folio, 1903-5

Alabama Geological Survey (Eugene A. Smith), 1903-15

Cooperative Agreements - Alabama, 1910

Geological Society of America, 1903, 1907, 1910

Yeates, William S., 1908

Martin, George C., 1903-11

Dall, William H., 1904-15

Stone, Ralph W., 1904-15

Bulletin on Gypsum Deposits, 1915-16

Mississippi Geological Survey, 1903-6

Hamlin, Homer, 1903-8

Paige, Sidney, 1903-12

Rive, William North, 1903-5

Heinze, Augustus, 1900-1903

Willard, Daniel E., 1903-4

Pirsson, Louis V., 1904, 1914

Pleisticene of Atlantic Coast, 1901-6

Fairchild, Herman L., 1903-4

Virginia Geological Survey (Thomas L. Watson), 1905-15

Cooperative Agreements - Virginia, 1912-15

Virginia Geological Survey (Thomas L. Watson), 1915

Personnel matters, 1904-15 (4 files)

Examination for Assistant Geologist, 1910-11

Bassler, Ray S., 1904-8

Bastin, Edson S., 1906-15

Gale, Hoyt S., 1905-15

Grant, Ulysses S., 1904-10

State of Wisconsin, Geological and Natural History Survey (W. O. Hotchkiss), 1910-15

Legislation, 1903-14

Phalen, William C., 1905-14

St. Louis World's Fair, 1904-5

Merrill, George P., 1905, 1915

Ball, Sydney H., 1906-10

Johnson, Willard D. (includes a draft classification scheme for a systematic classification of Geological Survey photographs"), 1905-17

Parker, Edward W., 1905-15

White, Israel C., 1907, 1911-14

Illinois Geological Survey (Frank W. De Wolf), 1908-15

Garrey, George H., 1906

Graton, Louis C., 1906-15

Controversy over Geological Survey employees "publications in technical journals," 1905

Smith, Carl D., 1910, 1915

Crider, Albert F. - State Geologist, Mississippi, 1908

General Land Office - Cooperation, 1907-14

Hess, Frank L., 1906-14

Harris, Gilbert, 1907-14 
Pratt, Joseph Hyde - North Carolina Geological and Economic Survey, 1907-13

Rathbun, Richard, 1906-15

Clarke, Frank W., 1906-10

Douglas, Edward M., 1906

Fisher, Cassius A., 1906-13

MacDonald, Donald F., 1911-14

Schultz, Alfred R., 1907-13

Coal Land Classification Work, 1906-15

Lines, Edwin F., 1908

Conference of State Geologists held in New York, 1906

Conference of State Geologists - discussion prompted by 1906 meeting, 1906-7

Geological Consulting Board, 1907

Conference of State Geologists held in Washington, D.C., 1907-8

Collection of deep well statistics, 1907-14 (2 files)

Program for Meeting of State Geologists in Washington, D.C., 1908

Proposed Conference of State Geologists to be held in Washington, D.C., 1910

State geologic surveys, 1909-10

Conference of State Geologists, 1911

Resolution of the Association for American State Geologists, 1912

Association of American State Geologists Meeting, 1914

Conference of State Geologists, 1915

Emmons, William H., 1907-13

Gordon, Charles H., 1908-13

McCaskey, Hiram D., 1907

Sterritt, Douglas B., 1906-8

South Dakota (Ellwood C. Perisho), 1907-10

Ground water investigations, 1906-14

Matson, George C., 1907-15

Blackwelder, Eliot, 1907-15

Van Horn, Frank B., 1907-12

Johannsen, Albert, 1907-13

Ball, Max W., 1915

Kramer, H. L., 1910

Analysis of oil and gas samples, 1913-14

Rich, John L., 1907-14

Shaw, Eugene W., 1910-15

Examination of mineral claims and resources in National Forests, 1907-15

Gardner, James H., 1907-15

Harder, Edmund C., 1907-14

Calvert, W. R., 1908-14

Smith, E. Eggleston, 1907-8

Orders, circulars, etc., 1907-10

Washburn, Chester W., 1909-14

Barnett, V. H., 1913

Stephenson, Lloyd W., 1913

Land Classification Board, 1908-14

Classification reports, 1914

National Conservation Commission, 1908-9

Analysis of rock samples taken near Harve, Montana, 1906-9

Woodruff, Elmer G., 1909-15

Reed, W. J., 1909 
194

195

196

197

198

199

200.1

200.5

200.10

200.17

200.30

200.35

200.40

200.43

200.44

200.50

200.55

200.60

200.61

200.62

200.66

200.65

200.67

200.68

200.70

200.71

200.75

200.76

200.77

200.85

200.90

200.94

200.99

201.1

202

203

204

217

219

220

221

222

223

224

225

225

226

228

229

230

231

Requests for geological work, 1908-10

California oil investigation, 1909-15

Breger, Carpel L., 1909-14

Goldman, Marcus I., 1909-14

Munn, Malcolm J., 1908-15

Butler, Burt S., 1908-14

Bureau of Indian Affairs, General, 1911-14

Bureau of Indian Affairs, Accounts, 1908-15

Colorado River Indian Reservation, 1914

Navajo Indian Reservation, 1912-13

Fort Hall Indian Reservation, 1911-14

Bois Fort Indian Reservation, Minnesota, 1911

Blackfeet Indian Reservation, 1911-12

Flathead Indian Reservation, 1911-15

Fort Peck Indian Reservation, 1908-11

Zuni Indian Reservation, 1912-14

Eastern Cherokee Reservation, 1909

Fort Berthold Indian Reservation, 1910-12

Standing Rock and Cheyenne River Indian Reservations, 1908-9

Sully's Hill National Park, 1913-14

Five Civilized Tribes (manganese deposits in McCurtin County), 1912

Oklahoma - General, 1911-15

Pawnee, Kaw, Otoe, Ponca, and Tonkawa Indian Reservation, 1912

Albion, Pushmataha County (examination of reported gold deposits), 1912-13

Choctaw Nation, 1912-13

Osage Nation, 1915

Klamath Indian Reservation, 1912-13

Umatilla Indian Reservation, 1911-12

Warm Springs, 1911-12

Colville Indian Reservation, 1912-14

Quenault Indian Reservation, 1913

Yakima Indian Reservation, 1912-13

Shoshone or Wind River Indian Reservation, 1909-13

Davis, John Allen, 1909

Alaska-Yukon Pacific Exposition, 1909

Bownocker, John A., 1912-15

Bancroft, Howland, 1911-14

Sloan, Earle - South Carolina State Geologist, 1910-15

Noble, Levi F., 1910-15

Tennessee Geological Survey, 1910-15

Tolman, Cyrus F., 1909-15

Larsen, Jr., Esper S., 1910, 1915

Pardee, Joseph T., 1912-13

Northern Pacific Railroad Land Grants, Classification of, 1910-14

Section of Non-metalliferous Ores and Iron - F. B. Van Horn, 1910-11

Section of Non-metalliferous Deposits, correspondence with Eliot Blackwelder, 1911-12

Berry, Edward W., 1910-15

Hill, James M., 1910,1913

Laney, Francis B., 1910-15

Prindle, Louis M., 1912-14

Kirk, Edwin, 1911-14 
Department of Commerce, 1914

Coast and Geodetic Survey, 1911-12

Bureau of Foreign and Domestic Commerce, 1914

Secretary of the Interior, 1910-15

Week's Law, 1911-14

Investigation of Ferry Lake, Louisiana, 1913-15

Department of Justice, 1910-16

Investigation of California oil fields, 1914-15

Navy Department, 1913-15

Post Office Department, 1911-15

State Department, 1912-14

Treasury Department, 1912-14

War Department, 1911-15

Agriculture Department, 1913-14

Bureau of Soils, 1911-16

Bureau of Plant Industry, 1914-15

Office Public Roads, 1914

Weather Bureau, 1913-15

Potash Investigations, 1906-14

Potash Investigations - Hoyt S. Gale, 1914-15

Potash Investigations - James H. Hance, 1911-12

Potash Investigations - Richard B. Dole, 1912

Potash Investigations - Charles E. Watson, 1912-13

Potash Investigations - Marcus I. Goldman, 1914

Potash - David H. Walker, 1914

Potash - work, 1912-13

Potash - locations, 1913-14

Texas - locations for potash exploration, 1915

Utah - locations for potash exploration, 1915

Potash - progress, 1912-14

Potash - examination of areas by request of the public, 1912

Potash - new discoveries, 1915

Potash - drilling, 1912-14

Potash - bids for drilling, 1911-15

Potash - Smoke Creek Desert drilling, 1915

Potash - Cooperation - Bureau of Soils, 1912

Potash - Samples - Nevada, 1912

Potash - Information to the public relative to work, 1912-15

Potash - production, 1915

Potash - drilling outfit, 1911-15

Potash - Sample and specimens, 1912-15

Potash - Statements of Accounts, 1915

Potash - work, assistants, 1914-15

General, 1911-14

Montana, 1913-14

Maine, 1914

Missouri, 1911-15

Nevada, 1911-15

Alabama, 1911

Ohio, 1915

Arizona, 1915 


\begin{tabular}{|c|c|}
\hline 242.50 & Foreign, 1913-15 \\
\hline 242.53 & California, 1911-14 \\
\hline 242.53 & New York, 1915 \\
\hline 242.53 & Washington, 1913-14 \\
\hline 242.55 & Louisiana, 1911 \\
\hline 242.55 & Maryland, 1911-15 \\
\hline 242.55 & Oklahoma, 1914-15 \\
\hline 242.55 & Oregon, 1913-14 \\
\hline 242.55 & Texas, 1913-15 \\
\hline 242.55 & Utah, 1914-15 \\
\hline 242.70 & Minnesota, 1914-15 \\
\hline 242.78 & Mexico, 1909-12 \\
\hline 242.78 & New Mexico, 1915 \\
\hline 242.78 & Arizona, 1913 \\
\hline 242.80 & South Carolina, 1913 \\
\hline 242.80 & Illinois, 1911 \\
\hline 242.80 & Kentucky, 1912-13 \\
\hline 242.80 & Tennessee, 1909-12 \\
\hline 242.82 & South America - David White, 1914 \\
\hline 242.82 & Indiana, 1915 \\
\hline 242.90 & Nebraska, 1911-15 \\
\hline 242.122 & Mississippi, 1911-15 \\
\hline 242.142 & Michigan, 1915 \\
\hline 242.145 & Pennsylvania, 1912-15 \\
\hline 242.145 & West Virginia, 1912-13 \\
\hline 244 & Indexing Geologic Notebooks, 1910-14 \\
\hline 245 & Bureau of Standards, 1911-15 \\
\hline 246 & Manuscripts, 1912-15 \\
\hline 246.4 & Bulletin 624, "Useful Minerals of the U.S.", 1912-15 \\
\hline 247 & Glacier National Park, 1911-14 \\
\hline 248 & Articles of Agreement and Contracts, 1911-15 \\
\hline 249 & Panama Canal Zone, 1910-15 \\
\hline 250 & New building, 1910-15 \\
\hline 251 & Udden, J. A., 1913-15 \\
\hline 252 & Hance, James H., 1912-15 \\
\hline 254 & Mitchell, Guy E., 1911, 1914 \\
\hline 255 & Deussen, Alexander, 1911-14 \\
\hline 256 & Parks, Emerson M., 1911-15 \\
\hline 258 & Hewett, Donnel F., 1912-14 \\
\hline 259 & Miser, Hugh D., 1911-15 \\
\hline 260 & Hancock, Eugene T., 1914 \\
\hline 261 & Chief Geologist, 1911-13 \\
\hline 262 & Corey, H. V., 1910, 1912 \\
\hline 263 & Hill, H. L., 1912 \\
\hline 264 & Paleontologic work, 1911-12 \\
\hline 265 & Minnesota, William H. Emmons, 1912-15 \\
\hline 265.10 & Cooperative Agreements - Minnesota, 1911-15 \\
\hline 266 & Miller, Benjamin L., 1912-14 \\
\hline 267 & Costa Rica-Panama Boundary Arbitration, 1911-13 \\
\hline 268 & Umpleby, Joseph B., 1912-14 \\
\hline 269 & Knoph, Adolph, 1912-14 \\
\hline
\end{tabular}




\begin{tabular}{|c|c|}
\hline 270 & Pack, Robert W., 1912-15 \\
\hline 271 & Mansfield, George R., 1912-15 \\
\hline 272 & Finch, Elmer G., 1913-14 \\
\hline 274 & Richards, Ralph W., 1912-15 \\
\hline 275 & Loughlin, Gerald F., 1914 \\
\hline 276 & Rogers, G. Sherbourne, 1913-15 \\
\hline 277 & Bauer, Clyde Max, 1913-15 \\
\hline 278 & Hunter, J. Fred, 1914 \\
\hline 279 & Brock, R. W. (Canadian Geological Survey), 1913 \\
\hline 280 & Hares, Charles J., 1914 \\
\hline 281 & Oregon Bureau of Mines and Geology, 1913-14 \\
\hline 281.10 & Cooperative Agreements - Oregon, 1913 \\
\hline 282 & Beekly, Albert L., 1913-14 \\
\hline 283 & Wood, Robert H., 1913-15 \\
\hline 284 & Condit, D. Dale, 1913-15 \\
\hline 285 & Herald, Frank A., 1913 \\
\hline 286 & Pishel, Max A., 1913 \\
\hline 287 & Matthes, François E., 1913-14 \\
\hline 288 & Katz, Frank J., 1913 \\
\hline 289 & American Institute of Mining Engineers, 1913 \\
\hline 290 & Hollick, Arthur, 1913 \\
\hline 291 & Hinds, Henry, 1911-15 \\
\hline 292 & Davis, Charles A., 1913-14 \\
\hline 293 & Barrell, Joseph, 1914 \\
\hline 294 & Bowen, Charles F., 1913 \\
\hline 295 & Jones, Jr., Edward Le Roy J., 1914-15 \\
\hline 296 & Wagemann, Carroll H., 1913-15 \\
\hline 297 & Schaller, Waldeman T., 1913-15 \\
\hline 298 & Sardeson, Frederick W., 1913-15 \\
\hline 299 & Winchester, Dean E., 1913-15 \\
\hline 300 & Stebinger, Eugene, 1914 \\
\hline 301 & Barbour, Edwin H. (Nebraska Geological Survey), 1913-15 \\
\hline 302 & Iowa Geological Survey - George F. Kay, 1914 \\
\hline 303 & Lee, Wallace, 1913-15 \\
\hline 304 & Howell, Ralph W., 1914 \\
\hline 305 & Publications (geologic railway guidebooks), 1913-16 \\
\hline 306 & Lloyd, E. Russell, 1914 \\
\hline 307 & Westgate, Lewis G., 1914-15 \\
\hline 308 & Fath, Arthur E., 1914-15 \\
\hline 310 & Weldman, Samuel, 1914-15 \\
\hline 311 & Petrographic Laboratory, 1914-15 \\
\hline 312 & Bonine, Chesleigh A., 1914-16 \\
\hline 314 & Clark, Frank R., 1915 \\
\hline 315 & English, Walter A., 1914 \\
\hline 316 & Heald, Kenneth C., 1914-15 \\
\hline 317 & Halberstadt, Baird, 1915 \\
\hline 319 & Savage, Thomas E., 1915 \\
\hline 320 & Jenney, Walter P., 1915-16 \\
\hline 322 & Mills, R. V. A., 1915 \\
\hline 323 & Hopkins, Oliver B., 1915 \\
\hline 324 & Robinson, Heath M., 1915-16 \\
\hline
\end{tabular}




\begin{tabular}{|c|c|}
\hline 373.33 & Geologic Map of North America, 1906-7 \\
\hline 400 & Panama-Pacific Exposition, 1914-15 \\
\hline 401 & Second Pan-American Scientific Congress, 1909, 1914-15 \\
\hline 405 & National Academy of Sciences, 1914-15, 1918 \\
\hline 409.1 & Bureau of Mines - Garnet Corundum Property, 1918 \\
\hline 425 & Field Equipment Section, 1914-15 \\
\hline 428 & Joint Information Board on Minerals and Derivatives, 1918 \\
\hline 467 & Patoka Folio, 1902-3 \\
\hline 468 & Lawson, Andrew C., 1902-15 \\
\hline 469 & Veatch, Arthur C., 1902-8 \\
\hline 470 & Hayes, C. Willard, 1902-15 \\
\hline 471 & Brown, Charles W., 1902-12 \\
\hline 472 & Warman, P. C. 1902-6 \\
\hline 473 & Instructions and plans for geologic work, 1903 \\
\hline 474 & St. Louis Exposition, 1902-6 \\
\hline 475 & Lists of State Geologists, 1902 \\
\hline 476.2 & Oil Fields (statistics), 1891-1901 \\
\hline 478 & Geologic Map of North America, 1907-10 (2 files) \\
\hline 489 & Ransome, Frederick L., 1902-15 \\
\hline 490 & Bailey, Willis S., 1903-14 \\
\hline 491 & Girty, George H., 1902-14 \\
\hline 493 & Walcott, Charles D., 1900-1915 \\
\hline 494 & Missouri Bureau of Geology and Mines, H. A. Buehler, 1901-15 \\
\hline 494.10 & Cooperative Agreements - Missouri, 1910, 1913 \\
\hline 495 & Spurr, Josiah E., 1901-13 \\
\hline 497 & Clements, J. Morgan, 1902-6 \\
\hline 501 & Smith, James P., 1902-14 \\
\hline 503 & Fuller, Bryon L., 1902-12 \\
\hline 504 & Emerson, Benjamin K., 1902-14 \\
\hline 505 & Tight, William G., 1902-9 \\
\hline 506 & Daly, Reginald A., 1902-3, 1910 \\
\hline 507 & Darton, Nelson H., 1902-15 \\
\hline 509 & Diller, Joseph S., 1902-14 \\
\hline 512 & Eldridge, George H., 1902-6 \\
\hline 514 & Stanton, Timothy W., 1902-15 \\
\hline 515 & Prosser, Charles S., 1902-4 \\
\hline 516 & Newell, F. W., 1903-14 \\
\hline 517 & Well logs, 1909-11 \\
\hline 519 & Fossils, 1902-4 \\
\hline 520 & Glenn, Leonidas C., 1902-15 \\
\hline 522 & Cross, Whitman, 1903-14 \\
\hline 523 & Emmons, Samuel F., 1899-1909 \\
\hline 524 & Professor Alpheus Hyatt, 1902 \\
\hline 525 & Shattuck, George B., 1902 \\
\hline 527 & Eckel, Edwin C., 1902-11 \\
\hline 528 & Jaggar, Thomas A., 1902-3 \\
\hline 530 & Yosemite Folio, 1902-3 \\
\hline 533 & [Administrative and] Annual Reports, 1902-3 \\
\hline 534 & Adams, George I., 1902-12 \\
\hline 537 & Collier, Arthur J., 1902-15 \\
\hline 538 & Dale, T. Nelson, 1900-1906 (2 files) \\
\hline
\end{tabular}




\begin{tabular}{|c|c|}
\hline 542 & Brownsville-Connellsville, Pennsylvania, Folio, 1902 \\
\hline 543 & New Jersey, 1902-8 \\
\hline 544 & Columbia Folio, 1903 \\
\hline 545 & Tioga-Elkland, 1903 \\
\hline 547 & Gaines Folio of Pennsylvania, 1902 \\
\hline 549 & Gilbert, Grove K., 1902-13 \\
\hline 550 & Keith, Arthur, 1902-15 \\
\hline 551 & Knight, Wilbur C., 1902-4 \\
\hline 552 & Kemp, James F., 1902-9 \\
\hline 553 & Hobbs, William H., 1902-15 \\
\hline 555 & Weller, Stuart, 1905, 1913-15 \\
\hline 556 & Moffit, Fred H., 1902-3 \\
\hline 557 & Leith, Charles K., 1902-15 \\
\hline 558 & Calkins, Frank C., 1902-15 \\
\hline 559 & Lewis, J. Volney, 1902-8 \\
\hline 560 & Atwood, Wallace W., 1902-15 \\
\hline 561 & Taff, Joseph A., 1902-3 \\
\hline 563 & Ries, Heinrich, 1902 \\
\hline 564 & Salisbury, Rollin D., 1902-15 \\
\hline 565 & Taff, Joseph A., 1902-14 \\
\hline 566 & Smith, George Otis, 1902-11 \\
\hline 567 & White, David, 1902-15 \\
\hline 568 & Ward, Lester F., 1897-1908 \\
\hline 570 & Bain, H. Foster, 1903-9 \\
\hline 571 & Becker, George F., 1902-15 \\
\hline 572 & Woolsey, Lester H., 1902-8 \\
\hline 573 & Wolff, John E., 1902-4, 1916 \\
\hline 574 & Spencer, Arthur C., 1902-15 \\
\hline 575 & Siebenthal, Claude E., 1902-15 \\
\hline 576 & Geologic Map of the United States, 1902-5, 1908-15 (2 files) \\
\hline- & Geologic Atlas of the United States, n.d. (3 files) \\
\hline 576.31 & Correspondence on suggested changes in folios, 1906 \\
\hline 577 & Renshawe, John M., 1902 \\
\hline 578 & Arkansas Geological Survey - A. H. Purdue and N. F. Drake, 1902-15 \\
\hline 579 & Committee on Geologic Classification and Nomenclature, 1902-15 \\
\hline 580 & Calhoun, Fred H. H., 1903-6 \\
\hline 581 & Indiana, Pennsylvania, Folio, 1902 \\
\hline 582 & Peck, Frederick B., 1902-8 \\
\hline 583 & Osborn, Henry F., 1902-15 \\
\hline 585 & La Forge, Laurence, 1902-15 \\
\hline 587 & Turner, Henry W., 1901-5, 1913-16 \\
\hline 588 & Campbell, Marius R., 1902-15 \\
\hline 589 & Butts, Charles, 1902-15 (2 files) \\
\hline 593 & Griswold, William T., 1902-14 \\
\hline 594 & Knowlton, Frank W., 1902-14 \\
\hline 595 & Publications, $1902-15$ \\
\hline 595.10 & Permission to publish outside of the Survey, 1914-15 \\
\hline 595.20 & "Contributions to General Geology", 1913-15 \\
\hline 597 & Stein, Robert, 1902 \\
\hline 598 & Taylor, Frank B., 1902-15 \\
\hline 599 & Devonian Paleontology, 1902-15 \\
\hline
\end{tabular}




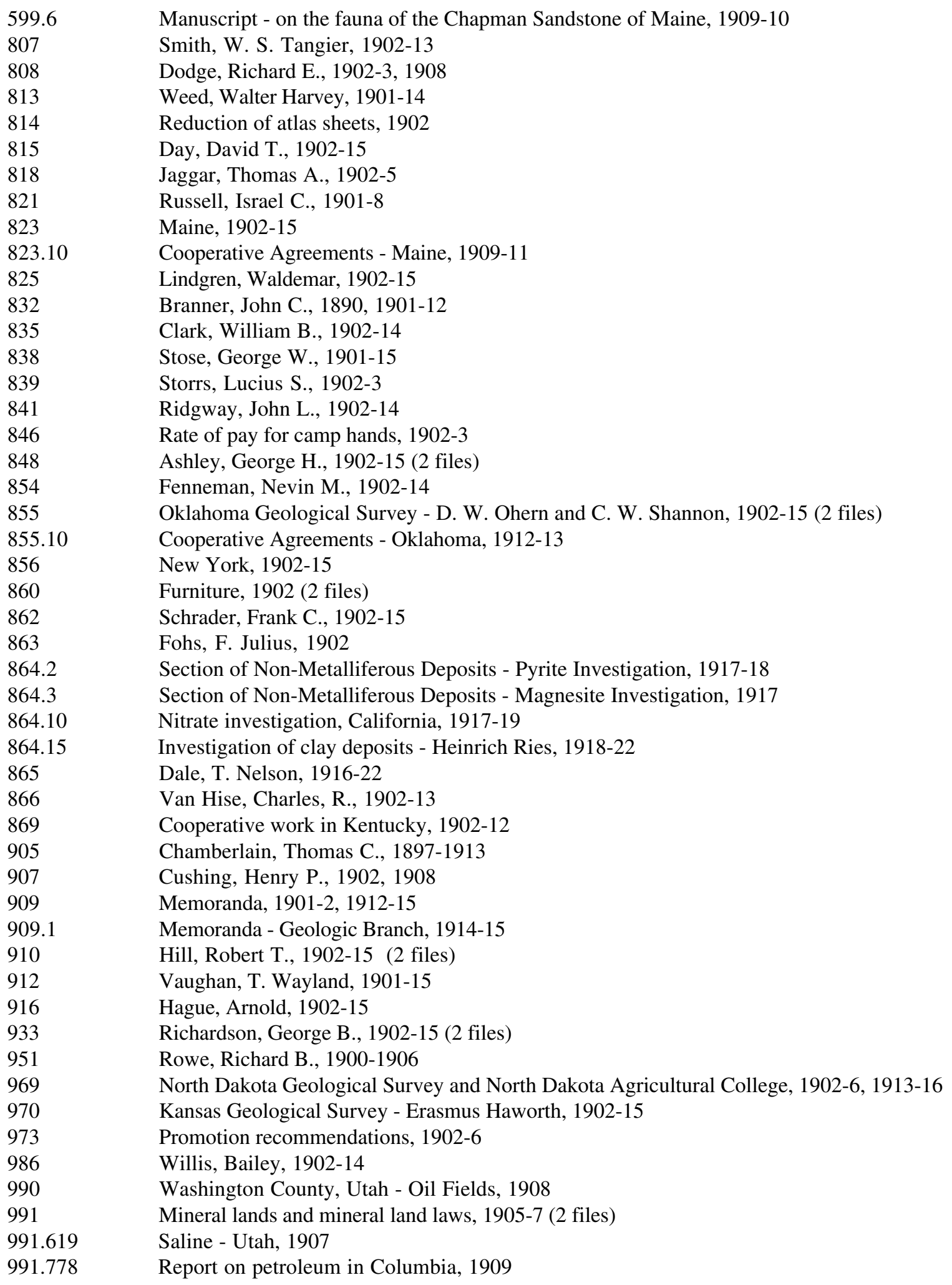




\section{Appendix 9}

Geologic Division - General Correspondence Files, 1899-1952 (entry 160)

004

004

004

0011

0012

020

020.4

020.5

025

025

026

060

061

061

061.5

061.51

061.6

061.61

061.62

061.620

061.63

061.64

061.66

062

062.6

065

066

066.4

067.1

067.2

---

070

0071

072

072.8

075

083

085

100.01

100.01

100.1

100.2
General and Miscellaneous (regarding committees, patents, property, monthly and annual reports, directives, and memorandums)

Organization, 1945-52

Fiftieth Anniversary of Geological Survey

Assignment of rooms, windows, floors, etc.

Space requirements

Survey representatives on committees, 1918-52

Committee on Geologic Time Scale

Coal Classification Committee

Committee on Stratigraphic Nomenclature

Recommendation of Committee on Geologic Names for adaptation of term Paleocene as a series and epoch term

Patents

Property - General

Field property - General

Committee on Geologic Names

Field property - Loan of

Field equipment - requests for repairs

Automobiles

Automobiles - Authority to purchase

Cost of upkeep

Statements - Automobile expenses

Authority to use personal car

Automobile accidents (2 files)

Vessel SS Eider (2 files)

Office Property

Typewriters and Dictaphones (2 files)

Telephones

Shipments - General

Shipment - Household Goods

Leases

Automobile storage (6 files)

Requests for personnel and specimen facilities; proposals to build new space; reports on storage space (3 files)

Annual report of Geologic Branch for fiscal year ended June 30, 1932

Annual reports of Geologic Branch, fiscal years 1933-35, 1937-40, 1943-45

Monthly reports, 1916-29

Monthly reports, Mineral Resources, 1916-25

Headquarters of Employees

Orders and Memorandums, 1937-40

Federal Employee Organizations

Memorandums to Boteler

Establishment of Positions (4 files)

Vacancies (3 files)

Employment Bulletins 


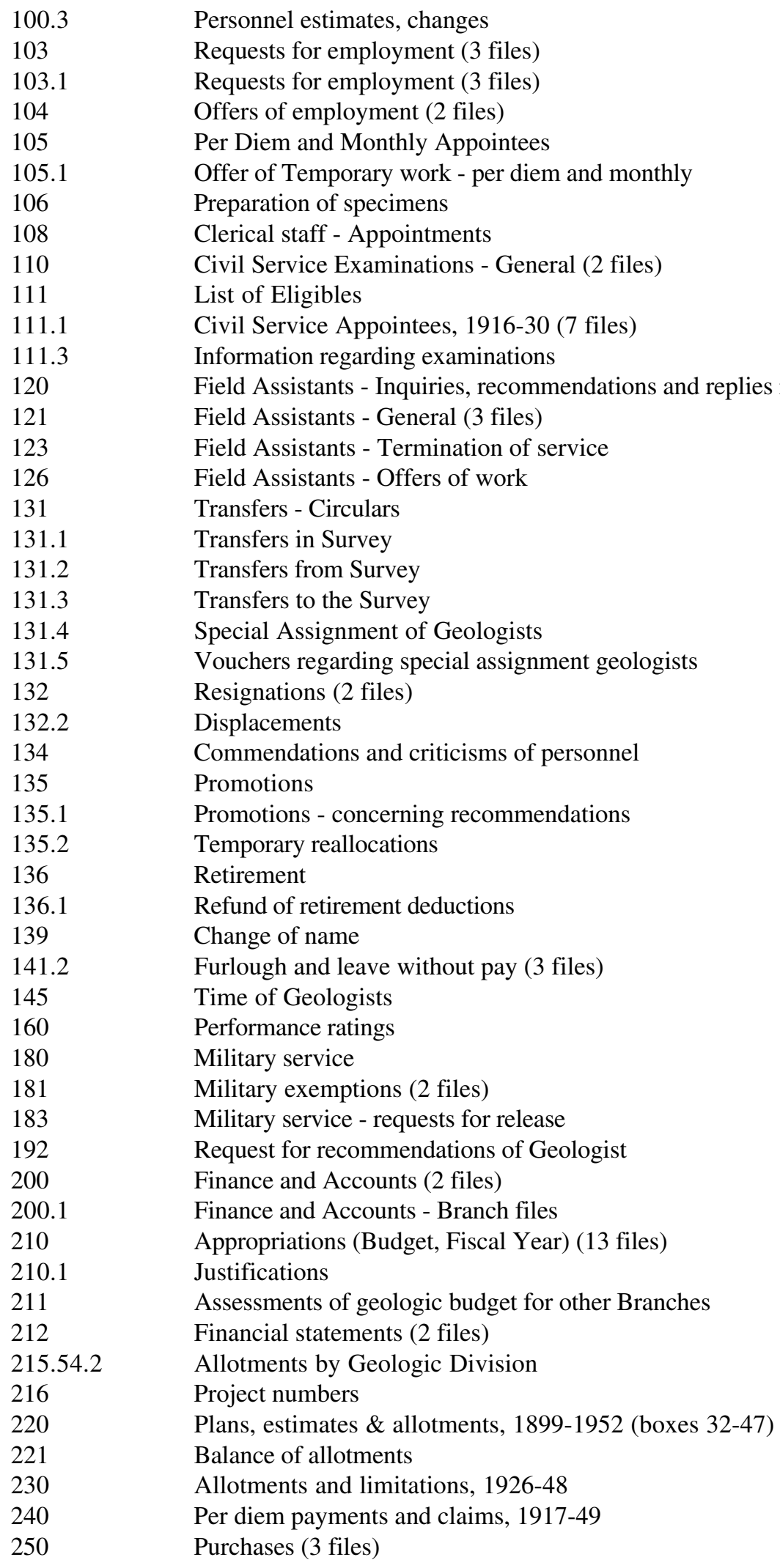




\begin{tabular}{|c|c|}
\hline 250.1 & Requests for quotations \\
\hline 250.2 & Defense order ratings \\
\hline 250.2 & Memorandum to Purchasing Officer \\
\hline 251.01 & Request for pictures taken from the air ( 2 files) \\
\hline 252 & Authority to purchase; preference ratings; priorities \\
\hline 254 & Contracts ( 2 files) \\
\hline 254.1 & Oil and gas contracts and purchases \\
\hline 260 & Employees Compensation Act (5 files) \\
\hline 270 & Accounts - General, 1916-42, 1949-52 (2 files) \\
\hline 270.1 & Adjustment of Accounts ( 2 files) \\
\hline 270.2 & Loans to Field Men \\
\hline 270.3 & Retirement Assessments \\
\hline 270.4 & Accounts - Disallowances \\
\hline 270.5 & Oil \& Gas Tax exemption \\
\hline 270.6 & Expenses incurred outside of the United States \\
\hline 270.06 & Application and authorization for allotments - men employed outside of United States \\
\hline 270.9 & Vouchers (3 files) \\
\hline 270.10 & Public vouchers \\
\hline 271 & Personal salaries and accounts, 1917-30, 1944-54 (boxes 53-54) \\
\hline 271.4 & Overtime - general \\
\hline 271.4 & Overtime - Alaska \\
\hline 274 & Transportation requests ( 3 files) \\
\hline 274.1 & Travel orders (2 files) \\
\hline 274.2 & Travel outside of the United States; travel by aircraft \\
\hline 279 & Reimbursement by other Branches \\
\hline 310.1 & Criticism of Survey publications, 1914-29 (2 files) \\
\hline 316 & Criticism of Geologic Folios, 1912-23 \\
\hline 321 & Manuscripts submitted for Survey publications, 1910-44 (boxes 57-58) \\
\hline 321 & Requests for Survey publications by outside organizations, 1949 \\
\hline 329 & Manuscripts submitted by outsiders for Survey publication, 1916-21 \\
\hline 330 & Publication of maps \\
\hline 333 & Prices of Geological Survey map publications \\
\hline 335 & Maps - Special Geologic and Economic \\
\hline 335.1 & Oil and Gas Investigation Series, 1916-49 \\
\hline 340 & Press bulletins, 1916-49 \\
\hline 350 & Service Book, 1925 \\
\hline 401 & White House - Executive Orders, 1919-49 (2 files) \\
\hline 401.1 & Coordinator of Inter-American affairs \\
\hline 402 & State Department - General, 1919-44, 1948-49 (3 files) \\
\hline 402.01 & Cooperation with Economic Cooperation Administrations in other countries \\
\hline 402.3 & $\begin{array}{l}\text { Correspondence with foreign embassies regarding Geological Survey overseas personnel and projects, } \\
\qquad 1916-40\end{array}$ \\
\hline 402.5 & Passport and Visa requests, $1919-49$ \\
\hline 403 & Treasury Department - General \\
\hline 403.01 & Treasury Department - Division of Disbursement (2 files) \\
\hline 403.2 & Internal Revenue \\
\hline 403.3 & Bureau of the Budget. 1922-49 (2 files) \\
\hline 403.31 & Bureau of the Budget - manpower ceiling (boxes 63-64) \\
\hline 403.4 & U.S. Public Health Service, 1917-49 \\
\hline 403.5 & Commission of Customs \\
\hline 403.6 & Treasury - Bureau of the Mint \\
\hline
\end{tabular}




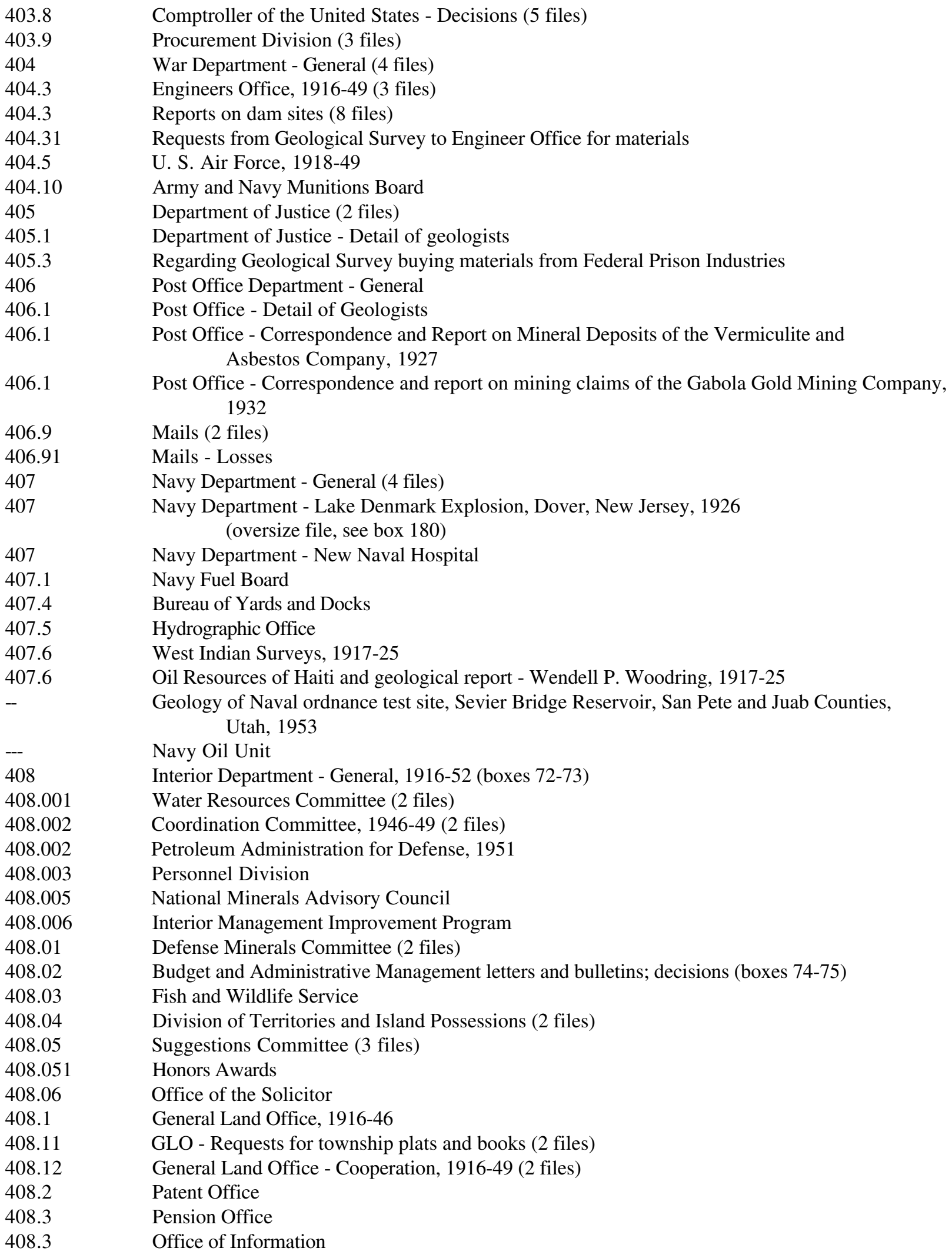




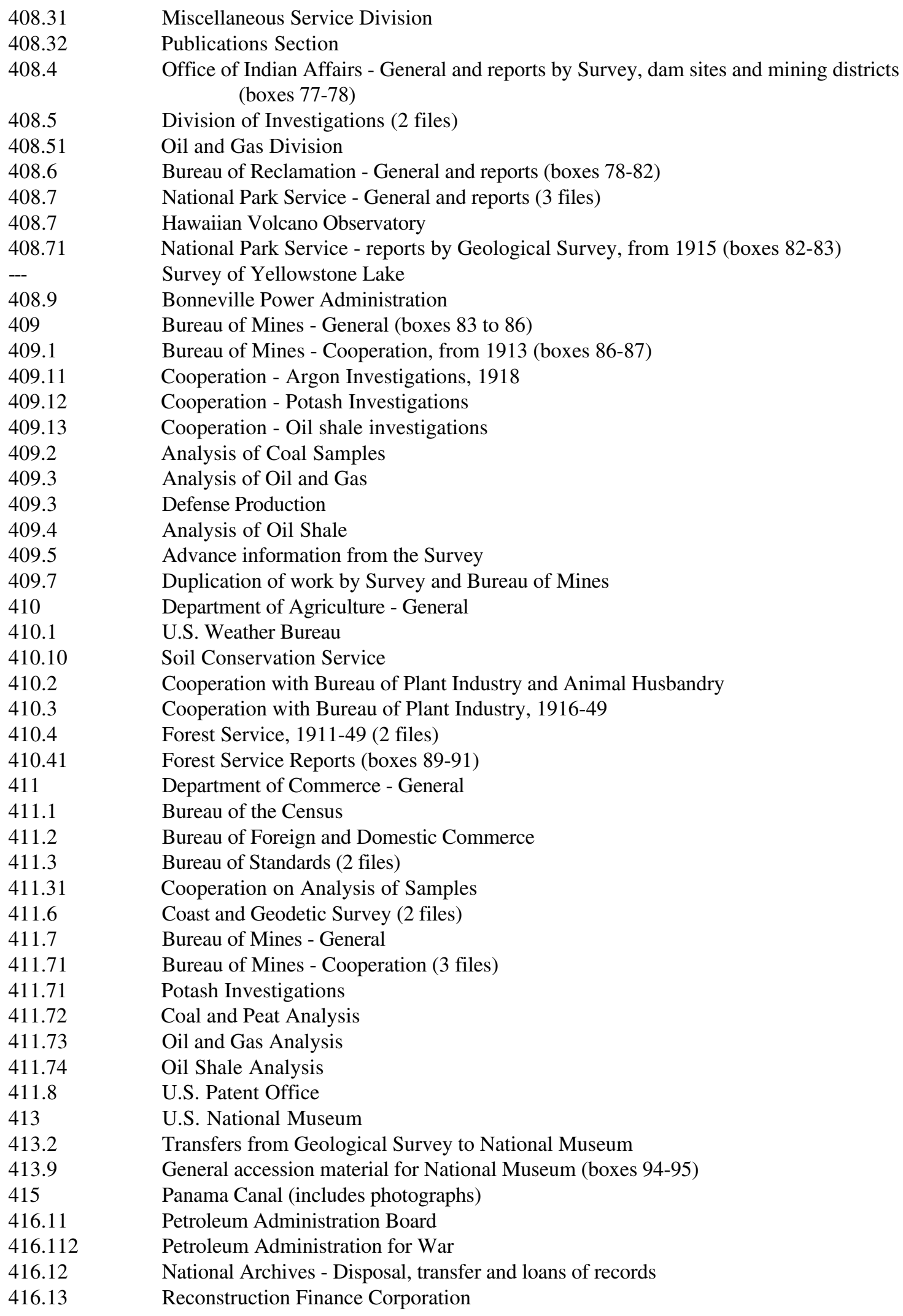




\begin{tabular}{|c|c|}
\hline 416.131 & Defense Plant Corporation (2 files) \\
\hline 416.132 & Metals Reserves Company (2 files) \\
\hline 416.133 & Colonial Mica Corporation \\
\hline 416.2 & Interstate Commerce Commission - Railroads \\
\hline 416.3 & Federal Trade Commission \\
\hline 416.5 & United States Board on Geographic Names \\
\hline 416.7 & Government Printing Office \\
\hline 416.8 & Public Buildings Administration \\
\hline 417.1 & Commission of Fine Arts \\
\hline 417.2 & United States Tariff Commission \\
\hline 417.3 & United States Coal Commission \\
\hline 417.4 & Federal Oil Conservation Board \\
\hline 417.5 & United States Civil Service Commission \\
\hline 417.8 & War Production Board (7 files) \\
\hline 417.9 & Joint Research and Development Board \\
\hline 417.91 & Plan for Aleutian Investigations \\
\hline 422 & Fuel Administration \\
\hline 423 & War Industries Board \\
\hline 425 & War Trade Board \\
\hline 426 & Director General of Railroads \\
\hline 427 & Room Registration Office \\
\hline 428 & Joint Information Board, Minerals and Derivatives \\
\hline 429 & Alien Property Custodian \\
\hline 430 & Capital Issues Committee \\
\hline 436 & Public Works \\
\hline 438 & Tennessee Valley Authority (2 files) \\
\hline 439 & National Resources Board \\
\hline 440.2 & Letters to Congressmen regarding work in the States ( 3 files) \\
\hline 441 & Missouri Valley Authority \\
\hline 442 & Missouri Basin Interagency Commission (2 files) \\
\hline 442.1 & Missouri Basin Administration Reports \\
\hline 450 & Council of National Defense \\
\hline 450.1 & Transportation Committee \\
\hline 450.2 & Committee on Fertilizers \\
\hline 451 & Council of National Defense - Cooperation \\
\hline 451.1 & Cooperation with Council of National Defense \\
\hline 452 & Council of National Defense - State Organizations ( 2 files) \\
\hline 453 & Council of National Defense - Committee on Fuels \\
\hline 460 & War Minerals Committee \\
\hline 460.1 & Subcommittee on Sulphur, pyrite, and manganese \\
\hline 461 & War Minerals Committee - Membership \\
\hline 470.1 & Federal Housing Administration \\
\hline 472 & Foreign Economic Administration (3 files) \\
\hline 477 & Office of Strategic Services \\
\hline 479 & War Assets Administration \\
\hline- & Committee for Cooperative Investigations Abroad \\
\hline- & Governmental Advisory Committee on Oceanography \\
\hline- & Lake Erie Project \\
\hline- & President's Scientific Research Board \\
\hline- & Pacific Southwest Field Committee \\
\hline 500 & Cooperation with and a list of State Geologists (2 files) \\
\hline
\end{tabular}




\begin{tabular}{|c|c|}
\hline 501 & Cooperation with Survey \\
\hline 510 & Alabama - General, 1916-49 \\
\hline 510.1 & Cooperative Agreements - Alabama \\
\hline 510.2 & Cooperative Projects - Alabama \\
\hline 510.6 & Accounts and Disbursements for Cooperative Work - Alabama \\
\hline 511 & Cooperative Projects - Arizona \\
\hline 511.2 & Cooperation - Arizona, Bureau of Mines \\
\hline 512 & Cooperation - Arkansas \\
\hline 513 & California - General \\
\hline 513.2 & Cooperation - California (3 files) \\
\hline 513.6 & Accounts and Disbursements for Cooperative Work - California \\
\hline 514 & Colorado - General \\
\hline 514.2 & Colorado - Cooperation (2 files) \\
\hline 514.6 & Accounts and Disbursements for Cooperative Work - Colorado \\
\hline 515 & Connecticut - General \\
\hline 515.2 & Cooperation - Connecticut \\
\hline 516 & Florida - General \\
\hline 516.2 & Correspondence re: report on the Mollusks of the Choctawhatchee Formation \\
\hline 516.2 & Revision of Report on Geology and Water Resources of Florida \\
\hline 516.2 & State Map of Florida \\
\hline 516.2 & Cooperation - Florida \\
\hline 516.6 & Accounts and Disbursements on Account Cooperation - Florida \\
\hline 516.6 & Agreements - Florida \\
\hline 516.9 & State Reports \\
\hline 517 & Georgia - General, 1913-49 \\
\hline 517.1 & Cooperative Agreements - Georgia \\
\hline 517.2 & Cooperation - Georgia, 1915-45 \\
\hline 517.2 & Physical Features of Georgia - proposed report \\
\hline 517.6 & Accounts and Disbursements on Account Cooperation - Georgia \\
\hline 517.9 & State Reports - Georgia \\
\hline 519.2 & Cooperation - Idaho \\
\hline 519.2 & Oil Investigations - Idaho \\
\hline 519.2 & Umpleby's work on ore deposits - Idaho \\
\hline 519.9 & State Reports - Idaho \\
\hline 519.9 & Seven Devils Region \\
\hline 520 & Illinois - General \\
\hline 520.1 & Agreements re: cooperative work - Illinois \\
\hline 520.2 & Cooperation - Illinois (includes separate files on various projects) \\
\hline 520.6 & Accounts and Disbursements on Account, Cooperation - Illinois \\
\hline 520.9 & State Reports - Illinois \\
\hline 521 & Indiana - General \\
\hline 521.2 & Cooperation - Indiana \\
\hline 521.6 & Accounts and Disbursements on Account Cooperation - Indiana \\
\hline 521.9 & State Publications - Indiana \\
\hline 522.1 & Cooperative Agreements - Iowa \\
\hline 522.9 & State Reports - Iowa \\
\hline 523 & Kansas - General \\
\hline 523.1 & Cooperative Agreements - Kansas \\
\hline 523.2 & Cooperation - Kansas (includes separate files for various projects) \\
\hline 523.6 & Accounts and Disbursements on Account Cooperation - Kansas \\
\hline 523.9 & State Reports - Kansas \\
\hline
\end{tabular}


Kentucky - General

Cooperative Agreements - Mississippian Investigations

Cooperation - Kansas (includes separate files on various projects) Accounts and Disbursements on Account Cooperation - Kentucky

State Reports - Kentucky

Cooperation - Louisiana

State Reports - Louisiana

Maryland - General

Cooperative Agreements - Maryland

Cooperation - Maryland

Accounts and Disbursements - Maryland

Michigan - General (2 files)

Cooperative Agreements - Michigan

Cooperation - Michigan (2 files)

Accounts and Disbursements - Michigan

Minnesota - General

Cooperative Agreements

Cooperation - Minnesota

State Reports - Minnesota

Mississippi - General

State Reports - Mississippi

Missouri - General (2 files)

Cooperation - Missouri

Accounts and Disbursements - Missouri

State Reports - Missouri

Montana - General

Cooperation - Montana

Accounts - Montana

Nebraska - General

State Report - Nebraska

Nevada - General

Cooperation - Nevada (2 files)

New Jersey - General

Cooperative Agreements - New Jersey

Cooperation - New Jersey

Accounts and Disbursements - New Jersey

New Mexico - General (2 files)

Cooperative Agreements - New Mexico

Cooperation - New Mexico (3 files)

Accounts and Disbursements - New Mexico

State Reports - New Mexico

New York - General

Cooperation - New York

North Carolina - General

Cooperative Agreements - North Carolina

Cooperation - North Carolina (3 files)

Accounts and Disbursements - North Carolina

North Dakota - General

Cooperation - North Dakota

Ohio - General

Cooperation - Ohio 


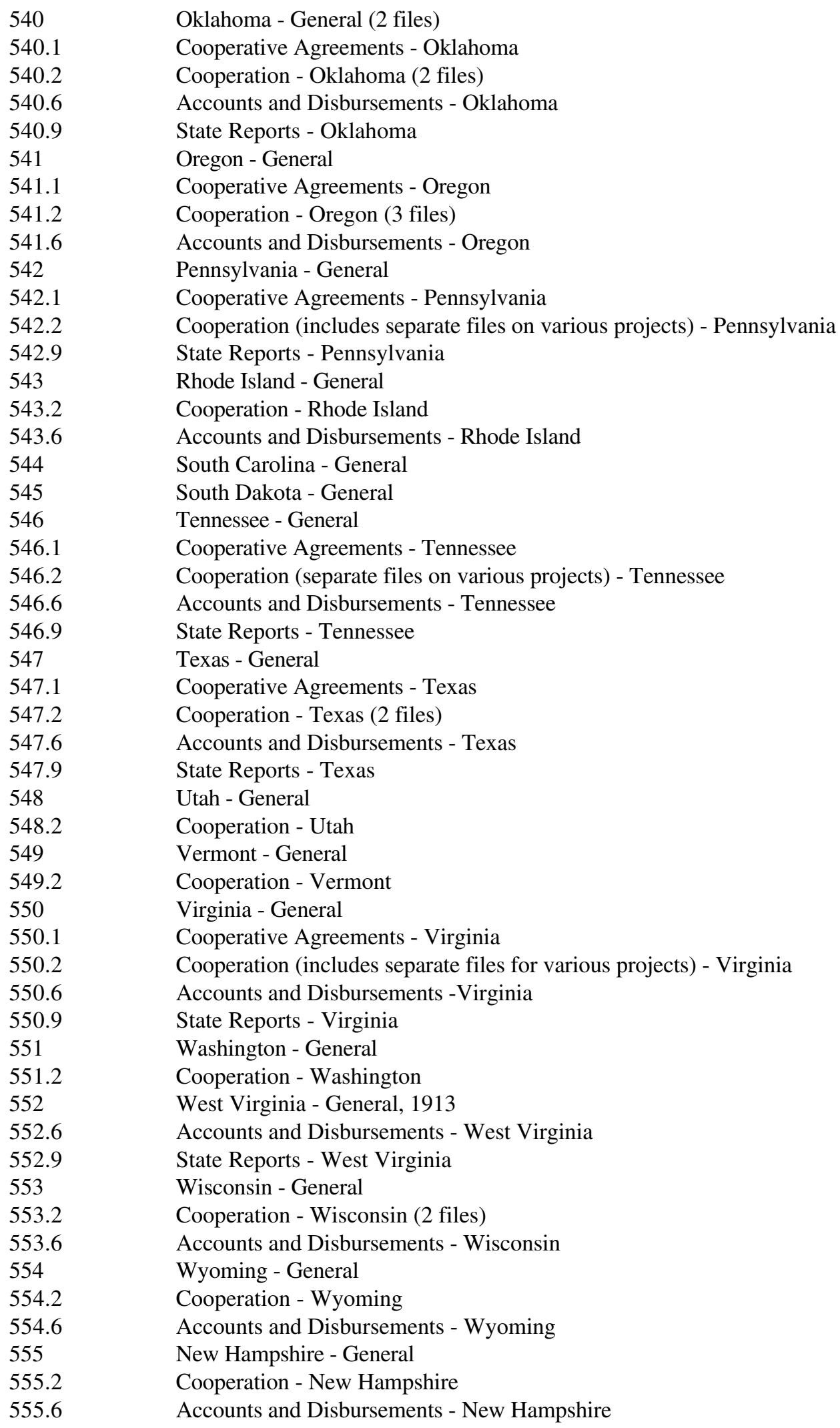

Oklahoma - General (2 files)

Cooperative Agreements - Oklahoma

Cooperation - Oklahoma (2 files)

Accounts and Disbursements - Oklahoma

State Reports - Oklahoma

Oregon - General

Cooperative Agreements - Oregon

Cooperation - Oregon (3 files)

Accounts and Disbursements - Oregon

Pennsylvania - General

Cooperative Agreements - Pennsylvania

Cooperation (includes separate files on various projects) - Pennsylvania

State Reports - Pennsylvania

Rhode Island - General

Cooperation - Rhode Island

Accounts and Disbursements - Rhode Island

South Carolina - General

South Dakota - General

Tennessee - General

Cooperative Agreements - Tennessee

Cooperation (separate files on various projects) - Tennessee

Accounts and Disbursements - Tennessee

State Reports - Tennessee

Texas - General

Cooperative Agreements - Texas

Cooperation - Texas (2 files)

Accounts and Disbursements - Texas

State Reports - Texas

Utah - General

Cooperation - Utah

Vermont - General

Cooperation - Vermont

Virginia - General

Cooperative Agreements - Virginia

Cooperation (includes separate files for various projects) - Virginia

Accounts and Disbursements -Virginia

State Reports - Virginia

Washington - General

Cooperation - Washington

West Virginia - General, 1913

Accounts and Disbursements - West Virginia

State Reports - West Virginia

Wisconsin - General

Cooperation - Wisconsin (2 files)

Accounts and Disbursements - Wisconsin

Wyoming - General

Cooperation - Wyoming

Accounts and Disbursements - Wyoming

New Hampshire - General

Cooperation - New Hampshire

Accounts and Disbursements - New Hampshire 


\begin{tabular}{|c|c|}
\hline 556 & Maine - General \\
\hline 556.1 & Cooperative Agreements - Maine \\
\hline 556.2 & Cooperation - Maine \\
\hline 557 & Massachusetts - General \\
\hline 557.1 & Cooperative Agreements -Massachusetts \\
\hline 557.2 & Cooperation - Massachusetts (3 files) \\
\hline 557.6 & Accounts and Disbursements - Massachusetts \\
\hline 557.9 & State Reports - Massachusetts \\
\hline 601 & Acknowledgments of Courtesies \\
\hline 601.1 & Memorials \\
\hline 601.2 & Addresses \\
\hline 602 & Commendations \\
\hline 603 & Complaints and Criticisms \\
\hline 604 & Introductions and interviews \\
\hline 605 & Invitations and announcements \\
\hline 606 & Loan of Survey Materials \\
\hline 606.1 & Loans of negatives \\
\hline 606.2 & Loan of advance publications (2 files) \\
\hline 606.3 & Loan of specimens \\
\hline 606.4 & Loan and gifts from Survey for Exhibition Purposes \\
\hline 606.5 & Loans and gifts; Maps and publications (2 files) \\
\hline 606.51 & Requests for reprints of Survey publications \\
\hline 607 & Permission to use Survey material (2 files) \\
\hline 607.2 & Papers for outside publication \\
\hline 608.2 & Recommendations, schools and courses \\
\hline 608.21 & Lectures by Survey members \\
\hline 608.3 & Recommendations, textbooks, etc. \\
\hline 609 & Lawsuits, testimony by geologists ( 2 files) \\
\hline 610 & Examinations - general ( 2 files $)$ \\
\hline 611 & Requests for geologic surveys - mineral lands (2 files) \\
\hline 613 & Requests for geologic examination - potash \\
\hline 618 & Requests for geologic examinations - cooperation (2 files) \\
\hline 618.1 & Requests for geologic examination - cooperation with railroads \\
\hline 620 & Texas - geologic map \\
\hline 621 & Miscellaneous nonmetals \\
\hline 621.01 & Magnesite \\
\hline 621.02 & Asbestos (2 files) \\
\hline 621.04 & Talc and soapstone \\
\hline 621.1 & Abrasives \\
\hline 621.2 & Clays, sands, etc. \\
\hline 621.21 & Materials for optical purposes \\
\hline 621.22 & Glass sand \\
\hline 621.3 & Gems and precious stones (2 files) \\
\hline 621.4 & Graphite \\
\hline 621.5 & Gypsum \\
\hline 621.6 & Mica \\
\hline 621.7 & Salts \\
\hline 621.8 & Sulphur and pyrite \\
\hline 621.9 & Feldspar and fluorspar \\
\hline 622 & Building and road materials, miscellaneous \\
\hline 622.1 & Asphalt and ozoerite ( 2 files) \\
\hline
\end{tabular}




$\begin{array}{ll}622.2 & \text { Cement } \\ 622.3 & \text { Granites and Marbles } \\ 622.4 & \text { Limestone and sandstones } \\ 622.8 & \text { Slate } \\ 623 & \text { Fertilizers - general } \\ 623.1 & \text { Phosphate } \\ 623.2 & \text { Potash and nitrate (4 files) } \\ 624 & \text { Fuels } \\ 624.1 & \text { Coal (both U. S. and foreign) (boxes 135-136) } \\ 624.15 & \text { Requests for information } \\ 624.2 & \text { Petroleum and natural gas (boxes 136-137) } \\ 624.20 & \text { Oil and gas wells (2 files) } \\ 624.202 & \text { Helium gas } \\ 624.21 & \text { Oil shale (3 files) } \\ 624.211 & \text { Ichthyol } \\ 624.212 & \text { Oil sands } \\ 624.22 & \text { Value of geologic work to oil companies } \\ 624.23 & \text { Leasing oil lands (2 files) } \\ 624.24 & \text { Oil lands - instruments for locating (2 files) } \\ 624.25 & \text { Oil and gas companies (boxes 138-139) } \\ 624.251 & \text { Oil pipe lines } \\ 624.26 & \text { Textbooks on oil geology } \\ 624.261 & \text { Geologic maps; oil maps } \\ 624.27 & \text { Estimates of supply of petroleum (2 files) } \\ 624.29 & \text { Investments - oil, gas, and oil shale } \\ 624.3 & \text { Peat (2 files) } \\ 624.31 & \text { Use of sphagnum moss in surgical dressing } \\ 625 & \text { Metals - General (9 files) } \\ 625.01 & \text { Chromite (2 files) } \\ 625.02 & \text { Red Bole } \\ 625.03 & \text { Arsenic } \\ 625.1 & \text { Aluminum and bauxite } \\ 625.2 & \text { Copper (3 files) } \\ 625.3 & \text { Gold and silver (2 files) } \\ 625.4 & \text { Iron and manganese (9 files) } \\ 625.5 & \text { Lead and zinc } \\ 625.6 & \text { Platinum (2 files) } \\ 625.7 & \text { Quicksilver } \\ 625.8 & \text { Rare metals } \\ 626 & \text { Mines } \\ 626.1 & \text { Mining companies } \\ 626.2 & \text { Investment information requests } \\ 626.3 & \text { Placer mining } \\ 626.4 & \text { Prospecting } \\ 626.5 & \text { Rods, divining, etc. } \\ 626.8 & \text { Ore reserves } \\ 627 & \text { Scientific and Technical - General } \\ 627.02 & \text { Temperature (requests for information) } \\ 627.03 & \text { Sedimentation } \\ 627.1 & \text { Earthquakes and volcanos } \\ 627.1 & \\ & \end{array}$




$\begin{array}{ll}627.2 & \text { Glaciers } \\ 627.2 & \text { Glaciers, foreign } \\ 627.3 & \text { Paleontology } \\ 627.3 & \text { Paleontology - Alaska } \\ 627.3 & \text { Paleontology, foreign, A-Z (7 files) } \\ 627.4 & \text { Petrography } \\ 627.5 & \text { Physiography } \\ 627.6 & \text { Stratigraphy } \\ 627.7 & \text { Nomenclature } \\ 627.8 & \text { Nomenclature } \\ 627.9 & \text { Wells } \\ 628 & \text { Specimens, general } \\ 628.1 & \text { Requests for information re: specimens analysis } \\ 628.2 & \text { Determination of specimens, United States and foreign (3 files) } \\ 628.3 & \text { Acknowledgment of specimens received by Geological Survey } \\ 628.4 & \text { Requests for specimens by Geological Survey } \\ 628.5 & \text { Re: shipments of specimens }\end{array}$

At this point the series contains files organized by the following categories: General, Alabama, Arizona, Arkansas, California, Colorado, Connecticut, Delaware, District of Columbia, Florida, Georgia, Idaho, Illinois, Indiana, Iowa, Kansas, Kentucky, Louisiana, Maine, Maryland, Massachusetts, Michigan, Minnesota, Mississippi, Missouri,

Montana, Nebraska, Nevada, New Hampshire, New Jersey, New Mexico, New York, North Carolina, North Dakota, Ohio, Oklahoma, Oregon, Pennsylvania, Rhode Island, South Carolina, South Dakota, Tennessee, Texas, Utah, Vermont, Virginia, Washington, West Virginia, Wisconsin, and Wyoming. Thereunder the files are organized by selected elements of the decimal classification scheme governing this series as shown below. Not all file elements exist for all the categories.

$\begin{array}{ll}607 & \text { Maps - Geological } \\ 608.3 & \text { Requests for information } \\ 609 & \text { Litigation; Testimony } \\ 610 & \text { Requests for geologic examination and surveys } \\ 611 & \text { Requests for examination of minerals lands } \\ 612 & \text { Requests for geologic examination - oil and gas } \\ 618 & \text { Formation names for maps; geologic boundary lines; employment on field parties } \\ 618.1 & \text { (Wyoming) Coal Basin Study } \\ 620 & \text { General } \\ 620 & \text { [Texas] Geologic map } \\ 620.02 & \text { Asbestos } \\ 621 & \text { Non-metals } \\ 621.01 & \text { Magnesite } \\ 621.04 & \text { Talc and soapstone } \\ 621.1 & \text { Abrasives } \\ 621.2 & \text { Clays, sands, and gravel } \\ 621.21 & \text { Silica, for optical glass manufacture } \\ 621.3 & \text { Gems and precious stones } \\ 621.5 & \text { Gypsum } \\ 621.6 & \text { Muscovite } \\ 621.7 & \text { Salts (except potash) } \\ 621.8 & \text { Sulphur } \\ 621.9 & \text { Feldspar and flourspar } \\ & \end{array}$


622 Building materials

622.1 Asphalt and ozalerite

622.2 Cement

622.3 Granite, marbles

622.4 Limestone and sandstone

622.8 Slate

623 Fertilizer

623.1 Phosphate

623.2 Potash and nitrate

624 Coal beds

624.1 Coal

624.2 Oil and gas

624.20 Oil and gas wells

624.202 Helium

624.21 Oil shale

624.212 Oil sand

624.25 Oil companies

624.261 Coal fields; Oil maps

624.27 Statistics on petroleum production

624.28 Promotional enterprises

624.3 Peat

625 Miscellaneous Metals

625.01 Chromite

625.1 Bauxite

625.2 Copper

625.3 Gold and Silver

625.4 Iron and manganese

625.5 Lead and zinc

625.6 Platinum

625.7 Quicksilver

625.8 Rare metals

625.9 Tin and nickel

626 Mines

626.1 Mining companies and mining districts

626.3 Placer mining

626.4 Prospecting

626.5 Rods, divining, etc.

627 Scientific and Technical

627.02 Temperatures in deep wells

627.03 Core samples

627.1 Earthquakes and volcanos

627.2 Glacial geology

627.3 Paleontology

627.5 Physiography

627.6 Stratigraphy

627.7 Water resources

627.8 [Texas] Frio Clay discussion

627.9 Well records, data

628 Specimens

628.1 Requests for information [assays, analyses]

628.2 Determinations of specimens 
661

662

663

663.1

663.2

663.3

664

664.1

664.3

664.4

665

665.1

665.2

665.3

666

666.1

667

667.1

667.2

668

668.1

668.2

670

670.1

670.2

670.3

671

671.01

671.1

671.2

671.3

671.4

671.5

671.6
Geologic investigations by nonsurvey members

Geologic investigations by nonsurvey members - paleontology

Geologic investigations by schools and colleges

Cooperation with outside individuals and organizations

Review of manuscripts

Conferences

American Geographical Society

Cosmos Club

American Museum of Natural History

American Association of Petroleum Geologists

American Association of Petroleum Geologists - Estimates of Petroleum reserves

American Mining Congress Bulletin

Society of Economic Geologists

American Petroleum Institute

Mining and Metallurgical Society of America (2 files)

Mining Conventions and Congress

Conservation Congresses and Conventions

National Academy of Sciences

National Academy of Sciences - Publications

Cooperation in study of Earth movements in California

National Research Council

Geological Society of America

Geological Society of America - papers

Geological Society of America - membership

Geological Society of America - meeting place

American Institute of Mining and Metallurgical Engineers

American Institute of Mining and Metallurgical Engineers, papers for publication

American Institute of Mining and Metallurgical Engineers, nominations

American Institute of Mining and Metallurgical Engineers, Division of Petroleum Technology

Pan Pacific Scientific Congress

Pan American Scientific Congress, papers for publication

Association of American Geographers

Association of American Geographers

Association of American Geographers - papers for publication

American Association for the Advancement of Science

American Association for the Advancement of Science, membership

American Association for the Advancement of Science, meetings

War Minerals - general (3 files)

War Minerals - deposits

War Minerals Administration Bill, 1918

War Minerals Relief Commission

Geologists to assist in War Minerals investigations (2 files)

Geologists to assist in War Minerals investigations - magnesium

Geologists to assist in War Minerals investigations - pyrite

Geologists to assist in War Minerals investigations - manganese (3 files)

Geologists to assist in War Minerals investigations - quicksilver (2 files)

Geologists to assist in War Minerals investigations - platinum

Geologists to assist in War Minerals investigations - tin (2 files)

Geologists to assist in War Minerals investigations - rare metals (2 files) 
Geologists to assist in War Minerals investigations - chromite

Geologists to assist in War Minerals investigations - nickel

Geologists to assist in War Minerals investigations - mica (2 files)

Military service of outsiders (2 files)

National Science Foundation, 1954

Alaska Branch

Conservation Branch

Chief Counsel

Chemistry and Physics Section

Chemistry and Physics - investigations

Suggestions for investigations

Van Orstrand

Geochemical Prospecting Unit

Organization of Section of Geochemistry and Petrology

Projects in Section of Geochemistry and Petrology

Specimen analysis

Equipment

Mineral Resources

Reports of foreign mineral deposits

Projects in Mineral Deposits Section

Report on Craters of the Moon National Monument, Idaho

Requests for Topographic Surveys, general

Topographic Maps

Correspondence with private individuals regarding participation on Geological Survey sponsored field trips

Report on occurrence of artisian water at U.S. Navy Yard at Bremerton, Washington

Division Field Equipment

Distribution and use of field equipment and other property

Distribution of Geological Survey publications

Division of Map Reproduction

Photographic Laboratory (requisitions for distribution of photographs)

Photomicrographic Laboratory

Publications Office

Section of Illustrations

Section of Map Editing (2 files)

Section of Texts

Cartographic Section

Office of Geologic Information and Reports

Requests for Control Data

Section of Engineering Geology - Projects

Section of Paleontology and Stratigraphy - Projects

Organization and work, 1916

Organization and Work - Geologic, Annual Report

Ten Year Program for fissionable materials

Comments on Six Year Plan, 1954-59

Memorandum for the Director

Memorandum for the record

Conference of Geologic Branch with various sections

Notes on meetings \& conferences

Administrative Research and Development

Requests for and assignments of temporary positions 


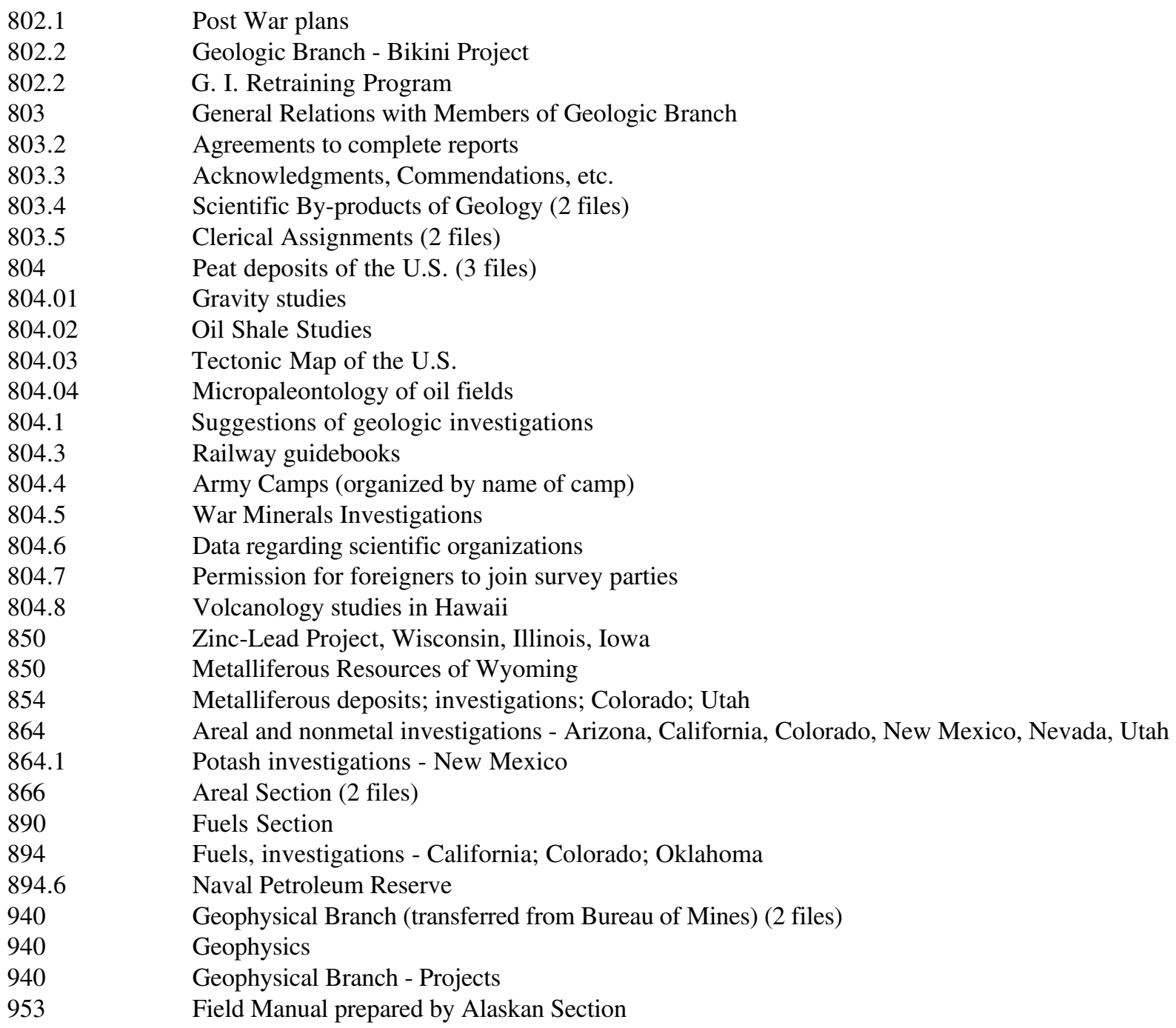




\section{Appendix 10}

Geologic Division - Records concerning Division Employees, 1930-53 (entry 164)

A - Miscellaneous, 1948-52

Adams, John W., 1947-52

Agnew, Allen F., 1942-52 (2 files)

Albee, Arden L., 1950-52

Albers, John P., 1942-51

Alexander, William Jasper, 1948-53

Almond, Hy, 1948-52

Allen, Victor, 1942-51

Allingham, John W., 1949-52

Anderson, Charles A., 1943-52 (3 files)

Anderson, Frank J., 1948-49

Andrew, Francis G., 1947-53 (2 files)

Andrews, Thomas G., 1945-52

Armstrong, Frank C., 1943-52 (2 files)

Arnold, David C., 1951-52

Atherton, Ruth, 1951-52

B - Miscellaneous, 1942-52

Bailey, Edgar H., 1943-52 (3 files)

Bailey, R. K., 1942-46

Bales, William E., 1952-53

Baker, Donald R., 1952

Bannerman, Harold M., 1947-53

Barnes, James V., 1947-50

Barton, William R., 1951-52

Bassett, Allen M., 1951-52

Bateman, Paul C., 1942-52 (2 files)

Bauer, Herman L., 1949-51

Baumgardner, Luther, 1951-52

Becraft, George E., 1950-52

Beelere, David O., 1949-53

Behre, Charles H., 1948-52

Bejnar, Waldemere, 1948-52

Bell, Henry, 1949-52

Bell, Kenneth G., 1950-52

Bell, Mendell M., 1948-51

Bergman. Keith S., 1951-52

Berliner, M. Howard, 1950-51

Beroni, Ernest P., 1948-52

Billings, Marland P., 1947-48

Bingham, Genevieve, 1950-51

Blackman, Doris H., 1950

Bodenlos, Alfred J., 1947-48

Bostwick, David A., 1948-53

Bowles, Charles Gilbert, 1950-53 
Boyes, Margaret, 1951-53

Bozion, C. N., 1943-53

Brasher, George K., 1950-53

Bridge, Josiah, 1943-51

Brobst, Donald A., 1948-52

Brock, Maurice R., 1951-52

Broedel, Carl H., 1950-52

Brokaw, Arnold L., 1944-53

Bromfield, Calvin S., 1951-52

Brown, C. Ervin, 1951-52

Brown, C. Norman, 1950-53

Brubaker, Lewis A., Jr., 1950-52

Brueggemeyer, William S., 1951-52

Bryner, Leonid, 1947-52

Bryson, Robert P., 1951-52 (2 files)

Buck, Katherine Lutz, 1948-52

Buddington, A. F., 1943-52 (2 files)

Buie, Bennette F., 1951-52

Burbank, Wilbur S., 1944-52

Bush, Alfred L., 1946-52

Butler, Arthur P., 1944-53

Butler, B. S., 1944-50

Byers, Frank M., 1952

Byers, Virginia P., 1947-50

C - Miscellaneous, 1943-52

Cadigan, Robert A., 1948-52

Cady, Wallace M., 1946-52 (2 files)

Caldwell, Dabney, 1952

Calkins, Frank C., 1944-53

Callaghan, Eugene, 1940-52

Cameron, Eugene N., 1945-52

Campbell, Arthur B., 1948-52

Campbell, Charles D., 1942-52

Campbell, Ian, 1942-53 (2 files)

Campbell, Russel H., 1951-52

Campbell, Robert M., 1947-50

Canney, Frank C., 1951-52

Cannon, Helen L., 1947-52

Cannon, Ralph S., 1942-52

Carlson, John E., 1951-52

Carlson, Relda, 1948-52 (2 files)

Carr, Martha S., 1947-52

Carr, Wilfred J., 1950-52

Cater, Fred W., 1942-52

Carter, William D., 1951-53

Cathcart, James B., 1945-52 (2 files)

Chai-Hsiang, Chao, 1946

Cavender, Wayne S., 1952

Chace, Frederick M., 1946-53

Cheney, Thomas M., 1951-52 
Chidester, Alfred H., 1945-52

Christman, Robert A., 1949-52

Cupples, Norman P., 1952

Cifelli, Richard, 1948-50

Clabaugh, Patricia S., 1946

Clabaugh, Stephen E., 1945-52

Clark, Dorothy M., 1950-52

Clark, Lorin D., 1946-52

Clifford, Maurine, 1951-52

Cloud, Preston E., 1945-53

Coats, Robert R., 1951-52

Collins, John J., 1949-52

Cook, Donna M., 1952

Compton, Robert R., 1947-51

Cooper, John R., 1942-52

Cornwall, Henry R., 1943-52

Craig, Lawrence C., 1945-52

Cozzetto, Anita W., 1950-53

Creasey, S. Cyrus, 1942-52

Cressman, Earle R., 1948-52

Crittenden, Max D., 1942-52

Crowder, Dwight F., 1951-53

Crowe, Mary B., 1949

Crumpton, Rusian P., 1950-51

D - Miscellaneous, 1948-52

Danielson, John E., 1947

Darby, Eleanor R., 1947-48

Davidson, David F., 1948-52

Davidson, Edward S., 1948-52

Davis, Robert E., 1951-53

Daily, M. Corinne (Dawson), 1948-49

Dean, Basil G., 1952

Decker, Mary Fern, 1949-52

Deiss, Charles F., 1945-52

Dellwig, Louis F., 1947-52

DeVore, George W., 1948-53

Dickson, Frank W., 1951-52

Dings, McClelland G., 1942-52

Disbrow, Alan E., 1948-52

Drone, Grace, 1952

Dryden, Lincoln, 1952

Dreyer, Robert M., 1946-47

Duncan, Donald C., 1941-47

Dunlap, John C., 1945-51

Dunlap, Shirley, 1948-51

Durrell, Cordell, 1945-52 (2 files)

Durrell, Mary, 1948-50

Dutro, Howard B., 1950-52

Dutro, J. Thomas, Jr., 1948-52

Dutton, Carl E., 1949-52 (2 files) 
E - Miscellaneous, 1948-52

Early, Margaret, 1952

Ebbley, Norman E., Jr., 1947-49

Eberlein, G. Donald, 1946-47

Eckel, Edwin B., 1940-52 (2 files)

Egly, Paul W., 1949-50

Ehlers, Ernest G., 1949

Eicher, Lee J., 1951

Ellis, Miller W., 1947-51

Engel, A. E. J., 1944-52 (2 files)

Engel, Celeste, 1947-52

Eric, John H., 1945-52

Erickson, George E., 1947-49

Erickson, Ralph L., 1951-52

Erickson, Algot J., 1950-52

Espenshade, Gilbert H., 1941-52

Evans, Owen D., 1951

Everhart, Donald L., 1946-53 (2 files)

Exner, Gertrude L., 1948-50

F - Miscellaneous, 1948-52

Faick, John N., 1950-52

Feeger, John A., 1951

Ferguson, Henry G., 1930-52

Fieldman, Dolf W., 1950-51

Finch, Warren I., 1948-52

Finlayson, Doris P., 1949-50

Fischer, Elizabeth G., 1947-53

Fischer, Richard P., 1943-52 (2 files)

Fix, Philip F., 1942-52

Flawn, Peter T., 1947-49

Flint, Arthur E., 1949-52 (2 files)

Flint, George M., Jr., 1952-53

Flint, Norman K., 1948-50

Folger, John J., 1948-49

Fox, Elinor L., 1948

Freedman, Jacob, 1949-52

Freeman, Val L., 1949-52

Freshour, Edith D., 1951-53

Frost, John E., 1949-51

Frieske, Fred D., 1950-51

Fries, Carl, Jr., 1939-43

Fryklund, Verne C., 1951-52

G - Miscellaneous, 1943-52

Gale, Hoyt S., 1939-52

Gallagher, David, 1941-52 (3 files)

Gardner, Kenneth W., 1947-52

Gardner, Louis S., 1939-53 
Gibson, Virginia L., 1948-52

Gilbert, Charles M., 1945-51

Gilbert, Cynthia C., 1951-52

Gildersleeve, Benjamin, 1951-52

Gilkey, Millard M., 1948-52

Gillerman. Elliott, 1945-52

Gilluly, James, 1942-53

Goddard, Edwin N., 1941-53

Good, Stanley E., 1949-50

Goode, Dorothy R., 1950-52

Goode, Harry D., 1950-52

Goodspeed, George E., 1948-50

Gordon, Mackenzie, 1940-51

Gordon, Ellis D., 1951-52

Gosman, Robert F., 1949-52

Gott, Garland B., 1949-52

Gould, Earl E., 1945

Gould, Howard R., 1951-52

Gower, Margaret, 1951-52

Gowdey, Frances S., 1950-52

Granger, Arthur E., 1941-53

Granger, Harry C., 1949-52

Granger, Janel Cook, 1948-53

Gray, Clifton H., 1951-52

Gregoire, Mary R., 1949-51

Griffitts, Wallace R., 1942-52

Griggs, Allen B., 1942-52

Gros, Frederick C., 1942-43

Gross, Eugene B., 1951-52

Grunig, James K., 1948-53

Gude, Arthur J., 1950-52

Gulbrandsen, Robert A., 1948-52

H - Miscellaneous, 1948-52

Hack, John T., 1949-52

Hagner, Arthur F., 1944-52

Hall, Darand A., 1941-43

Hall, Robert B., 1948-52

Hall, Wayne E., 1948-52

Hanley, Edward S., 1949-53

Hanley, John B., 1947-52

Hanson, Agnes R., 1949-52

Harbaugh, John W., 1950-51

Hardin, George C., Jr., 1946-47

Harrison, Jack E., 1951-52

Hasler, Marjorie O., 1952

Hasler, William J., 1951-52

Havens, Edna, 1952-53 (2 files)

Hawkes, Herbert E., 1941-52 (4 files)

Hay, Richard L., 1948-52

Henry, Margaret D., 1947-48 
Herbaly, Elmer L., 1948-50

Hernon, Robert M., 1948-52

Herrmann, Leo A., 1948-51

Hewett, D. Foster, 1936-52 (2 files)

Heyl, Allen V., 1945-52

Heyl, George R., 1942-48 (3 files)

Heyman, Arthur M., 1951-52

Hilpert, Doris R., 1948-51

Hilpert, Lowell S., 1942-52

Hill, James W., 1949-52

Hill, Louise, 1951-52

Hinrichs, E. Neal, 1948-51

Hobbs, Warren S., 1941-53 (2 files)

Holmes, Clifford N., 1948-52

Holser, William T., 1948-52

Hollister, Victor F., 1948-49

Honkala, Fred S., 1948-52

Hooker, Lucile A., 1948-52

Hoppin, Richard A., 1947-49

Hosterman, John W., 1949-52

Hotz, Preston E., 1942-52

Houser, Frederick N., 1949-51

Howard, Winifred, 1950-51

Howland, Arthur L., 1941-52

Huddleston, Shirley, 1951-52

Hudson, Lola N., 1951-52

Huff, Lyman C., 1947-52 (2 files)

Hughes, Mary E., 1949-51

Huleatt, William P., 1947-49

Hunt, Charles B., 1941-51

I - Miscellaneous, 1948-52

Icke, Hyman M., 1949-51

Izett, Amy Derr, 1952

J - Miscellaneous, 1948-52

Jackson, Everett D., 1949-52

Jahn, Jeanne, 1949-52

Jahns, Frances H., 1949-52

Jahns, Richard H., 1939-52

James, Harold L., 1946-52 (2 files)

Jaster, Marion C., 1949

Jicha, Henry L., 1949-51

Johnson, Donald H., 1950-51

Johnson, Henry S., 1948-52

Johnson, Robert B., 1944-47

Johnson, Robert F., 1948-52

Johnson, Virginia C., 1951-52

Jones, Charles L., 1945-52

Jones, William R., 1949-52 
K - Miscellaneous, 1944-52

Kaiser, Edward P., 1948-52

Katich, Philip J., 1951-52

Kelley, Vincent C., 1942-51

Kenefick, Joseph L., 1950-52

Kennedy, George C., 1947-52

Kennedy, Vance C., 1948-52

Kent, Deane F., 1943-51

Kesler, Thomas L,. 1946-51

Ketner, Keith B., 1949-52

Kiilsgaard, Thor H., 1950-52

King, Phillip B., 1950-52

King, Ralph H., 1941-50

King, Robert U., 1949-52

Kinkel, Arthur R., Jr., 1945-52

Kinney, Douglas M., 1943-49

Klaphaak, Madeline A., 1948-51

Klepper, Montis R., 1942-52 (2 files)

Klepser, Harry J., 1946-52

Knapp, Barbara B., 1949-52

Knechtel, Maxwell M., 1946-52

Kock, George S., Jr., 1948-52

Koschmann, Albert H., 1942-52 (3 files)

Krauskopf, Konrad B., 1942-52

Krieger, Medora H., 1945-52

Kuhn, Truman H., 1951-52

Kulp, J. Laurance, 1948-52

Kupfer, Donald H., 1943-52

Kupfer, Romaine L., 1949-52

L - Miscellaneous, 1949-52

Ladd, Harry S., 1942-43

Lakin, Hubert W., 1949-52

Lamey, Carl A., 1943-52

Lang, Andrew J., 1948-52

Lang, Walter B., 1939-52 (2 files)

Larsen, Esper S., 1942-45

Laskey, Samuel G., 1938-43, 1947-52 (7 files)

Laurence, Robert A., 1944-52

Lavel, William Norris, 1949

Law, Margaret R., 1950-52

Lawthers, Robert, 1951-52

Lee, Dorothy, 1952

Lee, Florence J., 1948-52

Lehner, Robert E., 1951-52

Lemish, John, 1948-52

Lemmon, Dwight M., 1939-52 (2 files)

Lemmon, Mary Elizabeth, 1948-49

Leonard, Benjamin F., 1943-52 (2 files)

Lough, Charles F., 1952

Lovering, Thomas G., 1948-52 
Lovering Thomas S., 1940-52 (4 files)

Lowell, Wayne R., 1945-52

Luedke, Robert G., 1951-52

Luukkonen, Bruno O., 1950

Luttrell, Gwendolyn W., 1948-51

Lyons, Edwin J., 1948-52

M - Miscellaneous, 1948-52

Mackin, J. Hoover, 1945-52

Macy, Frederick L., 1949

Maher, Stuart W., 1948-50

Malamphy, Mark C., 1941

Mansfield, George R., ca. 1942-45 (2 files)

Martin, Ruth, 1946-47

Maurice, Charles S., 1942

MacKallor, Jules A., 1948-52

MacKevett, Edward M., 1948-52

MacLachlan, James C., 1952

MacLaren, Donald R., 1952

MacNeil, F. Stearns, 1945-50

McAllister, James F., 1946-52

McCasland, Helen C., 1948-49

McCulloh, Thane H., 1949-52

McDermott, Esther T., 1948-50

McDonald, Ralph L., 1951-52

McFarland, Harry F., 1952

McFarland, Marianne, 1949

MsIlhenny, Theo. S., 1949-52

McKay, Edward J., 1947-52

McKelvey, Vincent E., 1947-52 (5 files)

McKeown, Francis A., 1952

McKnight, Edwin T., 1946-52

McNair, Andrew H., 1942-47 (2 files)

McNeal, Robert P., 1949-51

McLaughlin, Kenneth P., 1948-51

McLeod, Edith P., 1949

McLeod, William R., 1952

McReel, Albert, 1952

Mertie, John B., 1945-52

Meissner, Charles R., 1948

Merriam, Charles W., 1942-52

Meschter, Daniel Y., 1951-52

Millar, Wilton T., 1947-49

Miller, Florence W., 1950-52

Miller, Glenn A., 1952

Miller, Ralph L., 1942-45

Miller, Robert L., 1949

Miser, Hugh D., 1940-44

Monroe, Watson H., 1941

Moritas, Marguerite A., 1951-52

Moore, Frank B., 1948-52 
Moore, James G., 1950-52

Moore, Samuel L., 1951-52

Morris, Duane C., 1950

Morris, Hal T., 1948-52

Morris, Lavilla, 1951-52

Mudgett, Philip B., 1952

Muessig, Siegfried J., 1951-52

Mullens, Thomas E., 1949-52

Muller, Siemon W., 1947

Murphy, John F., 1948-50

Murphy, Thomas D., 1951-52

Myers, W. Bradley, 1942-52

Myers, William Howard, 1941-42

N - Miscellaneous, 1948-52

Narten, Perry F., 1948-52

Nelson, John N., 1943-52

Nelson, Ned E., 1951-52

Nelson, Vincent E., 1942-46

Neuerburg, George J., 1951-52

Neuschel, Sherman K., 1942-47

Neuschel, Virginia S., 1946-47

Newcomb, Edward L., 1949-52

Newhouse, Walter H., 1942-52

Newman, Alva L., 1951-52

Newman, William L., 1949-51

Nichols, Robert L., 1943-50 (2 files)

Nininger, Robert O., 1942-43

Noble, Levi F., 1940-48

Nolan, Thomas B., 1943-48

Norton, James J., 1946-52

O - Miscellaneous, 1948-52

Odell, James W., 1946

Olson, Jerry C., 1940-52 (2 files)

O'Malley, Frank Ward, 1948

O'Rourke, Joseph E., 1950-52

Oster, Thomas W., 1948-50

Osterstock, Robert W., 1948-51

Overstreet, William C., 1949-52

P - Miscellaneous, 1948-52

Page, Ben M., 1944-50

Page, James J., 1943-52

Page, Lincoln R., 1939-52 (6 files)

Park, Charles F., Jr., 1938-52 (2 files)

Pardee, Franklin G., 1946-50

Parker, John M., III, 1942-52

Parker, Raymond L., 1948-52

Patterson, Sam H., 1948-52

Patton, Priscilla C., 1948-51 
Patzwald, Fred, 1952

Pavlides, Louis, 1948-52

Payne, Oscar A., 1948-49

Peck, Dallas L., 1952

Pecora, William T., 1941-44

Pelnarsch, Dorothy C., 1952

Peoples, Joe Webb, 1939-52 (5 files)

Petersen, Richard G., 1947-52

Peterson, Nels P., 1942-52

Pettijohn, Francis J., 1945-52

Phoenix, David A., 1945-52

Pierce, William G., 1940-42

Pierson, Charles T., 1951-52

Plake, James N., 1952

Platt, Norman B., 1949

Plummer, Wayne L., 1949

Postel, A. William, 1947-52

Potter, Donald B., 1950-52

Powell, William J., 1945-48

Pratt, Walden P., 1949-51

Pray, Lloyd C., 1946-52

Proctor, Paul Dean, 1945-52

Puffett, Willard P., 1950-52

Q - Miscellaneous, 1949-52

R - Miscellaneous, 1946-52

Rabbitt, John C., 1943-48

Rainey, Henry C., III, 1950-52

Randall, Dolores M., 1949-51

Read, Charles B., 1942-47

Redden, Jack A., 1948-52

Reeves, Robert G., 1950-52

Reinemund, John A., 1942-45

Renshaw, J. R., 1952

Rinehart, Charles D., 1951

Reid, Mary, 1952

Reinhardt, Elmer V., 1948

Replogle, Bert K., 1950-51

Richards, Arthur, 1942-48

Richards, Ralph W., 1943-45

Rigby, Truman K., 1947

Roadifer, Roy E., 1948-52

Roberts, Ralph J., 1940-52 (2 files)

Roberts, Wayne A., 1949-52

Roberts, William B., III, 1948-52

Robertson, Jacques F., 1949-52

Robinson, Charles S., 1949-52

Rogers, Beryl Headrick, 1951

Rogers, Cleaves L., 1949

Rogers, John, 1943-50 
Rominger, Joseph F., 1942-44

Ross, Clyde P., 1934-52 (3 files)

Ross, Donald C., 1952

Rothrock, Howard E., 1945-46

Rove, Louis C., 1951-52

Rove, Olaf N., 1947-52 (2 files)

Rowse, William J., 1948-52

Rubey, William W., 1942-44

Rudberg, Theba, 1949-50

Runner, J. J., 1942-49

Ruppel, Edward T., 1948-52

Russell, Robert T., 1942-47

Ryan, John Donald, 1948-52

Rynearson, Garn A., 1942-51

S - Miscellaneous, 1948-52

Sample, Raymond Dewey, 1943-52

Sampson, Edward, 1943-45

Schassberger, Herman T., 1949-52

Scheid, Vernon E., 1943-52

Schenck, Mildred C., 1951

Schmidt, Robert G., 1951-52

Schmitt, Harrison, 1942

Schumacher, John I., 1948-51

Schwartz, George M., 1944-52

Scott, James B., 1951-52

Scudder, George D., 1950-51

Sears, Richard S., 1947-48

Segerstrom, Kenneth, 1942

Setzer, Carl L., 1948-49

Shainin, Vincent E., 1948-51

Shanks, Martha B., 1950-52

Sharp, Bryon J., 1949-50

Sharp, William N., 1949-52

Shawe, Daniel R., 1951-52

Sheldon, Eileen Bennett, 1949-52

Sheldon, Richard P., 1949-52

Shelton, John S., 1942-44

Shelton, Richard C., 1947

Shenon, Philip J., 1943-46 (3 files)

Sheridan, Douglas M., 1947-52

Shoemaker, Eugene M., 1948-52

Shride, Andrew F., 1942-52 (2 files)

Silver, Elizabeth, 1949

Silver, Leon T., 1948-52

Simmons, George C., 1950-52

Sims, Paul K., 1948-52

Singewald, Quentin D., 1941-52

Smart, Ross A., 1949-52

Smedley, Jack E., 1948-52

Smith, Clay T., 1939-44 
Smith, George I., 1952

Smith, J. Fred, 1951-52

Smith, Raymond J., 1951-52

Smith, Roscoe M., 1951-52

Smith, Ward C., 1938-52 (8 files)

Sobol, Harvey L., 1951-52

Sohn, I. Gregory, 1946-51

Sokoloff, V. P., 1947-52

Sorensen, Ruth K., 1948-50

Souder, Waren J., 1942

Sowers, George M., 1944-45

Spence, Franklin H., 1949-51

Staatz, Mortimer H., 1943-52

Stacy, John R., 1949-51

Stager, Harold K., 1948-51

Stagg, Bonnie M., 1951-52

Stead, Elinor F., 1949

Stead, Frank W., 1942-44

Steckler, F. Wayne, 1947

Stefansson, Karl, 1945

Stephens, Hal G., 1947-52

Stephenson, Edgar L., 1942-43

Steven, Thomas A., 1946-52

Stewart, Glenn W., 1945-52 (2 files)

Stewart, John H., 1951

Stewart, Robert H., 1948-52

Stieff, Lorin R., 1947-50

Still, Arthur R., 1949

Stoiber, Richard E., 1949-52

Stokes, Willian Lee, 1946-52

Stoll, Walter C., Jr., 1942-46 (2 files)

Stopper, Robert F., 1943-47 (2 files)

Stose, George W., 1940-41

Straczek, John A., 1940-45

Strange, Norma, 1951-52

Stringham, Bronson F., 1945-49

Strobell, John D., Jr., 1945-52

Stromquist, Arvid A., 1946-52 (2 files)

Strong, Richard, 1949

Stugard, Frederick, Jr., 1948-52

Sullwold, Harold H., 1942-44

Swanson, Roger W., 1943-52 (3 files)

Swinney, C. Melvin, 1942-52

T - Miscellaneous, 1949-52

Tandy, Charles W., 1949-51

Tatlock, Donald B., 1949-52

Teague, Kefton H., 1951-52

Thayer, Thomas P., 1939-52 (2 files)

Theisen, Mary M., 1949-51

Theobald, Paul K., Jr., 1951-52 
Thomas, Leo A., 1948-50

Thompson, George A., 1943-52

Thompson, Richard R., 1951-52

Thurston, Ralph H., 1948-52

Thurston, William R., 1944-51 (2 files)

Tillman, Chauncey G., 1950-52

Tillman, John A., Jr., 1948-52

Tolman. Carl A., 1942

Tooker, Edwin W., 1949-52

Trace, Robert D., 1948-51

Trask, Parker D., 1940-51 (2 files)

Trites, Albert F., Jr., 1945-52 (2 files)

Trow, James W., 1949-52

Tschanz, Charles M., 1949-52

Tuttle, Sherwood D., 1948-49

Tweto, Ogden, 1941-52

U - Miscellaneous, 1950-51

V - Miscellaneous, 1948-52

Van Alstine, Ralph E., 1946-52

Vanderwilt, John W., 1943-46

Varnes, David J., 1945-48

Vaughn, Richard H., 1950-51

Vhay, Jihn S., 1942-52

Vickers, Rollin C., 1951-52

Vitaliano, Charles J., 1943-52

W - Miscellaneous, 1946-52

Waage, Karl M., 1943-52

Walker, George W., 1943-52

Wallace, Robert E., 1949-52

Wallace, Stewart R., 1948-52

Warner, Lawrence A., 1948-52

Warner, Maurice A., 1950-52

Warren, Charles R., 1941

Waters, Aaron C., 1943-52

Wayland, Thomas E., 1948-52

Weaver, Charles E., 1949-50

Weeks, Robert A., 1947-52

Weir, Gordon W., 1949-52

Weiss, Paul L., 1949-52

Weissenborn, A. E., 1947-52 (3 files)

Welch, Phabian L., 1947-49

Wells, Francis G., 1939-52 (4 files)

West, Dorothy J., 1946-50

White, Amos M., 1951-52

White, Donald E., 1938-52 (4 files)

White, George N., 1952

White, Robert C., 1948-49

White, Walter S., 1942-52 (2 files) 
Whitebread, Donald H., 1952

Whitlow, Jesse W., 1951-52

Wileman, Frank L., 1948

Wier, Kenneth L., 1949-51

Wiese, John H., 1947

Willard, Bradford, 1943

Willard, Max E., 1942-52 (3 files)

Willey, Emerson, C., 1948-52

Williams, George A., 1951-52

Williams, Lois P., 1949-53

Williams, Marion J., 1949-52

Williams, William P., 1951-52

Wilmarth, Verl R., 1948-52

Wilpolt, Ralph H., 1942

Wilson, Ivan F., 1941-45

Withington, Charles F., 1948-51

Woodring, Wendell P., 1943-44

Wright, Dorothy A., 1948-49

Wright, Harold D., 1948-50

Wright, James C., 1949-52

Wright, Lauren A., 1942-47

Wright, Robert J., 1942-47

Wrucke, Chester T., 1951-52

Wyant, Donald G., 1940-52 (2 files)

XYZ - Miscellaneous, 1948-52

Yates, Robert G., 1941-52

Youngberg, Elton, A., 1951-52

Zellar, Robert A., 1949-52 


\section{Appendix 11}

Geologic Division - Geologists' Field Notebooks and related Records, 1867-1939 (entry 172)

\begin{tabular}{|c|c|}
\hline Number & $\underline{\text { Compiler }}$ \\
\hline 1 & E. Jacob \\
\hline 2 & E. Jacob \\
\hline 3 & E. Jacob \\
\hline 4 & E. Jacob \\
\hline 5 & E. Jacob \\
\hline 6 & E. Jacob \\
\hline 7 & E. Jacob \\
\hline 8 & E. Jacob \\
\hline 9 & $\begin{array}{l}\text { S. F. Emmons \& } \\
\text { E. Jacob }\end{array}$ \\
\hline 17 & E. Jacob \\
\hline 18 & E. Jacob \\
\hline 19 & E. Jacob \\
\hline 20 & S. F. Emmons \\
\hline 21 & S. F. Emmons \\
\hline 22 & S. F. Emmons \\
\hline 23 & S. F. Emmons \\
\hline 24 & S. F. Emmons \\
\hline 25 & S. F. Emmons \\
\hline 26 & J. E. Spurr \\
\hline 27 & J. E. Spurr \\
\hline 28 & S. F. Emmons \\
\hline 29 & Whitman Cross \\
\hline 30 & S. F. Emmons \\
\hline 31 & S. F. Emmons \\
\hline 32 & S. F. Emmons \\
\hline 33 & S. F. Emmons \\
\hline 34 & S. F. Emmons \\
\hline 35 & S. F. Emmons \\
\hline 36 & S. F. Emmons \\
\hline 37 & S. F. Emmons \\
\hline 38 & J. E. McCullock \\
\hline 39 & S. F. Emmons \\
\hline 40 & S. F. Emmons \\
\hline 41 & S. F. Emmons \\
\hline 42 & S. F. Emmons \\
\hline 43 & S. F. Emmons \\
\hline 44 & S. F. Emmons \\
\hline 45 & S. F. Emmons \\
\hline 46 & S. F. Emmons \\
\hline 47 & J. D. Irving \\
\hline 48 & J. D. Irving \\
\hline 49 & J. D. Irving \\
\hline 50 & J. D. Irving \\
\hline
\end{tabular}

Cover title or subject

Preliminary notes on Fryer Hill mines

Leadville Geology - upper localities

Carbonate Hill notes

Leadville geology - general features

Miscellaneous mines and more important prospects

Fryer Hill - Carbonate Hill - Iron Hill

Fryer Hill notes

Geology of the Ten Mile District, Colorado

Catalogue of Leadville rock and ore collection

Leadville, notes on miscellaneous shafts and tunnels

Notes on geology of the Ten Mile Mining District

Geology of the Ten Mile District

Notes on mines, Ten Mile District

Leadville notes: Penrose-Gray, Eagle; Henriette-Maid-Wolftone; GenegrodR. A. M.; Shenango-Highland Mary; Ibex 2nd \& 4th; Little Vinnie, Lillian-Lovejoy; Graham Park, and Stray-Horse Park

Leadville mines, notes, assays, drawings

Leadville mine notes

Leadville notes; general notes on mines and geological routes

Leadville Notes No. 1, mostly chemical notes, with abstracts of articles on ore deposits - genetic and chemical

Leadville notes

Leadville notes

Western Excursion; International Congress of Geologists; Wayside notes; notes on mines at Leadville, Colorado; Aspen, Colorado; Butte, Montana; also Bush Tunnel

Leadville notes

Leadville notes; Silver Cliff and Boulder; Fryer Hill; Iron Hill; Mike and Starr Region

Leadville Notes No. II - Dome, Printer Boy, Breece, North Iron, East Fryer, and Carbonate Hills; Ten Mile District

Leadville Notes No. III (list of mines)

Leadville Notes - Henriette, Maid, Mikado, Hussey, etc; Atlantic Co., Sellers, Mike and Star, Humbolt, R. A. M

Leadville, Shaft Book III, general sections through shafts and mines

Leadville, South Sheet II

Leadville, Shaft Book I, North Sheet I

Leadville notes

Leadville notes

Leadville notes - Leadville Flat, Carbonate Hill, East Fryer Hill, etc.

Leadville notes - California Gulch; Printer Boy Hill; Breece Hill; North Iron Hill; Carbonate Hill

Season of 1895 - Aspen, Colorado; Butte, Montana; Coeur d'Alene, Idaho; Idaho Basin, Idaho; Leadville, Colorado; Breckenridge, Colorado; Newlin Gulch, Colorado

Leadville notes No. 1, Bon Air; Bohn; A. V.; Midland; Penrose; Starr; Weldon; Cloud City; Midas; Down-town mines

Leadville notes, No. II, Coronado; Sixth Street; Toledo Avenue, Penrose, Starr, Northern Bison, Wolftons, Stevens, Whitecap, Montgomery claim, Bohn mine, Rose Emmett, Moyer Mine, D, H

Leadville notes No. III, A. Y. \& Minnie, Bruce and Little Ellen, Famous, Josie, Penn No. 1, Louise, Yak Tunnel, Resurrection, Ollie Read, Fryer Hill, Iowa Pass, Sedalia, S. Carbonate Hill, Sugarloaf District, Little Ellen, Cloud City, Mosquito Pass, South Winnie

Leadville notes No. IV, Adelaide Park, Black Prince, Penn No. 1, Carbonate Hill shafts, Doris shaft, D, H, No. 2, Big Six mines, Yak Tunnel,

Ibex No. 2, Minneapolis, Fitzhugh shaft, Small Hopes, Adams

Leadville notes

Leadville, General Notebook No. 1

Leadville notes, General Notebook No. 2, Brease Hill mine, Empire Gulch (head); Notes on granite, Yale Tunnel (Mike winze)

Leadville notes, memoranda

Leadville, specimen list $\underline{\text { Year(s) }}$

$1879-80$

1880

1880

1880

1880

1880

1880

Jan. 1883

1880

1880

1881-82

1882-83

$1882-83,1887-88$

1894, 1898

1894

n.d.

$1888,1890-95$

1881

1894

1894

1891

1890

1890

1890

1890

1890

$1890,1891,1894$

1890

1890

1894

890

1894

1894

1895

1901

1901

1901

1901

1900

1901

1901

1901

1901 
J. D. Irving

J. D. Irving

J. D. Irving

S. F. Emmons

S. F. Emmons

S. F. Emmons

J. D. Irving

J. D. Irving

J. D. Irving

S. F. Emmons

J. D. Irving

J. D. Irving

J. D. Irving

J. D. Irving

G. F. Loughlin

G. F. Loughlin

G. F. Loughlin

G. F. Loughlin

G. F. Loughlin

G. F. Loughlin

G. F. Loughlin

G. F. Loughlin

G. F. Loughlin

G. F. Loughlin

Loughlin, McCaskey

G. F. Loughlin

G. F. Loughlin

G. F. Loughlin

G. F. Loughlin

G. F. Loughlin

J. M. Hill

J. M. Hill

J. M. Hill

J. M. Hill

J. M. Hill

J. M. Hill

J. M. Hill

J. M. Hill

$\begin{array}{ll}216 & \text { J. M. Hill } \\ 217 & \text { J. M. Hill } \\ 269 & \text { F. L. Ransome } \\ 270 & \text { F. L. Ransome } \\ 271 & \text { F. L. Ransome } \\ 272 & \text { F. L. Ransome } \\ 273 & \text { F. L. Ransome } \\ 274 & \text { F. L. Ransome } \\ 274-A & \text { F. L. Ransome } \\ 275 & \text { F. L. Ransome } \\ & \\ 275-A & \text { F. L. Ransome } \\ 276 & \text { F. L. Ransome } \\ 276-A & \text { F. L. Ransome } \\ 277 & \text { F. L. Ransome } \\ 280-A & \text { F. L. Ransome } \\ 283 & \text { F. L. Ransome } \\ 284 & \text { F. L. Ransome } \\ 285 & \text { F. L. Ransome } \\ 286 & \text { G. W. Tower } \\ 286-\text { A } & \text { F. L. Ransome } \\ 287 & \text { F. L. Ransome }\end{array}$

Leadville notes, Plan Book No. 1 (loaned to USGS)

1901

Leadville, Colorado - Plan and Traverse Book No. 4

Leadville notes, Plan Book No. 3

Geological Map of west half of Leadville District, 1886; notes on Yankee Hill

Leadville notes No. 1

Leadville, Colorado - Reindeer, etc.

Leadville notes No. 2, "Transit Book 336"

Leadville notes, Section Book No.1; Irving and Dyson Section Book No. 2

Leadville - Black Hills, No.

Leadville notes, Section Book No. 1

Leadville notes, Plan Book No. 2

Leadville notes, June 15, 1910

Season of 1913, Leadville, Colorado

Season of 1913, Leadville, Colorado

Leadville, Colorado, zinc notes

Leadville, Colorado

Preston Quadrangle, Connecticut

Eastern Connecticut

Tintic District, Utah

Tintic District, Utah

Erickson, Desert, Columbia, W. \& N., Tintic Districts, Cottonwood Special, Utah

Tintic Mining District, Utah, notes on Downtown mines and map of North Tintic Mining District

East Tintic, Utah, maps, bibliography, and notes

Tintic Mining District - contains maps of the Balfinch mine, map and correspondence with the Dagmar Mining Co., blueprints of the Utah Apex Mining Co. at Bingham mines, and blueprints of the Eagle Eye Mining Co., mines of North Tintic Mining District [plus 2 loose maps]

Marysvale, Utah

Utah

Utah

Utah; and stone resources, Connecticut and Massachusetts

Idaho stone; Utah stone

Stone in central States

Black Hills National Forest, Notebook No. 1; Ouray, Montezuma, Medicine Bow, Pikes Peak, Chiricahua National Forests

Salida Sheet, Colorado. Examination of Post Office Department on fraud order; and Pecos, Jemez, Taos, and Lincoln National Forests

Examination of mining claims in National Forests; Notes on Economic Geology of S. E. Gunnison Co., Colorado

Nogales and Patagonia, Arizona

Nogales and Patagonia, Arizona

Nogales and Patagonia, Arizona

Sylvanite and Fremont Mining District, New Mexico

(Economic Rec. of the Sylvanite and Fremont M. D.

Grant Co., New Mexico, with claim map of Sylvanite)

Olinghouse and Ramsey sheets. Examination of Buster mine and mineral classification of odd numbered sections in T21 \& 22, R23, notes by E. M. D., P. M. for Department of Justice, accompanied by a claim map - White Horse or Olinghouse Mining District, Washoe County, Nevada

La Sal Mountains, Utah

Afterthought District, California (Examination of Afterthought Cooper Company's Mine for Post Office Department)

Sonora, California

Sonora, California

Big Trees Sheet, California

Mother Lode District, California

Mother Lode District, California

Mother Lode District, California

Bibliography notes, various subjects; (miscellaneous 4 in. x 6 in. cards)

Mother Lode District, California. Bundle of notes by Ransome on loose folded sheets

Native Iron in the Eruptive Rocks - investigation of thin sections

Mother Lode District, California

Connecticut Valley; Southern California; Brookville, New Jersey

Mother Lode District, California

Paradox Quadrangle, Colorado

Rico District, Colorado

Rico District, Colorado

Rico District, Colorado, field maps

Rico District, Colorado, abstract of Tower's notes on Rico mines

Gilpin Co., Colorado

Globe District, Arizona
1901

1901-4

1902

904-

1907

1901,1907

1901

1901

1901

1910

1913

1913

n.d.

$1913,1919,1922$

1901-5

1903, 1904, 1905

1911

1911

1912

n.d.

n.d.

n.d.

n.d.

1912

1912-15

n.d.

1915

1907-8

1907-8

1908

1909

1909

1909

1908

1910

1911-32

191

1895

1895

1896

1897

1897

1897

n.d.

1897

1897

1898

1897-99

1898

1899

1900

1900

1900

1900

1900

1901-2 


\begin{tabular}{|c|c|}
\hline 288 & F. L. Ransome \\
\hline 289 & F. L. Ransome \\
\hline 290 & J. D. Irving \\
\hline 291 & J. D. Irving \\
\hline 292 & F. L. Ransome \\
\hline 293 & F. L. Ransome \\
\hline 294 & F. L. Ransome \\
\hline 295 & F. L. Ransome \\
\hline 296 & F. L. Ransome \\
\hline 297 & F. L. Ransome \\
\hline 298 & J. Morgan Clements \\
\hline 299 & J. Morgan Clements \\
\hline 300 & J. Morgan Clements \\
\hline 301 & J. Morgan Clements \\
\hline 302 & F. L. Ransome \\
\hline 303 & F. L. Ransome \\
\hline 304 & F. L. Ransome \\
\hline 305 & F. L. Ransome \\
\hline 306 & F. L. Ransome \\
\hline 307 & F. L. Ransome \\
\hline 308 & F. L. Ransome \\
\hline 309 & F. L. Ransome \\
\hline 310 & F. L. Ransome \\
\hline 311 & F. L. Ransome \\
\hline 312 & F. L. Ransome \\
\hline 313 & F. L. Ransome \\
\hline 314 & F. L. Ransome \\
\hline 315 & F. L. Ransome \\
\hline 316 & F. L. Ransome \\
\hline 317 & F. L. Ransome \\
\hline 317-A & Edward R. Zalinski \\
\hline 318 & Edward R. Zalinski \\
\hline 319 & F. L. Ransome \\
\hline 319-A & F. L. Ransome \\
\hline 320 & F. L. Ransome \\
\hline 321 & F. L. Ransome \\
\hline 322 & F. L. Ransome \\
\hline $322-\mathrm{A}$ & G. H. Garrey \\
\hline 323 & F. L. Ransome \\
\hline 324 & F. L. Ransome \\
\hline 325 & F. L. Ransome \\
\hline 326 & F. L. Ransome \\
\hline 327 & F. L. Ransome \\
\hline $327-\mathrm{A}$ & F. L Ransome \\
\hline 328 & W. H. Emmons \\
\hline 329 & W. H. Emmons \\
\hline 330 & G. H. Garrey \\
\hline 331 & G. H. Garrey \\
\hline 331-B & F. L. Ransome \\
\hline 332 & F. L. Ransome \\
\hline 333 & E. S. Bastin \\
\hline 334 & F. L. Ransome \\
\hline 335 & F. L. Ransome \\
\hline 336 & F. L. Ransome \\
\hline 337 & F. L. Ransome \\
\hline no\# & [Ransome] \\
\hline $437-\mathrm{A}$ & Whitman Cross \\
\hline 437-B & E. B. Mathews \\
\hline 437-C & E. B. Mathews \\
\hline 438 & Whitman Cross \\
\hline $438-\mathrm{A}$ & Whitman Cross \\
\hline 438-B & Whitman Cross \\
\hline 438-C & Whitman Cross \\
\hline 438-D & Whitman Cross \\
\hline 438-E & Whitman Cross \\
\hline $438-\mathrm{F}$ & Whitman Cross \\
\hline $438-G$ & E. B. Mathews \\
\hline $438-\mathrm{H}$ & E. B. Mathews \\
\hline 439 & E. B. Mathews \\
\hline 439-A & Whitman Cross \\
\hline $439-B$ & Whitman Cross \\
\hline 439-C & Whitman Cross \\
\hline 439-D & Whitman Cross \\
\hline 439-E & Whitman Cross \\
\hline
\end{tabular}

Globe District, Arizona

1901-2

Globe District, Arizona

Globe District, Arizona

Globe Quadrangle, Arizona (field maps by J. D. Irving)

Globe Quadrangle, Arizona 1901-2

Bisbee, Arizona

Bisbee Quadrangle, Arizona

Bisbee Quadrangle, Arizona

Bisbee Quadrangle, Arizona

Bisbee Quadrangle, Arizona

Bisbee Quadrangle, Arizona 1902

Bisbee Quadrangle, Arizona

Bisbee Quadrangle, Arizona (field maps) 1902

Bisbee Quadrangle, Arizona (field maps) 1902

Bisbee Quadrangle, Arizona (field maps) 1902

Bisbee Quadrangle, Arizona (field maps by J. Morgan Clements) 1902

Cripple Creek, Colorado $1903-4$

Cripple Creek, Colorado 1903-4

Cripple Creek, Colorado 1903-4

Cripple Creek, Colorado $1903-4$

Cripple Creek, Colorado 1903-4

Cripple Creek, Colorado 1903-4

of 3 in. $x 5$ in. index car on the Cripple Creek District, Colorado

Coeur d'Alene District, Idaho

Coeur D'Alene District, Idaho

Coeur D'Alene District, Idaho

Coeur D'Alene District, Idaho

Coeur D'Alene District, Idaho, mill notes

Coeur d'Alene District, Idaho

Bullfrog District, Nevada

Searchlight and El Dorado, Nevada, Reconnaissance 1906

Bullfrog District, Nevada

Bullfrog District, Nevada

Bullfrog District, Nevada

Bullfrog District, Nevada

Goldfield District, Nevada

Goldfield District, Nevada

Goldfield District, Nevada

Goldfield District, Nevada

Goldfield District, Nevada

Nevada - Reconnaissance

Goldfield District, Nevada

Goldfield District, Nevada

Goldfield District, Nevada

Goldfield District, Nevada

Goldfield District, Nevada (3 in. x 5 in. index cards)

Breckenridge District, Colorado

Breckenridge District, Colorado

Breckenridge District, Colorado

Breckenridge District, Colorado

Breckenridge District, Colorado

Breckenridge District, Colorado. Maps with geologic notes

Maps showing a projected railway from Belize, British Honduras to S. Jose,

Guatemala, ca. 1890 (a note with the map states that it was found with Ransome's books)

Pikes Peak District, Colorado, sandstone dikes and sedimentary formations 1893

Pikes Peak District, Colorado 1893

Pikes Peak District, Colorado

San Juan District, Colorado

Pikes Peak District, Colorado

Pikes Peak District, Colorado

1893

Pikes Peak District, Colorado 1893

Pikes Peak District, Colorado 1893

Pikes Peak District, Colorado 1893

Pikes Peak District, Colorado 1893

Pikes Peak, Colorado; petrographic notes; notes on granite 1893-94

San Juan District, Colorado

Silver Cliff-Rosita Hills, Colorado, petrographic notes $1882-85$

Silver Cliff-Rosita Hills, Colorado, petrographic notes $\quad 1882-84$

Silver Cliff-Rosita Hills, Colorado $\quad$ 1883-84

Silver Cliff-Rosita Hills, Colorado $1883-84$

Silver Cliff-Rosita Hills, Colorado 
$\begin{array}{lr}\text { Silver Cliff-Rosita Hills, Colorado } & 1888 \\ \text { Silver Cliff-Rosita Hills, Colorado } & 1888\end{array}$

Silver Cliff-Rosita Hills, Colorado 1888

Silver Cliff-Rosita Hills, Colorado 1890

Silver Cliff-Rosita Hills, Colorado 1894

Silver Cliff-Rosita Hills, Colorado, folded field maps n.d.

Cripple Creek, Colorado 1894

Cripple Creek, Colorado 1894

Telluride Quadrangle, Colorado $\quad 1895$

Telluride Quadrangle, Colorado 1895

Telluride Quadrangle, Colorado 1895

Telluride Quadrangle, Colorado 1895

Telluride Quadrangle, Colorado 1895

Telluride Quadrangle, Colorado 1896

Telluride Quadrangle, Colorado 1896

La Plata Quadrangle, Colorado 1896

La Plata Quadrangle, Colorado 1896

La Plata Quadrangle, Colorado 1896

La Plata Quadrangle, Colorado 1896

La Plata and Durango Quadrangles, Colorado 1896

Durango Quadrangle, Colorado 1896

La Plata Quadrangle, Colorado 1897

La Plata Quadrangle, Colorado $\quad 1897$

Durango Quadrangle, Colorado 1897

Durango Quadrangle, Colorado 1897

Rico Quadrangle, Colorado 1897

Durango Quadrangle, Colorado 1897

La Plata Quadrangle, Colorado 1897

Rico Quadrangle, Colorado 1897

San Juan District, Colorado $\quad 1897-99$

Rico, LaPlata, and Durango Quadrangles, Colorado 1897

Rico Quadrangle, Colorado 1897

La Plata and Durango Quadrangles, Colorado 1897

Silverton and Engineer Mt. Quadrangles, Colorado $\quad 1898$

Rico Quadrangle, Colorado 1898

Rico Quadrangle, Colorado 1898

Rico Quadrangle, Colorado 1898

Rico Quadrangle, Colorado 1898

Durango Quadrangle, Colorado 1898

Rico Quadrangle, Colorado 1898

Rico Quadrangle, Colorado 1898

Rico Quadrangle, Colorado 1898

Silverton and Engineer Mt. Quadrangles, Colorado 1898

Durango Quadrangle, Colorado 1898

Durango Quadrangle, Colorado 1898

Engineer Mt., and Silverton Quadrangles, Colorado 1898

Silverton Quadrangle, Colorado 1899

Silverton and Ouray Quadrangles, Colorado 1899

Rico Special Quadrangle, Colorado 1899

Silverton Quadrangle, Colorado 1899

Rico Special Quadrangle, Colorado 1899

San Juan District, Colorado, mainly Pine River Valley 1899

Western Colorado District 1899

Silverton Quadrangle, Colorado 1899

Silverton Quadrangle, Colorado 1900

Silverton Quadrangle, Colorado 1900

Silverton Quadrangle, Colorado 1900

Needle Mts., Silverton, and Engineer Mt. Quadrangles, Colorado 1900

Animas Canyon District, Colorado 1900

Engineer Mt., Needle Mts., and Silverton Quadrangles, Colorado 1900

Engineer Mt. Quadrangle and Needle Mts., Colorado 1900

San Juan Valley, reconnaissance on New Mexico and Colorado 1901

Silverton Quadrangle, Colorado 190

Silverton Quadrangle, Colorado 1901

Needle Mountains Quadrangle, Colorado 1901

Gunnison Valley, Colorado, examination of proposed route
for Gunnison-Uncompaghre tunnel

Silverton Quadrangle, Colorado $\quad 1901,1903$

Needle Mountains Quadrangle, Colorado $\quad 1901$

Lower Animas Valley 1901

Silverton Quadrangle, Colorado 1901

Silverton Quadrangle, Colorado $\quad 1901$

Silverton Quadrangle, Colorado 1901

Silverton Quadrangle, Colorado 1901

Needle Mountains Quadrangle, Colorado 1901

Needle Mountains Quadrangle, Colorado 1903

Needle Mountains Quadrangle, Colorado 1903

Engineer Mountains Quadrangle, Colorado 1903-4 
Ernest Howe

Ernest Howe

Ernest Howe

Albert Johannsen

Albert Johannsen

Albert Johannsen

Whitman Cross

W. H. Emmons

W. H Emmons

Whitman Cross

L. H. Woolsey

George F. Kay

W. H. Emmons

Whitman Cross

Whitman Cross

Albert Johannsen

M. K. Shaler

G. I. Finlay

Whitman Cross

Whitman Cross

Whitman Cross

Howland Bancroft

Whitman Cross

Whitman Cross

Whitman Cross

Whitman Cross

Whitman Cross

Whitman Cross

Whitman Cross

Whitman Cross

Whitman Cross

Whitman Cross

J. M. Hill

J. M. Hill

J. M. Hill

757

J. M. Hill
Needle Mountains Quadrangle, Colorado

Needle Mountains Quadrangle, Colorado

Engineer Mt. Quadrangle, Colorado

Needle Mountains Quadrangle, Colorado

Needle Mountains Quadrangle, Colorado

Engineer Mountains Quadrangle, Colorado

Ouray Quadrangle, Colorado, tracing of American Nettie mine 1904

Rico Quadrangle

Durango Quadrangle, Division of Red Beds

Reconnaissance of western Colorado

Same as No. $527 \quad 1905$

Same as No. $527 \quad 1905$

Same as No. 527

Providenc

Engineer Mt. Quadrangle, Colorado

Engineer Mt. Quadrangle, Colorado

Engineer Mt. Quadrangle, Colorado

Engineer Mt. Quadrangle, Colorado

Highwood Mountains, Montana

Miscellaneous

Engineer Mt. and Durango Quadrangles

Engineer Mt. Quadrangle, Colorado

San Juan Region, Colorado, "question book"

Georgetown, Middle Park, Salida, and Del Norte, Colorado

Various districts, Colorado

Mosquito Range, Colorado, east of Leadville

Leadville and Mosquito Range, Colorado

Leadville and Mosquito Range, Colorado [missing]

Denver Basin, Colorado (Golden area)

Denver Basin, Colorado

Denver Basin, Colorado

Denver Basin, Colorado [missing]

Afterthought Copper Co., Shasta, California, "Typewritten report on the Afterthought Copper Co."

Report on Six Lode Claims, by the Manhattan Development Co., Cochise County, Arizona

Report on Cuba No. 1, and 42 other lode claims of the Colorado Smelting and Mining Co., situated in the Gunnison County National Forest, Gunnison County, Colorado

Report on 24 claims located by John Garcia conveyed to Eagle Mining and Improvement Company, Lincoln National Forest, Lincoln County, New Mexico

Report on the Florence and Olive Lode claims, Leadville National Forest, and Consolidated Mining District, Park County, Colorado

Report on Bob and Bun Lode Claim, Leadville National Forest, Mosquito Mining District - Lake County, Colorado

Report of the Castle Grand Placer, located in the La Salle National Forest, Miners Basin Mining District - Grand Co., Utah

Report on the Homestake Placer located by Peter and R. S. Lynch on the Holy Cross Mining District, Holy Cross National Forest, Eagle County, Colorado

Report on the Huff Gulch Placer, located by Cooper Anderson in the Montezuma National Forest, Lower San Miguel Mining District, San Miguel County, Colorado

Report on the 8 placer claims controlled by the Telluride Land and Lumber Company situated in Montezuma National Forest, San Miguel County, Colorado

Report on the Consolidated Bull Run, Mogul, and Big Springs placers located in the Ozark National Forest, Baxter County, Arkansas

Report on the Four-Lode claims located by Peter Barth in the James National Forest, Bromide Mining District, Rio Arriba County, New Mexico

Report on the 4 placer claims and 2 lode claims located by the Pecos Copper Co., in the Pecos River National Forest. Copper mining district, San Miguel Co., New Mexico

Report on the Asiatic placers 1, 2, 3, and 4, located in the Rio Grande National Forest, Conejos County, Colorado

Report on the Bitter Creek placer located by A. D. Hawk in the Red River Mining District, Taos National Forest, Taos County, New Mexico

Report on the Briggs placer located by G. Cusdorf, and others in the Rio Hord Mining District, Taos National Forest, Taos County, New Mexico

Report on the Buffalo placer located in the Teton National Forest, Uinta County, Wyoming

Report on the Uinta placer located in Teton National Forest, Uinta County, Wyoming

Report on a placer claim located by W. F. Cunningham in the Teton National Forest, Uinta County, Wyoming 


\begin{tabular}{|c|c|}
\hline 774 & J. M. Hill \\
\hline 776 & J. M. Hill \\
\hline 935 & F. P. Gulliver \\
\hline 936 & G. K. Gilbert \\
\hline 937 & G. K. Gilbert \\
\hline 938 & G. K. Gilbert \\
\hline 939 & G. K. Gilbert \\
\hline 940 & G. K. Gilbert \\
\hline 1072 & J. M. Boutwell \\
\hline 1108 & S. F. Emmons \\
\hline 1109 & S. F. Emmons \\
\hline 1110 & S. F. Emmons \\
\hline 1111 & S. F. Emmons \\
\hline 1112 & S. F. Emmons \\
\hline 1113 & S. F. Emmons \\
\hline 1114 & S. F. Emmons \\
\hline 1115 & S. F. Emmons \\
\hline 1116 & S. F. Emmons \\
\hline 1117 & S. F. Emmons \\
\hline 1118 & A. Lakes \\
\hline 1119 & A. Lakes \\
\hline 1120 & S. F. Emmons \\
\hline 1121 & S. F. Emmons \\
\hline 1122 & S. F. Emmons \\
\hline 1124 & S. F. Emmons \\
\hline 1125 & S. F. Emmons \\
\hline 1126 & S. F. Emmons \\
\hline 1127 & S. F. Emmons \\
\hline 1128 & S. F. Emmons \\
\hline 1129 & Eakins, Cross, Emmons \\
\hline 1130 & S. F. Emmons \\
\hline 1131 & Sherman G. Sackett \\
\hline 1132 & S. F. Emmons \\
\hline 1133 & S. F. Emmons \\
\hline 1134 & S. F. Emmons \\
\hline 1135 & S. F. Emmons \\
\hline 1136 & S. F. Emmons \\
\hline 1137 & S. F. Emmons \\
\hline 1138 & S. F. Emmons \\
\hline 1139 & S. F. Emmons \\
\hline 1140 & S. F. Emmons \\
\hline 1141 & S. F. Emmons \\
\hline 1142 & S. F. Emmons \\
\hline 1143 & S. F. Emmons \\
\hline 1144 & S. F. Emmons \\
\hline 1145 & S. F. Emmons \\
\hline 1146 & S. F. Emmons \\
\hline 1147 & S. F. Emmons \\
\hline 1148 & S. F. Emmons \\
\hline 1149 & S. F. Emmons \\
\hline 1151 & S. F. Emmons \\
\hline 1152 & S. F. Emmons \\
\hline 1153 & S. F. Emmons \\
\hline 1155 & S. F. Emmons \\
\hline 1156 & S. F. Emmons \\
\hline 1159 & S. F. Emmons \\
\hline 1160 & S. F. Emmons \\
\hline 1161 & S. F. Emmons \\
\hline 1164 & S. F. Emmons \\
\hline 1165 & S. F. Emmons \\
\hline 1167 & A. M. Rock \\
\hline 1168 & J. M. Boutwell \\
\hline 1169 & J. M. Boutwell \\
\hline 1170 & J. M. Boutwell \\
\hline 1171 & J. D. Irving \\
\hline
\end{tabular}

Report on the Pine Tree placer located by Emil Wolf in the Teton National Forest, Uinta County, Wyoming

Report on Bob and Bun Lode Claims, Leadville National Forest, Mosquito Mining District, Lake County, Colorado [missing]

Nepesta and Apishapa, Colorado

Apishapa and Nepesta, Pueblo, Colorado

Apishapa, Colorado

Apishapa, Colorado

Apishapa, Colorado, original field maps; Pueblo fossil list

Apishapa, Colorado; report on analyses of water, clay, fire tests, and reports of fossils

Clifton, Arizona

"Fortieth Parallel Survey"

"Fortieth Parallel Survey," geological field notes [missing]

Mining Districts of California and Nevada, mine notes [missing]

North Humbolt and Elkhead trips, sketches

Salt Lake Region, sketches

Original draft of "Diamond Frauds" (two envelopes)

Mosquito Range (Leadville, Colorado)

Mosquito Range (Leadville, Colorado)

Mosquito Range (Leadville, Colorado)

Mosquito Range (Leadville, Colorado)

Mosquito Range (Leadville, Colorado)

Mosquito Range (Leadville, Colorado)

Leadville District

Leadville District

Leadville District

Leadville District, Colorado

Leadville District, Colorado

"Original geological maps and drawings of the Leadville District"

Ten Mile, Gunnison and Aspen Quadrangles, Colorado

Silver Cliff District, Colorado

Silver Cliff, Rosita, Querida Quadrangles, Colorado

General notes on geological routes and mines, Colorado

Silver Cliff, Colorado, mills and smelters

Black Hills (Homestake), S. Dakota and Los Pilares mine, Montezuma District, near Nacozari, Mexico

Pyrite mines of Virginia, Nova Scotia gold mines, and Homestake production, South Dakota

Pyrite mines, Louisa County, Virginia

Gunnison Region, Colorado

Durance to Ouray, San Juan Co., Colorado. Wayside geological notes

Pueblo to Durango and Riverside to Ouray

Aspen, Irwin, Canon City, Kokomo, Silver Cliff and Breckenridge, Colorado

Maryland, Virginia, and Illinois, notes on mines

Lower California

Lower California (onyx)

Leadville, Silver Cliff, Cripple Creek and Breckenridge, Colorado; Mercus and Tintic, Utah

Tintic District, Park City, Bingham, Utah. Field notes

1880

1880

1880

1880

1880

1881

n.d.

n.d.

1880

1882,1887

1883

1882-84,1902, 1905

$1886-88$

1884

ca. 1891-1905

Western Maryland, Russia, Caucasus, Black Sea. Crimea

Isthmus of Panama, Peruvian Coast, Acari mines, Oroya Railroad

Black Hills, South Dakota; Mt. Stuart region, Washington; Keswick and Cross Valley, California

Ash Fork, Prescott, Jerome, Big Bug, Phoenix, Bisbee, Globe, Black Warrior, Morenci, Metcalf, Coronado, Mt. Clifton mines, Arizona

Silver City, Pinos, Altos, Hanover, Santa Rita, Burro Mountains, Cook's Peak, New Mexico; Idaho Springs, Central, Leadville, Yak County, Colorado

Unaweep, Rico, Silverton, and Cripple Creek, Colorado

Grand Encampment, Wyoming; Bungham, and Wasatch Quadrangles, Utah

Miscellaneous notes - Arizona, Colorado, Nevada, Mexico, Germany

Mines of Colorado, Wyoming and Utah

British Columbia, Nevada, Utah, Mexico; Contents: catalog and description of thin-sections and rock specimens

European mines and others, Utah and Europe

Colorado, Utah, Idaho, Oregon, and Cuba

Oregon, California, Arizona, New Mexico

Colorado, Utah and Arizona, notes on stock in various companies

Mines of various States

Three Forks sheet, Montana

Park City Mining District, Utah

Park City Mining District, Utah

Park City Mining District, Utah

Park City Mining District, Utah

Black Hills Region, South Dakota

1902

1902

1884

1886

1886

1887

1890

1893

1893

1894-95

1897

1897

1897

1898

1898

1898

1899

1901

1901-2

1902

1900

1902-5

1904

1904

1905

n.d.

n.d.

1903

1903

1903

1904

1899 


\begin{tabular}{|c|c|}
\hline 1172 & J. D. Irving \\
\hline 1173 & J. D. Irving \\
\hline 1174 & J. D. Irving \\
\hline 1175 & G. W. Tower \\
\hline 1176 & G. W. Tower \\
\hline 1177 & G. W. Tower \\
\hline 1178 & G. W. Tower \\
\hline 1179 & G. W. Tower \\
\hline 1180 & G. W. Tower \\
\hline 1181 & G. W. Tower \\
\hline 1182 & G. W. Tower \\
\hline 1183 & G. W. Tower \\
\hline 1184 & G. W. Tower \\
\hline 1185 & G. W. Tower \\
\hline 1186 & G. W. Tower \\
\hline 1187 & G. W. Tower \\
\hline 1187-A & S. F. Emmons \\
\hline 1443 & J. M. Hill \\
\hline 1444 & J. M. Hill \\
\hline 1445 & J. M. Hill \\
\hline 1446 & J. M. Hill \\
\hline 1447 & J. M. Hill \\
\hline 1457 & Whitman Cross \\
\hline 1457-A & Whitman Cross \\
\hline $1457-B$ & Whitman Cross \\
\hline $1457-\mathrm{C}$ & Whitman Cross \\
\hline 1457-D & Whitman Cross \\
\hline 1457-E & Whitman Cross \\
\hline $1457-\mathrm{F}$ & Whitman Cross \\
\hline $1457-\mathrm{G}$ & Whitman Cross \\
\hline $1457-\mathrm{H}$ & Whitman Cross \\
\hline 1457-I & Whitman Cross \\
\hline 1466 & J. F. Hunter \\
\hline 1470 & J. E. Spurr \\
\hline 1471 & J. E. Spurr \\
\hline 1472 & J. E. Spurr \\
\hline 1473 & J. E. Spurr \\
\hline 1474 & J. E. Spurr \\
\hline 1475 & J. E. Spurr \\
\hline 1476 & J. E. Spurr \\
\hline 1477 & J. E. Spurr \\
\hline 1478 & J. E. Spurr \\
\hline 1479 & G. H. Garrey \\
\hline 1480 & G. H. Garrey \\
\hline 1481 & G. H. Garrey \\
\hline 1482 & G. H. Garrey \\
\hline 1483 & G. H. Garrey \\
\hline 1484 & G. H. Garrey \\
\hline 1486 & G. H. Garrey \\
\hline 1487 & G. H. Garrey \\
\hline 1488 & G. H. Garrey \\
\hline 1620 & W. H. Emmons \\
\hline 1621 & W. H. Emmons \\
\hline 1622 & W. H. Emmons \\
\hline 1623 & W. H. Emmons \\
\hline 1798 & J. M. Hill \\
\hline 1847 & F. L. Ransome \\
\hline 1848 & F. L. Ransome \\
\hline 1849 & W. J. Sinclair \\
\hline 1850 & W. J. Sinclair \\
\hline 1851 & F. L. Ransome \\
\hline 1862 & S. F. Emmons \\
\hline 1863 & $\begin{array}{l}\text { S. F. Emmons } \\
\text { and others }\end{array}$ \\
\hline 1864 & S. F. Emmons \\
\hline 1898-I & - \\
\hline 1904 & F. L. Ransome \\
\hline 1905 & F. L. Ransome \\
\hline 1906 & F. L. Ransome \\
\hline 190 & F. L. Ransome \\
\hline 190 & F. L. Ransome \\
\hline
\end{tabular}

Black Hills Region, South Dakota 1899

Black Hills Region, South Dakota 1899

Black Hills Region, South Dakota 1899

Rico Quadrangle, Colorado 1898

Rico Quadrangle, Colorado 1898

Rico Quadrangle, Colorado 1898

Rico Quadrangle, Colorado $\quad 1898$

Deadwood, South Dakota 1898

Deadwood, South Dakota 1898

Tintic Quadrangle, Utah 1897

Tintic Quadrangle, Utah 1897

Tintic Quadrangle, Utah 1897

Tintic Quadrangle, Utah 1897

Tintic Quadrangle, Utah 1897

Tintic Quadrangle, Utah 1897

Microscopic notes on rocks from Tintic, Utah 1897

Butte, Montana (with correspondence, 1891-1904) 1896

Hawthorne Quadrangle, Nevada, notes with maps 1912

1912

Ivanpah Triangle, Yellow Pine District, Nevada 1912

Wellington, Markleville, Reno, and Granite Range Quadrangles, Nevada 1912

Lander County Quadrangle, Nevada 1912

Gunnison Region, Colorado 1890

Anthracite - Crested Butte, Colorado 1885

Crested Butte, Colorado 1885

Crested Butte, Colorado $\quad 1885$

Crested Butte, Colorado 1887

Anthracite, Colorado 1887

Anthracite, Colorado 1887

Anthracite - Crested Butte, Colorado 1887

Anthracite, Colorado 1890

Anthracite - Crested Butte, Colorado 1887

Miscellaneous and Gunnison Canyon, Colorado $\quad 1911-12$

Georgetown Quadrangle, Colorado, Field maps 1904

Georgetown Quadrangle, Colorado, Field maps 1904

Georgetown Quadrangle, Colorado, Field maps 1904

Georgetown, Colorado

Georgetown, Colorado 1904

Silver Plume Special Quadrangle, Colorado 1904

Silver Plume Special Quadrangle, Colorado 1904

Silver Plume Special, Colorado 1904

Central City, Colorado. Map Book No. 1

Georgetown Quadrangle, Colorado 1904

Silver Plume Special, Colorado 1904

Silver Plume Special, Colorado 1904

Silver Plume Special, Colorado 1904

Silver Plume Special, Colorado 1904

Silver Plume Special, Colorado 1904

Idaho Springs Special, Colorado 1905

Idaho Springs Special, Colorado 1905

Idaho Springs Special, Colorado 1905

Manhattan Quadrangle, Nevada 1906

Bullfrog Special Quadrangle, Nevada 1905-6

Bullfrog Special Quadrangle, Nevada $1905-6$

Bullfrog Special Quadrangle, Nevada

Phillipsburg, Dillon, Helena Quadrangles, Montana, maps with notes 1913

Northwest Boundary Reconnaissance, Port Hill, Idaho to Lake Osoyoos, Washington

Northwest Boundary Reconnaissance

Northwest Boundary Reconnaissance 1901

Northwest Boundary Reconnaissance 1901

Northwest Boundary Reconnaissance. Catalog of collection of rocks from a strip approximately 10 miles wide along the Northwest Boundary between Port Hill, Idaho, and Lake Osoyoos, Washington

"Survey Correspondence" (letters to S. F. Emmons, including plats)

Miscellaneous manuscripts and maps

1901

ca. $1880-84$

ca. 1890

Ten Mile District, Colorado, "Typewritten manuscript on the 10-mile district and notes on gold on Colorado"

Black Hills (Deadwood, Sturgis, etc.), California, Keswick Great Valley, Mt. Pleasant [missing]

Card catalogue describing thin sections from the Gold Field District, Nevada

Notes on thin sections from the Globe Quadrangle, Arizona

Card catalogue of thin sections from the Bisbee District, Arizona

Card catalogue of thin sections from Coeur d'Alene, Idaho

Rice, Colorado. Notes on thin sections

n.d.

n.d.

n.d.

1902-3

1902

1903-4

1900 


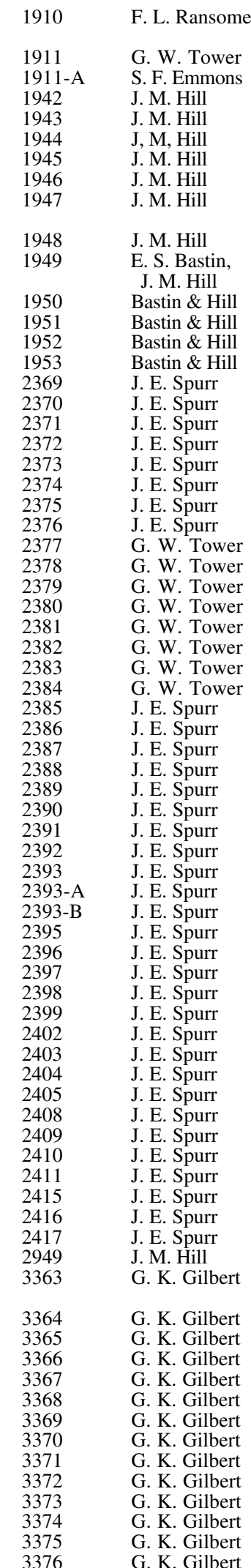

Card catalogue of rock specimens and thin sections from the Breckenridge District, Colorado

Microscopic notes on rocks from the Acari mines, Peru, South America n.d.

Ducktown, Tennessee 1909

Mt. Trumbull, Arizona

St. James, Nevada

Economic reconnaissance, Elko County, Nevada 1914

Economic reconnaissance, Lander County, Ravenwood District, Nevada 1914

Economic reconnaissance, Atlantic, Bristol and Patterson Districts, Nevada 1914

Economic reconnaissance, Nye County, and Troy, Iron Canyon, Willow
Creek Districts, Nevada

$\begin{array}{ll}\text { Economic reconnaissance, White Pine County, Nevada } & 1914\end{array}$

Mine notes, Central City, Colorado

Mine notes, Central City, Colorado

Mine notes, Central City, Colorado

Mine notes, Central City, Colorado

Mine notes, Central City, Colorado

Aspen Quadrangle, Colorado

Aspen Quadrangle, Colorado

Aspen Quadrangle, Colorado

Aspen Quadrangle, Colorado

Aspen Quadrangle, Colorado

Aspen Quadrangle, Colorado

Aspen Quadrangle, Colorado, notes on 4 in. x 6 in. cards 1895

Aspen Quadrangle, Colorado, analyses 1895

Aspen, Colorado 1895

Aspen, Colorado 1895

Aspen, Colorado $\quad 1895$

Aspen, Colorado 1895

Aspen, Colorado 1895

Aspen Quadrangle, Colorado, topographical maps 1895

Aspen Quadrangle, Colorado, mine maps 1895

Aspen Quadrangle, Colorado, mine maps 1895

Nevada District, Nevada 1899

Nevada and California 1899

Nevada and California 1899

Nevada and California 1899

Nevada and California 1899

Nevada and California $\quad 1899$

Nevada and California 1899

Nevada and California 1899

Nevada and California 1899

Nevada District, South of 40th parallel - $41 / 2$ in. x $61 / 2$ in. cards n.d.

Notes on photographs, Nevada and California 1899

Silver Peak, Nevada 1893

Silver Peak District, Nevada $\quad 1903$

Silver Peak District, Nevada 1903

Silver Peak District, Nevada, catalog of rocks 1903

Silver Peak District, Nevada, catalog of rocks 1903

Monte Cristo District, Washington 1900

Monte Cristo District, Washington 1900

Monte Cristo, Washington 1900

Monte Cristo, Washington 1900

Mercur District, Utah 1893

Mercur District, Utah

Mercur District, Utah 1893

Mercur District, Utah 1893

Encampment, Carbon County, Wyoming 1902

Encampment, Carbon County, Wyoming 1902

Encampment, Carbon County, Wyoming 1902

Fort Hall, Indian Reservation, Idaho 1914 The Great Lakes, Ohio, Michigan, Pennsylvania and New York,
index to notebooks

State Geological Survey of Ohio

State Geological Survey of Ohio

State Geological Survey of Ohio $\quad 1869-70$

State Geological Survey of Ohio $\quad 1869-70$

State Geological Survey of Ohio $1869-70$

Cahoes, New York 1868

Cahoes, New York 1870

Cahoes, New York 1868

"Wheeler Expedition," Nevada and Arizona

"Wheeler Expedition," Nevada and Arizona 1871

"Wheeler Expedition," Nevada and Arizona 1871

"Wheeler Expedition," Nevada and Arizona 1871

"Wheeler Expedition," Nevada and Arizona 1871 


\begin{tabular}{|c|c|}
\hline 3377 & G. K. Gilbert \\
\hline 3378 & G. K. Gilbert \\
\hline 3379 & G. K. Gilbert \\
\hline 3380 & G. K. Gilbert \\
\hline 3381 & G. K. Gilbert \\
\hline 3382 & G. K. Gilbert \\
\hline 3383 & G. K. Gilbert \\
\hline 3384 & G. K. Gilbert \\
\hline 3385 & G. K. Gilbert \\
\hline 3386 & G. K. Gilbert \\
\hline 3387 & G. K. Gilbert \\
\hline 3388 & G. K. Gilbert \\
\hline 3389 & G. K. Gilbert \\
\hline 3390 & G. K. Gilbert \\
\hline 3391 & G. K. Gilbert \\
\hline 3392 & G. K. Gilbert \\
\hline 3393 & G. K. Gilbert \\
\hline 3394 & G. K. Gilbert \\
\hline 3395 & G. K. Gilbert \\
\hline 3396 & G. K. Gilbert \\
\hline 3397 & G. K. Gilbert \\
\hline 3398 & G. K. Gilbert \\
\hline 3399 & G. K. Gilbert \\
\hline 3400 & G. K. Gilbert \\
\hline 3401 & G. K Gilbert \\
\hline 3402 & G. K Gilbert \\
\hline 3403 & G. K Gilbert \\
\hline 3404 & G. K Gilbert \\
\hline 3405 & G. K Gilbert \\
\hline 3406 & G. K Gilbert \\
\hline 3407 & G. K Gilbert \\
\hline 3408 & G. K Gilbert \\
\hline 3409 & G. K Gilbert \\
\hline 3410 & G. K Gilbert \\
\hline 3411 & G. K Gilbert \\
\hline 3412 & G. K. Gilbert \\
\hline 3413 & G. K. Gilbert \\
\hline 3414 & G. K. Gilbert \\
\hline 3415 & G. K. Gilbert \\
\hline 3416 & G. K. Gilbert \\
\hline 3417 & G. K. Gilbert \\
\hline 3418 & G. K. Gilbert \\
\hline 3419 & G. K. Gilbert \\
\hline 3420 & G. K. Gilbert \\
\hline 3421 & G. K. Gilbert \\
\hline 3422 & G. K. Gilbert \\
\hline 3423 & G. K. Gilbert \\
\hline 3424 & H. A. Wheeler \\
\hline 3425 & H. A. Wheeler \\
\hline 3426 & G. K. Gilbert \\
\hline 3427 & G. K. Gilbert \\
\hline 3428 & G. K. Gilbert \\
\hline 3429 & G. K. Gilbert \\
\hline 3430 & G. K. Gilbert \\
\hline 3431 & G. K. Gilbert \\
\hline 3432 & G. K. Gilbert \\
\hline 3433 & G. K. Gilbert \\
\hline 3434 & G. K. Gilbert \\
\hline 3435 & G. K. Gilbert \\
\hline 3436 & G. K. Gilbert \\
\hline 3437 & G. K. Gilbert \\
\hline 3438 & G. K. Gilbert \\
\hline 3439 & G. K. Gilbert \\
\hline 3440 & G. K. Gilbert \\
\hline 3441 & G. K. Gilbert \\
\hline 3442 & G. K. Gilbert \\
\hline 3443 & G. K. Gilbert \\
\hline 3444 & G. K. Gilbert \\
\hline 3445 & G. K. Gilbert \\
\hline 3446 & G. K. Gilbert \\
\hline 3447 & G. K. Gilbert \\
\hline 3448 & G. K. Gilbert \\
\hline 344 & G. K. Gilbert \\
\hline 3453 & G. K. Gilbert \\
\hline 345 & G. K. Gilbert \\
\hline & \\
\hline
\end{tabular}

"Wheeler Expedition," Nevada and Arizona 1871

"Wheeler Expedition," Nevada and Arizona 1871

"Wheeler Expedition" 1872

"Wheeler Expedition" 1872

"Wheeler Expedition" 1872

"Wheeler Expedition" 1872

"Wheeler Expedition" 1872

"Wheeler Expedition" 1873

"Wheeler Expedition" 1873

"Wheeler Expedition" 1873

"Wheeler Expedition" 1873

"Wheeler Expedition" 1873

Indexes to "Wheeler Expedition" notebooks 1873

Indexes to "Wheeler Expedition" notebooks 1871-72

Indexes Nos. 1 to 10, Notes on Utah, "Powell Survey" $1875-76$

Indexes Nos. 1 to 10, Notes on Utah, "Powell Survey" (loaned to USGS) 1875-76

Indexes Nos. 1 to 10, Notes on Utah, "Powell Survey" (loaned to USGS) 1875-76

Indexes Nos. 1 to 10, Notes on Utah, "Powell Survey" (loaned to USGS) 1875-76

Indexes Nos. 1 to 10, Notes on Utah, "Powell Survey" (loaned to USGS) 1875-76

Indexes Nos. 1 to 10, Notes on Utah, "Powell Survey" (loaned to USGS) 1875-76

Indexes Nos. 1 to 10, Notes on Utah, "Powell Survey" (loaned to USGS) 1875-76

Indexes Nos. 1 to 10, Notes on Utah, "Powell Survey' 1875-76

Indexes Nos. 1 to 10, Notes on Utah, "Powell Survey" (loaned to USGS) 1875-76

Indexes Nos. 1 to 10, Notes on Utah, "Powell Survey" (loaned to USGS) 1875-76

"Powell Survey" (loaned to USGS) 1877-78

"Powell Survey," Bonneville

"Powell Survey" (loaned to USGS)

"Powell Survey" (loaned to USGS)

"Powell Survey" (loaned to USGS)

"Powell Survey" (loaned to USGS)

"Powell Survey," Bonneville

"Powell Survey" (loaned to USGS)

"Powell Survey" (loaned to USGS)

"Powell Survey" (loaned to USGS)

"Powell Survey" (loaned to USGS)

Adams Center, New York

New York

Various Stations

Gunnison Series, Utah

Utah

Utah

Bonneville, Utah

Bonneville, Utah

Bonneville, Utah

Bonneville, Utah

Bonneville, Utah

Bonneville, Utah

Utah

Utah

Utah and California [missing]

Utah and California [missing]

Virginia and New Jersey

$1877-78$
1877

1877-78

$1877-78$

$1877-78$

$1877-78$

1877

1877-78

1877-78

1877-78

1877-78

1890

1885

1878

1878

1879

1879

1879

$1879-80$

1880

1880

1880

1880

1880

1880

1883

1883

1884

New York to Arizona 1884

New York

New York

New York

Pennsylvania, Tennessee, and Virginia

New York

New York

New York

New York

Tennessee

New York

North Bay, Canada, and Elmira, New York

1884
1885

1885

1885

1885-86

1886

1886

1886

1886-87

1887

1887

1887

1888

New York and Washington, D.C. 1889

$\begin{array}{ll}\text { New York and Washington, D.C. } & 1890 \\ \text { New York } & 1890\end{array}$

New Jersey and Pennsylvania

New York

1891

Excursion of the Fifth International Congress of Geologists

to Montana, Utah, Colorado, New Mexico, and Arizona

Arizona

Arizona

Colorado

Colorado

Colorado 


\begin{tabular}{|c|c|}
\hline 3456 & G. K. Gilbert \\
\hline 3457 & G. K. Gilbert \\
\hline 3458 & G. K. Gilbert \\
\hline 3459 & G. K. Gilbert \\
\hline 3460 & G. K. Gilbert \\
\hline 3461 & G. K. Gilbert \\
\hline 3462 & G. K. Gilbert \\
\hline 3463 & G. K. Gilbert \\
\hline 3464 & G. K. Gilbert \\
\hline 3465 & G. K. Gilbert \\
\hline 3466 & G. K. Gilbert \\
\hline 3467 & G. K. Gilbert \\
\hline 3468 & G. K. Gilbert \\
\hline 3469 & G. K. Gilbert \\
\hline 3470 & G. K. Gilbert \\
\hline 3471 & G. K. Gilbert \\
\hline 3472 & G. K. Gilbert \\
\hline 3473 & G. K. Gilbert \\
\hline 3474 & G. K. Gilbert \\
\hline 3475 & G. K. Gilbert \\
\hline 3476 & G. K. Gilbert \\
\hline 3477 & G. K. Gilbert \\
\hline 3478 & G. K. Gilbert \\
\hline 3479 & G. K. Gilbert \\
\hline 3480 & G. K. Gilbert \\
\hline 3481 & G. K. Gilbert \\
\hline 3482 & G. K. Gilbert \\
\hline \multicolumn{2}{|c|}{ (Begin duplicate numbers 3} \\
\hline 3483 & G. K. Gilbert \\
\hline 3483 & G. W. Tower \\
\hline 3484 & G. W. Tower \\
\hline 3484 & G. K. Gilbert \\
\hline 3485 & G. K. Gilbert \\
\hline 3485 & G. W. Tower \\
\hline 3486 & G. W. Tower \\
\hline 3486 & G. K. Gilbert \\
\hline 3487 & G. K. Gilbert \\
\hline 3487 & G. W. Tower \\
\hline 3488 & G. W. Tower \\
\hline 3488 & G. K. Gilbert \\
\hline 3489 & G. K. Gilbert \\
\hline 3489 & G. W. Tower \\
\hline
\end{tabular}

G. W. Tower
Colorado

Pueblo Quadrangle, Colorado

New York

Virginia and New York

New York

Colorado

Colorado

Colorado

Colorado

New York

Michigan and New York

New York

Ontario; New York

New York

New York

New York

New York

New York

New York

Harriman Expedition, New York to Yakutat, Alaska

Harriman Expedition, New York to Yakutat, Alaska

Mexico

Alaska

Washington and Oregon

Harriman Expedition, Washington and Oregon

Utah

Utah

Utah

Butte, Montana copper mines: Bellona, Colusa, Comanche, Dayton, Emma, Ensenada, Gaynon, Gambetta, Johnstown, Leonard Little Ida, Mt. View, Original, Pennsylvania, Rarus, Silver Bow, Virginius

Butte, Montana, silver mines: Allie Brown, Aplite, Atlantic, Butte and Boston, Goldflint, Highland, Hyde Park, Iowa, Kossuth, Lexington, Moody and Saulsey, Rainbow lode, W. P. Blake, Wappello

Utah

Butte, Montana, silver mines: Alice, Blue Wing, Currie, Garfield, Gray Rock, Hawkeye, Hibernia, Lexington, Magna Charta, Magnolia, Nettie, Parnell, Penrose

Butte, Montana, copper mines: Glengarry, Gray Rock, Johnston vein, Lloyd Tunnel, Mt. View, Penna, Rarus, Silver Bow, Windlass, Utah

Arizona

Butte, Montana, copper mines: Baltic, Bell, Bellona, Blue Jay, Buffalo, Colusa Parrott, Estalla, Green Mt., Moonlight, Mt. Consolidated, Pipestone Springs

New York

California

Butte, Montana, mines: Adams, Amy, Anaconda, Anderson, Atlantic, Belmont, Belle of Butte, Blackrock, Clinton, Colusa Parrott, Elm Orly, Gagnon, Grey Rock, Goldsmith, Hibernia, Homestake, Kit Carson, Lexington, Nettie, North Star, Odin, Old Glory, Oneida, Poser, Rainbow, Schmeityes, Silver Sides, Six O'clock, Snowdrift, Springfield, Valley, Wappello, Wedge

Butte, Montana, mines: Anaconda, Buffalo, Cuerpo Bayyo, Green Mt., Diamond Drill, Ground Squirrel, Mat, Modoc, Mountain Consolidated, Parrott, Ramsdell Parrott, Wake Up John

California

California

Butte, Montana: Modoc mine

Butte, Montana, Anaconda mines

California; Glen Echo Quarry, Maryland; and Stone Mountain, Georgia

New York, Michigan, and California

Butte, Tintic, catalogue of specimens, slides, cases, etc. n.d.

Boulder and Helena Quadrangles, Montana, mines 1899

California

Helena quadrangle, Montana 1899

California 1904

Boulder Hot Springs, Montana 1899

California; Mackinaw City, Michigan 1904

California $\quad 1905$

Montana, Mountain View cross cuts, Leonard and West Colusa levels $\quad 1900$ 


\begin{tabular}{|c|c|}
\hline 3498 & Joseph Barrell \\
\hline $\begin{array}{l}3498 \\
3499 \\
3499 \\
3500 \\
3500 \\
3501 \\
3501 \\
3502\end{array}$ & $\begin{array}{l}\text { G. K. Gilbert } \\
\text { G. K. Gilbert } \\
\text { Joseph Barrell } \\
\text { Joseph Barrell } \\
\text { G. K. Gilbert } \\
\text { G. K. Gilbert } \\
\text { Joseph Barrell } \\
\text { W. H. Weed }\end{array}$ \\
\hline $\begin{array}{l}3502 \\
3503 \\
3503 \\
3504 \\
3504 \\
3505 \\
3505 \\
3506 \\
3506 \\
3507 \\
3507 \\
3508\end{array}$ & $\begin{array}{l}\text { G. K. Gilbert } \\
\text { G. K. Gilbert } \\
\text { W. H. Weed } \\
\text { W. H. Weed } \\
\text { G. K. Gilbert } \\
\text { G. K. Gilbert } \\
\text { W. H. Weed } \\
\text { W. H. Weed } \\
\text { G. K. Gilbert } \\
\text { G. K. Gilbert } \\
\text { W. H. Weed } \\
\text { W. H. Weed }\end{array}$ \\
\hline $\begin{array}{l}3508 \\
3509 \\
3509 \\
3510 \\
3510 \\
3511 \\
3511 \\
3512 \\
3512\end{array}$ & $\begin{array}{l}\text { G. K. Gilbert } \\
\text { G. K. Gilbert } \\
\text { W. H. Weed } \\
\text { W. H. Weed } \\
\text { G. K. Gilbert } \\
\text { G. K. Gilbert } \\
\text { W. H. Weed } \\
\text { W. H. Weed } \\
\text { G. K. Gilbert }\end{array}$ \\
\hline 3513 & G. K. Gilbert \\
\hline $\begin{array}{l}3513 \\
3514 \\
3514 \\
3515 \\
3515 \\
3516 \\
3516 \\
3517 \\
3517 \\
3518 \\
3518 \\
3519 \\
3519 \\
3520 \\
3520 \\
3521 \\
3521 \\
3522 \\
3522 \\
3523\end{array}$ & $\begin{array}{l}\text { W. H. Weed } \\
\text { W. H. Weed } \\
\text { G. K. Gilbert } \\
\text { G. K. Gilbert } \\
\text { W. H. Weed } \\
\text { Johnson } \\
\text { G. K. Gilbert } \\
\text { W. H. Weed } \\
\text { G. K. Gilbert } \\
\text { G. K. Gilbert } \\
\text { W. H. Weed, Willi } \\
\text { W. H. Weed } \\
\text { G. K. Gilbert } \\
\text { W. H. Weed } \\
\text { G. K. Gilbert } \\
\text { W. H. Weed } \\
\text { G. K. Gilbert } \\
\text { G. K. Gilbert } \\
\text { W. H. Weed } \\
\text { W. H. Weed }\end{array}$ \\
\hline $\begin{array}{l}3523 \\
3524 \\
3524 \\
3525 \\
3525 \\
3526 \\
3526 \\
3526-\mathrm{A} \\
3526-\mathrm{B} \\
3526-\mathrm{C} \\
3526-\mathrm{E} \\
3526-\mathrm{F} \\
3526-\mathrm{G} \\
3526-\mathrm{H} \\
3526-\mathrm{I} \\
3526-\mathrm{J} \\
3526-\mathrm{K} \\
3526-\mathrm{L} \\
3527 \\
3527\end{array}$ & $\begin{array}{l}\text { G. K. Gilbert } \\
\text { G. K. Gilbert } \\
\text { W. H. Weed } \\
\text { G. K. Gilbert } \\
\text { W. H. Weed } \\
\text { G. K. Gilbert } \\
\text { W. H. Weed } \\
\text { A. J. Collier } \\
\text { A. J. Collier } \\
\text { F. S. Parker } \\
\text { George F. Taylor } \\
\text { Taylor, and others } \\
\text { F. S. Parker } \\
\text { F. S. Parker } \\
\text { F. S. Parker } \\
\text { F. S. Parker } \\
\text { F. S. Parker } \\
\text { F. S. Parker } \\
\text { G. K. Gilbert } \\
\text { R. W. Stone }\end{array}$ \\
\hline
\end{tabular}

Deer Lodge , Montana, reconnaissance surface work, Klondike crosscut from Silver Bow north, West Colusa levels 1900

California 1905

California $\quad 1905$

West Colusa levels (7th, 8th, 9th, and 10th), Montana

Marysville, Montana 1901

California 1905

California 1906

Marysville, Montana $\quad 1901$

Yellowstone Park Quadrangle, Wyoming. List of specimens
sent to laboratory

$\begin{array}{ll}\text { California } & 1906\end{array}$

California 1906

Red Lodge and Great Forks Quadrangles, Montana 1891

Publication, Geology and mineral resources of the Judith Mountains, Montana 1892

California $\quad 1907$

California 1907

Hot Springs Quadrangle, Montana $\quad 1891$

Notes on Neihart and vicinity, Montana 1893

California $\quad 1907-8$

California 1908

Neihart Quadrangle, Montana 1893

Neihart Quadrangle, Montana, notes on Crazy Mountains, Little Belt $\begin{array}{ll}\text { Mountains, and Highwood Mountains } & 1894 \\ & 1908\end{array}$

$\begin{array}{lr}\text { California } & 1908 \\ \text { Utah } & 1914\end{array}$

Utah $\quad 1914$

Neihart Quadrangle $\quad 1894$

Utah 1916

Sketches, Utah (Bonneville outlet and shorelines) $\quad 1879-80$

$\begin{array}{ll}\text { Butte, Montana } & 1896\end{array}$

Sketches: Station Butte, Desert Buttes, Mirage, Fish Spring Range, Jeff Davis Peak

Sketches of Desert Buttes, Station Butte, Dunderbery, and Pavant Butte; and notes on Mountain Lake, Virginia $\quad 1880-82$

1896

Boulder, Montana, Geological and Boulder Quadrangles 1897

California and Utah 1916-17

Utah

Jefferson County, Montana

Boulder Quadrangle, Montana

Sketches, Utah

Boulder, Montana, Geological notes on Boulder Quadrangles 1898

Index to 1875 notebooks n.d.

Index n.d.

Mostly Boulder Quadrangle, Montana; also Gibbonsville, etc., Elkhorn notes 1898

Little Belt Mountains, Montana, Neihart notes collection 1899

$\begin{array}{ll}\text { Index } & \text { n.d. } \\ \text { Butte, Montana, notes on the cooper mines in Butte } & 1899\end{array}$

Index

Butte, Montana. Notes on Butte mines 1899

Index n.d.

Card Index to notes on Niagara Falls n.d.

Butte, Montana 1899

Butte, Montana, notes and tables by Weed on Anaconda, Mommouth,
and other copper mines published in folio No. 38 $\begin{array}{cr}\text { and other copper mines published in folio No. 38 } & 1899 \\ \text { Lake Bonneville, Utah, Sketches } & 1880\end{array}$

Arizona, Sketches 1891

Butte, Montana, description of specimens from Butte District n.d.

Nevada City 1908

Butte, Montana. Notes on Butte mines 1900

Yuba Dam Project 1909

Butte, Montana 1901

Vertical angle traverse notebook, Dawson County, Montana 1929

Vertical range traverse notebook, Dawson County, Montana 1929

Montana. Notes, August 7 - September 18

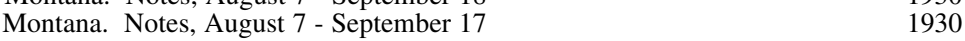

Montana. Notes, June 9 - August 4

Montana. Vertical Angle Traverse, Richland - Dawson Counties 1930

Montana. Vertical Angle Traverse, Richland - Dawson Counties 1930

Montana. Vertical Angle Traverse, Richland - Dawson Counties 1930

Montana. Vertical Angle Traverse, Richland - Dawson Counties 1930

Montana. Notes, June 9 - August 4

Montana. Richland - Dawson Survey, elevations of primary stations 1930

Computation notes and cross sections, Yuba Canyon 1909

Butte, Montana 1901 
E. C. Murphy

W. H. Weed

W. H. Weed

E. C. Murphy

E. C. Murphy

E. C. Murphy

W. H. Weed

W. H. Weed

E. C. Murphy

E. C. Murphy

W. H. Weed

E. C. Murphy

W. H. Weed

E. C. Murphy

W. H. Weed

E. C. Murphy

E. C. Murphy

E. C. Murphy

E. C. Murphy

E. C. Murphy

E. C. Murphy

E. C. Murphy

E. C. Murphy

E. C. Murphy

E. C. Murphy

E. C. Murphy
E. C. Murphy

E. C. Murphy

E. C. Murphy

E. C. Murphy

E. C. Murphy

E. C. Murphy

E. C. Murphy

E. C. Murphy

E. C. Murphy

E. C. Murphy

E. C. Murphy

E. C. Murphy

E. C. Murphy

Condit, Finch

\& Pardee

E. C. Murphy

E. C. Murphy

E. C. Murphy

E. C. Murphy

E. C. Murphy

E. C. Murphy

E. C. Murphy

E. C. Murphy

E. C. Murphy

E. C. Murphy

E. C. Murphy

E. C. Murphy

E. C. Murphy

E. C. Murphy

E. C. Murphy

E. C. Murphy

G. K. Gilbert

G. K. Gilbert

G. K. Gilbert

G. K. Gilbert

J. M. Boutwell

J. M. Boutwell
E. C. Murphy
Stony Point Quadrangle, Virginia

Nicaragua, notes on copper mines

Unbound material consisting chiefly of notes with correspondence, sketches and reports relating to investigations of hydraulic mining debris in the Sacramento, Feather, and Yuba Rivers, also including depth soundings in bays. The findings were published as Professional Paper No. 105.

California, notes on water transportation experiments Butte, Montana

Copper mines in Virginia and North Carolina

California, notes on water transportation experiments

Kendall Quadrangle, Montana

California, notes on water transportation experiments

California, notes on water transportation experiments

Copper mines, Butte Quadrangle, Montana

Elkhorn Mine

California, notes on water transportation experiments

California, notes on water transportation experiments

Butte, Montana. Notes and sketches

California, notes on water transportation experiments

California, notes on water transportation experiments 1907

List of mine maps, Butte, Montana

California, notes on water transportation experiments 1907

Debris Investigation Laboratory 1907

Debris Investigation Laboratory 1907

Debris Investigation Laboratory 1907

Debris Investigation Laboratory 1907

Debris Investigation Laboratory 1907

Debris Investigation Laboratory 1907

Debris Investigation Laboratory

Debris Investigation Laboratory 1907

Debris Investigation Laboratory 1907

Debris Investigation Laboratory 1907

Debris Investigation Laboratory

Debris Investigation Laboratory, Special Experiments

Debris Investigation Laboratory, Special Experiments

Three Forks, Yellowstone Park region, Montana, published in Bulletin 795-G, cards and maps

Debris Investigation Laboratory, Special Experiments

Debris Investigation Laboratory, Special Experiments 1908

Debris Investigation Laboratory, Special Experiments 1908

Debris Investigation Laboratory, Special Experiments 1908

Debris Investigation Laboratory, Special Experiments 1908

Debris Investigation Laboratory, Special Experiments 1908

Debris Investigation Laboratory, Special Experiments 1908

Debris Investigation Laboratory, Special Experiments 1908

Debris Investigation Laboratory, Special Experiments 1908

Debris Investigation Laboratory, Special Experiments 1908

Debris Investigation Laboratory, Special Experiments 1908

Debris Investigation Laboratory, Special Experiments 1908

Debris Investigation Laboratory, Special Experiments 1908

Debris Investigation Laboratory, Special Experiments 1909

Debris Investigation Laboratory, Special Experiments 1909

Debris Investigation Laboratory, Special Experiments 1909

Debris Investigation Laboratory, Special Experiments 1909

Berkeley, California, hydraulic laboratory notes 1907

Notes for Professional Paper 86

Notes for Professional Paper 86

Notes for Professional Paper 86

Sturgis, South Dakota, geological notes and list of specimens

Sturgis, South Dakota, geological notes and list of specimens
$1907-8$

1907

1908

1908

1908

1908

1908

1908

1908

1908

1908

1908

1908

1908

1908

1916

3-4, 1906

$-12,1914$

05

$-7$

9

07

.

.

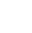

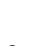

1907
n.d.

n.d.

n.d.

1898

1898 


$\begin{array}{ll}3599 & \text { J. M. Boutwell } \\ 3600 & \text { J. M. Boutwell } \\ 3601 & \text { J. M. Boutwell } \\ 3602 & \text { J. M. Boutwell } \\ 3603 & \text { J. M. Boutwell } \\ 3604 & \text { J. M. Boutwell } \\ 3661 & \text { W. H. Weed } \\ 3662 & \text { W. H. Weed } \\ 3663 & \text { W. H. Weed } \\ 3664 & \text { W. H. Weed } \\ 3665 & \text { W. H. Weed } \\ 3666 & \text { W. H. Weed } \\ 3667 & \text { W. H. Weed } \\ 3668 & \text { W. H. Weed } \\ 3669 & \text { W. H. Weed } \\ 3670 & \text { W. H. Weed } \\ 3671 & \text { W. H. Weed } \\ 3672 & \text { W. H. Weed } \\ 3673 & \text { W. H. Weed } \\ 3674 & \text { W. H. Weed } \\ 3675 & \text { W. H. Weed } \\ 3676 & \text { W. H. Weed } \\ 3677 & \text { W. H. Weed } \\ 3678 & \text { W. H. Weed } \\ 3679 & \text { W. H. Weed } \\ 3680 & \text { W. H. Weed } \\ 3824 & \text { F. L. Ransome } \\ 3825 & \text { F. L. Ransome } \\ 3826 & \text { F. L. Ransome } \\ 3826-\text { A } & \text { F. L. Ransome } \\ 3827 & \text { F. L. Ransome } \\ 3828 & \text { F. L. Ransome } \\ 3829 & \text { J. B. Umpleby } \\ & \\ 3830 & \text { J. B. Umpleby } \\ 3830-\text { A } & \text { F. L. Ransome } \\ & \\ 3833 & \\ 3830-\text { B } & \text { F. L. Ransome } \\ 3830-\text { C } & \text { F. L. Ransome } \\ 3830-\text { W. H. Weed } & \text { F. L. Ransome } \\ 3830-\text { E } & \text { F. L. Ransome } \\ 3830-\text { F } & \text { F. L. Ransome } \\ 3831 & \text { F. L. Ransome } \\ \text { F. L. Ransome } \\ & \text { W. H. Weed } \\ & \\ 3832 & \end{array}$

Sturgis and Spearfish, South Dakota, geological notes and lists of specimens

Spearfish, South Dakota, geologic notes and list of specimens

Sturgis, South Dakota, N. Half, geologic notes and maps

Sturgis, South Dakota, S. Half, geologic notes and maps

Spearfish, South Dakota, N. Half, geologic notes and maps

Spearfish, South Dakota, S. Half, geologic notes and maps

Butte, Montana, notes on mines

Butte, Montana, notes on Moose mine

Butte, Montana, notes on Berkley

Butte, Montana, notes on Mountain View mine

Butte, Montana, notes on Mountain View mine

Butte, Montana, notes on Blue Jay mine

Butte, Montana, Western Calusa and Leonard mines

Butte, Montana, Western Calusa and Leonard mines

Silver Bow mine - Butte, Montana

Silver Bow No. 1 and Silver Bow No. 3 mines

Notes on Pennsylvania and Montana mines

Notes on Pigeon, Stewart, Ella, Gagnon, Gem, and York mines, Montana

Notes on St. Lawrence mines, Montana

Notes on Jessie mine, Montana

Rarus mine, Montana

Rarus mine, Montana

Notes on Rarus, Pennsylvania and Coca mines, Montana

Parrot mine, Montana

Mt. Con., Green Mt., high ore, and diamond mines, Montana

Notes on Glengarry, Neva, and Gopher mines, Montana

Ray Quadrangle, Arizona (includes a description of specimens and fossils

Ray Quadrangle, Arizona (includes references to photographs taken in Ray Quadrangle)

Ray Quadrangle, Arizona

Ray Quadrangle, Arizona, drawings illustrating metamorphism of quartzite

Miami Special, Grand Canyon

Ray and Miami Districts, Arizona. Notebook No. 5

Ray Special, Miami Special, Arizona. Geological notes made during field season of 1910-11 including a list of specimens found in Ray Quadrangle

Ray Special and Miami Special, Arizona. Geological notes

Hailey, Idaho; Sumpter, Oregon; Yosemite, and Napa, California; Shasta County copper mines, California; Van Horn, Texas; Deming and Silver City, New Mexico; Franklin Furnace, New Jersey;

Santa Rita, New Mexico Quadrangles: Sanford, Livermore, San Jose, Los Ange

Cuyuna Range, Mesabi Range, Biwabik mine and Ironton, Minnesota; Miami mines, Inspiration Ridge, Ray - Hercules mines, Phoenix, Ojo, Arizona; Mogollon, Fanny mine, Cooney Canyon, New Mexico

Colorado River dams, California

Weaverville, Randburg, Chalome, Yuma and Big Trees Quadrangles, California

Colorado River, Nevada

4 in. x 6 in. card index of localities, specimens, and mines found in Books 1 to 5. Ray and Miami District, Arizona

Yellowstone Park, Midway Geyser Basin, Old Faithful Group, Giantess Group, Three Crater Group

Yellowstone Park, Giantess Group, Three Crater Group, Giantess Geyser, Grand and Turban indicators, River Group, Riverside Geyser, Castle Group, Castle Cone, Crystal Spring, Splendid, Giant Group, Oblong Springs on Little Firehole, Soda Geyser Group, Cascade Group, Emerald Group, Cliff Geyser, Solitary Spring, Camp Group, Marys Lake Sulphur Springs, Sulphur Creek Springs

Yellowstone Park, Red Terrace Spring, Fissure Group, Pink Cone Geyser, Goose Mud Lake, Perpetual Geyser, East Fork Springs, Fountain Group, Geyser Meadows; also Spring notes

Yellowstone Park, Mammoth Hot Springs

Yellowstone Park, Hot Springs notes, Norris Geyser Basin

Yellowstone Park, Norris Geyser Basin, Geyser Creek Springs Lower Geyser Basin, Egeria Springs, Upper Geyser Basin, Lone Star Basin, Springs of Twin Lakes

Yellowstone Park, Upper Geyser Basin, Shoshone Basin, Springs of Midway Geyser Basin, Springs of Rabbit Creek, Sour Creek Springs, Broad Creek Springs, Moss Creek (Orange Creek), Forest Springs

Yellowstone Park, list of collection of specimens

Yellowstone Park, Mammoth Hot Springs

Yellowstone Park, Lower Firehole: Butte Group, Camp Group, Sentinel Group, Twin Buttes, Fairy Falls Group, River Group, Norris Basin 


\begin{tabular}{|c|c|}
\hline $\begin{array}{l}3842 \\
3843 \\
3844\end{array}$ & $\begin{array}{l}\text { W. H. Weed } \\
\text { W. H. Weed } \\
\text { W. H. Weed }\end{array}$ \\
\hline $\begin{array}{l}3845 \\
3846 \\
3847 \\
3848 \\
3849 \\
3850\end{array}$ & $\begin{array}{l}\text { W. H. Weed } \\
\text { W. H. Weed } \\
\text { W. H. Weed } \\
\text { W. H. Weed } \\
\text { W. H. Weed } \\
\text { W. H. Weed }\end{array}$ \\
\hline $\begin{array}{l}3851 \\
3852 \\
3853 \\
3854 \\
3855 \\
3856\end{array}$ & $\begin{array}{l}\text { W. H. Weed } \\
\text { W. H. Weed } \\
\text { W. H. Weed } \\
\text { W. H. Weed } \\
\text { W. H. Weed } \\
\text { W. H. Weed }\end{array}$ \\
\hline $\begin{array}{l}3857 \\
3858 \\
3859 \\
3860 \\
3861 \\
3862 \\
3863 \\
3864 \\
3864-\mathrm{A} \\
3864-\mathrm{B} \\
3865 \\
3866 \\
3867 \\
3868 \\
3869\end{array}$ & $\begin{array}{l}\text { W. H. Weed } \\
\text { W. H. Weed } \\
\text { M. P. Redmond } \\
\text { W. H. Weed } \\
\text { W. H. Weed } \\
\text { W. H. Weed } \\
\text { W. H. Weed } \\
\text { W. H. Weed } \\
\text { W. H. Weed } \\
\text { W. H. Weed } \\
\text { Paul J. Dashiell } \\
\text { Louis V. Pirsson } \\
\text { J. H. Ropes } \\
\text { Arnold Hague } \\
\text { Arnold Hague }\end{array}$ \\
\hline $\begin{array}{l}3870 \\
3870-\mathrm{A} \\
3871\end{array}$ & $\begin{array}{l}\text { Arnold Hague } \\
\text { Arnold Hague } \\
\text { Henry Gannett }\end{array}$ \\
\hline 3872 & Henry Gannett \\
\hline 3873 & W. H. Weed \\
\hline 3874 & Arnold Hague \\
\hline 3875 & W. H. Weed \\
\hline $\begin{array}{l}3876 \\
3877\end{array}$ & $\begin{array}{l}\text { W. H. Weed } \\
\text { W. H. Weed }\end{array}$ \\
\hline $\begin{array}{l}3878 \\
3879 \\
3880 \\
3881 \\
3882\end{array}$ & $\begin{array}{l}\text { W. H. Holmes } \\
\text { W. H. Holmes } \\
\text { W. H. Holmes } \\
\text { W. H. Holmes } \\
\text { W. H. Holmes }\end{array}$ \\
\hline $\begin{array}{l}3883 \\
3884 \\
3885 \\
3886 \\
3887 \\
3888\end{array}$ & $\begin{array}{l}\text { George M. Wrigh } \\
\text { G. M. Wright } \\
\text { G. M. Wright } \\
\text { G. M. Wright } \\
\text { G. M. Wright } \\
\text { G. M. Wright }\end{array}$ \\
\hline $\begin{array}{l}3889 \\
3890 \\
3891 \\
3892 \\
3892-\mathrm{A}\end{array}$ & $\begin{array}{l}\text { G. M. Wright } \\
\text { G. M. Wright } \\
\text { G. M. Wright } \\
\text { G. M. Wright } \\
\text { T. A. Jaggar }\end{array}$ \\
\hline $\begin{array}{l}\text { 3892-B } \\
3892-\mathrm{C}\end{array}$ & $\begin{array}{l}\text { T. A. Jaggar } \\
\text { T. A. Jaggar }\end{array}$ \\
\hline $\begin{array}{l}3892-\mathrm{D} \\
3892-\mathrm{E} \\
3892-\mathrm{F} \\
3892-\mathrm{G} \\
3893\end{array}$ & $\begin{array}{l}\text { T. A. Jaggar } \\
\text { T. A. Jaggar } \\
\text { Arnold Hague } \\
\text { F. P. King } \\
\text { G. M. Wright }\end{array}$ \\
\hline
\end{tabular}

Yellowstone Park, Upper Geyser Basin, Geysers of Upper Basin

Yellowstone Park, Hot Springs notes

Yellowstone Park, Giant Geyser cone, Lower Basin, Upper Basin and general notes

Yellowstone Park Survey, diary of travels and observations

Yellowstone Park, Hot Springs areas

Yellowstone Park, Upper Geyser Basin

Yellowstone Park, Hot Spring localities [index in front of notebook] 1887

Yellowstone Park, notes of hot springs 1887

Yellowstone Park, Shoshone Geysers, Lakeshore Hot Springs,

Lower Firehole Springs

Yellowstone Park, general geological notes

Yellowstone Park, Meadow near Buttes relation of sinter and diatom to drift

Yellowstone Park, general notes

Yellowstone Park, general notes

Yellowstone Park, general notes

Yellowstone Park, notes on hot springs and geysers; diagram of springs along Yellowstone Lake

Yellowstone Park, coal notes

Yellowstone Park, coal notes

Yellowstone Park

Yellowstone Park, notes on coal

Yellowstone Park, Mammoth Hot Springs

Yellowstone Park; Boulder, Yellowstone, and Butte Quadrangles

Yellowstone Park, chemical analyses of specimens

Yellowstone Park, list of specimens collected by Hague and Weed

Yellowstone Park, index of note books

Yellowstone Park, Mammoth Hot Springs

Yellowstone Park, Swan Lake Valley, with specimen slide $\quad 1888$

Yellowstone Park, various localities with sketches 1889

Yellowstone Park

Yellowstone Park, Sylvan Pass trip

Yellowstone Park, "Trip Through the Park with the International Congress of Geologists"

Address book containing many foreign names and addresses

Yellowstone National Park; Montana; Washington; Oregon; California

Yellowstone Park, topographic notes and drawings (by Mushback), Shoshone Geyser Basin, Red Mountain Creek, Gibbon Fork, Norris Basin, Mammoth Springs

Yellowstone Park, topographic notes and drawings (by Mushback),

Shoshone Basin, Upper Geyser, Midway Springs, Lower Geyser 1878

Yellowstone Park, list of specimens collected by Weed, Iddings, and

Hague, Nos. 1261 to 2640

Yellowstone Park, catalogue of specimens of igneous rocks collected by J. P. Iddings and G. M. Wright

Yellowstone Park, list of specimens collected by Hague, Weed, Iddings, Wright and F. A. G., Nos. 2641 to 3383

Yellowstone Park, chemical analyses of specimens

Notes on foreign hot springs by Hutton, Carpenter, Koschkull, Hooker, Abbey, Daupree, and Nelson

Book of sketches for Colorado Division of the "Hayden Survey"

Colorado, books of sketches for Colorado Division of the "Hayden Survey"

Colorado, books of sketches for Colorado Division of the "Hayden Survey"

Colorado, books of sketches for Colorado Division of the "Hayden Survey"

Yellowstone Park, book of sketches for the Colorado Division of the "Hayden Survey"

Yellowstone Park, geologic notes and description of specimens

Yellowstone Park, geologic notes and description of specimens

Yellowstone Park, geologic notes and description of specimens

Yellowstone Park, geologic notes

Yellowstone Park, geologic notes

Notes and list of specimens: Crazy Mountains, Montana, and Yellowstone National Park

Yellowstone Park, geologic notes and descriptions of specimens

Yellowstone Park, geologic notes and descriptions of specimens

Yellowstone Park, geologic notes and descriptions of specimens

Yellowstone Park, geologic notes

Absaroka Range, Yellowstone Park Survey, including notes on rock specimens collected

Absaroka Range, Yellowstone Park Survey, including list of photographs

Absaroka Range, Yellowstone National Park, including notes on rock

Absaroka Range specimens collected

1887

1887

1888

1888

1889

1889

1890

1890

1890
1892

1897

1899

n.d.

1883-88

1883

1888
1889
1889

1889
1889

n.d.

n.d.

n.d.

1878

n.d.

n.d.

n.d.

1884

1874

1875

1878

1874

1878

1884

1884

1884

1884

1884

1885

1885

1885

1885

1885

1893

1893

Absaroka Range

Absaroka Range, notes on rock specimens collected

Crandall Creek sheet, Wyoming, and Ishawooa sheet

Yellowstone Park, geologic notes with a revision of portions of notes of previous years, and additions thereto 


\begin{tabular}{|c|c|c|c|}
\hline 3893-A & G. M. Wright & Yellowstone National Park, geologic notes & 1883 \\
\hline 3893-B & G. M. Wright & $\begin{array}{l}\text { Tertiary and Quaternary references to northern Rocky Mountains area } \\
\text { from published works n.d. }\end{array}$ & \\
\hline 3893-C & G. M. Wright & Yellowstone National Park, descriptive notes and list of specimens & $1883-84$ \\
\hline 3893-D & W. H. Weed & Abstracts from reports and papers containing observations upon hot & \\
\hline 3893-E & W. H. Weed & $\begin{array}{l}\text { springs and geysers of Yellowstone National Park } \\
\text { Yellowstone National Park Survey, chemical analyses of specimens and }\end{array}$ & n.d. \\
\hline 3893-F & J. P Iddings & $\begin{array}{l}\text { waters } \\
\text { Yellowstone National Park, field notes and mounted photographs }\end{array}$ & n.d. \\
\hline 3893-G & J. P. Iddings & Yellowstone National Park, field notes and mounted photographs & 1884 \\
\hline 3893-H & G. M. Wright & Yellowstone National Park, descriptive notes & 1884 \\
\hline 3893-I & G. M. Wright & Yellowstone National Park, descriptive notes & $1884-85$ \\
\hline 3893-J & G. M. Wright & Yellowstone National Park, descriptive notes and revisions of notes & 1885 \\
\hline $3893-\mathrm{K}$ & W. H. Weed & Yellowstone National Park, geyser observations and meteorological records & 1884 \\
\hline 3893-L & W. H. Weed & Yellowstone National Park, hot springs notes & 1884 \\
\hline 3893-M & W. H. Weed & Yellowstone National Park, hot springs notes & 1884 \\
\hline $3893-\mathrm{N}$ & W. H. Weed & Yellowstone National Park, hot springs notes & 1885 \\
\hline 3893-O & W. H. Weed & Yellowstone National Park, general geological notes & 1884 \\
\hline 3893-P & W. H. Weed & References to the Jurassic in published sources & n.d. \\
\hline 3893-Q & Joseph P. Iddings & Yellowstone National Park, field notes & 1885 \\
\hline 3893-R & J. P. Iddings & Yellowstone National Park, field notes & 1885 \\
\hline 3893-S & W. H. Weed & Yellowstone National Park, notes on geysers and hot springs & 1886 \\
\hline 3893-T & W. H. Weed & Yellowstone National Park, notes on hot springs & 1886 \\
\hline 3893-U & $\begin{array}{l}\text { J. Edward Whitfield, } \\
\text { L. G. Eakins }\end{array}$ & Yellowstone National Park, chemical analyses & $1887-92$ \\
\hline 3893-V & J. P. Iddings & Yellowstone National Park, field notes & 1887 \\
\hline $3893-W$ & J. P. Iddings & Yellowstone National Park, field notes & $1888-89$ \\
\hline $3893-\mathrm{X}$ & W. H. Weed & Yellowstone National Park area, geologic notes & $1886-87$ \\
\hline 3893-Y & W. H. Weed & Yellowstone National Park, hot springs notes & 1887 \\
\hline $3893-Z$ & W. H. Weed & Yellowstone National Park, hot springs notes & $1887-88$ \\
\hline $3893-Z 1$ & W. H. Weed & Yellowstone National Park, geologic notes & $1888-89$ \\
\hline $3893-Z 2$ & J. P. Iddings & Yellowstone National Park, field notes & $1889-90$ \\
\hline 3893-Z 3 & J. P. Iddings & Yellowstone National Park, field notes & 1890 \\
\hline 3893-Z 3 & [various] & Yellowstone National Park, list of specimens Nos. 1-1260 & n.d. \\
\hline $3893-Z 4$ & W. H. Weed & Yellowstone National Park, hot springs notes & 1888 \\
\hline 3893-Z 5 & J. P. Iddings & Yellowstone National Park & 1883 \\
\hline $3893-Z 6$ & J. P. Iddings & Yellowstone National Park & 1886 \\
\hline 3894 & -- & List of specimens collected by Hague and Emmons & n.d. \\
\hline 3894-A & Arnold Hague & Yellowstone National Park & 1884 \\
\hline 3894-B & Arnold Hague & Yellowstone National Park & 1884 \\
\hline 3894-C & Arnold Hague & Yellowstone National Park & 1885 \\
\hline 3894-D & Arnold Hague & Yellowstone National Park & 1885 \\
\hline 3894-E & Arnold Hague & Yellowstone National Park & 1886 \\
\hline $3894-\mathrm{F}$ & Arnold Hague & Yellowstone National Park & 1886 \\
\hline 3894-G & Arnold Hague & Yellowstone National Park & 1887 \\
\hline 3894-H & Arnold Hague & Yellowstone National Park & 1887 \\
\hline 3894-I & Arnold Hague & Yellowstone National Park & 1888 \\
\hline 3894-J & Arnold Hague & Yellowstone National Park & 1888 \\
\hline 3894-K & Arnold Hague & Yellowstone National Park & 1889 \\
\hline 3894-L & Arnold Hague & Yellowstone National Park & 1889 \\
\hline 3894-M & Arnold Hague & Yellowstone National Park & 1889 \\
\hline $3894-\mathrm{N}$ & Arnold Hague & Trip through Yellowstone National Park with the Fifth International & \\
\hline & & Congress of Geologists on their western excursion & 1891 \\
\hline $3894-\mathrm{O}$ & Arnold Hague & Yellowstone National Park & 1891 \\
\hline 3894-P & Arnold Hague & Yellowstone National Park & 1893 \\
\hline 3894-Q & Arnold Hague & Yellowstone National Park & 1893 \\
\hline 3894-R & Arnold Hague & Yellowstone National Park & 1897 \\
\hline $3894-\mathrm{S}$ & Arnold Hague & Yellowstone National Park & 1897 \\
\hline 3894-T & Arnold Hague & Yellowstone National Park & 1902 \\
\hline 3894-U & Arnold Hague & Yellowstone National Park & 1902 \\
\hline 3894-V & Ernest Howe & Yellowstone National Park & 1911 \\
\hline 3894-W & Arnold Hague & Yellowstone National Park & 1911 \\
\hline $3894-X$ & Arnold Hague & Yellowstone National Park & 1915 \\
\hline 3894-Y & Arnold Hague & Yellowstone National Park & n.d. \\
\hline 3894-Z & Arnold Hague & Yellowstone National Park, geysers & n.d. \\
\hline 3896 & Arnold Hague & Yellowstone National Park, list of specimens, Nos. 1 to 29, collected by & nd \\
\hline 3897 & Arnold Hague & 2 lists of specimens, Nos. 1 to 2825 from Washoe, and Nos. 1 to 484 & \\
\hline & & from Toyabee Mountains, Montana & n.d. \\
\hline 3898 & Arnold Hague & Chemical analyses of specimens from Mt. Rainier, Washington, and & \\
\hline & & localities in Wyoming & n.d. \\
\hline 3899 & Arnold Hague & Chemical analyses of specimens from mines & n.d. \\
\hline 3899-A & W. H. Weed & Yellowstone National Park, hot springs & 1883 \\
\hline 3899-B & W. H. Weed & Yellowstone National Park, geysers & n.d. \\
\hline 3899-C & W. H. Weed & Yellowstone National Park, geysers & 1883 \\
\hline 3936 & J. P. Iddings & Eureka District, Nevada & 1880 \\
\hline 3936-A & J. P. Iddings & Eureka District, Nevada & 1880 \\
\hline 3937 & W. E. Sanders & Yellowstone National Park & 1884 \\
\hline 3938 & Penfield & Yellowstone National Park & 1886 \\
\hline 3939 & J. P. Iddings & Yellowstone National Park, list of thin sections & 1883 \\
\hline 3940 & A. C. Gill & Yellowstone National Park & 1887 \\
\hline
\end{tabular}




$\begin{array}{ll}3941 & \text { J. P. Iddings } \\ 3942 & \text { J. P. Iddings } \\ 3943 & \text { J. P. Iddings } \\ 3944 & \text { J. P. Iddings } \\ 3945 & \text { J. P. Iddings } \\ 3946 & \text { J. P. Iddings } \\ 3947 & \text { J. P. Iddings } \\ 3948 & \text { J. P. Iddings } \\ 3949 & \text { J. P. Iddings } \\ 3950 & \text { J. P. Iddings } \\ 3951 & \text { J. P. Iddings } \\ 3952 & \text { J. P. Iddings } \\ 3953 & \text { J. P. Iddings } \\ 5208 & \text { F. L. Ransome } \\ 5209 & \text { F. L. Ransome } \\ 5210 & \text { F. L. Ransome } \\ 5211 & \text { F. L. Ransome } \\ 5212 & \text { F. L. Ransome } \\ 5213 & \text { F. L. Ransome } \\ 5214 & \text { F. L. Ransome } \\ 5215 & \text { F. L. Ransome } \\ 5216 & \text { F. L. Ransome } \\ 5217 & \text { H. A. J. Jenison } \\ 5218 & \text { F. L. Ransome } \\ 5243 & \text { Clarence King, } \\ & \text { S. F. Emmons } \\ 6000 & \text { J. D. Hague } \\ & \text { Wm. C. Alden }\end{array}$

6001

Wm. C. Alden

6002

6003

6004

6005

6006

6007

6008

6009

6010

6011

6012

6013

6014

6015

6016

6017

6018

6019

6020

6021

Wm. C. Alden

6022 Wm. C. Alden

6023

Wm. C. Alden

6024

Wm. C. Alden

6025
Yellowstone National Park

Yellowstone National Park

Yellowstone National Park

Yellowstone National Park

Yellowstone National Park

Yellowstone National Park

Yellowstone National Park

Yellowstone National Park

Yellowstone National Park

Yellowstone National Park

Yellowstone National Park

Yellowstone National Park

Yellowstone National Park

Notes on Oatman District, Arizona, Notebook No.

Notes on Oatman District, Arizona, Notebook No. 2

Notes on Oatman District, Arizona, Notebook No. 3

Notes on Oatman District, Arizona, Notebook No. 4

Notes on Oatman District, Arizona, Notebook No. 5

Notes on Oatman District, Arizona, Notebook No. 6

Notes on Oatman District, Arizona, Notebook No. 7

Notes on Oatman District, Arizona, Notebook No. 8

Notes on Oatman District, Arizona, Notebook No. 9

Notes on Oatman District, Arizona, Notebook No. 10

Notes on Oatman District, Arizona, Notebook No. 11

California. Descriptive catalogue of specimens collected on

U. S. Geological Exploration of the Fortieth Parallel

Glacial geology and physiography, Easton, Allentown, and Reading, Pennsylvania; Raritan and Passaic, New Jersey; New Castle and Zelienople, Pennsylvania; Equinoz, Vermont; Cape Cod and Martha's Vineyard, Massachusetts

Glacial geology and physiography, Saskatchewan, northwestern North Dakota and northeastern Montana (west to 109 degrees)

Glacial geology and physiography, Saskatchewan, northwestern North Dakota and northeastern Montana (west to 109 degrees)

Glacial geology and physiography, Connecticut River Valley, Connecticut, and Long Island, New York

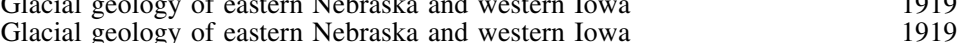

Glacial geology and physiography, North Dakota, Saskatchewan, and Montana 1920

Glacial geology and physiography, North Dakota, Saskatchewan, Alberta, and Montana

Glacial geology and physiography, North Dakota and Saskatchewan, Alberta, and Montana

Glacial geology and physiography, McKean and adjacent counties in Pennsylvania and New York, for the U. S. Forest Service

Glacial geology and physiography, North Dakota and west to 112 degrees in Montana and to Yellowstone Park

Glacial geology and physiography, North Dakota and west to 112 degrees in Montana and to Yellowstone Park

Glacial geology and physiography, Yellowstone Valley and east to Dickinson, North Dakota

Glacial geology and physiography, Dickinson, North Dakota, SW. to Yellowstone National Park and NW. to Great Falls, Montana

Glacial geology and physiography, Yellowstone National Park and north to Great Falls, Montana

Glacial geology and physiography, Great Falls, Montana, to Yellowstone Park, Wind River Valley, Big Horn Mountains, Wyoming

Glacial geology and physiography, Great Falls, Montana, S. to Yellowstone Park, Big Horn and Wind Rivers, Big Horn Mountains, Wyoming

Field conference, glacial geology of western Iowa, Council Bluffs, north and east and south to Iowa City

Glacial geology and physiography of Wind River Mountains, Green River and Jackson Hole

Glacial geology and physiography of Wind River Mountains, Jackson Hole, Green River, and SW. Wyoming and east to Cheyenne

Glacial geology and physiography, Laramie Mountains, Platte and Sweetwater Valleys to Jackson Hole; southwestern Wyoming, northeastern Utah, and North Park, Colorado

Glacial geology and physiography, Teton Mountains, northeastern Utah, and southwestern Wyoming

Glacial geology and physiography, Teton Mountains, SE. Idaho, NE. Utah and SW. Wyoming

Glacial geology and physiography, Teton Mountains, W. Wyoming and Green River, Uinta Mountains

Glacial geology and physiography, W. \& N. of Uinta Mountains, E. to Craig, Colorado and Sierra Madre Mountains

Glacial geology and physiography, Sierra Madre Mountains and Laramie Basin, Platte River N. to Casper, Wyoming

1

20

20


Glacial geology and physiography, Sweetwater River, Wind River Mountains, Wind River NW. to Yellowstone National Park and Jackson Hole, Wyoming

Glacial geology and physiography, Jackson Hole, Teton Mountains and west to Ashton, Idaho

Reconnaissance, glacial geology and physiography, Yellowstone National Park, Gallatin and Missouri Rivers N. to Helena and NW. to Flathead Basin, Glacier Park, and Missoula to Three Forks and south Montana

Reconnaissance, glacial geology and physiography, Flathead Basin, Mission Range, Clark Fork, SE. to Phillipsburg, Montana

Reconnaissance, glacial geology and physiography, Flint Creek Mountains, SE. to Three Forks, Madison River Valley and Mountains, Montana S. to Ashton, Idaho

Reconnaissance, glacial geology and physiography, Madison Valley, Big Hole and NW. down Clarks Fork, Thompson Falls, Montana

Reconnaissance, glacial geology and physiography, Thompson Falls, Montana, NW. down Clarks Fork, Spokane, and Ritzville, Washington

Reconnaissance, glacial geology and physiography, Washtucna to Grand Coulee and E., N. of Spokane, Pend Oreille River, Kootenai Valley east to Libby, Montana

Reconnaissance, glacial geology and physiography, Kootenai River, Flathead Basin; Missoula S. and E. to Monida, Montana

Reconnaissance, glacial geology and physiography, Yellowstone Park, Ashton, Idaho, NW. to Missoula and west to Spokane; SW. to Pasco and up Columbia River to Lake Chelan, Washington

Reconnaissance, glacial geology and physiography, Okanagan Valley, Columbia River and Spokane River and Pend Oreille River N. to 49 degrees, Washington

Reconnaissance, glacial geology and physiography, S. and N. of Spokane, N. Idaho, Clarks Fork Valley, Montana, and north; Flathead Basin and Swan Lake south to Blackfeet River and Missoula

Reconnaissance, glacial geology and physiography, Bitterroot Valley, Big Hole and Dillon, south to Monida, east and south to Ashton, Idaho

Reconnaissance, glacial geology and physiography, Madison and Missouri Rivers N. to Helena; Blackfoot River to Missoula, Glacier Park to Kootenai Valley

Reconnaissance, glacial geology and physiography, Kootenai Valley down to Bonners Ferry and Kootenai Lake, East to Flathead Basin, Clarks Fork, Thompson Falls east and south up Bitterroot Valley

Reconnaissance, glacial geology and physiography, Bitterroot Valley to Dillon, South to Monida; S. and E. to Ashton, Idaho

Reconnaissance, glacial geology and physiography, Ashton, Idaho, N. to Glacier Park, W. to Kootenay Lake and SE. to Thompson Falls, Montana

Reconnaissance, glacial geology and physiography, Ashton, Idaho, north; Madison and Gallatin Valleys; Blackfeet River and Flathead Basin Montana

Reconnaissance, glacial geology and physiography, Flathead Basin, Missoula, Bitterroot Valley, Big Hold, Dillon and Wise River, Montana

Reconnaissance, glacial geology and physiography, Wise River, Dillon and south to Lima, east to Ashton, Idaho

Field conferences with G. E. Condra, A. L. Lugn, and others, glacial geology, eastern half of Nebraska; traverses south, east, north and west from Lincoln (west to Gothanburg)

Reconnaissance, glacial geology and physiography, Yellowstone Park and Cody, Wyoming, north to Great Falls, Montana; W. and N. to and in Glacier National Park, Montana, Flathead Basin and W. to Plains

Reconnaissance, glacial geology and physiography, Plains to Missoula, Montana; to Cody, Wyoming; Yellowstone Park W. and N. to Dillon, Montana; Pioneer Mountains and Wise River; Big Hole Basin and Flathead Basin, Clarks Fork and E. to Helena; South to Butte, Ruby River, Spenser and Idaho Falls, Idaho

Reconnaissance, glacial geology and physiography, Idaho Falls N. to Missoula; W. to St. Regis and Clarks Fork, Montana; Coeur D'Alene Mountains, Flathead Basin, Bitterroot Valley, Blackfoot River, Montana; and Salmon and Lemhi Valleys and Mountains, Idaho Reconnaissance, glacial geology and physiography, Salmon and Lemhi Valleys, Idaho; Beaverhead County, Montana; south to Monida, Montana; Spencer to Gilmore, Idaho, and to Idaho Falls 
Reconnaissance, glacial geology and physiography, Idaho Falls down Snake River to Wallula and Columbia River, Bonneville Dam, Portland, Mt. Hood, Grand Coulee Dam to Spokane, Washington, and north to Pend Oreille and Kootenai Rivers, Missoula, Dillon, Madison Valley, Montana

Reconnaissance, glacial geology and physiography, Madison River to Dillon, Big Hole, Montana, to Salmon River south and west to Sawtooth Mountains, Lost River Range, Idaho, Craters of Moon to Idaho Falls

Boston south to Cape Cod and northwest to Lowell and Barre, Vermont; Springfield and north in Massachusetts

Field conferences, glacial geology, Illinois, Wisconsin, Missouri, Illinois, Kentucky, Iowa, Illinois

Topographic maps showing geologic field data, Yellowstone National Park, Wyoming [2 maps]

Topographic map showing geologic field data, Yellowstone National Park, Wyoming

Topographic map showing geologic field data, Yellowstone National Park, Wyoming

Topographic map showing geologic field data, Yellowstone National Park, Wyoming

Topographic map showing geologic field data, Bald Mountain, Wyoming

Topographic map showing geologic field data, Blue Mesa, Wyoming

Topographic map showing geologic field data, Cheyenne, Wyoming

Topographic map showing geologic field data, Cloud Peak, Wyoming Topographic map showing geologic field data, Como Ridge, Wyoming Topographic map showing geologic field data, Dayton, Wyoming Topographic map showing geologic field data, Fort McKinney, Wyoming Topographic map showing geologic field data, Fort Steele, Wyoming Topographic map showing geologic field data, Fremont Peak, Wyoming Topographic map showing geologic field data, Grand Teton, Wyoming Topographic map showing geologic field data, Grand Teton, Wyoming Topographic map showing geologic field data, Cross Creek, Wyoming Topographic map showing geologic field data, Gros Ventre, Wyoming Topographic map showing geologic field data, Hanna, Wyoming Topographic map showing geologic field data, Heartville, Wyoming Topographic map showing geologic field data, Ishawooa, Wyoming Topographic map showing geologic field data, Kirwin, Wyoming Topographic map showing geologic field data, Laramie, Wyoming Topographic maps showing geologic field data, Mt. Leidy, Wyoming (2 maps) n.d. Topographic map showing geologic field data, Medicine Bow, Wyoming n.d. Topographic map showing geologic field data, Meeteetsee, Wyoming 1921-36 Topographic map showing geologic field data, Oregon Basin, Wyoming 1921-36 Topographic map showing geologic field data, Saddleback Hills, Wyoming n.d. Topographic map showing geologic field data, Sheridan, Wyoming n.d. Topographic map showing geologic field data, Sherman, Wyoming n.d. Topographic map showing geologic field data, Walcott, Wyoming Topographic map showing geologic field data, Younts Peak, Wyoming Shoshone Irrigation map, Wyoming

Geologic notes by Alden on map published by the American Geographical Society of New York in 1928 titled "Channeled Scabland and Associated Features on the Columbia Plateau in Washington" Topographic maps showing geologic field data, Hahns Peak, Wyoming Topographic map showing geologic field data, Montpelier, Idaho Topographic map showing geologic field data, Priest Lake, Idaho Topographic map showing geologic field data, Rathdrum, Idaho Topographic map showing geologic field data, Colville, Utah Topographic map showing geologic field data, Gilbert Peak, Utah Topographic map showing geologic field data, Hayden Peak, Utah Topographic map showing geologic field data, Marsh Peak, Utah Topographic map showing geologic field data, Salt Lake Utah Topographic map showing geologic field data, Chelan, Washington Topographic map showing geologic field data, Chiwaukum, Washington Topographic map showing geologic field data, Chopaka, Washington Topographic map showing geologic field data, Colville, Washington Topographic map showing geologic field data, Connell, Washington Topographic maps showing geologic field data, Chewelah Washington [2 maps]

Topographic map showing geologic field data, Malaga, Washington Topographic map showing geologic field data, Okanogan, Washington Topographic map showing geologic field data, Osoyoos, Washington Topographic map showing geologic field data, Pasco, Washington Topographic map showing geologic field data, Quincy, Washington Topographic map showing geologic field data, Republic, Washington Topographic map showing geologic field data, Spokane, Washington Topographic map showing geologic field data, Washtucna, Washington Topographic map showing geologic field data, Wenatchee, Washington Geologic annotation, Salmon National Forest, Idaho Geologic reconnaissance map of the Colville Indian Reservation, Washington n.d. 
6056-zz Wm. C. Alden

11 Bailey Willis, Special

Agent, Tenth Census

L. E. Paddock,

Special Agent
Geologic annotation, Colville National Forest, Washington

Iron Ore Samples, Lake Superior Region, Michigan

Iron Ore Samples, Lake Superior Region, Michigan n.d.

1879

1887 


\section{Appendix 12}

Geologic Division - Microfiche Copies of Geologists' Field Notebooks, 1871-1969 (entry 173)

\begin{tabular}{ll} 
Number & Compiler \\
\hline [multiple & \\
fiche] & \\
& \\
2 & \\
3 & M. R. Campbell \\
4 & M. R. Campbell \\
5 & M. R. Campbell \\
7 [3] & M. R. Campbell \\
8 & M. R. Campbell; and others \\
9 & M. R. Campbell \\
& M. R. Campbell \\
10 & M. R. Campbell \\
11 & M. R. Campbell \\
12 & M. R. Campbell \\
13 & M. R. Campbell \\
14 & M. R. Campbell; T. Callaghan \\
15 & M. R. Campbell; C. David White \\
16 & M. R. Campbell \\
17 & M. R. Campbell \\
18 & M. R. Campbell; J. T. Callaghan \\
19 & M. R. Campbell \\
20 & M. R. Campbell \\
21 & M. R. Campbell \\
22 & M. R. Campbell \\
23 & M. R. Campbell \\
24 & M. R. Campbell \\
25 & M. R. Campbell \\
26 & M. R. Campbell \\
27 & M. R. Campbell \\
28 & M. R. Campbell; W. C. Mendenhall \\
$29[2]$ & M. R. Campbell; W. C. Mendenhall \\
$30[2]$ & M. R. Campbell; W. C. Mendenhall \\
$31[2]$ & M. R. Campbell; W. C. Mendenhall \\
$32[2]$ & M. R. Campbell; W. C. Mendenhall \\
$33[2]$ & M. R. Campbell; W. C. Mendenhall \\
34 & M. R. Campbell; C. David White \\
35 & M. R. Campbell \\
36 & M. R. Campbell \\
37 & M. R. Campbell \\
38 & M. R. Campbell \\
40 & M. R. Campbell \\
41 & M. R. Campbell \\
42 & M. R. Campbell \\
43 & M. R. Campbell \\
44 & M. R. Campbell \\
45 & M. R. Campbell \\
46 & M. R. Campbell; Joseph A. Taff \\
47 & M. R. Campbell; Joseph A. Taff \\
48 & M. R. Campbell; Joseph A. Taff \\
49 & M. R. Campbell; Joseph A. Taff \\
50 & M. R. Campbell; Joseph A. Taff \\
51 & M. R. Campbell; Joseph A. Taff \\
53 & M. R. Campbell; W. C. Mendenhall \\
$54[2]$ & M. R. Campbell; W. C. Mendenhall \\
$55[2]$ & M. R. Campbell; W. C. Mendenhall \\
$56[2]$ & M. R. Campbell; W. C. Mendenhall \\
$57[2]$ & M. R. Campbell; W. C. Mendenhall \\
$58[2]$ & M. R. Campbell; W. C. Mendenhall \\
$59[2]$ & M. R. Campbell; W. C. Mendenhall \\
60 & M. R. Campbell; W. C. Mendenhall \\
61 & M. R. Campbell \\
62 & M. R. Campbell \\
&
\end{tabular}

$\underline{\text { Geographic areas or topics }}$

$\underline{\text { Year(s) }}$

Estellville and Bristol, Tennessee 1891

Bristol, Tennessee 1891

Estellville and Bristol, Virginia / Tennessee 1891

Southwest Virginia/ and eastern Tennessee 1892

Pocahontas and Tazewell, Virginia / West Virginia 1893

Tazewell, West Virginia 1894

Tazewell, Pocahontus and Raleigh, Virginia / West Virginia

Raleigh and Hinton, West Virginia

Tazewell, Virginia / West Virginia 1894

Raleigh, West Virginia 1894

Raleigh and Hinton, West Virginia n.d.

Taxewell, Virginia / West Virginia 1894

Tazewell and Raleigh, Virginia / West Virginia 1894

Tazewell, Virginia / West Virginia 1904

Tazewell, Virginia / West Virginia 1894

Tazewell, Virginia / West Virginia 1894

Hinton, Raleigh and Kanawha Falls, West Virginia 1895

Kanawha Falls and Raleigh, West Virginia 1895

Raleigh, West Virginia 1895

Raleigh, West Virginia 1895

Kanawha Falls and Charleston, West Virginia 1895

Kanawha Falls and Charleston, West Virginia 1895

Kanawha Falls, West Virginia 1895

Bristol, Virginia 1895

New and Kanawha Rivers, West Virginia 1895

Oceana, West Virginia 1895

Raleigh and Kanawha Falls, West Virginia 1895

Raleigh and Kanawha Falls, West Virginia 1895

Raleigh and Kanawha Falls, West Virginia 1895

Raleigh and Kanawha Falls, West Virginia 1895

Kanawha Falls and Charleston, West Virginia 1895

Hinton and Raleigh, West Virginia 1895

Richmond, Kentucky 1896

London, Kentucky 1896

Standingstone, Tennessee 1896

Standingstone, Wartburg and Williamsburg,
Tennessee / Kentucky

Williamsburg, Manchester and Beattyville, Ky. $\quad 1896$

Beattyville and Richmond, Ky. $\quad 1896$

Richmond, Ky. 1896

New and Kanawha Rivers, West Virginia 1896

Raleigh, West Virginia 1896

Kentucky / Tennessee $\quad 1896$

Richmond, Kentucky 1896

London, Kentucky 1896

London, Kentucky

Standingstone, Tennessee

Standingstone and Wartburg. Tennessee- 1896

Wartburg, Williamsburg and London, 1896 Tennessee / Kentucky 1896

New and Kanawha Rivers, West Virginia 1896

Richmond, Kentucky 1896

London, Kentucky 1896

London and Standingstone, Tennessee / Kentucky 1896

Standingstone, Tennessee 1896

Standingstone, Williamsburg and London,
Tennessee / Kentucky

Beattyville and Richmond, Kentucky 1896

Beattyville and Richmond, Kentucky 1896

Saylersville, Beattyville and Prestonburg, Kentucky 1896

Saylersville and Beattyville, Kentucky 1897 


\begin{tabular}{|c|c|}
\hline 63 & M. R. Campbell \\
\hline 64 & M. R. Campbell \\
\hline 65 & M. R. Campbell \\
\hline 66 & M. R. Campbell \\
\hline 67 & M. R. Campbell \\
\hline 68 & M. R. Campbell; L. C. Glenn \\
\hline 69 & M. R. Campbell; L. C. Glenn \\
\hline 70 & M. R. Campbell; L. C. Glenn \\
\hline 71 & M. R. Campbell; L. C. Glenn \\
\hline 72 & M. R. Campbell; L. C. Glenn \\
\hline $73[2]$ & M. R. Campbell; W. C. Mendenhall \\
\hline 74 & M. R. Campbell; W. C. Mendenhall \\
\hline $75[2]$ & M. R. Campbell; W. C. Mendenhall \\
\hline $76[2]$ & M. R. Campbell; W. C. Mendenhall \\
\hline 77 & M. R. Campbell \\
\hline $77 \mathrm{~A}$ & M. R. Campbell \\
\hline 78 & M. R. Campbell \\
\hline 79 & M. R. Campbell; C. H. White \\
\hline 80 & M. R. Campbell; C. H. White \\
\hline 81 & M. R. Campbell; C. H. White \\
\hline 82 & M. R. Campbell; C. H. White \\
\hline 83 & M. R. Campbell \\
\hline $84[2]$ & M. R. Campbell \\
\hline 85 & M. R. Campbell \\
\hline 86 & M. R. Campbell \\
\hline 87 & M. R. Campbell; Myron L. Fuller \\
\hline 89 & M. R. Campbell; Myron L. Fuller \\
\hline 90 & M. R. Campbell; Myron L. Fuller \\
\hline 91 & M. R. Campbell; Myron L. Fuller \\
\hline 92 & Myron L. Fuller \\
\hline 93 & Myron L. Fuller \\
\hline 95 & M. R. Campbell; Myron L. Fuller \\
\hline 96 & Myron L. Fuller \\
\hline 97 & M. R. Campbell; J. D. Irving \\
\hline 98 & M. R. Campbell; J. D. Irving \\
\hline 99 & M. R. Campbell; J. D. Irving \\
\hline 100 & M. R. Campbell; J. D. Irving \\
\hline 101 & M. R. Campbell; J. D. Irving \\
\hline 102 & Myron L. Fuller; J. D. Irving \\
\hline 103 & M. L. Fuller; J. D. Irving \\
\hline 106 & M. R. Campbell; M. L. Fuller \\
\hline 107 & M. L. Fuller \\
\hline 108 & M. R. Campbell; M. L. Fuller \\
\hline 109 & M. R. Campbell \\
\hline 110 & M. R. Campbell \\
\hline 111 & M. R. Campbell \\
\hline 112 & M. R. Campbell; L. C. Glenn \\
\hline 113 & M. R. Campbell; L. C. Glenn \\
\hline 114 & M. R. Campbell; Lester H. Woolsey \\
\hline 115 & M. R. Campbell; Lester H. Woolsey \\
\hline 116 & M. R. Campbell; Lester H. Woolsey \\
\hline 117 & M. R. Campbell; Lester H. Woolsey \\
\hline 118 & M. R. Campbell; Lester H. Woolsey \\
\hline 119 & M. R. Campbell; Lester H. Woolsey \\
\hline 120 & M. R. Campbell; Lester H. Woolsey \\
\hline 121 & G. B. Richardson \\
\hline 122 & M. R. Campbell; G. B. Richardson \\
\hline 123 & Myron L. Fuller \\
\hline 124 & M. R. Campbell \\
\hline 125 & M. R. Campbell \\
\hline 126 & M. R. Campbell \\
\hline 127 & M. R. Campbell \\
\hline 137 & M. R. Campbell; Ralph W. Howell \\
\hline $137-\mathrm{A}$ & M. R. Campbell; Ralph W. Howell \\
\hline $137-\mathrm{B}$ & M. R. Campbell; Ralph W. Howell \\
\hline $137-\mathrm{C}$ & M. R. Campbell; Ralph W. Howell \\
\hline 137-D & M. R. Campbell \\
\hline 137-E & M. R. Campbell; Kent K. Kimball \\
\hline $137-\mathrm{F}$ & M. R. Campbell \\
\hline $137-\mathrm{G}$ & M. R. Campbell; Ralph W. Howell \\
\hline $137-\mathrm{H}$ & M. R. Campbell \\
\hline 137-I & M. R. Campbell \\
\hline 182 & M. R. Campbell; Lester H. Woolsey \\
\hline
\end{tabular}

Prestonburg and Huntington, Kentucky / West Virginia 1897 Huntington, West Virginia 1897

Huntington and Charleston, West Virginia 1896

Kingston and Wartburg, Tennessee 1897

Perisburg Earthquake, Virginia 1897

Beattyville, Saylersville and Prestonburg, Kentucky 1897

Beattyville, Saylersville and Prestonburg, Kentucky 1897

Prestonburg and Huntington, West Virignia 1897

Huntington and Charleston, West Virginia 1897

Charleston, West Virginia 1897

Beattyville, Saylorsburg and Prestonburg, Kentucky 1897

Beattyville and Saylersville, Kentucky 1897

Huntington, West Virginia 1896

Huntington and Charleston, West Virginia 1897

Raleigh, West Virginia 1898

Raleigh, West Virginia 1898

Bristol, Virginia / Tennessee 1898

Charleston and Oceana, West Virginia 1898

Oceana, West Virginia 1898

Charleston and Kanawha Falls, West Virginia 1898

Virginia / Tennessee / West Virginia 1898

Charleston, Kanawha Falls and Sutton, West Virginia 1899

Kanawha Falls and Raleigh, West Virginia 1899

Uniontown and Masontown, Pennsylvania 1900

Uniontown and Masontown, Pennsylvania 1900

Gaines and Elkland, Pennsylvania 1900

Uniontown and Masontown, Pennsylvania 1900

Uniontown and Masontown, Pennsylvania 1900

Uniontown and Masontown, Pennsylvania 1900

Gaines and Elkland, Pennsylvania 1900

Gaines and Elkland, Pennsylvania 1900

Boonville, Petersburg, and Carrollton, Indiana / Kentucky

Gaines and Elkland, Pennsylvania

Uniontown and Masontown, Pennsylvania

Uniontown and Masontown, Pennsylvania $\quad 1900$

Uniontown and Masontown, Pennsylvania 1900

Uniontown and Masontown, Pennsylvania 1900

Uniontown and Masontown, Pennsylvania 1900

Gaines and Elkland, Pennsylvania 1900

Gaines and Elkland, Pennsylvania 1900

Uniontown and Masontown, Pennsylvania oil well data

Gaines and Elkland, Pennsylvania - oil well data 1900

Boonville, Indiana 1900

Brownsville and Connellsville, Pennsylvania 1901

Brownsville and Connellsville, Pennsylvania $\quad 1900$

Latrobe, Pennsylvania

Brownsville and Connellsville, Pennsylvania 1900

Connellsville, Pennsylvania 1901

Latrobe, Pennsylvania 1901

Brownsville, Pennsylvania 1901

Brownsville, Pennsylvania 1901

Brownsville and Connellsville, Pennsylvania 1901

Brownsville and Connellsville, Pennsylvania 1901

Connellsville, Pennsylvania 1901

Connellsville and Latrobe, Pennsylvania 1901

Latrobe, Pennsylvania 1901

Latrobe, Pennsylvania 1901

Gaines oil field, Pennsylvania. 1901

Pennsylvania - oil well records 1901

Latrobe, Pennsylvania 1902

Kanawha Falls, West Virginia 1902

Section along the Allegheny River and vicinity
of Bradford, Pennsylvania

Valley coal fields, Virginia $\quad 1914$

Valley coal fields, Virginia 1914

Valley coal fields, Virginia 1914

Valley coal fields, Virginia $\quad 1914$

Valley coal fields, Virginia 1918,1923

Valley coal fields, Virginia 1923

Valley coal fields, Virginia 1923

Valley coal fields, Virginia 1923

Valley coal fields, Virginia 1923

Valley coal fields, Virginia 1924

Beaver, Pennsylvania 1902 


\begin{tabular}{|c|c|}
\hline $224[2]$ & Edson S. Bastin \\
\hline 225 & Edson S. Bastin \\
\hline 226 & Edson S. Bastin \\
\hline $227[2]$ & Edson S. Bastin \\
\hline 228 & Edson S. Bastin \\
\hline $229[2]$ & Edson S. Bastin \\
\hline $230[2]$ & Edson S. Bastin \\
\hline 234 & Charles Butts \\
\hline 235 & Charles Butts \\
\hline 236 & Charles Butts \\
\hline 250 & M. R. Campbell \\
\hline 251 & Charles Butts \\
\hline 252 & Charles Butts \\
\hline 253 & Charles Butts \\
\hline 254 & Charles Butts \\
\hline 255 & Charles Butts \\
\hline 256 & Charles Butts \\
\hline 257 & Charles Butts \\
\hline 258 & Charles Butts \\
\hline 259 & Charles Butts \\
\hline 260 & Charles Butts \\
\hline 261 & M. R. Campbell \\
\hline 301 & C. David White \\
\hline 302 & C. David White \\
\hline 303 & C. David White \\
\hline 309 [3] & $\begin{array}{l}\text { C. B. Hunt; Julian D. Sears; W. S. Pike; } \\
\text { R. W. Brown; D. A. Andrews }\end{array}$ \\
\hline $319[2]$ & Wilmot H. Bradley; R. D. Ohrenschall \\
\hline $319-\mathrm{A}[2]$ & Wilmot H. Bradley; R. D. Ohrenshall \\
\hline 319-B & Wilmot H. Bradley \\
\hline 319-C & Wilmot H. Bradley \\
\hline $320[3]$ & Wilmot H. Bradley; C. E. Erdmann \\
\hline 321 & Wilmot H. Bradley; Albert E. Wood \\
\hline 322 & Wilmot H. Bradley; Albert E. Wood \\
\hline $323[2]$ & Wilmot H. Bradley; D. W. St. Clair \\
\hline $324[2]$ & Wilmot H. Bradley \\
\hline $325[2]$ & Wilmot H. Bradley \\
\hline 326 & Wilmot H. Bradley \\
\hline $327[2]$ & Wilmot H. Bradley \\
\hline $328[2]$ & Wilmot H. Bradley \\
\hline 329 & Wilmot H. Bradley \\
\hline 330 & Wilmot H. Bradley \\
\hline 350-A & George F. Becker \\
\hline 350-B & George F. Becker \\
\hline $350-\mathrm{C}$ & George F. Becker \\
\hline $350-\mathrm{D}[2]$ & George F. Becker \\
\hline 350-E [4] & George F. Becker \\
\hline $350-\mathrm{F}[2]$ & George F. Becker \\
\hline $350-\mathrm{G}$ & George F. Becker \\
\hline $350-\mathrm{H}[2]$ & George F. Becker \\
\hline $350-\mathrm{I}$ & George F. Becker \\
\hline $350-\mathrm{K}[2]$ & George F. Becker; H. W. Turner \\
\hline $350-\mathrm{L}[3]$ & George F. Becker; Waldemar Lindgren \\
\hline 350-M [5] & George F. Becker \\
\hline $350-\mathrm{N}[5]$ & George F. Becker \\
\hline $350-\mathrm{O}[4]$ & George F. Becker; Waldemar Lindgren \\
\hline $350-\mathrm{P}[5]$ & George F. Becker \\
\hline $350-Q[3]$ & George F. Becker \\
\hline $350-\mathrm{R}[2]$ & George F. Becker \\
\hline $350-S[3]$ & George F. Becker \\
\hline $350-\mathrm{T}[2]$ & George F. Becker \\
\hline $350-U[3]$ & George F. Becker \\
\hline 420 & M. R. Campbell; N. M. Fenneman \\
\hline $423[2]$ & H. S. Gale \\
\hline $424[2]$ & H. S. Gale; Arthur K. Adams \\
\hline 425 & H. S. Gale; Arthur K. Adams \\
\hline $426[2]$ & H. S. Gale; R. D. Crawford \\
\hline
\end{tabular}

$\begin{array}{ll}\text { Rockland, Maine } & 1905 \\ \text { Rockland, Maine } & 1905\end{array}$

Rockland, Maine 1905

Pegmatites and general geology, Maine 1906

Maine 1906

Maine 1906

Maine 1906

Brownsville and Connellsville, Pennsylvania $\quad 1901$

Brownsville and Connellsville, Pennsylvania 1901

Brownsville and Connellsville, Pennsylvania 1901

Kittanning, Pennsylvania 1901

Kittanning, Pennsylvania 1901

Kittanning, Pennsylvania 1901

Kittanning, Pennsylvania 1901

Kittanning, Pennsylvania 1901

Rural Valley, Pennsylvania 1902-3

Rural Valley, Pennsylvania 1902-3

Rural Valley, Pennsylvania 1902-3

Rural Valley, Pennsylvania $1902-3$

Rural Valley, Pennsylvania 1902-3

Rural Valley, Pennsylvania 1902

Rural Valley, Pennsylvania 1902

Kentucky / Tennessee

Rhode Island / Kentucky / Missouri / Texas 1911

Colorado / New Mexico / Texas / Oklahoma / Kansas 1912

Mount Taylor, New Mexico

Uinta Basin, Colorado / Utah 1925

Uinta Basin, Colorado / Utah 1925

Uinta Basin, Colorado / Utah 1925

Uinta Basin, Colorado / Utah 1925

Rio Blanco County, Colorado 1924

Steuben, Yates and adjacent counties, New York 1934

Steuben, Yates and adjacent counties, New York 1934

Steuben, Yates and adjecent counties, New York 1935

Steuben, Yates and adjacent counties, New York 1934

Steuben, Yates and adjacent counties, New York 1934

Steuben, Yates and adjacent counties, New York 1934

Steuben, Yates and adjacent counties, New York 1935

Steuben, Yates and adjacent counties, New York 1935

Steuben, Yates and adjacent counties, New York 1935

Steuben, Yates and adjacent counties, New York 1936

Hyberbolic cycloids

Sierra Nevada mines, Utah /Nevada

Determination of specimens from Washington Oregon / California / Nevada / Arkansas / Utah / Wyoming

Handwritten lectures and newspaper articles regarding scientific lectures given by Becker various Notes on lead

Notes on tin

Structural results of faulting

Index to slides, Comstock Lode, Nevada

Eruptive rocks; Great Western Quicksilver Mine; Sulphur Bank

Basalts, andesites and granites, California / Nevada 1886

Classification of silver metals; silicates; gold production in California n.d.

Assorted Notes

Assorted Notes

Assorted Notes

Visalia, Mineral, King, Yosemite, California

Mormon Bar, Yosemite, Tiogo Mine, Mono Lake, Virginia Pass, Matterhorn Canyon and Hetch Hetchy, California

Itinerary from Rickey's to Markleeville, Alpine County to Charity Valley, White Dike near Clark's Fork and Meadow Dam Lake California

Mother Lode District, California 1897

Notes on mines in the Washoe District, Nevada n.d.

Yampa coal field, Colorado

Grand Hogback and Danforth Hills, Colorado 1906

Grand Hogback and Danforth Hills, Colorado 1906

Grand Hogback caol field, Colorado 1906

Coal fields, Colorado c. 1877

.d.

n.d.

n.d.

1889

1889

1906 


\begin{tabular}{|c|c|}
\hline 427 & H. S. Gale; R. D. Crawford \\
\hline 523 & C. Whitman Cross: Samuel F. Emmons \\
\hline 539 & C. Whitman Cross; Albert Johannsen \\
\hline $540[2]$ & C. Whitman Cross; Albert Johannsen \\
\hline $541[2]$ & C. Whitman Cross; Albert Johannsen \\
\hline $542[2]$ & C. Whitman Cross; Albert Johannsen \\
\hline 543 & C. Whitman Cross; Albert Johannsen \\
\hline $551[2]$ & C. Whitman Cross; Albert Johannsen \\
\hline 552 & C. Whitman Cross; Lester H. Woolsey \\
\hline 553 & C. Whitman Cross; G. I. Finlay \\
\hline 609 [3] & George H. Eldridge \\
\hline 610 & George H. Eldridge; L. G. Eakins \\
\hline $611[3]$ & George H. Eldridge \\
\hline & Samual F. Emmons; George H. Eldridge \\
\hline $623[3]$ & George H. Eldridge \\
\hline 624 & Samuel F. Emmons; L. G. Eakins \\
\hline 625 & Samuel F. Emmons; L. G. Eakins \\
\hline 715 & A. C. Veatch \\
\hline 716 & A. C. Veatch \\
\hline 717 & A. C. Veatch \\
\hline $718[2]$ & Archibald R. Marvine; Ferdinand V. Hayden \\
\hline 719 [2] & Archibald R. Marvine; Ferdinand V. Hayden \\
\hline $720[2]$ & Archibald R. Marvine; Ferdinand V. Hayden \\
\hline $721[2]$ & Archibald R. Marvine; Ferdinand V. Hayden \\
\hline $722[2]$ & Archibald R. Marvine; Ferdinand V. Hayden \\
\hline $723[2]$ & Archibald R. Marvine; Ferdinand V. Hayden \\
\hline 724 [3] & Archibald R. Marvine; Ferdinand V. Hayden \\
\hline $725[2]$ & Archibald R. Marvine; Ferdinand V. Hayden \\
\hline $726[2]$ & Archibald R. Marvine; Ferdinand V. Hayden \\
\hline $727[2]$ & Archibald R. Marvine; Ferdinand V. Hayden \\
\hline $728[2]$ & Archibald R. Marvine; Ferdinand V. Hayden \\
\hline $729[2]$ & Archibald R. Marvine; Ferdinand V. Hayden \\
\hline & Archibald R. Marvine; Ferdinand V. Hayden \\
\hline $731[3]$ & F. M. Endlich; Ferdinand V. Hayden \\
\hline $732[2]$ & F. M. Endlich; Ferdinand V. Hayden \\
\hline & F. M. Endlich; Ferdinand V. Hayden \\
\hline 734 [2] & F. M. Endlich; Ferdinand V. Hayden \\
\hline $735[2]$ & F. M. Endlich; Ferdinand V. Hayden \\
\hline 736 [2] & F. M. Endlich; Ferdinand V. Hayden \\
\hline $737[2]$ & F. M. Endlich; Ferdinand V. Hayden \\
\hline $830-\mathrm{C}[2]$ & Archibald R. Marvine \\
\hline $830-\mathrm{D}[2]$ & Archibald R. Marvine; G. B. Chittenden \\
\hline & Waldemar Lindgren \\
\hline 986 [2] & Waldemar Lindgren \\
\hline & Waldemar Lindgren \\
\hline 989 [3] & Waldemar Lindgren \\
\hline $990[2]$ & Waldemar Lindgren \\
\hline $991[2]$ & Waldemar Lindgren \\
\hline $992[2]$ & Waldemar Lindgren \\
\hline 993 [3] & Waldemar Lindgren \\
\hline $994[2]$ & Waldemar Lindgren \\
\hline 995 [3] & Waldemar Lindgren \\
\hline $996[2]$ & Waldemar Lindgren \\
\hline 997 [2] & Waldemar Lindgren \\
\hline $998[3]$ & Waldemar Lindgren \\
\hline 999 [3] & Waldemar Lindgren \\
\hline $1000[3]$ & Waldemar Lindgren \\
\hline 1001 [3] & Waldemar Lindgren \\
\hline 1002 [3] & Waldemar Lindgren \\
\hline 1003 [3] & Waldemar Lindgren \\
\hline 1004 [2] & Waldemar Lindgren \\
\hline 1005 [3] & Waldemar Lindgren \\
\hline $1006[3]$ & Waldemar Lindgren \\
\hline $1007[2]$ & Waldemar Lindgren \\
\hline 1008 [2] & Waldemar Lindgren \\
\hline 1009 [3] & Waldemar Lindgren \\
\hline $1010[2]$ & Waldemar Lindgren \\
\hline
\end{tabular}

Colorado

Montrose, west of Ouray, Colorado

San Cristobal, Colorado 1904

San Cristobal, Colorado $\quad$ 1904-5

San Cristobal, Colorado 1904-5

San Cristobal, Colorado 1904-5

San Cristobal, Colorado 1905

San Cristobal, Colorado 1906

San Cristobal, Colorado 1906

San Cristobal, Colorado 1906

Created Butte, Colorado 1885

Created Butte, Colorado 1885

Created Butte, Colorado 1885

Created Butte, Colorado 1885

Created Butte and Anthracite, Colorado 1888

Anthracite, Colorado

Created Butte and Anthracite, Colorado 1886

Oil district, Louisiana n.d.

Oil and gas district, Louisiana 1908

Personal notes and memorandums n.d.

Middle Park Division, Colorado 1873

Middle Park Division, Colorado 1873

Middle Park Division, Colorado 1873

Middle Park Division, Colorado 1873

Middle Park Division, Colorado 1873

Middle Park Division, Colorado 1873

Middle Park Division, Colorado / Wyoming 1874

First Division, Colorado

First Division, Colorado $\quad 1874$

First Division, Colorado 1874

First Division, Colorado

First Division, Colorado 1874

First Division, Colorado 1874

Colorado 1875

Colorado/ New Mexico 1875

Colorado 1875

Colorado 1873

Colorado 1873

Colorado 1874

Colorado 1874

Colorado 1873

Colorado 1874

Silver City, Idaho 1899

Marysville and vicinity, California 1886

Marysville and vicinity, California 1886

Goldbelt region, Nevada and Sierra Counties, California 1886

Goldbelt region, California 1886

Goldbelt region, California 1886

Goldbelt region, California 1886

Goldbelt region, Nevada County, California 1885

Goldbelt region, Nevada and Yuba Counties, California 1886-87

Goldbelt region, Yuba, Placer and Nevada

$$
\text { Counties, California }
$$

Goldbelt region, Placer, Nevada and Sierra Counties, California

Goldbelt region, Nevada, Placer and Yuba Counties, California

Goldbelt region, Yuba, Sutter and Nevada

Counties, California 1888

1887

1887

1887

Goldbelt region, Placer and Eldorado Counties, Calif. 1888

Goldbelt region, Placer, Nevada and Eldorado Counties, California

Goldbelt region, Eldorado County, California

Goldbelt region, Sacramento, Placer and Eldorado Counties, California

Goldbelt region, Eldorado and Placer Counties, Calif.

Goldbelt region, Sacramento, Eldorado and Placer Counties, California

Goldbelt region, Eldorado County, California

Goldbelt region, Placer, Yuba and Nevada Counties, California

Goldbelt region, Nevada, Yuba and Sierra Counties, California

Goldbelt region, Nevada and Placer Counties, Calif.

Goldbelt region, Nevada, Sacramento and Eldorado Counties, California

Goldbelt region, Eldorado County, California

\section{8}

1888

1889

1889

1889

1890

1890-91

1891

1891

1891

1893 


\begin{tabular}{|c|c|}
\hline 1012 [2] & Waldemar Lindgren \\
\hline $1014[3]$ & Waldemar Lindgren \\
\hline 1016 & Waldemar Lindgren \\
\hline 1016-A & Waldemar Lindgren \\
\hline 1018 & Waldemar Lindgren \\
\hline 1019 & Waldemar Lindgren \\
\hline $1020[2]$ & Waldemar Lindgren \\
\hline 1022 & Waldemar Lindgren \\
\hline 1028 & Waldemar Lindgren \\
\hline 1029 [2] & George F. Becker; H. W. Turner \\
\hline $1030[3]$ & George F. Becker; H. W. Turner \\
\hline $1031[2]$ & H. W. Turner \\
\hline $1032[2]$ & Waldemar Lindgren \\
\hline $1033[2]$ & Waldemar Lindgren \\
\hline 1036 & Waldemar Lindgren \\
\hline $1037[2]$ & Waldemar Lindgren \\
\hline 1040 [2] & Waldemar Lindgren; J. M. Boutwell \\
\hline 1041 & Waldemar Lindgren; J. M. Boutwell \\
\hline 1042 [2] & Waldemar Lindgren \\
\hline 1043 & Waldemar Lindgren \\
\hline 1045 [2] & Waldemar Lindgren \\
\hline 1046 & Waldemar Lindgren; E. C. E. Lord \\
\hline 1047 & Waldemar Lindgren \\
\hline 1049 & Waldemar Lindgren \\
\hline 1050 & Waldemar Lindgren \\
\hline $1051[2]$ & Waldemar Lindgren \\
\hline $1052[2]$ & Waldemar Lindgren \\
\hline $1053[2]$ & Waldemar Lindgren; F. C. Schrader \\
\hline 1054 [2] & Waldemar Lindgren; F. C. Schrader \\
\hline $1055[2]$ & Waldemar Lindgren; F. C. Schrader \\
\hline $1056[2]$ & Waldemar Lindgren; N. F. Drake \\
\hline 1058 & Waldemar Lindgren \\
\hline 1059 & Waldemar Lindgren \\
\hline $1060[2]$ & Waldemar Lindgren; W. A. Prichard \\
\hline $1061[3]$ & Waldemar Lindgren \\
\hline $1062[2]$ & Waldemar Lindgren \\
\hline $1063[2]$ & Waldemar Lindgren; H. R. Johnson \\
\hline 1064 & Waldemar Lindgren \\
\hline $1065[2]$ & Waldemar Lindgren \\
\hline $1066[2]$ & Waldemar Lindgren \\
\hline $1067[2]$ & Waldemar Lindgren \\
\hline 1068 & Waldemar Lindgren \\
\hline 1069 [2] & Waldemar Lindgren \\
\hline $1070[2]$ & Waldemar Lindgren \\
\hline $1071[2]$ & Waldemar Lindgren \\
\hline $1074[4]$ & Waldemar Lindgren \\
\hline $1075[2]$ & Waldemar Lindgren \\
\hline $1076[2]$ & Waldemar Lindgren \\
\hline 1077 & Waldemar Lindgren \\
\hline 1078 [2] & Waldemar Lindgren \\
\hline 1079 & Waldemar Lindgren \\
\hline 1080 [2] & Waldemar Lindgren; L. C. Graton \\
\hline $1081[2]$ & Waldemar Lindgren; L. C. Graton \\
\hline 1082 [2] & Waldemar Lindgren; L. C. Graton \\
\hline 1083 & Waldemar Lindgren; L. C. Graton \\
\hline 1084 [2] & Waldemar Lindgren; L. C. Graton \\
\hline $1085[2]$ & Waldemar Lindgren; L. C. Graton \\
\hline 1086 & Waldemar Lindgren; L. C. Graton \\
\hline 1087 [2] & Waldemar Lindgren \\
\hline 1088 & Waldemar Lindgren \\
\hline 1089 [2] & Waldemar Lindgren \\
\hline 1090 & Waldemar Lindgren \\
\hline $1091[2]$ & Waldemar Lindgren \\
\hline $1092[2]$ & Waldemar Lindgren \\
\hline 1093 & Waldemar Lindgren \\
\hline 1094 & Waldemar Lindgren \\
\hline 1095 & Waldemar Lindgren \\
\hline 1096 & Waldemar Lindgren \\
\hline 1097 & C. Whitman Cross; C. W. Purington \\
\hline 1098 & C. W. Purington \\
\hline 1099 [2] & C. Whitman Cross; C. W. Purington \\
\hline 1100 & C. Whitman Cross; C. W. Purington \\
\hline 1101 & C. Whitman Cross; C. W. Purington \\
\hline 1102 & C. Whitman Cross; C. W. Purington \\
\hline 1103 & C. Whitman Cross; C. W. Purington \\
\hline 1104 [2] & C. Whitman Cross; C. W. Purington \\
\hline 1107 & Samuel F. Emmons; C. W. Purington \\
\hline
\end{tabular}

Smartsville, California

Nevada City and Grass Valley, California n.d.

Placerville, California n.d.

Placerville, California $\quad 1901$

Sacramento, California n.d.

Colfax, California n.d.

Colfax, California n.d.

California

Markleeville, California / Nevada n.d.

Goldbelt, Alpine County, California 1887

Goldbelt, Alpine County, California 1888

Goldbelt region, Markleeville, California 1887

Pyramid Peak, California 1894

Pyramid Peak, California 1894

Pyramind Peak, California n.d.

California /Washington 1895

Foresthill to Centerville, California 1901

Clifton, Arizona 1901-2

California / Nevada 1885

Washington 1906

Boise, Idaho 1896

Boise, Idaho 1896

Idaho Basin 1896

Boise, Idaho 1896

Silver Crown District, Wyoming 1896

Silver City, Idaho 1897

Silver City, Idaho 1897

Silver City, Idaho 1897

Silver City, Idaho 1897

Idaho reconnaissance 1897

Silver City and Nampa, Idaho 1897

Catalog of collections, Silver City and Nampa, Idaho $\quad$ 1896-7

Hailey and Wood River District, Idaho 1896

Hailey and Wood River District, Idaho 1898

Bitter Root Mountains, Idaho 1899

Bitter Root Mountains, Idaho 1899

Bitter Root Mountains, Idaho 1899

Bitter Root Mountains, Idaho / Montana 1899

Eastern Oregon gold belt 1900

Eastern Oregon gold belt 1900

Eastern Oregon gold belt 1900

Eastern Oregon gold fields 1900

Clifton, Arizona $1901-2$

Clifton, Arizona $\quad 1901-2$

Clifton, Arizona

Clifton, Arizona 1901-2

Sierra Nevada, California 1901

Sierra Nevada, California 1901

Auriferous gravels, California 1902

Cripple Creek, Colorado 1903

Cripple Creek, Colorado 1903

Cripple Creek, Colorado 1903

Cripple Creek, Colorado 1903

Cripple Creek, Colorado 1903

Cripple Creek, Colorado 1903

Cripple Creek, Colorado 1904

Cripple Creek, Colorado 1904

Cripple Creek, Colorado 1904

Mines of Colorado 1904

Mines of Colorado; Cripple Creek 1904

Santa Fe and San Pedro, New Mexico 1905

Dora Ana and Luna mines, New Mexico 1905

Colorado/ Nevada / New Mexico / California 1906

Colorado / Arizona 1906-7

Rawhide and Aspen areas, Colorado / Nevada 1908

Sweden / Colorado / South Dakota 1910-11

Dahlonega minerals, Georgia 1906

Dahlonega minerals, Georgia n.d.

La Plata, Colorado 1896

La Plata, Colorado 1896

Rico and Telluride, Colorado 1896

Telluride, Colorado 1896

Telluride, Colorado 1896

Telluride, Colorado 1896

Telluride, Colorado 1896

Telluride, Colorado 1896

Rico, Colorado 1898 
1131 [3] James Gilluly; Chester W. Washburne

James Gilluly; Chester W. Washburne

1133

1134

1135

1150

1154

1157

1158

1162

1163

$1188[2]$

$1230[2]$

1231

1264

1265

1266 [2]

$1267[2]$

1268 [2]

1269

1270 [2]

1271 [2]

1328 [2]

1329

1330 [2]

1331

1332

1341

1342 [2]

1343

1344 [2]

1345

1346

1347 [2]

1348 [2]

1349

1350 [2]

1351

1352

1353

1354

1356

1357

1358

1359

1360

1361

1362 [2]

1363 [2]

1364 [2]

1365

1366 [2]

1367 [2]

1368

1369

1370

1371

1372

1373

1374

1375 [2]

1375-A [2]

1376

1377 [2]

1464 [2]

1482

1483 [2]

1484 [2

1485
James Gilluly; Chester W. Washburne

James Gilluly; Chester W. Washburne

James Gilluly; Chester W. Washburne

Samuel F. Emmons

Samuel F. Emmons

Samuel F. Emmons

Samuel F. Emmons

Samuel F. Emmons

Samuel F. Emmons

Samuel F. Emmons; Ellsworth Huntington

M. R. Campbell

G. O. Smith; W. C. Mendenhall

G. O. Smith; W. C. Mendenhall

Charles Willard Hayes; R. E. Dodge

Ralph Arnold

Ralph Arnold

Ralph Arnold

Ralph Arnold

Ralph Arnold

Ralph Arnold

Ralph Arnold

William C. Alden

William C. Alden

William C. Alden

William C. Alden

William C. Alden

Raphael Pumpelly; John E. Wolff

Raphael Pumpelly; John E. Wolff

Raphael Pumpelly; John E. Wolff

Raphael Pumpelly; John E. Wolff

Raphael Pumpelly; John E. Wolff

Raphael Pumpelly; John E. Wolff

Raphael Pumpelly; John E. Wolff

Raphael Pumpelly; John E. Wolff

Raphael Pumpelly; John E. Wolff

Raphael Pumpelly; John E. Wolff

Raphael Pumpelly; John E. Wolff

Raphael Pumpelly; John E. Wolff

Raphael Pumpelly; John E. Wolff

Raphael Pumpelly; John E. Wolff

Raphael Pumpelly; John E. Wolff

Raphael Pumpelly; John E. Wolff

Raphael Pumpelly; John E. Wolff

Raphael Pumpelly; John E. Wolff

Raphael Pumpelly; B. T. Putnam

Raphael Pumpelly; B. T. Putnam

Raphael Pumpelly; John E. Wolff; B. T. Putnam

Raphael Pumpelly; John E. Wolff;

C. W. Beals, Jr

Raphael Pumpelly; John E. Wolff;

C. W. Beals, Jr.

Raphael Pumpelly; John E. Wolff;

C. W. Beals, Jr

Raphael Pumpelly; John E. Wolff;

C. W. Beals, Jr.

Raphael Pumpelly; John E. Wolff; C. L. Whittle

Raphael Pumpelly; John E. Wolff; C. L. Whittle

Raphael Pumpelly; John E. Wolff; C. L. Whittle

Raphael Pumpelly; John E. Wolff; M. J. Vea

Raphael Pumpelly; John E. Wolff; M. J. Vea

Raphael Pumpelly; John E. Wolff; M. J. Vea

Raphael Pumpelly; John E. Wolff; M. J. Vea

Raphael Pumpelly; John E. Wolff; M. J. Vea

Raphael Pumpelly; John E. Wolff; M. J. Vea

John E. Wolff

Raphael Pumpelly; John E. Wolff; H. Boynton

Raphael Pumpelly; John E. Wolff,

James Walter; J. W. Goldthwait

J. Fred Hunter

James Gilluly; C. E. Park

James Gilluly

James Gilluly

James Gilluly
New York

Gouverneur, New York

Gouverneur, New York 1934

1934

Mexico / Missouri / Arkansas

British Columbia

$1900-03$

1903

$1902-4$

Reference Collection and memorandums

Uinta Mountains; Montana / Utah / Nevada; Mexican Congress

Cananea, Mexico

Coalville, Utah

Cleveland and Kingston, Tennessee

Mt. Stuart and Snoqualmie, Washington

Snoqualmie, Washington

Columbia and Linden, Tennessee

Santa Clara Valley District, California

Santa Maria and Summerland Districts, California

Santa Cruz and Coalinga Districts, California

Coalinga, California

Coalinga and McKittrick Districts, California

Midway and Sunset, California

Devil's Den, Temblor, McKittrick, Sunset and Carrigo Plains Districts, California

Chicago and Calumet, Illinois

Chicago and Calumet, Illinois

Chicago and Calumet, Illinois

Chicago Folio, Riverside Sheet, Illinois

Riverside Sheet, West Desplaines River, Illinois

North Adams, Berkshire County, Massachusetts

North Adams, Berkshire County, Massachusetts

North Adams, Berkshire County, Massachusetts

North Adams, Berkshire County, Massachusetts

Greylock, Massachusetts

Greylock, Massachusetts

Greylock, Massachusetts

Greylock, Massachusetts

Greylock, Massachusetts

Wallingford, Vermont

Bennington, Vermont

Bennington, Vermont

Bennington, Vermont

Taconic, Vermont / Massachusetts

Wilmington. Vermont

Wilmington, Vermont

Wilmington, Vermont

Equinox, Vermont / Massachusetts

North Adams, Berkshire County, Massachusetts

North Adams, Berkshire County, Massachusetts

North Adams, Berkshire County, Massachusetts

Rutland, Vermont

1906

1907

1902

1889

1899

1899

1894-95

1906

1906

1907

1907

1907

1907-8

1908

1896

1896

1897

1897

1897

1885

1885

1885

1885-86

1885

1885

1885

1887

1887-89

1888

1897

1897

1898

1899-1901

1901

1901

1901

1901

1885

1885

1886

1888

Rutland, Vermont

1888

Rutland, Vermont

1888

Rutland, Vermont

Greylock, Maine / Vermont

1890

1887

1890

1891

891

1891

1891

189

1892

1892

$1889-90$

$1897-98$

Rutland, Vermont

1901

1911

n.d.

1933

1934

n.d. 


\begin{tabular}{|c|c|}
\hline $1486[3]$ & James Gilluly \\
\hline 1512 & Charles Willard Hayes \\
\hline 1524 & Charles Willard Hayes; R. C. Dodge \\
\hline 1529 & Charles Willard Hayes \\
\hline 1530 & Charles Willard Hayes \\
\hline 1531 & Charles Willard Hayes \\
\hline 1532 & Charles Willard Hayes \\
\hline 1533 & Charles Willard Hayes \\
\hline 1534 & Charles Willard Hayes \\
\hline 1538 & Charles Willard Hayes; M. R. Campbell \\
\hline $1539[2]$ & M. R. Campbell; C. W. Hayes \\
\hline $1540[2]$ & M. R. Campbell; C. W. Hayes \\
\hline 1542 & Charles Willard Hayes; M. R. Campbell \\
\hline $1542-\mathrm{A}$ & M. R. Campbell \\
\hline $1542-\mathrm{C}$ & M. R. Campbell \\
\hline $1543[5]$ & Edson S. Bastin \\
\hline 1544 & Edson S. Bastin \\
\hline 1545 & Edson S. Bastin \\
\hline 1729 & John E. Wolff; Alfred H. Brooks \\
\hline 1729-A & $\begin{array}{l}\text { Arthur C. Spencer; Alfred H Brooks; } \\
\text { John E. Wolff }\end{array}$ \\
\hline 1729-E & $\begin{array}{l}\text { Arthur C. Spencer; Alfred H Brooks } \\
\text { John E. Wolff }\end{array}$ \\
\hline 1786 & Charles Willard Hayes \\
\hline 1866 & Waldemar Lindgren \\
\hline 1867 & Waldemar Lindgren \\
\hline 1868 & Waldemar Lindgren \\
\hline 1869 & Waldemar Lindgren \\
\hline 1870 & Waldemar Lindgren \\
\hline $1871[2]$ & Waldemar Lindgren \\
\hline 1872 & Waldemar Lindgren \\
\hline 1873 & Waldemar Lindgren \\
\hline 1887 & Joseph A. Taff; Alfred H. Brooks \\
\hline 1888 & Joseph A. Taff; Alfred H. Brooks \\
\hline 1889 & Joseph A. Taff; Alfred H. Brooks \\
\hline 1890 & Joseph A. Taff; Alfred H. Brooks \\
\hline 1891 & Joseph A. Taff; Alfred H. Brooks \\
\hline 1892 & Joseph A. Taff; Alfred H. Brooks \\
\hline $1912[2]$ & W. C. Mendenhall \\
\hline 1913 & W. C. Mendenhall \\
\hline 1914 & W. C. Mendenhall \\
\hline 1917 & W. C. Mendenhall; C. H. White \\
\hline 1918 & W. C. Mendenhall; C. H. White \\
\hline $1919[2]$ & W. C. Mendenhall; W. O. Clark \\
\hline 1920 & W. C. Mendenhall; W. O. Clark \\
\hline 1921 & W. C. Mendenhall; H. R. Johnson \\
\hline $1921-\mathrm{A}[2]$ & W. C. Mendenhall; E. S. Larsen \\
\hline 1921-B [2] & W. C. Mendenhall; E. S. Larsen \\
\hline $1922[2]$ & W. C. Mendenhall; E. S. Larsen \\
\hline 1923 & W. C. Mendenhall; E. S. Larsen \\
\hline 1924 & W. C. Mendenhall; E. S. Larsen \\
\hline 1925 & W. C. Mendenhall; E. S. Larsen \\
\hline 1942 & Julian D. Sears and others \\
\hline $1943[2]$ & Julian D. Sears; T. A. Hendricks \\
\hline 1944 & Julian D. Sears; H. O. Debeck \\
\hline 1945 [2] & Julian D. Sears; A. W. Quinn \\
\hline 1946 & Julian D. Sears; W. S. Pike, Jr. \\
\hline $1947[2]$ & Julian D. Sears \\
\hline 1953-B & Edson S. Bastin \\
\hline $1961[3]$ & Albert C. Peale \\
\hline $1963[2]$ & A. R. Marvine \\
\hline 1964 & Albert C. Peale; W. R. Taggart \\
\hline $1965[2]$ & Albert C. Peale; Ferdinand V. Hayden \\
\hline $1966[3]$ & Albert C. Peale \\
\hline 1967 & Albert C. Peale; Ferdinand V. Hayden \\
\hline 1968 [2] & Albert C. Peale; Ferdinand V. Hayden \\
\hline $1969[3]$ & Albert C. Peale \\
\hline
\end{tabular}

\begin{tabular}{ll} 
Ajo, Arizona & $1932-34$ \\
Sewanee, Tennessee & 1893 \\
Calhoun and Cleburne Counties, Alabama & 1895 \\
Arkansas Baxite & 1900 \\
Clays, Louisiana / Arkansas / Tennessee & 1900 \\
Texas oil fields & 1901 \\
Texas oil fields & 1901 \\
Reconnaissance, Colorado / Utah / Idaho & 1903 \\
Flat River Lead District, Missouri & 1905 \\
Cleveland and Murphy, Tennessee / North Carolina & 1889 \\
Cleveland and Dalton, Georgia / Tennessee & 1890 \\
Dalton, Ringgold, Rome, Ft. Payne, Tallapoosa, & \\
\multicolumn{2}{c}{ and Cartersville, Georgia / Alabama / } \\
Kingston and Cleveland, Tennessee & 1890 \\
Deep River coal fields, North Carolina & 1890 \\
Deer Creek coal field, Arizona & 1922 \\
Eastport, Maine & 1903 \\
Eastport, Maine & $1907-10$ \\
Eastport, Maine & $1907-10$ \\
Raritan, New Jersey & n.d. \\
& 1895
\end{tabular}

Franklin Furnace, New Jersey $\quad$ 1895-96

Franklin Furnace, New Jersey 1896

Phosphate Region, Tennessee 1894

Gold Belt Region, California n.d.

Gold Belt Collection, Placer County, California n.d.

Gold Belt Collection, Yuba County, California n.d.

Gold Belt Collection, Eldorado County, California n.d.

Gold Belt Collection, Alpine County, California n.d.

Gold Belt Collection, Nevada County, California n.d.

Gold Belt Collection, Sacramento County, California n.d.

Gold Belt Collection, Sutter County, California 1873

Buckhannon, West Virginia 1895

Buchhannon, West Virginia 1895

Buckhannon, West Virginia 1895

Buckhannon, West Virginia 1895

Buckhannon, West Virginia 1895

Buckhannon and Sutton, West Virginia 1895

Corona, California 1905

Corona, California 1906

Corona, south California / Yuba and American Rivers, north California 1910

Corona, California

Elsinore and San Bernardino, California 1903

$\begin{array}{ll}\text { Clsinore and San Bernardino, California } & 1903 \\ \text { Corona, California } & 1906\end{array}$

Corona, California 1906

Corona and Santa Ana, California 1908

Corona, California 1906

Corona, California $\quad 1906$

Corona, California 1906

Corona, California 1906-7

Corona, California $\quad 1907$

Corona, California 1910

Coal fields from Gallop eastward to Mt. Taylor,
New Mexico

Coal fields from Gallop eastward to Mt. Taylor, New Mexico

Coal fields from Gallop eastward to Mt. Taylor, New Mexico

Coal fields from Gallop eastward to Mt. Taylor, New Mexico

Coal fields from Gallop eastward to Mt. Taylor, New Mexico

Coal fields from Gallop eastward to Mt. Taylor, New Mexico

Clear Creek and Gilpin, Colorado - mills, flow sheets

Field notes and diary from permanent camp to

Denver, Colo. Yellowstone Lake, Wyoming 1871

South Park Division, Colorado $\quad 1873$

South Park Division, Colorado

South Park Division, Colorado 1873

South Park Division, Colorado 1873

South Park Division, Colorado 1873

Eagle, Colorado 1874 


\begin{tabular}{|c|c|c|c|}
\hline 1970 & Albert C. Peale; Ferdinand V. Hayden & Eagle, Colorado & 1874 \\
\hline 1971 & Albert C. Peale & Lake Creek, Gunnison River, Indian Creek, Colorado & 1875 \\
\hline 1972 [2] & Albert C. Peale & Colorado & 1875 \\
\hline 1973 & Albert C. Peale; Ferdinand V. Hayden & San Miguel and Book Cliffs, Colorado & 1876 \\
\hline $1974[2]$ & Albert C. Peale; Ferdinand V. Hayden & Green River Diversion, Wyoming / Colorado & 1877 \\
\hline 1975 & A. C. Peale & Mostly Yellowstone Park, Wyoming & 1878 \\
\hline $1976[2]$ & A. C. Peale & Yellowstone Park, Wyoming & 1878 \\
\hline $1977[2]$ & A. C. Peale & Yellowstone Park, Wyoming & 1878 \\
\hline 1978 & A. C. Peale & Gallatin and Yellowstone Park, Wyoming / Montana & 1878 \\
\hline $1980[2]$ & A. C. Peale & Bismarck, North Dakota & 1883 \\
\hline 1981 & A. C. Peale & Three Forks, Montana & 1884 \\
\hline 1982 & A. C. Peale & Livingston, Montana & 1885 \\
\hline 1984 & A. C. Peale & Hills east of Ft. Ellis, Montana & 1885 \\
\hline 1986 & A. C. Peale & Three Forks, Montana & 1886 \\
\hline $1987[2]$ & A. C. Peale & Three Forks, Montana & 1887 \\
\hline 1988 & A. C. Peale & Three Forks, Montana & 1887 \\
\hline 1989 & A. C. Peale & List of photographic exposures, Montana & 1888 \\
\hline 1990 & A. C. Peale & Three Forks, Montana & 1888 \\
\hline 1991 & A. C. Peale & Three Forks, Montana & 1888 \\
\hline 1992 & A. C. Peale & Three Forks, Montana & 1889 \\
\hline 1993 & A. C. Peale & Three Forks, Montana & 1889 \\
\hline 1994 & A. C. Peale & Three Forks, Montana & 1889 \\
\hline 1996 & A. C. Peale & Three Forks, Montana & 1890 \\
\hline 1997 & A. C. Peale & Three Forks, Montana & 1890 \\
\hline 1998 & A. C. Peale & Three Forks, Montana & 1891 \\
\hline 1999 [2] & A. C. Peale & Livingston, Three Forks and vicinity, Montana & 1891 \\
\hline 2000 & A. C. Peale & North Dakota & 1907 \\
\hline 2001 & A. C. Peale & $\begin{array}{l}\text { Record of fossils collected by Knowlton and Peale, } \\
\text { North Dakota }\end{array}$ & 1907 \\
\hline 2003 & A. C. Peale & Wyoming & 1910 \\
\hline 2005 & A. C. Peale & California & 1881 \\
\hline 2006 & A. C. Peale & Various Areas & n.d. \\
\hline 2007 & A. C. Peale & Various Areas & n.d. \\
\hline 2010 & A. C. Peale & List of recipients of the 1875 Annual Report & 1875 \\
\hline 2011 & A. C. Peale & Mineral waters & n.d. \\
\hline 2014 & A. E. Brown; Ferdinand V. Hayden & Montana / Wyoming & 1872 \\
\hline 2061-A & Adolph Knoph; E. L. Jones, Jr. & Yerington, Nevada & 1914 \\
\hline 2077-P [2] & N. H. Darton & Passaic, Paterson, Harlem and Tarrytown, NJ/ N. Y. & 1885 \\
\hline 2078 [2] & N. H. Darton & $\begin{array}{l}\text { Newark Group, Green Pond Mountain, dikes of NW. } \\
\text { New Jersey }\end{array}$ & 1886 \\
\hline 2079 & G. K. Gilbert; N. H. Darton & Central Appalachian Region, Virginia & 1887 \\
\hline 2080 & G. K. Gilbert; N. H. Darton & Staunton, Virginia & $1888-89$ \\
\hline 2081 & W. J. McGee; N. H. Darton & East Washington D.C. / Maryland & $1889-91$ \\
\hline $2082[2]$ & N. H. Darton & Washington D.C. / Maryland / Virginia & 1895 \\
\hline $2084[2]$ & N. H. Darton & Maryland / Virginia & $1890-93$ \\
\hline $2085[2]$ & N. H. Darton & Maryland / Virginia/ Delaware - coastal plain & $1891-92$ \\
\hline $2086[3]$ & N. H. Darton & Mostly Baltimore, Maryland & $1890-91$ \\
\hline $2087[2]$ & N. H. Darton & Maryland / Virginia & $1891-94$ \\
\hline 2088 & W. J. McGee; N. H. Darton & South Carolina coastal plain / Florida phosphates & $1890-95$ \\
\hline 2089 & N. H. Darton & Piedmont, Maryland / West Virginia & 1894 \\
\hline 2090 & N. H. Darton & Piedmont, Maryland / West Virginia & 1894 \\
\hline $2091[2]$ & N. H. Darton & Franklin and Monterey, Virginia / West Virginia & $1895-96$ \\
\hline $2093[2]$ & W. J. McGee; James Hall; N. H. Darton & New York State Geological Map & $1892-93$ \\
\hline \multirow[t]{2}{*}{$2095[2]$} & N. H. Darton; C. A. Fisher; & & \\
\hline & J. E. McFarland & Lincoln Sheet, Nebraska & $1896-97$ \\
\hline $2096[2]$ & N. H. Darton; C. A. Fisher & Wood River and Holdrege, Nebraska - well records & 1896 \\
\hline 2098 & N. H. Darton; J. E. McFarland & South Dakota / Nebraska / Wyoming - well records & 1896 \\
\hline $2100[2]$ & N. H. Darton; C. A. Fisher & Scotts Bluff, Nebraska & 1897 \\
\hline \multirow[t]{2}{*}{$2101[2]$} & N. H. Darton; C. A. Fisher; & & \\
\hline & J. E. McFarland & Nebraska & 1897 \\
\hline $2102[2]$ & N. H. Darton; C. A. Fisher & Nebraska & 1896 \\
\hline $2103[2]$ & N. H. Darton; C. A. Fisher & Nebraska - wells and irrigation & 1897 \\
\hline $2108[2]$ & F. H. Newell; N. H. Darton & Nebraska / South Dakota / Colorado / Wyoming & 1897 \\
\hline 2113 & N. H. Darton & South Dakota & $1898-99$ \\
\hline 2114 & N. H. Darton; George B. Richardson & Edgemont, Newcastle, Sundance, Wyoming / & \\
\hline 2115 & N. H. Darton; George B. Richardson & $\begin{array}{r}\text { South Dakota } \\
\text { Wyoming / South Dakota }\end{array}$ & $\begin{array}{l}1899- \\
1899\end{array}$ \\
\hline 2116 & N. H. Darton & Newcastle, Edgemont, and Lance Creek, Wyoming & 1899 \\
\hline $2116-\mathrm{A}[2]$ & N. H. Darton; W. S. T. Smith & Edgemont, South Dakota & 1900 \\
\hline 2117 & N. H. Darton; George B. Richardson; and others & Hermosa, South Dakota & 1899 \\
\hline 2118 & N. H. Darton; W. S. Tangier Smith & Sundance and Devils Tower, Wyoming & 1900 \\
\hline 2119 & N. H. Darton & Wyoming / South Dakota & 1900 \\
\hline 2120 & F. H. Newell; N. H. Darton & Big Bad Lands and eastward, South Dakota & $1901-2$ \\
\hline 2122 & N. H. Darton & Wyoming & $1901-2$ \\
\hline \multirow[t]{2}{*}{2124} & N. H. Darton; C. A. Fisher & & \\
\hline & A. J. Johannson & Wyoming & 1903 \\
\hline 2125 & N. H. Darton; C. A. Fisher & Dayton-Ft. McKinney, Big Horn Mountains, Wyoming & 1902 \\
\hline
\end{tabular}




\begin{tabular}{|c|c|}
\hline $\begin{array}{l}2126[2] \\
2127 \\
2128[2]\end{array}$ & $\begin{array}{l}\text { N. H. Darton; C. A. Fisher } \\
\text { N. H. Darton; C. A. Fisher } \\
\text { N. H. Darton; C. A. Fisher }\end{array}$ \\
\hline 2129 & $\begin{array}{l}\text { N. H. Darton; C. E. Siebenthal; } \\
\text { W. S. T. Smith }\end{array}$ \\
\hline 2130-A [2] & N. H. Darton; W. S. T. Smith \\
\hline 2131 & N. H. Darton \\
\hline 2132 & N. H. Darton; C. A. Fisher \\
\hline 2134 & N. H. Darton; E. G. Woodruff \\
\hline 2135 & N. H. Darton \\
\hline 2136 & N. H. Darton \\
\hline 2137 & N. H. Darton; C. A. Fisher \\
\hline 2138 & N. H. Darton; and others \\
\hline 2139 & N. H. Darton; E. G. Woodruff \\
\hline $2140[2]$ & N. H. Darton \\
\hline 2145 & N. H. Darton; E. H. Barbour \\
\hline $2146[2]$ & Cleophas C. O'Harra \\
\hline 2148 & N. H. Darton \\
\hline 2149 & J. A. Holmes; N. H. Darton \\
\hline 2150 & J. A. Holmes; N. H. Darton \\
\hline 2151-A & N. H. Darton; C. E. Siebenthal \\
\hline 2152 & N. H. Darton; Cleophas C. O'Harra \\
\hline 2154 & N. H. Darton; Cleophas C. O'Harra \\
\hline 2155 & Frederick L. Ransome \\
\hline 2156 & F. H. Newell; N. H. Darton \\
\hline $2158[2]$ & J. A. Holmes; N. H. Darton \\
\hline $2159[2]$ & N. H. Darton \\
\hline $2162[3]$ & T. C. Chamberlain; William C. Alden \\
\hline $2163[2]$ & $\begin{array}{l}\text { T. C. Chamberlain; William C. Alden } \\
\text { James H. Smith }\end{array}$ \\
\hline $2164[2]$ & $\begin{array}{l}\text { T. C. Chamberlain; William C. Alden } \\
\text { James H. Smith }\end{array}$ \\
\hline $2165[3]$ & T. C. Chamberlain; William C. Alden \\
\hline 2166 & $\begin{array}{l}\text { T. C. Chamberlain; William C. Alden } \\
\text { James H. Smith }\end{array}$ \\
\hline $2167[3]$ & T. C. Chamberlain; William C. Alden \\
\hline $2168[2]$ & T. C. Chamberlain; William C. Alden \\
\hline $2169[3]$ & T. C. Chamberlain; William C. Alden \\
\hline $2170[2]$ & T. C. Chamberlain; William C. Alden \\
\hline $2171[2]$ & T. C. Chamberlain; William C. Alden \\
\hline $2172[3]$ & T. C. Chamberlain; William C. Alden \\
\hline $2173[2]$ & T. C. Chamberlain; William C. Alden \\
\hline $2174[3]$ & T. C. Chamberlain; William C. Alden \\
\hline 2175 & T. C. Chamberlain; William C. Alden \\
\hline $2176[2]$ & T. C. Chamberlain; William C. Alden \\
\hline 2177 & T. C. Chamberlain; William C. Alden \\
\hline $2178[3]$ & T. C. Chamberlain; William C. Alden \\
\hline $2179[2]$ & T. C. Chamberlain; William C. Alden \\
\hline 2180 & T. C. Chamberlain; William C. Alden \\
\hline $2181[2]$ & T. C. Chamberlain; William C. Alden \\
\hline $2182[2]$ & T. C. Chamberlain; William C. Alden \\
\hline $2183[3]$ & William C. Alden \\
\hline $2184[3]$ & T. C. Chamberlain; William C. Alden \\
\hline $2185[3]$ & T. C. Chamberlain; William C. Alden \\
\hline $2186[3]$ & T. C. Chamberlain; William C. Alden \\
\hline $2187[3]$ & T. C. Chamberlain; William C. Alden \\
\hline 2188 & T. C. Chamberlain; William C. Alden \\
\hline $2189[2]$ & T. C. Chamberlain; William C. Alden \\
\hline $2190[3]$ & T. C. Chamberlain; William C. Alden \\
\hline $2191[3]$ & T. C. Chamberlain; William C. Alden \\
\hline & T. C. Chamberlain; William C. Alden \\
\hline & T. C. Chamberlain; William C. Alden \\
\hline $2194[2]$ & T. C. Chamberlain; William C. Alden \\
\hline $2195[2]$ & T. C. Chamberlain; William C. Alden \\
\hline $2196[2]$ & T. C. Chamberlain; William C. Alden \\
\hline $2197[2]$ & T. C. Chamberlain; William C. Alden \\
\hline $2198[2]$ & $\begin{array}{l}\text { T. C. Chamberlain; William C. Alden; } \\
\text { J. L. Tilton }\end{array}$ \\
\hline $2199[2]$ & T. C. Chamberlain; William C. Alden \\
\hline & $\begin{array}{l}\text { T. C. Chamberlain; William C. Alden; } \\
\text { George F. Kay }\end{array}$ \\
\hline $2203[2]$ & T. C. Chamberlain; William C. Alden \\
\hline & T. C. Chamberlain; William C. Alden \\
\hline & T. C. Chamberlain; William C. Alden \\
\hline & T. C. Chamberlain; William C. Alden \\
\hline
\end{tabular}

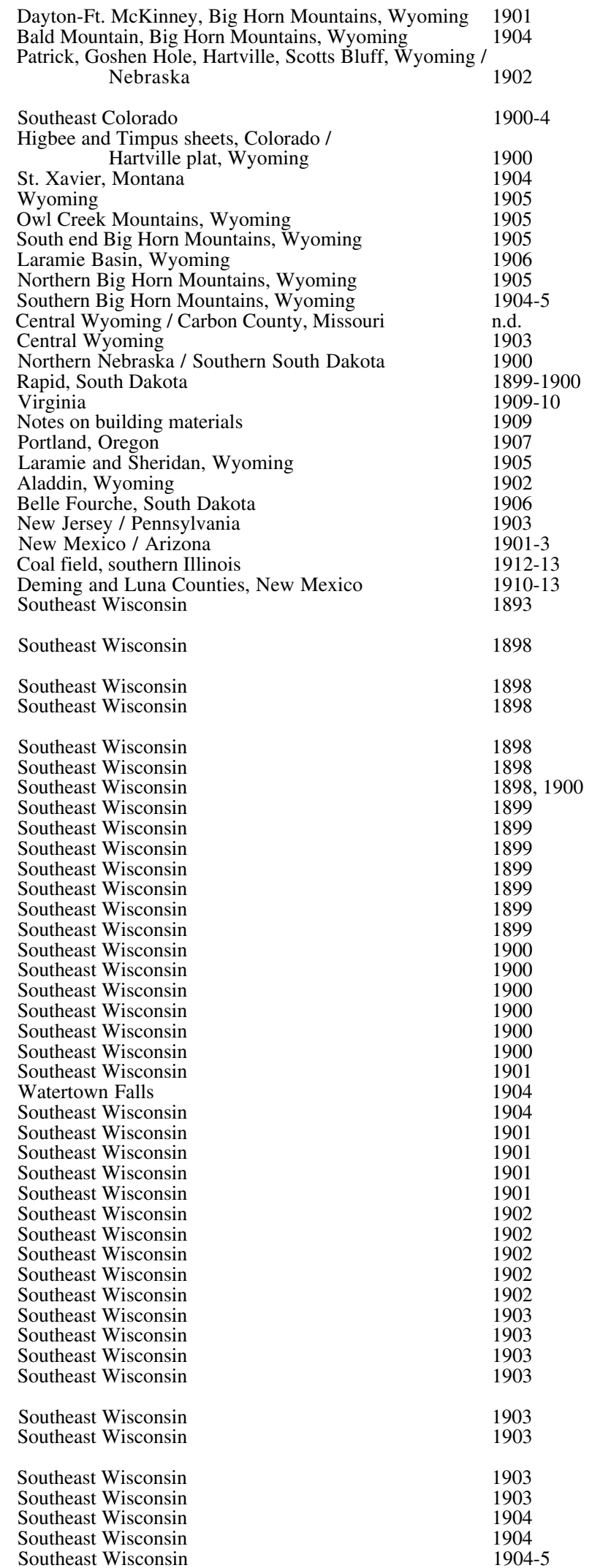


2207 [2] T. C. Chamberlain; William C. Alden; Allen D. Hole

2208 [2] T. C. Chamberlain; William C. Alden; C. G. Schatzer

2209 [2] T. C. Chamberlain; William C. Alden

2210 [3] T. C. Chamberlain; William C. Alden

T. C. Chamberlain; William C. Alden

2212 T. C. Chamberlain; William C. Alden;

2212 T. C. Chamberlain; William C. Alden;

2213 T. C. Chamberlain; William C. Alden; H. H. Barrows

2214 [2] T. C. Chamberlain; William C. Alden

2215 [2] T. C. Chamberlain; William C. Alden

2216 T. C. Chamberlain; William C. Alden

2217 [2] T. C. Chamberlain; William C. Alden

F. T. Thwaites

2218 T. C. Chamberlain; William C. Alden

R. D. Calkins

2219 [3] T. C. Chamberlain; William C. Alden

2220 [2] T. C. Chamberlain; William C. Alden

2221 [2] T. C. Chamberlain; William C. Alden

2222 [2] T. C. Chamberlain; William C. Alden

2223 T. C. Chamberlain; William C. Alden

2224 [2] T. C. Chamberlain; William C. Alden

2225 T. C. Chamberlain; William C. Alden

E. R. Scheffel

2226 [2] T. C. Chamberlain; William C. Alden

T. C. Chamberlain; William C. Alden

T. C. Chamberlain; William C. Alden

T. C. Chamberlain; William C. Alden

S. L. Stoner

T. C. Chamberlain; William C. Alden W. D. Jones

2231 William C. Alden; G. J. Miller

2232 [2] T. C. Chamberlain; William C. Alden

2234 T. C. Chamberlain; William C. Alden

2235

2236

2238

2242

T. C. Chamberlain; William C. Alden

T. C. Chamberlain; William C. Alden

T. C. Chamberlain; William C. Alden

T. C. Chamberlain; William C. Alden

T. C. Chamberlain; William C. Alden

T. C. Chamberlain; William C. Alden

T. C. Chamberlain; William C. Alden

M. L. Fuller; William C. Alden

M. L. Fuller; William C. Alden

T. C. Chamberlain; William C. Alden

T. C. Chamberlain; William C. Alden

M. R. Campbell; William C. Alden

M. R. Campbell; William C. Alden

M. R. Campbell; J. E. Thomas

William C. Alden; Eugene Stebinger

2264 [2] M. R. Campbell; William C. Alden

2265

2266

M. R. Campbell; William C. Alden

M. R. Campbell; Clifton S. Corbett

2266-A [2] M. R. Campbell; Clifton S. Corbett

2266-B

$2266-\mathrm{D}$

2267

M. R. Campbell; Clifton S. Corbett

M. R. Campbell; E. M. Parks

A. Keith; William C. Alden

A. Keith; William C. Alden

T. C. Chamberlain; William C. Alden

Southeast Wisconsin

$1904-5$

Southeast Wisconsin

Southeast Wisconsin

1904-5

Southeast Wisconsin

1905

Southeast Wisconsin 1905

Southeast Wisconsin

1905

Southeast Wisconsin 1905

Southeast Wisconsin 1907

Southeast Wisconsin 1907

Southeast Wisconsin 1907

$\begin{array}{ll}\text { Southeast Wisconsin } & 1907\end{array}$

Southeast Wisconsin 1907

Southeast Wisconsin 1897

Southeast Wisconsin 1906

Southeast Wisconsin 1908

Southeast Wisconsin 1909

Southeast Wisconsin 1909

Southeast Wisconsin 1909

Southeast Wisconsin $\quad 1909$

Southeast Wisconsin 1910

Southeast Wisconsin 1910

Southeast Wisconsin 1910

Southeast Wisconsin 1908

Southeast Wisconsin 1909

Southeast Wisconsin 1909

Northern Illinois 1908

Northern Illinois 1908

Illinois / Ohio / Wisconsin 1911

Brookfield, Massachusetts 1906-7

Worcester, Massachusetts 1906

Blackstone, Massachusetts 1906

Marlboro, Massachusetts 1906

Marlboro, Massachusetts 1906

Barre, Massachusetts 1907

Belchertown, Massachusetts 1907

Gaines and Elkland, Pennsylvania 1900

Gaines and Elkland, Pennsylvania 1900

Mt. Desert Island, Maine 1907

Mt. Desert Island, Maine 1907

Glacier National Park, Montana 1911

Glacier National Park, Montana 1911

Glacier National Park, Montana 1911

Blackfeet Indian Reservation, Montana /southern 1912

Glacier National Park, Montana $\quad 1913$

Glacier National Park, Montana 1913

Glacier National Park, Montana 1913

Glacier National Park, Montana 1911-14

Glacier National Park, Montana $\quad$ 1911-14

Glacier National Park, Montana 1911-14

Montana / North Dakota 1911

Maine / Massachusetts 1912

T. C. Chamberlain; William C. Alden; and others Wisconsin - well records

T. C. Chamberlain; William C. Alden; and others Wisconsin - well records

T. C. Chamberlain; William C. Alden; and others Wisconsin - well records

T. C. Chamberlain; William C. Alden; and others Wisconsin - well records

William C. Alden

William C. Alden

William C. Alden

William C. Alden

William C. Alden

William C. Alden

William C. Alden

William C. Alden; M. M. Leighton

William C. Alden; M. M. Leighton

William C. Alden; M. M. Leighton

William C. Alden; M. M. Leighton

Wisconsin - index of notebooks

Iowa / Illinois / Minnesota / North Dakota / Nebraska

Iowa / Illinois / Nebraska

Iowa

Iowa

Iowa / Minnesota

Iowa / Illinois / Minnesota

$\begin{array}{ll}\text { Nowa } & 1914 \\ \text { Northeastern Iowa } & 1914\end{array}$

Iowa 1914

Iowa 1915 


\begin{tabular}{|c|c|}
\hline 2285 & William C. Alden; M. M. Leighton \\
\hline $2286[2]$ & William C. Alden \\
\hline $2287[2]$ & William C. Alden \\
\hline $2288[2]$ & William C. Alden \\
\hline 2289 & William C. Alden \\
\hline 2290 & William C. Alden; M. M. Leighton \\
\hline $2291[2]$ & William C. Alden; M. M. Leighton \\
\hline $2292[2]$ & William C. Alden; M. M. Leighton \\
\hline $2293[2]$ & William C. Alden; M. M. Leighton \\
\hline $2328[3]$ & William C. Alden \\
\hline $2329[2]$ & T. C. Chamberlain; William C. Alden \\
\hline $2330[2]$ & William C. Alden \\
\hline $2415[2]$ & M. R. Campbell; W. C. Mendenhall \\
\hline 2416 & W. C. Mendenhall \\
\hline 2417 & M. R. Campbell \\
\hline 2418 & M. R. Campbell \\
\hline 2419 & M. R. Campbell \\
\hline 2420 & M. R. Campbell \\
\hline 2421 & M. R. Campbell \\
\hline 2422 & M. R. Campbell \\
\hline 2423 & M. R. Campbell \\
\hline 2424 & M. R. Campbell \\
\hline 2425 & M. R. Campbell \\
\hline 2426 & M. R. Campbell \\
\hline 2427-A & M. R. Campbell \\
\hline 2427-B & M. R. Campbell \\
\hline 2427-C & M. R. Campbell \\
\hline 2427-D & M. R. Campbell; Hammond Hutler \\
\hline 2427-E & M. R. Campbell \\
\hline 2428 & Joseph A. Taff; Alfred H. Brooks \\
\hline 2429 & Joseph A. Taff; Alfred H. Brooks \\
\hline 2434 & Charles Willard Hayes; W. T. Griswold \\
\hline 2501 & A. J. Collier; M. R. Campbell \\
\hline $2524[2]$ & J. H. Hance \\
\hline 2525 & C. W. Washburne \\
\hline 2527 & Ralph Arnold; Chester Washburn \\
\hline 2527-A & Ralph Arnold; and others \\
\hline 2541 & G. C. Martin \\
\hline 2542 & G. C. Martin \\
\hline 2543 & G. C. Martin \\
\hline $2562[2]$ & Joseph C. Taff \\
\hline $2633[2]$ & Waldemar Lindgren; G. H. Eldridge \\
\hline $2634[2]$ & Raphael Pumpelly \\
\hline 2635 & Raphael Pumpelly; G. H. Eldridge \\
\hline 2637 & Raphael Pumpelly; G. H. Eldridge \\
\hline $2669[2]$ & E. E. Smith \\
\hline $2670[2]$ & E. E. Smith \\
\hline 2671 & E. E. Smith \\
\hline $2672[2]$ & E. E. Smith \\
\hline $2673[2]$ & E. E. Smith \\
\hline $2674[2]$ & E. E. Smith \\
\hline 2675 & E. E. Smith \\
\hline 2676 [2] & J. A. Davis \\
\hline 2727 & C. A. Fisher \\
\hline 2747 & A. J. Collier \\
\hline 2748 & A. J. Collier \\
\hline $2749[2]$ & A. J. Collier \\
\hline 2751 & A. J. Collier \\
\hline 2752 & A. J. Collier \\
\hline 2765 & Carl D. Smith \\
\hline 2766 & Carl D. Smith \\
\hline $2767[2]$ & Carl D. Smith \\
\hline 2768 & Carl D. Smith; E. B. Hopkins \\
\hline 2769 & Carl D. Smith; E. B. Hopkins \\
\hline 2770 & Carl D. Smith; E. L. DeGolyer \\
\hline 2771 & Carl D. Smith; E. L. DeGolyer \\
\hline 2772 & Carl D. Smith; E. L. DeGolyer \\
\hline 2773 & Carl D. Smith; E. L. DeGolyer \\
\hline 2774 & C. D. Smith \\
\hline 2775 & Carl D. Smith \\
\hline 2776 & Carl D. Smith \\
\hline $2783[2]$ & Waldemar Lindgren \\
\hline $2784[2]$ & Waldemar Lindgren; F. C. Schrader \\
\hline $2792[2]$ & A. C. Veatch; Max A. Pishel \\
\hline 2793 & A. C. Veatch; Max A. Pishel \\
\hline $2794[2]$ & A. C. Veatch; M. W. Ball \\
\hline
\end{tabular}

\begin{tabular}{|c|c|}
\hline Iowa & 1914 \\
\hline Iowa & 1915 \\
\hline Iowa & 1915 \\
\hline Iowa & 1915 \\
\hline Iowa / Illinois / Minnesota / North Dakota & 1915 \\
\hline Iowa & 1915 \\
\hline Iowa & 1915 \\
\hline Iowa & 1915 \\
\hline Iowa & 1915 \\
\hline Geneva and Racine, Wisconsin & 1906 \\
\hline Southeast Wisconsin & n.d. \\
\hline Southeast Wisconsin & n.d. \\
\hline West Virginia & 1895 \\
\hline Clay, Clendinning and Charleston, West Virginia & 1895 \\
\hline Charleston, West Virginia & 1898 \\
\hline Oceana and Charleston, West Virginia & 1898 \\
\hline Pineville, Welch, Gilbert and Logan, West Virginia & 1898 \\
\hline Various areas, West Virginia & 1898 \\
\hline Clay and Clendemin, West Virginia & 1898 \\
\hline Glenville and Burnsville, West Virginia & 1899 \\
\hline Burnsville and Crawford, West Virginia & 1899 \\
\hline Burnsville, Sutton and Gassaway, West Virginia & 1899 \\
\hline Various areas, West Virginia & 1899 \\
\hline Various areas, West Virginia & 1899 \\
\hline Bluegrass region, Kentucky & 1898 \\
\hline Illinois / West Virginia & n.d. \\
\hline Danville, Illinois & 1899 \\
\hline Meadow Branch and Coal Field, West Virginia & 1903 \\
\hline Southwest Virginia coal field, & 1920 \\
\hline Sutton, West Virginia 1895 & \\
\hline Sutton, West Virginia 1895 & \\
\hline West Virginia / Ohio & 1901 \\
\hline Coal fields, Alaska & 1906 \\
\hline Glendive Lignite field, Montana & 1910 \\
\hline Western Oregon & $1902-4$ \\
\hline $\begin{array}{l}\text { Port Angeles, Crescent Lake, and Solduck River, } \\
\text { Washington }\end{array}$ & 1904 \\
\hline Santa Cruz, California & 1904 \\
\hline Denver Basin, Colorado & 1908 \\
\hline Denver Basin, Colorado & 1908 \\
\hline Denver Basin, Colorado & 1908 \\
\hline Durango, Salt Creek and Pagosa Springs, Colorado & $1906-7$ \\
\hline Bull Mountains, Montana & 1883 \\
\hline Bull Mountains coal field, Montana & 1881 \\
\hline Livingston coal field, Montana & 1882 \\
\hline Livingston coal field, Montana & $1882-83$ \\
\hline King and Kittitas, Washington & 1909 \\
\hline King and Kittitas, Washington & 1909 \\
\hline King and Kittitas, Washington & 1909 \\
\hline King and Kittitas, Washington & 1909 \\
\hline King and Kittitas, Washington & 1909 \\
\hline King and Kittitas, Washington & 1909 \\
\hline King and Kittitas, Washington & 1909 \\
\hline Little Powder River coal field, Wyoming & 1910 \\
\hline Big Horn Basin, Wyoming & 1904 \\
\hline Miles City, Montana & 1907 \\
\hline Miles City, Montana & 1907 \\
\hline Miles City, Montana & 1907 \\
\hline Miles City, Montana & 1907 \\
\hline Miles City, Montana & 1907 \\
\hline Fort Peck Indian Reservation, Montana & 1908 \\
\hline Fort Peck Indian Reservation, Montana & 1908 \\
\hline Fort Peck Indian Reservation, Montana & 1908 \\
\hline Fort Peck Indian Reservation, Montana & 1908 \\
\hline Fort Peck Indian Reservation, Montana & 1908 \\
\hline Fort Peck Indian Reservation, Montana & 1908 \\
\hline Fort Peck Indian Reservation, Montana & 1908 \\
\hline Fort Peck Indian Reservation, Montana & 1908 \\
\hline Fort Peck Indian Reservation, Montana & 1908 \\
\hline Fort Peck Indian Reservation, Montana & 1908 \\
\hline Fort Peck Indian Reservation, Montana & 1908 \\
\hline Fort Peck Indian Reservation, Montana & 1908 \\
\hline Chiricahua, Arizona & 1897 \\
\hline Chiricahua, Arizona & 1897 \\
\hline Carbon County, Wyoming & 1906 \\
\hline Carbon County, Wyoming & 1906 \\
\hline Carbon County, Wyoming & 1906 \\
\hline
\end{tabular}




\begin{tabular}{|c|c|}
\hline 2795 & A. C. Veatch; Jones \\
\hline 2796 [2] & A. C. Veatch \\
\hline 2797 & A. C. Veatch \\
\hline $2798[2]$ & A. C. Veatch; Max A. Pishel \\
\hline 2799 & A. C. Veatch; Spenser R. Logan \\
\hline $2800[2]$ & A. C. Veatch; Max A. Pishel \\
\hline $2801[2]$ & A. C. Veatch; Max A. Pishel \\
\hline 2802 & A. C. Veatch; M. W. Ball \\
\hline 2803 & A. C. Veatch; Max A. Pishel \\
\hline 2809 & A. C. Veatch \\
\hline 2814 & M. A. Pishel; C. F. Bowen \\
\hline $2815[2]$ & C. F. Bowen \\
\hline 2816 & C. F. Bowen \\
\hline 2817 & C. F. Bowen; G. M. Parks \\
\hline $2818[2]$ & C. F. Bowen \\
\hline $2838[2]$ & V. H. Barnett; A. W. Stickney \\
\hline 2839 & V. H. Barnett; R. Z. Pierce \\
\hline 2840 & V. H. Barnett; Frank Elliott \\
\hline $2841[2]$ & V. H. Barnett \\
\hline 2892 & Frank A. Herald \\
\hline $2897[7]$ & Frank A. Herald \\
\hline 2915 [4] & Ralph W. Stone; E. H. Finch \\
\hline $2920[2]$ & E. Russell Lloyd \\
\hline $2920-\mathrm{A}[2]$ & E. Russell Lloyd \\
\hline $2925[2]$ & Max A. Pishel \\
\hline $2925-\mathrm{A}$ & Max A. Pishel \\
\hline $2925-\mathrm{B}$ & Max A. Pishel \\
\hline 2925-C [3] & Max A. Pishel \\
\hline 2925-D & Max A. Pishel \\
\hline 2925-E & Max A. Pishel \\
\hline 2926 & Charles F. Bowen; H. Bassler \\
\hline $2927[2]$ & Charles F. Bowen \\
\hline 2937 & C. F. Lesher \\
\hline $2951[2]$ & A. C. Veatch \\
\hline 2952 & A. C. Veatch \\
\hline $2953[2]$ & A. C. Veatch; A. R. Schultz \\
\hline 2954 & A. C. Veatch; A. R. Schultz \\
\hline 2955 & A. C. Veatch; A. R. Schultz \\
\hline 2956 & A. C. Veatch; Carl D. Smith \\
\hline 2957 & A. C. Veatch; Carl D. Smith \\
\hline $2958[2]$ & A. C. Veatch; Max A. Pishel \\
\hline 2959 [2] & A. C. Veatch; Max A. Pishel \\
\hline 2960 & A. C. Veatch; Max A. Pishel \\
\hline 2961 & A. C. Veatch \\
\hline 2962 & A. C. Veatch \\
\hline 2963 & A. C. Veatch \\
\hline 2964 & A. C. Veatch \\
\hline 2965 & A. C. Veatch \\
\hline 2966 & A. C. Veatch \\
\hline 2967 & C. Max Bauer \\
\hline 2968 & C. Max Bauer \\
\hline 2969 & C. Max Bauer \\
\hline 2970 & C. Max Bauer \\
\hline 2971 & C. Max Bauer \\
\hline 2972 & C. Max Bauer \\
\hline 2983 & N. H. Darton \\
\hline 2983-A [2] & N. H. Darton \\
\hline 2985 & N. H. Darton \\
\hline 2986 & N. H. Darton \\
\hline 2987 & N. H. Darton \\
\hline 2987-B & N. H. Darton \\
\hline 2987-C & N. H. Darton \\
\hline 2987-D & Moore; Evans; LaRue \\
\hline 2987-E [2] & N. H. Darton \\
\hline 2987-F [2] & N. H. Darton \\
\hline 2987-H & N. H. Darton \\
\hline 2987-I & N. H. Darton \\
\hline 2987-K & N. H. Darton \\
\hline 2987-L & N. H. Darton \\
\hline 2987-M & N. H. Darton \\
\hline $2987-N$ & N. H. Darton \\
\hline
\end{tabular}

Carbon County, Wyoming 1906

Carbon County, Wyoming 1906

Carbon County, Wyoming 1906

Carbon County, Wyoming 1906

Carbon County, Wyoming 1906

Carbon County, Wyoming 1906

Carbon County, Wyoming 1906

Carbon County, Wyoming 1906

Carbon County, Wyoming

Carbon County, Wyoming 1906

Baker field, Montana 1910

Baker Field, Montana $\quad 1910$

Baker Field, Montana

Baker Field, Montana

Baker field, Montana 1910

Belle Fourche Valley, Wyoming 191

Belle Fourche Valley, Wyoming 1911

Belle Fourche Valley, Wyoming 1911

Belle Fourche Valley, Wyoming 1911

Williston lignite field, Fort Berthold, North Dakota 1911

Williston lignite field, North Dakota

Fort Benton, Nyack and Flathead Indian Reservation, Montana - phosphate notes

Cannonball lignite field, North Dakota

Cannonball lignite field, North Dakota 1914

Mancos Project, Colorado 1911

Red Mesa, Colorado 1911

Red Mesa, Colorado / New Mexico 1911

Red Mesa. Colorado / New Mexico 1911

Yakima Indian Reservation, Washington 1912

Red Mesa and Soda Canyon, Colorado 1911

Mussellshell to Judith, Montana 1912

Big Sandy and Cleveland fields, Montana 1912

Glendive, Montana

Coal and oil lands, Wyoming 1905

Coal and oil lands, Wyoming $\quad 1905$

Lincoln and Uinta, Wyoming 1905

Uinta, Wyoming 1905

Uinta, Wyoming 1905

Uinta, Wyoming 1905

Uinta and Lincoln, Wyoming 1905

Uinta and Lincoln, Wyoming 1905

Uinta and Lincoln, Wyoming 1905

Uinta and Lincoln, Wyoming 1905

Oil well logs, Wyoming 1905-6

Uinta, Wyoming 1905

Uinta, Wyoming 1905

Uinta, Wyoming

Uinta and Big Horn River Basin, Wyoming 1905

Uinta and Big Wind River Basin, Wyoming 1905

Fort Peck Project, Montana 1911

Fort Peck Project, Montana 1911

Fort Peck Project, Montana 1911

Fort Peck Project, Montana 1911

Fort Peck Project, Montana 1911

Fort Peck Project, Montana 1911

Newell, South Dakota $1912-15$

Geologic and topographic map, South Dakota 1935

Syracuse and Lakin, Kansas

South Dakota 1909-15

Spearfish, Sturgis, Deadwood and Black Hills, South Dakota

Kansas Colorado / New Mexico / Arizona, along route of the Santa Fe Railroad

1912

Arizona / California, along route of the Atchinson, Topeka and Santa Fe Railroad 1914

Grand Canyon, Arizona 1927

$\begin{array}{ll}\text { Arizona } & 1927 \\ \text { Arizona-21 }\end{array}$

Arizona 1921-23

Arizona 1915-23

List of fossils collected by Edward Sampson on the Fort Apache and San Carlos Indian Reservations, Arizona

$1920-22$

$\begin{array}{ll}\text { Flagstaff and Grand Canyon, Arizona } & 1914 \\ \text { Valencia County west of the Rio Grande, New Mexico } & 1913-16\end{array}$

Eastern New Mexico $1910-25$

New Mexico 


\begin{tabular}{|c|c|c|c|}
\hline 2987-O & N. H. Darton & Wingate, New Mexico & $1918-19$ \\
\hline 2987-P & N. H. Darton & New Mexico & ca. 1913 \\
\hline \multirow[t]{2}{*}{ 2987-Q } & N. H. Darton & San Andres, Guadalupe, and Sacramento & \\
\hline & & Mountains, New Mexico & $1913-15$ \\
\hline 2987-R & N. H. Darton & Gallina, Jemez and Abiquiu, New Mexico & $1913-17$ \\
\hline 2987-S & N. H. Darton & $\begin{array}{c}\text { Carthage, Oscura Peak, Quivera and San Pedro, } \\
\text { New Mexico }\end{array}$ & $1912-24$ \\
\hline 2987-U & N. H. Darton & LaJoya, New Mexico & $1913-16$ \\
\hline 2987-V & N. H. Darton & New Mexico & 1924 \\
\hline 2987-W [2] & N. H. Darton; J. B. Reeside & $\begin{array}{c}\text { Guadalupe Mountains and Carlsbad region, } \\
\text { New Mexico / Texas }\end{array}$ & 1925 \\
\hline $2987-Z$ & N. H. Darton & New Mexico & 1912 \\
\hline 2988 & N. H. Darton & Pennsylvania & 1911 \\
\hline 2988-A & N. H. Darton & Texas & $1925-26$ \\
\hline 2988-B & N. H. Darton & Texas Geologic Map & $1926-27$ \\
\hline $2988-\mathrm{C}$ & N. H. Darton & Menard-Segovia and Crane-Rankin, Texas & $1928-29$ \\
\hline 2988-D & N. H. Darton & Kent and Barstow, Texas & 1928 \\
\hline 2988-E [2] & N. H. Darton & Western Texas & 1929 \\
\hline $2988-\mathrm{F}$ & N. H. Darton & Texas & 1930 \\
\hline 2988-G & N. H. Darton & Texas Geologic Map & $1930-31$ \\
\hline $2988-\mathrm{H}$ & N. H. Darton & Texas & ca. 1927 \\
\hline \multirow[t]{2}{*}{2989 [2] } & N. H. Darton & $\begin{array}{l}\text { Along route of the Southern Pacific Railroad, } \\
\text { New Orleans to Los Angles, Louisiana / }\end{array}$ & \\
\hline & & Texas / New Mexico / Arizona / California & 1932 \\
\hline $3025[2]$ & E. Russell Lloyd & Cannonball lignite field, North Dakota & 1913 \\
\hline $3026[2]$ & E. Russell Lloyd & Cannonball lignite field, North Dakota & 1913 \\
\hline 3027 & E. Russell Lloyd & Cannonball lignite field, North Dakota & 1913 \\
\hline 3055 & L. J. Pepperberg & Milk River coal field, Montana & 1908 \\
\hline 3056 & L. J. Pepperberg & Milk River coal field, Montana & 1908 \\
\hline 3057 & L. J. Pepperberg & Milk River coal field, Montana & 1908 \\
\hline $3061[2]$ & L. J. Pepperberg & Milk River coal field, Montana & 1908 \\
\hline $3070-\mathrm{I}$ & Eugene Stebinger; Julian D. Sears & Possibilities of oil and gas in north central Montana & 1915 \\
\hline $3070-\mathrm{L}$ & Julian D. Sears; Wilmot H. Bradley & Moffat County, Colorado & 1921 \\
\hline 3070-M & Julian D. Sears; K. K. Landes & Moffet County, Colorado & 1921 \\
\hline $3070-\mathrm{N}$ & Julian D. Sears; Wilmot H. Bradley & Moffet County, Colorado & 1921 \\
\hline 3070-O & Julian D. Sears; K. K. Landes & Moffet County, Colorado & 1921 \\
\hline 3070-P [2] & Julian D. Sears & Moffet County, Colorado & 1921 \\
\hline $3070-Q$ & Julian D. Sears; Wilmot H. Bradley & Moffet County, Colorado & 1922 \\
\hline $3070-\mathrm{R}$ & Julian D. Sears; Wilmot H. Bradley & Moffet County, Colorado / Utah & 1922 \\
\hline $3070-S$ & Julian D. Sears; Wilmot H. Bradley & Moffet County, Colorado & 1922 \\
\hline 3070-T [3] & Julian D. Sears; Wilmot H. Bradley & Moffet County, Colorado & 1922 \\
\hline $3070-U$ & Julian D. Sears; James Gilluly & Moffet County, Colorado & 1922 \\
\hline $3070-V$ & Julian D. Sears & Moffet County, Colorado & $1921-22$ \\
\hline 3070-W & Julian D. Sears; James Gilluly & Moffet County, Colorado & 1922 \\
\hline \multirow[t]{2}{*}{$3037-X[7]$} & Julian D. Sears; P. C. Benedict & & \\
\hline & Q. D. Singewald & Baxter Basin gas field, Wyoming & 1923 \\
\hline \multirow[t]{2}{*}{ 3037-Y [2] } & Julian D. Sears; P. C. Benedict & & \\
\hline & Q. D. Singewald & Baxter Basin gas field, Wyoming & 1923 \\
\hline $3070-Z$ & Julian D. Sears; and others & $\begin{array}{c}\text { Vermilion Creek, stratigraphic sections and } \\
\text { coal cases, Colorado/ Wyoming }\end{array}$ & 1923 \\
\hline 3070-ZZ & Julian D. Sears & Wyoming map & n.d. \\
\hline $3112[2]$ & C. M. Bauer & Ekalaka coal field, Montana & 1913 \\
\hline 3143-W [22] & C. Whitman Cross & Specimen lists, Colorado / New Mexico & various \\
\hline $3143-\mathrm{X}[2]$ & C. Whitman Cross & Silver Cliff and Rosita Hills area, Colorado & n.d. \\
\hline $3164[2]$ & Adolph Knopf & Helena mining region, Montana & 1911 \\
\hline $3165[2]$ & Adolph Knopf; H. G. Ferguson & Helena mining region, Montana & 1911 \\
\hline $3255[2]$ & Adolph Knopf & Yerington, Nevada & 1914 \\
\hline $3256[2]$ & Adolph Knopf & Darwin, California & 1913 \\
\hline $3257[2]$ & Adolph Knopf & Inyo Range, California & 1912 \\
\hline 3258 & Adolph Knopf; F. H. Lahee & Bishop and Darwin, California & 1913 \\
\hline 3265 & Arthur Keith; Charles Willard Hayes & Monadock, New Hampshire & 1887 \\
\hline $3266[2]$ & Arthur Keith; Charles Willard Hayes & Monadock, New Hampshire & 1887 \\
\hline $3267[2]$ & Arthur Keith; Charles Willard Hayes & Monadock, New Hampshire & 1887 \\
\hline $3268[2]$ & Arthur Keith; Charles Willard Hayes & Monadock, New Hampshire & 1887 \\
\hline $3269[2]$ & Arthur Keith; Charles Willard Hayes & Monadock, New Hampshire & 1887 \\
\hline \multirow[t]{2}{*}{$3275[2]$} & Arthur Keith; Charles Willard Hayes; & & \\
\hline & W. J. Withrow & Rutland and Wallingford, Vermont & 1888 \\
\hline \multirow{3}{*}{$\begin{array}{l}3276[2] \\
3277\end{array}$} & Arthur Keith; Charles Willard Hayes; and others & Rutland and Wallingford, Vermont & $1888-89$ \\
\hline & Arthur Keith; Charles Willard Hayes; & & \\
\hline & W. J. Withrow & Rutland and Wallingford, Vermont & 1888 \\
\hline \multirow[t]{2}{*}{3278} & Arthur Keith; Charles Willard Hayes; & & \\
\hline & W. J. Withrow & Rutland and Wallingford, Vermont & 1888 \\
\hline \multirow[t]{2}{*}{$3279[2]$} & Arthur Keith; Charles Willard Hayes; & & \\
\hline & W. J. Withrow & Rutland and Wallingford, Vermont & 1888 \\
\hline $3280[2]$ & Arthur Keith; Charles Willard Hayes; and others & Rutland and Wallingford, Vermont & 1888 \\
\hline $3281[2]$ & $\begin{array}{l}\text { Arthur Keith; Charles Willard Hayes; } \\
\text { H. A. Craigin }\end{array}$ & Rutland and Wallingford, Vermont & 1888 \\
\hline
\end{tabular}




\begin{tabular}{|c|c|c|c|}
\hline 3282 & $\begin{array}{l}\text { Arthur Keith; Charles Willard Hayes; } \\
\text { H. L. Smyth }\end{array}$ & Rutland and Wallingford, Vermont & 1889 \\
\hline $3283[3]$ & Arthur Keith; Charles Willard Hayes; and others & Rutland and Wallingford, Vermont & 1888 \\
\hline $3283-\mathrm{A}$ & Charles Willard Hayes & Valuation coal lands on the public domain & ca. $1907-10$ \\
\hline $3284[2]$ & Charles Willard Hayes & Cuba & ca. 1891-1901 \\
\hline $3284-\mathrm{A}$ & Arthur Spencer & Cuba & 1901 \\
\hline 3284-B & Arthur Spencer & Cuba & 1901 \\
\hline 3397-A & G. F. Moulton; Nathan W. Bass & Cedar Creek, Montana & 1920 \\
\hline 3397-B & G. F. Moulton; Nathan W. Bass & Cedar Creek, Montana & 1921 \\
\hline $3397-\mathrm{C}$ & G. F. Moulton; Nathan W. Bass & Cedar Creek, Montana & 1921 \\
\hline \multirow{2}{*}{ 3397-D [2] } & G. F. Moulton; Nathan W. Bass; & & \\
\hline & M. M. Bramlette & Cedar Creek, Montana & 1921 \\
\hline 3464 & T. Nelson Dale & Massachusetts / New York & 1919 \\
\hline 3465 & T. Nelson Dale & New York / Connecticut & 1920 \\
\hline 3478 & L. M. Prindle & Clove, Troy and Kinderhook, New York & $1892-93$ \\
\hline 3595-B & M. R. Campbell; H. R. Bennett & Glacier National Park, Montana & $1911-14$ \\
\hline $3595-\mathrm{C}[2]$ & M. R. Campbell; Eugene Stebinger & Glacier National Park, Montana & $1911-14$ \\
\hline $3595-\mathrm{D}$ & M. R. Campbell; C. R. Williams & Glacier National Park, Montana & $1911-14$ \\
\hline 3680-A & Arthur A. Baker & Montana & 1924 \\
\hline $3755[2]$ & Julian D. Sears; Bleeker; Russell & Gallup coal field, New Mexico & $1919-20$ \\
\hline $3755-\mathrm{A}[3]$ & Julian D. Sears & Gallup coal fields, New Mexico & $1919-20$ \\
\hline $3755-\mathrm{B}[2]$ & Julian D. Sears; Langdon White & Gallup coal fields, New Mexico & 1920 \\
\hline \multirow[t]{2}{*}{$3755-\mathrm{C}^{-2]}$} & Julian D. Sears; C. P. Ross; & & \\
\hline & Wilmot H. Bradley & Gallup and Zuñi Basin, New Mexico & 1921 \\
\hline $3756[2]$ & Julian D. Sears; B. H. M. White & Gallop coal fields, New Mexico & 1919 \\
\hline 3763 & E. T. Hancock; Julian D. Sears & Lake Basin field, Montana & 1916 \\
\hline $3770[3]$ & $\begin{array}{l}\text { E. T. Hancock; Julian D. Sears; } \\
\text { Delbert Williams }\end{array}$ & Lake Basin field, Montana; New Salem Lignite field, & $1014-16$ \\
\hline 3831-A & Frederick L. Ransome & Bisbee, Arizona & 1918 \\
\hline $3831-\mathrm{B}[2]$ & Frederick L. Ransome; H. A. C. Jenison & Boulder Canyon, Arizona / Nevada & 1922 \\
\hline $4016[2]$ & Paul V. Roundy; William W. Rubey; and others & Pawhuska, Oklahoma & $1917-21$ \\
\hline $4018[2]$ & Paul V. Roundy; William W. Rubey; and others & Pawhuska, Oklahoma & $1917-21$ \\
\hline 4057 & W. T. Thom, Jr.; Nathan W. Bass & Crow Indian Reservation, Montana & 1921 \\
\hline 4057-A [2] & N. W. Bass and others & Tongue River coal field, Montana & 1923 \\
\hline $4057-\mathrm{B}$ & N. W. Bass and others & Tongue River coal field, Montana & 1923 \\
\hline $4057-\mathrm{C}[2]$ & N. W. Bass; R. F. Flint; J. B. Stone & Tongue river coal field, Montana & 1923 \\
\hline 4057-D & N. W. Bass; Paul D. Torrey & Tongue River coal field, Montana & 1923 \\
\hline 4057-E & N. W. Bass; Paul D. Torrey & Tongue River coal field, Montana & 1923 \\
\hline 4057-F [5] & N. W. Bass and others & Tongue River coal field, Montana & 1923 \\
\hline \multirow[t]{2}{*}{4058} & K. C. Heald; William W. Rubey; & & \\
\hline & L. G. Mosburg & El Dorado oil fields, Arkansas & 1921 \\
\hline \multirow[t]{2}{*}{4061} & William H. Rubey & Oil field reserves and estimates, Missouri / & \\
\hline & & Illinois / Kansas & 1921 \\
\hline \multirow[t]{2}{*}{4062} & William H. Rubey & Oil field reserves and estimates, Missouri / & \\
\hline & & Illinois / Kansas & 1921 \\
\hline 4089 & M. R. Campbell & Glacier National Park, Montana & 1911 \\
\hline $4090[2]$ & M. R. Campbell; J. R. Hoots & Glacier National Park, Montana & 1911 \\
\hline 4091 & M. R. Campbell; J. R. Hoots & Glacier National Park, Montana & 1911 \\
\hline $4092-\mathrm{A}$ & M. R. Campbell & Glacier National Park, Montana & 1913 \\
\hline 4092-B [2] & M. R. Campbell & St. Paul to Seattle, Various States & 1914 \\
\hline \multirow[t]{2}{*}{$4092-\mathrm{C}[3]$} & M. R. Campbell & Along the route of the Denver and Rio Grande & \\
\hline & & Railroad, Colorado / Utah & $1915-16$ \\
\hline 4171 & M. R. Campbell; H. B. C. Nitze & Roam Mountain, Tennessee & 1899 \\
\hline $4275-\mathrm{A}$ & A. E. Fath; N. W. Bass & Carbon and Sweetwater Counties, Wyoming & 1920 \\
\hline 4338 & Frederick L. Ransome; H. A. C. Jenison & Black Canyon, Arizona & 1923 \\
\hline 4339 & Frederick L. Ransome; H. A. C. Jenison & Black Canyon, Nevada / Arizona & 1923 \\
\hline 4340 & Frederick L. Ransome; H. A. C. Jenison & Virgin Valley, Nevada & 1923 \\
\hline $4341[2]$ & Arthur A. Baker; C. M. Clark & $\begin{array}{c}\text { Tongue River coal field and northward extension } \\
\text { of Sheridan coal field, Montana }\end{array}$ & 1924 \\
\hline \multirow[t]{2}{*}{4342} & Arthur A. Baker; C. M. Clark & Tongue River coal field and northward extension & \\
\hline & & of Sheridan coal field, Montana & 1924 \\
\hline 4343 & Arthur A. Baker; P. D. Torrey & Tongue River coal field and northward extension & \\
\hline \multirow{2}{*}{4344} & Arthur A Baker. P D Torrey & $\begin{array}{l}\text { of Sheridan coal field, Montana } \\
\text {. }\end{array}$ & \\
\hline & Arthur A. Baker; P. D. I orrey & $\begin{array}{l}\text { 1ongue River coal field and northward extension } \\
\text { of Sheridan coal field, Montana }\end{array}$ & 1924 \\
\hline 4345 & Arthur A. Baker & Tongue River coal field and northward extension & \\
\hline & & of Sheridan coal field, Montana & 1924 \\
\hline 4346 & Arthur A. Baker & Tongue River coal field and northward extension & \\
\hline & & of Sheridan coal field, Montana & 1924 \\
\hline 4347 & Arthur A. Baker & Northward extension of Sheridan coal field, Montana & 1924 \\
\hline 4348 & Arthur A. Baker; J. B. Stone & Northward extension of Sheridan coal field, Montana & 1924 \\
\hline 4349 & Arthur A. Baker; P. D. Torrey & Northward extension of Sheridan coal field, Montana & 1924 \\
\hline $4350[4]$ & Arthur A. Baker; C. E. Erdmann & Northward extension of Sheridan coal field, Montana & 1925 \\
\hline $4351[4]$ & Arthur A. Baker; C. E. Erdmann & Northward extension of Sheridan coal field, Montana & 1925 \\
\hline $4352[2]$ & Arthur A. Baker; C. E. Erdmann & Northward extension of Sheridan coal field, Montana & 1925 \\
\hline $4353[4]$ & Arthur A. Baker; C. E. Erdmann & Northward extension of Sheridan coal field, Montana & 1925 \\
\hline
\end{tabular}




\begin{tabular}{|c|c|}
\hline 4354 & Arthur A. Baker \\
\hline 4362 & Arthur C. Spencer; J. E. Wolff \\
\hline 4363 & Arthur C. Spencer \\
\hline $4364[2]$ & Arthur C. Spencer \\
\hline 4365 & Arthur C. Spencer \\
\hline 4366 & Arthur C. Spencer \\
\hline $4367[2]$ & Arthur C. Spencer \\
\hline 4368 & J. Volney Lewis \\
\hline $4369[3]$ & Arthur C. Spencer \\
\hline 4370 & Arthur C. Spencer \\
\hline 4371 & Arthur C. Spencer; Weeks \\
\hline $4372[2]$ & Arthur C. Spencer; Weeks \\
\hline 4373 & Arthur C. Spencer \\
\hline 4374 & Arthur C. Spencer \\
\hline 4375 & Arthur C. Spencer \\
\hline 4376 & Arthur C. Spencer \\
\hline 4377 & Arthur C. Spencer \\
\hline 4378 & Arthur C. Spencer \\
\hline 4379-A & Arthur C. Spencer \\
\hline $4380[2]$ & Arthur C. Spencer \\
\hline $4381[2]$ & Arthur C. Spencer \\
\hline 4382 & Arthur C. Spencer \\
\hline 4383 & Arthur C. Spencer \\
\hline 4384 & Arthur C. Spencer \\
\hline 4976 & James Gilluly \\
\hline 4976-A [2] & James Gilluly \\
\hline 4976-B [4] & James Gilluly \\
\hline 4976-C [6] & James Gilluly \\
\hline 5035 & W. S. Burbank \\
\hline $5036[2]$ & W. S. Burbank \\
\hline $5037[2]$ & W. S. Burbank \\
\hline $5113[3]$ & $\begin{array}{l}\text { K. F. Mather; Julian D. Sears; } \\
\text { James Gilluly; R. G. Lusk }\end{array}$ \\
\hline $5114[2]$ & $\begin{array}{l}\text { K. F. Mather; Julian D. Sears; } \\
\text { James Gilluly; R. G. Lusk }\end{array}$ \\
\hline 5114-A [2] & James Gilluly \\
\hline $5114-\mathrm{B}[3]$ & James Gilluly; Sidney Paige; and others \\
\hline $5114-\mathrm{C}$ & Sidney Paige \\
\hline $5114-\mathrm{D}$ & Sidney Paige \\
\hline 5114-E & Sidney Paige \\
\hline $5238-1[2]$ & $\begin{array}{l}\text { James Gilluly; J. E. Reed; } \\
\text { C. F. Park, Jr. }\end{array}$ \\
\hline $5238-2[4]$ & $\begin{array}{l}\text { James Gilluly; J. E. Reed; } \\
\text { C. F. Park, Jr. }\end{array}$ \\
\hline $5238-\mathrm{A}[3]$ & $\begin{array}{l}\text { James Gilluly; J. E. Reed; } \\
\text { C. F. Park, Jr. }\end{array}$ \\
\hline 5239 & James Gilluly; R. B. Stewart Keating, \\
\hline $5242[5]$ & C. Whitman Cross; Allen D. Hole \\
\hline 5244 & H. Hinds; David White \\
\hline 5245 & David White \\
\hline 5246 & David White \\
\hline $5247[2]$ & David White \\
\hline 5248 & David White \\
\hline 5249 & J. A. Taff; David White \\
\hline 5250 & David White \\
\hline 5251 & David White \\
\hline 5252 & David White \\
\hline 5253 & David White \\
\hline 5254 & David White \\
\hline $5254-\mathrm{A}$ & C. D. White \\
\hline $5254-B$ & C. D. White \\
\hline $5254-\mathrm{C}$ & C. D. White \\
\hline $5254-\mathrm{D}$ & C. D. White \\
\hline 5257-F [3] & $\begin{array}{l}\text { C. H. Dane; Julian D. Sears; } \\
\text { C. E. Erdman; and others }\end{array}$ \\
\hline 5257-G [2] & $\begin{array}{l}\text { C. H. Dane; Julian D. Sears; } \\
\text { C. E. Erdman; and others }\end{array}$ \\
\hline $5276[2]$ & Sidney Paige; A. C. Spencer \\
\hline 5277 & Sidney Paige; A. C. Spencer \\
\hline 5277-A & Sidney Paige \\
\hline 5288 & Sidney Paige \\
\hline 5289 & Sidney Paige \\
\hline 5290 & Sidney Paige \\
\hline 5291 & Harrington; Sidney Paige \\
\hline 5292 & D. G. Thompson; Sidney Paige \\
\hline 5293 & Sidney Paige \\
\hline 5294 & Sidney Paige \\
\hline
\end{tabular}

$\begin{array}{ll}\text { Steel Creek anticline, Wyoming } & 1925 \\ \text { Franklin Furnance, New Jersey } & 1904 \\ \text { Iron mines, New Jersey } & 1904 \\ \text { Iron ore - Triassic, Pennsylvania } & 1904 \\ \text { Montezuma, Colorado / Utah } & 1898 \\ \text { Encampment, Wyoming } & 1902 \\ \text { Encampment to Pearl, Wyoming / Colorado } & 1902 \\ \text { Encampment, Wyoming } & 1902 \\ \text { Ely District, Nevada } & 1909-10 \\ \text { Veteran mine, Ely District, Nevada } & 1911 \\ \text { Appalachian Forest, White Mountains, New Hampshire } & 1911 \\ \text { Twin Mountain to Cherry Mountain, New Hampshire } & 1911 \\ \text { Laramie District, Wyoming } & 1914 \\ \text { Atlantic District, Wyoming } & 1914 \\ \text { Atlantic District, Wyoming } & 1914 \\ \text { Thief Valley Dam Site, Oregon } & 1922 \\ \text { Salmon River Dam Site Surveys, Idaho } & 1922 \\ \text { Salmon River Dam Site Surveys, Idaho } & 1922 \\ \text { Salmon River Dam Site Surveys, Idaho } & 1922 \\ \text { Santa Rita, New Mexico } & 1914,1928 \\ \text { Santa Rita, New Mexico } & 1921 \\ \text { Santa Rita, New Mexico } & 1928,1931 \\ \text { Mine plats, Santa Rita, New Mexico } & 1928 \\ \text { Taylor Creek tine deposits, New Mexico } & 1928 \\ \text { San Rafael Swell, Utah } & 1924 \\ \text { San Rafael Swell, Utah } & 1924 \\ \text { San Rafael Swell, Utah } & 1924 \\ \text { San Rafael Swell, Utah } & 1924 \\ \text { Haiti } & 1920-21 \\ \text { Haiti } & 1920-21 \\ \text { Haiti } & 1920-21 \\ & \\ & \end{array}$

Northeast Colorado Project 1924

Northeast Colorado Project 1924

Stockton and Fairfield, Utah 1927

Stockton and Fairfield, Utah 1926

Stockton and Fairfield, Utah 1925

Stockton and Fairfield, Utah 1925

Stockton and Fairfield, Utah 1925

Eastern Oregon mining districts and Baker 1930

Eastern Oregon mining districts and Baker $\quad 1930$

Eastern Oregon mining districts and Baker 1930

$\begin{array}{ll}\text { Oregon } & 1929\end{array}$

Telluride, Colorado 1907

Clintwood and Bucu, Virginia n.d.

Oklahoma / Arkansas 1916

Alabama / Tennessee $\quad 1901$

Virginia / West Virginia 1901

Kingston to Sewanee, West Virginia / Ohio / Tennessee 1895

Buckhannon and Sutton, West Virginia 1895

Alabama / Tennessee 1901

Pennsylvania 1890

Greenland 1897

Tazwell, Virginia / West Virginia 1894

Raleigh and Piedmont, West Virginia 1894

Kansas / Oklahoma / Colorado n.d.

Tennessee / Kentucky 1910-11

West Virginia 1923

Maryland / West Virginia 1925

Salt Valley and Grand County, Utah 1927-29

Salt Valley and Grand County, Utah 1927-29

Llano, Texas 1903

Llano, Texas 1903

Llano, Texas 1903

Black Hills, South Dakota 1912

Black Hills, South Dakota

Black Hills, South Dakota

Black Hills, South Dakota

Black Hills, South Dakota 1913

Black Hills, South Dakota 1913

Black Hills, South Dakota 1913 


\begin{tabular}{|c|c|}
\hline 5295 & Sidney Paige \\
\hline 5296 & Sidney Paige \\
\hline 5312 & J. Basil Preston \\
\hline $5313[2]$ & M. N. Bramlette; J. Basil Preston \\
\hline $5314[2]$ & M. N. Branlette; H. S. Ramkin \\
\hline 5315 & M. N. Bramlette; A. C. Munyan \\
\hline 5326 & George B. Richardson \\
\hline 5328 & George B. Richardson; C. S. Jarvis \\
\hline $5359[2]$ & Edwin B. Eckel \\
\hline $5359-\mathrm{A}[2]$ & Edwin B. Eckel \\
\hline $5359-\mathrm{B}[2]$ & Edwin B. Eckel \\
\hline $5359-\mathrm{C}[2]$ & Edwin B. Eckel \\
\hline 5359-D [2] & Edwin B. Eckel \\
\hline $5359-\mathrm{E}$ & Edwin B. Eckel \\
\hline $5359-\mathrm{F}$ & Edwin B. Eckel \\
\hline 5359-G [2] & Edwin B. Eckel \\
\hline $5359-\mathrm{H}[2]$ & Edwin B. Eckel \\
\hline $5359-\mathrm{I}$ & Edwin B. Eckel \\
\hline 5359-J & Edwin B. Eckel \\
\hline $5359-\mathrm{K}$ & Edwin B. Eckel \\
\hline $5359-\mathrm{L}$ & Edwin B. Eckel \\
\hline $5360-\mathrm{A}[3]$ & Marcus I. Goldman; Arthur C. Spencer \\
\hline $5424[3]$ & William C. Alden; B. K. Emerson \\
\hline $5428[2]$ & William C. Alden; B. K. Emerson \\
\hline $5430[2]$ & $\begin{array}{l}\text { T. C. Chamberlain; William C. Alden; } \\
\text { B. K. Emerson }\end{array}$ \\
\hline $5447[2]$ & N. H. Darton \\
\hline 5448 & N. H. Darton \\
\hline $5449[2]$ & N. H. Darton \\
\hline $5462[3]$ & $\begin{array}{l}\text { Edwin T. McKnight; Julian D. Sears; } \\
\text { O. Murphy; J. B. Reeside, Jr. }\end{array}$ \\
\hline $5462-\mathrm{A}[3]$ & $\begin{array}{l}\text { Edwin T. McKnight; Julian D. Sears; } \\
\text { O. Murphy; J. B. Reeside, Jr. }\end{array}$ \\
\hline 5462-B & $\begin{array}{l}\text { Edwin T. McKnight; Julian D. Sears; } \\
\text { O. Murphy; J. B. Reeside, Jr. }\end{array}$ \\
\hline 5542 & C. Whitman Cross \\
\hline $5543[2]$ & C. Whitman Cross \\
\hline 5544 & C. Whitman Cross \\
\hline $5560[2]$ & Arthur A. Baker \\
\hline $5560-\mathrm{A}[5]$ & Arthur A. Baker \\
\hline $5560-\mathrm{B}$ & L. A. Kelley \\
\hline $5560-\mathrm{C}[4]$ & L. A. Kelley \\
\hline $5560-\mathrm{D}$ & L. W. Clark \\
\hline 5560-E [5] & L. W. Clark \\
\hline $5560-\mathrm{F}$ & J. B. Reeside \\
\hline $5560-\mathrm{G}[2]$ & L. G. Snow \\
\hline $5560-\mathrm{H}$ & R. M. Larsen \\
\hline $5561[2]$ & Arthur A. Baker \\
\hline $5561-\mathrm{A}[2]$ & Arthur A. Baker; Charles Brewer \\
\hline $5561-\mathrm{B}[6]$ & Arthur A. Baker \\
\hline $5561-\mathrm{C}[2]$ & Arthur A. Baker; Charles Brewer \\
\hline $5561-\mathrm{D}[3]$ & Arthur A. Baker; G H. Hansen \\
\hline $5561-\mathrm{E}[2]$ & Arthur A. Baker \\
\hline $5561-\mathrm{F}[4]$ & Arthur A. Baker \\
\hline $5561-\mathrm{G}[2]$ & Arthur A. Baker; C. V. Theis \\
\hline $5561-\mathrm{H}$ & Arthur A. Baker; M. I. Goldman \\
\hline $5561-\mathrm{I}$ & Arthur A. Baker; L. W. Clark \\
\hline $5561-\mathrm{J}[5]$ & Arthur A. Baker; L. W. Clark \\
\hline $5561-\mathrm{K}$ & Arthur A. Baker; C. V. Theis \\
\hline $5561-\mathrm{L}[3]$ & Arthur A. Baker \\
\hline $5562[2]$ & Arthur A. Baker \\
\hline $5562-\mathrm{A}[3]$ & Arthur A. Baker \\
\hline $5562-\mathrm{B}[2]$ & Arthur A. Baker; M. M. Knechtel \\
\hline $5562-\mathrm{C}$ & Arthur A. Baker; A. J. Eardley \\
\hline 5562-D [2] & Arthur A. Baker; A. J. Eardley \\
\hline $5562-\mathrm{E}$ & Arthur A. Baker; H. D. Curry \\
\hline $5562-\mathrm{F}$ & Arthur A. Baker; H. D. Curry \\
\hline $5562-\mathrm{G}$ & Arthur A. Baker; L. G. Henbest \\
\hline $5562-\mathrm{H}[2]$ & Arthur A. Baker; L. G. Henbest \\
\hline $5562-\mathrm{I}[5]$ & Arthur A. Baker \\
\hline $5562-\mathrm{J}[3]$ & Arthur A. Baker \\
\hline $5562-K[5]$ & Arthur A. Baker; R. L. Miller \\
\hline $5562-\mathrm{L}[2]$ & Arthur A. Baker; D. A. Andrews \\
\hline $5562-\mathrm{M}[4]$ & Arthur A. Baker \\
\hline 6025 & K. C. Heald; William W. Rubey \\
\hline $6026[2]$ & K. C. Heald; William W. Rubey \\
\hline 6027 & K. C. Heald; William W. Rubey \\
\hline
\end{tabular}

Black Hills, South Dakota

Black Hills, South Dakota

Fireclays, Tennessee

Fireclays, Tennessee

Talladega, Alabama

Clay investigations, Calloway County, Kentucky

Sanpete and Sevier valleys, Utah

Sanpete and Sevier valleys, Utah

Eastern Texas, brown iron areas

Eastern Texas, brown iron areas

Eastern Texas, brown iron areas

Eastern Texas, brown iron areas

Eastern Texas, brown iron areas

Eastern Texas, brown iron areas

Eastern Texas, brown iron areas

Eastern Texas, brown iron areas

Eastern Texas, brown iron areas

Eastern Texas, brown iron areas

Eastern Texas, brown iron areas

Eastern Texas, brown iron areas

Eastern Texas, brown iron areas

Belchertown and Barre, Massachusetts

Webster and Blackstone, Massachusetts

Massachusetts

Maryland / Virginia/ Washington, D.C.

Maryland / Virginia

Washington, D.C. and vicinity

Grand and San Juan Counties, Utah

Grand and San Juan Counties, Utah

c. 1913

c. 1913

1934

1934

1934

1934-35

1905

1905

1931-35

$1931-35$

1931-35

1931-35

$1931-35$

1931-35

1934

1931-35

1931-35

1931-35

1931-35

1931-35

1931-35

1939

n.d.

n.d.

n.d.

1934-38

ca. $1938-40$

various

1926

1926

Grand and San Juan Counties, Utah 1926-27

$\begin{array}{ll}\text { Mineralogical notes, Colorado } & 1882 \\ \text { Gunnison, Colo. } & 1885\end{array}$

Gunnison, Colo.

Leucite Hills, Wyoming

Monument Valley and Navajo Mountain Region, Utah

Monument Valley and Navajo Mountain Region, Utah

Monument Valley and Navajo Mountain Region, Utah

Monument Valley and Navajo Mountain Region, Utah

Monument Valley and Navajo Mountain Region, Utah

Monument Valley and Navajo Mountain Region, Utah

Monument Valley and Navajo Mountain Region, Utah

Monument Valley and Navajo Mountain Region, Utah

Monument Valley and Navajo Mountain Region, Utah

Southeastern Utah

Moab, Utah

Moab, Utah

Moab, Utah

Moab, Utah

Moab, Utah

Moab, Utah

Moab, Utah

Moab, Utah

Moab, Utah

Moab, Utah

Moab, Utah

Moab, Utah

Cataract Canyon region, Utah

Cataract Canyon and Green River Desert, Utah

Cataract Canyon and Green River Desert, Utah

Cataract Canyon and Green River Desert, Utah

Cataract Canyon and Green River Desert, Utah

Cataract Canyon and Green River Desert, Utah

Cataract Canyon and Green River Desert, Utah

Cataract Canyon and Green River Desert, Utah

Cataract Canyon and Green River Desert, Utah

Cataract Canyon and Green River Desert, Utah

Cataract Canyon and Green River Desert, Utah

Cataract Canyon and Green River Desert, Utah

Cataract Canyon and Green River Desert, Utah

Cataract Canyon and Green River Desert, Utah

Ingomar Dome, Montana

Ingomar Dome, Montana

Ingomar Dome, Montana
1883

1928

1928

1928

1928

1928

1928

1928

1928

1928

1926

1926

1926

1926

1926

1927

1927

1927

1927

1927

1927

1927

1927

1930

1930

1930

1930

1930

1930

1930

1930

1930

1931

1931

1931

1931

1931

1922

1922

1922 


\begin{tabular}{|c|c|c|c|}
\hline $6040[2]$ & C. Whitman Cross & Correspondence and reports, Colorado & $1882-90$ \\
\hline 6122 & C. David White & Southern anthracite coal field, Pennsylvania & 1899 \\
\hline 6123 & C. David White & West Virginia / Virginia / Kentucky & 1904 \\
\hline 6124 & C. David White & Kentucky / West Virginia / Ohio & $1905-6$ \\
\hline 6125 & C. David White & Tennessee/ Kentucky / West Virginia & $1895-96$ \\
\hline 6126 & C. David White & Wyoming and Sullivan, Pennsylvania & n.d. \\
\hline \multirow[t]{2}{*}{ No. 25} & Samuel G. Lasky; James Gilluly; & & \\
\hline & $\begin{array}{l}\text { R. F. Pettit } \\
\text { Samuel G } \text {. James Gillulv. }\end{array}$ & Little Hatchet Mountains, New Mexico & $1934-42$ \\
\hline No. 26 & $\begin{array}{l}\text { R. F. Pettit; John B. Reeside, Jr.; } \\
\text { Edgar O. Bowles }\end{array}$ & Little Hatchet Mountains, New Mexico & $1934-42$ \\
\hline No. 27 [2] & $\begin{array}{l}\text { S. G. Lasky; James Gilluly; } \\
\text { R. F. Pettit; J. B. Reeside, Jr.; } \\
\text { Edgar O. Bowles }\end{array}$ & Little Hatchet Mountains, New Mexico & $1934-42$ \\
\hline No. 31 [3] & George F. Becker & Letters and Papers & $1875-92$ \\
\hline No. $32[4]$ & George F. Becker; James D. Hague & Letters and Papers & $1875-92$ \\
\hline No. 33 & Edwin B. Eckel & Various mining districts, Colorado & 1932 \\
\hline No. 34 & Edwin B. Eckel & Various mining districts, Colorado & 1932 \\
\hline No. 127 & Julian D. Sears; Mendall McClellen Bell & Comb Ridge Project, Utah & 1953 \\
\hline No. 128 & Julian D. Sears; Mendall McClellen Bell & Comb Ridge Project, Utah & 1953 \\
\hline No. 129 & Julian D. Sears; M. H. Bergendahl & Comb Ridge Project, Utah & 1953 \\
\hline No. 130 & Julian D. Sears; M. H. Bergendahl & Comb Ridge Project, Utah & 1953 \\
\hline No. 131 & Julian D. Sears; M. A. Conti & Comb Ridge Project, Utah & 1953 \\
\hline No. 132 & Julian D. Sears; G. W. Fuller & Comb Ridge Project, Utah & 1953 \\
\hline No. 133 & Julian D. Sears; G. W. Fuller & Comb Ridge Project, Utah & 1953 \\
\hline No. 134 & Julian D. Sears; Chabot Kilburn & Comb Ridge Project, Utah & 1953 \\
\hline No. 135 & Julian D. Sears; Chabot Kilburn & Comb Ridge Project, Utah & 1953 \\
\hline No. 136 & Julian D. Sears; Sergius Harry Mamay & Comb Ridge Project, Utah & 1953 \\
\hline No. 137 & Julian D. Sears; Sergius Harry Mamay & Comb Ridge Project, Utah & 1953 \\
\hline No. 138 & Julian D. Sears; Warren L. Peterson & Comb Ridge Project, Utah & 1953 \\
\hline No. 139 & Julian D. Sears; Warren L. Peterson & Comb Ridge Project, Utah & 1953 \\
\hline No. 140 & Julian D. Sears; E. L. Yochelson & Comb Ridge Project, Utah & 1953 \\
\hline No. 141 & Julian D. Sears; E. L. Yochelson & Comb Ridge Project, Utah & 1953 \\
\hline \multirow[t]{2}{*}{ No. 142 [2] } & James Gilluly; Edgar Bowles; & & \\
\hline & R. S. Cannon, Jr. & Arizona & 1936 \\
\hline \multirow[t]{2}{*}{ No. 143 [2] } & James Gilluly; Edgar Bowles; & & \\
\hline & John Herbert Weiss & Central Cochise County, Arizona & $1936-40$ \\
\hline No. 144 [2] & James Gilluly & Central Cochise County, Arizona & $1936-40$ \\
\hline \multirow[t]{2}{*}{ No. 145} & James Gilluly; Edgar Bowles; & & \\
\hline & R. S. Cannon, Jr. & Central Cochise County, Arizona & $1936-40$ \\
\hline No. 146 & James Gilluly; Josiah Bridge & Central Cochise County, Arizona & $1936-40$ \\
\hline No. $147[2]$ & James Gilluly & Central Cochise County, Arizona & $1936-40$ \\
\hline No. 148 & James Gilluly; Edgar Bowles; & & \\
\hline & R. S. Cannon, Jr. & Central Cochise County, Arizona & 1939 \\
\hline \multirow[t]{2}{*}{ No. 149} & James Gilluly; Edgar Bowles; & & \\
\hline & R. S. Cannon, Jr. & Central Cochise County, Arizona & $1939-40$ \\
\hline No. 150 & Wilbur S. Burbank; Edwin N. Goddard & Twin Lakes diversion tunnel, Colorado & 1935 \\
\hline \multirow[t]{2}{*}{ No. 195} & James Gilluly & Arizona / California / Idaho / Montana / Nevada / & \\
\hline & & Oregon / Utah & 1943 \\
\hline No. $201[2]$ & Edwin B. Eckel & Mercury industry, Italy & 1945 \\
\hline No. 206 & A. C. Spencer & Deschutes. Oregon & 1934 \\
\hline No. 245 & Nathan W. Bass & Ashland coal field, Montana & $1923-24,1927-28$ \\
\hline No. 246 & Nathan W. Bass & Ashland coal field, Montana & $1923-24,1927-28$ \\
\hline No. $247[3]$ & Nathan W. Bass & Ashland coal field, Montana & $1923-24,1927-28$ \\
\hline No. 248 & Nathan W. Bass and others & Ashland coal field, Montana & $1923-24,1927-28$ \\
\hline No. 249 [5] & Nathan W. Bass and others & Ashland coal field, Montana & $1923-24,1927-28$ \\
\hline No. $250[2]$ & Nathan W. Bass and others & Ashland coal field, Montana & $1923-24,1927-28$ \\
\hline No. 251 & Nathan W. Bass and others & Ashland coal field, Montana & $1923-24,1927-28$ \\
\hline No. $252[4]$ & Nathan W. Bass and others & Ashland coal field, Montana & $1923-24,1927-28$ \\
\hline No. $253[3]$ & Nathan W. Bass and others & Ashland coal field, Montana & $1923-24,1927-28$ \\
\hline No. 254 & Nathan W. Bass; George E. Manger & Ashland coal field, Montana & 1023-24. $1927-28$ \\
\hline No. $255[4]$ & Nathan W. Bass and others & Ashland coal field, Montana & $1923-24,1927-28$ \\
\hline No. 256 & Nathan W. Bass; N. F. Stull & Ashland coal field, Montana & $1923-24,1927-28$ \\
\hline No. 257 & Nathan W. Bass; H. C. Tan & Ashland coal field, Montana & $1923-24,1927-28$ \\
\hline No. 292 & Nathan W. Bass; Arthur A. Baker & Geology and mineral fuels, Colorado / Utah / Wyoming & $1918-54$ \\
\hline No. 293 [2] & Nathan W. Bass & Geology and mineral fuels, Colorado / Utah / Wyoming & $1918-54$ \\
\hline No. 294 & Nathan W. Bass & Geology and mineral fuels, Colorado / Utah / Wyoming & $1918-54$ \\
\hline No. 295 & Nathan W. Bass & Geology and mineral fuels, Colorado / Utah / Wyoming & $1918-54$ \\
\hline No. $296[2]$ & Nathan W. Bass & Geology and mineral fuels, Colorado / Utah / Wyoming & $1918-54$ \\
\hline No. 297 [2] & Nathan W. Bass & Geology and mineral fuels, Colorado / Utah / Wyoming & $1918-54$ \\
\hline No. 298 & Nathan W. Bass & Geology and mineral fuels, Colorado / Utah / Wyoming & $1918-54$ \\
\hline No. 299 & Nathan W. Bass & Geology and mineral fuels, Colorado / Utah / Wyoming & $1918-54$ \\
\hline No. 300 & Nathan W. Bass & Geology and mineral fuels, Colorado / Utah / Wyoming & $1918-54$ \\
\hline No. 301 & Nathan W. Bass & Geology and mineral fuels, Colorado / Utah / Wyoming & $1918-54$ \\
\hline No. 302 & Nathan W. Bass & Geology and mineral fuels, Colorado / Utah / Wyoming & $1918-54$ \\
\hline No. 303 & Nathan W. Bass; Frank D. Spencer & Geology and mineral fuels, Colorado / Utah / Wyoming & $1918-54$ \\
\hline No. 304 [2] & Nathan W. Bass; Arthur A. Baker & Geology and mineral fuels, Colorado / Utah / Wyoming & $1918-54$ \\
\hline
\end{tabular}


No. 305 [4] Nathan W. Bass; M. R. Campbell

Franklin T. McCann; Lloyd Pierce

No. 308 [2] Nathan W. Bass; M. R. Campbell

No. $309 \quad$ Nathan W. Bass; M. R. Campbell;

Dean E. Winchester

No. 310 Nathan W. Bass; M. R. Campbell

No. 311

No. 312 [4]

No. 313

No. 314

No. 315

No. 316 [2]

No. $317[2]$

No. 318 [3]

No. 319

No. 320

No. $321[2]$

No. 322 [2]

No. 367 [3]

No. 368

No. 369

No. 370

No. 371

No. 372 [5]

No. 421

No. 422

No. 423

No. 424 [2]

No. 425

No. 442

Nathan W. Bass; M. R. Campbell

Nathan W. Bass; James B. Eby

Nathan W. Bass; James B. Eby; and others

Nathan W. Bass; J. B. Eby; Nels C. Beck

Nathan W. Bass and others

Nathan W. Bass and others

Nathan W. Bass; James B. Eby; N. C. Beck

Nathan W. Bass; James B. Eby; N. C. Beck

Nathan W. Bass; Kenneth K. Landers

Nathan W. Bass; Walter H. Newhouse;

James B. Eby

Nathan W. Bass; F. D. Spencer

Nathan W. Bass; F. D. Spencer

William W. Rubey

William W. Rubey

William W. Rubey

William W. Rubey

William W. Rubey

William W. Rubey; Carle Hamilton

Nathan W. Bass; F. D. Spencer

Nathan W. Bass; B. A. Elliott

Nathan W. Bass; B. A. Elliott

Nathan W. Bass

Nathan W. Bass

Wilmot H. Bradley; C. H. Dane

No. 443 [2] Wilmot H. Bradley; C. H. Dane; Julian D. Sears

No. 444

Wilmot H. Bradley; C. H. Dane

No. 477

No. 478

No. 479

No. 480 [3

No. 481

No. 482 [3]

No. 488

No. 978

No. 979

No. 980

No. 981

No. 982

No. 983

No. 984

No. 985

No. 986

No. 987

No. 988

No. 989

No. 990

No. 991

No. 992

No. 993

No. 994

No. 995

No. 996

No. 997

No. 998 [2]

No. 999 [2]

No. 1000[

No. 1001

Edwin B. Eckel; Arthur E. Granger

Edwin B. Ecke

Edwin B. Eckel; and others

John W. Huddle; Appleton J. Crowley;

Nathan W. Bass; and others

John W. Huddle; J. M. Gorman; Nathan W. Bass: and others

\section{T. Pierson}

Frederick L. Ransome; M. Gordon Gulley

Chester R. Longwell

William W. Rubey

William W. Rubey; Alec Stepanoff

William W. Rubey

William W. Rubey

William W. Rubey

William W. Rubey; Alec Stepanoff

William W. Rubey

William W. Rubey

William W. Rubey

William W. Rubey; Chester R. Longwell

William W. Rubey

William W. Rubey; Chester R. Longwell

William W. Rubey

William W. Rubey; Chester R. Longwel

William W. Rubey; Milton N. Bramlette

William W. Rubey

William W. Rubey; and others

William W. Rubey; Harold W. Hoots;

Alec Stepanoff

William W. Rubey; Harold W. Hoots

William W. Rubey; and others

William W. Rubey; and others

William W. Rubey; and others

William W. Rubey; Chester R. Longwell; Alec Stepanoff

No. 1002 [2] William W. Rubey; Chester R. Longwell

No. 1003
William W. Rubey
Geology and mineral fuels, Colorado / Utah / Wyoming 1918-54 Geology and mineral fuels, Colorado / Utah / Wyoming 1918-54 Geology and mineral fuels, Colorado / Utah / Wyoming 1918-54 Geology and mineral fuels, Colorado / Utah / Wyoming 1918-54

Geology and mineral fuels, Colorado / Utah / Wyoming 1918-54 Geology and mineral fuels, Colorado / Utah / Wyoming 1918-54 Geology and mineral fuels, Colorado / Utah / Wyoming 1918-54 Geology and mineral fuels, Colorado / Utah / Wyoming 1918-54 Geology and mineral fuels, Colorado / Utah / Wyoming 1918-54 Geology and mineral fuels, Colorado / Utah / Wyoming 1918-54 Geology and mineral fuels, Colorado / Utah / Wyoming 1918-54 Geology and mineral fuels, Colorado / Utah / Wyoming 1918-54 Geology and mineral fuels, Colorado / Utah / Wyoming 1918-54 Geology and mineral fuels, Colorado / Utah / Wyoming 1918-54 Geology and mineral fuels, Colorado / Utah / Wyoming 1918-54

Geology and mineral fuels, Colorado / Utah / Wyoming 1918-54 Geology and mineral fuels, Colorado / Utah / Wyoming 1918-54 Geology and mineral fuels, Colorado / Utah / Wyoming 1918-54 Pershing oil and gas fields, Oklahoma 1918-21 Pershing oil and gas fields, Oklahoma 1918-21 Pershing oil and gas fields, Oklahoma 1918-21 Pershing oil and gas fields, Oklahoma 1918-21 Pershing oil and gas fields, Oklahoma $1918-21$ Pershing oil and gas fields, Oklahoma 1918-21

Geology and mineral fuels, Colorado / Utah / Wyoming 1918-54 Geology and mineral fuels, Colorado / Utah / Wyoming 1918-54 Geology and mineral fuels, Colorado / Utah / Wyoming 1918-54 Geology and mineral fuels, Colorado / Utah / Wyoming 1918-54 Geology and mineral fuels, Colorado / Utah / Wyoming 1918-54 Sweetwater County and other areas, Wyoming / Colorado

Sweetwater County and other areas, Wyoming / Colorado

Sweetwater County and other areas, Wyoming / Colorado

Quicksilver deposits, California

California

Quicksilver deposits, California

1923

1923

$1936,1939-40$

n.d.

$1936,1939-40$

Duchesne, Uintah and Wasatch, Utah

$1945-47,1949$

Duchesne, Uintah and Wasatch, Utah

1945-47, 1949

Reconnaissance for radioactivity, San Juan Mountains, Colorado

Oatman Gold District, Arizona

Black Hills Rim Project

Black Hills Rim Project

Black Hills Rim Project

Black Hills Rim Project

Black Hills Rim Project

Black Hills Rim Project

Black Hills Rim Project

Black Hills Rim Project

Black Hills Rim Project

Black Hills Rim Project

Black Hills Rim Project

Black Hills Rim Project

Black Hills Rim Project

Black Hills Rim Project

Black Hills Rim Project

Black Hills Rim Project

Black Hills Rim Project

Black Hills Rim Project

n.d.

1921-26

1921-26

1921-26

1921-26

1921-26

1921-26

1921-26

1921-26

1921-26

1921-26

1921-26

1921-26

1921-26

1921-26

1921-26

1921-26

1921-26

Black Hills Rim Project

1921-26

1921-26

1921-26

1921-26

1921-26

Bim Project

1921-26

1921-26

Black Hills Rim Project

Black Hills Rim Project

1921-26 
No. 1004 [2] William W. Rubey; Harold W. Hoots; Alec Stepanoff

No. 1005 William W. Rubey

No. 1006 William W. Rubey; Harold W. Hoots

No. 1007 [2] William W. Rubey; and others

No. 1008 [2] William W. Rubey; and others

No. 1009 [3] William W. Rubey; Harold W. Hoots; Alec Stepanoff

No. 1010 [2] William W. Rubey; Chester R. Longwell; Alec Stepanoff

No. 1011 [2] William W. Rubey; Milton N. Bramlette

No. 1012 [2] William W. Rubey; Milton N. Bramlette; Frank A. Melton

No. 1013 William W. Rubey

No.1014 [6] William W. Rubey

No. 1097 Nathan W. Bass; Harley F. Barnes

No. 1098 [2] Nathan W. Bass

No. 1099 [2] Nathan W. Bass

No. 1100 Nathan W. Bass

No. 1101 [2] Nathan W. Bass

No. 1102 Nathan W. Bass

No. 1103 Nathan W. Bass

No. $1104 \quad$ Nathan W. Bass

No. 1105 Nathan W. Bass

No. 1106 Nathan W. Bass

No. 1107 Nathan W. Bass

No. 1108 Nathan W. Bass

No. 1109 Nathan W. Bass

No. 1110 [2] Nathan W. Bass

No. 1111 Nathan W. Bass

No. 1112 [2] Nathan W. Bass; John C. Benson

No. 1113 Nathan W. Bass; Frank G. Cooley

No. 1114 [2] Nathan W. Bass; Stuart A. Northrop

No. 1115 Nathan W. Bass; Stuart A. Northrop

No. 1116 Nathan W. Bass; Stuart A. Northrop

No. 1117 Nathan W. Bass; Stuart A. Northrop

No. 1118 Nathan W. Bass; Raymond C. Robeck;

James K. Weaver

No. 1119 Nathan W. Bass; Raymond C. Robeck

No. 1120 Nathan W. Bass; Raymond C. Robeck

No. 1121 Nathan W. Bass; Frank D. Spencer

No. 1122 Nathan W. Bass; Peter M. Thompson

No. 1123 Nathan W. Bass; James D. Vine

No. 1124 Nathan W. Bass; James D. Vine

No. 1125 Nathan W. Bass; James D. Vine

No. 1126 Nathan W. Bass; James K. Weaver

No. 1127 Nathan W. Bass; James K. Weaver

No. 1128 [4] Nathan W. Bass; and others

No. 1129 [2] Nathan W. Bass

No. 1145 Irving J. Witkind; Julian D. Sears

No. 1346 [2] William W. Rubey; Nathan W. Bass; John B. Reeside, Jr.

No. 1347 William W. Rubey; Milton N. Bramlette

No. 1348 [2] William W. Rubey; Nathan W. Bass

No. 1349 William W. Rubey

No. 1350 [3] Nathan W. Bass

No. 1351 [3] Nathan W. Bass

No. 1353 [11] Nathan W. Bass

No. 1354 [3] Nathan W. Bass

No. 1355 [3] Nathan W. Bass

No. 1356 [3] Nathan W. Bass

No. 1357 [4] Nathan W. Bass

No. 1358 Nathna W. Bass

No. 1359 Nathan W. Bass

No. 1360 Nathan W. Bass

No. 1361 [2] Nathan W. Bass; John B. Reeside

No. 1382 Nathan W. Bass

No. 1384 Nathan W. Bass

No. 1385 Nathan W. Bass

No. 1386 [5] Nathan W. Bass; Frank D. Spencer

No. 1387 [4] Nathan W. Bass

No. 1388 [5] Nathan W. Bass

No. 1389 [8] Nathan W. Bass
Black Hills Rim Project

Black Hills Rim Project

Black Hills Rim Project

Black Hills Rim Project

Black Hills Rim Project

Black Hills Rim Project

Black Hills Rim Project

Black Hills Rim Project

Black Hills Rim Project

Black Hills Rim Project

Black Hills Rim Project

Glenwood Springs, Colorado

Glenwood Springs, Colorado

Glenwood Springs, Colorado

Glenwood Springs, Colorado

Glenwood Springs, Colorado

Glenwood Springs, Colorado

Glenwood Springs, Colorado

Glenwood Springs, Colorado

Glenwood Springs, Colorado

Glenwood Springs, Colorado

Glenwood Springs, Colorado

Glenwood Springs, Colorado

Glenwood Springs, Colorado

Glenwood Springs, Colorado

Glenwood Springs, Colorado

Glenwood Springs, Colorado

Glenwood Springs, Colorado

Glenwood Springs, Colorado

Glenwood Springs, Colorado

Glenwood Springs, Colorado

Glenwood Springs, Colorado

Glenwood Springs, Colorado

Glenwood Springs, Colorado

Glenwood Springs, Colorado

Glenwood Springs, Colorado

Glenwood Springs, Colorado

Glenwood Springs, Colorado

Glenwood Springs, Colorado

Glenwood Springs, Colorado

Glenwood Springs, Colorado

Glenwood Springs, Colorado

Glenwood Springs, Colorado

Glenwood Springs, Colorado

Abajo (Blue) Mountains, Utah

1921-26

1921-26

1921-26

1921-26

1921-26

1921-26

1921-26

1921-26

1921-26

1921-26

1921-26

$1945,1947-54$

$1945,1947-54$

$1945,1947-54$

1945, 1947-54

$1945,1947-54$

$1945,1947-54$

$1945,1947-54$

1945, 1947-54

$1945,1947-54$

$1945,1947-54$

$1945,1947-54$

$1945,1947-54$

$1945,1947-54$

1945, 1947-54

1945, 1947-54

$1945,1947-54$

1945, 1947-54

1945, 1947-54

$1945,1947-54$

$1945,1947-54$

1945, 1947-54

1945, 1947-54

$1945,1947-54$

1945, 1947-54

1945, 1947-54

$1945,1947-54$

1945, 1947-54

1945, 1947-54

$1945,1947-54$

$1945,1947-54$

$1945,1947-54$

1945, 1947-54

1945, 1947-54

1950-56

Oil and gas resources in vicinity of Russell County, Kansas

Oil and gas resources in vicinity of Russell County, Kansas

1924

Oil and gas resources in vicinity of Russell County, Kansas

1924

1924

Oil and gas resources in vicinity of Russell County, Kansas

Cowley County and vicinity, Kansas

1924

1926

1926

n.d.

1924-25

$1924-25$

1924-25

1924-25

$1924-25$

$1924-25$

$1924-25$

$1924-25$

Central and western Kansas

Central and western Kansas

Geology and mineral fuels, Colorado / Utah / Wyoming 1918-54

Geology and mineral fuels, Colorado / Utah / Wyoming 1918-54

Geology and mineral fuels, Colorado / Utah / Wyoming 1918-54

Geology and mineral fuels, Colorado / Utah / Wyoming 1918-54

Geology and mineral fuels, Colorado / Utah / Wyoming 1918-54

Geology and mineral fuels, Colorado / Utah / Wyoming 1918-54

Geology and mineral fuels, Colorado / Utah / Wyoming 1918-54 
No. 1425 [3] Edwin B. Eckel; and others

No. 1426 [2] Edwin B. Eckel; and others

No. 1427 [2] Edwin B. Eckel; and others

No. 1428 [2] Edwin B. Eckel; and others

No. 1429 Edwin B. Eckel

No. 1430 [2] Edwin B. Eckel; and others

No. 1431 Edwin B. Eckel; F. W. Galbraith III; Arthur C. Spenser

No. 1432 [5] Edwin B. Ecke

No. 1433 [4] Edwin B. Eckel

No. 1434 [2] Edwin B. Eckel

No. $1503 \quad$ Edwin B. Eckel

No. $1520 \quad$ Edwin B. Eckel

No. $1521 \quad$ Edwin B. Eckel

No. 1522 Edwin B. Eckel;

No. 1523 [5] Edwin B. Eckel

No. 1543 [2] William W. Rubey; John R. Ball

No. 1544 [2] William W. Rubey

No. 1545 [2] William W. Rubey

No. 1546 William W. Rubey

No. 1547 [2] William W. Rubey

No. 1548 [2] William W. Rubey

No. 1549 [2] William W. Rubey; John R. Ball

No. 1550 [2] William W. Rubey; John R. Ball

No. 1551 [3] William W. Rubey; John R. Ball

No. 1762 [5] Irving J. Witkind; and others

No. 1763 [4] Irving J. Witkind; and others

No. 1764 [7] Irving J. Witkind; and others

No. 1979 [2] Nathan W. Bass; Stuart A. Northrop

No. 1980 [2] Wilmot H. Bradley

No. 1981 Wilmot H. Bradley

No. 1982 [2] Wilmot H. Bradley

No. 1983 Wilmot H. Bradley

No. 1984 Wilmot H. Bradley; Howard R. Gould

No. 1985 Wilmot H. Bradley; Howard R. Gould

No. 1986 Wilmot H. Bradley; Howard R. Gould

No. 1987

No. 1988

No. 1989

No. 1990

No. 1991

No. 1992 [2]

No. 1993

Wilmot H. Bradley

Wilmot H. Bradley

Wilmot H. Bradley; Peter Cooke

Wilmot H. Bradley

No. 1994 [4] Wilmot H. Bradley; A. B. Bassett;

William H. Condon

No. 1995 [2] Wilmot H. Bradley

No. 1996 [4] Wilmot H. Bradley; Howard R. Gould; Peter Cooke

No. 1997 [4] Wilmot H. Bradley; Peter Cooke

No. 2064 [2] Eleanora Bliss Knopf; James F. Bell

No. 2065 [2] Eleanora Bliss Knopf; Adolph Knopf

No. 2066 [2] Eleanora Bliss Knopf; and others

No. 2067 [2] Eleanora Bliss Knopf; Adolph Knopf

No. 2068 [2] Eleanora Bliss Knopf; Adolph Knopf

No. 2069 [2] Eleanora Bliss Knopf; G. V. Carroll; Adolph Knopf

No. 2070 [3] Eleanora Bliss Knopf; and others

No. 2071 [3] Eleanora Bliss Knopf; and others

No. 2086 Wilmot H. Bradley

No. 2087 [3] Wilmot H. Bradley; Frank S. Parker

No. 2343 Robert P. Bryson

No. $2784 \quad$ Nathan W. Bass

No. 2791 [3] Nathan W. Bass; C. E. Straub

No. 2792 [2] Nathan W. Bass

No. 2793 [2] Nathan W. Bass

No. 2794 [3] Nathan W. Bass; H. O. Woodbury

No. 2795 [2] Nathan W. Bass

No. 2796 Nathan W. Bass

No. 2797 [2] Nathan W. Bass

No. 2798 [2] Nathan W. Bass

No. 2803 [4] Nathan W. Bass

No. 2804 Nathan W. Bass

No. 2805 Nathan W. Bass

No. $2806 \quad$ Nathan W. Bass

No. $2807 \quad$ Nathan W. Bass
Geology and ore deposits of the La Plata District, Colo. 1935-37 Geology and ore deposits of the La Plata District, Colo. 1935-37 Geology and ore deposits of the La Plata District, Colo. 1935-37 Geology and ore deposits of the La Plata District, Colo. 1935-37 Geology and ore deposits of the La Plata District, Colo. 1935-37 Geology and ore deposits of the La Plata District, Colo. n.d.

Geology and ore deposits of the La Plata District, Colo. 1935-37 Geology and ore deposits of the La Plata District, Colo. 1935-37 Geology and ore deposits of the La Plata District, Colo. 1935-37 Geology and ore deposits of the La Plata District, Colo. 1935-37 California

Paraguay

Paraguay

Paraguay

Paraguay

Hardin and Brussels, Illinois

Hardin and Brussels, Illinois

Hardin and Brussels, Illinois

Hardin and Brussels, Illinois

Hardin and Brussels, Illinois

Hardin and Brussels, Illinois

Hardin and Brussels, Illinois

Hardin and Brussels, Illinois

Hardin and Brussels, Illinois

n.d.

1952

1952

1952

1952

1928-29

1928-29

1928-29

1928-29

$1928-29$

1928-29

1928-29

1928-29

1928-29

Geology and uranium-vanadium deposits, Arizona/ Utah 1951-55

Geology and uranium-vanadium deposits, Arizona/ Utah 1951-55

Geology and uranium-vanadium deposits, Arizona/ Utah 1951-55

Glenwood Springs, Colorado

$1945,1947-54$

Ecologic features of the Sagadahoe Bay tidal flat, Maine 1949-55

Ecologic features of the Sagadahoe Bay tidal flat, Maine 1949-55

Ecologic features of the Sagadahoe Bay tidal flat, Maine 1949-55

Ecologic features of the Sagadahoe Bay tidal flat, Maine 1949-55

Ecologic features of the Sagadahoe Bay tidal flat, Maine 1949-55

Ecologic features of the Sagadahoe Bay tidal flat, Maine 1949-55

Ecologic features of the Sagadahoe Bay tidal flat, Maine 1949-55

Ecologic features of the Sagadahoe Bay tidal flat, Maine 1949-55

Ecologic features of the Sagadahoe Bay tidal flat, Maine 1949-55

Ecologic features of the Sagadahoe Bay tidal flat, Maine 1949-55

Ecologic features of the Sagadahoe Bay tidal flat, Maine 1949-55

Ecologic features of the Sagadahoe Bay tidal flat, Maine 1949-55

Ecologic features of the Sagadahoe Bay tidal flat, Maine 1949-55

Ecologic features of the Sagadahoe Bay tidal flat, Maine 1949-55

Ecologic features of the Sagadahoe Bay tidal flat, Maine 1949-55 Ecologic features of the Sagadahoe Bay tidal flat, Maine 1949-55

Ecologic features of the Sagadahoe Bay tidal flat, Maine 1949-55 Ecologic features of the Sagadahoe Bay tidal flat, Maine 1949-55 Stissing Mountain and eastern New York 1925-54 Stissing Mountain and eastern New York 1925-54 Stissing Mountain and eastern New York 1925-54 Stissing Mountain and eastern New York 1925-54 Stissing Mountain and eastern New York 1927-33

Stissing Mountain and eastern New York 1925-54 Stissing Mountain and eastern New York 1925-54 Stissing Mountain and eastern New York 1927-33 Washakie Basin, Colorado / Wyoming 1933

Washakie Basin, Colorado / Wyoming 1933

Moorhead coal field, Montana 1940-63

Cowley County, Kansas

Los Animos County, Colo.

Model anticline, Colorado / Utah / Texas / New Mexico / Oklahoma / Kansas 1941-43

Model anticline, Colorado / Oklahoma / Texas / Utah / Kansas

Los Animos County, Colorado

$1941-43$

Model anticline, Colorado / Kansas / Utah /New Mexico 1941-43

Model anticline, Colorado / New Mexico 1941-43

Model anticline, Colorado 1941-43

Geology and mineral fuels, Colorado / Utah / Wyoming 1918-54

Crude oils and stratigraphy, Kansas / Oklahoma 1945-46, 1948

Geology and mineral fuels, Colorado / Utah/ Wyoming 1918-54

Geology and mineral fuels, Colorado / Utah / Wyoming 1918-54

Oil field areas of the Denver Basin, Colorado / Nebraska 1951, 1954-57

Oil field areas of the Denver Basin, Colorado / Nebraska 1951, 1954-57 
$\begin{array}{ll}\text { No. 2808 } & \text { Nathan W. Bass } \\ \text { No. 2809 } & \text { Nathan W. Bass } \\ \text { No. 2810 } & \text { Nathan W. Bass } \\ \text { No. 2811 } & \text { Nathan W. Bass } \\ \text { No. } 2812 & \text { Nathan W. Bass } \\ \text { No. 2813 [2] } & \text { Nathan W. Bass } \\ \text { No. 2814 [2] } & \text { Nathan W. Bass } \\ \text { No. 2815 } & \text { Nathan W. Bass } \\ \text { No. 2816 [2] } & \text { Nathan W. Bass; Edwin H. Ekburg }\end{array}$

$\begin{array}{ll}\text { No. 2817 } & \text { Nathan W. Bass } \\ \text { No. 2818 } & \text { Nathan W. Bass } \\ \text { No. 2819 } & \text { Nathan W. Bass } \\ \text { No. 2820 } & \text { Nathan W. Bass } \\ \text { No. 2821 } & \text { Nathan W. Bass } \\ \text { No. 2822 } & \text { Nathan W. Bass } \\ \text { No. 2823 [2] } & \text { Nathan W. Bass } \\ \text { No. 2845 } & \text { Nathan W. Bass } \\ \text { No. 2846 [2] } & \text { Nathan W. Bass } \\ \text { No. 2847 [2] } & \text { Nathan W. Bass }\end{array}$

No. 2948 [3] Nathan W. Bass; Joseph L. Borden No. 2849 [2] Nathan W. Bass

No. 2850 [2] Nathan W. Bass

No. 2851 [3] Nathan W. Bass; R. V. Henderson

No. 2852 Nathan W. Bass

No. 2853 [5] Nathan W. Bass; Harold D. Jenkins

No. 2854 Nathan W. Bass

No. 2855 Nathan W. Bass

No. 2856 Nathan W. Bass

No. 2857 Nathan W. Bass

No. 2858 Natnan W. Bass

No. 2859 Nathan W. Bass

No. $2860 \quad$ Nathan W. Bass

No. 3586 Donnel F. Hewett; William W. Rubey

No. 3587 Donnel F. Hewett; William W. Rubey

No. $3609 \quad$ Edwin T. McKnight; Edwin B. Eckel

No. $3610 \quad$ Edwin T. McKnight; Edwin B. Eckel

No. $3611 \quad$ Edwin T. McKnight; Edwin B. Eckel

No. 3697 William W. Rubey; Frank A. Melton

No. 3698 [5] William W. Rubey

No. 3699 [9] William W. Rubey; Alec Stepanoff

No. 4296 [2] Eleanora Bliss Knopf; and others

No. 5611 [3] William W. Rubey; S. S. Oriel

No. 5612 [2] William W. Rubey; J. I. Tracey, Jr.

No. 5613 [2] William W. Rubey; J. I. Tracey, Jr.

No. 5614 William W. Rubey; J. I. Tracey, Jr.

No. 5615 William W. Rubey; J. I. Tracey, Jr.

No. 5616-1 William W. Rubey; S. S. Oriel;

J. I. Tracey, Jr.; J. H. Bowie

No. 5616-2 William W. Rubey; J. I. Tracey, Jr.
Oil field areas of the Denver Basin, Colorado / Nebraska 1951, 1954-57 Oil field areas of the Denver Basin, Colorado / Nebraska 1951, 1954-57

Oil field areas of the Denver Basin, Colorado / Nebraska 1951, 1954-57

Oil field areas of the Denver Basin, Colorado / Nebraska 1951, 1954-57

Correlation of basal Permian and older rocks,

Utah / Colorado/ Arizona / New Mexico 1942-44

Correlation of basal Permian and older rocks, Colorado / New Mexico / Arizona / Utah 1942-44

Correlation of basal Permian and older rocks, Colorado / New Mexico / Arizona / Utah 1942-44

Correlation of basal Permian and older rocks, Colorado / New Mexico / Utah / Arizona 1942-44

Correlation of basal Permian and older rocks, Colorado / New Mexico / Utah / Arizona 1942-44

Correlation of basal Permian and older rocks, Arizona / Colorado/ Texas

Correlation of basal Permian and older rocks, Utah / New Mexico / Arizona / Colorado 1942-4

Correlation of basal Permian and older rocks, Colorado / New Mexico / Oklahoma

Correlation of basal Permian and older rocks, Colorado / Arizona / Utah

Correlation of basal Permian and older rocks, Utah / Arizona

various

1936

1929-32

Bartlesville shoestring sands, Kansas

Bartlesville shoestring sands, Kansas / Missouri / Colorado / New Mexico

Bartlesville shoestring sands, Kansas

Bartlesville shoestring sands, Kansas / Oklahoma

Bartlesville shoestring sands, Kansas / Oklahoma

Bartlesville shoestring sands, Kansas

Bartlesville shoestring sands, Kansas

Bartlesville shoestring sands, Oklahoma

Bartlesville shoestring sands, Kansas

Bartlesville shoestring sands, Kansas / Oklahoma

Bartlesville shoestring sands, Oklahoma / Atlantic Beaches

$1934-41$

1934-41

Bartlesville shoestring sands, Oklahoma 1934-41

Bartlesville shoestring sands, Oklahoma 1934-41

Bartlesville shoestring sands, Oklahoma 1934-41

Mineral resources around Boulder Dam, Nevada 1934

Mineral resources around Boulder Dam, Nevada 1934

Rico mining district, Colorado $\quad 1930-69$

Rico mining district, Colorado 1930-69

Rico mining district, Colorado 1930-69

Black Hills Rim Project, oil and gas possibilities $\quad$ 1921-26

Black Hills Rim Project, oil and gas possibilities 1921-26

Black Hills Rim Project, oil and gas possibilities 1921-26

McCalls Ferry District, Pennsylvania 1915-21

Sage and Kemmerer, Wyoming 1955-59

Sage and Kemmerer, Wyoming 1955

Sage and Kemmerer, Wyoming $1955-59$

Sage and Kemmerer, Wyoming $1955-59$

Sage and Kemmerer, Wyoming 1955-59

Sage and Kemmerer, Wyoming 1961

Sage and Kemmerer, Wyoming 1964 


\section{Appendix 13}

Geologic Division - Photographic Prints depicting Geological Formations and Features, ca. 1893-1906 (entry 204)

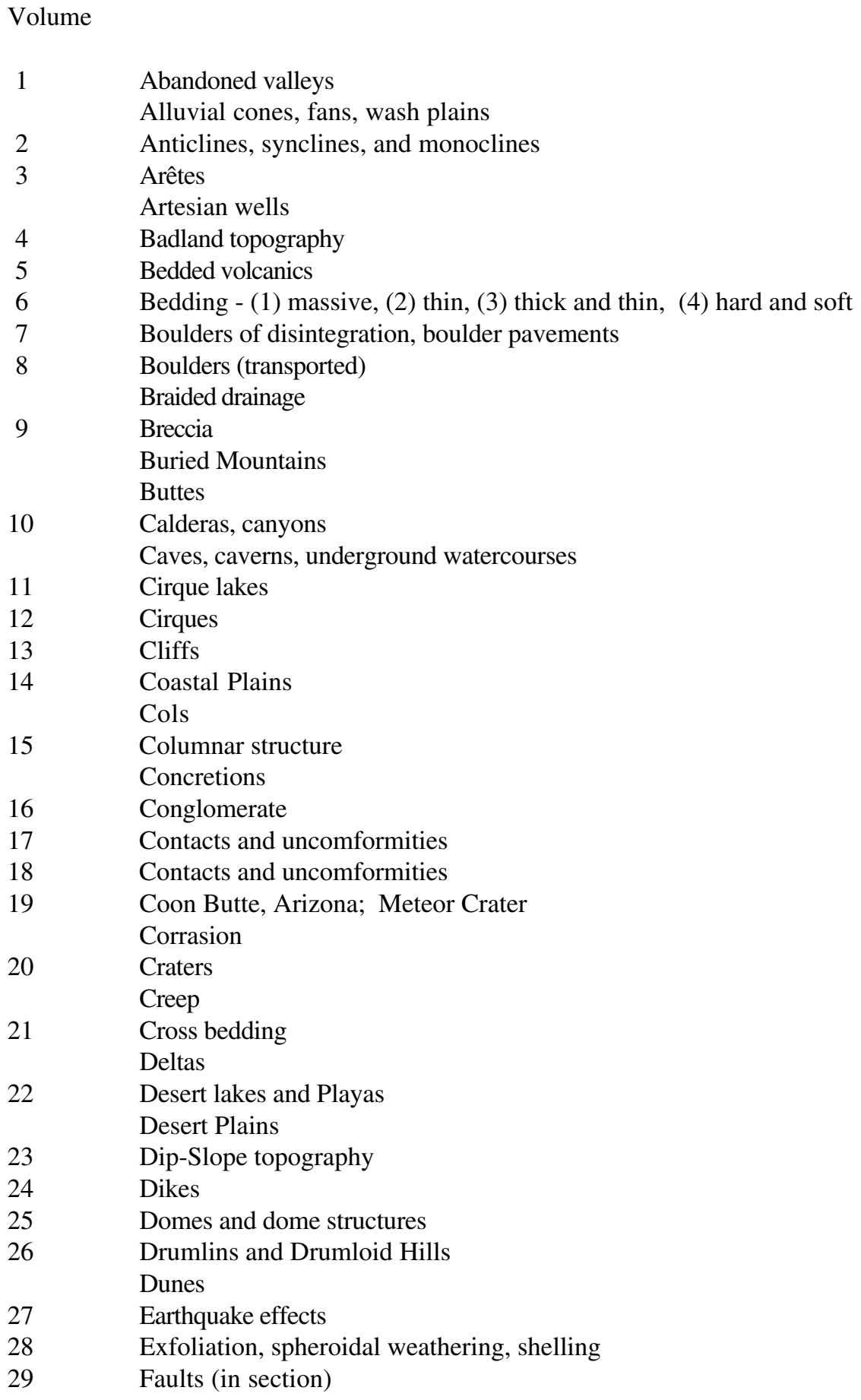


Fault topography

Fault-zone structures

Filled valleys

Fiords and fiord lakes

Flood plains

Floods and flood effects

Folding (experiments with)

Forelands and foreland islets

Fossils

Fossils

Geysers, hot springs, "Mud volcanos"

Geysers, hot springs, "Mud volcanos"

Glacial outwash

Glacial polish, striae, grooves, "chatter marks"

Glacier drainage

Glaciated valleys (Pleistocene): U-form, V-form

Glaciated valleys: wide-open, terraced, deep at head

Glaciated valleys: with meadow bottom, with chain lakes

Glaciated valleys: with fiord lakes, asymmetric cross-profiles, sap-line, contrasted floors and walls

Glaciated valleys: hanging

Glaciers : the glacier head, the glacier stream

Glaciers: the glacier foot

Glaciers: the glacier foot, cascading, hanging

Glaciers: glacier structures - banding, flexures, fractures, ablation effects

Grand Canyon

Gravel

Ground moraines

Ground water lakes

51 Hanging valleys (non-glacial)

Hogbacks, "Stonewalls"

52

Horizontal bedding

$53 \quad$ Horizontal sky lines

Hot-spring deposits (including geyser deposits)

Hot-spring deposits (including geyser deposits)

Icebergs, slush-ice, work of shore ice

Immature topography

$56 \quad$ Islands

$57 \quad$ Joints

58 Kames, eskers, osars, kettle moraines

Loccolithic mountains

Lakes (non-glacial)

59

Landslides, rockslides

60 Lava flows, and surface features

61 Lenses, "lentils" in sedimentary rocks

Lenses, in igneous rocks

Loess, "marl-loess"

Mammillary topography, mamelon hills

Meandering streams

63 Mines and mining: Alabama, Alaska

64 Mines and mining: Alaska

65 Mines and mining: Alaska 
Mines and mining: Alaska, Arizona, Arkansas

Mines and mining: California

Mines and mining: Colorado

Mines and mining: Connecticut, Georgia, Idaho, Indiana, Kansas, Kentucky, Michigan, Missouri, Montana, Nevada

Mines and mining: New Mexico, New York, North Carolina, Oregon, Pennsylvania, South Dakota, Tennessee

Mines and mining: Texas, Utah, Virginia, Washington, West Virginia, Wisconsin, Wyoming, Belgium, British Columbia, France, Germany, Unidentified

Moraines

Mountain fronts

Mountain parks

Mud cracks, sun cracks

Mud flows, mud streams, mud runs

Natural bridges

Névé

Niagara Falls (falls, rapids, gorge)

Northwest Boundary Monuments

Nunataks

Organic agencies in erosion

Peaks

Peaks

Peaks

Peneplains

Perched blocks (of differential weathering)

Pinnacle topography

Planation

Plateaus, mesas

Plication, crumbing, contortion

Plication, crumbing, contortion

Plucking

Post glacial erosion

Pot holes

Quarries

Rain erosion

Rifts, rift valleys

Ripple marks

Rivers

Roches moutonnées

Rock basins

Rock streams

Rock textures (including thin sections)

Shore-ice work

Shore topography

Shore topography

Sills, intrusive sheets

Slaty cleavage, stretching, crushing, flow, foliation, banding, schistosity

Slaty cleavage, stretching, crushing, flow, foliation, banding, schistosity

Sink holes

Snow-line

Snow-slide effects 


$\begin{array}{ll}96 & \text { Springs } \\ 97 & \text { Steams, valleys, canyons } \\ 98 & \text { Streams, valleys, canyons } \\ 99 & \text { Structure, control in erosion } \\ & \text { Subsisdence topography } \\ & \text { Sub-summit plateaus, shoulders, and terraces in glaciated mountains } \\ 100 & \text { Swamps } \\ & \text { Tabular residuals of mountain peneplains } \\ & \text { Talus } \\ & \text { Tepee buttes } \\ 101 & \text { Terraces: marine, lacustrine } \\ 102 & \text { Terraces: fluviatile, glacial, hot-spring, structural } \\ 103 & \text { Till } \\ & \text { Tufa (lacustrine deposits) } \\ 104 & \text { Veins } \\ 105 & \text { Volcanic ash } \\ & \text { Volcanic eruptions } \\ & \text { Volcanic necks, plugs, stocks, cores } \\ 106 & \text { Volcanos, cinder cones, lava cones } \\ 107 & \text { Waterfalls and cascades } \\ 108 & \text { Waterfalls and cascades } \\ 109 & \text { Waterfalls and cascades } \\ 110 & \text { Weather breccia (mantle rock, regolith) } \\ & \text { Weathering } \\ 111 & \text { Weathering } \\ 112 & \text { Weathering } \\ & \text { Yellowstone Falls }\end{array}$




\section{Appendix 14}

Paleontology and Stratigraphy Branch - Office Files of Josiah Bridge, 1922-53 (entry 209)

A, Miscellaneous, 1934-42

Acknowledgments, Eminence and Cardareva Quadrangles, 1931-32

A.I.M.M.E., 1948-52

B, Miscellaneous, 1930-44

B, General, 1944-53

Balk, Christina L., 1934-51

Barghoorn, Elso S., 1950-51

Barnes, Virgil, 1938-53 (2 files)

Ex-Bauxite Personnel, Personal Letters, 1945-46

Bauxite, Post War Plans, 1948

Bays, Carl A., 1935-40

Bell, W. Charles, 1944-50

Berdan, Jean, 1948-53

Berkey, Charles P., Project 149, 1934-35

Berkey, Charles P., Project 171, 1933-39

Berry, Edward M., 1933

Bevan, Arthur C., 1931-42

Bibliographies, Josiah Bridge, ca. 1937-50 (2 files)

Bibliographies and Notes for Lectures in Geology Courses, n.d.

Bills of Lading and Miscellaneous, ca, 1952

Biological Abstracts, ca, 1928-36

Bridge, Josiah, 1922-49

Bucher, Walter H., 1934-43

Buchler, H. A., 1930-41

Bucot, Arthur J., 1951-52

C, Miscellaneous, 1931-46

C, General, 1944-53

Cambrian Correlation Charts, ca. 1940-42

Campbell, E. Taylor, 1930-32

Catalogues, ca. 1926-40

Civil Service Examination Announcements, ca. 1936-42

Cloud, Preston E., 1931-52 (2 files)

Cloud, P. E., Ilano Uplift Project, 1943-46

Cooper, Bryon N., 1951-53

The Core Driller, ca. 1952

Cullison, James S., 1930-52 (4 files)

D, Miscellaneous, 1932-43

D, General, 1946-52

Decker, Charles E., 1931-52 (2 files)

Dott, Robert H., 1951

Dunbar, Carl O., 1932-44

Duncan, Helen, 1951-52

Dunlap, Jack C., 1944-48 
E, Miscellaneous, 1931-40

E, General, 1948-52

"Early Man, and His Culture in the New World," a partial bibliography, n.d.

F, Miscellaneous, 1932-46

F, General, 1946-51

Ferguson, Herman W., 1951-52

Fischer, Elizabeth C., 1943-49

Fisher, Donald W., 1949-51

Flower, Rousseau H., 1950-53

Folger, Anthony, 1945-47

Fowler, Laura J., 1932-40

G, Miscellaneous, 1930-42

G, General, 1945-53

Geologic Names Committee, 1930-53 (2 files)

Geological Society of America, 1935-48 (3 files)

Geological Society of America, Meetings, 1936-52 (4 files)

Geological Society of America, Nominations for membership, 1945-48

Geological Society of Washington, Constitution, n.d.

Geological Survey, Great Britain, 1931-37

Gilludy, James, 1937-51

Goldich, Sam S., 1945-53

Gould, Don B., 1930

Grave, Oliver R., 1930-39

Grohskopf, John G., 1948-51

Group Hospitalization, n.d.

H, Miscellaneous, 1931-42

H, General, 1945-52

Ham, William E., 1950-52

Heller, Robert L., 1947-49

Hoen and Company, A., 1930-31

Howell, Ben F., 1930-52 (2 files)

I, Miscellaneous, 1930-41

I, General, 1952

Illustrations, Professional Paper 186-M

International Geological Congress, 1931-33

J, Miscellaneous, 1931-42

J, General, 1948-52

Jones, Daniel J., 1951

K, Miscellaneous, 1930-43

K, General, 1937-53

Kansas Geological Society, 1935

Kay, G. Marshall, 1929-41

Kesler, Thomas L., 1949-52

King, Philip B., 1939-53

Knight, J. Brooks, 1931-39 
L, Miscellaneous, 1930-43

L, General, 1946-53

Ladd, Harry S., 1943-50

Laurence, Robert A., 1943-53

Lexicon of Stratigraphic Names Corrections [contents charged out in 1953]

Library, 1932-39

Lochman, Christina, 1930-44 (2 files)

Mc, Miscellaneous, 1931-39

Mc, General, 1951

McGerrigle, H. W., 1930-35

McQueen, H. S., 1930-42

M, Miscellaneous, 1931-44

M, General, 1946-53

Maher, Stuart W., 1951

Maine Project, 1941-42

Matthes, François E., 1930

Military Geology, 1945-47

Miller, Arthur K., 1929-42

Miser, Hugh D., 1930-52 (2 files)

Missouri Bureau of Geology and Mines, 1932

Monroe, Watson H., 1942

Moore, Raymond C., 1931-39

Muilenburg, Garrett A., 1930-52 (2 files)

N, Miscellaneous, 1931-42

N, General, 1949-53

National Research Council, ca. 1935

National Science Foundation, ca. 1952

O, Miscellaneous, 1935-40

O, General, 1952

Oder, Charles R. L., 1932-52

"Oil" Literature, n.d.

Olaf, Nylander, ca. 1941-42

P, Miscellaneous, 1931-43

P, General, 1944-52

Paleontological Research Institute, 1936

Paleontological Society, n.d.

Palmer, Allison R., 1950-52

Park, Charles F., 1945-52

Paulin Altimeter, ca. 1942-43

Pecora, William T., 1948-49

Personnel List, A-B, ca. 1945

Pick \& Hammer Club, 1948-50

Plummer, Fred B., 1932-41

Pond, Walter F., 1945-47 (2 files)

Princeton University, ca. 1942-48 
Q, Miscellaneous, 1935

Q, General, 1935-38

R, Miscellaneous, 1930-43

R, General, 1946-53

Raasch, Gilbert O., 1931-40

Read, Charles B., 1931-38

Reeside, John B., 1934-47 (2 files)

Reports on Collections, 1949

Reports on Fossils, ca. 1933

Reports of Eastern Regional Office, 1942-45 (2 files)

Rogers, John, 1940-52

Ruedemann, Rudolf, 1931-39

S, Miscellaneous, 1930-44

S, General, 1946-53

Sellards, E. H., 1931-37

Stauffer, Clinton R., 1931-38

Stose, George W. and Anna I. Jonas, 1930-36

Survey, Authorizations, Plans for field work etc., 1930-42

Survey, Director, Chief Geologist, 1932-42

Survey, Memorandums., 1925-43

Survey, Travel vouchers 1932-41

Symbols, Geologic, n.d.

T, Miscellaneous, 1930-38

T, General, 1945-53

Teaching Material, n.d.

Tennessee, Douglas Dam, ca. 1943

Tennessee, University of, Symposium, 1949

Thermal Analysis Unit, 1950-51

Trowbridge, Augustus, 1930-39

Trucks, Ford, 1934

Twenhofel, W. H., 1932-48 (2 files)

U, Miscellaneous, 1931-35

U, General, 1951-52

U.S.G.S., Bridge, J., Personal Papers (Administrative Items: field equipment, travel, etc.) (3 files)

U.S.G.S., Bridge, J., Personal Papers (Expenses \& Accounts) (3 files)

Ulrich Lectures at Columbia, ca. 1930-31

Ulrich, E. O., ca. 1932

U. S. National Museum, 1936-41

V, Miscellaneous, 1935

V, General, 1946-51

Vouchers

W, Miscellaneous, 1931-44

W, General, 1938-53

Whitcomb, Lawrence, 1931-40

White, Walter S., 1941-52 (2 files)

Woodward, Herbert P., 1951-52 


\section{Appendix 15}

Mineral Deposits Branch - General Administrative and Correspondence Files, 1909-53 (entry 219)

*Accretions to this series are shown at the end of this list.

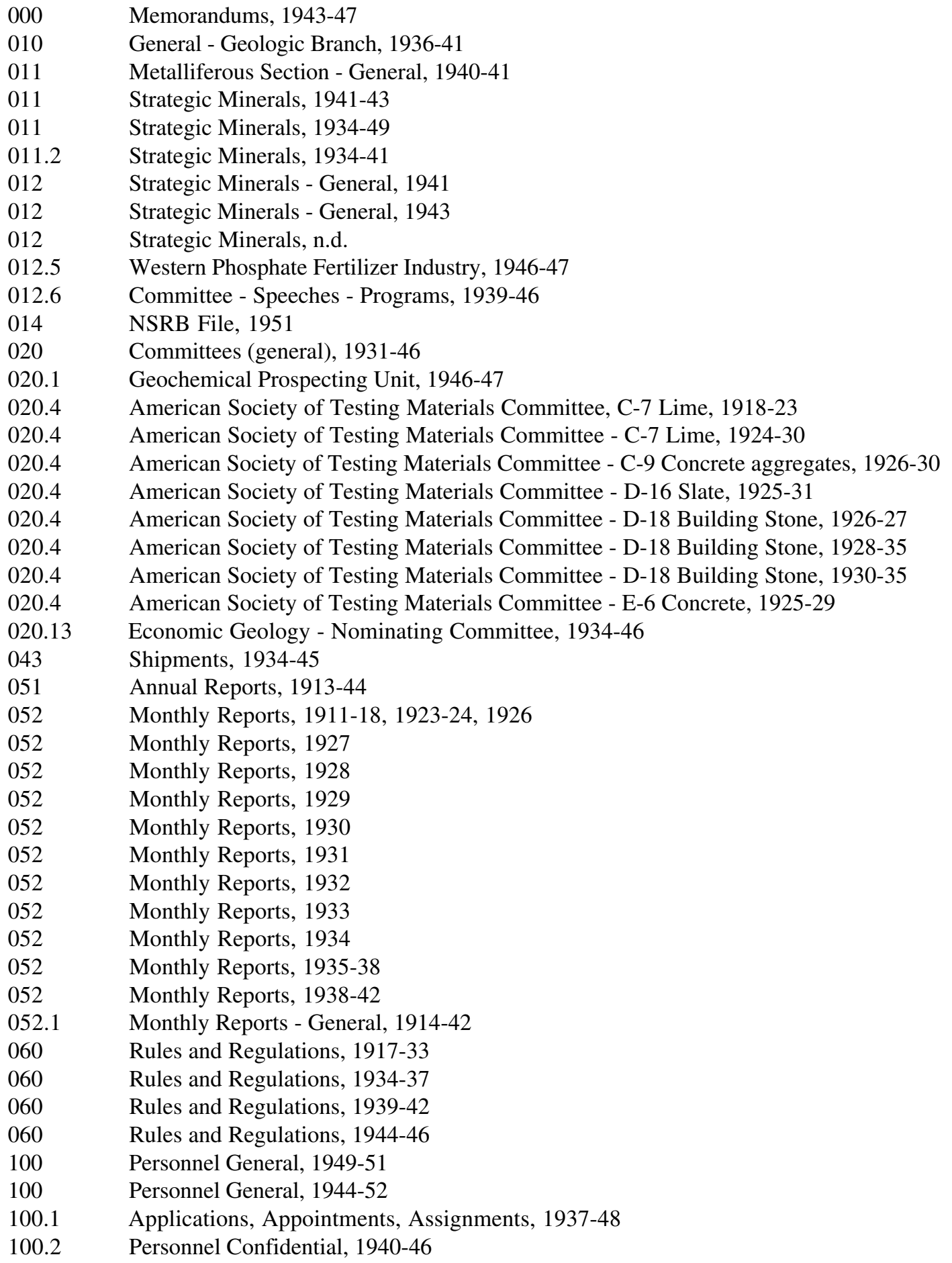




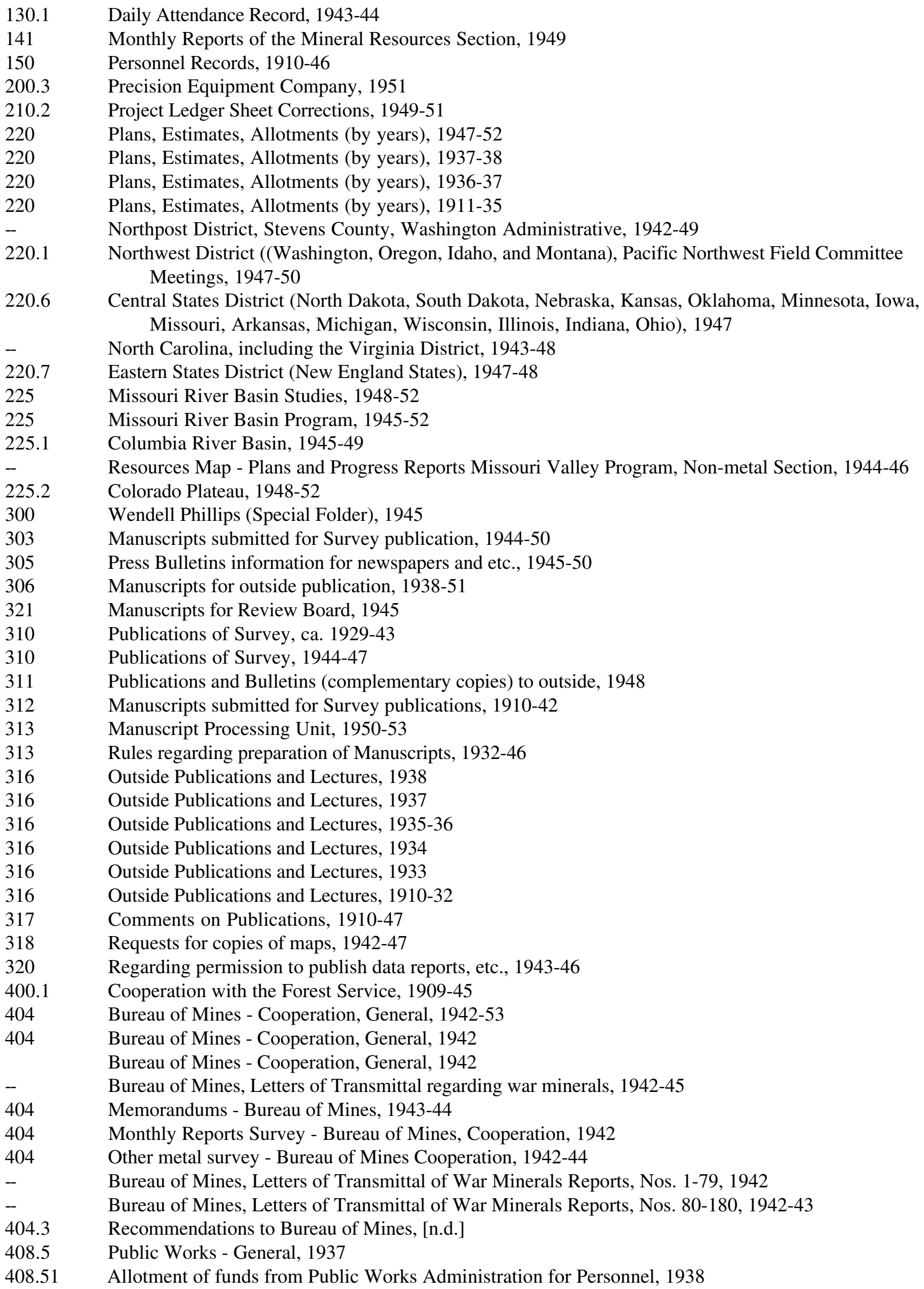


408.52 Public Works Administration Fund and projects, 1937-38

409 Cooperation of Survey on Bureau of Mines Projects, 1911-41

414.1 Memorandums for the Secretary, 1942-45

414.2 Interior - Bureau of Reclamation, 1934-53

414.7 Geologic Division (Field records), 1950-53

414.8 National Park Service, 1926-51

414.10 Office of Indian Affairs - Examinations, etc., 1913-53

414.62 Alaskan Branch, 1941-53

414.63 General Geology, 1950-53

414.65 Trace Elements, 1949-52

414.66 Conservation Branch, Land Classification, 1911-53

414.68 Memo, to Chief Chemist - Pegmatites, 1942

414.68 Division of Chemistry and Physics, 1914-53

414.73 Foreign Branch, 1950-53

$414.74 \quad$ Section of Paleontology, 1932-52

414.76 Topographic Branch, 1946-53

414.78 Water Resources Branch, 1931-53

419

419.1

Public Work - General, 1933-35

$419.46 \quad$ Marquette Range, 1934

425.54 Southern Appalachians - Gold (Johnston, Pardee, Currier, C. S. Ross), 1934-35

425.1 Weekly Reports, 1934-35

425.2 Estimates - Public Works Projects, 1934

425.3 Public Works - Applications, 1934

425.4 Public Works - Appointments, 1934-35

425.5 Projects (general, dam sites), etc., 1933-35

425.52 Tennessee zinc and gold, 1934

425.54 Southern Appalachians - Federal Projects, 1934-35

425.54 Southern Appalachians - Federal Projects, 1934-36

$-$

- $\quad$ War Production Board (Iron), 1942-43

- $\quad$ War Production Board, 1942-43

- $\quad$ Minerals Resources, Coordinating Division, War Production Board, August 1943, report "Estimated 1942 World Production of certain Major Strategic Minerals and Metals, and the Supply of each available to the United Nations and Axis Nations"

- $\quad$ Other metals, Reconstruction Finance Corporation, 1942-43

- $\quad$ Summary of raw minerals program, revised as of September 5, 1941

- $\quad$ Other metals - access roads, 1941-43

$434 \quad$ War Department, General, 1935-43

434 Army-Navy Munitions Board, General, 1937-44

- $\quad$ Manganese - Army-Navy Munitions Board, 1939-40

- $\quad$ Tin - Army-Navy Munitions Board, 1939

- $\quad$ Tungsten - Army-Navy Munitions Board, 1939-48

$436 \quad$ Nickel, 1941-46

- $\quad$ General Investigations by States, 1946-47

- $\quad$ Alabama Geological Survey, 1949-53

- $\quad$ Alabama Talladega gray ores, 1946-48

$510 \quad$ Arizona Bureau of Mines, 1918-47

$510 \quad$ Arizona Bureau of Mines, 1922-53

510.1 Investigations in Arizona - General, 1906-51

510.1 Investigations in Arizona - General, 1929-39

$510.1 \quad$ Arizona - Revision of Bulletin 587, [n.d.]

510.4 Strontium deposit near Aquila, Arizona, 1929

510.6 Dam sites in Arizona, ca. 1932 


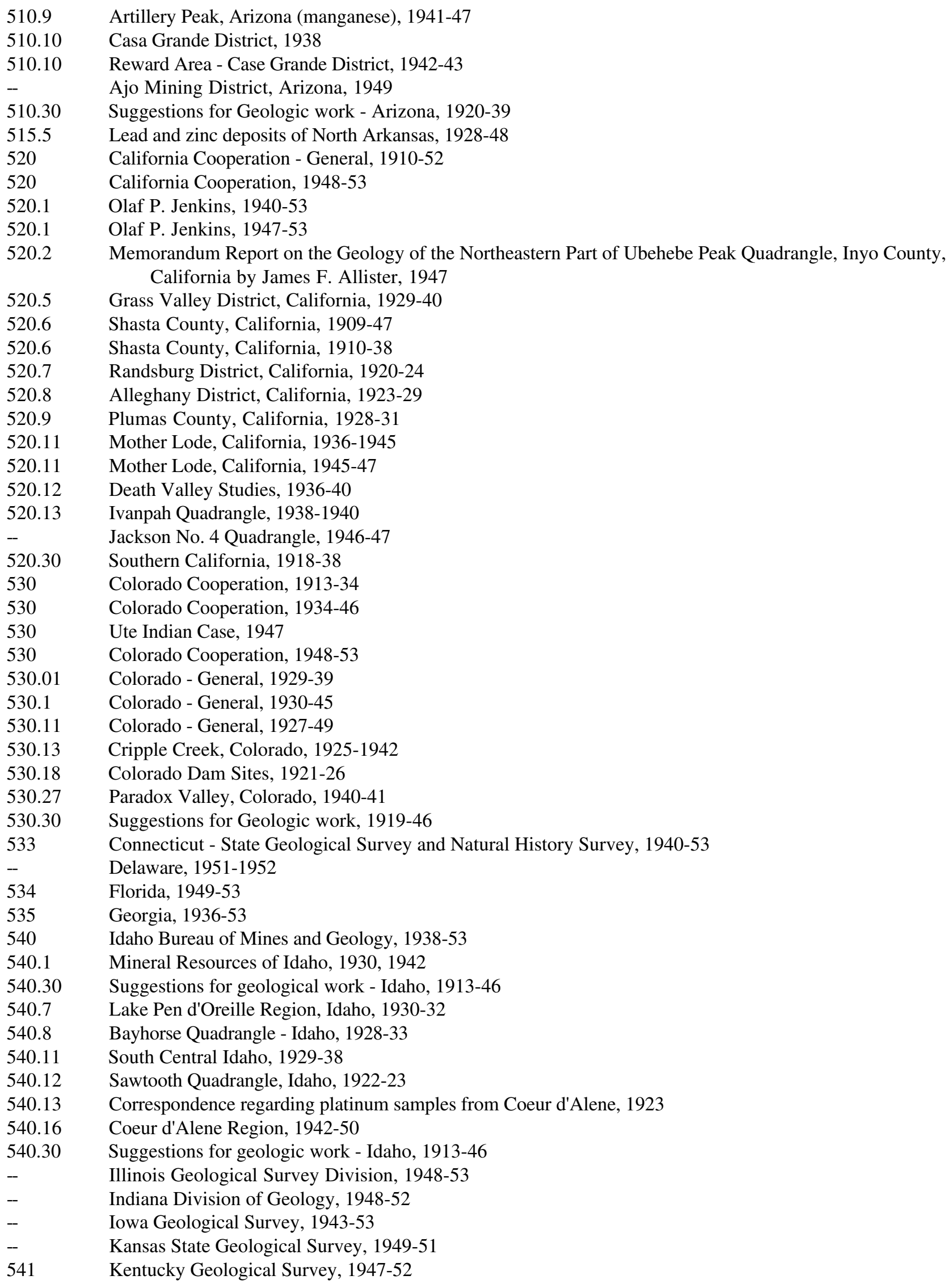




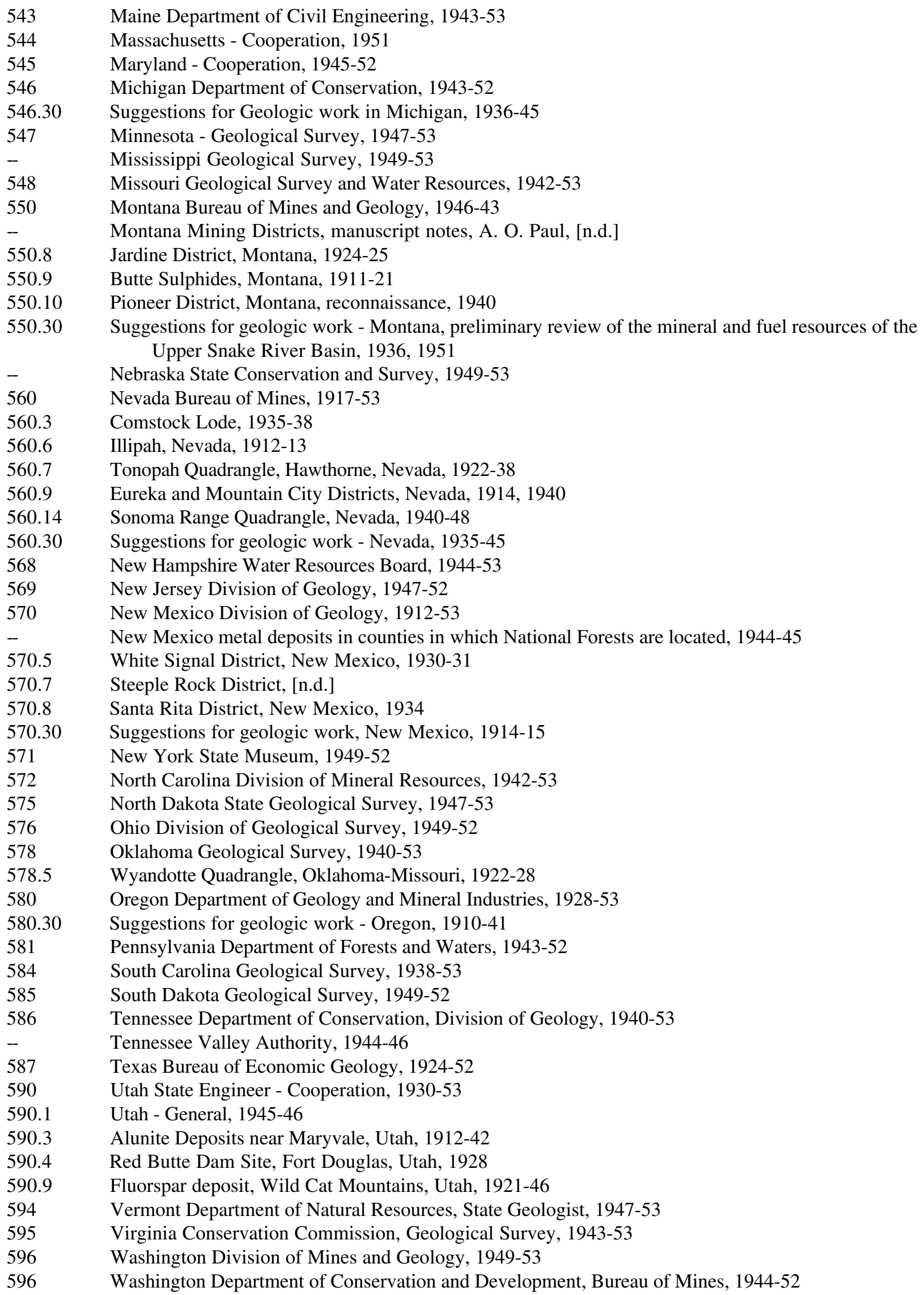


598 Wisconsin Geological and Natural History Survey, Geology Division, 1946-52

$599 \quad$ Wyoming Geological Survey, 1932-52

599.30 Suggestions for Geological Work - Wyoming, 1914-1947

$600 \quad$ Outside relations, 1921-39

$600 \quad$ Outside relations, 1940-42

$600 \quad$ Outside relations, 1945

$600 \quad$ Outside relations, 1948-49

$607 \quad$ Vanadium, 1945-48

624.1 Fifth Pacific Science Congress, 1931-33; Sixth Pacific Science Congress, 1939

*Accretions

$000 \quad$ General - Survey, 1946-47

$010 \quad$ General - Geologic Branch, 1947-52

$010.1 \quad$ Geochemistry and Petrology, 1948-52

010.2 Geochemical Prospecting Section, 1950-52

010.3 Geophysics Section Program, 1947-52

010.4 Geologic Division Program Office, 1949-52

010.5 Memoranda for Party Chiefs and Field Geologists, 1948-51

010.5 Memoranda for Party Chiefs and Field Geologists, 1951-52

010.6 Minutes of Branch Chiefs Meetings, 1949-52

010.6 Minutes of various meetings, 1948-52

$010.7 \quad$ U.S. Atomic Energy Commission, 1948-52

$010.7 \quad$ U.S. Atomic Energy Commission, 1949

010.8 Monthly reports for the Secretary, 1949-52

$010.9 \quad$ Miscellaneous Reports, 1951

010.10 Minutes of General Staff Meetings, 1950-52

$010.11 \quad$ Completed record sheets, ca. 1950

- $\quad$ Minutes of the Pacific Northwest Field Committee, 1950-52

- $\quad$ Minutes of the Southwest Field Committee, 1950-52

- $\quad$ Federal Interagency River Basin Committee, 1950-52

$011 \quad$ Memoranda - General, 1945-51

011 Memoranda - General, 1946-52

011 Strategic Minerals - General, 1937-39

$011 \quad$ Strategic Minerals - General, 1940

- $\quad$ Memorandum No. A-28, 1950

011.1 Project Review Board, 1949-51

$011.2 \quad$ Requisitions, 1948-52

011.3 Suggestions for Geologic work, 1917-48

011.3 Suggestions for Geologic work, 1949

011.4 National Mineral Industry - Resources, 1946-48

001.6 Mineral Mobilization Planning, n.d.

- $\quad$ Topographic Map needs, 1947

011.7 Topographic Map needs, 1949

011.8 Assignment of Project Numbers, 1949-50

- $\quad$ Outside Relations, 1943

- $\quad$ Outside Relations, 1944

- $\quad$ Outside Relations, 1948

-- $\quad$ Outside Relations, 1951

- $\quad$ Outside Relations, 1951-52

- $\quad$ Outside Relations, 1952-53

- $\quad$ Requisitions to the Library, 1950-52 
Mineral Exploration Agreements - by State:

Arizona, 1949

Arkansas, 1949-50

California, 1949-51

Colorado, 1948-52

Colorado, 1952-53

Idaho, 1948-49

Iowa, 1950-53

Iowa, 1952

Kansas, 1949

Montana, 1948-49

Nevada, 1950

New Mexico, 1950-51

New York, 1950-51

South Dakota, 1947-50

Tennessee, 1950

Utah, 1948-52

Utah, 1952-53

Vermont, 1950

Washington, 1950

Wisconsin, 1948-52

Wisconsin, 1949-53

Wyoming, 1948-52 


\section{Appendix 16}

Fuels Branch - General Administrative Files, 1925-53 (entry 268)

1. U.S. Geological Survey

1.a Conservation Division

1.b Branch of Map Distribution

1.d Topographic Division

1.e Water Resources Division

2. Geological Division

2.a Alaskan and Foreign

2.b Branch of Texts and Illustrations

2.d Engineering

2.e Fuels

2.f General

2.e-1 Monthly Reports - Branch News Letters

2.g Geochemistry \& Petrology

2.h Office of Geologic Reports

2.i Geophysics Branch

2.j Military

2.k Mineral Deposits

2.1 Paleographic and Stratigraphy

2.m Photo Lab

2.n Regional Office Reports

2.O-1 Letters, memo to Chief, TEPCO

2.O-2 Letters, memo from Chief, TEPCO

2.O-3 Correspondence with AEC

2.O-4 Security Information

2.O-5 Miscellaneous information regarding TEPCO

3. Other Bureaus

3.b Bureau of Mines

3.d Bureau of Reclamation

4. Budget Information

4.a Budget justification aides

4.d 1945 budget

4.e 1946 budget

4.f 1947 budget

4.g 1948 budget

4.h 1949 budget

4.i 1950 budget

4.j 1951 budget

$4.1 \quad 1952$ budget

4.m 1953 budget

5. Circulars, Orders, Memoranda

5.b Executive

5.c Survey

5.c-1 Chief Clerk's memos

5.c-2 Chief Geologist's memos

5.c-3 Director's memos 
5.c-4 Monthly reports to the Secretary

5.c-5 Management improvement cases \& reports

5.c-6 Memos form Executive Officer

10. Committees, Minutes of Meetings \& Miscellaneous Field Trips

10.a Coordination Committee

10.d Fourth World Power Conference

10.e Geologic Names Committee

10.f-1 Interdepartmental Petroleum Committee

10.g Third World Petroleum Congress

10.h General Staff Committee

10.j Committee on Designation of field offices for Interior Handbook

10.k Speeches, lectures \& papers

10.1 Columbia Basin Inter-Agency Committee

10.m Energy Resources Committee

10.p International Geological Congress - Algiers

10.q Paley Commission Recommendations

10.r Denver Advisory Council

10.s Munitions Board Interdepartmental Committee

12. Equipment

20. $\quad$ Maps

20.a Map Distribution, West of the Mississippi

20.d Map Data

20.e Preparation of Maps \& Reports

25. Miscellaneous

25.b Miscellaneous Correspondence

25.c Open File

25.e Dexter-Otto File

26. Nation-wide Surveys

26.b Letters to State Geologists regarding Survey work

28. Office and Buildings Correspondence

28.a Correspondence Procedure

28.c New Building Data

28.d Space Correspondence and Reports

30. Personnel

30.g Selective Service Numbers

30.o Thank You and Remembrances

30.p Bouquets

30.q Miscellaneous Instructions and Information

30.r Community Chest Reports

30.x Military Deferment Regulations

40.

Trips

40.a Baker

40.b Dane

40.c Miscellaneous Field Trips

40.e Monroe

40.g Miller 
45. Projects

45.c Continental Shelf (2 files)

45.c-1 Continental Shelf 1947 Estimate Geophysics Budget

45.c-2 Continental Shelf 1948 Estimate

45.d Coal Laboratory

45.e Co-op Agreements

45.f Drilling Contracts

45.g Naval Petroleum - R. Miller

45.h Pacific Northwest

45.i Program Correspondence

45.j Helium

45.k Yampa Coal Drilling

45.1 Korean Coal

45.m Southwest Washington Coal Field

45.o Suggested Projects (2 files)

45.p Missouri River Basin

45.q Unita Basin photogeology project

46. Publication

46.a Preparation of manuscripts for publication

46.b Publications - mailing regulations

46.c Publications - general editors list

48. Professional Societies

48.a A.A.P.G.

48.b A.I.M.E.

48.c G.S.A.

48.d Southeastern Geological Society

48.g A.A.A.S.

49. Requisitions, Orders, Supply Catalogs

49.a Aerial Photos

51. Technical Information

51.b Map Symbols \& Zip patterns

51.c Abbreviations for Scientific and Engineering Terms

51.d Germanium

51.e Proposed graduate courses in Geology 


\section{Appendix 17}

National Mapping Division - General Administrative Files, 1879-1947 (entry 288)

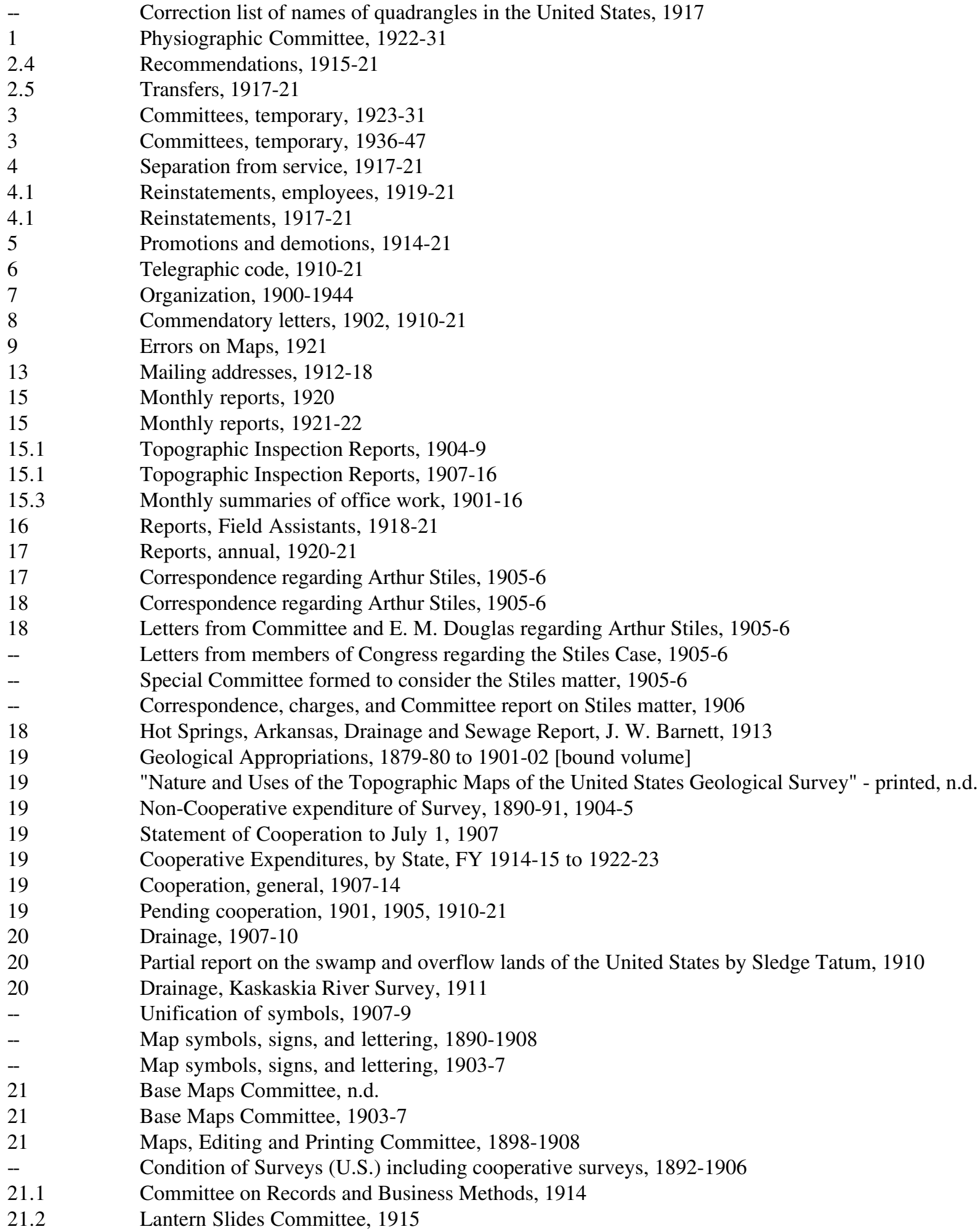


Financial Statements, 1920-23

Financial Statements, 1924-25

Per Diem, 1922-37

Definite requests for work, 1904-21

Allotment of funds for projects, 1911-21

Per Diem, 1918-47

Appropriations, ca. 1906-7

Appropriations, 1910-21

Travel Authorizations, 1922-34

Travel Authorizations, 1935-48

Correspondence with Board of Surveys and Maps, Engineering Council, and State Geologists, regarding the cost to complete mapping of the United States, 1919-21; and report of the

Federal Map Making Organizations on the topographic mapping of the United States, 1919

Attempt to increase appropriation, Sundry Civil Bill, 1920-21

Requests for information, 1921

Pay rolls, 1912, 1916, 1920

Bonds, 1911-16

Cost of work, estimate, 1922-34

Cost of work estimate, 1938-44

Clippings, ca. 1916-20

Highway data, 1920-21

Ordinance Survey Office, England, 1921

Per Diem Allowance, 1905-17

Per Diem Statements, 1912-14

Editing and engraving docket, 1911-21

Estimates, 1910-20

Press Bulletins, 1911-13

Instruction [2 files, charged out by USGS in 1963]

Instruction [2 files, charged out by USGS in 1963]

Instruction [charged out by USGS in 1963]

Instructions and Circulars regarding field work, 1902-43

Instruction and Circulars regarding field work, 1946-47

Instruction regarding clerical work, 1922-31

Instruction Appex, 1931-44

Instruction Appex, 1923, 1940, 1945-47

Instructions \& Circulars regarding Interior Department Building, 1922-34

Instructions \& Circulars regarding Interior Department Building, 1934-47

Instructions and Circulars regarding leave, etc., 1922-44

Instructions and Circulars regarding leave, etc., 1927-47

Instructions and Circulars, miscellaneous, 1922-33

Instructions and Circulars, miscellaneous, 1933-42

Instructions and Circulars, miscellaneous, 1943-47

Circular Letters, 1900-25

Circular Letters, 1926-32

Circular Letters, 1933-37

Circular Letters, Instruction, etc., 1938-42

Circular Letters, Instruction, etc., 1943-47

Mailing List, 1915

Suggestions, 1910-21

Change in sheet names, 1910-16

Change in sheet names, 1917-21

Symbols, 1910-16

Symbols, 1905-08

Bulletins, 1912-20 
101.3

101.3

101.3

102

102

102.1

Model Forms, 1915-20

Triangulation Stations, 1911-16

Leases, 1910-11

Map work, ca. 1908-22

Junior Topographers salaries, 1908-20

Assignments, 1910-20

Interior Building, 1904-20

Service Bulletin, 1915

Safes, 1919

Authority to purchase vehicles, automobiles, motors, etc., 1917-18

Automobile, 1919-20

Railway Guidebooks, 1913-16

Correspondence regarding base maps showing military posts camps in the vicinity of Washington, D.C., 1918-19

Conference on limitation of armaments, 1921

Base maps for geology, etc., [charged out by USGS in 1963]

Maps text for maps, etc., 1916-21

Renshawe's relief maps of the United States 1921

List of personnel, 1919-21

Interior Department, 1894, 1902-21

Agriculture Department, 1932-38

Department of Agriculture, 1938-44

Department of Agriculture, 1944-47

Bureau of Public Roads, 1922-42

Public Roads Advisors, 1938-44

Public Roads Administrations, 1945-47

Chief Clerk, 1911-21

Bureau of Soils, 1925-34

Bureau of Soils, 1935-38

Forest Service, 1922-38

Forest Service, Public Works Administration, 1933-34

Forest Service, 1938-47

Weather Bureau, 1922-34

Weather Bureau, 1935-47

Grand Canyon National Park, 1919-21

Mount Rainier National Park, 1920-21

National Parks, Miscellaneous, 1917-21

Yellowstone National Park, 1921

Yosemite National Park, 1919-20

Alaska Engineering Commission, 1914, 1919

Department of Commerce, 1922-34

Department of Commerce, 1936-47

General Land Office, 1902-21

Bureau of Standards, 1919-32

Bureau of Standards, 1936-47

Coast and Geodetic Survey, 1922-26

Coast and Geodetic Survey, 1926-30

Mississippi River Basin Maps, 1927-30

Coast and Geodetic Survey, 1931-44

Coast and Geodetic Survey, 1945-47

Coast mapping, 1927-47

Secretary of the Interior, 1922-37

Secretary of the Interior, 1938-47

Chief Clerk and Miscellaneous Officials, 1922-37 
102.1 Chief Clerk and Miscellaneous Officials, 1940-42

102.1 Chief Clerk and Miscellaneous Officials, 1940-47

102.2 Typing Committee regarding transfer of employees, 1941-42

102.2 Efficiency rating, 1940-45

102.2 Personnel Board, Interior Department, 1924-43

102.2 Personnel Board, Interior Department, 1943-47

102.3

Interior Department Suggestions Committee, 1944-47

Commissioner of Indian Affairs, 1901-18

103

Bureau of Education, 1931, 1942

104

104

105

105

106

106

106

106

106

106

106

107

107

109

110

General Land Office, 1922-34

General Land Office, 1935-47

Bureau of Mines, 1922-34

Bureau of Mines, 1935-47

Hawaii National Park, 1921-22

National Park Buildings and Reservation, Public Works Administration, 1933-34

National Park Service, 1922-39

National Park Service, 1922-44

National Park Service, 1924-38

National Park Service, 1945-47

Reclamation Service, 1914-36

Indian Office, 1925-34

Indian Office, 1935-47

Pension Bureau, 1926-27

Reclamation Service, 1945-47

Reclamation Service, 1946 (Report on water resources development - Nueces River Basin, Texas)

California, Shasta Valley Project, 1921-23

Reconnaissance maps, etc., 1904-21

Acting Director, 1913-21

Memorandums for Director, 1918-21

Director, Acting Director, and Administrative Geologist, 1922-37

111

Geological Survey, Public Works Administration [charged out by USGS in 1963]

Claude H. Birdseye, 1932-35

Chief Counsel, USGS, 1944-47

Correspondence and records management, 1945-47

Division of Accounts, 1922-29

Division of Accounts, 1929-33

Division of Accounts, 1933-39

112.1

Division of Accounts, 1933-40

112.1

Division of Accounts, 1937-45

112.1

Division of Accounts, 1946-47

112.1

112.2

Tax Exemption Reports, 1937-46

112.2

Library, 1923-34

Library, 1935-46

Stationery Clerk, 1911-13

112.2

112.3

112.3

113

113

113.3

113.3

Field Equipment Division, 1922-38

Field Equipment Divisions, 1937-47

Alaskan Division, 1924-33

Alaskan Division, 1934-46

Division Accounts, 1919-21

Memorandums and drafts of articles for publication, ca. 1916-23 
114

114

114.1

114

114.1

114.2

114.2

114.3

115

115

115

115

115.2

115.3

116

116

116

116

116

116

116.1

116.2

116.2

116.3

116.3

116.3

116.5

116.5

117

117

117

117.1

$-$

117.1

117.1

118.1

118

118

118

118.1

118.1

118.1

118.2

118.3

119

119

119

119.3

119.4

119.6

119.7

120

125

125
Miscellaneous memorandums, Geologic Branch, Chief Geologist, 1921-45

Chief Geologists, 1946-47

Geological Branch, 1922-34

Geological Branch, 1933-35

Miscellaneous members of Geological Branch, 1935-47

Mineral Resources Division, 1922-31

Mineral Resources Division, 1944

Chemical and Physical Research Division, 1922

Chief Geologist, 1903-21

Conservation Branch, 1922-34

Conservation Branch, 1933-39

Conservation Branch, 1935-47

Marius R. Campbell, 1914-21

Map Editor, 1911-12, 1920

Chief Topographic Engineer, 1921-34

Chief Topographic Engineer, 1933-40

Chief Topographic Engineer and Acting Chief Topographic Engineer, 1935-47

Gerald Fitzgerald, Acting Chief Topographic Engineer, 1946-47

George D. Whitmore under Chief Topographic Engineer, 1945-47

Robert H. Lyddan, Robert L. Moravetz, etc., Chief Topographic Engineer, 1946-47

Section of Cartography, Geological Survey [charged out by USGS in 1963]

Section of Computing, 1922-34

Section of Computing, 1935-47

Section of Inspection and Editing, 1922-38

Section of Inspection and Editing, 1935-47

Section of Relief Maps (cross reference to 210)

Section of Photographic Mapping, 1926-34

Section of Photographic Mapping, 1937-47

Chief Hydraulic Engineer, 1922-34

Chief Hydraulic Engineer, 1935-47

Surveys along the San Juan and Colorado Rivers in Utah, 1919-21

Water Resources Branch, 1923-34

Southern Regional Conference, Water Resources Branch, Montgomery, Alabama, 1946

Elevations and bench marks, inquiries A-K, 1935-47

Elevations and bench marks, inquiries L-W, 1935-47

Alaskan Mineral Resources, 1904, 1920-21

Section of Texts, 1922-34

Section of Texts, 1936-47

Federal Board of Survey and Maps, 1931-42

Section of Illustrations, 1925-29

Section of Illustrations, 1935

Engraving Division, 1922-44

Division of Engraving and Printing, 1933-39

Division map reproduction, Chief Engraver, 1945-47

Division of Distribution, 1922-46

Division of Distribution, 1946-47

Chief Topographic Engineer, 1905-21

Cartographic Section, 1920-21

Section of Inspection and Editing, 1915-20

Division of Military Surveys, 1917

Division of West Indian Surveys, 1919-23

Forest Atlas, 1908-9

Department of Justice, 1927-33

Department of Justice, 1935-47 
Inventions, 1942-45

Field Equipment Section, 1916-21

Department of Labor, 1922, 1925, 1931

Department of Labor, 1938-45

Navy Department, 1922-34

Navy Department, 1935-47

Post Office, 1922-43

Post Office, 1944-47

White House, 1927-36

White House, 1939, 1942

State Department File, 1924-31

State Department, 1935-47

Water Resources Branch, 1905- 1917-21

Treasury Department, 1925-36

Denver Office, 1911

Treasury Department, 1936-47

Chief Coordinator, Bureau of the Budget, 1921-44

Chief Coordinator, Bureau of the Budget, 1945-47

General Supply Committee, 1924-33

River Surveys, 1903-16

Engineer Office, B, 1918-34

Engineer Office, A, 1935-47

Engineer Office, C, 1922-31

Department of War, Aerial Surveys, 1933-35

U.S. Engineer Office, C, 1929-38

Chief of Engineers, C, 1938-47

Chief of Engineers, C, 1939-41

Chief of Engineers, C, 1941-44

General Staff, War Department, 1940-47

Engineer Office, D, 1937-44

Engineer Office, DE, 1924-34

Engineer Office, EF, 1935-41

Engineer Office, FGH, 1922-34

Engineer Office, GH, 1938-44

Engineer Office, IJK, 1922-34

Engineer Office, IJ, 1935-46

Engineer Office, KL, 1935-47

Engineer Office, LM, 1925-34

Engineer Office, M, 1935-47

Engineer Office, NO, 1925-33

Engineer Office, NO, 1935-47

Engineer Office, PQ, 1925-31

Engineer Office, PQ, 1936-47

Engineer Office, RS, 1923-34

Engineer Office, RS, 1935-45

Engineer Office, T, 1925-33

Engineer Office, T, 1936-47

Engineer Office, UVWXYZ, 1922-32

Engineer Office, UV, 1936-47

Engineer Office, W, 1936-46

Engineer Office Reserve Corps, 1922-25

Engineer Office Reserve Corps, 1929-38

Engineer Office Reserve Corps, Selective Service Records, A-L, 1939-47

Engineer Office Reserve Corps, Selective Service Records, M-Z, 1939-47 
132.4

132.5

132.5

133

133

134

134

134

135

135

136

136

136

137

137

138

138

139

139

140

140

140

141

141

141

142

142

142

142.1

143

143

143.1

144

144

145

146

146

147

148

148

149

150

150

150

150

151

152

153

$-$

155

155

155
General Staff, War Department, 1922-28

Miscellaneous, War Department, 1922-33

Miscellaneous Officers, War Department, 1936-47

Board of Surveys and Maps, 1918-33

Board of Surveys and Maps, 1934-47

Civil Service Commission, 1923-38

Civil Service Commission, 1936-47

Land Classification Board, 1908-21

Congressional Library, 1935-47

Library of Congress, 1925-31

General Accounting Office, 1922-35

General Accounting Office, 1935-38

General Accounting Office, 1939-46

International Boundary Commission, 1923-33

International Boundary Commission, 1935-47

Interstate Commerce Commission, 1922-27

Interstate Commerce Commission, 1942-47

Smithsonian Institution, 1922-32

Smithsonian Institution \& National Museum, 1937-38

U.S. Employees Compensation Commission, 1923-38

U.S. Employees Compensation Commission, 1938-47

Editor of Texts, 1912, 1919-20

U.S. Veterans Bureau, 1922-34

U.S. Veterans Bureau, 1932, 1945-46

U.S. Veterans Bureau, 1936-47

U.S. Geographic Board, 1924-36

U.S. Geographic Board, 1936-47

Section of Distribution, 1908-21

Stock Lists, 1919-21

Engraving Division, 1900-21

United States Supreme Court, 1920-29

Monthly Report of percentages of progress of military maps, 1918-21

Government Printing Office, 1922-34

Government Printing Office, 1935-44

Federal Board for Vocational Education, 1922-29

Federal Power Commission, 1922-26, 1931, 1934

Federal Power Commission, 1937-47

U.S. Coal Commission, 1923

Panama Canal, 1924-34

Panama Canal, 1935-43

Resettlement Administration, 1935-37, 1943

Post Office Department, 1907-21

Public Works Administration, 1936-37

Works Progress Administration Projects, 1937-41

Works Progress Administration, 1941-43

National Archives, 1937-47

Rural Electrification Administration, 1937-45

National Youth Administration, 1941-42

War Production Board, 1942-45

War Man Power Commission, 1942-44

Tennessee Valley Authority, 1934-40

Tennessee Valley Authority, James E. Goddard, 1936-37 
161

162

163

167

168

168

170

170

170

170.1

$170 \mathrm{~A}$

$170.1 \mathrm{~A}$

$170.1 \mathrm{~A}$

170.1B

$170.1 \mathrm{C}$

$170.1 \mathrm{~F}$

$170.1 \mathrm{G}$

170.3

170.3

170.4

170.6

170.11

170.14

170.10

170.11

170.15

170.16

170.17

170.18

170.19

170.21

170.22

170.23

170.24

170.26

170.27

170.30
Tennessee Valley Authority, Chattanooga, Thomas P. Pendleton, 1934-35

Tennessee Valley Authority, Chattanooga, Thomas P. Pendleton, 1935-37

Tennessee Valley Authority, Chattanooga, Correspondence, 1936

Tennessee Valley Authority, Chattanooga, Correspondence, 1936

Tennessee Valley Authority, Chattanooga, Correspondence, 1936

Tennessee Valley Authority, Chattanooga, Correspondence, 1936

Tennessee Valley Authority, Chattanooga, Correspondence, 1937

Tennessee Valley Authority, Chattanooga, Correspondence, 1937

Department of Commerce, 1917, 1920-21

Bureau of the Census, 1921

U.S. Coast and Geodetic Survey, 1907-21

Board of War Communication, 1942-43

Bureau of Standards, 1908-21

National Resources Planning Board, 1943

Public Buildings Administration, 1945-47

Department of Agriculture, 1906, 1907, 1910, 1917, 1919-21

Bureau of Public Roads, 1919-21

Bureau of Soils, 1914, 1920-21

Forest Service, 1906-21

Weather Bureau, 1921

United States Supreme Court, 1919-20

Stadia tables, 1909

Subsistence homesteads \& other relief, 1933-34

Map indexing \& other schemes, 1929-42

World War I, War Department, 1917-20

War Department, 1910, 1917, 1919-21

Chief of Engineers, 1905, 1911, 1918-21

Equipment furnished, foreign and U.S. use, bills, etc., 1918-20

War Department, 1918-20

Military Mapping Projects, 1916-21

Bills for surveys by USGS, 1919-21

Detail of USGS personnel to Army Engineers, 1917-18

Reports of progress on artillery site, etc., by State correspondence, 1919-21

Discharge of detailed USGS employees from military service, 1918-19

Central Division, 1921

Southern Department, 1919-21

Western Division, 1917

War Department Lists, 1917-19

Signal Corps, 1917-19

Military information, 1905-25

Progressive military maps, Army Service Schools, 1906, 1908, 1918-21

Director of Air Service, 1919-21

U.S. Lake Survey Office, 1920

Coast Artillery School, 1919-21

Army War College, 1917-21

Quartermaster's Department, 1917, 1919-21

Bureau of Insular Affairs, 1909-19

Ordnance Department, 1919-21

Cooperation with Geological Survey, 1916

USGS Employees applying for positions in Officer Reserve Corps, 1914-21

Adjutant General, 1917, 1919-21

USGS employees assigned to duty with reserve officer corps, 1917-18

Special Orders, military, 1919-20

Monthly reports of military surveys and maps, 1918-21 
170.32 \& 33 Circular, pamphlets, etc. War Department, 1918-19

170.34 472nd Engineers, 1918-19

$170.36 \quad$ Motor Transport Corps, 1919-20

170.37 Military Intelligence Division, 1919-21

170.38 Alaska Board of Road Commissioners, 1921

171

172

Panama Canal Commission, 1919-21

172

172.1

172.2

173

175

176

176.2

178

178.1

178.2

180

181

National Advisory Committee for Aeronautics, 1917-21

National Advisory Committee for Aeronautics, 1919-23

Aerial Photography \& Cameras, 1918-21

Stereoautographic apparatus, 1920-21

Department of State, 1918-21

Civil Service Commission, 1912-21

Treasury Department, 1904-21

Claims for disability by veterans, 1919-21

Navy Department, 1919-21

Reservoir sites, Navy Department, 1918-19

Parris Island, South Carolina, Navy Department, 1918

Department of Justice, 1913, 1919-21

Council of National Defense, 1919-21

Smithsonian Institution, 1920-21

National Museum, 1921

185

Interstate Commerce Commission, 1921

186

187

Federal Board for Vocational Education, 1919

U.S. Shipping Board, 1919-20

Government Printing Office, 1920-21

U.S. Geographic Board, 1919-21

Bureau of the Budget, 1921

Bureau of Efficiency, 1921

Congressional Library Directory, 1915

Pan American Union, 1919, 1921

General Supply Committee, 1920-21

General Accounting Office, 1921

Government surveys, 1911-14

Millionth Scale Map, 1908-34

Millionth Scale Map, 1935-47

Sheet name changes, 1922-30

Sheet name changes, 1930-40

Sheet name changes, 1941-47

Patents, etc., specifications, 1926

Engraving Dockets, 1922-34

Editing and Publication Dockets, 1935-42

Buchanan Bill, 1913-15

Boundaries, 1911, 1919-34

Boundaries, 1935-47

Woodland maps, 1922

Certified copies of maps, 1922-26

Base maps [file charged out by USGS in 1963]

Classification of roads, 1922-27

Cartographic relief techniques practiced by German mapmakers, 1927-29

Cartographic, relief, 1922-31

Cartographic, relief, 1936-46

Information regarding maps, 1933-38

Information regarding maps, 1938

Information regarding maps, 1939 
Information regarding maps, 1940

Information regarding maps, 1941

Information regarding maps, 1942

Information regarding maps, 1943

Information regarding maps, 1944-45

Information regarding maps, 1945

Marginal notations on maps, 1922-23, 1931

Marginal notations on maps, 1942-47

[file charged out by USGS in 1962]

Topographic mapping projects, A, ca. 1922-30

Topographic mapping projects, B, ca. 1923-25

Topographic mapping projects, C, ca. 1922-31

Topographic mapping projects, D, ca. 1922-26

Topographic mapping projects, E, ca. 1923-27

Topographic mapping projects, F, ca. 1922-32

Topographic mapping projects, G, ca. 1922-27

Topographic mapping projects, H, 1928

Topographic mapping projects, I, ca. 1923-34

Topographic mapping projects, K, ca. 1923-29

Topographic mapping projects, L, ca. 1922-27

Topographic mapping projects, M, ca. 1923-31

Topographic mapping projects, $\mathrm{N}$, ca. 1922-30

Topographic mapping projects, N; and New York Regional Maps, 1924-33

Topographic mapping projects, $\mathrm{P}$, ca. 1922-35

Philadelphia Regional Map, 1926-30

Topographic mapping projects, R, 1922-27

Topographic mapping projects, S, ca. 1924-34

Topographic mapping projects, T, ca. 1923-33

Topographic mapping projects, U, 1923

Virginia, Aerial Photography, 1923-24

W, Block Island, Rhode Island, 1922-24

W, Camp Devens, Massachusetts, 1922-25

W, Lecture Course, C. E. Cooke, Chanute Field, Illinois, 1923-25

W, Miscellaneous Correspondence, 1924-33

W, State Maps for Air Service, War Department, 1922-26

W, Fort Humphreys and vicinity, 1924-25

W, War Department (re detail Roscoe Reeves), 1922-23

W, War Department, (re detail Roscoe Reeves), 1924-25

W, West Virginia, Kanawha Farms, 1925

W, Wisconsin Survey Camp, 1921-32

W, Wisconsin, University of, re: assignment of John G. Staack, 1922-29

Y, Yellowstone National Park, level work, 1921-24

Z, Zion National Park, 1924

A-Z, 1934-43

Stock lists and reprints, 1929-47

Maps scales, 1922, 1937-40

River surveys, 1935-45

Inquiries regarding mapping, A, 1945-47

Inquiries regarding mapping, B, 1946-47

Inquiries regarding mapping, C, 1945-47

Inquires regarding mapping, D, 1945, 1947

Inquiries regarding mapping, E, 1945, 1947

Inquiries regarding mapping, F, 1945-47

Inquires regarding mapping, G, 1946-47 
Inquiries regarding mapping, $\mathrm{H}, 1946-47$

Annual Report, 1931-32

Annual Report, 1932-33

Annual Report, 1933-34

Annual Report, 1934-35

Annual Report, 1935-36

Annual Report, 1936-37

Annual Report, 1937-38

Annual Report, 1938-39

Annual Report, 1939-40

Annual Report, 1940-41

Annual Report, 1941-42

Annual Report, 1942-43

Herbert H. Hodgeson, Division Engineer, Correspondence, 1926-30

Herbert H. Hodgeson, Division Engineer, Correspondence, 1926-43

Harriman System, Geographic Index System, ca. 1927-28, 1939

Oregon Geographic Board, 1917-21

Reclamation Department, Texas, 1914-15, 1920

Personnel, A, ca. 1922-47

Personnel, B, ca. 1924-47

Personnel, C, ca. 1922-45

Personnel, C, ca. 1937-47

Personnel, D, ca. 1930-47

Personnel, E, ca. 1923-47

Personnel, F, ca. 1923-47

Personnel, G, ca. 1922-47

Personnel, H, ca. 1923-47

Personnel, I, ca. 1923-47

Personnel, K, ca. 1923-47

Personnel, L, ca. 1923-47

Personnel, M, ca. 1922-47

Personnel, N, ca. 1923-47

Personnel, P, ca. 1923-47

Personnel, R, ca. 1922-47

Personnel, S, ca. 1922-47

Personnel, S, ca. 1925-47

Personnel, T, ca. 1922-47

Personnel, T, ca. 1931-47

Personnel, U-V, ca. 1938-47

Personnel, W, ca. 1922-47 
Personnel, W, ca. 1922-47

Personnel, W, ca. 1924-47

Personnel, X-Y-Z, ca. 1924-46

Certifications, 1923-45

Certifications, 1945-47

Refusals to work, ca. 1917-34

Refusals to work, 1934-47

Promotions, 1923-27, 1935

Promotions, 1938-46

Recommendations for employees, A-Z, 1916-42

Recommendations for employees, A-R, ca. 1922-48

Recommendations for employees, S-Z, ca. 1926-47

Retirement from active service, 1934-47

Retirement and Death, 1920-34

Personnel Notes, 1933-34

Discharge of rodmen, 1927-33

Discharge of rodmen, 1934-47

Automobiles, 1920-25

Automobiles, 1925-30

Automobiles, 1931-37

Automobiles, 1933-47

Automobiles, 1937-38

Automobiles, 1938-40

Automobiles, 1940-47

Automobile personal use of, milage, 1931-34

Automobile personal use of, milage, 1935-47

Titles to cars, 1939-42

Gas rationing, 1942-46

Specifications proposals, etc., 1922-37

Specifications proposals, etc., 1937-43

Building plans, Atlantic Division, 1941-46

Building plans, Central Division, 1939-47

Building plans, Pacific Division, 1940-47

Building plans, Rocky Mountain Division, 1946

Miscellaneous building plans, 1936-47

Typewriters, 1923-34

Typewriters, 1935-47

Camp equipment, 1922-29

Camp equipment, 1937-38

Borrowing and loaning, general, 1927

Borrowing, loaning, and purchases, A, 1923-47

Borrowing, loaning, and purchases, B, 1923-46

Borrowing, loaning, and purchases, C, 1923-47

Borrowing, loaning, and purchases, D, 1923-44

Borrowing, loaning, and purchases, E, F, 1924-46

Borrowing, loaning, and purchases G, 1925-47

Borrowing, loaning, and purchases, H, 1922-44

Borrowing, loaning, and purchases, I,J, 1929-47

Borrowing, loaning, and purchases, K, 1924-45

Borrowing, loaning, and purchases, L, 1924-42

Borrowing, loaning, and purchases, M, 1923-44

Borrowing, loaning, and purchases, N, 1923-40

Borrowing, loaning, and purchases, O, P, Q, 1923-46

Borrowing, loaning, and purchases, R, 1923-42 
Borrowing, loaning, and purchases, S, 1939-46

Borrowing, loaning, and purchases, T, 1938-39

Borrowing, loaning, and purchases, U, 1940

Borrowing, loaning, and purchases, W, 1938-47

Directors' Annual Reports, 1922-38

Directors' Annual Reports, 1938-47

Directors' Reports, 1928-38

Directors' Reports, 1939-47

Reports of temporary employees (including field employees), 1939-47

Reports of Civil Service Employees (and temporary employees), 1934-39

Plans for reconversion from War to a Peace Time Basis, 1945

Reports, Miscellaneous, 1923-28, 1936

Reports, Miscellaneous, 1939-47

Increased Appropriations, 1922-34

Correspondence regarding increase of appropriation, Post war mapping, 1933-47

Topographic mapping and the Temple Act, 1916-34

Requests for surveys, 1921-35

Temple Act estimates, 1919

Requests for surveys, 1935-47

Military information, 1905-23

Possible cooperation, A-L, 1909, 1923-34

Possible cooperation, M-Z, 1920-38

Possible Cooperation, A-Z, 1922, 1927-45

Farm indexing system, 1934-35

Mapping programs by government bureaus, 1920-36

Land classification reports and correspondence, 1909, 1914-23

Exhibits, ca. 1920-45

Commendatory letters, 1923-35

Commendatory letters, 1929-47

Foreign correspondence, 1920-34

Foreign correspondence, 1935-47

Identification cards, 1922-40

Identification cards, 1941-47

Telegraphic code, 1924-30

Passes, 1926-34

Passes, 1935-47

State officials, A-K, 1927-44

State officials, L, 1938-44

State officials, M, 1922-44

State officials, N,O, 1924-34

State officials, P-W, 1922-44

State officials, A-W, 1942-47

State officials, 1945-47

Written reports, river surveys, land classification, ca. 1914-16

Written reports, river surveys, land classification, sample copies, ca. 1914-16

Damage claims, 1923-35

Damage claims, 1934-47

Lists, 1921-46

Lists, 1922-34

Organization, 1921-34

Organization, 1929-47

Orders for furniture and supplies, 1928-33

Orders for furniture and supplies, 1933-47

Articles for publication, 1919-34 
610

610

610

611

612

612

614

616

800

801

801

802

802

802

803

803

803

810

810

810

Articles for publication, 1932-47

Articles for publication, 1940, 1945-47

Articles on topographic mapping, 1915-49

Brazilian exploration, 1922-23

Conferences, 1919-31

Conferences, 1937-47

Acts, 1925-46

Clippings, 1922, 1929, 1947

City officials, A-Z, 1925-47

Carnegie Institution, 1922-30

Carnegie Institution, 1937, 1947

Pacific Power and Light Company, 1924-29

Lewis A. McArthur, Pacific Power and Light Company, 1930-38

Lewis A. McArthur, 1939-47

Miscellaneous data of interest, 1921-25

Miscellaneous data of interest, 1924-34

Miscellaneous data of interest, 1935-47

County officials, 1922-38

County Engineers, A-L, 1935-47

County Engineers, L-Z, 1936-47 


\section{Appendix 18}

National Mapping Division - General Administrative Files, ca. 1890-1953 (entry 289)

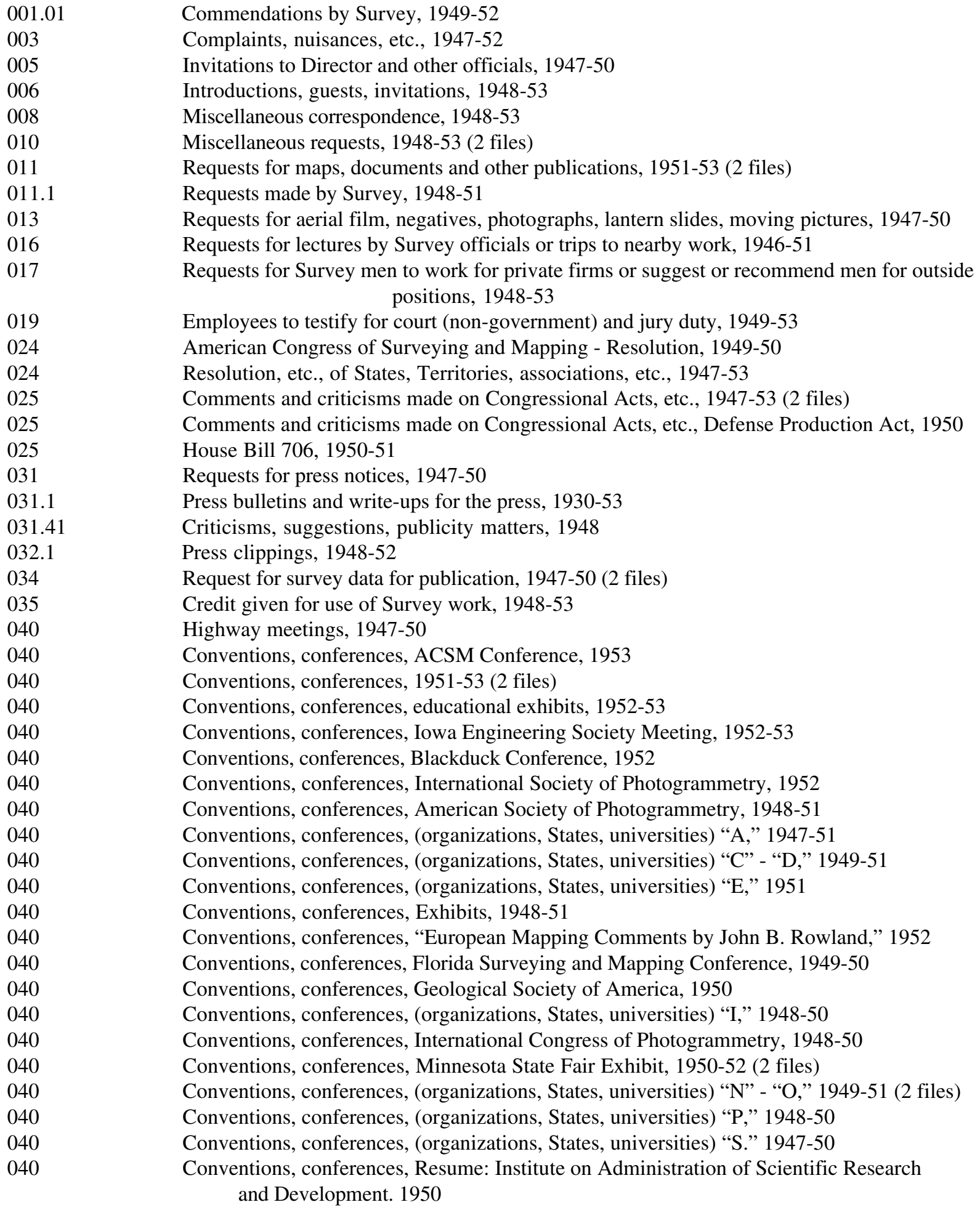


040

040

040

040

042

043

073

077

078

081

100.01

100.2

100.5

100.6

101

102

102.1

102.3

103.14

108

109

109.1

110.1

110.22

110.25

110.26

110.27

110.3

110.4

110.7

110.8

$100.111 \mathrm{C}$

110.111D

$110.111 \mathrm{~F}$

110.117

110.122

110.125

110.127

110.128

110.130

110.131

110.132

111

111

111

$111.01 \mathrm{a}$

$111.01 \mathrm{~b}$

$111.01 \mathrm{c}$

$111.01 \mathrm{~d}$

111.81

112.1

112.3

113
Conventions, conferences, (organizations, States, universities) “T," 1950-51

Conventions, conferences, (organizations, States, universities) "U," 1948-49

Conventions, conferences, (organizations, States, universities) "V," 1947-49

Conventions, conferences, (organizations, States, universities) "U" - "Z," 1950

Certificate of release - auto, 1948

Insurance - auto, 1947-51

Depository libraries for Geological Survey, 1947-53

Exchange privileges, 1949

Requisitions for translations by Survey, 1948

Patents by Survey employees; claims, etc., by government, 1947-53

Origin, development, organization, reorganization, etc., of Survey, 1951-52

Correspondence and Records Division, 1947-53

Library - Geological Survey, 1947-53

Division of Field Equipment, 1947-53

Debts of employees, 1948-51

Identification, passes, permission to take packages from building, 1948-53

Passes, building; permission to enter, etc., 1947-53

Credentials and identification cards, 1948

Certified copies, charges for; records loaned, etc., to private parties, 1949-51

[file charged out to the Survey in 1960]

Memoranda to and from the Executive Officer and Information Officer, 1946-50 (2 files)

Service and Supply Management Offices, 1949-53

Smithsonian Institution and National Museum, 1948-51

Work done for Commerce Department and Bureaus; Coast and Geodetic Survey, 1947-48

Information furnished by the Commerce Department and Bureaus, 1947-49

Information given to Commerce Department and Bureaus, 1947-49

National Production Authority, 1950-51

Panama Canal, 1949

International Boundary Commission, 1947-50

Interstate Commerce Commission, 1947

White House (Executive Office), 1950-51

War Assets Administration, 1947-48

National Research Council; Science Advisory Board, 1947-52

National Archives, 1947-50

Pan American Union, 1947

Veterans Administration, 1948-51

Federal Power Commission, 1947

Civil Aeronautics Administration, 1947-50

Tennessee Valley Authority, 1947-50

Federal Works Agency; General Services Administration, 1947-53

Library of Congress, Legislative Reference Service, 1947-52

Government Printing Office, 1948-51

Interior Department, Secretary of, etc.

Interior Department, Secretary of, etc., Reports to the Secretary, monthly F. Y. 1948, 1948-49

"Accomplishments of the Geological Survey under the Administration of President Truman," 1952

Chief Clerk (Dotson); P, S \& M (Maulding), 1947-52

Oil \& Gas Division; Power Division, 1947-53

Suggestions Committee, 1946-50

Division of Budget and Administration Management, 1947-53

Stores and Shipping Section, 1947-53

Attorney General's Opinions, etc.; Interior Department, Solicitor, 1947-52

Survey requested to furnish certified copies, statements, etc., 1948-53

Post Office Department, 1947-52 
114

114.1

114.12

114.2

115.1

115.3

115.4

116.4

116.6

116.7

117.3

117.5

117.7

118.12

118.2

118.21

118.5

118.6

118.8

118.100

118.111

118.112

119.2

119.3

119.4

119.5

119.6

119.7

120

121

132

133

134

137.5

140

141.001

141.001

141.001

141.10

141.11

141.16

141.02

141.04

142.02

142.03

142.04

142.04

142.05

142.06

142.07

142.07

142.07

142.08
Treasury Department, 1951-53

Decisions of the Comptroller, etc.; Bureau of Federal Supply, 1947-52

General Accounting Office; exceptions, Orders, etc., 1947-53

Free Entry from customs for Survey goods, 1947-48

Requests made to Civil Service Commission, etc., 1941-52

CSC Rules and Regulations with Amendments thereto, 1940-52

Monthly and Yearly Reports, etc., 1947-48

Information to or from State Department, 1947-50

Foreign Correspondence through State Department, 1947-52

State Department, requests for others, and Consular Agents, 1949

Work done by Navy Department, Information requested, 1947-52

Information requested by Navy (loan of maps, etc.), 1948-52

Work done for Navy Department, Hydrographic Office, 1947-52

Use of Field Equipment belonging to War Department, 1947-53

Work done for War Department, 1947-48

Work done by War Department for Survey, 1948

Use of War Department Information, Permission to make Maps and Photos, 1947-53

Information requested by or furnished War Department, 1947-53 (2 files)

Information and Maps furnished by War Department, 1948-53 (2 files)

Department of Defense, 1950-53

Central Intelligence, 1947-53

Army-Navy Petroleum Board, 1947

Requests to and from Weather Bureau, 1947-50

Requests to and from Forest Service, 1947-50

Work done by the Department of Agriculture for Survey, 1947-48

Information requested of the Department of Agriculture, 1947

Information requested by the Department of Agriculture, 1947-50

Photographic Sales, 1947-49

Temporary Field Employment; Letters of Employment, 1947-48

Authorization for temporary field employment; underaged, etc., 1947-48

Monthly Report of Director to Secretary, 1947-49

Annual Report to Director, 1947

Annual Reports of Director to Secretary, 1947-53

Special Reports, statements or articles prepared for Secretary or Department, 1948

Inter-agency Boards and Committees, 1951

General Staff Committee, Coordination Committee, Correspondence, 1946-53

General Staff Committee, Minutes, 201st to 363rd, 1950-53

Coordination Committee Minutes (later General Staff Committee), 1st to 200th, 1947-50

Health Committee, 1947-48

Management Improvement Committee, 1950-52

New England-New York Interagency Committee, 1949-53

Program Committee, 1948-53

Advisory Committee on Geographic Names; Domestic Names Committee, 1948-49

Executive Committee Correspondence, 1949-52

Management Services Committee, 1949-53 (2 files)

Pacific Northwest Committee, 1946-53

Pacific Northwest Coordination Committee, 1947-48

Missouri River Committee, 1948-53

Southwest Field Committee, 1948-53 (2 files)

Alaska Committee, 1948-53

"A Six Year Integrated Program for the Department of the Interior in Alaska, 1950-1955,"

A Report to the Secretary of the Interior, 1949

Alaska Field Committee, Minutes, 1949-51 (4 items)

Phoenix Field Committee, 1947-49 
Colorado River, Great Basin Field Committee, 1949-53

Geological Survey Advisory Committee, 1952-53

Budget Committee, 1948-53

Meeting of the Publications Committee, 1947-53

Safety Committee, 1951-52

Map Appraisal and Classification Committee, 1948-52

Committee on State Index Maps Policy, 1947-48

Joint Research and Development Board, 1947-50

Board on Geographic Names, 1947-53

President's Water Resources Policy Commission, 1950-51

President's Materials Policy Commission - "Paley Commission," 1951-53 (2 files)

Joint Committee on Printing, 1947-52

Interdepartmental Committees - Motor Development Board, Federal Specification Board, 1947-51

Committee on Foreign Cooperation, General Correspondence, 1948-53

Committee on Foreign Cooperation (Foreign Activities Committee), Minutes of Meetings, 1952-53

Personnel Announcements, 1950-53

Executive Officer's Orders, 1948-53 (2 files)

Correspondence, Interior Department, 1947-53

Executive Orders, 1947-53

Departmental Regulations, Honor Awards, 1948-50

Miscellaneous Circulars, Orders, etc., of other Departments, 1948-53

General and Miscellaneous Instructions, 1947-52

Military Leave, 1947-53

Leave to Per. Mo. WAE [while actually employed], or Per Diem Employees, 1948

Annual Leave, partial day leave, leave granted on separation, 1947-53

Tardiness, 1949

Overtime work, 1947-53

Sick leave, quarantine, 1947-53

Leave without pay, furlough, etc., 1947-53

Hours of labor, extension of, change in, etc., 1946-50

Mail, Special Reports on, etc., 1947-53

Personnel, 1947-53

C. S. eligibles, certification, etc., 1947-50

Probationary period, 1947-48

Promotions, Director's Policy Regarding Same, 1947-52

Details, 1947-50

Re: change of name by marriage, 1949-51

Transfers, etc., 1947-53

Oath, office; fanfold, etc., 1947-51

Resignations, etc., 1947-51

Personnel matters to be considered confidential, 1948-49

Accidents, disability or death of employees, 1948-52

[Instruction] Bureau of Employees Compensation, Report of Accidents, etc., 1947-53

[in alphabetical groupings by surnames of employees]

Statistical Statements, Tables, etc., regarding: Personnel, General and Official Register, 1949-53

Efficiency or Inefficiency Ratings, 1947-48

Retirement, 1947-52

Memorandums to and from Accounts Division, 1949-53

Payroll, 1947-53

Certification and Approval of Payroll; Mistakes Made, Changes, Additions, etc., 1949-53

Deduction due to Retirement and Bonds, 1948-53 


\begin{tabular}{|c|c|}
\hline 201.2 & Rules for Payroll; Pay due separated employees, 1949-53 \\
\hline 201.5 & Lost checks, etc., $1947-53$ \\
\hline 202 & Authority to approve accounts, 1952 \\
\hline 205 & Certification of accounts, $1947-50$ \\
\hline 207 & U.S. Depositories of Public Moneys; Certification of deposits, 1947-49 \\
\hline 208 & Correspondence regarding bills, accounts, claims to G. A. O., 1947-53 (2 files) \\
\hline 209 & Vouchers, disallowances, suspensions, etc., 1947-53 \\
\hline 210 & Budget Bureau, 1948-53 (4 files) \\
\hline 210 & Circular No. A-30, 1947-52 \\
\hline 210 & Atlantic, Central, Rocky Mountain, and Pacific Regions, 1949-51 \\
\hline 210 & Budget Bureau, 1947-48 \\
\hline 211 & Appropriations, Personnel Limitations, etc., 1947-50 \\
\hline 211 & Appropriations, Unexpected balances, surplus funds, etc., 1952-53 \\
\hline 211 & [Topographic Division Financial Plan], 1953 \\
\hline 211 & [Distribution of Overhead Charges], 1951 \\
\hline 211 & Project List - June 1951 and July 1, 1952 (2 items) \\
\hline 211.01 & Correspondence to and from State Officials, $1947-52$ \\
\hline 211.1 & Annual Estimates, Justifications, 1947-53 \\
\hline 211.2 & Urgent Deficiency, 1948-52 \\
\hline 212 & Allotments, 1947-53 (2 files) \\
\hline 220 & Authorization, travel, etc., 1947-53 \\
\hline 221 & Authorization for Expenditure; Field Work, 1948-53 (5 files) \\
\hline 230 & Leases, Contracts and Agreements except Cooperative, 1948-53 \\
\hline 230 & Parking Permits, $1947-53$ \\
\hline 231 & Space, leases - Reports, Instructions, 1946-53 \\
\hline 231 & Leases, space, etc., Atlantic Region, 1951-53 \\
\hline 231 & Atlantic Region, Business Building, 1946-53 \\
\hline 231 & Atlantic Region, Old Dominion Building, 1940-53 \\
\hline 231 & Atlantic Region, Arlington Medical Center Building, 1941-52 \\
\hline 231 & [Office Space, Rolla, Missouri], 1945-50 \\
\hline 231 & Space - Denver Office, 1946-50 \\
\hline 231 & Space, leases, Central Region, 1949-53 \\
\hline 231 & Space, leases, Pacific Region, 1946-53 (2 files) \\
\hline 232 & Contracts and Agreements, 1951-53 \\
\hline 240 & Bonds, Defaults; Recovery of Bonds, 1947-50 \\
\hline 250 & Transportation of Government Property and Employees, 1947-53 \\
\hline 250.1 & Travel Authority, 1947-53 \\
\hline 250.1 & Travel Authorizations, $1950-53$ \\
\hline 250.4 & Authority for transfer of household goods and personal property, 1947-52 \\
\hline 260 & Sale of aerial photos, maps, etc., $1947-50$ \\
\hline 270 & Claims, $1947-53$ (2 files) \\
\hline 281 & Per Diem, in lieu of Subsistence, 1947-53 \\
\hline 283 & Advances, $1947-53$ \\
\hline 286 & Authorization expenses paid one assignment to another, 1947-51 \\
\hline 300.1 & Purchase of Supplies, 1941-53 \\
\hline $300.101 \mathrm{~A}$ & Dealers - "A," regarding purchasing in general and aerial photography \\
\hline 300.101B & Bausch \& Lomb Optical Company \\
\hline $300.101 \mathrm{E}$ & Eastman Kodak Company; Engineering Service Corporation \\
\hline $300.101 \mathrm{~F}$ & Fairchild Aerial Surveys, Inc.; Fairchild Camera \& Instrument Corporation \\
\hline $300.101 \mathrm{G}$ & Dealers - "G" \\
\hline $300.101 \mathrm{H}$ & Dealers - "H" \\
\hline $300.101 \mathrm{H}$ & Hurd Mapping Company \\
\hline $300.101 \mathrm{~J}$ & Joe Jacobson Flying Service \\
\hline 300.101L-M & Dealers "L" - "M" \\
\hline
\end{tabular}


300.101P

300.101R-T

$300.101 \mathrm{~W}$

300.2

300.6

301.21

303.1

303.4

303.6

303.8

303.81

303.82

303.9

304.1

304.7

305

308

320.1

321

322

323

323

324

331

332.1

332.11

332.4

400

420

450

470

470

470

470

470

503.1A

$503.11 \mathrm{~A}$

$503.2 \mathrm{~A}$

503.2A

$503.2 \mathrm{~A}$

$503.21 \mathrm{~A}$

$503.3 \mathrm{~A}$

503.1B

503.2B

503.3B

503.31B

503.32B

503.4B

503.5B

$503.6 \mathrm{~B}$

503.7B
Pacific Air Industries; Park Aerial Surveys; Pennsylvania Aerial Surveys

Robinson Aerial Surveys, Inc.; Ryall Engineering Company; James W. Sewall Company; Harry Tubes, Inc.

Henry Wild Surveying Instruments Supply Company of America, Inc.

Requisitions for supplies, forms of, etc., 1947-52

Information regarding supplies and Survey equipment, auto reports, 1947-53

Permission for open market limitations to be increased, 1947-50

Unserviceable or abandoned; disposition of, reports, 1948-50

Instruments and property borrowed or loaned, 1942-51

Property returns and inventories, 1947-53

Transfer of instruments, property, etc., to Survey, 1947-52

Transfer of property to other departments, 1948-52

Transfer of property within the Survey, 1947-51

Surplus furniture and equipment, etc., 1947-52

External (except Department), 1950-52

Typewriter reports, correspondence, etc., 1947-53

Printing and binding requisitions, etc., 1947-52

Demonstrations, exhibition, etc., 1949-50

Estimates of equipment for NEW BUILDING, 1948-50

Quarters in public buildings - States, 1946-51

Maintenance and repairs, 1947-53

Request for additional space, except in public buildings, 1950-53

[Space - D. C.], 1938-49 (3 files)

Exchange of space, storing material, etc., 1948

Telegraph and teletype, 1947-53

Telephone, request for repairs, etc., 1949-53

Outside service (telephone), 1948-50

Telephone Directory, 1947-53

Geologic Branch, Chief Geologist, 1946-53 (3 files)

Requests for geologic information, 1950

Correspondence with personnel, "A" - "W"

Africa, 1949-52

Bolivia, 1951-52

Brazil, 1946-53

Burma, 1952-53

Geologic Division, cooperation, 1949-53

Chief Topographic Engineer, memorandums, 1947-53 (3 files)

Acting Chief Topographic Engineer, memorandums, 1947-53 (2 files)

Chief Topographic Engineer, memorandums, 1951-53

Assistant to Chief Topographic Engineer, memorandums, 1947-50

Truck requirements, Budget Circular A-30, 1945-53

Special Map Projects Section, memorandums, 1947-52

W. F. Zens, Chief Clerk, 1947-53

Plans and Coordination Branch memorandums, 1947-53 (3 files)

Map Information Office, memorandums, 1945-53 (2 files)

Plans and Estimates Section, memorandums, 1947-53 (2 files)

Plans Unit, W. C. Thompson, 1947-53

Plans Unit, B. P. Taylor, 1947-53 (2 files)

Production Control Section, R. F. Thurston, 1947-53 (5 files)

Report of the Production Control Section on the Operations of the Topographic Division for fiscal years 1950, 1951, 1952 (3 binders)

Coordination and Liaison Section, A. C. Stiefel and G. S. Druhot, 1947-53 (2 files)

Plans Unit, F. L. Witkege, 1946-53 (2 files)

Plans Unit, W. B. Upton, Jr., 1947-51 


\begin{tabular}{|c|c|}
\hline $503.8 \mathrm{~B}$ & Production Control Section, R. O. Maxson, 1948-53 (2 files) \\
\hline $503.8 \mathrm{~B}$ & Production Control Section, Cost Analysis Instruction, 1947-53 \\
\hline $503.8 \mathrm{~B}$ & Production Control Section, Cost of Maintaining and Expanding a Force, 1950-52 \\
\hline $503.8 \mathrm{~B}$ & Production Control Section, Definition of Operational Phase and related Codes, 1949-53 \\
\hline $503.8 \mathrm{~B}$ & Production Control Section, Instructions for the use of the EOR and FEOR, 1951-53 \\
\hline $503.8 \mathrm{~B}$ & Production Control Section, Operating Program - Charting and Presentation, 1949-53 \\
\hline $503.8 \mathrm{~B}$ & Production Control Section, Defense Program, 1951-53 \\
\hline $503.8 \mathrm{~B}$ & Production Control Section, Phase Definitions, 1951-53 \\
\hline $503.8 \mathrm{~B}$ & Production Control Section, Visits to Field Offices, 1949-53 \\
\hline 503.9B & Estimates Unit, F. M. Mann, 1947-53 (2 files) \\
\hline $503.1 \mathrm{G}$ & Research and Technical Control Branch, 1947-53 (2 files) \\
\hline $503.2 \mathrm{C}$ & Geodesy and Control Survey Section, R. M. Wilson, 1947-53 (2 files) \\
\hline $503.21 \mathrm{C}$ & Geodesy and Control Survey Section, J. L. Speert, 1947-53 \\
\hline $503.22 \mathrm{C}$ & Geodesy and Control Survey Section, H. D. Walker, 1948-53 \\
\hline $503.31 \mathrm{C}$ & Topographic Surveys Section, E. L. Hain, 1943-51 \\
\hline $503.31 \mathrm{C}$ & Topographic Surveys Section, C. H. Davey, 1947-53 (3 files) \\
\hline $503.31 \mathrm{C}$ & Topographic Surveys Section, C. S. Maltby, 1947-53 (2 files) \\
\hline $503.33 \mathrm{C}$ & Research and Development Unit, David Landen, 1949-53 (2 files) \\
\hline $503.33 \mathrm{C}$ & Research and Development Unit, Interim Report on Steptoe 1o Quadrangle, 1951 \\
\hline $503.4 \mathrm{C}$ & Photogrammetry Section, R. K. Bean, 1947-53 (4 files) \\
\hline $503.41 \mathrm{C}$ & Aerial Photography Unit, W. E. Harman, 1948-53 (2 files) \\
\hline $503.43 \mathrm{C}$ & Methods and Standards Unit, H. T. Kelsh, 1948-52 (2 files) \\
\hline $503.5 \mathrm{C}$ & Cartography and Map Editing Section, C. F. Fuechsel, 1947-53 (4 files) \\
\hline $503.51 \mathrm{C}$ & Inspection and Editing Unit, L. C. Moore, 1950-53 \\
\hline $503.51 \mathrm{C}$ & Inspection and Editing Unit, H. S. Lewis, 1947-49 \\
\hline $503.52 \mathrm{C}$ & Reproduction Inspection and Liaison Unit, J. H. Wyatt, 1948-51 \\
\hline $503.52 \mathrm{C}$ & Reproduction Inspection and Liaison Unit, H. N. Luber, 1947-48 \\
\hline $503.6 \mathrm{C}$ & Instrument Development Section, J. L. Buchmaster, 1950-53 \\
\hline 504 & Personnel Section, Reports, 1947-53 (2 files) \\
\hline 504 & Underage Field Assistants, 1948-53 \\
\hline 505 & Shaded Relief Maps, 1946-53 (6 files) \\
\hline 506 & Contract Mapping, 1947-53 (2 files) \\
\hline 510 & Alabama, 1948-53 \\
\hline 510 & Arizona, 1943-53 \\
\hline 510 & Arkansas, $1943-53$ \\
\hline 510 & California, 1943-53 (4 files) \\
\hline 510 & $\begin{array}{l}\text { California, "Report and Recommendations to the California State Reconstruction and } \\
\text { Reemployment Commission by the State Aerial Mapping Project Committee," } \\
\text { March } 1945 \text { [Printed] }\end{array}$ \\
\hline 510 & $\begin{array}{l}\text { California, "Progress Report on Topographic Mapping on California since January 1, 1946," } \\
\text { September } 1947 \text { [Printed] }\end{array}$ \\
\hline 510 & California, Post War, 1945-46 \\
\hline 510 & Colorado, $1945-53$ \\
\hline 510 & Connecticut, 1944-52 (2 files) \\
\hline 510 & Delaware, 1952 \\
\hline 510 & Florida, $1935-53$ (5 files) \\
\hline 510 & Florida, St. John's Watershed, 1951-53 \\
\hline 510 & Georgia, 1943-53 \\
\hline 510 & Guam [cross reference sheet only] \\
\hline 510 & Hawaii, 1947-53 (2 files) \\
\hline 510 & Idaho, 1944-52 \\
\hline 510 & Illinois, 1943-51 \\
\hline 510 & Iowa, 1943-52 \\
\hline 510 & Indiana, 1943-52 \\
\hline
\end{tabular}


Proceedings, East Central Branch Conference of the Water Resources Branch, November 7-9, 1946 [Bound]

510

510

510

510

510

510

510

510

510

510

510

510

510

510

510

510

510

510

510

510

510

510

510

510

510

510

510

510

510

510

510

510

510

510

510

510

510

510

510

510

510

510

510

510.2

515

516

530

532

538

539

540
Kansas, 1943-53

Kentucky, 1931-52 (2 files)

Louisiana, 1943-53

Maine, 1943-52

Maryland, 1945-52

Michigan, 1943-46

Minnesota, 1943-53

Mississippi, 1945-53

Missouri, 1943-47

Montana, 1945-53

Nebraska, 1943-52

Nevada, 1943-53

Nevada, Postwar Mapping, 1944

New Hampshire, 1943-53

New Jersey, 1951-53

New Mexico, 1943-52

New River Project, 1951-52

New York, 1943-53

North Carolina, 1943-53

North Dakota, 1943-49

Ohio, 1940-52 (3 files)

Oklahoma, 1943-51

Oklahoma, "Oklahoma Water," 1945

Oklahoma, "Description of Activities and Contemplated Future Programs of the Department of the Interior in the State of Oklahoma," December 1945 (2 copies)

Oregon, 1943-53

Pennsylvania, 1944-53

South Carolina, 1943-50

South Dakota, 1943-52

Tennessee, 1947-53

Texas, 1944-53 (3 files)

Texas, Postwar, 1946-51

Texas, Austin and Dallas, 1946-52

Texas, Progress Report, Texas Board of Water Engineers, September 1, 1942-August 31, 1944

Texas, Progress Report, Texas Board of Water Engineers, September 1, 1946-August 31, 1948

Texas, "Your Dallas of Tomorrow: A Master Plan for a Greater Dallas," 1943

Utah, 1943-52 (3 files)

Vermont, 1943

Virginia, 1943-53

Washington, 1943-52 (2 files)

Washington, "Modern Maps for Washington," 1946 (2 copies)

West Virginia, 1943-49

Wisconsin, 1946-52

Wyoming, 1943-53

Purchase by Survey from outside concerns, 1947-52

Aerial Topography and other Information requested by Survey, 1947-51

Aerial Topography and other Information furnished by Survey, 1947-53 (2 files)

Elevations and bench marks, 1947-52

Authority to move bench marks, "A" - "Z," 1947-52 (2 files)

Security map classification, War and Navy Departments, etc., 1947-53

Changes in quadrangle names, 1948-53

Topographic map methods, 1947-48 
Photogrammetry Section, 1947-48

Map scales, etc.; 1:500,000 State maps, 1947-50

Requests for status of topographic mapping in the U.S., 1947-53

Cooperation, 1948

Cooperating officials, including responses to the 1948 questionnaire, 1944-52

Cooperation: Topographic Mapping Policy Committee letters to State Geologists; uniform system of payment; engraving costs; budget letters, 1926-40

State meetings (Western) on national mapping, transcripts, 1944-45

Cooperation, Alabama, 1924-34

Cooperation, Alabama, acts and agreements, 1903-32

Cooperation, Arizona, acts and agreements, 1919-20

Cooperation, Arizona, Frank P. Trott, 1925-33

Cooperation, Arkansas, acts and agreements, 1927-53

Cooperation, Arkansas, cooperating officials, 1945-53

Cooperation, Arkansas, George C. Branner, 1927-35

Cooperation, Arkansas, PWA, 1936-44

Cooperation, California, 1937-53 (7 files)

Cooperation, California, agreements, 1903-52 (3 files)

Cooperation, California, University of California, 1914-15

Cooperation, California, City of Los Angeles, 1915

Cooperation, California, Los Angeles County, 1922-36 (2 files)

Cooperation, California, Reports, Acts, cooperation, 1900-47

Cooperation, California, Department of Engineering, 1908-36 (3 files)

Cooperation, California, Arthur P. Davis, East Bay Municipal Utility District, 1924-36

Cooperation, California, Southern California Edison Company, Colorado River Survey, 1921-29

Cooperation, Colorado, 1929-34

Cooperation, Colorado, Agreements, 1920-53

Cooperation, Colorado, Correspondence, 1951-53

Cooperation, Colorado, Denver Board of Water Commissioners - Platte River, 1944-48

Cooperation, Colorado, Metal Mining Fund, 1937-44

Cooperation, Colorado, C. W. Henderson, 1923-34 (2 files)

Cooperation, Colorado, Denver, 1932-45

Cooperation, Connecticut, 1948

Cooperation, Connecticut, Agreements, 1889-1958

Cooperation, Connecticut, Highway Commission, 1922-53

Cooperation, Cuba, 1919-21

Cooperation, Delaware, Agreements, 1926

Cooperation, Delaware, C. D. Buck, 1926-37

Cooperation, Georgia, 1925-52

Cooperation, Georgia, Agreements, 1926-53

Cooperation, Haiti, 1919-24

Cooperation, Hawaii, 1920-38

Cooperation, Hawaii, Acts and agreements, 1909-31

Cooperation, Hawaii, Reports, 1908-32

Cooperation, Idaho, Acts and agreements, 1912-25

Cooperation, Idaho, F. A. Thomson, 1924-27

Cooperation, Idaho, Leadore and Gilmore Areas, 1929-36

Cooperation, Illinois, 1918-53 (3 files)

Cooperation, Illinois, Acts and agreements, 1899-1951

Cooperation, Illinois, Chief Highway Engineer, 1919-34

Cooperation, Illinois, Reports, 1905-19

Cooperation, Indiana, 1919-53

Cooperation, Indiana, Agreements, 1919-53

Cooperation, Iowa, Acts and agreements, 1906-52 
Cooperation, Iowa, G. F. Kay, 1919-36

Cooperation, Iowa, Reports, 1911-52

Cooperation, Kansas, 1940-53 (2 files)

Cooperation, Kansas, Agreements, 1940-52

Cooperation, Kentucky, 1913-53 (2 files)

Cooperation, Kentucky, Acts and agreements, Reports, 1903-50

Cooperation, Kentucky, Jefferson County, 1948-52

Cooperation, Louisiana, 1904-53 (2 files)

Cooperation, Louisiana, Acts and agreements, 1903-51

Cooperation, Louisiana, Aerial surveys, 1932-41

Cooperation, Maine, 1906-53 (2 files)

Cooperation, Maine, Acts and agreements, 1899-1953

Cooperation, Maine, Aerial photographs, 1928-33

Cooperation, Maryland, 1943-51

Cooperation, Maryland, Acts and agreements, 1898-1947

Cooperation, Maryland, plans and reports, 1896-1933

Cooperation, Massachusetts, 1932-53 (2 files)

Cooperation, Massachusetts, Acts and agreements, 1932-51

Cooperation, Massachusetts, Mount Greylock, 1933

Cooperation, Michigan, 1925-52 (2 files)

Cooperation, Michigan, Acts and agreements, 1901-52

Cooperation, Michigan, Aerial photographs, 1927-31

Cooperation, Michigan, Department of Conservation, aerial photographs, 1937-39

Cooperation, Michigan, Isle Royale, aerial photographs, 1930-33

Cooperation, Michigan, State Highway Department, aerial photographs, 1932-44 (2 files)

Cooperation, Minnesota, Acts and agreements, 1909-52

Cooperation, Minnesota, State Geological Survey; State Drainage Engineer, 1910-53

Cooperation, Minnesota, Iron Range Resources and Rehabilitation Commission, 1947-53

Cooperation, Mississippi, Acts and agreements, 1901-25

Cooperation, Mississippi, E. N. Lowe, 1921-34

Cooperation, Missouri, 1923-53 (3 files)

Cooperation, Missouri, Acts and agreements, 1907-52

Cooperation, Missouri, aerial photographs, 1935-42

Cooperation, Missouri, St. Louis District Regional Planning Federation, 1929-33

Cooperation, Montana, Aerial photographs, Red Lodge, 1930-34

Cooperation, Montana, Flathead Project, 1928-37

Cooperation, Nebraska, Acts and agreements, 1911-16

Cooperation, Nevada, 1929-37, 1947-53 (3 files)

Cooperation, Nevada, agreements, 1947-51

Cooperation, New Hampshire, 1897-1937

Cooperation, New Hampshire, Acts and agreements, 1925-33

Cooperation, New Jersey, 1901

Cooperation, New Mexico, 1927-33

Cooperation, New Mexico, Acts and agreements, 1927-30

Cooperation, New York, 1920-52

Cooperation, New York, Acts and agreements, 1893-51

Cooperation, New York, Department of Public Works, 1931-34

Cooperation, New York, Rochester Regional Planning Board, 1929-37

Cooperation, New York, Palisades Park, 1926-32

Cooperation, North Carolina, 1924-53

Cooperation, North Carolina, Acts and agreements, 1901-51

Cooperation, North Dakota, 1922-53

Cooperation, North Dakota, Acts and agreements, 1919-51

Cooperation, Ohio, 1949-53 
Cooperation, Ohio, Acts and agreements, 1900-50

Cooperation, Ohio, Lucas County, 1934-36

Cooperation, Oklahoma, 1925-35

Cooperation, Oklahoma, Acts and agreements, 1905-48

Cooperation, Oklahoma, Tulsa County Planning Commission, 1951-53

Cooperation, Oklahoma, Oklahoma Planning and Resources Board, 1947-52

Cooperation, Oregon, 1924-34

Cooperation, Oregon, Acts and agreements, 1905-32

Cooperation, Pennsylvania, 1924-53

Cooperation, Pennsylvania, Acts and agreements, 1899-1951

Cooperation, Pennsylvania, aerial photography, 1935-41

Cooperation, Puerto Rico, 1912-23, 1934-53 (3 files)

Cooperation, Puerto Rico, Acts and agreements, 1935-48

Cooperation, Puerto Rico, aerial photography, 1937-43

Cooperation, Puerto Rico, PWA, 1934-38

Cooperation, Rhode Island, 1888-89

Cooperation, Santo Domingo, 1919-25

Cooperation, Santo Domingo, agreements, 1919-40

Cooperation, Santo Domingo, reports, 1919-21

Cooperation, Santo Domingo, office equipment, 1919-21

Cooperation, Santo Domingo, financial statements, 1919-21

Cooperation, South Carolina, Acts and agreements, 1933, 1952

Cooperation, South Carolina, relief council, 1933-44

Cooperation, South Dakota, Acts and agreements, 1921-22

Cooperation, Tennessee, 1924-37, 1949-53 (2 files)

Cooperation, Tennessee, Acts and agreements, 1909-52

Cooperation, Texas, Acts and agreements, 1912-32

Cooperation, Texas, City of Austin, 1952

Cooperation, Texas, Board of Water Engineers, 1924-38

Cooperation, Texas, State Reclamation Engineer, 1925-38

Cooperation, Texas, Winter Garden District, 1929-30

Cooperation, Texas, Cameron County, 1928-37

Cooperation, Texas, Galveston County, 1928-34

Cooperation, Texas, Harris County, 1915-27

Cooperation, Utah, 1924-52

Cooperation, Utah, Acts and agreements, 1922-51

Cooperation, Utah, Green River, 1922-26

Cooperation, Vermont, 1924-52

Cooperation, Vermont, Acts and agreements, 1913-52

Cooperation, Vermont, river surveys, 1928-30

Cooperation, Virginia, 1924-52 (3 files)

Cooperation, Virginia, Acts and agreements, 1903-52

Cooperation, Virginia, Shenandoah Park, 1927-36

Cooperation, Virginia, Levels, 1928-29

Cooperation, Washington, 1911-53

Cooperation, Washington, Acts and agreements, 1909-51

Cooperation, Washington, aerial photographs, 1936-41

Cooperation, Washington, Bremerton Water Department, 1946-49

Cooperation, Washington, Olympics Project, 1927-29

Cooperation, West Virginia, 1923-37

Cooperation, West Virginia, Acts and agreements, 1897-1930

Cooperation, Wisconsin, 1924-53 (3 files)

Cooperation, Wisconsin, Acts and agreements, 1895-1952

Cooperation, Wisconsin, aerial photographs, 1926-31, 1937-41 (2 files) 
Cooperation, Wisconsin, planimetric maps, 1937-42

Aeronautical Chart Service, 1947-53

Harvey T. Kelsh, Soil Conservation Service, 1947-53

Production and Marketing Administration, 1948-52

Nevada Proving Grounds, 1952-53

Army Map Service, 1948-53 (3 files)

Army Map Service, 1:250,000 scale, 1947-53

Army Map Service, observatory ties, 1952-53

Memorandum of Understanding, methods of testing contracted topographic maps, 1948

Grid Project file, 1951-52

Army Map Service, general correspondence and division engineer memorandums, 1945-47

Fort Mitchell, Alabama, 1946

Camp Beale, California, 1946-47

Camp Irwin, California, 1946-49

Fort Ord, California, 1945-47

Camp Carson, Colorado [cross reference sheet only]

Fort Benning, Georgia, 1945-49

Camp Ellis and Camp Ellis Maneuver Area, Illinois-Missouri, 1946-48 (2 files)

Camp Atterbury, Indiana, 1946-48

Fort Riley, Kansas, 1947-48

Camp Campbell, Kentucky-Tennessee, 1946-48

Fort Knox, Kentucky, 1945-48

Aberdeen Proving Ground, Maryland, 1947-48

Fort Custer, Michigan, 1946-48

Camp Shelby, Mississippi, 1946-48

Camp Crowder, Missouri, 1945-47

Fort Leavenworth, Missouri-Kansas, 1947-49

Fort Bragg, North Carolina, 1946-49

Wright Field, Ohio, 1945-46

Camp Gruber, Oklahoma, 1948

Fort Sill, Oklahoma, 1946-48

Camp Croft, South Carolina, 1948

Camp Campbell, Tennessee, 1946

Big Bend, Texas, 1946-48

Camp Bowie, Texas, 1947-49

Camp Hood, Texas, 1947-48

Camp Maxey, Texas-Oklahoma, 1947-48

A. P. Hill Military Reservation, Virginia, 1947-48

Camp McCoy, Wisconsin, 1947-48

Fort Francis E. Warren, Wyoming, 1946-49

Carrizo Mountains Project, 1949-52

Atomic Energy Commission, 1948-53 (2 files)

Atomic Energy Commission, Elk Ridge, Utah, 1952-53

Atomic Energy Commission, Marysvale, Utah, 1952-53

U. S. Air Force, 1947-53

Coast and Geodetic Survey, cooperation with, 1947-53 (2 files)

Columbia River Basin, 1947-49

Fish and Wildlife Service, 1947-52

Forest Service, 1939-53

Bureau of Indian Affairs, 1947-51

Bureau of Land Management, 1947-53

Bureau of Mines, 1947-53

National Bureau of Standards, 1947-52

Florida, 1947-48 


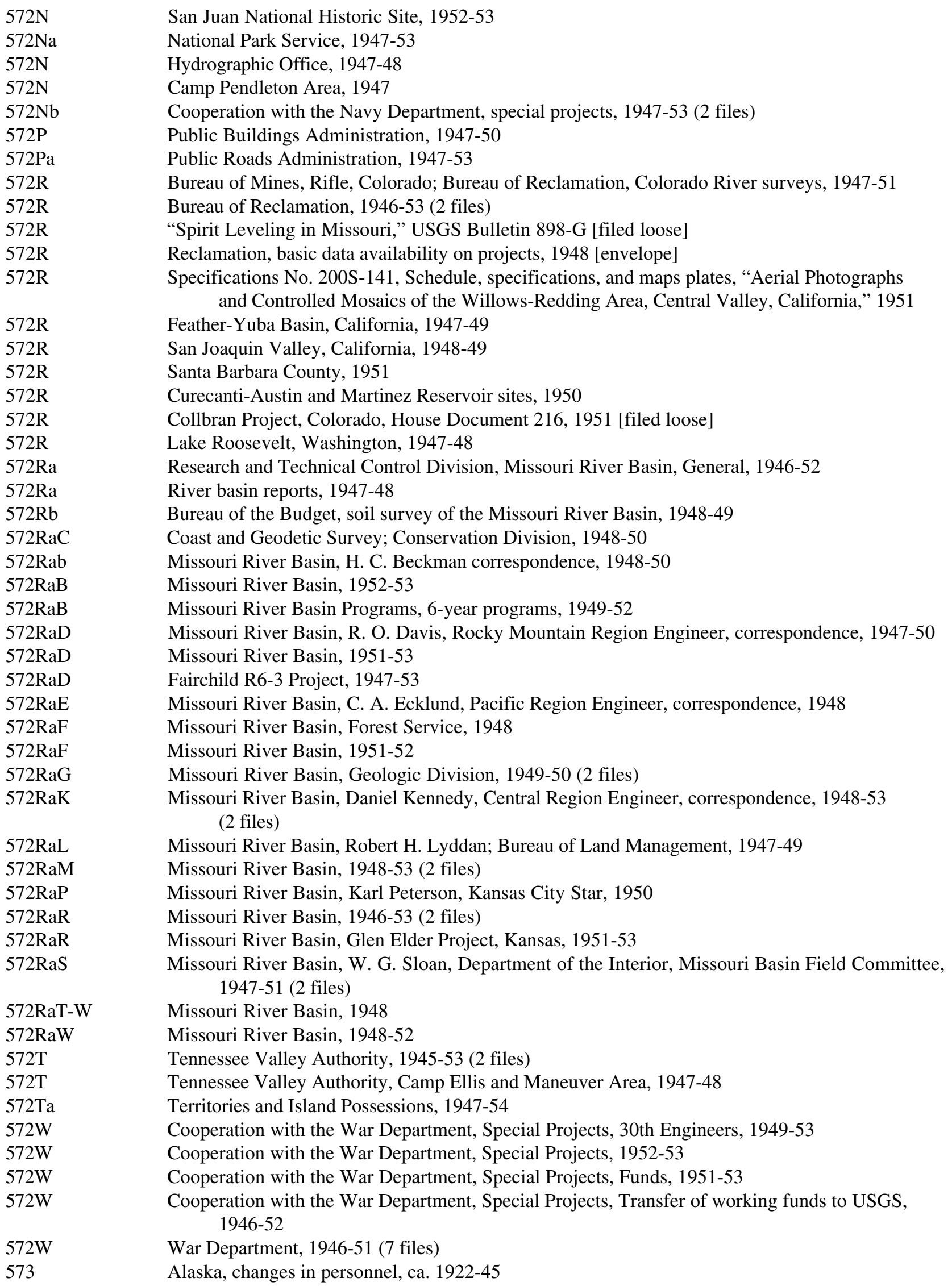




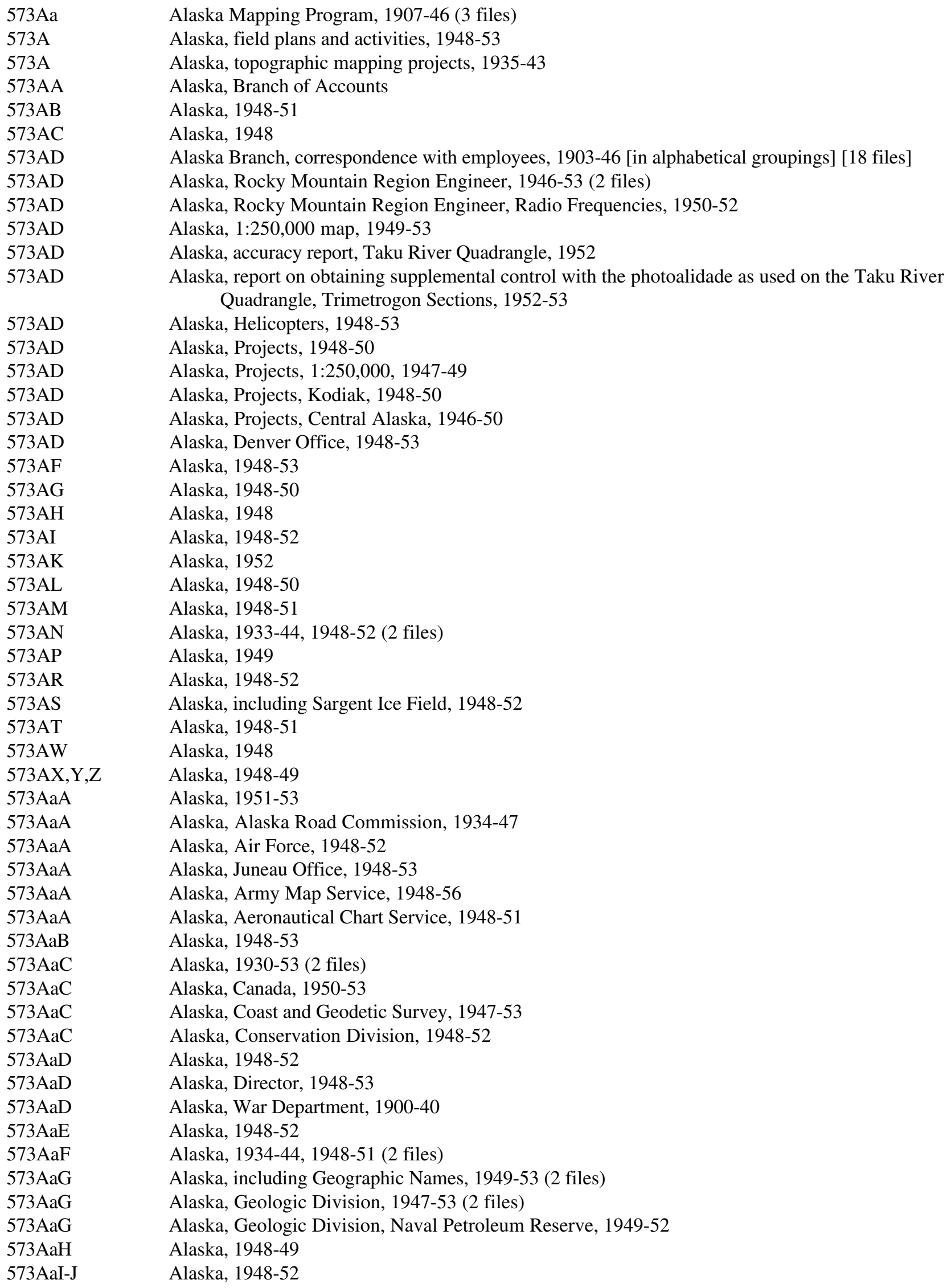

Alaska Mapping Program, 1907-46 (3 files)

Alaska, field plans and activities, 1948-53

Alaska, topographic mapping projects, 1935-43

Alaska, Branch of Accounts

Alaska, 1948-51

Alaska, 1948

Alaska Branch, correspondence with employees, 1903-46 [in alphabetical groupings] [18 files] Alaska, Rocky Mountain Region Engineer, 1946-53 (2 files)

Alaska, Rocky Mountain Region Engineer, Radio Frequencies, 1950-52

Alaska, 1:250,000 map, 1949-53

Alaska, accuracy report, Taku River Quadrangle, 1952

Alaska, report on obtaining supplemental control with the photoalidade as used on the Taku River Quadrangle, Trimetrogon Sections, 1952-53

Alaska, Helicopters, 1948-53

Alaska, Projects, 1948-50

Alaska, Projects, 1:250,000, 1947-49

Alaska, Projects, Kodiak, 1948-50

Alaska, Projects, Central Alaska, 1946-50

Alaska, Denver Office, 1948-53

Alaska, 1948-53

Alaska, 1948-50

Alaska, 1948

Alaska, 1948-52

Alaska, 1952

Alaska, 1948-50

Alaska, 1948-51

Alaska, 1933-44, 1948-52 (2 files)

Alaska, 1949

Alaska, 1948-52

Alaska, including Sargent Ice Field, 1948-52

Alaska, 1948-51

Alaska, 1948

Alaska, 1948-49

Alaska, 1951-53

Alaska, Alaska Road Commission, 1934-47

Alaska, Air Force, 1948-52

Alaska, Juneau Office, 1948-53

Alaska, Army Map Service, 1948-56

Alaska, Aeronautical Chart Service, 1948-51

Alaska, 1948-53

Alaska, 1930-53 (2 files)

Alaska, Canada, 1950-53

Alaska, Coast and Geodetic Survey, 1947-53

Alaska, Conservation Division, 1948-52

Alaska, 1948-52

Alaska, Director, 1948-53

Alaska, War Department, 1900-40

Alaska, 1948-52

Alaska, 1934-44, 1948-51 (2 files)

Alaska, including Geographic Names, 1949-53 (2 files)

Alaska, Geologic Division, 1947-53 (2 files)

Alaska, Geologic Division, Naval Petroleum Reserve, 1949-52

Alaska, 1948-49

Alaska, 1948-52 


\begin{tabular}{|c|c|}
\hline $573 \mathrm{AaK}$ & Alaska, 1948-50 \\
\hline $573 \mathrm{AaL}$ & Alaska, 1948-52 \\
\hline 573AaM & Alaska, 1948-51 \\
\hline 573AaN & Alaska, Navy Department, 1946-53 (3 files) \\
\hline $573 \mathrm{AaN}$ & Alaska, $1949-50$ \\
\hline $573 \mathrm{AaO}$ & Alaska, 1949-50 \\
\hline 573AaP-Q & Alaska, $1948-50$ \\
\hline 573AaR & Alaska, John C. Reed (Sr.), 1948-52 \\
\hline 573AaR & Alaska, Bureau of Reclamation, 1948-54 \\
\hline $573 \mathrm{AaS}$ & Alaska, $1949-52$ \\
\hline 573AaT & Alaska, 1948-53 \\
\hline 573AaU-V & Alaska, 1948-51 \\
\hline $573 \mathrm{AaW}$ & Alaska, 1948-52 \\
\hline 573AaW & Alaska, War Department, 1948-52 \\
\hline $573 \mathrm{AaW}$ & Alaska, 30th Engineers, 1950-53 \\
\hline $573 \mathrm{AaW}$ & Alaska, clearance of Alaska maps, 1948-53 [3 files and 1 envelope] \\
\hline $573 \mathrm{AaW}$ & Alaska, Bradford Washburn, 1948-53 \\
\hline $573 \mathrm{AaW}$ & Alaska, Francis L. Witkege, 1950-52 \\
\hline $573 \mathrm{C}$ & Cooperation, Conservation Division, Cooperative Projects, general, 1948-53 \\
\hline $573 \mathrm{C}$ & Cooperation, Conservation Division, California River Survey Drafting, 1947-48 \\
\hline $573 \mathrm{C}$ & Cooperation, Conservation Division, Grassy Quadrangle, Utah, 1947-49 \\
\hline $573 \mathrm{C}$ & Cooperation, Conservation Division, Grinnell and Sperry Glaciers, Montana, 1951-52 \\
\hline $573 \mathrm{C}$ & $\begin{array}{l}\text { Cooperation, Conservation Division, Middle Fork Flathead River and Hungry Horse Project, } \\
\text { Montana, } 1950\end{array}$ \\
\hline $573 \mathrm{C}$ & Cooperation, Conservation Division, Trinity River Project, California, 1950-52 \\
\hline $573 \mathrm{G}$ & $\begin{array}{l}\text { Cooperation, Geologic Branch, Photo Geology Research Project, Eureka-Seligman \#2 Project, } \\
\text { 1952-53 }\end{array}$ \\
\hline $573 \mathrm{G}$ & Cooperation, Geologic Branch, Special Project, Echo Park, Utah, etc., 1952-53 \\
\hline $573 \mathrm{G}$ & Cooperation, Geologic Branch, Kettle Falls, Washington, 1952-53 \\
\hline $573 \mathrm{G}$ & Cooperation, Geologic Branch, Special Project, repay work, 1946-52 (2 files) \\
\hline $573 \mathrm{G}$ & Cooperation, Geologic Branch, Tucson, Arizona, 1947-48 \\
\hline $573 \mathrm{G}$ & Cooperation, Geologic Branch, Batesville, Arkansas, 1948 \\
\hline $573 \mathrm{G}$ & Cooperation, Geologic Branch, Colorado Vanadium Project, Colorado, 1946-48 \\
\hline $573 \mathrm{G}$ & Cooperation, Geologic Branch, GS-EWA, Colorado Photo Project, 1947-48 \\
\hline $573 \mathrm{G}$ & Cooperation, Geologic Branch, Holy Cross, Colorado, 1948-49 \\
\hline $573 \mathrm{G}$ & Cooperation, Geologic Branch, Florida Special, 1948-49 \\
\hline $573 \mathrm{G}$ & Cooperation, Geologic Branch, Fort Benning, Georgia, shaded relief, 1947-49 \\
\hline $573 \mathrm{G}$ & Cooperation, Geologic Branch, Bear River, Idaho, 1946-50 \\
\hline $573 \mathrm{G}$ & Cooperation, Geologic Branch, Lyon Geology Project Idaho, 1947-49 \\
\hline $573 \mathrm{G}$ & Cooperation, Geologic Branch, Jacksonville Revision Project, Indiana, 1948 \\
\hline $573 \mathrm{G}$ & Cooperation, Geologic Branch, Anceney Quadrangle, Montana, 1947 \\
\hline $573 \mathrm{G}$ & Cooperation, Geologic Branch, Carson \#1 and \#2, and Mt. Rose, Nevada, 1948 \\
\hline $573 \mathrm{G}$ & Cooperation, Geologic Branch, Helper, Utah, 1948 \\
\hline $573 \mathrm{G}$ & $\begin{array}{l}\text { Cooperation, Geologic Branch, Special Project, Lead Zinc District, Southwestern Wisconsin, } \\
\text { 1949-50 }\end{array}$ \\
\hline $573 \mathrm{G}$ & Cooperation, Geologic Branch, Hartville, Wyoming, 1947 \\
\hline $573 \mathrm{G}$ & Cooperation, Geologic Branch, Korean maps, 1950 \\
\hline $573 \mathrm{G}$ & Cooperation, Geologic Branch, base map of Central America, 1947 \\
\hline $573 \mathrm{G}$ & Cooperation, Geologic Branch, China, shaded relief map, 1947-48 \\
\hline $573 \mathrm{G}$ & Cooperation, Geologic Branch, terrain diagram shading, 1947 \\
\hline $573 \mathrm{~W}$ & Cooperation, Water Resources Branch, Special Project, Britton SE, Oklahoma, 1950-52 \\
\hline $573 \mathrm{~W}$ & $\begin{array}{l}\text { Cooperation, Water Resources Branch, Brookhaven National Laboratory, Long Island, } \\
\text { New York, 1946-49 }\end{array}$ \\
\hline $573 \mathrm{~W}$ & Cooperation, Water Resources Branch, base map, 1:125,000, Eastern Tennessee, 1949 \\
\hline
\end{tabular}




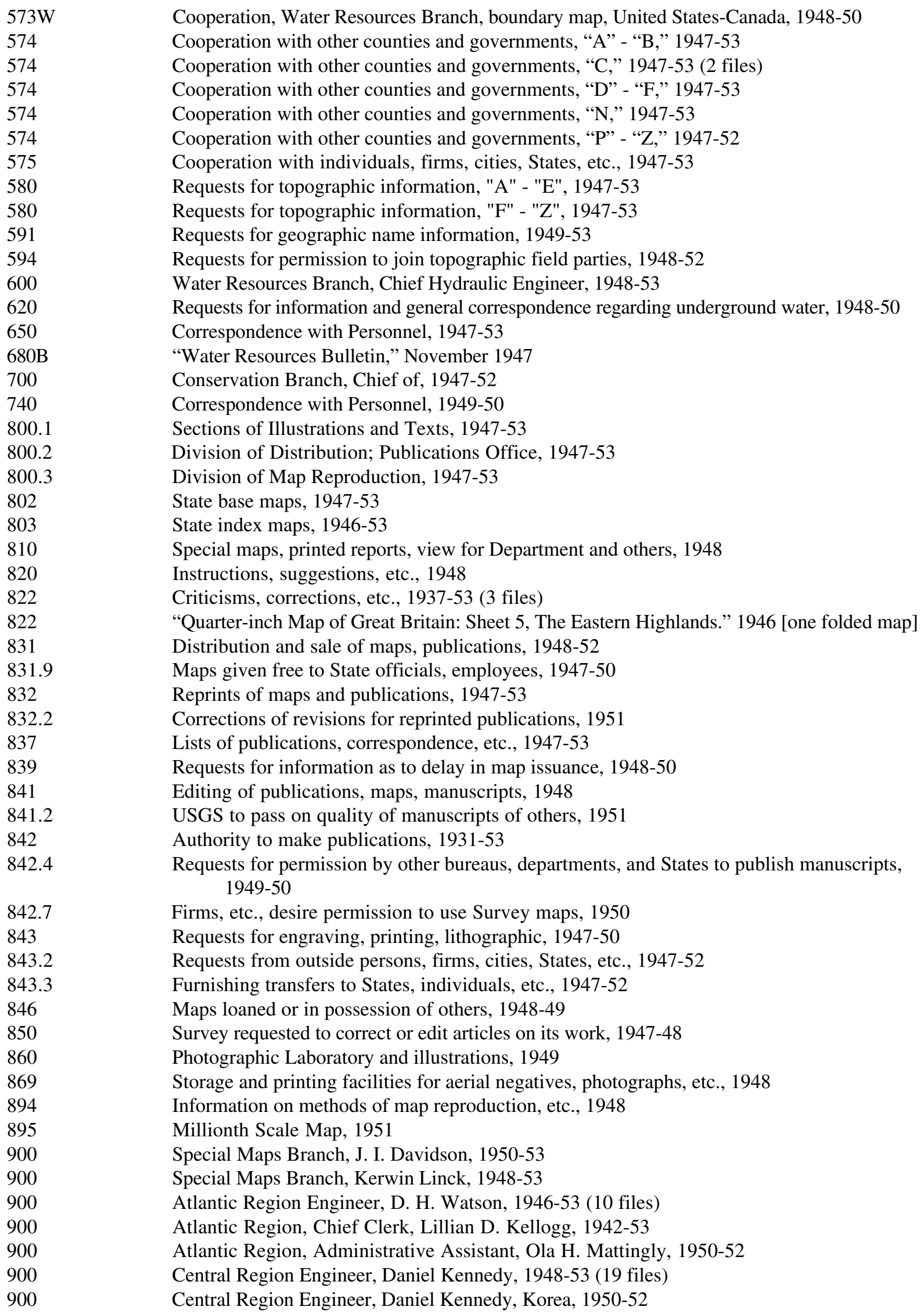


900

900

900

900

900

900
Central Region, Chief Clerk, Fred. B. Bryant, 1947-53 (5 files)

Rocky Mountain Region Engineer, R. O. Davis, 1946-53 (14 files)

Rocky Mountain Region, Chief Clerk, 1948-53 (4 files)

Pacific Region Engineer, C. A. Ecklund, 1947-53 (20 files)

Pacific Region, Program plans, 1951, 1953

Pacific Region, Chief Clerk, 1947-53 (2 files) 


\section{Appendix 19}

National Mapping Division - Correspondence of Officials in Charge of Field Surveys, 1918-49 (entry 296)

Bailey, Joe K. (Chattanooga, Tenn.) 1941-49

Burkland, Albert O. (Honolulu, Hawaii), 1921-32 (3 files)

Cooke, Charles E. (Austin, Tex., 1921-25

Davey, Charles H. (Chattanooga, Tenn.), 1935-36

Davidson, John I. (Chief, Trimetrogan Section, Washington, D. C.), 1947-49

Davis, George R. (Sacramento, Calif.), 1921-22

Druhot, George S. (Honolulu, Hawaii), 1927-30 (2 files); the file includes correspondence with Albert O. Burkland

Ecklund, Conrad A. (Sacramento, Calif.), 1923-47 (7 files)

Fisher, Charles R. (Chattanooga, Tenn.), 1934-37 (2 files)

Gerdine, Thomas G. (Sacramento, Calif.), 1923-33 (5 files)

Gleissner, Max J. (Denver, Colo.), 1925-49

Groff, Jr., Fred (Denver Colo.), 1926-41 (5 files)

Griffin, William H. (various field offices), 1924-35

Groninger, John G. (Chattanooga, Tenn.), 1936-49

Harrison, John P. (Sacramento, Calif.), 1923-47

Herron, William H. (Urbana, Ill. and State Geological Survey), 1922-30

Hodgeson, Herbert H. (Sacramento, Calif.), 1924-45 (3 files)

Hughes, Frank W. (Urbana, Ill. and other field offices), 1922-47

Kelley, L. A. (Sacramento, Calif.), 1925-47 (5 files)

Kendall, C. B. (White Plains, N. Y. and Columbia, S. C.), 1923-40 (2 files)

Kilmartin, Jerome O. (Puerto Rico), 1938-42 (2 files)

Lloyd, William J. (various field offices), 1918-38

Nelson, Clarence L. (Austin, Tex. and Board of Water Engineers), 1921-41 (4 files)

Nelson, Oscar H. (Detroit, Mich.), 1926-41 (2 files)

Pendleton, Thomas P. (Chattanooga, Tenn.), 1919-41 (8 files)

Pike, Albert (Island of Santo Domingo and various other field offices), 1919-46 (4 files)

Sadler, Carl L. (Central Division), 1938-48 (13 files) 


\section{Appendix 20}

National Mapping Division - Records Concerning Cooperative Mapping Projects, 1926-49 (entry 304)

Alabama District Engineer, 1928-30

Army River Surveys, Acts, Instructions, etc., 1926-29

List, Army District Engineer Offices, ca, 1936

Army Maps, "F", 1943-44

Army "France" Project, 1943-45

Army "Italy" Project, 1943-44

Alabama National Forest, 1929-30

Arizona, 1930

Ajo Mining District, Arizona, 1930-31

Globe \#2, Arizona \& Spencer Creek \#4, Arizona, 1943-47

Camp Verde, Arizona, 1931

Chiricahua National Monument, Arizona, 1932-33

Water Resources Branch level line near Lodi, California, 1932

Papago Indian Reservation surveys, Arizona, 1932

Salt River Project, Arizona, 1931-33

Sitgraves National Forest, Arizona, 1931-32

Arkansas bauxite area; Little Rock area, 1944-45

Ozark National Forest, Arkansas, 1929-31

Kramer, California - Borax mines; Searles Lake Quadrangle, 1931-32

San Francisco-Oakland Metropolitan District, 1937-41

California Cooperation, 1931-44

Fallbrook Naval Ammunition Depot, California, 1941-47

Crucero Quadrangle, California, 1928-29

Hoaglin Quadrangle, 1929-32

Kettleman Hills, California Cooperation, 1930-31

Kings River, California, 1931

Pilliken Chromite District, Eldorado County, California, 1943-44

Los Angeles County, California Cooperation, 1927-47 (7 files)

U. S. District Engineer, San Francisco, California, 1930-31

State Engineer, California, Cooperation, 1929-31

White River, California, 1931-32

Yosemite National Park, California, 1931-32

Yreka Quadrangle, California, 1932

Colorado State contour map, 1930-32

Everglades National Park, Florida, 1935-36

Pensacola Naval Air Station, Florida, 1930-32

Florida District Engineer, 1928-34

Georgia District Engineer, 1929-32

Georgia, Possible Cooperation, 1932-33

Bay Horse Quadrangle, Idaho, 1927-29

Craters of the Moons National Monument, Idaho, 1930-32

Irwin Quadrangle, Idaho,1929-32

Kootenai Project, Idaho, 1928-32

Latah County and Moscow, Idaho; Glendo Area, Wyoming, 1944-47

Idaho, Possible Cooperation, 1931

Idaho River Projects, 1928-29

Illinois District Engineer, Sagamon River, 1928-33

Iowa Cooperation, 1930-32 
Kansas Cooperation and W. P. A., 1937-40

Geologic Branch and Navy Department, Radar Ground Control Stations, Texas and Louisiana;

Shoran mapping equipment, 1946-47

Louisiana District Engineer, 1928

Maryland Unemployment Funds, 1933

Iron County, Michigan, 1943-47

Department of Justice, Washtenaw County, York Township, Michigan, 1931-32

Minnesota District Engineer, 1928-30

Bureau of Prisons, Sandstone, Minnesota, 1932-33

Minnesota National Guard, War Department, 1930

Roseau River, Minnesota, 1929-30

Minnesota, Possible Cooperation, Unemployment Funds, 1932-33

Mississippi District Engineer, 1928-31

Current River Power Company, Missouri, 1932-34

Seventh Corps Area, War Department, Ft. Leonard Wood, Missouri, 1940-41

Missouri District Engineer, 1928

Department of Justice, Prisons Bureau, Springfield, Missouri, 1931

Libby Quadrangle, Montana, 1928-31

Bison Range, Montana, 1927-30

Thompson and Trout Creek, Montana, 1931

Halleck Quadrangle, Nevada, 1929-31

Hawthorne Project, Nevada, 1927-29

War Department, New England Repay Funds, 1933

New Jersey Emergency Relief Administration, 1931-32

New Mexico, Cooperation, Geology, 1930-32

Pacific Division, General Plans, 1929-35 (2 files)

Lewisburg, Federal Prison Site, Pennsylvania, 1930-32

Philadelphia District Engineer, 1928-29

Pittsburgh District Engineer, 1928

Rhode Island, Providence Engineering Society, 1933

Pine Ridge Indian Reservation, South Dakota, 1930-31

Rosebud Indian Agency, South Dakota, 1930

Lewisburg, Tennessee, U. S. Department of Agriculture, 1929-30

Tennessee Valley Authority, 1933-47 (6 files)

Tennessee Valley Authority, Map and Map Reproduction Specifications, 1938-40

Tennessee Valley Authority, Aerial Photography in the Tennessee River Basin, "Invitation to Bid, Schedule, Contract and Specifications," 1936

Profile Tests of Multiples Mapping, Oswald Bald Quadrangle, Tennessee, 1937

Final Report, Planimetric Mapping Project, Tennessee River Basin, by C. H. Davey, ca. 1935

Proposed Big Bend National Park, Texas, 1935-36

Dalles County, Texas, 1930

Bryce Canyon, Utah, 1929-32

Richfield, Utah, 1931-32

Zion National Park, Utah, 1928-33

Fredericksburg and other battlefields, Virginia, 1931-32

Williamsburg, Virginia, 1931

Eatonville Quadrangle, Washington, 1930

Mt. Olympus, Aerial Photographs, 1929-36

Lower Columbia River Mapping, 1929-31

Upper Columbia River Mapping, 1929-32

Metaline Quadrangle, Washington, 1931-37

Subsistence Homesteads, Readsville, West Virginia, 1933-34

West Virginia District Engineer, 1929

Camp McCoy and Camp Williams, Wisconsin, 1930-32 
Grand Teton National Park, Wyoming, 1931

Jackson Quadrangle, Wyoming, 1928-33

Savery Creek, Wyoming, 1931-33

Yellowstone National Park, Wyoming, 1931

Wild [a survey-instrument company] - Theodolites, ca. 1940-42

Wild [a survey-instrument company] - Autograph, ca. 1928-29

Zeiss Level and other Instruments, 1929

Talpa Quadrangle, New Mexico, 1931-32

North Carolina Cooperation, 1930

North Carolina District Engineer, 1928

North Carolina Unemployment Funds 1933

Fort Totten Indian Agency, North Dakota, 1930-31

Cincinnati District Engineer, 1928-29

Cleveland Engineering Society, Ohio, 1936

El Reno Reservation, Oklahoma, Department of Justice, 1931

Crater Lake National Park, Oregon, 1931

Oregon Cooperation, the Dalles, 1929-31

Dayville Reservoir Site, Oregon, 1931

Dufur Quadrangle, Oregon, 1930-31

Lava Butte, Oregon, 1931

Mt. Washington Sheet and Maiden Peak Quadrangle, Oregon, 1928-32

Pendleton Quadrangle and Oregon Cooperation, 1919-31

Willamette Valley levels, Oregon, 1929-30

Smoky Mountains and Shenandoah National Parks, 1928-34

Mississippi River mapping, 1928-39

Mississippi River Basin maps; Water Resources Committee Meetings, Omaha, Nebraska, 1946

Missouri River Basin, Bureau of Reclamation and other Bureaus, 1945-48

Missouri River Basin Correspondence, 1945-48 [alphabetically A-Z]

Swan River Project, Montana, 1943

Atlantic Division, Special Surveys for Navy Department, 1941-42

Naval Oil Shale Reserves, 1945-48

Naval Oil Shale Reserves, Green River, Utah, 1945

Paradise Park, Gabbs Area, Nevada, 1944-48

Santa Rita Quadrangle, New Mexico, 1946

Columbia River Basin, 1944-47

Columbia River Basin Interagency Committee, 1946

International Columbia River Engineering Board, 1944-46

Galice and Dothan Areas, Oregon, 1944-45

Pacific Division Plans, 1936-46

Anthracite Region, Pennsylvania, Bureau of Mines, 1945

Bureau of Reclamation Projects, Pacific Division, 1945-46

Reservoir Sites for Reclamation Service, 1944-48

Base Maps, Soil Survey Division, U. S. Engineers, 1932

River Basins, Central Division, U. S. Engineers, 1943-47

Willamette Valley, Oregon, U. S. Engineers, 1935

U. S. Engineers, Reservoir Requests, Pacific Division, 1945

Maryvale, Utah, 1944-45

Elk Basin, Wyoming Project, 1943-45

Jackson Hole National Monument, 1943-49

Willow Creek District, Wyoming, 1942-43

National Resources Board, 1935-40

Proposed Surveying and Mapping Programs, 1934-36

Resolutions regarding expanded mapping programs, 1936-43

Outdoor map exhibit, 1934-35 
Paricutin Volcano, 1945-47

Drawing paper tests for field use, 1933

Specifications Governing River Surveys, 1944

Scales for Topographic Maps, 1932

Standard Map Scales for Metropolitan Districts, 1929-32 


\section{Appendix 21}

National Mapping Division -Records Concerning Aerial Mapping, 1927-48 (entry 307)

Alaska, miscellaneous correspondence, 1946-48

Alaska work, Denver personnel, 1946-48

Maine and New Hampshire, aerial, 1939-42

Montross, Virginia, aerial, 1930

Advertisements and contracts for aerial photography, New England south to Virginia, 1932-42

Selfridge Field Training Area - Detroit, Michigan and vicinity, 1930

Ely, Minnesota, Aerial Photographic Project, 1931-32

Jackson, Mississippi, Aerial Photographic Project, 1931

St. Louis, Missouri - aerial, 1932

Ozark Region, Missouri, aerial, 1935

Little Rocky Mountains Project, Montana, aerial, 1937-38

New Hampshire-Vermont, aerial, 1928-31

New Jersey, aerial, 1938

Catskill Quadrangle, New York, aerial, 1930-34

North Carolina and Virginia, aerial, 1938

North Dakota, aerial, 1935, 1938

Oklahoma, aerial, 1928, 1938-40

Honolulu [file charged out to USGS in 1962?]

Missouri, aerial, 1930-31

Alabama and Mississippi, aerial, 1939-42

Alabama, aerial, 1930-39

Arkansas, aerial, 1935, 1937-42 (2 files)

Arizona, California and Oregon, aerial, 1940-42

Arizona and California, aerial, 1932-33

Death Valley Area, California, aerial, 1931

Lakeport, California, aerial, 1931-36

Yosemite Valley Project, 1928-29

Delaware River, aerial, 1936

Connecticut, aerial, 1928-1934, 1938

District of Columbia and vicinity, aerial, 1937-41

Florida, aerial, 1935-38

Idaho, Montana, Oregon and Nevada, aerial, 1937-41

Newsome Quadrangle, Idaho, aerial, 1928-32

Kankakee and Sangamon Rivers, Indiana and Illinois, aerial, 1928

Indiana, aerial, 1934-42

Kentucky Mammoth Cave National Park, Kentucky, aerial, 1930-31

Kentucky, aerial, 1928-29

Ramapo Quadrangle, New Jersey, aerial photographs, 1935

Great Smoky Mountains National Park, 1929-32

Texas, aerial, 1936-40

Colorado and Utah, aerial, 1939-40

New York and Vermont, aerial, 1939-40

Pennsylvania, aerial, 1931-33

Tennessee, aerial, 1930-31

Virginia, aerial, 1931-32

Lexington \& Christianburg areas, Virginia, aerial, 1930-31

Charlottesville Quadrangle, Virginia, aerial, 1930-31

Colonial Monument, Virginia, aerial, 1929-33 
Accomac and Eastville Quadrangles, Virginia, aerial, 1930

South Carolina, Mississippi, Georgia and Alabama, aerial 1934-38

Natural Bridge, Virginia, aerial, 1928-29

Shenandoah National Park, Virginia, aerial, 1928-30

Lynchburg and Monteray Quadrangles, Virginia, aerial, 1936-41

Lower Columbia River, aerial, 1929

Upper Columbia River, aerial, 1929-35

Metaline Zinc Area Project, Washington, 1944-47

Stereoscopic Mapping from the Air, script for sound on film (2 files)

Zeiss Film, "Aerotopography," script for sound track, 1940-41

Agfa-Ansco Corporation, aerochrome film, 1929-37

Aeronautical Chart Service, 1946-48

Department of Agriculture, Field Service Branch, 1946-47

Agricultural Adjustment Agency and Soil Conservation Service, 1936-46 (2 files)

Craftint Manufacturing Company, products, 1934

Soil Conservation Service, Virginia, aerial, 1936-41

National Park Service, 1938

Photo film and paper tests, Bureau of Standards, 1936-37, 1940

Building for multiplex equipment at Chattanooga, 1938-40

Multiplex equipment, Zeiss correspondence, 1929, 1934-36

Robinson Standard Aerial Surveys, Inc, Contracts, 1945-47

Aerotopograph, 1927-30

Aerocartograph, miscellaneous, 1927

Aerocartograph, purchase, 1927-31

Air Corps, Hugershoff camera purchase, 1928-29

Air Coordination Committee, 1927

Multiplex Purchase Correspondence, 1939-47

Army Air Forces, 1939-47

Aero Service Corporation, 1942-47

Jack Ammann Photogrammetric Engineers, 1946-47

Estimates and Reports of Cost, aerial photographs, 1938-44

Lists of aerial photograph companies, ca. 1929, 1940

Camera, sereophoto equipment, Bagley Calculator, etc., 1940-44

Committee on Precision Cameras, American Society of Photogrammetry, 1938-39

U. S. Forest Service, 1936-45

Mark Hurd Mapping Company, 1947

Kargl Aerial Surveys, Inc., 1947

Park Aerial Surveys, Inc., 1946-47

Bureau of Reclamation, 1940-43

Air Corps, 1920-39, 1946 (3 files)

Bids, aerial photographs, 1928-31

Budget, aerial photographs, 1925-29

Comptroller, aerial photographs, 1928-30

Conference on Aerial Photographs, 1927

Corlett Patent, ca. 1919-30

Crampton, aerial photographs, 1928-29

Secretary of War, aerial photographs, 1925-32

Regarding sale of apparatus by James B. Harper, Receiver for Brock Wetmouth Inc., 1935-38

Stereoplanigraph, Bushkill Quadrangle, tests, 1932-43

Bushkill, Pennsylvania and New Jersey, aerial, 1931-34

Curtiss-Wright Flying Service, 1931-32

Multiplex equipment, Fairchild Aerial Surveys, Inc., correspondence, 1937-47

Fairchild Aerial Surveys, Inc. (aerocartograph test), ca. 1929-33

Automatic signal lamps and lighters, 1929 
Data, Photographic Mapping Section, 1930-31

Miscellaneous reports on aerial work, 1930-33

Forest Service, aerial photographs, 1928

Renting airplanes, 1929-30

Eastman Kodak Company, 1932

Bureau of Standards, test of film \& paper, 1929-32

Abrams Instrument Company, Contour Finder, 1939-41

Patents, Photo Mapping Methods, Straight Line, Radial Line, etc., ca. 1931-41

Photo film and paper test, 1937-40

American Geographical Society, aerial maps, Aviation Map Conference, 1929

Vertical Reflecting Projector, 1937-41

Aerial Photography \& Photogrametry Data, 1933-39

Stereoscopes, 1937-40

Geological Survey Multiplex Aero Project apparatus, an inventory, 1938

Multiplex correspondence, 1945-47

Pendleton multiplex correspondence, 1936-44 (4 files)

Aerial Mapping of Puerto Rico, 1940 


\section{Appendix 22}

National Mapping Division - Special Topographic Map Series, 1865, 1886-1983 (entry 342)

* Indicates maps that appear on a staff-compiled item list but were not in the file when this inventory was compiled; oversized items are filed separately. The date indicates the year in which the edition of the maps was printed.

The year usually appears in the title block. Dates taken from information shown elsewhere on the map are preceded by a "ca." for circa.

Title

Abrams Mountain and Vicinity

Acadia National Park and Vicinity

Acadia National Park and Vicinity

Acadia National Park and Vicinity

Acadia National Park and Vicinity

Acadia National Park and Vicinity

Acadia National Park and Vicinity

Acadia National Park and Vicinity

AjoMining District

Ajo Mining District

*Alamo National Forest

Alto Pass and Vicinity

Amargosa Region

*Antietam Battlefield

Appalachian Region

Arthurdale Farm Project (Sheet 2 of 2)

Aspen Special Map

Aspen and Vicinity

Austin Area, Reese River Mining District

Badlands National Monument and Vicinity

Badlands National Park

Bagdad Mining District

Bakersfield

Baltimore County and Baltimore City

Bandelier National Monument

Bandelier National Monument and Vicinity [oversized]

Bandelier National Monument and Vicinity (shaded relief) [oversized]

Banner Hill

Banner Hill

*Barnes Bridge

Berners Bay

Big Bar and Vicinity

Big Bethel Water Development

Bingham Mining Camp

Bingham Mining Camp

Bingham Mining Camp

Bisbee

Bisbee

Bisbee and Vicinity $\underline{\text { Place }}$

Colorado

Maine

Maine

Maine

Maine

Maine

Maine

Maine

Arizona

Arizona

New Mexico

Illinois

Nevada-California

Maryland

East Coast

West Virginia

Colorado

Colorado

Nevada

South Dakota

South Dakota

Arizona

California

Maryland

New Mexico

New Mexico

New Mexico

California

California

Texas

Alaska

California

Virginia

Utah

Utah

Utah

Arizona

Arizona

Arizona $\underline{\text { Scale }}$

$1: 12,000$

$1: 24,000$

$1: 24,000$

$1: 31,680$

$1: 31,680$

$1: 50,000$

$1: 62,500$

$1: 62,500$

$1: 6,000$

1:12,000

$1: 24,000$

$1: 24,000$

1:250,000

not given

$1: 2,500,000$

$1: 24,000$

$1: 9,600$

1:9,600

$1: 4,800$

$1: 62,500$

1:50,000

1:48,000

1:62,500

1:62,500

$1: 24,000$

1:24,000

1:24,000

1:14,400

1:14,400

1:31,680

$1: 62,500$

$1: 250,000$

1:20,000

1:20,000

1:20,000

1:20,000

1:12,000

1:12,000

1:12,000
Date

ca. 1929

ca. 1935

1956

1942

1952

1971

1931

1971

ca. 1931

ca. 1931

1914

ca. 1937

1906

1904

1965

ca. 1934

1898

1939

ca. 1937

1960

1981

n.d.

1906

1916

ca. 1937

1953

1960

1893

1903

1910

1908

1915

ca. 1919

1901

1917

1942

1902

1906

1948 
Black Canyon of the Gunnison National Monument

Black Canyon of the Gunnison National Monument

Bonanza and Vicinity

Breckenridge

Bridge Canyon

Bright Angel

Bryce Canyon National Park (North Third)

Bryce Canyon National Park (Middle Third)

Bryce Canyon National Park (South Third)

Bryce Canyon National Park

Bryce Canyon National Park

Bryce Canyon National Park

Bull Valley District

Bullfrog

Bullfrog

Butte

Butte

Butte

Calumet

Camp A.A. Humphreys

Camp A.A. Humphreys and Vicinity

Camp Bragg

Camp Carson and Vicinity

Camp Custer

Camp Devens and Vicinity (Groton Sheet)

Camp Devens and Vicinity (Marlboro Sheet)

Camp Devens and Vicinity

Camp Dix

Camp Dodge

Camp Gordon and Vicinity

*Camp Gordon and Vicinity

Camp Gordon and Vicinity

Camp Grant

Camp Grant and Vicinity

Camp Hancock

Camp Henry Knox

*Camp Jackson

Camp Lee (North Sheet)

Camp Lee (South Sheet)

Camp Lee

Camp MacArthur

Camp McClellan

Camp Meade

Camp Mills

Camp Albert L. Mills and Vicinity

Camp Pike

Camp Pike

Camp Sherman

Camp Sherman

Camp Taylor and Vicinity

Camp Taylor and Vicinity

Camp Travis

Camp Upton

Canyon de Chelly

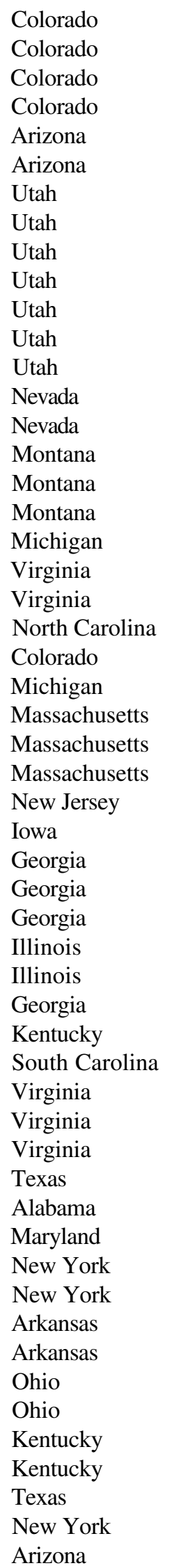

$1: 24,000$

$1: 24,000$

$1: 12,000$

$1: 24,000$

$1: 62,500$

$1: 48,000$

$1: 24,000$

$1: 24,000$

$1: 24,000$

$1: 31,680$

$1: 31,680$

$1: 31,680$

$1: 48,000$

$1: 24,000$

$1: 24,000$

$1: 15,000$

$1: 15,000$

$1: 15,000$

$1: 62.500$

$1: 125,000$

$1: 20,000$

$1: 10,000$

1:50,000

$1: 62,500$

$1: 62,500$

$1: 62,500$

$1: 62,500$

1:62,500

$1: 62,500$

1:125,000

1:125,000

1:125,000

1:62,500

1:20,000

$1: 10,000$

$1: 10,000$

1:10,000

$1: 62,500$

1:62,500

$1: 62,500$

1:125,000

1:125,000

1:62,500

$1: 62,500$

1:62,500

1:125,000

1:125,000

1:62,500

1:62,500

1:62,500

1:62,500

1:62,500

$1: 62,500$

1:250,000 ca. 1934

1950

1920

1910

1900

1903

ca. 1932

ca. 1932

ca. 1932

1939

1947

1957

1938

1906

1932

1896

1904

1926

1911

1918

ca. 1920

1919

ca. 1946

1918

1915

1917

1919

1918

1918

1917

1918

1919

1918

1925

ca. 1918

1920

ca. 1918

1917

1917

1918

1918

1918

1918

1918

1912

1910

1918

1917

1918

1912

1918

1904

1918

ca. 1921 
Canyon de Chelly National Monument

Canyonlands National Park and Vicinity [oversized]

Caribbean National Forest

Carlsbad Caverns National Park

Cartersville

Cedar Breaks National Monument

Cedar Breaks National Monument

Cedar Breaks National Monument

Central City

Central City

Central Owens Valley

Central Owens Valley

Central Valley (delta area)

Central Valley (north area)

Central Valley (south area)

Chancellorsville and Salem Church Battlefields

Chapel Hill

Charlottesville and Vicinity

Chattanooga Mining Area (Alta Basin and Vicinity)

Chattanooga Mining Area (Animas Forks Vicinity)

Chickamauga and Chattanooga National Military Park (Chickamauga Battlefield)

Chisos Mountains

Cliffside Structure Area

Coeur d'Alene District

Coeur d'Alene District

Coeur d'Alene District

Colonial National Historical Park

Colorado National Monument

Colorado National Monument

Colorado National Monument

Colorado National Monument (shaded relief)

Comstock Lode District

Cottonwood

Crater Lake National Park

Crater Lake National Park

Crater Lake National Park

Crater Lake National Park

Crater Lake National Park Extension

Crater Lake National Park (panoramic view)

Crater Lake National Park and Vicinity

Crater Lake National Park and Vicinity

Crater Lake National Park and Vicinity

Craters of the Moon National Monument

Craters of the Moon National Monument

Craters of the Moon National Monument

Craters of the Moon National Monument

Craters of the Moon National Monument

*Craters of the Moon National Monument

Creede and Vicinity

*Creede and Vicinity

*Cripple Creek

*Cripple Creek

*Culebra and Adjacent Islands

\begin{tabular}{|c|c|c|}
\hline Arizona & $1: 48,000$ & ca. 1938 \\
\hline Utah & $1: 62,500$ & 1968 \\
\hline Puerto Rico & $1: 63,360$ & 1908 \\
\hline New Mexico & $1: 24,000$ & ca. 1934 \\
\hline Georgia & $1: 62,500$ & 1906 \\
\hline Utah & $1: 12,000$ & ca. 1936 \\
\hline Utah & $1: 15,840$ & 1936 \\
\hline Utah & $1: 15,840$ & 1941 \\
\hline Colorado & $1: 12,000$ & 1906 \\
\hline Colorado & $1: 12,000$ & 1949 \\
\hline California & $1: 125,000$ & 1939 \\
\hline California & $1: 125,000$ & 1950 \\
\hline California & $1: 250,000$ & 1958 \\
\hline California & $1: 250,000$ & 1958 \\
\hline California & $1: 250,000$ & 1958 \\
\hline Virginia & $1: 24,000$ & ca. 1932 \\
\hline North Carolina & $1: 31,680$ & 1947 \\
\hline Virginia & $1: 31,680$ & 1935 \\
\hline Colorado & $1: 12,000$ & ca. 1936 \\
\hline Colorado & $1: 12,000$ & 1942 \\
\hline Georgia & $1: 9,600$ & ca. 1934 \\
\hline Texas & $1: 125,000$ & 1923 \\
\hline Texas & $1: 24,000$ & 1929 \\
\hline Idaho-Montana & $1: 62,500$ & 1901 \\
\hline Idaho-Montana & $1: 62,500$ & 1916 \\
\hline Idaho-Montana & $1: 62,500$ & 1939 \\
\hline Virginia & $1: 25,000$ & 1981 \\
\hline Colorado & $1: 24,000$ & 1962 \\
\hline Colorado & $1: 31,680$ & 1942 \\
\hline Colorado & $1: 31,680$ & 1948 \\
\hline Colorado & $1: 31,680$ & 1948 \\
\hline Nevada & $1: 24,000$ & ca. 1935 \\
\hline Utah & $1: 25,000$ & 1949 \\
\hline Oregon & $1: 62,500$ & ca. 1896 \\
\hline Oregon & $1: 62,500$ & 1903 \\
\hline Oregon & $1: 62,500$ & 1925 \\
\hline Oregon & $1: 62,500$ & 1931 \\
\hline Oregon & $1: 48,000$ & ca. 1933 \\
\hline Oregon & $1: 62,500$ & n.d. \\
\hline Oregon & $1: 62,500$ & 1933 \\
\hline Oregon & $1: 62,500$ & 1946 \\
\hline Oregon & $1: 62,500$ & 1956 \\
\hline Idaho & $1: 24,000$ & 1983 \\
\hline Idaho & $1: 31,680$ & ca. 1930 \\
\hline Idaho & $1: 31,680$ & 1933 \\
\hline Idaho & $1: 31,680$ & 1947 \\
\hline Idaho & $1: 31,680$ & 1957 \\
\hline Idaho & $1: 31,680$ & 1960 \\
\hline Colorado & $1: 24,000$ & 1910 \\
\hline Colorado & $1: 24,000$ & 1912 \\
\hline Colorado & $1: 25,000$ & 1895 \\
\hline Colorado & $1: 25,000$ & 1925 \\
\hline Puerto Rico & $1: 30,000$ & 1938 \\
\hline
\end{tabular}


*Custer Battlefield

Dahlonega District

*Dahlonega District

Dairy and Livestock Experiment Farm

Death Valley National Monument and Vicinity

Denver

Denver

Denver

Denver Mountain Area (shaded relief)

Denver Mountain Area

Denver Mountain Parks

Denver Mountain Parks

Devils Tower National Monument

Devils Tower National Monument

Devils Tower National Monument

Diamond Lake

Dinosaur National Monument [oversized]

Dinosaur National Monument [oversized]

Dinosaur National Monument

Dry Creek Area

Ducktown

Ducktown

Elk Basin

Elk Hills Naval Reserve No. 1

Elkhorn

Ely

Ely

Ely

Encampment

Encampment

Encampment

Eureka Mining District

Fairbanks

Flathead Lake Project (north half)

Flathead Lake Project (south half)

Fort Bayard

Fort Douglas

Fort Hall Indian Reservation

Fort Humphreys and Vicinity

Fort Knox and Vicinity

Fort Logan H. Roots

Fort Missoula Military Reservation

Fort Oglethorpe

Fort Omaha Special Balloon Field

Fort Omaha Balloon Field (northeast quarter)

Fort Omaha Balloon Field (northeast quarter)

Fort Omaha Balloon Field (northwest quarter)

Fort Omaha Balloon Field (northwest quarter)

Fort Omaha Balloon Field (southeast quarter)

Fort Omaha Balloon Field (southeast quarter)

Fort Omaha Balloon Field (southwest quarter)

Fort Omaha Balloon Field (southwest quarter)

\begin{tabular}{|c|c|c|}
\hline Montana & $1: 5,280$ & 1908 \\
\hline Georgia & $1: 36,000$ & 1907 \\
\hline Georgia & $1: 36,000$ & 1945 \\
\hline Tennessee & $1: 2,400$ & ca. 1929 \\
\hline California-Nevada & $1: 250,000$ & 1977 \\
\hline Colorado & $1: 125,000$ & 1892 \\
\hline Colorado & $1: 125,000$ & 1906 \\
\hline Colorado & $1: 125,000$ & 1932 \\
\hline Colorado & $1: 190,080$ & 1948 \\
\hline Colorado & $1: 190,080$ & 1950 \\
\hline Colorado & $1: 62,500$ & 1924 \\
\hline Colorado & $1: 62,500$ & 1939 \\
\hline Wyoming & $1: 4,800$ & ca. 1933 \\
\hline Wyoming & $1: 4,800$ & 1949 \\
\hline Wyoming & $1: 4,800$ & 1950 \\
\hline Oregon & $1: 96,000$ & ca. 1914 \\
\hline Utah-Colorado & $1: 62,500$ & 1945 \\
\hline Utah-Colorado & $1: 62,500$ & 1950 \\
\hline Utah-Colorado & $1: 62,500$ & 1966 \\
\hline Idaho & $1: 24,000$ & 1948 \\
\hline \multicolumn{3}{|l|}{ Tennessee-Georgia- } \\
\hline North Carolina & $1: 36,000$ & 1909 \\
\hline \multicolumn{3}{|l|}{ Tennessee-Georgia- } \\
\hline North Carolina & $1: 36,000$ & 1942 \\
\hline Wyoming-Montana & $1: 15,840$ & 1945 \\
\hline California & $1: 24,000$ & ca. 1927 \\
\hline Montana & $1: 31,250$ & ca. 1899 \\
\hline Nevada & $1: 30,000$ & 1907 \\
\hline Nevada & $1: 30,000$ & 1910 \\
\hline Nevada & $1: 30,000$ & 1916 \\
\hline Wyoming-Colorado & $1: 90,000$ & 1903 \\
\hline Wyoming-Colorado & $1: 90,000$ & 1926 \\
\hline Wyoming-Colorado & $1: 90,000$ & 1949 \\
\hline Nevada & $1: 24,000$ & 1931 \\
\hline Alaska & $1: 62,500$ & 1908 \\
\hline Montana & $1: 12,000$ & 1929 \\
\hline Montana & $1: 12,000$ & 1929 \\
\hline New Mexico & $1: 12,000$ & 1910 \\
\hline Utah & $1: 10,000$ & ca. 1925 \\
\hline Idaho & $1: 192,000$ & ca. 1913 \\
\hline Virginia & $1: 20,000$ & 1923 \\
\hline Kentucky & $1: 62,500$ & n.d. \\
\hline Arkansas & $1: 125,000$ & 1910 \\
\hline Montana & $1: 4,800$ & ca. 1908 \\
\hline Georgia & $1: 125,000$ & 1918 \\
\hline Nebraska & $1: 10,000$ & ca. 1918 \\
\hline Nebraska & $1: 20,000$ & ca. 1918 \\
\hline Nebraska & $1: 20,000$ & 1919 \\
\hline Nebraska & $1: 20,000$ & ca. 1918 \\
\hline Nebraska & $1: 20,000$ & 1918 \\
\hline Nebraska & $1: 20,000$ & ca. 1918 \\
\hline Nebraska & $1: 20,000$ & 1919 \\
\hline Nebraska & $1: 20,000$ & ca. 1918 \\
\hline Nebraska & $1: 20,000$ & 1918 \\
\hline
\end{tabular}


Fort Riley (north half)

Fort Riley (south half)

Franklin Battlefield, 1864

Franklin D. Roosevelt National Historic Site

Franklin Furnace

Franklin Furnace

Fredericksburg and Vicinity

Fredericksburg Battlefield [oversized]

Fredericksburg-Spotsylvania Battlefield National Monument

Frisco

Frisco

Genesee

Gettysburg Battlefield and Vicinity

Gettysburg and Vicinity [oversized]

Gilmore Mining District

Glacier National Park

Glacier National Park

Glacier National Park

Glacier National Park

Glacier National Park

Glacier National Park - Life Zones

Glacier National Park (panoramic view)

Glen Canyon National Recreation Area

Globe

Gogebic Iron Range (sheet 1)

Gogebic Iron Range (sheets 2 \& 3)

Gold Hill Mining Area

Goldfield

Goldfield

Goldfield

Grand Canyon National Monument

Grand Canyon National Monument

Grand Canyon National Monument

Grand Canyon National Park (west half) [oversized]

Grand Canyon National Park (east half) [oversized]

Grand Canyon National Park (west half) [oversized]

Grand Canyon National Park (east half) [oversized]

Grand Canyon National Park (west half) [oversized]

Grand Canyon National Park (east half) [oversized]

Grand Canyon National Park (west half) [oversized]

Grand Canyon National Park (east half)[oversized]

Grand Canyon National Park (east half)

Grand Central

Grand Coulee (sheet 1)

Grand Coulee (sheet 2)

Grand Coulee (sheet 3)

Grand Coulee (sheet 4)

*Grand Teton

Grand Teton [oversized]

Grand Teton [oversized]

Grand Teton

Grand Teton [oversized]

Grand Teton (shaded relief) [oversized]

\begin{tabular}{|c|c|c|}
\hline Kansas & $1: 20,000$ & ca. 1927 \\
\hline Kansas & $1: 20,000$ & ca. 1927 \\
\hline Tennessee & $1: 10,560$ & n.d. \\
\hline New York & $1: 960$ & 1946 \\
\hline New Jersey & $1: 14,400$ & 1899 \\
\hline New Jersey & $1: 14,400$ & 1910 \\
\hline Virginia & $1: 24,000$ & ca. 1931 \\
\hline Virginia & $1: 24,000$ & ca. 1934 \\
\hline Virginia & $1: 24,000$ & ca. 1934 \\
\hline Utah & $1: 62,500$ & 1906 \\
\hline Utah & $1: 62,500$ & 1911 \\
\hline California & $1: 31,680$ & 1893 \\
\hline Pennsylvania-Maryland & $1: 62,500$ & 1913 \\
\hline Pennsylvania & $1: 62,500$ & ca. 1929 \\
\hline Idaho & $1: 48,000$ & ca. 1931 \\
\hline Montana & $1: 125,000$ & 1911 \\
\hline Montana & $1: 125,000$ & 1914 \\
\hline Montana & $1: 125,000$ & 1927 \\
\hline Montana & $1: 125,000$ & 1932 \\
\hline Montana & $1: 125,000$ & 1948 \\
\hline Montana & $1: 125,000$ & n.d. \\
\hline Montana & $1: 187,500$ & n.d. \\
\hline Utah-Arizona & $1: 250,000$ & 1967 \\
\hline Arizona & $1: 12,000$ & 1902 \\
\hline Wisconsin & $1: 24,000$ & ca. 1921 \\
\hline Wisconsin & $1: 24,000$ & ca. 1921 \\
\hline Colorado & $1: 12,000$ & ca. 1938 \\
\hline Nevada & $1: 24,000$ & 1906 \\
\hline Nevada & $1: 24,000$ & 1909 \\
\hline Nevada & $1: 24,000$ & 1952 \\
\hline Arizona & $1: 48,000$ & ca. 1936 \\
\hline Arizona & $1: 48,000$ & 1944 \\
\hline Arizona & $1: 48,000$ & 1961 \\
\hline Arizona & $1: 48,000$ & 1927 \\
\hline Arizona & $1: 48,000$ & 1927 \\
\hline Arizona & $1: 48,000$ & 1939 \\
\hline Arizona & $1: 48,000$ & 1939 \\
\hline Arizona & $1: 48,000$ & 1948 \\
\hline Arizona & $1: 48,000$ & 1948 \\
\hline Arizona & $1: 48,000$ & 1961 \\
\hline Arizona & $1: 48,000$ & 1960 \\
\hline Arizona & $1: 48,000$ & 1960 \\
\hline Alaska & $1: 62,500$ & 1906 \\
\hline Washington & $1: 31,680$ & ca. 1930 \\
\hline Washington & $1: 31,680$ & ca. 1930 \\
\hline Washington & $1: 31,680$ & ca. 1930 \\
\hline Washington & $1: 31,680$ & ca. 1930 \\
\hline Wyoming & $1: 25,000$ & 1931 \\
\hline Wyoming & $1: 48,000$ & ca. 1935 \\
\hline Wyoming & $1: 62,500$ & 1948 \\
\hline Wyoming & $1: 62,500$ & 1951 \\
\hline Wyoming & $1: 62,500$ & 1958 \\
\hline Wyoming & $1: 62,500$ & 1958 \\
\hline
\end{tabular}


Grand Teton [oversized]

Grand Teton National Park

Grand Teton National Park

*Grand Teton National Park

Grand Teton National Park (shaded relief)

Grand Teton National Park

Grass Valley

Great Plains (Northern)

Great Sand Dunes National Monument

*Great Sand Dunes National Monument

Great Smoky Mountains National Park Proposed (23 sheets)

Great Smoky Mountains National Park

Great Smoky Mountains National Park (west half)

Great Smoky Mountains National Park (east half)

Great Smoky Mountains National Park (west half)

Great Smoky Mountains National Park (east half)

Great Smoky Mountains National Park (west half)

Great Smoky Mountains National Park (east half)

Great Smoky Mountains National Park (west half)

Great Smoky Mountains National Park (east half)

Great Smoky Mountains National Park and Vicinity

Great Smoky Mountains National Park and Vicinity (shaded relief)

Great Smoky Mountains National Park and Vicinity (shaded relief)

Great Smoky Mountains National Park and Vicinity

Great Smoky Mountains National Park and Vicinity (shaded relief)

Grimes Pass and Vicinity

Grinnell Glacier

Guilford Court House Battlefield and National Military Park

Hampton Roads and Vicinity

Helena

Herbert Domain (Tennessee State Coal Land)

*Hinsdale

*Hot Springs and Vicinity

Idaho Springs

Idaho Springs

Idaho-Washington Boundary Line

Idaho-Washington Boundary Line [oversized]

Independence Pass and Vicinity

Iron Mountain and Vicinity

Ironton and Vicinity

Iron Springs

Isle Royale (sheet 1) [oversized]

Isle Royale (sheet 2) [oversized]

Isle Royale National Park [oversized]

*Jasper County (mines)

Jasper County (mines)

Joplin District

Kellogg and Vicinity

\begin{tabular}{|c|c|c|}
\hline Wyoming & $1: 62,500$ & 1968 \\
\hline Wyoming & $1: 62,500$ & 1948 \\
\hline Wyoming & $1: 62,500$ & 1951 \\
\hline Wyoming & $1: 62,500$ & 1968 \\
\hline Wyoming & $1: 62,500$ & 1968 \\
\hline Wyoming & $1: 125,000$ & 1931 \\
\hline California & $1: 14,400$ & 1901 \\
\hline \multicolumn{3}{|l|}{ North Central } \\
\hline United States-Canada & $1: 2,000,000$ & 1926 \\
\hline Colorado & $1: 24,000$ & ca. 1937 \\
\hline Colorado & $1: 24,000$ & 1938 \\
\hline North Carolina-Tennessee & $1: 24,000$ & 1928-31 \\
\hline North Carolina-Tennessee & $1: 24,000$ & 1930 \\
\hline North Carolina-Tennessee & $1: 62,500$ & 1931 \\
\hline North Carolina-Tennessee & $1: 62,500$ & 1931 \\
\hline North Carolina-Tennessee & $1: 62,500$ & 1934 \\
\hline North Carolina-Tennessee & $1: 62,500$ & 1934 \\
\hline North Carolina-Tennessee & $1: 62,500$ & 1947 \\
\hline North Carolina-Tennessee & $1: 62,500$ & 1947 \\
\hline North Carolina-Tennessee & $1: 62,500$ & 1958 \\
\hline North Carolina-Tennessee & $1: 62,500$ & 1958 \\
\hline North Carolina-Tennessee & $1: 125,000$ & 1949 \\
\hline North Carolina-Tennessee & $1: 125,000$ & 1949 \\
\hline North Carolina-Tennessee & $1: 125,000$ & 1950 \\
\hline North Carolina-Tennessee & $1: 125,000$ & 1972 \\
\hline North Carolina-Tennessee & $1: 125,000$ & 1961 \\
\hline Idaho & $1: 24,000$ & ca. 1933 \\
\hline Montana & $1: 4,800$ & 1953 \\
\hline North Carolina & $1: 1,200$ & ca. 1934 \\
\hline Virginia & $1: 24,000$ & 1919 \\
\hline Montana & $1: 62,500$ & 1899 \\
\hline Tennessee & $1: 24,000$ & 1911 \\
\hline Montana & $1: 62,500$ & 1904 \\
\hline Arkansas & $1: 62,500$ & 1911 \\
\hline Colorado & $1: 12,000$ & 1906 \\
\hline Colorado & $1: 12,000$ & 1946 \\
\hline Idaho-Washington & $1 \mathrm{in.}=1.5 \mathrm{mi}$. & ca. 1908 \\
\hline Idaho-Washington & $1: 62,500$ & 1911 \\
\hline Colorado & $1: 48,000$ & 1932 \\
\hline California & $1: 20,000$ & ca. 1904 \\
\hline Colorado & 1:12,000 & ca. 1930 \\
\hline Utah & $1: 62,000$ & 1906 \\
\hline Michigan & $1: 31,680$ & ca. 1931 \\
\hline Michigan & $1: 31,680$ & ca. 1931 \\
\hline Michigan & $1: 62,500$ & 1957 \\
\hline Missouri & $1: 15,840$ & ca. 1919 \\
\hline Missouri & $1: 15,840$ & ca. 1922 \\
\hline Missouri-Kansas & $1: 62,500$ & 1906 \\
\hline Idaho & $1: 24,000$ & ca. 1937 \\
\hline
\end{tabular}


Kelly Field and Camp Travis

*Kern River Oil Field (north sheet)

Kern River Oil Field (north sheet)

Kern River Oil Field (south sheet)

King Hill Area

Kirkland

Kittitas Drainage District (north)

Kittitas Drainage District (south sheet 1)

Kittitas Drainage District (south sheet 2)

Kootenai River (sheets 3-9)

Kramer Borate District

La Barge

Lake County (portion of)

Lake Okeechobee

Langley Field

Lassen Peak

Lassen Volcanic National Park

Lassen Volcanic National Park

Lassen Volcanic National Park

Lassen Volcanic National Park

Lassen Volcanic National Park

Lassen Volcanic National Park

Lassen Volcanic National Park

Lassen Volcanic National Park and Vicinity (shaded relief)

Leadville

Leadville Mining District [oversized]

Leadville Mining District

Leadville No. 4

Leadville and Vicinity

Leonardville (south half)

Lewisburg Prison, proposed site

Lewisburg Prison, proposed reservation

Lincoln National Forest

Little Eightmile Mining District

Lonesome

Magdalena District

Magdalena District

Magdalena District

Mammoth Cave National Park

Mammoth Cave National Park (proposed)

Manhattan (north half)

Manhattan (south half)

Manhattan and Vicinity

Manitou

Manitou

Marquette

Marysville

Marysville

*Marysville Buttes and Vicinity

Menominee

Mesa Verde National Park

Mesa Verde National Park

Mesa Verde National Park
Texas

California

California

California

Idaho

New Mexico

Washington

Washington

Washington

Idaho

California

Wyoming

Tennessee

Florida

Virginia

California

California

California

California

California

California

California

California

California

Colorado

Colorado

Colorado

Colorado

Colorado

Kansas

Pennsylvania

Pennsylvania

New Mexico

Idaho

Montana

New Mexico

New Mexico

New Mexico

Kentucky

Kentucky

Kansas

Kansas

Nevada

Colorado

Colorado

Michigan

Montana

Montana

California

Michigan

Colorado

Colorado

Colorado
1:62,500

1:12,000

$1: 12,000$

1:12,000

$1: 24,000$

1:96,000

1:12,000

$1: 12,000$

1:12,000

$1: 12,000$

1:24,000

1:96,000

$1: 48,000$

$1: 63,360$

$1: 62,500$

$1: 250,000$

1:48,000

1:48,000

1:48,000

1:48,000

1:48,000

$1: 48,000$

1:62,500

1:62,500

$1: 9,600$

1:9,600

1:9,600

1:48,000

1:62,500

$1: 20,000$

1:1,200

$1: 4,800$

1:250,000

1:48,000

1:62,500

$1: 12,000$

$1: 12,000$

$1: 12,000$

$1: 31,680$

$1: 31,680$

$1: 20,000$

1:20,000

1:24,000

1:48,000

1:48,000

1:24,000

$1: 31,250$

$1: 31,250$

$1: 62,500$

$1: 62,500$

1:31,250

$1: 31,250$

$1: 31,250$
1918

1906

1915

1915

1948

ca. 1929

1941

1941

1941

ca. 1928

ca. 1932

1936

ca. 1928

ca. 1913

1918

1886

ca. 1926

1926

1929

1931

1939

1949

1957

1957

1910

1913

1913

ca. 1934

n.d.

ca. 1928

1930

1930

1948

1931

1906

1912

1932

1948

1930

1933

1928

1928

1916

1921

1936

ca. 1905

1901

1925

n.d.

1901

1915

1928

1936 


\author{
Mesa Verde National Park \\ * Mesa Verde National Park (panoramic) \\ Mesa Verde National Park \\ Mexican Springs Area \\ Miami Copper Belt \\ Miami Copper Belt \\ Mississippi River Valley (below Dubuque, Iowa) \\ Mohave City \\ Mono Lake and Vicinity \\ Mono Lake and Vicinity \\ Moon Mountain \\ Morristown National Historical Park \\ Mount Baker \\ Mount Hood and Vicinity \\ Mount Hood and Vicinity \\ Mount McKinley \\ Mount McKinley \\ Mount Rainier \\ Mount Rainier \\ Mount Rainier \\ Mount Rainier \\ *Mount Rainier \\ Mount Rainier \\ Mount Rainier \\ Mount Washington and Vicinity \\ Mullen and Vicinity \\ Mullen and Vicinity \\ National Bison Range \\ National Bison Range \\ National Bison Range \\ Naval Petroleum Reserve No. 1 \\ Naval Petroleum Reserve No. 1 \\ Nevada City \\ New Jersey Coast (4 sheets) \\ New Mexico, South Eastern \\ New Mexico, South Eastern \\ New Mexico, South Eastern \\ Niagara Falls \\ Niagara Gorge \\ Niagara River and Vicinity \\ Niagara River and Vicinity \\ Nisqually Glacier \\ Nisqually Glacier \\ Nisqually Glacier \\ Nisqually Glacier \\ Nisqually Glacier \\ Oahu (Island) \\ Oatman District \\ Ogema \\ Oil Center \\ Oil Center (South Sheet) \\ Old Dominion \\ Old Dominion \\ Olympic National Park and Vicinity
}

\begin{tabular}{|c|c|c|}
\hline Colorado & $1: 31,250$ & 1954 \\
\hline Colorado & $1: 31,250$ & n.d. \\
\hline Colorado & $1: 45,000$ & n.d. \\
\hline New Mexico & $1: 24,000$ & 1934 \\
\hline Arizona & $1: 12,000$ & 1912 \\
\hline Arizona & $1: 12,000$ & 1948 \\
\hline Iowa to Louisiana & $1: 1,000,000$ & 1927 \\
\hline Nevada & $1: 96,000$ & ca. 1926 \\
\hline California & $1: 125,000$ & 1939 \\
\hline California & $1: 125,000$ & 1950 \\
\hline Arizona & $1: 48,000$ & ca. 1927 \\
\hline New Jersey & $1: 9,600$ & 1934 \\
\hline Washington & $1: 250,000$ & 1947 \\
\hline Oregon-Washington & $1: 125,000$ & 1929 \\
\hline Oregon-Washington & $1: 125,000$ & 1948 \\
\hline Alaska & $1: 250,000$ & 1952 \\
\hline Alaska & $1: 250,000$ & 1972 \\
\hline Washington & $1: 62,500$ & 1913 \\
\hline Washington & $1: 62,500$ & 1915 \\
\hline Washington & $1: 62,500$ & 1923 \\
\hline Washington & $1: 62,500$ & 1934 \\
\hline Washington & $1: 62,500$ & 1938 \\
\hline Washington & $1: 62,500$ & 1947 \\
\hline Washington & $1: 62,500$ & 1955 \\
\hline New Hampshire-Maine & $1: 62,500$ & 1896 \\
\hline Idaho & $1: 24,000$ & 1942 \\
\hline Idaho & $1: 24,000$ & 1943 \\
\hline Montana & $1: 24,000$ & 1929 \\
\hline Montana & $1: 31,680$ & 1932 \\
\hline Montana & $1: 31,680$ & 1949 \\
\hline California & $1: 31,680$ & 1930 \\
\hline California & $1: 31,680$ & 1952 \\
\hline California & $1: 14,400$ & 1893 \\
\hline New Jersey & $1: 62,500$ & 1890 \\
\hline New Mexico & $1: 190,080$ & 1936 \\
\hline New Mexico & $1: 190,080$ & 1937 \\
\hline New Mexico & $1: 253,440$ & 1953 \\
\hline New York & $1: 62,500$ & 1921 \\
\hline New York-Canada & $1: 12,000$ & 1930 \\
\hline New York-Canada & $1: 62,500$ & 1911 \\
\hline New York-Canada & $1: 62,500$ & 1932 \\
\hline Washington & $1: 9,600$ & ca. 1946 \\
\hline Washington & $1: 10,000$ & 1976 \\
\hline Washington & $1: 12,000$ & 1955 \\
\hline Washington & $1: 12,000$ & 1959 \\
\hline Washington & $1: 12,000$ & 1961 \\
\hline Hawaii & $1: 62,500$ & 1917 \\
\hline Arizona & $1: 24,000$ & ca. 1917 \\
\hline Wisconsin & $1: 48,000$ & 1944 \\
\hline California & $1: 12,000$ & 1906 \\
\hline California & $1: 12,000$ & 1906 \\
\hline Arizona & $1: 12,000$ & 1917 \\
\hline Arizona & $1: 12,000$ & 1948 \\
\hline Washington & $1: 125,000$ & 1957 \\
\hline
\end{tabular}




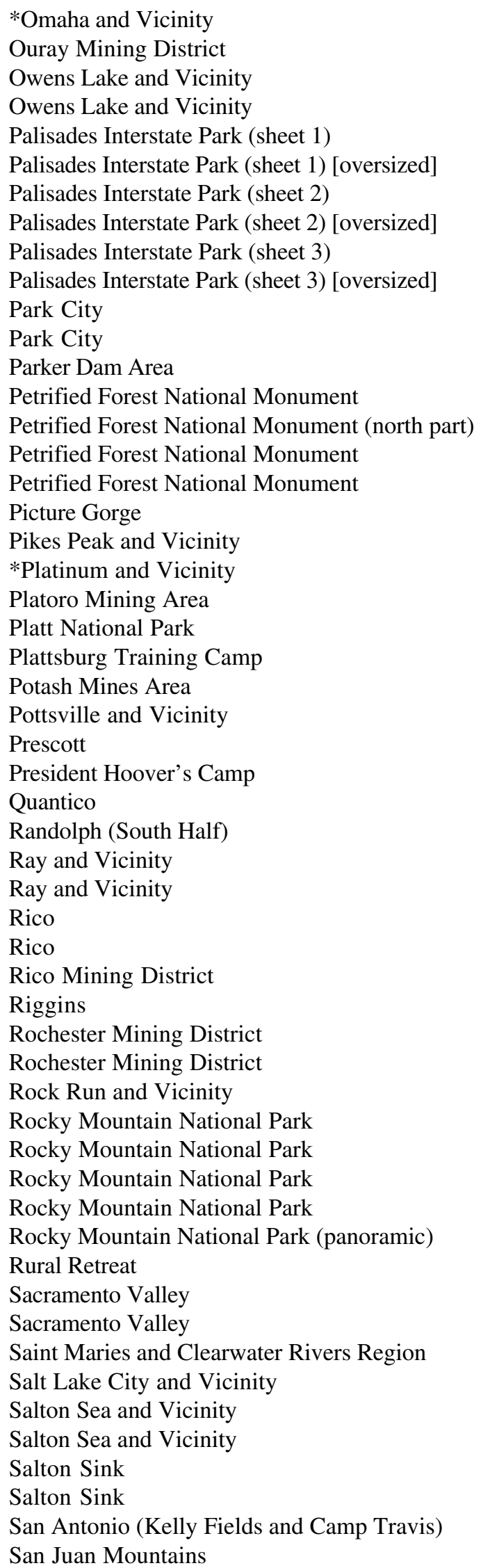

\begin{tabular}{|c|c|c|}
\hline Nebraska-Iowa & $1: 62,500$ & 1898 \\
\hline Colorado & $1: 12,000$ & 1930 \\
\hline California & $1: 125,000$ & 1939 \\
\hline California & $1: 125,000$ & 1951 \\
\hline New York & $1: 12,000$ & 1928 \\
\hline New York & $1: 12,000$ & 1928 \\
\hline New York & $1: 12,000$ & 1928 \\
\hline New York & $1: 12,000$ & 1928 \\
\hline New York & $1: 12,000$ & 1928 \\
\hline New York & $1: 12,000$ & 1928 \\
\hline Utah & $1: 25,000$ & 1903 \\
\hline Utah & $1: 25,000$ & 1927 \\
\hline California & $1: 62,500$ & 1950 \\
\hline Arizona & $1: 48,000$ & ca. 1934 \\
\hline Arizona & $1: 48,000$ & ca. 1934 \\
\hline Arizona & $1: 50,000$ & 1981 \\
\hline Arizona & $1: 62,500$ & 1939 \\
\hline Oregon & $1: 48,000$ & ca. 1925 \\
\hline Colorado & $1: 62,500$ & 1956 \\
\hline Alaska & $1: 62,500$ & 1937 \\
\hline Colorado & $1: 12,000$ & ca. 1936 \\
\hline Oklahoma & $1: 6,000$ & 1909 \\
\hline New York & $3 \mathrm{in} .=1 \mathrm{mi}$. & 1917 \\
\hline New Mexico & $1: 48,000$ & ca. 1935 \\
\hline Idaho-Montana & $1: 24,000$ & 1939 \\
\hline Arizona & $1: 63,360$ & 1948 \\
\hline Virginia & $1: 12,000$ & 1929 \\
\hline Virginia & $1: 10,000$ & 1933 \\
\hline Kansas & $1: 20,000$ & 1928 \\
\hline Arizona & $1: 12,000$ & 1912 \\
\hline Arizona & $1: 12,000$ & 1919 \\
\hline Colorado & $1: 23,600$ & 1899 \\
\hline Colorado & $1: 23,600$ & 1916 \\
\hline Colorado & $1: 12,000$ & 1930 \\
\hline Idaho & $1: 96,000$ & 1938 \\
\hline Nevada & $1: 24,000$ & 1916 \\
\hline Nevada & $1: 24,000$ & 1940 \\
\hline Alabama-Georgia & $1: 24,000$ & ca. 1941 \\
\hline Colorado & $1: 62,500$ & 1961 \\
\hline Colorado & $1: 125,000$ & 1931 \\
\hline Colorado & $1: 125,000$ & 1937 \\
\hline Colorado & $1: 125,000$ & 1951 \\
\hline Colorado & $1: 125,000$ & n.d. \\
\hline Virginia & $1: 48,000$ & 1931 \\
\hline California & $1: 250,000$ & 1911 \\
\hline California & $1: 250,000$ & 1913 \\
\hline Idaho & $1: 125,000$ & 1920 \\
\hline Utah & $1: 24,000$ & ca. 1934 \\
\hline California & $1: 62,500$ & 1928 \\
\hline California & $1: 62,500$ & 1944 \\
\hline California & $1: 500,000$ & 1921 \\
\hline California & $1: 500,000$ & 1947 \\
\hline Texas & $1: 62,500$ & 1918 \\
\hline Colorado & $1: 200,000$ & ca. 1923 \\
\hline
\end{tabular}


Santa Rita

Santa Rita

Santa Rita

Scotts Bluff National Monument

Scotts Bluff National Monument

Seattle (land classification)

Sequoia National Park (administrative map)

Sequoia and General Grant National Parks

Sequoia and General Grant National Parks

Sequoia and General Grant National Parks

Sequoia and General Grant National Parks

Sequoia and Kings Canyon National Parks

Sequoia and Kings Canyon National Parks

*Sequoia and Kings Canyon National Parks

Sequoia and Kings Canyon National Parks and Vicinity (shaded relief)

Seven Devils Mining District

Shasta Valley (sheets 1-16)

Shenandoah National Park (23 sheets, proposed)

Shenandoah National Park (north half, proposed)

Shenandoah National Park (south half, proposed)

*Shenandoah National Park (north half, proposed)

*Shenandoah National Park (south half, proposed)

Shenandoah National Park (north half)

Shenandoah National Park (south half)

Shenandoah National Park

Shenandoah National Park (proposed)

Shiloh National Military Park

Silver Plume

Silver Plume

Silverton and Vicinity

Smelterville and Vicinity

Snowmass Mountain and Vicinity

Snowmass Mountain and Vicinity

Southern California

Southern California \#1

Southern California \#1

Southern California \#1

Southern California \#2

Southern California \#2

Southern California \#3

Southern California \#3

Sperry Glacier

Sperry Glacier

Spring City Mining District

Sugarloaf-Saint Kevin Mining Districts

Summitville Mining Area

Superior Coal District

Tacoma (land classification)

Taos and Vicinity

Taylorsville

Taylorsville

Telluride Mining District

Tenmile District
New Mexico

New Mexico

New Mexico

Nebraska

Nebraska

Washington

California

California

California

California

California

California

California

California

California

Idaho-Oregon

California

Virginia

Virginia

Virginia

Virginia

Virginia

Virginia

Virginia

Virginia

Virginia

Tennessee

Colorado

Colorado

Colorado

Idaho

Colorado

Colorado

California

California

California

California

California

California

California

California

Montana

Montana

Missouri

Colorado

Colorado

Wyoming

Washington

New Mexico

California

California

Colorado

Colorado
1:24,000 $\quad 1909$

$1: 24,000 \quad 1937$

$1: 24,000 \quad 1946$

$1: 15,840 \quad 1939$

$1: 15,840 \quad 1944$

1:125,000 $\quad 1900$

1 in. $=1$ mi. n.d.

1:125,000 1909

$1: 125,000 \quad 1910$

$1: 125,000 \quad 1930$

$1: 125,000 \quad 1938$

$1: 125,000 \quad 1953$

$1: 125,000 \quad 1956$

$1: 125,000 \quad 1958$

$1: 125,000 \quad 1958$

$1: 48,000 \quad 1920$

$1: 24,000 \quad 1922$

$1: 24,000 \quad$ ca. 1927

$1: 62,500 \quad 1933$

$1: 62,500 \quad 1933$

$1: 62,500 \quad 1934$

$1: 62,500 \quad 1934$

$1: 62,500 \quad$ ca. 1930

$1: 62,500 \quad$ ca. 1930

$1: 72,000 \quad 1933$

$1: 125,000 \quad 1926$

$1: 9,600 \quad 1934$

$1: 12,000 \quad 1906$

$1: 12,000 \quad 1948$

$1: 12,000 \quad$ ca. 1931

$1: 24,000 \quad 1942$

$1: 31,680 \quad$ ca. 1930

$1: 31,680 \quad 1950$

$1: 250,000 \quad 1907$

$1: 250,000 \quad 1912$

$1: 250,000 \quad 1921$

$1: 250,000 \quad 1948$

$1: 250,000 \quad 1924$

$1: 250,000 \quad 1948$

$1: 250,000 \quad 1931$

$1: 250,000 \quad 1948$

$1: 4,800 \quad 1953$

$1: 6,000 \quad 1960$

1:24,000 ca. 1916

$1: 24,000 \quad$ ca. 1930

1:12,000 ca. 1936

$1: 24,000 \quad 1943$

$1: 125,000 \quad 1900$

$1: 125,000 \quad 1944$

$1: 31,680 \quad 1893$

$1: 31,680 \quad 1940$

$1: 12,000 \quad 1929$

$1: 31,680 \quad 1914$ 
Tenmile Mining District (north half)

Tenmile Mining District (south half)

Tennessee River Basin

Tennessee River Basin and adjoining areas (mineral resources)

Terlingua

Terlingua

Terlingua

Tintic Mining

Tintic Mining District

Tintic Mining (locator map)

Tinton and Vicinity

Tobias Peak (east half)

Tombstone

Tombstone

Tombstone and Vicinity

Tombstone Mining Map

Tongass National Forest

Tongass National Forest

Tonopah

Tuxekan

Tyrone

Tyrone

Valdez and Vicinity

Vanderbilt Mansion National Historic Site

Vicksburg National Military Park

Virginia Mining District

Wallace and Vicinity

Ward-Sunset Mining Area

White City, Kansas (north half)

White City, Kansas (south half)

Willamette Valley (8 sheets)

Willow Creek

Wind Cave National Park

Wind Cave National Park and Vicinity

Winnebago

Woodbine (north half)

Woodbine (south half)

Yellowstone National Park

Yellowstone National Park

Yellowstone National Park

Yellowstone National Park (administrative map)

Yellowstone National Park (shaded relief)

Yellowstone National Park, Cañon Sheet

Yellowstone National Park, Canyon Sheet

Yellowstone National Park, Canyon Sheet

Yellowstone National Park, Gallatin Sheet

Yellowstone National Park, Gallatin Sheet

Yellowstone National Park, Gallatin Sheet

Yellowstone National Park, Lake Sheet

Yellowstone National Park, Lake Sheet

Yellowstone National Park, Lake Sheet

Yellowstone National Park, Shoshone Sheet

Yellowstone National Park, Shoshone Sheet

\begin{tabular}{|c|c|c|}
\hline Colorado & $1: 12,000$ & 1942 \\
\hline Colorado & $1: 12,000$ & 1942 \\
\hline Tennessee & $1: 1,000,000$ & 1920 \\
\hline Tennessee & $1: 500,000$ & 1933 \\
\hline Texas & $1: 50,000$ & 1902 \\
\hline Texas & $1: 50,000$ & 1929 \\
\hline Texas & $1: 125,000$ & 1904 \\
\hline Utah & $1: 9,600$ & 1898 \\
\hline Utah & $1: 9,600$ & 1913 \\
\hline Utah & $1: 250,000$ & 1902 \\
\hline South Dakota-Wyoming & $1: 24,000$ & 1944 \\
\hline California & $1: 96,000$ & ca. 1936 \\
\hline Arizona & $1: 24,000$ & 1906 \\
\hline Arizona & $1: 24,000$ & 1942 \\
\hline Arizona & $1: 6,000$ & 1948 \\
\hline Arizona & $1: 6,000$ & 1908 \\
\hline Alaska & $1 \mathrm{in.}=12 \mathrm{mi}$. & 1946 \\
\hline Alaska & $1 \mathrm{in.}=12 \mathrm{mi}$. & 1951 \\
\hline Nevada & $1: 12,000$ & 1910 \\
\hline Alaska & $1: 62,500$ & 1948 \\
\hline New Mexico & $1: 24,000$ & 1922 \\
\hline New Mexico & $1: 24,000$ & 1948 \\
\hline Alaska & $1: 62,500$ & 1930 \\
\hline New York & $1: 3,600$ & 1946 \\
\hline Mississippi & $1: 9,600$ & 1935 \\
\hline New Mexico & $1: 24,000$ & 1931 \\
\hline Idaho & $1: 24,000$ & ca. 1937 \\
\hline Colorado & $1: 24,000$ & ca. 1937 \\
\hline Kansas & $1: 20,000$ & ca. 1927 \\
\hline Kansas & $1: 20,000$ & ca. 1927 \\
\hline Oregon & $1: 31,680$ & ca. 1909 \\
\hline Wyoming & $1: 24,000$ & 1945 \\
\hline South Dakota & $1: 24,000$ & ca. 1934 \\
\hline South Dakota & $1: 24,000$ & 1957 \\
\hline Wisconsin & $1: 62,500$ & 1911 \\
\hline Kansas & $1: 20,000$ & ca. 1927 \\
\hline Kansas & $1: 20,000$ & ca. 1927 \\
\hline Wyoming-Montana-Idaho & $1: 125,000$ & 1930 \\
\hline Wyoming-Montana-Idaho & $1: 125,000$ & 1954 \\
\hline Wyoming-Montana-Idaho & $1: 125,000$ & 1961 \\
\hline Wyoming-Montana-Idaho & $1: 125,000$ & 1912 \\
\hline Wyoming-Montana-Idaho & $1: 125,000$ & 1961 \\
\hline Wyoming & $1: 125,000$ & 1886 \\
\hline Wyoming & $1: 125,000$ & 1901 \\
\hline Wyoming & $1: 125,000$ & 1907 \\
\hline Wyoming & $1: 125,000$ & 1886 \\
\hline Wyoming & $1: 125,000$ & 1901 \\
\hline Wyoming & $1: 125,000$ & 1908 \\
\hline Wyoming & $1: 125,000$ & 1886 \\
\hline Wyoming & $1: 125,000$ & 1901 \\
\hline Wyoming & $1: 125,000$ & 1906 \\
\hline Wyoming & $1: 125,000$ & 1886 \\
\hline Wyoming & $1: 125,000$ & 1908 \\
\hline
\end{tabular}


Yellowstone National Park (panoramic map)

Yerington

Yerington

Yorktown Battlefield (east sheet)

Yorktown Battlefield

Yosemite National Park (administrative map)

Yosemite National Park (administrative map)

Yosemite National Park

Yosemite National Park

Yosemite National Park

Yosemite National Park and Vicinity

Yosemite National Park (panoramic map)

Yosemite Valley

Yosemite Valley

Yosemite Valley (shaded relief)

Yosemite Valley

Yosemite Valley (shaded relief)

Yosemite Valley [drawn by J. T. G.]

Zion (canyon section)

*Zion (canyon section)

Zion National Monument (northern part)

$\begin{array}{lll}\text { Wyoming-Montana-Idaho } & 1: 187,500 & \text { n.d. } \\ \text { Nevada } & 1: 24,000 & 1915 \\ \text { Nevada } & 1: 24,000 & 1951 \\ \text { Virginia } & 1: 4,800 & 1931 \\ \text { Virginia } & 1: 9,600 & 1931 \\ \text { California } & 1: 125,000 & 1909 \\ \text { California } & 1: 125,000 & 1910 \\ \text { California } & 1: 125,000 & 1932 \\ \text { California } & 1: 125,000 & 1948 \\ \text { California } & 1: 125,000 & 1953 \\ \text { California } & 1: 125,000 & 1958 \\ \text { California } & 1: 187,500 & \text { n.d. } \\ \text { California } & 1: 24,000 & 1922 \\ \text { California } & 1: 24,000 & 1949 \\ \text { California } & 1: 24,000 & 1949 \\ \text { California } & 1: 24,000 & 1958 \\ \text { California } & 1: 24,000 & 1958 \\ \text { California } & --- & 1865 \\ \text { Utah } & 1: 31,680 & 1957 \\ \text { Utah } & 1: 31,680 & 1964 \\ \text { Utah } & 1: 31,680 & 1946\end{array}$




\section{Appendix 23}

National Mapping Division - Plans and Coordination Branch - Administrative Files, 1942-60 (entry 405)

Miscellaneous memorandums to Atlantic Region and Central Region Engineers, 1950-53

Miscellaneous memorandums to Rocky Mountain Region Engineer, XA and XB Projects, and Pacific Region Engineer, 1948-53

Aerial photography for regions, 1949-53

Allotments and expenditures for regions, 1950-53

Bureau of Reclamation mapping for regions, 1949-53

Equipment for regions, 1948-53

Helicopter contracts, Rocky Mountain and Pacific Regions, 1948-57 (2 files)

Miscellaneous requisitions for regions and Washington Office, 1953-57

Office space for regions and Washington Office, 1949-57 (2 files)

Personnel for regions, 1949-56

Personnel, Plans and Coordination Branch, 1946-55 (2 files)

Personnel, bulletins, pamphlets and memorandums, 1952-59

Production control for regions, 1951-53

Projects done for the Army for regions, 1949-53

Cooperation - Atlantic Region, Connecticut, Delaware, Washington D. C., Georgia, and Indiana, 1946-53

Cooperation - Atlantic Region, Kentucky, 1948, 1950-53 (1 file and 1 bundle)

Cooperation - Atlantic Region, Maine, Maryland, Massachusetts, New Hampshire, New Jersey, New York, North Carolina, and Ohio, 1945-53 (1 file and 1 booklet)

Cooperation - Atlantic Region, Pennsylvania, Puerto Rico, South Carolina, Tennessee, Vermont, Virginia, Virgin Islands, 1946-53

Cooperation - Central Region, Alabama, Arkansas, Florida, Kansas, Iowa, Illinois, Louisiana, Mississippi, 1946-53

Cooperation - Central Region, Minnesota, Missouri, Nebraska, North Dakota, Oklahoma, South Dakota, Wisconsin, 1948-53 (1 file and 1 stapled report)

Cooperation - Rocky Mountain Region, Colorado, Montana, New Mexico, Wyoming, Texas, 1949-53

Cooperation - Rocky Mountain Region, Alaska, 1950-58 (3 files)

Cooperation - Pacific Region, Utah, Washington, Hawaii, 1949-53

Cooperation, Federal agencies - Atomic Energy Commission, US Air Force - Aeronautical Chart and Information Center, Forest Service, Department of Justice, US Navy, and Department of Agriculture, 1946-54

Topographic Division, fiscal procedures, 1948-53

Coast and Geodetic Survey, maps, 1947

Cooperation - Interior Department, Office of the Secretary, and Office of Territories, 1948-54

Cooperation - Interior Department, Bureau of Reclamation, National Park Service, Bureau of Mines, Bureau of Land Management, Bureau of Indian Affairs, 1945-54 (1 file, 1 booklet, and 1 unbound table)

Cooperation, USGS - Conservation Division, Geologic Division, Publications Office, and Water Resources Division, $1946-53$

Cooperation - Interior Department, Centennial Celebration, 1949

Management Improvement, Geological Survey, 1950-52

Memorandums and letters from Topographic Branches and units to Branch of Accounts, Branch of Map Distribution, Field Equipment, Topographic Division, and Information Officer; and miscellaneous letters from Survey divisions, 1946-53

Equipment - Office Equipment, elevation meter, helicopters, and stereo and photogrammetric equipment, 1946-55 ( 1 file and 2 booklets)

Reports and statistics, annual report for the Secretary, 1949-56

Topographic Division, articles and papers on topographic mapping, 1944-53 (1 file and 1 bundle)

Topographic Division, Security regulations, 1947-54

Topographic Division, technical memorandums of instructions, ca. 1942-49

Map distribution - sales and discontinuation, 1953-57 
Map production - schedule, 1956-58

Map production - progress on Federal Civil Defense Administration mapping, 1956-57

Map production - progress on miscellaneous mapping, 1955-58

Map production - Employee Operations Reports, 1953-59

Map production - miscellaneous mapping, 1954-56

Map production - costs, 1953-59

Map production - production, 1953-55

Map production - reports of 30th Engineer Battalion; monthly preparation of military and civil editions, 1953-58

Map production - machine tabulation and code numbers, 1953-56

Topographic Division, outside publications of interest to Topographic Engineers, report on the

Chief Topographic Engineer's field inspection trip 1950, miscellaneous letters written by

Cartography and Editing Section, 1948-53

Publicity, definitions for type mapping, policy statements, 1948-53

Topographic Division, map uses, specific cases, 1948-53

Pending legislation, 1947-52

House of Representatives booklets, ca. 1949-51

Topographic surveys - design calibration and instructions for use of equipment; drafting; features; domestic geographic names; Albuquerque Project, New Mexico; Colorado River Boundary Project; Devils Tower Project, Wyoming; New York, New Jersey, Connecticut, and Long Island, revision projects, 1953-60

Topographic surveys, Special Projects - Death Valley Project, California; El Cajon Project, California; Western Montana Project; Navy Oil Project; Cape Hatteras, North Carolina; Grand Canyon Project, Arizona; Sabine River Project, Texas; and Scribing, 1953-56

Topographic surveys - aerial photography, 1953-57

Topographic surveys - vehicles, 1951-57

From the Research and Technical Control Branch, miscellaneous memorandums to and from

Photogrammetry Section, Topographic Surveys Section, Geodesy Section, and Special Maps Branch, 1946-53 (1 file and 1 folder of booklets)

Information - film strips, motion pictures, policy, photographs, routine information, 1951-58

Information - publications of outside organizations, request for clearance before publication, and Boy Scout correspondence, 1953-58

Information - distribution and sale of USGS publications, 1951-57

Committees - Alaska Program, 1949-53

Committees - Alaska Program reports, 1951-52 (2 files)

Special projects - 1/1:000,000 scale maps; public works; Great Smoky Mountains National Park; Shenandoah National Park; Bureau of Reclamation; Department of Agriculture, 1947-51

"American Highways", October 1952 issue

Special projects - Missouri River Basin, 1946-50

Special projects - Missouri River Basin, field committee, 1946-49

Special projects - Missouri River Basin, reports, 1947-53

Special projects - Colorado River Basin, Columbia River Basin, 1946-53

Colorado River-Great Basin Region, reports, 1950-52 (4 items)

Columbia River Basin, report, 1949

Committees - Colorado River-Great Basin, committees, 1950-53

Committees - field committee representatives, field committee program reports, 1948-53

Mapping, Alaska, 1948-50

Alaska Committee, 1950-55

Committees - Pacific Northwest Field Committee; Pacific Northwest Coordination Committee; Pacific Central Field Committee, 1948-53 (1 file and 1 booklet)

Reed, Alaska Field Plan reports, 1948-57

Budget - budget justification, 1947-57 (4 files)

Budget - maps to accompany estimates for 1952, and the President's message for 1952

Budget pamphlets, ca. 1948

Budget - miscellaneous budget material, funds, estimates, etc.; report on topographic mapping, 20-year program; and Dr. Mahoney, Library of Congress, 1947-53 
Budget - analysis of obligations, 1953-55

Budget - regional costs (includes direct and indirect costs); and procedures for programming and coordination of topographic mapping, 1947-52

Committees - Inter-agency River Basin Committee, 1951-55 ( 1 file and 1 booklet)

Committees - Inter-agency Committee for the Arkansas-White-Red River Basin, 1950-53 (2 files)

Committees - New York-New England Interagency Committee, 1949-53

Committees - Missouri Basin Field Committee, 1949-53 [1 file and 2 booklets]

Committees - Missouri Basin Inter-agency Committee, river basin reports; Missouri Basin Survey Commission, $1948-53$

Committees - Missouri River Basin Committee, 1953-58

Committees - Pacific Southwest Committee; Pacific Southwest Federal Interagency Technical Committee, 1948-49

Committees - Southwest Field Committee, 1950-51

Committees - Southwest Field Committee, Region 6, 1948-54

Cooperation - Forest Service; Federal Security Agency; Public Health Service; Department of the Navy and Hydrographic Office; Soil Conservation Service; Public Roads Administration; Department of State; and Public Buildings Administration, 1946-53

Committees - SCAP, correspondence, 1948-58

Committees - SCAP, minutes, 1954-58

Committees - program analysis, 1954-56

General Staff Committee, 1949-57

General Staff Committee, review of other agency reports, 1958-59

Committees and meetings, miscellaneous, 1954-58

Committees - SCAP Study, checking, 1958-59

Professional Societies - Association of State Planning and Development Agencies; Pitkin Committee, 1947-49

Professional Societies - Rivers and Harbors Congress; National Reclamation Association; National Academy of Sciences; American Association of State Highway Officials; Association of Western State Engineers, $1946-50$

American Congress of Surveying and Mapping, election of officers, 1952

Correspondence - Plans Unit P\&C Branch, 1948-53

Correspondence - Plans and Estimates Section, P\&C Branch, 1946-53

Correspondence - Coordination and Liaison Section; Map Information Section; and Program Coordination Section, $1949-56$

Conferences - miscellaneous, Plans and Coordination Branch, 1949-56

Programs and Plans - projects, 1953-59

Programs and Plans - military, 1953-59

Programs and Plans - authorizations, 1953-59

Programs and Plans - authorizations and authorizations pending, 1956-58

Organization and management - suggestions and awards, 1948-59

Information - Press Releases and radio releases, 1953-59

Annual Reports of USGS to Secretary, 1946-54 [booklets]

Reports - field trips, 1957-59

Programs and Plans - priorities, 1957-58

Programs and Plans - aerial photo requests, 1956-58

Education, special training programs, foreign, 1953-58

President's Water Policy Commission, 1950-55 [1 file and 2 booklets]

Topographic maps for industrial location, 1956-58

Topographic maps as a tool in resources development, an article, 1958

Visitors schedules, 1954-60

Aerial mapping, 1957

Federal topographic mapping in the south, 1957

Cooperation - Army Map Service, 1946-54

Miscellaneous - memorandums and letters written by Chief, Plans and Coordination Branch,, 1953-54

Miscellaneous booklets 


\section{Appendix 24}

Water Resources Division - General Correspondence Files, 1907-53 (entry 412)

Accounting - Certifying Officers, 1942-44

Accounts - Miscellaneous Memorandums, 1943-48

Accounts - Adjustment of Charges, 1942-48

Activities - Water Resources Division, 1927-53

Addresses at Meetings, ca. 1916-47

Alaska Survey Committee, 1952-53 [minutes]

Alaskan Investigations, 1943-47

Appropriations and Allotments, 1931-47

Articles for Publication, 1932-40

Association of Western State Engineers, 1930-36

Attendance at Scientific Meetings, 1938-48

Attendance at Scientific Meetings, 1949

Attendance at Scientific Meetings, 1950-52

Attendance at Scientific Meetings, 1953

Authorized Certifying Officers, 1948-49

Automobile Accidents, 1928-40

Automobile Accidents, 1939

Automobile Accidents, 1940

Automobile Licenses - 1000 to T50879, Accidents (boxes 6-8)

Automobile Accidents, 1941

Automobile Accidents, 1942-47

Automobile Accidents, 1948

Benefits resulting from Stream Gaging Work, 1926

Bibliography on Theory and Practice of Hydraulics, 1932

Black \& Veath, 1948-53 [consulting engineers]

Bolivian Government, 1945

Bonding Companies, ca. 1942-48

Book Message, 1948-50

Book Message, 1951-52

Book Message, 1953

Books Technical, 1927-41

Branch Exhibit at Reclamation Association Meeting in Oklahoma City, November 1948

Branch Staff conferences and meetings, 1944-46

Budget and Administrative Management, 1943-49

Bureau of Efficiency, 1932

Canadian Government, 1940, 1948-53

Carpenter, Charles, 1950

Chandler, A. E., 1933-38

Checks - canceled and unclaimed, 1945-48

Chief Clerk - Geological Survey, 1941-48

Chief - Conservation Branch, 1916-48

Chief Coordinator, 1921-33

Chief Counsel for Survey, 1940-48

Chief, Ground Water Branch, 1943-52

Chief, Ground Water Branch, 1953

Chief Hydraulic Engineer, 1916-48

Chief - Section of Employment, 1931-48

Chief - Technical Coordination Branch, 1944-53 
Chief Topographic Engineer, 1922-48

Chief - Quality of Water Branch, 1943-53

Claim Case Files, 1952-53

Clearance Officer, 1944-47

Columbus Equipment Laboratory, 1947-48

Committees - Legislative, 1943-44

Committees - Reports of "Committee of One" appraiser of contributions to Water Resources Bulletin, 1932-38

Committees - Pacific Northwest Coordination Committee, 1947 [regionalization of Interior Department in Pacific Northwest]

Committee - San Francisco, 1946-47

Communication Officer, Interior, 1948

Conferences - Branch Chiefs, 1918-48 [minutes of meetings]

Conferences - District Engineers, 1916-47

Conferences - Lincoln, Nebraska, 1946-47

Congressional Delegation and Inspection Trip, 1947

Construction - Interagency Coordinating Committee, 1946

Construction - Interagency Coordinating Committee, Civilian Production Administration, and Veterans Emergency Housing Program, 1946

Cooperating Officials, 1949-52

Cooperation - General, 1926-51

Coordination Committee, 1946-47

Correspondence and Records, 1939-49

Costkeeping, 1922-26

Critchlow, Howard T. (State Water Policy Commission, New Jersey), 1918-40

Damage Claims, 1929-40

Denver Survey Committee, 1952-53

Development Work, 1933-47

Director, 1945-48

Director, 1941-44

Director, 1935-40

Director, 1916-34

Disallowances, 1933-47

Disbursing in the Field, 1944-45

Disbursing in Hawaii, 1925-32

Dispensary, employees, 1947-48

District Engineer Candidates, 1930

Division of Field Equipment, 1940-48

Division of Grazing, 1938-41

Dominion Water and Power Bureau, Canada, 1921-48

East Bay Municipal Utility District, 1927-32

Economy Act, 1932-34

Efficiency Bureau and Ratings, ca. 1919-47

Electrical World, 1921-24

Employment Bulletin, 1946-47

Engineering News-Record, 1920-45

Esso Standard Oil Company, 1948-52

Evaporation Studies, 1931-34

Executive Officer - Geological Survey, 1948

Exhibits and Expositions, 1926-53

Facilities for the Ground Water Branch, 1923-38

Fanfold Forms, 1940

Fathometers, 1944-46

Federal Emergency Relief Administration - Rules, 1933-39

Federal Prison Industries, Inc., 1935-38 
Federal Register, 1946

Federal Gaging Stations and replacement of transferred funds, 1945 (envelope and clipped bundle)

Federal Stations, 1947-48

Federal Type Stations, 1931-44

Federal Type Stations, 1935-46

Films and Lantern Slides, 1922-39

Finger Printing, 1931-45

Fire Marshall, 1929-36

First Aid Outfits, 1934-42

Fish and Wildlife Service, 1933-48

Flood Control Coordinating, 1939-45

Flood Control, 1947

Food Program, 1943

Foreign Assignment, 1951-53

Forest Service, 1910-25, 1931-44

Fowler, Frederick H. (District Engineer, U.S. Forest Service, San Francisco, Calif.), 1919-23

Friez, Julien P., \& Sons, 1923-49

Funds, Advance of, 1926-48

Geologic Branch, 1921-48

Greater Philadelphia - South Jersey Council, 1940-52

"Guinea Pig" letter, 1944 [natural resources of Wyoming]

Gurley, W. \& L. E., 1917-38

Haitian Correspondence, 1921-25

Haskin Service, 1948-53

Home Binding, 1931-32

Hours of Work, 1940-52

Hydraulic Laboratory Studies, 1938-46

Income Tax Return, 1933-40

Index of News Letters and Bulletins of the Water Resources Branch, 1918-32

Indian Office, 1918-48

Information Director, 1943-51

"Inside Interior" Periodical, 1948, 1950

Inspection of Water Resources Branch, 1925-26

Inspection of Field Offices, 1941-42

Instructions, 1939-44

Integrators, 1931-41

Inter-American Conferences, 1944-50

Inventions, 1947-49

Inventory of Property, ca. 1945-49

Inventory of Water Resources, 1925-28

Investigations, Water Resources, 1919, 1947

Itinerary and Correspondence regarding Inspection Tour by Members of House Appropriation Committee, ca. 1930-53 [alphabetically by surname of member of Congress]

Klamath Board of Review, 1922

Lake Survey Catamaran on Niagara River, 1931-37

Land Utilization, 1940-47

Land Utilization, 1948-50

Lees Ferry Mining Situation, 1931-35

Legislation

[J. H.] Levering Correspondence, ca. 1921

Library, 1942-48

Management Services Committee, 1949-53

Manuscript of Inventory of "Unpublished Hydrologic Data," Holland \& Jarvis, USGS Water-Supply Paper 837 [1938], n.d. 
"Marshall Plan" for investigating the water resources of California, 1921

Mexican Treaty, 1922-45

Military Service, etc., 1934-48

Miscellaneous - State File, 1940-44

Miscellaneous - American Society of Civil Engineers, 1939-45

Miscellaneous - Iowa Institute of Hydraulic Research, 1940-44

Miscellaneous, 1940-44

Miscellaneous, 1931-39

Miscellaneous, 1927-39, 1947

National Emergency Council, 1935-39

National Hydraulic Laboratory, 1922-40

National Park Service, 1913-47 (3 files)

National Research Council, 1919-23, 1933-34

National Resources Committee, 1936-41

National Resources Committee, 1934-36

National Resources Committee, 1935-39

National Resources Committee, Press Releases, 1934-36

National Resources Planning Committee, 1941-44

National Water Policy Report, 1940

Navy Department, 1916-30

New England Flood, 1927-30

News Items, 1934-39

Oath - Employees Authority to Administer, 1940-49

Organic Bill - HR 6900, HR 6235, HR 6257, 1948-51 (3 files)

Organic Bill - Department-proposed Minerals and Waters Bill, 1949-50

Overtime Approvals, 1952-53 (2 files)

Passage of turbid water through Lake Mead, 1937

Penalty Mail, 1946-53

Per Diem, 1928-50

Per Diem Rates, 1931-50

Per Diem - Unbound material [field office forms], 1949

Periodicals [empty]

Permanent War Memorial, 1949

Personal Car Use, 1928-51

Personnel Needs, 1945-53

Personnel Officer, ca. 1941-48

Petroleum Administration for War, 1943

Philippine Islands, 1945

Plans and Specifications, 1940

Precipitation [artificial], 1950-53

Printing and Binding, 1931-47

Procurement Division - Bulletins, 1934-38

Puerto Rico, 1943, 1946

Railway Express Agency, Inc., 1949-51

Reclamation, Bureau of, 1936-48

Reclamation - Colorado River below Davis Dam, 1942-46

Reclamation - San Luis Valley Agreement, 1946

Reclamation, Bureau of, 1950-51

Reclamation, Bureau of, 1948-49

Reclamation, Bureau of, ca. 1941, 1949-50 (2 files)

Reports - Mail Matter, 1951

Reports, 1949-51

Reports, 1952-53

Sea Water, 1947-52 
Secretary of the Interior, 1922-48

First Annual Report of the Secretary of the Interior to the Rio Grande Compact Commission, 1940

Silt Sampling Equipment and Methods, 1939-47

Snow Surveys, 1932-50

Solicitor, 1951

Solicitor's Office, 1948-50

Southwest Drought Report, ca. 1951

Southwest Louisiana Investigation, 1947-53

Soviet Hydro-Meteorological Mission, 1943-49

Staff Geologist, 1920-48

Standards, Bureau of, 1911

Suggestions Committee, 1948-50

Suggestions Committee, 1951

Suggestions Committee, 1944-48

Survey Representatives on Committees, 1950-52

Tennessee Valley Authority, 1933-35 (2 files)

Tennessee Valley Authority, 1936-48 (2 files)

Testimony in Law Suits, 1932-47

Travel Authorization, 1951-52

Travel Authorization, 1953

Travel Regulations, 1926-49

Treasury Department, 1907-48

Tydings Report, 1942

United Nations, 1948-49

United Nations Scientific Conference, 1949-53

Vouchers, Overdue, 1943-44

Valley Authority Conference, 1947

War Department Cooperation, 1928-32

War Department Cooperation, 1932-35

War Department, Army Corps of Engineers, correspondence regarding transfer of funds, 1929-32 (2 files)

War Housing, 1942-45

War Manpower, 1942-45

War and Post War Programs, 1942-46

Warm Springs Project, 1933-35

Water Resources Committee - Departmental - General, 1938-48 (2 files)

Water Resources Sub-Committee, 1948-49

Water Resources Committee, Interdepartmental Projects, 1944-45

Water Resources Committee, Minutes, 1944-45

Water Level Recorders, 1916

Weather Bureau, 1924-48

Well Drilling, 1917-47

"Why Continuous Stream Gaging," ca. 1928

Wolman, Dr. Abel, 1944-46

World Power Conference, 1925-27

"100th Anniversary" - Interior Department, 1949 


\section{Appendix 25}

Water Resources Division - Circular Letter File, 1918-53 (entry 415)

INDEX [annotated]

ACCOUNTING

Certifying officers, 1942-49

Ledger sheets and allotment letters, 1932-49 [summary information from 1918]

Washington Office expenditures, 1934-46

\section{APPROPRIATIONS AND ALLOTMENTS}

Gaging streams, 1921-49

General, 1930-49

Planning, 1945

Research and development, 1946

Statement of Effective Allotments, 1948

\section{ARMY ENGINEERS}

General, 1925-49

\section{AUTOMOBILES}

General, 1926-52

Personal car use, 1925-51

Specifications, 1938-41

BULLETIN

"Water Resources Bulletin," 1925-49 [includes an "Index of News Letters and Bulletins of the Water Resources Branch'" 1918-37, with periodic supplements to 1943]

\section{BUREAU OF RECLAMATION}

Investigation, 1946-48

Water-development reports, 1944

CIRCULAR LETTER FILE, 1933-53

COMMUNICATIONS

Installations, 1946

\section{CONSTRUCTION}

Authorization, 1946

\section{CONTRACTS}

Cableway equipment, 19381

Cooperative agreements, 1923-48

Instructions, 1921-40

Railroad and private property, 1928-52

CONTRACT AND LEASES, PREPARATION OF, 1937-46 (with inserts from ca. 1935) 


\section{COOPERATION}

Between districts, 1938

State, municipal, etc., 1926-51

\section{COST ESTIMATES}

Flood control, 1947

EARTHQUAKES, 1943

EMPLOYMENT

Ceilings, 1943-47

Federal Employment Stabilization Board, 1932

Form DI-207, 1943-48

General, 1923-50

Letters of employment, 1928-47

Political endorsements, 1934

Relief, 1934

Student aid, 1941

Temporary, for emergency working field, 1938-51

\section{EQUIPMENT}

Bridge piers, 1934

Cable, 1928-38

Cable connectors, 1932-36

Chain gage, 1930

Current meters, 1922-50

Development, 1929-31

Discharge integrators, 1925-46

Electrical, 1937-42

Enameled gage sections, 1928

Field Equipment Section, Columbus, 1948

General, 1923-51

General Schedule of Supplies (Class 18), 1941-52

Headphone receivers, 1935

Insulating socket, 1936

Levels, 1932-34

Microfilm, 1947

Notebook covers, 1934-35

Obsolete, 1933

Padlocks, 1928-33

Pygmy current meters, 1938-39

Rain gages, 1936

Reference marks, 1934

River measurements, structures for cableways, 1947

Sliding support, 1933

Sounding weights, 1943

Stock, 1929-52

Stop-watches, 1923-33

Stereophotography, 1950

Tapes, 1930-37

Water-stage recorders, 1923-48

Weights, 1923-43

Wire, 1934

Wire-weight gages, 1934-35 


\section{EXPLOSIVES}

Storage, 1951

FEDERAL EXPLOSIVES ACT, 1941-45

FEDERAL GAGING STATIONS, 1940-45

FEDERAL INTER-AGENCY SUBCOMMITTEE ON SEDIMENTATION, 1946 [minutes of the Third Meeting]

FEDERAL POWER COMMISSION

Appropriations, 1930-36

General, 1921-51

Records and reports, 1925-52

FEDERAL SPECIFICATIONS, 1940-42

FEDERAL SPECIFICATIONS BOARD, 1945

FIELD MANUAL, 1933-45

FIELD COMMITTEES, INTERIOR

Areas, regions, 1950-51

FLOODS

Computation of peak-discharge manual, 1948

FORMS

Compilation of hydrologic data, 1948

General, 1923-53

Purchase orders, 1944

\section{GENERAL}

Addresses and articles, 1935-50

American Geophysical Union, 1934-39

American Water Works Association, 1932-48

Attendance at scientific meetings, 1935-52

Correspondence, 1925-51

Court witnesses, 1932-52

Drainage basins, 1939

Economy Act, 1932-49

Exhibits, 1931-49

Federal Archives, 1936

Federal business associations, 1927-41

Federal employees' pay acts, 1945-48

Fellowships, 1952-53

Floods data, inventory of, 1938-39

Flood notifications, 1939

Franking privilege, 1920-49

Furlough, 1932-33

Gaging-station maps, 1939

Geologic Names Committee, 1953

Greetings to field staff, 1942

History of Water Resources Branch, 1938

Holidays, 1938-49 
Hours of work, 1936-55

Hydrologic investigations, 1940-48

Hydrologic symbols and glossary, 1932-33

Ice computations, 1941

Leave, 1926-52

Long-distance telephone calls, 1939-42

Low dams, 1939

Material, equipment and supplies, 1942

Memoranda for District Clerks, 1933

Miscellaneous information, 1920-50

National Emergency Council, 1938

New River Decision, 1940-41

Pamphlets, 1929-40

Personal telephone calls, 1932

Plans and specifications, 1928-38

Political activity , 1939-40

Pollution - investigation, 1947

Rainfall runoff, 1934-35

Receipt of orders, 1933-37

Reservoir inventory, 1947

Reservoir sites, 1937-38

Reservoir surveys, 1948

Retirement, 1927-52

Salvage campaign, 1944-45

Slope studies, 1932-40

Surface and ground water conditions, 1933-41

Surface water bibliography, 1932

Survey activities, 1938-46

Time, 1942-45

Typewriter service in D. C., 1934-35

Typewriters, 1942-50

Unpublished hydrologic data, 1936

War Savings Bond Campaign, 1941-46

Work for other Federal agencies, 1937-48

Work Progress Administration, 1935-38

\section{GROUND WATER DIVERSION}

Quality of ground water, 1946

The technical work of the division, 1945-46

HIGHWAY PROGRAM, 1946

\section{HYDROLOGIC DATA}

Basic-data program, 1950-51

Centralized data repositories, 1947

Interagency coordination of drainage area data, 1952

Subcommittee, 1945-49

Water Resources Policy Commission, 1950

INFORMATION DIGEST, 1952

INSIDE INTERIOR, 1944-50

LAWS, 1946-47 
LECTURES

Illustrative material, 1939-40

LEVELING DATA

U.S. Coast and Geodetic Survey, 1943

MANAGEMENT IMPROVEMENT, 1950

NATIONAL HYDRAULIC LABORATORY

Artificial controls, 1934

Current-meter performance, 1936-37

General, 1937

Intakes, 1936

NATIONAL RESOURCES PLANNING BOARD

General, 1934-41

OFFICE MANUAL

Analysis, computation, and publication of streamflow records, 1945

General, 1924-34

Handbook for Hydrologists, 1947

ORGANIZATION

Water Resources Branch, 1948-56

ORGANIZATION AND PERSONNEL DIRECTORY, 1952

OVERTIME

Compensation, 1942-45

PATENTS, 1930-47

PERSONNEL

Alaska, 1948

General, 1927-53

PHOTOGRAPHS

General, 1933-50

POLICY - COOPERATIVE RELATIONS, 1948-52

POST-WAR PLANS, 1944

PROPERTY

Conservation, 1942-48

(Survey) - Duplicating machines, 1946

Lists, 1928-48

Procedures, 1951-52

Safeguarding, 1941-43

\section{PUBLICATIONS}

Cooperative ground water, 1943

General, 1921-53

Survey, 1923-52 


\section{PUBLIC WORKS}

Appropriations and Allotments, 1933-38

Employment, 1933-38

Fiscal procedures and employment, 1938

General, 1933-39

Ledger sheets, 1934

Reports, 1933-39

\section{PURCHASES}

Federal Prison Industries, Inc., 1945-49

General, 1935-51

Negotiation of, 1945

Office machines, 1942

Priorities, 1941-51

Procurement Division Centers, 1945-50

\section{RECORDS}

General, 1948

Maximum-Discharge Files, 1941

Protection, 1951

\section{REPORTS}

Annual, 1919-47

Annual Stream Flow, 1922-48

Bureau of Labor Statistics, 1935-51

Developed Water-power, 1920-40

Drought, 1930-37

Federal Employment Stabilization Board, 1935

Flood, 1924-44

Gaging-station records for Washington Office, 1940-46

General, 1928-53

Ground Water, 1942-48

Index of river-measurement stations, 1946

Information relating to National Defense, 1940

Mail matter, 1939-53

Manuscript for annual reports on surface-water supply, 1940-46

Monthly, 1919-43

Oklahoma water, 1945

Overtime work, 1936

Quarterly (SW Branch), 1948-50

Requests for data, 1951-52

Review of Quality of Water Branch field offices, 1949

Sediment, 1943-52

Temporary employees, $1925-50$

Time (Form 9-1106), 1942-47

War Service, 1943-45

Water-quality inventory, 1948-49

\section{REPRODUCTIONS}

General, 1937-38

Photoflur plate, 1933 


\section{REQUISITIONS}

Equipment, 1930

Forms, 1930-40

General, 1935-52

RESEARCH

Techniques, principles, and equipment, 1950-51

SEDIMENT SAMPLING

Equipment, technique, and publications, 1944-48

SHIPPING

Bills of lading, 1926-50

Motor transport, 1938

SOIL AND MOISTURE CONSERVATION

Survey activities, 1941

SPACE

Building, 1941-52

SPECIFICATIONS

General, 1938-43

STATIONERY

Requisitions, 1928-50

STREAMFLOW MEASUREMENTS

Discharge measurements, 1948

Discharge measurements by wading, 1941

Methods of computation, 1950

SURVEY ACTIVITIES

General, 1938-41

TAX

Federal, 1935-50

General, 1931-51

State, local, etc., 1926-45

Telephone, 1932

TELEGRAMS

Instructions, 1922-50

TEMPERATURE

Surface water, 1948-49

TOPOGRAPHIC BRANCH

Level and transit data, 1946-50

TOPOGRAPHIC DIVISION

Mapping, 1949 
TOPOGRAPHIC MAPS

Information folders, 1948-53

TRAVEL

Advance of funds, 1928-42

Authorizations, 1927-52

General, 1923-53

Regulations, 1932-47

Subsistence, 1922-53

Transportation requests, $1920-50$

UNPUBLISHED INFORMATION

Ground-water open files, 1943-51

VOUCHERS

Adjustment, 1943-48

Expense, 1923-48

General, 1921-48

Payroll, 1923-50

Purchase, 1924-47

WAR PRODUCTION BOARD

Pig-iron Survey, 1942

WAR SERVICE

Summary, 1941-45

Water-level and pump surveys, 1943

WATER FACTS

Oklahoma, 1945

WATER RESOURCES ACTIVITIES, 1948

WATER RESOURCES COMMITTEE, 1944-46

WATER RESOURCES REVIEW, 1942-47

WATER UTILIZATION STUDIES, 1950-53

WEATHER BUREAU

General, 1936-41

Public Works, 1933-34

WELLS

Designation, 1944 


\section{Appendix 26}

Water Resources Division - Administrative Orders, Circulars, and Memorandums, 1915-55 (entry 416)

Budget and Finance Officer, 1949-53 (2 files)

Chief Clerk, Interior Department, 1928-53

Director of Personnel, 1946-53

Duplicating Section, Interior Department, 1951-53

Fair Employment Practices, 1948-52

Information Director, 1951-53

Memorandums to Division and Branch Chiefs, 1949-52 (2 files)

Memorandums to Divisions and Branches, 1953

Memorandums to employees, 1948-53

Memorandums to field offices, 1948-53

Memorandums for the files, 1949-53

Memorandums to the Guard Office, 1948-53

Memorandums to heads of bureaus and offices, 1947-50

Memorandums to heads of bureaus and offices, 1950-53 ( 2 files)

Memorandums for the record, 1948-53

Memorandums for Surface Water field offices, 1948-52

Miscellaneous Service Division, 1949-53

Orders - Departmental, 1946-53 (2 files)

Orders - Executive, 1924-52

Secretary of the Interior, 1949-53

Solicitor, 1952

Accounts Division, 1948-53 (4 files)

Acquisition of lands, or interests in lands by the Geological Survey, 1941-49

Administrative Circulars, 1951-53 (2 files)

Administrative Digest, 1952-53

Administrative Officer, 1952-53

Alaskan Investigations, 1948-53 (2 files)

Alaska Territory, 1948-53

Branch of Service and Supply, 1950-53

Budget Officer, 1921-53 (2 files)

Chief - Business and Clerical Section, 1948-52

Chief Counsel, Geological Survey, 1949-53 (2 files)

Chief, General Services Section, 1952-53

Chief, Surface Water Branch, 1952-53 (2 files)

Chief, Water Resources Division, 1949-55 (2 files)

Columbus Equipment Development Laboratory, 1949-52 (5 files)

Columbus Equipment Laboratory, 1951-53 (3 files)

Conservation Branch, 1949-52

Correspondence and Record Section, 1949-51

Director, 1949-52 (8 files)

Division of Distribution, 1922-52

Division Procedure, 1931-50 (2 files)

Esso Standard Oil Company, 1951-54

Executive Officer, 1949-53 (4 files)

Field Equipment Division, 1949

Fiscal Management, 1948-53

Fiscal Officer, Chief, 1948-52

Geologic Branch (Chief Geologist), 1949-53 
Gulf Oil Corporation, 1951-54

Information, Office of, 1949-53

Library, 1949-52

Map Information, 1941-53

Map Information, 1949-51

Map Reproduction, 1930-53

Orders - Survey, 1915-53 (2 files)

Paley Commission Report, 1952-53 (2 files)

Personnel Announcements, 1950-53

Personnel Branch (Employment and Record Section), 1949-53

Personnel Officer, 1949-53 (3 files)

Personnel Unit, 1949-52

Photographic Laboratory, 1949

Placement Assistant, 1951-53

President's Materials Policy Commission, 1950-51

Program for the Pacific Northwest, 1950 (bound booklet)

Program Control, 1951-53

Property Maintenance Section, 1949-53

Publication Section, 1949-53

Purchasing Officer, 1949-53

Records Management Officer, 1952

Section of Texts, 1919-53

Staff Geologist, 1949-53

Staff Officer, 1948-51

Staff Scientist (Pacific Northwest), 1950-53 (2 files)

Standard Oil Company, 1936-52

Topographic Division, Chief of, 1949-53

Water Resources Policy Commission, 1950-52 (4 files) 


\section{Appendix 27}

Water Resources Division - Correspondence Concerning District Engineers and Other Division Employees, 1908-57 (entry 433)

The position titles shown reflect the highest promotion or last duty station of the employee.

Many employees, especially district engineers, served in other positions and at other duty stations.

Adams, Robert W. (Engineer in Charge of Ground Water Investigations in Mississippi), 1941-46

Andrews, Grace C. (Secretary), 1955-57

Armentrout, Warren R. (Engineering Aid), 1941-46

Armstrong, Wallace (Hydraulic Engineer), 1931-51

Aronow, Saul (Geologist), 1947-54

Austin, Verle L. (Hydraulic Engineer), 1933-53

Bach, W. Kenneth (Hydraulic Engineer), 1938-54

Baldwin, G. Clyde. (District Engineer, Idaho Falls, Idaho), 1911-1928 (2 files)

Ballard, Howard A. (Engineering Aid), 1941-53

Barber, DeLoss H. (District Engineer, Montgomery, Ala.), 1924-53 (4 files)

Barksdale, Henry C. (Assistant Hydraulic Engineer, Trenton, N.J.; later New Jersey Department of Conservation and Development), 1923-29

Barrows, Edgar L. (Hydraulic Engineer), 1931-55

Bartlett, Ronald B., 1957 [1 page]

Batchelder, Charles L. (District Engineer, St. Paul, Minn.), 1918-39 (2 files)

Baumgartner, John A. (Assistant Engineer), 1923-30

Beardin, Hubert W. (Engineering Aid), 1942-49

Beckman, Henry C. (District Engineer, Rolla, Mo.), 1916-44 (7 files)

Beeler, Robert H. (Engineering Aid), 1949-56

Bell, Francis M. (District Engineer, Atlanta, Ga. and Chattanooga, Tenn.), 1928-38, 1941-45 (3 files)

Berkenbosch, John C., (Hydraulic Engineer), 1934-55

Bigwood, Burke L. (District Engineer, Hartford, Conn.), 1919-44 (3 files)

Bishop, Ernest W. (Geologist), 1949-55

Bolon, Harry C. (Associate Hydraulic Engineer), 1929-40

Booz, Gordon D. (Hydraulic Engineer), 1952-57

Boyer, Marion C. (Hyraulic Engineer), 1928-54

Brandvold, Glen E. (Engineering Aid), 1950-55

Brashears, Maurice L. (Geologist), 1936-52

Bratschi, William G. (Hydraulic Engineer), 1933-57

Briggs, Revoe C. (Hydraulic Engineer), 1924-47, 1949-56

Broadhurst, William L. (Geologist), 1942-53

Buchanan, Agnes D. (Administrative Assistant), 1922-55

Burchard, Edwin D. (District Engineer, Asheville, N.C.), 1919-49 (6 files)

Burnham, Willis L. (Geologist), 1952-57

Burt, Edward Mead (Geologist), 1951-55

Butler, Stanley S. (Hydraulic Engineer), 1940-55

Canfield, George H. (District Engineer, Portland, Oreg.), 1915-49 (5 files and loose material)

Cardwell, William D. E. (Geologist), 1950-56

Carson, Max H. (District Engineer, Honolulu, Hawaii), 1917-45 (4 files)

Christopherson, Fritz C. (District Engineer, Madison, Wis.), 1923-54 (4 files)

Corbett, Don M. (District Engineer, Indianapolis, Ind.), 1923-44 (3 files)

Covert, Clermont C. (District Engineer, Albany, N.Y.), 1911-26 (3 files)

Crandall, Lynn (District Engineer, Idaho Falls, Idaho) 1916-44 (2 files)

Crawford, Lawrence C. (District Engineer, Iowa City, Iowa), 1940-44 (3 files) 
Currier, Wayne A. (Engineering Aid, Albany District), 1942-45

Cutter, Russell C. (Engineer Aid, Boston, Mass.), 1945-46

Dale, Bertha K. (Engineer Draftsman), 1943-46

Dauelberg, Oskar T. (Hydraulic Engineer, Portland, Oreg.), 1942-46

Davies, David, L., Jr. (Hydraulic Engineer, Jackson, Miss.), 1939-46

Davis, J. D. (Assistant Engineer, Oklahoma City, Okla.), 1944-47

Davis, Thenton L. (Hydrographic Engineer, Atlanta, Ga.), 1943-46

Dickinson, William E. (District Engineer, Tucson, Ariz.; Hydraulic Engineer, Los Angeles, Calif.), 1916-40 (5 files and loose material)

Dirzulaitis, Joseph J., (Dual Appointment: District Engineer, University, Va., and Chief Engineer, State Conservation and Development Commission, Va.) (8 files)

Ebert, Fred C. (Hydrolic Engineer, Los Angeles, Calif.), 1914-43 (2 files)

Eisenlohr, William S., Jr. (Junior Engineer, Virginia District), 1928-29

Ellsworth, Clarence E. (District Engineer, Austin, Tex.), 1908-53 (9 files)

Emerson, Charles J. (Associate Engineer, San Francisco, Calif.), 1916-46

Erskine, Harlan M. (District Engineer, Charleston, W. Va.; Engineer in Charge, Pittsburgh, Pa.), 1940-44

Esterly, Nellie L. (Administrative Assistant), 1931-55

Ferguson, George E. (District Engineer, Ocala, Fla.), 1928-44 (2 files)

Fiedler, Albert G. (Associate Engineer, Roswell, N. Mex.; Engineer, Minneapolis, Minn.), 1918-29 (2 files)

Follansbee, Robert, (District Engineer, Denver, Colo.), 1909-49 (11 files)

Gardiner, John H. (District Engineer, Fort Smith, Ark. and Tucson, Ariz.), 1921-40 (6 files)

Godwin, Albert B. (Junior Engineer, Austin, Tex.), 1929

Gray, Glenn A. (District Engineer, Austin, Tex.), 1913-18

Grosbach, Homer E. (District Engineer, Indianapolis, Ind., and Chicago, Ill.), 1920-43 (6 files)

Grover, Nathan C. (Chief Hydraulic Engineer, USGS), 1913-39 (2 files)

Hagensen, Philip (Junior Hydraulic Engineer). 1941-48

Hall, Warren E. (District Engineer, Asheville, N.C.), 1910-36 (2 files)

Harrington, Arthur W. (District Engineer, Albany, N.Y.), 1917-44 (8 files)

Henshaw, Fred F. (District Engineer, Portland, Oreg), 1911-29 (3 files)

Hickerson, Homer C. (Junior Engineer, Louisville, Ky.), 1943-45

Hill, Henry F. (Assistant to the Chief Hydraulic Engineer, Boston, Mass.), 1922-46 (2 files)

Hoff, Joseph C. (Junior Clerk, St. Paul, Minn.), 1939-42

Horton, Albert H. (District Engineer, Newport, Ky., and Middle Atlantic States District, College Park, Md.; Chief, Division of Power Resources), 1911-45 (2 files)

Hoyt, John C. (Chief, Division of Surface Waters; Hydraulic Engineer), 1911-44 (3 files)

Hoyt, William G. (District Engineer, Upper Mississippi District, Madison, Wis.), 1911-32, 1934-50

(3 files and loose material)

Johnson, Berkeley (District Engineer, Lansing, Mich. and Santa Fe, N. Mex.), 1921-44 (7 files)

Jones, Edward E. (Associate Hydraulic Engineer, Tacoma, Wash.), 1919-31 (3 files)

Kaplan, Albert Bernard (Hydraulic Engineer), 1945-46

Karably, Louis S. (Geologist), 1946

Kasel, Rudolph G. (District Engineer, Iowa City, Iowa; Chief, Division of Surface Water), 1923-47 (7 files)

Kasner, Charlotte F. (Scientific Aid), 1943-46

Kessler, William (District Engineer, Charleston, W. Va.), 1929-41 (6 files)

King, W. R. (District Engineer, Chattanooga, Tenn.), 1915-35 (5 files)

Kinnison, Harvey B. (District Engineer, Boston, Mass.), 1918-44 (8 files)

Kremsky, Meyer (Hydraulic Engineer), 1937-46

Kunesh, Joseph F. (Port au Prince, Haiti; and District Engineer, Honolulu, Hawaii), 1916-48 (4 files)

Lamb, William A. (District Engineer, Helena, Mont.), 1911-38 (5 files and loose material)

Lamson, John L. (Associate Engineer), 1920-33

LaRue, Eugene C. (Hydraulic Engineer, Salt Lake City, Utah; and Portland, Oreg.), 1912-48 (10 files);

correspondence, notes, and draft reports of work for the Land Classification Board and other investigations, 1915-23 (7 bundles)

Lee, Lasley (District Engineer, Columbus, Ohio), 1921-38 (6 files and loose material) 
Lewis, Douglas D. (Junior Engineer, Tucson, Ariz.; Acting District Engineer, Lincoln, Nebr.), 1929-33, 1941-44 (2 files)

Mangan, John W. (District Engineer, Harrisburg, Pa.), 1923-44 (7 files)

McCashin, Clarance E. (District Engineer, Montgomery, Ala.; and Chattanooga, Tenn.), 1918-41 (7 files)

McGlashan, Harry D. (District Engineer, San Francisco, Calif.), 1911-44 (10 files); correspondence, memorandums, and telegrams regarding Fowler's plan (Forest Service) on investigating water-power resources, 1921 (1 file)

Meinzer, Oscar E. (Geologist in Charge, Division of Ground Water), 1915-40 (3 files)

Morgan, J. Holloway (District Engineer, Chicago, Ill.; District Engineer, Urbana, Ill.), 1916-43 (7 files)

Murphy, Edward C. (Hydraulic Engineer, Napa, Calif.), 1914-35 (3 files)

Newell, Thomas R. (District Engineer, Boise, Idaho), 1917-44 (6 files)

Osborne, Cecil J. (Junior Engineer, Denver, Colo.), 1938-46

Parker, Glenn L. (District Engineer, Tacoma, Wash.; Chief, Water Resources Branch), 1913-47 (11 files and loose materials)

Parker, Gordon E. (Junior Engineer, Indianapolis, Ind.), 1941

Parker, Philip S. (Junior Engineer, Denver, Colo.) 1923

Parkinson, Clyde P. (Assistant Engineer, Albany, N.Y.), 1936-47

Parsons, Charles C. (PWA Forman, Tacoma, Wash.), 1934-35

Parsons, Edwin D. (Junior Chemist, Roswell, N. Mex.), 1939-42

Parsons, Jacqueline F. (Clerk-Stenographer, Stafford, Ariz.), 1944-45

Parsons, Walter, J., JR. (Junior Engineer, Madison, Wis.; Helena, Mont.), 1926-30

Pashby, Gene E. (Engineering Aid, Pierre, S. Dak.), 1948

Patch, Mrs. Winifred Graham (Clerk-Stenographer, Tucson, Ariz.; Washington, D.C.), 1936-39

Patterson, Viola Ann (Temporary Stenographer, Columbus, Ohio), 1930

Paul, Duane Myron (Junior Hydraulic Engineer, Harrisburg, Pa.), 1934-39

Paul, Edith (Clerk), 1918-19

Paulsen, Carl G. (District Engineer, Boise, Idaho; Assistant Chief Hydraulic Engineer), 1918-46 (7 files)

Paulsen, Wesley W. (Junior Geologist, Long Beach, Calif.), 1942-46

Pearson, William H. (Laborer, Washington, D. C.), 1944-45

Pease, Russell S. (Junior Engineer, Boston, Mass.), 1938-39

Pellen, Goree M. (Assistant Clerk-Stenographer, Washington, D.C.), 1938-43

Pentz, Mervin A. (Assistant Geologist), 1933-36

Pepper, Jack W. (Hydraulic Engineer, Ocala, Fla.), 1939-46

Perrin, Charlotte (Steno, Indianapolis, Ind.), 1930-34

Perrin, William W. (Junior Engineer, Columbus, Ohio), 1922-24

Perry, Grace V. (Regarding an interview), 1931

Perrey, Joseph I. (Assistant Engineer, Columbus, Ohio), 1927-29

Peters, Harry S. (Junior Engineer, Topeka, Kans.), 1934-35

Peters, Ronald H. (PWA Application), 1936

Peterson, Dean F. (Junior Hydraulic Engineer, Salt Lake City, Utah), 1938-39

Petmecky, Mrs. Margaret K. (Clerk-Stenographer, Austin, Tex.), 1940-45

Petretic, George J. (Junior Chemist), 1936, 1942

Peyton, Jean (Clerk-Stenographer, Charlottesville, Va.), 1943-44

Peyton, Wythe M, Jr. (Junior Engineer, Asheville, N.C.), 1934-35

Pfarner, Chester W. (Junior Hydraulic Engineer, Albany, N.Y.), 1936

Phelps, Leonard C. (Junior Engineering Aide, Long Beach, Calif.), 1941-42

Philbin, Patrick (Skilled Laborer, Columbia River at the International Boundary), 1938-39

Phillips, E. L., 1931

Phillips, Jean F. (Junior Engineering Aid, Portland, Oreg.), 1943-44

Phillips, Kenneth N. (Associate Engineer, Portland, Oreg.), 1920-30

Pickens, William G. (Scientific Aid, Albuquerque, N. Mex.), 1948

Pickop, Edwin M. (Junior Engineer, Hawaiian District), 1920-22

Pierce, Charles H. (District Engineer, Boston, Mass.), 1917-31 (2 files)

Pierce, William G. (Junior Hydraulic Engineer), 1933-34

Pierce, William M. (Junior Hydraulic Engineer, Rolla, Mo.), 1939-43 
Pihlstrom, C. H. Dale (Junior Hydraulic Engineer, St. Paul, Minn.), 1942-45

Pinkney, Harold W. (Junior Engineer, Fort Smith, Ark.) 1934-36

Piper, Arthur M. (Assistant Geologist, Pittsburgh, Pa.), 1925-27

Pipkin, James D. (Junior Engineer, Fort Smith, Ark.), 1939-46

Platt, William T. (Chemist), 1946

Plesce, Anthony J. (Junior Clerk-Stenographer), 1942

Plunkett, John (Claim against U.S. for loss of horse), 1931

Plusnin, Basil A. (Junior Hydraulic Engineer, Albany, N.Y.), 1942-44

Podgorski, Edward J. (Geologist, Albany, N.Y.), 1945-46

Pogue, Richard W., 1930-31

Pole, M. Charlotte (Clerk-Stenographer, Baton Rouge, La.), 1942-44

Pool, Doris (Clerk-Stenographer, University, Ala.), 1942-43

Poor, Ernest R. (Re: Appointment), 1946

Porter, E. A. (District Engineer, Salt Lake City, Utah), 1911-15

Porteous, Lewis G. (Re: Appointment), 1941

Porter, Charles W. (Engineer Aid, Tucson, Ariz.), 1945

Porter, Livingston, Jr., (Geologist, Santa Barbara, Calif.), 1942-46

Poss, Robert J. ( Re: Appointment), 1930

Post, Arthur L. (Hydraulic Engineer, Rolla, Mo.), 1939-45

Post, Edward (Junior Engineer, Helena, Mont.), 1930-43

Potter, Frances (Temp, Clerk-Stenographer, Albuquerque, N. Mex.), 1937

Powell, Morrel A. (Junior Classifier), 1917-45

Powell, Ralph W. (Assistant Hydraulic Engineer, Columbus, Ohio), 1937-38

Powers, Howard A. (Geologist, Maui, Hawaii), 1932-34

Pratt, Mrs. Genevieve (Assistant Clerk-Stenographer, Salt Lake City, Utah), 1927

Pratt, Joseph Hyde (Engineer Consultant), 1938-41

Pratt, Oliver Laurens (Junior Engineer, Austin, Tex.), 1939-40

Price, Herman S. (Assistant Engineer, Helena, Mont.), 1919-21

Price, Jerome L. (Junior Engineering Aide, Baton Rouge, La.), 1942-43

Price, W. L. (Foreman, Ocala, Fla.), 1933-34

Prince, A. H. (Observer), 1930-36

Pringle, Thomas B. (Junior Engineer, South Charleston, W. Va.), 1933-34

Prior, Charles H. (Junior Engineer, Chattanooga, Tenn.), 1928

Pritchett, Henry C. (Assistant Engineer, Tucson, Ariz.), 1923-30

Prock, George D. (Junior Engineer, Austin, Tex.), 1941-42

Puffer, Charles G. (Field Assistant, Ariz.), 1918

Purton, Astley B. (District Engineer, Salt Lake City, Utah), 1917-42 (7 files)

Putz, Claire E. (Re Employment), 1928

Radack, Stanley B. (Geologist, Miami, Fla.), 1943-45

Radka, Lawrence E. (R:e Appointment), 1936

Rae, Mrs. Esther D. (Clerk-Stenographer, Denver, Colo.), 1919-21

Ramsey, Mrs. Marie T. (Clerk-Stenographer, Rolla, Mo.), 1936-42

Randall, Richard V. (Engineering Aide, Williston, N. Dak.), 1946

Randolph, Burr H. (Hydraulic Engineer, Iowa City, Iowa), 1939-46

Randolph, Mrs. Nora A. (Junior Clerk, Roswell, N. Mex.), 1928

Rano, Filamena C. (Junior Clerk-Stenographer, St. Paul, Minn.), 1940-43

Rarey, Nellouise (Clerk-Stenographer, Washington, D.C.), 1935

Raspet, Rudolph (Recorder, Hawaii), 1938-39

Rasmussen, Nels R. (Engineering Aid, Lansing, Mich.), 1947-48

Rau, Paul W., Jr. (Re: Appointment), 1941

Rauworth, Elizabeth B. (Re Appointment), 1933

Ray, Mrs. June F. (Junior Clerk-Stenographer, Savannah, Ga.), 1937-39

Ray, Mrs. Marina B. (Junior Clerk-Stenographer, Columbia, S.C.), 1936-39

Read, Robert B. (Re Appointment) 1942 
Reams, Sanford N. (Junior Engineer, Columbus, Ohio), 1934-35

Reed, Clarence R. (Junior Engineer, San Francisco, Calif.), 1928-29

Reed, Fred D. (Hyraulic Engineer, Denver, Colo.), 1936-39

Reed, Jim (Re: Appointment), 1931

Rehm, Wilda (Clerk-Stenographer, Tacoma, Wash.), 1943

Reichman, Mrs. Stella (Temporary Clerk, Salt Lake City, Utah), 1927

Reeves, Max D. (Junior Chemist), 1936-41

Reid, Harold Victor (Engineering Draftsman, Miami, Fla.), 1944

Reid, Margaret, A. (Junior Clerk-Stenographer, Albany, N.Y.), 1930

Reinhardt, Charles Orville (Re Appointment), 1939

Reinheimer, Herbert S. (Junior Engineering Aide, University, Miss.), 1941-42

Reker, Carl C. (Junior Geologist, Tallahassee, Fla.), 1942-46

Remington, Robert H. (Junior Engineer, Honolulu, Hawaii), 1920

Renick, B. Coleman (Assistant Geologist), 1923-27 (2 files)

Rice, Edward B. (District Engineer, Baton Rouge, La.), 1929-44

Rice, Roger C. (District Engineer, Tucson, Ariz.), 1916-23 (3 files)

Rupp, Vernon W. (Assistant Hydraulic Engineer, Asheville, N. C.), 1928-40 (2 files)

Saunders, John I. (District Engineer, Fort Smith, Ark.), 1924-44 (3 files)

Saville, Thorndike (Professor of Hydraulic and Sanitary Engineering; Dean, College of Engineering, New York University; Chief Engineer, Department of Conservation and Development, Chapel Hill, N.C.), 1924-38 (3 files and loose material)

Schrader, Floyd F. (Junior Engineer, University, Va.), 1929-31

Schumacher, K. Fritz (Re: Appointment), 1929

Smith, G. E. P. (Professor of Irrigation Engineering, University of Arizona), 1917-29

Snowden, James R. (Engineering Aid, Rolla, Mo.), 1942-44

Soule, Stephen B. (District Engineer, Madison, Wis.), 1920-38 (4 files)

Speer, Paul R. (District Engineer, St. Paul Minn.), 1926-29, 1932-36, 1939-44 (5 files)

Speigel, Jacob B. (District Engineer, Tokeka, Kansas), 1915-45 (8 files)

Stackpole, M. Reginald (District Engineer, Augusta, Maine), 1917-44 (3 files)

Stearns, Harold T. (Associate Geologist, and Senior Geologist, Honolulu, Hawaii), 1920-47, 1949

(5 files and loose material)

Sundstrom, Raymond W. (Re: Appointment), 1928

Tiencken, Wilfred P. (Junior Engineer, Indianapolis, Ind.), 1934-37

Thompson, David G. (Senior Geologist, Trenton, N. J.), 1917-27, 1931-43 (5 files)

Thomson. Medford T. (District Engineer, Atlanta, Ga.), 1939-44 (2 files)

Toth, Albert S. (Deferment File), 1943-44

Tuttle, Alonzo H. (District Engineer, Helena, Mont.), 1918-35, 1938-44 (4 files)

Twitchell, Trigg (Associate Engineer, Austin, Tex.), 1922-30

Veatch, Fred M. (Associate Engineer, Boise, Idaho; Hydraulic Engineer, St. Louis, Mo.; District Engineer,

Louisville, Ky. and Tacoma, Wash.), 1923-32, 1934-45 (8 files and loose material)

Wallace, Donald S. (District Engineer, Ocala, Fla., and Charlottesville, Va.), 1921-44 (6 files)

Waring, Gerald A. (Associate Geologist, Calif.), 1915-19, 1943 (1 file)

Wayne [formerly Wasylkiw], Myron A. (Hydraulic Engineer, Charleston, W. Va.), 1940-47 (2 files)

Wells, Joseph V. B. (District Engineer, Louisville, Ky.), 1929-37, 1940-44 (3 files and loose material)

White, Walter N. (Associate Hydraulic Engineer, Milford, Utah), 1925-27

Wiazeck, Mrs. Gladys Moses (Clerk-Stenographer, Middle Atlantic District), 1935-39

Widman, Mrs. Elizabeth A. (Engineering Aide, Lansing, Mich.), 1942-46

Wiitala, Sulo W. (Junior Engineer, Indianapolis, Ind.), 1940-46 (2 files)

Wiggins, Wilford C. (Junior Engineer), 1923-26

Wilcomb, Carroll F. (Assistant Hydraulic Engineer, Logan, Utah), 1945-46

Wilder, David S. (Junior Hydraulic Engineer, Rolla, Mo.), 1938-41

Wildman, John P. (Junior Engineer, Asheville, N.C.), 1930

Wile, Ruth H. (Clerh-Stenographer, College Park, Md.), 1944-45

Wiles, Ernest G. (Re: Appointment), 1934 
Wiley, Harry R. (Junior Engineer, South Charleston, W. Va.), 1934-35

Wilkinson, Marvin A. (Engineering Aide, Rolla, Mo.), 1946

Williams, Adrain H. (Junior Engineer, Tucson, Ariz.), 1927-29

Williams, David C. (Junior Hydraulic Engineer, Columbus, Ohio), 1938-43

Williams, H. T. (Re: Appointment), 1930

Williams, H. V. (Forman), 1934

Williams, M. Dean (Re: Appointment), 1943

Williams, W. Robert (Junior Engineer), 1938-46

Williams, Evelyn Caroline (Engineering Aide, Chattanooga, Tenn.), 1943-44

Williams, Gordon R. (Associate Hydraulic Engineer), 1930-41

Williams, Kenneth T. (Junior Chemist), 1929-33

Willis, Ernest L, Jr. (Junior Hydraulic Engineer, Austin, Tex.), 1938-41

Willman, Mrs. Lucy Mae (Junior Clerk, Asheville, N.C.), 1928-29

Wilson, Mrs. Edith C. (Junior Clerk-Stenographer, University, Miss.), 1940-42

Wilson, Mrs. Ruth (Clerk-Stenographer, Lawrence, Kans.), 1939-42

Wiltshire, Lucie M. (Copist), 1919-21

Wingate, Katherine A. (Junior Clerk-Stenographer), 1931-33

Winslow, Allen G. (Junior Hydraulic Engineer, Tucson, Ariz.), 1942

Withee, Warren (Hydraulic Engineer, Chatanooga, Tenn.), 1920-38 (2 files)

Witt, Philip A. (Junior Chemist, Austin, Tex.), 1942-43

Witte, Herbert Walter (Re: Appointment), 1938-39

Witter, Joan S. (Clerk-Stenographer, Washington, D.C.), 1933-34

Wolfe, Barbara A. (Junior Engineering Aid, Columbus, Ohio), 1943-44

Womersley, Mrs. Irene (Assistant Clerk-Stenographer, Portland, Oreg.), 1936-43

Wood, Auburn E. (Engineering Aide, Knoxville, Tenn.), 1943-44

Wood, Bertha (Junior Clerk-Stenographer, Charlottesville, Va.), 1942-43

Wood, Mrs. Martha Burns Kittle (Scientific Aid, Washington, D.C.), 1944

Woodworth, Rosemary (Junior Clerk-Stenographer, Urbana, Ill.), 1935-43

Woolley, Ralf R. (Senior Hydraulic Engineer, Salt Lake City, Utah), 1917-42 (10 files and loose material)

Woolrych, Edmund H. (Junior Engineer, St. Louis, Mo.), 1934-37

Worcester, Samuel A. (Junior Engineer), 1934-38

Workman, Effie T. (Sr. Clerk, Asheville, N.C.), 1920-45

Workman, Leroy Vernon (Re: Appointment), 1936

Woster, Howard C. (Junior Hydraulic Engineer, Tacoma, Wash.), 1929-38

Wyer, Samuel S. (Consulting Engineer, Columbus, Ohio), 1929

Yarborough, Robert W., Jr. (Junior Engineer, Austin, Tex.), 1933-37

Yarnell, D. L. (Senior Drainage Engineer, Department of Agriculture), 1930-33

Yearsley, Mrs. Elva H. (Clerk-Stenographer, Logan, Utah), 1943-45

Yeates, Phyllis (Clerk-Stenographer, Logan, Utah), 1945-46

Yeatman, Mrs. Elsie L. (Clerk-Stenographer, Denver, Colo.), 1929-30

York, James R. (Engineering Aide, Ocala, Fla.), 1945

Youngquist, C. Vernon (District Engineer, Columbus, Ohio), 1934-44 (3 files and loose material)

Zainey, Genevieve M. (Junior Clerk-Stenographer, Indianapolis, Ind.), 1942-43

Zander, Ruth (Clerk, Urbana, Ill.), 1934-35

Zaontz, Rita B. (Junior Stenographer, Columbus, Ohio), 1930

Zieno, Angelo (Junior Hydraulic Engineer, Albany, N.Y.), 1942 


\section{Appendix 28}

Water Resources Division - Records Concerning Interstate River Compacts and Regional Projects, 1923-54 (entry 455)

Arkansas River Compact, 1946-53

Belle Fourche River Compact, 1942-47

Canadian River Compact, 1950-52

Central Arizona, 1949-50

Cheyenne River Compact, 1948-50

Colorado River Authority, 1937-51

Colorado River Basin, 1940-50

Colorado River Compact, 1942-53

Colorado River Forecast Committee, 1945-48

Columbia River Basin, 1944-51

Columbia River Compact, 1952-53

Columbia River (unbound material), 1944-50

Columbia Valley Administration, Legislation, 1949

Costilla Creek Compact, 1946-47

Crab Creek, 1941-42

Davis Dam, 1950

Gila River Basin, 1940-41

International Columbia River Engineering Board, 1944-48

Kansas River Basin, 1948-49

Little Tallahatchie River Silt Project, 1938-40

Mississippi River Commission, 1941-47

Mississippi River Flood, 1927-28

Mississippi River Power Company, 1923-33

Missouri River Basin, 1945-53

Missouri River Basin Compact, 1952-54

North Platte River Investigation, 1945-48

Ohio River Basin, 1945-50

Ohio River Basin Laboratory, 1947

Phelps Dodge Corporation (Gila River), 1942-48

Potomac River Basin, 1945-50

Red River Compact, 1950

Republican River Compact, 1941-54

Rio Grande Compact Commission, 1939-53

Sabine River Compact, 1952-53

Safford Valley Report, 1945-47

St. Francis River Silt Project, 1938-40

Sanke River Compact, 1949-51

Upper Colorado River Basin Compact, 1944-53

Ute Creek, 1948

Wapato Project, 1936-42

Western States, Flood Hazard of Snow Cover, Winter, 1948-49

Wind River Basin, 1949-51

Yadkin-Pee Dee River Basin, 1940

Yellowstone River Compact, 1943-53 


\section{Appendix 29}

Water Resources Division - Records of the Subcommittee on Hydrologic Data of the Federal Interagency
River Basin Committee, 1947-48 (entry 491)

Map 1 Saco, Androscoggin, Presumpscot, Kennebec, Machias, St. Croix, and St. John River Basins [envelope \#3]

Map 2 Housatonic, Thames, and Merrimac River Basins - Lake Champlain Drainage [envelope \#3]

Map 3 Hudson River Basin and St. Lawrence Drainage in New York [envelope \#3]

Map 4 Susquehanna and Delaware River Basins [envelope \#3]

Map 5 Potomac, Rappahannock, York, and James River Basins [envelope \#4]

Map 6 Chowan, Roanoke, Tar, Neuse, and Cape Fear River Basins [envelope \#5]

Map 7 Pee Dee, Santee, and Edisto River Basins [envelope \#5]

Map 8 Savannah, Ogeechee, and Altamaha River Basins [envelope \#6]

Map 9 Satilla, St. Marys, St. Johns, and Suwannee River Basins [envelope \#6]

Map 10 Southern Florida Drainage [envelope \#6]

Map 11 Apalachicola and Ochlockonee River Basins [envelope \#6]

Map 12 Choctawhatchee, Yellow, Escambia, and Alabama River Basins [envelope \#6]

Map 13 Tombigbee, Pascagoula, and Pearl River Basins [envelope \#6]

Map 14 Mississippi River (Natchez to the mouth), Calcasieu, Mermentau, and Vermillion River Basins [envelopes \#6 \& \#7]

Map 15 Mississippi River (Helena to Natchez), Yazoo, Big Black, and Ouachita River Basins [envelopes \#6 \& \#7]

Map 16 Mississippi River (Chester to Helena), St. Francis River Basin [envelope \#6]

Map 17 Ohio River (Madison to Uniontown), Wabash River Basin [envelopes \#8 \& \#9]

Map 18 Tennessee River Basin (below Hales Bar Dam), Cumberland and Green River Basins [envelopes \#10 \& \#11]

Map 19 Ohio River (Point Pleasant to Madison), Kanawha, Big Sandy, Licking, Kentucky, Scioto, and Miami River Basins [envelope \#12]

Map 20 Tennessee River Basin (above Hales Bar Dam) [envelopes \#13 \& \#14]

Map 21 Ohio River Basin (above Point Pleasant), and Lake Erie Drainage [envelope \#15]

Map 22 Great Lakes Drainage (in Michigan) and Maumee River Basin [envelope \#16]

Map 23 Great Lakes Drainage (in Michigan and Wisconsin) [envelope \#17]

Map 24 Mississippi River (Louisiana to Chester), Illinois, Kaskaskia and Meramac River Basins [envelopes \#18 \& \#19]

Map 25 Mississippi River (Fairmont to Louisiana), Cedar, Skunk, and Des Moines River Basins [envelope \#20]

Map 26 Mississippi River (Prairie Du Chien to Rock Island), Rock and Wapsipinicon River Basins and Lake Michigan Drainage [envelope \#20]

Map 27 Mississippi River Basin (St. Paul to Prairie Du Chien), Wisconsin, Root, Chippewa, and St. Croix River Basins [envelope \#20]

Map 28 Mississippi River Basin (above St. Paul) [envelope \#20]

Map 29 Lake Superior and Lake of the Woods Drainage (in Minnesota) [envelope \#20]

Map 30 Red River of the North [envelope \#20]

Map 31 Missouri River (Nebraska City to Herman), Osage, Gasconade, and Grand River Basins [envelopes \#21 \& \#22]

Map 32 Smoky Hill and Lower Republican River Basins [envelopes \#21 \& \#22]

Map 33 Upper Republican River Basin, North Platte River (Ft. Laramie to North Platte) and South Platte River (Sublette to North Platte) [envelopes \#21 \& \#22]

Map 34 North Platte River Basin (above Ft. Laramie) South Platte Rive Basin (above Sublette) [envelopes \#21 \& \#22]

Map 35 Platte River Basin (below North Platte), Missouri River (above Blair to Nebraska City) [envelopes \#21 \& \#22]

Map 36 Platte River (Niobrara to above Blair), James and Big Sioux River Basins [envelopes \#21, \#22 \& \#23] 
Map 37 Missouri River (above Pierre to Niobrara), Niobrara and White River Basins [envelopes \#21 \& \#22]

Map 38 Missouri River (Mobridge to above Pierre), Cheyenne and Owl River Basins [envelope \#23]

Map 39 Missouri River (Williston to Mobridge), Grand, Cannonball, Heart and Little Missouri River Basins [envelope \#23]

Map 40 Missouri River (Zortman to Williston), Milk and Musselshell River Basins [envelope \#24]

Map 41 Missouri River Basin (above Zortman) [envelope \#25]

Map 42 Lower Yellowstone River - Tongue and Powder River Basins [envelope \#26]

Map 43 Upper Yellowstone River Basin [envelope \#29]

Map 44 Arkansas River (Van Buren to Little Rock), White River Basin [envelope \#27]

Map 45 Arkansas River (Tulsa to Van Buren), Grand, Verdigris and Lower Canadian River Basins [envelope \#27]

Map 46 Arkansas River (Garden City to Tulsa), Middle Canadian, Lower Cimarron and Salt Fork River Basins [envelope \#27]

Map 47 Arkansas River (Lamar to Garden City), Upper Cimarron and Upper Canadian River Basins [envelopes \#28, \#30 \& \#31]

Map 48 Rio Grande Basin (above Espanola) and Arkansas River Basin (above Lamar) [envelopes \#28, \#30 \& \#31]

Map 49 Red River (Denison to Grand Ecore), Little and Sulphur River Basins [envelopes \#7 \& \#32]

Map 50 Red River Basin (above Denison) [envelope \#31]

Map 51 Sabine, Naches and Trinity River Basin [envelopes \#30 \& \#31]

Map 52 Lower Brazos, Lower Colorado, Guadalupe, San Antonio and Nueces River Basins [envelopes \#30 \& \#31]

Map 53 Brozos River (South Bend to Washington), Little River Basin and Colorado River (Ballinger to Marble Falls), Llano and San Saba River Basin [envelopes \#30 \& \#31]

Map 54 Brozos River Basin (above South Bend), Colorado River Basin (above Ballinger [envelopes \#30 \& \# 31]

Map 55 Rio Grande (below Eagle Pass) [envelope \#31]

Map 56 Rio Grande (Fort Quitman to Eagle Pass) [envelope \#31]

Map 57 Rio Grande (Espanola to Fort Quitman) Rio Puerco Basin [envelopes \#30 \& \#31]

Map 58 Pecos River Basin (above Carsbad) [envelopes \#30 \& \#31]

Map 59 Colorado River (below Boulder Dam) Williams River Basin [envelopes \#31 \& \#33]

Map 60 Gila River Basin [envelope \#33]

Map 61 Little Colorado and San Juan River Basins [envelopes \#33, \#34 \& \#35]

Map 62 Colorado River (Halls Crossing to Boulder Dam) Virgin River Basin [envelopes \#33 \& \#36]

Map 63 Colorado River (above Halls Crossing), Gunnison, Delores and Fremont (or Dirty Devil) River Basin [envelopes \#37 \& \#38]

Map 64 Green River Basin [envelopes \#33 \& \#39]

Map 65 Great Salt Lake Basin [envelopes \#33 \& \#40]

Map 66 Sevier River Basin [envelopes \#33 \& \#41]

Map 67 Warner Lakes, Honey Lake, and Malheur Lake Drainage [envelopes \#42, \#43 \& \#44]

Map 68 Humbolt, Carson, and Truckee River Basins [envelopes \#33 \& \#45]

Map 69 Walker River (near Schurz) [no envelope found]

Map 70 Salton Sea and Southern California Coastal Drainage [envelopes \#33 \& \#48]

Map 70A Los Angeles, San Gabriel and Santa Ana River Basins [envelope \#48]

Map 71 San Joaquin, Kern, Santa Clara, Santa Ynez, Santa Maris and Salinas River Basins [envelope \#49]

Map 72 Sacramento, Eel and Russian River Basins [envelope \#50]

Map 73 Klamath, Rogue, and Umpqua River Basins [envelope \#51]

Map 74 Columbia River (below Umatilla), Willamette, Deschutes, John Day, Cowlitz, and Klickitat River Basins [envelope \#52]

Map 75 Columbia River (Grand Coulee to Umatilla), Yakima, Chelan, and Okanogan River Basins [envelope \#53]

Map 76 Columbia River (International Boundary to Grand Coulee), Pend Orielle, Spokane, and Lower Snake River Basins [envelope \#54]

Map 77 [no envelope or map found]

Map 78 Snake River (King Hill to below the Salmon River), Grand Ronde, Malheur, Owyhee, Boise, Weisner, and Payette River Basins [envelope \#55]

Map 79 Snake River Basin (above King Hill) and Salmon River Basin [envelope \#56] 


\section{Appendix 30}

Ground Water Branch - Administrative Correspondence Files, 1919-43 (entry 574)

Ground Water Branch, 1919-39

Abstracts

Accounts, Division of

Administrative Geologist

Agriculture, Department of

Air-Conditioning

Alabama - Inquiries

Alabama - Walter B. Jones, State Geologist

Albright, Horace M. (United States Potash Company)

American Association for the Advancement of Science

American Association of Petroleum Geologists

American Society of Civil Engineers

American Association of Water Well Drillers

American Water Works Association

Annual Reports

Andrews, David A.

Arizona - Cooperation

Arizona - Salt River Valley Water Users' Association

Arizona - Inquiries

Arkansas - Cooperation

Arkansas - Inquiries

Arkansas - Arkansas Geological Survey and Arkansas Agricultural Experiment Station

Automobile Insurance

A - Miscellaneous

Babcock, Horace M.

Bach, W. Kenneth

Baker, Roger C.

Barber, DeLoss H.

Barksdale, Henry C.

Bell, Francis M.

Bennett, Robert R.

Bigwood, Burke L.

Blank, Horace R.

Brashears, Maurice L., Jr.

Bridges, Thomas W.

Brown, Glen F.

Brown, Russell H.

Bryan, Kirk

Burchard, Edwin D.

Burleigh, Harry P.

Byers, Alan C.

B - Miscellaneous

Cady, Richard C.

California - geology and ground water hydrology of the Mokelumne area, by Arthur M. Piper, Hoyt S. Gale,

Harold E. Thomas, and Thomas W. Robinson, status of

California - East Bay Municipal Utility District

California - Los Angeles and Orange Counties

California - Mohave River Basin (David G. Thompson) 
California - Mokelumne River

California - Santa Ana Investigation (David G. Thompson)

California Well Drillers Association

California - inquiries

Carson, Max H.

Cederstrom, Dagfin J.

Chicago, University of

Chief Clerk

Chief Geologist

Chief Hydraulic Engineer

Civil Works Administration

Colby, Bruce R.

Cole, Charles F.

Collins, William D.

Colorado Water Well Drillers Association

Colorado - Inquiries

Colvin, Robert H.

Commerce, Department of

Connecticut - Cooperation

Connecticut - Inquiries

Conover, Clyde S.

Conservation Branch - Herman Stabler

Cooper, Hilton H., Jr.

Cosmos Club

Crandall, Lynn

Creech, Mrs. Hulda M.

Crickmay, Geoffrey W.

Cross, William P.

Cumley, James C.

C - Miscellaneous

Deep-well meter

Dennis, P. Eldon

Detweiler, Abraham L.

Director

Dirzulaitis, Joseph J.

District of Columbia

District Engineers' Conference, 1938

Drainage Basin Projects:

Columbia Basin Irrigation Project

Delaware River Drainage Basin

Minnesota Drainage

Lower Mississippi "A" Basin - Ouachita River Sub-basin

Neosho-Verdigris Basins

Tennessee River Basin

St. Francis Basin

D - Miscellaneous

Ebert, Fred C.

Eckel, Edwin B.

Economic Geologists, Society of

Engineering News-Record

E - Miscellaneous

Federal Club

Federal Power Commission

Federal Works Agency 
Ferris, John G.

Fiedler, Albert G.

Field Equipment, Division of

Fishel, Vinton C.

Florida

Florida Ship Canal

Florida, City of Pensacola

Florida - Cooperation and Florida State Geological Survey

Florida - Inquiries

Follansbee, Robert

Forrest, Kyle

Foster, Vellora M.

Frye, John C.

F - Miscellaneous

Gale, Hoyt S.

Gasoline purchases

Geological Congress, International

Geological Society of America

Geology, Journal of

George, William O.

Georgia

Georgia, Warm Springs

Georgia - Inquiries

Ground Water Estimates

Guam (Harold T. Stearns)

Guyton, William F.

G - Miscellaneous

Hale, William E.

Hall, George M.

Harrell, Marshall A.

Harrington, Arthur W.

Hartwell, Oliver W.

Hawaii

Hawaii - Cooperation

Hauser, Junius F.

Hewett, Donnel Foster

History of Science Society, The

Horton, Robert E.

Howell Drillers News

Hubbert, M. King, Prof (Columbia University)

Hydrologic Laboratory; Hydraulic Laboratory

$\mathrm{H}$ - Miscellaneous

Idaho - General

Idaho - Kootenai

Idaho - Snake River (Harold T. Stearns)

Idaho - Inquiries

Illinois

Illinois - East St. Louis Drainage District

Illinois State Geological Survey

Illinois Water Well Drillers Association

Illinois - Inquiries

Indian Affairs, Office of

Indiana

Indiana - Inquiries 


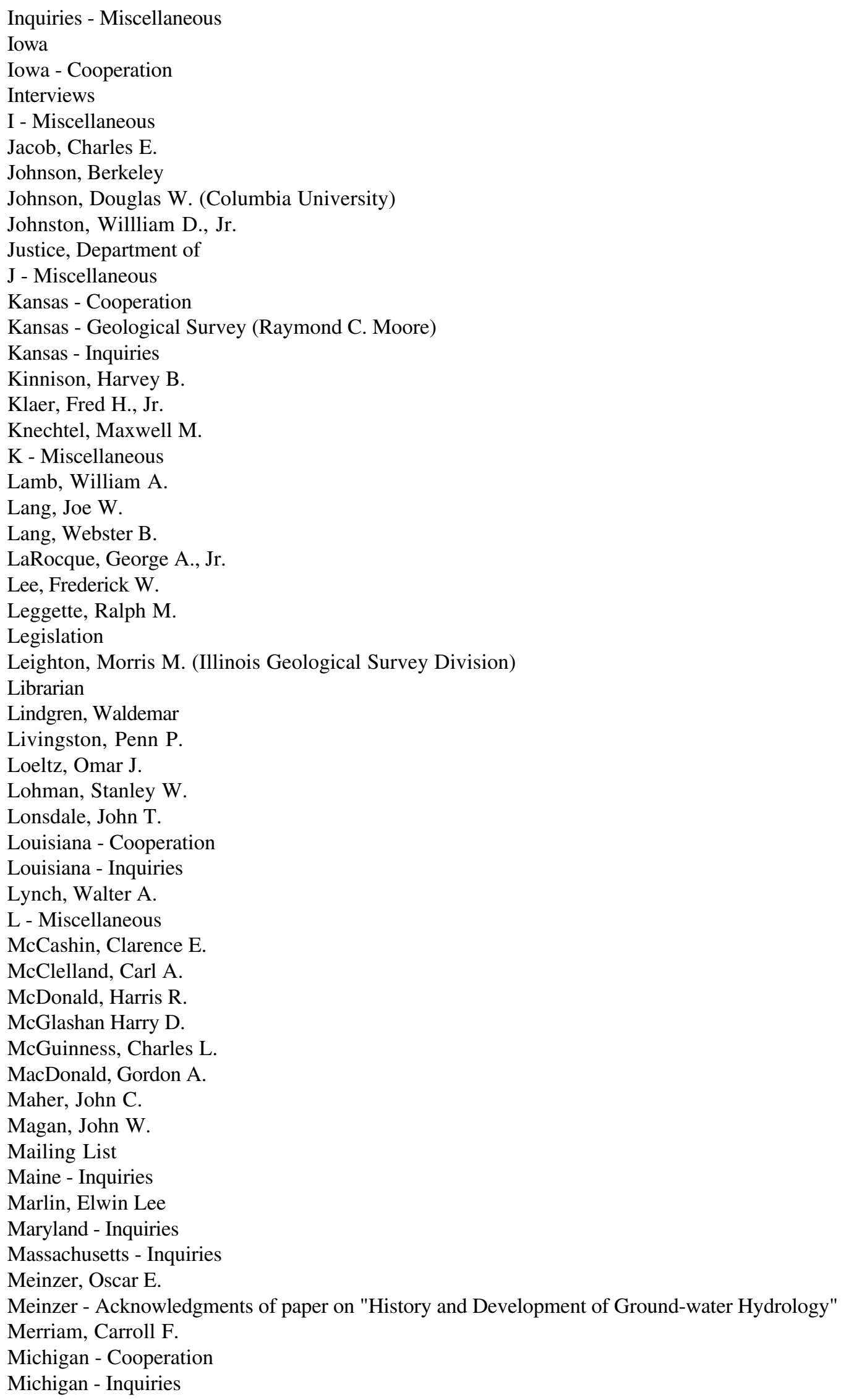


Mines, Bureau of

Minnesota Well Drillers Association

Minnesota - Inquiries

Mississippi - Cooperation

Mississippi Valley Committee

Mississippi - Inquiries

Missouri - Inquiries

Missouri Water Well Drillers Association

Monroe, Watson $\mathrm{H}$.

Montana - Flathead Lake

Montana - Inquiries

Morgan, Arthur M.

Morrison, Roger B.

Murphy, Franklin M.

Murray, C. Richard

$\mathrm{M}$ - Miscellaneous

National Emergency Council

National Park Service

National Research Council

National Resources Committee

Navy Department

Nebraska Conservation and Survey Division

Nebraska Well Drilling Association

Nebraska, State of

Nebraska - Cooperation

Nebraska - Condra, G. E., State Geologist

Nebraska - Inquiries

Nevada Agricultural Experiment Station

Nevada - Inquiries

Newell, Thomas R.

New Hampshire State Planning and Development Commission

New Hampshire - Inquiries

New Jersey - Cooperation

New Jersey

New Jersey Water Well Drillers Association

New Jersey - Inquiries

New Mexico - Cooperation

New Mexico - Conchas Dam

New Mexico - Lea County

New Mexico - Mimbres Valley

New Mexico - Silver City

New Mexico - Roswell Artesian Basin

New Mexico - Inquiries

New York - Department of Water Supply, Gas, and Electricity

New York - Inquiries

New York - Joint Legislative Committee, Frederick J. Slater

New York - Long Island, Miscellaneous

New York - Monroe County Regional Planning Board

New York - Nassau County

New York - Village of Ossining

New York - Suffolk County

New York - Water Power and Control Commission

News Items - For Secretary's Office

Noble, Levi F. 


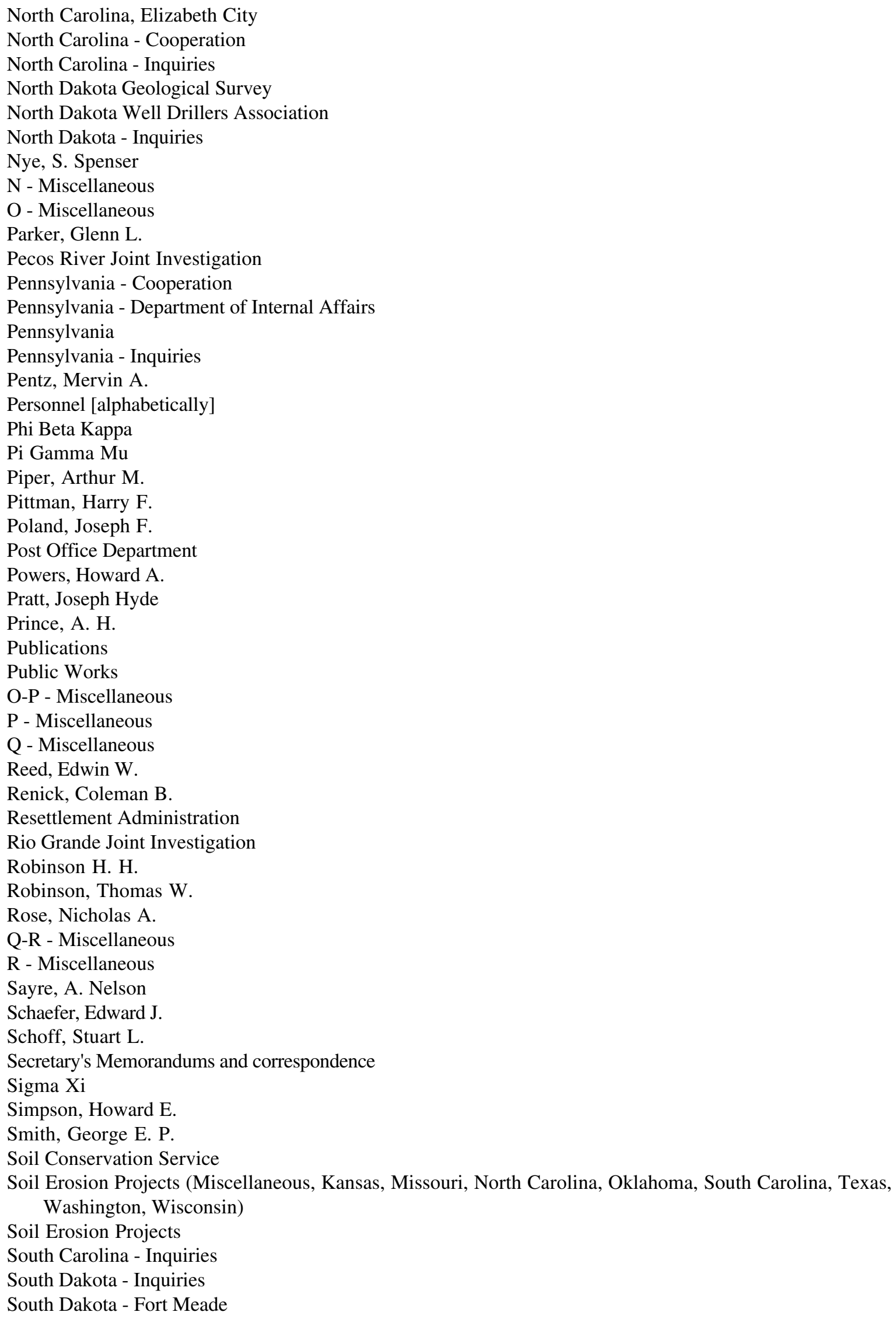


South Dakota - Timber Lake

Standards, Bureau of

Stearns, Harold T.

Stringfield, Victor T.

Subsistence Homesteads, Division of

Sundstrom, Raymond W.

S - Miscellaneous

Taylor, George C., Jr.

Taylor, George H.

Tennessee - Cooperation

Tennessee - Inquiries

Tennessee - Walter H. Pond, State Geologist

Tennessee - Miscellaneous

Texas - Inquiries

Theis, Charles V.

Thomas, Harold E.

Thompson, David G.

Tolman, Carl F. (Stanford University)

Topographic Branch

Treasury Department

Turner, Samuel F.

$\mathrm{T}$ - Miscellaneous

Utah State Engineer

Utah - Dam Sites

Utah - Nephi, Moroni, and Miscellaneous

Utah - Rehabilitation Board

Utah - Ogden

Utah - Salt Lake City

Utah - Salt Lake City Investigation

Utah - Inquiries

U - Miscellaneous

Vermont - Cooperation

Veterans Administration

Virgin Islands

Virginia - Cooperation

Virginia - Inquiries

$\mathrm{V}$ - Miscellaneous

Waite, Herbert A.

War Department

Waring. Gerald A. (Division of Grazing)

Warner, David C.

Warren, Moultrie A.

Washington Academy of Sciences

Washington - City of Tacoma

Washington - Inquiries

Water Resources Bulletin

Water Resources Committee

Water Works Engineering

Wells, Francis G.

Wenzel, Leland K.

Westendick, Frank C.

White, Walter N.

Wisconsin

Wisconsin - Inquiries 
Wisconsin Well Drillers Association

Works Progress Administration

Work Requested

Wyoming - Cooperation

Wyoming - Inquiries

W - Miscellaneous

$\mathrm{X}-\mathrm{Y}-\mathrm{Z}$ - Miscellaneous

Youngquist, C. Vernon

$\mathrm{Y}$ - Miscellaneous

Z - Miscellaneous

Ground Water Branch, 1940-41

Abstracts

Accounts, Division of

Adams, Robert W.

Administrative Geologist

Agriculture, Department of

Akin, P. Donald

Alabama - Cooperation

Alabama - Inquiries

American Association for the Advancement of Science

American Association of Petroleum Geologists

American Society of Civil Engineers

American State Geologists, Association of

American Water Works Association

Anderson, Keith E.

Annual Report (1940)

Arizona - Gila River

Arizona - Inquiries

Arkansas - Cooperation

Arkansas - Inquiries

A - Miscellaneous

Babcock, Horace W.

Bach, W. Kenneth

Bahama Islands - Inquiries

Baker, Roger C.

Barksdale, Henry C.

Bennett, Robert R.

Berthiaume, Sheridan A.

Brashears, Maurice L., Jr.

Bratton, Donald H.

Brown, Glen F.

Brown, Russell H.

Byran, Kirk

Byers, Alan C.

B - Miscellaneous

Cady, Richard C.

California - Santa Maria Valley

California - Santa Ynez River Basin

California - Inquiries

Carlston, Charles W.

Cederstrom, Dagfin J.

Chief Clerk

Chief Hydraulic Engineer 
Chief Geologist

Chief Topographic Engineer

Collins, William D.

Colorado - Inquiries

Colvin, Robert H.

Commerce, Department of

Connecticut - Inquiries

Conover, Clyde S.

Cooper, Hilton H., Jr.

Cross, William P.

Cuba - Inquiries

Cushing, Elliott M.

C - Miscellaneous

Defense Information

Delaware - Inquiries

Dennis, P. Eldon

Detweiler, Abraham L.

Director

District of Columbia - Inquiries

Drainage Basin Projects: Mobile-Suwannee River Basin; Pearl-Pascagoula River Basin; Miscellaneous Drainage Projects

Drescher, William J

Dupont de Nemours, E. I. \& Company

D - Miscellaneous

Economic Geologists, Society of

Economic Geology

Engineer News-Record

Erosion, Division of

E - Miscellaneous

Federal Power Commission

Fellom, Roger

Ferris, John G.

Fiedler, Albert G.

Field Equipment, Division of

Fishel, Vinton C.

Florida - Cooperation

Florida State Geological Survey

Florida - Inquiries

Foley, Frank C.

Foster, Vellora M.

Frye, John C.

F - Miscellaneous

Garrett, Arthur A.

Geological Society of America

Geophysical Section

George, William O.

Georgia Department of Natural Resources

Georgia - Inquiries

Gerardi, Anglo P.

Ground Water Estimates [mostly Indiana]

Guyton, William F.

$\mathrm{G}$ - Miscellaneous

Hale, William E.

Hart, Rodney 


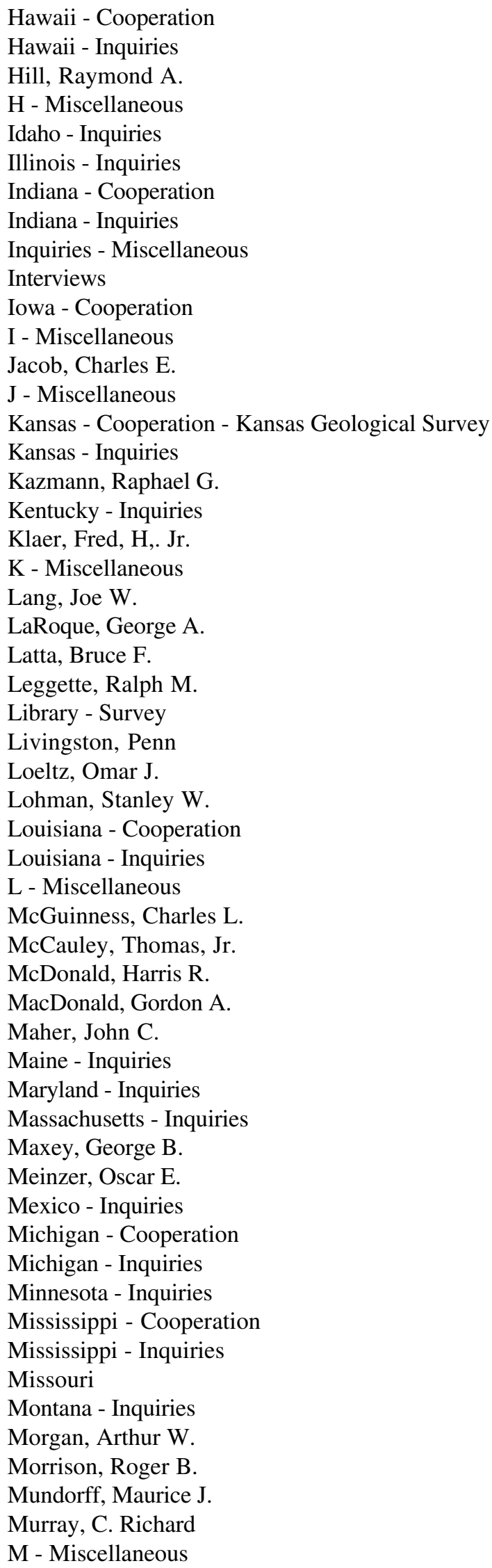


Nace, Raymond L.

National Resources Planning Board

National Research Council

Navy Department

Nebraska - Cooperation

Nebraska State Conservation and Survey Division

Nebraska - Inquiries

Nevada - Cooperation and Inquiries

Newcomb, Reuben C.

New Hampshire - Inquiries

New Jersey - Inquiries

New Mexico - Mimbres Valley

New Mexico - Inquiries

New York - Inquiries

New York - Water and Power Control Commission

North Carolina - Cooperation

North Carolina - Elizabeth City

North Carolina - Inquiries

North Carolina State Board of Health

North Dakota - Cooperation

North Dakota - Inquiries

$\mathrm{N}$ - Miscellaneous

Observation Wells - Committee on

Odum, Dr. Hilmar

Offsetting

Ogden, Evelyn M.

Ohio, Canton

Ohio, Canton (A. Nelson Sayre)

Ohio Chamber of Commerce

Ohio - Cooperation

Ohio - Inquiries

Ohio - Mill Creek Valley Conservation Association

Oklahoma Conservation Commission and Geological Survey

Oklahoma Geological Survey

Oklahoma - Inquires

Oregon

Oregon - Inquiries

$\mathrm{O}$ - Miscellaneous

Parker, Garald G.

Pecos River Joint Investigation

Pennsylvania - Cooperation (Department of the Internal Affairs)

Pennsylvania - Inquiries

Personnel

Phelps, Leonard C.

Piper, Arthur M.

Pittman, Harry F.

Poland, Joseph F.

Public Works Reports

P - Miscellaneous

Ranney Water Collector Corporation

Rasmussen, William C.

Reed, Edwin W.

Reports of Construction and Maintenance

Robinson, John W. 
Robinson, Thomas W.

Rose, Nicholas A.

$\mathrm{R}$ - Miscellaneous

Sayre, A. Nelson

Schaefer, Edward J.

Schoff, Stuart L

Smith, Clay T.

Soil Conservation Projects

South Carolina - Cooperation

South Carolina - Inquiries

South Dakota - Inquiries

Speer, Paul R.

Standards, Bureau of

Stearns, Harold T.

Stringfield, Victor T.

Stuart, Wilbur T.

Sundstrom, Raymond W.

S - Miscellaneous

Taylor, George C., Jr.

Taylor, George H.

Tennessee - Cooperation

Tennessee - Inquiries

Texas - Cooperation

Texas - Inquiries

Theis, Charles V.

Thomas, Harold E.

Thompson, David G.

Topographic Branch

Turner, Samuel F.

$\mathrm{T}$ - Miscellaneous

U. S. Employees' Compensation Commission

Upson, Joseph E.

Utah - Cooperation

U - Miscellaneous

Vermont - Inquiries

Virgin Islands

Virgin Islands - Inquiries

Virginia - Cooperation

Virginia - Inquiries

Virginia - Virginia Beach

V - Miscellaneous

Wahrhaftig, Clyde

Waite, Herbert A.

War Department

Waring, Gerald A.

Warren, Moultrie A.

Washington, - Inquiries

Wenzel, Leland K.

Westendick, Frank C.

West Virginia - Cooperation

West Virginia - Inquiries

Wheelan, Berea D.

White, Walter N.

Williams, Charles C. 
Wilson, Edith C.

Wilson, Woodrow W.

Womersley, Irene

Works Projects Administration

Worts, George F.

Wyoming - Cooperation

Wyoming - Inquiries

W - Miscellaneous

Youngquist, C. Vernon

Ground Water Branch, 1942

American Water Works Association

Anderson, Keith E.

Arizona - Gila River Conference

Arkansas - Cooperation

A - Miscellaneous

Barksdale, Henry C.

Bennett, Robert R.

Brashears, Maurice L.

Broadhurst, William L.

Brown, Glen F.

Brown, Russell $\mathrm{H}$.

B - Miscellaneous

Carlston, Charles W.

Cederstrom, Dagfin J.

Chief Geologist

Chief Hydraulic Engineer

Chief Topographic Engineer

Commerce, Department of

Cooper, Hilton $\mathrm{H}$.

C - Miscellaneous

Dennis, P. Eldon

Director

D - Miscellaneous

Economic Geology

E - Miscellaneous

Federal Power Commission

Federal Works Agency

Field Equipment, Division of

Fishel, Vinton C.

Florida State Geological Survey

Forms - General

Frye, John C.

F - Miscellaneous

George, William O.

Georgia - Cooperation

Graham, Jack B.

Greenlee, Arthur L.

Guyton, William F.

$\mathrm{G}$ - Miscellaneous

Hale, William E.

$\mathrm{H}$ - Miscellaneous

Indiana

I - Miscellaneous 
Jacob, Charles E.

Jeffords, Russell M.

Kazmann, Raphael G.

Klaer, Fred H., Jr.

$\mathrm{K}$ - Miscellaneous

Lang, Joe W.

LaRocque, George A.

Leggette, Ralph M.

Livingston, Penn

Lohman, Stanley W.

Louisiana - Cooperation

L - Miscellaneous

McDonald, Harris R.

McGuinness, Charles L.

Maher, John C.

Maryland - Cooperation

Maxey, George B.

Meinzer, Oscar E.

Meinzer, Oscar E. - Extra copies of Circular Memorandums by

Morgan, Arthur M.

Morrison, Roger B.

Mundorff, Maurice J.

M - Miscellaneous

Nace, Raymond L.

Navy Department

Nebraska Conservation and Survey Division

North Carolina, Elizabeth City

North Dakota State Geological Survey

N- Miscellaneous

Ohio - Cooperation and C. V. Youngquist

Oklahoma - Cooperation

O - Miscellaneous

Parker, Garald C.

Piper, Arthur L.

Pittman, Harry F.

Poland, Joseph F.

$\mathrm{P}$ - Miscellaneous

Rasmussen, William C.

Reclamation, Bureau of

Reed, Edwin W.

Robinson, Thomas W.

Rose, Nicholas A.

R - Miscellaneous

Sayre, A. Nelson

Schoff, Stuart L.

Stearns, Harold T.

Stringfield, Victor T.

Sundstrom, Raymond W.

Swenson, Frank A.

$\mathrm{S}$ - Miscellaneous

Taylor, George C., Jr.

Taylor, George $\mathrm{H}$.

Tennessee - Cooperation

Texas State Board of Water Engineers 
Theis, Charles V.

Thomas, Harold E.

Thompson, David G.

Turner, Samuel F.

$\mathrm{T}$ - Miscellaneous

U. S. Employees' Compensation Commission

Utah - Cooperation

$\mathrm{U}$ - Miscellaneous

Virginia - Cooperation

Virginia, Newport News

Waite, Herbert A.

War Department

Waring, Gerald A.

Warren, Moultrie A.

War work with cooperative funds

Water Resources Bulletin

Wenzel, Leland K.

Westendick, Frank C.

West Virginia Geological and Economic Survey

White, Walter N.

W - Miscellaneous

Ground Water Branch - 1943

Abstracts, Annotated Bibliography of Economic Geology

Accounts, Division of

Agriculture, Department of

Alaska Highway

American Water Works Association

Arizona - Cooperation

Arkansas - Cooperation

A - Miscellaneous

Baker, Roger C.

Barksdale, Henry C.

Bennett, Robert B.

Brashears, Maurice L.

Brenner, Freda S.

Broadhurst, William L.

Brown, Glen F.

Brown, Russell H.

Bryan, Kirk

B - Miscellaneous

Cady, Richard C.

California - Cooperation and Inquiries

Carlston, Charles W.

Cederstrom, Dagfin J.

Chief Geologist

Chief Hydraulic Engineer

Collins, William D.

Commerce, Department of

Conover, Clyde S.

Cooper, H. L., Jr.

Cross, William P.

Cushing, Elliott M.

C - Miscellaneous 
Delaware Cooperation and Inquiries

Dennis, P. Eldon

Denny, Eugene D.

Director

D - Miscellaneous

Economic Geology, Society of

E - Miscellaneous

Ferris, John G.

Field Equipment

Fielder, Albert G.

Fishel, Vinton C.

Florida - Cooperation and Inquiries

Foley, Frank C.

$\mathrm{F}$ - Miscellaneous

Geological Society of America

Georgia - Cooperation and Inquires

Gerardi, Angelo P.

Graham, Jack B.

Greenlee, Arthur L.

Guyton, William F.

$\mathrm{G}$ - Miscellaneous

Herrick, Stephen M.

$\mathrm{H}$ - Miscellaneous

Idaho - Cooperation

Illinois - Cooperation

Indiana - Cooperation

Inter-American Affairs (South America)

Iowa - Cooperation

I - Miscellaneous

Jacob, Charles E.

Jeffords, Russell M.

Kansas - Cooperation

Kazmann, Raphael G.

Kentucky - Cooperation and Inquiries

Klaer, Fred H., Jr.

LaRocque, George A.

Livingston, Penn $\mathrm{P}$.

Lohman, Stanley W.

Louisiana - Cooperation and Inquires

L - Miscellaneous

MacDonald, Gordon A.

McDonald, Harris R.

McGuinness, Charles L.

Maher, John C.

Maryland - Cooperation

Maxey, George B.

Meinzer, Oscar. E.

Michigan - Inquiries and Cooperation

Mines, Bureau of

Miscellaneous memorandums to field men

Mississippi - Cooperation

Morgan, Arthur M.

Mundorff, Maurice J. 
Murray, C. Richard

M - Miscellaneous

Nace, Raymond L.

National Planning Board

National Research Council

Nebraska - Cooperation and Inquiries

Nevada - Cooperation

New Jersey - Cooperation

New Mexico - Cooperation and Inquiries

North Carolina - Cooperation and Inquiries

North Dakota - Cooperation

$\mathrm{N}$ - Miscellaneous

Ohio - Cooperation and Inquires

Oklahoma - Cooperation

Open file - replies from field men to Oscar E. Meinzer

Parker, Garald G.

Pennsylvania - Inquiries and Cooperation

Piper, Arthur M.

Poland, Joseph P.

Purchasing Office, Memorandums to

Reclamation, Bureau of

Reed, Edwin W.

Robinson, Thomas W.

Rose, Nicholas A.

Sayre, A. Nelson

Schaefer, Edward J.

Standards, Bureau of

Stearns, Harold T.

Stringfield, Victor T.

Stuart, Wilbur T.

Sundstrom, Raymond W.

Taylor, George C., Jr.

Taylor, George $\mathrm{H}$.

Tennessee - Cooperation and Inquiries

Texas - Inquires and Cooperation

Theis, Charles V.

Thompson, David G.

Turner, Samuel F.

$\mathrm{T}$ - Miscellaneous

Unklesbay, Athel G.

Upson, Joseph E.

$\mathrm{U}$ - Miscellaneous

Virginia - Cooperation

Virgin Islands

Waite, Herbert A.

War Department

Warren, M. A.

West Virginia - Cooperation and Inquiries

White, Walter N.

Youngquist, Lewellyn W. 


\section{Appendix 31}

Ground Water Branch - Administrative Correspondence Files, 1944-53 (entry 575)

Ground Water Branch, 1944:

Alabama, Tuscaloosa

Arizona, Tucson

Arkansas - Cooperation

California - Long Beach and Santa Barbara

Florida - Miami and Tallahassee

Georgia, Savannah

Hawaii, Honolulu

Indiana, Indianapolis

Iowa, Iowa City

Kansas, Lawrence

Kentucky, Louisville

Louisiana, Baton Rouge

Maryland, Baltimore

Massachusetts

Michigan

Mississippi, University

Montana

Nebraska, Lincoln

Nevada, Las Vegas

New Jersey, Trenton

New Mexico, Albuquerque

New York, Jamaica, Long Island

North Carolina, Raleigh

North Dakota, Grand Forks

Ohio, Columbus

Oklahoma, Norman

Oregon, Portland

Pennsylvania, Philadelphia

Rhode Island

Tennessee, Memphis

Texas, Austin

Utah, Salt Lake City

Virginia, Charlottesville

West Virginia, Morgantown

Wisconsin

Wyoming, Cheyenne

Ground Water Branch, 1944:

Accounts, Division of

Agriculture, U. S. Department of

Alaskan Highway

American Water Works Association

A - Miscellaneous

B - Miscellaneous

Chief Geologist

Chief Hydraulic Engineer

Commerce, U.S. Department of 


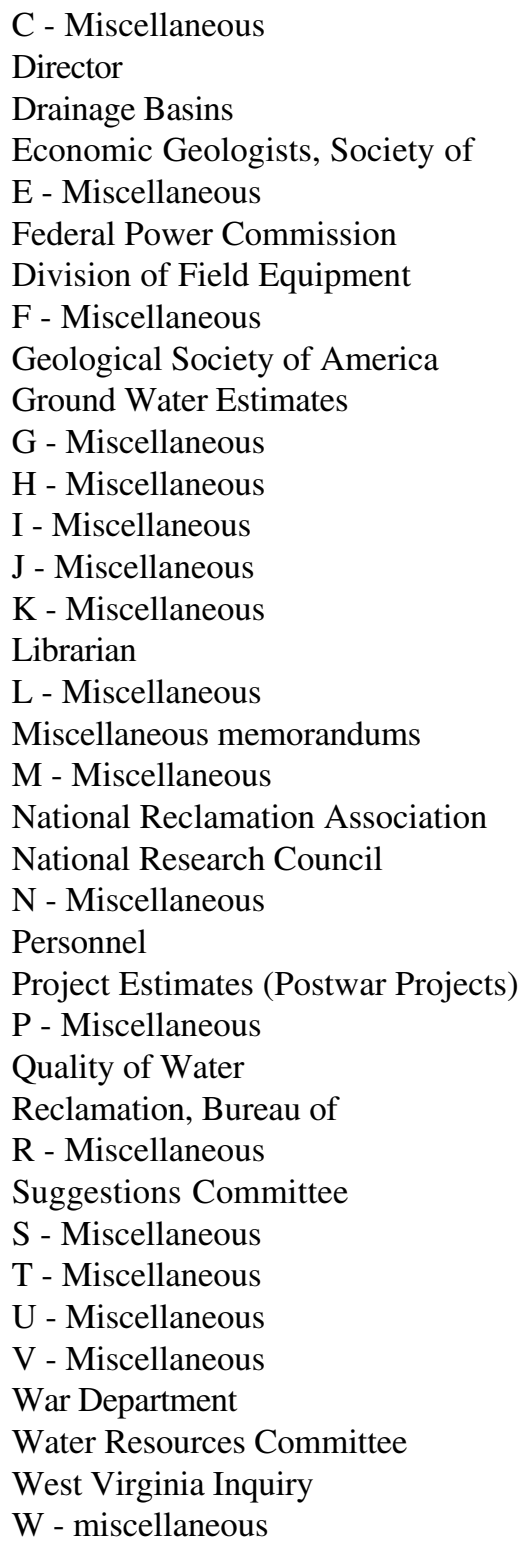

Ground Water Branch, 1945:

Alabama, Tuscaloosa

Arizona, Tucson

Arkansas

California, Long Beach and Santa Barbara

Colorado, Denver

Florida, Miami

Florida, Tallahassee

Georgia, Savannah

Hawaii, Honolulu

Idaho

Indiana, Indianapolis

Iowa, Iowa City

Kansas, Lawrence

Kentucky, Louisville

Louisiana, Baton Rouge 
Maryland, Baltimore

Massachusetts

Michigan

Mississippi, University

Nebraska, Lincoln

Nevada, Las Vegas

New Jersey, Trenton

New Mexico, Albuquerque

New York, Jamaica, Long Island

North Carolina, Raleigh

North Dakota, Grand Forks

Ohio, Columbus

Oklahoma, Norman

Oregon, Portland

Pennsylvania, Philadelphia

Rhode Island

South Dakota

Tennessee, Memphis

Texas, Austin

Utah, Salt Lake City

Virginia, Charlottesville

West Virginia, Morgantown

Wisconsin

Wyoming, Cheyenne

Ground Water Branch, 1945:

Accounts, Division of

American Society of Civil Engineers

American Water Works Association

Arkansas - Cooperation (El Dorado Investigation)

A - Miscellaneous

Branch Charges

B - Miscellaneous

Chief Geologist

Chief Hydraulic Engineer

Chile

Commerce, U. S. Department of

C - Miscellaneous

Director

D - Miscellaneous

Economic Geologists, Society of

Federal Power Commission

Division of Field Equipment

Geological Society of America

$\mathrm{H}$ - Miscellaneous

INCODEL (Interstate Commission on the Delaware River Basin)

I - Miscellaneous

Laboratory Methods

L - Miscellaneous

Michigan (Iron River Investigation)

Miscellaneous Memoranda

Miscellaneous Memoranda to Field Offices

Missouri River Basin Investigation

M - Miscellaneous 
Nevada (Steamboat Springs Investigation)

$\mathrm{N}$ - Miscellaneous

Property

Puerto Rico

P - Miscellaneous

Reclamation, Bureau of

$\mathrm{R}$ - Miscellaneous

Suggestions Committee

S - Miscellaneous

$\mathrm{T}$ - Miscellaneous

$\mathrm{U}$ - Miscellaneous

V - Miscellaneous

War Department

Water Works Engineering

Water Resources Committee

W - Miscellaneous

Ground Water Branch, 1946:

Alabama, Tuscaloosa

Arabia

Arizona, Tucson

Arkansas

California, Long Beach

California, Santa Barbara

Colorado, Denver

Florida, Miami

Florida, Tallahassee

Georgia, Atlanta

Hawaii, Honolulu

Idaho

Indiana, Indianapolis

Iowa, Iowa City

Kansas, Lawrence

Kentucky, Louisville

Louisiana, Baton Rouge

Maryland, Baltimore

Massachusetts

Michigan

Mississippi, University

Missouri River Basin Project

Nebraska, Lincoln

Nevada, Las Vegas

New Jersey, Trenton

New Mexico, Albuquerque

New York, Jamaica, Long Island

North Carolina, Raleigh

North Dakota, Grand Forks

Ohio, Columbus

Oklahoma, Norman

Oregon, Portland

Pennsylvania, Philadelphia

Rhode Island

South Dakota

Tennessee, Memphis 
Texas, Austin

Utah, Salt Lake City

Virginia, Charlottesville

West Virginia, Morgantown

Wisconsin

Wyoming, Cheyenne

Ground Water Branch, 1946:

Accounts, Division of

Agriculture, U. S. Department of

American Society of Civil Engineers

American Water Works Association

Budget Estimates

B - Miscellaneous

Chief Clerk

Chief Geologist

Chief Hydraulic Engineer

Columbia Basin

Commerce, U. S. Department of

Coordination Committee

C - Miscellaneous

Conference - Field Men

Conference - Ground Water and Water Resources; Regional Meeting, Water Resources Branch at Montgomery Alabama; East-Central Water Resources Conference at Indianapolis, Indiana

DeBuchananne, C. D. (accident)

Deferments

Director

Drainage Basins

Economic Geologists

Federal Power Commission

F - Miscellaneous

Geological Society of America

$\mathrm{H}$ - Miscellaneous

I - Miscellaneous

$\mathrm{J}$ - Miscellaneous

Laboratory

Librarian

L - Miscellaneous

Miscellaneous Memoranda

Miscellaneous Memoranda to Field

Mississippi, Upper Embayment Investigation

Missouri River Basin Project

M - Miscellaneous

$\mathrm{N}$ - Miscellaneous

Property

Puerto Rico

P - Miscellaneous

Reclamation, Bureau of

$\mathrm{R}$ - Miscellaneous

Suggestions Committee

$\mathrm{S}$ - Miscellaneous

Virgin Islands

War Department

W - Miscellaneous 
Ground Water Branch, 1947:

Accounts, Division of

American Association for the Advancement of Science

American Geophysical Union

American Water Works Association

Annual Reports - Secretary

Arkansas River Basin

A - Miscellaneous

Budget Estimates

B - Miscellaneous

Chief Geologist

Chief Hydraulic Engineer

Colorado River Basin

Columbia Basin

Commerce, U.S. Department of

Conference - Field Men

Cooperation Committee

Coordination Northwest (Piper)

C - Miscellaneous

Director

Economic Geologists, Society of

F - Miscellaneous

Geological Society of America

Ground Water Program

G - Miscellaneous

I - Miscellaneous

Joint Research and Development Board

$\mathrm{J}$ - Miscellaneous

Laboratory

Librarian

L - Miscellaneous

Miscellaneous Memoranda

Miscellaneous Memoranda to the Field

Missouri River Basin Project

M - Miscellaneous

$\mathrm{N}$ - Miscellaneous

Publications

Puerto Rico

$\mathrm{P}$ - Miscellaneous

P - Philippines, Palestine, Panama, Peru

Reclamation Association

Reclamation, Bureau of

Research and Development

$\mathrm{R}$ - Miscellaneous

Suggestions Committee

Superior Accomplishment Recommendation

$\mathrm{S}$ - Miscellaneous

War Department

W - Miscellaneous

Congressional Hearings - Material 
Ground Water Branch 1947:

Alabama, Tuscaloosa

Arizona, Tucson

Arkansas - Cooperation

California, Long Beach and Santa Barbara

Colorado, Denver

Florida, Miami and Tallahassee

Georgia, Atlanta

Hawaii, Honolulu

Idaho, Boise

Indiana, Indianapolis

Iowa, Iowa City

Kansas, Lawrence

Kentucky, Louisville

Louisiana, Baton Rouge

Maryland, Baltimore

Massachusetts, Boston

Michigan

Mississippi, University

Nebraska, Lincoln

Nevada, Carson City

New Jersey, Trenton

New Mexico, Albuquerque

New York (Jamaica and Albany)

North Carolina, Raleigh

North Dakota, Grand Forks

Ohio, Columbus

Oklahoma, Norman

Oregon, Portland

Pennsylvania, Philadelphia

Rhode Island

South Dakota

Tennessee, Memphis

Texas, Austin

Utah, Salt Lake City

Virginia, Charlottesville

West Virginia, Morgantown

Wisconsin, Madison

Wyoming, Cheyenne

Ground Water Branch, 1948-53:

Alabama, Tuscaloosa

Alaska, Arctic Ground Water Research

Alaska

Alaska, Bureau of Yards and Docks

Arizona, Holbrook, Phoenix, Navajo

Arizona, Tucson

Arkansas, Little Rock

Arkansas Bauxite Project

California, Santa Barbara

California, Sacramento

Colorado, Denver

Connecticut

Connecticut, Middletown 
Delaware

Florida, Miami

Florida, Tallahassee

Georgia, Atlanta

Guam, Trust Territory

Hawaii, Honolulu

Idaho, Boise

Illinois

Indiana, Indianapolis

Iowa, Iowa City

Kansas, Lawrence

Kentucky, Louisville

Louisiana, Baton Rouge

Maryland, Baltimore

Maryland, Salisbury

Massachusetts, Boston

Michigan, Ishpeming

Michigan, Lansing

Minnesota

Minnesota, Minneapolis

Minnesota, St. Paul

Mississippi

Mississippi, University

Montana

Montana, Billings

Nebraska, Lincoln

Nevada, Carson City

New Hampshire

New Jersey, Trenton

New Mexico, Albuquerque

New York, Jamaica, Mineola, and Albany

New York, Mineola

New York, Albany

North Carolina, Raleigh

North Dakota, Bismarck

North Dakota, Grand Forks

Ohio, Columbus

Oklahoma, Norman

Oregon, Portland

Pennsylvania, Philadelphia

Rhode Island

Rhode Island, Providence

South Carolina

South Dakota

Tennessee, Memphis

Texas, Austin

Texas, El Paso

Utah, Salt Lake City

Vermont

Virginia, Charlottesville

Virginia

Virgin Islands

Washington

Washington, Tacoma 
West Virginia

West Virginia, Morgantown

Wisconsin

Wisconsin, Madison

Wyoming

Wyoming, Cheyenne

Ground Water Branch 1948-53:

Acquisition of Lands

Alaska

Alaska Projects

American Geophysical Union

American Institute of Mining and Metallurgical Engineers

American Society of Civil Engineers

American Standards Association

American Water Works Association

Arid Zone, Committee on

Arkansas River Basin

Arkansas - Red-White River Basin Inter-agency Committee

Army, Department of

Artificial Recharge

Authorized Certifying Officers

Data for 1951 Automobile Report

A - Miscellaneous

Branch History

Budget Estimates

Bureau of Land Management

B - Miscellaneous

Carpenter, Charles

Central and Southern Florida Flood Control District

Central Arizona Project

Central Valley Basin, California

Chief Counsel

Chief Geologist

Chief Hydraulic Engineer

Colorado Projects

Colorado River Basin

Columbia Basin

Columbus Equipment Laboratory

Commerce, U.S. Department of

Conference - Field Men

Conservation Foundation

Cooperation Committee

Coordination - Northwest (Piper)

C - Miscellaneous

Director

Summary of Drilling Contracts

D - Miscellaneous

Economic Geologists, Society of

Employees Compensation, Bureau of

Equipment

Executive Officer

E - Miscellaneous

Federal Observation Well Program 


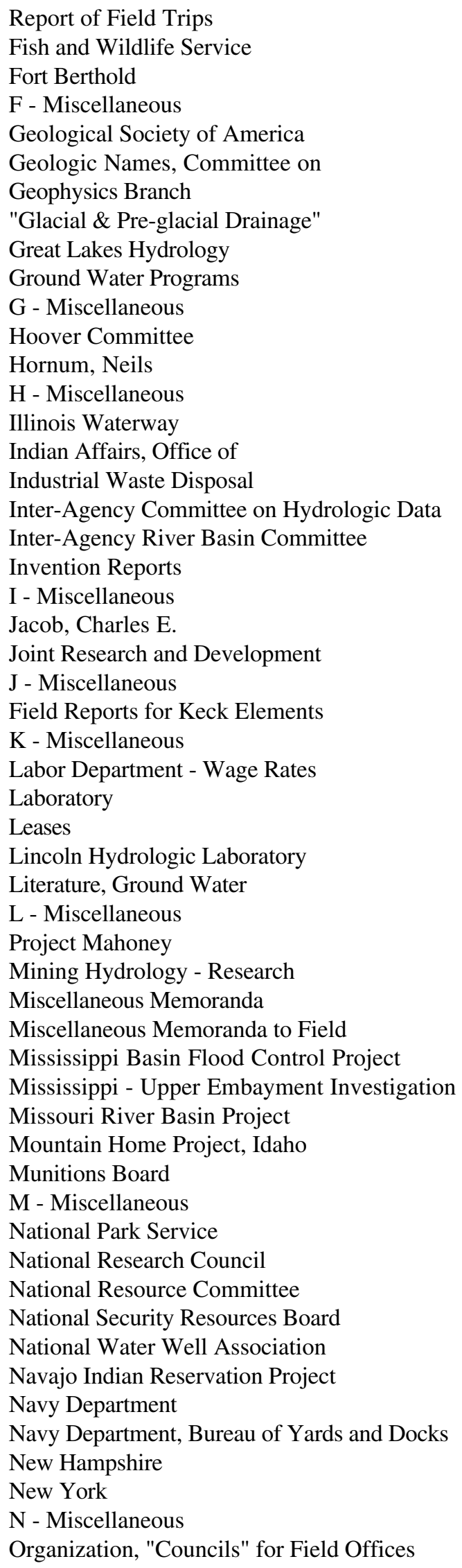


O - Miscellaneous

Pacific Northwest Council

Passamaquoddy Project, Army Corps of Engineers

Personnel

Phreatophytes (Salt Cedar) Investigations

Projects

Publications

Puerto Rico

$\mathrm{P}$ - Miscellaneous

Q - Miscellaneous

Radioactivity

Reclamation, Bureau of

Reconstruction Finance Corporation

Renewable Resources, Subcommittee on

Reports

Research

Research - Pine Barrens

Research - Eureka Mine, Nevada

Research and Development

Research Projects

R - Miscellaneous

Secretary's Office

Secretary's Report

Soil Conservation Service

Sonic Research Survey

Southwest Field Committee

Staff Geologist

State Cooperative Agreements

Suggestions Committee

Synthetic Fuel Plants, Data on

$\mathrm{S}$ - Miscellaneous

$\mathrm{T}$ - Miscellaneous

$\mathrm{U}$ - Miscellaneous

Virgin Islands

War Department

War Department, Sixth Army Area

Water Resources Committee

Water Well Journal

Well Drilling

Well Numbering (Systems)

Well Specifications

Well Specifications, No. 1086

W - Miscellaneous

$\mathrm{Y}$ - Miscellaneous 


\section{Appendix 32}

Quality of Water Branch - Records Concerning Field Offices and Laboratories, 1939-52 (entry 601)

Air Force, Department of, 1946-52

Alaska, General, 1918-50

Alaska, 1951-52

Alaska, Palmer Laboratory, 1950-51

Albuquerque - Proceedings of the Quality of Water Branch Sediment Conference, 1952

American Chemical Society, 1950-51

American Water Works Association - Chesapeake Section, 1949-52

American Water Works Association - Miami Conference, 1946-47

Arkansas, General, 1946-47

Arkansas, Fayetteville Laboratory, 1947-48

Arkansas, Fayetteville Laboratory, 1948-49

Arkansas, Fayetteville Laboratory, 1949-50

Arkansas, Fayetteville Laboratory, 1950-51

Arkansas, General, 1951-52

Army, Department of, 1942-52

California, 1948-51

California, 1951-52

Colorado River Basin, 1945-51

Columbia River Basin, 1944-50

Equipment Development Laboratory - Columbus Ohio, 1949-51

Fish and Wildlife Service, 1947-51

Florida, Ground Water, 1946-52

Florida, Ocala, Laboratory, 1951-52

Florida, South and Central (includes Everglades Project), 1948-52

Florida State Geological Survey (includes the St. Johns River), 1942-52

Florida, Tallahassee, 1946-52

Florida, Pinellas County, 1943-49

Iowa, 1940-50

Iowa, Surface Waters, 1939-52

Kentucky, 1949-52

Louisiana, 1944-49

Louisiana, 1949-51

Louisiana, Investigations in Southwestern Louisiana, 1950-52

Maryland, 1949-51

Michigan, 1946-51

Mississippi River Basin, 1947-52

Missouri River Basin, 1949

Missouri River Basin, 1949-50

Missouri River Basin, 1950

Missouri River Basin, 1950-51

Missouri River Basin, 1951

Missouri River Basin, 1952

Navy Department, 1946-52

Nevada - Steamboat Springs, 1944-46

New Mexico, Albuquerque, 1946-47

New Mexico, Albuquerque, 1947-48

New Mexico, Albuquerque, 1948-49

New Mexico, Albuquerque, 1949-50 
New Mexico, Albuquerque, 1950-51

New Mexico, Albuquerque, 1951-52

New Mexico, Albuquerque, (Frank C. Ames), 1951-52

New Mexico, Albuquerque, Sediment (Frank C. Ames), 1949-51

New Jersey, Ground Water, 1941-52

New York, 1947-52

North Carolina, Raleigh, 1946-47

North Carolina, Raleigh, 1947-48

North Carolina, Raleigh, 1948-49

North Carolina, Raleigh, 1949-50

North Carolina, Raleigh, 1950-51

North Carolina, Raleigh, 1951-52

Ohio, Water Resources Board, 1945-50

Ohio River Valley Water Sanitation Commission, 1948-50

Ohio, 1946-50

Ohio Regional Laboratory, 1947-48

Ohio Regional Laboratory, Columbus, 1948-49

Ohio Regional Laboratory, Columbus, Floor Plans, 1948

Ohio Regional Laboratory, Columbus, 1949-50

Ohio Regional Laboratory, Columbus, 1950-51

Ohio Regional Laboratory, Columbus, 1951-52

Ohio, Toledo Laboratory, 1947-48

Ohio, Toledo Laboratory, 1948-49

Oklahoma, Cooperation, 1946-47

Oklahoma, 1947-48

Oklahoma, Stillwater, 1948-49

Oklahoma, Stillwater Laboratory, 1949-50

Oklahoma, Stillwater Laboratory, 1950-51

Oklahoma, Stillwater Laboratory, 1951-52

Pacific Northwest, 1949-52

Pennsylvania, Ground Water, 1945-51

Pennsylvania, Surface Water (Projects), 1944-51

Pennsylvania, Schuylkill Haven Laboratory, 1947-52

Pennsylvania, 1946-52

Pennsylvania Requisitions, 1951

Pollution, 1947-50

Reclamation, Bureau of, 1945-52

Rubidoux Laboratory, 1945-52

Savannah River Salinity Studies, 1945-51

Schuylkill Haven, Pennsylvania; Philadelphia; Toledo - Purchase Orders, 1947-48

Schuylkill Haven, Pennsylvania; Philadelphia, Pa.; Columbus, Ohio, 1948-49 (Field Requisitions)

Schuylkill Haven, Pennsylvania; Philadelphia, Requisitions, 1948-50

South Carolina, Cooperation, 1945-51

Suggestions Committee

Temperature of Surface Waters, 1946-49

Tennessee, $1947-50$

Texas, Austin, 1946-47

Texas, Austin, 1947-48

Texas, Austin, 1948-49

Virginia, 1943-51

Washington Office, Quality of Water, Requisitions, 1949-50

Washington Office, Quality of Water, Requisitions, 1950-51

Water Utilization Committee, 1950-52 


\section{Appendix 33}

General Hydrology Branch - General Correspondence Files, 1920-59 (entry 636)

Organization and Management, Atlanta, Ernest L. Hendricks, 1952-56

Organization and Management, Salt Lake City, Harold V. Peterson, 1954

Organization and Management, Rocky Mountain Area, 1952-58

Organization and Management, Equipment Development - General, 1955-58

Organization and Management, Equipment Development, Laboratory (Keith S. Essex), 1956-59

Organization and Management, Equipment Research (EDL) (Arthur H. Frazier), 1941, 1956-59

Organization and Management, Delaware River Draft Report, 1958

Organization and Management, Project Hydrologist, Delaware River (Garald G. Parker [Sr.]), 1956-57

Organization and Management, Project Hydrologist, Delaware River (Garald G. Parker [Sr.]), 1958

Organization and Management, Project Hydrologist, International (Wilbur D. Simons), 1955-57

Organization and Management, Water Loss Investigations, 1949-57

Finance \& Budget Fiscal Records, 1945-48

Finance \& Budget, Technical Coordination Branch, 1949-54

Finance \& Budget Purchase Orders, FY 1951

Finance \& Budget Purchase Orders, Expense Vouchers, Travel Authorizations, FY 1952

Finance \& Budget Accounts Expense Vouchers, FY 1953

Finance \& Budget, Purchase Orders, FY 1953

Finance \& Budget, Expense Vouchers, Purchase Orders, Fiscal Matters, FY 1954

Finance \& Budget, Expense Vouchers, Travel Authorizations, Purchase Orders, Allotment Notices, FY 1955

Finance \& Budget, Purchase Orders, Expense Vouchers, Allotment Advices, FY 1956

Finance \& Budget, Allotment Advices, Fiscal Matters, FY 1957

Finance \& Budget, Expense Vouchers, Purchase Orders, FY 1957

Finance \& Budget, Allotment Advices, Fiscal Matters, FY 1958

Personnel, Analyzes \& Research, 1946-51

Personnel, Information, ca. 1941-59

Personnel, Miscellaneous, 1941-53

Programs \& Plans, Equipment Development Laboratory, 1955-59

Programs \& Plans, River Basin Studies, Delaware River, 1956

Programs \& Plans, River Basin Studies, Delaware River, 1957 (2 folders)

Districts, Albany District, 1940-50

Districts, Columbus District, 1939-50

Districts, Hartford District, 1940-50

Districts, Idaho Falls, 1952-53

Districts, San Francisco District - San Bernardino County, 1940-50

Districts, Tucson District, 1941-52

Sediment, Inter-Branch, 1948-54

Sediment, Salt Wahoo Basin, 1953

Soil \& Moisture Program of Bureau of Reclamation, 1946-49

Soil \& Moisture Conservation, Administrative, 1940-49

Soil \& Moisture Conservation, Administrative, 1950-52

Soil \& Moisture - Budget, 1940-53

Soil \& Moisture - Budget, 1950-52

Soil \& Moisture Conservation, Finance, 1940-50

Andreasen, Gordon E., 1948-53

Conklin, Howard L., 1948-56

Davenport, Royal W., 1933-58

Dickinson, William E., 1938-42

Dickman, Marian J., 1931-49 
Frese, Violet A., 1942-52

Graham, Jack B., 1942-54

Gumbel, E. J., 1941-53

Harbeck, G. Earl, Jr., 1945-53

Hendricks, Ernest L., 1952-53

Herlevi, Martha S., 1935-50

Hoyt, William G., 1954-56

Langbein, Walter B., 1938-52

Leopold, Luna B., 1950-53

McDonald, Charles C., 1946-53 (2 folders)

McDonald, Charles C., (Progress Reports), 1946-53

Muck, Kavanaugh, Musgrave, \& others, in Office of Land Utilization, 1940-44

Peterson, Harold V., Administrative, 1940-53 (3 folders)

Peterson, Harold V., Hydrologic Investigations, 1941-52 (2 files)

Peterson, Harold V. - Personnel, 1942-53 (2 files)

Piper, Arthur M., Pacific Northwest Water Resources Council, 1942-50

Fort Collins, (Bernard N. Rolfe), 1951-53

Rolfe, Bernard N. 1951-56

Sherman, Irving, 1946-51

Cooperation - Bonneville Power, University of Washington, 1952-55

Equipment Development - General Correspondence, 1948-55

Highway Research Board, 1920-49

Miscellaneous, 1934, 1948-50

Reservoir Inventory, 1947-52

War Department, Chief of Engineers, 1937-54

Water, General; Weather Forecasts, 1953-54

Water Utilization, - Requests for Information, 1942-51 


\section{Appendix 34}

General Hydrology Branch - Records concerning Programs and Projects, ca. 1915-58 (entry 637)

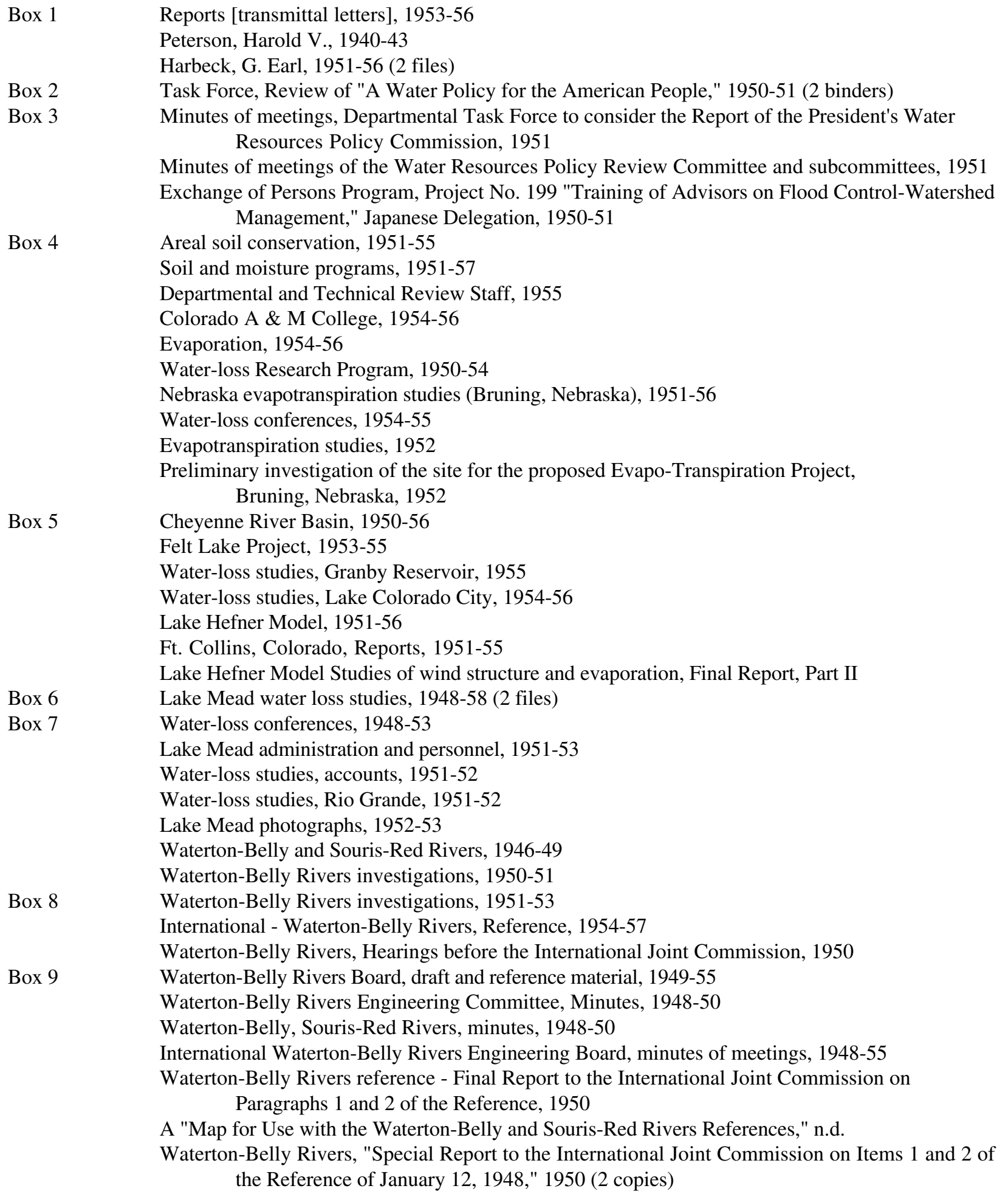


Box 10

Box 11

Box 12

Box 13

Box 14

Box 15

Box 16

Box 17

Box 18

Box 19
"International Joint Commission Waterton-Belly Reference Report by Special Engineering Committee, Canadian Proposal of April 1952," February 1954

"Study of Possible Plans Pursuant to the May 18, 1950 Minute of the International Joint Commission," 1951 (2 copies)

"Waterton-Belly Reference Report," by W. L. Foss, February 1952

Waterton River and Belly River, possible allocation of waters, n.d.

Reports to the International Joint Commission, Waterton-Belly Engineering Board, 1948-55

Waterton-Belly Rivers, reports, 1948-53

Columbia River Basin, Correspondence, 1944-55 (4 files)

Columbia River, 1936-41

Columbia River, International Boundary, 1942-53 (2 files)

Columbia River, International Boundary, Reference, 1939-43

Columbia River - Grand Coulee, Statements at Spokane Hearings, 1941

Columbia River - Grand Coulee, Studies 1-9, ca. 1941

"Backwater Investigations of the Columbia River Reservoir," 1940

Columbia River - Grande Coulee, Statement of Funds available for project planning, FY 1945, Region I

Columbia River - Grande Coulee, Statement of Engineer Advisors relating to the application of the Government of the U.S. for the right to operate the Grand Coulee Dam and Reservoir, 1941

Columbia River - Grande Coulee, relating to levels of the Columbia River at the International Boundary, 1940

Columbia River Engineering Board, International Joint Commission, Minutes of Meetings, September 15-16, 1944

International Columbia River Committee, Minutes, 1945-58

International Columbia River Engineering Board, minutes, 1944-49

International Columbia River Engineer, Board, Minutes, 1948-58 (2 files)

"Water Elevations at selected points along the Upper and Lower Arrow Lakes and Columbia River between Revelstoke, B.C. and Little Dalles, Wash., 1930-1933," by C. E. Webb (2 copies)

"Columbia River between Birchbank, British Columbia, and the Little Dalles, Washington: Water Elevations at Selected Observation Points, 1930-39," by Glenn L. Parker

"Columbia River Reservoir Backwater Studies," Joint Report of Engineer Advisors, 1941

"The Unit Fall Discharge Method: Applied to Open Channels under Backwater Conditions," 1937, by A. J. Matheson

"Backwater Studies: Grand Coulee Dam, Columbia River," 1940, by C. G. Cline

"Joint Report on Water Elevations, Columbia River in the vicinity of the International Boundary," 1941, by F. M. Veatch and C. E. Webb

Columbia River and tributaries in Canada, reports, 1944

"Columbia River and Tributaries in the U.S.: Progress Report," 1944

"Columbia River and Tributaries in the U.S.: Bibliography of Reports," 1944

"Columbia River and Tributaries in Canada: Bibliography of Reports," 1944

International Columbia River Engineering Committee, n.d.

"Water Resources of the Columbia River Basin: A Preliminary Report to the International Joint Commission," 1945 (2 copies)

"Columbia River Basin above Snake River: Index of Stream and Lake Gaging Stations, complied from records to September 30, 1946," 1947 (2 copies)

Columbia River Basin - Reports to the International Joint Committee, 1944-49

"Supplemental Joint Report on Water Elevations, Columbia River, in the vicinity of the International Boundary for the period August 1, 1941 to December 31, 1951," 1952

"Preliminary Report on the Mica Dam Site, Columbia River, B.C., 1954"

"Alternative Development of the Kootenay River in Canada: A Report of the Benefits to Canada of Diverting a part of the Kootenay River Flow to the Columbia River," 1954, by W. E. Warren

"The Development of the Snake River Projects as Reasonable Components of a System with both Hydro and Thermal-Electric Generating Resources," 1955, by Holland H. Houston 
Box 20

Box 21

Box 22

Box 23

Box 24

Box 25

Box 26

Box 27
"Preliminary Report on the Murphy Creek Site, Columbia River, B. C.," 1956

Photographs relating to the Columbia River Project, n.d. [envelope]

Columbia River - Boundary Computations, n.d.

Columbia River Water Level Observations, 1941-47

Columbia River Reservoir, 1942-56

"Okanagon River Flood Control Project and Its Effect upon Blueback Salmon," and other papers, 1950-52

"The Effect of the Okanagon Flood Control Project on the Flow of Water at the International Boundary," 1952

"Okanagon Flood Control Project and Similkameen River Plans," ca. 1952 [map]

Pend Oreille River, 1951-56

International - Pend Oreille River Investigation, 1951-52

International Joint Commission - Similkameen River, Reports, 1948-49

Columbia River Basin - Okanagon and Similkameen River, 1950-54

Tacoma District, General, 1927-47

Tacoma - Columbia River, Technical Data, ca. 1930-46

Helena District, General, 1929-53 (2 files)

International, General - Helena District, 1954-56

Kootenay River Report, Manuscript, n.d.

Lower Kootenay River Inspection Reports, 1932-58 (2 files)

Record for gaging stations on Kootenay River and tributaries below Kootenay Lake, 1925-33

Gage height records for stations on Kootenay Lake and Kootenay River south of the Lake in British Columbia, 1929-63

Gage height records for gages on the west arm of Kootenay Lake, B. C., 1930-38

"Compilation of Base Data, Kootenai River Investigation, Idaho," 1938

Kootenai River, General Technical, ca. 1936-49

Rating tables for Lower Kootenai River, ca. 1938-42

Kootenai Backwater Computations, ca. 1937-57

Kootenai River, 1941 - Rating Curve, Original Conditions, ca. 1927-41

Kootenai - Outflow computations, 1940-44

Kootenai, Inflow - Outflow, 1940-45

Base data, Kootenai Valley Investigations, 1943

Kootenai River, estimates of flow, Libby and Leonia, Montana, 1911-45

Katka Reservoir Site, Preliminary study, ca. 1916-44

Kootenai River at Tunnel 8 Damsite, 1945

Kootenay Lake at Kuskonook, B.C., ca. 1945

Kootenai River - Computations, Porthill to Klockman, ca. 1941-47

Discharge of Kootenay Lake at Corra Linn, 1940-46

Study of proposed modification of control procedure on Kootenay Lake, 1950-52

Kootenai River, Miscellaneous base data, ca. 1936-50

"Kootenay Lake Regulation - Storage diagram for original outlet conditions and available storage areas as of 1939-43," (2 copies)

"Report on Geologic Reconnaissance of the Clark Fork-Kootenai River, Development Plan, Lincoln and Sanders Counties, Montana," 1945

Clark Fork River, Chimney Rock Damsite, 1945

Kootenai River-Clark Fork, Combined Power Project Studies, 1945

Kootenai River, Libby Project, 1950-53

Ad Hoc Committee on the Libby Project, ca. 1951-55 (2 files)

International investigation - Libby Project, 1953-54

Duck Lake, ca. 1933-55

Grohman data and correspondence, 1939-51

Kootenai-Grohman Narrows, 1943-53

Kootenay River at Grohman, B.C., 1943-57 
"Development of the Discharge Curve for Kootenay River at Grohman, B.C., under Present Conditions," 1951 (2 copies)

"Comment and Hydraulic Studies re the Application of Peter Charles Bruner to the International Joint Commission," 1936

"Memorandum re High Water 1938, Kootenay Valley, Bonners Ferry, Idaho to Kootenay Landing," 1938

"Statement filed on Behalf of the Government of the Canada," 1938

"Application to the International Joint Commission for Permission for Storage of Water in Kootenay Lake in addition to the storage authorized by the Order of Approval dated the Eleventh Day of November, 1938"

"Kootenay River Discharge below Kootenay Lake," 1939

Memorandum concerning "Kootenay River Discharge below Kootenay Lake," by T. M. Paterson, 1940 (4 copies)

"First Annual Report (for the calendar year 1939) of the International Kootenay Lake Board of Control," 1940

"Memorandum re Kootenay Lake Storage Diagram," 1940

"Memorandum re Kootenay River Discharge, Discussion of Questions Raised by Mr. Davenport," 1940

"Memorandum re Conditions in the Kootenay Valley in the vicinity of Creston, British Columbia," 1940

"Memorandum re Kootenay River Discharge, Discussion of Points Raised in Mr. Davenport's Memorandum of August 12, 1940," 1940

"Development of the Discharge Curve and Storage Diagram for Original Outlet Conditions," 1941 ( 3 copies)

"Memorandum concerning the application of records of the Slocan River at Shoreacres, B.C. to the determination of the original stage-discharge relation of Kootenay River at Nelson, B.C.," 1941

"Consumptive Use of Water Studies in Idaho," 1945

"Preliminary Review of the Bull River Dam Site, Kootenay River, B.C.," 1950

"Preliminary Estimates of the Plumbob Dam Site, Kootenay River, B.C.," 1950

"Interim Report on Kootenay River to the International Joint Commission by the International Columbia River Engineering Board," October 3, 1950

"Kootenay River, An Interim Report to the International Joint Commission," November 1, 1950

"Libby Project, Kootenay River, A Report on the Application of the Government of the United States for Authority to Construct the Libby Project," 1951

"Memorandum Regarding Study of Control Procedure on Kootenay Lake during the Flood Season," 1952 ( 2 copies)

Box $30 \quad$ Sage Creek, 1945-51 (3 files)

"Report to the International Joint Commission on Floods in the Osoyoos Lake Area," 1946

Missouri River Basin, 1945-48

Box 31 St. Mary and Milk Rivers, reports and documents, 1915-42 (7 items, printed)

"St. Mary-Milk Rivers Project Report," 1949, by W. L. Foss

Great Lakes and St. Lawrence Waterway, reports and congressional documents (6 items printed)

Box 32 St. Paul District Office, General, 1928-51

International investigations, St. Paul District, 1954

Basswood River, 1940

Pigeon River, St. Paul District, 1933-47

Rainy River, St. Paul District, 1934-57

Souris River, St. Paul District, 1939-47

Red River, St. Paul District, 1933-52

International, Roseau River, Reference, 1949-53

Roseau River, St. Paul District, 1943-51

St. Paul District, Miscellaneous, 1933-42 
Box 33 Surface water and drainage, Minnesota, published reports and articles (13 items, printed) "The Montana Earthquakes of 1935," by Harold W. Scott

"Report of the International Joint Commission, United States and Canada, on the Pollution of Boundary Waters," 1951 (2 copies)

Box 34 "Water Resources of the Saint John River Basin, Quebec, Maine, New Brunswick," Interim report to the International Joint Commission, 1952 (3 volumes)

"Ice Drill," by A. E. Frazier, 1956

Box 35 Special Board, Interior, Principles regarding water and power, U.S. and Canada, 1951-55

Departmental Board on International Water and Power Projects, 1954-57 (2 files)

Departmental Board on International Water and Power Projects, Correspondence, 1955-58

Departmental Board on International Water and Power Projects, Reference material, 1953-57

Box 36

Pacific Northwest Governors' Policy Committee, 1954-58 (2 files)

Box 37 Mexican Treaty, 1944-45

Miscellaneous bound booklets 


\section{Appendix 35}

General Hydrology Branch - Reports and other Records concerning Water Sources for Livestock, 1942-59 (entry 638)

1942: $\quad$ "Geology and its effect on flood runoff in the Lower Moapa Valley, Nevada" "Proposed locations of wells in Arizona Grazing District No. 4, Kingman, Arizona" "Location of proposed well in the vicinity of Frazier Well, Hualpai Indian Reservation, Arizona" "Probable effects which may be expected on water resources on Indian lands located in Taos County, New Mexico, as a result of the drilling of wells in the vicinity of those lands by the Water Facilities Board"

"Prospective well sites for stock-watering purposes in Hurricane Grazing District No. 1, Arizona" "Proposed location of stock-water wells in Arizona Grazing District No. 2, Kingman District" "Location of prospective sites for stock wells in Arizona Grazing District No. 3"

"Location of stock-well sites in the Hopi Indian Reservation, Arizona"

"Suggestive water development program for wild life, Organ Pipe Cactus National Monument, Arizona"

"Location of prospective stock-water well sites and comments on other phases of soil and moisture activities being carried on in the Navajo Reservation, Arizona and New Mexico"

"Development of watering places for wild life in Wupatki National Monument, Arizona"

"Location of prospective well sites for stock-water wells in the Haulpai Indian Reservation, Arizona"

"Prospects for providing a ground water supply sufficient for irrigation of a proposed feed center located on the Hassayampa Plain near Wickenburg, Arizona"

"Prospective locations for stock-wells in the Big Sandy Valley, Arizona"

"Results of geophysical measurements on the Papago Indian Reservation, Arizona, and near Kingman, Arizona"

"Prospective stock-well sites in Arizona Grazing District No. 2"

"Some prospective stock-well sites in Nevada Grazing District No. 5"

"Some prospective stock-well sites in the Papago Indian Reservation, Arizona"

"Some prospective well locations in Arizona Grazing District No. 3"

"Observations regarding some proposed spring development in the Haulpai Indian Reservation, Arizona"

"Prospective stock-well sites in Arizona Grazing District No. 4, Graham and Greenlee Counties, Arizona"

"Development of springs and location of prospective stock-wells in Nevada Grazing District No. 5"

1944: $\quad$ "Some prospective stock-well sites in Nevada Grazing District No. 4"

"Results of recent resistivity explorations for stock-well locations in the Kingman Grazing District, Arizona"

"Prospect for developing ground-water supplies near Shiprock, New Mexico, and near Peach Springs, Arizona"

"Prospects for obtaining a school well near Nagesi Trading Post, San Juan County, New Mexico"

"Description of proposed stock-well sites in Grazing Districts Nos. 1, 2, 3, 4, 5, and 6, New Mexico"

"Investigation of proposed stock-well sites in Grazing Districts Nos. 2, 10, 3, and 4, Utah Region"

"Prospective stock-well sites in Vermillion Grazing District No. 11, Utah" 
1945: Prospective stock-well sites, stock tanks and spring developments in Escalante Grazing District No. 5, Utah"

"Prospective stock-well sites in Grand Grazing District No. 9, Utah"

"Proposed stock-well sites in the San Rafael Grazing District No. 7, Utah"

"Prospective stock-well sites in Duchesne Grazing District No. 8, Utah"

"Water supply at the Carson Colony, Jack's Valley Ranch and the Dresslerville Colony, Nevada"

"Prospective stock-well sites in the Virginia City Grazing District, Nevada"

"Prospective stock-well sites in Jordan Valley Grazing District No. 4, Oregon"

"Stock-water development in parts of the Owyhee Desert located west of the South Fork of the Owyhee River and south of the Nevada-Oregon Boundary. All within the Elko Grazing District"

"Stock water development in parts of the Pyramid Grazing District, Nevada"

"Suggestions concerning range water developments in parts of the Elko Grazing District, Nevada"

"Prospects for obtaining a successful well in the Ferguson Desert, Western Utah"

"Proposed stock-watering projects on public domain in Coconino, Maricopa, Yavapai and Yuma Counties, Arizona"

"Prospective stock water developments on Indian allotments in the Southwestern part of Oregon Grazing District No. 4"

"Stock-water supplies on public domain in Estancia Valley and Encino Basin, New Mexico"

1946: $\quad$ "Prospective stock-well sites in the Fort Hall Indian Reservation, Idaho"

"Prospective stock-well sites in Safford Grazing District No. 4, Graham and Greenlee Counties, Arizona"

"Prospective stock-well sites in the Bonneville and Pahvant Grazing Districts, Utah"

"Examination of proposed stock-well sites on public domain in Maricopa and Yavapai Counties, Arizona"

"Prospective stock-well sites in Maricopa Grazing District No. 3, Arizona"

"Location of prospective stock-well sites in the Goshute and Independence Valleys, Nevada"

"Domestic water supply for the Moapa Indian Agency, Nevada"

"Examination of proposed stock-well sites in Tensleep Grazing District 1, Wyoming"

"Examination of proposed stock-well sites on the Horse Prairie Soil and Moisture Project in Grazing District 5, Montana"

"Examination of proposed well site in Bridger Grazing District 4, Montana"

"Examination of proposed stock-well sites on public domain in Beaverhead and Madison Counties, Montana"

1947: $\quad$ "Prospective well sites on Adams and Anderson leases on public domain near Winkelman, Arizona"

"Examination of proposed well site on Wickenburg community allotment, Maricopa Grazing District 3, Arizona"

"Examination of proposed well sites in Wyoming Grazing District 2"

"Prospects of stock-water wells on the Arapahoe Tribal Pasture, Wind River Indian Reservation, Wyoming"

"Water-supply studies and investigations for proposed new school sites and enlargement of existing schools on the Navajo Indian Reservation"

"Examination of proposed stock-well sites on public domain in Pima County, Arizona"

"Proposed stock-well sites in Grazing Districts 1-4, 6 and 7, New Mexico"

"Proposed stock-well sites in the Indian Wells Valley and Cuddleback Lake Valley, California"

"Proposed stock-well sites in the San Rafael Grazing District No. 7, Utah"

"Proposed stock-well sites in the Western part of the Pahvant Grazing District No. 3, Utah" 
1948: $\quad$ "Failure of stock-water reservoirs in Rich County, Utah"

"Prospective stock-well sites in the Big Sandy Valley and in the area west of McCracken Mts., Arizona"

"Reservoir lining materials located in Escalante Grazing District No. 5, Utah"

"Examination of proposed well-site on stock trail near Mayoworth, Wyoming"

"Prospective stock-well sites on the Day and Stevens grazing allotments, Greenlee County, Arizona"

"Investigations of range-water prospects in part of the Wind River Indian Reservation, Wyoming"

"Location of prospective stock-well sites in the Ruby and Steptoe Valleys, Elko County Grazing District, Nevada"

"Prospective stock-well sites in the Paradox, Disappointment and Pioneer Valleys, Colorado"

"Prospective stock-well sites in the Lakeside Mountain Region, Utah"

"Stock water development in Little Gypsum and Pioneer Valleys, Montrose and San Miguel Counties, Colorado"

1949: $\quad$ "Range water resources of a part of the Elko Grazing District, Elko County, Nevada"

"Examination of proposed well-site in Cumberland Unit, Grazing District No. 4, Wyoming"

1950: $\quad$ "Prospective stock-well sites in Arizona Grazing District No. 2, Kingman, Arizona"

"Prospective stock-well sites in the Tule Valley and Charleston Mountain Area, Nevada"

"Prospective stock-well sites in the Arizona Grazing District No. 3, Wickenburg, Arizona"

"Prospective stock-watering sites in Bonneville Grazing District, Utah No. 2"

"Examination of proposed stockwell sites in Grazing District 5, Wyoming"

"Prospective stock-well sites in the Duckwater Area, Nye and White Pine Counties, Nevada"

1951: $\quad$ "Stock watering sites on parts of the Arizona Strip"

"Prospective stock-well sites in the Puddle Valley Area, Tooele County, Utah"

"Investigation of well site in Topaz Valley, Juab County, Utah"

"Examination of possible stock-water well sites in the Stansbury Mountain Area"

"Water losses from stock reservoirs in Cheyenne Basin as indicated by performance of observation reservoirs during 1950-1951 water year (supplement to report "the effect of stock reservoirs on runoff in the Cheyenne Basin above Angostura Dam)"

"Prospective stock-well sites in the area Southwest of Cuba, Sandoval County, New Mexico"

"Proposed stock-well site on the Alejandro Gallegos Allotment, Santa Fe County, New Mexico"

"Prospective stock-well sites in Trout Creek Area, Juab County, and Grassy Mountain Area, Salt Lake County, Utah"

"Stock water prospects and erosion problems in the Grand Gulch and Slick Horn Areas, San Juan County, Utah"

"Stock-well site investigations in the Desert Area Southeast of Escalante, Garfield County, Utah"

"Investigation of stock-water development possibilities, Arapahoe Ranch, Wind River Indian Reservation, Wyoming"

"Prospect for obtaining a well and for spring development along the east side of Cedar Mountain in unsurveyed T. 4 S., R. 11 W., Tooele County, Utah"

"Prospective stock-well site in the Dugway Mountain Area, Tooele County, Utah"

"Proposed stock-watering site on Moccasin Mountain, Mohave County, Arizona"

"General prospects of stock-water development by wells in the Nipple Rim, Seven Mile Ridge, and Great Divide Areas, Moffat County, Colorado"

"Water supply for the St. George, Washington County, Utah C. A. A. Station"

1952: $\quad$ "Island Ranch proposed stock-well site in Skull Valley, Tooele County, Utah"

"Examination of proposed well site near the Pryor Mountains in Bridger Grazing District 4, Carbon County, Montana"

"Examination of proposed well site in the Carter Draw Area, Grazing District 2, Fremont County, Wyoming" 
"Examination of 4 proposed well sites in Northwestern Natrona County near Lost Cabin, Wyoming"

"Prospective stock-well sites in Twin Falls Grazing District west of Malad, Oneida and Power Counties, Idaho"

"Further investigations for stock-watering sites on parts of the Arizona "Strip" "

"Investigations of possible stock-well sites in western Mesa County, Colorado"

"Location of prospective stock-well sites in the area west of Rio Grande, San Ysidro Grazing

District No. 1, New Mexico"

1953: $\quad$ "Stock-well investigation in the eastern part of Elko Grazing District, Nevada"

"Examination of proposed well site near Elk Mountain, Grazing District No. 4, Lincoln County, Wyoming"

"Prospective stock-well sites in the Honey Lake Grazing District a few miles east of Susanville, California, and in the Cal-Neva Unit near Flanigan, Nevada"

"Report of an examination of the Fort Duchesne, Utah, Area"

1954:

"Examination of proposed well sites in the Red Desert Area, Grazing District No. 4, Sweetwater County, Wyoming"

"Stock-well investigations along the Owyhee River in southeastern Oregon" (draft and report)

"Stock-well investigations in the Denio Area, Harney County, Oregon" (draft and report)

"A report of well-site investigations in four areas in Pyramid Grazing District, Humboldt County, Nevada"

"Examination of proposed well sites in the Sand Gulch and Crooks Mountain Areas, Fremont County, Wyoming"

"Prospective well sites near Kanab, Utah"

"Examination of the Bitner Well, Massacre Lake District, Nevada"

"Examination of proposed well sites in southern and eastern Elko County, Nevada"

"Examination of proposed well site in Gobbler Draw, Grazing District No. 1, Carbon County, Montana"

"Estimated precipitation and runoff for the Arizona Strip"

"Report of geological conditions at several reservoir sites in the Hurricane Wash Drainage Basin, Mohave County, Arizona"

"Stock-water development program for the Bonneville Grazing District, Tooele and Joab Counties, Utah"

"Report of geological conditions at several reservoir sites in the Hurricane Wash Drainage Basin, Mohave County, Arizona"

"Proposed well site near Bumblebee, Yavapai County, Arizona"

"Proposed well site locations in Elko County, Nevada"

"Prospective well sites in Nye and White Pine Counties, Nevada"

1955: $\quad$ "Proposed headquarters well site in the San Simon Valley near Bowie, Arizona"

"Supplemental stock-well studies in Utah, Tooele, and Juab Counties, Utah"

"Examination of proposed well sites in the Worland-Hyattville, and No Water Creek Areas, Washakie County, Wyoming"

"Examination of proposed well sites in the Whiskey Gap and Arkansas Creek Areas, Carbon County, Wyoming"

"Examination of proposed well sites near Fremont Butte, Grazing District No. 5, Sublette County, Wyoming"

"Examination of proposed stock-well sites near Muskrat Creek, Grazing District No. 2,

Fremont County, Wyoming"

"Examination of proposed well sites near Boulder Lake, Sublette County, Wyoming"

"Proposed test well in the Cane Spring Desert, Garfield County, Utah"

"Proposed land treatment program near Canon City, Bureau of Land Management District 8,

Colorado" 
"Prospective stock-wells in Boise Grazing District, Owyhee and Elmore Counties, Idaho"

"Prospective stock-wells in the Salmon Grazing District, Idaho"

"Examination of proposed Arrow Head Dam Site on E-K Creek, Natrona County, Wyoming"

1956:

"Prospective stock-well sites - Rio Grande Valley, New Mexico"

"Examination of proposed well sites near Baggs, Carbon County, Wyoming"

"Proposed well site on Jackson Wash, Washington County, Utah"

"Prospective stock-well sites in Nevada Grazing District No. 5, Lincoln County, Nevada"

"Examination of proposed well sites in Elko Grazing District, Nevada"

"Examination of proposed stock-well sites in Southeastern Montana, Powder River Grazing District No. 3"

"Examination of proposed stock-well site at Poncha Pass Reseeding Area, Saguache County, Colorado"

"Examination of proposed stock-well sites in Grazing District 5, Wyoming"

"Additional stock-well sites in the Honey Lake Grazing District, Lassen County, California"

"Stock-well investigations in Twin Falls and Owyhee Counties, Idaho"

"Examination of proposed well site in Grazing District 4, White Pine County, Nevada"

"Examination of proposed stock-well sites in Grazing District 5, Lincoln County, Idaho"

"Examination of selected grazing allotments in Bureau of Land Management Grazing District M-5 Montana, for development of stock-water wells"

"Proposed drilling on the Sand Hills Unit, Utah Grazing District No. 11"

"Investigation of proposed stock-well sites near Eagle, Colorado, in Colorado Grazing District 2"

"Investigation of proposed well sites on Bureau of Land Management District 4, Colorado"

"Further investigations and recommendations on the proposed Zumwalt Detention Structure Hurricane Wash, Arizona"

"Proposed well site in the Vance Agee Allotment near O'Neil, Elko County, Nevada"

"Proposed well sites in the La Sal Area, San Juan County, Utah"

"Examination of proposed dam sites in New Mexico, Districts 1 and 7"

"Examination of proposed well sites in Basin Grazing District, Harney County, Oregon"

"Proposed well site near Grassy Mountain, Tooele County, Utah"

"Development of stock-water sources in the Madeline Plains Community Watershed, Lassen County, California"

"Examination of proposed well sites on Eighteen Mile Creek Area in Bureau of Land Management District 4, Wyoming"

1958: $\quad$ "Examination of several proposed well sites and reservoir sites in the Arizona Strip, Mohave County, Arizona"

"Examination of proposed well sites on the west side of San Luis Valley, Colorado"

"Proposed well sites near Squaw Mountain, Southwestern Elko County, Nevada"

"Well site examinations in the Carson City Grazing District, Nevada"

"Examination of proposed well sites near Warren in Grazing District No. 4, Carbon County, Montana"

"Examination of proposed well locations in Northeastern Fergus County and eastern Petroleum County, Grazing District 6, Lewistown, Montana"

"Examination of proposed stock-well sites in Escalante Grazing District No. 5, Wayne County, Utah"

"Examination of proposed well sites in the Vermillion Grazing District 11, Utah"

"Examination of proposed well sites in Grazing District 5, Lincoln County, Idaho"

"Examination of proposed well sites in Grazing District 1, Owyhee and Twin Falls Counties, Idaho"

"Examination of proposed well sites in the Minidoka Division, District 3, Butte County, Idaho"

"Examination of proposed well sites on public domain in Esmeralda County, Nevada"

"Examination of proposed stock-well sites in Twin Falls Grazing District 2, Twin Falls County, Cassia County, and Oneida County, Idaho" 
"Examination of two grazing allotments near Saguache in the northwestern part of San Luis Valley, Colorado, for prospective stock-well sites"

"Proposed wells along the Tongue River and Powder River, Custer, Rosebud, and Powder River Counties, Montana"

1959: $\quad$ "Examination of proposed well site in Red Gulch Creek near Shell, Wyoming"

"Examination of seven proposed well sites in Grazing District No. 4, Carbon County, Montana"

"Proposed well site in Horse Hollow, Cedar City Valley, Iron County, Utah"

"Prospective stock-well sites in Lassen and Modoc Counties, California"

"Proposed test drilling near Fall River Mills, Shasta County, California"

"Hydrology of stock-water development in eastern part of Owyhee Grazing District, Idaho"

"Examination of proposed well sites in Eighteen Mile Canyon and Bridger Bench Areas in

Bureau of Land Management District 4, Wyoming"

"Proposed well sites on Grand Wash, Mohave County, Arizona"

"Examination of proposed well site areas along the north side of Fort Peck Reservoir and

Phillips and Valley Counties, Montana"

"Examination of three proposed well sites in Grazing District 5, Montana"

"Examination of proposed well site, Niobrara County, Wyoming"

"Proposed well sites in the Longview Grazing District, Oregon"

"Examination of proposed well site near Big Piney in Bureau of Land Management District 5, Wyoming"

"Examination of proposed well sites in Bureau of Land Management Grazing Districts 1 and 6, Garfield, Rio Blanco, and Moffatt Counties, Colorado" 


\section{Appendix 36}

General Hydrology Branch - General Files of the Reports Section, 1889-1966 (entry 639)

1800

1801

1802

1806

1807

1808

1809

1830

1831

1832

1833

1843

1844

1855

1856

1858

1965

1966

1967

1977

1981

1987

1992

1993

1994

1996

2062

2073

2183

2184

Broad River at Anthony Shoals, Georgia - W. J. Lester, 1905, 1906

Allotments and Appropriations, 1889-1908, 1935; Roster of Employees, 1905; Essays on

Water Resources Investigations of Survey, and Division of Hydrology, n.d.

Data regarding streams in San Diego and Riverside Counties, Calif., 1906: Floods in Southern California, 1914, 1916

Methods of obtaining flood discharge measurements, 1906

"Report on the Sawkill Watershed," Pennsylvania, n.d.

"Hydrographic Gazetteer Memoranda" for waterways in Minnesota, South Dakota, and Iowa, n.d.

Runoff data from New England stations, 1907-8; Runoff data for the Potomac River,

Shenandoah River, James River, Eastern Maryland Streams, Raritan River, Passaic River, Susquehanna River, Allegheny Drainage, Wabash Drainage, and Savannah River, ca. 1906

Elevations and Distances along the Mississippi River, n.d.

"Report of Water-power Reconnaissance in Southeastern Alaska," 1909-10, by John C. Hoyt accompanied by graphs, photographs, and maps

Minnesota River, 1906

"Mexico and Her Opportunities," by Winthrop E. Scarritt, 1906

"Cost of, and Intensity of Distribution of Gaging Stations to Properly Complete a Hydraulic Investigation of the Surface Water Resources of the United States," by R. H. Bolster, n.d.

Hydraulic Rams, Pumps, and Windmills, 1907-20; Report - "Discharge Measurements, Hydraulic Turbine Tests, U.S.R.S. Minidoka Project Idaho," by Eugene C. LaRue, 1910-11

"Report on water-supply available for the irrigation project of the Mountain Home Cooperative Irrigation Company," Idaho, 1917-18, by G. Clyde Baldwin

Graefenburg Hydrophysical Station, near Utica, New York, 1904-6

"Available Water-power at the United States Government Locks and Dams," n.d.; "Available Waterpower at Private Dams," n.d.; Chicago-Fort Wayne-Toledo Canal Company, n.d.

Replies concerning available data on surge at gaging stations, 1925 (in response to a request in the December, 1924 newsletter): Comments on fluctuations, 1941

Newspaper clippings and a list of "popular" articles on conservation, ca. 1908-11

Great Lakes and Saint Lawrence River, 1895, 1896, 1921, 1942

Lock-Bar Steel Pipe, 1907

Puerto Rico, Discharge Measurements, 1909, 1962

Mill Creek near Old Fort, North Carolina, 1907, 1931, 1950

(Head) Fall-Increasers, 1908

Sketch map showing the Platt National Park and the town site of Sulphur, Indian Territory, n.d.

Hauling Capacity--Steam and Electric Locomotives, n.d.

"Niobrara River near Spencer, Nebraska -- Description of station and Instructions for computing records, September 1940"

Nicholson Ship Log Company, 1904, 1907-8

Number of water-power centers listed by State and Territory, 1908; Estimate of streamflow and water-power in the United States, 1908; Graph showing "Floods on Alabama River at Selma, Ala., 1892-1907"

Mississippi and Ohio Rivers, flood and miscellaneous data, 1895-1914, 1927; Postcards of the Paris flood of 1910; Northeastern Flood, 1955-57; Far West Flood, 1955-58

Acts passed by Congress authorizing the construction of dams across navigable rivers for Power Purposes, 1896-1906; Available water-power at private dams, n.d.; Available water-power at the U.S. Government locks and dams, 1904; List of State Boards and Commissions of water supply, drainage, etc. n.d.; Maintenance charges, United States locks and dams, 1906; Norkfos Dam, Glommen, Norway, photograph and plotted charts, n.d. 
Map - Distribution of Under Ground Waters in the San Joaquin Valley, 1905

Comparisons of stations on Umpqua River, Oregon, n.d.

Comparisons of stations in Yakima Valley, 1904-9; Comparisons of stations on the Willamette, Deschutes, Umatilla and Grande Ronde Rivers, 1905-8; Hydrographic Chart of the Yakima River Watershed, 1909; Comparisons of stations on the Snake River, 1905-8

"Progress of Hydrometric Investigations in Massachusetts, 1910-1913," by C. C. Covert and C. H. Pierce

The New York Barge Canal, 1917-20; Straightening and dredging the channel of Canaleraga Creek, New York, 1915

Red Rock River, near Monida, Montana, 1911-12

Gaging stations in New England and Pennsylvania, 1908-10

Drainage area and rating curve errors in 1906, 1907, and 1908 reports, 1907-10

Memoranda for reading galleys and page proof of Water-Supply Papers, 1907-8; Stream measurements in Pennsylvania, 1908; Gage height ratings in Tennessee River Basin, 1904-9; Regarding a manuscript for the Ohio River Basin, 1909

Water-Supply Paper No. 244, regarding publication, 1909-10

Water-Supply Paper No. 245, regarding publication, 1909-10

Water-Supply Paper No. 250, regarding publication, 1909-10

"List of River Stations for Reports," - Washington and Oregon, ca. 1907; Data for 1908 progress report, Washington and Oregon, 1909; Notes on rating in Columbia River Drainage Basin Columbia River at the Dalles, n.d.

Water-Supply Paper No. 261, regarding publication, 1910-11

Water-Supply Paper No. 262, regarding publication 1910; and Part II, 1909 report, 1910

Water-Supply Paper No. 262, Part III, 1909 report, 1909-10

Reports on gaging stations for 1909 report, 1910

Water-Supply Paper No. 265, regarding publication, 1910-11

Water-Supply Paper No. 266, regarding publication, 1909-11

Water-Supply Paper No. 267, regarding publication, 1910-11

Water-Supply Paper No. 268, regarding publication, 1909-11

Water-Supply Paper No. 269, regarding publication, 1909-11

Water-Supply Paper No. 270, regarding publication, 1906-10

Water-Supply Paper No. 271, regarding publication, 1910-11; Station record analysis of East Fork Bruneau River near Three Creek, Idaho, 1953

Water-Supply Paper No. 272, regarding publication, 1910-11

Water-Supply Paper No. 281, and Federal Report, 1910, regarding publication, 1910-12

Water-Supply Paper No. 282, regarding publication, 1911

Water-Supply Paper No. 283, and 1910 Annual Report, 1911-12

Water-Supply Paper No. 284, and Part IV, 1910 Annual Report, 1911-12

Water-Supply Paper No. 285, regarding publication, 1911-12

Water-Supply Paper No. 286, and Part IV 1910 Annual Report, regarding publication, 1911-12

Water-Supply Paper No. 287, regarding publication, 1911

Water-Supply Paper No. 288, regarding publication, 1911

Water-Supply Paper No. 289, regarding publication, 1911-12

Water-Supply Paper No. 290, regarding publication, 1911-12

Water-Supply Paper No. 291, regarding publication, 1911-12

Water-Supply Papers Nos. 292 and 312, regarding publication, 1910-13

Accuracy of Discharge measurements made on Snake River at Neeley, Idaho, 1910-11

Discharge measurements for Gibbs Brook, near Crawfords, New Hampshire, 1912

Papers on "Ordinary Flow," 1914-15, 1934; Water Supply Paper No. 353, 1915; Reports on gaging-station maintenance and gaging-station card catalog, 1911 
Instructions regarding publications and reports, General, 1902-11; 1910 Instructions regarding publications and reports; 1911 Instructions regarding publications and reports; 1912 Instructions regarding publications and reports; Instructions re publications and reports, 1911-20; Instructions, Memorandums, etc. - Computing Section, 1911-12; Survey Circulars and Bulletins, 1933-43

3081-A

3081-B

3082

3083

3084

3085

3086

3087

3087-A

3088

3089

3090

3091

3092

3092-A

3092-C

3093

3100

3140

3174

3216

3218

3250

3306

3340

3434

3434-A

3512

3564

3741

3949

3950

3951

3953

4286

4389

4443

4770

4771
Observer's Instruction Book - proposed draft, 1908

Computation Rules, Discussion of, 1911

Gages - Installation and Instructions for reading, 1911-12, 1920

Automatic Gages, 1889-1957

Meters - tests, rating, and installation, 1897-1957

Cables and Cars, 1930-55; Arizona District - plans for cable cars, reels, protractors, 1922-25;

Methods of making systematic streamflow measurements, 1903-41

Vertical Velocity Curves, 1955-60

Velocity, maximum measured, 1948-59

Ice Measurements and Winter Work, 1908-49

Accuracy of steam gaging, 1903-57: replies to circular letter of November 14, 1903, 1903-4; replies to memorandum of February 27, 1920

Computations of discharge measurements, ca. 1904-59; "Notes on Basic Factors in the Determination of Rating Curves for flow of Streams," B. J. Peterson, and "River Discharge Rating Curves," J. H. Morgan, 1925-27

Reports, Progress, etc., 1906-8

Office Methods, 1903-58

Office Manual, 1920-55

Office Manual, Water Resources Branch Circular, October 5, 1945 (Replies and Summary), 1944-46

Radio in Stream Gaging, 1946-47

Eau Claire River at Wausau, Wisconsin (cross reference only, 1914)

"Report of Reconnaissance of Rockaway River Drainage Basin above Boonton, N.J.," ca. 1914

"Water Resources of the Jordan Valley District, Oregon," by L. W. Roush, 1914

"Water Resources of Salmon Falls Creek near San Jacinto and Contact, Nevada," by Arthur W. Harrington, 1914

Gaging station on Squaw Creek near Goldendale, Washington, 1912-13

Gaging station on Hood River near Tucker's Bridge, Oregon, 1913

Water-Supply Paper No, 370, regarding publication, 1914-15

Missouri River at Hermann, Missouri, Special Computations, 1898-1928

Discharge Integrators, 1914-66

Graph Subdivider, 1945-46

Canyon Creek, at Bowman's Dam, near Emigrant Gap, California, 1913-14

Little Tennessee River at Judson and Almond, North Carolina, Nantahala River at Almond, North Carolina, and the Tuckaseegee River at Bryson City, North Carolina, 1912-13

Massachusetts Special Report, 1915-16

"The Preservative Treatment of Farm Timbers," n.d.

"Partial Report--on the Swamp and Overflow Lands of the United States," Sledge Tatum, 1910; Miscellaneous pictures of swamps, probably collected by R. Follansbee during 1908-9

Level Rod Tripod, 1925; Gurley Levels, and Leupold and Voelpel Levels, 1913

Observations of Tidal Currents, 1914

Waterfalls, 1907-53

"Report on Cable Installation--Gila River near Clifton, Arizona," 1932

Datum Planes, 1912-14

Compilation of Monthly Discharge Records - Atlantic Coast Rivers, ca. 1897-1910; Monthly Discharge for Stations in Ohio River Basin, ca. 1901-10

Rainfall data, ca. 1874-1907 
Long-time Records of Stream Flow, 1915

Tests of Thirty Pound Sounding Weight, 1924

Mississippi River flow, 1923-24

Mississippi River Basin - Comparisons of Discharge (sample), 1934-58

Missouri River Adjustment sheets, 1938 (sample), H. C. Beckman, 1937-40

Ohio River Basin - Comparisons of Discharge (sample), 1939-41

Tennessee River Basin - Comparisons of Discharge (sample), 1939

Area in square miles, of 5 minute quadrilateral on earth's surface between latitudes 33 degrees and 42 degrees, 1937-54

"Report on Construction of Gaging Stations in Upper Little Colorado River Basin, Arizona," 1930 Garner Creek near Snellville, Georgia, 1954-61 


\section{Appendix 37}

Conservation Division - Mission Control Files, 1901-80 (entry 642)

The following is an alphabetical list of the major file headings found in entry 642 . Boxes containing files that are not listed appear below under the designation - Miscellaneous. A complete list of the file titles follows this list.

Coal - boxes 1-3

Committees - boxes 3-6, 13-16, 25-31, 33-35, 42-44, 54-60, 80, 81, 221

Computation - boxes $32,33,51-54$

Contracts - boxes 6-9, 22-25, 44-48, 50, 51, 221, 222

Cooperation - boxes 48-50, 64-71, 75-79, 101-173, 176-191, 222-237

Cooperative Agreements - boxes 81, 82

Crises - boxes 72-75, 191-206

Environment - box 82

Exploration - boxes 206-214

Geothermal Resources - boxes 214-216, 237-240

Helium - boxes 241, 242

Information - boxes 217-220, 242-264, 335

Land - boxes 275,276

Land, Determinations, Known Coal-Leasing Areas - boxes 277, 278

Land, Known Geothermal Resource Areas - boxes 336, 489, 490

Land, Withdrawals - boxes 490, 491

Leases - box 83

Legal - boxes 9-13, 16, 17-22, 35-41, 60-64, 289-291, 323-326, 330-343, 349-367, 373-379, 383-389, 410-413, $436-439,442-445,468-471,475-482,489,491-499$

Legal \& Legislation - boxes 82, 83

Mapping - boxes 367-369

Meetings - boxes 346-349, 380-383

Mines and Mining - boxes 83, 466-468

Mineral Commodities - boxes 465, 466

Minerals - boxes 83

Miscellaneous file-title headings - boxes 1, 80, 83, 87, 88, 90-100, 206, 214, 221, 359, 354, 488

Oil and Gas - boxes 83-87, 291-293, 316-323, 326-330, 390-393, 396, 397, 413-429, 432-436, 439-442, 449-465, $468,471-475,482-485,499-502$

Oil-Leasing Cases - box 96

Oil Shale - boxes 293, 294, 397-406, 445-448

Organization and Management - boxes 304-311, 313-316, 407-410, 429-432, 448, 449

Paleontology and Stratigraphy - box 311

Personnel - boxes 87, 311, 312

Phosphate - boxes 312, 313

Physical Exploration - box 369

Pollution - boxes 264-267, 298-300, 370-373, 393-396

Potash - boxes 281-283, 300, 343-346

Programs and Plans - boxes 272-274, 284, 294, 503-506

Reports and Statistics - boxes 87, 88, 268-271, 278-281, 285-288, 301-303

Research - boxes 295, 296

Resources and Classification - boxes 88, 89

Royalties - box 89

Safety and Health - boxes 89,90

Sodium - boxes 296, 297, 486

Sulphur - boxes $486-488$

Survey Advisory Committee - box 97

Water - boxes 488,489

Weather - box 489 
This is a complete list of the file titles found in entry 642. An alphabetical list of the major file headings comprising the entry precedes this list.

Box 1 Accounting [c.r. to Royalty Accounting Office and Administrative Office Files], n.d.

Asphalt \& Tar Sands, General, 1941, 1963-65

Asphalt \& Tar Sands, General, 1965-70

Asphalt \& Tar Sands, General, 1974-76

Asphalt \& Tar Sands, General, 1971-75

Coal, General, 1910-11, 1921-22, 1942-ca. 1952

Coal, General, 1957-69

Box 2 Coal, General, 1970-71

Coal, General, 1971-72

Coal, General, 1972-73

Coal, General, 1973

Coal, General, 1973

Coal, General, 1974

Box $3 \quad$ Coal, General, 1974-75

Coal, General, 1970, 1975-76

Coal Lands, Alaska, ca. 1915-17, 1948-75

Committees, Advisory Groups, General, ca. 1913, 1964-72

Committees, Advisory Groups, General, 1972-73

Box $4 \quad$ Committees, Advisory Groups, General, 1974

Committees, Advisory Groups, General, 1974-76

Committees, Advisory Groups, General, OCS, 1975-76

Committees, Advisory Groups, General, OCS, 1975

Committees, Advisory Groups, General, OCS, 1973-74

Committees, Advisory Groups, General, OCS, 1960-68

Committees, Advisory Groups, General, OCS, 1968-76

Box 5 Committees, Advisory Groups, General, OCS, ca. 1972

Committees, Advisory Groups, General, OCS, 1973-74

Committees, Advisory Groups, General, OCS, 1974-76

Committees, Advisory Groups, General, OCS, Review Committee on Safety of Continental Shelf Petroleum Operations, 1974-76

Committees, Advisory Groups, General, OCS, Review Committee on Safety of Continental Shelf Petroleum Operations, 1974

Box 6 Committees, Advisory Groups, OCS, [Federal] Council for Environmental Quality Task Force on Atlantic/Alaska Oil and Gas Development, 1973-75

Committees, Advisory Groups, OCS, [Federal] Council for Environmental Quality Task Force on Atlantic/Alaska Oil and Gas Development, 1974

Committees, Advisory Groups, OCS, [Federal] Council for Environmental Quality Task Force on Atlantic/Alaska Oil and Gas Development, 1974

Committees, Advisory Groups, OCS, Fishing Industry Advisory Group, 1967-71

Committees, Advisory Groups, General, Metal \& Nonmetal Mine Safety Advisory Committee, 1971-74

Contracts, General, Pocket for Letters, 1968-73

Box 7 Contracts, Gas Storage, Accident Field, Maryland, 1962-70

Contracts, Gas Storage, Aliso Canyon Field, California, 1967-72

Contracts, Gas Storage, Aliso Canyon Field, California, 1972-73

Contracts, Gas Storage, Asbury Creek, Colorado, 1962-65

Contracts, Gas Storage, Asbury Creek, Colorado, 1965-71

Contracts, Gas Storage, Baker Field, Montana, 1972-74

Contracts, Gas Storage, Bistineau, Louisiana, 1966-69

Box 8 Contracts, Gas Storage, Bistineau, Louisiana, ca. 1965

Contracts, Gas Storage, Bistineau, Louisiana, ca. 1966

Contracts, Gas Storage, Bistineau, Louisiana, n.d.

Contracts, Gas Storage, Bunker Hill Field, Wyoming, 1972

Contracts, Gas Storage, Chalk Creek, Utah, 1960-62 
Contracts, Gas Storage, Chalk Creek, Utah, 1961-68

Contracts, Gas Storage, Clinton Township, Ohio, 1953-54

Contracts, Gas Storage, Cobb, Montana, 1960-61

Contracts, Gas Storage, Dry Creek, Montana, 1966-67

Contracts, Gas Storage, Duffield Field, New Mexico [out on a USGS internal loan]

Contracts, Gas Storage, Dutcher Sand, Oklahoma, 1967

Contracts, Gas Storage, East Mahoney Dome Field, Wyoming, 1971-73

Contracts, Gas Storage, Fruita Field, Colorado, 1970-71

Legal, Claims and Litigations, Pauly Petroleum Inc. v. U.S., OCS, 1970

Box 10 Legal, Claims and Litigations, Pauly Petroleum Inc. v. U.S., OCS, 1970

Legal, Claims and Litigations, Pauly Petroleum Inc. v. U.S., OCS, 1971-72

Legal, Claims and Litigations, People of the State of California v. Union Oil, OCS, 1970

Legal, Claims and Litigations, Reyos et al v. First Security Bank, Utah [c.r. to legal sized folder see box 339]

Legal, Claims and Litigations, Walter Riley v. Bell Oil Company, 1970

Legal, Claims and Litigations, Santa Barbara and other Litigations, OCS, 1969-73

Legal, Claims and Litigations, Santa Barbara, Tort Claims, OCS [c.r. to legal sized folder - see box 339]

Legal, Claims and Litigations, Security Pacific National Bank v. U.S., OCS, 1969

Legal, Claims and Litigations, Seminole Nation v. U.S., 1954-ca. 1969

Legal, Claims and Litigations, Shoshone Tribe v. Hathaway, 1969

Legal, Claims and Litigations, Shoshone Tribe v. U.S., 1951-52

Legal, Claims and Litigations, Sierra Club v. Morton, 1973-74

Legal, Claims and Litigations, Sierra Club v. Morton, et al \& Shell Oil Company, 1974-75

Legal, Claims and Litigations, Simons v. Vinson \& Clark, 1966

Legal, Claims and Litigations, Simons v. Vinson \& Clark, 1966-76

Legal, Claims and Litigations, Simons v. Vinson \& Clark, 1967-76

Box 11 Legal, Claims and Litigations, Simons v. Vinson \& Clark, 1967

Legal, Claims and Litigations, Simons v. Vinson \& Clark, 1967

Legal, Claims and Litigations, Sinclair \& Cherry v. Krug, 1949

Legal, Claims and Litigations, Standard Oil of California v. Morton [c.r. to legal sized folder see box 339]

Legal, Claims and Litigations, State of California v. Union Oil, OCS, 1969-74

Legal, Claims and Litigations, Sun Oil et al v. U.S., OCS, 1971-72

Legal, Claims and Litigations, Sun Oil et al v. U.S., OCS, 1972-76

Legal, Claims and Litigations, Sun Oil et al v. U.S., OCS, 1972

Box 12 Legal, Claims and Litigations, Superior Oil v. Udall, OCS, 1968-73

Legal, Claims and Litigations, Tallman et al v. Udall, 1963-64

Legal, Claims and Litigations, Texaco Inc. v. Hickel, OCS, 1971-74

Legal, Claims and Litigations, Texas Pipe Line Co. v. Railroad Commission of Texas, 1937

Legal, Claims and Litigations, Margaret B. Thomas v. Krug, 1949

Legal, Claims and Litigations, TOSCO v. Udall, 1966

Legal, Claims and Litigations, Transwestern Pipeline v. Kerr-McGee, 1970-72

Legal, Claims and Litigations, Transwestern Pipeline v. Kerr-McGee, 1972-75

Legal, Claims and Litigations, Uintah \& White River Ute v. U. S., 1947, 1955-58

Legal, Claims and Litigations, Umpleby and Wasatch Development Company v. Udall, 1960-64

Legal, Claims and Litigations, U.S. v. Chevron Oil Co., OCS [c.r. filed in legal sized folder see box 336]

Legal, Claims and Litigations, U.S. v. Continental Oil Co., OCS, 1970

Legal, Claims and Litigations, U.S. v. Continental Oil Company \& General Petroleum Corporation, 1947-50

Legal, Claims and Litigations, U.S. v. Walter G. Davis et al, 1959

Legal, Claims and Litigations, U.S. v. Walter G. Davis et al, 1960-61

Box 13 Legal, Claims and Litigations, U.S. v. Walter G. Davis et al, 1962-64

Legal, Claims and Litigations, U.S. v. Energy Resources Technology Land, Inc., 1961-62

Committees, Congressional, House Appropriations Committee, 1965-76

Committees, Congressional, Interior \& Insular Affairs Committee, 1959-65 
Committees, Congressional, Interior \& Insular Affairs Committee, 1967-68

Committees, Congressional, Interior \& Insular Affairs Committee, 1969-70

Committees, Congressional, Petroleum Resources, Senate Special Committee to Investigate, 1945

Committees, Congressional, Petroleum Resources, Senate Special Committee to Investigate, 1945, 1973-74

Box $14 \quad$ Committees, Congressional, Interior \& Insular Affairs Committee, 1971

Committees, Congressional, Interior \& Insular Affairs Committee, 1972

Committees, Congressional, Interior \& Insular Affairs Committee, 1972

Committees, Congressional, Interior \& Insular Affairs Committee, 1972

Committees, Congressional, Interior \& Insular Affairs Committee, 1972

Committees, Congressional, Interior \& Insular Affairs Committee, 1973-74

Committees, Congressional, Interior \& Insular Affairs Committee, 1974-75

Box 15 Committees, Congressional, Interior \& Insular Affairs Committee, 1975-76

Committees, Congressional, Interior \& Insular Affairs Committee, n.d. [responses to questions]

Committees, Congressional, Interior \& Insular Affairs Committee, n.d. [responses to questions]

Committees, Congressional, Interior \& Insular Affairs Committee, n.d. [responses to questions]

Committees, Congressional, Interior \& Insular Affairs Committee, n.d. [responses to questions]

Committees, Congressional, Interior \& Insular Affairs Committee, n.d. [responses to questions]

Box 16 Committees, Congressional, Interior \& Insular Affairs Committee, 1969

Committees, Congressional, Interior \& Insular Affairs Committee, 1968-69

Committees, Congressional, Interior \& Insular Affairs Committee, 1969-70

Legal, Appeals, Dos Cuadras Field, OCS, 1969-74

Legal, Appeals, New Mexico, 1974

Legal, Appeals, Little Buffalo Basin, 1974-75

Legal, Appeals, Oakridge, 1973-75

Legal, Appeals, Robert B. Ferguson, 1975

Legal, Appeals, Mudlumps, 1962-63

Legal, Appeals, Mudlumps, 1963-69

Box 17 Legal, Appeals, Mudlumps [maps]

Legal, Laws and Regulations, CFR, General, 1969-76

Legal, Laws and Regulations, CFR, General, OCS, 1971-74

Legal, Laws and Regulations, CFR, Indian Regulations, 25CFR, 1908-09, 1915-22

Legal, Laws and Regulations, CFR, Indian Regulations, 25CFR, 1923-29

Legal, Laws and Regulations, CFR, Indian Regulations, 25CFR, 1927-33

Legal, Laws and Regulations, CFR, Indian Regulations, 25CFR, 1934-55

Box 18 Legal, Laws and Regulations, CFR, Indian Regulations, 25CFR, 1956-57

Legal, Laws and Regulations, CFR, Indian Regulations, 25CFR, 1958-76

Legal, Laws and Regulations, CFR, Leasing Regulations, Lake Mead, 1955, 1970

Legal, Laws and Regulations, CFR, Leasing Regulations, Public Domain, 1946-55

Legal, Laws and Regulations, CFR, Leasing Regulations, 1955-74

Legal, Laws and Regulations, CFR, Leasing Regulations, 1974-76

Legal, Laws and Regulations, CFR, Leasing Regulations, Acquired Land, 1947-55

Legal, Laws and Regulations, CFR, Leasing Regulations, Acquired Land, 1956-70

Box 19 Legal, Laws and Regulations, CFR, Leasing Regulations, Public Domain, 1970

Legal, Laws and Regulations, CFR, Leasing Offshore, 1971-76

Legal, Claims and Litigations, U.S. v. Featherstone, Olin et al, 1959-60

Legal, Claims and Litigations, U.S. v. Featherstone, Olin et al, 1960-63

Legal, Claims and Litigations, U.S. v. Featherstone, Olin et al, 1964-65

Legal, Claims and Litigations, U.S. v. Gulf, Tenneco \& Kerr-McGee, OCS, 1971

Legal, Claims and Litigations, U.S. v. Humble Oil Co., OCS, 1970-74

Legal, Claims and Litigations, U.S. v. Little Lake Misere Land Company, 1968-73

Legal, Claims and Litigations, U.S. v. Los Angeles \& Salt Lake Railroad Company, 1943-44

Legal, Claims and Litigations, U.S. v. Louisiana \& Humble Oil Company, 1962-68

Legal, Claims and Litigations, U.S. v. Mobil Oil Company, OCS, 1971

Box 20 Legal, Claims and Litigations, U.S. v. Pan American Petroleum Company, 1923-28

Legal, Claims and Litigations, U.S. v. Pan American Petroleum Company, 1929-30

Legal, Claims and Litigations, U.S. v. Pan American Petroleum Company, 1931-33 
Legal, Claims and Litigations, U.S. v. Phillips Petroleum Company et al, OCS, 1971

Legal, Claims and Litigations, U.S. v. Shell Oil Company, OCS [c.r. to legal sized folder see box 339]

Legal, Claims and Litigations, U.S. v. Texaco, Inc., 1973

Legal, Claims and Litigations, U.S. v. Union Carbide Corporation, 1970-74

Legal, Claims and Litigations, U.S. v. Union Carbide Corporation, 1973

Legal, Claims and Litigations, U.S. v. Frank Winegar et al [c.r. to legal sized folder - see boxes 340 and 341]

Legal, Claims and Litigations, U.S. v. Wyoming \& Ohio Oil Company, 1944-47

Legal, Claims and Litigations, U.S. ex rel Shoshone Tribe v. Seaton, 1956-58

Legal, Claims and Litigations, U.S. Royalty Oil Corporation v. Morton [c.r. to legal sized folder see box 339]

Box 21 Legal, Claims and Litigations, OCS, Weingand et al v. Hickel, 1969-70

Legal, Claims and Litigations, State, General, 1971-75

Legal, Claims and Litigations, State, General, OCS, 1971-75

Legal, Claims and Litigations, State Lease Conversion, OCS, 1953-57

Legal, Claims and Litigations, State Claims, U.S. v. Alaska, 1964-70

Legal, Claims and Litigations, State Claims, U.S. v. Alaska, OCS, 1967-73

Legal, Claims and Litigations, State Claims, U.S. v. California, OCS, 1947-54

Legal, Claims and Litigations, State Claims, U.S. v. California, OCS, 1951-74

Legal, Claims and Litigations, U.S. v. Louisiana, OCS, 1972-76

Legal, Claims and Litigations, State Claims, U.S. v. Maine et al, OCS, 1968-71

Box 22 Legal, Claims and Litigations, State Claims, U.S. v. Maine et al, OCS, 1971-72

Legal, Claims and Litigations, State Claims, U.S. v. Maryland et al, OCS, 1974

Legal, Claims and Litigations, U.S. v. Texas, OCS [c.r. to legal sized folder - not located]

Legal, Claims and Litigations, State Claims, U.S. v. Utah, 1958-74

Legal, Claims and Litigations, Mining Claims, General, 1953-70

Legal, Claims and Litigations, Mining Claims, General, OCS, 1958-71

Legal, Decisions, 1971-76

Legal, Decisions, 1976

Contracts, Gas Storage, Garland Field, Wyoming, 1956

Contracts, Gas Storage, Garland Field, Wyoming, 1956-58

Box 23 Contracts, Gas Storage, Glady Field, W. Va., 1958-63

Contracts, Gas Storage, Glady Field, W. Va., 1963-72

Contracts, Gas Storage, Las Milpas, New Mexico, 1972-73

Contracts, Gas Storage, Las Milpas, New Mexico, 1972

Contracts, Gas Storage, Las Milpas, New Mexico, 1972-73

Contracts, Gas Storage, Goodwell \& Norwick Fields, Michigan, 1947-68

Contracts, Gas Storage, Hugoton Field, Oklahoma, 1962-63

Box 24 Contracts, Gas Storage, Leroy Area, Wyoming, ca. 1970-72

Contracts, Gas Storage, North Oregon Basin, Wyoming, 1966

Contracts, Gas Storage, Oil Springs Field, Wyoming, 1951-73

Contracts, Gas Storage, Winterfield, Michigan, 1947-65

Contracts, Helium, General, 1968-72

Contracts, Helium, General, 1972

Contracts, Helium, Bow Knot, Utah, Associated Ventures, 1968-69

Contracts, Helium, Harley Dome, Utah, Lansdale Contract, 1965-68

Box 25 Contracts, Helium, Harley Dome, Utah, Lansdale Contract, 1968-74

Contracts, Helium, Paradox Basin, Utah, Rare Gas Resources, 1963-64

Committees, Bureau, Computer Liaison Committee [c.r. filed in Royalty Accounting Office and Administrative Office]

Committees, Bureau, Central Region Survey Committee, 1972-76

Committees, Bureau, Eastern Region Survey Committee, 1972-76

Committees, Bureau, General Staff Committee, 1957-63

Box 26 Committees, Bureau, General Staff Committee, 1964

Committees, Bureau, General Staff Committee, 1965 
Committees, Bureau, General Staff Committee, 1965-66

Committees, Bureau, General Staff Committee, 1966-67

Committees, Bureau, General Staff Committee, 1968

Committees, Bureau, General Staff Committee, 1969

Box 27

Committees, Bureau, General Staff Committee, 1969

Committees, Bureau, General Staff Committee, 1970-73

Committees, Bureau, Inter-Bureau Coordinating Committee on Outer Continental Shelf Minerals, 1975

Committees, Bureau, Inter-Division Committee on the OCS, 1970-75

Committees, Bureau, International Activities Committee, 1968-75

Committees, Bureau, National Atlas Planning Committee, 1974-75

Committees, Bureau, Pacific Coast Survey Committee, 1965-70

Committees, Bureau, Pacific Coast Survey Committee, 1970-72

Box 28 Committees, Bureau, Pacific Coast Survey Committee, 1968

Committees, Bureau, Publications Committee, 1972-75

Committees, Bureau, Rocky Mountain Survey Committee, 1965-72

Committees, Bureau, Survey Advisory Committee, 1956-61

Committees, Bureau, Survey Advisory Committee, 1960-63

Committees, Bureau, Western Regional Survey Committee, 1972-76

Committees, Congressional, Antitrust \& Monopoly Sub-Committee, 1967

Box 29 Committees, Congressional, Subcommittee on Activities of Regulating Agencies, OCS, 1974-75

Committees, Congressional, Subcommittee on Activities of Regulating Agencies, OCS, 1974-75

Committees, Congressional, Antitrust \& Monopoly Subcommittee, OCS, 1969-73

Committees, Congressional, Antitrust \& Monopoly Subcommittee, OCS, 1970-75

Committees, Congressional, Antitrust \& Monopoly Subcommittee, OCS, 1975

Committees, Congressional, Committee on Commerce, 1973-75

Committees, Congressional, Government Operations Committee, 1970

Box 30 Committees, Congressional, Government Operations Committee, 1971-73

Committees, Congressional, Government Operations Committee, 1974-76

Committees, Congressional, Government Operations Committee, OCS, 1972-74

Committees, Congressional, Government Operations Committee, 1974-76

Committees, Congressional, Government Operations Committee, OCS, 1972-73

Committees, Congressional, Government Operations Committee, OCS, 1972-73

Box 31 Committees, Congressional, Government Operations Committee, OCS, 1974

Committees, Congressional, Government Operations Committee, OCS, 1972-74

Committees, Congressional, Government Operations Committee, OCS, 1973

Committees, Congressional, Government Operations Committee, OCS, 1973

Committees, Congressional, Government Operations Committee, OCS, 1973

Box 32 Computation, General, 1972-74

Computation, General, 1974-76

Computation, General, OCS, 1971-76

Computation, General, OCS, 1972

Computation, General, OCS, 1972-75

Computation, General, OCS, ca. 1974

Box 33 Computation, General, OCS, 1971-74

Computation, General, OCS, 1976

Computation, General, OCS, 1973

Committees, Interdepartmental, Pacific Northwest Interagency Committee, 1971

Committees, Interdepartmental, Pacific Northwest River Basin Commission, 1968-70

Committees, Interdepartmental, Pacific Southwest Interagency Committee, 1968-74

Committees, Interdepartmental, Pacific Southwest Interagency Committee, 1970

Committees, Interdepartmental, Pacific Southwest Interagency Committee, 1971

Box 34 Committees, Interdepartmental, Pacific Southwest Interagency Committee, 1970-75

Committees, Interdepartmental, Southeast Basin Interagency Committee, 1969

Committees, Interdepartmental, Water Resources Interagency Committee, 1962-74

Committees, Interagency, BLM/USGS Interagency Committee for Program Coordination, 1974-75

Committees, Interagency, BLM/USGS Interagency Committee for Program Coordination, 1975-76 
Committees, Interagency, Federal Power Commission Task Force on Gas Curtailment, 1974

Committees, Interagency, Interagency Coal Task Force, 1973-74

Committees, Interagency, Interagency Committee for Marine Environmental Prediction, 1974

Committees, Interagency, General, 1974-76

Box 35 Committees, Interagency, General, 1975-76

Committees, Interagency, General, 1974-75

Legal, Claims and Litigations, General, 1974-76

Legal, Claims and Litigations, General, 1956, 1971-76

Legal, Claims and Litigations, Atlantic Richfield v. Hickel, 1969-75

Legal, Claims and Litigations, E. B. Bird et al. v. Oscar Chapman, 1950

Box 36 Legal, Claims and Litigations, Confederated Bands of Utes v. U.S., 1901, 1909-13, 1915, 1945-51

Legal, Claims and Litigations, County of Santa Barbara v. Hickel, OCS [c.r. to legal sized folder see boxes $336 \& 337]$

Legal, Claims and Litigations, County of Santa Barbara v. Malley, OCS [c.r. to legal sized folder see box 337]

Legal, Claims and Litigations, Alma Goettsch v. Krug, 1949

Legal, Claims and Litigations, Gulf, Mobil, Texaco, Union v., Morton, OCS [c.r. to legal sized folder - see box 337]

Legal, Claims and Litigations, Hall v. Union Oil, OCS [c.r. to legal sized folder - see box 337]

Legal, Claims and Litigations, Humble, Standard, ARCO v. Morton, OCS [c.r. to legal sized folder see box 337]

Legal, Claims and Litigations, Clayton \& Aimee Jones v. U.S., 1952

Legal, Claims and Litigations, Kansas-Nebraska Natural Gas v. Pan American Petroleum, 1960

Legal, Claims and Litigations, Kern County Refinery, Inc. v. Kleppe, et al [c.r. legal sized folder see box 338]

Legal, Claims and Litigations, Kern County Refinery, v. Schambeck et al [c.r. legal sized folder see box 338]

Legal, Claims and Litigations, Kern County Land Company v. Udall, 1965

Legal, Claims and Litigations, Kerr-McGee v. Morton et al [c.r. filed in legal sized folder see box 338]

Legal, Claims and Litigations, Thomas C. Lynch v. U. S., OCS [c.r. filed in legal sized folder see box 338]

Legal, Claims and Litigations, Mack Oil v. Nora Ned now Greenwood, 1960-69

Legal, Claims and Litigations, Mayhew v. McKay, OCS, 1964-65

Legal, Claims and Litigations, Duncan Miller v. Adjudicative Officers of USGS \& BLM, 1972-76

Legal, Claims and Litigations, Minnelusa Oil v. Continental Pipe Lines, 1942-43

Legal, Claims and Litigations, Mondakota Gas Co. v. Montana-Dakota Utilities Company, 1946-47

Legal, Claims and Litigations, Murphy Company et al v. Fontenot, 1954

Legal, Claims and Litigations, National Resources Defense Council v. Morton, OCS [c.r. filed in legal-sized folder - see box 338]

Box 37 Legal, Claims and Litigations, Navajo Tribe v. U.S., 1923, 1950-53

Legal, Claims and Litigations, Navajo Tribe v. U.S., 1954-59

Legal, Claims and Litigations, Navajo Tribe v. U.S., 1950-66

Legal, Claims and Litigations, Northern Natural Gas v. Grounds et al [c.r. filed in legal sized folder see box 338]

Legal, Claims and Litigations, Northern Pacific \& Colorado v. U.S., 1960

Legal, Claims and Litigations, Pan American Petroleum v. Udall, 1960-61

Legal, Claims and Litigations, Pan American Petroleum v. Udall, 1961-62

Legal, Claims and Litigations, Pan American Petroleum v. Udall, 1963

Legal, Claims and Litigations, Pan American Petroleum v. Udall, 1964-65

Legal, Claims and Litigations, Pan American Petroleum v. Udall, 1966-67

Box 38 Legal, Claims and Litigations, Pauley Petroleum Inc., v. U.S., OCS, 1969

Legal, Claims and Litigations, Pauley Petroleum Inc., v. U.S., OCS, 1970

Legal, Claims and Litigations, Pauley Petroleum Inc., v. U.S., OCS, 1970

Legal, Claims and Litigations, Pauley Petroleum Inc., v. U.S., OCS, 1970 
Legal, Claims and Litigations, Pauley Petroleum Inc., v. U.S., OCS, 1970

Legal, Appeals, General, 1935-69

Box $39 \quad$ Legal, Appeals, General, 1970-72

Legal, Appeals, General, 1973

Legal, Appeals, General, 1970-73

Legal, Appeals, General, 1974-75

Legal, Appeals, General, 1975-76

Box $40 \quad$ Legal, Appeals, General, 1974-76

Legal, Appeals, General, OCS, 1961-74

Legal, Appeals, General, OCS, 1974-76

Legal, Appeals, General, OCS, 1976

Legal, Appeals, General, Ida P. Cuffe, 1971-75

Legal, Appeals, Devon Development Corporation, 1964-75

Legal, Appeals, Wheless, 1971-73

Box $41 \quad$ Legal, Appeals, Kirkpatrick, 1969-74

Legal, Appeals, Dos Cuadras, OCS, 1972-74

Legal, Appeals, Lost Soldier Field [out on USGS internal loan]

Legal, Appeals, Rio Blanco, OCS, 1974-75

Legal, Appeals, OCS [out on USGS internal loan]

Legal, Appeals, OCS, 1974-75

Committees, Congressional, Interior \& Insular Affairs Committee, OCS, 1972

Committees, Congressional, Interior \& Insular Affairs Committee, OCS, 1972

Committees, Congressional, Interior \& Insular Affairs Committee, OCS, 1972

Box 42 Committees, Congressional, Interior \& Insular Affairs Committee, OCS, 1972

Committees, Congressional, Interior \& Insular Affairs Committee, OCS, 1972-75

Committees, Congressional, Interior \& Insular Affairs Committee, OCS, 1972

Committees, Congressional, Interior \& Insular Affairs Committee, OCS, 1972

Committees, Congressional, Interior \& Insular Affairs Committee, OCS, 1972

Box 43 Committees, Congressional, Interstate \& Foreign Commerce Committee, 1974-76

Committees, Congressional, Interstate \& Foreign Commerce Committee, 1975-76

Committees, Congressional, Interstate \& Foreign Commerce Committee, 1975

Committees, Congressional, Judiciary Committee, OCS, 1957-76

Committees, Congressional, Merchant Marine and Fisheries Committee, 1973-75

Committees, Congressional, Subcommittee on Mines and Mining, ca. 1974

Box 44 Committees, Congressional, Subcommittee on Mines and Mining, 1974-76

Committees, Congressional, Subcommittee on Mines and Mining, 1976

Committees, Congressional, Oceanography Subcommittee, OCS, 1967

Committees, Congressional, Interior \& Insular Affairs Committee, OCS, 1971-72

Committees, Congressional, Interior \& Insular Affairs Committee, OCS, 1970

Contracts, Gas Sales, General, OCS, 1959-74

Contracts, Gas Sales, General, OCS, 1964-74

Contracts, Gas Sales, Secretary Approved, Superior-Transcontinental, OCS, 1958-62

Box 45 Contracts, Gas Sales, Secretary Approved, Union-Truckline, OCS, 1958-61

Contracts, Gas Sales, Secretary Approved, CATC-Tennessee Gas Transmission, OCS, 1956-65

Contracts, Gas Sales, Unapproved, Pan American \& Texaco-United Fuel, OCS, 1966-70

Contracts, Gas Sales, Unapproved, Pan American \& Texaco-United Fuel, OCS, 1970

Contracts, Gas Sales, Supervisor Approved, Atlantic-Tennessee Gas Transmission, OCS, 1959-60

Contracts, Gas Sales, Secretary Approved, Shell-Tennessee Gas Transmission, OCS, 1959-63

Contracts, Gas Sales, Secretary Approved, Union-Transcontinental, OCS, 1959-63

Contracts, Gas Sales, Secretary Approved, Magnolia, Continental, Newmont-Tennessee, OCS, 1959-60

Contracts, Gas Sales, Secretary Approved, Pan American-Transcontinental, OCS, 1958-64 
Box 46

Box 47

Box 48

Box 49

Box 50

Box 51
Contracts, Gas Sales, Secretary Approved, Pan American-Transcontinental, OCS, 1963-70

Contracts, Gas Sales, Secretary Approved, Pan American-Transcontinental, OCS, 1959-62

Contracts, Gas Sales, Secretary Approved, Pan American-Transcontinental, OCS, 1962

Contracts, Gas Sales, Secretary Approved, Pan American-Transcontinental, OCS, 1962-63

Contracts, Gas Sales, Secretary Approved, Pan American-Transcontinental, OCS, 1961-63

Contracts, Gas Sales, Secretary Approved, Pan American-Transcontinental, OCS, 1959-64

Contracts, Gas Sales, Secretary Approved, Shell-Tennessee Gas Transmission, OCS, 1959-60

Contracts, Gas Sales, Secretary Approved, Zapata-Transcontinental, OCS, 1959-61

Contracts, Gas Sales, Secretary Approved, Pan American-Trunkline Gas, OCS, 1959-61

Contracts, Gas Sales, Secretary Approved, Union-Trunkline Gas, OCS, 1959-61

Contracts, Gas Sales, Secretary Approved, Tennessee-Transcontinental, OCS, 1960-63

Contracts, Gas Sales, Secretary Approved, CATC-Tennessee Gas Transmission, OCS, 1957-58

Contracts, Gas Sales, Unapproved, Pure-Marine \& Marine-Tennessee, OCS, 1951-58

Contracts, Gas Sales, Secretary Approved, Humble-Freeport Sulphur, OCS, ca. 1959

Contracts, Gas Sales, Supervisor Approved, Continental-Tennessee Gas Transmission, OCS, 1959-60

Contracts, Gas Sales, Supervisor Approved, Shell-Michigan Wisconsin Pipe Line Company, OCS, 1967

Contracts, Gas Sales, Supervisor Approved, Tidewater-Tennessee Gas Transmission, OCS, 1959-60

Contracts, Gas Sales, Supervisor Approved, CATC-Tennessee Gas Transmission, OCS, 1959-60

Contracts, Gas Sales, Pacific NW Pipeline-Phillips [c.r. to legal sized folder - boxes $221 \& 222$ ]

Contracts, Gas Sales, Settlement Agreements, OCS, 1962-65

Contracts, Gas Sales, General, 1960-76

Contracts, Gas Sales, General, 1944-54

Cooperation, Federal Agencies, General, OCS, 1972-75

Cooperation, Federal Agencies, General, 1974-76

Cooperation, Federal Agencies, General, OCS, 1961-71

Cooperation, Federal Agencies, General, OCS, 1972-76

Cooperation, Federal Agencies, General, 1946-74

Cooperation, Federal Agencies, Memoranda of Understanding, 1962-74

Cooperation, Federal Agencies, Memoranda of Understanding, 1974

Cooperation, Federal Agencies, Memoranda of Understanding, 1975-76

Cooperation, Federal Agencies, Memoranda of Understanding, 1976-77

Cooperation, Federal Agencies, Agriculture Department, General, 1943-44

Cooperation, Federal Agencies, Agriculture Department, General, 1945-74

Cooperation, Federal Agencies, Agriculture Department, General, 1937-43

Cooperation, Federal Agencies, Agriculture Department, General, 1975-76

Cooperation, Federal Agencies, Agriculture Department, Forest Service, 1944-50

Cooperation, Federal Agencies, Agriculture Department, Forest Service, 1911, 1915, 1918, 1921-22, 1941-43

Contracts, Helium, Paradox Basin, Utah, Rare Gas Resources, 1964-65

Contracts, Helium, Paradox Basin, Utah, Rare Gas Resources, 1964-65

Contracts, Helium, Paradox Basin, Utah, Rare Gas Resources, 1965-67

Contracts, Helium, Pinta Dome, Arizona, Kerr-McGee, 1959-62

Contracts, Helium, Pinta Dome, Arizona, Kerr-McGee, 1962-73

Contracts, Helium, Salt Wash, Utah, Shell Oil, 1963-64

Contracts, Helium, San Arroyo, Utah, Sinclair, 1964-67

Computation, Projects, D.O.R.I.S., 1975

Computation, Projects, FRRE, 1972-76

Computation, Projects, Hazards Analysis, OCS, 1972

Computation, Projects, Hazards Analysis, OCS, n.d.

Computation, Projects, Inspection System, 1974-75 
Computation, Projects, Lease Production \& Revenue, OCS, 1972

Computation, Projects, Lease Production \& Revenue, OCS, 1973

Box 52 Computation, Projects, Lease Production \& Revenue, OCS, 1974-75

Computation, Projects, Lease Production \& Revenue, OCS, 1974

Computation, Projects, Lease Production \& Revenue, OCS, 1974

Computation, Projects, Lease Production \& Revenue, OCS, 1974

Computation, Projects, Lease Production \& Revenue, OCS, 1974

Computation, Projects, Lease Production \& Revenue, OCS, 1974

Box 53 Computation, Projects, Lease Production \& Revenue, OCS, 1973

Computation, Projects, Lease Production \& Revenue, OCS, 1973

Computation, Projects, Lease Production \& Revenue, OCS, n.d.

Computation, Projects, Reservoir Simulation, OCS, 1971

Computation, Projects, Reservoir Simulation, OCS, 1972

Computation, Projects, Reservoir Simulation, OCS, 1972-73

Computation, Projects, Well Data System, OCS, 1970-71

Box 54 Computation, Projects, Well Data System, OCS, 1971-72

Computation, Projects, Well Data System, OCS, 1972-75

Computation, Projects, API Unique Identifiers, OCS, 1971-75

Committees, Congressional, Public Works Committee, OCS, 1967-69

Committees, Congressional, Public Works Committee, OCS, 1969

Committees, Congressional, Science \& Astronautics Committee, 1973-74

Committees, Congressional, Select Committee on the Outer Continental Shelf, 1975

Committees, Congressional, Senate Subcommittee on Minerals, Materials \& Fuels, 1974-76

Committees, Congressional, Senate Subcommittee on Minerals, Materials \& Fuels, 1975

Box 55 Committees, Congressional, Senate Subcommittee on Minerals, Materials \& Fuels, n.d.

Committees, Field, General, 1970-73

Committees, Field, Alaska Field Committee, 1967-72

Committees, Field, Missouri River Basin Field Committee, ca. 1970-76

Committees, Field, Missouri River Basin Field Committee, 1970

Committees, Field, Northeast Field Committee, 1970-75

Committees, Field, Southwest Field Committee, 1969-76

Committees, Field, North Central Field Committee, 1969-72

Committees, Field, Pacific Northwest Field Committee, 1969-72

Committees, Field, Pacific Southwest Field Committee, 1968-74

Box 56 Committees, Field, Pacific Southwest Field Committee, 1968

Committees, Division, Discounted Cash Flow, 1969-76

Committees, Interdepartmental, Arkansas-Red-White Basin, 1969

Committees, Interdepartmental, Coastal Zone R \& E Subcommittee, OCS, 1970-76

Committees, Interdepartmental, Coastal Zone R \& E Subcommittee, OCS, 1975

Box 57 Committees, Interdepartmental, Geothermal Environmental Advisory Board Panel, 1974-76

Committees, Interdepartmental, Missouri Basin Interagency Committee, 1951-71

Committees, Interdepartmental, Missouri Basin Interagency Committee, 1970-71

Committees, Interdepartmental, Missouri Basin Interagency Committee, 1970-71

Committees, Advisory Groups, Metals \& Nonmetal Mine Safety Advisory Committees, 1971-76

Committees, Advisory Groups, NATO Oil Spills Working Group, OCS, 1970

Box 58 Committees, Advisory Groups, NATO Oil Spills Working Group, OCS, 1970

Committees, Advisory Groups, NATO Oil Spills Working Group, OCS, 1970

Committees, Advisory Groups, NATO Oil Spills Working Group, OCS, 1970

Committees, Advisory Groups, NATO Oil Spills Working Group, OCS, 1970

Committees, Advisory, OCS, Safety \& Pollution Control Committee, 1970-72

Committees, Advisory, OCS, Safety \& Pollution Control Committee, 1973-74 
Box 59 Committees, Advisory, OCS, Safety \& Pollution Control Committee, 1974-76

Committees, Advisory, OCS, Safety \& Pollution Control Committee, 1976

Committees, Advisory, OCS, Safety \& Pollution Control Committee, 1972

Committees, Advisory, OSAPE, 1974-75

Committees, Advisory, OSAPE, 1973-76

Committees, Advisory, Oil Shale Environmental Advisory Panel, 1974-75

Box 60 Committees, Advisory, Oil Shale Environmental Advisory Panel, 1975-76

Committees, Advisory, Oil Shale Environmental Advisory Panel, 1975-76

Committees, Advisory, Oil Shale Environmental Advisory Panel, 1976

Committees, Advisory, Water Resources Council, 1968-71

Committees, Advisory, Alaska Survey Committee, 1951-76

Legal, Laws and Regulations, CRF, Leasing Regulations, Special Land Use Permit, 1967-70

Box 61 Legal, Laws and Regulations, CRF, Leasing, Rights of Way, Pipelines, 1954-70

Legal, Laws and Regulations, CRF, Leasing, Oil \& Gas (43 CFR 3100), 1947-76

Legal, Laws and Regulations, CRF, Leasing, Oil \& Gas (43 CFR 3100), 1974-75

Legal, Laws and Regulations, CRF, Leasing, Oil \& Gas Exploration, 1965-70

Legal, Laws and Regulations, CRF, Leasing, Oil \& Gas (43 CFR 3120-3129), 1908, 1920-55

Legal, Laws and Regulations, CRF, Leasing, Oil \& Gas (43 CFR 3120-3129), 1956-58

Legal, Laws and Regulations, CRF, Leasing, Oil \& Gas (43 CFR 3120-3129), 1959-69

Legal, Laws and Regulations, CRF, Leasing, Oil \& Gas (43 CFR 3380-3389, OCS, 1953-54

Box 62 Legal, Laws and Regulations, CRF, Leasing, Oil \& Gas (43 CFR 3380-3389, OCS, 1954

Legal, Laws and Regulations, CRF, Leasing, Oil \& Gas (43 CFR 3380-3389, OCS, 1956-69

Legal, Laws and Regulations, CRF, Leasing, Oil \& Gas (43 CFR 3380-3389, OCS, 1969

Legal, Laws and Regulations, CRF, Leasing, Oil \& Gas (43 CFR 3380-3389, OCS, 1969-70

Legal, Laws and Regulations, CRF, Leasing, Oil \& Gas, Forms, 1949-53

Legal, Laws and Regulations, CFR, Leasing, Oil \& Gas, Forms, OCS, 1954-76

Legal, Laws and Regulations, CRF, Leasing, Oil \& Gas, Forms, ca. 1971-72

Legal, Laws and Regulations, CRF, Leasing, Oil \& Gas, Helium, 1961-67

Box 63 Legal, Laws and Regulations, CRF, Leasing, Oil \& Gas, Helium, 1965-66

Legal, Laws and Regulations, CRF, Leasing, Oil \& Gas, Oil Shale, 1921-67

Legal, Laws and Regulations, CRF, Leasing, Oil \& Gas, Oil Shale, 1967

Legal, Laws and Regulations, CRF, Leasing, Oil \& Gas, Oil Shale, 1967

Legal, Laws and Regulations, CRF, Leasing, Oil \& Gas, Oil Shale, 1967

Legal, Laws and Regulations, CRF, Leasing, Oil \& Gas, Oil Shale, 1967

Legal, Laws and Regulations, CRF, Leasing, Oil \& Gas, Oil Shale, 1967-68

Legal, Laws and Regulations, CRF, Leasing, Other Minerals, Asphalt, 1961-70

Legal, Laws and Regulations, CRF, Leasing, Other Minerals, Geothermal (43 CFR 207), 1963-70

Legal, Laws and Regulations, CRF, Leasing, Other Minerals, Geothermal (43 CFR 207), 1974

Legal, Laws and Regulations, CRF, Leasing, Geothermal (43 CFR 3200), 1970-71

Box 64 Legal, Laws and Regulations, CRF, Leasing, Geothermal (43 CFR 3200), 1971-74

Legal, Laws and Regulations, CRF, Leasing, Geothermal (43 CFR 3200), 1971-73

Cooperation, Federal Agencies, Agriculture Department, Forest Service, ca. 1950-54

Cooperation, Federal Agencies, Agriculture Department, Forest Service, 1957-71

Cooperation, Federal Agencies, Agriculture Department, Forest Service, 1971-74

Cooperation, Federal Agencies, Agriculture Department, Forest Service, ca. 1958-72 [maps]

Box 65 Cooperation, Federal Agencies, Agriculture Department, Forest Service, 1975-76

Cooperation, Federal Agencies, Agriculture Department, Forest Service, Homochitto National Forest, Mississippi, 1943-72

Cooperation, Federal Agencies, Agriculture Department, Forest Service, Kaibab National Forest, Arizona, 1961-64 
Cooperation, Federal Agencies, Agriculture Department, Forest Service, Los Padres National Forest, California, 1949-70

Cooperation, Federal Agencies, Agriculture Department, Forest Service, Los Padres National Forest, California, 1971-73

Cooperation, Federal Agencies, Agriculture Department, Forest Service, Los Padres National Forest, California, ca. 1971 [maps]

Box 66

Box 67

Box 68

Box 69

Box 70
Cooperation, Federal Agencies, Agriculture Department, Forest Service, Los Padres National Forest, California, ca. 1968-71 [maps]

Cooperation, Federal Agencies, Agriculture Department, Forest Service, Ocala National Forest, Florida, 1971-73

Cooperation, Federal Agencies, Agriculture Department, Forest Service, Osceola National Forest, Florida, 1969-74

Cooperation, Federal Agencies, Atomic Energy Commission, General, 1948-66

Cooperation, Federal Agencies, Atomic Energy Commission, General, 1967-76

Cooperation, Federal Agencies, Atomic Energy Commission, General, ca. 1965-70

Cooperation, Federal Agencies, Atomic Energy Commission, General, ca. 1970

Cooperation, Federal Agencies, Atomic Energy Commission, General, n.d. [maps]

Cooperation, Federal Agencies, Atomic Energy Commission, General, n.d. [maps]

Cooperation, Federal Agencies, Atomic Energy Commission, General, n.d. [maps]

Cooperation, Federal Agencies, Atomic Energy Commission, General, 1969

Cooperation, Federal Agencies, Atomic Energy Commission, Plowshare, Rio Blanco, Colorado, Contract, 1970-72

Cooperation, Federal Agencies, Atomic Energy Commission, Plowshare, Rio Blanco, Colorado, Correspondence, 1973-76

Cooperation, Federal Agencies, Atomic Energy Commission, Plowshare, Rio Blanco, Colorado, Feasibility Study, 1971-73

Cooperation, Federal Agencies, Atomic Energy Commission, Plowshare, Rulison, Colorado, Clippings, ca. 1969-71

Cooperation, Federal Agencies, Atomic Energy Commission, Plowshare, Rulison, Colorado, Clippings, ca. 1969

Cooperation, Federal Agencies, Atomic Energy Commission, Plowshare, Rulison, Colorado, Clippings, ca. 1969

Cooperation, Federal Agencies, Atomic Energy Commission, Plowshare, Rulison, Colorado, Contract, 1969

Cooperation, Federal Agencies, Atomic Energy Commission, Plowshare, Rulison, Colorado, Contract, $1969-70$

Cooperation, Federal Agencies, Atomic Energy Commission, Plowshare, Rulison, Colorado, Correspondence, 1968-69

Cooperation, Federal Agencies, Atomic Energy Commission, Plowshare, Rulison, Colorado, Correspondence, 1969-74

Cooperation, Federal Agencies, Atomic Energy Commission, Plowshare, Rulison, Colorado, Engineering Data, 1968-69

Cooperation, Federal Agencies, Atomic Energy Commission, Plowshare, Rulison, Colorado, Engineering Data, 1970-71

Cooperation, Federal Agencies, Atomic Energy Commission, Plowshare, Rulison, Colorado, Engineering Data, 1969-70

Cooperation, Federal Agencies, Atomic Energy Commission, Plowshare, Rulison, Colorado, Feasibility Study, 1969

Cooperation, Federal Agencies, Atomic Energy Commission, Plowshare, Rulison, Colorado, Land Utilization, 1968-74

Cooperation, Federal Agencies, Atomic Energy Commission, Plowshare, Rulison, Colorado, Land Utilization, ca. 1966-67 
Box 71 Cooperation, Federal Agencies, Atomic Energy Commission, Plowshare, Rulison, Colorado, Litigation, 1970

Cooperation, Federal Agencies, Atomic Energy Commission, Plowshare, Rulison, Colorado, Litigation, 1970

Box $72 \quad$ Crises, General, ca. 1969-76

Crises, General, ca. 1974-76

Crises, General, ca. 1961-75

Crises, General, ca. 1961-63

Crises, General, ca. 1952-72

Box 73 Crises, General, ca. 1951-64

Crises, General, ca. 1958-72

Crises, Accident Investigation Reports, OCS, 1971

Crises, Accident Investigation Reports, OCS, 1971-72

Crises, Accident Investigation Reports, OCS, 1972-74

Crises, Accident Investigation Reports, OCS, 1972-74

Box $74 \quad$ Crises, Accident Investigation Reports, OCS, 1974-75

Crises, Accident Investigation Reports, OCS, 1975-76

Crises, Accident Investigation Reports, OCS, 1974-75

Crises, Accident Investigation Reports, OCS, 1974-75

Crises, Earthquakes, General, ca. 1964-73

Box 75 Crises, General, OCS, 1963-72

Crises, General, OCS, 1972-74

Crises, General, OCS, 1974-76

Cooperation, Federal Agencies, Interior Department, Bureau of Indian Affairs, Osage Agency, Oklahoma, 1956-70

Cooperation, Federal Agencies, Interior Department, Bureau of Indian Affairs, Osage Agency, Oklahoma, 1944

Box 76 Cooperation, Federal Agencies, Interior Department, Bureau of Indian Affairs, Osage Agency, Oklahoma, 1948 Cooperation, Federal Agencies, Interior Department, Bureau of Indian Affairs, Osage Agency, Oklahoma, 1948

Cooperation, Federal Agencies, Interior Department, Bureau of Indian Affairs, Osage Agency, Oklahoma, 1948 [tables]

Cooperation, Federal Agencies, Interior Department, Bureau of Indian Affairs, Palm Springs Office, California, 1963-68

Cooperation, Federal Agencies, Interior Department, Bureau of Indian Affairs, Papago Agency, Arizona, 1913, 1918, 1921, 1947-59

Cooperation, Federal Agencies, Interior Department, Bureau of Indian Affairs, Pawnee Agency, Oklahoma, 1912, 1924-26, 1928-67

Box 77 Cooperation, Federal Agencies, Interior Department, Bureau of Indian Affairs, Pima Agency, Arizona, 1911,1916-18, 1946

Cooperation, Federal Agencies, Interior Department, Bureau of Indian Affairs, Pine Ridge Agency, South Dakota, 1915-16, 1920, 1944-72

Cooperation, Federal Agencies, Interior Department, Bureau of Indian Affairs, Quapaw Area Field Office, Oklahoma, 1958

Cooperation, Federal Agencies, Interior Department, Bureau of Indian Affairs, Red Lake Agency, Minnesota, 1960

Cooperation, Federal Agencies, Interior Department, Bureau of Indian Affairs, Riverside Area Field Office, California, 1911, 1958-63

Cooperation, Federal Agencies, Interior Department, Bureau of Indian Affairs, Rosebud Agency, South Dakota, 1911, 1956-72 
Cooperation, Federal Agencies, Interior Department, Bureau of Indian Affairs, Seminole Agency, Florida, 1965-74

Cooperation, Federal Agencies, Interior Department, Bureau of Indian Affairs, Shawnee Agency, Oklahoma, 1916, 1923-24, 1932-68

Cooperation, Federal Agencies, Interior Department, Bureau of Indian Affairs, Southeast Alaska Agency, Alaska, [c.r. Alaska, Klukwan Reservation] n.d.

Cooperation, Federal Agencies, Interior Department, Bureau of Indian Affairs, Southern Pueblo Agency, New Mexico, 1945-71

Cooperation, Federal Agencies, Interior Department, Bureau of Indian Affairs, Southern Pueblo Agency, New Mexico [maps]

Cooperation, Federal Agencies, Interior Department, Bureau of Indian Affairs, Standing Rock Agency, South Dakota \& North Dakota, 1909, 1911, 1913, 1915, 1969

Box 78

Box 79

Box 80

Cooperation, Federal Agencies, Interior Department, Bureau of Indian Affairs, Turtle Mountain Agency, North Dakota, 1910, 1912-14, 1916, 1961

Cooperation, Federal Agencies, Interior Department, Bureau of Indian Affairs, Uintah \& Ouray Agency, Utah, 1902, 1910-12, 1914-15, 1917-18, 1931-55

Cooperation, Federal Agencies, Interior Department, Bureau of Indian Affairs, Uintah \& Ouray Agency, Utah, 1965-73

Cooperation, Federal Agencies, Interior Department, Bureau of Indian Affairs, Umatilla Sub-gency, Oregon, 1911,1913

Cooperation, Federal Agencies, Interior Department, Bureau of Indian Affairs, Warm Springs Agency, Oregon, 1911, 1958-59

Cooperation, Federal Agencies, Interior Department, Bureau of Indian Affairs, Western Washington Agency, Washington, 1911, 1913-14, 1934-69

Cooperation, Federal Agencies, Interior Department, Bureau of Indian Affairs, Wind River Agency, Wyoming, 1909-12

Cooperation, Federal Agencies, Interior Department, Bureau of Indian Affairs, Wind River Agency, Wyoming, 1912-13

Cooperation, Federal Agencies, Interior Department, Bureau of Indian Affairs, Wind River Agency, Wyoming, 1914-24

Cooperation, Federal Agencies, Interior Department, Bureau of Indian Affairs, Wind River Agency, Wyoming, 1924-32

Administrative Management, 1 - Automation and Mechanization, 1977

Administrative Management, 2 - Communication Management, 1977-80

Administrative Management, 4 - Emergency Planning, 1979

Administrative Management, 5 - Financial Management, 1980

Administrative Management, 7-1 Instructional Memorandum, 1978

Administrative Management, 8 - Organization \& Functions, 1979-80

Administrative Management, 8 - Organization \& Functions, 1977-80

Administrative Management, 8 - Organization \& Functions, 1978-80

Administrative Management, 10 - Records Management, 1979

Administrative Management, 11 - Management Studies, 1979-80

Administrative Management, 11 - Management Studies, 1977

Budget, 1-2 Briefing Material \& Fact Book, 1979

Budget, 1-4 Estimates, 1977

Budget, 3 - Congressional Hearings, 1978-80

Budget, 4 - Funding Plan, 1978

Budget, 5 - Management by Objectives, 1976-77

Committees, Organization \& Meetings, 1 - Advisory, 1976-80

Committees, Organization \& Meetings, 1 - Advisory, Oil Shale Research Information Committee (O. S. R. I. C.), 1976 
Committees, Organization \& Meetings, 1 - Advisory, Oil Shale Environmental Advisory Panel, 1976

Committees, Organization \& Meetings, 2 - Department, 1977-78

Committees, Organization \& Meetings, 2 - Department, 1977

Committees, Organization \& Meetings, 3 - General, 1976-80

Committees, Organization \& Meetings, 3 - Geological Survey, Eastern Region Survey Committee, 1976-77

Committees, Organization \& Meetings, 3 - Geological Survey, Central Region Survey Committee, 1976-77

Committees, Organization \& Meetings, 3 - Geological Survey, Alaska Survey Committee, 1977

Committees, Organization \& Meetings, 3 - Geological Survey, Western Region Survey Committee, 1976-77

Committees, Organization \& Meetings, 4 - Interagency, 1975-79

Committees, Organization \& Meetings, 4 - Interagency, 1976-77

Committees, Organization \& Meetings, 5 - Others, 1976-80

Cooperative Agreements, 1 - Department of Agriculture, 1976-77

Cooperative Agreements, 3 - Department of Commerce, National Oceanographic and Atmospheric Administration (NOAA), 1976

Cooperative Agreements, 3-1 Internal Revenue Service, 1978

Cooperative Agreements, 4 - Department of Defense, 1978-81

Cooperative Agreements, 5 - Federal Power Commission, 1976-78

Cooperative Agreements, 6 - General Accounting Office, 1978-80

Cooperative Agreements, 7 - General Services Administration, 1976

Cooperative Agreements, 8 - Department of the Interior, 1977-78

Cooperative Agreements, 8-2 Bureau of Land Management, 1977-81

Cooperative Agreements, 8-3 Bureau of Mines, 1977

Box 82 Cooperative Agreements, 8-4 USGS - Inter-division, 1975-79

Cooperative Agreements, 8-5 Fish and Wildlife Service, 1978

Cooperative Agreements, 8-6 Office of Inspector General, 1980

Cooperative Agreements, 13 - Department of Transportation, 1977

Cooperative Agreements, 15 - International, 1977-78

Cooperative Agreements, 16 - Scientific and Professional, 1976

Cooperative Agreements, 17 - States \& Local Government, 1977-78

Cooperative Agreements, 18 - Energy Department, 1978-81

Cooperative Agreements, 18 - Energy Department, 1977-78

Cooperative Agreements, 18 - Energy Department, 1977-78

Environment, 1 - Environmental Implementation Statement, 1976-80

Environment, 3 - Clean Air, 1979

Environment, 7 - Drilling, 1979

Environment, 11 - Environmental Impact Analysis Program, 1977-79

Environment, 12 - Environmental Implementation Statement, 1977

Legal \& Legislation, Legal, General, 1981

Legal \& Legislation, 2 - Congressional Relations, 1977-80

Legal \& Legislation, 6 - Federal Register Notices, 1979-80

Legal \& Legislation, 7 - Legislation, 1977-80

Legal \& Legislation, 7-1 House Bills, 1977-79

Box 83 Legal \& Legislation, 8 - Opinions and Decisions, 1977-79

Legal \& Legislation, 9 - Patents and Inventions, 1979

Legal \& Legislation, 12-3 Secretarial, 1976-79

Leases, 1 - Plans \& Policies, 1976-77

Leases, 2 - Lease Management, 1976-80 
Leases, 2-4 Lease Management, Bids, 1976

Leases, 2-11 Lease Management, Geothermal Leases, 1976-79

Leases, 2-14 Lease Management, Known Recoverable Coal Resource Areas, 1976

Leases, 2-27 Sales, 1977-79

Leases, 2-33 Lease Management Studies, 1976,

Leases, 2-36 Systems, 1978

Leases, 2-38 Tracts, 1976

Leases, 2-41 Withdrawals \& Restorations, 1976

Mines and Mining, 2-1 OCS, 1977

Mines and Mining, 2-2 Onshore, 1976-80

Minerals, Marine, 1- Plans and Policy, 1978-80

Minerals, Onshore, 1 - Plans and Policy, 1977-81

Minerals, Onshore, 5 - Discounted Cash Flow, 1977

Minerals, Onshore, 8 - Exploration, 1979

Office Services, 1 - Building Services, 1979

Office Services, 5 - Reproduction and Distribution, 1979

Office Services, 7 - Correspondence Control System, 1979

Oil and Gas, Marine, 1 - Plans and Policy, 1977-78

Box 84

Oil and Gas, Marine, 3 - Development, 1978-79

Oil and Gas, Marine, 3-3 Utilization, 1978

Oil and Gas, Marine, 3-4 Plans, 1978

Oil and Gas, Marine, 5-1 Drilling, 1976-80

Oil and Gas, Marine, 8 - Maximizing, 1977

Oil and Gas, Marine, 10 - OCS Orders, 1978-80

Oil and Gas, Marine, 10-3 Gulf Coast, 1976

Oil and Gas, Marine, 11 - Platforms, 1978

Oil and Gas, Marine, 12 - Production Controls, 1977-78

Oil and Gas, Marine, 12 - Production Controls, 1977

Oil and Gas, Marine, 12 - Production Controls, 1977-78

Oil and Gas, Marine, 12 - Production Controls, 1978

Box $85 \quad$ Oil and Gas, Marine, 12 - Production Controls, 1978

Oil and Gas, Marine, 12 - Production Controls, 1978

Oil and Gas, Marine, 12 - Production Controls, 1977-78

Oil and Gas, Marine, 12 - Production Controls, 1977

Oil and Gas, Marine, 12 - Production Controls, 1977

Box $86 \quad$ Oil and Gas, Marine, 12 - Production Controls, 1977

Oil and Gas, Marine, 12 - Production Controls, 1977

Oil and Gas, Marine, 12 - Production Controls, 1976-77

Oil and Gas, Marine, 15 - Sales, 1976-77

Oil and Gas, Marine, 17 - Transportation, 1978-79

Oil and Gas, Marine, 19 - Prices, 1976

Oil and Gas, Onshore, 1 - Plans and Policy, 1980-81

Oil and Gas, Onshore, 2 - Development. 1977

Oil and Gas, Onshore, 4-1 Drilling, 1979-80

Oil and Gas, Onshore, 5-4 Natural, 1978-79

Oil and Gas, Onshore, 7-1 Secondary Recovery, 1977-78

Oil and Gas, Onshore, 8 - Petroleum Reserves, 1979-80

Box 87 Oil and Gas, Onshore, 8 - Petroleum Reserves, 1980-81

Oil and Gas, Onshore, 9 - Production Controls, 1976-77

Oil and Gas, Onshore, 14 - Wells, 1979

Oil and Gas, Onshore, 15 - Archeological Clearances, 1976 
Personnel, 3 - Attendance and Leave, 1980

Personnel, 4 - Awards and Incentives, 1979-80

Personnel, 6 - Conduct and Discipline, 1978-79

Personnel, 7 - Employees Services and Activities, 1980

Personnel, 8 - Employment, 1977-80

Personnel, 9 - Evaluation, 1979

Personnel, 12 - Orientation and Training, 1977-78

Personnel, 13 - Position Classification, 1979-80

Personnel, 15 - Retirement, 1980

Personnel, 16 - Security, 1980

Personnel, 17 - Staffing, 1976-79

Procurement, 1 - Bids and Contracts, 1976-77

Procurement, 3 - Equipment and Supplies, 1977-80

Public Information, 1 - Anonymous and Crank Letters, 1977

Public Information, 3 - Commendations, 1979-81

Public Information, 4 - Criticism, 1977-79

Public Information, 5 - Engagements and Invitations, 1978-81

Public Information, 6 - Exhibits, Fairs and Expositions, 1977-80

Public Information, 7 - Press, Radio and Television, 1978-80

Public Information, 8 - Requests, 1977-79

Public Information, 9 - Speeches, 1979

Public Information, 11 - Oil and Gas Information Program, 1979

Public Information, 11 - Responses, 1978-79

Reports and Statistics, General, 1976-80

Reports and Statistics, 1 - Leave Status, OCS, 1979

Reports and Statistics, 1 - Monthly, Area Geothermal, 1979-80

Box 88 Reports and Statistics, 1 - Monthly, Area Geothermal, 1976

Reports and Statistics, 1 - Monthly, Area Geothermal, 1976

Reports and Statistics, 1 - Monthly, Leasing Summary, Offshore Mineral Fluids, 1976

Reports and Statistics, 1 - Monthly, Area Oil Shale Activity Report, 1976-79

Reports and Statistics, 1 - Monthly, RCM - Western Region, 1976-77

Reports and Statistics, 2 - Quarterly, Lease Sales, Mineral Fluids, 1976

Reports and Statistics, 3-1 Royalty Accounting Statistics, 1979

Reports and Statistics, 4 - International Oil Development, 1976-77

Reports and Statistics, 5 - Solicitor's Reports, 1976-78

Reports and Statistics, 6 - Forms Management, 1976-78

Reports and Statistics, 6 - Conservation Division Publication Activity, 1976-77

$\mathrm{R} \& \mathrm{D}, 1974-78$

Resources and Classification, 1 - Plans and Policy, 1977-80

Resources and Classification, 2 - Charts and Maps, 1978

Resources and Classification, 2-1 CRO/CDP, 1978-79

Box 89 Resources and Classification, 4-1 Lands, 1977-80

Resources and Classification, 4-2 Resources, 1977-80

Resources and Classification, 5-1 Oil and Gas, 1977-79

Resources and Classification, 5-2 Other Resources, 1979

Resources and Classification, 7 - Water-power, 1977-78

Royalties, 1 - Plans and Policy, 1980

Royalties, 2 - Accounting and Collection Procedures, 1977-80

Royalties, 2-1 Revised Royalty Accounting System, 1979-80

Royalties, 2-1 Revised Royalty Accounting System, 1980

Royalties, 2-1 Revised Royalty Accounting System, 1980-81 
Royalties, 3-1 GAO, 1977

Safety and Health, General, 1979-80

Safety and Health, 1 - Policy and Plans, 1977

Safety and Health, 2-1 Blowouts, 1977-80

Safety and Health, 2-7 Spills, 1977-80

Safety and Health, 3 - Inspection, 1976

Safety and Health, 2-1 (A) Pennzoil, 1977

Safety and Health, 2-1 (A) Pennzoil, 1976-77

Box $90 \quad$ Safety and Health, 2-1 (A) Pennzoil, 1977

Safety and Health, 2-1 (A) Pennzoil, 1977

Safety and Health, 2-1 (A) Pennzoil, 1977

Safety and Health, 2-1 (A) Pennzoil, 1977

Travel and Transportation, 1 - Allowances, 1979

Travel and Transportation, 2 - Transportation, 1979

Miscellaneous Correspondence, October 1976

Box 91 Miscellaneous Correspondence, November 1976

Miscellaneous Correspondence, December 1976

Miscellaneous Correspondence, January 1977

Miscellaneous Correspondence, February 1977

Miscellaneous Correspondence, March 1977

Miscellaneous Correspondence, March 1977

Box 92 Miscellaneous Correspondence, March 1977

Miscellaneous Correspondence, April 1977

Miscellaneous Correspondence, April 1977

Miscellaneous Correspondence, May 1977

Miscellaneous Correspondence, June 1977

Miscellaneous Correspondence, July 1977

Box 93 Miscellaneous Correspondence, August 1977

Miscellaneous Correspondence, September 1977

Miscellaneous Correspondence, October 1977

Miscellaneous Correspondence, November 1977

Miscellaneous Correspondence, January 1978

Miscellaneous Correspondence, February 1978

Miscellaneous Correspondence, March 1978

Miscellaneous Correspondence, March-April 1978

Box 94 Miscellaneous Correspondence, May-June 1978

Miscellaneous Correspondence, February-May 1978

Miscellaneous Correspondence, June 1978

Miscellaneous Correspondence, June-July 1978

Miscellaneous Correspondence, August-September 1978

Miscellaneous Correspondence, September 1978

Miscellaneous Correspondence, October 1978

Miscellaneous Correspondence, November 1978

Miscellaneous Correspondence, December 1978

Box 95 Miscellaneous Correspondence, January 1979

Miscellaneous Correspondence, February 1979

Miscellaneous Correspondence, March 1979

Miscellaneous Correspondence, April 1979

Miscellaneous Correspondence, May 1979

Miscellaneous Correspondence, June 1979

Miscellaneous Correspondence, July 1979 
Miscellaneous Correspondence, July-August 1979

Miscellaneous Correspondence, November 1979-December 1981

Miscellaneous Correspondence, 1981

Senate Resolution 53, 1941

Senate Resolution 53, 1941

Box 96

Senate Resolution 53, 1941

Oil and Gas Prices, ca. 1921-41

Plugging Holes, Validating Holes, ca. 1925-39

Oil-Leasing Cases, etc., 1922-34

Oil-Leasing Cases, etc., 1934-36

Oil-Leasing Cases, etc., 1937-38

Box 97

Rights-of-Way, 1909, 1913-41

Royalty Oil Sale, 1939-49

Extension Act, 1935-39

Survey Advisory Committee, 1953-60

Notes for the Survey Advisory Board Conference, November 28, 1958

Notes for the Survey Advisory Board Conference, September 18-19, 1961

Notes for the Survey Advisory Board Conference, November 30 - December 1, 1962

Notes for the Survey Advisory Board Conference, May 15-16, 1963

Notes for the Survey Advisory Board Conference, December 4-5, 1963

Notes for the Survey Advisory Board Conference, November 9-10, 1964

Box 98 President's Materials Policy Commission (Paley Commission), 1951-52

Louisiana - Interior Agreement, 1956

Cane Creek - Potash - Withdrawal, 1960-61

"Conservation by Conversation," by Harold J. Duncan, March 6, 1951 (an address to the members of the Pick and Hammer Club)

Navy, ca. 1927-43

Grazing, Public Domain, ca. 1931-32

"Rise and Fall of the Public Domain," by Herman Stabler, 1932; and "The Public Domain," by Clay Tallman, 1941

Competitive Leasing, 1961

Box $99 \quad$ Wyoming Industry, ca. 1930

Oil in Wyoming, ca. 1930

Statement before the Committee on Public Lands, House of Representatives, April 17, 1935, by

Herman Stabler, "Volume of Administrative Work"

Royalty Drilling, Casper Artesia, Washington Hearings, ca. 1942

Wildcats [Development of Oil Reserves], ca. 1933-41

Amended Lease Forms and Regulations, ca. 1947-52

BLM Conference, Billings, Montana, July 14, 1952

Unit Memorandums, ca. 1936

Box 100 Statement by Assistant Secretary Oscar L. Chapman, Department of the Interior, before the Senate Special Committee Investigating Petroleum Resources, June 25, 1945

Statements - regarding USGS conservation activities, April 1960; and "Highlights - Oil and Gas Leasing Branch, FY 1957"

Paper prepared for presentation by Robert E. Spratt regarding mineral classification, 1961; and copies of other papers

Helium Hearings, Navajo Tribe v. United States, ca. 1955

"Memorandum on Examples of Waste as Defined by H.R. 7372, Hale B. Soyster, 1939

Cole Bill, Petroleum Exploration, 1940-41

Miscellaneous correspondence and statements regarding mineral exploration and development, ca. $1941-42$ 
Notes on the production of crude oil, ca. 1941

Teapot Dome, Newspaper Clippings, 1925 [1]

Teapot Dome, Newspaper Clippings, 1925 [2]

Box 101

Cooperation, Federal Agencies, Atomic Energy Commission, Plowshare, Gasbuggy, New Mexico, Reports, [printed] ca. 1968-72

Cooperation, Federal Agencies, Atomic Energy Commission, Plowshare, Gasbuggy, New Mexico, Reports, [printed] ca. 1965-71

Cooperation, Federal Agencies, Atomic Energy Commission, Plowshare, Gasbuggy, New Mexico, Reports, ca. 1967-72

Cooperation, Federal Agencies, Atomic Energy Commission, Plowshare, Gasbuggy, New Mexico, Logs, n.d.

Cooperation, Federal Agencies, Atomic Energy Commission, Plowshare, Gasbuggy, New Mexico, Logs, n.d.

Box 102 Cooperation, Federal Agencies, Atomic Energy Commission, Plowshare, Gasbuggy, New Mexico, Reports, ca. 1967

Cooperation, Federal Agencies, Atomic Energy Commission, Plowshare, Gasbuggy, New Mexico, Contract, 1966-67

Cooperation, Federal Agencies, Atomic Energy Commission, Plowshare, Gasbuggy, New Mexico, Correspondence, 1965-69

Cooperation, Federal Agencies, Atomic Energy Commission, Plowshare, Gasbuggy, New Mexico, Engineering Data, 1965-69

Cooperation, Federal Agencies, Atomic Energy Commission, Plowshare, Gasbuggy, New Mexico, Feasibility Study, 1965

Cooperation, Federal Agencies, Atomic Energy Commission, Plowshare, Gasbuggy, New Mexico, Land Utilization, 1967

Cooperation, Federal Agencies, Atomic Energy Commission, Plowshare, Gasbuggy, New Mexico, Meetings, 1965-68

Cooperation, Federal Agencies, Atomic Energy Commission, Plowshare, Dragon Trail, Colorado, Correspondence, 1968-69

Cooperation, Federal Agencies, Atomic Energy Commission, Plowshare, Dragon Trail, Colorado, Land Utilization ca. 1968

Cooperation, Federal Agencies, Atomic Energy Commission, Plowshare, Dragon Trial, Colorado, Technical Plan, 1968

Cooperation, Federal Agencies, Atomic Energy Commission, Plowshare, Rio Blanco, Colorado, Meetings, ca. 1970-74

Box 103 Cooperation, Federal Agencies, Atomic Energy Commission, Plowshare, Bronco, Colorado, Land Utilization, 1966-68

Cooperation, Federal Agencies, Atomic Energy Commission, Plowshare, Bronco, Colorado, Meetings, 1968-70

Cooperation, Federal Agencies, Atomic Energy Commission, Plowshare, Bronco, Colorado, Meetings, 1966-68

Cooperation, Federal Agencies, Atomic Energy Commission, Plowshare, Bronco, Colorado, Operating Agreement, 1966-68

Box 104 Cooperation, Federal Agencies, Atomic Energy Commission, Plowshare, Bronco, Colorado, Proposed Contract, $1967-70$

Cooperation, Federal Agencies, Atomic Energy Commission, Plowshare, Rulison, Colorado, Litigation, n.d.

Cooperation, Federal Agencies, Atomic Energy Commission, Plowshare, Rulison, Colorado, Litigation, n.d.

Cooperation, Federal Agencies, Atomic Energy Commission, Plowshare, Rulison, Colorado, Litigation, 1970 
Cooperation, Federal Agencies, Atomic Energy Commission, Plowshare, Rulison, Colorado, Litigation, n.d.

Cooperation, Federal Agencies, Atomic Energy Commission, Plowshare, Rulison, Colorado, Litigation, 1969-70

Cooperation, Federal Agencies, Atomic Energy Commission, Plowshare, Rio Blanco, Colorado, Meetings, 1973

Cooperation, Federal Agencies, Atomic Energy Commission, Plowshare, Rio Blanco, Colorado, Meetings, ca. 1972

Cooperation, Federal Agencies, Atomic Energy Commission, Plowshare, Rio Blanco, Colorado, Meetings, 1972

Cooperation, Federal Agencies, Atomic Energy Commission, Plowshare, Rio Blanco, Colorado, Meetings, 1972

Cooperation, Federal Agencies, Atomic Energy Commission, Plowshare, Rio Blanco, Colorado, Correspondence, 1970-71

Cooperation, Federal Agencies, Atomic Energy Commission, Plowshare, Rio Blanco, Colorado, Correspondence, 1972

Box 106 Cooperation, Federal Agencies, Atomic Energy Commission, Plowshare, Gnome, New Mexico, Contract, 1961

Cooperation, Federal Agencies, Atomic Energy Commission, Plowshare, Gnome, New Mexico, Correspondence, 1969-71

Cooperation, Federal Agencies, Atomic Energy Commission, Plowshare, Gnome, New Mexico, Correspondence, 1958-62

Cooperation, Federal Agencies, Atomic Energy Commission, Plowshare, Gnome, New Mexico, Engineering Data, 1959-61

Cooperation, Federal Agencies, Atomic Energy Commission, Plowshare, Gnome, New Mexico, Feasibility Study, 1958

Cooperation, Federal Agencies, Atomic Energy Commission, Plowshare, Gnome, New Mexico, Land Utilization, n.d.

Cooperation, Federal Agencies, Atomic Energy Commission, Plowshare, Gnome, New Mexico, Meetings, 1958-61

Cooperation, Federal Agencies, Atomic Energy Commission, Plowshare, Gnome, New Mexico, Reports, ca. 1962

Cooperation, Federal Agencies, Atomic Energy Commission, Plowshare, Ketch, Ariz., Correspondence, ca. 1968

Cooperation, Federal Agencies, Atomic Energy Commission, Plowshare, Pinedale, Wyoming, Contract, 1968-69

Cooperation, Federal Agencies, Atomic Energy Commission, Plowshare, Pinedale, Wyoming, Correspondence, 1968-71

Cooperation, Federal Agencies, Atomic Energy Commission, Plowshare, Pinedale, Wyoming, Correspondence, 1970

Cooperation, Federal Agencies, Atomic Energy Commission, Plowshare, Pinedale, Wyoming, Correspondence, 1970

Box 107 Cooperation, Federal Agencies, Atomic Energy Commission, Plowshare, Pinedale, Wyoming, Correspondence, 1969-70

Cooperation, Federal Agencies, Atomic Energy Commission, Plowshare, Pinedale, Engineering Data, 1969-70

Cooperation, Federal Agencies, Atomic Energy Commission, Plowshare, Pinedale, Feasibility Study, 1968

Cooperation, Federal Agencies, Atomic Energy Commission, Plowshare, Pinedale, Meetings, 1968-69 
Cooperation, Federal Agencies, Atomic Energy Commission, Plowshare, Pinedale, Reports, (printed items) 1970-71

Cooperation, Federal Agencies, Atomic Energy Commission, Plowshare, Oregon Geothermal Project, Oregon, 1969-70

Cooperation, Federal Agencies, Atomic Energy Commission, Plowshare, Utah, Feasibility Study, ca. 1970

Cooperation, Federal Agencies, Atomic Energy Commission, Plowshare, Utah, Feasibility Study, 1971

Box 108

Cooperation, Federal Agencies, Atomic Energy Commission, Plowshare, Wasp, Wyoming, Contract, 1969

Cooperation, Federal Agencies, Atomic Energy Commission, Plowshare, Wasp, Wyoming,Correspondence, 1969-71

Cooperation, Federal Agencies, Atomic Energy Commission, Plowshare, Wasp, Wyoming, Correspondence, Maps, n.d.

Cooperation, Federal Agencies, Atomic Energy Commission, Plowshare, Wasp, Wyoming, Correspondence, Maps, n.d.

Cooperation, Federal Agencies, Atomic Energy Commission, Plowshare, Wasp, Wyoming, Engineering Data, 1969

Cooperation, Federal Agencies, Atomic Energy Commission, Plowshare, Wasp, Wyoming, Feasibility Study, 1968-69

Cooperation, Federal Agencies, Atomic Energy Commission, Plowshare, Wasp, Wyoming, Feasibility Study, 1969

Cooperation, Federal Agencies, Atomic Energy Commission, Plowshare, Wasp, Wyoming, Feasibility Study, Maps, n.d.

Box 109 Cooperation, Federal Agencies, Atomic Energy Commission, Plowshare, Wasp, Wyoming, Land Utilization, 1969

Cooperation, Federal Agencies, Atomic Energy Commission, Plowshare, Wasp, Wyoming, Meetings, 1967-70

Cooperation, Federal Agencies, Atomic Energy Commission, Plowshare, Thunderbird Project, Wyoming, 1968-74

Cooperation, Federal Agencies, Atomic Energy Commission, Plowshare, Rulison, Colorado, Meetings, 1968-69

Cooperation, Federal Agencies, Atomic Energy Commission, Plowshare, Rulison, Colorado, Plans and Evaluation, 1969

Cooperation, Federal Agencies, Atomic Energy Commission, Plowshare, Rulison, Colorado, Plans and Evaluation, 1969-76

Cooperation, Federal Agencies, Atomic Energy Commission, Plowshare, Rulison, Colorado, Plans and Evaluation, 1968

Cooperation, Federal Agencies, Atomic Energy Commission, Plowshare, Rulison, Colorado, Plans and Evaluation, 1969

Box 110 Cooperation, Federal Agencies, Atomic Energy Commission, Plowshare, Rulison, Colorado, Plans and Evaluation, 1969

Cooperation, Federal Agencies, Defense Department, Army, General, 1964-76

Cooperation, Federal Agencies, Defense Department, Army, General, 1927-64

Cooperation, Federal Agencies, Defense Department, Army, General, [maps], n.d.

Cooperation, Federal Agencies, Defense Department, Air Force, Victoria Auxiliary Field, Kansas, 1953-60

Cooperation, Federal Agencies, Defense Department, Air Force, Vance A.F.B., Oklahoma, [Maps], n.d.

Box 111 Cooperation, Federal Agencies, Defense Department, Air Force, Vance A.F.B., Oklahoma, 1964-68 Cooperation, Federal Agencies, Defense Department, Air Force, Travis A.F.B., California, 1948-66 
Cooperation, Federal Agencies, Defense Department, Air Force, Travis A.F.B., California, [Maps], n.d.

Cooperation, Federal Agencies, Defense Department, Air Force, Smoky Hill A.F.B., Kansas, ca. 1950-55

Cooperation, Federal Agencies, Defense Department, Air Force, Perrin A.F.B., Texas, [maps], n.
Cooperation, Federal Agencies, Defense Department, Air Force, Perrin A.F.B., Texas, 1957-71

Cooperation, Federal Agencies, Defense Department, Air Force, Perrin A.F.B., Texas, 1957-67

Cooperation, Federal Agencies, Defense Department, Air Force, Perrin A.F.B., Texas, 1955-56

Cooperation, Federal Agencies, Defense Department, Air Force, Lowery Field, Colorado, 1948-60

Cooperation, Federal Agencies, Defense Department, Air Force, Fire Island, Alaska, 1965-66

Cooperation, Federal Agencies, Defense Department, Air Force, Ellington A.F.B., Texas, 1964-68

Cooperation, Federal Agencies, Defense Department, Air Force, Ellington A.F.B., Texas, 1937-38

Cooperation, Federal Agencies, Defense Department, Air Force, Dyess A.F.B., 1960-73

Box 113 Cooperation, Federal Agencies, Defense Department, Air Force, Dyess A.F.B., [maps], n.d.

Cooperation, Federal Agencies, Defense Department, General, OCS, 1958-75

Cooperation, Federal Agencies, Defense Department, General, OCS, ca. 1950-76

Cooperation, Federal Agencies, Defense Department, Air Force, General, 1949-73

Cooperation, Federal Agencies, Defense Department, Army, Cactus Ordnance Works, Texas, 1948-65

Cooperation, Federal Agencies, Defense Department, Army, Camp Breckinridge, Kentucky, 1950-55

Cooperation, Federal Agencies, Defense Department, Army, Camp Breckinridge, Kentucky, 1956-66

Box 114 Cooperation, Federal Agencies, Defense Department, Army, Camp Breckinridge, Kentucky, [maps], n.d.

Cooperation, Federal Agencies, Defense Department, Army, Fort Chaffee, Arkansas, 1959-68

Cooperation, Federal Agencies, Defense Department, Army, Fort Chaffee, Arkansas, ca. 1968-75

Cooperation, Federal Agencies, Defense Department, Army, Fort Sill, Oklahoma, 1943-55

Cooperation, Federal Agencies, Defense Department, Army, Fort Sill, Oklahoma, [maps], n.d.

Box 115 Cooperation, Federal Agencies, Defense Department, Army, Fort Sill, Oklahoma, 1957-72

Cooperation, Federal Agencies, Defense Department, Army, Marine City, Michigan, 1966-68

Cooperation, Federal Agencies, Defense Department, Army, Sioux Ordnance Depot, Nebraska, 1949-52

Cooperation, Federal Agencies, Defense Department, Army, Sioux Ordnance Depot, Nebraska, 1956-69

Cooperation, Federal Agencies, Defense Department, Army, Sioux Ordnance Depot, Nebraska, 1969-76

Cooperation, Federal Agencies, Defense Department, Army Corps of Engineers, General, 1968-76

Box 116 Cooperation, Federal Agencies, Defense Department, Army Corps of Engineers, General, OCS, 1950-66

Cooperation, Federal Agencies, Defense Department, Army Corps of Engineers, General, OCS, 1967-69

Cooperation, Federal Agencies, Defense Department, Army Corps of Engineers, General, OCS, 1969-72

Cooperation, Federal Agencies, Defense Department, Army Corps of Engineers, General, OCS, 1971-76

Cooperation, Federal Agencies, Defense Department, Army Corps of Engineers, Fairways, OCS, 1955-67

Box 117 Cooperation, Federal Agencies, Defense Department, Navy, Concord Ammunition Depot, California, 1959-63

Cooperation, Federal Agencies, Defense Department, Navy, Concord Ammunition Depot, California, 1959-68 
Cooperation, Federal Agencies, Defense Department, Navy, Concord Ammunition Depot, California, [maps], ca. 1964

Cooperation, Federal Agencies, Defense Department, Navy, Concord Ammunition Depot, California, maps], n.d.

Cooperation, Federal Agencies, Defense Department, Navy, Canton Ordnance Plant, Ohio, 1946-62

Box 118 Cooperation, Federal Agencies, Defense Department, Navy, Camp Wallace, Texas, 1952-72

Cooperation, Federal Agencies, Defense Department, Navy, Camp Wallace, Texas, [maps], n.d.

Cooperation, Federal Agencies, Defense Department, Navy, General, 1949-76

Cooperation, Federal Agencies, Defense Department, Navy, General, OCS, 1954-76

Cooperation, Federal Agencies, Defense Department, Army Corps of Engineers, Warning Area, Texas, Matagorda, OCS, 1948-67

Cooperation, Federal Agencies, Defense Department, Army Corps of Engineers, Warning Area, Louisiana, OCS, 1956-67

Box 119 Cooperation, Federal Agencies, Defense Department, Army Corps of Engineers, Warning Area, Texas, Corpus Christi, OCS, 1954-62

Cooperation, Federal Agencies, Defense Department, Army Corps of Engineers, Warning Area, Texas, Corpus Christi, OCS, 1954-71

Cooperation, Federal Agencies, Defense Department, Army Corps of Engineers, Warning Area, Texas, Corpus Christi, OCS, [maps], n.d.

Cooperation, Federal Agencies, Defense Department, Army Corps of Engineers, Warning Area, Louisiana, OCS, 1954-67

Cooperation, Federal Agencies, Defense Department, Army Corps of Engineers, Warning Area, Florida Gulf, OCS, 1956-64

Cooperation, Federal Agencies, Defense Department, Army Corps of Engineers, Warning Area, Florida East, OCS, 1960-65

Cooperation, Federal Agencies, Defense Department, Army Corps of Engineers, Warning Area, California, OCS, 1961-65

Cooperation, Federal Agencies, Defense Department, Army Corps of Engineers, Flood Control Projects, 1950-72

Box 120 Cooperation, Federal Agencies, Defense Department, Army Corps of Engineers, Flood Control Projects 1949-50

Cooperation, Federal Agencies, Defense Department, Army Corps of Engineers, Flood Control Projects, [maps] ca. 1949

Cooperation, Federal Agencies, Defense Department, Naval Petroleum Reserves, General, Annual Reports, Reserves 1 \& 2, 1972-73

Cooperation, Federal Agencies, Defense Department, Naval Petroleum Reserves, General, Annual Reports, Reserves 1 \& 2, 1970-71

Cooperation, Federal Agencies, Defense Department, Naval Petroleum Reserves, General, Annual Reports, Reserves 1 \& 2, 1966-67

Box 121 Cooperation, Federal Agencies, Defense Department, Naval Petroleum Reserves, General, Annual Reports, Reserves 1 \& 2, 1964-65

Cooperation, Federal Agencies, Defense Department, Naval Petroleum Reserves, General, ca. $1959-74$

Cooperation, Federal Agencies, Defense Department, Naval Petroleum Reserves, General, 1938-76

Cooperation, Federal Agencies, Defense Department, Naval Petroleum Reserves, General, 1918-37

Cooperation, Federal Agencies, Defense Department, Naval Petroleum Reserves, General, 1908-17

Box 122 Cooperation, Federal Agencies, Defense Department, Navy, Seal Beach Ammunition Depot, California, 1955-59

Cooperation, Federal Agencies, Defense Department, Navy, Seal Beach Ammunition Depot, California, [maps], n.d.

Cooperation, Federal Agencies, Defense Department, Navy, Point Mugu, California, 1949-68 
Cooperation, Federal Agencies, Defense Department, Navy, Orange, Texas, 1952-63

Cooperation, Federal Agencies, Defense Department, Navy, Houma Naval Air Station, Louisiana, 1953-55

Cooperation, Federal Agencies, Defense Department, Navy, McAlester Ammunition Depot, Oklahoma, 1959-72

Cooperation, Federal Agencies, Defense Department, Navy, McAlester Ammunition Depot, Oklahoma, [maps], n.d.

Cooperation, Federal Agencies, Defense Department, Navy, Corpus Christi Airfield, Texas, [maps], ca. 1955

Box 123 Cooperation, Federal Agencies, Defense Department, Navy, Corpus Christi Airfield, Texas, [maps], n.d.

Cooperation, Federal Agencies, Defense Department, Navy, Corpus Christi Airfield, Texas, 1962-70

Cooperation, Federal Agencies, Defense Department, Navy, Corpus Christi Airfield, Texas, 1948-55

Cooperation, Federal Agencies, Defense Department, Navy, Corpus Christi Airfield, Texas, 1956-61

Cooperation, Federal Agencies, Defense Department, Naval Petroleum Reserve No. 3, Teapot Dome, Wyoming, 1923-25

Box 124 Cooperation, Federal Agencies, Defense Department, Naval Petroleum Reserve No. 1, Elk Hills, California, 1922-23

Cooperation, Federal Agencies, Defense Department, Naval Petroleum Reserve No. 1, Elk Hills, California, 1924-28

Cooperation, Federal Agencies, Defense Department, Naval Petroleum Reserve No. 1, Elk Hills, California, 1934-46

Cooperation, Federal Agencies, Defense Department, Naval Petroleum Reserve No. 1, Elk Hills, California, 1947-48

Cooperation, Federal Agencies, Defense Department, Naval Petroleum Reserve No. 1, Elk Hills, California, 1949-51

Box 125 Cooperation, Federal Agencies, Defense Department, Naval Petroleum Reserve No. 1, Elk Hills, California, 1957-74

Cooperation, Federal Agencies, Defense Department, Naval Petroleum Reserve No. 1, Elk Hills, California, 1928-33

Cooperation, Federal Agencies, Defense Department, Naval Petroleum Reserve No. 1, Elk Hills, California, (printed items and maps), ca. 1947

Cooperation, Federal Agencies, Defense Department, Naval Petroleum Reserve No. 1, Elk Hills, California, (hearing transcripts), 1948

Cooperation, Federal Agencies, Defense Department, Naval Petroleum Reserve No. 1, Elk Hills, California, (monthly production statistics), ca. 1922-26

Box 126 Cooperation, Federal Agencies, Defense Department, Naval Petroleum Reserve No. 1, Elk Hills, California, (oil production statistics), 1927

Cooperation, Federal Agencies, Defense Department, Naval Petroleum Reserve No. 1, Elk Hills, California, 1912-21

Cooperation, Federal Agencies, Defense Department, Naval Reserves, General, Annual Reports, Reserves $1 \& 2,1962$

Cooperation, Federal Agencies, Defense Department, Naval Reserves, General, Annual Reports, Reserves 1 \& 2, ca. 1955-59

Cooperation, Federal Agencies, Defense Department, Naval Reserves, General, Annual Reports, Reserves $1 \& 2,1958$

Box 127 Cooperation, Federal Agencies, Defense Department, Naval Reserves, General, Annual Reports, Reserves 1 \& 2, 1957

Cooperation, Federal Agencies, Defense Department, Naval Petroleum Reserve No. 4 [out on internal loan - within USGS] 
Cooperation, Federal Agencies, Defense Department, Naval Petroleum Reserve No. 3, Teapot Dome, Wyoming, 1967-73

Cooperation, Federal Agencies, Defense Department, [typescript "History of the Naval Petroleum Reserves," complied by R. G. Tracie, Senior Petroleum Engineer, Navy Department], 1937 [1]

Cooperation, Federal Agencies, Defense Department, [typescript "History of the Naval Petroleum Reserves," complied by R. G. Tracie, Senior Petroleum Engineer, Navy Department], 1937 [2]

Cooperation, Federal Agencies, Defense Department, [printed volume "A History of the Naval

Petroleum Reserves and of the Development of the Present National Policy Respecting

Them" by Reginald W. Ragland, ca. 1944

Cooperation, Federal Agencies, Defense Department, [printed volume "A History of the Naval

Petroleum Reserves and of the Development of the Present National Policy Respecting

Them" by Reginald W. Ragland, ca. 1944 [maps]

Box 128

Box 129

Box 130

Box 131

Box 132
Cooperation, Federal Agencies, Federal Power Commission, Natural Gas, 1944-55

Cooperation, Federal Agencies, Federal Power Commission, Natural Gas, 1958-75

Cooperation, Federal Agencies, Federal Power Commission, Natural Gas, OCS, 1974-75

Cooperation, Federal Agencies, Federal Power Commission, Natural Gas, 1975-76

Cooperation, Federal Agencies, Federal Power Commission, Natural Gas, ca. 1971

Cooperation, Federal Agencies, Federal Power Commission, Natural Gas, ca. 1976

Cooperation, Federal Agencies, Federal Power Commission, Natural Gas, ca. 1973

Cooperation, Federal Agencies, Federal Power Commission, Natural Gas, ca. 1971

Cooperation, Federal Agencies, Defense Department, Naval Petroleum Reserve, No. 4, Alaska Reserve, 1956-64

Cooperation, Federal Agencies, Defense Department, Naval Petroleum Reserve, No. 4, Alaska Reserve, 1965-69

Cooperation, Federal Agencies, Defense Department, Naval Petroleum Reserve, No. 4, Alaska Reserve, 1969

Cooperation, Federal Agencies, Defense Department, Naval Petroleum Reserve, No. 4, Alaska Reserve, 1970-76

Cooperation, Federal Agencies, Defense Department, Naval Petroleum Reserve, No. 4, Alaska Reserve, 1976

Cooperation, Federal Agencies, Defense Department, Naval Petroleum Reserve, Proposed, Caddo, Louisiana, 1914-17

Cooperation, Federal Agencies, Defense Department, Naval Petroleum Reserve, Proposed, Osage, Oklahoma, 1911, 1913-17, 1921-37

Cooperation, Federal Agencies, Defense Department, Naval Oil Shale Reserve, General, 1916-75

Cooperation, Federal Agencies, Defense Department, Naval Oil Shale Reserve, No. 1, 1916-24

Cooperation, Federal Agencies, Defense Department, Naval Oil Shale Reserve, No. 2, 1916-61

Cooperation, Federal Agencies, Defense Department, Naval Oil Shale Reserve, No. 3, 1916-70

Cooperation, Federal Agencies, General Services Administration, 1971

Cooperation, Federal Agencies, General Services Administration, 1970

Cooperation, Federal Agencies, General Services Administration, 1970

Cooperation, Federal Agencies, General Services Administration, 1970

Cooperation, Federal Agencies, General Services Administration, 1969-70

Cooperation, Federal Agencies, General Services Administration, 1967-69

Cooperation, Federal Agencies, General Services Administration, 1969

Cooperation, Federal Agencies, General Services Administration, 1968-69

Cooperation, Federal Agencies, General Services Administration, 1968

Cooperation, Federal Agencies, Federal Power Commission, Power, 1921-74

Cooperation, Federal Agencies, Federal Power Commission, Natural Gas, 1960-73 
Cooperation, Federal Agencies, Federal Power Commission, Natural Gas, 1975

Cooperation, Federal Agencies, Federal Power Commission, Natural Gas, 1975

Cooperation, Federal Agencies, Federal Power Commission, Natural Gas, 1975

Box 133 Cooperation, Federal Agencies, Federal Power Commission, Natural Gas, 1975

Cooperation, Federal Agencies, Federal Power Commission, Natural Gas, 1975

Cooperation, Federal Agencies, Federal Power Commission, Natural Gas, 1976

Cooperation, Federal Agencies, Federal Power Commission, Natural Gas, 1973-75

Cooperation, Federal Agencies, Interior Department, Bureau of Indian Affairs, Anadarko Agency, Oklahoma, 1956-72

Cooperation, Federal Agencies, Interior Department, Bureau of Indian Affairs, Anadarko Agency, Oklahoma, 1911, 1922-46

Box 134 Cooperation, Federal Agencies, Interior Department, Bureau of Indian Affairs, Anchorage Agency, Alaska, 968-71

Cooperation, Federal Agencies, Interior Department, Bureau of Indian Affairs, Anchorage Agency, Alaska, 1967

Cooperation, Federal Agencies, Interior Department, Bureau of Indian Affairs, Anchorage Agency, Alaska, 1964-67

Cooperation, Federal Agencies, Interior Department, Bureau of Indian Affairs, Anchorage Agency, Alaska, 1964

Cooperation, Federal Agencies, Interior Department, Bureau of Indian Affairs, Anchorage Agency, Alaska, 1961-63

Cooperation, Federal Agencies, Interior Department, Bureau of Indian Affairs, Anchorage Agency, Alaska, [maps], n.d.

Box 135 Cooperation, Federal Agencies, Interior Department, Bureau of Indian Affairs, Anchorage Agency, Alaska, ca. 1963

Cooperation, Federal Agencies, Interior Department, Bureau of Indian Affairs, General, ca. 1961

Cooperation, Federal Agencies, Interior Department, Bureau of Indian Affairs, General, 1959-69

Cooperation, Federal Agencies, Interior Department, Bureau of Indian Affairs, General, [plats] 1958-60

Cooperation, Federal Agencies, Interior Department, Bureau of Indian Affairs, General, 1909-16, 1918, 1927-55

Box 136 Cooperation, Federal Agencies, Interior Department, Bureau of Indian Affairs, General, 1956-74

Cooperation, Federal Agencies, Interior Department, Bureau of Indian Affairs, General, 1962-75

Cooperation, Federal Agencies, Housing and Urban Development, ca. 1972

Cooperation, Federal Agencies, Housing and Urban Development, 1954-75

Cooperation, Federal Agencies, General Services Administration, 1971-75

Box 137 Cooperation, Federal Agencies, General Services Administration, Huntington Beach P.O., California, 1955-76

Cooperation, Federal Agencies, Interior Department, Bureau of Indian Affairs, Blackfeet Agency, Montana, 1912, 1920-37

Cooperation, Federal Agencies, Interior Department, Bureau of Indian Affairs, Blackfeet Agency, Montana, 1937-38

Cooperation, Federal Agencies, Interior Department, Bureau of Indian Affairs, Blackfeet Agency, Montana, 1939-41

Cooperation, Federal Agencies, Interior Department, Bureau of Indian Affairs, Blackfeet Agency, Montana, 1940-46

Box 138 Cooperation, Federal Agencies, Interior Department, Bureau of Indian Affairs, Blackfeet Agency, Montana, 1947-55

Cooperation, Federal Agencies, Interior Department, Bureau of Indian Affairs, Blackfeet Agency, Montana, 1956-59 
Cooperation, Federal Agencies, Interior Department, Bureau of Indian Affairs, Blackfeet Agency, Montana, 1960-61

Cooperation, Federal Agencies, Interior Department, Bureau of Indian Affairs, Blackfeet Agency, Montana, 1962-76

Cooperation, Federal Agencies, Interior Department, Bureau of Indian Affairs, Blackfeet Agency, Montana, 1976

Box 139

Cooperation, Federal Agencies, Interior Department, Bureau of Indian Affairs, California Agency, California, 1959

Cooperation, Federal Agencies, Interior Department, Bureau of Indian Affairs, Cheyenne River Agency, South Dakota, 1908-09, 1911-13, 1915-68

Cooperation, Federal Agencies, Interior Department, Bureau of Indian Affairs, Choctaw Agency, Louisiana, 1936-57

Cooperation, Federal Agencies, Interior Department, Bureau of Indian Affairs, Colorado River Agency, Arizona \& California, 1911-15

Cooperation, Federal Agencies, Interior Department, Bureau of Indian Affairs, Colville Agency, Washington, 1887, 1906, 1911-15

Cooperation, Federal Agencies, Interior Department, Bureau of Indian Affairs, Colville Agency, Washington, 1916-72

Cooperation, Federal Agencies, Interior Department, Bureau of Indian Affairs, Colville Agency, Washington, [maps], ca. 1958

Cooperation, Federal Agencies, Interior Department, Bureau of Indian Affairs, Concho Agency, Oklahoma, 1945-58

Cooperation, Federal Agencies, Interior Department, Bureau of Indian Affairs, Consolidated Ute Agency, Colorado \& New Mexico, 1911, 1915-52

Box 140 Cooperation, Federal Agencies, Interior Department, Bureau of Indian Affairs, Consolidated Ute Agency, Colorado \& New Mexico, 1953-55

Cooperation, Federal Agencies, Interior Department, Bureau of Indian Affairs, Consolidated Ute Agency, Colorado \& New Mexico, 1956-73

Cooperation, Federal Agencies, Interior Department, Bureau of Indian Affairs, Consolidated Ute Agency, Colorado \& New Mexico, [maps], ca. 1954

Cooperation, Federal Agencies, Interior Department, Bureau of Indian Affairs, Crow Agency, Montana, 1912, 1916-33

Cooperation, Federal Agencies, Interior Department, Bureau of Indian Affairs, Crow Agency, Montana, 1934-55

Cooperation, Federal Agencies, Interior Department, Bureau of Indian Affairs, Crow Agency, Montana, 1956-72

Box 141 Cooperation, Federal Agencies, Interior Department, Bureau of Indian Affairs, Five Civilized Tribes Agency, Oklahoma, 1909-13, 1915-17

Cooperation, Federal Agencies, Interior Department, Bureau of Indian Affairs, Five Civilized Tribes Agency, Oklahoma, 1933-49

Cooperation, Federal Agencies, Interior Department, Bureau of Indian Affairs, Five Civilized Tribes Agency, Oklahoma, 1950-56

Cooperation, Federal Agencies, Interior Department, Bureau of Indian Affairs, Five Civilized Tribes Agency, Oklahoma, 1957-69

Cooperation, Federal Agencies, Interior Department, Bureau of Indian Affairs, Five Civilized Tribes Agency, Oklahoma, 1969

Cooperation, Federal Agencies, Interior Department, Bureau of Indian Affairs, Five Civilized Tribes Agency, Oklahoma, 1970-73

Box 142 Cooperation, Federal Agencies, Interior Department, Bureau of Indian Affairs, Five Civilized Tribes Agency, Oklahoma, [maps], n.d. 
Cooperation, Federal Agencies, Interior Department, Bureau of Indian Affairs, Five Civilized Tribes Agency, Oklahoma, [maps], n.d.

Cooperation, Federal Agencies, Interior Department, Bureau of Indian Affairs, Five Civilized Tribes Agency, Oklahoma, [maps], n.d.

Cooperation, Federal Agencies, Interior Department, Bureau of Indian Affairs, Flathead Agency, Montana, 1909-16, 1928-74

Cooperation, Federal Agencies, Interior Department, Bureau of Indian Affairs, Fort Apache Agency, Arizona, 1961-67

Box 143 Cooperation, Federal Agencies, Interior Department, Bureau of Indian Affairs, Fort Belknap Consolidated Agency, Montana, 1921-73

Cooperation, Federal Agencies, Interior Department, Bureau of Indian Affairs, Fort Berthold, North Dakota, 1909-14, 1916-17, 1946-55

Cooperation, Federal Agencies, Interior Department, Bureau of Indian Affairs, Fort Berthold, North Dakota, 1956

Cooperation, Federal Agencies, Interior Department, Bureau of Indian Affairs, Fort Berthold, North Dakota, 1956

Cooperation, Federal Agencies, Interior Department, Bureau of Indian Affairs, Fort Berthold, North Dakota, 1957-60

Cooperation, Federal Agencies, Interior Department, Bureau of Indian Affairs, Fort Berthold, North Dakota, 1961-71

Cooperation, Federal Agencies, Interior Department, Bureau of Indian Affairs, Fort Hall Agency, Idaho, 1911-17, 1920-71

Box 144 Cooperation, Federal Agencies, Interior Department, Bureau of Indian Affairs, Fort Peck Agency, Montana, 1911-18, 1939-52

Cooperation, Federal Agencies, Interior Department, Bureau of Indian Affairs, Fort Peck Agency, Montana, 1952-55

Cooperation, Federal Agencies, Interior Department, Bureau of Indian Affairs, Fort Peck Agency, Montana, [an.d. maps] ca. 1956-61

Cooperation, Federal Agencies, Interior Department, Bureau of Indian Affairs, Fort Peck Agency, Montana, 1959-61

Cooperation, Federal Agencies, Interior Department, Bureau of Indian Affairs, Fort Peck Agency, Montana, 1956-61

Cooperation, Federal Agencies, Interior Department, Bureau of Indian Affairs, Fort Peck Agency, Montana, 1961

Box 145 Cooperation, Federal Agencies, Interior Department, Bureau of Indian Affairs, Fort Peck Agency, Montana, 1961-63

Cooperation, Federal Agencies, Interior Department, Bureau of Indian Affairs, Fort Peck Agency, Montana, 1963-66

Cooperation, Federal Agencies, Interior Department, Bureau of Indian Affairs, Fort Peck Agency, Montana, 1966-72

Cooperation, Federal Agencies, Interior Department, Bureau of Indian Affairs, Great Lakes Agency, Wisconsin \& Michigan, 1911, 1929-60

Cooperation, Federal Agencies, Interior Department, Bureau of Indian Affairs, Hoopa Area Field Office, California, 1911, 1958-59

Cooperation, Federal Agencies, Interior Department, Bureau of Indian Affairs, Hopi Agency, Arizona, 1960-68

Cooperation, Federal Agencies, Interior Department, Bureau of Indian Affairs, Horton Agency, Kansas \& Nebraska, 1958

Cooperation, Federal Agencies, Interior Department, Bureau of Indian Affairs, Jicarilla Agency, New Mexico, 1940-75 
Cooperation, Federal Agencies, Interior Department, Bureau of Indian Affairs, Klamath Agency, Oregon, 1911, 1913-14, 1916, 1956-63

Cooperation, Federal Agencies, Interior Department, Bureau of Indian Affairs, Minnesota Agency, Minnesota, 1956-72

Cooperation, Federal Agencies, Interior Department, Bureau of Indian Affairs, Navajo Agency, New Mexico, Utah \& Arizona, 1929-40

Cooperation, Federal Agencies, Interior Department, Bureau of Indian Affairs, Navajo Agency, New Mexico, Utah \& Arizona, 1941-43

Cooperation, Federal Agencies, Interior Department, Bureau of Indian Affairs, Navajo Agency, New Mexico, Utah \& Arizona, 1943

Cooperation, Federal Agencies, Interior Department, Bureau of Indian Affairs, Navajo Agency, New Mexico, Utah \& Arizona, 1944-46

Cooperation, Federal Agencies, Interior Department, Bureau of Indian Affairs, Navajo Agency, New Mexico, Utah \& Arizona, 1947-49

Cooperation, Federal Agencies, Interior Department, Bureau of Indian Affairs, Navajo Agency, New Mexico, Utah \& Arizona, 1950-55

Box 147 Cooperation, Federal Agencies, Interior Department, Bureau of Indian Affairs, Navajo Agency, New Mexico, Utah \& Arizona, 1955-56

Cooperation, Federal Agencies, Interior Department, Bureau of Indian Affairs, Navajo Agency, New Mexico, Utah \& Arizona, 1956-57

Cooperation, Federal Agencies, Interior Department, Bureau of Indian Affairs, Navajo Agency, New Mexico, Utah \& Arizona, 1957-58

Cooperation, Federal Agencies, Interior Department, Bureau of Indian Affairs, Navajo Agency, New Mexico, Utah \& Arizona, 1958

Cooperation, Federal Agencies, Interior Department, Bureau of Indian Affairs, Navajo Agency, New Mexico, Utah \& Arizona, 1958-59

Box 148 Cooperation, Federal Agencies, Interior Department, Bureau of Indian Affairs, Navajo Agency, New Mexico, Utah \& Arizona, 1959-60

Cooperation, Federal Agencies, Interior Department, Bureau of Indian Affairs, Navajo Agency, New Mexico, Utah \& Arizona, 1960

Cooperation, Federal Agencies, Interior Department, Bureau of Indian Affairs, Navajo Agency, New Mexico, Utah \& Arizona, 1960-61

Cooperation, Federal Agencies, Interior Department, Bureau of Indian Affairs, Navajo Agency, New Mexico, Utah \& Arizona, 1961-62

Cooperation, Federal Agencies, Interior Department, Bureau of Indian Affairs, Navajo Agency, New Mexico, Utah \& Arizona, 1963-64

Cooperation, Federal Agencies, Interior Department, Bureau of Indian Affairs, Navajo Agency, New Mexico, Utah \& Arizona, 1965- 69

Box 149 Cooperation, Federal Agencies, Interior Department, Bureau of Indian Affairs, Navajo Agency, New Mexico, Utah \& Arizona, 1969-71

Cooperation, Federal Agencies, Interior Department, Bureau of Indian Affairs, Navajo Agency, New Mexico, Utah \& Arizona, 1964-73

Cooperation, Federal Agencies, Interior Department, Bureau of Indian Affairs, Navajo Agency, New Mexico, Utah \& Arizona, [maps], n.d.

Cooperation, Federal Agencies, Interior Department, Bureau of Indian Affairs, Navajo Agency, New Mexico, Utah \& Arizona, [maps], n.d.

Cooperation, Federal Agencies, Interior Department, Bureau of Indian Affairs, Nevada Agency, Nevada \& Idaho, 1954-72

Cooperation, Federal Agencies, Interior Department, Bureau of Indian Affairs, New York Agency, New York, 1936, 1944 
Cooperation, Federal Agencies, Interior Department, Bureau of Indian Affairs, Northern Cheyenne Agency, Montana, 1911, 1949-74

Cooperation, Federal Agencies, Interior Department, Bureau of Indian Affairs, Northern Idaho Agency, Idaho, 1912, 1958-61

Box 150

Cooperation, Federal Agencies, Interior Department, Bureau of Indian Affairs, Osage Agency, Oklahoma, 1912, 1916-32

Cooperation, Federal Agencies, Interior Department, Bureau of Indian Affairs, Osage Agency, Oklahoma, 1933-36

Cooperation, Federal Agencies, Interior Department, Bureau of Indian Affairs, Osage Agency, Oklahoma, 1937-38

Cooperation, Federal Agencies, Interior Department, Bureau of Indian Affairs, Osage Agency, Oklahoma, 1939-44

Box 151 Cooperation, Federal Agencies, Interior Department, Bureau of Indian Affairs, Osage Agency, Oklahoma, 1945-48

Cooperation, Federal Agencies, Interior Department, Bureau of Indian Affairs, Osage Agency, Oklahoma, 1949-55

Cooperation, Federal Agencies, Interior Department, Bureau of Indian Affairs, Wind River Agency, Wyoming, 1933-35

Cooperation, Federal Agencies, Interior Department, Bureau of Indian Affairs, Wind River Agency, Wyoming, 1936-38

Cooperation, Federal Agencies, Interior Department, Bureau of Indian Affairs, Wind River Agency, Wyoming, 1938

Box 152 Cooperation, Federal Agencies, Interior Department, Bureau of Indian Affairs, Wind River Agency, Wyoming, 1938-39

Cooperation, Federal Agencies, Interior Department, Bureau of Indian Affairs, Wind River Agency, Wyoming, 1939-40

Cooperation, Federal Agencies, Interior Department, Bureau of Indian Affairs, Wind River Agency, Wyoming, 1940-41

Cooperation, Federal Agencies, Interior Department, Bureau of Indian Affairs, Wind River Agency, Wyoming, 1941-42

Cooperation, Federal Agencies, Interior Department, Bureau of Indian Affairs, Wind River Agency, Wyoming, 1942-44

Cooperation, Federal Agencies, Interior Department, Bureau of Indian Affairs, Wind River Agency, Wyoming, 1945-49

Box 153 Cooperation, Federal Agencies, Interior Department, Bureau of Indian Affairs, Wind River Agency, Wyoming, 1950-55

Cooperation, Federal Agencies, Interior Department, Bureau of Indian Affairs, Wind River Agency, Wyoming, 1956-59

Cooperation, Federal Agencies, Interior Department, Bureau of Indian Affairs, Wind River Agency, Wyoming, 1959-60

Cooperation, Federal Agencies, Interior Department, Bureau of Indian Affairs, Wind River Agency, Wyoming, 1961-63

Cooperation, Federal Agencies, Interior Department, Bureau of Indian Affairs, Wind River Agency, Wyoming, 1963

Cooperation, Federal Agencies, Interior Department, Bureau of Indian Affairs, Wind River Agency, Wyoming, 1964-65

Box 154 Cooperation, Federal Agencies, Interior Department, Bureau of Indian Affairs, Wind River Agency, Wyoming, 1966-69

Cooperation, Federal Agencies, Interior Department, Bureau of Indian Affairs, Wind River Agency, Wyoming, 1969-71 
Box 155

Box 156

Box 157

Box 158

Box 159
Cooperation, Federal Agencies, Interior Department, Bureau of Indian Affairs, Wind River Agency, Wyoming, [maps] ca. 1969

Cooperation, Federal Agencies, Interior Department, Bureau of Indian Affairs, Wind River Agency, Wyoming, [maps], ca. 1933

Cooperation, Federal Agencies, Interior Department, Bureau of Indian Affairs, Winnebago Agency, Nebraska \& Iowa, 1909, 1911, 1958

Cooperation, Federal Agencies, Interior Department, Bureau of Indian Affairs, Yakima Agency, Washington, 1911-14, 1958-71

Cooperation, Federal Agencies, Interior Department, Bureau of Indian Affairs, Zuni Agency, New Mexico, 1911-14, 1935, 1955

Cooperation, Federal Agencies, Interior Department, Bureau of Land Management, Accounting Memorandum of Understanding [c.r. filed in Royalty Accounting Office]

Cooperation, Federal Agencies, Interior Department, Bureau of Land Management, General, 1906-10

Cooperation, Federal Agencies, Interior Department, Bureau of Land Management, General, 1911-12

Cooperation, Federal Agencies, Interior Department, Bureau of Land Management, General, 1913-15

Cooperation, Federal Agencies, Interior Department, Bureau of Land Management, General, 1916-23

Cooperation, Federal Agencies, Interior Department, Bureau of Land Management, General, 1923-29, 1931-35, 1937-46

Cooperation, Federal Agencies, Interior Department, Bureau of Land Management, General, 1947-50

Cooperation, Federal Agencies, Interior Department, Bureau of Land Management, General, 1951-52

Cooperation, Federal Agencies, Interior Department, Bureau of Land Management, General, 1953-55

Cooperation, Federal Agencies, Interior Department, Bureau of Land Management, General, 1956-58

Cooperation, Federal Agencies, Interior Department, Bureau of Land Management, General, 1959-61

Cooperation, Federal Agencies, Interior Department, Bureau of Land Management, General, 1962

Cooperation, Federal Agencies, Interior Department, Bureau of Land Management, General, 1963-65

Cooperation, Federal Agencies, Interior Department, Bureau of Land Management, General, 1966-68

Cooperation, Federal Agencies, Interior Department, Bureau of Land Management, General, 1969-70

Cooperation, Federal Agencies, Interior Department, Bureau of Land Management, General, 1970

Cooperation, Federal Agencies, Interior Department, Bureau of Land Management, General, 1971

Cooperation, Federal Agencies, Interior Department, Bureau of Land Management, General, 1971-72

Cooperation, Federal Agencies, Interior Department, Bureau of Land Management, General, 1972

Cooperation, Federal Agencies, Interior Department, Bureau of Land Management, General, 1973-74

Cooperation, Federal Agencies, Interior Department, Bureau of Land Management, General, 1974-76

Cooperation, Federal Agencies, Interior Department, Bureau of Land Management, General, OCS, 1970-73

Cooperation, Federal Agencies, Interior Department, Bureau of Land Management, General, OCS, 1973-76

Cooperation, Federal Agencies, Interior Department, Bureau of Land Management, General, OCS, ca. 1972

Cooperation, Federal Agencies, Interior Department, Bureau of Land Management, General, OCS, n.d.

Cooperation, Federal Agencies, Interior Department, Bureau of Land Management, Corporate Name Change, 1960-69

Cooperation, Federal Agencies, Interior Department, Bureau of Land Management, Corporate Name Change, 1969-70

Cooperation, Federal Agencies, Interior Department, Bureau of Land Management, Corporate Name Change, 1971-72

Cooperation, Federal Agencies, Interior Department, Bureau of Land Management, Corporate Name Change, 1973-74

Cooperation, Federal Agencies, Interior Department, Bureau of Land Management, Evaluation of Tracts, 1967-68 
Cooperation, Federal Agencies, Interior Department, Bureau of Land Management, Evaluation of Tracts, 1969

Cooperation, Federal Agencies, Interior Department, Bureau of Land Management, Evaluation of Tracts, 1969-76

Box 160

Cooperation, Federal Agencies, Interior Department, Bureau of Land Management, Evaluation of Tracts, OCS, 1961-70

Cooperation, Federal Agencies, Interior Department, Bureau of Land Management, Evaluation of Tracts, OCS, 1970-71

Cooperation, Federal Agencies, Interior Department, Bureau of Land Management, Evaluation of Tracts, OCS, 1972-73

Cooperation, Federal Agencies, Interior Department, Bureau of Land Management, Evaluation of Tracts, OCS, 1973-74

Cooperation, Federal Agencies, Interior Department, Bureau of Land Management, Evaluation of Tracts, OCS, 1974-76

Box 161 Cooperation, Federal Agencies, Interior Department, Bureau of Land Management, Evaluation of Tracts, OCS, ca. 1972

Cooperation, Federal Agencies, Interior Department, Bureau of Land Management, Alaska, 1913, 1921-74

Cooperation, Federal Agencies, Interior Department, Bureau of Land Management, Arizona, 1912-25

Cooperation, Federal Agencies, Interior Department, Bureau of Land Management, Arizona, 1925-28, 1930-46

Box 162 Cooperation, Federal Agencies, Interior Department, Bureau of Land Management, California, 1912-32, 1934-45

Cooperation, Federal Agencies, Interior Department, Bureau of Land Management, Colorado, ca. $1910,1912-13,1915-32,1934-72$

Cooperation, Federal Agencies, Interior Department, Bureau of Land Management, Idaho, 1912-27, 1929-44

Cooperation, Federal Agencies, Interior Department, Bureau of Land Management, Montana, 1912-19, 1922-45

Box 163 Cooperation, Federal Agencies, Interior Department, Bureau of Land Management, Nebraska, 1918-23

Cooperation, Federal Agencies, Interior Department, Bureau of Land Management, Nevada, 1912-13, 1917-40

Cooperation, Federal Agencies, Interior Department, Bureau of Land Management, New Mexico, 1908, 1912-14, 1917-28, 1930-45

Cooperation, Federal Agencies, Interior Department, Bureau of Land Management, Oregon, 1912-22, 1926-46

Cooperation, Federal Agencies, Interior Department, Bureau of Land Management, Utah, 1909, 1912 19, 1922-33, 1935-74

Cooperation, Federal Agencies, Interior Department, Bureau of Land Management, Washington, 191214, 1917-41

Cooperation, Federal Agencies, Interior Department, Bureau of Land Management, Wyoming, 1905, 1910-20

Box 164

Cooperation, Federal Agencies, Interior Department, Bureau of Land Management, Wyoming, 1920-46

Cooperation, Federal Agencies, Interior Department, Bureau of Land Management, Long Beach Post Office, California, 1948-55

Cooperation, Federal Agencies, Interior Department, Bureau of Land Management, Long Beach Post Office, California, 1956-74

Cooperation, Federal Agencies, Interior Department, Bureau of Land Management, Long Beach Post Office, California, ca. 1964 
Cooperation, Federal Agencies, Interior Department, Bureau of Land Management, Reservoir Projects, $1955-71$

Cooperation, Federal Agencies, Interior Department, Bureau of Mines. General, 1922-69

Cooperation, Federal Agencies, Interior Department, Bureau of Mines. General, 1971-75

Box 165 Cooperation, Federal Agencies, Interior Department, Bureau of Mines. General, OCS, ca. 1968-73

Cooperation, Federal Agencies, Interior Department, Bureau of Outdoor Recreation, General, 1962-73

Cooperation, Federal Agencies, Interior Department, Bureau of Outdoor Recreation, General, ca.197071 [printed reports]

Cooperation, Federal Agencies, Interior Department, Bureau of Outdoor Recreation, General, ca. 1969 [printed reports]

Cooperation, Federal Agencies, Interior Department, Bureau of Reclamation, General, 1908, 1910, 1940-74

Cooperation, Federal Agencies, Interior Department, Bureau of Reclamation, Projects, 1941-55

Cooperation, Federal Agencies, Interior Department, Bureau of Reclamation, Projects, 1956-74

Box 166 Cooperation, Federal Agencies, Interior Department, Bureau of Sport Fisheries and Wildlife, General, 1935-55

Cooperation, Federal Agencies, Interior Department, Bureau of Sport Fisheries and Wildlife, General, 1956-58

Cooperation, Federal Agencies, Interior Department, Bureau of Sport Fisheries and Wildlife, General, 1959-62

Cooperation, Federal Agencies, Interior Department, Bureau of Sport Fisheries and Wildlife, General, 1963-75

Cooperation, Federal Agencies, Interior Department, Bureau of Sport Fisheries and Wildlife, General, 1975-76

Cooperation, Federal Agencies, Interior Department, Bureau of Sport Fisheries and Wildlife, Arctic National Wildlife Refuge, Alaska, 1964

Box 167 Cooperation, Federal Agencies, Interior Department, Bureau of Sport Fisheries and Wildlife, Arctic National Wildlife Refuge, Alaska, 1954-70

Cooperation, Federal Agencies, Interior Department, Bureau of Sport Fisheries and Wildlife, Breton Wildlife Refuge, Louisiana, 1937-69

Cooperation, Federal Agencies, Interior Department, Bureau of Sport Fisheries and Wildlife, Lacassine Wildlife Refuge, Louisiana, 1941-68

Cooperation, Federal Agencies, Interior Department, Bureau of Sport Fisheries and Wildlife, Salt Plains Wildlife Refuge, Oklahoma, 1957-61

Cooperation, Federal Agencies, Interior Department, Bureau of Sport Fisheries and Wildlife, Salt Plains Wildlife Refuge, Oklahoma, 1962-70

Cooperation, Federal Agencies, Interior Department, Bureau of Sport Fisheries and Wildlife, J. Clark Saylor Refuge, North Dakota, 1953-55

Box 168 Cooperation, Federal Agencies, Interior Department, Bureau of Sport Fisheries and Wildlife, J. Clark Saylor Refuge, North Dakota, 1956-64

Cooperation, Federal Agencies, Interior Department, Bureau of Sport Fisheries and Wildlife, J. Clark Saylor Refuge, North Dakota, 1965-74

Cooperation, Federal Agencies, Interior Department, Bureau of Sport Fisheries and Wildlife, J. Clark Saylor Refuge, North Dakota, [maps], ca. 1956

Cooperation, Federal Agencies, Interior Department, Bureau of Sport Fisheries and Wildlife, Upper Souris Wildlife Refuge, North Dakota, 1964-72

Cooperation, Federal Agencies, Interior Department, National Park Service, National Monuments, General, 1915, 1954-72

Cooperation, Federal Agencies, Interior Department, National Park Service, Aztec Ruins National Monument, New Mexico, 1952 
Cooperation, Federal Agencies, Interior Department, National Park Service, Jackson Hole National Monument, Wyoming, 1947

\section{Box 169}

\section{Box 170}

Box 171

Box 172

Box 173 Cooperation, Federal Agencies, Interior Department, National Park Service, Jackson Hole National Monument, Wyoming, 1958-63

Cooperation, Federal Agencies, Interior Department, National Park Service, General, 1910, 1946-75

Cooperation, Federal Agencies, Interior Department, National Park Service, Canyonlands National Park, Utah, 1961-66

Cooperation, Federal Agencies, Interior Department, National Park Service, Canyonlands National Park, Utah, [maps], n.d.

Cooperation, Federal Agencies, Interior Department, National Park Service, Canyonlands National Park, Utah, [maps], n.d.

Cooperation, Federal Agencies, Interior Department, National Park Service, Everglades National Park, Florida, 1948-70

Cooperation, Federal Agencies, Interior Department, National Park Service, Everglades National Park, Florida, [maps], n.d.

Cooperation, Federal Agencies, Interior Department, National Park Service, Everglades National Park, Florida, [maps], n.d.

Cooperation, Federal Agencies, Interior Department, National Park Service, Everglades National Park, Florida, [maps], n.d.

Cooperation, Federal Agencies, Interior Department, National Park Service, Everglades National Park, Florida, [maps], n.d.

Cooperation, Federal Agencies, Interior Department, National Park Service, Grand Canyon National Park, Arizona, 1959-62

Cooperation, Federal Agencies, Interior Department, National Park Service, Grand Canyon National Park, Arizona, 1963-68

Cooperation, Federal Agencies, Interior Department, National Park Service, Theodore Roosevelt National Park, North Dakota, ca. 1953-66

Cooperation, Federal Agencies, Interior Department, National Park Service, Theodore Roosevelt National Park, North Dakota, 1967-73

Cooperation, Federal Agencies, Interior Department, National Park Service, Theodore Roosevelt National Park, North Dakota, [maps], n.d.

Cooperation, Federal Agencies, Interior Department, Bureau of Commercial Fisheries OCS, 1964-74

Cooperation, Federal Agencies, Interior Department, Alaska Power Administration, 1970

Cooperation, Federal Agencies, Justice Department, General, 1970-76

Cooperation, Federal Agencies, National Aeronautics and Space Administration, General, 1965-67

Cooperation, Federal Agencies, National Aeronautics and Space Administration, General, 1968-73

Cooperation, Federal Agencies, National Aeronautics and Space Administration, General, 1969-73

Cooperation, Federal Agencies, National Aeronautics and Space Administration, General, 1974-75

Cooperation, Federal Agencies, National Aeronautics and Space Administration, General, ca. 1973-74

Cooperation, Federal Agencies, National Aeronautics and Space Administration, General, ca. 1972

Cooperation, Federal Agencies, National Aeronautics and Space Administration, General, ca. 1970

Cooperation, Federal Agencies, National Aeronautics and Space Administration, General, ca. 1967-69

Cooperation, Federal Agencies, National Aeronautics and Space Administration, General, ca. 1967

Cooperation, Federal Agencies, National Aeronautics and Space Administration, General, OCS, 1970-72

Cooperation, Federal Agencies, National Aeronautics and Space Administration, General, OCS, 1972-75

Cooperation, Federal Agencies, National Aeronautics and Space Administration, General, OCS, ca. 1970 
Cooperation, International, Canada, OCS, 1954-76

Cooperation, International, Canada, OCS, ca. 1970

Cooperation, International, Alien Property, General, 1957-75

Cooperation, International, Alien Property, Gustav E. Ablff, 1960-64

Cooperation, International, Alien Property, Adolff Realty Co., 1951-52

Cooperation, International, Alien Property, Tokio Ajioka, 1955

Cooperation, International, Alien Property, John Albers, 1954

Cooperation, International, Alien Property, Amerlagene, Inc., 1954-58

Cooperation, International, Alien Property, John Barbieri, 1954-55

Cooperation, International, Alien Property, Charles \& Theodore Barner, 1953

Cooperation, International, Alien Property, Elsie Bigalke, 1958-64

Cooperation, International, Alien Property, Anna Brandenburg, 1958

Cooperation, International, Alien Property, Frank Brehm, 1951-52

Cooperation, International, Alien Property, Albert Breitung, 1958

Box 174 Cooperation, International, Alien Property, Sophie Brentano, 1950

Cooperation, International, Alien Property, Elizabeth Burkhardt, 1954-64

Cooperation, International, Alien Property, Anna M. Butte, 1952

Cooperation, International, Alien Property, Mary Dambach, 1956

Cooperation, International, Alien Property, Franz Dichiser, 1958

Cooperation, International, Alien Property, William F. Detert, 1951

Cooperation, International, Alien Property, Arthur Eckoldt, 1958

Cooperation, International, Alien Property, Willy Elbel, 1950-54

Cooperation, International, Alien Property, Xaxier Fuchs, 1951

Cooperation, International, Alien Property, Karoline Gentes, 1949

Cooperation, International, Alien Property, Johanna Goeltl, 1953

Cooperation, International, Alien Property, Anna Groll, 1949

Cooperation, International, Alien Property, Mary A. Grzesiak \& Berta M. Lissner, 1951-57

Cooperation, International, Alien Property, Marta Hauser, 1949

Cooperation, International, Alien Property, Martha Hofman \& Margaet Kessler, 1958-64

Cooperation, International, Alien Property, Emilie Hosemann, 1950-58

Cooperation, International, Alien Property, Metta Hoyer, 1951

Cooperation, International, Alien Property, Else Huhs, 1958-64

Cooperation, International, Alien Property, John Hunken, 1956

Cooperation, International, Alien Property, Takeshi Inokuchi, 1951

Cooperation, International, Alien Property, Kameichi Kawano, 1951

Cooperation, International, Alien Property, Alice King, 1949-55

Cooperation, International, Alien Property, Toshio Koyama, 1953-54

Box 175 Cooperation, International, Alien Property, George Knoke, 1953-56

Cooperation, International, Alien Property, Sibylle Kretzschmar, 1958

Cooperation, International, Alien Property, Conrad Mann, 1949-55

Cooperation, International, Alien Property, Dora Marquardt, 1952

Cooperation, International, Alien Property, Marie Marsden, 1948-56

Cooperation, International, Alien Property, Anna Michaelis, 1958

Cooperation, International, Alien Property, Elizabeth Muth, 1950

Cooperation, International, Alien Property, Werner Nelle, 1958

Cooperation, International, Alien Property, Meta Neumann, 1954

Cooperation, International, Alien Property, Shigeo Otsuke, 1956-58

Cooperation, International, Alien Property, Herman Paepcke, 1958-64

Cooperation, International, Alien Property, Maria Paulsen \& Helene Nagel, 1962

Cooperation, International, Alien Property, Anna Petz, 1950

Cooperation, International, Alien Property, Paul Pfofferkorn, 1958 
Box 176

Cooperation, International, Alien Property, Otto Radamsky, 1958-63

Cooperation, International, Alien Property, Joseph Reusch, 1958-60

Cooperation, International, Alien Property, Henry Ronkendorf, 1951

Cooperation, International, Alien Property, Paul Rudolph, 1950-64

Cooperation, International, Alien Property, Henry Schaefer, 1949

Cooperation, International, Alien Property, Carl Schmeusser, 1953-58

Cooperation, International, Alien Property, Annie Schoener \& Emilie Rensing, 1965

Cooperation, International, Alien Property, Christian Stapel, 1948-64

Cooperation, International, Alien Property, Volkman Steinart, 1954

Cooperation, International, Alien Property, Hermann Stover, 1949-50

Cooperation, International, Alien Property, Anna Stromeyer, 1948-64

Cooperation, International, Alien Property, Marie Stumpf, 1950

Cooperation, International, Alien Property, Karoline Suck, 1953

Cooperation, International, Alien Property, Margareta Taubmann, 1958

Cooperation, International, Alien Property, Herman Tegeler, 1958

Cooperation, International, Alien Property, Oskar Teuber, 1951

Cooperation, International, Alien Property, Carl Tillman, 1949-58

Cooperation, International, Alien Property, Jrma Unkel, 1958

Cooperation, International, Alien Property, Louis Versel, 1953

Cooperation, International, Alien Property, Emil Voigh, 1945-60

Cooperation, International, Alien Property, Elsa Voith, 1952

Cooperation, International, Alien Property, Helene Varbeck, 1950-51

Cooperation, International, Alien Property, Fred Wilkening, 1950-60

Cooperation, International, Alien Property, T. Jinjuro Yamanaka \& T. Mizutani, 1953

Cooperation, International, Alien Property, T. K. Yatsu, 1949-55

Cooperation, Scientific and Professional, General, 1961-75

Cooperation, Scientific and Professional, General, 1975-76

Box 177 Cooperation, Scientific and Professional, General, OCS, 1970-76

Cooperation, Scientific and Professional, American Association of Petroleum Geologists, 1967-74

Cooperation, Scientific and Professional, American Petroleum Institute, 1969-72

Cooperation, Scientific and Professional, American Petroleum Institute, 1972-73

Cooperation, Scientific and Professional, American Petroleum Institute, 1973-76

Cooperation, Scientific and Professional, Association of American State Geologists, 1961-73

Cooperation, Scientific and Professional, Fishing Industry, OCS, 1947-55

Box 178 Cooperation, Scientific and Professional, Fishing Industry, OCS, 1956-64

Cooperation, Scientific and Professional, Fishing Industry, OCS, 1965-68

Cooperation, Scientific and Professional, Fishing Industry, OCS, 1969

Cooperation, Scientific and Professional, Fishing Industry, OCS, 1970-74

Cooperation, Scientific and Professional, National Academy of Sciences, 1963-76

Cooperation, Scientific and Professional, National Academy of Sciences, 1974-75

Box 179 Cooperation, Scientific and Professional, National Commission on Materials Policy, 1973

Cooperation, Scientific and Professional, National Petroleum Council, 1950-69

Cooperation, Scientific and Professional, National Petroleum Council, 1970-75

Cooperation, Scientific and Professional, National Petroleum Council, 1970-71

Cooperation, Scientific and Professional, Texas Independent Producers and Royalty Owners Association (TIPRO) Resolution, OCS, 1964-70

Cooperation, State, General, 1924-72

Cooperation, State, General, 1973-76

Cooperation, State, General, 1972-73

Box 180 Cooperation, State, General, OCS, 1940-53

Cooperation, State, General, OCS, 1969-71 
Cooperation, State, General, OCS, 1971-75

Cooperation, State, General, OCS, 1975

Cooperation, State, General, OCS, 1975

Cooperation, State, Alabama, General, 1970-73

Cooperation, State, Alabama, General, OCS, 1970-75

Box 181 Cooperation, State, Alaska, General, 1954-66

Cooperation, State, Alaska, General, 1967-71

Cooperation, State, Alaska, General, 1972-76

Cooperation, State, Alaska, General, OCS, 1949-76

Cooperation, State, California, General, 1962-76

Cooperation, State, California, General, OCS, 1939-48

Box 182 Cooperation, State, California, General, OCS, 1949-55

Cooperation, State, California, General, OCS, 1956-60

Cooperation, State, California, General, OCS, 1961-62

Cooperation, State, California, General, OCS, 1963-67

Cooperation, State, California, General, OCS, 1968-69

Box 183 Cooperation, State, California, General, OCS, 1969-70

Cooperation, State, California, General, OCS, 1969

Cooperation, State, California, General, OCS, 1969

Cooperation, State, California, General, OCS, 1970

Cooperation, State, California, General, OCS, 1970-71

Cooperation, State, California, General, OCS, 1971-76

Box 184 Cooperation, State, California, General, OCS, 1964-72

Cooperation, State, California, General, OCS, 1960-71

Cooperation, State, California, General, OCS, n.d.

Cooperation, State, California, General, OCS, n.d.

Cooperation, State, California, General, OCS, 1971

Cooperation, State, California, General, OCS, 1969-70

Box 185 Cooperation, State, California, Comprehensive Ocean Area Plan (COAP) Progress, OCS, 1970-72

Cooperation, State, Florida, General, 1971-75

Cooperation, State, Florida, General, OCS, 1951-73

Cooperation, State, Louisiana, General, 1971-75

Cooperation, State, Louisiana, General, OCS, 1950-55

Cooperation, State, Louisiana, General, OCS, 1954-67

Cooperation, State, Louisiana, General, OCS, 1968-71

Cooperation, State, Louisiana, General, OCS, 1972-75

Cooperation, State, Mississippi, General, OCS, 1951-56

Box 186 Cooperation, State, Oregon, General, 1971-72

Cooperation, State, Oregon, General, OCS, 1961-68

Cooperation, State, Texas, General, 1971-75

Cooperation, State, Texas, General, OCS, 1948-58

Cooperation, State, Texas, General, OCS, 1956-73

Cooperation, State, Washington, General, 1970-72

Cooperation, State, Washington, General, OCS, 1962-70

Cooperation, State, Cooperative Agreement, Alabama, OCS, 1958-71

Cooperation, State, Cooperative Agreement, Alaska, OCS, 1964-72

Cooperation, State, Cooperative Agreement, Atlantic Coast, OCS, 1960-73

Cooperation, State, Cooperative Agreement, California, OCS, 1953-61

Cooperation, State, Cooperative Agreement, Florida, OCS, 1954-56

Cooperation, State, Cooperative Agreement, Georgia, OCS, 1960

Cooperation, State, Cooperative Agreement, Louisiana, OCS, 1953-54 
Box 187 Cooperation, State, Cooperative Agreement, Mississippi Proposed, OCS, 1952-58

Cooperation, State, Cooperative Agreement, Oregon \& Washington, OCS, 1961

Cooperation, State, Cooperative Agreement, Texas, OCS, 1953-73

Cooperation, State, Lease Sales, Alaska, 1959-61

Cooperation, State, Lease Sales, Alaska, 1962-69

Cooperation, State, Lease Sales, Alabama, OCS, 1956-58

Cooperation, State, Lease Sales, California, OCS, 1946-55

Cooperation, State, Lease Sales, California, OCS, 1964-66

Box 188 Cooperation, State, Lease Sales, Louisiana, OCS, 1951-55

Cooperation, State, Lease Sales, Louisiana, OCS, 1955-59

Cooperation, State, Lease Sales, Louisiana, OCS, 1960-61

Cooperation, State, Lease Sales, Louisiana, OCS, 1962-64

Cooperation, State, Lease Sales, Montana, 1975-76

Cooperation, State, Lease Sales, New Mexico, 1975-76

Cooperation, State, Lease Sales, North Dakota, 1975

Box 189 Cooperation, State, Lease Sales, Oklahoma. 1971-72

Cooperation, State, Lease Sales, Oklahoma. 1972-76

Cooperation, State, Lease Sales, Oregon, OCS, 1964

Cooperation, State, Lease Sales, Texas, OCS, 1953-55

Cooperation, State, Lease Sales, Texas, OCS, 1955-65

Cooperation, State, Lease Sales, Texas, OCS, 1966-69

Cooperation, State, Lease Sales, Washington, OCS, 1964

Cooperation, State, Lease Sales, Wyoming, 1975

Cooperation, State, Interstate Oil Compact Commission, Directories, 1955-71

Box 190 Cooperation, State, Interstate Oil Compact Commission, Reports and Papers, 1948-70

Cooperation, State, Interstate Oil Compact Commission, Reports and Papers, 1947-48

Cooperation, State, Interstate Oil Compact Commission, Reports and Papers, 1946-48

Cooperation, State, Interstate Oil Compact Commission, Reports and Papers, 1971-76

Cooperation, State, Interstate Oil Compact Commission, Forms - Statute and Regulations, ca. $1944-46$

Cooperation, State, Interstate Oil Compact Commission, Forms - Statute and Regulations, ca. 1944

Cooperation, State, Interstate Oil Compact Commission, Forms - Statute and Regulations, ca. 1969

Box 191 Cooperation, State, Interstate Oil Compact Commission, Secondary Recovery, 1956-61

Cooperation, State, Interstate Oil Compact Commission, Oil Imports, 1957

Crises, Fires and Explosions, General, 1972-76

Crises, Fires and Explosions, General, OCS, 1959-72

Crises, Fires and Explosions, General, OCS, 1972-75

Crises, Fires and Explosions, General, OCS, 1975

Crises, Fires and Explosions, General, OCS, 1975-76

Box 192 Crises, Fires and Explosions, General, OCS, 1975

Crises, Fires and Explosions, General, OCS, ca. 1975

Crises, Fires and Explosions, 2-10-70, Main Pass Block 41, OCS, 1970

Crises, Fires and Explosions, 2-10-70, Main Pass Block 41, OCS, 1970

Crises, Fires and Explosions, 2-10-70, Main Pass Block 41, OCS, 1970

Box 193 Crises, Fires and Explosions, 2-10-70, Main Pass Block 41, OCS, 1970

Crises, Fires and Explosions, 2-10-70, Main Pass Block 41, OCS, 1970

Crises, Fires and Explosions, 2-10-70, Main Pass Block 41, OCS, 1970

Crises, Fires and Explosions, 2-10-70, Main Pass Block 41, OCS, 1970-71

Crises, Fires and Explosions, 2-10-70, Main Pass Block 41, OCS, ca. 1970

Crises, Fires and Explosions, 2-10-70, Main Pass Block 41, OCS, ca. 1970

Box 194 Crises, Fires and Explosions, 2-10-70, Main Pass Block 41, OCS, 1970 
Box 195

Box 196

Box 197

Box 198

Box 199

Box 200

Box 201
Crises, Fires and Explosions, 12-1-70, South Timbalier, Block 26, OCS, 1970-71

Crises, Fires and Explosions, 12-1-70, South Timbalier, Block 26, OCS, 1970

Crises, Fires and Explosions, 12-1-70, South Timbalier, Block 26, OCS, 1970

Crises, Fires and Explosions, 12-1-70, South Timbalier, Block 26, OCS, 1970

Crises, Fires and Explosions, 12-1-70, South Timbalier, Block 26, OCS, 1971

Crises, Fires and Explosions, 12-1-70, South Timbalier, Block 26, OCS, 1971

Crises, Fires and Explosions, 12-1-70, South Timbalier, Block 26, OCS, 1971

Crises, Fires and Explosions, 12-1-70, South Timbalier, Block 26, OCS, 1971

Crises, Fires and Explosions, 12-1-70, South Timbalier, Block 26, OCS, 1971

Crises, Fires and Explosions, 12-1-70, South Timbalier, Block 26, OCS, 1971

Crises, Fires and Explosions, 12-1-70, South Timbalier, Block 26, OCS, 1971

Crises, Fires and Explosions, 12-1-70, South Timbalier, Block 26, OCS, 1970

Crises, Fires and Explosions, 12-1-70, South Timbalier, Block 26, OCS, 1971-74

Crises, Fires and Explosions, 10-16-71, Eugene Island, Block 215, OCS, 1971

Crises, Fires and Explosions, 10-16-71, Eugene Island, Block 215, OCS, 1971

Crises, Fires and Explosions, 10-16-71, Eugene Island, Block 215, OCS, 1971-72

Crises, Fires and Explosions, 10-16-71, Eugene Island, Block 215, OCS, 1971

Crises, Hurricanes, General, OCS, 1971-74

Crises, Hurricanes, Betsy, OCS, 1965-67

Crises, Hurricanes, Hilda, OCS, 1964-65

Crises, Hurricanes, Camille, OCS, 1969-70

Crises, Hurricanes, Carmen, OCS, 1974-75

Crises, Oil Spills, General, 1971-75

Crises, Oil Spills, General, 1972-75

Crises, Oil Spills, General, 1975

Crises, Oil Spills, General, 1974-75

Crises, Oil Spills, General, 1976

Crises, Oil Spills, General, ca. 1971-75

Crises, Oil Spills, General, ca. 1970

Crises, Oil Spills, General, [maps], n.d.

Crises, Oil Spills, General, OCS, 1966-70

Crises, Oil Spills, General, OCS, 1970-75

Crises, Oil Spills, General, OCS, 1974-76

Crises, Oil Spills, General, OCS, 1976

Crises, Oil Spills, 1-28-69, Santa Barbara, OCS, 1965-69

Crises, Oil Spills, 1-28-69, Santa Barbara, OCS, 1969

Crises, Oil Spills, 1-28-69, Santa Barbara, OCS, 1969

Crises, Oil Spills, 1-28-69, Santa Barbara, OCS, 1969

Crises, Oil Spills, 1-28-69, Santa Barbara, OCS, 1969

Crises, Oil Spills, 1-28-69, Santa Barbara, OCS, 1969

Crises, Oil Spills, 1-28-69, Santa Barbara, OCS, 1969

Crises, Oil Spills, 1-28-69, Santa Barbara, OCS, 1969

Crises, Oil Spills, 1-28-69, Santa Barbara, OCS, 1969

Crises, Oil Spills, 1-28-69, Santa Barbara, OCS, 1969

Crises, Oil Spills, 1-28-69, Santa Barbara, OCS, 1970

Crises, Oil Spills, 1-28-69, Santa Barbara, OCS, 1970

Crises, Oil Spills, 1-28-69, Santa Barbara, OCS, 1970

Crises, Oil Spills, 1-28-69, Santa Barbara, OCS, 1970

Crises, Oil Spills, 1-28-69, Santa Barbara, OCS, 1970

Crises, Oil Spills, 1-28-69, Santa Barbara, OCS, 1970 
Box 202 Crises, Oil Spills, 1-28-69, Santa Barbara, OCS, 1970-71

Crises, Oil Spills, 1-28-69, Santa Barbara, OCS, 1971

Crises, Oil Spills, 1-28-69, Santa Barbara, OCS, 1971

Crises, Oil Spills, 1-28-69, Santa Barbara, OCS, 1971

Crises, Oil Spills, 1-28-69, Santa Barbara, OCS, 1971-72

Crises, Oil Spills, 1-28-69, Santa Barbara, OCS, 1972-73

Box 203 Crises, Oil Spills, 1-28-69, Santa Barbara, OCS, 1969

Crises, Oil Spills, 1-28-69, Santa Barbara, OCS, ca. 1972

Crises, Oil Spills, 1-28-69, Santa Barbara, OCS, 1969

Crises, Oil Spills, 1-28-69, Santa Barbara, OCS, ca. 1969

Crises, Oil Spills, 1-28-69, Santa Barbara, OCS, ca. 1969

Crises, Oil Spills, 1-28-69, Santa Barbara, OCS, ca. 1969

Box $204 \quad$ Crises, Oil Spills, 1-28-69, Santa Barbara, OCS, ca. 1971

Crises, Oil Spills, 1-28-69, Santa Barbara, OCS, [maps], n.d.

Crises, Oil Spills, 1-28-69, Santa Barbara, OCS, [maps], n.d.

Crises, Oil Spills, 1-28-69, Santa Barbara, OCS, ca. 1969

Crises, Oil Spills, 1-28-69, Santa Barbara, OCS, ca. 1969

Crises, Oil Spills, 1-28-69, Santa Barbara, OCS, ca. 1969

Box 205 Crises, Oil Spills, 1-28-69, Santa Barbara, OCS, ca. 1969

Crises, Oil Spills, 1-28-69, Santa Barbara, OCS, 1970-71

Crises, Oil Spills, 1-28-69, Santa Barbara, OCS, ca. 1969

Crises, Oil Spills, 1-28-69, Santa Barbara, OCS, ca. 1970

Crises, Oil Spills, 1-28-69, Santa Barbara, OCS, ca. 1968-69

Crises, Shipwrecks, General, OCS, 1965-75

Crises, Shipwrecks, 4-26-70, Little Bubber, OCS, 1970

Box 206 Crises, Saltwater Spills, General, 1974-76

Crises, Saltwater Spills, General, 1976

Exhibits, General, 1975-76

Exploration, Oil \& Gas, General, ca. 1966-75

Exploration, Oil \& Gas, General, OCS, 1962-73

Exploration, Oil \& Gas, General, OCS, 1971-73

Exploration, Oil \& Gas, General, OCS, 1973-76

Exploration, Oil \& Gas, Alaska, 1953-69

Exploration, Oil \& Gas, Alaska, OCS, 1962-64

Box 207 Exploration, Oil \& Gas, Alaska, OCS, 1965

Exploration, Oil \& Gas, Alaska, OCS, 1966-67

Exploration, Oil \& Gas, Alaska, OCS, 1968

Exploration, Oil \& Gas, Alaska, OCS, 1969

Exploration, Oil \& Gas, Alaska, OCS, 1969

Exploration, Oil \& Gas, Alaska, OCS, 1970

Exploration, Oil \& Gas, Alaska, OCS, 1970-71

Box 208 Exploration, Oil \& Gas, Alaska, OCS, 1971

Exploration, Oil \& Gas, Alaska, OCS, 1972

Exploration, Oil \& Gas, Alaska, OCS, 1973

Exploration, Oil \& Gas, Alaska, OCS, 1974-76

Exploration, Oil \& Gas, Alaska, OCS, ca. 1964

Exploration, Oil \& Gas, Alaska, OCS, ca. 1964

Exploration, Oil \& Gas, Alaska, OCS, ca. 1968

Box 209 Exploration, Oil \& Gas, Alaska, OCS, [maps], ca. 1971

Exploration, Oil \& Gas, Alaska, OCS, [maps], ca. 1970

Exploration, Oil \& Gas, Alaska, OCS, [maps], ca. 1970 
Box 210

Box 211

Box 212

Box 213

Box 214

Box 215

Box 216
Exploration, Oil \& Gas, Alaska, OCS, [maps], ca. 1968 Exploration, Oil \& Gas, Atlantic Coast, OCS, 1960-66 Exploration, Oil \& Gas, Atlantic Coast, OCS, 1967 Exploration, Oil \& Gas, Atlantic Coast, OCS, 1968-69 Exploration, Oil \& Gas, Atlantic Coast, OCS, 1970-71 Exploration, Oil \& Gas, Atlantic Coast, OCS, 1972-75 Exploration, Oil \& Gas, Atlantic Coast, OCS, [maps], ca. 1960-67 Exploration, Oil \& Gas, Gulf Coast, OCS, 1950-54 Exploration, Oil \& Gas, Gulf Coast, OCS, 1954-55 Exploration, Oil \& Gas, Gulf Coast, OCS, 1956-59 Exploration, Oil \& Gas, Gulf Coast, OCS, 1960-64 Exploration, Oil \& Gas, Gulf Coast, OCS, 1964-65 Exploration, Oil \& Gas, Gulf Coast, OCS, 1965 Exploration, Oil \& Gas, Gulf Coast, OCS, 1965 Exploration, Oil \& Gas, Gulf Coast, OCS, 1966-67 Exploration, Oil \& Gas, Gulf Coast, OCS, 1967-70 Exploration, Oil \& Gas, Gulf Coast, OCS, 1970-75 Exploration, Oil \& Gas, Gulf Coast, OCS, [maps], ca. 1966 Exploration, Oil \& Gas, Pacific Coast, OCS, 1948-55 Exploration, Oil \& Gas, Pacific Coast, OCS, 1956-61 Exploration, Oil \& Gas, Pacific Coast, OCS, 1962-63 Exploration, Oil \& Gas, Pacific Coast, OCS, 1964 Exploration, Oil \& Gas, Pacific Coast, OCS, 1964 Exploration, Oil \& Gas, Pacific Coast, OCS, 1965 Exploration, Oil \& Gas, Pacific Coast, OCS, 1965 Exploration, Oil \& Gas, Pacific Coast, OCS, 1965 Exploration, Oil \& Gas, Pacific Coast, OCS, 1966 Exploration, Oil \& Gas, Pacific Coast, OCS, 1967-68 Exploration, Oil \& Gas, Pacific Coast, OCS, 1969-71 Exploration, Oil \& Gas, Pacific Coast, OCS, 1971 Exploration, Oil \& Gas, Pacific Coast, OCS, 1971-74 Exploration, Oil \& Gas, Pacific Coast, OCS, [maps], ca. 1973 Exploration, Oil \& Gas, Pacific Coast, OCS, ca. 1961-62 Exploration, Oil \& Gas, Pacific Coast, OCS, n.d. Exploration, Other Minerals, General, OCS, 1967-74

Exploration, Other Minerals, Alaska, OCS, 1966-74

Exploration, Other Minerals, Atlantic Coast, OCS, 1966-70

Exploration, Other Minerals, Atlantic Coast, OCS, 1970-73

Exploration, Other Minerals, Gulf Coast, OCS, 1966-67

Exploration, Other Minerals, Pacific Coast, OCS, 1961-74

Forms [c.r. filed in Administrative Office and Royalty Accounting Office] Geothermal Resources, General, 1960-62

Geothermal Resources, General, 1963

Geothermal Resources, General, 1964-65

Geothermal Resources, General, 1966

Geothermal Resources, General, 1967

Geothermal Resources, General, 1967

Geothermal Resources, General, 1967-68

Geothermal Resources, General, 1969-70

Geothermal Resources, General, 1970

Geothermal Resources, General, 1971 
Geothermal Resources, General, 1971

Geothermal Resources, General, 1971

Geothermal Resources, General, 1971-72

Geothermal Resources, General, 1972-74

Box 217 Information, General, 1974-75

Information, General, 1975

Information, General, 1976

Information, General, 1976

Box 218 Information, General, ca. 1974

Information, Distribution, Regulations, 1966-74

Information, Distribution, Regulations, OCS, 1953-69

Information, Distribution, Regulations, OCS, 1970-71

Information, Distribution, Regulations, OCS, 1971-74

Information, General Policies, Proprietary Data, 1932-71

Information, General Policies, Proprietary Data, 1971-72

Information, General Policies, Proprietary Data, 1973-76

Box 219 Information, General Policies, Proprietary Data, OCS, 1966-68

Information, General Policies, Proprietary Data, OCS, 1968-69

Information, General Policies, Proprietary Data, OCS, 1969

Information, General Policies, Proprietary Data, OCS, 1969

Information, General Policies, Proprietary Data, OCS, 1969-71

Box 220 Information, General Policies, Proprietary Data, OCS, 1972-75

Information, General Policies, Proprietary Data, OCS, 1975-76

Information, Departmental Fact Sheets, 1974

Information, GS Publications, Regulatory Operations, OCS, 1972-74

Information, Outside Publications, ca. 1973

Box 221 Duplicates - Held by Special Request, ca. 1970-72

Committees, Congressional, Government Operations Committee, 1973

Committees, Congressional, Government Operations Committee, 1973-74

Contracts, Gas Storage, General, 1976

Contracts, Gas Sales, Pacific Northwest Pipeline - Phillips, 1954-55

Contracts, Gas Sales, Pacific Northwest Pipeline - Phillips, 1955

Contracts, Gas Sales, Pacific Northwest Pipeline - Phillips, 1955

Contracts, Gas Sales, Pacific Northwest Pipeline - Phillips, 1955

Box 222 Contracts, Gas Sales, Pacific Northwest Pipeline - Phillips, 1955

Contracts, Gas Sales, Pacific Northwest Pipeline - Phillips, 1955

Contracts, Gas Sales, Pacific Northwest Pipeline - Phillips, 1956-57

Cooperation, Federal Agencies, Agriculture Department, Forest Service, Los Padres National Forest, California, 1972-74

Cooperation, Federal Agencies, Interior Department, Bureau of Indian Affairs, Jicarilla Agency, New Mexico, 1973-74

Cooperation, Federal Agencies, Interior Department, Bureau of Land Management, Corporate Name Change, 1971

Cooperation, Petroleum Reserves, Elk Hills, California, \#1, 1974

Cooperation, Transportation Department, Coast Guard, General, OCS, ca. 1975

Cooperation, General Accounting Office, OCS, 1976

Box 223 Cooperation, Petroleum Geology of Naval Petroleum Reserve \#1, Elk Hills, California, 1973 (Technical Letter)

Cooperation, Petroleum Geology of Naval Petroleum Reserve \#1, Elk Hills, California, 1973

Cooperation, Petroleum Geology of Naval Petroleum Reserve \#1, Elk Hills, California, 1973

Cooperation, Petroleum Geology of Naval Petroleum Reserve \#1, Elk Hills, California, 1973 
Cooperation, Petroleum Geology of Naval Petroleum Reserve \#1, Elk Hills, California, 1973 Cooperation, Petroleum Geology of Naval Petroleum Reserve \#1, Elk Hills, California, 1973 Cooperation, Petroleum Geology of Naval Petroleum Reserve \#1, Elk Hills, California, 1973 Cooperation, Environmental Impact Statements, Projects involving E.I.S., ca. 1974-75

Cooperation, Federal Agencies, Public Land Law Review Commission, Requests for Proposal, 1967-68

Cooperation, Federal Agencies, Public Land Law Review Commission, Requests for Proposal, 1968

Cooperation, Federal Agencies, Public Land Law Review Commission, Proposed Study Plans, 1967-70

Cooperation, Federal Agencies, Public Land Law Review Commission, Proposed Study Plans, n.d.

Cooperation, Federal Agencies, Public Land Law Review Commission, Proposed Study Plans, 1968

Box 225 Cooperation, Federal Agencies, Public Land Law Review Commission, OCS, 1967-68

Cooperation, Federal Agencies, Public Land Law Review Commission, OCS, 1968-70

Cooperation, Federal Agencies, Public Land Law Review Commission, OCS, ca. 1970

Cooperation, Federal Agencies, Public Land Law Review Commission, OCS, ca. 1970

Cooperation, Federal Agencies, Public Land Law Review Commission, OCS, ca. 1970

Cooperation, Federal Agencies, Public Land Law Review Commission, OCS, ca. 1970

Box 226 Cooperation, Federal Agencies, Public Land Law Review Commission, OCS, ca. 1970

Cooperation, Federal Agencies, Public Land Law Review Commission, OCS, ca. 1970

Cooperation, Federal Agencies, Public Land Law Review Commission, General, 1966

Cooperation, Federal Agencies, Public Land Law Review Commission, General, 1966

Cooperation, Federal Agencies, Public Land Law Review Commission, General, 1967

Cooperation, Federal Agencies, Public Land Law Review Commission, General, 1967

Cooperation, Federal Agencies, Public Land Law Review Commission, General, 1968

Box 227 Cooperation, Federal Agencies, Public Land Law Review Commission, General, 1968

Cooperation, Federal Agencies, Public Land Law Review Commission, General, 1968

Cooperation, Federal Agencies, Public Land Law Review Commission, General, 1968

Cooperation, Federal Agencies, Public Land Law Review Commission, General, 1968-69

Cooperation, Federal Agencies, Public Land Law Review Commission, General, 1969

Cooperation, Federal Agencies, Public Land Law Review Commission, General, 1969

Cooperation, Federal Agencies, Public Land Law Review Commission, General, 1970

Box 228 Cooperation, Federal Agencies, Public Land Law Review Commission, General, 1970

Cooperation, Federal Agencies, Public Land Law Review Commission, General, 1970

Cooperation, Federal Agencies, Public Land Law Review Commission, General, 1970

Cooperation, Federal Agencies, Public Land Law Review Commission, General, 1971

Cooperation, Federal Agencies, General Accounting Office, General, 1972-76

Cooperation, Federal Agencies, General Accounting Office, General, 1973-74

Box 229 Cooperation, Federal Agencies, General Accounting Office, General, 1975-76

Cooperation, Federal Agencies, General Accounting Office, General, ca. 1976

Cooperation, Federal Agencies, General Accounting Office, General, ca. 1975

Cooperation, Federal Agencies, General Accounting Office, General, ca. 1974

Cooperation, Federal Agencies, General Accounting Office, General, ca. 1975

Cooperation, Federal Agencies, General Accounting Office, General, 1975-76

Cooperation, Federal Agencies, Atomic Energy Commission, Plowshare, 1958-71

Box $230 \quad$ Cooperation, Federal Agencies, Atomic Energy Commission, Plowshare, 1969-76

Cooperation, Federal Agencies, Atomic Energy Commission, Plowshare, ca. 1973

Cooperation, Federal Agencies, Atomic Energy Commission, Plowshare, ca. 1969

Cooperation, Federal Agencies, Atomic Energy Commission, Plowshare, ca. 1972

Cooperation, Federal Agencies, Atomic Energy Commission, Plowshare, ca. 1964

Box 231 Cooperation, Federal Agencies, Atomic Energy Commission, Plowshare, ca. 1969 
Cooperation, Federal Agencies, Atomic Energy Commission, Energy Research and Development Administration (ERDA) - Proposed, Carlsbad Waste Disposal Site, 1973-76

Cooperation, Federal Agencies, Atomic Energy Commission, Energy Research and Development Administration (ERDA) - Proposed, Carlsbad Waste Disposal Site, ca, 1973

Cooperation, Federal Agencies, Atomic Energy Commission, Energy Research and Development Administration (ERDA) - Proposed, Carlsbad Waste Disposal Site, ca. 1973

Cooperation, Federal Agencies, Atomic Energy Commission, Energy Research and Development Administration (ERDA) - Proposed, Carlsbad Waste Disposal Site, ca, 1972

Cooperation, Federal Agencies, Atomic Energy Commission, Energy Research and Development Administration (ERDA) - Proposed, Carlsbad Waste Disposal Site, ca. 1973

Cooperation, Federal Agencies, Atomic Energy Commission, Energy Research and Development Administration (ERDA) - Proposed, Carlsbad Waste Disposal Site, ca, 1973

Box 233

Box 234

Cooperation, Federal Agencies, Atomic Energy Commission, Energy Research and Development Administration (EDRA), Geothermal Loan Guaranty Program, 1975-76

Cooperation, Federal Agencies, Atomic Energy Commission, Energy Research and Development Administration (EDRA), Geothermal Loan Guaranty Program, 1975-76

Cooperation, Federal Agencies, Atomic Energy Commission, Plowshare Projects, General, ca. 1973

Cooperation, Federal Agencies, Atomic Energy Commission, Plowshare, Bronco, Colorado, Correspondence, 1966-68

Cooperation, Federal Agencies, Atomic Energy Commission, Plowshare, Bronco, Colorado, Correspondence, 1968-72

Cooperation, Federal Agencies, Atomic Energy Commission, Plowshare, Bronco, Colorado, Engineering Data, 1967-68

Cooperation, Federal Agencies, Atomic Energy Commission, Plowshare, Bronco, Colorado, Feasibility Study, 1967-68

Cooperation, Federal Agencies, Atomic Energy Commission, Plowshare, Bronco, Colorado, Feasibility Study, 1967

Cooperation, Federal Agencies, National Aeronautics and Space Administration, EROS Staff Meeting, 1967-74

Cooperation, Federal Agencies, Tennessee Valley Authority, General, 1949-56

Cooperation, Federal Agencies, Transportation Department, General, 1974-75

Cooperation, Federal Agencies, OCS, 1968-76

Cooperation, Federal Agencies, OCS, 1975

Cooperation, Federal Agencies, Transportation Department, Coast Guard, General, OCS, 1955

Cooperation, Federal Agencies, Transportation Department, Coast Guard, General, OCS, 1956-67

Cooperation, Federal Agencies, Transportation Department, Coast Guard, General, OCS, 1969-75

Cooperation, Federal Agencies, Transportation Department, Coast Guard, General, OCS, 1976

Cooperation, Federal Agencies, Transportation Department, Coast Guard, General, OCS, 1957-71

Cooperation, Federal Agencies, Veterans Administration, Clarksburg VA Hospital, W. Va., 1949-50

Cooperation, Federal Agencies, Veterans Administration, Long Beach VA Hospital, California, 1948-51

Cooperation, Federal Agencies, Veterans Administration, Long Beach VA Hospital, California, 1965-67

Cooperation, Federal Agencies, Veterans Administration, Sawtelle VA Hospital, California, 1956-66

Cooperation, Federal Agencies, Veterans Administration, Sawtelle VA Hospital, California, 1967-68

Cooperation, Federal Agencies, Veterans Administration, Sawtelle VA Hospital, California, 1968-69

Cooperation, Federal Agencies, Veterans Administration, Sawtelle VA Hospital, California, 1968-69

Box 235 Cooperation, Federal Agencies, Veterans Administration, Shreveport VA Center, Louisiana, 1957-67

Cooperation, Federal Agencies, National Oceanographic and Atmospheric Administration, General, OCS, 1972-76

Cooperation, International, General, 1912, 1950-72 
Cooperation, International, General, 1973

Cooperation, International, General, 1975-76

Cooperation, International, General, OCS, 1964-70

Cooperation, International, General, OCS, 1971-73

Box 236 Cooperation, International, General, OCS, 1974-76

Cooperation, International, General, OCS, 1975-76

Cooperation, International, General, OCS, ca. 1974-75

Cooperation, International, Australia, OCS, 1966-76

Cooperation, International, Canada, 1968-76

Cooperation, International, Canada, ca. 1969

Box 237 Cooperation, International, Canada, ca. 1971

Geothermal Resources, General, 1974

Geothermal Resources, General, 1975

Geothermal Resources, General, 1976

Geothermal Resources, General, ca. 1971-72

Box 238 Geothermal Resources, General, ca. 1964-71

Geothermal Resources, General, ca. 1966

Geothermal Resources, General, [maps] ca. 1967

Geothermal Resources, General, [maps], n.d.

Geothermal Resources, Resources Minutes, General, 1974

Geothermal Resources, Resources Minutes, Alaska, 1971

Geothermal Resources, Resources Minutes, Arizona, 1974

Geothermal Resources, Resources Minutes, California, ca. 1971-75

Geothermal Resources, Resources Minutes, Colorado, 1974

Geothermal Resources, Resources Minutes, Idaho, ca. 1971-76

Box 239 Geothermal Resources, Resources Minutes, Montana, ca. 1971-74

Geothermal Resources, Resources Minutes, Nevada, 1974-75

Geothermal Resources, Resources Minutes, Nevada, ca. 1976

Geothermal Resources, Resources Minutes, New Mexico, 1975

Geothermal Resources, Resources Minutes, Oregon, 1974-76

Geothermal Resources, Resources Minutes, Utah, ca. 1971-75

Geothermal Resources, Resources Minutes, Washington, 1974

Geothermal Resources, Special Well Use, 1964-72

Geothermal Resources, Lease Sales, Competitive, General, 1974-76

Geothermal Resources, Lease Sales, Competitive, Arizona, 1975

Geothermal Resources, Lease Sales, Competitive, California, 1973-75

Geothermal Resources, Lease Sales, Competitive, Nevada, 1974-75

Box 240 Geothermal Resources, Lease Sales, Competitive, New Mexico, 1975

Geothermal Resources, Lease Sales, Competitive, Oregon, 1974-75

Geothermal Resources, Lease Sales, Competitive, Utah, 1974-76

Geothermal Resources, Lease Sales, Competitive, General, 1973-76

Geothermal Resources, Non-Competitive Leasing, General, 1974-76

Geothermal Resources, Non-Competitive Leasing, General, 1976

Geothermal Resources, Operational, GRO Orders, 1974-75

Geothermal Resources, Operational, GRO Orders, 1976

Box $241 \quad$ Helium, General, 1943-50

Helium, General, 1951-53

Helium, General, 1961-64

Helium, General, 1965-69

Helium, General, 1969-73

Helium, General, ca. 1963 
Helium, General, ca. 1960-63

Helium, General, ca. 1964

Box 242 Helium, Reserve No. 1, Woodside, Utah, 1925-59

Helium, Reserve No. 1, Woodside, Utah, 1960-61

Helium, Reserve No. 1, Woodside, Utah, 1963-65

Helium, Reserve No. 2, Harley Dome, Utah, 1932-64

Information, General, 1970-71

Information, General, 1971

Information, General, 1971-72

Information, General, 1972-73

Box 243 Information, General, 1973

Information, General, 1973-74

Information, Requests, Taxpayer, General, 1965-66

Information, Requests, Taxpayer, General, 1967-69

Information, Requests, Taxpayer, General, 1969-70

Box 244 Information, Requests, Taxpayer, General, 1970-72

Information, Requests, Taxpayer, General, 1972-73

Information, Requests, Taxpayer, General, 1973-74

Information, Requests, Taxpayer, General, 1974-75

Box 245 Information, Requests, Taxpayer, General, 1975

Information, Requests, Taxpayer, General, 1975-76

Information, Requests, Taxpayer, General, OCS, 1955-70

Information, Requests, Taxpayer, General, OCS, 1970

Box 246 Information, Requests, Taxpayer, General, OCS, 1970-71

Information, Requests, Taxpayer, General, OCS, 1971-74

Information, Requests, Taxpayer, General, OCS, 1975

Information, Requests, Taxpayer, General, OCS, 1975

Information, Requests, Taxpayer, General, OCS, 1975

Box 247 Information, Requests, Taxpayer, General, OCS, 1975

Information, Requests, Taxpayer, General, OCS, 1975

Information, Requests, Taxpayer, General, OCS, 1976

Information, Requests, Taxpayer, General, OCS, 1976

Information, Requests, Taxpayer, Santa Barbara, OCS, 1969

Information, Requests, Taxpayer, Santa Barbara, OCS, 1969

Box 248 Information, Requests, Taxpayer, Santa Barbara, OCS, 1969

Information, Requests, Taxpayer, Santa Barbara, OCS, 1969

Information, Requests, Taxpayer, Santa Barbara, OCS, 1969

Information, Requests, Taxpayer, Santa Barbara, OCS, 1969

Information, Requests, Taxpayer, Santa Barbara, OCS, 1969

Box 249 Information, Requests, Taxpayer, Santa Barbara, OCS, 1970

Information, Requests, Taxpayer, Santa Barbara, OCS, 1970

Information, Requests, Taxpayer, Santa Barbara, OCS, 1970

Information, Requests, Taxpayer, Santa Barbara, OCS, 1970

Information, Requests, Taxpayer, Santa Barbara, OCS, 1970

Information, Requests, Taxpayer, Santa Barbara, OCS, 1970

Box 250 Information, Requests, Taxpayer, Santa Barbara, OCS, 1970

Information, Requests, Taxpayer, Santa Barbara, OCS, 1970

Information, Requests, Taxpayer, Santa Barbara, OCS, 1970

Information, Requests, Taxpayer, Santa Barbara, OCS, 1970

Information, Requests, Taxpayer, Santa Barbara, OCS, 1970

Information, Requests, Taxpayer, Santa Barbara, OCS, 1970 
Box 251 Information, Requests, Taxpayer, Santa Barbara, OCS, 1970 Information, Requests, Taxpayer, Santa Barbara, OCS, 1970 Information, Requests, Taxpayer, Santa Barbara, OCS, 1970 Information, Requests, Taxpayer, Santa Barbara, OCS, 1970 Information, Requests, Taxpayer, Santa Barbara, OCS, 1970 Information, Requests, Taxpayer, Santa Barbara, OCS, 1970

Box 252 Information, Requests, Taxpayer, Santa Barbara, OCS, 1970 Information, Requests, Taxpayer, Santa Barbara, OCS, 1970 Information, Requests, Taxpayer, Santa Barbara, OCS, 1970 Information, Requests, Taxpayer, Santa Barbara, OCS, 1971 Information, Requests, Taxpayer, Santa Barbara, OCS, 1971 Information, Requests, Taxpayer, Santa Barbara, OCS, 1971

Box 253 Information, Requests, Taxpayer, Santa Barbara, OCS, 1971-72 Information, Requests, Taxpayer, Santa Barbara, OCS, 1973 Information, Requests, Taxpayer, Santa Barbara, OCS, 1973-76 Information, Requests, Taxpayer, Santa Barbara, Get Oil Out, Inc. (GOO), OCS, 1969-73 Information, Requests, Taxpayer, Santa Barbara, Get Oil Out, Inc. (GOO), OCS, 1974-76

Box 254 Information, Requests, Taxpayer, Santa Barbara, Favorable, OCS, 1969-70 Information, Requests, Taxpayer, Santa Barbara, Favorable, OCS, 1971-75 Information, Requests, Taxpayer, Main Pass Block 41, OCS, 1970 Information, Requests, Taxpayer, Main Pass Block 41, OCS, 1970 Information, Requests, Taxpayer, Main Pass Block 41, OCS, 1970 Information, Requests, Taxpayer, Main Pass Block 41, OCS, 1970 Information, Requests, Taxpayer, Main Pass Block 41, OCS, 1970 Information, Requests, Taxpayer, Main Pass Block 41, OCS, 1970

Box 255 Information, Requests, Taxpayer, Main Pass Block 41, OCS, 1970 Information, Requests, Taxpayer, Main Pass Block 41, OCS, 1970-71 Information, Requests, Congressional, General, 1943-67 Information, Requests, Congressional, General, 1967-68 Information, Requests, Congressional, General, 1969 Information, Requests, Congressional, General, 1969 Information, Requests, Congressional, General, 1970 Box 256 Information, Requests, Congressional, General, 1970 Information, Requests, Congressional, General, 1971 Information, Requests, Congressional, General, 1971 Information, Requests, Congressional, General, 1971-72 Information, Requests, Congressional, General, 1972 Box 257 Information, Requests, Congressional, General, 1972 Information, Requests, Congressional, General, 1972 Information, Requests, Congressional, General, 1972 Information, Requests, Congressional, General, 1972-73 Information, Requests, Congressional, General, 1973

Box 258 Information, Requests, Congressional, General, 1973-74 Information, Requests, Congressional, General, 1974 Information, Requests, Congressional, General, 1974 Information, Requests, Congressional, General, 1974 Information, Requests, Congressional, General, 1974-75

Box 259 Information, Requests, Congressional, General, 1975 Information, Requests, Congressional, General, 1975 Information, Requests, Congressional, General, 1975-76 Information, Requests, Congressional, General, OCS, 1953-67 Information, Requests, Congressional, General, OCS, 1968 
Box 260 Information, Requests, Congressional, General, OCS, 1969 Information, Requests, Congressional, General, OCS, 1969 Information, Requests, Congressional, General, OCS, 1970 Information, Requests, Congressional, General, OCS, 1970 Information, Requests, Congressional, General, OCS, 1970 Information, Requests, Congressional, General, OCS, 1970 Information, Requests, Congressional, General, OCS, 1970

Box 261 Information, Requests, Congressional, General, OCS, 1970 Information, Requests, Congressional, General, OCS, 1970 Information, Requests, Congressional, General, OCS, 1971 Information, Requests, Congressional, General, OCS, 1971 Information, Requests, Congressional, General, OCS, 1971 Information, Requests, Congressional, General, OCS, 1972 Information, Requests, Congressional, General, OCS, 1972

Box 262 Information, Requests, Congressional, General, OCS, 1973 Information, Requests, Congressional, General, OCS, 1974 Information, Requests, Congressional, General, OCS, 1974 Information, Requests, Congressional, General, OCS, 1974-75 Information, Requests, Congressional, General, OCS, 1975

Box 263 Information, Requests, Congressional, General, OCS, 1976 Information, Requests, Congressional, General, OCS, ca. 1971-75 Information, Requests, Congressional, Santa Barbara, OCS, 1968-69 Information, Requests, Congressional, Santa Barbara, OCS, 1969 Information, Requests, Congressional, Santa Barbara, OCS, 1969 Information, Requests, Congressional, Santa Barbara, OCS, 1970 Information, Requests, Congressional, Santa Barbara, OCS, 1970 Information, Requests, Congressional, Santa Barbara, OCS, 1971-73

Box 264 Information, Requests, Congressional, Santa Barbara, OCS, 1974-75 Information, Requests, Congressional, Main Pass Block 41, OCS, 1970 Information, Requests, Congressional, Main Pass Block 41, OCS, 1970 Information, Royalty Accounting [c.r. filed in Royalty Accounting Office] Pollution, Contingency Plan, Regional, OCS, 1968-70

Pollution, Contingency Plan, Regional, OCS, 1971-74 Pollution, Contingency Plan, Regional, OCS, n.d. Pollution, Contingency Plan, Regional, OCS, n.d. Pollution, Contingency Plan, Regional, OCS, n.d.

Box 265 Pollution, Contingency Plan, Regional, OCS, n.d. Pollution, Contingency Plan, Regional, OCS, n.d. Pollution, Contingency Plan, Regional, OCS, n.d. Pollution, Contingency Plan, Regional, OCS, n.d. Pollution, Contingency Plan, Regional, OCS, n.d.

Box 266 Pollution, Contingency Plan, National, OCS, 1968-71

Pollution, Contingency Plan, National, OCS, 1971

Pollution, Contingency Plan, National, OCS, 1972

Pollution, Contingency Plan, National, OCS, 1972

Pollution, Contingency Plan, National, OCS, 1972

Pollution, Contingency Plan, National, OCS, 1973

Pollution, Contingency Plan, California, OCS, 1969-72

Pollution, Lake Erie, 1968-69

Box 267 Pollution, Lake Erie, 1969

Pollution, Lake Erie, 1969-70 
Pollution, Suggestions, OCS, 1968-69

Pollution, Suggestions, OCS, 1969

Pollution, Suggestions, OCS, 1969

Pollution, Suggestions, OCS, 1969

Pollution, Suggestions, OCS, 1969

Pollution, Suggestions, OCS, 1969

Pollution, Suggestions, OCS, 1969

Box 268

Reports and Statistics, General, 1951-75

Reports and Statistics, General, 1975-76

Reports and Statistics, General, 1975-76

Reports and Statistics, General, 1976

Reports and Statistics, General, ca. 1971-76

Reports and Statistics, General, n.d.

Box 269 Reports and Statistics, General, OCS, ca. 1973

Reports and Statistics, General, OCS, n.d.

Reports and Statistics, General, OCS, n.d.

Reports and Statistics, General, OCS, n.d.

Box $270 \quad$ Reports and Statistics, Reports, Bureau, Annual Review, 1960-75

Reports and Statistics, Reports, Bureau, Historical Report, Truman Administration, ca. 1952

Reports and Statistics, Reports, Bureau, Historical Report, Truman Administration, ca. 1952

Reports and Statistics, Reports, Bureau, State Reports, Mineral-Water Resources, Alaska-California, ca. 1963-67

Reports and Statistics, Reports, Bureau, State Reports, Mineral-Water Resources, Colorado-Montana, ca. 1963-74

Reports and Statistics, Reports, Bureau, State Reports, Mineral-Water Resources, NebraskaSouth Dakota, ca. 1963-68

Reports and Statistics, Reports, Bureau, State Reports, Mineral-Water Resources, TennesseeWashington, ca. 1963-64

Reports and Statistics, Bureau, Weekly Reports the Secretary on Oil \& Gas Activities - Federal and Indian Lands, 1974

Box 271 Reports and Statistics, Division, Conservation Division, Bimonthly Publications Reports, ca. 1975-76

Reports and Statistics, Division, Computer Application - Resources \& Production Data, 1975

Reports and Statistics, Division, Monthly Drilling Activity, General, 1975-76

Reports and Statistics, Division, Evaluation Standards and Publications Section Monthly Report, 1974

Reports and Statistics, Division, Area Geothermal Office Monthly Report, 1974-75

Reports and Statistics, Division, Area Geothermal Office Monthly Report, 1976

Reports and Statistics, Division, Area Oil Shale Office Monthly Report, 1974-75

Reports and Statistics, Division, Operations Standards and Directives Section Monthly Report, 1976

Reports and Statistics, Division, Regional Conservation Manager Monthly Report (Central), 1973-75

Reports and Statistics, Division, Regional Conservation Manager Monthly Report (Eastern Region), 1973-74

Box 272 Programs and Plans, Long Range Plans, 1951-76

Programs and Plans, Monitored Objectives, 1973-74

Programs and Plans, Monitored Objectives, 1974-75

Programs and Plans, Monitored Objectives, 1976

Programs and Plans, Special, Alaska Field Program, 1968-72

Programs and Plans, Special, Alaska Field Program, ca. 1966-70

Box 273 Programs and Plans, Special, Coal-Leasing Program, 1975-76

Programs and Plans, Special, Coal-Leasing Program, 1976 
Box 274

Box 275

Box 276

Box 277

Box 278
Programs and Plans, Special, Coal-Leasing Program, 1976

Programs and Plans, Special, Coal-Leasing Program, 1975

Programs and Plans, Special, Continental Slope Environmental Program, 1974

Programs and Plans, Special, Core-Sampling Program, Atlantic, OCS, 1975

Programs and Plans, Special, Continental Offshore Stratigraphic Tests, OCS, 1974-75

Programs and Plans, Special, Continental Offshore Stratigraphic Tests (C)ST), OCS, 1975-76

Programs and Plans, Special, Continental Offshore Stratigraphic Tests (COST), OCS, 1975-76

Programs and Plans, Special, Energy-Policy Options, 1973-74

Programs and Plans, Special, Environmental-Impact Analysis Program, 1974-75

Programs and Plans, Special, Energy-Minerals Rehabilitation Inventory Analysis, 1974-75

Programs and Plans, Special, Federal Assistance Review (FAR) Program, 1969-71

Programs and Plans, Special, Federal Assistant Review (FAR) Program, 1972

Land, Classification, General, 1906-10

Land, Classification, General, 1911-15

Land, Classification, General, 1916-55

Land, Classification, General, 1960-76

Land, Classification, General, 1976

Land, Classification, Coal, 1907-15

Land, Classification, Coal, 1917-76

Land, Classification, Coal, Hanna and Carbon Basins, Wyoming, ca. 1973

Land, Classification, Coal, Powder River Basin, Wyoming, ca. 1973

Land, Classification, Coal, Powder River Basin, Wyoming, ca. 1973

Land, Classification, Oil \& Gas, 1912-74

Land, Determinations, Known Coal-Leasing Areas, General, 1974-76

Land, Determinations, Known Coal-Leasing Areas, Burns Creek-Thirteen Mile Creek, ca. 1975

Land, Determinations, Known Coal-Leasing Areas, Burns Creek-Thirteen Mile Creek, 1974-76

Land, Determinations, Known Coal-Leasing Areas, Book Cliffs, 1974

Land, Determinations, Known Coal-Leasing Areas, Danforth Hills, 1974

Land, Determinations, Known Coal-Leasing Areas, Grass Creek, 1975

Land, Determinations, Known Coal-Leasing Areas, Hazen, North Dakota, 1975

Land, Determinations, Known Coal-Leasing Areas, Henry Mountains, 1974

Land, Determinations, Known Coal-Leasing Areas, Kaiparowits, 1974-75

Land, Determinations, Known Coal-Leasing Areas, Kemmerer, 1974

Land, Determinations, Known Coal-Leasing Areas, Rock Springs, 1974

Land, Determinations, Known Coal-Leasing Areas, Wasatch Plateau, 1974

Land, Determinations, Known Coal-Leasing Areas, Wilbaux-Beach, 1974

Land, Determinations, Known Coal-Leasing Areas, Williston-Avoca, 1975

Land, Determinations, Known Coal-Leasing Areas, Yampa, 1974

Land, Determinations, Known Geothermal-Resource Areas, General, 1974-76

Land, Determinations, Known Geothermal-Resource Areas, General, 1975-76

Land, Determinations, Known Geothermal-Resource Areas, Alamosa County, California, 1974

Land, Determinations, Known Geothermal-Resource Areas, Belknap-Foley Hot Springs, Oregon, 1974

Land, Determinations, Known Geothermal-Resource Areas, Boewawe, Nevada, 1974

Land, Determinations, Known Geothermal-Resource Areas, Bodie, Calif., 1975

Land, Determinations, Known Geothermal-Resource Areas, Bolder Hot Springs, Montana, 1975

Land, Determinations, Known Geothermal-Resource Areas, Brady-Hazen, Nevada, 1974

Land, Determinations, Known Geothermal-Resource Areas, Burns Butte, Oregon, 1974

Land, Determinations, Known Geothermal-Resource Areas, Castle Creek, Idaho, 1975

Land, Determinations, Known Geothermal-Resource Areas, Clifton, Ariz., 1974

Land, Determinations, Known Geothermal-Resource Areas, Corwin Springs, Montana, 1975-76 
Land, Determinations, Known Geothermal-Resource Areas, Cove Fort-Sulphrudale, Utah, 1974-75

Land, Determinations, Known Geothermal-Resource Areas, Crump Geyser, Oregon, 1975

Land, Determinations, Known Geothermal-Resource Areas, Geysers-Calistoga, California, 1974-75

Land, Determinations, Known Geothermal-Resource Areas, Gila Hot Springs, New Mexico, 1975

Reports and Statistics, Reports, Division, Regional Conservation Mamger, Monthly Report, Eastern, 1975

Reports and Statistics, Reports, Division, Regional Conservation Manager, Monthly Report, Gulf, 1973-74

Reports and Statistics, Reports, Division, Regional Conservation Manager, Monthly Report, Western, 1973-75

Reports and Statistics, Reports, Division, Regional Conservation Manager, Monthly Report, Western, 1975-76

Box 279 Reports and Statistics, Reports, Division, Drilling Report, Santa Barbara, OCS, 1969

Reports and Statistics, Reports, Division, Drilling Report, Santa Barbara, OCS, 1969

Reports and Statistics, Reports, Division, Drilling Report, Santa Barbara, OCS, 1969

Reports and Statistics, Reports, Division, Drilling Report, Santa Barbara, OCS, 1969

Reports and Statistics, Reports, Division, Drilling Report, Santa Barbara, OCS, 1969

Box 280 Reports and Statistics, Reports, Division, Drilling Report, Santa Barbara, OCS, 1969

Reports and Statistics, Reports, Division, Drilling Report, Santa Barbara, OCS, 1969

Reports and Statistics, Reports, Division, Drilling Report, Santa Barbara, OCS, 1969

Reports and Statistics, Reports, Division, Drilling Report, Santa Barbara, OCS, 1970

Reports and Statistics, Reports, Division, Drilling Report, Santa Barbara, OCS, 1970

Reports and Statistics, Reports, Division, Drilling Report, Santa Barbara, OCS, 1970

Box 281 Reports and Statistics, Reports, Division, Drilling Report, Santa Barbara, OCS, 1970

Reports and Statistics, Reports, Division, Drilling Report, Santa Barbara, OCS, 1970

Potash, New Mexico, Potash Area, 1970-73

Potash, New Mexico, Potash Area, 1973

Potash, New Mexico, Potash Area, 1974-76

Box 282 Potash, New Mexico, Potash Area, 1975-76

Potash, New Mexico, Potash Area, 1974

Potash, New Mexico, Potash Area, Presentation of the New Mexico Oil \& Gas Association Re: Potash, ca. 1970-73

Potash, New Mexico, Potash Area, Presentation of the New Mexico Oil \& Gas Association Re: Potash, n.d.

Potash, Transcript of Case No. 5193 BELCO Petroleum Corporation for the New Mexico Oil Conservation Commission Hearing, 1974

Potash, Transcript of Case No. 5193 BELCO Petroleum Corporation for the New Mexico Oil Conservation Commission Hearing, 1974

Potash, Transcript of Case No. 5193 BELCO Petroleum Corporation for the New Mexico Oil Conservation Commission Hearing, 1974

Box 283 Potash, New Mexico, Potash Area, Testimony of Hearing - April 15, 1964, Pan American Petroleum Corporation, 1964-65

Potash, New Mexico, Potash Area, Testimony of Hearing - April 15, 1964, Pan American Petroleum Corporation, 1964

Potash, New Mexico, Potash Area, Maps and Appeal of Potash Company of America, ca. 1951

Potash, New Mexico, Potash Area, Maps and Appeal of Potash Company of America, n.d.

Potash, New Mexico, Potash Area, Maps and Appeal of Potash Company of America, n.d.

Potash, New Mexico, Potash Area, Maps and Appeal of Potash Company of America, n.d.

Box $284 \quad$ Programs and Plans, General, 1970-74

Programs and Plans, General, 1974-75

Programs and Plans, General, 1975-76 
Programs and Plans, General, 1975-76

Programs and Plans, General, OCS, 1973-76

Box 285 Reports and Statistics, Reports, Division, Drilling Report, Santa Barbara, OCS, 1970 Reports and Statistics, Reports, Division, Drilling Report, Santa Barbara, OCS, 1970 Reports and Statistics, Reports, Division, Drilling Report, Santa Barbara, OCS, 1970 Reports and Statistics, Reports, Division, Drilling Report, Santa Barbara, OCS, 1970 Reports and Statistics, Reports, Division, Drilling Report, Santa Barbara, OCS, 1970

Box 286 Reports and Statistics, Reports, Division, Drilling Report, Santa Barbara, OCS, 1970 Reports and Statistics, Reports, Division, Drilling Report, Santa Barbara, OCS, 1970 Reports and Statistics, Reports, Division, Drilling Report, Santa Barbara, OCS, 1971 Reports and Statistics, Reports, Division, Drilling Report, Santa Barbara, OCS, 1971 Reports and Statistics, Reports, Division, Drilling Report, Santa Barbara, OCS, 1971 Reports and Statistics, Reports, Division, Drilling Report, Santa Barbara, OCS, 1971 Box 287 Reports and Statistics, Reports, Division, Drilling Report, Santa Barbara, OCS, 1971 Reports and Statistics, Reports, Division, Drilling Report, Santa Barbara, OCS, 1972 Reports and Statistics, Reports, Division, Drilling Report, Santa Barbara, OCS, 1972 Reports and Statistics, Reports, Division, Drilling Report, Santa Barbara, OCS, 1973-76 Reports and Statistics, Evaluation Reports, OCS, Biweekly Report/Status of Lease-Tract Evaluation, OCS Sales, 1973-76

Box $288 \quad$ Reports and Statistics, Non-Government Reports, 1925-72

Reports and Statistics, Non-Government Reports, 1925

Reports and Statistics, Non-Government Reports, OCS, 1971-73

Reports and Statistics, Non-Government Reports, OCS, ca. 1972

Reports and Statistics, Non-Government Reports, OCS, ca. 1971

Reports and Statistics, Non-Government Reports, OCS, n.d.

Box 289 Legal, Power of Attorney, "B", ca. 1962-65

Legal, Power of Attorney, "C", ca. 1954-72

Legal, Power of Attorney, Continental Oil Company, 1962-71

Legal, Power of Attorney, "D-E-F-G", ca. 1952-73

Legal, Power of Attorney, "H-I-J-K-L", ca. 1951-70

Legal, Power of Attorney, "M", ca. 1960-71

Legal, Power of Attorney, Mobil Oil Corporation, ca. 1960-72

Legal, Power of Attorney, Mobil Oil Corporation, 1969-71

Box 290 Legal, Power of Attorney, Mobil Oil Corporation, 1971-73

Legal, Power of Attorney, "N-O", ca. 1959-72

Legal, Power of Attorney, "P-Q-R", ca. 1954-70

Legal, Power of Attorney, "S-So", ca. 1952-65

Legal, Power of Attorney, "Sp-Sz", ca. 1951-68

Legal, Power of Attorney, "T", ca. 1952-72

Legal, Power Of Attorney, Texaco Inc., ca. 1963-76

Box 291 Legal, Power of Attorney, "U-V-W-X-Y-Z", ca. 1959-76

Oil and Gas, Exploration and Development, Utilization Circular, ca. 1969

Oil and Gas, Exploration and Development, Utilization Circular, ca. 1969

Oil and Gas, Exploration and Development, Utilization Circular, ca. 1971

Oil and Gas, Exploration and Development, Utilization Circular, 1971-72

Oil and Gas, Utilization of OCS, Oil \& Gas Operations, 1975-76

Oil and Gas, Leasing, General, ca. 1975

Oil and Gas, Leasing Schedules, OCS, ca. 1976

Oil and Gas, Leasing Schedules, OCS, n.d.

Box 292 Oil and Gas, Calls for Nominations, California, Leasing, OCS, \#35, 1975

Oil and Gas, Calls for Nominations, Southeastern Bering Sea, Leasing, OCS, \#45, 1974 
Oil and Gas, Lease Sales, General, n.d.

Oil and Gas, Lease Sales, Texas, South, Leasing, OCS, \#37, 1975

Oil and Gas, Production, General, OCS, ca. 1976

Oil and Gas, Production, General, OCS, n.d.

Oil and Gas, Production, General, OCS, n.d.

Oil and Gas, Production, General, OCS, n.d.

Oil and Gas, Shut-In, Oil \& Gas, Wells, OCS, 1973

Box 293

Oil and Gas, Shut-In, Oil \& Gas, Wells, OCS, 1973-74

Oil and Gas, Safety, OCS, ca. 1970

Oil and Gas, Safety, OCS, ca. 1970

Oil and Gas, Safety, OCS, ca. 1969-70

Oil and Gas, Safety, OCS, ca. 1968-70

Oil Shale, General, 1976

Oil Shale, General, n.d.

Box 294 Oil Shale, General, ca. 1975

Programs and Plans, Continental Offshore Stratigraphic Tests, OCS, 1975

Programs and Plans, Continental Offshore Stratigraphic Tests, OCS, 1975

Programs and Plans, Continental Offshore Stratigraphic Tests, OCS, 1975

Programs and Plans, Continental Offshore Stratigraphic Tests, OCS, n.d.

Box 295 Research, Oceanography, OCS, 1966

Research, Oceanography, OCS, 1967-68

Research, Oceanography, OCS, 1968

Research, Oceanography, OCS, 1968

Research, Oceanography, OCS, 1968

Box 296 Research, Oceanography, OCS, 1969-71

Research, Oceanography, OCS, 1972-73

Research, Oceanography, OCS, n.d.

Sodium, General, 1964-66

Sodium, General, 1967

Sodium, General, 1967

Sodium, General, 1967-68

Box 297 Sodium, General, 1968

Sodium, General, 1968

Sodium, General, 1968

Sodium, General, 1968

Sodium, General, 1969

Sodium, General, 1969

Sodium, General, 1970

Box 298 Pollution, Suggestions, OCS, ca. 1972-73

Pollution, Suggestions, OCS, n.d.

Pollution, Suggestions, OCS, n.d.

Pollution, Suggestions, OCS, 1970

Pollution, Suggestions, OCS, 1970

Pollution, Suggestions, OCS, 1970

Box 299 Pollution, Suggestions, OCS, 1970

Pollution, Suggestions, OCS, 1970

Pollution, Suggestions, OCS, 1970

Pollution, Suggestions, OCS, 1970

Pollution, Suggestions, OCS, 1970

Pollution, Suggestions, OCS, 1970

Pollution, Suggestions, OCS, 1971

Pollution, Suggestions, OCS, 1971-72 
Box $300 \quad$ Pollution, Suggestions, OCS, 1973

Pollution, Environmental Monitoring, 1973

Potash, General, 1916, 1922-25, 1930-70

Potash, General, 1971-76

Potash, General, 1976

Potash, Seven Mile Area, Utah, 1957-61

Potash, Seven Mile Area, Utah, 1961

Potash, Searles Lake, California, 1973-75

Box $301 \quad$ Reports and Statistics, Interior, Solicitor, Monthly Report, 1975

Reports and Statistics, Interior, Solicitor's Weekly Briefing Memos, 1974-76

Reports and Statistics, Interior, Energy Indicators Report, 1973-74

Reports and Statistics, Interior, Energy Indicators Report, 1974

Reports and Statistics, Interior, Energy Indicators Report, 1973

Reports and Statistics, General Services Administration, Monthly Reports, 1975-76

Reports and Statistics, Statistics, General, 1909-10

Reports and Statistics, Statistics, General, 1974-76

Reports and Statistics, Statistics, General, 1975

Box 302 Reports and Statistics, Statistics, General, OCS, 1948-55

Reports and Statistics, Statistics, General, OCS, 1956-62

Reports and Statistics, Statistics, General, OCS, 1963-69

Reports and Statistics, Statistics, General, OCS, 1970-76

Reports and Statistics, Correspondence Statistics, 1912, 1915-75

Reports and Statistics, Statistics, Inspection Frequency, 1974-76

Reports and Statistics, Statistics, Lease Lists, OCS, 1962-65

Reports and Statistics, Statistics, Lease Lists, OCS, 1966-69

Reports and Statistics, Statistics, Lease Lists, OCS, 1970-76

Reports and Statistics, Statistics, Major Well Shut-ins, OCS, 1975-76

Reports and Statistics, Statistics, Notices to Drill (NID'S), MAFLA Leases, 1974

Box 303 Reports and Statistics, Public Land Statistics, 1946-49

Reports and Statistics, Public Land Statistics, 1950-55

Reports and Statistics, Public Land Statistics, ca. 1961-76

Reports and Statistics, Public Land Statistics, 1968-74

Reports and Statistics, Statistics, Submerged-Well Lists, OCS, ca. 1967-75

Reports and Statistics, Statistics, Submerged-Well Lists, OCS, 1971-76

Reports and Statistics, Statistics, Unit Statistics, 1972-76

Reports and Statistics, Statistics, Well \& Lease Status Summary, OCS, 1975

Reports and Statistics, Statistics, Well \& Lease Status Summary, OCS, 1975

Reports and Statistics, Statistics, Well \& Lease Status Summary, OCS, 1975

Box $304 \quad$ Organization and Management, Studies, General, 1971-74

Organization and Management, Studies, General, 1975-76

Organization and Management, Studies, General, 1975

Box 305 Organization and Management, Studies, General, 1975

Organization and Management, Studies, General, OCS, 1970-74

Organization and Management, Studies, General, OCS, 1975-76

Organization and Management, Studies, General, OCS, 1974-75

Organization and Management, Studies, General, OCS, ca. 1974

Organization and Management, Energy Studies, 1960-71

Box $306 \quad$ Organization and Management, Energy Studies, 1971

Organization and Management, Energy Studies, 1971

Organization and Management, Energy Studies, 1971-73

Organization and Management, Energy Studies, 1973-75 
Organization and Management, Energy Studies, ca. 1973-74

Organization and Management, Energy Studies, n.d.

Box $307 \quad$ Organization and Management, Energy Studies, n.d.

Organization and Management, Energy Studies, n.d.

Organization and Management, Energy Studies, OCS, 1963-72

Organization and Management, Studies, OCS, Leasing-Policy Study (McKelvey), 1968

Organization and Management, Studies, OCS, Leasing-Policy Study (McKelvey), 1968

Organization and Management, Studies, OCS, Leasing-Policy Study (McKelvey), 1968

Organization and Management, Studies, OCS, Leasing-Policy Study (McKelvey), 1968

Box $308 \quad$ Organization and Management, Studies, OCS, Leasing-Policy Study (McKelvey), 1968

Organization and Management, Studies, OCS, Leasing-Policy Study (McKelvey), 1968

Organization and Management, Studies, OCS, Leasing-Policy Study (McKelvey), 1968

Organization and Management, Studies, OCS, Leasing-Policy Study (McKelvey), 1968

Organization and Management, Studies, OCS, Leasing-Policy Study (McKelvey), 1968

Organization and Management, Studies, OCS, Leasing-Policy Study (McKelvey), 1968

Box 309 Organization and Management, Studies, OCS, Leasing-Policy Study (McKelvey), 1968

Organization and Management, Studies, OCS, Leasing-Policy Study (McKelvey), 1969

Organization and Management, Studies, OCS, Leasing-Policy Study (McKelvey), 1968

Organization and Management, Studies, OCS, Leasing-Policy Study (McKelvey), 1968-69

Organization and Management, Studies, Paley Commission, 1952

Organization and Management, Studies, Pollution Study, OCS, 1967

Box $310 \quad$ Organization and Management, Studies, Princeton Report, 1950-51

Organization and Management, Studies, "Think" Paper on Coal, 1975-76

Organization and Management, Studies, Tulane University Study, OCS, 1958

Organization and Management, Studies, User Charges, 1963-73

Organization and Management, Studies, User Charges, 1966

Organization and Management, Studies, User Charges, n.d.

Organization and Management, Studies, Van Pelt Committee Study, 1953-54

Organization and Management, Studies, Van Pelt Committee Study, 1954-55

Box $311 \quad$ Organization and Management, Studies, Van Pelt Committee Study, 1956

Paleontology and Stratigraphy, General, 1954-73

Personnel, Delegation of Authority, General, 1915-53

Personnel, Delegation of Authority, General, 1962-75

Personnel, Delegation of Authority, General, OCS, 1947-76

Personnel, Delegation of Authority, Units, 1947-76

Personnel, Task Forces, General, 1969-76

Personnel, Task Forces, General, 1976

Box 312 Personnel, Task Forces, General, 1976

Phosphate, General, 1911, 1913-14, 1917, 1940-47

Phosphate, General, 1948

Phosphate, General, 1949-55

Phosphate, General, 1956-69

Phosphate, General, 1971-74

Phosphate, General, 1974-75

Box 313 Phosphate, General, 1975-76

Phosphate, General, OCS, 1960-61

Phosphate, General, OCS, 1962-64

Phosphate, General, OCS, 1965-66

Phosphate, General, OCS, 1967-71

Phosphate, General, OCS, ca. 1961-62

Organization and Management, Administrative Issuances, GLO Circulars, 1933-46 
Box 314 Organization and Management, Establishment, Reorganization, General, 1909, 1931-46

Organization and Management, Establishment, Reorganization, General, 1971-76

Organization and Management, Establishment, Reorganization, Department of Natural Resources, 1971

Organization and Management, Establishment, Reorganization, Department of Natural Resources, 1971

Organization and Management, Establishment, Reorganization, Department of Natural Resources, 1971-75

Organization and Management, Procedures \& Methods, 1906-07, 1909-15, 1917-41

Organization and Management, Procedures \& Methods, 1969-76

Organization and Management, Procedures \& Methods, 30-Day Delay, General, 1971-72

Box 315 Organization and Management, Procedures \& Methods, 30-Day Delay, General, 1972

Organization and Management, Procedures \& Methods, 30-Day Delay, General, 1972

Organization and Management, Procedures \& Methods, 30-Day Delay, Comments, 1971-72

Organization and Management, Procedures \& Methods, 30-Day Delay, Comments, 1972

Organization and Management, Procedures \& Methods, 30-Day Delay, Comments, 1972

Organization and Management, Procedures \& Methods, 30-Day Delay, Comments, 1972

Organization and Management, Procedures \& Methods, 30-Day Delay, Comments, 1972

Organization and Management, Procedures \& Methods, 30-Day Delay, Comments, 1972

Box 316 Organization and Management, Procedures \& Methods, 30-Day Delay, Comments, 1972

Organization and Management, Procedures \& Methods, 30-Day Delay, Comments, 1972

Organization and Management, Procedures \& Methods, 30-Day Delay, Comments, 1972

Organization and Management, Procedures \& Methods, 30-Day Delay, Comments, 1972

Organization and Management, Procedures \& Methods, 30-Day Delay, Comments, 1972

Organization and Management, Procedures \& Methods, 30-Day Delay, Comments, 1972

Oil and Gas, Notice to Leases, General, OCS, 1972-76

Box 317 Oil and Gas, Notice to Leases-2B, 1975

Oil and Gas, Notice to Leases-3, 1974

Oil and Gas, Notice to Leases-4, 1974-76

Oil and Gas, Notice to Leases-5, 1975-76

Oil and Gas, Notice to Leases-5, ca. 1974-76

Oil and Gas, Notice to Leases-6, 1975-76

Oil and Gas, Notice to Leases-6, 1975

Oil and Gas, Notice to Leases-6, 1976

Oil and Gas, Notice to Leases-6, 1975-76

Box 318 Oil and Gas, Notice to Leases-6, 1976

Oil and Gas, Notice to Leases-6, 1975

Oil and Gas, Notice to Leases-8, 1976

Oil and Gas, Reserves, 1915, 1953-58

Oil and Gas, Reserves, 1958

Oil and Gas, Reserves, 1959

Oil and Gas, Reserves, 1963-69

Oil and Gas, Reserves, 1971-74

Box $319 \quad$ Oil and Gas, Reserves, 1974-75

Oil and Gas, Reserves, OCS, 1948-74

Oil and Gas, Reserves, OCS, 1975-76

Oil and Gas, Safety, OCS, 1955-64

Oil and Gas, Safety, OCS, 1965-70

Oil and Gas, Competitive Lease Sales, California (5-14-63), Leasing, OCS, 1962

Oil and Gas, Competitive Lease Sales, California (5-14-63), Leasing, OCS, 1963 
Box 320 Oil and Gas, Competitive Lease Sales, California (12-15-66). Drainage, OCS, 1966

Oil and Gas, Competitive Lease Sales, California (2-6-68), Leasing, OCS, 1966-67

Oil and Gas, Competitive Lease Sales, California (2-6-68), Leasing, OCS, 1967

Oil and Gas, Competitive Lease Sales, California (12-75), Leasing, OCS, \#35, 1975-76

Oil and Gas, Competitive Lease Sales, California (12-75), Leasing, OCS, \#35, 1975-76

Oil and Gas, Competitive Lease Sales, California (12-75), Leasing, OCS, \#35, 1975

Box 321 Oil and Gas, Competitive Lease Sales, California (12-75), Leasing, OCS, \#35, 1973-74

Oil and Gas, Competitive Lease Sales, California (2-6-68), Leasing, OCS, 1968

Oil and Gas, Competitive Lease Sales, California (2-6-68), Leasing, OCS, 1967

Oil and Gas, Competitive Lease Sales, Florida (5-26-59), Leasing, 1956-59

Oil and Gas, Competitive Lease Sales, Florida (5-26-59), Leasing, ca. 1957

Oil and Gas, Competitive Lease Sales, Louisiana (10-13-54), Leasing, OCS, 1954-60

Oil and Gas, Competitive Lease Sales, Louisiana (8-11-59), Drainage, OCS, 1958-59

Oil and Gas, Competitive Lease Sales, Louisiana (10-9-62), Drainage, OCS, 1961-65

Box 322 Oil and Gas, Competitive Lease Sales, Louisiana (4-28-64), Drainage, OCS, 1963-64

Oil and Gas, Competitive Lease Sales, Louisiana (3-29-66), Drainage, OCS, 1965-66

Oil and Gas, Competitive Lease Sales, Louisiana (10-18-66), Drainage, OCS, 1966

Oil and Gas, Competitive Lease Sales, Louisiana (6-13-67), Leasing, OCS, 1966-67

Oil and Gas, Competitive Lease Sales, Louisiana (6-13-67), Leasing, OCS, 1967

Oil and Gas, Competitive Lease Sales, Louisiana (6-13-67), Leasing, OCS, 1967

Oil and Gas, Competitive Lease Sales, Louisiana (1969 3 pt.), Drainage, OCS, 1968

Box 323 Oil and Gas, Competitive Lease Sales, Louisiana (1969 3 pt.), Drainage, OCS, 1968-70

Oil and Gas, Competitive Lease Sales, Louisiana (1969 3 pt.), Drainage, OCS, 1969-70

Legal, Federal Legislation, 91st Congress (House), 1969-70

Legal, Federal Legislation, 91st Congress (House), 1969

Legal, Federal Legislation, 91st Congress (House), 1969-70

Box 324 Legal, Federal Legislation, 91st Congress, Unnumbered, 1969-71

Legal, Federal Legislation, 91st Congress, Unnumbered, 1969-71

Legal, Federal Legislation, 91st Congress, Mineral Leasing Reforms Legislation, 1970-71

Legal, Federal Legislation, 91st Congress, Mineral Leasing Reforms Legislation, 1970-71

Legal, Federal Legislation, 91st Congress, Mineral Leasing Reforms Legislation, 1970-71

Box 325 Legal, Federal Legislation, 92nd Congress (Senate), 1971-72

Legal, Federal Legislation, 92nd Congress (Senate), 1971

Legal, Federal Legislation, 92nd Congress (House), 1971-72

Legal, Federal Legislation, 92nd Congress (House), 1971

Legal, Federal Legislation, 92nd Congress (House), 1971

Box 326 Legal, Federal Legislation, 92nd Congress (House), 1971-72

Legal, Federal Legislation, 92nd Congress, Unnumbered, 1971-73

Legal, Federal Legislation, 92nd Congress, Unnumbered, 1970-71

Oil and Gas, Competitive Lease Sales, Western Louisiana (12-15-70), Leasing, OCS, Hearing (July 14-16, 1970), Vol. 1-B \& 2, 1970

Oil and Gas, Competitive Lease Sales, Western Louisiana (12-15-70), Leasing, OCS, Hearing (July 14-16, 1970), Vol. 1-B \& 2, 1970

Box 327 Oil and Gas, Competitive Lease Sales, Western Louisiana (12-15-70), Leasing, OCS, Hearing (July 14-16, 1970), Vol. 1-B \& 2, 1970

Oil and Gas, Competitive Lease Sales, Western Louisiana (12-15-70), Leasing, OCS, Hearing (July 14-16, 1970), Vol. 1B \& 2, 1970

Oil and Gas, Competitive Lease Sales, Western Louisiana (12-15-70), Leasing, OCS, Hearing (July 14-16, 1970), Vol. 1 \& 1A, 1970

Oil and Gas, Competitive Lease Sales, Western Louisiana (12-15-70), Leasing, OCS, Hearing (July 14-16, 1970), Vol. 1 \& 1A, 1970 
Box 328

Box 329

Box 330

Box 331

Box 332

Box 333

Box 334
Oil and Gas, Competitive Lease Sales, Western Louisiana (12-15-70), Leasing, OCS, Hearing (July 14-16, 1970), Vol. 1 \& 1A, 1970

Oil and Gas, Competitive Lease Sales, Western Louisiana (12-15-70), Leasing, OCS, Hearing (July 14-16, 1970), Vol. 1 \& 1A, 1970

Oil and Gas, Competitive Lease Sales, Western Louisiana (12-15-70), Leasing, OCS, 1967-70

Oil and Gas, Competitive Lease Sales, Western Louisiana (12-15-70), Leasing, OCS, 1969

Oil and Gas, Competitive Lease Sales, Western Louisiana (12-15-70), Leasing, OCS, 1970

Oil and Gas, Competitive Lease Sales, Western Louisiana (12-15-70), Leasing, OCS, 1970

Oil and Gas, Competitive Lease Sales, Western Louisiana (12-15-70), Leasing, OCS, 1970

Oil and Gas, Competitive Lease Sales, Western Louisiana (12-15-70), Leasing, OCS, 1970

Oil and Gas, Competitive Lease Sales, Western Louisiana (12-15-70), Leasing, OCS, 1970

Oil and Gas, Competitive Lease Sales, Western Louisiana (12-15-70), Leasing, OCS, 1970

Oil and Gas, Competitive Lease Sales, Western Louisiana (12-15-70), Leasing, OCS, 1970-76

Oil and Gas, Competitive Lease Sales, Louisiana (7-21-70), Drainage, OCS, 1969-70

Oil and Gas, Competitive Lease Sales, Louisiana (7-21-70), Drainage, OCS, 1970-71

Oil and Gas, Competitive Lease Sales, Louisiana (1969 3 pt.), Drainage, OCS, n.d., charts

Oil and Gas, Competitive Lease Sales, Louisiana (1969 3 pt.), Drainage, OCS, n.d., charts

Legal, Appeals, New Mexico, Potash, GS-63-OFF, 1973

Legal, Appeals, New Mexico, Potash, GS-63-OFF, 1973

Legal, Appeals, New Mexico, Potash, GS-63-OFF, 1973

Legal, Appeals, East Cameron Block 14 Field, Louisiana (GS-64-O\&G), 1973-74

Legal, Oil \& Gas, (30 CFR 221), 1974

Legal, Oil \& Gas, (30 CFR 221), 1974

Legal, Oil \& Gas, (30 CFR 221), 1974

Legal, Oil \& Gas, (30 CFR 221), 1974-75

Legal, Oil \& Gas, (30 CFR 221), 1974

Legal, Oil \& Gas, (30 CFR 221), 1974

Legal, Oil \& Gas, (30 CFR 221), 1974-75

Legal, Laws and Regulations, CFR, Operating, Oil \& Gas, (30 CFR 250), ca. 1975

Legal, Laws and Regulations, CFR, Operating, Oil \& Gas, (30 CFR 250), n.d.

Legal, Laws and Regulations, CFR, Operating, Oil \& Gas, (30 CFR 250), n.d.

Legal, Laws and Regulations, CFR, Operating, Oil \& Gas, (30 CFR 250), n.d.

Legal, Laws and Regulations, CFR, Operating, Oil \& Gas, (30 CFR 250), 1969

Legal, Laws and Regulations, CFR, Operating, Oil \& Gas, Unit Forms of Agreement, 1947-49

Legal, Laws and Regulations, CFR, Operating, Oil \& Gas, Unit Forms of Agreement, 1950-55

Legal, Laws and Regulations, CFR, Operating, Oil \& Gas, Unit Forms of Agreement, 1957

Legal, Laws and Regulations, CFR, Operating, Oil \& Gas, Unit Forms of Agreement, 1958-61

Legal, Laws and Regulations, CFR, Operating, Oil \& Gas, Unit Forms of Agreement, 1962-68

Legal, Laws and Regulations, CFR, Operating, Oil \& Gas, Unit Forms of Agreement, 1968

Legal, Laws and Regulations, CFR, Operating, Oil \& Gas, Unit Forms of Agreement, OCS, 1968-71

Legal, Laws and Regulations, CFR, Operating, Oil \& Gas, Unit Forms of Agreement, OCS, 1972-75

Legal, Laws and Regulations, CFR, Operating, Oil \& Gas, Unit Forms of Agreement, Alaska, 1960-67

Legal, Laws and Regulations, CFR, Operating, Oil \& Gas, Unit Forms of Agreement, Alaska, 1967-68

Legal, Other Minerals, Coal (30 CFR 211 \& 216), 1979

Legal, Alaska Orders, OCS, 1975

Legal, Gulf Coast Orders, OCS, 1973-74

Legal, Gulf Coast Orders, OCS, 1973-74 
Box 336 Land, Known Geothermal-resource Areas, Roosevelt Hot Springs, 1976

Land, Known Geothermal-resource Areas, Roosevelt Hot Springs, [maps], n.d.

Legal, Claims \& Litigations, General, 1974-76

Legal, Claims \& Litigations, General, OCS, 1975-76

Legal, Claims \& Litigations, General, OCS, 1975

Legal, Claims \& Litigations, General, OCS, n.d.

Legal, Claims \& Litigations, U. S. v. Chevron Oil Co., OCS, 1970

Legal, Claims \& Litigations, County of Santa Barbara v. Hickel, OCS, 1970-76

Box 337 Legal, Claims \& Litigations, County of Santa Barbara v. Hickel, OCS, 1969-70

Legal, Claims \& Litigations, County of Santa Barbara v. Malley, OCS, 1969-70

Legal, Claims \& Litigations, Gulf, Mobil, Texaco, Union v. Morton, OCS, 1971

Legal, Claims \& Litigations, Gulf, Mobil, Texaco, Union v. Morton, OCS, 1971-73

Legal, Claims \& Litigations, Hall v. Union Oil, OCS, 1969

Legal, Claims \& Litigations, Humble, Standard, ARColorado v. Morton, OCS, 1971-72

Box 338 Legal, Claims \& Litigations, Kern County Refinery v. Kleppe et al., 1972

Legal, Claims \& Litigations, Kern County Refinery v. Schambeck et al., 1972

Legal, Claims \& Litigations, Thomas C. Lynch v. U. S., OCS, 1970-71

Legal, Claims \& Litigations, Kerr-McGee v. Morton et al., 1971

Legal, Claims \& Litigations, Natural Resources Defense Council v. Morton, OCS, 1970-75

Legal, Claims \& Litigations, Northern Natural Gas v. Grounds et al., ca. 1963-68

Legal, Claims \& Litigations, Northern Natural Gas v. Grounds et al., ca. 1973

Box 339 Legal, Claims \& Litigations, Powell et al. v. Morton et al, 1972-73

Legal, Claims \& Litigations, Nola Grace Ptasynski v. Hathaway et al., 1975

Legal, Claims \& Litigations, Reyos et al. v. First Security Bank, Utah, 1967-68

Legal, Claims \& Litigations, Santa Barbara, Tort Claims, OCS, 1969-70

Legal, Claims \& Litigations, U. S. v. Shell Oil Co., OCS, 1971

Legal, Claims \& Litigations, Simons v. Vinson \& Clark, 1975

Legal, Claims \& Litigations, Standard Oil of California v. Morton et al., 1971-72

Legal, Claims \& Litigations, Standard Oil of California v. Morton et al., 1971-72

Legal, Claims \& Litigations, State of California v. Morton et al., OCS, 1975

Legal, Claims \& Litigations, Union, Gulf, Mobil, Texaco v. Morton, OCS, 1969-75

Legal, Claims \& Litigations, U. S. Royalty Oil Corp. v. Morton, 1971-75

Box $340 \quad$ Legal, Claims \& Litigations, U. S. v. Frank Winegar et al., 1965-67

Legal, Claims \& Litigations, U. S. v. Frank Winegar et al., n.d.

Legal, Claims \& Litigations, U. S. v. Frank Winegar et al., n.d.

Legal, Claims \& Litigations, U. S. v. Frank Winegar et al., n.d.

Legal, Claims \& Litigations, U. S. v. Frank Winegar et al., n.d.

Box 341 Legal, Claims \& Litigations, U. S. v. Frank Winegar et al., n.d.

Legal, Claims \& Litigations, U. S. v. Union Carbide Corp., 1973-74

Legal, State Claims and Litigations, U. S. v. Louisiana, OCS, (\#9 Original), 1976

Legal, Appeals, General, 1967-74

Legal, Appeals, General, OCS, 1972

Legal, Appeals, General, OCS, 1973

Legal, Appeals, Kettlemen Hills (Middle Dome), 1972-73

Legal, Appeals, Lost Soldier Field, Well Counts, 1974-77 
Box 342 Legal, Appeals, "Appeal - Well Count - Lost Soldier Unit," Lost Soldier Field, Wyoming, IBLA 72-136 Atlantic Richfield, GS-44, 1962-71

Legal, Appeals, "Appeal - Well Count - Lost Soldier Unit," Lost Soldier Filed, Wyoming, IBLA 72-136 Atlantic Richfield, GS-44, ca. 1974

Legal, Appeals, "Appeal - Well Count - Lost Soldier Unit," Lost Soldier Filed, Wyoming,

IBLA 72-136 Atlantic Richfield, GS-44, ca. 1971

Legal, Appeals, Kirkpatrick (GS-52- O\&G), ca. 1973-74

Legal, Appeals, West Cameron Block 71 \& 149 Field, (GS-59-O\&G), ca. 1971-74

Legal, Appeals, Bullhook Unit (GS-62-O\&G), ca. 1973-74

Box $343 \quad$ Legal, Appeals, Bullhook Unit (GS-62-O\&G), ca. 1972-74

Legal, Appeals, New Mexico, Potash (GS-63-O\&G), 1973-75

Potash, Searles Lake Area, California, 1973-76

Potash, Searles Lake Area, California, ca. 1973

Potash, Searles Lake Area, California, ca. 1973

Potash, Searles Lake Area, California, ca. 1973

Potash, Cane Creek Area, Utah, ca. 1960-63

Box 344 Potash, Cane Creek Area, Utah, 1960

Potash, Cane Creek Area, Utah, 1960-61

Potash, Cane Creek Area, Utah, 1962-68

Potash, Cane Creek Area, Utah, 1935-60

Potash, Cane Creek Area, Utah, [plats], ca. 1960

Box 345 Potash, Cane Creek Area, Utah, 1960

Potash, New Mexico, Potash Area, 1931-51

Potash, New Mexico, Potash Area, 1951

Potash, New Mexico, Potash Area, 1951

Potash, New Mexico, Potash Area, 1951-52

Potash, New Mexico, Potash Area, 1953-56

Box 346 Potash, New Mexico, Potash Area, 1956-57

Potash, New Mexico, Potash Area, 1958-62

Potash, New Mexico, Potash Area, 1963-64

Potash, New Mexico, Potash Area, 1965-69

Meetings, Interior Department, 1975

Meetings, Interior Department, 1975

Box 347 Meetings, Interior Department, 1975-76

Meetings, Interior Department, ca. 1974

Meetings, Interior Department, ca. 1974

Meetings, Interior Department, 1975-76

Meetings, Interior Department, OCS, 1954-73

Meetings, Interior Department, OCS, 1975-76

Box 348 Meetings, Interior Department, OCS, 1973-74

Meetings, Interior Department, OCS, 1975-76

Meetings, Interior Department, RCM Conferences, 1973-76

Meetings, International, 1969-75

Meetings, International, (printed items) 1971

Box 349 Meetings, International, Energy Resources Conservation Board, Calgary, Alberta, Canada, (December 1973), 1974

Meetings, International, OCS, 1956-71

Meetings, International, OCS, ca. 1956

Meetings, International, OCS, ca. 1958

Legal, Federal Legislation, 82nd Congress, 1949-52

Legal, Federal Legislation, 82nd Congress, ca. 1951-52 
Box $350 \quad$ Legal, Federal Legislation, 81st Congress, ca. 1949-50

Legal, Federal Legislation, 81st Congress, ca. 1949-50

Legal, Federal Legislation, 81st Congress, ca. 1949-51

Legal, Federal Legislation, 80th Congress, 1947-48

Legal, Federal Legislation, 80th Congress, 1947-48

Legal, Federal Legislation, 80th Congress, 1947

Box $351 \quad$ Legal, Federal Legislation, 79th Congress, ca. 1945-47

Legal, Federal Legislation, 67th - 78th Congress, ca. 1937-44

Legal, Federal Legislation, 67th - 78th Congress, ca. 1924-38

Legal, Federal Legislation, 63rd - 66th Congress, ca. 1914-20

Legal, Federal Legislation, 63rd - 66th Congress, ca. 1913-16

Box 352 Legal, Federal Legislation, 63rd - 66th Congress, ca. 1913-16

Legal, Federal Legislation, Beginning - 62nd Congress, 1907, 1909-11

Legal, Federal Legislation, Beginning - 62nd Congress, 1909-11

Legal, Federal Legislation, Beginning - 62nd Congress, 1909, 1911-13

Legal, Laws and Regulations, State, Louisiana Regulations, ca. 1927-53

Legal, Laws and Regulations, State, Louisiana Regulations, 1954

Legal, Laws and Regulations, State, Louisiana Regulations, ca. 1956-69

Box 353 Legal, Laws and Regulations, State, Louisiana Statewide Orders, ca. 1940-53

Legal, Laws and Regulations, State, Louisiana Statewide Orders, ca. 1956-67

Legal, Laws and Regulations, State, Louisiana Statewide Orders, ca. 1968-71

Legal, Laws and Regulations, State, Ohio Regulations, ca. 1917-72

Legal, Laws and Regulations, State, Oregon Regulations, ca. 1961-69

Legal, Laws and Regulations, State, Oregon Regulations, ca. 1969-75

Legal, Laws and Regulations, State, Pennsylvania Regulations, ca. 1927-68

Legal, Laws and Regulations, State, Pennsylvania Regulations, ca. 1969

Legal, Laws and Regulations, State, Texas Regulations, ca. 1923-54

Box 354 Legal, Laws and Regulations, State, Texas Regulations, ca. 1956-68

Legal, Laws and Regulations, State, Texas Regulations, 1969

Legal, Supervisor's Orders, OCS Orders, General, 1974-76

Legal, Laws and Regulations, Alaska Coast Orders, OCS, ca. 1969-74

Legal, Laws and Regulations, Alaska Coast Orders, OCS, 1974-75

Legal, Laws and Regulations, Alaska Coast Orders, OCS, 1975-76

Box 355 Legal, Laws and Regulations, Alaska Coast Orders, OCS, 1974-76

Legal, Laws and Regulations, Alaska Coast Orders, OCS, 1974-76

Legal, Laws and Regulations, Alaska Coast Orders, OCS, 1974-76

Legal, Laws and Regulations, Gulf Coast Orders, OCS, 1969-70

Legal, Laws and Regulations, Gulf Coast Orders, OCS, 1971-74

Legal, Laws and Regulations, Gulf Coast Orders, OCS, 1958-71

Box 356 Legal, Laws and Regulations, Pacific Coast Orders, OCS, 1970-71

Legal, Laws and Regulations, Pacific Coast Orders, OCS, 1971

Legal, Laws and Regulations, Pacific Coast Orders, OCS, 1971

Legal, Laws and Regulations, Pacific Coast Orders, OCS, 1972-74

Legal, Laws and Regulations, Pacific Coast Orders, OCS, 1974

Box 357 Legal, Laws and Regulations, Pacific Coast Orders, OCS, 1973-74

Legal, Laws and Regulations, Pacific Coast Orders, OCS, 1974

Legal, Laws and Regulations, Pacific Coast Orders, OCS, 1974-76

Legal, Laws and Regulations, Pacific Coast Orders, OCS, 1974-76

Legal, Laws and Regulations, Pacific Coast Orders, OCS, 1974

Box 358 Legal, Laws and Regulations, Atlantic Coast Orders, OCS, 1974-75

Legal, Laws and Regulations, Atlantic Coast Orders, OCS, 1976 
Box 359

Box 360

Box 361

Box 362

Box 363

Box 364

Box 365

Box 366
Legal, Laws and Regulations, Atlantic Coast Orders, OCS, 1976 Legal, Laws and Regulations, Atlantic Coast Orders, OCS, 1976 Legal, Laws and Regulations, Atlantic Coast Orders, OCS, 1975 Legal, Laws and Regulations, Field Rules, 1958-74 Legal, Laws and Regulations, Field Rules, OCS, Bay Marchand to Grand Isle, ca. 1969-74 Legal, Laws and Regulations, Field Rules, OCS, High Island to Maine Pass, ca. 1969-74 Legal, Laws and Regulations, Field Rules, OCS, Ship Shoal to South Marsh, ca. 1969-74 Legal, Laws and Regulations, Field Rules, OCS, South Pass to South Timbalier, ca. 1969-73 Legal, Laws and Regulations, Field Rules, OCS, Tiger Shoal to Vermillion, ca. 1969-74 Legal, Laws and Regulations, Field Rules, OCS, West Cameron to West Delta, ca. 1969-74 Legal, Private Laws, Pearl Marr Case, 1970

Legal, Laws and Regulations, Geological \& Geophysical (30 CFR 251), OCS, 1974 Legal, Laws and Regulations, Geological \& Geophysical (30 CFR 251), OCS, 1974-75 Legal, Laws and Regulations, Geological \& Geophysical (30 CFR 251), OCS, 1974 Legal, Laws and Regulations, Geological \& Geophysical (30 CFR 251), OCS, 1975 Legal, Laws and Regulations, Geological \& Geophysical (30 CFR 251), OCS, 1975 Legal, Laws and Regulations, Geological \& Geophysical (30 CFR 251), OCS, 1976 Legal, Laws and Regulations, Geological \& Geophysical (30 CFR 251), OCS, 1976 Legal, Laws and Regulations, Geological \& Geophysical (30 CFR 251), OCS, 1975 Legal, Laws and Regulations, Geological \& Geophysical (30 CFR 251), OCS, ca. 1969 Legal, Laws and Regulations, Geological \& Geophysical (30 CFR 251), OCS, ca. 1969 Legal, Laws and Regulations, Geological \& Geophysical (30 CFR 251), OCS, ca. 1969 Legal, Laws and Regulations, Oil \& Gas, Royalty Oil (30 CFR 225), 1971-76 Legal, Laws and Regulations, Oil \& Gas, Royalty Oil (30 CFR 225), 1976 Legal, Laws and Regulations, Oil \& Gas, Royalty Oil (30 CFR 225a), 1971-76 Legal, Laws and Regulations, Oil \& Gas, Royalty Oil (30 CFR 225a), 1976 Legal, Laws and Regulations, Oil \& Gas, Royalty Oil (30 CFR 225a), 1976 Legal, Laws and Regulations, Oil \& Gas, Helium (30 CFR 1 \& 2), ca. 1938-64 Legal, Laws and Regulations, Other Minerals, Coal (30 CFR 211 \& 216), 1975 Legal, Laws and Regulations, Other Minerals, Coal (30 CFR 211 \& 216), 1975-76 Legal, Laws and Regulations, Other Minerals, Coal (30 CFR 211 \& 216), 1976 Legal, Laws and Regulations, Other Minerals, Coal (30 CFR 211 \& 216), 1976 Legal, Laws and Regulations, Other Minerals, Coal (30 CFR 211 \& 216), ca.1973-75 Legal, Laws and Regulations, Other Minerals, Coal (30 CFR 211 \& 216), ca. 1973 Legal, Laws and Regulations, Other Minerals, Coal (30 CFR 211), n.d. Legal, Laws and Regulations, Other Minerals, Coal (30 CFR 211), n.d. Legal, Laws and Regulations, Other Minerals, Coal (30 CFR 211), n.d. Legal, Laws and Regulations, Other Minerals, Coal (30 CFR 211), ca. 1975 Legal, Laws and Regulations, Other Minerals, Coal (30 CFR 211), ca. 1972-74 Legal, Laws and Regulations, Other Minerals, Coal (30 CFR 211), ca. 1973 Legal, Laws and Regulations, Operating Geothermal (30 CFR 270), ca. 1975 Legal, Laws and Regulations, Operating Geothermal (30 CFR 270), ca. 1975 Legal, Laws and Regulations, Operating Geothermal (30 CFR 270), ca. 1975 Legal, Laws and Regulations, Operating Geothermal (30 CFR 270), ca. 1971 Legal, Laws and Regulations, Operating Geothermal (30 CFR 270), ca. 1971 Legal, Laws and Regulations, Operating Geothermal (30 CFR 270), ca. 1971 Legal, Laws and Regulations, Operating Geothermal (30 CFR 270), 1972-76 Legal, Laws and Regulations, Operating Geothermal (30 CFR 270), 1975

Legal, Laws and Regulations, Operating Geothermal (30 CFR 270), 1975

Legal, Federal Legislation, 93rd Congress, House, ca. 1975-76

Legal, Federal Legislation, 93rd Congress, House, ca. 1976

Legal, Federal Legislation, 93rd Congress, House, ca. 1973-76 
Box 367 Legal, Federal Legislation, 93rd Congress, House, ca. 1967-74

Legal, Federal Legislation, 93rd Congress, House, ca. 1973-74

Legal, Power of Attorney [c.r. filed in legal sized folder - see boxes 289-291 \& 335]

Legal, Power of Attorney, 1976

Legal, Power of Attorney, 1975-76

Mapping, General, 1933, 1956-74

Box $368 \quad$ Mapping, General, 1974-76

Mapping, General, OCS, 1954-55

Mapping, General, OCS, 1956-76

Mapping, General, OCS, [maps], n.d.

Mapping, General, OCS, [maps], n.d.

Mapping, Topographic Mapping, 1966-69

Mapping, Topographic Mapping, 1951-76

Box 369 Mapping, Topographic Mapping, 1969-72

Mapping, Topographic Mapping, [maps], ca. 1974-75

Meetings, General, 1975-76

Meetings, Interior Department, 1968-75

Meetings, Interior Department, 1974-75

Physical Exploration, Core Storage, 1952-75

Box $370 \quad$ Pollution, General, 1964-66

Pollution, General, 1967

Pollution, General, 1968

Pollution, General, 1969-70

Pollution, General, 1971

Pollution, General, 1972-76

Box 371 Pollution, General, ca. 1968-73

Pollution, General, OCS, 1966-67

Pollution, General, OCS, 1968

Pollution, General, OCS, 1969

Pollution, General, OCS, 1969

Pollution, General, OCS, 1969

Pollution, General, OCS, 1970

Box $372 \quad$ Pollution, General, OCS, 1970

Pollution, General, OCS, 1970

Pollution, General, OCS, 1970

Pollution, General, OCS, 1971

Pollution, General, OCS, 1971

Pollution, General, OCS, 1972-73

Box $373 \quad$ Pollution, General, OCS, 1972-75

Legal, Laws and Regulations, Pollution, Oil Discharge (18 CFR 610), OCS, 1970

Legal, Laws and Regulations, Pollution, Oil Discharge (18 CFR 610), OCS, 1970-75

Legal, Laws and Regulations, Transportation, Pipelines (49 CFR 180-199), 1969-75

Legal, Laws and Regulations, Transportation, Pipelines (49 CFR 180-199), 1975

Legal, Laws and Regulations, Forest Service (36 CFR 251), 1966-75

Legal, Laws and Regulations, Coast Guard (33 CFR -), 1971-72

Legal, Laws and Regulations, Foreign, General, [printed item] 1967

Legal, Laws and Regulations, Foreign, General, 1908-74

Box 374 Legal, Laws and Regulations, Foreign, General, OCS, ca. 1966-72

Legal, Laws and Regulations, Foreign, General, OCS, ca. 1962-72

Legal, Laws and Regulations, Foreign, General, OCS, ca. 1968

Legal, Laws and Regulations, Foreign, General, OCS, ca. 1962

Legal, Laws and Regulations, Foreign, General, OCS, ca. 1967

Legal, Laws and Regulations, Foreign, Philippine Leasing Laws, 1920-49

Box 375 Legal, Laws and Regulations, Foreign, Philippine Leasing Laws, 1949-55 
Box 376

Box 377

Box 378

Box 379

Box 380

Box 381

Box 382
Legal, Laws and Regulations, Foreign, Philippine Leasing Laws, 1970 Legal, Laws and Regulations, International Laws, OCS, 1954-68 Legal, Laws and Regulations, International Laws, OCS, 1969-70 Legal, Laws and Regulations, International Laws, OCS, 1970-76 Legal, Laws and Regulations, Public Laws, General, 1908-30 Legal, Laws and Regulations, Public Laws, General, ca. 1971-74 Legal, Laws and Regulations, Public Laws, General, 1932-65 Legal, Laws and Regulations, Public Laws, General, 1974-76 Legal, Laws and Regulations, Public Laws, General, 1976 Legal, Laws and Regulations, Public Laws, General, ca. 1971-75 Legal, Laws and Regulations, Gulf Coast Orders, OCS Order No. 11, 1972-74 Legal, Laws and Regulations, Gulf Coast Orders, OCS Order No. 11, 1974-76 Legal, Laws and Regulations, Gulf Coast Orders, OCS Order No. 14, 1974 Legal, Laws and Regulations, Gulf Coast Orders, OCS Order No. 14, 1974-76 Legal, Laws and Regulations, Gulf Coast Orders, OCS, 1958-69 Legal, Laws and Regulations, Gulf Coast Orders, OCS, 1969 Legal, Laws and Regulations, Gulf Coast Orders, OCS, 1969 Legal, Laws and Regulations, Gulf Coast Orders, OCS, 1970-71 Legal, Laws and Regulations, Gulf Coast Orders, OCS, 1971-74 Legal, Laws and Regulations, Gulf Coast Orders, OCS, 1974-75 Legal, Laws and Regulations, Gulf Coast Orders, OCS, 1975-76 Legal, Laws and Regulations, Gulf Coast Orders, OCS, 1974-75 Legal, Laws and Regulations, Gulf Coast Orders, OCS, 1976 Legal, Laws and Regulations, Gulf Coast Orders, OCS, 1975 Legal, Laws and Regulations, Gulf Coast Orders, OCS, ca. 1970 Legal, Laws and Regulations, Gulf Coast Orders, OCS, ca. 1970-72 Legal, Laws and Regulations, Pacific Coast Orders, OCS, 1965-69 Legal, Laws and Regulations, Pacific Coast Orders, OCS, 1969 Legal, Laws and Regulations, Pacific Coast Orders, OCS, 1969-70 Legal, Laws and Regulations, Pacific Coast Orders, OCS, 1970

Meetings, International, OCS, 1955-71

Meetings, International, OCS, 1972-75

Meetings, Non-Government, Technical, 1969

Meetings, Non-Government, Technical, 1969-71

Meetings, Non-Government, Technical, 1972-73

Meetings, Non-Government, Technical, 1974-76

Meetings, Non-Government, Technical, 1973-74

Meetings, Non-Government, Technical, ca. 1976

Meetings, Non-Government, Technical, ca. 1974

Meetings, Non-Government, Technical, ca. 1972

Meetings, Non-Government, Technical, OCS, 1967-69

Meetings, Non-Government, Technical, OCS, 1970

Meetings, Non-Government, Technical, OCS, 1971

Meetings, Non-Government, Technical, OCS, 1972

Meetings, Non-Government, Technical, OCS, 1972

Meetings, Non-Government, Technical, OCS, 1973

Meetings, Non-Government, Technical, OCS, 1973-75

Meetings, Non-Government, Technical, OCS, 1975-76

Meetings, Non-Government, Technical, OCS, ca. 1974-75 
Box 383 Meetings, Non-Government, Technical, OCS, ca. 1973

Legal, Federal Legislation, 83rd Congress, 1953-54

Legal, Federal Legislation, 83rd Congress, 1953-54

Legal, Federal Legislation, 83rd Congress, 1953

Legal, Federal Legislation, 83rd Congress, 1953-55

Box $384 \quad$ Legal, Federal Legislation, 84th Congress, 1955-56

Legal, Federal Legislation, 84th Congress, 1955

Legal, Federal Legislation, 84th Congress, 1955-56

Legal, Federal Legislation, 85th Congress, 1956-58

Legal, Federal Legislation, 86th Congress, 1959-60

Box 385 Legal, Federal Legislation, 86th Congress, 1959-61

Legal, Federal Legislation, 87th Congress, Senate, 1961-63

Legal, Federal Legislation, 87th Congress, Senate, 1961

Legal, Federal Legislation, 87th Congress, Senate, 1961-62

Legal, Federal Legislation, 87th Congress, House, 1961-62

Legal, Federal Legislation, 87th Congress, House, 1961-62

Box 386 Legal, Federal Legislation, 87th Congress, House, 1961

Legal, Federal Legislation, 87th Congress, House, 1961-62

Legal, Federal Legislation, 88th Congress, Senate, 1963-64

Legal, Federal Legislation, 88th Congress, Senate, 1963-64

Legal, Federal Legislation, 88th Congress, Senate, 1963-64

Legal, Federal Legislation, 88th Congress, House, 1963-64

Box 387 Legal, Federal Legislation, 88th Congress, House, 1963-64

Legal, Federal Legislation, 88th Congress, House, 1963-64

Legal, Federal Legislation, 88th Congress, House, 1963-64

Legal, Federal Legislation, 89th Congress, Senate, 1966

Legal, Federal Legislation, 89th Congress, Senate, 1965-66

Legal, Federal Legislation, 89th Congress, Senate, 1965-66

Box 388 Legal, Federal Legislation, 89th Congress, House, 1965-66

Legal, Federal Legislation, 89th Congress, House, 1965-66

Legal, Federal Legislation, 89th Congress, House, 1964-65

Legal, Federal Legislation, 90th Congress, 1967-68

Legal, Federal Legislation, 90th Congress, 1967

Legal, Federal Legislation, 90th Congress, 1967-68

Box 389 Legal, Federal Legislation, 90th Congress, 1967

Legal, Federal Legislation, 90th Congress, 1967-68

Legal, Federal Legislation, 91st Congress, Senate, 1969-76

Legal, Federal Legislation, 91st Congress, Senate, 1969-70

Legal, Federal Legislation, 91st Congress, Senate, 1970

Legal, Federal Legislation, 91st Congress, Senate, 1969-70

Box 390 Oil and Gas, Drilling Operations, General, 1926, 1928-31, 1933-76

Oil and Gas, Drilling Operations, General, OCS, 1963-74

Oil and Gas, Drilling Operations, General, OCS, 1974

Oil and Gas, Drilling Operations, General, OCS, 1975

Box $391 \quad$ Oil and Gas, Drilling Operations, General, OCS, 1976

Oil and Gas, Drilling Operations, General, OCS, 1976

Oil and Gas, Drilling Operations, General, OCS, 1975

Oil and Gas, Drilling Operations, General, OCS, 1975

Box 392 Oil and Gas, Drilling Operations, General, OCS, ca. 1966

Oil and Gas, Drilling Operations, General, OCS, ca. 1965 
Box 393

Box 394

Box 395

Box 396

Box 397

Box 398

Box 399

Box 400
Oil and Gas, Drilling Operations, General, OCS, 1976

Oil and Gas, Drilling Operations, Slant-Hole Drilling, ca. 1954

Oil and Gas, Drilling Operations, Slant-Hole Drilling, 1956-65

Oil and Gas, Drilling Operations, Slant-Hole Drilling, OCS, 1963-75

Oil and Gas, Drilling Operations, Underwater Completions, OCS, 1963-68

Oil and Gas, Drilling Operations, Underwater Completions, OCS, 1968-75

Oil and Gas, Exploration \& Development, General, 1964-76

Oil and Gas, Exploration \& Development, General, OCS, ca. 1956-75

Pollution, Suggestions, OCS, ca. 1970

Pollution, Suggestions, OCS, ca. 1968

Pollution, Suggestions, OCS, ca. 1968-69

Pollution, Suggestions, OCS, ca. 1970

Pollution, Suggestions, OCS, ca. 1970

Pollution, Suggestions, OCS, ca. 1970

Pollution, Suggestions, OCS, ca. 1969-70

Pollution, General, OCS, ca. 1969-73

Pollution, General, OCS, ca. 1973

Pollution, General, OCS, ca. 1969

Pollution, General, OCS, ca. 1969

Pollution, General, OCS, ca. 1967

Pollution, General, OCS, ca. 1970

Pollution, General, OCS, ca. 1969

Pollution, General, OCS, ca. 1972

Pollution, General, OCS, ca. 1969

Pollution, Contingency Plan, Regional, OCS, 1970

Pollution, Contingency Plan, Regional, OCS, 1970

Pollution, Contingency Plan, Regional, OCS, 1970

Pollution, Contingency Plan, Regional, OCS, 1970

Oil and Gas, Deepwater Ports, 1973

Oil and Gas, Deepwater Ports, 1973

Oil and Gas, Reefs, Artificial Fishing Reefs, OCS, 1974

Oil and Gas, Royalty Bidding \& Bonus, OCS, 1973-75

Oil and Gas, Royalty Bidding \& Bonus, OCS, 1975-77

Oil and Gas, Royalty Bidding \& Bonus, OCS, 1972

Oil Shale, General, 1916, 1920-29

Oil Shale, General, 1930-31

Oil Shale, General, 1932-55

Oil Shale, General, 1956-63

Oil Shale, General, 1964

Oil Shale, General, 1964

Oil Shale, General, 1964

Oil Shale, General, 1965

Oil Shale, General, 1966

Oil Shale, General, 1966

Oil Shale, General, 1967

Oil Shale, General, 1967

Oil Shale, General, 1967

Oil Shale, General, 1967

Oil Shale, General, 1968

Oil Shale, General, 1968

Oil Shale, General, 1968 
Oil Shale, General, 1968

Oil Shale, General, 1968

Box $401 \quad$ Oil Shale, General, 1968

Oil Shale, General, 1968-69

Oil Shale, General, 1969

Oil Shale, General, 1969-70

Oil Shale, General, 1970

Oil Shale, General, 1970

Box $402 \quad$ Oil Shale, General, 1970-71

Oil Shale, General, 1971

Oil Shale, General, 1971

Oil Shale, General, 1971-73

Oil Shale, General, 1973

Box $403 \quad$ Oil Shale, General, 1973-74

Oil Shale, General, 1974

Oil Shale, General, 1974-75

Oil Shale, General, 1975

Box $404 \quad$ Oil Shale, General, 1976

Oil Shale, General, 1976

Oil Shale, General, ca. 1974-75

Oil Shale, General, ca. 1975

Oil Shale, General, ca. 1976

Oil Shale, General, ca. 1970

Box 405 Oil Shale, General, ca. 1967-75

Oil Shale, General, ca. 1969

Oil Shale, General, ca. 1968-69

Oil Shale, General, ca. 1969

Oil Shale, General, ca. 1968

Oil Shale, General, ca. 1968

Box $406 \quad$ Oil Shale, General, ca. 1968

Oil Shale, General, ca. 1966-71

Oil Shale, General, ca. 1976

Oil Shale, General, ca. 1975

Oil Shale, General, ca. 1975

Box 407 Organization and Management, Studies, Future Petroleum Supply Study, 1966-68

Organization and Management, Studies, Future Petroleum Supply Study, 1968

Organization and Management, Studies, Future Petroleum Supply Study, 1966-68

Organization and Management, Studies, Hoover Commission Study, 1948-57

Organization and Management, Studies, Hoover Commission Study, 1948

Organization and Management, Studies, Hoover Commission Study, (printed items) 1949

Organization and Management, Studies, Hydrogen Sulfide Study, 1973-75

Organization and Management, Studies, Interagency Energy Mineral Reclamation, 1973

Box $408 \quad$ Organization and Management, Studies, Manual Reporting System, 1974-76

Organization and Management, Studies, Manual Reporting System, 1975

Organization and Management, Studies, Manual Reporting System, 1974

Organization and Management, Studies, Metric System Study, 1971-76

Organization and Management, Studies, Mineral Leasing (Broadbent) Study, 1965-66

Organization and Management, Studies, Mississippi Delta Study, OCS, 1974

Organization and Management, Studies, National Ocean Policy Study, 1974-75

Box 409 Organization and Management, Studies, North Central Power Study, 1972

Organization and Management, Studies, Northern Great Plains Resource Program, 1973-74 
Box 410

Box 411

Box 412

Box 413

Box 414

Box 415

Box 416
Organization and Management, Studies, Onshore-Lease Management Study, 1973-74 Organization and Management, Studies, Onshore-Lease Management Study, 1974-76 Organization and Management, Studies, Onshore-Lease Management Study, 1975

Organization and Management, Studies, Onshore Oil \& Gas Royalty Accounting System, 1975 Organization and Management, Studies, OCS, Leasing-Policy Studies (McKelvey), 1968 Organization and Management, Studies, OCS, Leasing-Policy Studies (McKelvey), 1968 Organization and Management, Studies, OCS, Leasing-Policy Studies (McKelvey), 1968 Legal, Federal Legislation, 92nd Congress, (Mineral-Leasing Reforms Legislation), 1973-74 Legal, Federal Legislation, 92nd Congress, (Mineral-Leasing Reforms Legislation), 1973-74 Legal, Federal Legislation, 93rd Congress, Senate, 1975-76

Legal, Federal Legislation, 93rd Congress, Senate, 1975

Legal, Federal Legislation, 93rd Congress, Senate, 1974-75

Legal, Federal Legislation, 93rd Congress, Senate, 1975-76

Legal, Federal Legislation, 93rd Congress, Senate, 1975-76

Legal, Federal Legislation, 93rd Congress, Senate, 1974-75

Legal, Federal Legislation, 93rd Congress, Senate, 1974

Legal, Federal Legislation, 93rd Congress, Unnumbered, 1973

Legal, Federal Legislation, 93rd Congress, House, 1974-75

Legal, Federal Legislation, 93rd Congress, House, 1974-75

Legal, Federal Legislation, 93rd Congress, House, 1974-75

Legal, Federal Legislation, 93rd Congress, House, 1974

Legal, Federal Legislation, 93rd Congress, House, 1973-74

Legal, Federal Legislation, 94th Congress, House Resolutions, 1975-76

Legal, Federal Legislation, 94th Congress, House Resolutions, 1976

Legal, Federal Legislation, 94th Congress, House Resolutions, 1975

Oil and Gas, Exploration \& Development, Communitization Agreements, 1972-76

Oil and Gas, Geologic Structures, 1920, 1932, 1938, 1946-76

Oil and Gas, Gases, Natural Gas, General, 1937-76

Oil and Gas, Gases, Natural Gas, General, ca. 1970-73

Oil and Gas, Gases, Natural Gas, General, (printed items) ca. 1973

Oil and Gas, Gases, Natural Gas, General, OCS, 1969-70

Oil and Gas, Gases, Natural Gas, General, OCS, 1970-71

Oil and Gas, Gases, Natural Gas, General, OCS, 1972

Oil and Gas, Gases, Natural Gas, General, OCS, 1973-75

Oil and Gas, Gases, Natural Gas, General, OCS, 1972

Oil and Gas, Gases, Natural Gas Flaring, OCS, 1968-72

Oil and Gas, Gases, Natural Gas Flaring, OCS, 1973-76

Oil and Gas, Gases, Natural Gas Flaring, OCS, Comments to FPC, 1972

Oil and Gas, Gases, Natural Gas Flaring, OCS, Comments to FPC, 1972

Oil and Gas, Gases, Natural Gas Flaring, 1958-76

Oil and Gas, Gases, Natural Gas Processing, OCS, 1958-60

Oil and Gas, Gases, Natural Gas Processing, OCS, 1961-65

Oil and Gas, Gases, Natural Gas Processing, OCS, 1966-68

Oil and Gas, Gases, Natural Gas Processing, OCS, 1970

Oil and Gas, Gases, Natural Gas Processing, OCS, 1971-72

Oil and Gas, Gases, Natural Gas Processing, OCS, 1971

Oil and Gas, Gases, Natural Gas Processing, OCS, 1971

Oil and Gas, Leasing, General, 1914, 1920-54

Oil and Gas, Leasing, General, 1960-75

Oil and Gas, Leasing, General, 1963

Oil and Gas, Leasing, General, 1963 
Box 417 Oil and Gas, Leasing, General, OCS, 1974

Oil and Gas, Leasing, General, OCS, 1974

Oil and Gas, Leasing, General, OCS, 1975-76

Oil and Gas, Leasing, General, OCS, ca. 1974-75

Oil and Gas, Leasing, Acquired Land, 1941, 1948-74

Oil and Gas, Leasing, Alaska, 1936, 1944-64

Oil and Gas, Leasing, Alaska, 1936, 1965-71

Box $418 \quad$ Oil and Gas, Leasing, Alaska [maps], ca. 1964

Oil and Gas, Leasing, Alaska [maps], ca. 1966

Oil and Gas, Leasing, Alaska [maps], ca. 1966

Oil and Gas, Leasing, Alaska [maps], ca. 1962

Oil and Gas, Leasing, Alaska [maps], ca. 1965

Oil and Gas, Leasing, Alaska [maps], ca. 1962

Box 419 Oil and Gas, Leasing, Alaska, OCS, 1968-74

Oil and Gas, Leasing, Assignments, 1927, 1932, 1938-70

Oil and Gas, Leasing, Assignments, OCS, 1955-76

Oil and Gas, Leasing, Extensions, 1927, 1932-75

Oil and Gas, Leasing, Extensions, OCS, 1960-76

Oil and Gas, Leasing, Suspensions, 1971-76

Oil and Gas, Leasing, Suspensions, 1975-76

Oil and Gas, Leasing, Suspensions, OCS, 1955-71

Oil and Gas, Leasing, Suspensions, OCS, 1971

Box $420 \quad$ Oil and Gas, Leasing, Suspensions, OCS, 1971-74

Oil and Gas, Leasing, Suspensions, OCS, 1974-75

Oil and Gas, Leasing, Suspensions, OCS, 1976

Oil and Gas, Leasing, Suspensions, OCS, 1976

Oil and Gas, Leasing, Suspensions, OCS, 1974-75

Oil and Gas, Leasing, Terminations, 1959-75

Box 421 Oil and Gas, Leasing, Terminations, OCS, 1957-68

Oil and Gas, Leasing, Terminations, OCS, 1969-72

Oil and Gas, Leasing, Terminations, OCS, 1973-76

Oil and Gas, Leasing, Production Memos, OCS, 1967-71

Oil and Gas, Leasing, Production Memos, OCS, 1972

Oil and Gas, Leasing, Production Memos, OCS, 1972

Box 422 Oil and Gas, Leasing, Production Memos, OCS, 1972-73

Oil and Gas, Leasing, Production Memos, OCS, 1973

Oil and Gas, Leasing, Production Memos, OCS, 1973-74

Oil and Gas, Leasing, Production Memos, OCS, 1974

Oil and Gas, Leasing, Production Memos, OCS, 1974-76

Oil and Gas, Leasing, Production Memos, OCS, 1976

Box 423 Oil and Gas, Leasing, Suspension Extension Memos, OCS, 1971-72

Oil and Gas, Leasing, Suspension Extension Memos, OCS, 1972-73

Oil and Gas, Leasing, Suspension Extension Memos, OCS, 1973-74

Oil and Gas, Leasing, Suspension Extension Memos, OCS, 1974-75

Oil and Gas, Leasing, Suspension Extension Memos, OCS, 1975-76

Box 424 Oil and Gas, Competitive Leasing, General, 1952-75

Oil and Gas, Competitive Leasing, General, 1970-73

Oil and Gas, Competitive Leasing, General, 1973-74

Oil and Gas, Competitive Leasing, General, 1975-76

Oil and Gas, Competitive Leasing, General, 1976

Oil and Gas, Competitive Leasing, General, OCS, 1953-55 
Oil and Gas, Competitive Leasing, General, OCS, 1956-60

Oil and Gas, Competitive Leasing, General, OCS, 1961-67

Box 425 Oil and Gas, Competitive Leasing, General, OCS, 1967

Oil and Gas, Competitive Leasing, General, OCS, 1967-68

Oil and Gas, Competitive Leasing, General, OCS, 1968

Oil and Gas, Competitive Leasing, General, OCS, 1968

Oil and Gas, Competitive Leasing, General, OCS, 1969

Oil and Gas, Competitive Leasing, General, OCS, 1969

Box 426 Oil and Gas, Competitive Leasing, General, OCS, 1969-70

Oil and Gas, Safety, OCS, 1970

Oil and Gas, Safety, OCS, 1971

Oil and Gas, Safety, OCS, 1971

Oil and Gas, Safety, OCS, 1971-72

Oil and Gas, Safety, OCS, 1972-73

Oil and Gas, Safety, OCS, 1973

Box 427 Oil and Gas, Safety, OCS, 1973-74

Oil and Gas, Safety, OCS, 1974-76

Oil and Gas, Safety, OCS, 1976

Oil and Gas, Safety, OCS (printed items), ca. 1975

Oil and Gas, Safety, OCS (printed items), ca. 1976

Oil and Gas, Secondary Recovery, 1964-75

Box $428 \quad$ Oil and Gas, Secondary Recovery, OCS, 1956-75

Oil and Gas, Storage, General, 1975-76

Oil and Gas, Storage, General, 1976

Oil and Gas, Storage, General, Subsurface, OCS, 1959-74

Oil and Gas, Transport Systems, Barging, General, OCS, 1955-58

Oil and Gas, Transport Systems, Barging, General, OCS, 1959

Oil and Gas, Transport Systems, Barging, General, OCS, 1960-65

Oil and Gas, Transport Systems, Barging, Appeals, General, OCS, 1955-74

Box 429 Oil and Gas, Transport Systems, Barging, Appeals, General, OCS, ca. 1961

Oil and Gas, Transport Systems, Barging, Appeals, General, OCS, n.d.

Oil and Gas, Transport Systems, Barging, Appeals, General, OCS, ca. 1963

Organization and Management, Administrative Issuances, General Orders, 1631-1772, 1942

Organization and Management, Administrative Issuances, General Orders, 1775-1912, 1942-43

Organization and Management, Administrative Issuances, General Orders, 1915-2198, 1944-46

Box $430 \quad$ Organization and Management, Administrative Issuances, General Orders, 2205-2286, 1946

Organization and Management, Administrative Issuances, General Orders, 2287-2397, 1947

Organization and Management, Administrative Issuances, General Orders, 2401-2506, 1948

Organization and Management, Administrative Issuances, General Orders, 2507-2509, 1949-57

Organization and Management, Administrative Issuances, General Orders, 2510-2570A, 1949-50

Organization and Management, Administrative Issuances, General Orders, 2605-2611, 1950

Organization and Management, Administrative Issuances, General Orders, 2612-2711, 1951-52

Organization and Management, Administrative Issuances, General Orders, 2712-2807, 1953-55

Box 431 Organization and Management, Administrative Issuances, General Orders, 2811-2926, 1956-69

Organization and Management, Administrative Issuances, General Orders, 2928-2974, 1970-75

Organization and Management, Administrative Issuances, General Orders, 2976-2994, 1975-76

Organization and Management, Survey Orders, 1-80, 1911-17

Organization and Management, Survey Orders, 81-170, 1917-48

Organization and Management, Survey Orders, 171-252 [and related correspondence], 1948-76 
Box 432 Organization and Management, Administrative Issuances, LCB \& CD Circulars, 1-50, 1912-20 Organization and Management, Administrative Issuances, LCB \& CD Circulars, 51-97, 720, 1921-44, 1975-76

Organization and Management, GLO Circulars, No. 24-594, 1911-18

Organization and Management, GLO Circulars, No. 629-966, 1918-24

Organization and Management, GLO Circulars, No. 1004-1295, 1925-33

Oil and Gas, Competitive Leasing Recommendations, 1965

Oil and Gas, Competitive Leasing Recommendations, 1965

Box $433 \quad$ Oil and Gas, Competitive Leasing Recommendations, 1966

Oil and Gas, Competitive Leasing Recommendations, 1966

Oil and Gas, Competitive Leasing Recommendations, 1966

Oil and Gas, Competitive Leasing Recommendations, 1966

Oil and Gas, Competitive Leasing Recommendations, 1966-67

Oil and Gas, Competitive Leasing Recommendations, 1967

Oil and Gas, Competitive Leasing Recommendations, 1967

Oil and Gas, Competitive Leasing Recommendations, 1967

Box $434 \quad$ Oil and Gas, Competitive Leasing Recommendations, 1967

Oil and Gas, Competitive Leasing Recommendations, 1968

Oil and Gas, Competitive Leasing Recommendations, 1968

Oil and Gas, Competitive Leasing Recommendations, 1968-69

Oil and Gas, Competitive Leasing Recommendations, 1969

Oil and Gas, Competitive Leasing Recommendations, 1969

Oil and Gas, Competitive Leasing Recommendations, 1969

Oil and Gas, Competitive Leasing Recommendations, 1970

Box $435 \quad$ Oil and Gas, Competitive Leasing Recommendations, 1970

Oil and Gas, Competitive Leasing Recommendations, 1970

Oil and Gas, Competitive Leasing Recommendations, 1970-71

Oil and Gas, Competitive Leasing Recommendations, 1971

Oil and Gas, Competitive Leasing Recommendations, 1971

Oil and Gas, Competitive Leasing Recommendations, 1971

Oil and Gas, Competitive Leasing Recommendations, 1971-72

Box $436 \quad$ Oil and Gas, Competitive Leasing Recommendations, 1972

Legal, Laws \& Regulations, Public Laws, Multiple Use Act, ca. 1954-67

Legal, Laws \& Regulations, Public Laws, National Historic Preservation Act, 1974-76

Legal, Laws \& Regulations, Public Laws, National Historic Preservation Act, 1974

Legal, Laws \& Regulations, Public Laws, General, OCS, ca. 1966-76

Legal, Laws \& Regulations, Public Laws, Coastal Zone Management Act, 1975-76

Legal, Laws \& Regulations, Public Laws, Deepwater Port Act of 1974, OCS, 1974-75

Legal, Laws \& Regulations, Public Laws, OCS Lands Act (83-212), OCS, 1974

Box 437 Legal, Laws \& Regulations, Public Laws, OCS Lands Act (83-212), OCS, 1974-76

Legal, Laws \& Regulations, Public Laws, Privacy Act of 1974, 1975-76

Legal, Laws \& Regulations, Public Laws, Resource Recovery Act of 1970, 1970-71

Legal, Laws \& Regulations, Public Laws, Submerged Lands Act (83-31), OCS, 1953-75

Legal, Laws \& Regulations, Public Laws, Water Quality Improvement Act of 1970, 1970-73

Legal, Laws \& Regulations, Public Laws, Wilderness Act (88-577), 1964-75

Legal, Laws \& Regulations, Royalty Accounting Regulations [c.r. filed in Royalty Accounting Office]

Legal, Laws \& Regulations, State Regulations, General, 1913-58

Legal, Laws \& Regulations, State Regulations, General, 1960-76

Legal, Laws \& Regulations, State, Alabama, Regulations, 1958-76 
Box 438 Legal, Laws \& Regulations, State, Alaska, Regulations, ca. 1955-59

Legal, Laws \& Regulations, State, Alaska, Regulations, 1960-66

Legal, Laws \& Regulations, State, Alaska, Regulations, 1967-73

Legal, Laws \& Regulations, State, California, Regulations, 1911-55

Legal, Laws \& Regulations, State, California, Regulations, 1961-68

Legal, Laws \& Regulations, State, California, Regulations, 1969-75

Legal, Laws \& Regulations, State, Colorado, Regulations, ca. 1965-75

Box 439 Legal, Laws \& Regulations, State, Florida, Regulations, 1945-69

Oil and Gas, Competitive Lease Sales, Louisiana-Texas (3-13, 16-62), Leasing, OCS, 1961-62

Oil and Gas, Competitive Lease Sales, Louisiana-Texas (3-13, 16-62), Leasing, OCS, 1962-64

Oil and Gas, Competitive Lease Sales, Louisiana-Texas (3-13, 16-62), Leasing, OCS, 1964-67

Oil and Gas, Lease Sales, MAFLA, Gulf of Mexico (Deep) (2-18-76) Leasing, OCS, (\#41), 1975-76

Oil and Gas, Lease Sales, Middle Atlantic Area (8-17-76), Leasing, OCS, (\#40), 1974-76

Oil and Gas, Lease Sales, Louisiana-East Texas (7-30-74), Leasing, OCS (\#S-1), 1974

Oil and Gas, Competitive Lease Sales, Oregon-Washington (10-1-64), Leasing, OCS, 1963-64

Box 440

Oil and Gas, Competitive Lease Sales, Oregon-Washington (10-1-64), Leasing, OCS, [charts] ca. 1964

Oil and Gas, Competitive Lease Sales, Texas (11-9-54), Leasing, OCS, 1954

Oil and Gas, Competitive Lease Sales, Texas (5-21-68), Leasing, OCS, 1967

Oil and Gas, Competitive Lease Sales, Texas (5-21-68), Leasing, OCS, 1967

Oil and Gas, Competitive Lease Sales, Texas (5-21-68), Leasing, OCS, 1967-68

Oil and Gas, Competitive Lease Sales, Texas (5-21-68), Leasing, OCS, 1968

Oil and Gas, Competitive Lease Sales, Texas (5-21-68), Leasing, OCS, 1968-70

Box 441 Oil and Gas, Competitive Lease Sales, Texas (5-21-68), Leasing, OCS, [charts], n.d.

Oil and Gas, Competitive Lease Sales, Texas-Louisiana (6-19-73), Leasing, OCS, 1969-72

Oil and Gas, Competitive Lease Sales, Texas-Louisiana (6-19-73), Leasing, OCS, 1972

Oil and Gas, Competitive Lease Sales, Texas-Louisiana (6-19-73), Leasing, OCS, 1973-75

Oil and Gas, Competitive Lease Sales, Texas, Eastern (5-29-74), Leasing, OCS (\#34), 1973-74

Oil and Gas, Competitive Lease Sales, Texas, South (2-4-75), Leasing, OCS (\#37), 1974-76

Box 442 Oil and Gas, Competitive Lease Sales, Texas, East (5-28-75), Deep, OCS (\#38), 1973-75

Oil and Gas, Competitive Lease Sales, Texas, Southeast \& Louisiana, Southwest (5-28-75), Leasing, OCS (\#38A), 1975

Legal, Laws \& Regulations, CFR, Leasing, Geothermal (43 CFR 3200), 1973-75

Legal, Laws \& Regulations, CFR, Leasing, Geothermal (43 CFR 3200), 1975-76

Legal, Laws \& Regulations, CFR, Leasing, Geothermal (43 CFR 3200), 1974-75

Legal, Laws \& Regulations, CFR, Leasing, Other Minerals, Coal, (43 CFR 3130-3139), 1921-55

Legal, Laws \& Regulations, CFR, Leasing, Other Minerals, Coal, (43 CFR 3130-3139), 1959-67

Legal, Laws \& Regulations, CFR, Leasing, Other Minerals, Coal, (43 CFR 3130-3139), 1969-70

Legal, Laws \& Regulations, CFR, Leasing, Other Minerals, Mining Forms, ca. 1975

Box 443 Legal, Laws \& Regulations, CFR, Leasing, Other Minerals, (43 CFR 3500), 1971-76

Legal, Laws \& Regulations, CFR, Leasing, Other Minerals, (43 CFR 3500), 1976

Legal, Laws \& Regulations, CFR, Leasing, Other Minerals, (43 CFR 3500), 1976

Legal, Laws \& Regulations, CFR, Leasing, Other Minerals, Phosphate (43 CFR 3160-3169), 1921-48

Legal, Laws \& Regulations, CFR, Leasing, Other Minerals, Phosphate (43 CFR 3160-3169), 1948-55

Box $444 \quad$ Legal, Laws \& Regulations, CFR, Leasing, Other Minerals, Phosphate (43 CFR 3160-3169), 1961-70

Legal, Laws \& Regulations, CFR, Leasing, Other Minerals, Potassium (43 CFR 3140-3149), $1912-17$ 
Legal, Laws \& Regulations, CFR, Leasing, Other Minerals, Potassium (43 CFR 3140-3149), 1918-52

Legal, Laws \& Regulations, CFR, Leasing, Other Minerals, Potassium (43 CFR 3140-3149), 1952-55

Legal, Laws \& Regulations, CFR, Leasing, Other Minerals, Potassium (43 CFR 3140-3149), 1956-70

Legal, Laws \& Regulations, CFR, Leasing, Other Minerals, Sodium (43 CFR 3150-3159), 1928-54

Legal, Laws \& Regulations, CFR, Leasing, Other Minerals, Sodium (43 CFR 3150-3159), 1961-70

Legal, Laws \& Regulations, CFR, Leasing, Other Minerals, Sulphur (43 CFR 3180-3189), ca. $1956-70$

Box 445 Legal, Laws \& Regulations, CFR, Leasing, Other Minerals, Surface Exploration (43 CFR 23), ca. 1967

Legal, Laws \& Regulations, CFR, Leasing, Other Minerals, Surface Exploration (43 CFR 23), 1969-71

Legal, Laws \& Regulations, CFR, Leasing, Other Minerals, Surface Exploration (43 CFR 23), ca. $1973-75$

Legal, Laws \& Regulations, CFR, Leasing, Other Minerals, Surface Exploration (43 CFR 3041), 1975-76

Oil Shale, Miscellaneous Reports and Exhibits, General, ca. 1964

Oil Shale, Miscellaneous Reports and Exhibits, General, ca. 1964

Box $446 \quad$ Oil Shale, Miscellaneous Reports and Exhibits, General, ca. 1964

Oil Shale, Miscellaneous Reports and Exhibits, General, ca. 1964-65

Oil Shale, Maps, General, ca. 1974

Oil Shale, Maps, General, n.d.

Oil Shale, Maps, General, n.d.

Box $447 \quad$ Oil Shale, Maury Travis, General, ca. 1974

Oil Shale, Cameron \& Jones, 1959-67

Oil Shale, Cameron \& Jones, 1968-71

Oil Shale, OSRIC [Oil Shale Research Information Center], 1967-68

Oil Shale, OSRIC (Oil Shale Research Information Center), 1969-70

Oil Shale, OSRIC (Oil Shale Research Information Center), 1971

Oil Shale, OSRIC (Oil Shale Research Information Center), 1972-76

Box 448 Oil Shale, TOSCO (The Oil Shale Corporation), 1963-68

Oil Shale, TOSCO (The Oil Shale Corporation), 1969-76

Organization and Management, Administrative Issuances, General Orders, Unnumbered - 65, 1909-25

Organization and Management, Administrative Issuances, General Orders, 74-713, 1925-33

Organization and Management, Administrative Issuances, General Orders, 721-1132, 1933-36

Organization and Management, Administrative Issuances, General Orders, 1140-1336, 1937-38

Organization and Management, Administrative Issuances, General Orders, 1339-1536, 1939-40

Box 449 Organization and Management, Administrative Issuances, General Orders, 1543-1628, 1941

Oil and Gas, Non-competitive Leasing, General, 1947-76

Oil and Gas, Private Leasing, 1970

Oil and Gas, Oil Fields, General, 1911, 1915-16, 1919, 1922, 1933-76

Oil and Gas, William N. Barbat Analysis, Wertz and Lost Soldier Oil Fields, Wyoming, ca. 1972-74

Oil and Gas, Oil Fields, General, 1955-76

Oil and Gas, Platforms, Platform Installation, General, OCS, 1974-75

Box $450 \quad$ Oil and Gas, Platforms, Platform Installation, General, OCS, 1975

Oil and Gas, Platforms, Platform Installation, General, OCS, 1975

Oil and Gas, Platforms, Platform Installation, General, OCS, 1975-76 
Oil and Gas, Prices, 1969-76

Oil and Gas, Production, General, 1915, 1950-76

Oil and Gas, Production, General, OCS, 1964-76

Box $451 \quad$ Oil and Gas, Production, General, OCS, 1974-76

Oil and Gas, Production, General, OCS, 1976

Oil and Gas, Production, General, OCS, 1976

Oil and Gas, Production, Maximum Efficient Rates, General, OCS, 1968-71

Oil and Gas, Production, Maximum Efficient Rates, General, OCS, 1971

Box 452 Oil and Gas, Production, Maximum Efficient Rates, General, OCS, 1971-75

Oil and Gas, Production, Maximum Efficient Rates, General, OCS, 1976

Oil and Gas, Production, Maximum Efficient Rates, General, OCS, 1976

Oil and Gas, Production, Maximum Efficient Rates, Approvals, OCS, 1971

Oil and Gas, Production, Maximum Efficient Rates, Approvals, OCS, 1971

Oil and Gas, Production, Maximum Efficient Rates, Approvals, OCS, 1971

Box $453 \quad$ Oil and Gas, Production, Maximum Efficient Rates, Approvals, OCS, 1971

Oil and Gas, Production, Maximum Efficient Rates, Approvals, OCS, 1971

Oil and Gas, Production, Maximum Efficient Rates, Approvals, OCS, 1971-72

Oil and Gas, Production, Maximum Efficient Rates, Approvals, OCS, 1972-76

Oil and Gas, Shut-in Oil \& Gas Wells, General, 1973-74

Oil and Gas, Shut-in Oil \& Gas Wells, General, 1975

Oil and Gas, Shut-in Oil \& Gas Wells, General, 1975-76

Oil and Gas, Shut-in Oil \& Gas Wells, General, 1976

Box 454 Oil and Gas, Shut-in Oil \& Gas Wells, General, OCS, 1973-74

Oil and Gas, Shut-in Oil \& Gas Wells, General, OCS, 1975

Oil and Gas, Shut-in Oil \& Gas Wells, General, OCS, 1975

Oil and Gas, Shut-in Oil \& Gas Wells, General, OCS, 1974-75

Oil and Gas, Production, Proration, Allowables, General, OCS, 1966-72

Oil and Gas, Production, Proration, Allowables, Louisiana, OCS, 1953-55

Box 455 Oil and Gas, Production, Proration, Allowables, Louisiana, OCS, 1956-57

Oil and Gas, Production, Proration, Allowables, Louisiana, OCS, 1957-65

Oil and Gas, Production, Proration, Allowables, Louisiana, OCS, 1965

Oil and Gas, Production, Proration, Allowables, Louisiana, OCS, 1965

Oil and Gas, Production, Proration, Allowables, Louisiana, OCS, 1965-66

Oil and Gas, Production, Proration, Allowables, Louisiana, OCS, 1966

Oil and Gas, Production, Proration, Allowables, Louisiana, OCS, 1967

Oil and Gas, Production, Proration, Allowables, Louisiana, OCS, 1967

Box 456 Oil and Gas, Production, Proration, Allowables, Louisiana, OCS, 1967-69

Oil and Gas, Production, Proration, Allowables, Louisiana, OCS, 1970-72

Oil and Gas, Production, Proration, Allowables, Louisiana, OCS, 1965

Oil and Gas, Production, Proration, Allowables, Louisiana, OCS, 1965

Oil and Gas, Production, Proration-Allowables, Texas, OCS, 1964-65

Oil and Gas, Production, Proration-Allowables, Texas, OCS, 1965

Oil and Gas, Production, Proration-Allowables, Texas, OCS, 1965

Box 457 Oil and Gas, Production, Proration-Allowables, Texas, OCS, 1966-67

Oil and Gas, Production, Proration-Allowables, Texas, OCS, 1968-72

Oil and Gas, Production, Measurement, 1932

Oil and Gas, Production, Measurement, 1932

Oil and Gas, Production, Measurement, 1932-33

Oil and Gas, Production, Measurement, 1933

Oil and Gas, Production, Measurement, 1933

Oil and Gas, Production, Measurement, 1933 
Box $458 \quad$ Oil and Gas, Production, Measurement, 1933-34

Oil and Gas, Production, Measurement, 1935-36

Oil and Gas, Production, Measurement, 1937-54

Oil and Gas, Production, Measurement, 1969-74

Oil and Gas, Notice to Leases, General, 1972-76

Oil and Gas, Notice to Leases, General, 1974-76

Oil and Gas, Transport Systems, Barging Appeals, California Company, OCS, 1960-75

Oil and Gas, Transport Systems, Barging Appeals, Forest Oil, OCS, 1958-63

Oil and Gas, Transport Systems, Barging Appeals, Gulf Oil, OCS, 1956-63

Box 459 Oil and Gas, Transport Systems, Barging Appeals, Mecom, OCS, 1958-66

Oil and Gas, Transport Systems, Barging Appeals, Ocean Drilling Company, OCS, 1961-74

Oil and Gas, Transport Systems, Barging Appeals, Shell Oil, OCS, 1956-63

Oil and Gas, Transport Systems, Barging Appeals, Sinclair Oil, OCS, 1957-63

Oil and Gas, Transport Systems, Barging Appeals, Superior, OCS [out on a USGS internal loan]

Oil and Gas, Transport Systems, Barging Appeals, Tenneco Oil, OCS, 1961-63

Oil and Gas, Transport Systems, Barging Appeals, Union Oil, OCS, 1968-75

Oil and Gas, Transport Systems, Barging Appeals, Union Producing Company, OCS, 1960-63

Oil and Gas, Transport Systems, Pipelines, General, 1946-76

Oil and Gas, Transport Systems, Pipelines, Trans Alaska Pipeline System (TAPS), 1969-74

Oil and Gas, Transport Systems, Pipelines, General, OCS, 1951-55

Oil and Gas, Transport Systems, Pipelines, General, OCS, 1956-66

Box $460 \quad$ Oil and Gas, Transport Systems, Pipelines, General, OCS, 1966

Oil and Gas, Transport Systems, Pipelines, General, OCS, 1968

Oil and Gas, Transport Systems, Pipelines, General, OCS, 1966

Oil and Gas, Transport Systems, Pipelines, General, OCS, 1969-70

Oil and Gas, Transport Systems, Pipelines, General, OCS, 1971-72

Oil and Gas, Transport Systems, Pipelines, General, OCS, 1973-76

Oil and Gas, Transport Systems, Pipelines, General, OCS, 1973

Box $461 \quad$ Oil and Gas, Transport Systems, Pipelines, General, OCS, (printed items \& plats) ca. 1972

Oil and Gas, Pipelines, Pipeline Safety, OCS (Bi-weekly Reports), 1972-73

Oil and Gas, Transport Systems, Pipelines, Trans Alaska Pipeline System (TAPS), n.d.

Oil and Gas, Transport Systems, Deepwater Ports, General, OCS, 1973

Oil and Gas, Transport Systems, Deepwater Ports, General, OCS, 1974-76

Oil and Gas, Transport Systems, Deepwater Ports, General, OCS, 1974

Oil and Gas, Transport Systems, Deepwater Ports, General, 1974

Box $462 \quad$ Oil and Gas, Competitive Leasing Recommendations, 1972

Oil and Gas, Competitive Leasing Recommendations, 1972

Oil and Gas, Competitive Leasing Recommendations, 1973-76

Oil and Gas, Competitive Lease Sales, Calls for Nominations, Alaska, Cook Inlet, Leasing, OCS, 1966-76

Oil and Gas, Calls for Nominations, North Atlantic Area, Leasing, OCS, 1975-76

Oil and Gas, Calls for Nominations, South Atlantic Area, Leasing, OCS, 1976

Box $463 \quad$ Oil and Gas, Calls for Nominations, Gulf of Mexico, Drainage, OCS (\#44), 1975-76

Oil and Gas, Calls for Nominations, Southeastern Bering Sea, Leasing, OCS (\#45), 1975-76

Oil and Gas, Calls for Nominations, Gulf of Alaska, OCS (\#46), 1975-76

Oil and Gas, Calls for Nominations, Gulf of Mexico, OCS, Deep (\#47), 1976

Oil and Gas, Calls for Nominations, Southern California, Leasing, OCS (\#48), 1976

Oil and Gas, Lease Sales, General, 1975-76

Oil and Gas, Lease Sales, Alabama, Mississippi \& Florida (12-20-73), Leasing, OCS, 1967-73

Oil and Gas, Lease Sales, Alabama, Mississippi \& Florida (12-20-73), Leasing, OCS, 1973

Oil and Gas, Lease Sales, Alabama, Mississippi \& Florida (12-20-73), Leasing, OCS, 1973 
Box 464 Oil and Gas, Lease Sales, Alabama, Mississippi \& Florida (12-20-73), Leasing, OCS, 1974

Oil and Gas, Lease Sales, Alaska Gulf (4-13-76), Leasing, OCS, 1966-68

Oil and Gas, Lease Sales, Alaska Gulf (4-13-76), Leasing, OCS, 1969-75

Oil and Gas, Lease Sales, Alaska Gulf (4-13-76), Leasing, OCS, 1976

Oil and Gas, Lease Sales, Alaska Gulf (4-13-76), Leasing, OCS, 1976

Oil and Gas, Lease Sales, Alaska Gulf (4-13-76), Leasing, OCS, 1976

Box $465 \quad$ Oil and Gas, Lease Sales, Alaska Gulf (4-13-76), Leasing, OCS, 1974

Oil and Gas, Competitive Lease Sales, California (5-14-63), Leasing, OCS, 1962

Mineral Commodities, General, 1949-76

Mineral Commodities, General, 1974

Mineral Commodities, General, OCS, 1968-74

Mineral Commodities, Bentonite, 1967-75

Mineral Commodities, Nickel, 1953-55

Box 466 Mineral Commodities, Nickel, 1956-66

Mineral Commodities, Nickel, 1966-75

Mineral Commodities, Sand \& Gravel, General, 1974

Mineral Commodities, Sand \& Gravel, OCS, 1968-70

Mineral Commodities, Sand \& Gravel, OCS, 1971-75

Mineral Commodities, Sand \& Gravel, OCS, ca. 1973

Mineral Commodities, Sodium Salts, OCS, 1960

Mineral Commodities, Sodium Salts, Salt Lease Sale (9-5-67), OCS, 1967

Mines and Mining, Operations, General, 1972-76

Box 467 Mines and Mining, Operations, General, [printed item] 1973

Mines and Mining, Operations, Underground Mining, 1920, 1967-70

Mines and Mining, Operations, Strip Mining, 1965-75

Mines and Mining, Operations, Strip Mining, 1975-76

Mines and Mining, Operations, Strip Mining, 1975

Mines and Mining, Operations, Strip Mining, (printed items), n.d.

Mines and Mining, Operations, OCS, Mining, 1974-75

Box 468 Mines and Mining, Operations, OCS, Mining, 1967-73

Mines and Mining, Operations, OCS, Mining, 1975

Oil and Gas, Discoveries, General, 1957-76

Legal, Public Laws, Endangered Species Act of 1973, 1974-76

Legal, Public Laws, Federal Energy Administration Act of 1974, 1974-75

Legal, Public Laws, Federal Farm Mortgage Corporation, 1950-51

Legal, Public Laws, Federal Farm Mortgage Corporation, 1951-55

Legal, Public Laws, Federal Farm Mortgage Corporation, 1956-66

Legal, Public Laws, Freedom of Information Act, 1975

Box 469 Legal, Public Laws, Freedom of Information Act, 1972-75

Legal, Public Laws, Freedom of Information Act, 1975

Legal, Public Laws, Freedom of Information Act, 1975-76

Legal, Public Laws, Freedom of Information Act, 1976

Legal, Public Laws, Freedom of Information Act, 1976

Box 470 Legal, Public Laws, Geothermal Energy Research, Development \& Demonstration Act of 1974, 1974-76

Legal, Laws and Regulations, Great Salt Lake Relicated Lands, 1938-66

Legal, Laws and Regulations, Great Salt Lake Relicated Lands, 1966-71

Legal, Laws and Regulations, Great Salt Lake Relicated Lands, [plats] 1965

Legal, Laws and Regulations, Public Laws, Lignite Mining, 1962-73

Legal, Laws and Regulations, Public Laws, Mineral Leasing Act of 1920, 1920-55

Legal, Laws and Regulations, Public Laws, Mineral Leasing Act of 1920, 1958-76

Legal, Laws and Regulations, Public Laws, Mineral Leasing Act of 1920, 1976 
Box $471 \quad$ Legal, Laws and Regulations, Public Laws, Mineral Leasing Act of 1920, 1973-75 Legal, Laws and Regulations, Public Laws, Mineral Leasing Act of 1975, 1975-76 Legal, Laws and Regulations, Public Laws, Mineral Leasing Act of 1975, 1975-76 Legal, Laws and Regulations, Public Laws, Mining Laws, 1927-56 Legal, Laws and Regulations, Public Laws, Mining Laws, 1963-75 Legal, Laws and Regulations, Public Laws, Mining Laws, 1974-75

Box $472 \quad$ Oil and Gas, Competitive Lease Sales, Louisiana West (12-15-70), Leasing, OCS, Hearings, 1970 Oil and Gas, Competitive Lease Sales, Louisiana West (12-15-70), Leasing, OCS, Hearings, 1970

Oil and Gas, Competitive Lease Sales, Louisiana (11-4-71), Drainage, OCS, 1971

Oil and Gas, Competitive Lease Sales, Louisiana (11-4-71), Drainage, OCS, 1971-72

Oil and Gas, Competitive Lease Sales, Louisiana East (9-12-72), Leasing, OCS, 1970

Oil and Gas, Competitive Lease Sales, Louisiana East (9-12-72), Leasing, OCS, 1971

Oil and Gas, Competitive Lease Sales, Louisiana East (9-12-72), Leasing, OCS, 1971-75

Box $473 \quad$ Oil and Gas, Competitive Lease Sales, Louisiana East (9-12-72), Leasing, OCS, 1971

Oil and Gas, Competitive Lease Sales, Louisiana East (9-12-72), Leasing, OCS, 1971

Oil and Gas, Competitive Lease Sales, Louisiana (12-19-72), Leasing, OCS, 1971

Oil and Gas, Competitive Lease Sales, Louisiana (12-19-72), Leasing, OCS, 1971-72

Oil and Gas, Competitive Lease Sales, Louisiana (12-19-72), Leasing, OCS, 1973

Oil and Gas, Lease Sales, Louisiana (3-28-74), Leasing, OCS, 1974

Box $474 \quad$ Oil and Gas, Lease Sales, Louisiana (3-28-74), Leasing, OCS, 1974

Oil and Gas, Lease Sales, Louisiana (10-16-74), Leasing, OCS, 1972-74

Oil and Gas, Lease Sales, Louisiana (10-16-74), Leasing, OCS, 1974-76

Oil and Gas, Competitive Lease Sales, Louisiana-Texas (7-12-55), Leasing, OCS, 1955

Oil and Gas, Competitive Lease Sales, Louisiana-Texas (2-24-60), Leasing, OCS, 1956-59

Oil and Gas, Competitive Lease Sales, Louisiana-Texas (2-24-60), Leasing, OCS, 1960-65

Box $475 \quad$ Oil and Gas, Competitive Lease Sales, Louisiana-Texas (2-24-60), Leasing, OCS, [plats], n.d. Legal, Laws \& Regulations (30 CFR), General, 1927-76

Legal, Laws \& Regulations, CFR, Operating, Oil \& Gas (30 CDR 221), 1919-75

Legal, Laws \& Regulations, CFR, Operating, Oil \& Gas (30 CDR 221), 1975-76

Legal, Laws \& Regulations, CFR, Operating, Oil \& Gas (30 CDR 250), OCS, 1953

Legal, Laws \& Regulations, CFR, Operating, Oil \& Gas (30 CDR 250), OCS, 1954

Box $476 \quad$ Legal, Laws \& Regulations, CFR, Operating, Oil \& Gas (30 CDR 250), OCS, 1956-67

Legal, Laws \& Regulations, CFR, Operating, Oil \& Gas (30 CDR 250), OCS, 1968-69

Legal, Laws \& Regulations, CFR, Operating, Oil \& Gas (30 CDR 250), OCS, 1969

Legal, Laws \& Regulations, CFR, Operating, Oil \& Gas (30 CDR 250), OCS, 1969

Legal, Laws \& Regulations, CFR, Operating, Oil \& Gas (30 CDR 250), OCS, 1969

Legal, Laws \& Regulations, CFR, Operating, Oil \& Gas (30 CDR 250), OCS, 1969

Box 477 Legal, Laws \& Regulations, CFR, Operating, Oil \& Gas (30 CDR 250), OCS, $1970-74$

Legal, Laws \& Regulations, CFR, Operating, Oil \& Gas (30 CDR 250), OCS, 1975

Legal, Laws \& Regulations, CFR, Operating, Oil \& Gas (30 CDR 250), OCS, 1975-76

Legal, Laws \& Regulations, CFR, Operating, Oil \& Gas (30 CDR 250), OCS, 1975

Box $478 \quad$ Legal, Laws \& Regulations, CFR, Operating, Oil \& Gas (30 CDR 250), OCS, 1971-73

Legal, Laws \& Regulations, CFR, Operating, Oil \& Gas (30 CDR 250), OCS, 1973-74

Legal, Laws \& Regulations, CFR, Operating, Oil \& Gas (30 CDR 250), OCS, 1975

Legal, Laws \& Regulations, CFR, Operating, Oil \& Gas, Geological \& Geophysical (30 CFR 251), OCS, 1963-74

Legal, Laws \& Regulations, Gulf Coast Orders, OCS Order No. 2, 1974-76

Box 479 Legal, Laws \& Regulations, Gulf Coast Orders, OCS Order No. 5, 1960-72

Legal, Laws \& Regulations, Gulf Coast Orders, OCS Order No. 5, 1972-75

Legal, Laws \& Regulations, Gulf Coast Orders, OCS Order No. 6, 1969-76 
Box 480

Box 481

Box 482

Box 483

Box 484

Box 485

Box 486

Box 487
Legal, Laws \& Regulations, Gulf Coast Orders, OCS Order No. 8, 1969-70 Legal, Laws \& Regulations, Gulf Coast Orders, OCS Order No. 8, 1970-74 Legal, Laws \& Regulations, Gulf Coast Orders, OCS Order No. 8, 1975-76 Legal, Laws \& Regulations, Gulf Coast Orders, OCS Order No. 8, 1974 Legal, Laws \& Regulations, Gulf Coast Orders, OCS Order No. 8, 1974 Legal, Laws \& Regulations, Gulf Coast Orders, OCS Order No. 8, 1972-76 Legal, Laws \& Regulations, Gulf Coast Orders, OCS Order No. 8, ca. 1973 Legal, Laws \& Regulations, Gulf Coast Orders, OCS Order No. 8, ca. 1974 Legal, Laws \& Regulations, Gulf Coast Orders, OCS Order No. 8, ca. 1974 Legal, Laws \& Regulations, Gulf Coast Orders, OCS Order No. 9, 1971-73 Legal, Laws \& Regulations, Gulf Coast Orders, OCS Order No. 9, 1971 Legal, Laws \& Regulations, Gulf Coast Orders, OCS Order No. 9, 1974 Legal, Laws \& Regulations, Gulf Coast Orders, OCS Order No. 9, 1974-75 Legal, Laws \& Regulations, Gulf Coast Orders, OCS Order No. 11, 1970-72 Oil and Gas, Exploration \& Development, General, OCS, 1975-76

Oil and Gas, Exploration \& Development, General, OCS, 1974-76

Oil and Gas, Exploration \& Development, Development Contracts, Alaska, 1955-68

Oil and Gas, Exploration \& Development, Development Contracts, Alaska, 1969-70

Oil and Gas, Exploration \& Development, Units, General, 1932-49

Oil and Gas, Exploration \& Development, Units, General, 1949-51

Oil and Gas, Exploration \& Development, Units, General, 1952-53

Oil and Gas, Exploration \& Development, Units, General, 1953-55

Oil and Gas, Exploration \& Development, Units, General, 1956-57

Oil and Gas, Exploration \& Development, Units, General, 1957-59

Oil and Gas, Exploration \& Development, Units, General, 1960-61

Oil and Gas, Exploration \& Development, Units, General, 1962-63

Oil and Gas, Exploration \& Development, Units, General, 1963-66

Oil and Gas, Exploration \& Development, Units, General, 1967-76

Oil and Gas, Exploration \& Development, Units, General, OCS, 1967-76

Oil and Gas, Exploration \& Development, Agreement, List \#1, ca. 1973

Oil and Gas, Exploration \& Development, Agreement, List \#2, ca. 1971

Oil and Gas, Exploration \& Development, Units, Alaska, 1953-65

Oil and Gas, Exploration \& Development, Units, Alaska, 1966-74

Oil and Gas, Exploration \& Development, Units, Alaska, [plats], n.d.

Oil and Gas, Exploration \& Development, Units, Alaska, [plats], n.d.

Oil and Gas, Exploration \& Development, Units, Utilization of OCS Oil \& Gas Operations, 1975-76

Oil and Gas, Exploration \& Development, Utilization, General, OCS, 1974

Oil and Gas, Exploration \& Development, Utilization Circular [c.r. filed in legal sized folder see box 291]

Sodium, General, 1971-76

Sodium, General, 1976

Sodium, General, [plats] n.d.

Sodium, Zeolites, 1967-74

Sulphur, General, 1951

Sulphur, General, OCS, 1953-69

Sulphur, General, OCS, 1956-68

Sulphur, General, OCS, ca. 1953

Sulphur, Sale, Louisiana (10-13-54), OCS, 1954

Sulphur, Sale, Louisiana (5-13-69), OCS, 1967-68

Sulphur, Sale, Louisiana (5-13-69), OCS, 1968

Sulphur, Sale, Louisiana (5-13-69), OCS, 1969 
Box 488

Box 489

Box 490
Sulphur, Sale, Louisiana (5-13-69), OCS, 1969

Sulphur, Sale, Louisiana (5-13-69), OCS, 1970

Sulphur, Sale, Louisiana (5-13-69), OCS, ca. 1969

Sulphur, Sale, Texas (12-14-65), 1964-65

Sulphur, Sale, Texas (12-14-65), 1965-66

Sulphur, Sale, Texas (12-14-65), 1967-68

Transportation, General, OCS, 1961-74

Water, Wells, General, 1957-75

Water, Wells, General, 1975

Water, Wells, General, 1975

Water, Wells, Reserve No. 107, 1926-35

Water, Wells, Reserve No. 107, 1935

Water, Wells, Reserve No. 107, 1936-44

Water, Wells, Reserve No. 107, 1956-68

Water, Rivers \& Streams, Colorado River, Arizona, 1924-25

Water, Rivers \& Streams, Colorado River, Arizona, 1926-40

Weather, General, OCS, 1955

Weather, General, OCS, 1969-73

Legal, Appeals, Thunderbird Resources Inc., 1973-76

Legal, Appeals, Thunderbird Resources Inc., 1973-75

Land, Determinations, Known Geothermal-Resource Areas, Gillard Hot Springs, Arizona, 1974

Land, Determinations, Known Geothermal-Resource Areas, Indian Heaven, Washington, 1975

Land, Determinations, Known Geothermal-Resource Areas, Kennedy Hot Springs, Washington, 1974

Land, Determinations, Known Geothermal-Resource Areas, Kilbourne Hole, New Mexico, 1975

Land, Determinations, Known Geothermal-Resource Areas, Lake City - Surprise Valley, California, 1975

Land, Determinations, Known Geothermal-Resource Areas, Little Horse Mountain, California, 1975

Land, Determinations, Known Geothermal-Resource Areas, Lovelady Ridge, California, 1975

Land, Determinations, Known Geothermal-Resource Areas, Lower Frisco Hot Springs, New Mexico, 1975

Land, Determinations, Known Geothermal-Resource Areas, Lund, Utah, 1975

Land, Determinations, Known Geothermal-Resource Areas, Marysville, Montana, 1975

Land, Determinations, Known Geothermal-Resource Areas, McCredie Hot Springs, Colorado, 1974

Land, Determinations, Known Geothermal-Resource Areas, Mineral Hot Springs, Colorado, 1974

Land, Determinations, Known Geothermal-Resource Areas, Mountain Home, Idaho, 1975

Land, Determinations, Known Geothermal-Resource Areas, Mt. St. Helens, Washington, 1975

Land, Determinations, Known Geothermal-Resource Areas, Poncha, Colorado, 1974

Land, Determinations, Known Geothermal-Resource Areas, Radium Springs, New Mexico, 1975

Land, Determinations, Known Geothermal-Resource Areas, Roosevelt Hot Springs, Utah, 1975-76

Land, Determinations, Known Geothermal-Resource Areas, Rye Patch, Nevada, 1975

Land, Determinations, Known Geothermal-Resource Areas, San Emidio Desert, Nevada, 1975

Land, Determinations, Known Geothermal-Resource Areas, San Ysidro, New Mexico, 1975

Land, Determinations, Known Geothermal-Resource Areas, Thermo Hot Springs, Utah, 1975

Land, Determinations, Known Geothermal-Resource Areas, Vale Hot Springs, Oregon, 1974

Land, Determinations, Known Geothermal-Resource Areas, Valley View Hot Springs, Colorado, 1974

Land, Determinations, Known Geothermal-Resource Areas, Wilson Hot Springs, Nevada, 1975

Land, Determinations, Known Geothermal-Resource Areas, Witter Springs, Calif., 1975

Land, Withdrawals, General, 1910-11

Land, Withdrawals, General, 1912

Land, Withdrawals, General, 1913-14 
Land, Withdrawals, General, 1915-17

Land, Withdrawals, General, 1918-19, 1921, 1925-75

Land, Withdrawals, Alabama thru Alaska, 1899, 1905, 1908, 1911, 1914-76

Land, Withdrawals, Arizona thru Florida, 1910-76

Land, Withdrawals, Idaho thru North Dakota, 1907-76

Box $491 \quad$ Land, Withdrawals, Oregon thru Wyoming, 1915-73

Land, Withdrawals, Air Navigation Sites, 1928-44

Land, Withdrawals, Coal, 1909-12, 1914, 1916, 1919, 1931-73

Land, Withdrawals, Geothermal (AEC), 1974

Land, Withdrawals, Oil \& Gas, 1911, 1916-76

Land, Withdrawals, Recreation Sites, 1925-65

Legal, Claims \& Litigations, General, 1916-70

Box 492 Legal, Claims \& Litigations, General, 1971-72

Legal, Claims \& Litigations, General, 1973-74

Legal, Claims \& Litigations, General, 1976

Legal, Claims \& Litigations, General, 1975-76

Legal, Claims \& Litigations, General, 1935-75

Legal, Laws \& Regulations, CFR, Operating, Mining, General (30 CFR 231), 1921

Box 493 Legal, Laws \& Regulations, CFR, Operating, Mining, General (30 CFR 231), 1921-23, 1949

Legal, Laws \& Regulations, CFR, Operating, Mining, General (30 CFR 231), 1966-69

Legal, Laws \& Regulations, CFR, Operating, Mining, General (30 CFR 231), 1970-71

Legal, Laws \& Regulations, CFR, Operating, Mining, General (30 CFR 231), 1971

Legal, Laws \& Regulations, CFR, Operating, Mining, General (30 CFR 231), 1972

Legal, Laws \& Regulations, CFR, Operating, Mining, General (30 CFR 231), 1974-76

Legal, Laws \& Regulations, CFR, Operating, Mining, General (30 CFR 231), 1972-73

Box 494 Legal, Laws \& Regulations, CFR, Operating, Mining, General (30 CFR 231), 1976

Legal, Laws \& Regulations, CFR, Operating, Mining, General (30 CFR 260), OCS, 1968-69

Legal, Laws \& Regulations, CFR, Operating, Mining, General (30 CFR 260), OCS, 1969

Legal, Laws \& Regulations, CFR, Operating, Mining, General (30 CFR 260), OCS, 1970

Legal, Laws \& Regulations, CFR, Operating, Mining, General (30 CFR 260), OCS, 1970

Legal, Laws \& Regulations, CFR, Operating, Mining, General (30 CFR 260), OCS, 1971

Legal, Laws \& Regulations, CFR, Operating, Mining, General (30 CFR 260), OCS, 1972-73

Legal, Laws \& Regulations, CFR, Operating, Mining, General (30 CFR 260), OCS, 1974-76

Legal, Laws \& Regulations, CFR, Operating, Mining, Coal (30 CFR 75, 201 \& 211), 1920-69

Box 495 Legal, Laws \& Regulations, CFR, Operating, Mining, Coal (30 CFR 75, 201 \& 211), 1970

Legal, Laws \& Regulations, CFR, Operating, Mining, Coal (30 CFR 75, 201 \& 211), 1971-72

Legal, Laws \& Regulations, CFR, Operating, Mining, Coal (30 CFR 75, 201 \& 211), 1973-76

Legal, Laws \& Regulations, CFR, Operating, Mining, Coal (30 CFR 75, 201 \& 211), 1975-76

Legal, Laws \& Regulations, CFR, Operating, Mining, Coal (30 CFR 75, 201 \& 211), n.d.

Legal, Other Minerals, Coal (30 CFR 211 \& 216), 1973-74

Box $496 \quad$ Legal, Other Minerals, Coal (30 CFR $211 \& 216), 1975$

Legal, Operating Regulations, Royalty Oil Allocation (10 CFR 200), 1974-76

Legal, Operating Regulations, Royalty Oil Allocation (10 CFR 200), 1973-76

Legal, Laws \& Regulations, CFR, Operating, Oil \& Gas (30 CFR 226), 1942-43

Legal, Laws \& Regulations, CFR, Operating, Oil \& Gas (30 CFR 226), 1943

Box 497 Legal, Laws \& Regulations, CFR, Operating, Oil \& Gas (30 CFR 226), 1943-45

Legal, Laws \& Regulations, CFR, Operating, Oil \& Gas (30 CFR 226), 1946-51

Legal, Laws \& Regulations, CFR, Operating, Oil \& Gas (30 CFR 226), 1951-75

Legal, Laws \& Regulations, CFR, Operating, Oil \& Gas (30 CFR 226), 1943

Legal, Laws \& Regulations, CFR, Operating, Oil \& Gas (30 CFR 226), 1943 
Legal, Laws \& Regulations, CFR, Operating, Oil \& Gas (30 CFR 226), 1943

Legal, Laws \& Regulations, CFR, Operating, Oil \& Gas, Unit Forms of Agreement [c.r. filed in

legal sized folders - see box 333]
Legal, Laws \& Regulations, CFR, Operating, Oil \& Gas, Unit Forms of Agreement, OCS [c.r. filed

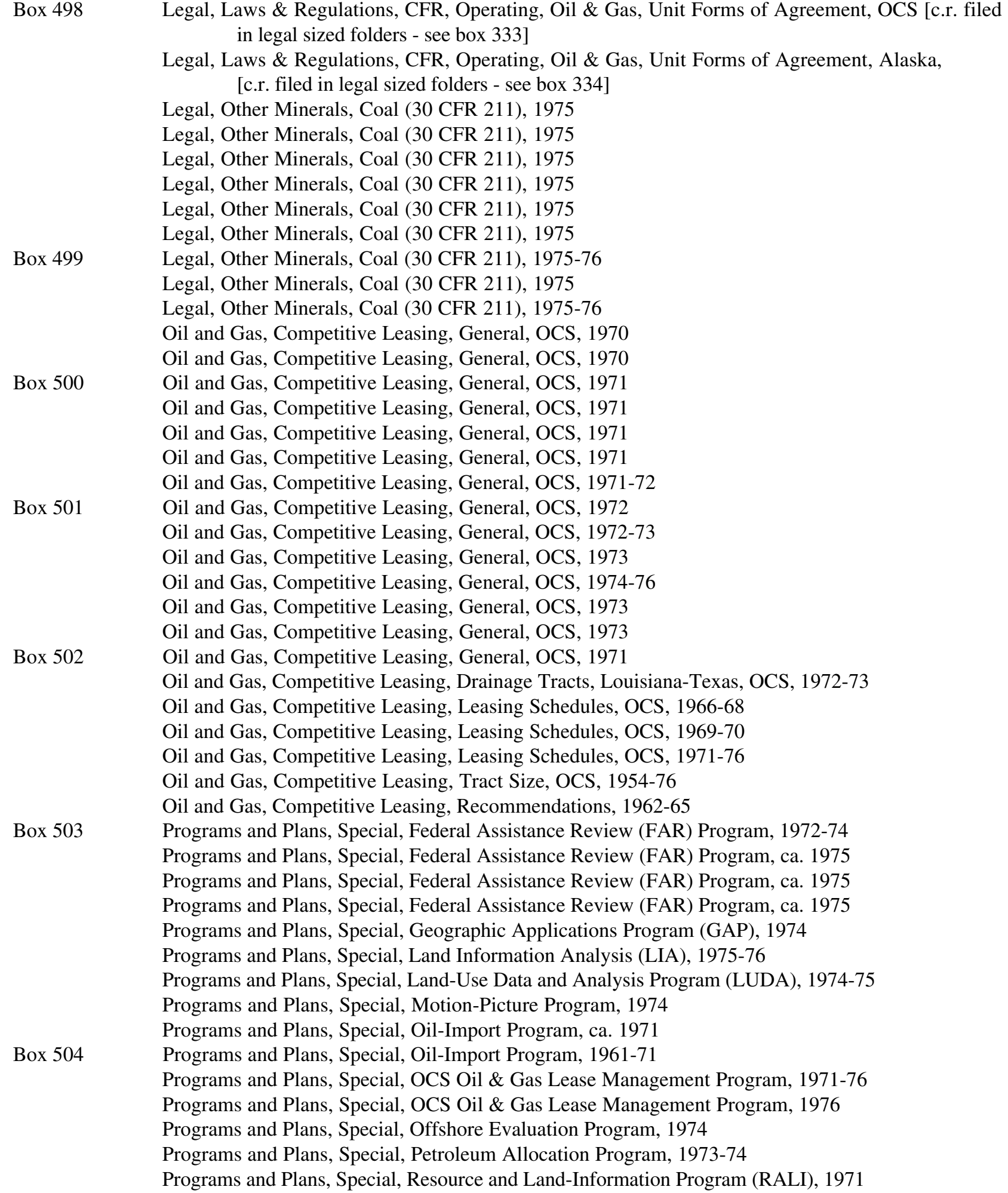


Programs and Plans, Special, Resource and Land-Information Program (RALI), 1972

Programs and Plans, Special, Resource and Land-Information Program (RALI), 1972

Programs and Plans, Special, Resource and Land-Information Program (RALI), 1972

Programs and Plans, Special, Resource and Land-Information Program (RALI), 1972

Box $505 \quad$ Programs and Plans, Special, Resource and Land-Information Program (RALI), 1972-73

Programs and Plans, Special, Resource and Land-Information Program (RALI), 1974-76

Programs and Plans, Special, Resource and Land-Information Program (RALI), 1972-76

Programs and Plans, Special, Resource and Land-Information Program (RALI), ca. 1971

Programs and Plans, Special, Resource and Land-Information Program (RALI), ca. 1971

Box 506

Programs and Plans, Special, Requests for Proposals (RFP), 1974-76

Programs and Plans, Special, Requests for Proposals (RFP), 1974-76

Programs and Plans, Special, Seaswab, OCS, 1975

Programs and Plans, Special, Shallow-Core Program, Gulf of Alaska, 1975

Programs and Plans, Special, Systems Design Analysis Program (SDA), 1974-75

Programs and Plans, Special, Urban-Area Studies Program (UAS), 1974

Programs and Plans, Special, War Program, 1942 


\section{Appendix 38}

Conservation Division - Reports and other Records concerning the Operation of Power Systems on Federal Lands, 1909-48 (entry 644)

Adirondack Electric Power Corporation, 1917

Alaska Gastineau Mining Company, 1918-48

Alaska Treadwell Gold Mining Company, ca. 1914

Alturas Electric Power Company, 1916

(The) American Gas Company, 1917

American Light and Traction Company, 1910-14

American Potash and Chemical Corporation, 1932-44

American Power and Light Company. 1911, 1913, 1916

American Public Utilities Company, 1917

American Telephone and Telegraph Company, 1913, 1916

American Waterworks and Electric Company, 1914

Anderson-Cottonwood Irrigation District, 1916-17

Arizona Gas and Electric (see: Public Utilities Consolidated Corporation)

Arizona Edison Company, 1934-44

Arizona Power Company, 1915-44

Arizona, State of - Sacotion to Florence Power Line, 1921

Arkansas Valley Railway, Light and Power Company, 1916

Ashton \& St. Anthony Power Company, Ltd. (see: Warm Springs Power Company)

August Mining Company, 1917-22

Augusta-Aiken Railway \& Electric Corporation of South Carolina, 1916

Bagdad Copper Company, 1942-44

(The) Baltimore \& Ohio Railroad Company, 1915

(The) Bard Creek Mining Company, 1921-25

Bay State Street Railway Company, 1916

Beaver River Power \& Light Company, 1915

Bend Water, Light \& Power Company, 1915

Black Canyon Irrigation District, 1914

Black Rock Power \& Irrigation District, 1918-33 (also see: Priest Rapids Irrigation District)

Black Stream Electric Company, 1915

Blue Hill Street Railway Company, 1915

Board of Directors of State Institutions, 1924

Bristol Silver Mine Company, 1932-43

Buckhorn Mines Company, 1917

Butte, Anaconda and Pacific Railway, 1915

Cain, J. S. (Standard Power Plant), 1921-24

California Electric Power Company, 1941-44 (also see: (The) Nevada-California Electric Corporation)

California-Oregon Power Company, 1918-45

California-Pacific Utilities Company, 1944

California Railway and Power Commission, 1914

California State Water Commission, 1919-26

California Telephone \& Light Company (see: Mt. Konocti Light \& Power Company)

Calumet \& Arizona Mining Company, 1918-30

Carolina Power \& Light Company, 1943-48

Castle Dome, 1944 
Cedar Rapids Manufacturing \& Power Company, 1915

Central Arizona, 1942-44

Central California Gas Company, 1914

Central Illinois Light Company, 1915

Central Maine Power Company, 1915

Chesapeake \& Potomac Telephone Company, 1916

Chicago, Milwaukee \& St. Paul Railway Company, 1924-44

Christmas Copper Company, 1918-37

(The) Cincinnati Gas \& Electric Company, 1916

Citizens Utilities Company, 1936-44

Cleveland Electric Illuminating Company, Ohio, 1909

Coachella Valley Ice and Electric Company, 1916-17

Coast Counties Gas \& Electric Company, 1917

Coast Valleys Gas \& Electric Company, 1914

Cokeville Light and Power Company, 1917-24

(The) Colorado Power Company, 1912-22

Colorado Springs Light, Heat and Power Company, 1915-16

Columbia Basin Irrigation Project, 1919-20

Commonwealth Edison Company, 1914

Community Public Service Company, 1942-44

(The) Connecticut Power Company, 1913

Consolidated Electric Light Company, 1917

Consolidated Gas Electric Light and Power Company of Baltimore, 1916

Consumers' Ditch Company, 1916

Consumers' Power Company, 1917-20

Coronado Copper and Zinc Company, 1944

Cuyamaca Water Company, 1917

Dallas Electric Company, 1916

Deming Ice and Electric Company, 1943-44

Denver and Rio Grande Railroad (later Denver and Rio Grande Western Railroad), 1916, 1942-44

Denver Gas \& Electric Light Company, 1916

Denver Union Water Company, 1914

Deschutes Power Company, 1916-27

Desert Power \& Water Company, 1918-32

Detroit Edison Company, 1918

Dominguez Water Company, 1915

Duquesne Light Company, 1917

Eastern Oregon Light \& Power Company, 1915

Economy Mines Company, 1918-44

Electric Properties Company, 1907-11

Elkhorn Power Line (cross reference: reports filed with Oscar Rohn)

Elko Lamoille Power Company, 1916-44

Elmore Irrigated Farms Association, 1917

El Paso Electric Company, 1941-44

Empire Water Company, 1915

Ermont Mines Inc., 1943-44

Escondido Utilities Company, 1915

Everett Gas Company, 1915

Farmers Reservoir and Irrigation Company, 1917

Flathead Irrigation Project, Montana (Indian Service), 1931-44

Fontana Power Company, 1916 
Fresno Farms Company, 1915

Gallup Electric Light and Power, 1944

Garden City Telephone, Light \& Manufacturing Company, 1916

Gem Irrigation District, 1917, 1919

General Electric Company, 1912, 1914

(The) General Gas \& Electric Company, 1916

Georgia-Carolina Power Company, 1918

Glenwood Light \& Water Company, 1919-45

Goldfield Consolidated Water Company, 1916

Goose Lake Valley Irrigation Company, 1917

Grand Canyon Power Development Company, 1916

Grangeville Electric Light \& Power Company, 1918-27

Grays Harbor Railway \& Light Company, 1915

Great Falls Power Company, 1914-17

Great Northern Power Company, 1916

Great Northern Utilities Company, 1930-44

Great Shoshone and Twin Falls Water Power Company, 1911-15

Great Western Power Company, 1915-35

Hagan Power and Light Company, 1928-33

Half Moon Bay Light and Power Company, 1914

Harkness, Sarah (McGammon, Idaho), 1915

Harmony Mines Company, 1934-35

Helena Light \& Railway Company, 1916

Hood River Gas \& Electric Company, 1915

Hope Metals Company, 1929-34, 1936, 1942-43

Horse Heaven Irrigation District, 1917, 1920

Huntington Land and Improvement Company, 1914

(The) Hydraulic Power Company of Niagara Falls, 1916

Idaho Farm Development Company, 1919

Idaho Irrigation Company, 1917

Idaho Light and Power Company, 1915

Idaho-Oregon Light and Power Company, 1913, 1915

Idaho Power \& Light Company, 1916, 1943-44, 1947

Idaho Power Company, 1917, 1936-41

Idaho Traction Company, 1915

Imperial Water Company, No. 1, 1917

Indiana Power and Water Company, 1916

Inland Power \& Light Company, 1927-38, 1942

(The) Inland Utilities Company, 1940-44

Intermountain Power Company, 1919-30

Intermountain Railway, Light \& Power Company, 1918

International Traction Company, 1916

Iowa Railway and Light Company, 1915

Jefferson City Light, Heat \& Power Company, 1916

Kansas City Railways Company, 1916

Kaiser Company, Inc., 1944

Kennecott Copper Corporation, 1934-44

King Hill Project, 1920

Kings River Reclamation and Conservation District, 1916

Kremmling Light \& Power Company, 1944

Lahontan Power Company, 1914 
Lake Fork Milling \& Power Company, 1929, 1933, 1935

Lake Hemet Water Company, 1917

Lake Superior District Power Company, 1941-44

Laurentide Power Company, Ltd., 1916

Lewiston Flat Irrigation District, 1919

Lewiston-Sweetwater Irrigation Company, 1917

Lincoln Electric Cooperative, Inc., 1941

Lincoln Water \& Light Comapny, 1916

Lindsay-Strathmore Irrigation District, 1916

Longmont, City of, 1919-43

Los Angeles, Department of Water \& Power, 1919-44

Los Angeles, City of, 1915-19

Los Angeles Municipal League, 1916

Los Angeles Railway Corporation, 1914-15

Loveland, City of, 1916-48

Malad Reservoir Company, 1914

Manhattan Ice, Light and Power Company, 1915

Matanuska Electric Association, Inc., 1943-44

McGammon, Idaho, Village of, 1916 (also see: Sarah Harkness)

Meadows Light \& Power Company, 1916

Mesilla Valley Electric Company, 1930-40

Methow-Okanogan Project, 1920

Miami Conservancy District, Ohio, 1917

(The) Middle West Utilities Company, 1917-21

Millard Land \& Water Company, 1919

Minnesota Power \& Light Company, 1928

Mississippi Power Company, 1943-44

Modesto Irrigation District, 1915

Moffat Coal Company, 1929-44

Mokelumne River Power Company, 1916-19

Mono Mining Company, 1925-32

Montana-Dakota Utilities Company, 1941-44

Montana Power Company, 1915-48

Montana Railroad and Public Service Commission, 1917

Montgomery Hydroelectric Company, 1917

(The) Morenci Water and Electric Company, 1943-44

Mosca Irrigation District, 1915

Mt. Konocti Light \& Power Company (California Telephone \& Light Company), 1915-23, 1928

Mountain King Mining Company, 1916-21

Mountain State Power Company, 1930-42

(The) Nevada-California Electric Corporation, 1915-40 (also see: California Electric Power Company)

Nevada Consolidated Copper Company (formerly Ray Consolidated Copper Company), 1921-41

Nevada Valleys Power Company, 1915-29

Nevada Power Company, 1918-35

New Jersey Public Service Corporation, 1915

New Mexico Power Company, 1942-44

Niagara Falls Power Company, 1913, 1916

Niagara, Lockport \& Ontario Power Company, 1916

Nogales Electric, Ice \& Water Company, 1915

Norfolk \& Western Railway Company, 1917

Northern California Power Company, 1916 
Northern Idaho \& Montana Power Company, 1917

Northern New York Power Corporation, 1915

Northern Ohio Electric Corporation, 1916

Northern States Power Company, 1916

Northwest Light \& Water Company, 1916

Northwest Transmission Company, 1927-29

Northwestern Electric Company, 1915

Oakley Irrigation Project, 1914

Ochoco Irrigation District, 1921

Ogden, Logan and Idaho Railway Company, 1914

Okanogan County Public Power, Public Utility District No. 1, 1948

Ophir Hill Consolidated Mining Company, 1920-28

Ora Corporation, 1915

Oro Electric Corporation, 1911, 1916

Oregon Short Line R. R., 1914

Pacific Coast Borax Company, 1942-44

Pacific Electric Railway Company, 1912, 1917

Pacific Gas and Electric Company, 1915-40

Pacific Light and Power Corporation, 1915-17

Pacific Portland Cement Company, Consolidated, 1923-27

Pacific Power Corporation, 1916-17

Pacific Power \& Light Company, 1910-44

Pacific Public Service Corporation, 1917

Palouse Irrigation Project, 1916

Penobscot Mining Company, 1918-29

Phelps Dodge Corporation, 1919-44

Phillips Development Company, 1927-28

Pima County, 1942-43

Pit River Power Project, 1920

Pittsburgh Railways Company, 1917

Plumas Sierra Rural Electric Co-operative, 1944

Pocatello Water Company, 1915

Portland Railway, Light \& Power Company, 1916

Portneuf-March Valley Irrigation Company, 1913

Potomac Electric Power Company, 1916

Power System - Department of Water and Power, 1944

Prairie Power Company, 1918

Priest Rapids Irrigation District (also see: Black Rock Power \& Irrigation District), 1934-43

Providence Mining Corporation, 1941

Provo Reservoir Company, 1915, 1920

Public Service Company of Colorado, 1924-44

Public Utilities Consolidated Corporation, 1917-38

Puget Sound International Railway \& Power Company, 1916

Puget Sound Power and Light Company, 1944

Puget Sound Traction, Light \& Power Company, 1919

Rawlins Electric Company, 1942-43

Salmon River Power and Light Company, 1917-29

Salt River Project, 1916

Salt River Valley Water Users Association, 1925-42

San Diego Consolidated Gas \& Electric Company, 1916, 1934-43

San Joaquin Light and Power Company, 1920-34 
Santa Barbara Gas \& Electric Company, 1915

Schmidt \& Mace, 1916

Seattle, City of, 1918, 1920

Seattle Lighting Company, 1915

Seminole Power Company, 1918-33

Sespe Light \& Power Company of Los Angeles, n.d.

Shawinigan Water and Power Company, 1916

(The) Shoshone County Power Company, 1918-28

Sierra \& San Francisco Power Company, 1916-20

Sierra Electric Power Company, 1916

Sierra Pacific Power Company (also see: Truckee River Power Company), 1928-44

Silver Star, 1943

Sinks Canyon Power Company, 1920

Snowstorm Consolidated Mines, 1917

South Carolina Light, Power and Railway Company, 1912

Southeast Colorado Power Association, 1946

Southern Arizona Power Company, 1923-28

Southern California Edison Company, Ltd., 1915-44

Southern California Gas Company, 1912, 1917-18

Southern Counties Gas Company, 1915

Southern Idaho Water Power Company, 1915

Southern Pacific Utilities Company, 1913

Southern Power Company, 1916

(The) Southern Sierras Power Company, 1915-35

Southern Wyoming Utilities Company, 1941-44

Southwestern Portland Cement Company, 1942-44

Stannard, E. T., 1920

Stanolind Oil and Gas Company, 1932-48

Steifer Mining Company, 1917-44

Stevens County Electric Cooperative, Inc., 1942-44

Stone and Webster, 1915-16

Stonewall Electric Company, 1942-44

Suburban Light and Power Company, 1917

South Side Gas \& Electric Company, 1915

Spokane \& Inland Empire Railroad Company, 1919

Spring Valley Water Company, 1917

Standard Consolidated Mining Company, 1915

Swan Creek Electric Company, 1915

Thompson Falls Power Company, 1916 (also see: Montana Power Company)

Toronto Power Company, Ltd., 1914

Tri-County Light \& Power Company, 1916

Trinchera Irrigation District, 1915

Truckee River Power Company (also see: Sierra Pacific Power Company), 1914-29

(The) Tucson Gas, Electric, Light \& Power Company, 1942-44

Tulare County Power Company, 1915

Twentynine Palms Air Academy, 1943

Twin Falls North Side Land and Water Company, 1919

Twin Falls Oakley Land \& Water Company, n.d.

Twin Falls-Salmon River Land \& Water Company, 1917

Union Pacific Coal Company, 1922-45

(The) United Gas and Electric Corporation, 1915 
United Light \& Power Company, 1915, 1924

United Light and Railways Company, 1924

United Missouri River Power Company, n.d.

United Railroads of San Francisco, 1915

United States Engineers (War Department), 1936-43

United States Fuel Company, 1916-44

United States Gypsum Company, 1938-44

United States Irrigation Service, 1936-40

United States Potash Company, 1932-44

United States Public Service Company, 1917

United Verde Copper Company, 1916, 1944

Utah Line, 1943

Utah Power \& Light Company, 1916-44, 1947

Utah Securities Corporation, 1912, 1916

Utah Water Storage Association, 1920

Vernal Milling and Light Company, 1916-24

Virginia Railway and Power Company, 1912-17

Wapinitia Irrigation Company, n.d.

Warm Springs Power Company (Ashton \& St. Anthony Power Company, Ltd.), 1920-23

Washington Irrigation \& Development Company, 1920

(The) Washington Water Power Company, 1915-48

Waterpower Development Association, 1916

Waterpower Development League, 1916

Wenatchee Valley Gas \& Electric Company, n.d.

West Coast Power Company, 1943

West Okanogan Valley Irrigation District, 1916

West Virginia Traction \& Electric Company, 1917

Western Colorado Power Company, 1918-47

Western States Gas and Electric Company, 1917

Western States Utilities Company, 1925-42

Westinghouse Electric \& Manufacturing Company, 1917

Weyerhaeuser Lumber Company, 1915

Winslow Electric Light \& Power Company, 1916

Wisconsin Railway, Light and Power Company, 1913-14

Wishart, Cameron, and Herrin, n.d.

Yosemite Power Company, 1916 


\section{Appendix 39}

Water and Power Branch - Records concerning Land and Stream Classification, 1894-1961 (entry 675)

D-100-1-1

D-100-1-1 1/2

D-100-1-3

D-100-1-4

D-100-1-5

D-100-1-6

D-100-1-7

D-100-1-8

D-100-1-9

D-100-2-1

D-100-2-2

D-100-2-3

D-100-2-4

D-100-2-5

D-100-3-1

D-100-3-2

D-100-3-3

D-100-4-1

D-100-4-2

D-100-4-3

D-100-4-4

D-100-4-5

D-100-4-6

D-100-4-7

D-100-4-8

D-100-4-9

D-100-4-10

D-100-4-11

D-100-4-12

D-100-4-13

D-100-4-14

D-100-4-15

D-100-5-1

D-100-5-2

D-100-5-3

D-100-5-4

D-100-5-5
"Norwalk Harbor, Connecticut," 1906 [59th Cong., 2d Sess., HR Doc 262]

Central Maine Power Company, 1913 [brochures]

"Redevelopment of Old Canal Power at Cohoes Falls, NY", 1915 [article]

"Connecticut River, between Hartford, Connecticut, and Holyoke, Massachusetts," 1915 [64th Cong., 1st Sess., HR Doc. 417]

International Joint Commission, "In the Matter of the Applications of the St. Croix Water Power Company and the Sprague's Falls Manufacturing Company, Limited," Order and Opinion, 1915 [bound item]

"St. Croix River, Maine," 1930 [71st Cong., 3d Sess., HR Doc. 643]

"Pamunkey River, Virginia," 1930 [71st Cong., 2d Sess., HR Doc. 54]

"Patuxent River, Maryland," 1930 [71st Cong., 2d Sess., HR Doc. 463]

"Merrimac River, Massachusetts, between Haverhill and Lowell," 1911 [62nd Cong., 1st Sess., HR Doc. 9]

Developed Water-power of Georgia, 1914 [statistical table and articles]

Hafer, Claude, "Hydro-Electric Power Installations in Northern Georgia," 1914 [article]

Improvement of Coosa River, Georgia and Alabama, 1916 [printed hearings]

"Meherrin River, Virginia and North Carolina," 1930 [71st Cong., 2d Sess., HR Doc. 446]

"Yadkin-Pee Dee River and Its Tributaries, North Carolina and South Carolina," 1944 [78th Cong., 2d Sess., HR Doc. 652]

Locations of water power-sites on the Muskingum River, Ohio, 1908

Switzer J. A., "Recent Water-power Developments in Tennessee," 1914 [article]

"Salt River, Kentucky," 1930 [71st Cong. 2d Sess., HR Doc. 477]

[Charge card]

O'Neill, William and Horton, Albert H., Location of Potential Water Power in Various Michigan Townships, 1908

Diversion of water from the Niagara River, 1912-14, hearings and other papers

Power companies at Niagara Falls, 1913 [brochures]

"Red River of the North, Minnesota and North Dakota," 1915 [63rd Cong., 3rd Sess., HR Doc. 1666]

Brown, John C., Special Agent, Letter regarding a field examination of homestead entries along the banks of the Sturgeon and Little Fork Rivers, Minnesota, 1913

"Manistique River, Michigan," 1929 [71st Cong., 2d Sess., HR Doc. 56]

"Big Crazy River, New York," 1930 [71st Cong., 2d Sess., HR Doc., 490]

"Winooshi River, Vermont," 1931 [71st Cong., 3d Sess., HR Doc. 785]

"Peshtigo River, Wisconsin," 1930 [71st Cong., 2d Sess., HR Doc., 491]

"Oconto River, Wisconsin," 1930 [71st Cong., 2d Sess., HR Doc. 489]

"Ausable River, New York," 1930 [71st Cong., 2d Sess., HR Doc. 488]

"Poultney River, New York and Vermont," 1930 [71st Cong., 2d Sess., HR Doc., 485]

"Winooshi River, Vermont," 1931 [71st Cong., 3d Sess., HR Doc. 785]

"Missisquoi River, Vermont," 1930 [71st Cong., 2d Sess., HR Doc. 496]

[Charge card]

[Charge card]

"Kankakee River, Illinois and Indiana," 1931 [71st Cong., 3d Sess., HR Doc., 784]

"St. Croix River, Wisconsin and Minnesota," 1930 [71st Cong., 2d Sess., HR Doc. 462]

"Fox River, Wisconsin and Illinois," 1930 [71st Cong., 2d Sess, HR Doc., 410] 
D-100-5-6
D-100-5-8
D-100-5-9
D-100-6-1
D-100-6-2

D-100-6-3

D-100-6-4

D-100-6-5

D-100-6A-1

D-100-6A-2

D-100-6A-3

D-100-6A-4

D-100-6A-5

D-100-6A-6

D-100-6A-7

D-100-6A-8

D-100-6A-9

D-100-6A-10

D-100-6A-11

D-100-6A-12

D-100-6A-13

D-100-6A-14

D-100-6A-15

D-100-6B-1

D-100-6B-2

D-100-6B-3

D-100-6B-4

D-100-6B-5

D-100-6B-6

D-100-6B-7

D-100-6B-8
"Wisconsin River, Wisconsin," 1930 [71st Cong., 2d Sess., HR Doc. 259]

"Pembina River and Tributaries, North Dakota," 1944 [78th Cong., 2d Sess., HR Doc., 565]

"Des Moines River, Iowa," 1944 [78th Cong., 2d Sess., HR Doc., 651]

Census Bureau, Irrigation in the Arid States, 1909-11 (printed items)

Correspondence and forms concerning water rights adjudicated by the Wyoming Board of Control, 1916-26

Newell, Frederick H., "A Report on the Management of Property of the Canada Land and Irrigation Company, Ltd.," 1918, and "Proposed Joint Report on Reclamation of Northern Semi-arid Region," 1918

Land Classification Reports of Northern and Central Great Plains, Western Colorado and Utah, 1929-33 [several authors]

U. S. Geological Survey, "Mineral and Water Resources of Wyoming," 1959

Murphy, Edward C., Report on Land Withdrawn for Water-power Purposes along the Red Rock Creek (River), Red Rock Lakes, and Beaverhead River, Montana, 1911

Richards, Raymond, Location of power-sites in various counties in Montana, 1908

Regarding an appropriation by the Pine View Ditch Company of water from Indian Creek, 1914; Brief of report by E. C. Galbraith relative to the project of the Pine View Ditch Company, n.d.

Archibald, George B., Mineral Inspector, Letter regarding investigations of the Big Hole Basin, Montana, 1909

Lamb, William A., Letters concerning land restoration, Madison River Project, Montana, 1911

Letters concerning the Big Hole River Basin, Montana, 1917-19

Memorandum of data regarding dam and reservoir on West Fork of Wise River, Montana, 1919

Murphy, Edward C., Memorandum on present status of Lima Irrigation Project, Montana, 1919

Plats showing location of creeks and ditches in Montana [possibly relating to water-rights case of Donavan Ranch Company], n.d.

Deeds, John F. and White, Walter N., "Water-power and Irrigation in Madison River Basin, Montana," 1924; Locke, J. G., "Report on Madison Irrigation Project," 1909

Deeds, John F. and White, Walter N., "Water Utilization Report - Big Hole River Basin, Montana,", 1925

Statistical reports from the Forest Service regarding stream gaging and ditch evaluations in Montana, 1910-24 [includes some data from 1886]

Deeds, John F. and White, Walter N., "Preliminary report on water supply and its utilization in the Basins of Jefferson, Beaverhead, and Big Hole Rivers, Montana," 1925

Red Rock River, Montana, 1945 [township diagrams]

Soward, Kenneth S., Reconnaissance examination of the Taylor Fork (Eldridge) dam site, Gallatin County, Montana, 1954

U. S. Reclamation Service, Results of Reclamation Work, 1902-11 [printed chart]

Lamb, William A., "Report on Water-power in the Blackfeet Indian Reservation, Teton County," Montana, 1911

Richards, Raymond, Location of power-sites in certain townships in Montana, 1908 [completed forms]

Kramer, Edwin W., Capacities of Madison and Missouri River plants of Montana Power Company and effects of storage in the Hebgen Reservoir on Madison River, 1913

Heron, Kenneth A., "The Valier - Montana Irrigation Project," 1915 [article]

Letters concerning irrigation pumping projects in Prickly Pear Valley, Montana, 1914

Stream Assessments, Montana, n.d.

Savage, Hiram N. and Williams, Charles P., "Sun River Project, Montana, Water Supply" 1912; LaRue, Eugene C., Memorandum concerning irrigation possibilities in the Sun and Teton River Basins, Montana, 1912 
D-100-6B-9

D-100-6B-10

D-100-6B-11

D-100-6B-12

D-100-6B-13

D-100-6B-14

D-100-6B-15

D-100-6B-16

D-100-6B-17

D-100-6B-18

D-100-6C-1

D-100-6C-2

D-100-6C-3

D-100-6C-4

D-100-6C-5

D-100-6C-6

D-100-6C-8

D-100-6D-1

D-100-6D-2

D-100-6D-3

D-100-6E-1

D-100-6E-2

D-100-6F-1

D-100-6F-2

D-100-6F-3

D-100-6F-4
Deeds, John F., Memorandum concerning the irrigation of lands under the Marias Sub-project and Blackfeet Project of the Reclamation Service, 1916

Letters concerning the classification of lands under the Spring Valley Unit of the Sun River Project, Montana, 1916

Murphy, Edward C., "Water Utilization in Birch Creek Drainage, Montana," 1916

Murphy, Edward C., "Water Utilization in Teton River Drainage, Montana," 1917; Murphy, Edward C., Memorandum on the Drouth in Montana: Its effects on land classification, 1919; Murphy, Edward C., "Report on Great Falls, HE 1395," Montana, 1918

Murphy, Edward C., The possibilities of irrigation under a large project diverting from the Dearborn River, Montana, 1918

Surface Water of the Blackfeet Indian Reservation, Montana, 1912

Hoyt, John C., Power-site withdrawals on the Missouri River, 1909

Leighton, Marshall O., Power-site withdrawals on Smith River, Montana, 1910

Debler, Erdman B, Irrigable lands in Blackfeet Indian Reservation, Montana, 1924

"Examination of the Missouri River from Three Forks to Canyon Ferry, Montana," 1894 [53rd Cong., 2d Sess, HR Doc. 96]

Murphy, Edward C., "Report on the Land Withdrawn for Water-power Purposes along the Judith River, Montana," 1911; Jones, Benjamin E., Memorandum on power-site lands along the Judith River, Montana, n.d.

Murphy, Edward C., Memorandum on Irrigation Possibilities in Lower Valley Musselshell River, Montana, 1917; White, Walter N., Comment on Murphy's report on Musselshell Irrigation District, 1917; Murphy, Edward C., Memorandum regarding the status of the Musselshell Valley Irrigation District, 1917

Murphy, Edward C., Memorandum on Water Supply and Status of Flatwillow Irrigation Project, Montana, 1917; Archibald, George B., Extracts from his report on Flatwillow Creek, Montana, 1911

Deeds, John F., "Land Classification of Lower Musselshell River Bottoms," Montana, 1920

Deeds, John F. and Brooks, Luster R., "Land Classification Report: Missouri River bottom lands from Fort Benton, Montana to Montana-North Dakota State Line," 1925 [with color coded land classification maps]

Public Service Commission of Montana, "Harlowton-Durand Irrigation District (Project No. 9) in Wheatland County, Montana: Final Report on the Feasibility of the Project," 1923

Eagleton Quadrangle, Montana, 1952 [map]

Fort Belknap Indian Reservation, Montana, 1911 [61st Cong, 3r Sess., S. Doc. 806]

Stabler, Herman, Conner, Ralph M. and Wells, Charles W., A letter concerning the tentative adjudication of water rights on Milk River and Tributaries, 1915

"Milk River, Montana," 1943 [78th Cong., 1st Sess., S. Doc 103]

Lamb, William A., "Water-power Investigation on Fort Peck Indian Reservation," 1911

Smith, George O., Letter concerning power-site and reservoir possibilities of the Fort Peck Reservation, Montana, 1912; Activities of the Fort Peck District Corps of Engineers, Montana, 1953

Lamb, William A., "Report on Power-site Reserve No. 155, Stillwater River, Montana," 1910; Murphy, Edward C., "Report on Land Withdrawn for Water-power Purposes Along the Bowlder River, Montana," 1911; Hoyt, John C., "Report on Examination of power-site withdrawals along Clarks Fork, Wyoming," 1910; Richards, Raymond, Location of powersites in Montana along the Yellowstone River, 1908 [forms]

Murphy, Edward C., "Report on Land Withdrawn from entry for water-power purposes along the Yellowstone River in Montana," 1911

Kimball, Russell, Plat showing Allison and Bent Ranch, Big Horn County, Wyoming, 1904

White, Walter N., Letter concerning field examination of pending enlarged-homestead petitions in Montana, 1913 
D-100-6F-6

D-100-6G-1

D-100-6G-2

D-100-6G-3

D-100-6G-4

D-100-6G-5

D-100-6G-6

D-100-6G-7

D-100-6G-8

D-100-6G-9

D-100-6G-10

D-100-6G-11

D-100-6G-12

D-100-6G-13

D-100-6G-14

D-100-6G-15

D-100-6G-16

D-100-6G-17

D-100-6G-18

D-100-6H-1

D-100-6H-2

D-100-6H-3

D-100-6H-4

D-100-6H-5

D-100-6H-6

D-100-6H-7

D-100-6H-8

D-100-6H-9

D-100-6H-10

D-100-6H-11

D-100-6H-12

D-100-6H-13

D-100-6H-14

D-100-6H-14B

D-100-6H-15

D-100-6J-1
Jones, Benjamin E., Memorandum concerning flood control on the Yellowstone River, Montana, 1948

Map showing the Lower Yellowstone Project, North Dakota-Montana

"Yellowstone River, Montana," 1911 [62nd Cong., 1st Sess., HR Doc. 83]

Lamb, William A., Water Right Adjudications in the Tongue River Valley, Montana, 1917

Murphy, Edward C., Memorandum on irrigation by pumping from Yellowstone River, 1919

Mulder, Jacob C., Memorandum concerning Rock Creek, Wyoming, 1918

Mulder, Jacob C., Memorandum concerning the Johnson County Irrigation District, Wyoming, 1918

Mulder, Jacob C., Memorandum concerning Clear Creek, Wyoming, 1918

Mulder, Jacob C., Memorandum concerning Crazy Woman Creek, Wyoming, 1918

[charge card]

Mulder, Jacob C., Memorandum concerning the Little Powder River, Wyoming, 1919

Mulder, Jacob C., Memorandum concerning the Powder River, Wyoming, 1918

Mulder, Jacob C., Memorandum concerning the Powder River, Wyoming, 1918

Murphy, Edward C., Memorandum on irrigation possibilities along Powder River, Montana, 1919

Location of power-sites along Clear Creek in Wyoming, 1917 [forms]

Jones, Edward E., Letter concerning a field examination of lands involved in petitions for designation under the enlarged-homestead acts within the Powder and Tongue River Basins, Wyoming, 1920

Stebinger, Eugene, Surface-water data from Sidney Lignite Field Eastern Montana, 1912

Rogers, G. Sherbourne, "Report concerning the water resources of the Little Sheep Mountain Coal Field, Montana," 1912

Farquhar, Robert E., and Whiting, John A., "Water-power Resources, Bighorn National Forest, Wyoming," 1944

Scott, Winfield W., Letter concerning possible power-sites on the Crow Reservation, Montana, 1911

[Charge card]

Hoyt, John C., "Report on examination of power-site withdrawals on No Wood River, Wyoming," 1910

LaRue, Eugene C., Letter concerning power- and reservoir-site possibilities on the Crow Indian Reservation lying east of the Big Horn River, 1912

Memorandum concerning the restoration of lands located on the Shoshone River, 1913

[charge card]

Heroy, William B., "Hydroelectric Plant at Thermopolis, Wyoming," 1914

[charge card]

Plat of Big Horn River and Big Horn County Canal, n.d.

[charge card]

[charge card]

Hewett, D. Foster, Summary of potable waters and springs found in the Wiley and Meeteetse Quadrangles, Wyoming, 1912

Jones, Edward E., "Report of Field examination of the land involved in the restoration of Wyoming Carey Act Segregation List No. 51," 1923

[charge card]

[charge card]

[charge card]

Chandler, Elwyn F., "Report on Fort Berthold Indian Reservation, in North Dakota," 1910;

Smith, George Otis, Letter concerning power-site and reservoir possibilities of the Standing Rock Reservation, North Dakota and South Dakota, 1911 
D-100-6J-2

D-100-6J-3

D-100-6J-4

D-100-6J-5

D-100-6J-6

D-100-6J-7

D-100-6J-8

D-100-6J-9

D-100-6J-10

D-100-6J-11

D-100-6J-12

D-100-6J-13

D-100-6J-14

D-100-6K-1

D-100-6K-2

D-100-6K-3

D-100-6K-4

D-100-6K-5

D-100-6K-6

D-100-6K-7

D-100-6K-8

D-100-6K-9

D-100-6K-10

D-100-6K-11

D-100-6K-12

D-100-6L-1

D-100-6L-2

D-100-6L-3

D-100-6L-4

D-100-6L-5
Chandler, Elwyn F., "Supplementary Report on Power and Reservoir Sites on the Standing Rock Indian Reservation, North and South Dakota," 1911; Little Missouri Project, Reconnaissance Surveys and Report, 1909

Heroy, William B., "North Fork of Grand River Project," North Dakota, 1916

Grosbach, Homer E., Memorandum regarding the Missouri River at Little Bend, North Dakota, 1904-5

[Duplicate of D-100-6J-3 and filed with D-100-6J-3]

Winchester, Dean E., Letter concerning surface water supply conditions in Perkins and Hardy Counties, South Dakota, 1912

Parks, Emerson M., Letter concerning waterholes in Harding County, South Dakota, 1912

[Filed with D-100-6J-2]

White, Walter N., "The Valley of Box Elder Creek," Montana, 1916

Sopp, Francis J., "Report on Little Missouri River," North Dakota, 1918; Data concerning bottom lands, Little Missouri Valley, n.d.; Sopp, Francis J., Letter concerning field examination on the Little Missouri River, 1917

Heroy, William B., Memorandum relative to the designation under the enlarged-homestead act of lands in Kidder, Logan, and McIntosh Counties, North Dakota, 1915

Mulder, Jacob C., Memorandum regarding the Little Missouri River, North Dakota, 1918

Murphy, Edward C., Memorandum on Little Missouri Irrigation Project, Montana, 1919

Jones, Edward E, Letter concerning field examinations of land involved in petitions for designation under the enlarged- and stock-raising-homestead acts in the Missouri River Basin, North Dakota, 1920

Lea, Samuel H., "The Hydroelectric Plant of the Black Hills Traction Company," South Dakota, 1907 [typescript copy of an article]

Blackstone, Richard, "The Hydro-Electric Power Plant of the Homestake Mining Company," South Dakota, 1914 [article]; Blackstone, Richard, "Homestake Hydroelectric Power Plant," South Dakota, 1914 [article]

Derr, Homer M., "Report of the State Engineer of South Dakota on the Angostura Irrigation Project," 1913; and related correspondence, 1916-19

Winchester, Dean E., Letter concerning the surface-water-supply conditions in Converse County, Wyoming, 1912

Mulder, Jacob C., Memorandum concerning the Belle Fourche River Valley, n.d.

Mulder, Jacob C., Memorandum concerning the Cheyenne River Valley, 1918

Mulder, Jacob C., Memorandum concerning the Borelder Valley, 1918

Mulder, Jacob C., Memorandum concerning Spring Creek in the Black Hills, 1918

Mulder, Jacob C., Memorandum concerning the Belle Fourche River, 1918

Mulder, Jacob C., Memorandum concerning the Upper Cheyenne River, 1918

Jones, Edward E., Letter regarding a field examination of land involved in petitions for designation under the enlarged-homestead act within the Cheyenne, Belle Fourche, Little Missouri, and Little Powder River Basins, Wyoming, 1920

Tubbs, Nelson J., Memorandum of water-power on Belle Fourche River, Wyoming, 1926

Olberg, Charles R., "Irrigation Report on Pine Ridge Reservation, South Dakota," 1910

Rizer, Henry C., Letter concerning an examination of the power-site and reservoir possibilities within the Rosebud Reservation, South Dakota, 1911; Chandler, C. F., "Supplementary Report on Power and Reservoir Sites on the Rosebud Indian Reservation, South Dakota," 1911; Chandler, C. F., "Reconnaissance and Gaging on the Rosebud and Pine Ridge Indian Reservations, South Dakota," 1911 [the letter and reports concern the White River]

LaRue, Eugene C., "Power and Reservoir Site Report on Pine Ridge Reservation, South Dakota," 1912

Plats of the profile of Cameron Ditch, Washington County, Nebraska, 1911

Dobson, Arthur A. and others, Location of power-sites in Nebraska, 1908 [forms] 
D-100-6L-6

D-100-6L-7

D-100-6L-8

D-100-6L-9

D-100-6M-1

D-100-6N-1

D-100-6N-2

D-100-6N-3

D-100-6N-4

D-100-6N-5

D-100-6N-6

D-100-6N-7

D-100-6N-8

D-100-6N-9

D-100-6N-10

D-100-6N-11

D-100-6N-12

D-100-6N-13

D-100-6N-14

D-100-6N-15

D-100-6N-16

D-100-6N-17

D-100-6N-18

D-100-6N-18b

D-100-6N-19

D-100-6N-20

D-100-6N-21

D-100-6N-22
Grosbach, Homer E., Letter concerning an examination of the Niobrara River and Minnechaduza Creek, within the former Fort Niobrara Military Reservation, Nebraska, 1913

Robinson, Doane, "Dam Sites on the Missouri River in South Dakota," [booklet]

Mulder, Jacob C., Memorandum regarding the White River Valley, 1918

Jones, Edward E., Letter concerning a field examination of land involved in petitions for designation under the stock-raising and enlarged-homestead acts in the Missouri River drainage, South Dakota, 1920

Location of power-sites in Nebraska, 1902-08

Hoyt, John C., "Report on examination of power-site withdrawals on North Platte River, Wyoming," 1910 [accompanied by a brochure titled "Irrigated Farms of Amazing Fertility on the Far-famed Laramie Plains, Wyoming," issued by the Rock Creek Conservation Company, n.d.]

Plats of a proposed canal line from Alcova to flats of North Casper, Natrona County, Wyoming, 1903,1906

Plats of Pathfinder Reservoir, Wyoming, 1910

Henny, David C., Walter Raymond F., and Weiss, Andrew, Memorandum regarding the Water Supply - North Platte Project, Wyoming, 1915

Correspondence and plat concerning an appropriation of water from North Platte River for power purposes, Wyoming, 1916

Mulder, Jacob C., "Report on Le Prele Ditch and Reservoir Company, Wyoming," 1918 (later the North Platte Valley Irrigation Company)

Mulder, Jacob C., Memorandum concerning North Chugwater Creek, Wyoming, 1919

Mulder, Jacob C., Memorandum concerning the North Platte River, Wyoming, 1918

Mulder, Jacob C., Memorandum regarding Le Prele Creek, Wagonhound Creek, Sheep Creek, Labonte Creek, Little Medicine Bow River, and North Laramie River, Wyoming, 1918

Extracts from a report on irrigation possibilities along North Platte River Basin, 1919

Jones, Edward E., "Report on Examination of Power-site No 413 on Cottonwood Creek," Wyoming, 1919

Jones, Edward E., Concerning a field examination of lands within the Laramie River Basin, Wyoming, 1920

Jones, Edward E., Concerning a field examination of lands within the Big Horn and Sweetwater River Basins, Wyoming, 1920

Jones, Edward E., Memorandum regarding certain lands in the North Platte River Basin, Wyoming, 1920

Jones, Edward E., Concerning a field examination of land on the North Platte and Cheyenne River Basins, Wyoming, 1920

Jones, Edward E., Concerning a field examination of land in the North Platte and Green River Basins, Colorado, 1921

Stanton, Oscar D., "Report on the Character of certain lands under the proposed ditch of the Walden Ditch and Reservoir Company," Wyoming, 1922

Jones, Edward E., "Report on power-site withdrawal No. 169, Encampment River, Wyoming," 1924

[same as above]

Jones, Edward E., "Report on power-site Reserves No. 4 \& No. 435, North Platte River, Wyoming," 1924

Jones, Edward E., "Report on Reconnaissance of Sweetwater River, Wyoming," 1924

Farquhar, Robert E., Whiting, John A., and Huckeby, H. Minor, "Water-power Resources,Medicine Bow National Forest, Wyoming," 1944

Follansbee, Robert, "Report on Permit granted the Seminole Power Company to develop power on North Platte River at Seminole Canyon, Wyoming," 1929 
D-100-6O-1

D-100-6O-2

D-100-6O-3

D-100-6O-4

D-100-6O-5

D-100-6O-6

D-100-6O-7

D-100-6O-8

D-100-6O-9

D-100-6O-10

D-100-6O-11

D-100-6O-12

D-100-6O-13

D-100-6O-14

D-100-6O-15

D-100-6O-16

D-100-6O-17

D-100-6O-18

D-100-6O-18b

D-100-6O-19

D-100-6O-20

D-100-6O-21

D-100-6O-22

D-100-6O-23

D-100-6P-1

D-100-7-1
North Sterling Irrigation District, Colorado, 1912 [brochures, newspapers clippings, and report on bondholders meeting]

Stanley Dam and Irrigation System, Colorado, n.d. [newspaper clippings]

Leighton, Marshall O., "Report on Power-site Withdrawal No. 78, South Boulder Creek, Colorado," 1912

Location of power-sites in Colorado, 1908 [forms]

LaRue, Eugene C., "Report covering Enlarged-homestead Petition affecting South Platte Valley, Colorado," 1913

McFadden, George C., Statement of water flow of Cache la Poudre River, Colorado, 1909

USGS Press Bulletin No. 346, "Conservation of Groundwater Supplies in Lodgepole Valley, Nebraska and Wyoming," 1917

White, Walter N., "Report relative to combined projects of the on Riverside Reservoir and Land Company and Riverside Irrigation District, and the project of the North Sterling Irrigation District, Colorado," 1915

Jones, Edward E., Concerning a field examination of land involved in petitions for designation under the enlarged-homestead acts within the South Platte and Laramie River Drainage Basins, Colorado, 1919

Location of power-sites along North St. Vrain Creek, Colorado, 1917

Jones, Edward E., Concerning a field examination of land involved in petitions for designation under the stock-raising and enlarged-homestead acts in the South Platte River Basin, Colorado, 1920

Jones, Edward E., Concerning a field examination of land involved in petitions for designation under the stock-raising and enlarged-homestead acts in the South Platte River Basin, Colorado, 1921

Jones, Edward E., Concerning a field examination of land involved in petitions for designation under the stock-raising and enlarged-homestead acts in the South Platte River Basin, Colorado, 1922

Follansbee, Robert, "Report on application of Mrs. Alice B. Jones for preliminary permit for development of power on North St. Vrain Creek, Colorado, Federal Power Commission Project No. 347," 1922

Jones, Edward E., "Report upon the potential power value of South Platte River above South Platte, Colorado," 1923

Jones, Edward E., "Report on the application of Frederick W. Wasen for certain power-site lands on Clear Creek, Colorado," 1923

Jones, Edward E., "Report on the application of St. George Mines Company, Inc. for certain power-site lands on Clear Creek, Colorado," 1923

Jones, Edward E., "Report of my Reconnaissance of that part of the basin of South Platte River lying north and west of Denver, Colorado," 1924

Jones, Benjamin E., Power-classification sheets for the Big Thompson River, Boulder Creek, Cache La Poudre River, Clear Creek, Lefthand Creek, Middle and South Boulder Creeks, and Middle St. Vrain and South St. Vrain Creeks, Colorado, ca. 1943

Code, W. E. and Brooks, L. R., "Report on Special Pumping Study in Weld County, Colorado," 1930; Code, W. E., "Report on Drainage by Pumping on Two Colorado Farms in 1930";

Code, W. E., "Cost of Pumping for Irrigation in Colorado," 1932

"Cherry Creek and Tributaries, Colorado," 1939 [76th Cong., 1st Sess., HR Doc. 426]

[charge card]

Farquhar, Robert E., "Water-power Resources, Roosevelt National Forest, Colorado," 1940

Lundgren, E. Leonard, "Report upon application of George B. McFadden for a preliminary power permit on the Cache La Poudre River," Colorado, 1914

Location of power-sites in Nebraska, 1904-8 [forms]

Brittain, Doss, "Pumping problems of the Joplin District," Missouri 1908 [article] 
D-100-7-2

D-100-7-3

D-100-7-4

D-100-7-5

D-100-7A-1

D-100-7A-2

D-100-7A-3

D-100-7A-4

D-100-7A-5

D-100-7A-6

D-100-7A-7

D-100-7A-8

D-100-7A-9

D-100-7A-10

D-100-7A-11

D-100-7A-12

D-100-7A-13

D-100-7A-14

D-100-7A-15

D-100-7A-15b

D-100-7A-16

D-100-7A-17

D-100-7A-18

D-100-7A-18b

D-100-7A-19

D-100-7A-20

D-100-7A-21

D-100-7A-22
Ellsworth, Clarence E., Memorandum regarding the White River, Ark., 1916

Gray, Glenn A., "Arkansas River Basin, New Mexico," 1916

"Water Service Reports" for various plants or systems in Texas, 1917 [forms]

Department of the Interior Press Release, Regarding the disposition of power from the Denison Dam, Texas; Grand River Dam, Oklahoma; Norfolk Dam, Arkansas, 1943

Harding, Sidney T., "Report on examination of power-site withdrawals Nos. 131 and 127, Grape Creek, No. 2, Colorado," 1912; Jones, R. M., "The Pikes Peak Power Transmission," Colorado, 1902 [transcribed article]

Location of power-sites in Colorado, 1908 [forms]

LaRue, Eugene C., "Report on Applications for Designations of Lands under the Enlarged Homestead Act, Arkansas Valley, Colorado," 1913

Follanbee, Robert, "Report of the Hydroelectric development in connection with Colorado Springs Water Supply," 1914

Filings on Apache Creek, 1888-1913 [oversize sheets]

Rohde, Charles, Proposed Pueblo Irrigation District Project in Colorado, 1913; Lurton, J. P., "Preliminary report on Lida Reservoir and Western Slope Waters for the Pueblo Irrigation District, owned by Charles Rohde and Frederick Porter," 1912; Lurton, J. P., "Report on the Proposed Water Supply and Distributing Canals for the Pueblo Irrigation District," 1912

Weiland, Adelbert A., Concerning the Swink Ditch and Reservoir Company, Colorado, 1916; Weiland, Adelbert A., "Storage Possibilities on the Purgatorie River," Colorado, 1916 [A report for W. S. Partridge, Manager of the Arkansas Valley Sugar Beet and Irrigated Land Company)

LaRue, Eugene C., "Irrigation in the Huerfano River Basin, Colorado," 1916

Miscellaneous Data - Arkansas River Valley, Colorado, 1916

LaRue, Eugene C., Concerning a report on enlarged-homestead entries in the Grape Creek Basin, Colorado, 1916

Neale, J. R., Model Land and Irrigation Company Project, Colorado, ca. 1916

Jones, Edward E., Regarding a field examination of land involved in petitions for designation nder the stock-raising and enlarged-homestead acts within the exterior limits of the Two Buttes Irrigation District, Lamar, Colorado Land District, 1920

Jones, Edward E., Regarding a field examination of land involved in petitions for designation under the stock-raising and enlarged-homesteads acts within the Arkansas River Basin, Colorado, 1920

Jones, Edward E., Regarding a field examination of land involved in petitions for designation under the stock-raising and enlarged-homestead acts within the Arkansas River Basin, Colorado, 1921

Jones, Edward E., "Reconnaissance Report of the power-site reserves adjacent to Arkansas River west of Pueblo, Colorado," 1925

Power-classification sheets, Arkansas River, n.d.

Jones, Edward E., "Reconnaissance Report of power-site reserves - Grape Creek, Colorado," 1921

Jones, Edward E., "Report on power-site reserves adjacent to Beaver Creek, Colorado," 1922

Jones, Edward E., "Reconnaissance of potential power resources on the tributaries of the Arkansas River above Salida, Colorado," 1922

Power-classifications sheets, Arkansas River Basin, n.d.

Follansbee, Robert, "Report on application of Southern Colorado Power Company for preliminary permit for development of power on Grape Creek, Colorado," 1924

Plats showing location of constructed irrigation ditches in parts of townships $71 \mathrm{~W} ., 72 \mathrm{~W}$., and 73 W., in Colorado, n.d.

Norcross, Theodore W., Concerning a report on application of the Princeton Mining Company for a final water permit for development of plant on Chalk Creek, Colorado, 1911

Farquhar, Robert E., "Water-power Resources, Cochetopa National Forest, Colorado," 1940 
"Fountaine Que Bouille (Fountain) River and Its Tributaries, Colorado," 1943 [78th Cong., 1st Sess., HR Doc. 186]

D-100-7A-24

D-100-7C-1

D-100-7C-2

D-100-7C-3

D-100-7C-4

D-100-7C-5

D-100-7D-2

D-100-7D-3

D-100-7H-1

D-100-7O-6

D-100-7P-1

D-100-8-1

D-100-8-3

D-100-8-4

D-100-8-5

D-100-8-6

D-100-8A-1

D-100-8A-2

D-100-8A-3

D-100-8B-1

D-100-8B-2

D-100-8B-3

D-100-8B-4

D-100-8B-5

D-100-8B-6

D-100-8B-7

D-100-8B-8

D-100-8B-9

D-100-8B-10
"Fryingpan-Arkansas Project, Colorado," 1952 [82nd Cong., 2d Sess., S. Doc 106]

Correspondence, memorandums and newspaper clippings and other records concerning the Canadian River Valley, New Mexico, 1910

Murphy, Edward C., "Water-power Utilization in New Mexico, Part 9, Mora River and Its Tributaries," 1916

Mulder, Jacob C., and Sanchez, Manuel E., "General discussion of Ute Creek Basin, New Mexico," 1917

[file contents transferred to the Grazing Service - now filed as G. B. \#25, New Mexico]

Gray, Glenn A., Photographs of Mora River, New Mexico, 1914

"Irrigation from Reservoirs in Western Kansas and Oklahoma," 1913 [62nd Cong., 3d Sess., S. Doc. 1021]

Jones, Edward E., Regarding a field examination of lands involved in petitions for designation under the stock-raising and enlarged-homestead acts within the Arkansas River Basin and the San Luis Park Region, Colorado, 1922

Department of Interior, Press Release, "Ground Water Supplies for Rice Irrigation in Grand Prairie Region, Arkansas," 1931

"Ouachita River from Camden to Arkadelphia, Arkansas," 1912 [62nd Cong., 2d Sess., HR Doc. 588]

"Ouachita River from Camden to Arkadelphia, Arkansas," 1912 [62nd Cong., 2d Sess., HR Doc. 588]

Bureau of the Census Press Release, "Texas Irrigation Statistics," 1911

[Various authors], Memorandums on the power possibilities of various creeks in New Mexico, 1916

Heroy, William B. and Stabler, Herman, Water-power Minutes, Safety Map of New Mexico: Stream classification of New Mexico waters according to hydrologic index, 1917

Farquhar, Robert E., "Water-power Resources - Rio Grande National Forest, Colorado," 1940 [charge card]

White, Walter N., "Report on San Luis Valley," Colorado, 1916 [loaned to Water Resources Branch in 1936]

Thompson, Harry, "Report on Moffat Irrigation and Drainage District," Saguache County, Colorado., 1917

Stannard, Jay D. and Miller, Dalton G., "Cooperative Report, Drainage and Water Development, San Luis Valley, Colorado," 1915

Gray, Glenn A., "Nambe Falls Power-site," New Mexico, n.d.; Finch, James A., Costilla Creek, Colorado., 1912; Perry Rueben, San Jose River, 1910; Miller, Charles D., "The Irrigation Resources of New Mexico," 1911

Davenport, Royal W., Memorandum on a study of the water supply situation in the San Luis Valley, Colorado., 1915

Murphy, Edward C., "Water-power Utilization in New Mexico," 1916

Bulletin No. 685 [missing]

Follansbee, Robert, "Report on application of Molybdenum Corporation of America for license and preliminary permit for development of power on Red River, New Mexico," 1923

Middle Rio Grande Conservancy Project, Albuquerque, New Mexico, 1928

Heron, Kenneth A., "The San Juan - Willow Creek - Rio Grande Project," 1933

New Mexico Water Resources, 1944 [Hearings - 78th Cong., 2d Sess., S. Res. 304]

Doolittle, Richard, N., "Summary of Investigations on Red River and Tributaries, New Mexico," 1950; Doolittle, Richard N., "Supplemental Report on Water Possibilities of Red River and Tributaries, New Mexico," 1951

[Charge card] 
D-100-8B-11

D-100-8C-1

D-100-8C-2

D-100-8C-3

D-100-8C-5

D-100-8D-1

D-100-8D-2

D-100-8D-3

D-100-8F-1

D-100-8F-2

D-100-8F-3

D-100-8F-4

D-100-8F-5

D-100-8F-6

D-100-8F-7

D-100-8F-8

D-100-8F-9

D-100-8F-10

D-100-8F-11

D-100-8F-12

D-100-8F-13

D-100-8F-14

D-100-8G-1

D-100-8H-1

D-100-8H-2

D-100-8J-1

D-100-8K-1

D-100-8K-2

D-100-8M-1

D-100-8M-2

D-100-8N-1

D-100-9-1

D-100-9-2
Review of water-power withdrawals, 1957-59

Crowder, Enoch H., Memorandum by the Judge Advocate General regarding the diversion of the waters of the Rio Grande for irrigation purposes, 1911

"Rio Grande, New Mexico," 1914 [63rd Cong. 2d Sess., HR Doc. 1144]

Baldwin, Ernest H., "Excavation for the Foundation of Elephant Butte Dam," 1915 [article]

Department of the Interior Press Release, Elephant Butte Dam, Rio Grande Project in New Mexico, 1938

Plats of the ground-water area of Tularosa Basin, New Mexico, 1911

Murphy, Edward C., "Water-power Utilization in New Mexico, Part 3, Tularosa River," New Mexico, 1916

Blake, Harry E., Report and related records on the ground-water conditions of the Estancia Valley, New Mexico, 1918

Carroll, James A., Letter concerning the Mescalaro Indian Reservation, New Mexico, and the streams within the reservation that could be used for power development, 1910

Plat of reservoir \#2 (Avalon Reservoir), Eddy County, New Mexico, n.d.

Murphy, Edward C., "Water-power Utilization in New Mexico, Pt. 5, Hondo River, Ruidoso and Bonito Creeks," 1916

[charge card]

Schuyler, James D., "Report on Irrigation and Water Storage in the Lower Pecos Valley, Texas," 1916

Gray, Glenn A., "Report on Water-power Possibilities of Pecos River," New Mexico, 1916

Meinzer, Oscar E. "On Field Investigations of Lands in the Roswell Artesian Basin in Pecos Valley, New Mexico," 1916

LaRue, Eugene C., Regarding a report on irrigation development in Pecos Valley, New Mexico, 1917

Lee, Willis T., Two reports on Carlsbad, New Mexico, 1911, 1923

Lee, Willis T., "Report on Red Bluff Dam Site on Pecos River, New Mexico," 1923

Teeter, Earl E., Excerpts from a report on preliminary investigation for Penasco River Irrigation, Hope Project, New Mexico, 1924

Spicer, H., Cecil, "Report on the Electrical Resistivity determinations over the Potash area near Carlsbad, New Mexico," 1940

Senkpiel, William C., "Summary of certain investigations in Pecos River Basin, New Mexico and Texas," 1942

Letters regarding the Pecos River Basin, New Mexico and Texas, 1956-57

Murphy, Edward C., "Water Utilization in New Mexico, Part 7, Sacramento River," California 1916

Blake, Harry E., "Report on the Ground Water Conditions of the Portales Basin, New Mexico," 1918

Meinzer, Oscar E., Regarding ground-water investigations in New Mexico, 1909

Department of Interior Press Release, Ground-water resources of Webb County, Texas, 1933

Department of the Interior Press Release, Underground-water resources of Atascosa and

Frio Counties, Texas, 1932

Department of the Interior Press Release, Ground-water resources of Duval County, Texas, 1933

Turner, Samuel F., "Mineral-Water Supply of the Mineral Wells Area, Texas," 1934

"Whitney Dam, Texas," 1939 [76th Cong. 1st Sess., HR Doc. 390]

Department of the Interior Press Release, Ground-Water resources of the Houston-Galveston Area, Texas, 1932

[charge card]

Padgett, Harold D., "Report on data collected in Utah in connection with the Colorado River Water Right Investigation," 1917 
D-100-9-3

D-100-9-4

D-100-9-5

D-100-9-6

D-100-9A-1

D-100-9A-2

D-100-9A-3

D-100-9A-4

D-100-9A-5

D-100-9B-1

D-100-9B-2

D-100-9B-3

D-100-9B-4

D-100-9B-5

D-100-9B-5

D-100-9B-6

D-100-9B-8

D-100-9B-9

D-100-9B-9b

D-100-9B-10

D-100-9B-11

D-100-9B-12

D-100-9B-13

D-100-9B-14

D-100-9B-15
Memorandums concerning power possibilities on the Gila River, San Juan River Basin, San Francisco River and tributaries, and Colorado River Basin, New Mexico, 1916

Follansbee, Robert, Memorandum, letters, and data concerning a report on evaporation in the Colorado River Basin, New Mexico, 1925, 1954

Reports, newspaper clippings and congressional documents concerning the Boulder Canyon Project, Arizona, California and Nevada, 1908-36

Piper, Arthur M., "Geologic Features of certain dam sites in the Bear River, Colorado River and Rio Grande Basins," Utah, Wyoming, Colorado, Arizona, New Mexico, 1936-37

Hoyt, John C., "Report on Examination of Power-site Withdrawals in the Upper Green River Drainage," Wyoming, 1910

Woolley, Ralf R., "A Report on Water-power Possibilities in Upper Green River Basin above Green River, Wyoming," 1920

Woolley, Ralf R., "Report on F. W. P. No. 165 (26929 Utah) at Flaming Gorge on the Green River in Utah and Wyoming," 1923

Woolley, Ralf R., and Cottrell, F. W., "Preliminary Report on proposed gravity diversion from Green River to Bear River in Southwestern Wyoming," 1935

Johnson, Arthur, Green River above Green River, Wyoming [photographs], 1959

Leighton, Marshall O., "Report on power-site withdrawal No. 101, San Raphael River, Utah on Green River, Utah, 1910; Leighton, Marshall O., "Report on Power-site Withdrawal No. 144, Price River, Utah," 1910; Leighton, Marshall O., "Report concerning an Investigation of that portion of the Power-site Withdrawal No. 42, Green River, Utah," 1910

LaRue, Eugene C., "Report relative to the power possibilities on Lower White River, Colorado and Utah," 1911

LaRue, Eugene C., "Report on power-site withdrawals No. 7 and No. 38, Ashley Creek and tributaries, Salt Lake Meridian, Utah," 1911; "Surveys and examinations of Uinta Indian Reservation, Utah," 1902 [57th Cong., 1st Sess., HR Doc. 671]

LaRue, Eugene C., "Report on power possibilities on the following Utah streams: Lake Fork Creek, Duchesne River, Strawberry River, Red River, Current Creek," 1911

LaRue, Eugene C., Examination of the plan and profile sheet of the Green, Duchesne, and White River, Utah, 1916

Babb, Cyrus B., "Report on the investigation of the water supply of the Uinta Indian Reservation," Utah 1900

Hancock, Eugene T., Letter regarding the Meeker Quadrangle, Colorado, 1912

Jones, Edward E., Reconnaissance - power-site reserves No 254 and No. 31, White River, Colorado, 1920

Woolley, Ralf R. and Jacob, Clarence C., "Water Supply of Uinta Basin, Utah, and Its Utilization," 1922

Power-classification sheets, Rock Creek, Lake Fork Creek, Whiterock River, Utah, n.d.

Woolley, Ralf R., "Report on Ratliff Project on Green River near Jensen, Utah," 1923

Woolley, Ralf R., "A Boat Trip down Green River from Green River, Wyoming to Green River, Utah, July 10 - September 14, 1922"

Woolley, Ralf R., "Report on the Value of Lands in Big Brush Creek Gorge for Water Storage or Power Purposes, Uinta County, Utah," 1929

Woolley, Ralf R. "Report on Recommendation of Forest Service regarding changes in Power Classification and Withdrawals in Ashley and Wasatch National Forests, Utah," 1932; Martin, J. P., "Report upon Power Resources and Withdrawals for Power Purposes upon the Ashley and Wasatch National Forests," Utah 1932

Shenon, Phillip J., "Geology at several dam sites on Huntington Creek, near Huntington, Utah," 1934

Eckel, Edwin B., "Geology of dam sites on the Green and Yampa Rivers, Utah and Colorado," 1939 
D-100-9B-16

D-100-9B-17

D-100-9C-1

D-100-9C-2

D-100-9C-2a

D-100-9C-2b

D-100-9C-3

D-100-9D-1

D-100-9D-2

D-100-9D-3

D-100-9D-4

D-100-9D-6

D-100-9D-7

D-100-9D-8

D-100-9D-8.5

D-100-9D-10

D-100-9D-11

D-100-9D-12

D-100-9D-13

D-100-9D-14

D-100-9D-15

D-100-9D-15b

D-100-9D-16

D-100-9D-16b

D-100-9D-17

D-100-9D-17b

D-100-9D-18

D-100-9D-19

D-100-9D-20

D-100-9D-21

D-100-9D-22

D-100-9D-23
Farquhar, Robert E., "Water-power Resources - White River National Forest, Colorado," 1940

Woolley, Ralf R., "Preliminary Report on Federal Water-power Project 290 on Huntington Creek in Emery County, Utah," 1922

LaRue, Eugene C., Report on Yampa River and tributaries, Colorado, 1911

Oakey, Warren, "Report on the power and storage possibilities of Yampa River between Craig, Colorado and the junction of Yampa and Green Rivers," 1924

Computations and plats - Yampa River, n.d.

Oakey, Warren, Land-classification sheets, Yampa River, 1924

Huckeby, H. Minor and Farquhar, Robert E., Water-Power Resources, Routt National Forest, Colorado, 1942

Leighton, Marshall O., "Report on water-power withdrawals Nos. 116 and 119, covering Grand River from its source in Colorado to its Junction with the Green River in Utah," 1910

Harding, Sidney T., "Report on Examination of Temporary Power-site Withdrawal on Blue River, Colorado," 1911

Leighton, Marshall O., Report on examination of water-power withdrawals in the Eagle River Valley, Colorado, 1911

Location of power-sites along the Colorado River and tributaries, 1908

Porter, Elmer A., Mill Creek, Moab Valley, Utah, 1914

[charge card]

[filed as D-100-9D-11]

Sandstom, E. P., Limbocker, T. F., and McGintry R. A., "A Fruit Survey of Mesa County," Colorado, 1917 [Bulletin 223, February 1917, The Agricultural Experiment Station of the Colorado Agricultural College]

Jones, Edward E., "Field examination of land involved in petitions for designation under the enlarged and stock-raising homestead acts in the Colorado River Basin," Colorado, 1921

Follansbee, Robert, "Report on Application of William J. Barker for preliminary permit for development of Kremmling Reservoir site, Colorado," 1922

Jones, Edward E., "Report on power value of Plateau Creek," Colorado, 1922

Edwards, Robert F., Memorandum regarding the Blue River, Colorado from Dillon to Mouth, 1922

Edwards, Robert F., Memorandum regarding the Williams Fork River outside of Arapahoe National Forest, Colorado, 1922

Jones, Edward E., "Power Resources of Blue River, Colorado," 1924

Jones, Edward E., Recommendations on the classification of power-site lands along the Blue River, Colorado, 1925

Jones, Edward E., "Power Resources of Eagle River, Colorado," 1925

Jones, Edward, E., Recommendations relative to restoration and withdrawal of power-site lands along Eagle River, Colorado, 1925

Jones, Edward E., "Power resources of Roaring Fork, Smowmass to Mouth only (not including tributaries)," 1925

Jones, Edward, E., Recommendations relative to restoration and withdrawal of power-site lands along Roaring Fork, 1925

Jones, Edward E., "Power Resources of San Miguel River, Colorado," 1925

Jones, Edward E., "Power resources of Dolores River, Colorado," 1925

Erdmann, Charles E., Account and photos of flood waters in Hunter (Little Salt) Wash (August 1926), Colorado, 1932

Follansbee, Robert, "Report on application of Denver and Salt Lake Western Railroad Company for right of way from Orestod to Dotsero, Colorado along Colorado River," 1925

Farquhar, Robert E., "Water-power Resources - Grand Mesa National Forest, Colorado," 1940

Farquhar, Robert E, "Water-power Resources - Holy Cross National Forest, Colorado," 1940 
D-100-9D-24

D-100-9D-25

D-100-9D-25b

D-100-9D-26

D-100-9D-27

D-100-9E-1

D-100-9E-2

D-100-9E-3

D-100-9E-5

D-100-9E-6

D-100-9E-7

D-100-9E-8

D-100-9E-9

D-100-9E-10

D-100-9E-10b

D-100-9E-10c

D-100-9E-11

D-100-9E-12

D-100-9E-13

D-100-9E-14

D-100-9E-15

D-100-9E-16

D-100-9F-1

D-100-9F-2

D-100-9F-3

D-100-9F-4

D-100-9F-5

D-100-9F-6

D-100-9F-7

D-100-9F-9

D-100-9F-10

D-100-9F-11

D-100-9G-1
Finley, Emmett A., Memorandum concerning reconnaissance of dam sites on Eagle River between Leadville and Eagle, Colorado, 1951

Lawrence, Fred F., "Water-power Resources of the Crystal River, Colorado," 1953

Power-classification sheets, Crystal River, Colorado

Regarding the application of Radium Copper Mining Company, Colorado, 1911

Tefft, Henry D., Withdrawals in the Roaring Fork Drainage Basin, Colorado, 1956

Russell, Garfield H., "Report of power withdrawals on Cochetopa Creek," Colorado, 1911

Location of power-sites along Gunnison stream, Colorado, 1908

Kreutzer, William R., "Report for Forest Atlas, Gunnison National Forest, Colorado," 1909

Jones, Edward E., Field examination of land involved in petitions under the enlarged-homestead and stock-raising acts in the Grand River Basin, Colorado, 1921

Jones, Edward E., "Reconnaissance - Power-site Reserves Nos. 27 and 50, Taylor and Gunnison River, Colorado," 1920

Jones, Edward E., "Reconnaissance - Power-site Reserve No. 50, East River, Colorado," 1920

Jones, Edward E., "Reconnaissance - Power-site Reserves Nos. 254 and 43, Cochetopa Creek, Colorado," 1920

Stanton, [Oscar D.] Reconnaissance Report on the irrigation development in Forked Tongue, Surface Creek, Leroux Creek Valleys, and adjacent mesas, Delta County, Colorado, 1923

[charge card]

Recommendation for withdrawal based on field examination of Taylor River, Colorado, n.d.

Jones, Edward E., "Power Resources of Taylor River, Colorado," 1925

Stanton, Oscar D., Water-power possibilities on Muddy Creek, Colorado, 1926

Nordeen, Carl E., "Power and Irrigation Resources of East and Slate Rivers, Colorado," 1926

Spicer, H. Cecil, "Estimate of depth to bed rock at some dam sites in the Gunnison, Little Colorado, and Zuni River Basins, Colorado and Arizona, based on Resistivity Measurements, 1938-39"

Follansbee, Robert, "Report on application of R. D. Webb for preliminary permit for development of power on Lake Fork, Colorado," 1929

Larson, Ernest O., Memorandum regarding power studies - Upper Gunnison River Upper Colorado River Basin, Colorado, 1946

Crandell, Dwight R., "The Slumgullion Mudflow and its suitability as a damsite," Colorado, 1958

Sawyer, Kenneth, Regarding Diamond Drill operations at junction of Green and Grand Rivers, Colorado River Storage Investigation, Utah, 1914

Blueprint profile of Colorado, Green, and Grand Rivers, n.d.

Davis, Robert M., Water-power Minutes - Safety Map of Arizona, 1918

LaRue, Eugene C., Letter regarding trip to Ferry, Ariz., 1915

LaRue, Eugene C., Extracts from diary of Eugene C. LaRue while on boat trip from Green River, Utah to Lee Ferry, Arizona, 1921

Woolley, Ralf R., "Classification of Lands in Power-site Reserve along Fremont River in Wayne County, Utah," 1923

Paige, Sidney, "The Geology of Cataract Canyon, Colorado River, Utah, with respect to location of damsites," 1923

Bryan, Lester L., "Water-power-classification Report on powersite lands on Colorado River in the vicinity of Lees Ferry, Arizona," 1932

Bryan, Kirk, "The Geologic Setting of the Lees Ferry Dam site," Arizona, ca. 1922

Miser, Hugh D. and Paige, Sidney, "The Glen Canyon of the Colorado between the mouths of Warm and Wahweap Creeks," Arizona and Utah, 1922

Animas power development in Colorado, n.d.; Location of power-sites in San Juan and La Plata Counties, Colorado, n.d.; Churchill, Clarence A., Letter regarding the Jicarilla Reservation and the La Jara Lake Reservoir site, New Mexico, 1910 
D-100-9G-2

D-100-9G-3

D-100-9G-4

D-100-9G-5

D-100-9G-6

D-100-9G-6b

D-100-9G-7

D-100-9G-8

D-100-9G-9

D-100-9G-10

D-100-9G-11

D-100-9H-1

D-100-9H-3

D-100-9J-1

D-100-9J-2

D-100-9J-3

D-100-9J-4

D-100-9J-5

D-100-9J-6

D-100-9J-7

D-100-9J-8

D-100-9J-9

D-100-9K-1

D-100-9K-2

D-100-9L-1

D-100-9L-2

D-100-9L-3

D-100-9L-4

D-100-9L-5

D-100-9L-6
Murphy, Edward C., "Report on Water-power Possibilities on Hogback Canal, Navajo Indian Reservation, New Mexico," 1914

[charge card]

[charge card]

Miser, Hugh D., San Juan River, Southeast Utah, 1923 [accompanied by an album of photographs]

LaRue, Eugene C., "Water-power on the San Juan River," Colorado \& Utah, 1928 [Part 1]

LaRue, Eugene C., "Water-power on the San Juan River," Colorado \& Utah, 1928 [Part 2]; Power-classification sheets

Shenon, Philip J., "Geologic Report on the Arboles Damsite in Northwestern New Mexico," 1933

Shenon, Philip J., "Geologic Report on the Trujillo Damsites in Southwestern Colorado," 1933

Report on depth of alluvial fill in Los Pinos River Valley at Consolidated Ute Reservation Agency at Ignacio, Colorado, 1936; Erdmann, Charles E., "Report on Depth to Bedrock at Pine River Damsite, La Plata County, Colorado," 1936

Florida Project, Colorado, 1939

[charge card]

Murphy, Edward C., "Water-power Utilization in Arizona, Bright Angel Creek," 1915

Moore, Raymond C., "Geologic Report on the Grand Canyon of the Colorado River, with special reference to Water Control and Power Development," 1926

Murphy, Edward C., Report on the lands withdrawn from entry for water-power purposes along the Little Colorado River, Arizona, 1911

Robinson, Herbert F., Letter reporting on power and reservoir sites on reservations within his jurisdiction, New Mexico, 1910 [Western Navajo, Navajo Extension, Navajo, Hupai, Jicarilla, Southern Ute, Taos]

Murphy, Edward C., "Water-power possibilities in Arizona - Little Colorado River and tributaries," 1915

LaRue, Eugene C., Correspondence regarding power development in the Little Colorado Basin, New Mexico \& Arizona, 1914

Holbrook, George F., Memorandum regarding the power value of the Little Colorado River, 1929

Eckel, Edwin B., "Geology of some dam sites on Little Colorado River and Its Tributaries, Arizona," 1939

Spicer, H. Cecil, "Report on Resistivity Measurements with Estimates of Depth to Bedrock at certain Dam Sites on the Little Colorado River and Tributaries," 1939

Helland, Randolph O., "Water Utilization in the Little Colorado River Basin, Arizona and New Mexico," 1948

"Little Colorado River, Arizona and New Mexico," 1944 [78th Cong., 2d Sess, HR Doc. 648]

Young, A. A., "Land Classification of the Muddy Valley, Clarke County, Nevada," 1928

King, Thomas R. and Malone, [no first name given] "Engineering Report on Moapa Valley Area, Clarke County, Nevada," 1928

Jacob, Clarence C., "Report on Desert Claim of Riley Johnson on Bill Williams River, Arizona," 1911

Balliet, Letson, "The Colorado River Hydro-Electric Project," 1914 [article]

"Colorado River, California and Arizona," 1914 [63rd Cong., 2d Sess., HR Doc. 114]

Application of the Empire Water Company to appropriate waters of Coyote Creek, San Bernardino, California, 1912

"Production of lands and property in the Imperial Valley, California," 1915 [63rd Cong., 3d Sess., HR Doc. 1476]

Murphy, Edward C., "Water-power Utilization in Arizona, Bill Williams River and Tributaries," 1915 
D-100-9L-7

D-100-9L-8

D-100-9L-9

D-100-9L-10

D-100-9L-11

D-100-9L-12

D-100-9L-13

D-100-9L-14

D-100-9L-15

D-100-9L-15b

D-100-9L-16

D-100-9L-17

D-100-9M-1

D-100-9M-2

D-100-9M-3

D-100-9M-4

D-100-9M-5

D-100-9M-6

D-100-9M-7

D-100-9M-8

D-100-9M-9

D-100-9M-10

D-100-9M-11

D-100-9M-12

D-100-9M-13

D-100-9M-14

D-100-9M-15

D-100-9M-16

D-100-9M-17
Hulin, Carlton D., "Report on the Geology of the Stony Gorge Reservoir and Dam Site, Orland Project, California," 1926

LaRue, Eugene C., "Report on Available Water Supply for North End and Imperial North Side Water Companies, Imperial Valley, California," 1914

All-American Canal Board (Elwood Mead, Walter W. Schlecht, and Carl E. Grunsky), "The All-American Canal," 1919

U. S. Bureau of Reclamation, "Report on problems of Imperial Valley and Vicinity," California, 1922

USGS Press Notice, Ground water in Piute Valley, Nevada, 1922

LaRue, Eugene C., "Preliminary Report - Mohave Valley Reservoir Site, Colorado River, Arizona - California," 1923

Arizona Engineering Commission, "Report based on Reconnaissance Investigation of Arizona Land Irrigable from the Colorado River," 1922-23

Hewett, D. Foster, "A Geologic Report on the Eldorado Canon Damsite, Colorado River, Nevada \& Arizona, 1924

Holbrook, George F., "Report on Probable Future Stages of Salton Sea," California, 1927

Holbrook, George F., Recommendations contained in above report, 1927

Eckel, Edwin B., "Geology of Dam Sites on Williams River and Kirkland Creek, Arizona," 1940

Hannum, Warren T., Memorandum regarding flood control of Bill Williams River and its tributaries, Arizona, 1941

Weaver, Lewis M., Letter regarding Box Canyon and San Carlos River on the San Carlos Reservation, Arizona, 1910; McQuigg, Henry J., Letter regarding the Santa Cruz Valley, Arizona, 1911; Newspaper clipping on the Box Canyon controversy, 1911

Murphy, Edward C., "Report on Lands Withdrawn for Water-power Purposes Along the Gila River in Arizona and New Mexico," 1912

Murphy, Edward C., "Report on Water power-sites and Reservoir Sites on Gila River Indian Reservation, Arizona," 1912

Davis, Arthur P., "Report on the Irrigation Investigation for the benefit of the Pima and other Indians on the Gila Indian Reservation, Arizona," 1896 [54th Cong., 2d Sess., Sen. Doc. No. 27]

Murphy, Edward C., Letter regarding an examination of lands in the Upper Gila Drainage, New Mexico, 1914

Murphy, Edward C., "Water-power Utilization in Arizona," 1915; Murphy, Edward C., "Waterpower Utilization in New Mexico," 1915

Berry, Oral J., "Water Supply of San Simon Artesian Belt," Arizona, 1918

Diversion dam on the Gila River at a site above Florence, Arizona, 1916 [printed]

LaRue, Eugene C., Letter regarding a proposal to irrigate land in the vicinity of Queen Creek, Arizona, 1918

Murphy, Edward C., Memorandum on irrigation from ground water in the Casa Grande Valley, Arizona, 1920

Smith, G. E. P., "Report on the Water Supply and Irrigation Possibilities of Lands in the Casa Grande Valley," Arizona, 1921

Nordeen, Carl E., "Ground Water in Casa Grande Valley, Arizona," 1924

Deeds, John F., "Ground water irrigation - Queen Creek Basin and vicinity, Arizona," 1925

Fraps, J. A., "Report on the Arizona Water Conservation District," 1929

Davenport, Royal W., Memorandum of studies of precipitation and runoff of the drainage basin of Gila River above San Carlos Reservoir, Arizona, 1936

McClure, Thomas M., "Eleventh Biennial Report of the State Engineer of New Mexico," 193234 [bound volume]

Nordeen, Carl E., "Power value of Eagle Creek, Arizona," 1939 
D-100-9M-18

D-100-9M-19

D-100-9M-20

D-100-9N-1

D-100-9N-2

D-100-9N-3

D-100-9N-4

D-100-9N-5

D-100-9N-6

D-100-9N-7

D-100-9N-8

D-100-9N-9

D-100-9P-1

D-100-10-1

D-100-10-2

D-100-10-3

D-100-10-4

D-100-10-5

D-100-10-6

D-100-10-7

D-100-10-8

D-100-10A-1

D-100-10A-2

D-100-10A-3

D-100-10A-4

D-100-10A-5

D-100-10A-6

D-100-10A-7

D-100-10A-8

D-100-10A-9

D-100-10A-10

D-100-10A-11
Senkpiel, William C., "Report on the power-site value of certain withdrawn lands along the upper Gila River and Tributaries of New Mexico," 1940

[charge card]

Tefft, Henry D., Report on waterpower withdrawals in areas 9MA, 9MB, and 9MC in Arizona, 1957 (Gila River Drainage)

Crouse, Cornelius W., Letter regarding power-sites within the Fort Apache Indian Reservation, Arizona, 1910

Murphy, Edward C., "Report on Water power-sites and Reservoir Sites on Salt River Indian Reservation, Arizona," 1912

Murphy, Edward C., "Water-power Utilization in Arizona - Salt River and Small Tributaries," 1915

Ellsworth, Clarence E., "Paradise-Verde Irrigation District," Arizona, 1918

Norviel, W. S., Statement of the State Water Commissioner of Arizona, 1922

Nordeen, Carl E., Report on Carrick and Mangham Aqua Fria Lands and Irrigation Company and Phoenix Western Irrigation Project, Arizona, 1922

Marr, James C., "Drainage by means of Pumping from Wells in Salt River Valley, Arizona," 1926 [printed]; Department of Agriculture, Bulletin 1456, "Report on Project No. 425(28157 Arizona), n.d.

Woolley, Ralf R., "Application to Federal Power Commission by J. L. Fish for Preliminary Permit on Salt River in East-Central Arizona," 1923

Girand, John, "Water Supply on Upper Salt River, Arizona," 1938

Murphy, Edward C., "Water-power Utilization in Arizona - White River Wash," 1915

Hays, David W., "The Walker River Basin," California and Nevada, 1909; "Power and Irrigation on Walker River," 1911

LaRue, Eugene C., Examination of lot 4, Section 4, T. 6 S., R. 3 E. on Provo River, Utah, 1910

Murphy, Edward C., "Report on the lands withdrawn for water-power purposes along the Walker River in California and Nevada," 1911

Hearings - United States of America v. Hydro-Electric of Company of California, 1911-12

Map, profile, and miscellaneous data, Los Angeles Aqueduct, California, 1911 [complements of William Mulholland]

Thurtell, Henry, Statement concerning claims to water of Walker River and Its Tributaries in Nevada, 1912; Los Angeles Aquaduct, California, 1913

Plats and charts of the Tahoe National Forest, California and Nevada, ca. 1909

Post, R. B., Location of power-sites on Silvies River, Oregon, 1909 [form]

H. E. G. [initialed memorandum], Memorandum on Willow Creek California, 1912

Henshaw, Fred F., "Report on Water supply for Warner Lake Irrigation Project, 1913

Henshaw, Fred F., "Water Supply for Warner Lake Irrigation Company's Project," 1912

Article in Morning Oregonian regarding lease given for power plant at Lake Summer and Lake Albert, 1915

Plat of Warner Valley, Oregon, n.d.

Breithaupt, L. R., "Grains for the Dry Lands of Central Oregon," 1917 [pamphlet]

Blake, Harry E., Report on ground-water conditions of Harney Basin, Oregon, 1919

Barr, ---, and Cunningham, John W., "Report on Silver Lake Irrigation Project," Oregon, 1919

Cooper, R. D., and Henshaw, Fred F., "Water Supply of Silver Creek Valley, Harney County, Oregon," 1923

Piper, Arthur M., and Robinson, Thomas W., "Ground Water for Irrigation in the Harney Basin, Oregon," 1931 [press release]

Helland, Randolph O., and Miller, J. Charles, "Water Utilization in the Chewaucan River Basin, Oregon," 1938 
D-100-10A-13

D-100-10B-1

D-100-10B-2

D-100-10B-3

D-100-10C-1

D-100-10C-2

D-100-10D-1

D-100-10D-2

D-100-10D-4

D-100-10D-5

D-100-10E-1

D-100-10E-2

D-100-10E-3

D-100-10E-4

D-100-10E-5

D-100-10E-6

D-100-10E-7

D-100-10G-1

D-100-10G-2

D-100-10G-3

D-100-10G-4

D-100-10G-5

D-100-10G-6

D-100-10G-7

D-100-10G-8

D-100-10G-9

D-100-10G-10

D-100-10G-11

D-100-10G-12
Miller, J. Charles, Big Valley Dam Site, Oregon," 1939; Helland, Randolph O., "Summary of Investigations on Deep Creek, tributary to Warner Valley," Oregon, 1940

"Hydroelectric Development at Verde," Nevada 1912 [article]

Application for a permit to appropriate water from the Truckee River, California, 1912

Bureau of Reclamation, "Status Report - Washoe Project, Nevada and California," 1952

Eckel, Edwin B., "Geology of Markleeville, California, Dam Site," 1940

Pumphrey, Harold L., "Water-power Resources in the Upper Carson River Basin, California and Nevada," 1954

Bryan, Kirk, "Geologic Report on Reservoir Sites for Storage of Flood Waters on Paradise Valley, Nevada," 1922

Malone, George W., "Humboldt River Distribution and Different Features affecting these deliveries for the Years 1927 to 1931, Inclusive," Nevada, 1932

Eckel, Edwin B., "Geology of several Dam Sites on Tributaries of the Humboldt River, Nevada," 1940

Bryan, Lester L., "Summary of Investigations on Little Humboldt River and Tributaries, Nevada," 1940

Application for appropriation of water from the East Walker River, Utah, 1913

Woolley, Ralf R., "General Report on the State of Nevada," 1919; Kearney, W. M., "Waters of the Humboldt River and its Tributaries," Nevada, 1916; Case, Seymour, "Waters of the Humboldt River and its tributaries," Nevada, 1918

Kerr, Gerald M., "Report on Irrigation Possibilities in the Walker River Basin with Special Reference to the Walker River Irrigation District," 1920

Blomgren, Walter E., "Report on Water Supply and Storage Investigations of Walker River Indian Reservation, Nevada," 1926 [69th Cong., 2d Sess. HR Doc. 767]

Ryan, E. G., Concerning a survey of Gem Lake Reservoir Flood Line, California, 1913; Regarding applications to appropriate water from Rush Creek, Silver Lake, Agnew Lake, and Gem Lake, California, 1913

Application to appropriate waters from Leevining Creek, California, 1913

Fowler, Frederick H., "Application of Pacific Power Corporation for final Water-power Permit," California, 1916 [Leevining Creek Project]

Stabler, Herman, Memorandum on water resources of Big Pine, Baker, Birch, McGee, Horton, Pine, and Rock Creeks (tributaries of Owens River), Inyo County, California, n.d.; Merrill, Oscar C., Memorandum on power and irrigation values of Pine Creek, Inyo National Forest, and comparison with Big Pine Creek, California, 1913

Correspondence regarding the situation in Owens Valley and the proposed diversion from a tributary of Mono Lake, California, 1913

Application to appropriate waters from Goodale Creek and Lava Canyon Creek, California, 1912

Application to appropriate water from Lone Pine Creek (sometimes called Mt. Whitney Creek),

California, 1913

Application appropriate water from Silver Canyon Creek, California, 1912

Van Norden, Rudolph W., "System of Southern Sierras Power Company," Nevada, 1913 [printed]

Application to appropriate water from Cartago Creek, California, 1913

Application to appropriate water from Big Pine Creek, California, 1912

Application to appropriate water from catchment area of North Fork of Big Pine Creek, and South Fork Big Pine Creek, California, 1914

Field notes and specifications of diversion dam, conduit, pipe line, and power house site for Inyo-

Cerro Gordo Mining and Power Company, California, 1914; Application to appropriate

water from Lone Pine Creek, California, 1914

Plats of the Los Angeles Aquaduct, California, n.d.

[Cross reference to D-100-10G-1] 
D-100-10G-13

D-100-10G-14

D-100-10H-1

D-100-10H-2

D-100-10H-3

D-100-10H-4

D-100-10H-5

D-100-10H-6

D-100-10H-7

D-100-10H-8

D-100-10H-9

D-100-10H-10

D-100-10H-11

D-100-10H-12

D-100-10H-13

D-100-10H-14

D-100-10H-15

D-100-10H-16

D-100-10H-17

D-100-10H-18

D-100-10H-19

D-100-10H-20

D-100-10H-21

D-100-10H-22

D-100-10H-23

D-100-10H-24

D-100-10H-25

D-100-10H-26

D-100-10H-27

D-100-10H-28

D-100-10H-29

D-100-10H-30

D-100-10H-31

D-100-10H-32

D-100-10H-32a
Thompson, David G., "Special Report on Ground Water Conditions in Indian Wells Valley, California," 1920

Palmes, Leroy A., Letter regarding desert-land entries in Independence and Visalia Land Districts, California, 1910

Plat of Bear River Valley and Irrigation System, Utah, n.d.

Location of power-sites on Odgen River, Utah, n.d.

LaRue, Eugene C., "Report on water-power and Irrigation projects on Bear River in Idaho and Utah, 1913; LaRue, Eugene C., Plus supplemental data, 1913

LaRue, Eugene C., Letters regarding power possibilities on the Weber River, Utah, 1914

Stanrod, D. W., Judge, Decrees regarding Samaria Lake Irrigating Company v. M. S. Williams, and other cases, ca. 1895-1903

LaRue, Eugene C., Letter and report on power-site and reservoir possibilities of the Blacksmith Fork River, Utah, 1914

Advertisement for public-utility investments, 1914

Notes on wells and streams in Utah, n.d.

Article from the Salt Lake Tribune on drilling wells to meet the needs of Ogden City, Utah, 1914

Newcomb, Lewis, Use of water in Malad Valley, Idaho, 1913

LaRue, Eugene C., Letters regarding the Utah Conservation Company, 1914, 1916

Jacob, Clarence C., "Report on Seepage Losses from State Reservoir on Logan River, Utah," 1916

Stabler, Herman, Notes on inspection of part of power system of Utah Power and Light Company, 1916

Heroy, William B., Field examination regarding enlarged-homestead petitions in the vicinity of Holbrook, Oneida County, Idaho, 1912

Copies of water decisions in Utah Court, 1919

Plats of the Cache National Forest, n.d.

Parker, A. F., "The Utah Water Storage Association, Engineer's Report," Utah, 1920

Final water rights decree on Bear River, Idaho, 1920

Woolley, Ralf R., "Classification of Power-site Reserves in Bear River Basin in Idaho and Utah," 1921

Woolley, Ralf R., "Reservoirs and Reservoir Sites in Bear River Basin," Idaho \& Utah, 1924

Woolley, Ralf R., "Classification of Lands, Power-site Reserves, Weber River Basin," Northern Utah, 1923

Grover, Nathan C., Memorandum regarding report on Empire Irrigation District at Five Mile Meadow, near Soda Springs, Idaho, 1923

Power-classification data on Big Cotton, and Santaquin Creeks, Utah, n.d.

Correspondence regarding the unauthorized occupancy of public lands by the Utah Power and Light Company, 1925

Stearns, Harold T., "Report on the leakage of Malad Reservoir near Malad City, Idaho," 1925

Woolley, Ralf R., Letter regarding power resources along Left Hand Fork of the South Fork of Ogden River, 1927

Woolley, Ralf R., "Report on Classification of Land in Provo Canyon, Utah," 1928

Stearns, Harold T., "Preliminary examination of Lava and Mink Creek Dam sites on Bear River, Idaho," 1928

"Geology of Mink Dam Site," Idaho, n.d.

Woolley, Ralf R., Township plats showing the status of lands adjacent to Weber River, Utah, 1930

Woolley, Ralf R., Reservoir sites on Big Cottonwood Creek, Utah, 1921

Woolley, Ralf R., "Report on classification of lands in Big Cottonwood Canyon," Utah, 1932

Power-classification sheet - T. 2 S., R. 2 E., Section 14, n.d. 
D-100-10H-33

D-100-10H-34

D-100-10H-35

D-100-10H-36

D-100-10H-37

D-100-10H-38

D-100-10J-1

D-100-10J-2

D-100-10J-3

D-100-10J-4

D-100-10J-5

D-100-10J-7

D-100-10J-8

D-100-10J-9

D-100-10J-9b

D-100-10J-11

D-100-10J-12

D-100-10J-13

D-100-10J-14

D-100-10K-4

D-100-10L-1

D-100-10N-1

D-100-10N-2

D-100-10N-4

D-100-10N-5

D-100-10N-6

D-100-10N-7

D-100-10N-8

D-100-11-1

D-100-11-2
Leggette, Ralph M. and Taylor, George H., Press release on ground-water supplies in the vicinity of Salt Lake City, Utah, 1932

Department of the Interior Press Release, Water supplies for irrigation in Malad and Curlew Valleys, Idaho, 1932

Woolley, Ralf R., Power-classification sheets covering certain lands in Salt Lake Base and Meridian, 1926

Woolley, Ralf R., "Classification of Power-site Reserves in Provo River Basin, North Central, Utah," 1937

Griswald, Gilbert R., Map, pictures, and newspaper clippings on the Willard Canyon Area, Utah, 1936-37

"Weber Basin Project, Utah," 1949 [81st Cong., 2d Sess., Sen. Doc. 147]

Porter, Elmer A., "Report showing water resources data collected during 1914 on the Sevier River," Utah, 1914

Jacob, Clarence C., "Report on Water Resources, Sevier River Basin," Utah, 1915

Holley, Robert A., "Report on Underground Water Resources of the Beaver Valley of the Beaver Valley in the vicinity of Milford, Utah," 1920

Porter, Elmer A., "Report of Water Commissioner for Lower Sevier River," Utah 1917

Ryan Archie D., "Report on the Water Rights - Lower Sevier River," Utah, 1920

Davenport, Royal W., Memorandum regarding water-power development on Salina Creek, Utah, 1919

Woolley, Ralf R., "Classification of lands in power-site Reserve \#199 along Beaver River in Beaver County, Utah," 1923

White, Walter N. and Falck, Depue, "Report relative to land classification and utilization of ground water in Escalante Valley, Utah," 1925

Collins, William D., Memorandum regarding analysis of ground-water samples from the Escalante Desert, Utah, 1923; White, Walter N., Memorandum regarding the character of lands in the Escalante Desert Region, Utah, 1923

Waring, Gerald A., Note concerning the character of certain homestead entries in Utah, 1916

White, Walter N., Notes on water supply, irrigation and drainage in the Delta Area, Utah, with classification of relinquished Carey Act lands, 1926

[charge card]

Mitchelson, Albert T., Letter concerning the Spring City Light and Milling Company, Utah, 1910

Ryan, Archie D., Appraisal report on the land in Steptoe Valley, Nevada, 1921

Chandler, A. E., "Railroad Valley Company," Nevada, 1912 [booklet]

Grover, Nathan C., List of wells in Superior Valley, California, 1916

Palmer, Leroy A., Investigation of the underground water supply of Antelope Valley, California, 1916

Tait, Clarence E., "Report on the utilization of Mojave River for Irrigation in Victor Valley, California," 1918

Thompson, David G., Memorandum regarding an appeal of C. C. Ritchey's application in Antelope Valley, California, 1921

Application to appropriate water from Little Rock Creek, California, 1912

Application to appropriate water from East Fork of the West Fork of the Mojave River, California, 1912

Application of the Little Rock Power and Water Company to appropriate water from the Little Rock Creek, California, 1914

Galloway, J. D., Hydro-Electric Power Plants in California, 1912 [article]; "Electric Power Plants in the Mining Districts of Northern California," 1901 [transcribed article]

Van Norden, Rudolph W., "San Joaquin Light \& Power Corporation," California, 1912 [article]; Advertisements for investment opportunities in power companies, 1913; Baun, F. G., "Economic Value of Electric Transmission," 1914 [article] 
D-100-11-3

D-100-11A-1

D-100-11A-2

D-100-11A-3

D-100-11A-4

D-100-11A-5

D-100-11A-6

D-100-11A-7

D-100-11A-8

D-100-11A-9

D-100-11A-10

D-100-11A-11

D-100-11A-12

D-100-11A-13

D-100-11A-14

D-100-11A-15

D-100-11A-16

D-100-11A-16b

D-100-11A-17

D-100-11A-18

D-100-11A-19

D-100-11A-20

D-100-11A-21

D-100-11A-22

D-100-11A-22b

D-100-11A-23

D-100-11A-24

D-100-11A-25

D-100-11A-26

D-100-11A-28

D-100-11A-29

D-100-11A-30
Summary and recommendations of the Bechtel report on the Feather River Project, California, n.d. [brochure]; "Flood Control Pays," 1956 [brochure]

Mortsolf, Jesse B., Letters regarding power-sites on Klamath Indian Reservation, Oregon, and Hoopa Valley Reservation, California, 1910; Steele, O. G., "Novel Wooden Tower Line Construction," 1912 [article]

Location of power-sites on the Klamath River, Oregon, 1908-9

Henshaw, Fred F., "Preliminary Report on Water Resources of Klamath Indian Reservation in Oregon," 1913

Ahern, Jeremiah, "Reconnaissance of Shasta Valley, California," 1902

Application to appropriate water from Canon Creek, California, 1912

Application to appropriate water from Coffee Creek, California, 1912

Application to appropriate water from the South Fork of the Trinity River, California, 1912

Blueprint plat showing flume line of Trinity Exploration Company on Coffee Creek, California, 1913

Powerhouses in operation - California Division, ca. 1912

Plat showing flume line of E. A. Willsee, Carryville, Trinity County, California, 1913

LaRue, Eugene C., "Water-power Possibilities in Portion of Klamath River Basin, Oregon, and power-classification of O. \& C. R. R. Grant Lands," 1916

Memorandum regarding possible water power-sites in lands recommended for restoration in the Klamath Region Oregon and California, 1910

[charge card]

Holbrook, George F., Township plats detailing the status of lands affected by the transmission line of the California-Oregon Power Company in the Lake View Land District, 1920

LaRue, Eugene C., "Report on Water-power Value of Klamath River from Keno, Oregon to Willow Creek, California," 1921

LaRue, Eugene C., "Klamath River and its Utilization," 1921

[charge card]

LaRue, Eugene C., "Agricultural Resources of Hayfork Valley," California, 1923

Holbrook, George F., "Report of survey of Klamath River from Keno, Oregon to mouth of Horse Creek," California, 1923

Henshaw, Fred F., "Report to the Federal Power Commission on Application for License on Klamath River, Oregon, by the California-Oregon Power Company, 1928

Lapham, Macy H. and others, "Report on Soils and Agricultural Conditions in Lower Klamath Lake, Oregon and California," 1925

Tubbs, Nelson J., "The Potential Water-power of Revested Oregon and California Railroad Grant Lands in the Basin of Jenny Creek, Oregon," 1928

Hammatt, W. C., "Report on Proposed Water Supply for the Medford Irrigation District," Oregon, 1918 [booklet]; Tubbs, Nelson J., "The Potential Water-power of Revested Oregon and California Railroad Grant Lands on and near Buck Lake, Oregon," 1929

Power-classification sheets, 1929

Littlefield, T. R., "Report of Dam Site Surveys, District 5 - California," 1918

Kramer, Edwin W. and others, "Water Resources of the Klamath Basin, Oregon and California," 1932

"Report to the Federal Power Commission on the Uses of the Trinity River, California," ca. 1923

Bryan, Lester L., "Summary of Investigations on Trinity River and Tributaries, California," 1940

Johnson, Frederick A., "Report on Water Possibilities of North Fort Trinity River, California," 1948

Johnson, Frederick A., "Report on Water-power Possibilities of New River, California," 1948

Johnson, Frederick A., "Report on Water-power Possibilities of Lower Trinity River, California," 1949 
D-100-11A-31

D-100-11A-32

D-100-11A-33

D-100-11A-34

D-100-11A-35

D-100-11B-1

D-100-11B-2

D-100-11B-3

D-100-11B-4

D-100-11B-5

D-100-11B-6

D-100-11B-7

D-100-11B-8

D-100-11B-9

D-100-11B-11

D-100-11B-12

D-100-11B-13

D-100-11B-14

D-100-11B-15

D-100-11B-16

D-100-11B-17

D-100-11B-18

D-100-11B-19

D-100-11C-1

D-100-11C-2

D-100-11C-3

D-100-11C-4

D-100-11C-5

D-100-11C-7
Johnson, Frederick A., "Report on Water-power Possibilities of South Fork Trinity River, California," 1948

Johnson, Frederick A., "Report on Power Possibilities of Stuart Fork of Trinity River, California," 1950

Henshaw, Fred F., "Preliminary Report on Water Resources of Klamath Indian Reservation, Oregon," 1912

Gere, Willard C., "Dam Sites - South Fork Trinity River, California," 1951

Sax, Kenneth W., Bench-mark lists of Klamath River, California and Oregon, 1953-55

"The water-power plants of the Northern California Power Company," 1913; Murphy, Edward C., "Report on the land withdrawn for water-power purposes along the Pitt River, California," 1911

U. S. Reclamation Service, Topographic maps of reservoir and dam sites along the Pitt River and tributaries in northern California, 1904

U. S. Reclamation Service, Map of the Iron Canyon Reservoir site on the Sacramento River, California, 1904

Application to appropriate water from Deer Creek, California, 1912

Application to appropriate water from Weaver Lake and McMurray Lake, California, 1912

Application to appropriate water from the Fall River, Oregon, 1914

Application to appropriate water from creek fed by springs, Modoc County, California, 1914

Plat of proposed power ditch of Thomas H. and William Vestal on Pitt River, Lassen County, California, ca. 1914

Grosbach, Homer E., Memorandum regarding power on Beegum Creek, California, 1916

"What the Pitt River Development Means to the West," [reprinted from the Journal of Electricity and Western Industry], 1922

LaRue, Eugene C., "Water-power Report - McCloud River Basin, California," 1920

Holbrook, George F., "Water-power Report of the Pitt River above Fall River and of Fall River, California," 1920

Guy, David L., Memorandum regarding power value of Indian allotments adjacent to Pitt River in the stretch between Fall River and Sacramento River, 1920

Woolley, Ralf R., "Classification of Lands in Power-site Reserve in Cow Creek Basin in Shasta County, California," 1929

Department of the Interior Press Release, Successful conclusion of water-rights negotiations for Central Valley Project, California, 1938

Bryan, Lester L., Summary of investigations on Sacramento River and tributaries above Red Bluff, California, 1940

Bryan, Lester L., "Water-power Resources of Mill Creek and Deer Creek, California," 1941

"Sacramento River and tributaries, California, from Collinsville to Shasta Dam," 1944 [78th Congress, 2d Sess., HR Doc. 649]

Murphy, Edward C., "Report on Land Withdrawn for Water-power Purposes along the North Fork of Feather River, California," 1911

Murphy, Edward C., "Report on the Land Withdrawn for Water-power Purposes along the Yuba River, California," 1911; Huber, W. L., "District Engineer's Report on Applications for preliminary water-power permits," 1911

Articles on Lake Spaulding and Bear River, California, 1912-13 [printed]; Blueprint topographic maps of certain lakes in California, 1911-12

Dodge, E. L., "Reconstruction of Fordyce Dam," California, 1912 [article]

Murphy, Edward C., "Report on Second Amended Application of the Western Pacific Railway Company for Right-of-Way for a Railway from a point near Oroville, California, to a point near Keddie, California," 1912

Grunsky, Carl E., "San Francisco Water Supply Investigation - Feather River Project," California, 1912; Grunsky, Carl E., "North Fork of Yuba River Project: Copy of the Report on San Francisco Water Supply, Progress Report, August 12, 1901," 
D-100-11C-8

D-100-11C-9

D-100-11C-9 1/2

D-100-11C-10

D-100-11C-11

D-100-11C-12

D-100-11C-13

D-100-11C-14

D-100-11C-15

D-100-11C-16

D-100-11C-18

D-100-11C-19

D-100-11C-20

D-100-11C-21

D-100-11C-22

D-100-11C-23

D-100-11C-24

D-100-11C-25

D-100-11C-26

D-100-11C-27

D-100-11C-28

D-100-11C-29

D-100-11C-30

D-100-11C-30b

D-100-11C-31

D-100-11D-1

D-100-11D-3
Blueprint plats of the location of canals along the Middle Fork of the Feather and Fall Rivers, 1913

Applications to appropriate water from the Middle Fork of the North Fork of the Feather River, California, 1913

Maps of power project, J. A. Bunting Company, Yuba River, n.d.

Application at appropriate water from North Canon Creek, California, 1913

Application to appropriate water from the Yuba River, California, 1912

Application to appropriate water from the Fall River, Nevada, 1912

Application for power development on Indian Creek, Red Clover Creek, and Last Chance Creek, California, 1913

Application to appropriate water from Middle Fork of Feather and Fall Rivers, California, 1912

Application to appropriate water from Hamlin Creek, California, 1912

Application to appropriate water from the South Fork of Middle Yuba River, California, 1913

Application to appropriate water from South Fork of North Fork of Yuba River, California, 1914

Eastwood, John S., "Los Verjels Dam, a Multiple Arched Structure," California, 1914 [article]

Application to appropriate water from the East Fork of Lights Creek, California, 1914

LaRue, Eugene C., Letter regarding Big Meadows Reservoir Site, California, 1920

McGlashan, Harry D., "Report on the application of the Pacific Gas and Electric Company, to the Capital Issues Committee for permission to issue securities in order to enlarge their South Yuba-Bear River Hydroelectric System," California, 1918

Murphy, Edward C., "Report on Oroville-Wyandotte and Honcut-Yuba Irrigation Districts," California, 1921

Murphy, Edward C., "Report on Water-power Projects in Middle Fork Feather River Drainage, proposed by Lars Jorgensen" California, 1921

Plat of Kohler and Swartz Ditch, 1914

McGlashen, Harry D., Black Rock Placer Mining District, South Fork Yuba River, California, 1934

Kramer, Edwin W., "Report to Federal Power Commission on Yuba Development Company Project No. 187, Excelsior Water and Mining Company Project No. 237, and Nevada Irrigation District," California, 1921; Kramer, Edwin W., "Report to the Federal Power Commission on Yuba Development Company, Bullard's Bar Unit Project No. 187," California, 1922

"Pacific Gas and Electric Company asks license for 6 dam project on the Feather River," California, 1937 [transcribed article]

Logan, Eugene, "Report on Power Withdrawals on South Fork of the Feather River," California, 1936

Invitation for bids, schedules, specifications, drawings, topographic maps, and aerial photographs for reservoir sites and other areas, Region II, California, 1946; "Office Report on Comparison of Oroville, Big Bend, and Bidwell Bar Reservoir Sites for Development of Feather River," 1949; Johnson, Frederick A., Summary reports regarding a group of reservoir sites in the Sierra Nevada from the Feather River to the Cosumnes River, California, 1950; Johnson, Frederick A., "Some Reservoir Sites in the Sierra Nevada, California," 1950;

Johnson, Frederick A., "Memorandum reports regarding a group of reservoir sites in the Sierra Nevada from the Feather River to the Cosumnes River, California," 1949

Power-classification sheets, n.d.

Miller, J. Charles, Dam sites, North Fork Yuba River, California, 1950

Murphy, Edward C., "Preliminary Report on the withdrawals for water-power purposes along the Mokelumne, Stanislaus and Tuolumne Rivers, 1910

Sibley, Robert, "Western States Gas and Electric Company at Stockton,," California 1912 [article] 
D-100-11D-4

D-100-11D-5

D-100-11D-6

D-100-11D-7

D-100-11D-8

D-100-11D-8 n

D-100-11D-9

D-100-11D-12

D-100-11D-13

D-100-11D-14

D-100-11D-15

D-100-11D-16

D-100-11D-19

D-100-11D-20

D-100-11D-21

D-100-11D-22

D-100-11E-1

D-100-11E-2

D-100-11E-2 1/2

D-100-11E-10

D-100-11E-10a

D-100-11E-11

D-100-11E-12

D-100-11E-13

D-100-11E-13b

D-100-11F- 1

D-100-11F-2

D-100-11F-3

D-100-11F-4

D-100-11F-5

D-100-11F-6

D-100-11F-7

D-100-11F-8

D-100-11F-9
Map of the Rancho Rio de los Americanos and vicinity, California, 1910

Plats of transmission lines of Invincible Mines Consolidated Company, and ditch and power house of Horse Shoe Bar Power Company, California, 1912

Application to appropriate water from the North Fork of the American River, California, 1912 Application to appropriate water from the North Fork of the American River, California, 1913

"Mokolumne River, California," 1914 [63rd Cong., 2d Sess., HR Doc. 1160]

Application to appropriate water from Volcano Canyon in Bath Mining District, California, 1912

License from California State Water Commission granting J. F. Thompson the right to use the waters of the Volcano Canyon, 1912

Sacramento River Floods, Hearings before the House of Representatives, 1916

Dort, Joseph C., "Report to the Federal Power Commission on Western States Gas and Electric Company, American River Development Project No. 78," California, 1921

McGlashan, Harry D., "Report on Petition filed by Robert C. Brinkley, Cobb, California, for the Cancellation of Power-site Reserve No. 560 [partial], California," 1923

McGlashan, Harry D., "Report on the power value of Cosumnes River," California, 1928

Bryan, Everett N., "Report of Napa Valley Investigation," California, 1932

Farley, W. R., "Report on Power Withdrawals on Middle Fork of the American River," California, 1935

Thompson, Stanley W. R., "Summary Investigations on Cache Creek and Tributaries, California," 1940

Farley, W. R., "Report on Power Withdrawals on the South Fork of the American River, Eldorado National Forest, California," 1936

Johnson, Frederick A., "Extracts from Uncompleted Report on Water-powers of the North Fork and North Fork of Middle Fork American River, California," 1952

Application to appropriate water from the South Fork of the Eel River, California, 1913

Plat of Northwestern Power Project, California, 1912

Application to appropriate water from the North Eel River, California, 1912

Tubbs, Nelson J., Reconnaissance of Mad River, California, 1922

Power-classification sheets, n.d.

Stearns, Harold T., "Geology of Mill Creek and Elk Creek Dam Sites and Round Valley Reservoir Site," California, 1927

Griffin, R. H., "Report on Proposed Power Withdrawals on North and Middle Forks of the Eel River," California, 1935

Tubbs, Nelson J., "Reconnaissance Report of Eel River Basin, California," 1924

Tubbs, Nelson J., "Appendix to Reconnaissance Report of Eel River Basin, California," 1924

Murphy, Edward C., "Report on Withdrawals for Water Purposes along the Tuolumne River, California," 1911; Edmonson, Alonzo P., Letter regarding a power-site on Tule River 5 miles above Tule River School, California," 1910; Stanislaus and San Joaquin Water Company, California, n.d. [booklet]

Murphy, Edward C., "Report on the Withdrawals for Water-power Purposes along the Stanislaus River, California," 1911; "The Irrigation works of the Modesto and Turlock Districts, California, n.d. [transcribed article]; Crozier, H. W., "The Construction of the Stanislaus Line," 1912

"Coast Counties Gas and Electric Company," California, 1912 [article]

Whitney, C. W., "The Kern River No. 1 Power Plant of the Edison Electric Company, Los Angeles," California, 1907. Parts I and II [transcribed article]

Van Norden, Rudolph W., "San Francisco's Proposed Water Supply," California, 1912 [article]

Application to appropriate water from Merced River, California, 1912

Application to appropriate water from the San Joaquin River, California, 1912

Application to appropriate water from Bull Creek, California, 1912

Staack, John G., "San Joaquin River, California," 1912 
D-100-11F-10

D-100-11F-11

D-100-11F-12

D-100-11F-13

D-100-11F-14

D-100-11F-15

D-100-11F-15 1/2

D-100-11F-16

D-100-11F-17

D-100-11F-18

D-100-11F-19

D-100-11F-20

D-100-11F-21

D-100-11F-22

D-100-11F-23

D-100-11F-24

D-100-11F-25

D-100-11F-26

D-100-11F-27

D-100-11F-28

D-100-11F-29

D-100-11F-30

D-100-11F-31

D-100-11F-32

D-100-11F-33

D-100-11G-1

D-100-11G-2

D-100-11G-3

D-100-11G-4
Application to appropriate water from the San Joaquin River, California, 1912

Application to appropriate flood and freshet waters from Highland Creek, California, 1913

Blueprint plat showing reservoirs, ditches, and transmission of Tuolumne Water and Power Company, California, 1913

Madden, Marsden, "San Francisco's side of the Hetch Hetchy Controversy," California, 1911 [article]; other articles relating to Hetch Hetchy; Van Norden, Rudolph W., "System of the Mt. Whitney Power and Electric Company," 1913 \{article]

Map of the Oakdale Irrigation District, California, n.d.

Watson, Eden B., "Soil Survey of the Merced Area," California, 1916 [booklet]; "The Tuolumne and other California Rivers," 1913 [63rd Cong., 1st Sess., Sen. Doc. 246]

McGlashan, Harry D., Letter regarding power development on Merced River, California, 1917

Reddick, J. P., Memorandum regarding irrigation possibilities around Tulare Lake and southeasterly in San Joaquin Valley, California, 1918

Freeman, [no initials], "Brief of Sierra Club in Opposition to Grant of Hetch-Hetchy Valley to San Francisco for a Water Supply," California, 1912

Murphy, Edward C., Memorandum on Irrigation pumping development since 1907 in Southern San Joaquim Valley, California, 1919

Murphy, Edward, C., Well data in San Joaquin Valley, California, ca. 1904-17

LaRue, Eugene C., "Report on Merced Irrigation District, California," 1921

Murphy, Edward C., Concerning applications to Restoration to Entry of certain lands in Powersite Reserve No. 471, North Fork Kaweah River, California, 1921

Murphy, Edward C., "Report on Utilization of Water in Kaweah River Drainage above the Forks near Three Rivers, California," 1922

Noble, Levi F., "Report on the Character of the Rock Foundation at the Millerson Dam Site in Madera and Fresno Counties, California," 1922

Sulliger, Herman N., "Report on Utilization of Flood Waters of Tuolumne, Merced, San Joaquin, Kings, and Kern Rivers in Southern California," 1920

Logan, E., "Report on Power Withdrawals on South and Middle Forks of the Kings River," California, 1935

"Kings River Project in California," 1940 [76th Cong., 3rd Sess., HR Doc. 631]

Bryan, Lester L., "Summary of Investigations on Kern River and Tributaries, California," 1941

Bryan, Lester L., "Summary of Investigations on Kings River and Tributaries, California," 1941 [includes a tracing cloth key map]

Serex, John F., "Report to Federal Power Commission on the Status of Lands included in Pine Flat Reservoir withdrawals, California," 1937

Extracts from project planning report - "North Fork Kings River Development Central Valley Basin Plan, California," 1949

Johnson, Frederick A., "Preliminary report on the Waterpower Possibilities of the North Fork Kaweah River, California," 1951

Rumph, Richard W., "Cherry Valley Reservoir Site No. 29," California, 1954

Van Sickle, Donald M., "Preliminary Geologic report on Dam Sites, Chowchilla River, Madera County, California," 1954

Spalsbury, Ross L., Letter regarding possible reservoir sites on the Potero Reservation California, 1911; Sullivan, William T., Letter regarding possible reservoir sites on the Malki Indian Agency, California, 1910; Frank, Amos R., Letter regarding possible reservoir sites on the Santa Ysabel Reservation, California, 1910

Jessup, Walter, E., "Big Creek Hydro-Electric Power Development," California, 1914 [article]; Sibley, Robert, "The Pacific Light and Power System," 1912 [article]

Fowler, Charles E., "Water-power Plants with Long-Distance Electric Transmission in Southern California," n.d. \{transcribed article]

Application to appropriate water from East Fork of Mountain Home Streams, California, 1912 
Applications to appropriate water from Big Creek, Canal Creek, and Big Tijunga River, California, 1912

D-100-11G-6

D-100-11G-7

D-100-11G-9

D-100-11G-10

D-100-11G-11

D-100-11G-12

D-100-11G-13

D-100-11G-14

D-100-11G-15

D-100-11G-16

D-100-12-1

D-100-12-2

D-100-12-3

D-100-12-4

D-100-12-5

D-100-12-6

D-100-12-7

D-100-12A-1

D-100-12A-2

D-100-12A-3

D-100-12A-4

D-100-12A-5

D-100-12A-6

D-100-12A-7

D-100-12B-1

D-100-12B-2

D-100-12B-3

D-100-12B-5

D-100-12B-6

D-100-12B-7

D-100-12C-1
Application to appropriate water from Boulder Creek, California, 1913

Applications to appropriate water from Sur and Big Sur Rivers, California, 1912

Application to appropriate water from Butano Creek, California, 1912

Application to appropriate water from the South Fork of the San Jacinto River, California, 1913

McGlashan, Harry D., "Calaveras Hydraulic-Fill Earth Dam: Its partial failure and probable plan for rebuilding, California," 1918

Harroun, Philip E., "Report to the Water Commission of the East Bay Cities on Water Supply for the Cities of Oakland, Berkeley, Alameda, and Richmond, California," 1920

LaRue, Eugene C., "Water-power Report - San Luis Rey River, California," 1922

Tubbs, Nelson J., Memorandum of power values on upper Santa Ysabel Creek, California, 1923

McGlashan, Harry D., Memorandum regarding organization of the Vista Irrigation District, California, 1924

Geophysical Engineering Corporation, "Monk Hill Seismograph Survey," California, n.d.

Lists of irrigation companies in Montana, Wyoming, Utah, 1910; Bureau of the Census, Irrigation Statistics for Oregon and Washington, 1911

Jacobs, Joseph, Study of irrigation possibilities in Central Oregon, 1912

Crawford, W. H., "Power Situation in Oregon," 1914 [article]

Kramer, Edwin W., Extracts from Water-power in Montana, n.d.

Canfield, George H., Tabulation showing developed storage reservoirs, Oregon, 1934

Parker, Glenn L., Data regarding potential water resources in Columbia River Basin and Pacific Coast drainage in Washington and Oregon, 1934

Helland, Randolph O. and Miller, J. Charles, Memorandum and reports regarding dam sites in Eastern Washington and Oregon, 1946

Lamb, William, "Report on power-site withdrawals on Kootenai River, Montana - Idaho," 1910

Kramer, Edwin W., "Value of Lands for Water-power Purposes Lying Adjacent or near the Moyie River in the Pend Oreille National Forest," Idaho, 1912

"Kootenai River, Idaho," 1915 [63rd Cong., 3d Sess., HR Doc. 1588]; "Corps of Engineers Activities in Western Montana," 1952-53

Erdmann, Charles E., "Report on the Geology of the Katka Tunnel No. 8, and Kootenai Falls Dam Sites on the Kootenai River, Idaho and Montana," 1935

Various memorandums regarding Meadow Creek Dam Site - Moyie River, Idaho, 1953

Soward, Kenneth S., "Preliminary Report on the Geology of the Eileen and Meadow Creek Dam Sites, Moyie River, Idaho," 1954

Colbert, Jesse L., "Water-power Resources of Moyie River, Idaho," 1954

Murphy, Edward C., "Report on Land Withdrawn for Water-power Purposes along the Bitterroot River, Montana," 1913; Murphy, Edward C., "Report on Power-site Reserve No. 110, West Fork Bitterroot River, Montana," 1913; Leighton, Marshall O., Letter concerning inspection of power-site withdrawals on Hellgate River, Montana, 1910

Leighton, Marshall O., "Report on inspection of water-power-site withdrawal along the Big Blackfoot River, Montana," 1910;

Sibley, Robert, "Hunting Reservoir Sites in the High Rockies," Montana, 1911 [article]

Article concerning plans for power at Maxville, Montana, 1915 [printed]

Erdmann, Charles E., "Preliminary Report on the Geology of Two Dam Sites on Nevada Creek, Powell County, Montana," 1935

Holland, Randolph O., "Water Utilization in the Blackfoot River, Montana," 1946

Murphy, Edward C., and others, Report and correspondence regarding water-power sites along the Flathead River and on the Flathead Indian Reservation, Montana, 1910-12 
D-100-12C-2 Stockton, Robert S., and others, Reports and correspondence regarding water-power and irrigation projects on the Flathead Indian Reservation and Jocko Valley, Montana, 1902-12

D-100-12C-6 LaRue, Eugene C., "Report showing Power and Reservoir Site Possibilities - Flathead Indian Reservation, Montana," 1913

D-100-12C-7

D-100-12C-8

Stewart, John E., Letter concerning undeveloped power sites in Montana, 1909

Tubbs, Nelson J., "Reconnaissance Report of Coram North Branch of Great Northern Railway and its relation to Power Development Possibilities in Flathead River and Its Middle Fork," Montana, 1921

D-100-12C-9 Jones, Benjamin E., "Preliminary Report of Power-site Reconnaissance of South Fork of Flathead River," Montana, 1922

D-100-12C-10 Jones, Benjamin E., "Report on Power-site Value of withdrawn lands along Eastern Boundary of Flathead Indian Reservation, Montana," 1922

D-100-12C-11

D-100-12C-12

D-100-12C-13

D-100-12C-14

D-100--12C-15

D-100-12C-16

D-100-12C-17

Jones, Edward E., "Reconnaissance Report of South Fork Flathead River," Montana, 1924

Gault, Homer J., "Report on Storage Possibilities in Small Lakes above Flathead Lake, Montana," 1923

Parker, Glenn L., "Storage Regulation in Flathead Basin for Power and its effect on the Columbia Basin Project," 1926

Pardee, Joseph T., "Geology of Dam Sites on South Fork of Flathead River below Hungry Horse Creek, Flathead County, Montana," 1927

Erdmann, Charles E. and Hurwitz, G. L., "Transcripts of field notes to accompany geologic map of Hungary Horse Dam and Reservoir Site, South Fork of Flathead River, Flathead County, Montana," 1934-36

Erdmann, Charles E., "Reconnaissance Report on Lower Jocko Lake Dam Site, Missoula County, Montana," 1935

Erdmann, Charles E., "Report on the Geology of the Hungary Horse Dam and Reservoir Site, South Fork Flathead River, Flathead County, Montana," 1937; Erdmann, Charles E., Memorandum concerning a dam site reconnaissance of the Middle Fork of Flathead River, Montana, 1937

D-100-12C-18

Erdmann, Charles E., Memorandum concerning geologic work near the South Fork of Flathead River, Montana, 1939

D-100-12C-19 Thies, Roland K., "Geophysical Investigation of Hungry Horse Reservoir Project, Flathead County, Montana," 1937

D-100-12C-20

D-100-12C-21

D-100-12C-22

D-100-12C-23

D-100-12C-24

D-100-12C-25

D-100-12D-1

D-100-12D-1c

D-100-12D-2

D-100-12D-3

D-100-12D-4

Johnson, Arthur and others, Investigations of the Flathead River and Tributaries, Montana, 1940-45

Erdmann, Charles E. and Bateman, Andrew F., "Summary Report on Geology of Abbott Gorge," Montana, 1947

"Hungry Horse Dam, Montana," 1944 [78th Cong., 2d Sess., HR Doc. 643]

Soward, Kenneth S., Memorandum concerning the Sloan Bridge Diversion Scheme and the possibility of an alternative for the Oxbow Dam Site on Lower Flathead River, Montana, 1954

Soward, Kenneth S., "Geology of Power-sites on the Upper Tributaries of the Columbia River in Idaho and Montana," 1957

Soward, Kenneth S., "Geology of Dam Sites on the Upper Tributaries of the Columbia River in Idaho and Montana," 1960

Lamb, William A., "Report on Power-sites along Clark Fork River," 1910

Lamb, William A., "Report on Power-site Withdrawals along Clark Fork River, Montana," 1910

Henshaw, Fred F., "Report on possibilities of regulating Lake Pend Oreille, Idaho," 1912

Plat of location of the Idaho and Washington Northern Railroad, Newport to Cement Post Office, n.d.

Leighton, Marshall O., Report on power withdrawals on Pend Oreille River, Washington," 1911 
D-100-12D-5

D-100-12D-6

D-100-12D-7

D-100-12D-8

D-100-12D-9

D-100-12D-10

D-100-12D-11

D-100-12D-12

D-100-12D-13

D-100-12D-14

D-100-12D-15

D-100-12E-1

D-100-12E-2

D-100-12E-3

D-100-12E-4

D-100-12E-5

D-100-12E-6

D-100-12E-7

D-100-12E-8

D-100-12E-9

D-100-12E-10

D-100-12E-11

D-100-12E-12

D-100-12E-13

D-100-12E-13b

D-100-12E-14

D-100-12E-15
Murphy, Edward C. and others, Report and correspondence regarding Calispel Lake, Washington, and Mohawk Lode Mining Claim in the Kaniksu National Forest, Washington, 1909-12

Postcards showing views of various creeks and rivers in Washington and Oregon, ca. 1910

Kramer, Edwin W., "Water Power-site at Rock Island Gorge on the Clark Fork River," Montana, 1912

Krejci, Milo W., "The Metaline Plant of the Inland Portland Cement Company, Metaline Falls, Washington," 1918 [article]

Parker, Glenn L., "Columbia Basin Investigation, Appendix C, Water Supply and Power Analysis," 1924; "Report of the Federal Power Commission on the Uses of the Upper Columbia River, " 1925; "The Columbia Basin Project [Hearings, HR 7446], 1932 and other reports

Murphy, Edward C., "Water Supply of Streams - Clark Fork, Columbia River Drainage Basin, Montana," 1927

Johnson, Arthur, "Summary of Investigations on Pend Oreille River, Pend Oreille Lake, and Priest River, Washington and Idaho," 1941; Johnson, Arthur, Memorandum regarding boundary dam site, Pend Oreille River, Washington, 1953

Bashore, Harry W., "Rathdrum Prairie Project, Idaho," 1932 [booklet]

Sloan, William G., "Cabinet Gorge Power Project, Idaho," 1938

Erdmann, Charles E., "Report on Geologic Reconnaissance of the Clark Fork - Kootenai River Development Plan, Lincoln and Sanders Counties, Montana, 1945

Johnson, Frederick A. and Simons, W. D., "Flood Profiles and Discharges of the Pend Oreille River," 1946; Johnson, Frederick A., Memorandum regarding Pend Oreille River below Z Canyon near Metaline Falls, Washington, 1954

Leighton, Marshall O., Memorandum regarding power possibilities along Columbia River and letter containing report of inspection of Columbia River from Canadian boundary to Kettle Falls, 1911

Memorandum regarding power possibilities on Columbia River, 1911; Tufts, William. O., "Cataldo Quadrangle, Land Classification," 1911; Leighton, Marshall O., Letter regarding water-power withdrawal No. 51, Little Pend Oreille River, 1910

Stevens, John C., Letters concerning examinations of terminal lands at mouth of Spokane River, Clark Fork River and Little Falls, Washington, 1909

"Irrigation in the Spokane Valley," Washington, and other articles on Spokane, 1912

Murphy, Edward C., "Report on reconnaissance for water-power and reservoir sites of part of Colville Indian Reservation, Washington," 1912

"The nine-mile Station of the Spokane and Inland Empire Railway," 1907 [transcribed article]

Burt, William B., "Report as to power-site withdrawals on Little Pend Oreille River, Spokane, Washington," 1913

Topographic map of St. Joe - Clearwater Region, Idaho, n.d.

"St. Marys and St. Joe Rivers, Idaho," 1914 [63rd Cong., 2d Sess. HR Doc. 990]

"Columbia River, Washington from Grand Rickey (or Rapids) to International Boundary Line," 1914 [63rd Cong., 2d Sess., HR Doc. 1112]

Kramer, Edwin W., Value of lands for water power in T. 44 N., R. 3 E. on Marble Creek," Idaho, 1915

[Filed with D-100-12E-3]

Federal Power Commission, "Memorandum of power possibilities of Little Pend Oreille River, Washington," 1922

Power-classification sheets, n.d.

Blueprint plat showing the Big Bend Transit Company's (successor to the Adams County Electric Transit Company) Power-site and overflow lands along the Spokane River, 1909

Power-classification sheets, Coeur d'Alene Lake, Idaho, 1930 
D-100-12E-16

D-100-12E-17

D-100-12E-18

D-100-12E-19

D-100-12E-20

D-100-12F-1

D-100-12F-2

D-100-12F-3

D-100-12F-4

D-100-12F-5

D-100-12F-6

D-100-12F-7

D-100-12F-8

D-100-12F-9

D-100-12F-10

D-100-12F-11

D-100-12F-12

D-100-12F-13

D-100-12F-14

D-100-12F-14b

D-100-12F-15

D-100-12F-16

D-100-12F-17

D-100-12F-17b

D-100-12F-18

D-100-12F-19

D-100-12G-1

D-100-12G-2
Hoyt, William G., "Report on Power-site Reserve Lands along South Fork of Coeur d'Alene River," Idaho and Montana, 1932

Parker, Glenn L., "Observations of stage at selected points along Columbia River between Birckbank, B.C. and Little Dalles, Washington," 1930-32

Johnson, Arthur, Summary of investigations on Coeur d'Alene River, Idaho, from South Fork to Mile 59," 1940

Howes, H. E., "Report on Propriety of Classifying as Valuable for Power-sites Lands along the Kettle River, Washington, lying partially within Colville National Forest," 1944

Colbert, Jesse L. and Giles, Gordon C., "Review of Water-power Withdrawal, Kettle River, Washington," 1956

Salzman, Francis X., Letter regarding the Klickitat River and Toppenish and Satus Creeks, 1910"; and Letters regarding power-sites on the Yakima Indian Reservation, Washington, 1910-11

Henshaw, Fred F., "Preliminary report on Water Resources of Colville Indian Reservation, Washington," 1911; Webster, John M., Letter regarding possible power-sites on Colville and Spokane Reservations, Washington, 1911

Jacobs, Joseph, "Quincy Valley Irrigation Project," Washington, 1910

Report on Kittitas Reclamation District, Washington, (transferred to 929019-F in 1920)

Gray, J. H. and Worthington, Irving, "Report upon an irrigation canal extending from the West Boundary of Kittitas County through the Kittitas, Yakima and Moxee Valleys and land adjacent to the west Bank of the Columbia River," Washington," 1903

Martin, James W., "Conservation Report on the Yakima Indian Reservation and Special Report on Atanum Storage," Washington, 1911

"Key City Light and Power Company," Washington, 1914 [article]

Murphy, Edward C., Letters regarding power-site withdrawal, Bonaparte Creek, Washington, 1913

LaRue, Eugene C., "Power and Reservoir Site Possibilities, Yakima Indian Reservation, Washington," 1913; Director, USGS, Letter to the Commissioner of Indian Affairs regarding power-site and reservoir possibilities within the Yakima Indian Reservation, 1914

Township plats, withdrawal No, 136, Columbia River Section One, from Canadian Boundary to Mouth of the Spokane River, Washington, n.d.

Parker, Glenn L., "Report on power and irrigation possibilities of Similkameen River," Washington. ca. 1912

Tubbs, Nelson J., "Report on development of power possibilities on Sanpoil River," Washington, 1919

Tubbs, Nelson J., "Reconnaissance Report of power development possibilities in Entiat River Valley, Washington," 1920

Davenport, Royal W., "Memorandum regarding power possibilities of power-site reserve lands on Naches River, Washington," 1922

Power-classification sheet, n.d.

Plat of Greater Wenatchee Irrigation Project, Washington, 1922

Pardee, Joseph T., "Geology of Reservoir Sites near Washtucna and Kahlotus, Washington," 1928

Bryan, Lester L., "Water-power Resources of Hall Creek, Sanpoil and Nespelem Rivers, Washington," 1929

Bryan, Lester L., "Classification Report to accompany report on Water-power Resources of Hall Creek, Sanpoil and Nespelem River, Washington," 1930

Johnson, Arthur, "Summary of Investigations on Sheep Creek, Similkameen River and Chewack Creek, Washington," 1942

Priest Rapids and Cougrar Hydroelectric Projects, 1954 [Congressional Hearings]

Letters, plats and profile concerning the Snake River, Butte and Market Lake Canal, 1910

[file includes commercial brochures for the communities of Hailey and Blackfoot, Idaho]

LaRue, Eugene C., "Power Report on Blackfoot River and Fort Hall Indian Reservation," Idaho, 1911 
LaRue, Eugene C., "Power Possibilities between the Milner Dam and the Minidoka Dam," Idaho, 1911

D-100-12G-4

D-100-12G-5

D-100-12G-5 1/2

D-100-12G-6 1/2

D-100-12G-7

D-100-12G-8

D-100-12G-9

D-100-12G-10

D-100-12G-11

D-100-12G-12

D-100-12G-13

D-100-12G-14

D-100-12G-15

D-100-12G-16

D-100-12G-17

D-100--12G-18

D-100-12G-19

D-100-12G-20

D-100-12G-21

D-100-12G-22

D-100-12G-23

D-100-12G-24

D-100-12G-25

D-100-12G-26

D-100-12G-27

D-100-12G-28

D-100-12G-29

D-100-12G-30

D-100-12G-31

D-100-12G-32

D-100-12G-33

D-100-12G-34

D-100-12G-35

D-100-12G-36

D-100-12G-37
Newspaper clippings regarding power development in Southern Idaho, 1911

Decree - Roxburg Irrigation Company et al. v Teton Irrigation Canal Company et al., Idaho, 1910

LaRue, Eugene C., Report on Lot 7, Sec. 7, T. 1 S., R. 37 E., Boise Meridian, Idaho, 1912

Location of power-sites along the Snake River, Idaho, n.d. [forms]

American Falls, Idaho, ca. 1910 [commercial brochure]

Wilcox, E. A., "Water-power Resources of Southern Idaho," 1913 [article]

Caldwell, Andrew F., and others, Court Decision and correspondence relative to the rights of the Fort Hall Indian Reservation on Bannock Creek, Idaho, 1907; Crandall, Lynn, "New Storage on Snake River for Irrigation Use above Milner, Idaho," 1955

Map of Oregon Short Line Railroad showing various irrigation projects with attached statement of Carey Act projects and U.S. Reclamation Service projects, 1913

Plats of Dubois Project, Idaho, 1904; Map of Snake River Basin, Idaho, 1909

Heroy, William B., "Twin Falls Project - Water Losses," Idaho, 1914

Harrington, Arthur W., "Water Resources of Salmon Falls Creek near San Jacinto and Contact, Nevada," 1914

Dibble, Barry, "Cost of Pumping for Irrigation," Idaho 1915 [article]

Umpleby, Joseph B., "Report on leakage near the head of the Blackfoot (Fort Hall) Reservoir, Idaho," 1914

Decreed water rights Malad or Big Wood River and its tributaries, Idaho, 1909

Stabler, Herman, Notes on Inspection of Big Wood River, Idaho, 1916

Stabler, Herman, Notes on Inspection of power possibilities at Upper and Lower Salmon Falls, Snake River, Idaho, 1916

LaRue, Eugene C., List of power-sites in Great Basin District, Idaho, Utah, Nevada, 1909

Map of the Minidoka Project, Idaho, 1917

Baldwin, G. Clyde, "Hydrometric Work on Upper Snake River," Wyoming and Idaho, 1917

Heroy, William B., Field investigation of water supply of certain lands in Blaine County, Idaho, 1912

Heroy, William B., Field examination of lands in T. 2 S., R. 33 E., Boise Meridian, Idaho, 1912

Heroy, William B., Petitions for designation under enlarged-homestead acts, Boise Meridian, Idaho, 1912

Heroy, William B., Examination of water supply of Arbon Valley, Idaho, 1914

Heroy, William B., Field examination of an area on the east side of the Raft River Valley, Idaho, 1912

Heroy, William B., Investigation of the water supply of lands included in petitions for designation under the provisions of the Enlarged-homestead Act, Idaho, 1911

Heroy, William B, Field examination of lands embraced in pending enlarged-homestead petitions, Idaho, 1912

Heroy, William B., Examination of an area in the vicinity of Naf, Idaho, 1912

Heroy, William B., Examination of certain land in Idaho embraced in petitions for designation under the enlarged-homestead act, 1912

Heroy, William B., Examination of the Upper Snake River Drainage Basin, Idaho, 1914

Blueprints of logs of about thirty wells in Southern and Central Idaho located along the various lines of the Oregon Short Line Railroad, 1918

LaRue, Eugene C., Dubois Reclamation Project, Idaho, 1910

Blake, Harry E., "Report on Camas Prairie, Idaho," 1919

Baldwin, G. Clyde, "Hydrometric work on Upper Snake River," Wyoming and Idaho," 1918

Woolley, Ralf R., "A Report on Water power-sites on Blackfoot River," Idaho 1919

Woolley, Ralf R., "A Report on Water power-sites in Lower Canyon, South Fork of Snake River," Idaho, 1919 
D-100-12G-38

D-100-12G-39

D-100-12G-41

D-100-12G-43

D-100-12G-44

D-100-12G-45

D-100-12G-47

D-100-12G-48

D-100-12G-50

D-100-12G-51

D-100-12G-51b

D-100-12G-51c

D-100-12G-53

D-100-12G-54

D-100-12G-57

D-100-12G-60

D-100-12G-62

D-100-12G-64

D-100-12G-68

D-100-12G-69

D-100-12G-70

D-100-12G-70a

D-100-12G-73

D-100-12G-76

D-100-12G-77

D-100-12G-82

D-100-12G-86

D-100-12G-88

D-100-12G-90

D-100-12G-92
Peterson, John Q., Memorandum regarding ground-water conditions near Mud Lake, Idaho, 1920

Woolley, Ralf R., "A Report on Water power-sites on a portion of Henry's Fork of the Snake River above St. Anthony, Idaho," 1920

Woolley, Ralf R., "Mud Lake in Fremont County, Idaho," 1920

Hoyt, William G., "Report Relative to Application of Idaho Power Company for a Preliminary Permit to develop Twin Falls Site on Snake River, Idaho," 1921

Hoyt, William G., "Report relative to Application of Idaho Power Company for a Preliminary Permit to develop Upper Salmon Falls Site on the Snake River, Idaho," 1921

Lists: Irrigation Districts (Idaho), n.d.; Carey Act Projects, n.d.; Irrigation Companies of Record, n.d.; Pumping Projects completed and in Operation, 1921

Woolley, Ralf R., "Possible Power Development on the Snake River and its tributaries in Southern Idaho," 1919

Board of Engineers, "Report to Consider Projects in Snake River Valley which may affect the proposed American Falls Reservoir and the available water supply," 1920

Bryan, Lester L. and Stearns, Harold T., "Preliminary Report on water resources Mud Lake Basin, Idaho," 1923

Hoyt, William G., "Report relative to Water-power Resources of Snake River and Status of public lands between Milner and Weiser, Idaho," 1922

Status of lands adjacent to the Snake River between Milner and the mouth

Copies of photographic negatives showing construction on Idaho streams, 1921-22

Stearns, Harold T., "Report on the Geology of the proposed reservoir, dam, and tunnel of the Dubois Project, Vat Island Park, Idaho," 1924

Tappan, C. E., "Report covering water measurements and Studies of Stream Flow of Snake River between Milner and Shoshone Falls," 1923

Stearns, Harold, T., Memorandum regarding the Portneuf Springs, Idaho, 1925

Newell, Thomas R., "Segregation of Water Resources - American Falls Basin and American Falls Reservoir (Water District No, 36, April 15 to October 15, 1927)," 1928

Nordeen, Carl E., "Report on character of lands relinquished under Carey Act Lists Nos. 4, 6, 11, and 13," 1926

Stearns, Harold T., "Quantity of Ground Water in Raft River Valley, Idaho," 1929

Mansfield, George R., Dam sites in Grand Canyon of South Fork, Snake River, Wyoming," 1931

Chapman, S. H., "Report on Canal Deliveries from Big and Little Wood Rivers, Districts 7-AB and 11-AB and Different Features affecting these deliveries, also other stream data, for irrigation year ending September 10, 1929"

Bryan, Lester L., "Water-power Resources of Snake River between Jackson Hole and Alpine, Wyoming," 1932

Bryan, Lester L., "Power-site classification report on Snake River, Wyoming," 1932

Martin, J. P., "Report upon the Proposal of the USGS for a power withdrawal along the Snake River in Wyoming and the conflicts of the Star Valley, Yellowstone, and Hobeck Canyon Forest Highways with Power Withdrawals," 1933

Erdmann, Charles E., Resistivity work at dam sites on Little Wood River, Idaho, 1935

Debler, Erdman B. and Riter, J. R., "Report on Upper Snake River Storage Investigations," 1935, Volume I Snake River above Idaho Falls

Eckel, Edwin B., "Geologic Notes on several dam sites in Southern Idaho," 1939

"Report on Palisades Dam Project," 1941

Lawrence, Fred F., "Summary of Investigation - Small streams in Idaho," 1942

Helland, Randolph O., Memorandum regarding power-site reserves in the Salmon Falls Creek Basin, Idaho and Nevada, 1947

Helland, Randolph O., Memorandum regarding power sites in the Snake River from mouth to Bliss, Idaho, 1951 
D-100-12G-93

D-100-12G-94

D-100-12H-1

D-100-12H-2

D-100-12H-3

D-100-12H-4

D-100-12H-5

D-100-12H-5

D-100-12H-6

D-100-12H-7

D-100-12H-8

D-100-12H-8

D-100-12H-9

D-100-12H-10

D-100-12H-10

D-100-12H-11

D-100-12H-12

D-100-12H-13

D-100-12H-14

D-100-12H-15

D-100-12H-16

D-100-12H-17

D-100-12H-18

D-100-12H-19

D-100-12H-20

D-100-12H-21

D-100-12H-22

D-100-12H-23

D-100-12H-24
"Burns Creek Dam, Power Plant and Reservoir, Palisades Project, Idaho," 1957 [85th Cong., 1st Sess., HR Doc. 147]

Johnson, Arthur, Gros Ventre River, Wyoming - Miscellaneous pictures, 1959

Leighton, Marshall O., Regarding power-site withdrawals on the Snake River between Weiser, Idaho and mouth of Clearwater River, 1919

Letters and other items concerning work on streams in Idaho and Oregon, 1910-11

Henshaw, Fred F., Examination of lands withdrawn in connection with the Malheur Project, 1910

Burkland, Albert O., Meadows Quadrangle - Land Classification Idaho, 1911; "Examination of Snake River, Washington and Oregon," 1899 [56th Cong. 1st Sess., HR Doc. 75]

Murphy, Edward C., "Report on the land withdrawn for water-power purposes along the Owyhee River, Oregon," 1911

Burt, William B., "The Willow River Land \& Irrigation Company, Vale Land District, Oregon," 1914; Letters about the Willow River Land and Irrigation District, 1914-17

Water power-sites on Wallowa, Boise, and Payette Rivers, 1908

LaRue, Eugene C., "Power Report on a 75-mile Section of the Snake River in Idaho and Right of Way (Boise 091110) of the Minidoka \& Southwestern Railroad Company," 1913

Beebe, John C., "Value for Water-power of the Lands applied for under the Act of June 11, 1906 along the Snake River in T. 23, 24 and 25 N., R. 2 and 3 W. on the Nez Perce National Forest," 1912

Murphy, Edward C., Letter regarding power and reservoir purposes of Crooked and Rattlesnake Creeks, Oregon, 1912

Murphy, Edward C., Letter regarding enlarged-homestead petition 3620 for the designation of Baker and Union Counties, Oregon, under the enlarged-homestead act, 1913

Roush, Leroy W., Letters regarding water resources of the Jordan Valley District, and Cow Creek Lakes, Oregon, 1914

Henshaw, Fred F., Letter regarding possibilities of the utilization of the Duncan Ferry Reservoir site on the Owyhee River, 1914

Trenner, W. H., Water-power site at Swan Falls, Snake River, Idaho, 1915 [form]

Hanna, Frank W., Letter regarding storage requirements of the Arrowrock Reservoir, 1911

Finch, Elmer H., Memorandum regarding power-sites in the Sumpter Quadrangle, Oregon, 1914

Memorandum regarding the Upper Grande Ronde River, Oregon, 1916

Stabler, Herman, Notes on inspection of Lower Boise River, Idaho, 1916

Henshaw, Fred F., Letter regarding the Vale Land District, 1910

Henshaw, Fred F., Letter regarding the Lower Grande Ronde, Wallowa, and Minam Rivers and Joseph Creek in Washington and Oregon, 1910

Baldwin, G. Clyde, "Report on Water Supply available for the irrigation project of the Mountain Home Cooperative Irrigation Company," Idaho, 1918

Murphy, Edward C., "Report on Fifteen Townships in Wallowa County, Oregon, for designation under the enlarged-homestead Act," 1912

Murphy, Edward C., "Report on character of land in Sections 8 and 9, Township 1 South, Range 44 East, Willamette Meridian, and its suitability for designation under the enlarged homestead act, Oregon, 1913

Tubbs, Nelson J., Letter regarding an examination of the Grande Ronde River below La Grande, 1920

Tubbs, Nelson J., "Reconnaissance report of power development possibilities contained in lands along the Grande Ronde River above the mouth of Starkey Creek and included in Power-site Reserves Nos. 529, 553, and 585," 1920

Hoyt, William G., "Power possibilities - Snake River between Weiser and Lewiston, Idaho," 1921

Hoyt, William G., "Report relative to Application of Elmore Copper Company for a Preliminary Permit to develop a power-site on the South Fork of the Boise River, Idaho," 1921 
Hoyt, William G., "Report relative to application of City of Boise, Idaho, for a preliminary permit to develop water power-sites on the North and South Forks of the Payette River, Idaho," 1921

D-100-12H-26

D-100-12H-28

D-100-12H-29

D-100-12H-30

D-100-12H-31

D-100-12H-32

D-100-12H-33

D-100-12H-34

D-100-12H-35

D-100-12H-36

D-100-12H-36b

D-100-12H-36c

D-100-12H-38

D-100-12H-39

D-100-12H-39b

D-100-12H-40

D-100-12H-40b

D-100-12H-41

D-100-12H-42

D-100-12H-42b

D-100-12H-43

D-100-12H-44

D-100-12H-45

D-100-12H-46

D-100-12H-47

D-100-12H-49

D-100-12H-50

D-100-12H-51

D-100-12H-52

D-100-12H-53

Oakey, Warren, "Report on Canal deliveries from Boise River and different features affecting these deliveries for the irrigation season of 1921," 1922

Hoyt, William G., "Report relative to water-power resources of the Payette River, Idaho," 1922

Hoyt, William G., "Report relative to water-power resources of the Boise River, Idaho," 1922

Edwards, Robert F., "Power Reserves Oregon, Owyhee River, Oregon, from Duncan Ferry Reservoir Site to Mouth," 1923

Bryan, Kirk, Concerning the Owyhee Project report, 1923

Memorandum regarding the geology of the Snake River Canyon, 1921

Hoyt, William G., "Report on Application of Pacific Power and Light Company Preliminary Permit - Snake River," Idaho, 1922

Hoyt, William G., "Power-classification of lands along the Snake River between Huntington, Oregon, and Lewiston, Idaho, 1924,"

Bond, J. B., "Report - Payette Storage, Boise Project, Idaho," 1926

Hoyt, William G., "Storage and power possibilities, Payette River Basin, Idaho," 1927

Hoyt, William G., "Classification Report to accompany Report on Storage and Power Possibilities, Payette River Basin, Idaho," 1927

Hoyt, William G., Negatives, tracings and charts to accompany a report on storage and power possibilities, Payette River Basin, 1927

Helland, Randolph O., "Report on Power-site Value of Joseph Creek, Oregon," 1932

[charge card]

"Boise River Classification Report and Power-classification Sheets," n.d.

Helland, Randolph O., "Water-power Resources of the Imnaha River and tributaries, Oregon, with Geology of Dam Site by Joseph T. Pardee," ca. 1931

Power-classification sheets, Imnaha River, Oregon, n.d.

Welsh, William E., "Report on Canal Deliveries from Boise River and different features affecting these deliveries for the irrigation season of 1929," 1930 (Water District No. 12-A.)

Helland, Randolph O.,"Potential water-power in the Grande Ronde River Basin, Oregon and Washington, with Geology of Dam Sites by Joseph T. Pardee," 1935

Power-classification sheets, n.d.

McAllister, L. A., Letter regarding the Powder River Reservoir at the Bowen Valley Site, Oregon, 1932

Helland, Randolph O., "Preliminary Report on Catherine Creek Reservoir Site near Union, Oregon, and description of Geology by Philip J. Shenon," 1934

"Boise River, Idaho," 1940 [76th Cong., 3d Sess., HR Doc. 957]

Cannon, Ralph S., "Preliminary Report on the Geology of the Brown and Spangler Dam Sites, Mann Creek, Washington County, Idaho," 1938

Johnson, Arthur, "Summary of investigations in the Weiser River Basin, Idaho," 1941

Howes, H. E., "Report on Propriety of Classifying as Valuable for Power-sites Land in the Grande Ronde River Basin lying wholly, or in part, within the Wallowa and Whitman National Forests," Oregon, 1934

Helland, Randolph O., "Water Utilization in the Grande Ronde River, Washington and Oregon," 1947

Helland, Randolph O., Memorandum regarding power-site reserves in the Malheur River Basin, Oregon, 1947

Helland, Randolph O., Memorandum regarding power-site reserves in the Owyhee River Basin, Oregon, 1947

Johnson, Frederick A., "Report on Water Utilization Possibilities in the Upper Bruneau River Basin, Idaho-Nevada," 1949 
D-100-12H-54

D-100-12H-55

D-100-12H-56

D-100-12H-57

D-100-12J-1

D-100-12J-2

D-100-12J-3

D-100-12J-4

D-100-12J-5

D-100-12J-5b

D-100-12J-6

D-100-12J-7

D-100-12J-7b

D-100-12J-9

D-100-12J-10

D-100-12J-10b

D-100-12J-10c

D-100-12J-11

D-100-12J-12

D-100-12J-13

D-100-12K-1

D-100-12K-2

D-100-12K-3

D-100-12K-4

D-100-12K-5

D-100-12K-5b

D-100-12K-6

D-100-12K-7

D-100-12L-1

D-100-12L-2

D-100-12L-3

D-100-12M-1
Helland, Randolph O., "Water Utilization in the Weiser River Basin, Idaho," 1949

Helland, Randolph O., Memorandum regarding: Water Utilization in the Payette River Basin, Idaho," 1949

LaRue, Eugene C., "Right of Way Report, Clearwater Valley Railroad Company, Grande Ronde River, Oregon-Washington," 1912

Letters regarding Boise River and Lucky Peak Reservoir Site, Idaho, 1949-55

Helland, Randolph O., "Water Utilization in the Salmon River Basin, Idaho," 1949

Baldwin, G. Clyde, Letters concerning the Meadows Light and Power Company, Goose Creek, Idaho, 1917

LaRue, Eugene C., "Report on Right of Way Applications of the Gilmore and Pittsburgh Railroad Company on the Salmon River below Salmon City, Idaho," 1913

[charge card]

Hoyt, William G., "Report relative to Water-power Resources of Salmon River and Status of Public Lands between Salmon, Idaho, and mouth of Salmon River," 1949

Status of lands adjacent to Salmon River, Idaho, n.d.

[charge card]

Hoyt, William G., "Storage Possibilities in Bear Valley and Stanley Basin, Idaho," 1926

Hoyt, William G., "Classification Report on Bear Valley and Stanley Basin, Idaho," 1926

[charge card]

Bryan, Lester L., "Water-power Resources of Panther Creek, Middle Fork of Salmon River, South Fork of Salmon River, and major tributaries, Idaho," 1931

Bryan, Lester L., "Power-site classification report on Panther Creek, Middle Fork Salmon River, South Fork Salmon River and Tributaries," Idaho, 1933

Bryan, Lester L., Photo album, South Fork Salmon River and tributaries, and Middle Fork Payette River and Silver Creek, Idaho, 1929

Helland, Randolph O., "Water Utilization in the Salmon River Basin, Idaho," 1949

LaRue, Eugene C., Letter concerning right-of-way applications, Lemhi and Salmon River Valley Railroad, Lemhi River, Idaho, 1912

"Sevier River near Redmond, Utah," 1944 [78th Cong., 2d Sess., HR Doc. 614]

Grover, Nathan C. Memorandum relative to power-site withdrawals Nos. 106 and 140, Clearwater River, Idaho, ca. 1911

Leighton, Marshall O., "Report on Power-site Withdrawals in the Basin of the Clearwater River, Idaho," 1910

Water-power sites on the Clearwater River, Idaho, n.d. [forms]

Murphy, Edward C., "Report on Power-site Withdrawals on South Fork Clearwater River, Idaho," 1913

Oakey, Warren, "Storage and Power Possibilities, Clearwater River Basin, Idaho," 1927

Oakey, Warren and others, "Classification of lands, Clearwater River Basin, Idaho," 1927

Helland, Randolph O., Memorandum regarding: Water Utilization in the Clearwater River Basin, Idaho, 1950

Kramer, Edwin W., "Application of the Pierce Company, Limited, for a water-power permit of 100 horsepower or less," 1918 (Oro Fino Creek, Idaho)

Blueprint map pf the Palouse Project, Washington \& Idaho, 1914

Parker, Glenn L., Summary of power plants in the State of Washington, 1920

Waldron, Howard H. and Gard, Leonard M., "Preliminary Report on the Geology of part of the Lower Snake River Canyon, Washington," 1951

Leighton, Marshall O., Inspection of lands withdrawn for power purposes in Deschutes River Basin, Oregon, 1910; Stevens, John C., Letter listing 40 acre tracts bordering White Salmon River, Oregon, 1909; Covey, Claude C., Letter regarding power-sites on Warm Springs Indian Reservation, Oregon, 1910 
D-100-12M-2 Diagram showing relation of withdrawals and railroad rights-of-way along Deschutes River, Oregon, n.d.; Newspaper articles regarding irrigation projects (Umatilla Project, Tumalo Project), 1912, 1915

D-100-12M-3

D-100-12M-4

D-100-12M-5

D-100-12M-6

D-100-12M-7

D-100-12M-8

D-100-12M-9

D-100-12M-10

D-100-12M-11

D-100-12M-12

D-100-12M-13

D-100-12M-14

D-100-12M-15

D-100-12M-16

D-100-12M-17

D-100-12M-18

D-100-12M-19

D-100-12M-20

D-100-12M-21

D-100-12M-22

D-100-12M-23

D-100-12M-24

D-100-12M-25

D-100-12M-26

D-100-12M-27

D-100-12M-28

D-100-12M-28a

D-100-12M-30
"Preliminary Report and estimates for hydroelectric power development on the Deschutes River in Sherman and Wasco Counties, Oregon," 1912

Henshaw, Fred F. and others, Uses of Klickitat River water for irrigation, Washington and Oregon, 1912, 1939

Murphy, Edward C., "Report on Water-power and Reservoir Sites on Warm Springs Indian Reservation, Oregon," 1912

Location of power-sites along the Walla Walla and White Rivers, Oregon, 1908-9 [forms]

Halloran, Arthur H., "Pacific Power and Light Company," 1912 [article]

Hincks, Harvey W., "Irrigation and Power Possibilities of the Warm Springs Indian Reservation, Oregon," 1912

Memorandum regarding water-power for lumbering in vicinity of Wind River, Washington, 1913

Murphy, Edward C., "Report on Crooked River, Oregon, with Special Reference to the Utilization of Crooked River and Its Tributaries for irrigation and water-power," 1913

Township plats and map showing proposed location of flume line, Klickitat Power Project, Washington, 1908

Articles on Columbia River Power Project, Oregon, 1915

Laurgaard, Olaf, "Report on Suttles Lake Irrigation District, Jefferson County, Oregon," 1915

Allen, Lawrence R., Letter regarding water-power withdrawals on Metolius River, Oregon, 1910

LaRue, Eugene C. and others, Power development at Pringle Falls, Oregon, 1916-17

LaRue, Eugene C., "Reconnaissance Report showing possibilities for developing water-power in the Basin of Sandy River, Oregon, for purposes of classifying the O. \& C. R. R. Grant lands therein as to their value for purposes of power development," 1917

Debler, Erdman, "Report on water supply for Greater Umatilla Project," Oregon, 1919

Crosby, William O. and others, Report and data on Benham Falls Reservoir Site, Oregon, 1920

Deschutes River Board, "Report to Federal Power Commission on Uses of Deschutes River, Oregon," 1921; Reinsking, V. H., "Power Developments, Replacements and Local Power Market in Upper Deschutes Basin, Oregon," 1921; Classification sheets, Gila River, Arizona, n.d.

Henshaw, Fred F., Examination of land bordering Sandy River, Oregon, 1921

Henshaw, Fred F., "Report on Applications to the FPC for Preliminary Permits on Deschutes River, Oregon," 1921

Tubbs, Nelson J., "Reconnaissance report of John Day River, Oregon," 1922

Parker, Glenn L., "Umatilla Rapids Investigation, Water Supply Analyses," 1924

[charge card]

Stearns, Harold T., Memorandum regarding feasibility of the proposed Metolius Dam on the Deschutes River, Jefferson County, Oregon, 1925

Stearns, Harold T., "Geologic Examination of Dam sites on Crooked River, Jefferson County, Oregon," 1925

Stearns, Harold T., "Memorandum regarding artesian areas in Southern Oregon and Northern California," 1925; Stearns, Harold T., "Memorandum regarding Big Springs in Oregon," 1925

Murphy, Edward C., "Water Supply of Streams in Division 12 M. O.," Oregon, 1926 [Sandy River, Bull Run River, Little Sandy River, Salmon River]

Murphy, Edward C., "Water Supply of Streams in Division 12 M. O. Umatilla River Basin," 1926; Murphy, Edward C., "Lines of Equal Thirty-Year Run-off for the Western Part of Oregon," 1926

Jones, Edward E., "Reconnaissance along the Lower stretches of the Washougal River, Washington," 1927 
D-100-12M-31
D-100-12M-33
D-100-12M-34
D-100-12M-34b
D-100-12M-34c

D-100-12M-35

D-100-12M-36

D-100-12M-37

D-100-12M-38

D-100-12M-39

D-100-12M-40

D-100-12M-41

D-100-12M-43

D-100-12M-44

D-100-12M-45

D-100-12M-46

D-100-12M-47

D-100-12M-48

D-100-12M-48b

D-100-12M-49

D-100-12M-50

D-100-12M-51

D-100-12M-52

D-100-12N-1

D-100-12N-2

D-100-12N-3

D-100-12N-4

D-100-12N-5

D-100-12N-6

D-100-12N-7

D-100-12N-8 [charge card]

[charge card]

Johnson, Arthur, "Water-power resources of Walla Walla River, Oregon," 1933

Power-classification reports on the Walla Walla River, Oregon, n.d.

Johnson, Arthur and others, Reports and data concerning the Walla Walla River Basin, 1930-33

Piper, Arthur M., Ground water for irrigation in the Dalles Region, North-Central Oregon, 1932 [press release]

Erdmann, Charles E., "Report on Geologic Investigation of Miscellaneous Dam Sites on the Walla Walla River and the South Fork of the Walla Walla River, in the vicinity of MiltonFreewater, Oregon," ca. 1933 [accompanied by an album of photographs]

Piper, Arthur M. and others, "Ground water in the Walla Walla Basin, Oregon-Washington," 1933 [press release]

Bryan, Lester L., "Preliminary Report on Water-power Resources of Hood River, Oregon, with recommendations for lands proposed for power-site classification," 1933

Towle, Foster, "A Report on the Pendleton Project, Umatilla River Investigations, Oregon," 1935

Erdmann, Charles E., "Report on Geologic Reconnaissance of Klickitat Project, Washington, for U. S. Indian Irrigation Service, Wapato, Washington," 1936

Howes, H. E., "Report on Water-power withdrawals proposed by the U. S. Geological Survey of lands in the Hood River Basin in Mt. Hood National Forest, Oregon," 1938

Jones, Benjamin E., "Water-power Resources of Sandy River, Oregon," 1940

Dater, Philip E., "Memorandum regarding application for extension of time of preliminary permit, Oregon-California Hydroelectric Company," 1927

Robinson, John W., "Jack Creek Dam Site on the Metolius River, Oregon," 1943

Helland, Randolph O., Power-classification sheets for the Deschutes River, Oregon, 1944

Helland, Randolph O., "Water utilization in the White River Basin, Oregon," 1944

Helland, Randolph O., "Water utilization of streams on the Warm Springs Indian Reservation, Oregon," 1944

Power-classification sheets, n.d.

Helland, Randolph O., "Water utilization in the Crooked River Basin, Oregon," 1950

Helland, Randolph O., Memorandum regarding the geology of Pelton and Metolius Dam Sites, Oregon, 1950

Williams, Ira A. and Nickell, F. A., Reports on the geologic conditions of the Metolius and Pelton damsites, Deschutes River, Oregon, 1935

Miller, A. H., Excerpt from Corps of Engineers survey report on Umatilla River and Tributaries, Oregon, 1955

Fuller, Edwin S., "Report on water possibilities on the former Grande Ronde Indian Reservation, Oregon," 1911; Stevens, John C., Descriptions of tracts and lots bordering Lewis and Toutle Rivers, Oregon, 1909; Halloran, A. H., "The Oregon Power Company," 1911 [article]

Murphy, Edward C., "Report on lands Withdrawn for Power Purposes along the Molalla and McKenzie Rivers and Callapooya Creek, Oregon," 1911

Henshaw, Fred H., Letters regarding plant of the Kalama Light and Power Company, Oregon, 1912

McGlashan, Harry D., Location of power-sites along the Santiam, Willamette, Clackamas, Rickreall (La Creole), Marys, and Long Tom Rivers, and Silver Creek Oregon, 1908 [forms]

Murphy, Edward C., "Value for Water-power Purposes of Land in SE 1/4, Section 19, T. 7 N., R. 3 E., Willamette Meridian," Washington, 1912

Halloran, Arthur H., "Portland Railway, Light and Power," Oregon, 1913 [article]

"Columbia River at Cathlamet, Washington," 1913 [63rd Cong., 1st Sess., HR Doc. 120]

Peaslee, W. D., "The Wapato Lake Drainage Project," Oregon, 1914 [article] 
LaRue, Eugene C., "Reconnaissance Report showing possibilities for development of water power in Willamette River Basin, Oregon, for purposes of water-power-classification of Oregon and California Railroad Grants Lands," 1917

D-100-12N-10

D-100-12N-11

D-100-12N-11b

D-100-12N-12

D-100-12N-12b

D-100-12N-13

D-100-12N-14

D-100-12N-15

D-100-12N-16

D-100-12N-17

D-100-12N-18

D-100-12N-19

D-100-12N-19b

D-100-12N-20

D-100-12N-20b

D-100-12N-21

D-100-12N-21a

D-100-12N-22

D-100-12N-22a

D-100-12N-23

D-100-12N-23a

D-100-12N-24

D-100-12N-24a

D-100-12N-25

D-100-12N-25a

D-100-12N-26

D-100-12N-26b

D-100-12N-27

D-100-12N-28

D-100-12N-31

D-100-12N-32

D-100-12N-33

D-100-12N-33b
LaRue, Eugene C., "Precipitation in Oregon west of the Cascade Range," 1917

Davenport, Royal W., Memorandum regarding power possibilities of Clackamus River below River Mill, Oregon, 1922

Power-classification sheet

Davenport, Royal W., Memorandum of investigation of power possibilities of South Fork Scappoose Creek, Oregon, 1922

Power-classification sheets

Davenport, Royal W., Memorandums regarding power possibilities of Dairy and McKay Creeks, Oregon, 1922

Kramer, Edwin W., "Report to Federal Power Commission on Portland Railway Light and Power Company - Clackamus River Projects, Nos. 135 and 234," Oregon, 1924

Guy, David J., Memorandums regarding an investigation of power-site lands involved in the application filed by W. W. Miller, Scotts Mills, Oregon, 1921

Murphy, Edward C., "Water Supply of Streams in Division 12N, A-6, Willamette River Drainage," Oregon, 1926

Murphy, Edward C., Results obtained at gaging stations (in areas 12N, 12M, 12R) in Oregon having long records, 1926

Jessup, Louie T., "A Preliminary Report on Outlet Drainage Systems for Willamette Valley, Oregon," 1925

Helland, Randolph O., "Water-power Resources of Molalla River Basin, Oregon," 1927

Power-classification sheets, n.d.

Helland, Randolph O., "Water-powers of Coast Fork of Willamette River and tributaries, Oregon," 1927

Power-classification sheets

Helland, Randolph O., "Potential Water-power of Tualatin River, Oregon," 1929

Power-classification sheet

Helland, Randolph O., "Potential Water-power of Pudding River, Oregon," 1929

Power-classification sheets

Helland, Randolph O., "Potential Water-power of Big Luckiamute River, Oregon," 1929

Power-classification sheet

Helland, Randolph O., "Potential Water-power of Richreall Creek, Oregon," 1929

Power-classification sheet

Helland, Randolph O., "Potential Water-power of North Yamhill River and Mill Creek, Oregon," 1929

Power-classification sheet

Jones, Benjamin E., and Stearns, Harold T., "Water-power Resources of McKenzie River and tributaries, Oregon," 1929

Power-classification sheets and township diagrams

Pardee, Joseph T., Memorandum regarding an examination of dam sites on the Cowlitz, Cispus, Toutle, and Lewis Rivers, Washington, 1929

Department of the Interior Press Release, "Ground water for irrigation in Yamhill County, Oregon," 1931

Cowlitz River and Tributaries, Washington, 1931, 1940 [congressional documents]

"Lewis River, Washington," 1930 [71st Cong., 3r Sess., HR Doc. 680]

Jones, Benjamin E. and Piper, Arthur M., "Water-power Resources of Santiam River and tributaries, Oregon," 1933

Power-classification sheets and township diagrams 
D-100-12N-34

D-100-12N-35

D-100-12N-36

D-100-12N-37

D-100-12N-38

D-100-12N-39

D-100-12N-40

D-100-12N-41

D-100-12N-42

D-100-12N-43

D-100-12N-44

D-100-12N-45

D-100-12N-46

D-100-12N-47

D-100-12N-48

D-100-12N-49

D-100-12N-50

D-100-12N-51

D-100-12N-52

D-100-12N-53

D-100-12N-54

D-100-12N-56

D-100-12N-57

D-100-12N-57a

D-100-12N-58

D-100-12N-58a

D-100-12O-1

D-100-12O-2

D-100-12O-3

D-100-12O-4

D-100-12O-4b
Jones, Benjamin E., "Results of Resistivity Measurements at Tunnel Creek Dam Site, North Santiam River, Oregon," 1933

Johnson, Arthur, "Summary of Investigations on Lewis River and tributaries, Washington," 1945 Howes, H. E., "Report on Power Withdrawals Proposed by the United States Geological Survey on North Santiam and Breitenbush Rivers in Willamette National Forest, Oregon," 1936

Jones, Benjamin E., "Report on Resistivity Measurements at Eight dam sites in Willamette Valley, Oregon," ca. 1936

McKitrick, W. E., "Geology of Dam Sites - Long Tom River, Coast Fork [of] Willamette [River], Row River," 1937

McKitrick, W. E., "Geology of Dam Sites on the Middle Fork of the Willamette River and tributaries," 1937

McKitrick, W. E., "Geology of Dam Sites on the McKenzie River," 1937

McKitrick, W. E., "Geology of Dam Sites North, Middle and South Santiam Rivers and Calapooya River," 1937

Johnson, Arthur, "Summary of Investigations on Toutle River and tributaries, Washington," 1940

Johnson, Arthur, "Summary of investigations on Cowlitz River and tributaries, Washington," 1940

Erdmann, Charles E., "Report on Geologic Reconnaissance of Shut-in Dam Site, Cowlitz River, Lewis County, Washington," 1942

Piper, Arthur M., "Damsites in the Willamette and Siletz River Basins of Western Oregon," 1931

Erdmann, Charles E and Warren, Walter, "Report on the Geology of Three Dam sites on Toutle River, Cowlitz and Skamania Counties, Washington," 1938

Jones, Benjamin E. and others, Letters, report and memorandum regarding shut-in dam sites, Cowlitz River, Washington, 1944-49

Erdmann, Charles E. and Warren, Walter, "Preliminary report on the Geology of miscellaneous Dam Sites on Cowlitz River above Castle Rock, Washington," 1943

Piper, Arthur M., "Geologic Conditions at certain dam sites in the Willamette River Basin, Oregon," 1937

Helland, Randolph O., "Water Utilization in the Clackamas River Basin, Oregon," 1945 [charge card]

Bateman, Andrew F. and others, Big Bottom Dam Site, Lewis River, Washington, 1952

Erdmann, Charles E., and Bateman, Andrew F., "Geology of Dam sites on Southwestern Washington," 1951

Bateman, Andrew F., "Buried channels behind the right abutment of Yale Dam, Cowlitz County, Washington," 1953

Hodge, Edwin T., "Geology of Dam Site on McKenzie River," Oregon, 1931 [prepared for the Eugene, Oregon, Water Board]

Colbert, Jesse L., "Review of waterpower withdrawals in McKenzie River Basin, Oregon," 1961

Colbert, Jesse L., "Review of waterpower withdrawals in McKenzie River Basin, Oregon," 1961

Neal, Donald W., "Review of waterpower withdrawals in Middle Fork, Willamette River Basin, Oregon," 1961

Neal, Donald W., "Review of waterpower withdrawals in Middle Fork, Willamette River Basin, Oregon," 1961

Parker, Glenn L., "Preliminary Report on the Power Possibilities in Quiniaut Indian Reservation, Washington," 1911

Uhden, C. F., "Wynooche River Development," Washington, 1925

Jones, Edward E., "Power Resources of Wynooche River," Washington, 1928

Jones, Edward E., "Power Resources of Quinault River," Washington, 1930

Tables showing monthly mean discharge of Quinault River, Washington, 1911-12;

Power-classification sheets, n.d. 
D-100-12O-5

D-100-12O-6

D-100-12O-6b

D-100-12O-7

D-100-12O-8

D-100-12O-8b

D-100-12O-9

D-100-12O-10

D-100-12O-11

D-100-12P-1

D-100-12P-2

D-100-12P-3

D-100-12P-4

D-100-12P-5

D-100-12P-6

D-100-12P-7

D-100-12P-8

D-100-12P-9

D-100-12P-10

D-100-12P-11

D-100-12P-12

D-100-12P-12b

D-100-12P-13

D-100-12P-13b

D-100-12P-14

D-100-12P-15

D-100-12P-15b

D-100-12P-16

D-100-12P-17

D-100-12P-17b

D-100-12P-18

D-100-12P-18b

D-100-12P-19
Jones, Edward E., "Power Resources of Soleduck and Lyre Rivers," Washington, 1930

Jones, Edward E., "Power Resources of Bogachiel and Ozette Rivers, Washington," 1930

Power-classification sheet, n.d.

Piper, Arthur M., "Damsites on the Hoh and Calawah Rivers, Washington," 1931

Bryan, Lester L., "Water-power Resources of Hoh River, Washington," 1931; Howes, H. E., "Report on Power Value of Hoh River, Olympic National Forest, Washington," 1932

Bryan, Lester, L., "Power-site Classification Report on Hoh River, Washington," 1932

Johnson, Arthur, Memorandum regarding storage possibilities in the Satsop River Basin, 1939

Lawrence, Fred F., "Summary of investigations on Chehalis River and tributaries, Washington," 1942

Johnson, Arthur, "Summary of investigations on Olympic Peninsula streams, Washington," 1942

Henshaw, Fred F., and others, Reports, letters and other records concerning water-power lands on the Skagit, Nooksack, Skykomish, and Puyallup Rivers, Washington, 1898-1910

Electric Railway and Lighting Properties, 1908-14 [brochure]; Murphy, Edward C., "Report on Power-site Withdrawal No. 160, Jackman Creek," Washington, 1912

"The Hydraulic Power Plant on the Puyallup River near Tacoma," Washington, 1904 [transcribed article]; Van Nordeen, Rudolph W., "Puget Sound Traction, Light and Power Company's System," Washington, 1912 [article]

Pfau, Arnold, "The White River Plant," Washington, 1912 [article]

Murphy, Edward C., "Report on Water-power Possibilities of Land in Sections 23, 25, and 35, T. 22 N., R. 5 W., Skokomish River, Washington," 1912

Evans, Llewellyn, "Tacoma Municipal Power Plant," Washington, 1913 [article]

Plats of Washington State that show the power plants and transmission lines of Stone and Webster interests and of municipalities and other power companies, n.d.

"Skagit River, Washington," 1914 [63rd Cong., 2d Sess., HR Doc. 935]

Fowler, Charles E., "Leakage from Cedar Lake Reservoir, Seattle Water-Supply," Washington, n.d. [article]

Bateman, Andrew F. and others, Correspondence and reports regarding power-sites along Nooksack, Skagit, and Sauk Rivers and power for city of Seattle, Washington, 1915-16, 1948

"The Nisqually Hydro-Electric Plant of the City of Tacoma, Washington," 1910 [article]

Jones, Edward E, "Power Resources of North and South Forks Skokomish River," Washington, 1926; "Skokomish River, Mason County, Washington," 1943 [78th Cong., 1st Sess., HR Doc 267].

Power-classification sheets

Jones, Edward E., "Power Resources of Lillwaup Creek, Hamma Hamma River, Dosewallips River," Washington, 1926

Power-classification sheets

Memorandum regarding Power possibilities in Skagit Basin, Washington, 1926

Jones, Edward E., "Power Resources of Duckabush River, Quilcene River, Dungeness River," Washington, 1927

Power-classification sheets

Pardee, Joseph T., "Report on Geology of Damsites on Skagit and Sauk Rivers, Washington," ca. 1926

Calkins, Donald J. F., "Report upon the Power Value of certain Lands crossed by or in the vicinity of the Hartford Eastern Railway, through Township 30 North, Ranges 8, 9, and 10 East, Willamette Meridian," Washington, 1929

Power-classification of lands, n.d.

Jones, Edward E., "Power Resources of Elwha River, Washington," 1927

Power-classification sheets, n.d.

List of prospective reservoir sites in the State of Washington, n.d. 
D-100-12P-20

D-100-12P-21

D-100-12P-22

D-100-12P-23

D-100-12P-24

D-100-12P-25

D-100-12P-26

D-100-12P-27

D-100-12P-28

D-100-12P-28b

D-100-12P-29

D-100-12P-30

D-100-12R-1

D-100-12R-2

D-100-12R-4

D-100-12R-5

D-100-12R-6

D-100-12R-7

D-100-12R-8

D-100-12R-9

D-100-12R-10

D-100-12R-11

D-100-12R-12

D-100-12R-13
Parker, Glenn L., "Report on the Power Value of certain lands along Sultan River in Washington," 1925

"Stilaguamish River, Washington," 1930 [71st Cong., 3d Sess. HR Doc. 657]

"Stilaguamish River, Washington," 1930 [71st Cong., 3d Sess. HR Doc. 657]

Pardee, Joseph T., "Geology of Damsites on the South Fork of Nooksack River and Queets River, Washington," 1932

Johnson, Arthur and others, Reports and studies regarding the Nisqually Glacier, Washington, $1937-51$

Pardee, Joseph T., "Report of Preliminary Examination of Damsite on Carbon River," Washington, 1939

Johnson, Arthur, "Summary of investigations in Sauk River Reservoir Site, Washington," 1939

Erdmann, Charles E. and Warren, Walter, "Report on the Geology of Miscellaneous Dam and Tunnel Sites, Upper Basin of the Nooksack River, Whatcom and Skagit Counties, Washington," 1942

Helland, Randolph O., "Water utilization in the Nooksack River, Washington," 1941; Miller, J. Charles, "Geologic Reconnaissance Mile 18 Dam Site, Nooksack River, Washington," n.d.; Miller, J. Charles, "Geologic Reconnaissance, Maple Falls Dam Site, Nooksack River, Washington," n.d.

Power-classification sheets

Lawrence, Fred F., "Water-power Resources of Hamma Hamma, Duckabush, and Dosewallips Rivers, Washington," 1952

Calkins, Donald J. F., "Report on inspection of Baker River Power Plant at Concrete, Washington," 1925

Murphy, Edward C., "Report on Reserve Nos. 161 and 167, Rogue River," Oregon, 1911

Newspaper clipping regarding the enforcement of Representative Hawley's Siletz settlers bill, 1912

Murphy, Edward C., "Report on lands withdrawn for water-power purposes on the North Fork of Umpqua River," Oregon, 1912

Murphy, Edward C., "Report on Power-site Reserve No. 284 on South Fork Coquille River, Oregon," 1912; Applications by James H. Owen to appropriate water from the South Fork of Smith River and Main Smith River, California, 1912

Henshaw, Fred F., Letter regarding power possibilities on the Umpqua River between Roseburg and Elkton, Oregon, 1914

LaRue, Eugene C., "Reconnaissance Report showing possibilities for water-power development in Rogue River Basin, Oregon, for the purpose of the water-power classification of Oregon and California Railroad Grant lands" 1916

LaRue, Eugene C., "Reconnaissance Report showing possibilities for development of water power in the Basin of Umpqua River, Oregon, for the purpose of the water-power classification of Oregon and California Railroad Grant lands," 1917

LaRue, Eugene C., "Reconnaissance Report relating to possibilities for development of waterpower in the basins of the coast streams in Western Oregon for the purpose of the waterpower classification of The O. \& C. R. R. Grant Lands," 1917

Henshaw, Fred F., "Report on Application of Rogue River Valley Canal Company for Fish Lake and Fourmile Lake Reservoirs (Roseburg 06649)," 1912

LaRue, Eugene C., "Report showing Water-power Value of certain government lands involved in the proposition of the Coos Bay Lumber Company to exchange certain of its lands for lands owned by the U. S. Government," 1919

LaRue, Eugene C., "Water-power Classification of Lands in Coos Bay Wagon Road Grant, Oregon," 1920

Jones, Benjamin E., "Report on power-site reserves in Suislaw River Basin, Oregon," 1922 
D-100-12R-14 Murphy, Edward C., "Water supply of streams entering the Pacific Ocean between Columbia and Klamath Rivers, Division 12R, Precipitation," 1923

D-100-12R-14a Murphy, Edward C., "Water Supply of Streams entering the Pacific Ocean between the Columbia and Klamath Rivers, Part A of Division 12R," 1923

D-100-12R-14b Murphy, Edward C., "Water Supply of Streams entering the Pacific Ocean between the Columbia and Klamath Rivers, Part B of Division 12R," 1923

D-100-12R-14c

D-100-12R-14d

D-100-12R-14e

D-100-12R-15

D-100-12R-15b

D-100-12R-16

D-100-12R-17

D-100-12R-17b

D-100-12R-18

D-100-12R-19

D-100-12R-20

D-100-12R-20b

D-100-12R-21

D-100-12R-22

D-100-12R-24

D-100-12R-24b

D-100-12R-25

D-100-12R-25b

D-100-12R-26

D-100-12R-27

D-100-12R-27b

D-100-12R-28

D-100-12R-29

D-100-12R-30

D-100-12R-30b

D-100-12R-32

D-100-12R-32b

Murphy, Edward C., "Water Supply of Streams entering the Pacific Ocean between the Columbia and Klamath Rivers, Part C of Division 12R," 1924

Murphy, Edward C., "Water Supply of Streams entering the Pacific Ocean between the Columbia and Klamath Rivers, Part D of Division 12R," 1924

Murphy, Edward C., "Water Supply of Streams entering the Pacific Ocean between the Columbia and Klamath Rivers, Part E of Division 12R," 1924

Davenport Royal W., "Memorandum of investigation of power possibilities of Alsea River and tributaries," Oregon, 1922

Power-classification sheets, n.d.

"Memorandum regarding power possibilities of Lower Rogue River, Oregon," 1922

Davenport, Royal W., "Memorandum of investigation of power possibilities of Big Elk Creek, Oregon," 1922

Power-classification sheets, n.d.

Oakey, Warren, Memorandum on Eagle Point Irrigation District, Oregon, 1923

Jones, Benjamin E., "Report on the potential water-power in Trask, Nestucca, and Smith River Basins, Oregon," 1924

Jones, Benjamin E. and Oakey, Warren, "Report on the potential water-power of Nehalem and Wilson River Basins in Oregon," 1924

Power-classification sheets

Lundgren, Leonard, "Preliminary Report on the Diamond Lake Storage Reservoir and the North Umpqua and the Lower Umpqua Water-power Projects," Oregon, 1916

Murphy, Edward C., "Duration of flow of streams in Oregon," 1925

Jones, Benjamin E. and Oakey, Warren, "Water-power in the Rogue River Drainage Basin, Oregon," 1926

Power-classification sheets

Hoyt, William G., "Water Supply and Utilization, Coquille River Basin, Oregon, and relation to Timber Resources," 1926

Hoyt, William G. "Power-classification, Coquille River Basin," n.d.

Stearns, Harold T., "Geologic Examination of Reservoir and Dam Sites in the Drainage Basins of Rogue, Umpqua, Siletz, and McKenzie Rivers in Western Oregon," 1926

Jones, Benjamin E. and Stearns, Harold T., "Water-power resources of Umpqua River and tributaries, Oregon," 1927

Power-classification sheets

Woodward, W. M. H., Memorandum regarding California-Oregon Power Company and field Examination of two Reservoir Sites on Upper North Umpqua River, Oregon, 1928

Helland, Randolph O., "Potential power of Yaquina River, Oregon," 1929

Jones, Benjamin E, and Stearns, Harold T., "Water-power Resources of Siletz River Basin, Oregon," 1931; Helland, Randolph O., Memorandum regarding power development on Siletz River, Oregon, 1955

Power-classification sheets

Tubbs, Nelson J., "Preliminary Report on the Potential Power of Smith River Basin,

Del Norte County, California," 1927-34

Power-classification sheets 
D-100-12R-33

D-100-12R-34

D-100-12R-34b

D-100-12R-35

D-100-12R-35b

D-100-12R-35c

D-100-12R-36

D-100-12R-37

D-100-12R-37b

D-100-12R-38

D-100-12R-39

D-100-12R-40

D-100-12R-40b

D-100-12R-41

D-100-12R-42

D-100-12R-43

D-100-12R-44

D-100-12R-45

D-100-12R-46

D-100-12R-47

D-100-12R-48

D-100-12R-49

D-100-13-2

D-100-13-3

D-100-13-4

D-100-13-5

D-100-13-6

D-100-13-7
Piper, Arthur M., "Geologic features of Dam Sites in the Nehalem, Rogue, and Willamette River Basins, Oregon," 1935-37

Helland, Randolph O., "Water Utilization within the Nehalem River Basin, Oregon, with Geology of Dam Sites by Arthur M. Piper," 1937

Power-classification sheets and township diagrams

Helland, Randolph O., "Water Utilization in the basins of South Umpqua River and Cow Creek, Oregon," 1939; Miller, J. Charles, "Geologic Reconnaissance, Tiller Dam Site, T. 30 S., R. 2 W., Willamette Meridian, Oregon," 1939

Power-classification sheets, n.d.

"Land Classification Sheets for South Umpqua River and Cow Creek, Oregon," n.d.

Griffin Robert H., "Report on Proposed Classification for Power Value of Lands, Smith River, Siskiyou National Forest," California, 1939

Helland, Randolph O., "Water Utilization in Tributaries of the Rogue River, Oregon, with Geology of dam sites by Arthur M. Piper and J. Charles Miller," 1940

Power-classification sheets

Henny, David C., "Preliminary Report to Directors Medford Irrigation District on Beaver, Keene, and Bear Creek Project and on Little Butte, Four Mile and Bear Creek Project," 1919

Helland, Randolph O. and others, Report on reservoir sites on the Alsea River, Oregon, 1945, 1949, 1952

Helland, Randolph O., "Water Utilization in the Coos River Basin, Oregon," 1947

Power-classification sheets

Karrick, S. N., "Preliminary Examination Report for Flood Control and Allied Purposes on Smith River and Tributaries, California and Oregon," 1948 [partial copy]

Helland, Randolph O., "Water Utilization in the Sixes River Basin, Oregon," 1950; Miller, J. Charles, Memorandum regarding an examination of Dam Site North of Union Creek Resort on the Rogue River, Oregon, 1951

Helland, Randolph O., "Water-power of the Coast Streams of Oregon," 1953

Sax, Kenneth W., "List of Bench Marks found or established during surveys of Wilson River, Oregon, to Mile 29 and tributaries, 1954-55"

Sax, Kenneth W., "List of Bench Marks found or established during surveys of Trask River, Oregon from vicinity of Gold Creek to Mile 11.6 and tributaries, 1954-55"

Sax, Kenneth W., "List of Bench Marks found or established during surveys of Nestucca River, Oregon, from vicinity of mile 23.2 and tributaries, 1954-55"

Sax, Kenneth W., "List of Bench Marks found or established during surveys of South Fork Coos River, Oregon, from vicinity of Dellwood to mile 22, Williams River to mile 10, 1954-55"

Young, Loyd L. and Colbert, Jesse L., "Water-power Resources in Nehalem River Basin, Oregon," with Piper, Arthur M. and Gaskill, David L., "Preliminary Geology of Dam and Reservoir Sites," 1959

Young, Loyd L., "Water-power Resources in Trask River Basin, Oregon," 1960

Dater, Philip H., "District Engineer's Report upon Preliminary Application of E. P. Kennedy (Alaska-Treadwell Gold Mining Company regarding hydroelectric development near Juneau, Alaska,)" 1913

Lundgren, Leonard, "General Report on Water-powers in Southeastern Alaska," 1915

Canfield, George H., "Report on Applications of W. E. Epperson and Copper Harbor Pulp and Power Company to Federal Power Commission for Preliminary Permit," Alaska 1921

Canfield, George H., "Report on Application for Preliminary Permit to Federal Power Commission by R. L. Weeks," Alaska, 1921

Canfield, George H., "Report on Application of L. J. Vogter to the Federal Power Commission for a Preliminary Permit," Alaska, 1921

Canfield, George H., "Report on Application of Alaskan-American Paper Corporation to the Federal Power Commission for a License," Alaska, 1921 
D-100-13-8

D-100-13-9

D-100-13-10

D-100-13-11

D-100-13-12

D-100-13-13

D-100-13-14

D-100-13-15

D-100-13-16

D-100-13-17

D-100-13-19

D-100-13-20

D-100-13-21

D-100-13-22

D-100-13-23

D-100-13-24

D-100-13-25

D-100-13-26

D-100-13-27

D-100-13-28

D-100-13-29

D-100-14-1

D-100-14-2

D-100-14-2a

D-100-14-3
Canfield, George H., "Report on Application of Paul Butler to the Federal Power Commission for a Preliminary Permit," Alaska, 1921

Canfield, George H., "Report on Application of Maurice D. Leehey to the Federal Power Commission for Preliminary Permit," Alaska, 1921

Canfield, George H., "Report on Application of Alaska Development and Mineral Company to the Federal Power Commission for Preliminary Permit," Alaska, 1921

Canfield, George H., "Report on Application of J. G. Galvin to the Federal Power Commission for Preliminary Permit," Alaska, 1921

Canfield, George H., "Report on Application Wrangell Pulp and Paper Company to the Federal Power Commission for Preliminary Permit," Alaska, 1921

Canfield, George H., "Report on Application of Town of Petersburg, Alaska, to the Federal Power Commission for a License," 1921

Canfield, George H., "Report on Application of Alaska Endicott Mining and Milling Company to the Federal Power Commission for Preliminary Permit," Alaska, 1921

Canfield, George H., "Report on Application of Speel River Project, Inc., to the Federal Power Commission for License for Tease Lake and Preliminary Permit for Crater Lake, Long Lake, and Speel River," Alaska, 1921

Ageton, Richard V., Letter regarding the Construction of the Salmon Creek Dam of the Alaska Gastineau Mining Company, near Juneau, Alaska, 1936

Dort, Joseph C., "Report to the Federal Power Commission on the Water-powers of Southeastern Alaska," 1924; Federal Power Commission and Forest Service, "Water-powers - Southeast Alaska," 1947

Lawrence, Fred F., "Water-power Resources of Scenery Creek near Petersburg, Alaska," 1950

Twenhofel, William S., "Geology of Proposed Blue Lake Dam Site and Tunnel near Sitka, Alaska," 1950

Twenhofel, William S. and Johnson, Arthur, "An Analysis of Potential Industrial Sites in the Upper Lynn Canal Area, Alaska," 1950

Miller, John Charles, "Geology of Water-power-sites on Crater Lake, Long Lake, and the Speel River near Juneau, Alaska," 1956

Miller, John Charles, "Geology of Water-power-sites on Scenery Creek, Cascade Creek, and Delta Creek near Petersburg, Alaska," 1955

Colbert, Jesse L., "Preliminary report on Water-power Resources of Cascade Creek, Scenery Creek and Delta Creek near Petersburg, Alaska," 1955

Johnson, Frederick A., "Water-power Possibilities of Crater Lake, Long Lake and Speel River near Juneau, Alaska," 1955

Plafker, George, "Geologic Investigations of Proposed Sheep Creek, Carlson Creek, and Turner Lake Power-sites, Alaska," 1956

Johnson, Frederick A., "Water-power Possibilities of Sheep Creek, Carlson Creek, Lake Dorothy and Turner Lake near Juneau, Alaska," 1957

Johnson, Arthur, "Inspection report of Salmon Creek Dam near Juneau, Alaska," 1956

Soward, Kenneth S., "Geology of Baranof Lake and Carbon Lake Power-sites, Baranof Island, Southeastern Alaska," ca. 1957

"Tanana River and Chena Slough, Alaska," 1938 [75th Cong., 3d Sess., HR Doc. 561]

Bateman, Andrew F., "Reconnaissance Report on Geology of Eklutna Lake Dam Site and Conduit Route near Anchorage, Alaska," 1947; Johnson, Arthur, "Preliminary Report on Waterpower resources of Eklutna Creek, Alaska," 1947; Barnes, F. F., "Preliminary Report on the Geology along the Route of a proposed tunnel to develop Hydroelectric Power from Eklutna Lake, Alaska," 1947

"Eklutna Project," 1948

Johnson, Arthur, "Water-power possibilities in the general vicinity of Anchorage and on the Kenai Peninsula, Alaska," 1948 


\begin{tabular}{|c|c|}
\hline D-100-14-4 & Johnson, Arthur, "Susitna River, Alaska," 1948 \\
\hline D-100-14-5 & Lawrence, Fred F., "Knik River Flood of July-August, 1948," 1949 \\
\hline D-100-14-6 & $\begin{array}{l}\text { Johnson, Arthur, "Preliminary Report on Water-power Resources of Power Creek near Cordova, } \\
\text { Alaska," 1949; Miller, Don J., "Geology at the site of a proposed Dam and Reservoir on } \\
\text { Power Creek near Cordova, Alaska," } 1951\end{array}$ \\
\hline D-100-14-7 & $\begin{array}{l}\text { Lawrence, Fred F., "Preliminary Report on Water-power Resources of Little Susitna River and } \\
\text { Cottonwood Creek, Alaska," } 1949\end{array}$ \\
\hline D-100-14-8 & Johnson, Arthur, "Report on Reconnaissance of Lake Chackachamna, Alaska," 1950 \\
\hline D-100-14-9 & $\begin{array}{l}\text { Colbert, Jesse L., "Water Utilization, Ship Creek near Anchorage, Alaska," 1951; } \\
\text { Dobrovolny, Ernest, "Preliminary Report on the Geology of two Dam Sites on Ship Creek } \\
\text { near Anchorage, Alaska," } 1952\end{array}$ \\
\hline D-100-14-10 & Johnson, Arthur, "Reconnaissance Report on Chickaloon River, Alaska," 1950 \\
\hline D-100-14-11 & $\begin{array}{l}\text { Johnson, Frederick A., "Preliminary Report on the Water-power Possibilities of the Seldovia } \\
\text { River, Alaska," } 1954\end{array}$ \\
\hline D-100-14-12 & Letters concerning power-site classification of Copper River, Alaska, 1953 \\
\hline D-100-14-13 & $\begin{array}{l}\text { Johnson, Arthur, "Preliminary Report on the Potential Water-power of Grant, Ptarmigan, Cooper, } \\
\text { and Crescent Lakes of the Kenai Peninsula near Seward, Alaska," } 1955\end{array}$ \\
\hline D-100-14-14 & $\begin{array}{l}\text { Johnson, Frederick A., "Water-power Possibilities of Bradley Lake, Alaska," } 1956 \text { [includes a } \\
\text { chapter titled "Tentative Geologic Conclusions on Bradley Lake Power-site," by Kenneth S. } \\
\text { Soward, 1956] }\end{array}$ \\
\hline D-100-14-15 & $\begin{array}{l}\text { Johnson, Frederick A., "Report on Homestead Applications (Anchorage River Basin), Alaska," } \\
1955\end{array}$ \\
\hline D-100-14-16 & $\begin{array}{l}\text { Bateman, Andrew F., "Reconnaissance Report on Geology of Lower Eagle River Valley, Alaska," } \\
1948\end{array}$ \\
\hline D-100-14-17 & Jackson, Bruce L., "Potential Water-power of Lake Chakachamna, Alaska," 1961 \\
\hline D-100-14-18 & $\begin{array}{l}\text { Indermuhle, Vernon C., "Preliminary Report on the Water-power Resources of Snow River, } \\
\text { Nellie Juan Lake and Lost Lake, Kenai Peninsula, Alaska," } 1961\end{array}$ \\
\hline
\end{tabular}




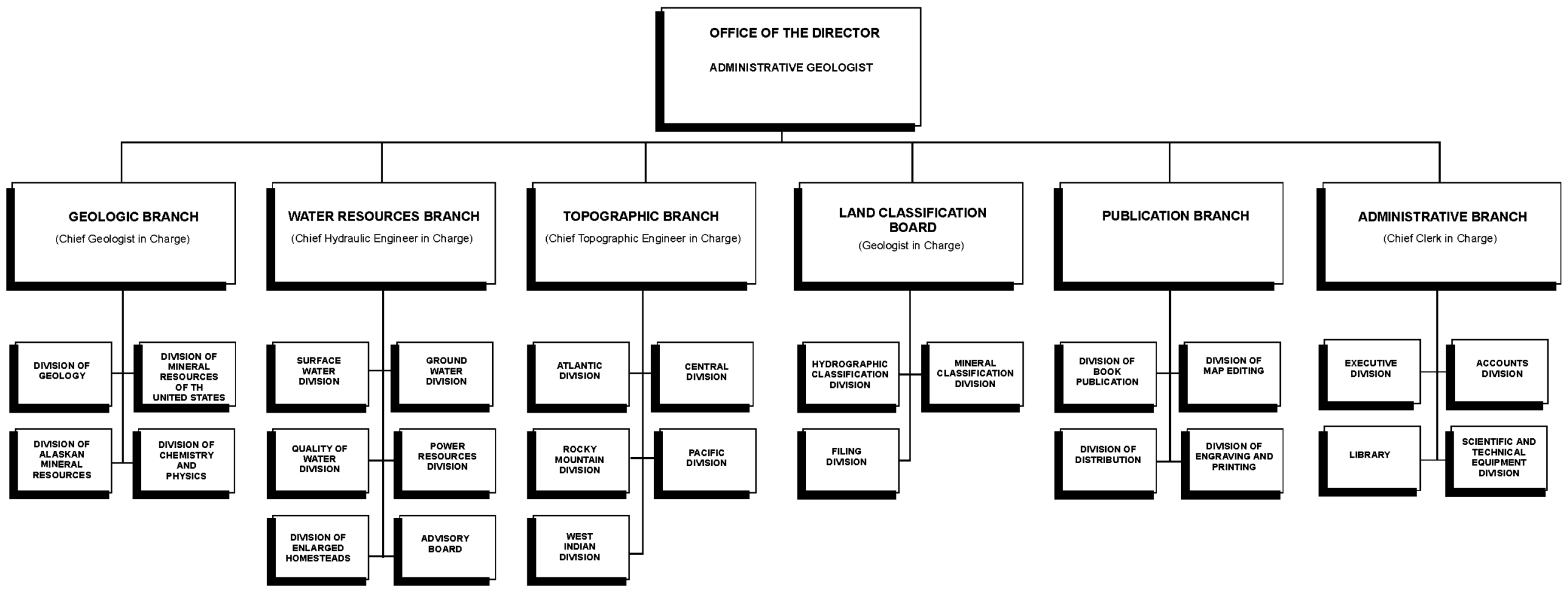

ORGANIZATION OF THE GEOLOGICAL SURVEY DEPARTMENT OF THE INTERIOR July 1, 1958

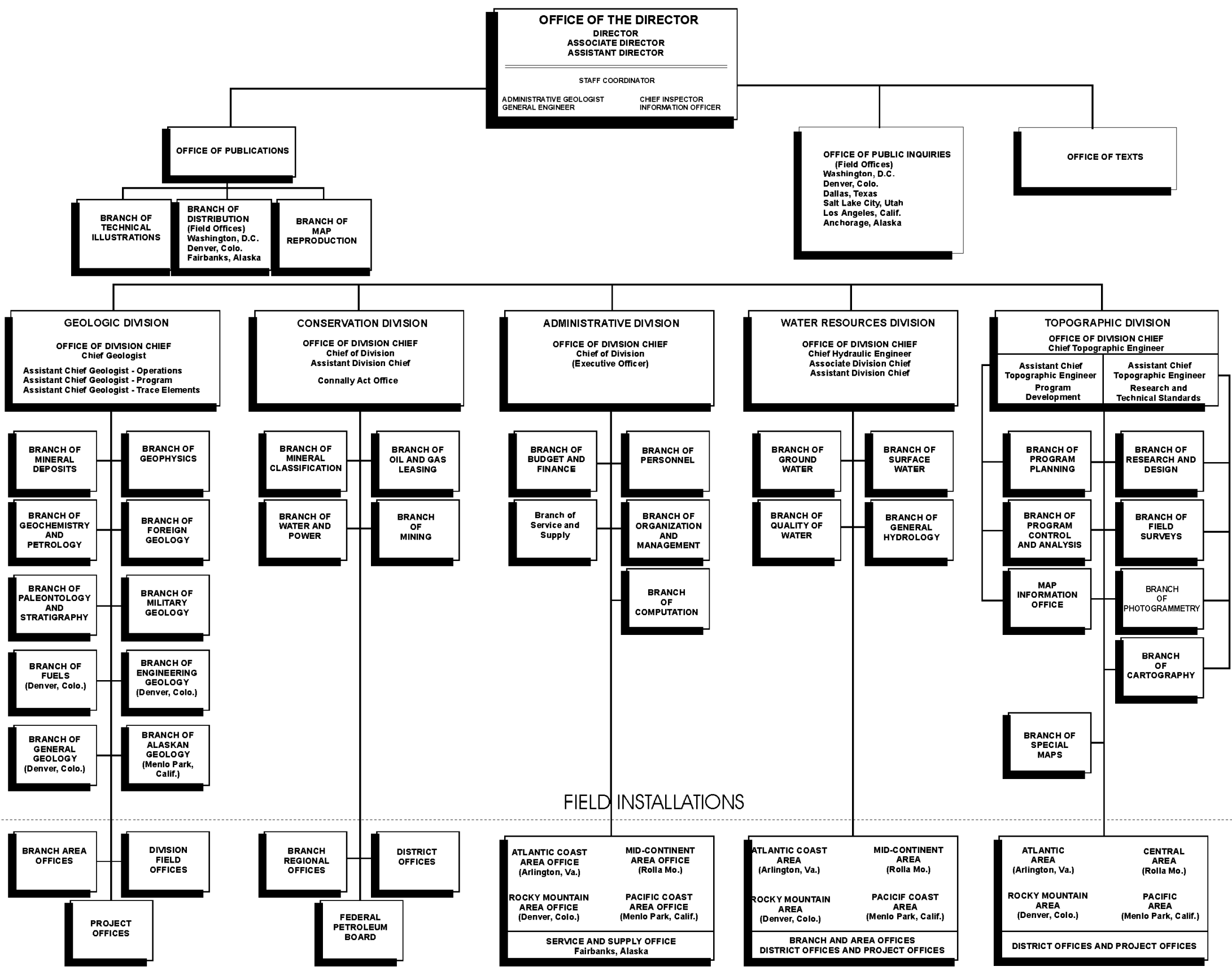

